\title{
The Diary of Heinrich Witt
}

\author{
Volume 7
}

\author{
Edited by
}

Ulrich Mücke

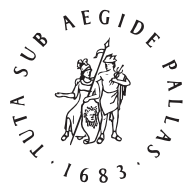

B R I L L

LEIDEN | BOSTON 


\section{[1] Volume VII}

\section{Commenced in Lima on the $27^{\text {th }}$ of October 1877 by Mr. James Bryson. [2]}

\section{Residence in Lima.}

From Friday, $20^{\text {th }}$ to Tuesday, $37^{\text {st }}$ of March 1868. On Friday $20^{\text {th }}$ we returned to Chorrillos, but without our cook Achipe, who under the pretence of indisposition remained in Lima; a countryman of his whom he had recommended in his stead did by no means answer the purpose; perhaps he did not know how to purchase in the market place, perhaps cheated us. At all events the meals which he placed on the table were not such as we had a right to expect from the money we gave him, thus my poor wife was always in hot water, not on her own account, nor on mine, because we were both indifferent about our eating and drinking, but our son Juan was rather particular; also Melchor Velarde and Arthur Heeren came now and then uninvited, and then the mere idea that the dishes might not be to their liking sufficed to put my dear Mariquita momentarily out of humour. The price of provisions was certainly rising in an extraordinary manner, for all such as could, and had the means, came to this place flying from the yellow fever which was committing havoc in Callao, and had shown itself in Lima. Except Sundays and holidays I went to town every day. In the train the yellow fever was the topic of conversation. In Lima I attended to my usual occupations, and one morning I ventured to ascend San Cristoval, though violent exercise was at the time strictly prohibited by medical men.

In the course of these, as well as the preceding days, the Municipality of Lima was beleagured by great numbers of the lowest classes of the Lima population, all eager to obtain their certificates of citizenship - Cartas de Ciudadania. They were the men of the day, they were the effective members of the clubs, they paraded the streets with military music and banners displayed; they, each paid from four to twelve rials a day, called "el Pueblo Soberano", were the main voters, the principal electors, and decided the fate of the country!

The last steamer brought the news of Earl Derby's resign [...] of bad health, and Mr. Disraeli had by order [...] [3] taken his place. In the United States things looked queer. On the $21^{\text {st }}$ of February President Johnson ordered Mr. Stanton, Minister of War, to give up the War Department to General Thomas who occupied an inferior situation in the same department. Stanton refused to obey, and ordered Thomas to go to his post and to do his duty as

(C) KONINKLIJKE BRILL NV, LEIDEN, 2016 | DOI 10.1163/9789004307247_002

This is an open access chapter distributed under the terms of the prevailing CC-BY-NC License at the time of publication. 
heretofore. This, Thomas would not, whereupon Stanton ordered his arrest. On Thomas giving bail he was immediately placed at liberty and the Supreme Court decided that he had been improperly arrested, whereupon he brought an action against Stanton, demanding $\$ 150,000$ damages.

Meanwhile Stanton had placed the order of the President before the House of Representatives, who being for the greater part Republicans, Ultras or Radicals, supported Stanton, and resolved that the President had made himself guilty of a violation of the Constitution; accordingly an accusation would be formed within a few days, and laid before the Senate. The American Constitution says that the President of the Republic cannot remove without the consent of the Senate, any Minister previously named by him, but Johnson said that he had not named Stanton, for Stanton was one of Lincoln's Ministers, only tolerated him in the office, and that therefore the just mentioned article of the Constitution was literally not applicable to this case.

Wednesday, $7^{\text {st }}$ of April 1868. The elections began; scaffoldings were erected in the Plaza de Armas for the parish of El Sagrario, and in other open places for the four parishes: Santa Ana, San Sebastian, San Marcelo, and San Lázaro. There was some fighting between the different parties; two men they said were killed, and several wounded, but upon the whole it went off pretty quietly, and José Balta's party generally triumphed. In Chorrillos nothing particular occurred. From Callao the man-of-war "Rimac" had come in, so that now there were five Peruvian men-of-war in the bay, which had all left Callao for fear of the epidemic. As to my family affairs we had to turn off the Chinese cook, and meanwhile our black servant woman Pet[_] had taken upon herself the kitchen department, which she manag [...] fairly. [4]

Friday, $3^{\text {rd }}$ of April. After my usual bath and light breakfast I took the 9 O'clock train for Lima; on the course of the day I went to the Plaza Mayor to see how things were going on. A number of people dressed in jackets, ponchos, and the like, were ranged in files like soldiers ready to ascend the scaffolding, and to give their votes. Of decently dressed people hardly any were to be seen mixed up with this mob.

By last steamer arrived from Europe Pezet's ex-ministers P. J. Calderon and Evaristo Gomez-Sanchez who were immediately arrested, but placed in liberty after a short detention. However, the arrest of the latter, cousin of Dr. José Luis Gomez-Sanchez, Minister of Finance, had, as it was said, been the cause of this gentleman's giving in his resignation, which was accepted. From Europe we learned that Mr. Disraeli had formed his cabinet; this was, if I am not mistaken, the first instance since the time of William Pitt that a mere commoner without a title had been Prime-Minister of England. In the United States on the $5^{\text {th }}$ 
and $6^{\text {th }}$ of March the Senate constituted itself as Tribunal of Justice, under the Presidency of Mr. Chase, and of Mr. Nelson, the latter of the Supreme Court of Justice. On the $13^{\text {th }}$ the House of Representatives was to bring in its accusation against President Johnson, and meanwhile Stanton continued Minister for War.

The young King Louis II of Bavaria had died at the age of 23 whilst his grandfather Louis I, more than 80 years of age, of Lola Montes notoriety, was still alive. (The death of King Louis was a false report.)

Wednesday, $8^{\text {th }}$ of April. The steamer, corresponding to the French, one from St. Nazaire arrived in Callao; on board of her came Dr. Leon Dreyfus, partner of his brother Augustus, with his newly married wife - a young French lady. They, fearing the yellow fever, asked for permission to be transhipped on board of a small steamer for Chorrillos which insignificant favor was denied them by the authorities.

From the United States we learned that the advocates of President Johnson had asked for forty days to prepare their defence, and only ten days had been granted them.

Thursday, $9^{\text {th }}$, Holy Thursday, and Friday, $10^{\text {th }}$, Good Friday. I remained in Chorrillos [...] knew what to do with myself; the temperature was getti[_] [5] what cooler, which change I particularly observed when bathing. Nevertheless the yellow fever was by no means on the decrease - the contrary was rather the case.

Sunday, $12^{\text {th }}$ of April 1868. Easter Sunday. I went to town and paid a number of necessary visits. J. J. Helguera, with whom in 1846 and 1847 I was well acquainted when he was one of the subalterns in the Treasury, and who of late had been chief treasurer, was named Minister of Finances in lieu of José Luis Gomez Sanchez.

The elections were over; they had by no means been uniform. On the contrary, there had been dualidades, and even trialidades and thus at the meeting of the Colegios Electorales, there would be electors for three parties, and the majority would then have to decide which were the legitimate electors. For instance, for the Parish del Sagrario there had been three mesas, one in the Plaza de Armas, another in the Plazuela de Santo Domingo, and a third in that of San Pedro. Those who had made themselves masters of the first named were friends of General Echenique. At the second the adherents of José Balta preponderated, and at the third a party, the chief of which my original does not give, prevailed.

From Monday, $13^{\text {th }}$ to Friday, $24^{\text {th }}$ of April. A great number of people residing in Callao and Lima were attacked by the yellow fever, and not a few fell victims to this dreadful epidemic. The "Comercio" stated that from the $1^{\text {st }}$ to $7^{\text {th }}$ of April there had been 122 deaths in Lima, and that on the $23^{\text {rd }} 86$ had died, whilst 
in Callao, where the population had considerably decreased by emigration, deaths had not decreased in proportion. Miraflores, El Barranco, and Chorrillos were crowded with people who came from Lima in the evening, and returned in the morning to their avocations. I was of the number, whilst Juan but seldom ventured to town. I was told by a reliable person that about this time the train between Lima and Chorrillos, and vice versa, made daily about $\$ 1000$ gross. It was observed by the medical men that new comers from Europe, as well as such as came to Lima from the Interior, were most exposed to the fever, whilst the old settlers had not of much to fear.

On the $22^{\text {nd }}$ Rosa, her husband, two female, and one male [...] [6] embarked on board the steamer "Limeña" for Panamá, thence via Colon for St. Nazaire. They took with them Juancito Garland, to be placed in Mr. Schuller's boarding school near Hamburg. I was extremely sorry to part with the little fellow, for whom I had taken a great affection; he could not be persuaded to bid good-by to his mama-Qui, and thus went away without seeing her. On Tuesday the $21^{\text {st I }}$ dined with him, Enrique, and Enriqueta, whilst Garland, Guillermo, and Antonio took this meal with Rosa. In the evening at about 8 the latter, who appeared to be very sad, came to say farewell to me. On the $22^{\text {nd }}$ the whole party went to Callao by the 8 O'clock train; Garland, Dr. Middendorf, and the book-keeper Möller accompanied them on board; there were many passengers besides them, amongst whom I will only mention Santiago Távara for Payta, and for Europe Mr. Porterie, hitherto head of Thomas Lachambre \& Co. of Lima, who had the politeness to take leave of me: his place was taken by a Mr. Mortier. Garland and Juan now took charge of the firm of Schutte \& Co., but had little to do. As to politics, the only thing certain was that there was much dissatisfaction with the present administration, whose members, it was well known, only cared for their own pockets. Domingo Gamio, and Diego Masias, the President's right and left hand were named respectively Administrador de la Aduana del Callao, and Director de la Moneda de Lima - two of the most lucrative situations in the Republic at the disposal of the Executive. César Rivero, a native of Arequipa, was named Governor of the Chincha Islands, which appointment gave great dissatisfaction, for not only was he a notorious gambler, but in every other respect he stood low in general estimation. In Arequipa, the Electors were almost unanimously for Pedro Diez de Canseco, President, and Domingo Gamio as first Vice-president.

On Friday died Fermin Miota, a tall robust man, son-in-law of Anselmo Centeno; a few days previously Mrs. Logan, a young English lady, recently married to Mr. Logan, Chief of Dickson Harker \& Co. Merkel, Callao agent died a fortnight or three weeks back; so did a German-Swiss, Niederer, and his young wife; in the house of Felipe Coz had died his father, and mother-in-law, 
two sisters-in-law, and [_] servants. General Cisneros and Hamilton had been ill, [...] Catharine Campion, a superior Irish girl [...] [7] servant, was lying ill; also in Chorrillos, three children of Doña Ponte, but the medical men said there was no fear of their lives.

Tuesday, $28^{\text {th }}$ of April 1868. The Comercio stated that from the $1^{\text {st }}$ to the 24 inst. 868 persons had died of the yellow fever in Callao; on the $27^{\text {th }}$ died in Lima 105, and on the same day Gerike, Richard Eggert, and Woodgate fell ill; the two former respectively chiefs of the firms of Graham Rowe \& Co. and F. S. Isaac \& Co.; the third, clerk in the latter house. Enrique Garland slept this day in bed violently perspiring, it was a slight attack. Our servant Juan went to town, there to be cured by his wife. Mrs. Miota had been ill, but was getting better; her daughter Virginia had also caught the fever.

Wednesday, $30^{\text {th }}$ of April. Last night died young Stromsdörfer, clerk of Ph. Ott \& Co. and brother of the partner in Paris.

Friday, $7^{\text {st }}$ of May. Mr. Barker, my lector and secretary, came to me in a coach to tell me he felt very poorly, that it was probably the fever, which had taken hold of him, and that therefore he could not do his customary work.

Saturday, $2^{\text {nd }}$ of May. Second anniversary of the victory of this date in 1866 , but no one thought of celebrating it; the yellow fever was uppermost in every one's mind. In Chorrillos the men-of-war fired a salute in the course of the day.

Sunday, $3^{\text {rd }}$ of May. We learned that Richard Eggert had died in Lima: he, the younger brother of Charles Eggert, late of Gibb's firm had been much respected and well liked by all his acquaintances. But few visitors called on my wife. I went to the family of Dr. Morales, where some had just recovered, whilst an aunt had fallen ill. At Dr. Ribeyro's a servant lay sick; at Henry's they were in the same predicament. Doña Ponte's eldest boy, who had been very ill, had fortunately escaped. This day Col. Balta and family came to Chorrillos, and took up their quarters in Sepulveda's rancho.

Monday, $4^{\text {th }}$. Felipe Barreda told me that one of his grandsons, Manuel Pardo's second son, was lying dangerously ill. At Enriqueta's in Lima, I was told of the death of Woodgate, clerk in Isaac's firm. Polis who signed per procuration in the same establishment, complet [...] up, had removed to Chorrillos to recruit his health [...] [8] Charles Möller, another clerk, had received licence to go to his family in Arequipa, and thus they had been obliged to shut up their store and office. In our house in Chorrillos none of us had as yet been infected. I myself took an early bath and went frequently, if not daily, to Lima. Antonio Garland was with us.

Thursday, $7^{\text {th }}$ of May. In Lima died an Italian Opera singer and two other Italians, Cipriani and Perfumo, Bianchi's partner. In Chorrillos Pardo's son, twelve years of age, Mr. Blakely, inventor of that description of cannon which 
bears his name, and his lady, who had preceded him to the grave by four days. Notwithstanding these many deaths, medical men opined that the fever had much abated in Callao and was on the decrease in Lima.

This morning the sea was uncommonly agitated, and hardly had I ventured down the lady's stairs when a tremendous wave took hold of me, knocked me off my legs, and tumbled me about like a ball: I had just recovered my footing when another wave threw me against the stairs. Fortunately I was not hurt, but got out of the water as quickly as I could.

English papers, which Juan read to me, gave the news that the English army in Abyssinia had reached a high plateau in the Interior, and that King Theodore was likely to offer resistance. General Napier had had an interview with a discontented Chief, who ruled the Northern province of Abyssinia, called Tigre.

Friday, $8^{\text {th }}$ of May. I learned from Garland that on the previous day the Minister of Finance, Helguera, had called together the different guano consignees from whom he had demanded a new loan of $\mathrm{S} / 5,000,000$ wherewith to make a part payment to Mr. Henry Meiggs, with whom a few days previously a contract had been signed for the construction of a railway from the Coast to Arequipa for the sum of $\mathrm{S} / 12,000,0000$. Mr. Meiggs was a North-American, who had gained a great reputation by his prompt and satisfactory completion of the Valparaiso and Santiago Railway. The rumour went, and probably not without foundation, that Meiggs had spent in bribes nearly a million of Soles in order to obtain this contract; how much [...] ident and the members of his family received was not [...] [9] known; to each of the five ministers he had probably paid S/100.00o and Diego Masias made no secret of the fact that for his services he had been remunerated with $\$ 100,000$ (dollars). Garland, who had been present at the meeting, for Schutte \& Co., was of opinion that the Consignees neither could, nor would give a single rial.

Saturday, $9^{\text {th }}$ of May 1868 . In town I enquired from Mr. Henry how his junior partner Mr. Alfred Böhl, who had fallen sick of the fever, was getting on; both he and Dr. Middendorf told me that his case was a serious one. This Alfred was the third son of the Böhls of Hamburg, who had shown my wife and myself so much attention when there in $1854 / 5$.

Sunday, $10^{\text {th }}$. Garland and Manuel Velarde were with us at dinner.

Monday, $11^{\text {th }}$. My birthday. Enriqueta, as I had expected, came to congratulate me. Juan, still fearful of the fever, went to Lima by the 1 train, thence to Callao, where he embarked on board the merchant steamer for Chile. One of Felipe Barreda's sons went with him.

Tuesday, $12^{\text {th }}$. My wife and I paid several visits in the evening. To General Freyre and wife - he had been named Prefect of Tacna - to General Guarda and wife, to Mr. and Mrs. Felipe Barreda, to Mr. and Mrs. José Canevaro with 
whom lived Elster and his lady, and finally to Mr. and Mrs. Mariano Felipe PazSoldan. Of course we were on foot, a proof that my wife was in good health. The fever was, if not the sole, at least the main topic of conversation. We heard of the death of a young German, whom Hülsenbeck - Mrs. Freyre's brother-inlaw - had left in charge of his business when he departed for Europe some time previously. Henry's son James had recovered, whilst his daughter Lily was lying ill, also Manuel Pardo's and Dr. Sandoval's little girls were on the sick list. Dr. Chavez, compadre of Enriqueta and secretary of the Archbishop Goyeneche, had likewise been ill, but was recovering. At Dr. Davila's in Chorrillos the mother, two daughters, and one son had had the fever.

From Wednesday, $13^{\text {th }}$ to Saturday, $16^{\text {th }}$ of May. Though the water began to feel cold, I continued my bathing early in the morning; I then took a light breakfast, and with the 9 train went to town, where in my office Mr. Barker, who had recovered, was with me [...] past four. I had to look after my law-suit against the [...] [10] which progressed slowly, and never failed to look in at Enriqueta's. I returned by the 5 train to Chorrillos, where we dined immediately after my arrival, often in company of Arthur Heeren. In the course of these days died amongst others Toribio Pacheco, a very clever man, one of Prado's ministers during his dictatorship; also Fransen, clerk of Grönewald in Bodegones. Alfred Böhl, Dr. Middendorf said, was likely to escape; on the other hand Mons. Lesseps had fallen ill. Enrique Garland, who had been much pulled down, was with us, to recruit his strength. Garland felt poorly, but his wife was certain that what he suffered from was merely tertian fever.

The results of the elections became gradually known. Hitherto, with the exception of Arequipa, where Pedro Diez Canseco, R. Vargas Machuca and Domingo Gamio had been chosen for President, first and second Vice-president respectively, Col. José Balta had everywhere an overwhelming majority, whilst for Vice-presidents were named Lopez Lavalle, Vargas Machuca, Herencio Zevallos, Miguel San Roman, Melchor Vidaurre etc., without any one of them being certain of the absolute majority.

Sunday, $17^{\text {th }}$ of May. We spent this day a little differently from our usual humdrum way of living. Dr. José Gregorio Paz-Soldan had invited us to pass the day with him in his estate of San Isidro, situated about half-way between Chorrillos and Miraflores, not far from the sea. My wife, Enrique Garland, and I took the Chorrillos train to Miraflores Station, where a small, covered one horse carriage belonging to the Doctor waited for us; and after a short pleasant drive, passing the estate of Santa Cruz, formerly the property of the Soyers, now belonging to Adrian Vielich, we alighted at a splendid flight of stairs leading up to the palacelike house, which the Doctor had recently rebuilt. There were only he, his wife Doña Jesus, his big, goodnatured son Jose Luis, and wife, a certain Lizarraga, 
very intimate in the family, and Dr. Juan Mariano Cosio, Vocal of the Supreme Court of Justice; this last named was always very stiff and reserved; however on this occasion he thawed up a little, and tried to make himself agreeable. Don Gregorio showed me all over his large airy house provided with a mi [...] not yet concluded, nor completely furnished, but when [...] [11] would in all probability be a splendid mansion. With Dr. Cosio I played at drafts, and contrary to my expectation he beat me more than I him; accompanied by him I walked round the extensive orchard, where all the orange trees were cut down, a blight having fallen upon them, a wide passage ran all round covered with trellis work, which sustained abundance of vines, the stems of some of them of uncommon thickness, perhaps a century old. From José Luis I gained two games of chess and together with Don Gregorio, Dr. Cosio, and Enrique walked to the very extensive olive grove, whereupon Don Gregorio showed us over many buildings belonging to the estate - amongst others the large store, where the oil presses were put up. More than 100 people lived on his estate, amongst whom a colony of Italians, who annually purchased from him the crop of olives on the tree, and made the oil on the spot.

Four O'clock p.m. had been fixed upon for a cock fight, which, being known in the neighbourhood, many men were attracted to this, to them interesting spectacle; they were negroes, sambos, cholos, all on horse back, in their ponchos, with wide brimmed hats, and big rowelled spurs. The ring they formed prevented our seeing anything of what was going on within, and meanwhile we amused ourselves with the lively scene presented by these men, who, much excited, gesticulated, vociferated, and shouted as is their custom on such occasions; at five we were called to dinner, which was good, the wines plentiful, for the Doctor prided himself upon his being a great connaiseur, and a still greater consumer of the juice of the vine. My wife sat to his right, I to his left, Dr. Cosio to Mrs. Paz-Soldan's right.

At half past six we drove back to the Miraflores station - it was a beautiful starlight night - and to Chorrillos we returned per train, both my wife and myself well pleased with the kind and frank manner, with which we had been treated.

Monday, $18^{\text {th }}$ of May. At 11.30 died in Chorrillos Monsieur Edmond de Lesseps, French Chargé d'Affaires and Consul General in Perú, cousin of the famous Ferdinand de Lesseps, the enterprizing planner of the Suez Canal. Mr. Edmond had passed several years of his life as French Consul in Egypt and Syria, where it appeared to me that he had a [...] not European habits. A short time before his illness [...] [12] one evening to our rancho a good deal in the wind, where all the time he was with us he spoke exclusively of the extraordinary mercantile capacity of Mr. Lazky, the Polish Jew, and partner of Thomson 
Bonar \& Co., a man certainly very clever, but not in the best repute as to his integrity. In the "Comercio" an article appeared, in which he was highly eulogized. The nine O'clock train on Tuesday morning, $19^{\text {th }}$ of May took his corpse to town, and he was quietly interred, few honors being shown him. A circular note from the Minister of Foreign Affairs to the members of the Diplomatic and Consular Corps said that the sanitary regulations at present in force regarding interments did not allow that the funeral honors due to his rank could be shown him.

Alfred Böhl, though extremely weak, was getting better. Our servant Angel complained of indisposition, whereupon my wife and self apprehensive of infection, sent him off to Lima, where he applied to the Chinese Doctor, now much in vogue, who assured him that he had not the fever, but a violent cold.

Various news came by last mail; it was probable that Mr. Johnson, President of the United States, would be found guilty by the Senate, where the Radicals or Republicans had a great majority. On the $12^{\text {th }}$ of March whilst Queen Victoria's second son, Prince Alfred, was at a pic-nic party near Sydney in New Holland; an Irish Fenian, named O'farrell, made an attempt to murder him. Coming from behind he placed the muzzle of his revolver close to the Prince's backbone and would of course have killed him, if the back-bone had been shot through, but strange to say the ball took a slightly different direction, passed between the $9^{\text {th }}$ rib and spine, and lodged under the breast-bone, whence it was cut out on the third day, and in a fortnight the Prince was so well that he could again appear in public. With difficulty had the police and marines been able to save the assassin from the rage of the populace; a few days after the deed was done he was tried before the proper tribunal and sentenced to death.

In Abyssinia the English Expedition - the cost of which was estimated at $£ 5,000,000$ - had attained the object, for which it was sent [...]. On the $13^{\text {th }}$ of April, Easter Sunday, the English troops comma [...] Sir Robert Napier took by assault - only fifteen men [...] [13] wounded - the fortified capital of King Theodore, called Magdala. When the soldiers penetrated into the interior of the palace, King Theodore was found lying dead on the ground; it was uncertain whether he had committed suicide or had been struck down by a hostile ball. Much treasure, amongst which four golden crowns and many arms, became the booty of the victors; the loss of the Abyssinians was differently stated, of course much greater than that of the English; the remainder of the army surrendered. Two sons of the King were made prisoners, and the English captives, men, women, and children, to the number of 60 , were set at liberty. All this being achieved nothing else was thought of, but to return home.

Rumours were afloat that Denmark was negotiating the sale of the island of St. Croix in the West Indies to France. In a retired spot near Munich a duel had 
been fought between Barons Budberg and Meyendorf, the latter ex-ambassador, the former present ambassador of Russia at the Tuilleries. They had long been on bad terms and found no other way to settle their differences but this; at the first shot Von Budberg fell, severely, not mortally wounded. Prince Humberto, second child of King Victor Emmanuel, had married his cousin Margaret.

From Saturday, $23^{\text {rd }}$ to Monday, $25^{\text {th }}$ of May 1868 . The weather was variable. Sometimes it was foggy and cool, sometimes the sun was out, and the temperature considerably warmer. These changes could not but be prejudicial to the health. The fever, though less, did not diminish so much as it was expected it would have done with the setting in of the cooler season. I myself felt a little indisposed, but quickly got over it after taking an infusion of hot water upon Linden blossom, which caused a profuse perspiration. Dr. Middendorf assured me that of the yellow fever I had nothing to fear, but that the fever and ague might perhaps again pay me a visit.

Sunday, $3^{\text {st }}$ of May. Whitsunday. By this time I had left off bathing, not exactly because the water had become too cold, but because more than once the sea had been unusually high and agitated, so that I could hardly keep my ground, and felt no pleasure in [...] continually on the defence against the beating of the [...]. [14] Instead of going to the water I climbed up to the top of the Morro, and in the course of the forenoon made several calls. On Monday, $1^{\text {st }}$ of June I did the same in Lima.

Tuesday, $2^{\text {nd }}$. I was the whole forenoon in the office of Dr. Palacios listening to his dictation of the Escrito de Agravios in my suit against the Sotomayors. It was concluded on Wednesday, $3^{\text {rd }}$ in the evening, so that I had to remain in Lima until the 9 train. This escrito was to be presented to the Superior Court.

The yellow fever was at last diminishing in Lima, Callao and Chorrillos. Now and then however a known person still fell ill; for instance within these days José Maria Perez of the Superior Court. On the other hand, the fever was fast spreading up the coast, to Islay, Mollendo and Tambo. The north Steamer brought the news that Lord Henry Brougham, the renowned lawyer - in his time one of the defenders of Queen Caroline - in later years Lord Chancellor, and who in the course of his long life had in every political question taken the liberal side, had died in his $80^{\text {th }}$ year in his country seat near Cannes on the Shores of the Mediterranean. In the United States the suit against Mr. Johnson, the President, had been put off for some time, whilst that against Jefferson Davis, ex-President of the Confederate States was to come on ere long.

The Panama Star \& Herald gave the following succinct account of the cause of the Abyssinian Expedition. The predecessor of King Theodore was King John, the last of the Mahomedan line who ruled over Abyssinia. In $185^{\circ}$ 
Li Kassa headed a rebellion against his sovereign, was favoured by fortune, and might already then have attained the goal of his ambition - the throne of Abyssinia - had not the prime-minister, Ras Ali, interfered, given him his daughter in marriage, and induced him to lay down the arms; but Li Kassa could not be quiet, he warred against Egypt, where he was less successful than he had been against King John. The life he led with his wife was not a happy one; he believed himself to be slighted by her. This he attributed to her father, King John friend, and he resolved to let all three feel the weight of his displeasure. He called to life the revolutionary elements, which had been lying dormant, quickly was he once more at the head of an army; [...] King John, and was crowned by the Bishop of Salar [...] [15] name of Theodore, the Christian King of Abyssinia. In 1848 Mr. Plowden, English Consul at Massowah, had concluded a commercial treaty with the Abyssinian Government in the time of King John; this treaty was set at nought by King Theodore, and Mr. Plowden was killed by a predatory band. He was succeeded as British Consul by Capt. Cameron, which gentleman was apparently treated by King Theodore with friendship and kindness, but underhand his official measures were thwarted everywhere; nevertheless, he was entrusted by the King with an autograph letter addressed to Queen Victoria, in which he requested her assistance in the execution of his project of forming an Ethiopian Empire. Her answer was a negative one, which, signed by Lord John Russell as Secretary for Foreign Affairs, Capt. Cameron delivered to King Theodore on his return to Abyssinia. Hereupon, not only he, but also the English missionaries and every European resident in Abyssinia, was thrown into prison; to obtain their liberty, the British Government began diplomatic negotiations, which were carried on for some time, but when convinced of their fruitlessness the Expedition against Abyssinia was resolved upon. The command was given to Sir Robert Napier, and it led to the triumphant result, of which I have already said a few words. Magdala the Capital, the papers said, had been razed to the ground.

Wednesday, $17^{\text {th }}$ of June. On the $27^{\text {th }}$ March and following days part of the Sandwich Islands had been the theatre of terrible convulsions of nature. Earthquakes rent the earth asunder; an island rose from the bottom of the sea and volcanoes - mainly that called Mauna Loa - belched forth fire, stones, and ashes, spreading the latter far and wide.

In Washington the Senate had decided the important question, whether President Johnson had or had not transgressed the Constitution of the Country. Two thirds of the votes were required to condemn him; thus the number of voters being 54, 19 sufficed to absolve him, and 19 voted in his favor.

Here in Lima and the environs the yellow fever, though decidedly on the wane, still carried off a victim now and then; young Pividal of Tacna, 23 years of 
age, in Gibbs's employ, died on Saturday last; in Chorrillos Dr. Manuel Morales, Fiscal of the Superior Court was $t$ [...] Sunday. In Islay the fever had committed dread [...] [16] corpses were said to have been left unburied in the houses, where they putrified and spread contagion around. There had been no medical man, no apothecary shop; all who could, fled to the neighbouring valleys and Islay had been almost deserted. This at least was the account which the papers gave; and all this misery was owing to the want of the most common foresight; a battalion of soldiers, sent from Callao to Islay, had been infected by the fever, and thus carried with them the germ of the epidemic.

Meanwhile, Mr. Henry Meiggs, the contractor for the Arequipa railway, was actually at work with hundreds of Chilian labourers both at the port of Mejia and on the Pampa near the Tambo de la Joya.

From Thursday, $18^{\text {th }}$ to Tuesday, $30^{\text {th }}$ of June. In the first days of this fortnight my wife was suffering from her chronic disease, the tumour, which however Dr. Middendorf, like every other medical man, who had examined her, pronounced not to be of a dangerous nature. Gradually she got better, and with her health her good spirits returned. We then went out in the evenings and spent amongst others that of the $24^{\text {th }}$ of June in the rancho of Doña Juana Guise, whose Saint's day it was, in company of many of her friends, who had come to congratulate her. Dr. Morales, who had recovered, was there with his family. Garland, Enriqueta, Guillermo, and Enrique came now and then to see us in Chorrillos. At breakfast and dinner Arthur Heeren was frequently with us; in the evening Mariano Blas de la Fuente was seldom wanting; female visitors also dropped in, but in the day time my wife was much by herself, and she was desirous to remove to Lima, which we hoped we might shortly do if the fever did but abate. Francia, the music master, the husband of Rosa Lopez Aldana, had fallen sick of the fever. Edward Knauer had also had a slight attack. As regards myself I went to town on working days, and was in the habit of starting from Chorrillos on foot at 8.30, so that I reached the Barranco or Surco station just in time for the Chorrillos train. This is the prettiest spot on the whole line; both behind the station where the ticket-seller lived in a small wooden house, and in front of it on the other side of the rails grow olive, orange, and banana trees. On Sundays and holidays, when I did not go to town, I frequently took violent [...] climbing from the very beach to the highest point of the $[\ldots][17]$ and sometimes back again the same precipitous road, no doubt the more dangerous feat of the two.

Saturday, $4^{\text {th }}$ of July. Mr. Baker being prevented by indisposition from attending, I climbed up San Cristoval, and though I had not done so for several weeks past, I reached the summit without being fatigued. Alfred Böhl now and then came to me in Chorrillos, and we played chess, which certainly did 
no good to my eyes; it was however one of the few amusements which still remained to me. Chorrillos was fast getting empty, and farewell visits were with us the order of the day, or rather of the evening. By last steamer Rosa wrote to my wife and to Enriqueta, also Juancito to his mother; they had had a rough passage; even at the very last moment when entering St. Nazaire, the pilot run the "Florida", a screw-steamer, upon a sandbank from which they got off without any damage, but not without a good fright. In Paris they had taken up their quarters in the Bristol Hotel, Place Vendôme. Amalia, Rosa said, was extremely thin and extenuated; of Lavalle no mention was made; Corina and Cordes had arrived from Hamburg. The latter in Dr. Lacosta's opinion in a very precarious state of health, which had brought about a reconciliation between the high contracting parties: father and son-in-law.

From England the political news was that in consequence of the departure of Queen Victoria with the junior members of the Royal family for Balmoral her country seat in the North of Scotland - a Mr. Reardon, member for Athlone in Ireland, had made a motion that the queen should be advised either to abdicate in favor of the prince of Wales, or to name a regency during her absence, of which the said prince should be the head. This motion was hooted, not even admitted to discussion; however, in the Times there appeared an article, in which the Cabinet was blamed for having allowed the Queen to take this journey at a time when a ministerial crisis was daily expected.

In the United States General Stanton had resigned, and President Johnson named General Schoefield his successor in the War Office. From Abyssinia the English army under Sir Robert Napier was fast retiring, he taking with him the widowed queen, and the young prince nine or ten years old, who was to be placed for education under the [...] clergyman in Bombay. In Abyssinia several parties $[\ldots][18]$ for the ascendancy, and the whole country was in a state of lamentable confusion.

Friday, $10^{\text {th }}$ of July 1868 . We were astir at an early hour, and having packed up nearly everything the previous day, my wife and I, together with Juan the servant, and Peta the black woman were ready for the 9 O'clock train, and we left Chorrillos after a residence of more than 8 months. Our Chinese cook Achipe, who had again joined us, had been sent off the previous evening, so that on our arrival we found breakfast ready. Enriqueta was with us the whole day; Garland and some of the children joined us at dinner. Barker came to me for the first time at seven in the evening, and I arranged with him that henceforth he should do so every day Sundays excepted.

Sunday, 12 of July. Before breakfast I was up to the top of San Cristoval. In the forenoon I made my calls, whilst my wife had several visitors with her. Adolfo, son of the Vocal Alvarez, and Enrique Garland dined with us. 
Monday, $13^{\text {th }}$ of July. Wegnern was with me at 8 O'clock a.m. With him I had come to the understanding that he should come four times in the week, and read to me in German. This day he began Goethe's novel Wilhelm Meister, with which, notwithstanding its great reputation, I was not yet acquainted. The three other mornings of the week I intended to devote to a regular ascent of San Cristoval.

By the St. Nazaire Steamer Garland received a letter from his brother-inlaw, who wrote that Cordes was very poorly; no doubt grief had prevented Conradina from writing. This being Antonio's birthday we dined at Garland's, and again on

Saturday, $18^{\text {th }}$, together with Arthur Heeren, who was shortly to leave for Europe, where in all probability he would marry one of the two sisters of his intimate friend Carlos Candamo. The three were the natural children of Don Pedro Gonzales de Candamo who had recognized them as his before he died, and left to them his enormous wealth supposed at the time to have amounted to 15 million dollars - say 7 millions to Carlos and 4 millions to each of his two sisters.

Monday, $20^{\text {th }}$ of July. During all last week the Chamber of Deputies and the Senate held their preparatory sittings for quali $[\ldots]$ newly elected Deputies and Senators, that is to say [...] [19] in each of these two chambers decided whether the Senator or Deputy, the merits of whose case was under discussion, had been legally elected or not. I have already previously said that justice was a secondary consideration; only he was qualified of whom the majority knew that he belonged to their party. On the $18^{\text {th }}$ Rafael Velarde had the satisfaction of being qualified as Deputy for the Province of Condesuyos in the Department of Arequipa, his dual having been a certain Cornejo, Vocal of the Superior Court of Justice of Arequipa.

The yellow fever had by this time nearly disappeared; nevertheless, a new comer either from the Interior or from abroad had occasionally still to suffer from it.

From Europe we learned that the Queen of Abyssinia had died in the English Camp; from our family in Paris that Cordes continued ill.

Tuesday, $27^{\text {st }}$ and Thursday, $23^{\text {rd }}$ of July 1868 . In the forenoon of these two days the funeral of the late Don Ramon Castilla was celebrated with unusual pomp. I, in my official capacity, was invited and attended both times. The first day the President and his ministers, a great number of military men, Generals, and Colonels, the members of the Supreme and Superior Courts of Justice, the Diplomatic and Consular Corps, and perhaps some others whom I do not recollect, assembled in the narrow saloon of the palace. Thence we marched 
in procession two by two, the streets lined by soldiers, behind which a compact mass of spectators of all classes, as far as the Callao Railway Station. On our going, those lowest in rank preceded, thus the Superior Court walked before the Consular and Diplomatic bodies, behind them the Supreme Court, whilst on our return from the station to the "Sagrario" - the small church between the Cathedral and the Archiepiscopal palace - the order of march was reversed.

First came the coffin, carried on shoulders with a black, handsomely embroidered pall, the ribbons hanging down from the same being held on the one side by Generals Echenique, Alvisuri, and Dr. Carpio; on the other by Mosquera of New Granada, Dr. Benavente, Chargé of Bolivia, and Dr. Ribeyro of the Supreme Court; next, the hearse drawn by [...] and splendidly decked out, then the Government ca [...] [20] likewise drawn by four horses, covered with black, the President and Ministers, a few generals, the Supreme Court, the Diplomatic and Consular bodies, the Superior Court, and I do not know how many others, the rear being brought up by infantry, cavalry, and artillery. The procession took up more than three "cuadras" in length. Bands of music were playing continually, and besides the many people who crowded the streets, the balconies were filled with lookers-on. When we had reached the "Sagrario" all dispersed, and I was home near four o'clock. The Diplomatic corps was but poorly represented; if I remember correctly only Benavente from Bolivia and Garon from Italy were present; neither was the Consular Corps complete. The Sagrario was fitted up as a "Chapelle Ardente"; the interior was hung with black. The coffin stood somewhat elevated; and lamps and candles were burning day and night. On the $23^{\text {rd }}$ at 10.30 we again assembled in the palace, and at 11.30 a procession similar to that described on the $21^{\text {st }}$ crossed the Plaza de Armas to the Cathedral. On our way thither, pretty good order was preserved, but when in the Church we were lost in the multitude, and had to squeeze ourselves through as well as we could. The space between the organ and the high altar was filled with rows of chairs, and there we took our seats. A splendid catafalco was erected, lit up by numerous lamps and tapers. To the right of us sat the musical performers; Mr. Tate of the house of Graham Rowe \& Co., played the organ. Both music and singing were very fine, but to my taste the whole affair lasted much too long, the more so as I understood hardly anything of the sermon preached in praise of the deceased. The Church was crowded to excess, and twice apprehensions were entertained of a conflagration; first, one of the spirit lamps flared up, next, some of the hangings caught fire; however, both times the flames were quickly extinguished, and we in the centre hardly noted what had occurred. Near 4 O'clock the solemnity was over, when I hastened to Enriqueta's apartments where from the balconies we saw the 
funeral procession pass by on its way to the pantheon; behind the hearse drove the government's coach, followed by about 50 carriages. The coffin was to be deposited in a handsome mausoleum erected at the ex[_] of the nation.

Saturday, $25^{\text {th }}$ of July. The Beneficencia gave a [...] [21] honor of Manuel Pardo, who, as one of the Directors of this establishment, had during the late epidemic distinguished himself by the extraordinary care and attention which he had bestowed upon those who were lying ill in the various hospitals. I had been invited, but did not go.

Sunday, $26^{\text {th }}$ of July 1868 . We had at dinner Garland, Enriqueta, their two eldest sons, Alfred Böhl, and Adolfo Alvarez. Rafael and Manuel Velarde came in to take tea, and this little party went off very well as it was always the case at our house. This day in the Congress the presidents were elected: General Echenique, president; Dr. Antonio Arenas, Vice in the Senate; in the Chamber of Deputies: Dr. Oviedo, president; Ybarra from Jauja, Vice. Rafael Velarde lost the latter Vice-presidency by one vote: he had 34, Ybarra 35.

Monday, $27^{\text {th }}$ of July. Mr. Wilthew, British Consul in Callao, who had been present on the $25^{\text {th }}$ at the banquet given to Manuel Pardo, told me that everything had been nicely arranged, and that all the guests, about seventy in number, seemed to have been well pleased. They had assembled in the house of the late Pedro Gonzales de Candamo, now occupied by Francisco de Paula Boza, left by the deceased in charge of his business, and one of the Directors of the Beneficencia; thence they had walked to Maury's hotel where an excellent dinner had been served. Bishop Tordoya, another Director, had taken the head of the table. Of the many discourses delivered, and toasts given, that of Dr. Melchor Vidaurre had been most to the liking of my informant. A small golden tablet with an appropriate inscription was handed by the Committee of the Beneficencia to Pardo, who was even accompanied home by some of the guests. The remainder played rocambor till a late hour. I was rather surprised to learn that none of the Diplomatic body had been invited, whilst the Consuls had.

Tuesday, $28^{\text {th }}$. Congress was opened, and as it was always the case I received an invitation from the Minister of Foreign Affairs to be present at this solemnity. At 12.45 I went to Don Bernardo Roca y Garzon's - Consul for his Holiness and with him I [...] the Congress Hall; we, and some of our colleagues, after waiti $[\ldots]$ in the ante-chamber, walked through the $[\ldots][22]$ by the master of ceremonies, and ascended the stairs to the gallery destined for the Diplomatic and Consular Corps, to the right of the President's chair. A small number of the members of the two bodies were present. Below in the hall the Deputies were assembled, presided by Dr. Oviedo, who after some routine business read a short speech, and named a commission to invite the Senate to join them. 
When the Senators had entered, General Echenique took the chair; he named two commissions, one to fetch President Canseco, the other to receive him in the hall. After a quarter of an hour Canseco and his Ministers made their appearance; the latter sat down amongst the members of Congress, whilst Canseco and Echenique took their seats under the canopy at the extremity of the hall, the latter to the right, the former to the left. Canseco then drew out his printed message, rose, and read it, but so low, and with such a miserable voice as to give general discontent; nobody understood a word of what he said, and one of the crowd cried out in a loud voice "mas fuerte". When Canseco had finished, Echenique rose and spoke a few words, loud and distinct, which gained him much applause. This closed the ceremony. The Diplomatic and Consular bodies now drove off in their carriages to the palace where they had to wait for a short time in the office of the Minister for Foreign Affairs until Canseco arrived, who had come on foot from the Congress, accompanied by a numerous cortège. We were admitted, congratulated him, shook hands, sat down, and walked off. I then hastened home, changed my dress, and went to Enriqueta's, where many had assembled to see the carriages and high personages pass and repass between the Congress Hall and the palace. We remained to dinner; with us Rafael Velarde, his wife, and daughter Zoyla, Manuel Velarde, and Antonio Martinez. My wife and I retired at about 10 O'clock.

In the theatre, which, I was told, had been crowded, and where Canseco and his Ministers had occupied the Government box, a young man called Delgado appeared on the stage between the acts and began discoursing on the vicious administration of Canseco's government now drawing to a close, but though what he said was the $t[\ldots]$ nd nothing but the truth, he, as he might have foreseen, [...] to proceed, and hardly had he pronounced a few [...] [23] when the police arrested him, carried him off, and lodged him in the barrack of Santo Tomás. This day, as well as

Wednesday, $29^{\text {th }}$ of July horse races were held on the Bella Vista race-ground, at which on the first day Peter Gallagher, and on the second Pomar, brotherin-law of Tenaud, Manuela Flores' son by her second husband, were severely injured; when careering at full tilt, they came down with their horses, which were frightened by dogs running between their legs.

Saturday, $7^{\text {st }}$ of August. From Paris Mr. and Mrs. Schutte wrote that they entertained serious apprehensions for Cordes' life; not only did he suffer acute pains, but - and here the danger lay - the arteries leading both to his heart and to his throat were excessively swollen. Mr. Schutte continued to be subject to fainting fits, the same as he had been in Lima.

The Congress took a step which nobody had expected; they proceeded to examine all the documents of the electoral colleges which had voted for 
the presidency of José Balta; they found them in order and resolved that on the following day, he should take his oath as President of the Republic; this measure, though it took everybody by surprise, was generally approved of.

Sunday, $2^{\text {nd }}$. At my barber's I heard that Dr. Don Felipe Barriga y Alvarez had died in Piura whither he had gone to recover his health; he he was Vocal of the Superior Court, much esteemed for his uprightness and left a pretty young wife with three children in very reduced circumstances. After breakfast I waited and waited for Mr. George Barker, who did not come till half past one when I went out to pay some visits. I was a long time with Dr. José Luiz Gomez Sanchez, who, strange to say, did not allude to the money which I had lent him during the time of the dictatorship, and which by this time was long overdue. Doña Josefa, the widow of Dr. Prada, and mother-in-law of Dr. Domingo Mendoza y Boza, was very agreeable; so was Don Domingo himself when he came in. Only a few days previously he had been named by Canseco's government provisional Vocal of the Superior Court, and he knew that I had interested myself for him, he gave me his [...] done so. Another visit I paid was to Mrs. [...] [24] pleasant and clever North American lady, just returned from Chile after a long absence. Mariquita and I dined at Garland's. In the evening when we sent to enquire for the health of Juan Aliaga, who had been ill for a few days, the answer we received was that he had died at 6 p.m., surrounded by his wife, two daughters, their husbands La Croix and Da Ponte, his third unmarried daughter Manuela, and his eldest son Juan, with which latter, as well as with his wife he had frequently been on very bad terms, but now in his last moments all differences had been made up; his youngest son Carlos, ensign in a regiment of cavalry, came in after his father had expired. Don Juan was a direct descendant of Don Diego Aliaga, "Guerrero en ambos Mundos" who had come to Perú with Pizarro. He belonged to the highest aristocracy of Lima, and at the death of his father, el Conde de Lurigancho, was left in possession of a very large entailed property. Between 1820 and 1830 he married Manuela de la Puente, daughter of the Marques de Villafuerte; but unfortunately this man, so brilliantly situated in life, without being dissipated, nor a gambler, nor a drunkard, did not know how to take care of his fortune. Already in 1836 his creditors were called together, when he still possessed one million of dollars in landed property and houses, which was then divided between himself and his immediate successor, his son Juan. He continued squandering what remained; in 1864 I bought from him and his family the house in the Calle de Zarate, which was the cause of so many lawsuits to me; often had he, miserably dressed, come to me and begged me to advance him $\$ 25$ on account of a small annual payment, which I had to make him, as stipulated in one of the clauses in the purchase of the house. As regards the character of 
his son and successor Juan Aliaga y Puente, no decided opinion could as yet be formed, nevertheless, what was known of him made his acquaintances fear that his head was not better organized than that of his father had been.

Monday, $3^{\text {rd }}$ of August 1868. Again I waited for Mr. Barker, but in vain. In the forenoon I spent several hours in the corredors of the tribunals, and with infinite trouble succeeded in making Dr. Arau[_] lawyer of the Sotomayors, deliver up the autos which he had $[\ldots]$ possession much longer than permitted by law [...] [25] At 10 p.m. I went to the house of Don Juan Aliaga where a great many of his and his family's friends were assembled to accompany the body to the Church of Santo Domingo. The coffin was carried - as it is the custom - on the shoulders of some men, and was followed by a long cortège of gentlemen walking two by two; my companion was Franco Sagastabeytia.

Tuesday, $4^{\text {th }}$ of August 1868. Mr. Barker sent word that he was ill of the fever and ague. In the forenoon I took a walk over the lower range of San Cristoval, which took me an hour and a half. Time hung heavily on my hands, and feeling out of sorts I went to bed before 8 O'clock. Colonel José Balta, President since Sunday last, formed his cabinet. It consisted of: Pedro Galvez, brother of José Galvez, Minister of War of the dictator, who was blown up on the $2^{\text {nd }}$ of May 1866, Minister of the Interior and President of the Council, Dr. Barrenechea, Minister for Foreign Affairs, who had acted in the same capacity during the Constitutional term of Prado's rule; Dr. Francisco Garcia Calderon, Minister of Finance, he was an Arequipa lawyer, advocate for the Banco Hipotecario and had been oficial Mayor in the Finance Ministry during Prado's time; Lawyer Luciano Benjamin Cisneros, a clever man, but whose moral character did not stand high in general estimation, Minister of Justice; and Juan Francisco Balta, the President's elder brother, Minister of War. Upon the whole, I entertained a good opinion of this cabinet, at least a better one than of Canseco's.

Wednesday, $5^{\text {th }}$ of August 1868. After breakfast I went to the Church of Santo Domingo to be present at the funeral of Juan Aliaga, which was celebrated with great pomp, the more so as his predecessors in times long gone by had conferred great benefits on this convent. The customary prayers and mass being over, the coffin was carried through the four porticoes of the cloister, a privelege enjoyed by the members of the Aliaga family; behind the same walked the friars and many gentlemen, lighted tapers in their hands; next the coffin was deposited in a spacious Chapel - el General - another honor done to the Aliagas. Here again prayers were recited, in the midst of which young Juan rushed out much affected, with streaming eyes; and finally the coffin was carried through the Church to the he[_] which was waiting in the street, the same, and quite as splen [...] as at Castilla's funeral; twenty four ca [...] [26] it to the pantheon. 
On this day I expressed myself in my original in the following terms on Goethe's Wilhelm Meister, read to me at the time by Wegnern. "I admire the easy style of the writer, and above all, the great power which he has over the German language; nevertheless I am disappointed, and it is clear to me that the taste of the public has undergone a considerable change since the close of the last, and the beginning of the present century, when the book was written. It abounds in clever, and perhaps even deep philosophical remarks, but on the other hand love scenes, not veiled over as the present sense of decency requires, frequently turn up, and are dwelt upon with particular gusto - actors, plays, the stage etc. are treated on with such minuteness as if they were the main business of life; the lines of demarcation between the nobility and commoners is drawn with a to me ridiculous sharpness. In one word, the generation for which Wilhelm Meister is written has long gone by, whilst Schiller's master pieces will live for ever."

Thursday, $6^{\text {th }}$ of August. Mr. Barker, though not yet quite recovered, came to my office and resumed his customary occupations.

Friday, $7^{\text {th }}$. Dr. José Luis Gomez-Sanchez sent me the $\$ 3300$ which he owed me, and upon which I charged no interest.

Saturday, $8^{\text {th }}$. The funeral of Genl. Pardo de Zela, a native of Spain, and one of the oldest generals in the Peruvian service, was celebrated in the Church of Santo Domingo. Garland received a letter from Mr. Schutte in Paris, who wrote that Cordes was a little better, but that he had no hopes of his recovery.

Wednesday, $12^{\text {th }}$. My son Juan returned from Chile.

In the forenoon my case against the Sotomayors came on in the Superior Court, and the time was taken up with the reading of "la relacion", or succinct account of the case drawn out by the relator appointed for that purpose. For the last two or three days I had taken every step in my power to ensure a favourable issue. In person I had waited upon several of the Vocales, and been received in a more or less polite manner; others, with whom I was less ac $[\ldots]$ and I had endeavoured to influence through mu [...] [27] In the evening, Jose Maria Sancho Davila, one of the richest men of Lima, past the prime of life, married Fortunata Nieto, a good-looking young lady, daughter of General Domingo Nieto, a character well known in Peruvian politics, not distinguished by a shining capacity or brilliant deeds.

Thursday, $13^{\text {th }}$ of August 1868. In the Superior Court my suit against the Sotomayors did not continue to be heard, for all the members of this tribunal were cited to the palace to be present at the audience given by President Balta to Antonio, son of the well known general Juan José Flores, come hither in the capacity of Envoy Extraordinary for the Republic of Ecuador. 
At ten minutes to 5 p.m. an earthquake was felt, which, I was sure, lasted longer than any other I had hitherto experienced. I thought its duration might have been from two and a half to three minutes, others gave it as many as four. The doors of our drawing room shook so violently that we at first believed somebody was trying to open them from the inside. Mariquita was so frightened that she ran down stairs, and did not stop until she reached the corner of the street; I of course followed her. Exactly an hour later we had another shock, but less violent and shorter.

Friday, $14^{\text {th }}$. During the night a third shock was felt; in Callao the sea rose to such a degree as to sweep over the mole, and inundate the lower part of the town.

The whole forenoon was taken up in the Superior Court by the pleading of Dr. José Aranivar, the lawyer of the Sotomayors. I was not present, having been invited by the Diplomatic Corps to attend a meeting of theirs in the office of the Bolivian Minister. Sousa Ferreira was the senior of the Consuls, but as he abstained from all interference I had to go in lieu of him. It was resolved that on the following day both Corps should present themselves to the new President. Also the speech, drawn out and to be delivered by Benavente, was read and approved of. On my return home the Circular notes of invitation to all the members of the Consular body had to be written in my office, and as my servant was not acquainted with their domicile, I had to go with him and point $[\ldots]$ tive houses. [28]

In the course of this day a melancholy accident occurred; Dr. Corpancho, a well known physician, was called by a certain Iglesias, in former times Prefect of Cajamarca, to attend to a little girl of his who lay sick. The child had a revolver in her hand, which the Doctor, believing it to be unloaded, took from her, and whilst he held it, it went off, the ball striking the father, Iglesias, who was severely wounded.

Saturday, $15^{\text {th }}$ of August. "New brooms sweep clean". This old adage was once more verified; Government and Congress rivalled each other in giving, the one decrees, the other laws, with the avowed purpose of bettering the situation of the country, of which certainly it stood in great need. Recruiting was prohibited under severe penalties, and such soldiers as were desirous of leaving the service were permitted to do so. The establishment which went by the name of the "Inspection of the National Guard" was abolished and this was a saving to the government of $\$ 270,000$ annually. All grades given to military men, contrary to the Constitution were swept away by one law, in consequence of which a great many Generals and Colonels were struck off the military list. Another law deprived the Vice-Presidents of the salary they had 
hitherto enjoyed, unless they were called to take charge of the government. A contract made by the ex-minister of war, Alvisuri, for the purchase of a number of rifles had been submitted by the present minister of finance to the fiscal, to have his opinion on the subject. Hereupon Alvisuri published in the papers a most insolent letter directed to Garcia Calderon, taxing him with ignorance and levity in his proceedings; and now Alvisuri was accused of want of respect to the established authorities, and would be judged accordingly. As far as here, I thought all was well done, but I rather doubted whether the Congress had acted prudently in electing for first Vice-president Herencio Zeballos, and not General Lopez Lavalle. The former was known to be a turbulent ambitious man, whilst the other, whom I had often seen at my lawyer's, seemed to be of a quiet disposition.

On the night from $13^{\text {th }}$ to $14^{\text {th }}$ Callao suffered great damage by water; on the night from $14^{\text {th }}$ to $15^{\text {th }}$ it suffered from a fire wh [...] out at about $10 \mathrm{p} . \mathrm{m}$. in the "Hotel de la Confianza" whence $[. .$.$] row of houses towards the Alameda,$ amongst [...] [29] of Telmo Larrañaga, and that of a druggist. It stretched over the way, destroyed part of the portal called de Dañino, and it was as late as 5 in the morning before it could be got under. To its extinction the Italian and French fire-brigades, which had hastened to the port as soon as the advice reached Lima, contributed considerably; the President and his Ministers had also been on the spot at an early hour. The loss sustained was calculated to amount to $\$ 1,000,000$ of which, as far as I knew, 19,000 were insured with the South Amer. Insurance Company in Lima, and \$150,000 with the Royal Insurance Company, represented by John Mathison.

As agreed on the previous day, the members of the Diplomatic [and] Consular bodies assembled in the office of the Minister for Foreign Affairs. All were present except Edward Müller, Consul for Belgium, and Alexander Westphal, Consul for Austria and Hamburg. Dr. Barrenechea ushered us into the receiving room, and presented us one by one on our entering to the President Col. José Balta. He was a man of about 54, rather dark, not of the sambo, but of the cholo complexion, his countenance heavy, not intellectual. He stood erect under the canopy, his Ministers on both sides of him, we in a half circle in front. Dr. Benavente on our left extremity pronounced his speech, to which Balta replied, reading from a paper, which he held in his hand. Hereupon we went to an adjoining room, conversed a few words and retired. The ceremony lasted till about 3 O'clock. In the evening Mr. Barker did not come, neither on Sunday, $16^{\text {th }}$, Monday, $17^{\text {th }}$, nor Tuesday, $18^{\text {th }}$ of August and I began to be dissatisfied with his repeated absence, for I suspected that its cause was not indisposition, as he pretended, but intoxication. 
On Sunday news was received per Steamer from Pisco and Ica; in the latter place, as well as in the estates in the neighbourhood, the earthquake of the $13^{\text {th }}$ had done considerable damage. In the town a fire had broken out in consequence, and several houses had been burned [...]. Pisco had suffered from an inroad of the sea, which [...] from the $13^{\text {th }}$ to the $14^{\text {th }}$ at about the same hour as [...] [30] say from 9 p.m. onwards, had done much injury. It carried away part of the mole, and damaged to a great extent the storehouses built near the beach: many launches were also destroyed. My nephew John Limpricht, who when last in Pisco had bought 400 botijas of Aguardiente, deposited in one of the stores, went thither per steamer on Monday to look after them and had the satisfaction, as it might be called, to find that only the half had been smashed. As there was a probability that the article would now rise in price, he flattered himself that he would still make [_] profit, though but a small one. It was reported in Pisco that five [_] in the vicinity of Ica, amongst which Palpa and Nasca, had had [_] same fate as that town. On Sunday morning I with my servant Juan went per train to Chorrillos to have a look at my rancho, which had not suffered in the least, though, as a lady who lived close by assured me, it had shaken most violently. On the beach, several canoes of the Indians had been knocked to pieces by the sea. A few hundred yards more to the North, at a spot called "Agua Dulce", the ranchos used by the bathers had been swept away, and in the Barranco the property of Domaier had suffered a little. Nicolas Rodrigo, whom I met on the malecon, invited me to breakfast with him, which I did; the meal was very clean and good, exactly the same as in my own house. On Monday forenoon Dr. Aranivar finished his pleading, and after him my lawyer Dr. Palacios spoke, only for one hour but entirely to my satisfaction.

About this time Juan Aliaga y Puente, whose father had hardly been dead about a fortnight, celebrated his marriage with a woman who did not enjoy the best reputation, Rafaela Cavallero; several years had he been living with her, and three children was the result of their connection.

Wednesday, $19^{\text {th }}$ of August. Little Maria Garland completed this day her second year, and thus my wife and I, together with Dr. Middendorf dined with Enriqueta and her husband. When returning home at 10.30 we noted that officers were running to and fro, and at the post-office many people were waiting and talking eagerly; I enquired, [_]ned that by the steamer sad news had been received from [...] [31]

Thursday, $20^{\text {th }}$ of August 1868 . The papers gave some particulars of the news received. Speaking of Arequipa, they began with the words "ya no existe"; further on they said that not one church had remained standing and that not one house had remained habitable; fortunately however after the first shock 
had been felt, all who could move, left their houses and ran to the open places, so that the number of victims had not been so great as might have been expected; nevertheless, all such as lay sick in hospitals, or were imprisoned, had been killed by the walls falling upon them. One must not forget that the roofs of the greater part of the houses in Arequipa are vaulted, and that consequently when the key-stone gives way, all falls in. The neighbouring valleys, as well as Mollendo, Mejia and Tambo, had likewise suffered much; in many places the earth opened and water gushed forth. Islay had, comparatively speaking, suffered little; being situated on the high rocky coast, it was not reached by the roaring element. However; the houses built of brick or adobes had come to the ground, whilst those made of timber had remained standing; of the Custom-house nothing was said, whence I concluded that it had escaped. Some said that Moquegua had likewise been destroyed, but the papers made no mention of this town. The valley of Lucumba had suffered like the rest, Tacna on the other hand but little, whilst Arica was, one might say, totally destroyed. The houses were thrown down by the shock and then washed away by the sea: there were at the time in the Bay the Peruvian man-of-war "America", the North American man-of-war "Wateree", the pontoon "Fridonia" of the same nation, and three merchant vessels. The Comercio said that they were totally lost, and part of their respective crews drowned. The "America", moored further out than any other of her companions, was carried for some distance up the land by the waves, and on their retiring left there high and dry. Part of the Arica railway was destroyed; some telegraph poles shared the same fate. The village of Zama had disappeared; there the sea swept over the land as far as two miles - from the beach of the new port of Mejia, where the Arequipa railway was to terminate. A great many articles brought thither by Mr. Meiggs for the construction of the railway were washed away. Iquique and Mejillones $[\ldots]$ fared much better; in the former place they were now without drink [...] the establishment in which salt-water was converted [...] [32] was gone. In the Chincha Islands a considerable part of the mole was carried away, and many of the vessels anchored there for the purpose of taking in guano had been much injured; the sea retired, then returned with great violence, and knocked them against each other; all the launches used to load guano went to pieces.

The previous night a horrible crime was committed here in Lima. Carmen, the pretty young daughter and only child of the highly respected judge Melchor Vidaurre, about 15 or 16 years of age, was returning home from a visit at about 10 p.m. Close to her house she was attacked by an individual who stabled her twice in the breast with a knife; fortunately the violence of the blows was broken by the whalebone or steel of her corset; the medical men, who were immediately on the spot, declared that her wounds were very severe, but 
perhaps might not be fatal; the perpetrator was a native of Ecuador and had been porter in the Doctor's house. What had induced him to commit the deed was not known, at least not to the public; he was arrested and would probably be condemned to fifteen years imprisonment in the penitentiary.

Sunday, $23^{\text {rd }}$ of August. Last night at 10 O'clock we were again seriously alarmed; the bells of the churches made known by their tolling that a fire had broken out somewhere. I went out, and together with José Vicente del Campo, who lived opposite our house, made my way through the crowd as far as the beginning of the cuadra de Boza, in which direction, somewhat behind José Vicente Oyague's, a house was burning. Engines came, the fire soon decreased, and we returned home, convinced that there was no danger. At 1 O'clock again the ringing of the fire-bell made me rise, but as it soon ceased I did not go into the street.

More particulars, relative to the Earthquake, were published. Pisagua had not fared better than Mejillones. In Iquique the two principal Nitrate establishments, those of Gildemeister \& Co. and W. Gibbs \& Co. were totally swept away by the sea. The loss of the latter was roughly calculated at half a million dollars; the former had in their stores 50,000 quintals of Nitrate, which found a watery gr[_] an old German gentleman, long in their employ, was drowned, [...] ere Mr. Wm. Billinghurst, well known in those parts, and [...]. In Arica, the "Wateree", built [...] [33] little draught, was not much damaged. Charles L. Worm, Danish Vice-Cónsul had both his legs broken. The valley of Tambo and Ilo, the Port of Moquegua, were totally desolated; the earthquake, the overflowing of the river, the rushing in of the sea jointly had spared nothing. Moquegua was destroyed like Arequipa, but of its fate not many details were known as yet. In Arequipa the Chapel and Convent of Santa Catalina, the Prefectura, the Cabildo, and the Portal of San Agustin were still standing on the $16^{\text {th }}$, the latest date received thence; until that day about 70 or 80 shocks had been counted since that of the $13^{\text {th }}$. As far as I understood, the number of houses levelled to the ground was not very great; of by far the greater proportion the roofs had fallen in, leaving the walls standing, but so unsound and so much injured that probably it would be necessary to raze them to the ground before beginning with their reconstruction. Finally, such as appeared entire were rent in many places, and nobody ventured to remain within their precincts. Thousands of the inhabitants had emigrated into the open country or taken up their abode in the open places under tents; a large proportion without the necessary clothing to shelter themselves against the cold night air. Provisions were extremely scarce, toasted maiz and water, it was said, were the sustenance of many; even the river had turned turbid. Chocavento, the large estate of Pedro Dinegri near Acarí, extending to the coast, bought 
many years back for a mere song from the heirs of Manuel Velarde's fatherin-law, had likewise suffered. The new port of Chala and many neighbouring villages had fared like the rest.

As soon as these melancholy details became known, the Government took measures to assist the sufferers by sending to the South provisions and money on board the Peruvian man-of-war "Union", and of foreign men-of war which had volunteered their services. The bad condition of the "Union" obliged her to return to Callao before reaching her destination; all she had on board was transhipped to the "Independencia", which started without loss of time.

Friday, $28^{\text {th }}$ of August 1868. From Maria Arauzo I received [...] ated Arequipa the $22^{\text {nd }}$; she and her relations [...] [34] and Celima were living under a tent in the Plazuela de Santo Domingo, where the latter had been confined of a strong, healthy child. The house which they had hitherto occupied was so injured that Doña Maria requested me to cease paying the rent as I had done hitherto. At the time of the shock, she had not moved from her habitation, whilst Cayetana and Celima, who had been in the street, had been wounded by stones falling upon them. Doña Maria added that at the time of her writing the earth had not yet recovered its normal state of tranquillity. Also with us in Lima slight shocks continued to be felt. Dr. Tomás Davila, upon whom I called, told me that the loss on his estate near Moquegua had been great, owing mainly to the destruction of the large earthen vessels in which the juice of the grape was kept and allowed to ferment; also the still for making rum had been broken. The Guano Consignees placed at the disposal of the Government $\$ 500$,ooo without remuneration or interest. Andrés Alvarez Calderon, the rich contractor for loading guano vessels, Meiggs, the North American Contractor for the Arequipa railway, and José Canevaro Jr. contributed $\$ 50,000, \$ 50$,ooo, and $\$ 12,000$ respectively for the purpose of alleviating the miseries of the sufferers in the South. The German Relief Association, or Beneficencia, put a subscription on foot for the same purpose.

In Talcahuana in Chile, situated in $37^{\circ}$ South latitude, the sea rose on the same $13^{\text {th }}$ of August, rushed in and submerged part of the port. The family Carbajal had lost a large proportion of the little property they had in Arequipa; the same had been the case with the families of the Velardes, and of Antonio Martinez. Doña Dolores Harmsen's beautiful house, in the building of which her husband had laid out a very large sum of money, had fallen in.

Saturday, $29^{\text {th }}$ of August. The previous evening Rafael Velarde brought us bad news regarding our suit against the Sotomayors. Dr. José Maria Perez, one of the Vocales of the $2^{\text {nd }}$ Chamber which had to decide the question, had informed his intimate friend Lino de la Barrera, Rafael's father-in-law, that the three ju[_] 
had not agreed, or what is called here technically "Que ha [...]." This advice, as may well be conceived [...] [35] pass an unquiet night, and this morning early I went out to Chorrillos for the purpose of seeing Dr. Perez, who resided there. Melchor Velarde, to whom I went first, sent his eldest son to the Doctor, who gave the verbal answer that all he could let me know was that we had only one vote in our favor viz. his, and those of Alzamora and José Eusebio Sanchez against us. On my return to Lima, I learned that Dr. Bernardino Leon would probably be called in to decide the question, and my wife and I now entertained little hopes of gaining in the Superior Court, for we knew that Leon was intimate with Aranivar, lawyer of the Sotomayors. At 2 O'clock I went to a meeting in the office of the Telegraph Company to discuss its statutes. The president, Dr. Pedro Galvez, Minister for the Interior, not attending, his place was taken by Mariano Felipe Paz-Soldan, one of the Directors, besides whom were present: his son Carlos, manager or "gerente", Andres Alvarez Calderon, Carlos Delgado, Pablo Vivero, Flores Guerra, a certain HElguero, the Frenchman Schmidt of the South American Insurance Coy., Bluhme, the Danish engineer, Federico Marriott, the rich José Unánue, Garland in representation of his brother-in-law, myself, and two or three more, with whom I was not acquainted. The discussion was animated, and almost all took part in it; it was I who made the first and, I believe, principal observation to the effect that the company should be dissolved as soon as a loss were ascertained, whilst the original idea was to make its duration 25 years without any such saving clause. It was past 5 when we broke up.

Whilst we had been occupied in the manner just described, Thomas Podmore, about 28 years of age, lost his life through his own imprudence. He was the nephew of John Tarmer, had married one of the sisters of Dr. Fernando Palacios, by whom he had two children, and was employed as head clerk in Staunton \& White's foundry. Being a good horseman, he was in the habit of making his horse jump over the bars placed in the town to prevent the thoroughfare, where a street was under repair. This day he made the attempt at the corner of the Plaza and la Calle del Correo; the horse fell with and upon him; he received fearful injuries on his head and was carried home senseless.

Sunday, $30^{\text {th }}$ of August 1868. This morning when I went to Dr. [...] house to enquire how Podmore was. I received the [...] [36] that he had died the previous night at 8 O'clock.

From Monday, $37^{\text {st }}$ of August to Wednesday, $2^{\text {nd }}$ of September Mr. Barker did not come, and on

Thursday, $3^{\text {rd }}$ of September I received a note from him, in which he said that after the conduct, which he had observed towards me, he was ashamed to shew 
his face again, and begged me to send the balance due to him, which I did. On the same day I made an arrangement - similar to that with Barker - with Mr. George Graham.

The Steamer from the North came in without bringing correspondence from Europe, owing to the non-arrival of the steamer from Southampton at Colon. The news received from Ecuador was terrific. In Guayaquil the earthquake of the $13^{\text {th }}$ August had been felt, without any injury being done; but on the $16^{\text {th }}$ at 1.20 a.m. another earthquake shook Quito and its environs with tremendous violence. The damage done in Quito was great, not overwhelming; the churches and public buildings suffered most; of private houses hardly one escaped without being rent; but few, it would seem, came to the ground. Nevertheless, the same as in Arequipa, the inhabitants were living under tents in the open air. A little further North, in the province of Imbabura, the havoc committed had been immense, its capital Ibarra was represented as a heap of ruins, and of its inhabitants five sixths were said to have lost their lives. The town of Otávalo had disappeared. Cotacachi and other neighbouring places had shared a similar fate. The victims were numbered by tens of thousands, but probably there was some exaggeration in these accounts. Close by are the volcanoes of Cotacachi and Ocampo, which were supposed to have been the cause of this convulsion.

From Friday, $4^{\text {th }}$ to Friday, $11^{\text {th }}$ of September 1868. During this week Mr. Graham came regularly, and we attended to our usual occupations.

From the Southern parts of Perú details of the earthquake were coming in, and the first accounts had certainly not been exaggerated. From Caravelí, for instance, we learned th $[. .$.$] had been very great. Enriqueta al [...] [37] letters$ from her friends in Arequipa, who all told the same sad tale of what they had suffered and still were suffering. The Minister of Justice, Dr. Luciano Benjamin Cisneros, the Bishop Dr. Tordoya, and other members of the Committee, sent thither by the Government, had arrived and were distributing the money, provisions, and clothing which they had taken with them. Chocano, the Prefect of Arequipa, had been deposed; General Lopez Lavalle, the unsuccessful candidate for the first Vice-presidency, was to take his place.

In the United States the comet called Encke's - which reappears regularly every $31 / 2$ years or thereabouts - became visible about the middle of August. The Steamer, corresponding to the French, from St. Nazaire arrived and brought the English mail due since the $1^{\text {st }}$ of the month. From Europe and the United States there was no news of interest. Cordes was still alive, but there were no hopes of his recovery. 
From Saturday, $12^{\text {th }}$ to Monday, $27^{\text {st }}$ of September 1868 . On the $17^{\text {th }}$ the steamer from the North arrived by which Garland received a letter from Mr. Schutte, advising the death of Cordes, who expired in Paris in the Hotel du Louvre on the $11^{\text {th }}$ August at 6 p.m. The last few minutes he had been without pain, and a moment before he breathed his last he had been conversing with his medical adviser Dr. Acosta. Mr. Schutte added that his funeral had been "respectable and decent", favourite expressions of his, which on this occasion he might as well have omitted. Our entire family went immediately into mourning, and my wife and Enriqueta declared that for at least one month they would abstain from all visiting. Many cards of condolence were sent in to my wife; also persons whom we had not seen in our house for many years came to express their sympathy, for instance Dr. Gallagher, Frederic Marriott, and Charles Bergmann. On the $18^{\text {th }}$ at 3 a.m. Mr. Stanhope Prevost died after prolonged and dreadful sufferings. More than thirteen years had elapsed since he felt the first symptom of the paralysis, which had reduced him to a helpless cripple, and finally put an end to his existence. At about 10 in the evening I went to his house where several gentl [...] assembled, who accompanied his corpse to the Church of [...] [38] Domingo, where on the following morning the funeral service was held, at which I was also present. Mr. Stanhope Prevost was a native of the United States, but had nothing of the Yankee about him; he was in every respect an English gentleman; he came to Perú in the first years of the Independence then a very young man. I have a dim recollection that once I saw his father, but when and where, I cannot say. When he grew up, he became partner of Edward Macall, and at the time that the firm of Edward Macall \& Co. joined that of Alsop \& Co., and their united business was carried on by the latter firm, Mr. Prevost became partner of that house. His infirmities soon after prevented him from taking an active share in the business, and to the end of his life he was a sleeping partner, consulted in emergencies. He was married to Maria Moreyra, whose mother, as will be seen by the genealogical table $\mathrm{N}^{\circ} 8$, Vol. VI, descended from old Querejazú, and who therefore was considered as belonging to the aristocracy of Lima.

Where the father Moreyra came from I have not learned, but to judge from the dark complexion of Mrs. Prevost and all her sisters and brothers, the conclusion may be drawn that his progenitor, or progenitrix, not many generations back, was born under the burning sun of Africa. Mr. Prevost left five children, four sons and one daughter; the mental capacities of the eldest and youngest son, Juan and Luis, seem to be somewhat affected by the physical infirmities of the father, whilst the two others, Enrique and Carlos, are fine 
young men, who under the firm of Prevost \& Co. carry on the business. The youngest child Mariana has become the wife of the Chilian Chargé Godoy. (This last paragraph I add November, $8^{\text {th }}$ 1877).

The following morning I was again in the same Church of Santo Domingo at the obsequies of the wife of Andrés Alvarez Calderon, who breathed her last on the $18^{\text {th }}$ at 6 p.m. and who, as everybody knew, had been the victim of her husband's ill-treatment. I considered this attention due to the widower, because at the request of Rafael Velarde he had rendered me a service by speaking on my behalf to Dr. Bernardino Leon who, as above said, had to decide my case against the Sotomayors [_] who had already deferred doing so for more than a fortn [...] Pablo Vivero had also spoken to the same judge [...] [39] favor; nevertheless, I placed no reliance on him. Every steamer from the South brought emigrants, who abandoned their places of abode, rendered uninhabitable by the late disaster.

Friday, $9^{\text {th }}$ of October 1868. The last English Steamer brought a letter from Rosa, in which she gave an account of Cordes' last moments. She, Conradina, who was taking hold of her husband's hand, and the Doctor were present. Cordes himself had felt that the artery had burst; just before he breathed his last he opened his eyes in an extraordinary manner, and then closed them for ever. He was buried in the Cemetery of "Le Père de la Chaise"; his sister Natalia had arrived in Paris. Lavalle, in a very bad state of health, together with Amalia had gone to the baths of Ems; their children they had left with Rosa.

In Arequipa earthquakes were still experienced now and then; on the $30^{\text {th }}$ September there had been a pretty severe one, owing to which some walls already in a tottering condition came to the ground. From Talcahuana they wrote that the sea had again been uncommonly agitated. In Gibraltar an earthquake was felt on the $19^{\text {th }}$ August. Here in Lima hardly anything of note occurred. With the President and his cabinet, the Limeños were upon the whole satisfied, nor did they give any cause for just complaint. Of the Congress the same could not be said; on the $7^{\text {th }}$ inst., notwithstanding a very strong opposition, Col. Francisco Diez de Canseco was proclaimed $2^{\text {nd }}$ Vice-president of the Republic, by 66 against 51 votes.

Limpricht, quite as good a chess-player as I, came now and then in the evening to play a game however never more than one, for fear of injuring my eyes:

At last, after a very long delay, my case against the Sotomayors was taken up by Dr. Leon. Dr. Aranivar pleaded first, then my lawyer Dr. Palacios.

President Balta fixed upon Wednesday of each week for his reception in the evening. I also received an invitation from Barrenechea, but did not intend to go. It was said that neither smoking nor playing $[\ldots]$ cards would be permitted. 
In appendix under $\mathrm{N}^{\circ} 1$, a cutting [...] paper is affixed which treats in the eclipse of the $[\ldots][40]$ to have taken place on the $18^{\text {th }}$ August.

Friday, $16^{\text {th }}$ of October. Dr. Melchor Vidaurre threw up his post as member of the Superior Court of Justice, owing to reprimands lately addressed to him by Dr. Barrenechea, who during the absence of Luciano Benjamin Cisneros, had acted as Minister of Justice.

Two swindling transactions gave rise to much talk in the Commercial World of Lima. The one was perpetrated by Mariano Osma, son-in-law of Felipe Pardo and brother-in-law of Felipe Barreda, consequently connected with the first families of Lima; he presented for discount several pagarées bearing his own and Pedro Paz-Soldan's signature; one of them for $\$ 500$ was brought to me by the broker Mogaburu, which I discounted; fortunately, the amount being but small, Osma himself came to me and paid it; other persons, to wit José Vicente del Campo, the Bank of Perú, and I do not know who else, had not the same good luck, they held similar documents to a much larger amount. Pedro Paz Soldan declared the signatures were not his, refused to pay, and from Mariano Osma nothing could be got. A man who called himself Medina Celi, but whose nationality and real name nobody knew, was the hero of the other swindle. He enquired of Roca Pratolongo, the Italian timber merchant, whether he could furnish him with some gold Soles, and Pratolongo referred him to Bianchi, with whom he closed the bargain; Bianchi procured five hundred gold "Soles", which he sold to Medina Celi at $\$ 26.2$ rls each, a little above the current market rate, but was fool enough to deliver them to him against a cheque upon the London \& Mexican Bank, without having previously ascertained whether the cheque would be honoured or not; it was refused payment, and when Bianchi went to the hotel where Medina Celi and his accomplices lodged, they had decamped, taking of course the money with them; but to the astonishment of everybody, they were discovered and arrested a few days later, with nearly the entire amount in their possession.

About this time I took shares in two companies which were about being formed for the construction of railways, viz. S/10,00o in the Lima Huacho Railway Company, and S/20,00o in the Pasco Mineral Railway Company. Of the provisional Committee for directing the latter [...] named one of the members, together with Manuel Pardo [...] [41] Sagastabeytia, Nicolas Rodrigo, and José de la Riva Agüero. We had had two meetings; between 5 and 600,00o Soles had been subscribed, and 1,300,000 were required as per estimate presented by the engineers Wyman and Harrison.

To-day the Superior Court decided against me in my case with the Sotomayors, Dr. Leon having voted with Alzamora and Sanchez against Perez, which latter confirmed the sentence given in my favor by the Juez de $1^{\text {a }}$ Instancia. The other 
three said that I had had no right to demand the disoccupation of the house, or to raise the rent fixed by Aliaga. The appeal to the Supreme Court still lay open to me, of which I of course intended to avail myself.

Wednesday, $27^{\text {st }}$ of October 1868 . The steamer which arrived on the $18^{\text {th }}$ brought the important news received in New York [?] Electric cable that from the $20^{\text {th }}$ to $30^{\text {th }}$ September the revolution in Spain headed by Generals Prim and Espartero had completely triumphed, and that the Queen Isabel who had fled to Bayonne, had no chance of recovering the throne. Mr. Schutte wrote to Garland from Paris that Lavalle was lying so ill in Ems that Rosa had left for this watering place to render Amalia assistance in her troubles. In Arequipa earthquakes still continued; Doña Candelaria Möller wrote to her son Don Carlos - at the time in Lima and looking for a situation - that on the $13^{\text {th }}$ of this month they had had a very severe shock. Maria Arauzo wrote that she did not yet venture to return to her dwelling, and that she still lived under a tent in the plaza. In Copiapó likewise an earthquake had been felt, and the daily papers informed us that on the $13^{\text {th }}$ August the Pacific Ocean was violently agitated, and rose to a great height on the Shores of the Sandwich Islands, and the same occurred early on the morning of the $15^{\text {th }}$ Aug. in New Zealand, and on the Eastern Coast of New Holland.

Sunday, $25^{\text {th }}$ of October. I was the whole forenoon in the office of my lawyer Dr. Palacios, who commenced dictating the rough draft of the "escrito de nulidad" in my great case against the Sotomayors. Dr. Luciano Benjamin Cisneros, who had returned from the South, gave in his [_]signation as Minister of Justice.

Monday, $26^{\text {th }}$ of October. This morning I was present at the [...] [42] of Doña Josefa Palacios, an elderly lady, one of the two spinster daughters of the late Doña Ignacia.

Friday, $30^{\text {th }}$ of October. My lawsuits gave me much annoyance and cost me a deal of money. The "escrito de Nulidad", in which my lawyer endeavoured to prove the injustice of the sentence of the Superior Court, and which I presented this day, had occupied him, I should think, about nine hours; for the

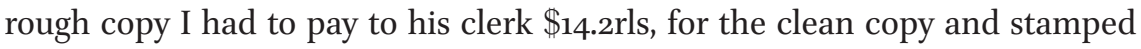
paper $\$ 30$.

In the evening our Chinese Cook Achipe, who had been with us since 1852, and our servant Juan, whom we had had in our service for many years, both men of violent tempers, had a furious quarrel on the occasion of the boiling of the water required for our tea; the latter, who was undoubtedly in the wrong, gave the former a fierce blow in the face, which infuriated the Chinaman to 
such a degree that the blow-giver had to fly for his life. In order to keep Achipe within bounds I called in a policeman.

Saturday, $37^{\text {st }}$. Early in the morning Achipe left the house and did not return in the course of the day.

Friday, $6^{\text {th }}$ of November. The Sotomayors gave in an escrito demanding the payment of the $\$ 30,000$ deposited, they giving a guarantee to my satisfaction for the re-payment, in case the Supreme Court should give sentence in my favor. Dr. Palacios said that this demand was according to law, but it was always in my power to throw impediments in the way by declining to admit the guarantee presented by them.

The news from Europe by last mail informed us that it was all over with the Queen of Spain, but who would be her successor, nobody could surmise. Lavalle continued very ill and was expected in Paris from Ems, together with Amalia and Rosa. The Paraguayos, with their President Lopez, were gradually losing ground against the overwhelming forces of their allied enemies, the Brazilians, the Argentines, and Uruguayos. They had lost the strong fortresses of Curupaiti and Humaiti, and were retreating towards their capital Asuncion. In Peruvian politics nothing of great importance occurred. The Congress met daily, but did little. Rafael Velarde, who of late had been unwell, did not act at present [...] icuous part in the Chamber of Deputies as he had [...] [43] beginning; he said that nearly all his colleagues inclined towards Herencio Zeballos, the VicePresident, who, as was generally apprehended, was intriguing for the overthrow of Balta, to whom, as the legitimate authority, Don Rafael and a few others adhered. The post of Minister of Justice, left vacant by the retirement of Dr. Cisneros, had not been filled, Dr. Barrenechea, the Minister for Foreign Affairs, having provisionally taken charge of this department also. In the Superior Court of Justice the vacancy caused by the death of Dr. Barriga had been filled by Teodoro de la Rosa. Dr. Carbajal, our good friend, notwithstanding all his efforts, had not been able to obtain this preferment.

Mr. Graham, whose chest would not allow him to read aloud for any length of time, threw up his office as lector and confined himself to that of secretary, whilst a Mr. William Long, introduced by him, came for two hours in the morning, and one in the evening to read to me.

Monday, $9^{\text {th }}$ of November 1868. My wife, who had given up all hopes of Achipe's returning, found herself under the necessity of engaging another cook, a negro. Whilst we had been without this necessary member of our domestic establishment, we had had to rely for our meals on Enriqueta's kindness. 
Tuesday, $17^{\text {th }}$ of November. We received a letter from Corina, who seemed to be disconsolate - as no doubt she really was - for the loss of her husband. Of Cordes' death we had received advice on the $17^{\text {th }}$ Septr.; this day, exactly two months later, whilst we were at Garland's, celebrating the birthday of Enrique, letters were brought in, which communicated to us that Lavalle, Amalia's husband, had breathed his last in Paris on the $16^{\text {th }}$ Octr. at 7 in the morning.

The Queen of Spain, who had taken up her residence in Pau, had published a solemn protest against the revolutionary party which had dethroned her.

About this time Juan Diez removed to our rancho in Chorrillos, where he engaged a servant and took his meals; now and then he came to town.

The guarantee proposed by the Sotomayors was Miguel Vigil, whose daughter Octavia was married to Federico, the eldest son [...] Jacinta Sotomayor; [...] efused to admit him [...] [44] plea that he was a public employé.

Dr. Mariano Alvarez, whose reputation was not the very best, was named to fill the place of Dr. Melchor Vidaurre, the most immaculate and most respected of all judges in the Superior and Supreme Courts.

The President and Vice president were said to have had a serious altercation; the former warned the latter to take care of himself, for he, Balta, knew that Zevallos was conspiring against him and held the threads of all his intrigues.

Thursday, $19^{\text {th }}$ of November. To celebrate the Saint's day of his wife Isabel Barreda, Manuel Mendoza y Boza gave an evening party in the splendid saloon of his house lately refitted and refurnished with great elegance. Of ladies only some of the family were present; of gentlemen a great many, perhaps a hundred, I of the number. When I walked in, I could not distinguish nor recognize anybody, and of course rejoiced when Don Manuel came up to me, whom I begged to present me to his lady, and as soon as he had complied with my wish, I made my exit and went over to Garland's, in whose house a few friends usually met on Thursday evenings, some of whom played rocambor, others conversed. Manuel Costas, who was Senator for the Department of Puno, Francisco Sagastabeytia, Langshaw, Dr. Middendorf, Manuel and Melchor Velarde, Antonio Martinez, Adolfo Alvarez, Johannes Limpricht, my wife and myself, generally constituted the party; we two were in the habit of retiring at 11, the card-players remaining till past 1 O'clock.

Saturday, $21^{\text {st }}$ of November. I was actually surprised to see the many presents amongst which sweet meats of all descriptions - which were sent in to my wife, whose Saint's-day it was. At dinner we were merely Mariquita, Juan, and myself, Rafael Velarde, the Garlands, and Johannes Limpricht, but after dinner so many people came in that our rooms gradually filled: Dr. Morales, wife and daughter, Mrs. Carbajal and daughters, Mr. and Mrs. Mariano Paz-Soldan, Mrs. Hobson, Mrs. Bergmann, Dolores Puente (these two latter had their rocambor, of which I was glad), Rafael's wife, daughter, and two brothers 
etc. Juan made himself very agreeable to the young ladies; he showed the $[\ldots]$ and various engravings; my wife and myself [...] [45] with one and the other, and did our best to make our guests find themselves at home; first we had tea, at a later hour ices, and past 11 the party broke up.

Sunday, $22^{\text {nd }}$ of November 1868 . My wife was unwell, and remained in bed.

Saturday, $28^{\text {th }}$. Enrique Garland fell ill; at first we thought it was merely a cold, but on

Monday, $30^{\text {th }}$ Middendorf apprehended that it was something more serious, for his pulse was extremely irregular, which the Doctor could not account for.

I insured my house in which we lived, Calle del Correo, as well as the furniture, against fire risk, at $1 \%$ for 1 year, with the South American Insurance Company - of which I myself was a shareholder - the house in $\$ 40,000$ the furniture in $\$ 25,000$.

Dr. Teodoro de la Rosa was named Minister of Justice, whilst Dr. Barrenechea confined himself to his own Department, that of Foreign Affairs. With Bishop Huertas of Puno some disputes had arisen; the Bishop was in Lima and Barrenechea, as Minister of Justice, had ordered him to return to his Diocese within a month, whilst the Bishop insisted upon his having a right to absent himself from his Diocese for three months without anybody, and least of all the Civil power having a right to interfere. Moreover, this Bishop Huertas whilst in Puno, had convoked a Synod to his Curates, which Synod had laid down and published certain rules without presenting them to the government for approval. As regards this latter case, Dr. Don José Gregorio PazSoldan proved in a very clever Vista-fiscal, published in the papers, that the Bishop had passed the limits of his authority. The treasury of the Government continued empty; for Octr. and Novr. no civil employé, no officers, no deputies, no widows - in short nobody - had been paid except the common soldiers. Dr. Garcia Calderon, Minister of Finance, knew of no other means to obtain money than by applying to the guano consignees, which measure the Deputies were as yet not inclined to approve; I however was convinced that by and by dire necessity would force them to acquiesce.

Saturday, $12^{\text {th }}$ of December. Enrique Garland, though not compl [...] was so much better that he could venture into the [...] [46] On the other hand, my wife these last two or three days was suffering from a violent pain just under the left breast, which prevented her from sleeping during the night, and kept her in bed during the day. Dr. Middendorf was not yet certain whether it arose from flatulence, or whether it was neuralgia. Achipe, our Chinese cook, had returned, to my wife's great satisfaction.

The disputes between the Executive and the Bishop of Puno, referred to on the $30^{\text {th }}$ ulto, if not yet arranged by the new Minister Teodoro de la Rosa, were at all events in a fair way of settlement. 
The Treasury was still empty. Christmas was close at hand, and still the public creditors were not paid, not even for October and Novr. last. Garcia Calderon, Minister of Finance, published a statement which showed that if no extraordinary measures were resorted to, the expenses for 1869 and 1870 would exceed the revenue by nearly nineteen million Soles.

Within the last few days the arrival of an Indian from the Interior caused some stir in Lima. It was said that he was the son of the Chief of the tribe called Ahuarunas, and that he had come to Lima for the purpose of soliciting the assistance of the Peruvian Government against other savage tribes, his enemies, who had vanquished the Ahuarunas in several engagements. He was kindly received, shewn to Santa Catalina and other places and had left again for Lambayeque, thence to return to his own country, the Pampas, on the other side of the Cordillera, without, as far as I was aware, having obtained his object.

In Pisagua many of the inhabitants had died of the yellow fever, and many more had fled to other places; when the last steamer left Iquique, the epidemic had not reached that port.

From Europe we learned that earthquakes had been felt in England and in Moldavia, also that Vesuvius was in full activity, and had destroyed several dwellings in its vicinity. Rossini had died in Paris in his $77^{\text {th }}$ year, also the Archbishop of Canterbury and Baron Lionel Rothschild in London. After Cordes' death his two junior part [...] vank, a Swiss, and Cheatham, an Englishman, had continued [...] in Manchester under their own name, and had [...] [47] their circulars a very short time back: now by the last steamer we learned that Cheatham, in the prime of life, and apparently a very strong man, had likewise gone to his last account. Conradina wrote me that she had given orders for the sale of the house in Hamburg, bought hardly six months previously. In Spain the provisional government continued to hold the reins; there was not the slightest chance for the Queen's return; but who knew whether the two parties, the one in favor of monarchy, the other friendly to the republican system, would not fall out amongst themselves.

In the United States General Grant had been elected President and a certain Colefax, Vice President, by a great majority. It was Genl. Grant who by the taking of Richmond had put an end to the Civil War. Colefax was a name unknown to me.

Sunday, $13^{\text {th }}$ of December 1868 . Though my wife passed a very bad night, she was not so ill as to prevent my going out.

In the forenoon I made my usual round of calls, and at 6.30 went to a dinnerparty given by Dr. Gregorio Paz-Soldan in celebration of his wife's birthday, to which he had invited me. I was there at the appointed hour and was not a little surprised to find in the inner saloon, where the three ladies, Doña Jesus 
the hostess, Don Gregorio's daughter Petita, married to Carlos Paz-Soldan, and Doña Iñez, the wife of his son José Luis, were sitting, also the President Don José Balta, to whom of course I had to make my bow, whilst two of his Ministers, Pedro Galvez and Barrenechea rose to salute me. In the other saloon I conversed a little with Dr. Teodoro de la Rosa, Minister of Justice, and Dr. Bernardo Muñoz, President of the Supreme Court. It was nearly 7.30 when we walked into the dining saloon, where from 28 to 30 guests sat down. Besides those already mentioned, there were General Echenique, President of the Senate, General Medina, Emilio Althaus, one of the two managers of the Bank of Perú, Dr. Ureta, one of the two Fiscales of the Supreme Court, Amunategui, proprietor of the newspaper "El Comercio", Garcia Calderon, Minister of Finance, Juan Mariano Goyeneche Jr., Alayza, married to one of Pedro Paz-Soldan's daughters, and a few others whom I did not know. Balta's brother, Minister for War, was not there, neither [...] Doctor's two brothers, Pedro and Mariano, the former absent in his estat [...] the latter on bad terms with Don Gregorio. Everyt [...] [48] splendid. The soup plates were of silver, as were also the dinner plates, of which three stood before each guest; the glasses and decanters all cut glass, whilst the porcelain was by no means tasteful, and inferior, as far as I could judge, to that bought by me when in Berlin in 1855 . Both dinner and dessert, which latter was laid out in a separate saloon, were profuse in the extreme, and had been furnished by an hotelkeeper. Wines abundant and, I believe, very good. Notwithstanding all this magnificence, it was the most tedious, stupid party imaginable. The voice of the host was mostly heard, and when he got in the wind - as he always did on similar occasions - he twice offended, and I may say insulted, his right hand neighbour General Echenique. To his left sat Dr. Bernardo Muñoz, next to whom I, the only foreigner in the party, and to my left Doña Inez; opposite Dr. Gregorio, his wife, the President, and Ministers. I rejoiced when we rose at about 10, and when the others went to take coffee I cut my stick. At home I found my wife still up and pretty well, but in the night from Sunday to

Monday, $14^{\text {th }}$ of December at 3.30 a.m. she called me not having slept a wink, and suffering at the moment from severe pains in the belly. Enriqueta was sent for, Dr. Middendorf came; I telegraphed to Juan, who came in without loss of time, and still past 5 p.m. my wife was really ill, and fears were entertained that she would have an attack of colic. It was Enriqueta, not the Doctor, who cured her; he wanted to give her quinine pills, which we were all opposed to, and succeeded in dissuading him from, whilst Enriqueta recollected that against flatulence there was no better remedy than the essence of Anisseed, and with the Doctor's consent two or three drops were given to my wife, which allayed the pains. Dr. Middendorf came at 11 O'clock for the fourth time and remained 
till midnight when he left my wife in a much more tranquil state than she had been for many hours. She slept well during the night and rose on

Tuesday, $15^{\text {th }}$ feeling well, but extremely weak. Towards evening the pains again came on; the essence of anisseed, of which she took a few drops, had no effect, and consequently she, Enriqueta and I agreed, without the Doctor's cognisance, to call in the Doctora, who was in gr [...] te for the cure of bowel and similar disorders. I went to her [...] and brought some remedies with me, which we [...] [49] administered, and did good. Dr. Middendorf came at midnight, and it was 1.30 on

Wednesday, $16^{\text {th }}$ of December before I lay down. Enriqueta had a bed made on the sofa in my wife's bedroom, and the night passed quietly.

Thursday, $17^{\text {th }}$. The Doctora and Doctor came twice in the course of the day, and both agreed - without knowing each other's opinion - that fever and ague was at the bottom of my wife's illness; she was however so well that Enriqueta could pass the night in her own house, whilst in the day time she was constantly with us and nursed her mother with indefatigable care.

The Government continued without money. Some time back the Minister of Finance had presented a project to Congress to raise funds by making new contracts with the guano consignees, and consequently one of the two finance committees was ordered to report on the same; its members were divided in their opinions; the minority approved of it, the majority presented another project totally impracticable, and its glaring stupidity was so clearly demonstrated in an article in the "Comercio" that the Committee thought proper to withdraw the same; and the members of the Congress, probably convinced of their incompetence to treat on matters of Finance, decided upon calling to their assistance 16 individuals to hear what they had to say on this weighty matter. These were: Drs. Paz-Soldan and Ureta, Fiscales of the Supreme Court, both very clever men in their line, but totally ignorant of Financial affairs (The former was wise enough to stay away), Dr. Manuel Ortiz Zevallos, this was a very clever lawyer and supposed to know something about finances; at all events under Castilla's administration he had been Minister in this department; it was also known that at that time he had made a handsome fortune, but neither the thousands, which he had then amassed nor the considerable immovable property both in town and the country, which was his wife's, the Marchioness of Torre-Tagle, could satisfy the all-absorbing demands which the gaming table made upon his purse, Julian Zaracondegui, James Henry, William Brauns, Gericke, J. F. Lembcke, the four latter respectively the Chiefs of William Gibbs \& Co., Fred Huth Gruning \& Co., Graham Rowe \& Co., and J. F. Lembcke \& Co., Emilio Althaus, Francisco Cal [...] Mr. Ford 
Managers respectively of the three banks [...] [50] Lima, "Del Perú, "La Providencia", and "London, Mexico and South America". The last eight named, with the exception of Calderon, were all more or less of the opinion that the Government could not do better than apply to the guano Consignees; Calderon, who had a plan of his own to lend money to the Government, was opposed to this scheme; so was a certain Derteano, a man in no very good repute, who had been interested some years back in the conversion of the Bolivian coin. Besides, those enumerated there were present Enrique Ayulo, partner of Dorca \& Ayulo, Pedro Carillo, ex-Minister of Finance, well versed in guano affairs, and Luis Cáceres, clerk of one of the Government offices, very clever at accounts. The lawyer Luciano B. Cisneros, late Minister of Justice, had also been called, but did not go.

Friday, $18^{\text {th }}$ of December 1868. My wife again suffered severely last evening; however, opening medicine and injections, the only remedies which were continually applied by both Doctor and Doctora, had their usual effect, so that towards midnight she felt more easy.

By the last steamer from the North no news of importance reached us. General Wright had suddenly died in Guayaquil of a stroke of apoplexy; whilst here he was always boasting to me that he could eat heartily at dinner and supper, that he could drink beer, sherry, and champagne at one meal, and all this without experiencing any bad consequence. Now we saw the result of it.

Saturday, $19^{\text {th }}$ of December. Since my wife's illness, I ceased taking my early morning walks, for I did not like to absent myself from my house for any length of time. At tea we had generally more visitors than when my wife was in perfect good health.

Sunday, $20^{\text {th }}$. I remained at home to receive the few visitors who came; my wife passed a good day and night, but on

Monday, $27^{\text {st }}$ about 5 p.m. she again felt pains, and towards midnight Dr. Middendorf gave her twelve drops of laudanum. On

Tuesday, $22^{\text {nd }}$ I called in Dr. Macedo, who examined the patient very carefully declared that there was no organic defect whatever and agreed with Dr. Middendorf that it was intermittent fever, which was the cause of her sufferings; accordingly, quinine was resorted $[\ldots] 3^{2}$ grains -2.048 grammes were administered in [...] [51] twelve hours; they had the effect which was expected and on

Wednesday, $23^{\text {rd }}$ of December for the first time, my wife was free of the pains from which for a few days previously she had regularly suffered at the same hour.

Thursday, $24^{\text {th }}$. My wife got up for a short time, and we were in hopes that all danger was now over. 
As regards my lawsuit against the Sotomayors it had been touch and go. Dr. Aranivar did all in his power to have the "Autos" sent up to the Supreme court in the present month so that Dr. Ureta had to give the Vista-fiscal, but for this very reason we laboured in the opposite direction. On Saturday at 3 p.m. the note was already signed for the purpose of remitting the papers to the Supreme Court, but we were just in time to present an escrito, again another on Monday, and the last, today at 3 p.m., so that now the autos could not be forwarded to the Supreme Court till January, when Dr. José Gregorio Paz-Soldan would be the Fiscal for judicial affairs. To understand this, it must be borne in mind that Drs. Ureta and Paz-Soldan were Fiscales both for the Government and for the Supreme Tribunal of Justice, and by turns, one month the one attended to the affairs of the one, the other to the affairs of the other. This day the "Punto" began, and would last till the $7^{\text {th }}$ January, that is to say, during this fortnight all judicial proceedings would be stopped. The members of the Supreme Court, before breaking up for this "punto", according to regulation chose their president for the ensuing year, and their election fell, to my great sorrow, on old Dr. Francisco Javier Mariategui, who of all the Vocales was the most decided friend of the Sotomayors, for he was very intimate with Dr. Francisco de Paula Vigil, brother of Federico Sotomayor's father-inlaw; and it was also owing to his, Mariategui's influence, that in August 1863 the Supreme Court declared my suit against the Sotomayors, gained in the inferior tribunal, and in the Superior Court, and with the Vista-Fiscal in my favor, to be a "causa ordinaria", not "ejecutiva".

Garcia Calderon, Minister of Finance, had given in his resignation and this for a very good reason; with the consent of the President he [_] ented to the Chamber of Deputies a project to borrow from the gua $[\ldots] \$ 2,000,000$ allowing them the exchange of 400 and [...] [52] at 5\% annually, and whilst this was being debated in the Chamber of Deputies the President Oviedo received a letter from Balta, in which he was requested to bring in an amendment to the effect that the loan should be proposed to all mercantile establishments in Lima, and not exclusively to the Consignees. Of course, Calderon was much annoyed at the President's acting in opposition to what he had himself agreed to. He told Manuel Velarde, in whose house he occupied a suite of rooms, that it was impossible to serve a man who had no respect for his own word. In the evening of this day the Finance Ministry was provisionally taken charge of by Dr. Barrenechea, Minister for Foreign Affairs, and with him and the President Balta, the guano consignees - Garland of the number - had a very long conference, the result of which was the loan of $\$ 2,000,000$ on the above conditions. The money was immediately paid into the Treasury; even on the morning of 
Friday, $25^{\text {th }}$ of December, Christmas-day, the Bank of Perú kept open to furnish the specie required, and thus if not all, at least the greater part of the anxious expectants were satisfied. At 12.30 a.m. Dr. Felipe Pardo, a man of great repute and considerable acquirements, died at the age of 62, after long protracted sufferings; for many years he had been paralytic, unable to move and blind, but his intellect always clear, and not in the least affected. He was the husband of Petronila Lavalle, whom he had married in the $25^{\text {th }}$ December $183^{2}$, and as early as ten years after his marriage he had felt the first symptoms of paralysis. Manuel Pardo, Minister of Finance at the time of Prado's dictatorship, was his eldest son.

In the forenoon I remained at home to receive those who called to enquire for my wife's health.

Saturday, $26^{\text {th }}$. I ventured to absent myself for about two hours, and before breakfast accomplished a quick ascent of San Cristoval. Somewhat past nine I went to the Church of Santo Domingo to attend the funeral of Don Felipe Pardo. The Chief mourners were: Barrenechea, the Minister who represented the Government, José Pardo, a younger brother of the deceased, many years Peruvian Minister in Chile, Juanito and Carlos Aliaga, whose father and Felipe Pardo had been first cousins, then the Soyers, relations from Mrs. Pardo's side. Pardo, bel [...] family of Aliaga, for his mother had borne this na [...] [53] had the privelege of being carried through the cloisters of the Convent, then to a large apartment called "El General", where certain religious ceremonies were performed before the coffin was carried to the hearse, in the same manner as it had been done at the funeral of Juan Aliaga y Calatayud.

The papers said that the Paraguayos had once more repulsed an attack of the allied army; all their efforts were now directed to the defence of their last stronghold - their capital Asuncion.

Monday, $28^{\text {th }}$ of December 1868. This day a great funeral ceremony was celebrated in the Church of Santo Domingo in honor of the mortal remains of General O'Higgins, who, a Chilian by birth. came to Perú, if I am not much mistaken, sometime before the battle of Ayacucho, and distinguished himself in the War of Independence, when those who were at the time at the head of the Peruvian Government recompensed his services with the donation of two valuable estates in the valley of Cañete, confiscated Spanish property. About a fortnight ago a commission headed by the Chilian Admiral Blanco Encalada arrived in Callao on board the Chilian men-of-war "Chacabuco", "Esmeralda", and "O'Higgins" for the purpose of conveying the general's corpse to his native country. To-day it had been removed from the Pantheon with great military pomp to the Church, whence on the following day it was to be taken to the railroad station, then to Callao, per train, and on board. This General O'Higgins 
had a natural son Don Demetrio, who inherited the Cañete estates; he, Don Demetrio, according to all accounts, for I was not personally acquainted with him, was good-natured, but stupid and ignorant; in Paris he had squandered away a large part of his fortune, whereupon he returned to Perú and three or four weeks ago accidentally poisoned himself. He had been in the habit of keeping in his room - for what purpose I cannot say - some poisonous liquid, which, taken in extremely small quantities, did no harm; one day he mistook the quantity and poured into his liquor - of which he was but too fond - more than he should have done, and in a few hours he was a corpse. Three natural children, by different mothers, had now started up as claimants to the estates, one of whom was represented by the notorious Dr. Fernando Casós. [54]

1869

From Friday, $7^{\text {st }}$ to Monday, $4^{\text {th }}$ of January. My wife's health had somewhat improved; however, she did not rise before twelve O'clock, and retired to rest at 6 p.m. Both the Doctor and the Doctora, as well as the family flattered themselves that the intermittent fever had left her.

On new-year's-day, also on Sunday, the $3^{\text {rd }}$, she had many visitors with her, a thing she liked above all; I therefore could well leave her and make my round of calls.

Of the various law-suits arising from the purchase of the house only one but that the principal, against the Sotomayors - was still pending. As far as I could judge at the time, all would depend upon the vote of Dr. Miguel Carpio, for I counted upon Alvarez, Muñoz, and Ribeyro, whilst the Sotomayors had in their favor Mariategui and Cosio; thus if one of the three former was not called - and this depended upon the President Mariategui - it was clear that Carpio's was the casting-vote.

The steamer which came in on the first brought from England the news of a change in Ministry; Disraeli and the Tories had gone out, and Gladstone as Premier, with his party, had come in. In Paris several hot-headed Republicans had been arrested, who had intended to celebrate with great pomp the anniversary of the death of a certain Baudin who fell on the $2^{\text {nd }}$ December 1851 defending the barricades. In Spain the Republicans and Monarchists did not pull well together.

News of a private nature was that Mrs. Henry Moss had expired in England after long, protracted, and excruciating sufferings. Mr. Barton wrote to Mr. Wilthew that a post-mortem examination had shewn that a tumour 38 inches long and 7 inches thick had been pressing upon her leg, probably he 
meant her thigh. Mrs. Moss, the daughter [_] Mr. Sealy, many years ago British Vice-Consul in Lima [...] both beloved and respected; my wife and myself had [...] [55] been on intimate terms with her. Her husband was Henry Moss, of a Jewish family, probably baptized, Mrs. Barton's cousin, a very good-natured man, and extremely fond of his wife. He was the chief of the well-known Callao agency H. Moss \& Co. Hardly had we learned of Mrs. Moss' death when we received the advice that another good friend of ours, Doña Francisca Rocafuerte of Guayaquil, 82 years old, had followed to the grave her son-inlaw General Wright, of whose death I gave the particulars a few pages back. Doña Francisca, the sister of Don Vicente Rocafuerte, and widow of a certain Señor Rico, related to General La-Mar, the first Constitutional President of independent Perú, belonged to one of the first families of Ecuador; for some time she had been looked upon as queen of Guayaquil; her daughters in their youth were the "belles" of that town, and with their numerous cousins formed the nucleus of the best society there. By and by the girls became married women; the one was Mrs. Luzarraga, the other Mrs. Charles Pflücker, the third married General Wright, who after the death of his first wife took the fifth, Josefa, for his companion. They had children, their children had children; some, for instance the family Luzarraga, emigrated to Paris where they lost the greater part of the large fortune left them by their father: the children of Genl. Wright did not fare better; in one word, the star of the Ricos was no more in the ascendant.

Within the last few years only the sons of Charles Pflucker in Lima have been favoured with the smiles of fortune, which they well deserve for their intelligence activity, and perseverence in working the silver mines of Castro Virreyna. (These lines I dictate in November 1877).

On the $2^{\text {nd }}$ the Chamber of Deputies was the theatre of violent altercations. Dr. Barrenechea, as Minister for Finance had been called on to give some explanations on the subject of the new consolidation of various descriptions of the floating debt; Barrenechea, apparently in bad humour would not enter into explanations, and gave the Congress the name of "El Campo de Agramante"; when called to order for using this expression, he excused himself with saying that he meant it to refer only to the Finance Committee, the five members of which had given not less than three different opinions on the same subject. I learned upon [...] that Ariosto in his poem of "Orlando Furioso" made [...] [56] visit the field of Agramante where he found everything in anarchy and confusion, and thus the Chamber of Deputies might well resent the Minister's expression as an insult to them; accordingly, an overwhelming majority without any loss of time passed a vote of censure upon him. In the nocturnal session of full Congress - when Deputies and Senators meet jointly - there was 
another row: the barra, that is to say the audience, vociferated so loudly that the President Genl. Echenique ordered them to be turned out, but as the small guard of 20 soldiers was unable to carry the order into effect, Echenique had nothing better to do than to close the session.

Friday, $8^{\text {th }}$ of January 1869 . Last night was similar to one of those which we spent in 1865 when my wife was so dangerously ill. After the intermittent fever had been chased away by administering large doses of quinine, she by no means recovered her strength so rapidly as we had expected, on the contrary she was continually ailing and felt pains in many parts of the body. Yesterday morning however she was so well that Enriqueta went to her house and Juan to Chorrillos at the usual hour of 5 p.m., but hardly was he gone when Mariquita once more had a relapse. Dr. Middendorf came at 6, at 10, and again at midnight, when he remained till half past two this morning. The fever from which she suffered was not very violent for her pulsation did not exceed 90 in the minute, but she felt a weakness and disquietude which passed all conception. Dr. Middendorf gave her a little water coñac and laudanum which at last made her fall asleep at 3 in the morning, when I also lay down. Enriqueta did not take off her clothes during the night. The Doctor insisted upon my wife going to Chorrillos, but she was now too ill to move. At 3 p.m. the fever had undergone no change.

From Saturday, $9^{\text {th }}$ to Thursday, $14^{\text {th }}$ of January. This was a sad week. The Doctors, it is true, said that my wife's case was by no means desperate, because no vital organ was impaired, but I was not of their opinion; I believed that she was very dangerously ill, and that there was but little hope of her again rising from her couch. The fever, the "fatiga", the restlessness and [_]uietude, though they left her for a few hours, always returned, [...] sometimes with less violence, and always towards [...] [57] that an opiate had to be given her nearly every night to enable her to sleep, were it but for a few hours. The night from Sunday to Monday was a particularly bad one; Mariquita, and of course Enriqueta, hardly slept a wink, neither had I much rest. On Monday she continued extremely restless; she herself expressed a wish that Padre Gual of the Descalzos, a monk in great repute for piety, should be called. Manuel Velarde went for him; he came, she made her confession, after which the extreme unction was administered. On the friar's coming out of the bedroom I met him; probably he did not know me, for without circumlocution he said to me the following words: "no pasará la media noche." I need not say what I felt on hearing this sentence from the mouth of a man supposed to be well acquainted with the symptoms of death. I also sent for the notary Palacios, who came along with his brother the lawyer, but her will my wife would not make, saying that her head was not clear enough. 
On Tuesday morning she awoke so well, without any fever, that Dr. Middendorf thought the consultation of medical men, which he had advised, say he himself, Drs. Bravo, Macedo, and Odriozola, might be dispensed with. Shortly after my wife again sent for Padre Gual and had some conversation with him. About an hour later the "beatico", or host, was brought by Dr. Chavez, the Archbishop's secretary, accompanied by the usual paraphernalia of lanterns carried by little boys, and a small bell carried by another, and rung when the occasion required: before the consecrated wafer was put into my wife's mouth she had to assent to every part of the Catholic creed, or confession of faith. I of course knelt down with the other inmates; but could not help envying in my mind all those persons, of whatsoever creed they might be, who had implicit faith in every religious dogma taught them in their childhood. At 3 p.m. again the fever made its appearance; at 9 Middendorf came, an opiate was given my wife which made her sleep, but on Wednesday morning she was in about the same state as the previous evening. The above enumerated medical men met at 10 a.m. and again at 7 p.m. when they prescribed for my wife 6 pills containing quinine and valeriana, which were given her at midnight, 3 , and 6 O'clock in the morning; at about 4 O'clock I rose, being awakened [_] some trifling noise in the bedroom; my wife was once more suffering [...] of fever, and her restlessness was such that she herself [...] [58] Enriqueta for a few drops of laudanum. At 5.30 she again fell asleep, and I also went to bed; Enriqueta hardly ever lay down, and I wondered how she could stand this incessant fatigue. On Thursday morning my wife was certainly a little better and stronger, though her stomach was still so weak that all she could take was a little broth and the juice of beefsteak, the solid part of which she again spat out. Nevertheless, her voice was generally clear and distinct, her memory unimpaired, and her intellect unclouded. Once or twice she cried out for her Mamma. Juan behaved admirably and she was extremely fond of him. Two nights Goya, Manuel Velarde's wife, kept Enriqueta company, also Doña Isabel, the mother of Doña Peta, Prada's widow, who (Doña Isabel) had been my wife's schoolfellow in Arequipa. The Velardes of course continually came in, and enquiries were made for my wife's health by a great number of persons; I myself removed from my bedroom to a sofa in the salita, where I slept. I told my German lector Wegnern not to come for the present; Mr. Long read but seldom to me, and even when he did I could hardly give my attention to him; my early walks I had also given up.

Instead of Barrenechea a certain Nicolas Pierola, an unknown young man, was named Minister of Finance; he was the son of that Pierola who was Echenique's Finance Minister at the time of the great consolidation; at 
present he kept an insignificant shop in the Calle de Melchor Malo, and owed his unexpected preferment to the strong recommendation of the said General, with whom he was distantly related.

Friday, $15^{\text {th }}$ of January. At 7 p.m. last night the medical men found my wife so much improved in her health that they did not think it necessary to repeat the consultation; I however begged them to return this morning, and it was well that I did so for at 9.30 last night when my wife awoke from an apparently sound sleep she suffered severely from the "fatiga", or oppression in the stomach, which, accompanied by slight fever, lasted the whole night, and this morning she was undoubtedly worse than 24 hours previously.

Yesterday, the interior of the palace was the theatre of a scandalous scene, which clearly proved that Col.JoséBalta, who could not masterhis own passions, was certainly not the proper person [...] a country. In the "Comercio" of the $13^{\text {th }}$ an art [...] [59] signed by a certain Capt. Odiaga, who had recently been deprived of his rank in the army; whereupon on the $14^{\text {th }}$ Balta called Manuel Amunategui, owner and editor of the "Comercio", before him, reprimanded him in the most furious manner for having allowed such an article to appear in the paper; and - this was at least the general report - went so far as to order him to be shot on the spot, which sentence was not carried out owing to the interference of the Ministers, principally to that of Balta's brother, the Minister of War.

Saturday, $16^{\text {th }}$ of January 1869 . This morning my wife awoke weaker than ever, and the Doctors insisted upon having her removed to Chorrillos as soon as she could possibly bear it. We changed her bed-room; she now occupied as such our former salita where we used to take tea, which was somewhat larger and more airy than her previous dormitory. We told Drs. Odriozola and Macedo not to return until again sent for.

During the fortnight that the Punto had lasted, the entire Judicature had been transferred to a spacious, airy building, which many years back had answered the purpose of the Lima Custom-House, and in later times, when Dr. Cano was Minister, been transformed into a college. The rooms and saloons were suitable for the Jueces de $1^{\text {a }}$ Instancia, as well as for the Superior and Supreme Courts. There were also the offices of the Secretaries; a few rooms were allotted to the notaries who had most business; in one word, the entire building with its many apartments was exclusively dedicated to judicial proceedings and for a certainty answered the purpose much better than those miserable rooms which the Superior Courts had occupied in the Palace. This building went henceforth by the name of "El Palacio de Justicia". All lawyers, mine, Dr. Palacios of the number very naturally took up their quarters in the vicinity. To myself this removal was inconvenient, for the palace of Justice 
being 8 cuadras distant from my house I required from ten minutes to a quarter of an hour to go thither and to my lawyer, whilst hitherto as long as the Courts of Justice were in the palace, and the lawyer lived close by, I could run there and [_] back in my room in two or three minutes.

In the afternoon I sent my secretary, Mr. Graham [...] [6o] his business; he was useful to me, because he was acquainted with his own and the Spanish languages, but at the same time he had a particular knack of making himself disagreeable on every possible occasion; the final reason was his coming long after his fixed hour, and going away by far too early. Long, whom I liked very well, also read to me for the last time this evening.

Sunday, $17^{\text {th }}$ of January. Once more Mariquita had passed a bad night, and her sufferings did not diminish in the course of the day; I did nothing else but go in and out her bedroom, sit in the corredor, answer enquiries for her health, and receive visitors. Middendorf dined with us, and remained till midnight.

Monday, $18^{\text {th }}$. After having passed a quiet night, Mariquita felt much better when she awoke; she rose at about 11, and sitting in an arm chair stayed up for about two hours. I therefore had no objection to attend the meeting of the shareholders in the Cerro de Pasco Railway Company, which was held in the apartment of the Banco Hipotecario; it was meant to be a general one; however, present were only: Manuel Pardo, Nicolas Rodrigo, Francisco Sagastebeytia, José de la Riva Agüero, and myself, the five provisional Directors; further, young Gallagher representing his father the Doctor, Graña, Dr. Sandoval, Francisco Bohorquez, a miner of the Cerro, and José Jimenez, a rich cholo who had made his fortune by usury. These individuals represented more than half of the capital hitherto subscribed, and we therefore proceeded to business. Riva-Agüero read the statutes originally drawn out by Sagastabeytia and corrected by the Directors; they were approved with some trifling modifications suggested by Bohorquez and Jimenez. This over, the provisional directors were re-elected; it was past four when I got home and found my wife as well as in the morning. Towards evening she commenced complaining of heat, which increased into fever, and lasted as I was told on

Tuesday, $19^{\text {th }}$ till One O'clock when she had to take some drops of laudanum to make her sleep. This morning she was by far not so well as she had been the previous morning, but improved in the course of the day, so much so that at the Doctor's earnest desi [...] to remove to Chorrillos without loss of time. I [...] [61] thither, accompanied by the servant to get everything arranged and cleaned, and on

Wednesday, $20^{\text {th }}$ of January at 10 O'clock we followed him, which was done with much more facility than I had anticipated. Mariquita was carried down stairs in a chair to the carriage, which drove very slowly to the Chorrillos 
Railway Station; there Manuel Velarde expected her again with an arm-chair, in which she was conveyed to a railway carriage, which I had engaged exclusively for ourselves, and which was occupied by my wife, Enriqueta, Guillermo, Dr. Middendorf, a certain Doña Trinidad whom we took with us to render any assistance required, myself, and the servant Juan. On the previous evening our excellent black servant woman Peta fell suddenly ill of bronquitis and had therefore to be left behind in Lima. On our arrival in Chorrillos again an armchair was waiting for Mariquita at the terminus, and when she sat down on the sofa in our rancho, she was by no means so tired as I had apprehended; she was of course much agitated, and Dr. Middendorf ordered her to bed with the least possible delay. The bed had been placed in the large saloon for the benefit of the fresh air; nevertheless, the heat was very oppresive, and this was the only thing my wife complained of; fever, fortunately, she had none. For me it was a very dull day; I had not the slightest occupation, and the glaring sun did not allow me to go out of doors. I took a bath at 4.30 which was excellent. We then dined; Middendorf had again come from Lima and joined us. Mariquita continued comparatively speaking well till 8 O'clock, when I left and returned per train to Lima; here I called on Doña Goya, Manuel Velarde's wife, and Gregorio Paz-Soldan, and by 10 was in bed and asleep.

The change which my house presented was striking; on the preceding evenings all the rooms had been open and lit up; Enriqueta, Doña Goya, the servant women, some friends, especially the family of the Prada's, were busy in the inner apartments, whilst the cuadra and corredor were filled with the nearest relations, who were anxiously awaiting advices regarding the patient's health; then Dr. Middendorf came, and [_] with us for some time, visitors came, Dolores Puente, Mrs. Berg [...] the Morales, Doña Rosalia Delgado de Garcia [...] [62] and others, and all had to be attended to; thus seldom did I get to bed, or rather to my sofa, before midnight, or 1 O'clock in the morning. Now it was quite the reverse, all quiet, none at home except myself and the servants; Peta in bed, nursed by another negress, the washer-woman Isabel.

Thursday, $27^{\text {st }}$ of January 1869 . I had arranged with Enriqueta that she should send me a telegram, if there was the slightest change for the worse in Mariquita's health, and as I did not receive any in the course of the day I felt quite happy. At 5 I went to Chorrillos per train, dined there together with Middendorf and returned at 8 O'clock accompanied by Enriqueta, who ventured to leave her mother for a few hours to the care of a good nurse, the black girl Virginia. It was astonishing how much good the few hours residence in Chorrillos had already done my wife; she began to recover her strength, and had appetite.

Friday, $22^{\text {nd }}$ of January. Enriqueta returned to her mother; I remained in Lima and in the evening whilst losing a game of chess to Limpricht, the Doctor 
entered with the good news that my wife was progressing quite as well as, if not better, than he had expected.

In the course of the day the Shareholders of the South American Insurance Company - in which I held 20 shares of \$10oo each - met. The Directory communicated to them the state of the Company's affairs, when it was unanimously resolved that for last year no dividend could be paid, and the small balance of $\$ 28$, ooo to the credit of Profit and Loss be carried to Reserve Fund. The losses incurred both upon sea and fire risk had absorbed not only all the premiums gained, but also a considerable part of the interest made on loans. The Reserve Fund now came up to $\$ 100,000$ and the paid up capital was $10 \%$ upon $\$ 2,000,000$ or $\$ 200$, ooo.

Saturday, $23^{\text {rd }}$ of January. Before breakfast, which meal, as well as dinner, I took at Garland's when in town, I ascended San Cristoval, but did so with less ease than formerly; the anxiety about my wife had no doubt pulled me down a little. In the evening I went to Chorrillos.

Sunday, $24^{\text {th }}$ of January. I bathed twice in the course of the [...] was getting on well, but had too many visits [...] [63] Doctor was by no means pleased with, for they excited her spirits, whilst he prescribed rest.

Monday, $25^{\text {th }}$ ofJanuary 1869 . My law-suit was not to be lost sight of; and thus this day I called upon Dr. Alvarez, whom I did not find in, but had a long talk with his insignificant and good-natured wife Doña Mariquita. Next, on Dr. José Luis Gomez Sanchez, who was particularly polite: "tell Doña Mariquita", he said, "not to trouble herself about the lawsuit, her friends will take care of that."

Tuesday, $26^{\text {th }}$. A general meeting of Shareholders in the Pasco Railway Coy. was convoked, but on my going to the Banco Hipotecario I found there more or less the same as on the $18^{\text {th }}$. The contract with Wyman \& Harrison, the original concessionists, was read aloud and approved with trifling alterations. On the proceedings of the provisional Directory, of which an account was given, no observation was made. It was further resolved that two calls should be made on the shareholders of $10 \%$ each on the subscribed capital, the one payable on the $28^{\text {th }}$ February, the other on the $14^{\text {th }}$ March.

Thursday, $28^{\text {th }}$. The Congress closed its sittings, and on

Friday, $29^{\text {th }}$ the "Comision Permanente" was installed. Rafael Velarde, though protected by the Government, had not had the good fortune to be elected one of its members; Dr. Manuel Arenas was its President, Evaristo Gomez-Sanchez, Pezet's ex-minister, Vice.

Saturday, $30^{\text {th }}$. In the forenoon of this day I attended a meeting of shareholders in the Chancay Railway Company, which was held in the Exchange Rooms in the Consulado building. A great many persons were present, amongst whom three lawyers: Dr. Palacios, Dr. Aranivar, and Dr. Pasapera, and there was so 
much disputing, so much discussing, so much talking, that I, accustomed to the quiet manner in which business was transacted in the Pasco Railway Company's and South American Insurance Company's meetings, soon left the room disgusted with what I had witnessed.

I have said a few pages back that Mariano Osma had been found guilty of forging the signature of Pedro Paz-Soldan; soon after [_] was declared insolvent by the Consulado, and Gaspar Puente, whose [...] to be found in the genealogical table in appendix $\mathrm{N}^{\circ}[\ldots]$ [64] was, much against his will, named "Depositario", and directed not to make any payments to said Mariano Osma, whereupon, whilst Don Gaspar was quietly walking the street on the afternoon of this day, Osma, unaware came upon him from behind, gave him heavy blows on the back with a big stick and inflicted a deep wound just above the left eye, from which the blood gushed forth. Don Gaspar drew a revolver and fired into the air; further mischief was prevented by the interference of Dr. Rosas who accidentally passed by. Don Gaspar was carried into the house of Don Manuel Pardo, who occupied the ground floor, whilst Osma, married to one of Pardo's sisters, took refuge with his mother in the first story of the same house.

Sunday, $33^{\text {st }}$ of January. This day I remained in Chorrillos, and bathed as I was in the habit of doing. Amongst other calls I made one upon Don Vicente Gonzales, my fellow passenger on board the "Vicar of Bray" in 1843. He was not in, having gone to the North to look after the valuable property he there possessed, but his wife Emilia, one of the daughters of Luis Orbegoso - for a few years President of Perú - who, to educate her daughters, had with the whole family been for many years in Europe, was at home, and I found her to be a particularly agreeable lady. Within the last few days my wife's health had considerably improved, and she herself felt a notable increase in strength.

Advices were received that near a place called Angostura, the Paraguayos had been totally defeated by the overwhelming forces of the allied enemies, who had entered, plundered, and sacked the Capital Asuncion, which it was said they had found without inhabitants. Lopez, the President of the Paraguayos, had fled to the mountainous part of the country. The steamer "Arica", belonging to the English Company, had run aground at the entrance of the Port of Pacasmayo; the vessel was totally lost, but the passengers and part of the cargo were saved. In a hacienda near Guadalupe a Chinese labourer, who had been reprimanded on the previous day, slew in the depth of night his master (a certain Vera), the wife, four children, of which the youngest was an infant still in the cradle, and one other member of the family; he made use of an axe to perpetrate his murderous deed, which bei [...] the street door to 
two free Chinamen, robbed al [...] [65] worth, mounted his master's horse and made his escape.

In the "Nacional" of Saturday the $29^{\text {th }}$ the late ex-minister Garcia Urrutia, who died some time ago in Europe, was spoken of in rather offensive terms, which so much inflamed the ire of one of his sons, resident in Lima, that he this day entered the office where Rafael Vial - one of the editors of the said paper - was quietly writing, took up a heavy glass inkstand, threw it into his face, broke his nose, and left him covered with blood and ink.

Monday, $7^{\text {st }}$ of February 1869. Again one of the Garcia Urrutias went to the printing-office of the "Nacional", apparently for the purpose of entering into an altercation with the other editor Pazos, but this time he fared badly; the employés fell upon him, gave him a good thrashing, and turned him out.

In the course of the forenoon I called upon Gaspar Puente to enquire how he felt; he was in bed, with his face bandaged, but, asfar as I could judge, by no means desperately wounded. Many people were with him, with whom I was not acquainted, and I therefore remained but a few minutes.

Tuesday, $2^{\text {nd }}$ of February. Candlemas. I spent in Chorrillos.

Wednesday, $3^{r d}$. For the first time Mr. Charles Duval, a Frenchman, came to me to serve as lector and secretary. I had become acquainted with him some time previously when Mejer, then my secretary, introduced him to read when he himself was otherwise occupied. Since Graham's leaving, my nephew Johannes Limpricht had written for me my original diary; he also came to me now and then in the evening to play a game of chess; he was an opponent who gave me much trouble, not so a certain Tomas Solar y Reyes, a Chilian, with whom I played a game or so in Chorrillos and whom I had met in the house of Dr. Pedro Carbajal, one of whose daughters he had married. This gentleman, the Doctor, and his family were at the time in a pitiful situation; he, when Vocal of the Superior Court in Tacna had been an active partizan of Col. Prado, who, to recompense his services, promoted him to the Superior Court of Justice in Lima, but when Prado fell, Carbajal also came to the ground. He lost his place in the Superior Court and, notwithstanding all his efforts, could not obtain another permanent post. Provisionally, he was employed in a commission formed to fix the amount of the claims made [_] Callao shop and storekeepers for the losses sustained on the $6^{\text {th }}$ No [...] Vol. 6 page 710 - and whilst this lasted he was [...] [66] ments, but as soon as it had done its work, he would again be without any income; he had opened his study as lawyer, but not one litigant had come near him. His and his wife's small property in Arequipa had been much injured by the earthquake; of all his grown-up daughters only one was married to the said Solar; his son Pedro was consumptive and had had to 
go to the Sierra; one of his daughters, Enriqueta, died suddenly in January 1868, having, as it was suspected, poisoned herself, and now, to fill up the measure, the youngest, Manuela, had turned crazy and been placed under the care of Dr. Ulloa. What an accumulation of misfortunes!

I mentioned in December of last year that Dr. Palacios then did his utmost to prevent the autos in my lawsuit being sent up to Dr. Ureta for his Vista-fiscal; we attained our object, and I expected that in January immediately after the "Punto" they would have been remitted to Dr. J. G. Paz-Soldan; but Dr. Aranivar was as wide awake as we, he gave in escrito after escrito, and succeeded in delaying the transmission until the month of February, when without fail the autos would fall into the hands of Ureta, from whom I expected no favourable Vista.

In the Republic of Ecuador Dr. Don Gabriel Garcia Moreno had brought about a sudden and unexpected revolution; the previous President was turned out, and on the $17^{\text {th }}$ January Garcia Moreno proclaimed in Quito provisional President; on the $20^{\text {th }}$ he was already in Guayaquil, where the Guayaquileños followed the example given them by the Quiteños. Several influential persons known to be opposed to Garcia Moreno were arrested, and sent out of the country.

From Sunday, $7^{\text {th }}$ to Sunday, $28^{\text {th }}$ of February. Partly for the sake of change, partly in order to escape the carnival hubbub in Chorrillos, my wife resolved to pass a short time in Lima; she however did not return to her own house Calle del Correo, for we feared that owing to our bedrooms being rather confined, the oppressive heat in the present season might retard her complete convalescence, but to Enriqueta's apartments No 96 Calle de Zarate, where a large saloon was placed at her disposal. I also took my meals at the Garlands, but otherwise I spent the day [...] slept in my own house. Mr. Duval came to me with [...] [67] and I had every reason to be satisfied with him. On Sunday the $7^{\text {th }}$, first Carnival day, Dr. Jervacio Alvarez of the Supreme Court, and the Fiscal, Dr. José Gregorio Paz-Soldan called upon my wife, and when speaking about the law-suit against the Sotomayors, expressed themselves in a manner which gave my wife great hopes of a favourable issue. This day I for the first time met at Enriqueta's dinner-table a Franciscan Friar Zapata, who many years ago had been chaplain to my wife's father, Col Sierra, on his estate in the valley of Majes; he was apparently good-natured, but beyond measure stupid and ignorant, and it really grieved me to see such a man invested with the Sacerdotal dignity.

On Monday the $8^{\text {th }}$ I climbed up San Cristoval, but again experienced great difficulty in accomplishing the ascent, so weak did I feel. By and by I picked up my strength, and day after day I ascended before breakfast; once I did it even 
three times consecutively. On my return home, I was in the habit of lying down on my bed for about half an hour, before going to Garland's.

Towards the end of the month, I ceased my early excursions for the environs of Lima were swarming with robbers; on the $8^{\text {th }}$ a gang of them attacked and plundered a house and shop in the Alameda del Acho, killed, if the papers might be believed, four policemen, and then made off to the Cerro de San Cristoval with their booty. On Thursday $11^{\text {th }}$ the shareholders in the Banco Hipotecario met, when everything done by the Directors and the manager Don José de la Riva Agüero was approved, the latter informed the meeting that though the law given by the Dictator Prado at the time of the foundation of the bank to the effect that immovable property might be sold by public sale for one half of its estimated value instead of $2 / 3^{\text {rds }}$ as until then, had been confirmed by the Chamber of Deputies and the Senate, yet it was very doubtful whether the Executive would put its "cúmplase" upon it, for the President Balta, who - be it said on passant - had not a single idea of his own, had been made to believe that the gains made by the new bank were extravagant, and that therefore no favor should be done to them.

In Lima and its immediate vicinity, the yellow-fever hardly showed $[. .$.$] this$ year; at all events only a few cases had come to my knowledge $[. .$.$] hand in the$ intermediate ports such as Islay, Arica [...] [68] Iquique and Pisagua, deaths were frequent; I learned from Garland that in Gildemeisters establishment in the last named port not less than six persons had died of the epidemic.

A few pages back I gave an account of a terrible murder committed by a Chinaman in the neighbourhood of the town of Guadalupe; he was discovered by the police, and when about being carried to prison the populace threw itself upon the feeble guard, overpowered the same, and got the Chinaman into their own hands; they wetted him all over with spirit of turpentine, threw him into a blazing fire from which he managed to escape, was again overtaken, again thrown into the fire, and consumed to ashes.

The Steamer "Santiago", belonging to the P.S.N. Coy., which had left Valparaiso for Liverpool, was wrecked on the $25^{\text {th }}$ January in the Straits of Magellan, on a hitherto unknown rock. Two sailors and a boy were lost; the remainder of the crew and all the passengers were saved by the British Manof-war "Nassau", which took them to Montevideo. On the last Carnival day, the $9^{\text {th }}$ inst., when Col. Narciso Arestegui, Prefect of Puno, and some friends, were taking a pleasure-trip upon the lake "Titicaca", through the imprudence of some one on board who was probably tipsy, the launch was upset; six of the party were drowned amongst whom the Prefect, seven were saved.

On the $25^{\text {th }}$ December last President Johnson of the United States published a general amnesty in which of course Jefferson Davis, the ex-President of the 
Southern Confederation, and his Ministers were included. St. Thomas, after all, was not to be sold to the United States; the Danish Government had insisted upon the suffrages of the inhabitants of the Island in favor of the sale being a sine qua non condition in the treaty; and now it appeared that the St. Thomas people were adverse to the transfer.

The representative of the Suez Canal in London, M. Daniel Longe, had made known that on the $1^{\text {st }}$ October 1869 said canal would be opened to vessels of all nations, at which time its depth would be 26 feet, its breadth at the bottom 74 on the surface 328 .

About this time a company of Chinese Actors arrived from San Francisco; not far from the convent of Santa Clara they obt [...] house in which they were to perform. The only reason why I $[\ldots]$ this event was to show how the Chinese population [...] [69] in Lima, for these actors would not have come hither, if they were not certain of a numerous and paying audience.

I received a letter from my friend Henry Sieveking of Altona, who communicated to me the death of his cousin Mr. Edward Sieveking of London; the date he did not give. Mr. Edward Sieveking was my Senior by at least 10 years, for when I was with Gibbs in 1823 and 1824, Henry was clerk in his counting house. He, a native of Hamburg, was a very agreeable, clever, and well educated man; all his life time he had been engaged in mercantile pursuits and never succeeded in making a fortune; he was first in partnership with Mr. Kock, also from Hamburg. When they separated, he carried on business on his own account, and when I was in London in 1844, I became acquainted with him through the recommendation of his cousin in Altona. In 1851 when I was in London, together with Mr. Schutte, and we were in search of houses ready to open as a blank credit, Mr. Sieveking - then Edward Sieveking and Son - had no objection to render us this service. The crisis of 1857 upset him; our drafts on the firm were taken up by Cotesworth \& Powell, and the wool, against which these bills were drawn, having been made over to the last mentioned firm we escaped without loss. After this misfortune Mr. Sieveking and his son Gustavus joined a young man, Mr. Droop, who gave his money, they their experience, and once more they launched on the sea of mercantile enterprize. How they fared I do not know, but what I know is that Mr. Edward Sieveking, after the loss of his dearly beloved wife, the daughter of Senator Meyer, did not again lift up his head, and in a few years followed her to the grave.

From Monday, st $^{\text {st }}$ to Thursday, $11^{\text {th }}$ of March 1869. In the first days of the month, Mariquita and I, who had been taught by the experience made on the $11^{\text {th }}$ January - see page 57 - that one should always be prepared for the last hour, both in spiritual and temporal matters, resolved to have our testaments drawn out without loss of time, and accordingly I spent several 
evenings in the office of my lawyer Dr. Palacios, who wrote them [...] self both in rough and the clean copies, besides which he wrote [...] two escrituras in virtue of which Mariquita [...] [70] the house Calle del Correo for $\$ 35,000$ and I to Enriqueta that Calle de Zarate for $\$ 80,000$. They giving us cartas de pago, or receipts, drawn out before a notary for the said sums as having been paid them by me on account of the inheritance which some day or other would fall to their share after my wife's decease.

On the $8^{\text {th }}$ my wife left Enriqueta's house, but instead of returning to Chorrillos, as we at first intended to do, we removed to our quarters in the house Calle del Correo, where for the present our salita or parlor continued to be used as Mariquita's bedroom, whilst that formerly hers was now mine. The Fiscal, Dr. Ureta, gave - as I had expected - his Vista against me, contenting himself with a mere confirmation of the sentence of the Superior Court, without giving any reason why. Dr. José Gregorio Paz-Soldan assured us that he had done his utmost to influence his colleague, but without having succeeded in altering the opinion he had formed.

Rafael Velarde was named "Visitador" of all the Custom-Houses in Perú and began with looking into the affairs of that of Callao. In its proper place, I have stated that Andrés Alvarez Calderon obtained from General Castilla when at the helm, the contract for loading the guano vessels at the Chincha Islands, at the rate of $83 / 4$ rials the ton of guano actually landed; his contract having expired not long ago the loading was publicly put up for competition, and Don Pablo Vivero jointly with several others secured it for $81 / 2$ rials the ton; accordingly, they came to terms with Alvarez Calderon of whom they bought all the stock on hand, such as Chinese labourers, rails, launches, machinery, shoots, etc: for the enormous sum of $\$ 450$, ooo less $15 \%$, for which proportion Alvarez Calderon retained an interest in the contract.

Of course, these new contractors considered they had now secured the business, when all of a sudden Augusto Althaus came forward and offered to load the vessels at a still cheaper rate; however, within a few days his competition was silenced, the new contractors allowing him an interest of $5 \%$.

After long negotiations with the new finance Minister Nico [...] Pierola, the Guano consignees were about this time on the point $[\ldots]$ a new loan to the Government an [...] [71] 7.500,000 Soles - interest on the outlay to be $5 \%$, commission for drawing $1 / 2 \mathrm{~d}$ per sol, and the exchange at which the advance was to be credited them $45 \mathrm{~d}$.

On the $24^{\text {th }}$ February Valparaiso had been desolated by a great conflagration; many stores and dwelling houses were destroyed and many known names, such as Alsop \& Co., Schutte Drost \& Co., Belloc, Prieto, Ossa, Graham Rowe, and others were found among the sufferers. 
Three of the firemen, two young Englishmen and one Chilian, lost their lives; also a French sailor was taken on board a French man-of-war with both legs broken.

From Europe there was no news of particular importance; in Spain everything was still in an unsettled state. For some time fears were entertained of a war between Turkey and Greece, but the great powers had interfered, and probably the differences would be settled. In the Island of Cuba a rising had taken place against the Spanish authorities and blood had been shed.

Six months ago, Lembcke had spoken to me about a new bank which he and Zaracondegui thought of establishing; I then told him that I would certainly take a share in it; for a long time the plan had remained in abeyance, but suddenly it had revived, and Lembcke had obtained many signatures. At the same time, the Banco del Perú, of which Emilio Althaus and Miceno Espantoso were the managers, endeavoured to crush the new establishment by increasing their own capital to 4,000,000 Soles and issuing new shares which they succeeded in disposing of at an enormous premium say $\$ 25,000$ on a capital of 60,000 paid up; they were very desirous that I should take a share and urged me through Juan to do so; for some time I felt inclined, but at last I preferred to enter with Lembcke, to the great annoyance of Althaus and Espantoso whilst Juan invested a considerable proportion of his fortune in the old bank, that del Perú, paying the enormous premium just mentioned.

On the $11^{\text {th }}$ I was present at a banquet given by the President in the palace. Together with Garland, who was invited as guano consignee, I went there at somewhat before six, dressed not in [_]iform, but in black, with my Dannebrog cross affixed. [...] President his brother the Minister of War [...] [72] Minister for Foreign Affairs, all in black, received us, who were of the first who arrived; by and by the saloon filled, and I suppose it was about 7 when we removed to the dining hall, where a very long narrow table was laid out. The President Don José Balta took his seat in the centre; opposite to him Barrenechea, next to them the Diplomatic agents and the Peruvian Ministers; my seat was the $4^{\text {th }}$ or $5^{\text {th }}$ to the left of the President. To my right I had the well known ex-President of New Granada, General Cipriano Tomás Mosquera, next to him Godoy, the Chilian Minister; to my left José Vicente Oyague, Belgian Consul General; then Edward Müller, Belgian Vice Consul. Opposite to me sat Lembcke and Brauns, respectively Swedish and Norwegian, and Austrian Consul General, the latter creating great sensation with his bran new scarlet uniform. To enumerate all present is impossible; I neither knew, nor recollected them. Besides the Diplomatic and Consular Corps there were the French Admiral Clouet of the "Astrée" with his suite, some Peruvian military men, the Guano consignees, and several private gentlemen, such as Manuel Pardo, José de la Riva 
Agüero, Manuel Villate, Juan Ugarte, and others. The dinner was sumptuous, as it always was on such occasions. I ate very little and drank less. Oyague got in the wind, as it was always his custom; but with General Mosquera I had a good deal of talk; I brought to his recollection that I had seen him in Santiago in December 1842, in the house of Mr. Hunnäus - see page 827 Vol. I - and I was rather surprised that such a great man, as Mosquera certainly was in the annals of South American politics, should have been so communicative, for he spoke to me about his family, his property, his campaigns, his medals, the sword of honour presented to him, the probability of his being re-elected President of the United States of Colombia etc.; he even made me put my finger to his jaw-bone in order that I might touch the hole which whilst fighting near Barbacoas in 1824 a Spanish bullet had made, passing right through from one side to the other, and slightly wounding the under part of his tongue. At about 9 O'clock [_] President gave a toast to the welfare of the countries repre [...] [73] Minister replied, upon which Barrenechea got up and spoke a few words, all rose, I took my hat, and unperceived was about the first who left the apartment, and went to Garland's where as said above on Thursday evenings some friends were in the habit of meeting to play rocambor. I was in bed before 11 .

From Friday, $12^{\text {th }}$ to Wednesday, $37^{\text {st }}$ of March 1869. The "Comercio" of Saturday the $13^{\text {th }}$ contained a decree which caused great surprise, and at the same time much satisfaction. All the employés in the Callao Customhouse, except the Vista Pedro Astete, believed to be an honest man, had been discharged. This was the work of the Visitador Rafael Velarde, but such a sweeping measure he could not have taken without the consent of the President. Hopes were now entertained that the contraband which of late had been carried on to a frightful extent would be put a stop to. Friday the $19^{\text {th }}$ was the Dia de Dolores and San José, which accidentally fell this year on the same day. I called upon Dolores Puente and several Josés and Josefas, also on the President José Balta, who however was not in having gone to the Alameda de Acho where the foundation stone was being laid to a new iron bridge, which by contract Don Enrique Armero had bound himself to construct within twenty months from the Barranca, a spot on the left side of the river, a little higher up than the convent of San Francisco, across the river to the oval between the two Alamedas de Acho. Besides the President, a number of persons had been invited to this solemnity to whom Armero gave a lunch in the public-house called the Tivoli, kept by a German Bocklemann. The price which Armero was to receive for the work was 300,000 Soles in monthly instalments of $S / 15,000$, and it was calculated that besides the handsome sum which Armero in all probability had paid to Pedro Galvez, Minister for the Interior, he would make 
a large profit on his contract. In the Municipality there existed an estimate drawn out by a French engineer towards the end of Prado's administration, who proposed to make a stone bridge on the same spot for $\mathrm{S} / 110,000$. In the evening I went with Enrique and Guillermo Garland to see the equestrian [...] [74] erected in the large public garden, called "de la Aurora"; though I had a seat as near the Circus as possible, I could not distinguish anything, and I left at 9.30, when half the performance was over, to fetch my wife and Enriqueta from Dolores Puente with whoms they had spent the evening.

The subscription to the new bank progressed in a manner which by far surpassed my expectation; 100 shares of 40,000 dollars were issued, and there were not a few, I amongst them, who subscribed for two shares. The first $11 / 2 \%$ deposit was to be paid in ere long. Notwithstanding the favourable idea entertained of this new establishment, I for my part was at a loss to conceive how so many banks, now four in number - the Providencia, London \& Mexico, Perú, and the new one de Lima - could do a business large enough to ensure a fair dividend.

The yellow fever had not yet entirely subsided. In Lima and Callao we had occasionally one case or the other; as for instance the wife and a daughter of Pedro Balta, Prefect of Lima and brother of the President, and Montero, talented Peruvian artist, for whose picture "The Funerals of Atahualpa", the Government had paid him $\$ 25,000$ besides gracing him with a gold medal. He was on the point of returning to Europe to continue his studies when death overtook him. On the Coast between Callao and Valparaiso many fell victims to the epidemic. I may mention Juanita, daughter of James Gibson and married to Jefferson, Port Agent in Arica, sister of Anita, who in 1854 was the first who had been carried off in Lima by this disease, then not yet known by the medical men to be the fatal yellow-fever. Also Edward Harmsen, son-inlaw of William Harmsen, of which latter gentleman I may say a few words on this occasion. About $183^{1}$ or $32 \mathrm{Mr}$. C. W. Schutte begged of me to procure him a good clerk; accordingly, I wrote to my friend Sieveking of Altona, who immediately sent out a young man, said William Harmsen, a native of Hamburg. On his arrival he made himself very useful; he knew of mercantile affairs more than his principal; he was more sagacious, and to say the tru [...] cunning; when in $1838 \mathrm{C}$. W. Schutte stopped payment [...] lished himself on his own account in [...] [75] married Dolores Averasturi, a nice young lady, Mrs. Schutte's particular friend, and not without money. Harmsen began in a small way receiving trifling consignments from Chile; gradually manufactured goods came consigned to him from Europe; he entered largely into the purchase of sheep and Alpaca wool, and in the course of a few years raised his house to 
a high standing in the Arequipa Mercantile World. It was affirmed that he had made much money by a traffic which was certainly not legitimate; the Bolivian four rial pieces were then the only coin circulating in Arequipa and everybody knew that their intrinsic value was much less than that of the Spanish dollar, which two of them represented. Harmsen received considerable quantities of this coin from the United States in barrels which apparently contained nails, put them into circulation, and consequently made a profit which in truth corresponded to the Government, whilst the public did not suffer, for Harmsen's four rial pieces were of as good a standard as those coined in Potosi. Not long before his death he called to Arequipa a nephew of his, Edward, then in Valparaiso, and gave him in marriage his eldest daughter Elizabeth. After his decease, which event I have chronicled in this diary, Edward quarrelled with his father-in-law's partner Möller, and carried on the business, but it was soon seen that the head of William Harmsen was wanting, and quickly did the firm lose its former credit. Some years later he and an Englishman, Mr. Pickering, were the original promoters of a railway to be constructed between Arequipa and the Coast. Harmsen obtained the concession from the Government, and provided with a copy of the contract Pickering started for England, where he flattered himself he would find no difficulty to form a company and to procure the money required. However, he succeeded neither in the one nor the other and, if I mistake not, did not even return to Perú. Under these circumstances it was a fortunate thing for the family of Harmsen that when Mr. Henry Meiggs took this railway on hand, he stood in need of the plans, the drawing out of which had cost Harmsen a considerable sum of money, and agreed to pay for them $\$ 100,000$. He also engaged him as his agent [_] Arequipa, and as such he went to Islay, where as already said [...] victim to the epidemic. [76]

On the $28^{\text {th }}$, Easter Sunday, the whole family of the Garlands and Adolfo Alvarez were with us at dinner; at a later hour came Rafael Velarde, his wife Josefa, and daughter Zoyla, also Manuel with Goya and Adela. There could be no great amusement, and I was glad when my wife and I were again by ourselves at 11 p.m. On Easter Monday I went to Chorrillos, bathed, breakfasted with Juan, who occupied our rancho. With us were Manuel Costas, Bonifaz, oficial-mayor of the finance ministry, and José Maria Peña. Somewhat later I made several calls; amongst others upon Mr. Brauns, who had built a very pretty house on the site of the old rancho, which I had sold him some time back. His wife, the handsome Carmen Becherel, did not show herself, and we thus sat down to a game of chess, which I gained. From Brauns' I went to J. A. Ribeyro, Vocal of the Supreme Court, which visit had been the principal object of my going down. 
The suit against the Sotomayors was pending in the Supreme Court; Ribeyro, Gomez-Sanchez, Muñoz and Alvarez were desirous that it should be decided erelong - at least so they said - whilst Dr. Mariategui, the President of the Tribunal, delayed it from day to day, at present under the pretence that Dr. Miguel Carpio's presence was required, and this Vocal - it is true - had been ill for at least a month, and was not likely soon to recover.

A new Municipality had formed itself in Lima, the members of which named for its chief, or Alcalde, Don Manuel Pardo.

A Convention had been concluded between the United States of Columbia (formerly New Granada) and the Government of the United States, for the cutting of a canal through the Isthmus of Panamá; the latter were to do the work, the canal to be their property as well as a tract of land 6 miles in width on each side: the New Granada Government was to receive part of the clear profits. The cost was estimated at one hundred million dollars, but as the preliminary studies had not been commenced, my opinion was that this was a mere guess.

Monday, $5^{\text {th }}$ of April 1869. My suit against the Sotomayors at last came on. It was my lawyer's turn to plead first, but whilst he did so, the President Mariategui gave such evident proofs of displeasure and pulled out his watch so frequently that Dr. Palacios [...] was on this occasion nearly disconcerted [...] [77] some of Mariategui's colleagues told me that they had noted his undisguised partiality.

Tuesday, $6^{\text {th }}$ of April 1869. Aranivar pleaded for the Sotomayors, but began so early and spoke so little that when Dr. Palacios and I entered the Court, he had already concluded his discourse. I need hardly say that all this time my wife and myself were in a state of continual agitation.

We learned from our relations in Paris that Corina, though thin as a skeleton was gradually getting the better of the overwhelming grief felt at the loss of her husband, and that Amalia, also thin and suffering from a slight cough, was otherwise in good health and recovering her fine complexion. Mr. Schutte had rented in an hotel Rue Presbourg, outside of l'arc de l'Etoile, two stories and a half, which they had furnished with elegance; also in other respects they were living in style.

The news from the United States was that General Ulisses S. Grant had taken his oath as President of the United States on the $4^{\text {th }}$ of March. When forming his Cabinet, he called to the Finances Mr. Stewart, owner of large stores of manufactured articles in New York, an Irishman by birth, more than 70 years of age, and of enormous wealth; however, as the laws of the United States do not allow an importer to be Minister of Finances, the President had 
to annul his nomination, and entrusted the Finance Ministry to Mr. Boutwell of Massachussets, a decided Protectionist.

Monday, $12^{\text {th }}$ of April. Juan came in from Chorrillos.

Tuesday, $13^{\text {th }}$ of April. At the farewell dinner we had with us the family Garland and J. P. Escobar, partner of Ruden in Payta, an acquaintance of Garland, and Juan.

Wednesday, $14^{\text {th }}$. By the 8 O'clock train Garland, his two eldest sons, and I accompanied my son to Callao. Enrique and I went with him on board of the Steamer, gave him our last embrace, and returned by the 11 O'clock train. Juan was very sad; my wife and I much regretted his departure.

A very considerable number of the shareholders of the new Banc [...] Lima, as well as the two managers Julian Zaracondegui and [...] assembled at 2 p.m. in the house of the latter [...] [78] of electing the Directors. Manuel Salcedo, owner of the estate of Talambo, not easily to be forgotten for the outrages which were committed there, and which gave the Spaniards the pretext for the declaration of war in 1864, was the provisional President; Zuloaga and Boza the secretaries. The choice fell upon: John Renner, the rich Jew from Hamburg, with 88 votes, Manuel Argumaniz from Ica, who had taken an active share in the formation of the bank, myself, Juan de Dios Calderon, a respectable elderly man, Francisco Sagastabeytia, for many years clerk of Domingo Elias afterwards engaged in mining pursuits in the Cerro de Pasco and in every respect an honourable character - Juan Ugarte, a Spaniard, wealthy, and much respected, Valentin Gil, a man in the prime of life, who had made a fair fortune as Storekeeper in Bodegones, Gustave Heudebert, a Frenchman of the firm of Errequeta \& Heudebert, Manuel Ortiz de Villate, a miner from the Cerro, a clever and upright man - the votes in their favor varied from 84 to 82 - José Muro, belonging to the family of the Delgados of Lambayeque, sharp and cunning had 6o odd, and a certain Amancio Castillo, quite unknown to me, 40 odd.

Friday, $16^{\text {th }}$ of April. The eleven Directors and the two managers who were also Directors met again at Lembcke's. Manuel Argumaniz was elected President, I Vice President, and though I begged earnestly to be excused, my prayers were of no avail, and I had to accept the post. It was also resolved that by the steamer of the 28 inst. Argumaniz should start for the United States and Europe to get the notes engraved and to purchase all books and writing materials which he might consider necessary. The cost, estimated at $\$ 30,000$, he offered to defray himself, charging $1 \%$ upon the outlay until his return and reimbursement. A long debate ensued on the quantity and proportion of the notes which were to be ordered, and the following was at last decided upon: 


$\begin{array}{clll} & S / 1,000,000 & \text { in notes of } & 1 \text { Sol } \\ & S / 3,000,000 & \text { in notes of } & 4 \text { Sol } \\ & S / 2,000,000 & \text { in notes of } & 8 \text { Sol } \\ & S / 1,000,000 & \text { in notes of } & 20 \text { Sol } \\ & S / 1,000,000 & \text { in notes of } & 80 \text { Sol } \\ & S / 1,000,000 & \text { in notes of } & 400 \text { Sol } \\ \text { Total } & \text { S/9,000,000 } & & \end{array}$

which appeared to me too lar [...] [79] amount, but the general opinion was that as the plates formed the principal part of the expense, it would be advisable to have a superabundance of notes made at once. Muro was chosen Secretary; Zaracondegui, Sagastabeytia, and Villate were named to draw out the rules - statutes - of the bank.

Saturday, $17^{\text {th }}$ of April 1869. This days steamer brought warlike rumours from Europe. The Gaulois, a Paris paper, said that Napoleon had asked explanations from the Berlin Cabinet why in the Western provinces of Prussia the troops had been placed in a state of readiness. In France all officers and soldiers on furlough had been recalled, and 100,000 fresh conscripts been voted by the Legislative bodies.

Sunday, $18^{\text {th }}$ of April. In the course of the last week Pedro Galvez resigned his post as Minister of the Interior; his last act on Thursday was that of opening various proposals made for the construction of a railway from Lima to Pisco. The preference would probably be given either to that made by Antonio Salinas, or to that of Andrés Alvarez Calderon. Manuel Ferreyros, a Naval officer, was named as Galvez's successor.

This day I called upon Dr. Ribeyro for I knew that the Autos in my suit were in his possession, and that he intended to examine them carefully.

Monday, $19^{\text {th }}$ of April. My wife and Enriqueta called upon Mrs. Ribeyro and daughters. We knew that a great deal depended upon Dr. Ribeyro's opinion, and it was therefore of the last necessity to keep on the best terms with him. About this time a certain Dr. Flor, owner of the house, called that "de Aldavas" contiguous to mine 96 Zarate, pretended that he had a right to open a window into a yard behind the last of the shops gained from Varela, which he affirmed had only been temporarily blocked up. I insisted that he had no such right, but resolved to give way rather than again go to law about such a trifle.

Tuesday, $27^{\text {th }}$ of April. The new Municipality consisted of an unusual large number of persons called in by the Alcalde Manuel Pardo; even a German gardener Klug, who had the botanic gardens under his charge, was amongst them. In the papers appeared a clever document signed by Pardo which showed: Firstly, what were the improvements which the town of Lima [_] 
od most in need of; secondly, what the cost of these improvements wo [...]; thirdly, how much was the yearly income of the Municipality; [...] [80] were the annual expenses; and fithly how much was the deficit.

Rafael Velarde as Visitador was doing wonders; the income of the Callao Custom-house had much increased within the last few weeks; the dispatch of wheat had augmented four fold.

Rumours were afloat, though I did not believe them, that Melgarejo, President of Bolivia, threatened the Southern Departments of Perú with an invasion. It was also said that the notorious Lizardo Montero had made an attempt to bring about a revolution on board the "Huascar" anchored in Chorrillos Bay, but had failed.

Friday, $30^{\text {th }}$ of April. In the course of the month the yellow-fever had gradually decreased. In the first fortnight or so we still heard of some people having died of the same, as for instance two individuals of Chiarini's equestrian Company; also in the intermediate ports it had carried off a few, but now at the end of the month we might say that it had entirely disappeared, and I was in hopes that henceforth it would be no more necessary for me to notice it.

In my usual way of living there was no change. I took my walk in the morning, but did not climb up the Cerro. More than once my presence was required at the meetings of the Directory of the Banco de Lima, and in the evening Limpricht came pretty often to play a game at chess; of late I had lost more games than formerly.

Saturday, $7^{\text {st }}$ of May. During the last two months, Mr. Duval under my direction had been occupied with writing up my commercial books till the $28^{\text {th }}$ February and balancing them on said date, on which I was in the habit of closing my mercantile year. The result was satisfactory; I was able to add $\$ 38$,ooo to Stock Account. The principal item to the credit of Profit and Loss consisted in $\$ 37,000$ credited me by the extinct firm of H. W. \& S. for interest on money lent them by me; the largest amount to the debit was that of $\$ 9000$ for house-keeping expenses.

Sunday, $2^{\text {nd }}$ and Monday, $3^{\text {rd }}$ of May. Civic holidays, which passed over here in Lima in a very quiet manner. On the $2^{\text {nd }}$, the third anniversary of the repulse of the Spaniards from Callao, rockets were let off $[\ldots]$ in the evening there were fireworks in the [...]. [81] In Callao the bust of José Galvez, Minister for War, who on the $2^{\text {nd }}$ May 1866 was killed by an explosion in the turret of Santa Rosa, was solemnly uncovered. On the $3^{\text {rd I }}$ was present at about 2 O'clock in the house of the Vocal Ribeyro at a raffle, which his wife and daughters had got up to defray part of the expenses, which they would have to incur in the course of the month in celebrating some religious festivities in the Church del Sagrario, of which Doña Eulalia had been named the patroness, and situated 
as we were at the time, with regard to the Doctor, my wife, and Enriqueta, had been obliged to take some tickets. Hardly had I entered the room when the Doctor came up to me, saying that within a few days my case against the Sotomayors would certainly be decided.

From Juan we had letters from Colon where he had gone on board the "Seine" and been well accommodated. The small-pox was at the time raging in Panama, for which reason he had gone right through to the Atlantic side. Some alteration had been introduced in the route of the steamers; before entering Southampton they would touch at Plymonth and Cherbourg.

From the papers I gleaned the following: The Austrian and Bavarian Governments had granted many furloughs, which seemed to prove that the warlike rumours of which I spoke a fortnight back had little foundation. Mr. Gladstone, the new Prime Minister in the United Kingdom, was proceeding gradually and steadily with the disestablishment of the Anglican Church in Ireland.

A splendid ironclad monitor, the "Captain", had been launched from the dockyard of Laird \& Co. Liverpool; she measured 4200 tons register, and was put in motion by twin screws; the boilers were heated by 28 furnaces; she carried on deck two turrets, each provided with two six-hundred pounders, on the poop and prow one, one-hundred and fifty-pounder. She was built of teak with a thick iron sheathing and another iron skin inside. In the construction of muskets great improvements had been introduced of late; in the Crimean War the muskets used by the English Infantry reached 9o, the carabines 200 yards; the Enfields now [_] use reached 1200 yards. In the war against the Caffres, seve [...] it was calculated that 85,000 shots were [...] [82] 25 men; on the PrussianAustrian war entire battalions were said to have been overthrown by one single discharge from the needle-guns.

The debt of the United States amounted more or less to 2,500,000,000 hard dollars; the import duties collected in the course of a week at several of the principal ports, including San Francisco in California, came to 51/2 million dollars. The population of the United States in 1860 was $31,000,000$, now 38,000,000.

It will be remembered that $M$. Achilles Allier, a respectable and well educated Frenchman, who lived here in Lima for many years and who, together with Don Francisco Quiroz, was the first who called the attention of the Peruvian Government to the immense riches which the country possessed in the deposits of guano, married a woman rather below his rank in life, who had a daughter, Bárbara, of whom her stepfather was dotingly fond. She was married to a certain Lajara, the natural son of a respectable Arequipeño of the same name; their son, a good for nothing fellow, was known in Paris and 
Madrid as Count Lajara. In a theatre of the latter place he had an altercation with a young deputy called Olazaga; a duel ensued; they fought with swords; Olazaga was killed on the spot and Lajara fled to Portugal.

Tuesday, $4^{\text {th }}$ of May. We learned this morning that Dr. Ribeyro was lying dangerously ill; he had thrown up a quantity of blood arising, as the physicians said, from a hemorrhage of the stomach. This would once more retard the decision of my suit.

Sunday, $9^{\text {th }}$. Accompanied by Mr. Duval, my secretary, I climbed up San Cristoval; we made our ascent from the Lurigancho side, which is the longest and consequently the easiest. We descended up again the ridge where stands the cave I have more than once referred to, descended behind the "altillo" and made our way back along the acequia, which runs at the foot of the mountain; altogether it was a trying job, for the sun was out. Duval was knocked up; I lay down for a quarter of an hour, and then attended to my usual occupations, amongst which was a call upon Mrs. Hobson, the agreeable North American lady who intended to leave for the United States on the $14^{\text {th }}$. In the evening however I felt uncommonly sleepy.

Monday, $10^{\text {th }}$ of May. We had a meeting of the Directors of the [...] [83] which I presided as Vice-President, Argumaniz the President having embarked on the $28^{\text {th }}$ ulto. Juan Ugarte, Second Vice, moved that all the proceedings of the Directory should be kept secret, which was agreed to. I proposed as a remuneration for the two gerentes $\$ 5000$ annually each, the same which those of the Banco del Perú received, besides which fixed salary, $5 \%$ on the nett profits, after deducting $9 \%$ interest on the capital, and $10 \%$ of the gains to form a reserve fund. To my astonishment, Manuel Villate made the amendment that considering the station in life held by Zaracondegui and Lembcke, they should be paid each 6000 , and not $\$ 5000$ annually, which amendment passed by a majority of 7 to 3 .

Tuesday, $11^{\text {th }}$ of May 1869 . Seventy years of age. Heaven be praised strong in body and mind; my sight however was as weak as ever. Mariquita, Enriqueta, and her children all presented me with some trifle; they, Garland, Manuel Velarde, Dr. Jervacio Alvarez, and Dr. Middendorf dined with us. Alvarez was rather taciturn whilst Dr. Middendorf made but a poor speech when proposing my health. Though no rocambor was played, the time passed away quickly.

Friday, $14^{\text {th }}$ of May. By this day's steamer Mr. and Mrs. Hobson departed for New York, probably not to return. For the present young Osterling took charge of the business of the firm, and Evans, Dr. Gallagher's son-in-law, who had quarrelled with his Callao partner, O'Connor, entered Alsop's as Salesman. Mr. Edward Müller of the firm of Grisar \& Co. also left for Europe, leaving in his place a certain Peltzer. 
The steamer which arrived from Panamá brought me two congratulatory letters to my birthday, the one from Mrs. Bobertag, the other from Mrs. Knauer.

In a decree published on the previous day, the Peruvian Government declared that they looked upon the Cuba insurgents as belligerents, which step was owing to the representations made by a certain Dr. Valiente who not long back had arrived from Cuba as special envoy accredited to the Peruvian Government.

Sunday, $16^{\text {th }}$ of May. I called upon Dr. Ribeyro who had completely [_]overed from his late dangerous illness, but had not yet gone to the [...]. There were several other visitors present which [...] [84] my speaking to him about our suit.

Tuesday, $18^{\text {th }}$ of May. Mariquita called on Ribeyro's wife Doña Eulalia who gave her the good news that her husband, Muñoz, and Alvarez were agreed amongst themselves. Rafael Velarde came the same evening and told us that Ribeyro had sent him word that he would remit to the court his opinion in writing. This day as well as

Wednesday, $19^{\text {th }}$ I ascended San Cristoval early in the morning without the slightest difficulty. Chess-playing I thought prudent to give up for some time, I having of late strained my eyes more than I ought to have done.

A long time back, under the administration of Prado, José Antonio Garcia y Garcia had been sent to the United States with the object of purchasing or getting made for the Government two iron-clad monitors; he made the purchase, but, as it turned out, a very bad one, viz.: that of two monitors which had been originally built for river navigation and which were unfit for crossing a rough sea such as that in the neighbourhood of the Cape. Garcia had them named the "Manco Capac" and "Atahualpa", and advice was received of their safe arrival in St. Thomas together with a transport, the "Marañon".

Guichard, who for many years had been in the employ of H. W. \& S. as collecting clerk, left the house, and Enrique Garland got his place under the particular care of the Cashkeeper Wagner.

Monday, $24^{\text {th }}$ of May. Dr. Ribeyro returned to the Supreme Court, and anxiously did my wife and I wait for the decision of our suit. On

Wednesday, $26^{\text {th }}$ it was to have come on, but Dr. Cosio stayed away.

Thursday, $27^{\text {th }}$ was a holiday, Corpus Christi, and nothing could be done.

Friday. $28^{\text {th }}$. The Court occupied itself with other suits. In the course of the day, Doña Eulalia called upon my wife and was less friendly than on previous occasions; she said that poor people like the Sotomayors ought not to be oppressed, and that she had told her husband that we would be satisfied with receiving till the $5^{\text {th }}$ August - the day when the lease of the Sotomayors for 27 years expired - the rent at which Aliaga had let them the house, and from 
that day onward the rent which [_] had demanded. My wife replied that he was much mistaken [...] sent without loss of time for Dr. Alvarez [...] [85] Velarde. The former assured us that he would always stand by us; the latter promised to see Dr. Ribeyro. My wife and I were so dejected that we hardly ate anything at dinner; at a later hour, Rafael returned and gave us an account of his interview with Ribeyro to whom he had spoken in very plain terms, and had again secured him in our interest.

Saturday, $29^{\text {th }}$. Once more Doña Eulalia came to see my wife, and was less stiff than she had been the previous day, but complained that Rafael had been rather too severe upon her husband. At 2 I went to the Justice-Hall, where I met Dr. Alvarez in the corredor, who merely said that all was going on well. About an hour later, he came to see my wife and told her as a great secret that "la nulidad estaba declarada", and that he, Muñoz, and Ribeyro had given their votes for the nulidad, Mariategui and Cosio against it; the latter particularly had been like a "mountain cat" (gato-montés) saying that, in his opinion, on the day when I made the purchase in February 1864, the Sotomayors ought to have received the $\$ 30,000$ and have remained living in the house until their lease fell due, at the rate stipulated with Aliaga of $\$ 1400$ annually. Mariategui, without taking an active part, confirmed all Cosio said however as those two formed the minority they were placed "hors de combat", and the further discussion devolved on the three other judges. Hardly was Alvarez gone, when Don Gregorio Paz-Soldan came to give us the same news, which Mariategui had communicated to him.

Sunday, $30^{\text {th }}$ of May. This day the procession of Corpus Christi passed our house; to see it, Rafael Velarde and family came; they took their lunch, also remained to dinner when we were joined by Garland's family. I, in the course of the forenoon, went to see Dr. Gomez Sanchez who warned me that the worst, which could happen for me, was if between the three judges in my favor a difference of opinion were to arise, or, as the legal term is, "si hubiese discordia"; accordingly on

Monday, $3{ }^{s^{s t}}$ of May I wrote a few words to Dr. Alvarez, begging him rather to make some concessions to his colleagues than to differ from them. This note Enrique took, and whom should he find there but Doña Jacinta in close confabulation with the Doctor. Enrique was however wide awake and enquired for his son Adolphus who had been ill of late. We were again down in the month until we received the message which Dr. Alv [...] through Garland that on the following day all [...] [86] to our satisfaction.

Tuesday, ${ }^{\text {st }}$ of June. At 1.30 I received a note from Dr. Palacios informing me that we had gained; at 3 the sentence was published; it said that during the 
whole time the law-suit had lasted, we were to receive the rent which which the house ought to have produced; this rent until the expiration of Sotomayor's lease, say $5^{\text {th }}$ August last, and from that date onwards until the house were delivered to me, the rent which I had demanded, say I had demanded, say, \$6oo monthly, besides the rent of the apartments which Garland occupied. This sentence had two draw-backs; the one, that two arbiters, one from each side, had to be named in order to value what the house ought to have produced, and if these two did not agree, the judge would have to name a third to decide the question. The second draw-back was that the sentence did not determine, whether the Sotomayors had to deliver up to me the house empty, and free of all tenants, or whether the trouble of turning them out was to fall to my lot. Dr. Alvarez and my lawyer Dr. Palacios opined that the house should be delivered empty; whilst Dr. Ribeyro, to whom I went on

Wednesday, $2^{\text {nd }}$ in the morning to give him my thanks, thought that as the house was now mine and nobody disputed my right to it, I ought to turn out the tenants, if I did not want them to remain. He further told me that the idea of valuing the rent had been that of Dr. Alvarez, whilst the opinion of himself and Muñoz had been to adjudge to me the interest on the $\$ 30,000$, in which case I should of course have fared worse.

The news from Europe was not of a pacific nature. France and Prussia continued their armaments.

Thursday, $3^{\text {rd }}$. Dr. Aranivar gave in an "escrito" asking for a modification of the sentence, to the effect that the Sotomayors ought to pay no rent whatever since the $5^{\text {th }}$ of August last, because on that day they had declared themselves willing to deliver up the house to me. In the evening Duval and I went to the escribano Escobar where the former made an abstract of the whole expediente to which Aranivar had referred; it was true that on the $5^{\text {th }}$ of August they had offered to deliver up the house, but had coupled this offer with the demand for the payment of the $\$ 30$,000 deposited with Zaracondegui; moreover, the procurador [_] who presented the escrito did not subjoin a copy of his power.

Saturday, $5^{\text {th }}$. Dr. Palacios' reply, founded on the two [...] [87] referred to on the $3^{\text {rd }}$ was given in, and on

Monday, $7^{\text {th }}$ of June the Supreme Court declared "Que no habia lugar a la modificacion". The Autos were remitted to the Superior Court and would in due course reach the Juez del $1^{\text {a }}$ Instancia.

The great railroad from East to West of the United States, crossing the whole breadth of North America, had been concluded; it measured from the Missouri to San Francisco 600 leagues, and its construction had taken four years; the two 
last rails on both ends, the extremities of which were of silver, had been fixed with golden nails.

Le Comte d'Eu, eldest son of the Duke de Nemours, consequently grandson of King Louis Philippe, who had married a sister of the present Emperor of Brazil, had taken the command of the Brazilian army in Paraguay; Lopez, the President of this Republic, still held out.

Saturday, $12^{\text {th }}$ of June. An escrito of the Sotomayors, to the effect that the house with its tenants was at my disposal, was notified to me, to which, without loss of time, my lawyer replied that I was ready to receive it, but free of all tenants.

Sunday, $13^{\text {th }}$. San Antonio. My wife and myself spent the evening with the family of Dr. Morales, whose eldest daughter is called Antonia. The party was rather numerous; there was singing and playing, and all all seemed to enjoy themselves. Only I, owing to my weak sight, could hardly distinguish anyone, and was content with conversing with the host. I was glad when at 10 my wife made me a sign to retire.

Monday, $14^{\text {th }}$. It came to our knowledge that in the course of the preceding week Doña Jacinta Sotomayor and her son Federico had done all in their power to damage the house, now mine; they had destroyed the hearth, cut down the trees in the garden, pulled down the cielos rasos, and paper-hanging, carried of the glass-doors - to these they had a right - etc.

Benigno Vigil, brother of Octavia, Federica Sotomayor's wife, had died as Peruvian Charge de Affaires in Santiago de Chile, and his praise was sung in the Lima papers. For some time past the Indians who lived on the estate of Hualcará in the valley of Cañete, owned by the Chilian Ramos, had had continual disputes with him. Who was in the right, I had not been able to ascertain, but the upshot was that the former had [...] the law into their own hands, and risen in arms against [...] [88] [_]tuted authorities; to put them down, the President's brother Pedro Balta, Prefect of Lima, was dispatched thither at the head of some regular troops.

Wednesday, $16^{\text {th }}$ of June. Dr. Ramon Patron, Juez de $1^{\text {a }}$ Instancia, sentenced that my house Calle de Zarate should be delivered up to me by the Sotomayors free of all tenants except Garland and family, whom I wished to remain in the apartments which they occupied.

Thursday, $17^{\text {th }}$. Dr. Patron's sentence of the $16^{\text {th }}$ was to be notified to all the members of the Sotomayor family, which again caused some delay. I named the architect José Manuel Villa to value for me the rent which the house should have given during the time of the law-suit, which nomination was approved of by the judge, and now the Sotomayors had to name their appraiser. 
I received a letter from Juan dated London $16^{\text {th }}$ May; he wrote that he had had a fine passage as far as Plymouth, but between Plymouth and Cherbourg, and Cherbourg and Southampton the weather had been bad. He spoke with admiration of the breakwater at Cherbourg. Amalia and Conradina continued in a poor state of health; the former suffered from palpitation of the heart, and from dreadful headache; the latter's chest or throat seemed to be effected, and Dr. Acosta had dispatched her posthaste to the mineral waters of Eaux bonnes in the Pyrenees. Schutte was always very weak in the head and suffering from a nervous cough. The two-Peruvian monitors proceeded gradually on their voyage. We learned that they had left St. Thomas and reached Barbadoes; from Barbadoes they intended to steam to Demerara; the little quantity of coal which they and the two other steamers which had them in tow could carry obliged them to make such short stages.

Wednesday, $23^{\text {rd }}$ of June. My house Calle de Zarate was delivered up to me at 3 p.m. by Lorenzo Sotomayor in the presence of a Juez de Paz, Domingo Romero, and the escribano Manuel Escobar; it was in a very bad condition, and a great many keys were wanting, but as I did not intend to make any further claim on the Sotomayors, I made no observations.

Thursday, $24^{\text {th }}$ of June. At an early hour I was up the Cerro. About this time the ascents of San Cristoval on Sundays and holidays had become for me a habit not to be deviated from. It being the day of San Juan [...] the customary calls, and the evening Mariquita and I [...] [89] with Doña Juana Guise. The party there assembled was similar to that of the other day at Dr. Morales'; this time I was able to distinguish the ladies of the family, Dr. Morales, Dr. Isaac Suero, Dr. Melchor Vidaurre, and a few more. At 11 when the young folks began dancing my wife and I retired.

Sunday, $27^{\text {th }}$ of June 1869 . The mutiny in Cañete seemed to have been a myth; according to some, it had been quickly quelled, accordingly to others, there had been no rising whatever.

The papers published various nominations: that of Dr. Ribeyro as Peruvian Plenipotentiary in Bolivia which he declined; that of Ignacio Noboa, Peruvian Minister in Chile; that of Emilio Bonifaz as Secretary to the Peruvian Legation in Paris and Chargé in the same place after the withdrawal of Francisco Rivero, hitherto Peruvian Minister in that Capital; and finally that of Andrés Alvarez Calderon, Peruvian Chargé in Italy ad-honorem.

Monday, $28^{\text {th }}$. Said Alvarez Calderon embarked on board the steamer with a suite of from 26 to 30 persons, amongst whom his newly married wife Rosa Mascaro, who to the surprise of every one, had not long ago given her hand to this man, of whom it was known that his previous wife had died in consequence of his ill treatment. 
Friday, $9^{\text {th }}$ of July. This day died suddenly Theodore Muller, Consul General for the North German Confederation; he had been in good health suffering merely from a slight cough; when putting on one of his boots he made a strong effort, which caused the bursting of a blood vessel; the blood rushed out of his mouth, and in less than five minutes he was a corpse. Antonio Sousa-Ferreyra, Consul General for Brazil and Senior of the Consular Corps, had entirely retired from active service, and thus I, the next in seniority after him, went to see Barrenechea, who refused to grant a military cortége to the funeral, because the deceased was only Consul General and not Chargé.

Saturday, $10^{\text {th }}$. I sent round a circular, inviting all the members of Diplomatic and Consular Corps to be present at the funerals and on

Sunday, $11^{\text {th }}$ at 9.15 I went to the house of the deceased, Calle de Jesus Nazereno, a great many people were already assembled, more than a hundred in number, amongst whom the Peruvian Minister for Foreign Affairs, the Chargés for France, England, and Italy, the [...] -resident of the United States of Colombia etc. Twel[_] [9o] men, six and six by turn, of the German club, carried the coffin, covered with the flag of the North German Confederation. The two last mentioned of the Diplomatic Corps, Barrenechea and I, held the black ribbons attached to the coffin, and thus we all walked in procession, two by two, to the Callao railway-station in San Juan de Dios; here Barrenechea, who made his excuses to me, and a few others, remained behind. The coffin was placed in a car, appropriately fitted up, and the Diplomatic and Consular Agents had the Government carriage for themselves; it was an extra train which took us as far down as opposite Bellavista, where we alighted, and again walked two by two behind the coffin to the Protestant Cemetery. Here it was received by an English clergyman, not by the Revd. Mr. Henry, who was absent; it was not placed in the Chapel, as I had seen it done on previous occasions, but close to the open grave, standing upon the bier; the clergyman read the funeralservice, and after the coffin had been lowered into the grave, many of those present threw flowers upon it. Upon me, such protestant funerals never failed to make an impression, but too quickly obliterated by my daily occupations. Mr. Charles Weiss, the Consular Agent for the North German Confederation in Callao, begged me to be present at his taking the inventory of the Consular archives, which I agreed to, but which took up the entire forenoon of

Tuesday, $13^{\text {th }}$ and Wednesday, $14^{\text {th }}$ of July. Even the iron chest, with all the documents in it, was carried to my house. As regards Müller's private affairs, the Peruvian authorities interfered for no will was found; Plenge, of the firm of Plenge \& Kast was named depositary.

Thursday, $15^{\text {th }}$. At 10 p.m. many gentlemen, I amongst them, assembled in the house of Doña Estanislaa Bergmann, who once more had suffered a severe 
blow by the death of her youngest son Estanislao. He had been brought up in Germany, on his return entered the counting-house of the firm, but soon gave evidence of his great predilection for the bottle; it was this unfortunate vice which put an end to his existence in the prime of life. We accompanied the corpse to the convent of San Francisco, and on

Friday, $16^{\text {th }}$ I was present at the funeral.

We were once more in the Courts of Justice on [...] [91] [_]ject of my house Calle de Zarate. I mentioned on the $16^{\text {th }}$ June that I had named the architect Jose Manuel Villa to be my appraiser. The Sotomayors named on their part Gaspar Puente who, to my great surprise, admitted this commission; however, as he was not of the guild, or as they call it here "del numero", Dr. Palacios thought proper that we should decline admitting him as appraiser; thus we gave in an escrito to this effect, and our recusation having been denied us by Dr. Patron, we appealed to the Superior Court, one of whose members, Dr. Mariano Dorado, a great friend of mine, because I lent him money without charging interest, told me in the strictest confidence that two of the three had annulled the sentence of the Juez de $1^{a}$ Instancia, and Dr. J. M. Perez would now be called in "para derrimir la discordia".

About this time the prophecy of a German astronomer of some repute called Fallb and residing in Graetz, caused great dismay amongst the population; he had written a letter to Westphal of Huth's house, which was translated and published in the Lima papers, in which he predicted that on the $7^{\text {th }}, 8^{\text {th }}$ or $9^{\text {th }}$ of August 1869 severe earthquakes would be felt in Mexico, Ecuador and Perú, and that the earthquake of $30^{\text {th }}$ Septr. or $1^{\text {st }}$ Octr. of this year, would be more dreadful in its effects than that of $13^{\text {th }}$ August 1868. He had likewise written a pamphlet, which Lembcke had in his possession, but which was not yet published in Lima; in it he explained the theory of earthquakes; his hypothesis was that earthquakes were caused by the pressure which at certain times the sun and the moon exercise upon the waters of the earth. The president Balta and his five ministers continued to rule the country as they could, which was saying but little in their favor.

The finances were in their customary dilapidated condition, and Garland was of opinion that the Finance Ministry would erelong have to apply for to the guano consignees for pecuniary assistance; of this he was the more certain, because it was generally known that neither a Commissioner sent by the bankers Erlanger \& Co. of Paris, nor Luis Benjamin Cisneros, who had arrived from Havre, where for some time he had been Peruvian Consul, on behalf of another firm, had come to terms with the Government as regards a loan for which they were authorized to make proposals. In the meanwhile public works were not at a stand-still; on the contrary [_]me progress was being made 
with the construction of the iron bridge $[\ldots]$ the Rimac, and with that of the three railways, the one [...] [92] to Huacho, the other in the Cerro de Pasco, and the third from the Coast to Arequipa. This day the sealed tenders for the construction of a railway from Callao to the Oroya, a place on the other side of the Cordillera, by way of the Quebrada de Matucanas, were opened; there were three proposals; one signed by Meiggs, the second by Manuel Montero, and the third by a certain Christian. The cost was estimated at from 15,000,000 to $S / 27,600,000$; there were many conditions to form part of the contract, which I did not specify, because I had the firm conviction that the Government had not the means to carry out such expensive undertakings.

Not long ago Pedro Galvez, when Minister of the Interior, concluded a contract with the Italian Tiravanti for the making of a cart road from Lima to Callao for S/700,00o; the present Minister Ferreyros annulled the contract, but paid for the very small part already concluded S/80,ooo. The Finance Minister Pierola, about 15 days back, agreed to pay General Rivas more or less $\$ 70,000$, which, after the taking of Arequipa by General Castilla in 1858, the VicePresident Dr. Mar had authorized a certain Espinosa to promise to Rivas on his delivering up to the then established government the frigate "Apurimac", at the time the last hope of the revolutionary party Thus it seemed that this claim of Rivas was a just one; however, the other Ministers looked upon it in another light, and the President Balta and Barrenechea, the Minister for Foreign Affairs, countersigned the decree, annulled what his other minister Pierola had done; and nevertheless, Pierola did not throw up his post!

About this period the house of Templemann \& Bergmann was uncommonly hard up for ready money, and its credit had much declined, as a proof of which I may mention that for $\$ 40,000$ which they borrowed from various persons they had to pay $11 / 2 \%$ monthly interest; and a pagaré of theirs of $\$ 10$,ooo which I had discounted on the $1^{\text {st }}$ January last, and which fell due on the $1^{\text {st }}$ July, the cashkeeper Wagner had found the greatest difficulty in collecting; it was not paid until the $12^{\text {th }}$.

In my usual occupations there was hardly any change; a good deal of time was taken up by the remodelling of the old diaries, also by my attendance at several meetings of the Directory of the Banco de Lima which establishment would probably begin its operations on the $1^{\text {st }}$ Oct.

Saturday, $17^{\text {th }}$ of July. In the evening three Peruvian men [...] [93] the "Huascar" "Independencia" and "Union", conveyed the President and a very large party, nearly a hundred in number, amongst whom Garland, by invitation to Pisco, to inaugurate the railway to Ica, for the construction of which young José Canevaro and two or three more had obtained a concession from the Government which guaranteed $7 \%$ annual interest on an outlay of $\mathrm{S} / 1,300,000$. 
I asked Canevaro whether they intended to offer any shares to the public, to which he replied in the negative.

Monday, $19^{\text {th }}$ of July 1869 . I was for the first time present at a meeting of the shareholders of the Lima Gas Company, where I represented 20 shares of my own and 54 belonging to Juan of $\$ 500$ each, which at different periods we had bought from Domingo Castañeda at par. A partial dividend for this year of $4 \%$ was paid. I learned that in the course of $1868,68,000,000$ cubic feet of gas had been produced in the factory, 56,000,000 sold to the public and to the Government, and consequently the loss came came to 12,000,00o cubic feet or about $18 \%$ in 1867 the loss came to 17 .

Tuesday, $20^{\text {th }}$ of July. In the evening my wife and myself paid a visit of condolence to Mrs. Bergmann and to her son Federico. Whilst my wife conversed with his lady Julia Cavenecia I had a long talk with him on the subject of the "Muelle- Darsena". As this is the first time that this word turns up in my diary, I must say a few words about it. The Muelle Darsena is a dock which three or four Capitalists in England and France who had formed a company, proposed to construct in the bay of Callao, on their own account and at their own cost. After a long series of years the Dock was to revert to the Government. They however calculated that as all merchant vessels were to discharge their cargo in this dock, the dues, much higher than those hitherto charged, would cover them not only for the original outlay, but also secure to them a fair interest. Moreover, a large piece of ground would be gained for their benefit by filling up with stones and earth part of the sea between the shore and the dock, which was to be built at a short distance from the land. It was also expected that smuggling would now be thoroughly eradicated, thus the Government favoured the project, whilst the Callao Agents and some Lima merchants spoke and wrote against it. The [...] merely gave their name; they were the representatives [...] [94] the necessary measures to obtain the concession; for this their trouble they were to be interested a certain percentage in the undertaking without any outlay of money. Don Federico spoke to me in a very different strain; he said that they, the Bergmanns, were the only interested, that they had bought out the other parties whose shares they had purchased at long credits, and that the estimate came to $S / 7,000,000$. In the same breath he complained of great scarcity of money and added that it was difficult to borrow any, even with the best guarantees.

By last mail one male and two female servants who had lived in Paris with Rosita and family arrived here under the charge of the dentist Dupuch; the most respectable of the three, Marcelina, who remained with Enriqueta, gave a sad account of all poor Rosa had to suffer from the bad temper of her husband. Garland told me that in Europe the Mutzenbecher in Hamburg, Schutte in 
Paris, and the Peruvian Fiscal Sanz were continually at variance, and that it was impossible for him to foresee what would be the result of their incessant altercations.

Sunday, $25^{\text {th }}$ of July. My law-suit had progressed one step. The Superior Court, viz: the three Vocales Rospigliosi, Dorado, and Perez revoked the sentence of Dr. Patron, and decided that the appraiser of the rent should be one "del numero"; only Dr. Leon was of the contrary opinion.

Monday, $26^{\text {th }}$. The tenders for the construction of the Muelle-Darsena in Callao were opened, and as that of the Bergmann's was the only one, the contract was adjudicated to them. By last South steamer news were received of the departure of Prado and his wife from Rio Janeiro by the steamer through the Straits of Magellan; also of the sudden death of Felipe Pardo, younger brother of Manuel, who had been implicated in the last revolutionary intrigues of Montero on board the "Huascar".

In Spain the reins of government had been taken by a regency with General Serrano as its chief.

Wednesday, $28^{\text {th }}$ of July. Whilst we were at breakfast, Rafael Velarde came in and told us that last night he had been called by the President, who had named him his Minister for the Interior instead of Manuel Ferreyros, and that this day at 11 O'clock he was to take the oath.

From Barrenechea, Minister for Foreign Affairs, I had recei [...] invitation to accompany the President Balta, who inte [...] [95] open this day in person at 3 p.m. the exhibition of Peruvian produce and manufactured articles held in the splendid building called the "Colejio de artes y Oficios". Manuel Pardo, the Alcalde, had had the first idea of this exhibition about two months ago, and now by the death of his brother Felipe, he was prevented from being present. On account of my bad sight, I did not like to go by myself to such receptions, and I therefore went to the palace accompanied by Mr. Roca y Garzon, the Papal Consul General. A great many people, perhaps 100 in number, amongst whom the Diplomatic and Consular Corps, assembled in the long narrow saloon in which the President usually received, and after he had made his appearance we all, two by two, walked to the "Colegio". The passage, or "saguan", as it is called, was hung with red drapery, and lined on both sides with the Peruvian, French, and Italian firemen in their gala uniform, who acted as policemen. We stopped in this passage and the President read a discourse, of which I heard only the last words: "Señores, está abierta la Exposicion del año 1869". For some time we continued walking in procession; then everybody strolled about as he liked. The whole looked extremely well. The college itself was a splendid building with two patios, around which and in the passages the various articles were tastefully and skilfully arranged. I, of course, owing to my weak sight could 
distinguish but little. There were many paintings, some by Merino, said to be really good, exquisite drawings, machinery made in the foundry of Bella Vista, handsome furniture, a cannon, revolvers, various articles of wood cut out with great skill, biscuits of all classes, also macaroni, oil from Paz-Soldan's chacra, various produce from the estate of Falcalá in the North, mineral produce from the province of Tarapacá and the Cerro de Pasco, a beautiful iron door destined for the Banco de Lima, also a bear, jaguar, some horses, dogs of a particular breed, and many many other things of which I repeat I saw but little. A tight boot and the consequent pain obliged me to retire long before the President. The evening my wife and I were invited to spend at Federico Marriott's, whose birthday it was. I went at nine O'clock, my wife having gone somewhat earlier; except her, all the other ladies belonged to the family; of gentlemen the number was great, but my bad sight always prevented me from enjoying such parties. All can [...] some had been at the fireworks, some at the club, oth [...] [96] the theatre, the ladies could not get carriages; it was past ten when tea was served, rocambor tables were formed at past eleven, and when we left at midnight, they were playing and singing and would probably begin to dance.

Thursday, $29^{\text {th }}$ of July 1869. In celebration of the anniversary of the Independence, a shooting-match with rifles was held in the Plain of Amancaes (the distance is not given in my original), and the prize was gained by a German smith called Schmidt, who was hardly ever known to be sober. Manuel Pardo, the Alcalde, handed him the prize which consisted of a gold medal and two gold ounces.

Friday, $30^{\text {th }}$ of July. This day races on the Pampa del Pino, outside the Cocharcas gate, celebrated the anniversary. The numble of people present was said to have come up to 20,000 , no doubt a great exaggeration. Theodore Gortsch, the cousin of the Bergmanns and their cash keeper who ran the race known as the steeple chase, had a severe fall; his horse should have cleared the last hurdle, but touched it and came down with and upon him; had it not been for the fall, he would have been the first in, now another on a comparatively poor horse gained the prize. One of the sons of Cucalon was also thrown, but neither he nor Gortsch was dangerously injured.

Saturday, $3{ }^{s t}$ of July. There was a review, or as they call it here "Simulacro", in the Pampa of Amancaes. The President invited a great many persons to the lunch given there; I had also received an invitation, but sent in my excuse. More than 600 people sat down at three long tables, the one presided by the President Balta, the second by the Minister of Finance, Pierola, the third by the Minister of the Interior Rafael Velarde. Lecaros, the owner of Maury's Hotel, furnished both eatables and drinkables, which, as well as the attendance, as I afterwards learned, had been very good. 
Manuel Ferreyros, whose post as Minister for the Interior had been taken by Rafael Velarde, was suddenly ordered to embark on board the man of war "Union", Captain Lino de la Barrera, for Rio Janeiro; the object of his going thither was to take charge of the two monitores "Manco-Capac" and "Atahualpa", which it was calculated would arrive in the said port about the same time with him. There were a few who apprehended that Mariano Ignacio Prado, who with his lady had left Valparaiso for the said port of Rio, intended to make himself master of the two monitores, either to [...] Perú and to oust Balta if it could be done or to go in [...] [97] Cubanos. I for my part did not believe in Prado's having formed any such plan.

Juan wrote us from London that the English physician, whom he had consulted, seemed to have discovered the real cause of the pains in his body, which he attributed to disorder in the liver and kidneys, and Juan was in hopes that in about three weeks the Doctor would send him off completely cured to some mineral bath or other in Germany.

From Sunday, ${ }^{\text {st }}$ to Sunday, $8^{\text {th }}$ of August 1869 . This week both my wife and myself were somewhat indisposed; with me it was no great matter, but as Mariquita complained of a numbness in her right arm and of giddiness in awaking in the morning, Middendorf ordered five leeches to be applied behind her right ear, which did her good.

The Sotomayors named an architect, Jacobo Lopez Castilla, to be their appraiser, who had not yet taken his oath, whilst mine, Villa, had done so. On the $6^{\text {th }}$ in the evening Dr. Muñoz came to tell us that Fco. J. Mariategui had resigned his post as Vocal of the Supreme Court, and begged us to avail ourselves of the influence which we supposed we had with Rafael Velarde, that the Government would admit his resignation. On Sunday the $8^{\text {th }}$ he again came and communicated that Mariategui had withdrawn his resignation, because Dr. La Rosa, Minister of Justice, had apologized to him for some harsh expressions made use of in an official dispatch to said Mariategui. This day the $8^{\text {th }}$ - arrived by the French steamer various persons well known in Lima society: Carlos Elias and his lady, Carlos Candamo and his brother Manuel, Juan Martin, the second son of General Echenique, and Agustus Dreyfus, the head of the firm of Dreyfus Bros. \& Co. of Paris; these last mentioned Candamo, Echenique, and Dreyfus were known to have come with the object of treating with the Government for the purchase or consignment of guano, and for the advances to be made on such sale or consignment.

Monday, $9^{\text {th }}$ of August. The whole day Dreyfus was closeted with the Minister of Finance, Pierola. A few explanatory words may not come amiss here. Six or eight months previously, Dreyfus and C. W. Schutte of Paris had been on the most intimate terms, and it is highly probable that the latter, 
whose foibl [...] speak of his mercantile operations and of their profitable [...] [98] the first who opened Dreyfus' eyes to the immense gains which might be made in the guano business. At the same time Schutte sold to him his share in the Banco del Perú, and as, according to the statutes of this establishment, no new shareholder could be admitted without the approval of the other shareholders, Dreyfus was ballotted for, and by a great majority not admitted. Even Miceno Espantoso, married to the sister of Dreyfus' wife, abstained from voting; he could not vote against him, owing to his relationship; he would not vote for him, because he did not consider him a proper person to be received amongst the shareholders. All this was a clear proof of the total want of credit the firm of Dreyfus had at the time in the Lima Commercial World. Dreyfus, without the slightest reason, threw the blame of his ill-success upon Schutte, who not only was totally innocent, but had even interested himself with some shareholders to give their votes to Dreyfus. Mrs. Dreyfus (Sofia Bergmann) had left Paris for the baths in Germany without taking leave of Mrs. Schutte. On board the same steamer Juan Bazo and Irene had embarked in St. Nazaire, but had landed in Guayaquil, where the sister of the former, Josefa, married to Anibal Gonzales, had met with a dreadful accident; when sewing she had pricked a finger of her right hand with a needle, this slight wound had caused an inflammation first of the finger, then of the hand, finally of the arm, and to save her life it had been considered necessary by the Guayaquil physicians to amputate this limb, the arm, which had been done accordingly.

Astronomer Falb had predicted that the $7^{\text {th }} 8^{\text {th }}$ and $9^{\text {th }}$ of August were the days when severe earthquakes would be felt along the coast of Perú; fortunately, they passed over quietly, though without doubt ever since the $13^{\text {th }}$ August 1868 earthquakes, more or less severe, had been frequent occurrences.

Another submarine cable had been laid between Brest and St. Pierre on the Isle of Michelon, thence to be prolonged to the mainland.

The "Great Eastern" had been employed in laying it, and apparently no particular difficulty had been encountered.

The Paraguayos were still fighting against the overwhelming forces of their enemies. Also the Cubanos continued in their revolt.

This day expired Dr. Miguel Carpio, a man well known in Pe $[\ldots]$ he had filled many high posts both in Peru and Bolivia [...] [99] than four weeks back had resigned the Vocalia in the Supreme Court and yet he died a poor man, much to his honor.

Sunday, $15^{\text {th }}$ of August 1869. It became known that Carlos Candamo who held full power from the South American Company established in London would not enter into competition with Dreyfus, being convinced beforehand that he would be outbid; moreover, there seemed little doubt that this latter 
gentleman, by weighty means, had gained over the Minister Pierola and other influential persons. On Monday last he had arrived; already on Tuesday the Minister sent for Benito Valdeavellano and told him that, as Dreyfus had made proposals for a loan, the guano consignees had to do the same before ten in the evening of the same day, and with great difficulty Don Benito obtained a respite till 10 a.m. of the following day. At that hour he and José Canevaro Jr. went to the palace and, the Minister being absent at Carpio's funeral, were received by the President, who prolonged the term for 24 hours. Meanwhile, the Guano consignees had several meetings and at last agreed to make the following offer: $20,000,000$ dollars, at $95 \%$ and $5 \%$ annual interest, of which $\$ 4,000,000$ cash, the remainder in monthly instalments; Garland very reluctantly affixed the signature of Schutte \& Co. to the proposal, for the credit which had been opened for the firm in London did not exceed one million, and Schutte's insctructions were so confused and contradictory that Garland was sure to be blamed for whatsoever he might do. The report went that the President and his brother, the Minister of War, had been favourably inclined to the consignees, but that they had been talked over by a certain Ruso and now sided with Dreyfus.

Wednesday, $18^{\text {th }}$ of August. About midday Lembcke came with the news that the proposal of Dreyfus for a loan to the Government had been accepted; he added that he, Dreyfus, had offered to the Banco de Lima an interest in the business for $\$ 100,000$ (a mere song) further, that all his business should go through the Banco de Lima. Very naturally, Lembcke was in high spirits and was of opinion that a meeting of the Directory should be convened, to which I replied that he was quite right in what he was doing, but that as far as I was concerned I would neither pr [...] be present at this meeting, because as Schutte \& Co., [...] [100] consignees I thought it improper to give a vote in an affair connected with guano businees.

Thursday, $19^{\text {th }}$ of August. The following native capitalists Juan Mar. Goyeneche y Gamio, Pedro Dinegri é hijos, José Unanue, José Maria Sancho Dávila, José Vicente Oyague, Dorca, Ayulo \& Co., José Fco. Canevaro, Felipe Barreda y Osma, and Emilio Althaus, presented a petition to the Government, in which they, in virtue of a law given on the $6^{\text {th }}$ Novr. 1849 to the effect that in all guano business natives, if offering to the Government the same advantages as foreigners, were to have the preference, requested that the contract with Dreyfus be annulled in as far as they not only accepted the same conditions which had been agreed to with Dreyfus, but would even better these conditions in any way which the Government might think proper, so as to ensure to the same an advantage of $S / 200,000$ annually. They had an audience from the President, who did not receive them as well as they had expected; 
on the contrary, he told them that the contract with Dreyfus was concluded, that there was no use in speaking any more on the subject, and that if he had exceeded his faculties, he had to account to the Congress for what he had done.

This was the Saint's day of Dr. José Luis Gomez Sanchez and the birth-day of Maria Garland, who completed her third year. The former I congratulated in his own house, whilst to celebrate the latter Enriqueta had invited to dinner Mariquita and myself, Rafael Velarde, wife, and daughter Zoila, Rafael's sister Juana with her daughter Isabel, Melchor, and two Franciscan friars. I sat near Rafael and we were both of the same opinion, though he as Minister could not express himself in clear terms, that the guano consignees had been beaten by Dreyfus, owing partly to their want of activity, and mainly to their not having come forward with sufficiently heavy bribes.

Friday, $20^{\text {th }}$ of August. There was a numerous gathering of the native capitalists in the Banco del Perú; they were determined not to give in without further resistance.

The principal conditions of the contract concluded by the firm of Dreyfus with the Government were the following: he purchased 2,00o[_] tons of guano at the following rates, for what existed in European de [...] for what he exported - the Government having to place th [...] [101] free on board at $\mathrm{S} / 36.50$, and for what was afloat at 35.50 . Cargoes not to be insured, and if any were lost, such loss to be on account of the Government. The present consignees, except those of the United States, as soon as they were covered for what the Government owed them, had to pay over to him the nett proceeds, which he credited the Government less $4 \%$ commission. As soon as the terms of the various consignments expired, he had a right to sell in the market which had thus become open. He advanced to Government immediately S/2,400,000 and every subsequent month $\mathrm{S} / 700,000$, charging interest at $5 \%$.

Notwithstanding what I said above, relative to Carlos Candamo he had also come forward, and his proposal was upon the whole more advantageous than Dreyfus's, especially because he only required the consignments to France, to the Island of Mauritius, to Belgium, to Germany, and to the Baltic, leaving thus many markets at the Government's disposal.

The Steamer from the North brought hardly any advice of interest. The Sultan of Turkey and the Viceroy of Egypt were on bad terms. The French sub-marine Atlantic cable from Brest, which we already knew had reached St. Pierre, was now actually landed in Duxburg, Massachussets, and thus there were now three cables across the Atlantic, two English and one French. Mariano Felipe Paz-Soldan, who arrived from Europe and the United States, was likely to propose to the Government the laying of the submarine cable from Tumbes to Panamá, touching in Santa Elena, Ecuador, and Buenaventura 
in Nueva Granada. On the $13^{\text {th }}$ June there had been a violent eruption of the Volcano Icalzo in San Salvador, and on the $16^{\text {th }}$ July a severe earthquake had been experienced in Pasto, Nueva Granada.

Sunday, $2^{\text {nd }}$ of August 1869. Dreyfus's loan kept the whole town in agitation. The "Nacional" contained many interesting articles regarding it, also the copies of two escritos presented by the native Capitalists of Lima to the Supreme Court of Justice on the $20^{\text {th }}$. Already on the $21^{\text {st }}$, this Tribunal sentenced in conformity with what the Capitalists had asked for; the following is an extract of the sentence: "ha admitido [_] demanda de retracto interpuesta por los capitalistas Nacionales, y [...] traslado de ella como de la peticion para que no [...] [102] ha ordenado el arraigo de Dreyfus hasta que constituya apoderado. En la querella de despojo ha pedido informe al Ministro de Hacienda".

The legal term "retracto" means a demand to be placed in the same position as that occupied by him against whom the retracto is directed; for instance, if a house is sold by auction the purchaser runs, according to Peruvian laws, the risk that any one of the family of the seller comes forward and claims the property for the same price at which it has been sold, merely because he is a relation, and this is called "el derecho de retracto". By the term "despojo" is understood the complaint of being deprived of what one considers to be one's right.

The sum of $\$ 3,000,000$ which Dreyfus promised to pay to the Government within a month, the Lima capitalists had also deposited into the hands of the Supreme Court in cheques upon the Banco del Perú, accepted by the establishment, the one for $\$ 1,000,000$ drawn by Felipe Barreda, the second for a similar sum by Carlos Candamo, the third for $\$ 500,000$ by José Maria Sancho Dávila, and how the last $\$ 500,000$ were made up, Garland, who was my informant, did not recollect.

Emilio Althaus, representing the native capitalists, made another proposal to the Government; Dreyfus charged $5 \%$ interest, they would charge 4; Dreyfus deducted $4 \%$ from the Nett proceeds of the sales of the consignees, they would deduct 3 , and these $3 \%$ were not to surpass $33 / 4 \%$ upon the amount advanced. The natives also bound themselves to offer $80 \%$ of the business to the public at large; in self defence Dreyfus put an advertizement in the newspapers, in which he offered to all natives the share which they might be inclined to take in the business concluded by him with the Government, and that those who liked might subscribe their names and the amount for which they wished to be interested in his office, until the $3^{\text {rd }}$ September.

By this steamer embarked for Hamburg our former clerk John Hamilton, who - as I was told - had made an arrangement with some Lima merchants to purchase on their account the newly invented dynamite, an explosive substance well adapted for mining purposes. 
Saturday, $28^{\text {th }}$ of August. During the whole of this week the "Comercio" and the "Nacional" were filled almost exclusively with articles, some in fav $[\ldots]$ in favor of the natives. Dreyfus answered [...] [103] regarding the retracto, saying that the Nacionales having "interpuesto la querella de despojo", they had acted contrary to law, because two suits the one for "retracto", the other for "despojo", could not be instituted at the same time. This escrito was signed by Dr. Luciano Benjamin Cisneros, to which the natives, whose lawyer was Quimper, for whom signed another lawyer Dr. Manuel Perez, answered and proved that both demands might be made jointly, the "retracto" against Dreyfus, "la querella de despojo" against the Government. This "escrito" was presented on the $26^{\text {th }}$, and the same day the Supreme Court sent the "expediente" to the Fiscal Ureta; meanwhile, it was reported, though I was not certain of the exactness of this rumour, that Dreyfus had delivered to the Government $\$ 3,000,000$ in bills on England, with which to pay the loan made by Valdeavellano three months back for the same sum; he had likewise applied to Lembcke as one of the gerentes of the Banco de Lima, proposing to him that the bank should take his bills for a large sum, and pay him cash for the same. On the same day the Directors met in Lembcke's house, I in the chair. The majority seemed to be inclined to enter into this business for it was certainly a lucrative one, and if we declined, Dreyfus might apply to another Bank; nevertheless, I, Juan Ugarte, and Manuel O. de Villate being for different reasons opposed to the proposal, no resolution was come to, and the decision put off to the next meeting.

In Arequipa, Arica, Tacna, and Iquique earthquakes were repeatedly felt on the $20^{\text {th }} 21^{\text {st }}$ and $22^{\text {nd }}$; this news, which was received by the last South Steamer, gave new fuel to the apprehensions of the inhabitants of Lima, many of whom looked forward with dread to the last days of September and the first of October, the days fixed upon by Falb for the universal ruin. On the $27^{\text {th }}$ Ureta gave his Vista-Fiscal, to the effect that the "Nacionales" were completely in the right in demanding the "retracto" and at the same time in complaining of the "despojo", because the former was directed against Dreyfus, the latter against the Government, and because, though they were different demands, they were not contradictory and led to the same end; this Vista might have raised the hopes of the "Nacionales" had it not been for the informe addressed by the Minister of Finance to the Supreme Court, dated the same day, the $27^{\text {th }}$, and published in [...] nal" of this evening in which after giving a not [...] [104] statement of the hard and uncompromising manner in which the guano consignees had invariably conducted themselves towards the Peruvian Government when it required money, tried to prove - and in my opinion in a great measure succeeded in proving - that the resolutions of the Congress of $6^{\text {th }}$ Novr. 1849, and again of May 186o, were only temporal, provisional, and 
applicable to the particular cases then laid before the Congress, and could on no account serve as a general rule. If Pierola was correct in this view of the affair - and the Supreme Court had to decide if he was or not - the Nacionales would have of course no right to the retracto or, in other words, to be subrogated in Dreyfus's place. In conclusion, Pierola said that the Government was resolved to carry on the contract with Dreyfus at all events in spite of every obstacle and impediment, and expressed a hope that the Supreme Court would abstain from deciding a case in which they had no jurisdiction. It was said, and I believed it was true, that Althaus in the name of the "Nacionales" had made an offer to the Government of $\$ 2,000,000$ over and above the amount offered by Dreyfus.

This day at 12 O'clock the Directors of the Banco de Lima had again a meeting; only Sagastabeytia was absent. Manuel O. de Villate, Juan Ugarte, and I continued in our opposition to enter into any business with Dreyfus. Ugarte left before we voted. Villate proposed that this being an important case, according to one of the articles in the statutes of the bank, a general meeting of the shareholders should be convoked; only I voted with, all others against him. Then Lembcke moved that the Gerentes, together with some of the Directors, should be empowered to treat with Dreyfus, who required the sum of $S / 350,000$, which motion was carried against the opposition of Villate and myself; whereupon Heudebert, Renner, and Muro were chosen to treat with Dreyfus in conjunction with the two managers, Zaracondegui and Lembcke.

Monday, $30^{\text {th }}$ of August 1869. In the houses of the various Rosas, upon whom I called, I met many visitors; the general theme of conversation was however not the contract Dreyfus, but the prophecies of Falb. My wife being quiet by herself went to spend the day with Enriqueta.

Tuesday, $3^{\text {st }}$ of August. The Directors of the Banco de Lima aga [...] Lembcke's. Villate was absent which I much [...] [105] for he spoke well; and he and I generally agreed in our views. As regards the pecuniary assistance which Dreyfus required from the bank, the five commissioners had had a meeting with him, when he haughtily rejected their proposals; he made his, which we again threw overboard. After some discussion, in which I did not fail to repeat that I was decidedly against the business and added that - as the majority had resolved in its favor - it was now my duty to act in concert with them, Lembcke came forward with an account of what had occurred, viz. that Ford, the manager of the London Bank of Mexico and South America, was willing to give one third of the half million required by Dreyfus; if the Lima Bank would give the other two thirds, and the security offered by Dreyfus was satisfactory. Now the security to be demanded and the conditions upon which the business might be done were fully discussed. Ugarte left before we came to 
any decision, but Heudebert now stood up in opposition to the measure under debate; this of course came too late, and even if he had spoken on previous occasions as clearly as he did now, the majority would have carried it against him, Villate, Ugarte, and myself. When I came home at 4.30, I was greeted with two pieces of news: the one, that the two appraisers of the rent due to me by the Sotomayors, Villa for myself, Lopez Castilla for them, had come to terms and fixed upon \$39o monthly, which valuation, though extremely low, I had necessarily to submit to. The other, that the Government had ordered that henceforth the soldiers were no more to be paid in bank notes, and that if any of them existed in the military chest they were to be immediately exchanged for coined money: this blow was aimed exclusively at the Banco del Perú, because it was well known that the native capitalists, who carried on the war against Dreyfus and his contract, were, if not exclusively at least for the greater part the shareholders in this bank. The President Balta, it was said, had expressed himself in the following terms: "Ya no me inspira confianza el Banco del Perú.". I was much affected by this news, slept little, and at 5.45 on

Wednesday, ${ }^{\text {st }}$ of September was already on my way to the summit of San Cristoval. In the course of the day, it became apparent that the Government's order had made not the slightest impression upon the Li [...] world. It is true that the lowest classes beca [...] [106] for a moment, and hastened to change their notes, but without loss of time the bank took very efficient steps; a person was stationed in the market-place with a sufficient quantity of money to change every note presented; they also made known by placards stuck upon the corners of the streets that the houses of Dorca Ayulo Dinegri Hermanos, Canevaro, Barreda y Osma, Candamo, and the Banco Hipotecario were ready to exchange for coined money all the notes of the Banco del Perú, which might be presented.

Thursday, $2^{\text {nd }}$ of September. At somewhat past 7 p.m. I paid my visit of condolence to Dr. J. M. Perez Vocal of the Superior Court, whose wife had died a few days ago; his daughter Alejandrina was married to young Lino de la Barrera, Rafael Velarde's brother-in-law, who as already said commanded the Corvette "Union", in which the ex-minister Ferreyros took his passage for Rio Janeiro. At Perez I met José Maria Varela and two other gentlemen who knew me, but whom I did not recognize. The conversation turned on Falb's prophecies, on Dreyfus' contract, and on the prohibition given by Tomas Gutierrez, Inspector of the army, to receive paper-money in payment. From Dr. Perez house I went to Garland's, where, as it was customary on Thursdays, a few friends had met to play at rocambor. The next day, the $3^{\text {rd }}$, being Garland's birthday, Enriqueta had prepared a nice little supper which was not her habit 
on other Thursdays. Though there were but few guests, we remained together till two O'clock in the morning of

Friday, $3^{\text {rd }}$ of September when I walked home, whilst my wife remained with Enriqueta, it being a very rainy night.

The Directors of the Lima Bank had again their meeting in Lembcke's house, Ugarte and Sagastabeytia being absent. Zaracondegui to my astonishment took his seat next to me, not at the bottom of the table close to Lembcke, his companion as Gerente. This latter was the first to speak and stated that Mr. Ford, Manager of the London Bank of M. \& S. A., had withdrawn his offer to take one third in the loan of half a million Soles to be made by this and the Lima Banks to Dreyfus, against his bills on Europe endorsed by the Peruvian Government. Dreyfus had not been able to show a letter from his correspondent "La société pour favoriser l'industrie et le commerce" in which he was authorized to modify the contract which ad referendum had been concluded in Paris with the agents of [...] Government Toribio Sanz, and Juan Martin Eche[_]. [107] To make up for this want of authorization, Dreyfus had assured the delegates of our bank that his friends in Paris at their last meeting had given him a vote of confidence. When Lembcke had sat down, I rose and said that in the last meeting of the Directory we had unanimously made a full authorization of Dreyfus a sine qua non, and as Dreyfus had not been able to presen $[\ldots]$ was a natural consequence that the bank could not enter into any business with him. Next rose Heudebert saying that the business with Dreyfus was dangerous, unprofitable, precipitate; he spoke very well and detailedly. Then came Manuel O. de Villate, who carried conviction with him. "There was", he said, "as yet no bank established, why should we give nearly half of our funds in coined money, not in paper, to one single individual who would give us bills in payment, for the acceptance of which we had no security? A bank was for the public in general, not for one man only". He went so far as to say that if Dreyfus were to carry out his promise to keep his account with the bank, this would be not only not advantageous but prejudicial, for he might draw at once for half a million of soles in cash, if the Government were to persist in their present whim not to admit bank notes. Heudebert and I said that this promise was of no value, for if Dreyfus were to go to other banks, certainly we could not take him before a Court of justice to force him to remain with us. Also his promise to bring to Lima a million of dollars in gold or silver we looked upon as valueless; whence would he bring the money? If from Chile, he would have to sell his bills there, and who would take them? In this manner we discussed the case for nearly an hour, Lembcke being the only one who took up the cudgels for Dreyfus. Renner said a few words which led to nothing. 
I begged Zaracondegui to give his opinion; he replied that he had nothing to add to Lembcke's statement. Finally, Villate said that it was necessary to come to a decision, and requested me as President to state the question in debate in a few words, whereupon I very slowly and deliberately - in Spanish of course - expressed myself as follows: "the gentlemen who are of opinion that the bank should lend to the firm of Dreyfus the sum of $S / 500,000$ against their drafts will be good enough to stand up; those who opine that the bank should not make such a loan will remain seated". Only Lembcke rose, and thus the question was negatived. A few other points of little importance [...] ussed and it was resolved that the first $25 \%$ of $[\ldots]$ [108] the $11 / 2 \%$ already paid, should be asked for from the shareholders, to be paid in within a months time.

Saturday, $4^{\text {th }}$ of September. Though in the previous evening the Directory of the Banco de Lima broke up as late as 9 p.m., already half an hour later the President Balta knew the result of our deliberations. From Antonio Martinez, who was employed in one of the Government offices under Dr. Quimper, the Minister of the Interior, we learned as a certain fact that Valdeavellano \& Co. who were entitled to demand the payment of the $\$ 3,000$,ooo lent to the Government a few months back, had declared that in consideration of the Financial difficulties in which the President found himself at the time, they would be satisfied with two millions in good bills, but the other million they required cash down.

Tuesday, $7^{\text {th }}$. On this day I presented an escrito to the Juez de $1^{\text {a }}$ Instancia, in which I asked him to approve the valuation of the rent put upon my house by the two appraisers, in as far as the family Sotomayor who had been notified in due time had allowed three days to elapse without having made any observation.

Thursday, $9^{\text {th }}$ of September. Earthquakes more or less severe were experienced about this time all along the Coast from Ecuador to Chile. The purser of the Steamer "Payta", one of the sons of Lucius Richardson, wrote on the $26^{\text {th }}$ August from Caldera that when the steamer on her voyage to Valparaiso found herself on the $24^{\text {th }}$ July at about $11 / 2$ p.m. three miles off the coast, 49 miles south of Arica, and with 75 fathoms water, she felt a most severe shock, so much so that the greater part of the glass and earthenware fell down and was broken, that an iron chest weighing from 1000 to $1200 \mathrm{lbs}$ moved four inches, and that the compasses got out of order. All round the vessel for some distance, the water was in commotion and bubbled up as if it were boiling. The shock lasted 55 seconds and was succeeded by other shocks of less violence till 4 p.m. In Iquique it was likewise felt, in Cobija not. I learned from Dr. Davila that on the same day and at the same hour a strong shock 
had been experienced in the valley of Moquegua, which injured some of the new buildings he was constructing in his hacienda, the old ones having been destroyed by the earthquake of $13^{\text {th }}$ August of last year.

The case of Dreyfus was not yet decided in the Supreme Court [...] [109] Luciano Benjamin Cisneros, Dreyfus's lawyer, had presented a very clever escrito, in which he tried to prove that the Supreme Court was not competent to decide on the "retracto" which being a demand made by a private individual - the Nacionales - against another private individual Dreyfus - ought to be begun before a Juez de $1^{\text {a }}$ Instancia, whilst Dr. Davila of the Superior Court, with whom I spoke on the subject, was of opinion that - as the "retracto" was an incident of the despojo which the Nacionales had instituted against the Government - the Supreme Court was competent to decide on this question, the "retracto". Ureta's Vista-fiscal was now anxiously looked for. In the meanwhile, all the money which Dreyfus had been able to procure was $\mathrm{S} / 5^{0,000}$ from the London Bank of M. \& S. A., a mere nothing under the circumstances. Rumours were afloat that it was the intention of the Government to annul the Municipality, and this for no other reason but because Manuel Pardo, the Alcalde, was a friend of those who called themselves the Nacionales.

Edward Knauer communicated to me the sad news that in July last had died his cousin Teresa, the only daughter of Henry Sieveking and Teresa Reincke; she had hardly reached her $30^{\text {th }}$ year, was married to a certain Mr. Behn, and had lately been confined. On the day of her death she rose and breakfasted as usual; at 1 p.m. she sat down to write a few words when suddenly she felt unwell, the dry nurse, for she herself nursed her child, placed her on a sofa, she drew twice a deep breath, and expired.

Sunday, $19^{\text {th }}$ of September 1869. The apprehensions of the earthquakes, predicted by Falb, occupied the minds of many people; not a few intended leaving the town for the surrounding villages and farms about the $25^{\text {th }}$ of this month, others had built wooden huts in their yards; however, for the greater part the fear was confined to the fair sex, though there were also a few of those who should have known better, who were of opinion that some precautions ought to be taken.

The Judge Patron had with the consent of both parties approved the already mentioned valuation of the rent of my house, and therefore it was now my turn to show in an escrito how much the Sotomayors had to receive of the $\$ 30,000$ deposited at Zaracondegui; by my calculation [...] to $\$ 9285$. This no doubt looked a very fair result and [...] [110] Mariquita and I, particularly the former, rejoiced at our having gained, but the money which we had had 
to disburse in order to obtain our object had been no trifle. Did my dear wife not say to me more than once "they have left me without a trinket; broaches, necklaces, all has fallen into the hands of these insatiable harpies". Besides, my ledger shews that in judicial expenses, including my lawyer's fees, I spent about $\$ 7000$ and that "Expenses to accelerate the suit" came up to about $\$ 8000$.

Juan Aliaga y Puente, whose lawyers were Dr. Manuel Ortiz de Zevallos and Fernando Palacios, obtained a sentence from the Judge de $1^{\text {a }}$ Instancia, Dr. Patron, which said that he had a right to the half of all the property which, belonging to the Mayorazgo, had been sold by his father, and accordingly about a week back a great many persons who during the life time of the father had bought houses from him, had been notified that the son had a right to half the property; about forty of them - at least so Dr. Palacios told me - had given in their counter-escrito, in which they defended the right which they had to the property sold to them by the father Juan Aliaga y Calatayud. My house Calle de Zarate and the shops Calle de Aldavas I purchased from the father with the consent of all the children, including the eldest son Juan Aliaga y Puente, and moreover about a fortnight or three weeks back I obtained from the latter a document drawn out before Francisco Palacios, public notary, in which he again ratified those two sales; thus I was quite safe, and the architect Villa was now drawing out an estimate of the cost of the repairs which might be necessary.

Dreyfus and his contract continued to be the theme of many conversations, and the "Comercio" particularly teemed with articles pro and con. Ureta's Vista-fiscal proving that the Supreme Court was competent to decide the question of "despojo", was a very able document; nevertheless, the lawyers Loayza and Casós published their refutations of the same. In the Comision Permanente Manuel Francisco Benavides presented an excellent informe, proving that the Government had infringed the Constitution by making the contract with Dreyfus; nevertheless this man had obtained money - to what amount I did not know - not only from the Bank of London M. \& S. A., but also from the house of F. Huth Grun [...] by William Brauns, who had endorsed his bills. [...] [111] the pleading in this case, viz.: - on the question whether the Supreme Court was competent or not - began. I was at the door of the Tribunal before 12, when it was already besieged by many persons, and when the door was opened, there was such a rush and crush as I had only experienced at the door of London Theatres; I thought that the frame works of the door would be broken to pieces; opposite the canopy under which the judges - in this case Dr. José Luis Gomez-Sanchez, as President, Alvarez and Muñoz, which three formed la primera sala - were sitting, was the bar; inside the same sat the 
relator before a table. The room outside the bar was left for the public, whilst along the wall on each side of the open place between the relator's table, and the somewhat raised ground where the Vocales sat, stood a bench, a wooden railing in front, destined for the lawyer of each party, and the party interested. The crowd was such that I could not see who occupied the bench on the left side of the Tribunal, probably there were Dr. Luciano B. Cisneros, Dreyfus and perhaps one or two more. The bench on the right side was filled with the native capitalists, amongst whom I recognized Felipe Barreda, José Maria SanchoDavila, Emilio Althaus, and young José Canevaro, who was the last, and next to him a small open space was left, into which a native, whom I did not know, and I squeezed ourselves. Manuel Perez, the lawyer for the native capitalists, declined pleading first, but was over-ruled by Dr. Gomez-Sanchez, and then delivered his speech which lasted full two hours: twice he was applauded, when the President recommended moderation to the audience. He principally attempted to prove - and I think he succeeded - firstly that the Supreme Court was competent; secondly that the laws of 1849 and 1860, in which the Congress determined that natives in all guano business were to be preferred to foreigners, were in force and had not been annulled by the authorization given by the Congress in January 1869 to the Government, for the purpose of raising money in order to make up the deficit of the budget; and thirdly that the other party was decidedly wrong when asserting that the "despojo" was only applicable to a material, tangible thing; he said, and very correctly "que se podia tambien despojar de derechos" - that one could also be despoiled of one's rights.

On the $18^{\text {th }}$ Cisneros pleaded for Dreyfus; I did not go, but was told that [...] was as crowded as on the previous day. Young Adolfo Alv [...] [112] decided partizan of Dreyfus, told me that Cisneros had been inspired; to Guillermo he said that Cisneros was the first orator of the age, whilst I learned from others that he mostly occupied himself with holding up to public execration the Consignees and their usurious practices, thus mixing up the old consignees with the present National capitalists, no doubt very clever tactics in order to rouse the cry against the latter; he did not finish his pleading and continued on Monday, $20^{\text {th }}$ and Tuesday, $21^{\text {st }}$ of September.

Wednesday, $22^{\text {nd }}$ of September. Dr. Perez replied a few words; also Emilio Althaus was allowed to speak in behalf of the native capitalists. I was told that all three days the audience had been quite as numerous as in the previous week.

Thursday, $23^{\text {rd }}$ of September. My wife and myself, Garland, Enriqueta, Enrique, Guillermo, and Antonio, Melchor Velarde, his wife, and three eldest 
daughters, and a great many other persons, perhaps sixty in number - Rafael and his wife were not there - were present at the wedding of Adela, Manuel Velarde's only daughter, with Baltazar Aranivar. Adela was a young girl, just growing into womanhood, of a rather dark complexion without any mental or physical attractions; her education had been but indifferent; on the other hand, she was good-natured, and above all, after the death of her father and mother would inherit a small fortune consisting of two or three houses left to her mother by her parents. Aranivar was nephew of the lawyer Don José, his father, at the time Governor of Islay, being a natural son of Dr. Nicolas Aranivar, many years back vocal of the Supreme Tribunal in Lima. This Baltazar was of an unprepossessing exterior; his address was far from pleasant; he had no money of his own, nor sufficient capacity to make a fortune by his own exertions; he worked as amanuensis on the office of the lawyer Francisco Garcia Calderon; also occasionally as private secretary of Rafael Velarde whilst Minister. How did then the match come about? He married the small fortune which he saw looming in the distance; she, brought up in the strictest seclusion, became enamoured of the first man who presented himself. Dr. Santos Chavez, Archbishop Goyeneche's Secretary, performed the ceremony, and the father and mother of the bride were the "padrinos". We went [...] came back at 10.30. It was a very stupid party [...] [113] such parties generally are, and to me the more so for the frequently given reason that I cannot see nor recognize. I conversed a few words with Pedro Paz-Soldan, Antonio Prada, Manuel Velarde, Dr. Juan Mariano Goyeneche; I also distinguished General Mendiburu and Dr. Garcia Calderon. Garland had the good luck to have a rocambor table arranged for him.

The nearer we approached the $30^{\text {th }}$ September the more apprehensive the people became. From Callao many had emigrated to Bellavista; and the removal from Lima to Chorrillos, Miraflores, and farms in the neighbourhood commenced. Lembcke and Cucalon had rooms made of boards built for them in the Botanic Garden. Judges secured themselves and families apartments in the Palace of Justice for there the inner yard was very large and the buildings consisted of the ground floor only.

Saturday, $25^{\text {th }}$ of September 1869 . It became known that the members of the first Chamber of the Supreme Court had voted in Dreyfus's case. Dr. Gomez Sanchez gave it as his opinion that the Court was not competent to decide on the question; in other words, his vote was in favor of Dreyfus; Dr. Muñoz had voted for the competency. As yet it was a secret with whom of the two Dr. Jervacio Alvarez sided.

The steamer from Valparaiso brought Dreyfus $\$ 250,000$ mostly in gold condors. 
The notary Escobar told me that the correctness of the account made out by me, and according to which the family Sotomayor remained my creditors for $\$ 9285$ had been impugned by them.

Sunday, $26^{\text {th }}$ of September. Dr. Jervacio Alvarez, who paid my wife one of his usual Sunday visits, told her in conversation that he had voted for the competency of the Court, thus there were now two votes in favor of, one against the same. She also learned that Dr. Alzamora of the Second Chamber had been called in, for three unanimous votes were required to decide a question.

Tuesday, $28^{\text {th }}$ of September. Articles in the daily papers continued to treat on Dreyfus's question, but the interest hitherto taken in the same began to abate.

Wednesday, $29^{\text {th }}$ of September. Mariquita infected by the apprehensions created [...] Falb's prophecies, busied herself with taking down and rem [...] [114] room - which she considered the safest in the house - nearly all the porcelain ware and Bohemian glass which we had in our parlour and drawingroom, and on

Thursday, $30^{\text {th }}$ of September when we in the evening went to Enriqueta's habitual party she remained with her daughter, because the yard in the house being very spacious she thought that in case of a "terremoto" she would have better chance to escape than in our house Calle del Correo with a comparatively speaking small "patio". This day the architect Villa began his work in my house Calle de Zarate: the sobrestante (overseer) a certain Muñoz, whom he had engaged, I had to pay as much as $\$ 3.11$ daily.

Saturday, $2^{\text {nd }}$ of October. As said above, the Sotomayors had found fault with my account of the balance due by me to them; the Juez de $1^{\text {a }}$ Instancia took no notice of their remarks and repeated his order to me to pay the sum which I had declared myself willing to do; they appealed, and this day the autos went up to the Second Chamber of the Superior Court, which consisted of Drs. Eusebio Sanchez, Mariategui Jr., and José Maria Perez. Meanwhile my lawyer Dr. Palacios had asked Melchor Velarde for a loan of \$100o on account of the fees which he would have to receive from me. Melchor had lent him the money, which I most naturally had to advance to him. This day I paid the first account of architect Villa, amounting to \$66.6rls. I calculated at the time that the total of the repairs would not exceed $\$ 30,000$. With the architect I made the arrangement that for his trouble I would pay him a commission of $8 \%$ on the disburses which would pass through his hands.

The day having passed over without "terremoto" and even without "temblor" my wife returned to her house, and in the night to

Sunday, $3^{\text {rd }}$ of October, at 12.15, a shock, but a slight one, was felt. 
From Europe and the United States no news of importance. A new submarine cable from a German Port in the North Sea to the United States had been contracted for by the Prussian Government to be concluded within two years. The Canal of Suez was to be solemnly opened on the $16^{\text {th }}$ of November. Corina, to strengthen her system, had been ordered by her Paris medical adviser Dr. Acosta to go to the well known [...] place of Spa, where the the waters are ferruginous; for [...] [115] she had taken with her old Doña Jesus Bedoya; also Juan had remained in Spa for a few days. Edward Knauer informed me that Maria Gaenslie, one of the daughters of his sister Emily, was engaged to marry George, the eldest son of my friend Charles Semper by his second wife Luisa Reincke. This young man was very favourably situated; his father having admitted him, jointly with Otto, the eldest son by his first wife, as partner in his very lucrative manufactory of died woollen yarn.

Monday, $4^{\text {th }}$ of October. This was a fatal day for Dreyfus and his partizans. Alzamora voted with Muñoz and Alvarez, and consequently the first Chamber of the Supreme Court had declared their competency in the Dreyfus question. In the Comision Permanente 8 against 6 had voted that the Government had infringed the Constitution by the celebration of the contract with Dreyfus, and that therefore, in conformity with the Constitution, the first representation should be made to the Executive. The President, Dr. Antonio Arenas, who, it was known, would have sided with the majority if necessary, did not vote. Minister Pierola was ill, and during his illness the Minister of Justice, Teodoro de la Rosa, had provisionally taken charge of the Ministry.

Upon enquiring from the Secretary of the Second chamber of the Supreme Court how my case with the Sotomayors stood, I learnt to my great surprise that on the previous day the three Vocales, to none of whom I had said a single word on the subject, had already sentenced in my favor confirming the sentence of the Juez de $1^{\text {a }}$ Instancia and ordered the Sotomayors to pay me within three days the twenty and odd thousand dollars demanded by me, which sum would have to be deducted from the $\$ 30,000$ deposited at Zaracondegui's and the balance handed over to them. Dr. Aranivar without loss of time "interpuso nulidad", that is to say he appealed to the Supreme Court and already on Friday, $8^{\text {th }}$ of October his procurador took away the autos para fundar la nulidad, thus there was now the same story over again, and though the Sotomayors had not a shadow of justice, I could not but fear the animosity of Mariategui, and the great influence which he had with his two colleagues Cosio and Alzamora. Dr. Palacios [...] that it was impossible for me to lose, and also the [...] [116] Alvarez, whom I consulted, said that I need not be alarmed. In my house Architect Villa continued demolishing the shops once Varela's in the Calle 
de Aldavas; there we intended to build two large stores, two smaller ones, and three or four shops, also Altos with staircase from the street.

In the Dreyfus affair nothing of importance had occurred since last Monday, and as Dreyfus had not appealed to the second chamber, the Fiscal had been ordered to give his vista on the Despojo, of which the "National Capitalists" complained. Meanwhile, there was no money in the Treasury, and the Treasury Bonds, the second series of which, amounting to about half a million due since the $30^{\text {th }}$ September, had hitherto not been paid. Melchor Velarde, who held a good many of them, told me that Dreyfus received them at par giving in payment his drafts of England, but I believed that few if any would make this exchange, one paper for the other. These bonds were issued by the Government six months back to reimburse the military men and civil employes for the deduction from their salaries, to which they had been obliged to submit during the period of Prado's Dictatorship, which reimbursement the Executive had been authorized to make by last Congress. I myself had had some of the bonds, which about a month back I realized with a gain of more or less five hundred dollars.

The $5^{\text {th }}$ October, the last day fixed upon by astronomer Falb for his universal crash, having passed over without any particular disturbance, the various inhabitants of Lima and Callao, who had emigrated to the right and to the left, had by this time gradually returned to their respective dwellings, some of them not a little ashamed of their extravagant fears.

Saturday, $9^{\text {th }}$ of October 1869. Juan Baso and Irene arrived from Guayaquil. The letters from the family in Europe told us that Conradina was still in Spa, and that Schutte, Rosa, Amalia, and children had gone to Vevay.

Saturday, $16^{\text {th }}$. The Supreme Court sent the expediente relativ[_] to my new dispute with the family Sotomayor to the Vista, Dr. Toribio Ureta, who had the well merited fame of being extremely dilatory in his [...] whilst his colleague Dr. Paz Soldan was the very rever [...] [117]

Sunday, $17^{\text {th }}$ of October 1869 . Enriqueta received a letter from her brother Juan, who informed her that he had accepted an invitation from Mr. John Bryce to spend a week or so at his beautiful country-house on the Coast, close to Exmouth, where he expected to meet Mr. and Mrs. Cotes, Mrs. Read and daughters, Manl. Quintana and wife, and others. The Schuttes had returned to Paris from their excursion to Switzerland. Advices had been received by the Peruvian Colony in Paris that the contract which Dreyfus had concluded before his departure had been ratified in Lima, and that the National Capitalists had made a counter-representation, which news had created great excitement. 
Tuesday, $19^{\text {th }}$ of October. The Dreyfus question was in statu quo; my opinion was that the longer he had the contract without its being annulled, the greater was the probability of its never being cancelled. A day or two ago his enemies were in great hopes that Pierola would leave the ministry, for it was known that he and the President had had a violent dispute, nevertheless, the quarrel had been made up and he remained in office; it was also rumoured, though not known for a certainty, that Dreyfus had managed to pay into the treasury the sum of $S / 700,000$ a monthly instalment as per contract.

The papers stated the Napoleon, who had of late been very ill, but was now recovering, thought of abdicating in favor of his son as soon as this latter reached his $14^{\text {th }}$ year, which he would do on the $16^{\text {th }}$ March 1870 , and when he would be declared of age. The Empress had been in Corsica and was making preparations for her journey to the East to be present at the opening of the Suez Canal.

Friday, $22^{\text {nd }}$ of October. Mariquita, who always read the "Nacional" before breakfast, came unexpectedly upon an article which said that Velarde, Minister for the Interior, Barrenechea for Foreign Affairs, and La Rosa for Justice had jointly given in their resignation. I immediately went to Rafael, who told me that it was certainly so, that as yet they had received no reply, and that meanwhile the Minister for War, Francisco Balta, the President's elder brother, had requested them at all events to attend this day in their respective offices, to which they [...] nsented. [118]

Saturday, $23^{\text {rd }}$ of October. The Fiscal Ureta - who this time had been somewhat quicker in his dispatch than usual, probably because Rafael Velarde, when Minister, had spoken to him in my behalf - gave in his Vista, in which he acknowledged the correctness of my calculation of the sum due to me by the Sotomayors, with the only difference that he deducted rent for 8 days, because according to him - and for aught I knew he was right - the suit began not on the $28^{\text {th }}$ February as I had said, but on the $8^{\text {th }}$ March 1864 .

Sunday, $24^{\text {th }}$ of October. More than twenty years ago when our Enriqueta, not yet married, was in the bloom of her youth, we had been in the habit of inviting on this day, when the procession del Rosario on its return to the Church of Santo Domingo passed our house about sunset, a small dancing party, which lasted till 1 or 2 in the morning and which never failed to give satisfaction to our guests. Now times had changed; instead of staying at home to wait for our friends we went to the house of Rafael Velarde to congratulate him on his Saint's day. His saloons - not over spacious - were crowded; of ladies there were the relations of himself and his wife: Mrs. Diego Masias, her sister Tránsito Llosa, and two daughters of Rosa Mercedes Riglos, Pedro Orbegoso's widow, playfellows of Zoila Velarde. The number of gentlemen was great: Melchor 
Velarde, Dr. J. M. Perez, Garland and Diego Masias who formed one rocambor table, four other gentlemen unknown to me, who sat down to another table, the lawyer Francisco Garcia Calderon, his amanuensis Baltazar Aranivar, the Prefect General Segura, the ex-Minister for Foreign Affairs, Barrenechea, a certain Gonzales, a little Cholo from San Pedro, clever and sharp, decidedly an opposition man, Serapio Orbegoso son of the late President (these two, members of the Comision Permanente), Dr. Ignacio Tavara, Dr. Arosemena, José Muro, Dr. Tordoya, Bishop of Tiberiopolis, and some more. At ten O'clock we were ushered to the dining-room where the table stood covered with tea and coffee, ices and jellies, and other good things; the ladies found room to sit down; the gentlemen remained standing. The Ministerial crisis and the Dreyfus Contract were exclusively the topics of conversation. All kinds of reports [...] some false found listeners if not believers. "The [...] [119] had hinted to Pierola that he should resign, which he had done accordingly". "The Ministry for the Interior had been offered to Col. Secada that of Foreign Affairs to Mesones; that of Finances to young José Canevaro, also to Juan Mariano Goyeneche y Gamio, but both had declined accepting it!" "Dreyfus had offered to the Government to pay monthly 1 million Soles instead of 700,00o as the contract said" etc. etc. Mariquita and I walked home at 11.30.

Wednesday, $27^{\text {th }}$ of October 1869. At an unusually early hour Mariategui, as President of the Supreme Court, called my case. Aranibar, who no doubt was instructed before hand, was ready and pleaded. My lawyer Dr. Palacios, of whom Mariategui well knew that he being Juez de Alzada, would not be in his office at such an early hour, hurried to the Court as soon as the porter went for him, but Mariategui would not wait, and consequently Palacios did not plead. All this I learned from Dr. Alvarez, who told me that the partiality of Mariategui in favor of Aranivar passed all bounds; nevertheless, he gave me hopes that Muñoz and Ribeyro would vote with him. I went to these two, and on

Thursday, $28^{\text {th }}$ of October the said three confirmed Ureta's vista, Mariategui and Cosio again voting against me. Now the documents had again to be returned to the Juzgado de $1^{a}$ Instancia, and I was curious to see what argument Aranivar would now hit upon to delay once more the conclusion of this interminable suit.

Garland had as usual his Thursday evening party; there were not less than three rocambor tables, each with four players, and as Enriqueta intended to go to Chorrillos within a few days she had thought proper to treat her friends to a supper as she would probably not see them again for some time. For me it would have lasted too long, thus I went home at 11 O'clock, whilst my wife remained and even slept there. 
Friday, $29^{\text {th }}$ of October. The resignations of the four Ministers were accepted by the President through the medium of his brother, the Minister of War, who remained in his post, those of Velarde, La Rosa, and Barrenechea, in very dry terms, that of Pierola with many thanks $[\ldots]$ the great services he had rendered the country during the [...] [120] he had held office. A new Cabinet was formed, which certainly did not deserve the Confidence of the country. Mariano Felipe Paz-Soldan was named Minister for Justice and Ecclesiastical affairs, Mariano Dorado, hitherto in the Superior Court, accepted that of Foreign Affairs, Col. Secada, who had occasionally been Prefect in one or other of the Departments, took charge of the Interior, and Angulo, who had on various occasions been chief of some inferior office or other and who in my opinion could know little about finances, was raised to the Finance Ministry, all four in the understanding that they should support Dreyfus's Contract.

Sunday, $30^{\text {th }}$ of October. This was the fifth Saturday that I paid the "planillas" or accounts of weekly expenses of the architect Villa, who continued demolishing the shop Calle de Aldavas. Until this day inclusive I had paid \$2208.

Saturday, $6^{\text {th }}$ of November. In the case of the National Capitalists against the Government complaining that the contract with Dreyfus deprived them of the rights of preference which they had in all guano business, Dr. GomezSanchez, as it was expected, gave his vote that they had no right to complain, Alvarez and Muñoz that they had; thereupon, Dr. Alzamorra was called in to decide and this day - contrary to general expectation - he gave his vote with Gomez-Sanchez; now there being two against two, Dr. Juan Antonio Ribeyro was named.

My own suit against the Sotomayors had undergone no change; the documents were returned from the Supreme to the Superior Court, where they still lay, for neither the Sotomayors nor I had as yet been willing to pay the four or eight rials which were required to pass them to the Juez de $1^{\text {a }}$ Instancia.

Melchor Velarde had been dangerously ill in the first days of last week. Dr. Grau said that he was suffering from "pulmonia", inflammation of the lungs, Consultations of several physicians were held; he was bled and a blister put on his chest; now he was considered out of danger. I went twice a day to enquire for him; when admitted to his bedroom, he appeared to me beyond conception weak. His elder brother Manuel had been ill for nearly five months of a [...] pain in the sole of his foot which as yet had [...] [121] all the remedies of the various physicians to whom he had applied.

By last steamer I had no letter from Juan, who was still with Mr. John Bryce at his country-seat near Exmouth. Rosa wrote Enriqueta that their whole family was again united in Paris, and that Adela Luzarraga, the widow of Tomasa, had 
died, leaving two children, Maria Ana, and Manuel both immensely rich. The Empress Eugénie had arrived in Constantinople, whence she, the Sultan, and Francis Joseph - Emperor of Austria - were to proceed jointly to the Suez Canal to be present at its solemn opening. One paper said that the French Emperor, who had recovered his health, had addressed a very energetic note to the Cabinet of Berlin, in which he set forth that if the Grand Duchy of Baden were admitted into the North German Confederation he should look upon it as a casus-belli. The famous Paris preacher Père Jacinte, Carmelite Friar, had in some measure separated from the Catholic persuasion; at all events he had declared himself opposed to the infallibility of the Pope, and demanded full freedom of speech in the Ecumenical Council, which on the $8^{\text {th }}$ December was to open its sessions in Rome; for this request he was likely to be excommunicated. Also the well-known Scotch clergyman, Dr. Cummings, had directed a letter to the Catholic Archbishop of Westminster, Dr. Manning, asking whether in case he were to attend the Council freedom of discussion would be permitted to him, to which he had received from the Pope himself an answer in the negative. From my cousin Francis Willink, the wife of Dr. John Cresswell, I received a letter dated Winchmore Hill, Septr. $26^{\text {th }}$ in which she informed me that they were in great excitement, because as a branch of the Great Northern Railway was to pass through their village, she and her mother would be obliged to leave their houses and to remove to another, where it was their intention to form one family, she, her husband, her two youngest children, her mother now 80 years of age, and her brother Diederich, clerk in the Australian Union Bank. Her eldest boy Willink, weak in mind and body, continued under the care of her husband's mother; her daughter Henrietta was, [_] her friends said, a pretty and clever girl, whilst her son Francis, wh [...] him in 1863 was a beautiful, extremely fair [...] [122] fellow, was so short sighted that he found the greatest difficulty in attending to his studies.

Sunday, $7^{\text {th }}$ of November 1869. Dr. Ribeyro, who as yesterday said, was to decide the important Dreyfus question, paid this forenoon one of his usual Sunday visits to my wife; he, as in duty bound, affected the strictest impartiality; nevertheless, from one or two expressions, which escaped him, Mariquita inferred that he was well inclined towards the native Capitalists. The rumour went that Alzamorra had sided with Muñoz, and that Alvarez had passed over to Gomez-Sanchez, that is to say to Dreyfus's side. If this were true, Mariquita and I felt confident that he had been influenced by his son Adolfo whom we knew to be a staunch partizan of the Dreyfus party, and intimate with the brothers Cisneros, one of whom was Dreyfus's lawyer.

In the course of last week, Dr. Pedro Saavedra, Minister under Prado when Dictator, was arrested; perhaps his imprisonment had some connection with 
the military disturbances which had lately occurred in the Fort of Santa Catalina.

The $13^{\text {th }}$ of November being Mrs. Bergmann's Saints day we had in former years been in the habit of spending this evening with her; this year however we found ourselves under the necessity of giving the preference to Don Diego Masias, who had formally invited us to his house to celebrate his Saint's day. Col. Diego Masias was a native of Arequipa, where in former times he and Don Domingo Gamio had been known as the two most efficient ringleaders of the Arequipa mob, of which they had given proofs on several occasions. Masias had some fortune of his own, and in the beginning of the year had received a gratification of at least $\$ 100,000$ from $\mathrm{H}$. Meiggs, the Arequipa railway contractor, for having made use of the influence which he had with the President Canseco, in his Meigg's behalf. Such an increase of his fortune induced him to settle over to Lima, where he bought in public sale, the handsome and large house opposite the side wall of the Hall of Justice, hitherto the property of Manuela and Rosa Osma, for which he paid $\$ 43,000$. The reason that he got such a nice house [_] a comparatively small sum, was that the first story was occup [...] notorious Mariano Osma - or rather by his family [...] [123] himself was at the time safely lodged in one of the public prisons - and with this man nobody, unless a "fear nothing" like Masias, liked to come into contact. He had laid out some money in the repairs of the house, also in the fitting up and furnishing of the saloons, which this evening he for the first time threw open to his friends. Of ladies there were besides the hostess and her sister Tránsito Llosa, my wife and Enriqueta, Mrs. Rafael Velarde, Elena, daughter of Pedro PazSoldan, married to Alaiza, a Mrs. Ramos, wife of the ex-treasurer of Arequipa and one or two more. The gentlemen I need not enumerate. Conversation, rocambor, and dancing filled up the time; I wanted to get away early but could not find my hat and stick and had thus to partake of the refreshments laid out in the dining room. My wife was placed at the head of the table. I sat between Mrs. Masias and Mrs. Ramos. After we had risen, I was allowed to leave, but on condition that I did not take my wife with me, and on

Sunday, $14^{\text {th }}$ of November when I awoke, I found she had not come home at all, because the night having been very wet she had preferred remaining at Enriqueta's, whose house was three cuadras nearer that of Masias than ours.

The state of Melchor Velarde's health had so far improved that his medical adviser was certain of his recovery; also the pains in the sole of his brother Manuel's foot were gradually giving way to the judicious treatment of the Sambo physician Almenavar.

Tuesday, $16^{\text {th }}$ of November. By the advice of Dr. Middendorf who was of opinion that the fresh Chorrillos air and fine sea breeze would do Enriqueta 
much good - for she was always suffering from migraine - the whole family of the Garlands removed this day to our rancho in Chorrillos. Garland, the father, had to come in daily; Enrique and Guillermo remained in town and took their meals in my house. Mariquita, who was desirous to escape being in Lima on the $21^{\text {st }}$ her birthday, when she was certain that the house would get filled with uninvited guests, accompanied her daughter; I also went with them, but returned and in the evening had with me first Duval for [_]ding, next Limpricht for a game at chess.

Wednesday, $17^{\text {th }}$ of November. Enrique's birthday - We all dined in [...] [124] Juan's letter was dated Paris $15^{\text {th }}$ October. He had seen Rosa and family and frequently dined with them. Earl Derby died on the $23^{\text {rd }}$ of October at the age of seventy. On the $22^{\text {nd }}$ October Empress Eugénie arrived at Alexandria. There was every probability that the Duke of Genoa, son of Victor Emmanuel, King of Italy, would be elected King of Spain.

In Lima nothing new. The Dreyfus question dragged on, and the longer the decision was delayed, the more certain was he of keeping the contract; his lawyer had recused Dr. Muñoz, one of the Vocales of Supreme Tribunal, because he had stood Godfather to Carlos Candamo, one of the natives who was carrying on the suit against him. Candamo had now withdrawn his signature, but at all events an impediment had been thrown into the way, which would again put off the sentence.

Sunday, $27^{\text {st }}$ of November. Though this was my wife's birthday, it was as late as 2 p.m. before I went to Chorrillos, having first paid a visit to Dr. José Luiz Gomez Sanchez, whom I had not seen for some time. On my arrival, my wife - to whom I took my usual present of ten gold ounces - told me that the first large bouquet sent her had been that from Don Diego Masias, the second from Doña Estanislaa Bergmann, the third from Johannes Limpricht, who by indisposition was prevented from presenting it personally. Enriqueta's and Garland's gifts were pretty and valuable; Guillermo, Enrique, even the servant girls, none would remain behind, gave something according to his or her means. To my and my wife's astonishment, not so to that of the Garlands who had prepared themselves before hand, several friends came from Lima: Dr. Jervacio Alvarez, his son Adolfo, his grand-daughter Aurora Santillana, Dr. Middendorf and Linnich of Huth's house, Juan Bazo and Irene, Rafael Velarde and wife, Dr. Lucio Barrios and his little boy, Santiago and Ignacio Távara, and Anto. Martinez, further General Cisneros and his two grown up daughters, who at the time resided in Chorrillos. All these and our own family found room at the table, covered with many good things, and my wife and I, when left by ourselves, could not but regret that Enriqueta should have gone to such expense on our account. I had still some [_] of Roederer's champagne left, 
which was excellent, also the $[\ldots]$ in one word, all seemed to be in good spirit and [...] [125] themselves. Before and after dinner rocambor was, of course, the occupation of the gentlemen. When it got dark, General Cisneros had a piano brought from his rooms in the ground floor of Cucalon's house. He also fetched a military band, and thus there was music enough for the young folks to dance till about 10, when it was time to return to Lima.

One of the sons of Lembcke, very intimate at the Cisneros, also formed one of the party, and to the astonishment of everybody, even Pedro Cisneros Jr. ventured to show his face; however, nobody took any notice of him, which he richly deserved.

Tuesday, $23^{\text {rd }}$ of November 1869 . In the papers appeared a translation of a letter in which the Jewish firm Leiden Premsel \& Co. of Paris, to whom, as well as to La Société Général of Paris, Dreyfus, even before his contract had been ratified, had ceded $40 \%$ in the guano business on condition of their finding the funds necessary, proposed to other bankers on the continent a subinterest. Dreyfus, in the Comercio of Saturday in an article signed by his firm, declared that this letter was not authentic, whereupon Thomas Lachambre \& Co. of Lima inserted a few words in last night's "Comercio" affirming that their firm in Paris had received a copy of the letter from a banker to whom the original from Leiden Premsel \& Co. had been addressed.

My lawsuit was again at a stand-still, for notwithstanding the sentence of the Supreme Court upon which the Juez de $1^{\text {a }}$ Instancia founded his, that Zaracondegui should be notified to deliver to me $\$ 20.584$ (say $\$ 20,715$ originally claimed by me, less 131 error discovered by Ureta) and that the balance should be handed to the Sotomayors, Dr. Aranivar had appealed to the Superior Court, because as he said, there was an evident mistake of about $\$ 3000$ and that I having the money in my possession - not Zaracondegui - should have been notified.

Wednesday, $24^{\text {th }}$ of November. I went to Chorrillos and remained till Thursday morning.

Friday, $26^{\text {th }}$ of November. This day the Dreyfus Contract received two heavy blows. The Comision Permanente decided by a majority [_] seven to six that the second representation which the Constitu [...] should be made to Government for having in [...] [126] constitution when making the contract, and at about the same hour, the Supreme Court, viz.: Muñoz, Alzamorra and Ribeyro, against Gomez-Sanchez and Alvarez decided "Que habia despojo", which prompt decision had not been expected by any one. Only on the day previous Gomez-Sanchez, Alvarez, and Alzamorra, had declared that there was no ground for the recusation of Muñoz, and this their opinion they had founded upon the Vista-fiscal of Ureta, who pointed out the difference between 
baptism by water, and baptism by oil; the former, according to the Catholic religion, causes a spiritual parentage to exist between the Godfather and the Godchild, the latter, not, and Muñoz was the Godfather of Carlos Candamo at the baptism with oil not with water.

In the Comision Permanente the Contract with the Government and Templemann \& Bergmann for the construction of the Muelle Darsena, or Dock, in Callao, was approved by a majority of eight to five. Dr. Pedro Galvez was named Peruvian Minister in London and Paris, Luis Mesones in Rio Janeiro

Sunday, $28^{\text {th }}$ of November. This morning I started at 5:45 a.m., walked nearly as far as the Chacarilla in the valley of Lurigancho, thence climbed up the ridge of hills to the left, and up and down. I reached the pass behind the altillo, then up again the steep ascent I came to the natural cave in form of a shell, down to the pass behind the convent de los Descalzos, up to the summit of San Cristoval and down to where the "paseo militar" finishes, whence along the two Alamedas del Acho, I reached my house at 9.15.

When Duval was gone, I paid as many as eleven visits, and was in good time for the 5 O'clock train for Chorrillos. Middendorf, Linich, Ignacio Tavara, Enrique dined with the family; the three first named, and Garland played rocambor the whole day long till 1o O'clock.

Tuesday, $30^{\text {th }}$ of November. The second Fiscal, José Gregorio Paz-Soldan, to whom the sentence of the Supreme Court in the Dreyfus question, as regards "el despojo", had been notified, gave in his Vista [...] nding the rescision of the Dreyfus Contract, whereupon the [...] of the Supreme Court - GomezSanchez Alz [...] [127] Muñoz, and Alvarez - decided that this demand of the Vista should be made known to the second chamber of the same court.

Mariano Felipe Paz-Soldan, as Minister for Justice and Ecclesiastical Affairs, had requested that the Bishop of Puno, Huertas, for various acts of disobedience to the Supreme Government, should be called to account before a court of justice, to which demand the President and the other Ministers immediately acceded; meanwhile, the Bishop had absented himself without permission and embarked for Europe in order to be present at the Grand Council convened by the Pope for the $8^{\text {th }}$ December.

I went out to Chorrillos mainly for the purpose of consulting with my wife, whether the sons of the lately deceased Chilian Ramos, owner of the Cañete sugar plantation, were proper persons to whom to let the two largest stores which we were building in the Calle de Aldavas, and for which they had applied to me as soon as they might be concluded.

Wednesday, ${ }^{\text {st }}$ of December 1869. The Directors of the "Banco de Lima" met for the first time in a house Calle de Mantas, owned by Julian Zaracondegui, which we had rented from him at $\$ 500$ monthly, the upper story being relet 
to the sons of Lembcke for $\$ 100$. It was a house with a very narrow façade, but of considerable depth, and with a splendid vault for keeping money, in every respect well adapted for a bank. The principal object of our meeting was to name the clerks of the establishment, and very naturally our choice fell upon such as were most recommended by the Gerentes. Climaco Basombrio, a cousin of Juan Bazo, hitherto cashkeeper in the Banco del Perú, obtained the same post in our bank. John Donner was to fill the situation of bookkeeper, if he could present a guarantee of $\$ 25,000$ required by the Statutes. This Donner, a native of Altona, was the same of whom I have already made mention, son of Otto Donner, Admiral in the Prussian service.

Thursday, $2^{\text {nd }}$ of December. The sentence of the Supreme Court, relative to the despojo, which declared that the National Capitalists had been deprived of their just right to the Guano Consignment was notified [...] Government. Dreyfus received by the Steamer fifty thou [...] [128] Sovereigns, and nearly \$200,000 in American gold.

Juan wrote me that the chilblains, his everlasting enemy, obliged him to leave Paris for Nizza.

Wednesday, $8^{\text {th }}$ of December. Every Sunday and holiday I was in the habit of going out to Chorrillos; so I did this day, Dia de la Concepción, and was joined in the train by Dr. Lucio Barrios, who told me that the official paper "El Peruano" had published a decree signed by the Minister of Finance, Angulo, with the rubrica of the President, which deprived Schutte \& Co. of the consignment of guano to Germany and other countries, and commissioned Toribio Sanz, Fiscal Agent in Europe, to receive within a fortnight after the receipt of the order, from Schutte \& Co.'s agents all the stock of guano on hand, and to make good to them all their disburses. Lucio Barrios was a lawyer with a small fortune of his own and little practice in his profession; his acquaintance I had made at Enriqueta's evening parties, where Melchor Velarde had introduced him. When in Chorrillos I learned from Garland that the above thundering decree was the natural consequence of the refusal of Schutte \& Co., represented by him, to hand, in conformity with Supreme orders, to the firm of Dreyfus and to their agents, copies of the fortnightly accounts which they, like the other guano consignees, had to present to the Peruvian Government.

Thursday, $9^{\text {th }}$ of December. Arrived from Europe, Arthur Heeren with his young wife, Carlos Candamo's eldest sister, and Alexander Westphal, head of Huth's establishment, with his lady, a native of the United States.

Saturday, ${ }^{\text {th }}$ of December. This morning before 9 O'clock I went to see Dr. Teodoro de la Rosa, President of the first Chamber of the Superior Court, in which my case with the Sotomayors had been sleeping for the last three weeks, and begged him to dispatch it promptly; he promised to do so and kept his 
word for when I went at 3.30 to the Secretary's office, I received the welcome news that the Superior Court had confirmed the sentence of the inferior judge, and ordered the payment of the sums respectively to the Sotomayors and to myself.

This night's "Nacional" published a loose sheet in which it $[. .$.$] known$ that the National Capitalists had proposed [...] [129] Government, in case it would annul the Dreyfus Contract, and offer the guano business to general competition - I supposed by means of tenders - they, the National Capitalists, declared themselves ready to reimburse Dreyfus for all his outlay, by means of bills upon Europe, and to advance monthly $S / 1,000,000$ until it were decided who would have the business, merely on condition that the successful competitor made good to them the amount disbursed, together with $5 \%$ annual interest. Meanwhile, Dreyfus and the Bank of London, managed by Frederic Ford, who rendered him great assistance, continued to receive money by every steamer.

Sunday, $12^{\text {th }}$ of December 1869 . When making my round of visits, I called upon Mr. and Mrs. Westphal in Huth's house; whilst I was with them, Dr. McLean, and Brauns, Dreyfus came in; he seemed to be quite at home. I made him a slight, almost imperceptible bow, which he probably returned, but I was not able to distinguish, whether he did so or not, and whilst he talked with the gentlemen in Spanish, I conversed with Mrs. Westphal in English. When I left, I again bowed to him very slightly.

At 5 I went to Chorrillos. Middendorf, Ignacio Tavara, Rafael Velarde, and Limpricht dined with the family. Rocambor was as usually resorted to, to while away the time.

Tuesday, $14^{\text {th }}$. In the evening I again went out, and on

Wednesday, $15^{\text {th }}$ after taking a bath, I found on my return to the rancho the architect Villa who had come to consult with my wife and myself about the repairs of our house Calle de Zarate and Aldavas.

In the Banco de Lima the first $25 \%$ of the amount subscribed had to be paid; of course, I handed in my cheque on the Banco del Perú, where hitherto I had kept my account; other shareholders did the same, and thus a large amount of silver Soles passed from that bank to the Banco de Lima.

I saw by the papers that a company was about being formed for the purpose of constructing a new railway from the town of Ferreñafe at a short distance in the Interior, through a rich district covered with rice and [...] gar plantations, to the Port of Eten. The capital was to be 1 million Soles [...] S/80o,ooo had been subscribed say $S / 100,000[\ldots][130]$ following eight: Cotes and Althaus, José Canevaro é hijos, Delgado Herm. é hijos, Ruden \& Co., Juan A. Garcia y Garcia, Enrique Meiggs, Tenaud and Pomar, and Carlos G. Candamo. As I was at this time flush of cash, for my capital hitherto lent to Schutte was being 
gradually returned to me, I went to Emilio Althaus, President of the new Company, and asked him, whether I could obtain one fourth of one of the two shares which had not yet been subscribed for, to which I received an answer in the affirmative.

This day Schutte \& Co. presented their escrito to the first chamber of the Supreme Tribunal, in which they complained of having been unjustly deprived of their guano consignment, secured to them by previous contracts, at the foot of which escrito without loss of time the said chamber consisting of GomezSanchez, Alvarez, and Muñoz ordered the following words to be written: "Informe el Ministro del Ramo". Francisco Garcia Calderon was now the lawyer of Schutte \& Co. Luciano B. Cisneros, formerly employed by them, had in reality made himself guilty of the, in a lawyer unpardonable crime of defending at the same time two parties inimical to each other; whilst he was paid for defending S. \& Co., guano consignees to Germany etc., he entered the service of Dreyfus \& Co., whose object was to obtain for themselves the guano consignments to every country in Europe.

Sunday, $19^{\text {th }}$ of December. This day as usual I spent in Chorrillos, bathed, played chess with Limpricht, and made some calls, one upon Mrs. Arthur Heeren, an insignificant lady, who could not boast of any personal attraction. Vicente Camacho, who had lately arrived from Europe, dined with us.

Monday, $20^{\text {th }}$ of December. Arthur Heeren, who sat next to me in the train, spoke all the while from Chorrillos to Lima about a recent invention made in England by a certain Mr. Hodgson. It was called the Aerial railway and Heeren, who had made some arrangement with Hodgson, thought of introducing it into Perú wheresoever it might answer. As far as I could understand, this new invention consisted in a number of poles all of the same height, placed at certain distance from each other: at the top of each a small wheel is fastened, and at each extremity of the row of poles stands one cylinder; over the wheels $[\ldots]$ a wire-rope put in motion [_] a stationary [...] [131] To this rope packages of small weight are fastened, which are carried along by the rope moved by the engine. I may say in anticipation that this plan, though tried in many places, has not answered the expectations entertained by the inventor.

This day appeared a decree of the Minister of Finance which said that, after having taken the opinion of the Council of Ministers, it was the intention of the Executive to place the Incidente as he called it - and which Incidente was nothing less than the sentence of the Supreme Court of the $26^{\text {th }}$ Nov., which had declared that the National Capitalists had been deprived of their rights before the Congress, to meet on the $28^{\text {th }}$ July of next year, and this was to be done because the Supreme Court and the Executive interpreted in a different manner the authorization which the last Congress had given to the Government 
for making up the deficit in the budget. The decree was, of course, graced with the rubrica of His Excellency, and this was done notwithstanding the written declaration given by Emlio Althaus, as President of the native Capitalists, that they were ready to "responder por los daños y perjuicios, que con arreglo á las leyes del Pais pudiesen declararse á favor de Dreyfus Hermanos y Cá., y contra el estado", which declaration they had given in reply to a question verbally asked by the Minister of Finance on the $15^{\text {th }}$ whether they, the native Capitalists, were willing to make good to Dreyfus the legal claims which he might make against the Government if his contract were cancelled.

Friday, $24^{\text {th }}$ of December. The Directors of the Banco de Lima were assembled for full two hours. Firstly, it was resolved that the bank should begin operations

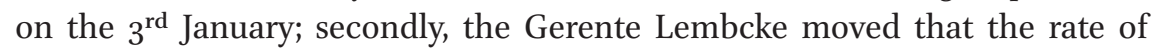
interest or discount, hitherto here in Lima $12 \%$ p.a. should be reduced to ten and even to $9 \%$, which motion was approved, mine being the only dissenting voice and vote; thirdly, Sagastabeytia and I, co-directors of the Pasco Railway Company, proposed that the bank should lend the same on the security of the railway the sum of $S / 140,000$ I having declared that I was willing to lend S/6o,ooo to the said company. Sagastabeytia and I then left the room, and on our return were informed [_] the Directory would not make the loan the security being considered [_]ient; fourthly A certain Vicente Silva lessee of [...] [132] of San Pedro in Lurin, asked for a loan of S/100,000 upon the mortgage of the movable property on the estate, the land itself belonging to the Convent of La Buena Muerte. Zaracondegui and Castillo advocated his request. I took no share in the discussion, not being acquainted with the merits of the case, and it was finally resolved not to make the loan unless Silva bettered the Security.

Saturday, $25^{\text {th }}$ and Sunday, $26^{\text {th }}$ of December. These two Christmas days I spent partly in town, partly in Chorrillos. When in town I climbed up San Cristoval, when in Chorrillos I took as many baths as I prudently could. I also made my usual calls; for instance upon the two vocales Ribeyro and Alvarez, congratulating the former for his having been named President of the Supreme Court. Alvarez told me that Ribeyro had been chosen merely by a majority of 1 over his rival candidate Mariategui.

In Chorrillos I saw the Ministers Mariano Dorado and Mariano Felipe PazSoldan, who at the meeting of the Council of Ministers of which I spoke on the 20 inst., had opined that the Executive should submit to the sentence of the Supreme Court, but had been overruled by the three other Ministers Francisco Balta, Secada, and Angulo. At breakfast and dinner we had various friends Limpricht, Camacho, Melchor Velarde, Antonio Martinez, Adolfo Alvarez, and others. 
After protracted sufferings caused by an abscess in the liver died in Chorrillos young Thomas Buckley, nephew of Thomas Wheelock, leaving his widow, an Estenos, with several children and without money.

Monday, $27^{\text {th }}$. At 2 p.m. Emilio Althaus whilst walking in the street was arrested, and taken first to the Intendencia, then to the Carceletas, in the Plaza de la Inquisicion - why, nobody knew, though all suspected that it was on account of his unflinching opposition to the Dreyfus Contract. Within these last few days two contracts for the construction of two railways were secured by Enrique Meiggs: the one form Callao, passing Lima, up the quebrada de San Juan de Matucanas to La Oroya, a small place on the other side of the Cordillera; the other from Arequipa to Puno. For the building of the former, which was to be concluded within six years, Government purposed issuing bonds to $[\ldots]$ unt of $S / 27,600,000$ or their equivalent in the coin of the cou $[\ldots]$ [133] they were to be sold, interest on them to be $6 \%$ redemption $2 \%$ annually. That from Arequipa to Puno was to be concluded in three years and to cost, in the same manner as the previous one, $\mathrm{S} / 32,000,000$.

Dreyfus \& Co. had made a new proposal to the Government; they bound themselves to introduce into the management of the present Guano Consignments savings to the extent of 3,000,00o Soles, and if the savings did not come up to his amount, they themselves would make good difference.

Tuesday, $28^{\text {th }}$ of December 1869 . By this day's steamer embarked for Europe Augustus Dreyfus, accompanied by his brother-in-law Carlos Bergmann which latter went in all probability with the object of forming a company in Europe, which would furnish the funds necessary for the construction of the Callao Muelle Dársena. Carlos Candamo left on board the same vessel.

The firm of Dreyfus made known that all such as had taken an interest in their contract with the Government had to pay the amount subscribed in three instalments, viz.: on the $20^{\text {th }}$ January, $20^{\text {th }}$ February, and $20^{\text {th }}$ March.

Emilio Althaus was placed before the criminal judge Carrillo, who took his declarations. To the Comision Permanente he presented a petition complaining of his illegal arrest, which petition, notwithstanding the representations of Oviedo, Ybarra, Benavides, and Luna, members of this board, was not received by its Vice President Evaristo Gomez Sanchez under the pretence that it was drawn out in disrespectful terms.

On the $5^{\text {th }}$ November died in London Mr. George Peabody, a native of the United States, and head of the well known and immensely rich firm which bore his name. On the $17^{\text {th }}$ November the Canal of Suez was opened with great solemnity - forty steamers went through from Port Said to Suez. Present were: Empress Eugénie, Francis Joseph the Emperor of Austria, the Vice-roy of Egypt, and many other high potentates. 
Wednesday, $29^{\text {th }}$ of December. This morning I climbed up San Cristoval from a point where I had never done it before, viz.: at that part of the road to Lurigancho which was called "el mal paso", and where the rock formerly blocking up the road had been blasted away to make room for a pretty wide passage; it was a very fatiguing ascent.

[_] the forenoon the broker Marty came to me with [...] [134] \$500o signed by John Gallagher, father and son, which I was ready to discount at $12 \%$, but now the bad effect of the resolution taken by the Banco de Lima on the $24^{\text {th }}$ made itself manifest; Marty would not allow me more than $10 \%$ this being the rate fixed upon by the said bank, and also by "La Providencia". At a later hour I went to Chorrillos, and on

Thursday, $30^{\text {th }}$ of December accompanied my wife and daughter to town; the former had again been ailing a little. At about two in the afternoon I went to see Emilio Althaus in the Carceletas; I had to ask the officer on guard for permission to enter, and then had to pass through two iron grated doors with a turnkey at each, to the former of whom I had to give up my stick. Althaus, together with General Bustamante previously arrested because pasquins against the President José Balta had been found upon his person, were lodged in an extremely spacious vaulted apartment - in former times the Chapel of the Inquisition; the walls were whitewashed, the floor bricked; towards one extremity, opposite to the door, the floor was raised two or three steps, and boarded; the canopy, under which the Inquisitors used to sit, still remained; here stood a table, several chairs, benches, and the bedsteads of the two prisoners. Visitors there were six or eight, and whilst I was there Francis Bryce and Vicente Hurtado, the Lima managers of the Guano Consignment to the United States, came in. Althaus told me that he had passed the first night after his arrest in a nasty, dirty prison; he seemed however to be in good spirits and expected that on the following day the bail, or garantia de haz as it is called here, given for his personal appearance by Antonio Salinas and Domingo Laos, both landed proprietors, would be admitted, which however on

Friday, $33^{s t}$ was refused by the Judge Carrillo, though the Fiscal Agent had opined for admitting the same.

1870

Saturday, $7^{\text {st }}$ of January. The following is a literal copy of what I wrote in my original diary. "Again a year had elapsed; it commenced in [...] dismal manner with the dangerous illness of my wife, but [...] [135] be praised already towards the end of January she was fast recovering, and since then the state of her 
health has been pretty fair; may she be preserved to me for many many years is my first prayer; my second is for Enriqueta, little Maria and family, the third for myself and the conservation of my eyes."

I had gone to bed at the usual hour of 10.30 and awoke when the clock struck twelve, thus by a mere chance I began this year, not in a state of oblivion. I rose 5, when it was not yet full daylight, left the house a quarter of an hour later, walked down the two Alamedas del Acho, el paseo militar, climbed up San Cristoval, and hastened down the other side without stopping or resting anywhere, so that I was back before seven, but then I again lay down and slept for an hour.

I saw by the Nacional that in the Comision Permanente, when Dr. Arenas presided, Evaristo Gomez-Sanchez had been decidedly in the minority; accordingly Emilio Althaus's protest had been passed to a commitee consisting of Ybarra and Orbegoso. At 12.45 I was in one of the rooms belonging to the Ministry for Foreign Affairs, where gradually all the members of the Diplomatic and Consular Corps assembled; having waited for about half an hour, we were informed that the President was ready to receive our congratulations for the new year, and accordingly we - the Diplomatic Corps two by two, then the Consular Corps Souza Ferreira and I, behind us Lembcke and Escardó and so on - walked to the receiving room where the President stood at the opposite extremity. We then ranged ourselves in a large half circle; Benavente for Bolivia, the Senior, spoke a few words to which José Balta replied, reading from a paper which he held in his hand, whereupon we all the one after the other shook hands with him and marched out again back to the office of the Minister for Foreign Affairs. Here great indecision prevailed whether we should go with the President in procession to Monserrate where the foundation stone for the Transandine Railroad was to be laid; the Diplomatic Corps would not attend, the Consular Corps decided upon going, and thus we formed part of the long cortège, which occupying many cuadras, walked from the palace in the heat of the sun - for it was a cloudless day - as far as Monserrate. Our place was before the members of the Supreme Court; along the streets the soldiers stood one file on each side and kept order, but when we [...] the scaffolding where the President and Meiggs were to har [...] [136] the assembled multitude and the Archbishop was to bless the first stone; the crowd was such that we could not move a step; there we stood wedged in, the Minister Angulo, Lembcke, myself, Anselmo Centeno, a fat Friar, and a genteel-looking little woman, exposed like the rest to the scorching rays of the sun. I believe we remained there more than half an hour, until at last I decided upon breaking through the press and to make the best of my way home; it was now 3.30. 
I thought of not going to the lunch which Henry Meiggs gave in the locality of El Colegio Militar, close to the Church del Espiritu Santo, but ceded to my wife's persuasion and went. The first coup d'oeil was really pretty; in the first extensive patio five large tables were set out covered with good cheer; all the pillars were entwined with flowers, and adorned with white and red, the Peruvian colors. I obtained a seat near Lembcke; opposite sat Roca and Escardó. As usual, I ate little and drank nothing. Military music was playing; many toasts were given and received with uproarious applause. The President's toast was: "al $1^{\circ}$ de Enero de 1870". Meiggs read a long speech in English, Fernando Casós, Manuel Cisneros, Ybarra talked without end; Dr. Benavente said he wished he could carry Meiggs to Bolivia in his waistcoat pocket. ('t would have been better for Perú had he done so $-21^{\text {st }}$ December 1877.) Manuel Pardo's short speech was rational; Ignacio Tavara was then called for, he stood up on a chair, and what I mostly noted of his harangue was the frequent repetition of the words "public works". I was home by 6 O'clock, but so sleepy that I turned in without loss of time. Limpricht had dined with my wife; the latter went to see Enriqueta, who was suffering from migraine, and I got up again for an hour or so when she returned.

Sunday, $2^{\text {nd }}$ of January 1870 . At 12 'clock the Directory of the Banco de Lima assembled in the locality of the bank; the room where we met was nearly taken up by a large table and the chairs which stood around. I sat at the one end in an arm chair, to my left the Secretary Muro; opposite to me at the foot of the table the gerente Lembcke, who from the very first took the lead and arrogated some superiority over his colleague Zaracondegui, who sat to his right; the other members took their seats where they pleased. The first thing we did was to have the acta, or protocol, of the last meeting read by the secretary; this done I asked whether any one had an observation to make; in case no answer was received, I declared that the acta was approved, sig [...] the book and the secretary after me; if on the contrary on [...] [137] observations were made, they were noted down by the secretary and inserted in this day's protocol. Next, Lembcke made known that some persons had asked for credits, others for loans; they were granted or refused as the majority deemed advisable. The nomination of the bank's lawyer was discussed; and in opposition to my clearly expressed desire Dr. José Aranivar, recommended by Lembcke, was chosen nearly unanimously, I voting for Francisco Garcia Calderon, Sagastabeytia for Dr. Oviedo. The cashkeeper was called in, and declared that all shareholders had paid in their first 25\%; Gustavus Heudebert, Director del Turno, and I, as President, went to the vault and counted the boxes, each said to contain $\mathrm{S} / 4800$ and found the amount correct. 
The remainder of the day I stayed at home; my wife had many visitors; the Garlands dined with us, and at tea we had Dolores Puente, Linnich and Limpricht, with whom I played a game at chess.

Monday, $3^{\text {rd }}$ of January 1870 . When it struck six, I was already descending San Cristoval. The Banco de Lima commenced its operations, and I heard that the President had honored the establishment with his visit. At 2 p.m. I went to a meeting in the Banco Hipotecario where eight or ten members assembled and elected José Muro and Franco Sagastabeytia for the purpose of examining the accounts of last year.

Thursday, $6^{\text {th }}$ of January. Twelfth day, or the Holy Epiphany, in Spanish Dia de los Reyes, when one thousand eight hundred and seventy years ago - as it is said in Perú - the three Kings, Gaspar the white gentleman, Baltazar the Indian, and Melchor the negro, went to pay their respects to the child Jesus lying in the manger!

Manuel Velarde, whose pains in the sole of his foot had gradually diminished, invited a few friends to dine with him, in celebration of the Saint's day of his son-in-law Aranivar. The following sat down: Don Manuel, his excellent wife Goya, his daughter Adela, her husband Aranivar, Col. Noya, tenant of the ground floor in Velarde's house, a certain Manuel Espejo, José Rey de Castro, and myself. Everything was very nice, well cooked, and well served; the conversation general and lively, and I was much better pleased than I had anticipated.

Sunday, $9^{\text {th }}$ of January. This day Emilio Althaus was once more a $[\ldots]$ now in the barracks of Guadalupe. The criminal [...] [138] of the Superior Court had ordered his liberation; the Fiscal had appealed to the Supreme Court; Dr. Jose Gregorio Paz-Soldan as Fiscal opined that the appeal was improcedente (without foundation) whereupon by order of the Supreme Court he was released on the $8^{\text {th }}$, but hardly was he a few moments at liberty when driving with his mother and two friends through the Calle de Trapitos, a police agent stopped the coach, made him descend, and enter another one, in which he took him to the barracks of Guadalupe where he was kept "incomunicado", that is to say, nobody was allowed to see him. The petition to the Comision Permanente, which, as above said, was referred to a Committee of two members who gave their opinion on the same, was returned to Althaus, it being unanimously considered that its terms were disrespectful. Since the Lima bank had begun its operations, nobody applied to me for discounting; Federico Bergmann had to be sure asked me for a loan of forty or fifty thousand dollars, which I however had declined to grant him.

The most interesting news come by the steamer was the opening of the Ecumenical Council in Rome on the $8^{\text {th }}$ of December; it consisted of the Pope, 
55 Cardinals, 11 Patriarchs, 927 Archbishops, Bishops and Abbots, 22 mitred Abbots, and 27 Generals of religious orders; the opening ceremony lasted five hours. The meeting took place in the Consistorial Saloon of the Vatican, and its next meeting would probably not again take place until after the Holy Epiphany. Everybody present was allowed to make a motion, but this motion had to be drawn out in writing, and presented to a committee named by the Pope which was to decide whether such a motion was admissible or not. A papal bull recommended great secrecy in all proceedings of the Council, and prohibited its members to dissent from its decisions.

For some time past, thirty gunboats had been building on account of the Spanish Government in some dockyards of the United States; as soon as this came to the knowledge of Col. Freyre, Peruvian Minister in Washington, he represented to Mr. Fish, Minister for Foreign Affairs, that Perú and Spain being at war, the Cabinet of Washington, a neutral power, ought not to permit the departure of these gunboats, to which request Mr. Fish acceded; however, the case having been brought before the Tribunals of Justice, it had been vie $[. .$.$] different light and the gunboats permitted to sail for$ their [...] [139] in all probability the Island of Cuba, there to act against the insurgents.

Tuesday, $11^{\text {th }}$ of January 1870 . This morning I made a strange mistake. I awoke in the night, looked at my watch which I thought pointed at 5 O'clock, rose, dressed, called the porter Salinas to open the street-door and started for San Cristoval, but when in the street, it appeared to me that the light, which was in fact moonlight, was not the dawn of the morning. I therefore asked some people, whom I met, what O'clock it was, who replied that it had just struck one; of course I hastened back home and went to bed.

Wednesday, ${ }^{\text {th }}$ of January. Permission having been granted to Emilio Althaus to receive his friends in his prison. I went to see him in the barracks of Guadalupe, where the room in which he was lodged was of moderate dimensions and poorly furnished. A few persons were with him, amongst whom his mother Doña Manuela; sitting on the bed, and apparently much afflicted. On

Friday, $14^{\text {th }}$ of January, he was finally released.

This day I arranged with Zaracondegui the payment of the $\$ 20,584$ which, in confirmity with the sentence of the Supreme Court, he had to deliver to me of the $\$ 30,000$ deposited in his hands; that is to say, he gave back to me the vále which on the $15^{\text {th }}$ March 1864 Enrique Witt and Schutte had signed in his favor; the Escribano Escobar notified that he had delivered to me, and I had received from him the said $\$ 20,584$ to which certificate both Zaracondegui and I affixed our signature, and for the balance of $\$ 9416$ which 
the Sotomayors had to receive I gave Zaracondegui a cheque of Schutte \& Co. on the Bank of Perú.

Saturday, $15^{\text {th }}$ of January. The four shops under my house Calle de Zarate were sold by public auction in the Justice Hall. At about 12.30 the Notary Escobar, who took his place exactly in the door which opened from the anteroom of Dr. Galindo, Juez de $1^{\text {a }}$ Instancia, into the corridor, made known that the shops situated in the Calle de Zarate Numbers 92, 94, 98 and 100 valued at 11,00o and odd dollars were to be sold. The porter repeated his words. The first offers were made by Dr. Lucio Barrios, whom I had commissioned to bid for me, and by Seberiano, brother of Clara Sotomayor's husband. When I made my appearance $\$ 8100$ had been [ ... then I also bidding, the sum went up to $\$ 12,100$. It was now $[\ldots][140]$ minutes to two, and according to law at two precisely the bidding was to cease. Whilst I went away for a few moments to fetch Dr. Palacios, the offers were raised to $\$ 15,000$. I bid once or twice and then retired into the back ground. At about five minutes to two all present were called into the inner room, where Dr. Galindo sat behind a table, his watch in his hand and a small bell before him; Dr. Palacios took his seat close to him and I stood near the Doctor, all watch in hand, the notary Escobar and the porter at the door repeating the offers made, which now went at a rapid rate, Barrios always fifty dollars more than the last offer; $\$ 15,000$, cincuenta mas; 15,500 , cincuenta mas; Dr. Palacios 16,00o; Barrios cincuenta mas; somebody 16,500, cincuenta mas; Palacios $\$ 17,000$ cincuenta mas; Dr. Palacios 18,00o; Barrios, cincuenta mas: the bell rang, who has got them, Palacios or Barrios? The Notary Escobar, "Barrios is noted down", and all was over. I hastened to my house, where my wife was delighted with the purchase we had made.

Sunday, $16^{\text {th }}$ of January. Since Tuesday I had not again been out at an early hour. This morning I rose at 5 , made the customary ascent, and was back by seven.

Old Dr. Francisco Javier Mariategui had retired from the Supreme Court. It was the custom for the President, the members of the Supreme and the Superior Courts, as well as other judges, to visit the prisons of Lima on the $24^{\text {th }}$ December when all proceedings in the Hall of Justice were over; this time Mariategui had not attended, whereupon the Minister of Justice, Mariano Felipe Paz-Soldan, who was on bad terms with Mariategui, for this latter had published not long ago in "El Nacional" very severe strictures on Paz-Soldan's history of the Independence of Perú, addressed him repeatedly official notes asking him to explain the reasons for his non-attendance, to which Mariategui had not vouchsafed to give an answer; then he was fined $10 \%$ on his monthly emolument for dereliction of duty, which was succeeded by his giving in 
his resignation, and this was immediately accepted. On the other hand, the resignation of Dr. José Luis Gomez Sanchez was not admitted.

Monday, $17^{\text {th }}$ of January. The Sotomayors received from Zaracondegui the balance of the $\$ 30,000$, say $\$ 9416$ for which they gave their receipt, and they had now to cancel the escritura, or mortgage, upon the house, Calle de Zarate for $\$ 30,000$ which at the time they settled their accounts with [...] Aliaga y Calatayud this latter had signed in their fav [...] [141] present the Sotomayors being paid, and the house having become my property it was in my interest that the mortgage were cancelled, and if they did not do it within three days, the judge would do it "de oficio".

A number of gamblers had been assembled playing at dice in a house in the neighbourhood of Santa Rosa de los Padres, when they were surprised by a gang of thieves, who cleared out everything: about $\$ 25$,000 in money, watches, revolvers, hats, coats, etc., etc.; it was said that one gambler, a German, escaped without losing anything by concealing himself under the hearth in the kitchen.

Thursday, $20^{\text {th }}$ of January 1870. The Directors of the Cerro de Pasco Mineral Railway Company had a meeting in the locality of El Banco Hipotecario; we were: Manuel Pardo, Sagastabeytia, Riva Agüero and myself. Rodrigo being prevented from attending by indisposition. We agreed that the plan presented by Pardo should be laid before the general meeting of shareholders to be held on the following day, on which day

Friday, $27^{\text {st }}$ the number required to form a quorum did not assemble, and the meeting was put off for a week.

Saturday, $2^{\text {nd }}$. The shareholders of the South American Insurance Company met in the Exchange Rooms in the first story of the Consulado; hardly twenty were present. Ruden presided; Schmidt, a Frenchman, the Manager read the statement of the transaction of last year. The result was very satisfactory owing principally to the circumstance that on fire risks no loss had been sustained, whilst the premiums received for sea risks had by far surpassed the few losses suffered on this account. On a paid up Capital of $\$ 200$,000 the nett gain of 1869 , including interest amounted to $\$ 86$, o39 of which, $\$ 36$, ooo say $18 \%$ were to be divided amongst the shareholders, and the balance to be added to reserve fund, which consisted at present of $\$ 150,400$.

In the Dreyfus affair the only thing new was that the two fiscales Paz-Soldan and Ureta had published an extensive and luminous "Vista" in which they made manifest that the Government had infringed the Constitution when refusing to obey the mandate of the Supreme Court.

I resumed my early morning walks; I was in the habit of starting between 5 and 6 a.m., and was back from the summit of San Cristoval somewhat less 
than two hours, then lay down for an hour or so, and of [...] was always in very good time for our breakfast at 10; from [...] [142] till 4 Duval was with me, and we occupied ourselves with the remodelling and copying afresh of my old diaries, in which we were now up to January 1845 . Hardly could I ever remain quietly at home the whole forenoon, something or other always called me into the street. At 4 p.m. I frequently went to my other house to see how the work was going on; at 5 we dined, either Guillermo or Enrique with us; after dinner I walked to the Alameda; sometimes not. At 7 Duval returned and remained till 8; at 8:30 we took tea either by ourselves, with the Garlands, or somebody else who might drop in. Limpricht came regularly twice, sometimes three times a week to play at chess; and at 10 or 10.30 I myself went below to see the street door locked and then went to bed. Mariquita dined frequently at Garlands. On Thursday evenings we were always there, when Garland had his rocambor party, which lasted till 1 in the morning, or even later whilst we retired at 11.30. On Sundays and holidays Duval was only with me in the morning; from 2 to 5 p.m. I had to pay my visits which never came to an end, for the gentlemen upon whose ladies I called returned the visit to my wife, and then of course I had to go again. The evening of these days were rather tedious to me, for I did not know how to occupy myself. Mariquita was upon the whole in good health, though she believed her tumour was somewhat increasing in size.

Friday, $28^{\text {th }}$ of January. The general meeting of the shareholders of the Cerro de Pasco railway took place, and the plan, drawn out by Manuel Pardo and acceded to by the other four Directors, was approved; the capital was to be increased from 850 to 900,000 Soles, but for the present, shares to the amount of $S / 600,000$ only were to be issued, because it was expected that the shares would rise in value as soon as it became known that a train had commenced running, were it even for a short distance, and then the remaining S/300,000 shares might be sold at a premium. This was the calculation at the time. To make up the $S / 600,000, S / 18$,ooo were wanting, which if not taken by the public, the Directors were willing to distribute amongst themselves. $S / 150,000$ required to go on with the work would be lent by Enrique Barreda y Osma and myself, he two thirds, I one third, at $9 \%$ p.a.

Saturday, $29^{\text {th }}$. The shareholders of the Banco Hipotecario assembled. The Gerente Riva Agüero read the statement of the proceedings of last [...] declared that the dividend would be $13 \%$ upon the paid up ca [...] [143] S/6oo on each share of $1000 \mathrm{~S} / \mathrm{Noml}$. and that about S/90oo would be added to the reserve fund. This being approved, Pedro Denegri proposed a vote of thanks to Riva Agüero and an increase in his annual remuneration; the former Riva Agüero accepted with gratitude, the latter he decidedly refused; at last it was determined that the Directory should arrange this affair with him. Since the 
beginning of the year, not a single document had been brought to me for discounting; however, Schutte \& Co., Bartolomé Araoz, and I jointly lent to Cotes \& Althaus $\$ 150,000$, each party one third, one half for 7 , the other half for 8 months, and at $8 \%$ annual interest.

Monday, $3^{\text {st }}$ of January 1870 . To the great satisfaction of all interested in the Lima and Huacho Railway, the papers announced that as far as the river Pasamayo the railway was actually concluded, and that within six weeks or so, when the waters of this river, swollen at the present period, were likely to subside, a bridge would be thrown across, and the railway concluded to Chancay, half way to Huacho. All such as were curious to see what had actually been done were allowed a free passage in the trains.

Sunday, $6^{\text {th }}$ of February. Early in the morning I climbed up San Cristoval; in the course of the day I multiplied in my head six numbers by six numbers, and drew the square root to prove the correctness of the multiplication; and in the evening I gained a game of chess from Johannes Limpricht. These feats I noted in my original to show that my mental and physical capacities - my weak sight excepted - were not on the wane.

The Lima papers in the beginning of the week contained an abridged balance sheet of each of the banks established here, dated $31^{\text {st } J a n u a r y . ~ T h i s ~ w a s ~}$ done in accordance with the Supreme decree which ordered the publication of such statements at the end of each month. The European newspapers of December 1869, when summing up the events of the year, ranked amongst those of greatest importance: Firstly, the laying of the second English and first French Atlantic submarine electric cable. Secondly, the conclusion of the railway 1000 leagues in length across the United States of North America from the Atlantic to the Pacific Ocean, and thirdly, the opening of the Suez Canal, of which some details will be found on a later date.

The North American papers spoke of the death of Mr. Staunton, of whose [...] with President Johnson I gave an account page 3. This [...] [144] though brought up to the law was raised by President Lincoln, to he War Office immediately after the discovery of the shameful frauds committed by Mr. Cameron and his dimissal. Mr. Staunton contributed in a great measure to the overthrow of the Confederates and the pacification of the country. To reward his services President Grant named him President of the Supreme Court of Justice, but he died before taking charge of this post. Of a private nature were the death of Mr. Barlet, formerly partner of Messier of Lima, which occurred in Paris, and that of Andres Bello in Valparaiso, who left his widow Matilde Codecido penniless and with several children. Bello's father was he whose work on international law had in course of time become a frequently referred to authority. 
I signed this day the escritura by which I bound myself to lend to the Cerro de Pasco Railway Company S/50,00o at 9\% p.a. payable by me in eight monthly instalments, the first six of $S / 6000$ the two last of $S / 7000$ each, whilst José de la Riva Agüero in the name of the company came under the obligation to pay me the interest every three months, and to return to me the capital one year after the date of each receipt.

Saturday, $12^{\text {th }}$ of February 1870 . The most important news brought by last mail was the murder committed by Prince Pierre Napoleon, cousin of the Emperor by his second marriage; he was born in 1815 , and was consequently about 54 years of age. M. Henry Rochefort, a red Republican, had frequently insulted the Prince in the columns of the Marseillaise, of which paper he was one of the writers and editor, whereupon the Prince wrote him a note in which he told him that he lived in such and such a house, and was always to be found at home; this was a clear provocation to a duel, and accordingly M. Grousset, coeditor of La Marseillaise, sent to the prince a written challenge by two friends of his, M. Victor Noir and M. Fouville. On the $10^{\text {th }}$ January about noon they were admitted by the Prince who received them with the words that he wanted Rochefort, not his creatures; high words ensued. So far the accounts given by the Prince and by Fouville agreed, but the Prince stated that Noir having given him a box on the ear, he shot him dead on the spot, whilst Fouville affirmed that it was the Prince who gave the blow and fired simultaneously, whereupon he, Fouville, drew his pistol and fired, also the Prince once more discharged $[\ldots]$ but these last shots did no harm. The Prince imm [...] [145] gave himself up to the police, and he, being a member of the Imperial family, was to be tried by the Supreme Court of Justice. Rochefort published on the following day in La Marseillaise a most violent and indecent diatribe against the family of Napoleon, whereupon the Minister denounced him in the Chamber of Deputies, of which he was a member, and from which he was now expelled by the votes of an overwhelming majority; for some days Paris was in a state of excitement, but tranquillity was restored, owing to the efforts of the police and the presence in the capital of not less than 100,000 troops of the line.

I commenced a new suit against the Sotomayors. The escritura for $\$ 30,000$ of which I spoke page 140, could not be cancelled in the notary's office without affixing stamps to the amount of $300 \$$; these, according to law, had to be paid for by the receiver of the money, the Sotomayors, but owing to an oversight of my lawyer, or more properly speaking of the notary Escobar, the sum was not kept back when the balance of $\$ 9416$ was handed to the Sotomayors; their lawyer Aranivar refused paying this trifle, and I presented an escrito to the Juez de $1^{a}$ Instancia in which I demanded the payment. 
Sunday, $13^{\text {th }}$ of February 1870 . By the two train I went to Chorrillos, bathed, made many calls, walked across the hills to the Salto del Fraile and at 6 p.m. was at Arthur Heeren's, who had invited me to dine with him. He and his lady had rented the large rancho of Col. Freire, which about three years back had been occupied by Mr. and Mrs. Cordes. I got my seat to the left of Mrs. Heeren; to her right sat Mr. Edward Muller; the other guests were Juan Bazo and his wife Irene, a very agreeable Peruvian whose name I did not learn, and Manuel Candamo. Everything was nice and as it should be; the conversation - in which however I took no great share - was general and lively. Manuel Candamo was a half brother of Carlos and his two sisters, by the same mother, but not recognized by Pedro Gonzales de Candamo; nevertheless, the three legitimized children, who amongst them had inherited about $\$ 17,000$,000, behaved handsomely to Manuel, they looked upon him as their brother, did not dispute his taking the name of Candamo, made him a present of $\$ 100,000$ and Don Carlos left him jointly with Arthur Heeren in charge of his business in Lima.

Tuesday, $15^{\text {th }}$ of February. The Juez de $1^{\text {a }}$ Instancia Don Ramon [...] [146] in view of my escrito presented a few days back sentenced that the Sotomayors were to deliver to the notary-public the stamps to the amount of $\$ 300$ required to cancel the escritura.

Saturday, $19^{\text {th }}$ of February. Twice during this week - the exact dates not given - the Directors of the Banco de Lima assembled. I presiding as hitherto for Manuel Argumaniz who had returned from Europe did not choose to attend. The statutes of the Bank, drawn up by three Directors, were approved with trifling modifications; two large loans were granted, the one to Henry Meiggs, the other to the brothers Montero, both for construction of railways, for the Monteros had received a concession for building railways in the province of Tarapacá; of Meiggs's mention has been made.

The Comision Permanente, by a majority of 10 to 3 , resolved that the first representation allowed them by the Constitution should be made to the Executive for not having obeyed the mandates of the Supreme Court in the Dreyfus question. Regarding Henry Rochefort the steamers brought the following particulars: the Chamber of Deputies condemned him to a fine of 10,000 francs, to an incarceration of 6 months, and to the loss of his political rights, whilst at the same time he did not lose his seat in the Chamber, an apparent contradiction, which might be explained by supposing that he would remain in the Chamber as long as the present sittings lasted, but after their closure, he would be subjected to the imprisonment as well as to the loss of his political rights. 
Wednesday, $23^{\text {rd }}$ of February. In a meeting of the Directors of the Banco de Lima the Gerente Lembcke made known that a landed proprietor, José Manuel Herrera, had applied for a considerable loan. This was the first time I heard his name mentioned, but as Zaracondegui, Castillo, and Juan Ugarte - whose opinion I valued highly - spoke in his favor, I offered no opposition and the loan was granted. Lembcke further informed us that to Montero Brothers and $\mathrm{H}$. Meiggs the sums of money which we had resolved to lend them had been paid, and they handed in the requisite securities.

Saturday, $26^{\text {th }}$ of February. Hardly had the above sentence of Dr. Patron been notified to the family Sotomayor, when their lawyer Aranivar presented a virulent escrito, in which he refused to deliver the stamps; this escr [...] by my lawyer in a very proper manner and led [...] [147] sentence of Dr. Ramon Patron, in which he reiterated his order for the delivery of the stamps. The notifications of these sentences had hitherto cost me about 10 dollars, for they had to be made to Doña Jacinta, her two daughters and three sons, some residing in Lima, others in Chorrillos. I now put an end to this abuse by having the notifications made to their procurador Munar. The progress which we made in the repairs of our house was not so rapid as we could have wished, the cause of which was the scarcity of common labourers, who being employed in the many public and private works now about being constructed, asked 10 and 12 rials for their daily wages. Nicolas de Pierola resumed his seat in the Cabinet as Minister of Finances; during his temporary absence, Angulo had been nothing but a tool in his hands.

From Sunday, $27^{\text {th }}$ of February to Tuesday, $7^{\text {st }}$ of March. Carnival days, which Mariquita spent with the Garlands, where I also took my meals. In celebration of Guillermo's birthday on the $28^{\text {th }}$, Garland had invited Dr. Barrios, Dr. Middendorf, and Vicente Camacho to dine with him. These four gentlemen played rocambor the whole day long, no great amusement to those who did not play. The boys diverted themselves throwing water and eggs from the balconies; to me it was a very dull time, particularly Tuesday, when Duval did not come because, as he said, he had twice made an attempt, and twice been driven home, having been thoroughly wetted.

Saturday, $5^{\text {th }}$ of March. Manuel Argumaniz gave an account to the Directory of the Banco de Lima of what he had done on behalf and for the benefit of the same during his absence in the United States and England. The notes which he had got made in New York were certainly pretty enough, and the paper of very good quality: he had also taken very proper steps for obviating the possibility of any falsification in the future, but otherwise the mercantile arrangements made by him with Maitland Phelps \& Co. of New-York, and with Rothschild of London and Paris, upon which he prided himself a good deal, 
were not worth a pinch of snuff; consequently the meeting was a disagreeable one; he looked upon us as ungrateful beings for not knowing how to apreciate his extraordinary services, whil $[\ldots]$ of opinion that his services were of the common order [...] [148] About this time the river Rimac was swollen to an uncommon height. The Nacional said that it was carrying more water than it had done for the last fifty years. In the wall of the oval between the two Alamedas de Acho, where the Statue of Columbus stood, it had made a breach perhaps twelve to fifteen varas long, all which had fallen in. The waters had overflown a good deal of cultivated land, which within the last few years had been gained from the river, and still higher up at the end of el paseo militar, where I was in the habit of ascending San Cristoval, it had overflown its bed but had again receded; thereabouts all was wet to the very basis of this ridge of hills; further down, on the other side of the bridge it had carried off into the sea an enormous mass of sweepings and rubbish, which had been accumulating for a series of years; even the Northern part of Callao had been threatened; the authorities however took immediately the necessary measures; many soldiers were set at work; they dug a new canal, and through the same the river had found its way into the sea; also the bridge across the Rimac, which Enrique Armero was about constructing, had suffered from the swollen river.

In the Republic of Ecuador Garcia Moreno continued at the helm; he ruled as a despot of the middle ages - he ordered executions and bowed to the Church. Last steamer brought he news of the death of Mr. Samuel Bright of Gibbs Bright \& Co. of Liverpool at the age of 72. I was slightly acquainted with him and had always found him a very pleasant man. In 1823, when I was in the house of Antony Gibbs \& Sons of London, he came over from Hamburg, where he had served as volunteer in the house of Luddendorf \& Co. and passed through for Liverpool where he established the above firm, and in course of time raised it to a very high rank in the Commercial world. Through his own marriage, and through the marriages of his sons and daughters, he was connected with the commercial aristocracy of Liverpool. Page 76 I spoke of the convention concluded between the Government of the United States of North America and the United States of Colombia for cutting a canal through the Isthmus of Panamá. On the $26^{\text {th }}$ January the treaty was actually signed, and it was said that the amount required for doing the work had already been subscribed by French and North American Capitalists.

Saturday, $12^{\text {th }}$ of March. Manuel Amunategui, the proprietor of [...] [149] was arrested, taken to la Intendencia, and again set at liberty on

Sunday, $13^{\text {th }}$ of March. The St. Nazaire steamer brought the news that a great majority in the French Chamber of Deputies had voted the arrest of the 
Deputy Rochefort, which had accordingly been carried into effect, and the consequence of which had been an "emeute" on the $6^{\text {th }} 7^{\text {th }}$ and $8^{\text {th }}$ of February which, though it lasted three days, had not been of a serious nature, and been suppressed without the interference of the soldiery. The case against Pierre Napoleon was to be tried in Tours by the Supreme Court.

Monday, $14^{\text {th }}$ of March. Judge Patron resolved that if the procurador Munar did not hand in the amount of the stamps within twenty-four hours to the Notary public Francisco Palacios, the chattels of the responsible party were to be embargoed. Lambayeque had been in danger from the overflowing of the river in its neighbourhood; the Lima and Chancay railroad had also suffered from the great rising of the river Chillon, whilst the Rimac had gone down a little. In the "Nacional" a decree of the Minister for the Interior, Secada, was reprinted in virtue of which the Government guaranteed to the Lima Huacho Railway Company, $7 \%$ annual interest on a capital of $\$ 3,000,000$.

Saturday, $19^{\text {th }}$ of March. San José. By the 12 p.m. train I went to Chorrillos together with the servant Juan; we entered our rancho where everything was in good order. I then took my sea bath, made some calls, but found few of my acquaintances at home; they having for the greater part gone to Lima to prepare for the ball, which was to be given in the Congress Hall to the President José Balta. I remained some time with the daughters of Dr. Ribeyro, with Doña Josefa Ulloa, widow of Dr. Prada, with Melchor Velarde, and at the earnest request of Manuel Velarde and wife stayed with them for dinner. With Rafael Velarde I went at a later hour to Federico Bergmann, whom we found in bed suffering from the effects of a fall, which a few weeks previously he had had in Chorrillos. He was pretty well and expected soon to be able to remove to Lima, where in the absence of his brother Carlos his presence was much required. Rafael at the time had some intimacy with the Bergmanns, for whilst he had been Minister, they, in order to secure his good will in the Muelle Dársena question, had [_] oned a pagaré in his favor for a pretty large amount; otherwise, he $[\ldots]$ certainly not have called upon him. In Lima I found [...] [150] Araoz keeping my wife and Enriqueta company. This gentleman frequently took tea with us, and I rejoiced when he came, for having travelled about a great deal he had always something to say for himself, and when we two were together our conversation never was at a stand still.

Sunday, $20^{\text {th }}$ of March. Last night's ball had gone off well, though some families who considered themselves to belong to the first aristocracy of Lima had not been present. The first quadrille, with which the ball was opened, in which the President figured with Mrs. Jerningham and Benavente, for Bolivia Senior of the Diplomatic Corps, with Mrs. President, presented a very strange melange; thus for instance there was the French Minister Plenipotentiary, a Baron, and the Ecuatorian Chargé Luque, who had been the owner of a livery 
stable in Lima. Little Dorado, the Minister for Foreign Affairs, danced with Mrs. Brauns, the very handsome Carmen Becherel, of whose little finger he took a firm hold, and never let go; there danced Mrs. Cipriano Correa, respectably married to be sure, but the daughter of Veyan the ironmonger over the way, Mrs. Evaristo Gomez-Sanchez, the daughter of a mantequero or lard boiler, and so on. Of the gentlemen hardly one knew the figures and they made a mess of it. Lembcke had the great honor to be called in, probably because Sousa-Ferreira and I being absent, he was the Senior of the Consular Body. This morning at near 7 the last of the dancers left the saloon. Of the Supreme, only Vidaurre, the lately made Vocal, was present, of the Superior Court only Dr. Paredes. José Canevaro, José Vicente Oyague, and Benito Valdeavellano were there, their wives not.

In Juan's letter of $13^{\text {th }}$ February he wrote me that Dreyfus had offered him a share of $S / 200,000$ in his guano contract, of which he was willing to let me have the half, both the one and the other to be kept secret. Juan considered the business to be extremely profitable, very safe, and not likely to be annulled; the reasons for this his opinion, he added, he could not give me for the present.

Saturday, $26^{\text {th }}$ of March. In the course of this week the escritura for the cancelment of the mortgage on my house, so frequently spoken of, was at last drawn out in the office of the notary Francisco Palacios and signed by the Sotomayors, who had also handed in the so long fought for stamps.

Monday, $28^{\text {th }}$ of March. Guillermo Garland, whom I had told th [...] to take a trip on the just concluded Chancay rail [...] [151] municated this my wish to a friend of his, Oswald, one of the sons of Julius Pflücker, an engineer on the line, who was most willing to comply with the same, and had thus cited us for this morning at an early hour outside the Portada de Guia; we were there at 6.30, he did not come to 7.15, when he made us enter a second class carriage, quite new and comfortable enough, but so many times had we to move backwards and forwards, and so frequent were the starts and the stops that it was full 9.15 before the locomotive carrying us with it was fairly on the move. The open stony place just before the gate, called the "Pedregal", and the battle fought there on the $21^{\text {st }}$ August 1838 I have described Vol. I page 202 and following; this we crossed, passed a small wooden bridge, and then steamed along the high road now partly converted into a railway, farms and estates, chacras and haciendas on both sides, just the same perhaps a little better taken care of than when I last passed through here in July 1842. The continuation of the chain of hills coming from Amancaes turns northward, then trends inland, whilst to the left, that is to say seawards, the view is open except at some distance to the North, where a small chain of heights running along the coast becomes visible. The first few houses to the right are called Puente de Palo, then to the left the chacra or farm called Pallao, owned by Isidro Aramburu, "el cojo", and 
rented of late by the Arequipeño General Fernando Alvizuri, who came hither in the beginning of 1868 as Ministers of War with the President Pedro Diez Canseco, and then understood how to mend his fortune. On the other, the right side, follows the pretty chacra owned by Aliaga, called Aliaga, which I visited once or twice whilst it was rented by Francisco Quiroz, who drew a handsome income from the same, solely by the sale of milk. Opposite, close by, follows "La Muleria", of little extent, the property of Lembcke. A little further on, our progress was stopped by several cars standing on the line, which were being filled with earth; when filled they moved on, and we behind them. To the left, on the same side with La Muleria, is the farm of Anapuquio, owned by a certain Manuel Olivera of Callao, where Tomás Solar Reyes, son-in-law of Dr. Carbajal, had his establishment for making saltpetre. Between the dwelling houses of Anapuquio, and the next Chacra, Infantas, the property of the widow of José Maria Sotomayor, and rented by the brothers Perez, the distance is considerable, and between them, on the opposite side, is the spot $[\ldots]$ "Reparticion", where the road to the valley of Caravallo and then to [...] [152] Cerro de Pasco, branches off to the right, whilst the main road, which we followed, runs due North. On comparing this account with that given page 205 Vol. I, a small discrepancy will be observed; the present is the correct one. "Las Piedras Gordas" there mentioned are not at La Reparticion, but higher up in the Valley of Caravallo. Next to the Chacra of Infantas comes that of Pro, whose proprietor is Nicolas Rodrigo, and finally, close to the river, Chillon on the right side, like Aliaga's, all the others being on the left, Chacra Cerro owned by Elguera. We were now close to our destination, but had again to wait, for the cars before us had now to be unloaded; the earth being required to widen the embankment upon which the rails were placed; this being accomplished, we stepped over all these cars to the beautiful bridge which had been built across the river Chillon, insignificant in the dry season, a violent and powerful torrent when it rains in the Interior; even this year it had overflown its banks and injured the railway; the bridge was therefore built at a great height above the highest level which the river can ever attain; there are no pillars in the bed of the river to sustain the structure, but on both sides, at a distance of 200 feet are erected two solid stone basements, upon each of which stand two strong iron pillars of considerable height; from each of these two pillars to that standing opposite reach two iron beams, each 200 feet long, the one on the top, the other at the foot, at a proper height above the highest level of the river. The lower of the two is sustained by many beams of smaller dimensions fastened to the higher beam above and running slantingly, thus it will be seen that below, above the river, we have two long beams running parallel, across these are 
placed strong wooden beams at short distances from each other, but as they were not yet covered over lengthways, I had to ask the assistance of some one, who lent me his hand whilst we walked across. This bridge appeared to me to be of excellent workmanship; the iron materials had come from Baltimore. Several gentlemen, who had come with us from Lima, passed on to Ancon on a locomotive which was waiting on the other side of the bridge and returned in the evening to Lima jointly with another party who had accompanied to said port young José Canevaro and wife, Ramon Montero, his sister Doña Carmen, Dr. Rosas and others, who were on their way to Europe. Young Pflucker, Guillermo, and I returned by the same train, and were back at la Portada in 25 minutes, the distance being three leagues. [...] 11 O'clock and the heat in the wide street of Malambo wh [...] [153] home, was really insupportable.

In the course of the day I received from José Vicente Oyague a loan of $\$ 60$, ooo at $7 \%$ annual interest for 6 months, which I required for the shares which Juan and I had taken in the Dreyfus Contract.

In the evening a daring robbery was attempted which in the general opinion might have been altogether prevented by Sevilla, Intendente of Lima, who had received advice that a gang of robbers was to assemble at a certain hour in the large square or Plaza de Armas, thence to proceed to the attack of a house on the other side of the bridge near the Church of Copacabana belonging to a widow, Mrs. Miller. Only three policemen, without arms, were sent thither who very naturally locked themselves in; the robbers appeared, other policemen were sent in pursuit of them, a fight ensued, and shots were exchanged, when a certain Major Arciniega, who lived in the neighbourhood, on hearing the noise came with his revolver to take his share in the fray. The chief of the banditti, Manuel Campo Mantilla, fired at him; the bullet lodged in his belly, whereupon Arciniega, though severely wounded discharged his revolver, and Mantilla fell dead on the spot, seeing which the rest fled and dispersed.

Tuesday, $29^{\text {th }}$ of March. News were received from Jauja that Ibarra, the clever and well known Deputy for that town, was lying dangerously ill without hopes of recovery. Rafael Velarde was deprived of his post as Visitador de las Aduanas, which he owed in all probability to the enmity of the minister of finance Dr. Pierola. In the course of the forenoon I took the $\$ 60,000$ borrowed from José Vicente Oyague to Dreyfus's office where I contented myself with a receipt given by W. Scheel, one of the partners, which merely said: "recibido por cuenta de Don Juan Diez de la Torre".

Friday, ${ }^{\text {st }}$ of April. I paid my first monthly instalment of $\$ 7500$ of the loan which I had bound myself to make to the Cerro de Pasco Mineral Railway Company to its secretary José de la Riva Agüero in the locality of the Banco 
Hipotecario. Thence I went to the Banco de Lima where the usual monthly meeting took place; Lembcke read the letter in which Argumaniz gave in his resignation both as Director and President of the Directory, and certainly had I been treated as he had been, I should have done the same, for in the last meeting (my original does not say clearly whether it was in that of $5^{\text {th }}$ March or in another not noted down) every alteration [...] dification which he proposed in the statutes had been rejected [...] [154] Whilst his letter was under discussion, he left the room; I, out of mere delicacy, was against admitting the resignation. Lembcke was of the contrary opinion, and nearly all went with him; Argumaniz' resignation was admitted, and by acclamation - not by regular voting - I was chosen President, Juan de Ugarte, Vice, and Juan de Dios Calderon $2^{\text {nd }}$ Vice President. Argumaniz' request for a copy of the last acta was likewise denied him; "it would be a bad antecedent", some said; others, "he may come and take the copies himself". Finally, I being the Director de Turno for April, Renner who had been the same for March delivered to me the keys of the vault. I went below with the cash-keeper and counted the boxes.

Saturday, $2^{\text {nd }}$ of April 1870. I found myself under the necessity of borrowing another $\$ 60,000$ this time from the South American Insurance Company, presided by Alexander Ruden, for 1 year and at 8\%; I offered my and Juan's signatures de mancomun et insolidum, but Mr. Ruden preferred tangible security, and I handed him as such Juan's shares in the National Guano Company as well as those in the Lima Gas Company.

Sunday, $3^{\text {rd }}$ of April. The whole of the preceding week I had been more or less unwell having caught a cold after having been exposed on Monday to the tremendous heat in the Calle de Malambo. This had prevented me from taking my usual early walks however this morning I was again at my post near the cross on the top of San Cristoval, at 7 a.m.

Friday, $8^{\text {th }}$ of April. Dia de los Dolores. Both my wife and daughter were prevented by a slight inflammation of the bowels to leave their respective houses, for which reason I went in the evening to Doña Dolores Puente to present to her their and my congratulations.

Saturday, $9^{\text {th }}$. The entire week I, as Director de Turno, was every day in the Banco de Lima from 3 till 3.30. The two gerentes and I consulted which of the documents, accepted bills, pagarées, or vales, which had been presented for discounting, should be received by the bank, and which should be rejected; after having decided, which we generally did in a few minutes, the result was noted down in a book kept for the purpose and signed by us three. This was the rule of procedure to which every Director, when his monthly turn came round, had strictly to conform. 
Notwithstanding the $\$ 120$,000 which I had borrowed of late I was by [...] flush of money; $\$ 50,000$ I had lent to Cotes and Althaus [...] [155] ago, S/200,000 I had paid to Dreyfus for Juan and myself. On the $31^{\text {st }}$ March I had paid the second $25 \%$, say $\$ 20,000$, on age of my Banco de Lima shares, 17,500 francs I had to remit to Juan; every month I had to make a payment to the Pasco Railway Company, and finally, the weekly expenses for the repairs of my house, now amounting to $\$ 23,000$, were by no means inconsiderable - and taking all this together, I did not see the way clear before me till the $1^{\text {st }}$ July when the fourth $\$ 100,000$ from Schutte \& Co. fell due, without taking up more money on interest, a thing which went much against my grain.

Sunday, $10^{\text {th }}$ of April 1870. This day, early in the morning, died Tomás Valle, Vocal of the Superior Court of Justice in Lima, married to Catalina Osma. Ybarra, Deputy for Jauja, of whose dangerous illness I have spoken also, expired in the course of these days.

Rafael Velarde was elected Deputy to the next Congress, for Chuquibamba, as his suplente, Silvestre Gutierrez. These elections however were not legal for it is the Congress and not the Executive which has to ordain new elections, and these of Velarde and Gutierrez took place in virtue of Government orders.

Enrique Garland left the employ of Schutte \& Co., the business of which firm was fast decreasing, and through the influence of Rafael Velarde obtained a situation in the office of Henry Meiggs, the railway Contractor.

Thursday, 14 ${ }^{\text {th }}$, Holy Thursday, and Friday, $15^{\text {th }}$ of April, Holy Friday. Very tedious days; the heat was such that it kept me within doors, and Duval, my lector, left me in the forenoon at 1.30 and did not return in the evening.

Saturday, $16^{\text {th }}$ of April. In celebration of the conclusion of the Chancay railway, a lunch was given this day in the Ancon Terminus by the acting manager, a certain Garcia, to which the President, three of his Ministers, the President of the Supreme Court, the Vocal Melchor Vidaurre, and many hangers on, amongst whom Guillermo, friend of Oswald Pflücker the engineer, went out per train.

Per Steamer I received from my son Juan, a few lines dated Nice $13^{\text {th }}$ March, in which he did not say a single word about his and my shares in the Dreyfus Contract, regarding which he had been so eloquent in his previous communications. This was a disappointment to me for rumours were afloat, which from day to day obtained more credit, and [...] said that the European holders of Peruvian Bonds had embar [...] [156] the proceeds of the sales of the guano in the hands of Thomson Bonar \& Co., Consignees for the United Kingdom, Thomas Lachambre \& Co. for France, and Sescau Valdeavellano \& Co. for Belgium. If this were true, I feared that the bankers who had hitherto 
assisted Dreyfus with their funds, and who of course had counted upon a speedy reimbursement of their outlay, through the payments to be received from these various consignees, would withdraw their assistance and leave Dreyfus in the lurch. His firm here had drawn by last steamer about $£_{150,000,}$ a clear proof that in Lima their credit was already well established. Juan likewise asked me for a remittance of $£ 1000$ which, as will be seen from what I have said above, came at a rather inconvenient moment.

We learned that the trial of Prince Pierre Bonaparte had commenced on the $28^{\text {th }}$ March in Tours before la haute Cour de justice. I may mention here that since the beginning of the year, and the formation of the cabinet with Emile Olivier as President, the autocrat rule of Luis Napoleon had suffered a severe shock. France had now a really constitutional government; the chambers were not as hitherto mere instruments in the hands of the Emperor and it might be said that the French nation at last enjoyed some degree of liberty.

By this time I was interested in several joint-stock companies: in the Banco de Lima, where I was President of the Directory, the Pasco Mineral Railway Company, where I was one of the Directors, the South American Insurance Company, the Telegraph Company, the Banco Hipotecario, the Lima Gas Coy., the Lima Water Coy., and the Huacho Railway Coy., of which six last mentioned I was only a shareholder. Sometimes general meetings took place; more frequent were the meetings of the Directories, both the one and the other occupied some of my time, which in a great measure was also taken up by the remodelling of my old diaries, which I had read over to me three, four, and perhaps five times, and even then I was not always quite certain whether the turning of the one phrase or other might not be defective. Twice, perhaps three times a day I went to the other house to see how the workmen were getting on; lawsuits I had none at present, except an insignificant one carried on by J. M. Varela against Juan Aliaga y Puente for whom I had to stand up.

Sunday, $17^{\text {th }}$ of April. Easter. All the Garlands, Bartol [...] [157] and Antonio Martinez were with us at dinner. Architect Villa came in the evening, and one with another the time passed pleasantly and quickly till past 10, when we were again left by ourselves.

Monday, $18^{\text {th }}$ of April 1870 . The steamers lately arrived brought the news of the death of three persons, every one remarkable in his own sphere of life. Firstly, General Lopez, President of Paraguay, the heroic defender of his native country; he and the small army which he had with him were defeated on the last day of February, or the first day of March by the Brazilian General Camara. Lopez, severely wounded, fell into the hands of the enemy, but as he refused to surrender was shot down; his mistress, La Señora Lynch, with four 
or five children, gave herself up to the Brazilian General. Secondly, Mr. John Burlingham; this gentleman, native of the United States, had reached a high post in the Diplomatic service of the Emperor of China; he accompanied a Chinese Embassy which had visited the Capital of the United States and those of various European Empires, with the cabinets of which, treaties had been concluded. He died in St. Petersburg of pulmonary disease. Thirdly, Enrique de Bourbon, cousin of the ex-queen of Spain and son of Don Francisco de Paula, brother of the late King Ferdinand VII; he was killed in a duel by the Duke of Montpensier married to his cousin Luisa; Queen Isabel's sister.

Friday, $22^{\text {nd }}$ of April. This day died Doña Manuela Flores but a few minutes after my wife and Enriqueta, accompanied by Garland, had been in her house to enquire how she was. Not three weeks had elapsed since I had been last with her, when she was as talkative and agreeable as ever. She had been a good friend of my wife's, and I had been acquainted with her ever since my arrival in Arequipa when she had not yet contracted matrimony with Col. Clemente Althaus. Her four sons, Augusto, Emilio and Clemente Althaus, and Julio Tenaud had conducted themselves in an exemplary manner during her illness; they and a superior English servant woman rendered her every service she stood in need of, which, her illness having been dysentery, had not always been of an agreeable nature.

Saturday, $23^{\text {rd }}$ of April. Once more I have to record a death, that of Lino de la Barrera, Rafael Velarde's father-in-law, who expired after long and protracted sufferings.

At 7 p.m. I went to the house of José Luis Gomez Sanchez to [...] [158] with him on the death of a daughter of his Eloiza, who of late had died in Arequipa. The Doctor, who sat in a darkned room, seemed to be very sad, and only his friend General Miguel Medina was with him. He and I left before 8 as it is the custom on occasion of such condolatory visits.

Sunday, $24^{\text {th }}$ of April. At 10 p.m. I was in the house of the deceased Don Lino de la Barrera, whose corpse a considerable number of gentlemen, I, amongst them, accompanied to the Church of La Merced in the manner which I have described on previous occasions. Whilst I, together with Enrique and Guillermo Garland, rendered this last mark of attention to Don Rafael Velarde's father-inlaw, Mr. Garland did the same to the family of Doña Manuela Althaus, whose coffin was carried to the same Church of La Merced.

From Monday, $25^{\text {th }}$ to Wednesday, $27^{\text {th }}$ of April. The funerals of the two persons, whose death I have commemorated in the previous lines, as well as that of Enrique Berckemeyer, were celebrated consecutively in the forenoon of these three days in the Church of La Merced, the same black hangings with 
which the Interior was covered serving on all three occasions; I was present every time. The funeral of Mrs. Althaus was most numerously attended, whilst Enrique Berckemeyer was buried with military honors; he, a native of Hamburg, in his youth and even in the first years of his manhood rather a bit of a scamp, had become more steady as he advanced in years, and of late been employed by Dr. Benavente, Minister for Bolivia, as his secretary. Benavente had sent invitations to the menbers of the Diplomatic and Consular Corps, of whom a large proportion attended. It was rather strange that military honors, which had been refused to Mr. Möller, Consul General of the North German Confederation, had been granted to a mere secretary of a Bolivian Legation. I found an explanation in the circumstance that General Melgarejo, President of Bolivia, had placed a certain General Antesana before a Court Martial for having passed the Peruvian frontier in pursuit of Bolivian political offenders, and for having made himself guilty there, of acts inconsistent with the deference due to a friendly power; and now, as an act of reciprocal good [...] President Balta had thought proper to show this extraordin [...] [159] of respect to the secretary of a Bolivian Legation.

A North American man-of-war, which came in from Panamá, brought the news that the Supreme Court of Justice in Tours had declared Prince Pierre Napoleon not guilty, which sentence had given rise to such dissatisfaction all over France that the Emperor had thought prudent to banish him the country.

Wednesday, $11^{\text {th }}$ of May 1870 . This day I entered my $72^{\text {nd }}$ year in a less perfect state of health than I generally enjoyed, and this I no doubt owed to my own imprudence; I had ascended and particularly descended the Cerro of San Cristoval wearing boots too short for my foot, and thus the toes, and particularly the great toe, had been cramped and caused me considerable pain; this pain, in my opinion, had spread upwards to the tendons in the calves and even in the thighs, though Dr. Middendorf called it rheumatism in the muscles and even sciatica. I had no acute sufferings; however, three days I remained in bed and at night time I slept but little.

This morning Enriqueta with the little boys and Maria were with me at an early hour bringing nosegays and trifling presents; also my dear Mariquita did never forget me on this day. All the Garlands dined with us. Little Antonio was very pale, for he had had severe pains about the heart, and the Doctor had thought proper to apply a blister. Nevertheless, he and the whole party were in good spirits, myself excepted who suffered so much from the pains in the calf and the thigh that I had to rise from table at 7 O'clock and to go to bed, but also here I found no alleviation, and hardly had I an hour's sleep the whole night. 
In the afternoon arrived in Callao Bay, after a voyage from New York of fifteen months eighteen days, the two monitors "Manco Capac" and "Atahualpa", together with the two steamers which had them in tow.

Thursday, $12^{\text {th }}$ of May 1870 . At my request a blister was applied to my painful thigh. In the evening when it was dressed, Dr. Middendorf put some morphine in the raw wound, which gave me a sound night's rest, and on

Friday, $13^{\text {th }}$ of May the pain was gone.

The Dreyfus question, which some time back had kept the Commercial [...] Lima in continual agitation, had altogether subsided and [...] [16o] this time nothing was said nor heard about it. On the $16^{\text {th }}$ April I spoke of the rumours then afloat that the proceeds of the guano sales had been embargoed by the Peruvian Bondholders in the hands of the different guano consignees; these were now confirmed by an article in the official paper "El Peruano" as regards France and Belgium; it however added the consolatory news that these embargoes had again been taken off. Juan's letter from Nice, in which he wrote me of his excursion to Milan and Turin, could of course contain no intelligence of what had been doing in Paris. From my cousin Diederich Willink I received a letter, which informed me of the death of his mother, whom I used to call my "dear little English Aunt", and of whom I was really very fond; it had occurred on the $19^{\text {th }}$ March in Winchmore Hill, and its immediate cause was the construction of a branch railway to this village - the family had been obliged to remove to new quarters; and this removal in the cold winter months, added to the apartment in her new dwelling being probably not quite so comfortable and convenient as her previous one, brought on a bad cold; then repeated attacks of bronchitis, to which she succumbed, having reached her $82^{\text {nd }}$ year.

Last night Maria Araos, the only daughter of our good friend Don Bartolomé, was united in marriage to Rufino, one of the sons of General Torrico, of whom Juan, who had some time back travelled in his company through the United States, entertained a very good opinion.

The steamer from the South brought the news of the assassination of Urquiza, ex-President of the Argentine Confederacy, and at the time of his death Governor of the Province of Entre Rios. In his political opinions he was not in complete unison with Sarmiento, President of that Republic, especially with regard to the war against Paraguay. He was believed to have been the richest individual in the whole of South America, and his immense wealth was based upon a solid foundation of extensive landed property. By the same steamer advices were received of one of the customary drunken bouts of Melgarejo, President of Bolivia; at a banquet given by him he got drunk, insulted the Brazilian Chargé, taxed his Government with the murder of President Lopez 
of Paraguay, then threw a plate of soup into his face. When his Ministers tried to interfere, he kicked the Prime Minister Muñoz and illtreated another called Ribeyro. Octavio, the youngest son of General Santa Cruz, did not fare better; the considerable property which $[\ldots]$ or rather his widow and family possess in Bolivia Melgar [...] [161] threatened to sequestrate, and finally he said that within a fortnight the head quarters of the Bolivian army should be in Puno.

Saturday, $14^{\text {th }}$ of May. From Johannes Limpricht, who a few weeks previously had embarked for Chile for the re-establishment of his health, I received a pleasant letter dated from the baths of Cauquenes, situated to the South of Santiago de Chile. From Valparaiso to Santiago he had of course gone per train, whence he continued his journey on the Southern line for 3 hours, and then per coach for two hours more. Cauquenes lies 3660 feet above the level of the sea, at the foot of the Cordillera, between two ridges of wood-covered hills; the river of the same name flows through this narrow valley, the two banks of which are connected with each other by a rope bridge in the Indian fashion. The hotel, at the time kept by a German, was built on a small platform about 100 feet above the bed of the river, had accomodation for 200 guests, and was, as Limpricht wrote, in every respect superior to the Lima hotels. On his first arrival he made more than one attempt to obtain some pretty and extensive view, for which purpose he climbed up more than 1000 feet without however obtaining his object, for mountains higher than that the top of which he had reached surrounded him on all sides; he then contented himself with taking his walks in the valley, which was pretty and picturesque, and one with another he was much pleased with his residence in this place.

Sunday, $15^{\text {th }}$ of May. This morning died Dr. Buenaventura Seoane, who in the course of his chequered life had been soldier, schoolmaster, and shopkeeper. By the Peruvian Government he had been employed in various Ministerial offices, and even sent as Chargé to the one or the other of the neighbouring South American Republics; this proves that he was a man of versatility and capacity, but upright he was not, and even had he ever enjoyed a fair reputation, he would have lost it by his conduct at the time of the consolidation under Echenique in 1853. Then it was he who had to give his written opinions on the claims for indemnization made by the sufferers during the war of the Independence, and never did he give a favourable opinion without being well feed. In the forenoon I remained at home, and together with Mariquita received the usual Sunday visitors.

Wednesday, $18^{\text {th }}$ of May. Two short letters from Juan dated $16^{\text {th }}$ and $17^{\text {th }}$ [...] Paris caused me great surprise. In the first he informed [...] [162] that he had annulled his agreement with Dreyfus to take $\$ 200$,000 interest in Dreyfus Contract with the Peruvian Government; and in the second, which he 
wrote after having spoken with Dreyfus, just returned from London, he again changed his mind - he kept an interest, but reduced it on his and my account to $\$ 80,000$; accordingly, the firm here had to return to me $\$ 120,000$.

Thursday, $19^{\text {th }}$ of May 1870 . At 3 p.m. Dammort, one of the partners of Dreyfus's firm in Lima, was in my office and delivered to me against my receipt two cheques on the Banco de Londres, the one for 9o, the other for $\$ 30,000$, which I handed respectively to the Banco del Perú and "Lima", for at the time I had an account open with both banks. By means of this unexpected payment, and the $\$ 100,000$ to be received on the $1^{\text {st }}$ July, I was, as John Hayne used to say, again on velvet, and instead of seeing before me any difficulty in meeting my engagements, I had now money to spare to be placed at interest.

I went, at Garland's particular request, to his usual Thursday party, for he had invited a Mr. Ochsenius, a native of Frankfort, just arrived from Europe, and recommended to Schutte \& Co. by John Henry Schroeder \& Co. of London; he was sent hither by the well known Paris bankers Erlanger \& Co. for the purpose of settling some disputes which this firm had with Montero Bros., the Railway contractors for the province of Tarapaca. Whilst the other gentlemen sat at their rocambor tables, and the ladies conversed amongst themselves, he and I played a game at chess, which I gained. Mariquita and I walked home at 11.30, and though it was a mild night, yet my being out at so late an hour did me harm, for on Friday when I awoke my pains in the calf were again much worse than they had been for some time past: Dr. Middendorf had cured them with morphine introduced into the wound formed by a small blister, now he prescribed tepid baths.

Saturday, $27^{\text {st }}$ of May. The "Nacional" of last night explained in some measure why the embargo upon the guano in the hands of the European Guano Consignees - of which I spoke on the $13^{\text {th }}$ inst. - had been taken off. The holders of Peruvian Bonds, instead of insisting as they had done hitherto upon the retention in the hands of the Consignees of interest for 3 six-months, on their bonds, contented themselves with the interest for $1[\ldots]$. The last quotation in London of Peruvian Bonds [...] [163] was 86\%; those of 1862 stood above par. In Lima the exchange on London was - bills of Dreyfus and the London Bank of M. \& S. A. 90 d/st., 45 1/2d per sol equal to $362 / 5$ d per dollar, whilst other houses drew at $361 / 4 \mathrm{~d}$. I myself took for Juan $£ 450 \mathrm{M}$. G. Chavez on the General South American Company in London, at the latter rate.

This day died old Barrenechea, father of the ex-Minister.

Wednesday, $25^{\text {th }}$ of May. I went to the office of Dr. Palacios, who in my presence dictated an escrito to the Superior Court, in which I appealed against the sentence of the Juez de $1^{\text {a }}$ Instancia Dr. Galindo, who had decided that Juan Aliaga y Puente should pay to José Maria Varela the sum of 300 and odd 
dollars, being the $4 \%$ Alcabala which he, Varela, had had to disburse when many years back he bought from Juan Aliaga y Calatayud the shops calle de Aldavas, now my property. This walk to Dr. Palacios's was once more too much for my suffering calf, and again the pains made themselves felt. To the Banco de Lima, hardly two cuadras distant, I never failed to go.

Thursday, $26^{\text {th }}$. Ascension Day. Mariquita and I did not leave the house.

Some changes took place in Balta's cabinet; the lawyer Jorge Loayza was named Minister for Foreign Affairs instead of Dorado, and Dr. José Aranivar for Finances in place of Mariano Felipe Paz-Soldan.

Limpricht returned from Chile, his health perfectly reestablished, thanks to the baths of Cauquenes.

Monday, $30^{\text {th }}$. Last evening an accident occurred on the Ancon Railway. The train left Ancon at 5 p.m. with about 500 passengers in seven carriages; at the entrance of the chacra of Infantas, rented by the Perez, a branch from the main line led into the chacra; by inadvertency this was left open, so that the train, instead of following as it ought the straight line to Lima, turned off; as soon as the engine driver observed the mistake, he sounded the alarm bell, let the steam escape, and did all in his power to bring the train to a standstill, but in vain; it went on, came off the rails, and stopped six or seven varas distant from the counting-house of the Perez. The stoker, who jumped off from his post, was the only one killed, several who threw themselves off from their seats were injured, whilst those who did not move remain [...] or two O'clock in the morning when another train [...] [164] the passengers to Lima.

Wednesday, ${ }^{\text {st }}$ of June 1870 . The north steamer arrived. In Paris many persons had been arrested; it was said that a widely spread conspiracy against the Emperor and his Government had been discovered, and that all kinds of arms, bombs, and granades had been found: workmen of all descriptions had struck work, and an Italian banker Cernuschi, resident in Paris, who had subscribed 200,00o francs to one of their unions, had been expelled from France and on his arrival in Geneva met there the same fate.

In the environs of Athens an event had occurred which gave but a poor opinion of the Greek police regulations. A party of English noblemen and gentlemen, amongst whom the son of the Duke of Newcastle, together with a few ladies, and the secretary of the Italian Legation, being on a pedestrian excursion, were surprised by a party of banditti, who carried them off to a fastness where their headquarters were. Negotiations for the ransom of the prisoners were commenced - the reason why they were not carried out was not given - then troops were sent against the fort, but before they could take it, part of the captives were already killed viz.: 1 noblemam, 3 gentlemen, and 5 servants. After the taking of the fort, some of the robbers were 
caught and executed, others effected their escape. Such an atrocious deed, perpetrated close to the capital of a civilized country, raised great indignation all over Europe. Not only the British Government, but the Governments of all the great Powers remonstrated with the Cabinet of Athens, in consequence of which the there Minister for the Interior gave in his resignation.

A dreadful accident had taken place in Richmond, State of Virginia. Two candidates for the Mayoralty of this place had agreed to lay their respective claims before the Court of Justice, which was to decide the question. The members of the Tribunal assembled in the second story of the Government building called the Capitol, which, constructed in 1812 had since then undergone no repairs: more than 400 persons filled the hall and corridors; suddenly a subterranean rumbling noise was heard, and one or two minutes later the floor gave way and all were precipitated to a depth of from 26 to 27 feet into the saloon where the Deputies used to hold their meetings, but who fortunately had not yet assembled; 56 people were killed, and many more, about 10o, severely wounded. Only one part of the floor, about 12 feet long, remained intact, and here sat the two judges, and the [...] of the daily papers who of course escaped unhurt. [165] Page 130 I tried to give some idea of a recent invention, the Aerial railway, Arthur Heeren had some time previously applied to the Peruvian Government for a privelege to introduce this invention into the territory of Perú, which was refused him. Again he asked for permission to construct this aerial railway from the port of Pisagua to the saltpetre establishments in the interior, by which means he calculated the transport of the saltpetre would be much cheapened. Once more he received a negative answer, and this time probably for no other reason but because this method for conveying salpetre would injure the interest of the brothers Montero, the Constructors of the Tarapacá railways and President Balta's intimate friends. From the papers I saw that in Broadway, New-York, a trial had been made with this invention, but as it would appear not with the best success, for a box laden with iron carried along this railway came to the ground, with it another box in which some passengers had taken their seats, of whom fortunately none was injured.

Sunday, $5^{\text {th }}$ and Monday, $6^{\text {th }}$ of June. Whitsuntide. Each day I managed to get through with ten calls, the first day on foot, the second in a carriage.

Thursday, $9^{\text {th }}$. In the evening we went to Garland's. Mr. Ochsenius came in, merely with the object to play at chess with me, and to prove to me that he was by far the stronger of the two; he had studied the game, which I never had.

Friday, $10^{\text {th }}$ of June. In the evening Mariquita and I paid three visits: to Mrs. Lacharriere née Telleria, Mrs. Isabel Elias, and Doña Manuela Sendeja de Beltran, and returned home well pleased. 
Sunday, $19^{\text {th }}$. Though my leg had not yet recovered its normal strength, I walked this morning down the street of Santo Domingo as far as where formerly the gate of Monserrate stood. Meiggs' railway from Callao to the Oroya was concluded as far as here; thence it was to proceed through the bed of the river - where at least 400 labourers were at work - to the other side of Lima about the mill of Martinete, where it was again to take the terra firme, and then to continue through the Quebrada of San Juan de Matucanas. Also in that direction a good deal had been done.

About this time Garland, as representative of Schutte \& Co., found himself in a very disagreeable correspondence with the President of the Comision Fiscal, Col. Joaquin Torrico, a person of whom it was well known that his greatest $[. .$.$] was to vex, annoy, and injure his neighbours when and where$ [...] [166] in his power to do so; his colleagues were Dr. Don Manuel Ortiz de Zevallos, and Dr. Juan José Araoz, one of the sons of our good friend Don Bartolomé, and the object of the commission was to examine all the accounts of the guano consignees here, in Europe, and in the United States; consequently, Joaquin Torrico as President had asked from Schutte \& Co. a letter, in which they ordered their agents in Hamburg to hold all their books and accounts at the disposal of the commission. Garland's answer said that, as the Executive had deprived Schutte \& Co. by an arbitrary order of the Guano Consignment in Germany, they had ceased being consignees, and not being consignees, they could not comply with Torrico's request, who of course did not content himself with such a reply. The contents of Juan's letter by last mail were to me quite unexpected; he had again such a good opinion of Dreyfus's business that he had applied for an increase of his share and obtained with the greatest difficulty leave to interest himself for $\$ 150,000$ that is to say for $\$ 70,000$ more than the $\$ 80,000$ already taken by him on his and my account. Of these $\$ 150,000$ he would keep for himself $\$ 50,000$ and offered to me the remaining $\$ 100,000$. Now this letter arrived immediately after Garland had explained to Juan by last steamer that, according to his calculations, taking as a basis the stock of guano existing on the islands according to a survey held on the Government's account by an engineer, Davis, all the guano would be consumed in eight years, when if Dreyfus continued making his monthly payments of $S / 1,000$, ooo besides paying for the redemption of, and interest on the Anglo-Peruvian debt, he would be in advance to the Peruvian Government for $\mathrm{S} / 10,000,000$ at the expiration of the eight years, without having the means of covering himself. Juan, I thought, might say, "if this calculation is correct, Dreyfus's business is a bad one, and he, Witt, knowing of it should not have augmented our interest notwithstanding my order". On the other hand, I considered that it was not likely that Dreyfus and all who acted with him 
should have bound themselves to make such enormous payments, if they were not convinced that the guano on hand sufficed to cover them; moreover, Juan's order was absolute; and finally, I bore in mind that Garland's calculations had on more than one occasion turned out erroneous. Weighing all the preceding, I determined to pay to Dreyfus $\$ 45,000$ say $\$ 20,000$ for Juan, raising his share to $\$ 50,000$ and $\$ 25,000$ for me raising my share to $\$ 75,000$; and these $\$ 45,000[\ldots]$ ulated, I could manage to disburse without running myself too [...]. [167] The only news of importance from Europe was that the universal suffrage, or Plebiscite in France, taken on the $8^{\text {th }}$ May had approved the late political changes introduced in the Government, viz.: The substitution of a Constitutional Government to the personal Imperial rule, as it had been the case till the $1^{\text {st }}$ January. The round numbers were $7,300,000$ votes in favor, 1,400,000 against, which included 160,000 votes of the army in favor, and 40,000 against the measure.

Thursday, ${ }^{\text {rd }}$ of June 1870 . Mr. Duval was, he said, suffering from a liver complaint, which for several days past had prevented him from coming in the evening; this day he even left me at 3 O'clock, and I availed myself of the leisure hours to walk as far as the mill of Martinete, where I descended into the river and was highly pleased with the progress made in the construction of Meiggs' railway. I returned by the Maravillas gate in time for dinner.

Friday, $24^{\text {th }}$. The day of San Juan, when the Valley of Amancaes is usually visited by many of the Lima population, on foot, on horseback, in carriages, all bringing home with them loads of the yellow lilly called Amancaes. I walked out soon after breakfast and found the roads swarming with people, as yet all perfectly sober: on my return three Sambos, singing and yelling, passed close to me; one of them, with the words "Oiga Ud. Señor", passed his hand over my waistcoat, for my coat was unbuttoned, no doubt in the expectation of finding the chain to which the watch is suspended, but very prudently I had left it at home. At a later hour I called upon the Juans and Juanas of my acquaintance; Doña Juana Carbajal and Doña Juana Guise had invited us to spend the evening with them respectively, but we preferred staying at home. The Garlands dined with us; Limpricht played chess with me, Antonio Martinez came, and the day passed by in a pleasant manner.

Sunday, $26^{\text {th }}$ of June. At 5.50 p.m. just as my wife, Guillermo and I had risen from dinner we felt two severe and distinct shocks of an earthquake.

Monday, $27^{\text {th }}$. Mariano Bustamante, one of the sons of our good friend Don Pedro José of Arequipa, educated in Europe for engineering, arrived from Arequipa, being engaged by Henry Meiggs to work on the Oroya line; he told me that the Arequipa railway from the Coast, as far as 10 leagues on the other side of La Joya was concluded, and that there was not the slightest 
doubt [...] that it would be carried on as far as the town itself, but the diffi [...] [168] had now arisen which place to choose for the port, for Mejia, close to the valley of Tambo, and Mollendo, eight leagues further Northward are both exposed to wind and waves, and sometimes the landing, if not entirely impossible is connected with the greatest difficulty and danger. These two ports were at the time connected by a provisional railroad running along the beach. Islay, hitherto the port of Arequipa, and, comparatively speaking, a safe roadstead is again four leagues to leeward of Mollendo, but the beach from the one place to the other is crossed by many ravines, over which viaducts would have to be thrown to render the construction of a railway possible, and this would again require the disburse of millions of Soles.

Col. Secada, hitherto Minister for the Interior, generally believed to be guilty of the grossest peculations, gave in his resignation, which was accepted in the dryest terms, and Col. Santa Maria, one of the members of the Comision Permanente, named in his place.

Tuesday, $28^{\text {th }}$ of June. This day embarked for Europe Col. Joaquin Torrico and Juan José Araoz, two of the members of the Committee named for examining the accounts of the guano Consignees. Araoz took his wife Carolina Sotomayor with him, and they were accompanied by clerks and amanuenses. Dr. Manuel Ortiz de Zevallos did not go, probably because his son, the lawyer Ricardo, was shortly to be married to Carmen, the daughter of Dr. Melchor Vidaurre, whose life, it will be remembered, was attempted by a servant of hers in August 1868.

In last night's papers appeared an advertizement signed by the Gerente of the London Bank of M. \& S. A. saying that from the $1^{\text {st }}$ July onwards the bank would discount to all such as kept their accounts with the same, documents provided with satisfactory signatures, if at 30 days or less, at $6 \%$, if at 9o days or less at $7 \%$, and if at 180 days or less at $8 \%$ p.a. Immediately ran to the Lima Bank to consult with the gerentes. Lembcke opined we should advertize that henceforth the Banco de Lima would not receive the notes of the London Bank of M. \& S. A. because firstly, the means of this establishment were not known in Lima, secondly, because the circulation of their notes had lately much increased. Zaracondegui thought it would be best to advertize that we were ready to discount on the same terms as the London Bank, and moreover, allow $5 \%$ interest in a/curr [...] of $4 \%$ annually as hitherto. At 1 O'clock all the [...] [169] met. Both Lembcke's and Zaracondegui's propositions were rejected; Castillo's, seconded by Heudebert, Gil, and myself, was approved, and we consequently resolved that our advertizement in the papers should make known to the public that the Banco de Lima would discount on the same terms as the Banco de Londres, not only to those who kept their accounts 
with the bank, but to all who would present satisfactory documents. In the evening a general meeting of the shareholders took place in the premises; the hall is rather narrow however just wide enough. On the left when entering are the desks of the clerks; to the right a long narrow table was placed, between the same and the wall the Directors took their seats, I in the centre, to my right the secretary Muro; all around, chairs were placed for the shareholders. After the last Acta had been read and approved, I said in an audible voice that the sole object of the meeting was to choose three Directors instead of Juan Ugarte, who had died, Manuel Argumaniz who had resigned, and Manuel Ortiz de Villate, who had been absent for six months, which was equal to a vacancy. Provisionally, we had named M. J. Zuloaga, Agustin Escudero, and José Herce, and our nomination was ratified by a vast majority. We had done by 8 p.m. At home I met Don Bartolomé Araoz, who kept me company till 10, whilst Dolores Puente was in the bedroom with my wife, who was suffering from a cold.

Wednesday, $29^{\text {th }}$ of June 1870. San Pablo y San Pedro.

Some months back disturbances had broken out amongst the Indian population of the Department of Puno, and it was well known that the Bishop Huerta was at the bottom of them; he was now absent having gone to the Ecumenical Council of Rome and left in his stead another Huerta, who had trod in the footsteps of his predecessor; the Prefect however thought proper to arrest him and to send him to Lima, where he was detained in the Archiepiscopal palace, whilst a third, a certain Ruiz, who tried to do the same as the Huertas had done, was deprived of his ecclesiastical authority, and thus tranquillity was restored in the department.

Thursday, $30^{\text {th }}$ of June. This day the first Chamber of the Supreme Court consisting of Gomez-Sanchez, Alvarez and Alzamora confirmed the Vista Fiscal of Paz Soldan and declared that the house of Schutte \& Co. had been unjustly deprived by the Executive of their Guano Consignment to Germany and ordered that they [_] be replaced in the same situation in which they found themselves bef [...] [170] or $9^{\text {th }}$ December 1869 when the Executive annulled the contract, and Dr. Ureta, the $2^{\text {nd }}$ Fiscal, gave his Vista to the effect that there was no room for appeal to the $2^{\text {nd }}$ Chamber, because the sentence of the first chamber was founded on justice.

Sunday, $3^{\text {rd }}$ of July. Last week under pretence of illness Mr. Duval was but seldom with me. This day we had at dinner Mr. Charles Ochsenius, as yet unable to come to an arrangement with the Monteros, Bartolomé Araoz less talkative than when we were by ourselves - Mariano Bustamante, the young engineer who, to judge from his conversation had made good use of his residence in Europe, Manuel Velarde, Garland, with Enrique and Guillermo, and Rafael Velarde, who, with his usual fluency of language, informed all those 
who liked to listen to him that after Secada's resignation the post of Minister of the Interior had been offered to him, but that he had refused it, because as sometime back he had withdrawn from the cabinet, being averse to the Dreyfus Contract, if he were now again to enter it, he had either to defend the contract, which would injure his reputation, or speak against it, which would offend the President, to whom he was grateful for his offer. "By and by something will turn up" he said. Enriqueta, who was expecting her confinement, had remained at home.

In the forenoon of this day Dr. Benavente, Bolivian Minister in Perú, in a public audience gave ample satisfaction to President Balta for the outrages committed by Genl. Antesana on Peruvian territory.

By last steamer I had letters from my son Juan and from Alejandro Garland; the former wrote from Kissingen complaining as usual of rheumatic pains; the latter from Paris wrote to my great surprise that by advice of his aunt Rosa and Mr. Schutte he thought of paying us a visit, so that we might expect him by the next steamer in company with Francisco Prada. The advices which reached us relative to the bonds given by the Peruvian Government to Henry Meiggs in part payment of the railways to be constructed by him, were of a somewhat contradictory nature. Schwartze of London wrote to Lembcke that John Henry Schroeder \& Co. would bring them into the London market at $82 \mathrm{1} / 2 \%$; Zaracondegui received a letter which said that there was a great demand for them, and the correspondent of the "Nacional" gave the following account: Montero and Arizola were dispatched by President Balta to sign the bonds; Meiggs sent young Caneva [...] [171] sudden they received a note from La Torre Bueno, former Minister of Perú in Brazil now resident in Paris, informing them that he, being duly authorized by the Peruvian Government, had disposed of $£_{5,000,000}$ of these bonds to the house of Dreyfus at $80 \%$ a very high price. Some Spanish banditti, following the example of these in Greece, had carried off four English gentlemen who had been outside the fortress of Gibraltar on Spanish territory, and though the Spanish Government had not only done their utmost to discover whither they had been taken, but also offered a large ransom, as yet no trace had been found of them.

Sunday, $10^{\text {th }}$ of July 1870 . President Balta gave a dinner party to Dr. Benavente in order to celebrate the reestablishment of friendly relations between Peru and Bolivia. I was invited and went in uniform together with Brauns, whom I had requested to call upon me, as in account of my shortsightedness I did not like to go by myself. When we arrived at 6 p.m. there were but few assembled. Elmore, the Oficial Mayor of the Ministry for Foreign Affairs, met us at the entrance of the saloon and accompanied us to the President, with whom we shook hands; he then introduced me to Dr. Loayza, Minister for Foreign 
Affairs, with whom I was not acquainted. The party was very small, consisting of the President, his five Ministers, the two Vice Presidents Herencio Zeballos and Francisco Diez de Canseco, General Echenique President of the Senate, Dr. Oviedo President of the Deputies, Dr. Ribeyro President of the Supreme Court, the Diplomatic and Consular Corps, and a few others, whom I did not recognize. At the usual large parties we Consuls General generally sat more or less about the middle of the table; this time there were so few guests that on the one side Oyague, Consul General for Belgium, was the very last; I sat to his right, Brent, Secretary of the North American Legation, to my right, opposite to me Lembcke, opposite to Oyague Brauns; at the other end of the table Roca and Escardó. Dinner was exquisite, wines very good, at least so my two neighbours said, who took their full share of them. All the time we were at dinner, the military band of the Peruvian Man-of-war "Independencia" played; this band consisted of Germans, all excellent performers, contracted in Hamburg.

Monday, $17^{\text {th }}$ of July. Mr. Duval continued to stay away under pretence of indisposition, thus I should not have known what to do with myself, had I not been called to a meeting of the Directors of the Pasco Railway Company, and [_] to one of those of the Banco de Lima; Zuloaga and Escudero, newly ele $[\ldots][172]$

Tuesday, $12^{\text {th }}$ of July. The steamer from the North, corresponding to that from St. Nazaire, and which arrived on the $8^{\text {th }}$, brought all kinds of news.

The Spanish brigands had for a handsome ransom given up their English captives; then they had been pursued by Spanish soldiers, who had overtaken them, killed some and, as it was said, found part of the money still upon them. On the $7^{\text {th }}$ June a conflagration destroyed a large part of Constantinople; about 7000 houses, amongst which some belonging to the foreign Ambassadors and Diplomatic characters in the suburb of Pera, were devoured by the flames. A few lives were lost, and the damage done to the immovable and movable property was calculated at $£_{25,000,000}$ in all probability an over estimate. On the $8^{\text {th }}$ June the famous English novelist Charles Dickens, whilst residing in his country-house, was struck by apoplexy at his own dinner table and died instantaneously.

Mr. Henry Kendall, for a long time Peruvian Consul in London, an old but not intimate acquaintance of mine, had also gone to his last account. Many, many years back I rode together with him and various others from Quilca, or Islay, to Arequipa, and then it was he first came to Perú; afterwards he was the manager of the house of Naylors Kendall \& Co. in Lima, during which period he and his very agreeable wife, an English lady, occasionally gave evening parties, at which my wife and I were present. When he left for Europe Peter Conroy remained in his stead, and it is but too well known what an account 
this latter gave of the trust placed in him. When my wife and I were in London in 1863, Mr. Kendall paid us a long and agreeable visit; this was of course the last time I saw him; perhaps he was 75 years of age when he died. It will be remembered that Jerome, the youngest brother of Napoleon I, married when a youth a Miss Patterson, a native of the United States, by whom he had a son, also called Jerome. When the Emperor Napoleon was in the zenith of his power, he obliged his brother to repudiate this his first wife and to take in her stead a princess of the Royal family of Wirtemberg: Jerome, the son, presented himself several years ago in France, at the time this father's death, claiming part his property, in which he failed as might have been expected. We now heard of his death.

The present Pope, Mastei Ferretti was born in 1792; he was [...] throne on the $17^{\text {th }}$ June 1846 , thus he was at this time in [...] [173] beginning of the $25^{\text {th }}$ year of his reign, and it was generally believed by true Catholics that no Pope could reign longer than St. Peter, who for 25 years, 2 months, and 21 days had been firstly Bishop of Antioch and afterwards of Rome. St. Peter died in 67 A.C. since when we have had 256 Popes, of whom Pius VI sat on the throne 24 years, 8 months, 14 days; he died in 1799 in French imprisonment.

Minister Pierola told Lembcke that the Peruvian Government had purchased the bonds given to Meiggs for the construction of the two railways at $79 \%$, and thus if the new loan was sold at a higher rate, the profits would be for the Government. La Société Générale of Paris, the great supporter of Dreyfus, had brought this loan into the market at $821 / 2 \%$, and the Lima house of Dreyfus published an advertizement in the papers stating that they had received a telegram dated Paris $18^{\text {th }}$ June, to the effect that $£ 52,000$, ooo had been signed though only £12,00o, ooo were required. The price was not quoted, but it was added that the scrip was at a premium. Garland received advice that not only his son Alejandro, but also Geraldo, would be with us on the $17^{\text {th }}$ rather unexpected to be sure.

Mr. Von Bunsen, Chargé d'affaires for the North German Confederacy, accredited to the Lima Government, had arrived, but though it was the custom for the new Chargés to present themselves to the members not only of the Diplomatic, but also of the Consular Corps, he had thought proper not to do so; to Brauns and Lembcke he paid a visit not as Chargé but as private individual; to me he did not come at all. This Von Bunsen was a son of the famous Roman Antiquarian, who for many years was accredited by the Prussian Government to his Holiness and made a prolonged stay in the eternal City.

This forenoon when I was by chance in the Callao Railway Station, J.F. Johnson made his appearance en route for Europe. He told me that Juan Antonio Garcia y Garcia who had returned from his Diplomatic 
mission to La Paz, brought with him a very strong and well founded representation to the Executive, signed by many of the first men of Arequipa, Puno, and Cuzco praying the President not to authorize the construction of the Railway from Tacna to the frontiers of Bolivia. On the $7^{\text {th }}$ inst. the sealed tenders for this railway were opened in the Ministry of the Interior; Campbell of Tacna offered to make [...] S/32,000.00o; there were other proposals none lower than S/ [...] [174] The railroad from Ilo to Moquegua. Montero Bros. declared themselves willing to build for $\mathrm{S} / 4,200,000$; other proposals, amongst which that of William, the son of Henry Wyman, ran up as high as S/8,ooo,ooo.

Wednesday, $13^{\text {th }}$ of July 1870 . After a long interval Mr. Duval appeared this day at 11 a.m. and about two hours later, whilst I left my house for a short time, he again made his exit; his pretence was continual indisposition and severe pains.

Thursday, $14^{\text {th }}$ of July. A dinner party was given by subscription to Mr. Von Bunsen, by the Germans resident in Lima; neither Lembcke, nor Brauns, nor I was present; the reason why the two former did'nt attend, I did not learn; as regards myself I had told Mr. Ochsenius, who took a great interest in getting up this dinner, that it would be useless to send the subscription sheet to me, if Mr. Von Bunsen did not previously pay me his official visit and express some thanks for the trouble I had taken with the archives of the Consulate of the North German Confederation. At the request of Mr. Weiss, Vice-Consul in Callao, I, after the sudden death of Mr. Möller, had been present at the taking of the inventory; the iron chest with the archive was carried to my house, and every time that Mr. Weiss had come for some document or other, I had invariably and willingly attended to him: all this, I thought, deserved some acknowledgement.

Friday, $15^{\text {th }}$ of July. Mr. Duval continued to absent himself, thus I, having nothing better to do, walked to Callao upon the railway recently constructed by Henry Meiggs; it was finished, but not carefully concluded; here and there both sleepers and rails when I trod on them moved and sounded. The country between Lima and Callao is a plain with a gentle fall towards the sea of from three to four hundred feet; thus no serious difficulties were in the way to lay this railway, full two leagues long. It runs on the left bank of the Rimac at a short distance from its bed upon a somewhat elevated ground. On both sides extend fields, some cultivated, others lying fallow; about half way the line cuts right through a small mound, an old Indian Huaca. On nearing Callao, one small li[_] branches off to the right, another to the left, I walked straight on and entered to the Port where Wholey's saw-mill stood, and where I noted several timber yards. On my reaching the terminus at 2.50 , I found that the train had $\mathrm{j}[\ldots] \mathrm{l}$ had to wait till [_] when I returned [...] [175] good time for our dinner which we usually took at 5 p.m. 
About this time a crime came to light, the perpetrators of which remained unknown. General Hovey, the North American Chargé, who occupied the ground-floor of the house situated in the street, known as that of General La Fuente, and belonging to a certain Bartolo Manrique, observed on Tuesday last a very offensive smell which seemed to come from Manrique's apartments upstairs; he gave advice to the police, the room was opened, and poor Manrique was found strangled and his corpse in an advanced state of putrefaction. The servant had disappeared, and it was supposed that he, alone, or with accomplices, had been the murderer and the robber of the considerable amount of gold which it was known Manrique had in his possession. (In after times the belief gained ground that General Hovey himself was the Criminal $-16^{\text {th }}$ January 1878 ).

I had known Manrique for a great length of time; when I first came to Lima, he and Thomas Wheelock were clerks at Tayleur \& Co., and it was said at the time that they speculated, the one being cash-keeper, the other collectingclerk, with the funds of the house. When Wheelock rose to be manager, Manrique remained for some time as clerk; he then left, and his name became first known when he sold the house in the Calle de Mantas - the altos of which my wife and I occupied till we removed to the Calle del Correo in $1842-$ to José Maria Varela, for $\$ 50,000$ in gold. He next purchased a house in the Calle de Negreiros where Jerningham lived for some time; also this he sold and finally bought that in which he was murdered, and which had been the property of Joaquin Ortiz. He was a bachelor, a gambler, and at the same time very economical.

Saturday, $16^{\text {th }}$ of July 1870 . Of Duval I knew nothing; I expected him every day, but he never made his appearance. My nephew Johannes Limpricht was good enough to write my diary and to read to me occasionally when he had leisure.

Sunday, $17^{\text {th }}$. This day we dined at the Garlands in expectation of the arrival of Alejandro and Geraldo; they however did not come until

Monday, $18^{\text {th }}$ when we again took our meal jointly. Both young men made a pleasant impression upon all of us. Alejandro was a tall, good looking youth, whilst Geraldo, only 14 months younger than his brother, was very [...]. [176]

Tuesday, $19^{\text {th }}$ of July. I took a long walk with Alejandro and Geraldo and was much pleased with the rational conversation and good German of Alejandro. $\mathrm{He}$, at all events, was quite ready and willing to return to Europe there to continue his studies.

Wednesday, $20^{\text {th }}$. I at last began to suspect that there was something wrong with Duval, and therefore made my enquiries, when I discovered that on the $14^{\text {th }}$ inst. he had embarked on board the steamer for the North his destination 
being New-York. He had taken with him a woman, with whom he had lived for some time, and their baby, whilst another child of his, born in Guayaquil, he had left in charge of an aunt of his mistress. In my office nothing was wanting but to my servant Juan; he remained owing \$200 for which he had signed a pagaré at high interest and two months credit.

Saturday, $23^{\text {rd }}$ of July. This week was in a great measure taken up with my endeavours to find a suitable person in lieu of Charles Duval; many presented themselves, but as yet I had not come to terms with any one. Johannes Limpricht and Alejandro Garland did the necessary writing work for me. This morning at about 7 Mariquita was sent for from Garland's; I went there as usually at 9.30 to look at the progress made in the building of the house and when entering Enriqueta's bedroom was much surprised to find her in bed and an infant girl in my wife's arms; she had seen the light of day at about 7.30. My wife told me that she was thin and small - otherwise both mother and child were doing well. At about 11 when I returned to my house, one of the servant girls, who came to fetch something, told me that Enriqueta was very ill. I hastened to Garland's. Whilst Don Geraldo, Mariquita, the mid-wife Joaquina, and the children had been sitting at breakfast, they were suddenly roused by the cry that Enriqueta was dying; the blood, instead of taking its usual course, had risen upwards and was apparently suffocating her. Mariquita thought that her daughter was expiring; however, Joaquina took efficient steps - fortunately there was ether in the house, which Enriqueta was made to inhale - ice was fetched, which was placed upon various parts of her body, ice water with vinegar was poured into her mouth, and thus she recovered. A Dr. Romero, whom Garland met in the streets, first came, then Dr. Middendorf who re [...] nearly the whole day. Already in the afternoon Enriqueta [...] [177] of danger; Mariquita remained with her daughter: on

Sunday morning she was again with me.

Monday, $25^{\text {th }}$ of July. This day I engaged for lector and secretary an Irishman, called Thomas R. Rees; on Monday $1^{\text {st }}$ August he promised to come and to begin his work.

Enriqueta's baby was christened by the Archbishop's secretary José Santos Chavez and named Corina Geraldina del Carmen; the ceremony was a very simple one; my wife, who stood Godmother for Corina Schutte, held the infant in her arms, and the clergyman sprinkled a little tepid water over her and baptized her in the name of the Father, Son, and Holy Ghost. Her eldest brother Enrique was Godfather.

Wednesday, $27^{\text {th }}$ of July. The Senators and Deputies who, as it was the custom, had for the last fortnight been holding their preparatory sessions in 
their respective localities, chose this day their presidents; the former elected General Rufino Echenique, Dr. Antonio Arenas for Vice, the latter Dr. Manuel B. Cisneros, and Dr. Oviedo.

Thursday, $28^{\text {th }}$ of July. Anniversary of the Independence. The Congress was installed, to which for the first time the Consular Corps was not invited. Lembcke told me the reason was that the original hall being under repairs, the gallery in the present provisional one was not large enough to hold all the Diplomatic and Consular Agents; this might be true, but I suspected that the Government's object was to show that there existed a difference between the two bodies. At about 3 I went to Garland's house and from the balcony saw them all return from the Congress: first came the President, on foot, surrounded by his suite, and followed by the members of the Superior and Supreme Courts, after whom came several battalions of infantry, and about 400 cavalry, all which made a very fine show. The message which the President had read in the Congress was published in the daily papers; he praised himself and all that he had done in the two years of his rule, averted to the settlement of the dispute with Bolivia, gave a short account of the clerical disorder in the Department of Puno, and above all gave a severe rub to the Supreme Court for having interfered on two occasions with the prerogatives of the Executive. In the evening of this day, also of the $27^{\text {th }}$, there were fireworks in the Plaza Mayor.

Friday, $29^{\text {th }}$ of July. One of the yards of the Convent of San Ped [...] [178] fitted up for the distribution of the prizes to teachers and pupils of the various Municipal schools in Lima. Having received an entrance-ticket, I went there at 1 O'clock. The extensive, quadrangular open place in the middle was entirely occupied by the boys on the right, the girls on the left side, sitting on benches, the former cleanly dressed, the latter decked out with much finery. Exactly in front a low scaffolding was erected in the middle of which a canopy for the President, who however was not present, his place being taken by the Vice-President Herencio Zevallos, accompanied by Aranivar, Minister of Justice.

On each side of the President's seat were placed five rows of chairs for the members of the Municipality and all the gentlemen who had received cards of invitation. I sat between Gaspar Puente and Dr.José Gregorio Paz-Soldan; close by sat Vidaurre and Lembcke; here also many of the Deputies and Senators took their places. All the corridors below and above were filled with people one with another there were certainly 5000. The proceedings began with the National hymn, which the children sang or rather screamed, accompanied by music, then the German band of musicians from on board the "Independencia" played, whereupon Dr. Tejeda, President of the Commission of Instruction, which formed a section of the Municipality, ascended the scaffolding in 
front of the canopy and read a very long account of what the Municipality had done in favor of these schools, of which there were 22 in Lima. When he had finished, Manuel Pardo, the Alcalde of the Municipality, from the other scaffolding said that Dr. Tejeda had stated what had been done, he would now say what remained to be done; he dwelt particularly upon the want of funds, without an augmentation of which it was impossible for the Municipality to enlarge the circle of operations. He was applauded on more than one occasion, in which to my great surprise even Dr. Paz-Soldan, certainly not a friend of his, joined. Then, Dr. Aranivar answered, but of his speech I could not understand a word. Finally, the secretary of the Commission of Instruction delivered gold and silver medals, first to the teachers, both male and female who had distinguished themselves by their attention to their duties; a certain Antonio Carbajal received both the gold and the silver medal, then the boys and girls were called who deserved to be rewarded; a little negro boy, about eleven or twelve years of age, the son of a maker of rockets, received amongst others a gold and a silver medal, he was much applauded [_]lly to such parents as had taken most interest in making their [_] [179] go to school and in looking after them, small remunerations in money were given. The ceremony was over by about 4 O'clock. I remained for a long time standing at the door to see the children walk out two by two, each division preceded by a small banner, upon which the number of the school to which they belonged was painted.

Mrs. Garland was getting on as well as could be expected; she was however very weak, and the babe, whom she nursed herself, did not allow her a night's undisturbed rest.

Sunday, $3^{\text {st }}$ of July 1870 . The passing of the train from Monserrate under the stone bridge to Martinete with the President, his suite, the members of the Congress, the Municipals, and other persons invited by Meiggs, was the great thing of the day. On both sides the river was lined with innumerable spectators. I went as far as the oval where the statue of Columbus was placed, before I could find an open space. Here I stood for a long time waiting to see what was coming, was joined by Don Bartolomé Araoz, and at last when the train passed in the bed of the river, was hardly able to distinguish much more than the smoke of the engine. In the evening I suffered from a bad cold.

Monday, ${ }^{\text {st }}$ of August. Mr. Rees came in the morning and commenced his occupations. My cold was such that had I acted prudently, I should have remained at home; nevertheless, I went to the Banco de Lima the Directors of which regularly assembled at the beginning of the month. After dinner I was obliged to lie down; my throat was swollen so that I could hardly speak. Dr. Middendorf was called, and he ordered me to remain in bed, which I did for three days. 
From Tuesday, $2^{\text {nd }}$ to Thursday, $4^{\text {th }}$ of August, when Mr. Rees occasionally read to me.

Saturday, $6^{\text {th }}$ of August. This day I for the first time was again in my office. By the North steamer we learned that Earl Clarendon, Secretary of State, had died. In Pekin the populace had set fire to the Catholic Chapel and killed the secretary of the French Legation, several French sisters of Charity, a few other Frenchmen, and three Russians.

Here in Lima the Senate and Chamber of Deputies met regularly [...] bill of importance which passed both houses unanimously was [...] [180] which granted complete amnesty to all political offenders, whether in prison or in exile. A Deputy, Fernandini, had moved that the Congress should make a solemn declaration that it did not approve of, nor coincide with the ideas expressed in the President's message as regards the Supreme Court; Benavides in the Senate that those acts which had been sent in to the Executive by various towns in the Republic approving the financial measures of the Government and the Dreyfus Contract, should be declared an attack on the dignity of the Congress, and that the authorities who had assisted in drawing them up should be deprived of their posts. Both Fernandini's and Benavides' motions were referred to their respective committees, whence they would perhaps resuscitate some day or other.

Friday, $12^{\text {th }}$ of August. In the Congress the Government gained a victory over the opposition. A motion had been made, accusing Santa Maria, Minister of the Interior, of an infraction of the Constitution. He had passed a note to the Prefect of Lima instructing him to prohibit the editors of newspapers from admitting in their columns any article offensive to any power in amity with Perú. This was very naturally considered as being a restriction of the liberty of the Press, and accordingly contrary to the Constitution; nevertheless, the motion was lost by a majority of 12, 47 against 35 . On the $8^{\text {th }}$ the steamer from the North arrived bringing news by cable to the $21^{\text {st }}$ July. It was of the greatest importance. On the $15^{\text {th }}$ of the same month France declared war against Prussia. The following was the pretext of which Napoleon availed himself: General Prym, who had been one of the prime movers in the revolution against Queen Isabel of Spain, had now brought it about that the crown of this country was offered to Prince Leopold Hohenzollern Siegmaringen, married to Antonia, sister of the present King of Portugal. As soon as this came to the knowledge of the French Cabinet, it passed a note to that of Berlin, stating that the election of this Prince to the Spanish throne would be considered as a "casus belli", to which the answer was given that, though the Prince was a nearer relation to Napoleon than to the King of Prussia, the latter, as head of the house of Hohenzollern, declared that Prince Leopold would not accept the crown. Napoleon, not satisfied with 
this declaration, sent another note in which he demanded a promise that a Prussian prince should never ascend the Spanish throne. This was going too far; no answer w [...] sent, whereupon the French Minister at Berlin M. Be [...] [181] King William to the watering place of Ems, and in the public promenade pestered him for a reply. The King of Prussia sent him about his business, and the consequence was the declaration of war on the $15^{\text {th }}$ July. France seemed to be quite ready, Prussia not, though it was expected that owing to the excellent military organization of the latter country, hardly five days would be required to put the necessary number of men under arms.

Napoleon had already named the Marshals and Generals who should command the 8 corps into which his army was divided. In both countries the enthusiasm was very great. The house of M. Thiers who delivered a speech in the Chamber of Deputies in favor of peace had to be protected by the police against the outrages of the mob. There was every probability that Bavaria, Wirtemberg, and Baden would join the North German Confederation. Here in Lima a subscription was set on foot which would probably run up to $S / 20,000$ if not more; the amount would be remitted to Berlin there to be distributed amongst such of the wounded as might require pecuniary assistance.

The following genealogical sketch gives an idea of how Prince Leopold was allied to the Napoleons.

Napoleon I

His stepdaughter

Stefanie Viscountess

Beauharnais married

Prince Charles of

Baden, and had issue

Josephine

$\begin{array}{ll}\text { whose sister married } & \text { Murat King of Naples } \\ & \text { His daughter Antoinette } \\ \text { married Charles of } & \text { Hohenzollern- } \\ & \text { Siegmaringen. Their } \\ & \text { son was } \\ & \text { Carl Anton }\end{array}$

Leopold, married to

Antonia, sister of Luis, King of Portugal

On the $13^{\text {th }}$ July the Ecumenical Council in Rome resolved by a vast majority that the infallibility of the Pope was henceforth to be held as a dogma of the Roman Catholic Church. This news, important as it was, was, one might say, lost in the all-absorbing question of the war.

Bishop Huertas, the author of all the ecclesiastical disorders in Puno [...] and was allowed to proceed to his diocese [...] [182] Senate a motion was made by the Government, and carried unanimously that the proceedings in the dispute between this Bishop and the Supreme Court should be quashed. 
Thursday, $18^{\text {th }}$ of August 1870 . This day I made a very unpleasant discovery. I presented for payment to Myer \& Raybaud a bill for $\$ 2825$ drawn on the $18^{\text {th }}$ June, at $60 \mathrm{~d} /$ st., and bearing the acceptance of said firm and the signature of Claudio Rebagliati as drawer and endorser. Mr. Isaac Myer, partner of the firm, said at once that the signature was not his. Rebagliati affirmed the same and on

Friday, $19^{\text {th }}$ of August at my request, made the corresponding declaration upon oath before the judge Manuel Patron.

We dined at Garlands to celebrate the birthday of little Maria, who this day completed her fourth year; there were besides us and the family Rafael Velarde, Manuel Velarde with his silly son-in-law Baltazar Aranivar, Dr. Middendorf, and Limpricht. Maria received many presents; she was in excellent spirits, amused us all, and even at ten O'clock was not inclined to go to bed. Col. Masias came in after dinner to make up the rocambor table, also Goya, Manuel's wife, and her daughter Adela. We left at eleven O'clock.

Saturday, $20^{\text {th }}$ of August. It took me several hours to obtain the necessary signatures to give force and validity to the declarations relative to Duval's fraud, which document, together with a full power of attorney, I gave to my nephew Johannes Limpricht, who intended to leave on the following day for New York, where he might perhaps succeed in discovering my former clerk Charles Duval, who, it was evident had forged the signatures and certainly shown some ingenuity in cheating me out of the money. On the $17^{\text {th }}$ or $18^{\text {th }}$ June he had come to my office and presented me the bill which he told me Rebagliati was desirous to discount; before giving him a reply I ordered him to go to Myer \& Raybaud, owners of the valuable jewelry shop under Felipe Varela's house and to ask them, whether the signature was theirs, and the bill was in order - of course he returned with an affirmative answer - "then", I said, "let Rebagliati endorse the bill in blank, and here is a cheque for the amount less the discount, which you will deliver to him and bring back the bill". Duval cashed the cheque, and [...] and I now wrote a letter to Rebagliati asking him [...] [183] cheque had ever been delivered to him; he answered at foot that it had not, which he ratified by declaration on oath, and this letter I likewise delivered to Limpricht.

Sunday, $21^{\text {st }}$ of August 1870 . Bishop Huerta had not yet gone to Puno, nor was he likely soon to go, for the Chamber of Deputies had declared almost unanimously, only 6 being against it, that they did not accede to the bill passed in the Senate to the effect that the proceedings of the Supreme Court against the said Bishop should be quashed. Now in conformity with the Constitution, both chambers were to meet, and the majority, in all probability against 
Huerta, would decide whether the case against the Bishop was to be carried on in the Supreme Court or not.

In the Chamber of Deputies Gonzales of San Pedro and Puga of Cajamarca demanded the cancelment of the Dreyfus Contract. The motion, which was drawn up in a very conciliatory spirit, was passed to the Committee of Finances, and the General opinion was that at the time of its discussion it would be lost, the Government being secure of a vast majority. In the Senate stormy sessions had been held arising from the "actas populares", which I have already mentioned. Francisco Benavides of Arequipa distinguished himself as a clever, energetic member of the opposition, but in all probability his efforts would be unavailing.

The steamer from Panamá brought nothing of importance from the theatre of war. The news by cable went to the $24^{\text {th }}$ July, only 3 days later than those by the steamer of the $2^{\text {nd }}$. Juan wrote a long letter from Dívonne near Geneva, dated $13^{\text {th }}$ July, two days before the declaration of war. About this time Mr. Pfaff, who kept a store in the Calle de Bodegones where he sold British and German Manufactured goods by the piece, received a letter from his partner Edward Knawer, one of the sons of my good friend Emily Reincke, who some months previously had gone to Europe on a visit. He wrote him that in a German watering-place he had met a young lady with whom he was such pleased that he had offered her his hand, which she had accepted, that their marriage would shortly take place, and that they would then come to Lima. The young lady's name was Fritsch; she was a native of Mexico, had lost her parents, both Hamburgers, and had been for some time for her education under the charge of Knawer's sister Emily [...] that she was good-looking, well brought up, and $[\ldots][184]$ small fortune of her own, which latter circumstance, probably communicated to him by his sister, might, I thought - without doing him any injustice - have accelerated his rather sudden resolution. His excellent father, Mr. George N. Knawer was lying dangerously ill with little hopes of recovery.

The subscription for the German wounded, above spoken of, came up to about S/23,00o for which a bill was taken from Arthur Heeren, which Von Bunsen remitted directly to Von Bismarck. Lembcke, Consul for Sweden and Norway, and Brauns, Consul General for Austria, made themselves conspicuous by not contributing. Charles Pflücker, the two Gildemeisters, Schutte \& Co., and Renner, subscribed each S/10oo. Scheel, the two Rehders jointly, Heeren and I, each $\mathrm{S} / 800$. The remainder was made up by smaller sums.

Monday, $22^{\text {th }}$ of August. Limpricht left for Europe, via the United States. In the Congress no measure of particular importance had as yet been carried, except that already mentioned of the general amnesty. The two parties were 
preparing and measuring their forces for the great combat, which no doubt would take place when the Dreyfus contract came on the tapis. The daily papers published many articles against, hardly any in favor of the same.

The repairs of my house Calle de Zarate continued on a large scale and already came up to more than $\$ 40,000$ and as yet I saw no end to them so that I began to be a little uneasy about the matter.

Sunday, $28^{\text {th }}$ of August. The Steamer "Bolivar" arrived from Panamá bringing authentic news from the theatre of war to the $3^{\text {rd }}$ August. On the $2^{\text {nd }}$ the French had passed the frontier of the Rhenish Provinces and dislodged the Prussians from Saarbrück; it was from all accounts a very trifling affair, yet the French made much fuss about it, spoke of the "élan" of the soldiers and of the baptism of fire, which the Prince Imperial had received on this occasion. On the $3^{\text {rd }}$ August the Prussian troops invaded France between Weissenberg and Lauterburg, took a small place, Geishel, with the bayonet, and destroyed many miles of railroad, which seemed to have been their only object. A body of Bavarian soldiers fought on the side of the North Germans, which proved that the South Germans had decided to stand side by side their northern brethern in this national struggle. The German Corps d'armée were stationed more or less in the follow [...] 80,000 men in the neighbourhood of Berlin, more [...] [185] 100,000 under the Duke of Mecklenburg-Schwerin, and above 6o,00o under Falkenstein to protect the Elbe and the Duchies, about 100,000 under Herwarth Von Bittenfeld in the neighbourhood of the Weser and Ems. In the Rhenish Provinces Prince Frederic Charles had the command; under him stood General Steinmetz at Cologne with 100,00o men; and the Prince Royal at the head of 106,00o men in the vicinity of Strasburg. It seemed to me very strange that at this time an English man-of-war had been dispatched for the purpose of conveying to England the Princess Victoria, Spouse of the Prince Royal of Prussia. The French troops were divided as follows: the first Corps under Marshal Mac Mahon in Strasburg, the second under General Frossard in St. Arnaud, the third under Marshal Bazaine in Metz, the fourth under General Ladmirault in Thionville, the fifth under General Failly in Bitsch, the sixth under Marshal Canrobert in Chalon, the seventh under General Donay in Belfort, the eigth under General Bourbaky at head-quarters.

Monday, $29^{\text {th }}$ of August 1870 . Mr. Rees having sent word that a violent cold prevented him from coming to my office, I availed myself of the leisure hours to make once more an ascent of San Cristoval, which I of course accomplished, but not with such ease as four months previously when I used to climb up three or four times a week. When descending, I knocked my left knee against a protruding rock, which caused me such excruciating pain that I nearly fainted, and had to rest for several minutes. 
Thursday, ${ }^{\text {st }}$ of September. The steamer which arrived this day brought from the theatre of war no later news than that already come to hand by the "Bolivar". All European powers had declared that they would keep neutral in the present war between Germany and France. Only England had made the condition that if either of the two were to invade the territory of Belgium, then she would take sides with the opposite party. A project, dated some time back, of a secret treaty to be concluded between France and Prussia was published in the Times, which did little honor to either of the two. Its purport was that Prussia would allow France to annex the Grand Duchy of Luxembourg and would not impede the invasion of Belgium, on condition that France did not oppose the unity of Germany. Now each of the two parties tried [_] throw the onus of this iniquitous plan upon the other. Von Bismarck affirmed [...] was drawn out, and laid before him by Benedetti, the French Am[_] [186] in Berlin, whilst Benedetti asserted that though written by him, it was dictated by Von Bismarck, which latter had, it was generally believed, communicated its contents to the English paper.

Friday, $2^{\text {nd }}$ of September. I made another discovery. Charles Duval not only had defrauded me of the $\$ 2825$ spoken of above, but two other pagarées, which at the time he told me were brought for discounting by the broker Mugaburu, also turned out to be forgeries, and Mugaburu, whom I called up, assured me that he had never brought them, the one for $\$ 2885$ due this day, purporting to be signed by Manuel Lasarte, the other for $\$ 1770$ due September $26^{\text {th }}$ with the signature of A. Larco \& Co., each endorsed with the signature E. Baulot \& Co. I resolved to wait until I heard from Limpricht before I went to the expense of ratifying in a judicial manner these documents, as I had done with Myer and Raybaud's acceptance.

Saturday, $3^{\text {rd }}$ of September. The losses which I had sustained by Duval's forgeries were more than made up for by the receipt of $\$ 29,995$ which this day Garland paid me, by order and on account of Mr. C. W. Schutte of Paris; this amount was the current interest at $6 \%$ p.a. on an old debt of his, for which I held a pagaré for $\$ 19,432.51 / 2$ rls dated the 31 Augt. 1838 and on which, though the principal had been paid on different occasions, no interest whatever had been made good to me since his stoppage in September 1838 . More than once Mr. Schutte had declared that this interest should not be paid to me until after his death, and as I was aware that I had no legal right for claiming the same - because when in December $185_{1}$ I settled with his creditors, I also had to give him a legal discharge - I was not a little surprised at this change in his resolution. Garland attributed it to many earnest representations which he had made to him on the subject, I to a strong, energetic, perhaps even violent letter which I had written to Rosa some five or six months previously, when 
she had made an offer of a present to my wife which the latter had refused to accept. Howsoever this might have been, at all events I got the money, which came in very good time when the repairs of my house swallowed up such a large proportion of my capital.

At last Mr. Rees, after an absence of nearly a week, reappeared apparently in good health.

This morning I was present at the funeral of John Dartnell, husband [_] Mercedes Guise who had died a short time back at the Guaña [...]. [187] It being Garland's birthday, my wife and I dined with him and the family in the usual quiet manner, but for the evening Enriqueta had invited a pretty large party, which gradually assembled from 8 till 9.30. At 10.30 when tea had been taken, three rocambor tables were formed, to one of which sat down M. Francisco Benavides from Arequipa, the opposition Senator, Ignacio Távara the Government Deputy, Dr. Patron, and Dr. Middendorf, at the other Daponte, Juan Mariano Goyeneche y Gamio, Melchor Velarde, and Juan Baso; these played at $\mathrm{S} / 2$ the point, the former at S/1. Garland and Manuel Velarde were lookers on. At the third table sat down Doña Dolores Puente, Baltazar Aranivar, Antonio Martinez, and young Sayan, a friend of Guillermo's. The remainder, except myself, who walked up and down and looked at the one and the other, amused themselves with Monte at very low stakes; they were my wife, Enriqueta, her five sons, Irene, Baso's wife, and Adela, the wife of Aranivar. It was as late as 1 O'clock when we sat down to an excellent supper and nearly 2 before we were home.

Sunday, $4^{\text {th }}$ of September. I was up betimes, took a cup of tea, and by 9 O'clock was at the station of the Chancay railway, finished as far as the river Pasamayo. The station is on the other side of the bridge, close to the right bank of the river exactly opposite the Church of Santa Rosa de los Padres on the left bank. The fare as far as Ancon was first-class $S / 1$, second class 50 octs. I was surprised at the number of people who took their tickets; I suppose there were between four and five hundred. The train started long after the appointed time. For a minute or so the line runs parallel with the river, then turning to the right; we arrived at another station outside the Portada de Guia, and it was as late as 10.15 before we got again under weigh. On a previous occasion I have described the road as far as the river Chillon. After having stopped for a minute or so at the Hacienda de Infantas, and again at that of Pró, we crossed the river over the splendid bridge, which at the time of my last visit was in progress of construction; on the other side the country was but little cultivated, their being as far as Ancon but two estates, San Lorenzo to the left and Copacabana to the right. Having passed the Chillon, the road skirts for a considerable time 
the ridge of hills which we had to our left. The ground was overgrown with reeds, and to obtain a solid foundation, it had been necessary to cut many canals, which had drawn off the water. The road ascending, and the train [...] we made but slow progress and had to stop several times. [...] [188] small village called Puente de Piedra there is another station, and I wondered at the activity which prevailed here, some people leaving, and many more entering the train. Henceforward the ground was extremely sandy and still continued to ascend; we crossed a ravine over a viaduct, which passage appeared to me rather dangerous; the viaduct is made of enormous beams rammed into the ground, and who knows whether this ground is solid, more likely it is not. Across them other beams were placed, upon which the rails, on one side at the very edge. Were the train here to get off the rails, all would infallibly be precipitated into a depth of 50 or 60 feet, where the bottom to be sure is of the softest sand. Here, more or less the descent to Ancon commenced; the road made such a curve that after two or three minutes we were again exactly opposite the viaduct. We had now everywhere nothing but sand, at a short distance the sea before us. At 12.15, three hours and a quarter after we had left Lima, we arrived in the Ancon terminus, a very extensive establishment. We, that is to say Garland, Antonio, Melchor Velarde, da Ponte, and I, who had come together from Lima, went to the hotel where we took our breakfast in company with a great many passengers; I myself had no appetite, but the others said they were faint with fasting. Thence we went to a certain Col. Castañon, whom the Government some time back had authorized to allot to all such as would apply, a certain piece of ground gratis, for the purpose of drawing dwellers to this port; my wife and Enriqueta applied in due time, but the sites $\mathrm{N}^{\circ} 124 \mathrm{~A}$ and B, conceded to them - and to which we were accompanied by Castañon's son - each 25 varas in front and 36 varas deep, were by no means to our liking; they were situated in the S. E. corner, about three cuadras distant from the sea.

On the $19^{\text {th }}$ July 1842 - see page 751 of Vol. I - I had been in Ancon when there stood but two miserable huts; now of course it had considerably changed, but after all I thought it but a miserable place, especially as there was no water, which had to be brought thither by train, either from the river Pasamayo or from that of Chillon. The bay, only open to the North, is very spacious and always quiet; to the west the coast protrudes somewhat further than that to the East of the bay, and the sandy beach, as well as some other pieces of ground of the same nature, is encircled at a short distance by equally barren and sandy hills; of course the line cuts through them where they are lowest. The bathing ground was said to be exc [...] hard ground without a pebble shelving down very gradually [189] distance from hill to hill along the beach may be 
two miles. Parallel with the beach, fifty or sixty paces distant, the Lima and Huacho railway Company had built a row of very narrow wooden houses, of which some had been sold, and others were still for sale; a corridor runs in front of of them; behind them a wide street not paved, on the other side of which the Indians had their dwellings, made of reed or mats. To the right, that is to say Eastward, are the buildings of the company; not far from them the President Balta and his brother, the Minister at War, were constructing their houses. Having returned from our walk we called upon Colonel Masias, who on account of the health of his children had taken rooms in the hotel. Garland and some others sat down to rocambor. I looked on, roamed about, and whiled away the time as well as I could. The train immediately after our arrival had left for the river Pasamayo; the road thither is no doubt very dangerous, the whole distance about an hour. It is constructed on the side of the high, sandy coast, about half way between the sea, at a considerable depth below, and the top of the hill, at an equal height above. The train returned from Pasamayo at 4.30; we took our seats and reached Lima quite in the dark, before 7. My good wife had waited dinner for me until this late hour. It was an interesting trip, but not likely to be soon repeated by me.

Monday, $5^{\text {th }}$ of September. By telegraph, advices were received of a formidable rising of the Chinese labourers in the haciendas of the Valleys of Pativilca, Barranca, and Supe. Their number was said to be as great as 4000 . The owners of the estates had been spared by the Chinese, not so the Stewards and overseers, who had invariably been murdered. The Prefect of Lima with a battalion of infantry, some cavalry, and part of the police left, in order to put down this dangerous rising; many of the owners of the estates who were in Lima went with him; amongst whom young Canaval, Benito Valdeavellano's brother-in-law, who was to have been married this night to Enriqueta Bolivar, a cousin of Manuel Pardo.

Sunday, $17^{\text {th }}$ of September. Nothing further had been heard about the rising of the Chinese since the departure of the troops; we only knew that of all the haciendas that of Canaval had suffered most. The Chinese, when attacking la "Barranca", were repulsed with some loss, and it was supposed that they had dispersed and [...] the Monte. [190]

About a fortnight back a fearful murder had been attempted, fortunately not accomplished. The following are the details. Some years back had come to Lima as Chargé d'Affaires for the Republic of Venezuela Don Enrique Perez de Velasco, a very well educated and agreeable gentleman; he had not been here a long time when a revolution broke out in his native country, and those who rose to the Supreme power being hostile to the political party to which he 
belonged, not only deprived him of his post, but prohibited him from returning. Soon after he was joined here in Lima by his wife and several children, but his resources being rather scanty he found himself soon in straightened circumstances, when Nicholas Rodrigo tendered him a helping hand and gave an interest to him, to his son-in-law Herce, and to one of his own silly sons, in a wholesale store which he opened in the Calle de Judios. Velasco being in want of a cook, Rodrigo told him he could procure him one who understood his art, but who had a very bad character. Velasco said he would run the risk, engaged him, and had to pay for his self confidence. The Chinaman, being a very late riser, he ordered one of his sons, a mere lad, to call him up every morning at an early hour; the Chinaman exasperated at being deprived of his great delight to lie long in bed, resolved to wreak his wrath upon the innocent boy. One day when the two were alone in a room, he shut and bolted the door, drew his knife, and made a fierce attack upon young Velasco, who, a brave little fellow, defended himself valiantly and though stabled in seven places, managed to open the door and to escape. None of his wounds when examined was found to be fatal.

Monday, $12^{\text {th }}$ of September. Both in the fore and afternoon telegraphic dispatches arrived from Huarmey, where the steamer from Panamá had been obliged to put in for want of coals. They brought advices of the greatest importance from the theatre of war, but besides being abrupt - as telegrams always are - they were extremely confused, so that it was next to impossible to form a clear idea of what had actually occurred. Certain it was that everywhere the German Armies had made great progress. From that side where, as we had learned the other day, the Prince Imperial had received his "baptism of fire", General Steinmetz had pushed right into the country, beaten the French on the $14^{\text {th }}, 16^{\text {th }}$, and $17^{\text {th }}$ of August, and had forced Marshal Bazaine to shut himself up in Metz. On the [...] same month the Prince Royal of Prussia had [_] after [...] [191] desperate resistance on the part of the French, a decisive victory over Marshal Mac Mahon, at a place called Wörth, North of Strasburg, West of Lauterburg and South of Weissenburg. The French attributed the loss of the battle to the enormous disproportion in the forces of the two armies; they pretended that on their side fought 35,000; on the side of their enemies 140,000 men. This was an undoubted falsehood, but were it true, it would only prove the superiority of the strategy of the Prussian Chief of the Staff, Count Von Moltke, and the utter want of combination on the part of the French leaders. Mac Mahon had retired towards Chalons sur Marne where he had been joined by the Emperor and his son, who were received with signs of discontent by the Garde Mobile, and it was expected that he would make a stand here, where 
in former years the Emperor used to hold his splendid annual reviews. Prince Frederic William had occupied Nancy, the Capital of Lorraine, and on the $21^{\text {st }}$ his vanguard had reached Vitry, a short distance to the South East of Chalons. A German Governor for Alsace and Lorraine had already been named by King William. In Paris, orders had been given by the Regency, of which the Empress was the Chief, to begin working at the fortifications; for her own person she had made preparations to fly to Belgium, if circumstances should oblige her to take this extreme step. The entire Ministry Ollivier, whose advent in the beginning of the year had been hailed with such enthusiasm, had resigned. He himself having been hissed in the street of Paris had departed for Italy. The Minister for War Le Bouf was looked upon as the main cause of the disasters which had overtaken the French armies. As a salve to their wounded pride, the French affirmed in their bulletins that the loss of the Germans in these different sanguinary battles had been as 5 to 2 , and that the high roads both in France and Germany were covered with trains of wounded. One French General said in his order of the day that the French Infantry fired much too fast, and that one French soldier spent in one day as much ammunition as the Germans did in three. Rome had been evacuated by the French garrison, and it was rumoured that his Holiness was fortifying the Eternal city against the approach of the Italian forces.

Mr. Schutte and family had left Paris for Brighton; he said in a [...] France look very black; Peruvian Bonds [...] [192] sold". Juan wrote from Divonne on the $6^{\text {th }}$, before he knew of any decisive action, that the word credit had disappeared from the Commercial World, that mistrust reigned everywhere, and that failures were the order of the day. Here in Lima the Congress did nothing worth noting; the Deputies were wasting their time discussing a bill on public works, instead of treating of the budget and the Dreyfus question, both of the greatest importance. This day, to my great regret, Don Bartolomé Araoz left for his sugar estates in Abancaes.

Saturday, $17^{\text {th }}$ of September. In the course of the previous and the present week, several meetings of the shareholders both of the Lima and Huacho and of the Cerro de Pasco Mineral Railway Company were held; of the former the Directors, with whom I was acquainted, were Nicolas Rodrigo, Emilio Althaus and Graña. The first of the three, the President, told me that the company was at the brink of insolvency. They could neither sell the bonds, lent them by the Government, nor return the money, which they owed to same; consequently he, Rodrigo, had a personal interview with the President José Balta and induced him to make the Government take half an interest in the Railway, the money owing being considered as a payment on account; this, after some discussion, was approved by the other Directors. The money already paid or 
to be paid in by the shareholders amounted to $1,335,000$ or $1,350,000 S /$, and for a similar sum the Government would be interested. The Directory was to consist henceforth of five members, two to be named by the original company, two by the Government (of these, one an Engineer), and the President of the Directory was to be chosen by the Government out of three proposed by the Company; the President to have no vote unless the other four could not agree, the five Directors to be paid each $2 \%$ of the nett gains after deducting $6 \%$ interest on the capital invested, to be paid to all shareholders. I thought the Company might well congratulate itself for having made such an arrangement. The Cerro de Pasco Railway Company, of which I was one of the 5 Directors, was also short of funds, arising from the circumstance that at the time the shares were issued, Manuel Pardo was of opinion - all acquiescing with him, though I rather reluctantly - that in course of time the remaining shares would find purchasers at a premium, and for this reason the issue was then stopped. Now it did not turn on so, and though all the shares amounting to $S / 530.000$ had been paid [...] Barreda had lent 100,00o, I 50,00o Soles still more [...] [193] was required, for none was in the chest, and no shares could be disposed of, the work had to go on; and the workmen be paid. At one meeting it was resolved that $\mathrm{S} / 45^{0,000}$ should be raised upon bonds to be issued by the company at $93 \%$, which were to gain $8 \%$ annual interest, with $4 \%$ annual redemption. Then Francisco Bohorquez, one of the shareholders, and a Pasco miner, asked for an interview with the Directors, and gave as his opinion that the money could be obtained more cheaply from the Government. We authorized him to apply to Pierola, Minister of Finance, and the result of his interview was that the Government would lend us S/500,000 of the new "deuda consolidada" at par the company bearing the loss in the sale, we paying $6 \%$ annual interest and $4 \%$ redemption. The $2 \%$ difference between 6 and $8 \%$ interest would, of course, be a great saving, nevertheless, I opposed this new plan most decidedly, because in my opinion if bad news regarding Dreyfus or the Société Générale were to come from Europe, the Government would find themselves hard pushed for money and perhaps stop the redemption of the vales, and then these papers already at $92 \%$ might become altogether unsaleable. I was partly backed by Rodrigo and Riva Agüero, and I finally so far prevailed that application to the Government should be deferred, and S/100,00o borrowed on the above mentioned terms.

The Minister of Finance laid before the chamber of Deputies his budget for $1871 / 72$; he made the revenue of the two years jointly run up to nearly 59 millions of Soles, and the expenses to 1,060,00o Soles less. Last night the North Steamer arrived. La Croix, the French shopkeeper, Isabela Aliaga's husband, had died in Panamá. Juan's letter, dated Divonne $12^{\text {th }}$ August, brought of 
course no political news of particular interest. By submarine cable to Santiago de Cuba, thence per steamer to Colon, we had advices from Europe to the $3^{\text {rd }}$ September. Napoleon was said to be a prisoner in the hands of the Germans, a piece of news too good to be true. Mac Mahon had made no stand at Chalons as had been expected; he had marched towards Rheims, thence towards the Belgian frontier, where his army, 80,00o strong, had again been defeated and obliged to lay down their arms. Before signing the capitulation, he had ordered General Failly to be shot as a traitor.

This was Enriqueta's birthday; my wife and I dined with her and the family. Rafael Velarde came in, so did Manuel, his daughter Adela [...] husband Aranivar. Rafael related to us what had happened [...] [194] the Chamber of Deputies. The Dreyfus Contract had previously been submitted to three committees, two of finance, one of justice; and been approved by all three. In this day's session the opposition demanded that the contract should again be submitted to another committee, that of legislation. The Government, or Dreyfus party, was averse to this motion; the discussion was very animated, and when the votes were counted 34 were in favor, 43 against it. Then the opposition exclaimed that the voting had been irregular, and that the votes should again be taken, but by name; this the President Manuel B. Cisneros agreed to, and the result was the following: 41 against, 40 in favor; thus the Government had only the majority by one single vote.

In the Nacional, a letter, dated August $16^{\text {th }}$, was published from their London correspondent, who attributed all the reverses of the French to bad generalship. On the $9^{\text {th }}$ August when the Ministry Ollivier was turned out by the Corps Legislatif, one member said: "our soldiers have fought like lions", to which another made the addition "yes, as lions led by asses". Before hostilities commenced, the German troops were grouped as follows: Most to the South in the neighbourhood of Strasburg 140,000 under the command of the Prince Royal, a little more to the North the army of the centre, called also that of the King, 120,000 commanded by General Steinmetz, and still further North, about Saarbruck, about 200,00o under the King's nephew Frederic Charles. Mac Mahon, the hero of Magenta, previous to the defeat sustained at Wörth, had been beaten at Weissenburg, and General Frossard, who had acquired some fame for the victory gained by him over the Italian Liberals at Mentana, was the very same who at the first encounter with Steinmitz's forces near Forbach, West of Saarbruck, was beaten; and driven inland.

Tuesday, $20^{\text {th }}$ of September 1870. Our servant Juan fell ill, suffering from an inflammation of the lungs; the want of his services was much felt by us, though the porter Salinas did all he could to replace him. 
Thursday, $22^{\text {nd }}$ of September. Violent altercations took place in the Chamber of Deputies. The opposition party did all in its power to put off Dreyfus's question till the arrival of the next steamer, for they were in expectation that the news from Paris would be so unfavourable that the Contra [...] be annulled owing to Dreyfus's incapacity to [...] [195] On the other hand, the Government party were doing all they could to have it approved before the end of the month. This day the row was such that hardly anything was done, and in the anteroom blows were exchanged. Antonio Martinez, who in fact had no business to be there, said a few words praising the conduct of Domingo Gamio, the violent anti-Dreyfusista, when he was fallen upon by a lot of Dreyfus's partizans. He, of course, defended himself, but was walked off to the police office by an officer and two soldiers.

Friday, $23^{\text {rd }}$ of September 1870. Martinez was placed in liberty. In the Congress the same question again came on, when the Government gained a decisive victory, 53 votes being for the continuation of the discussion of the contract, and only 34 against it. Villa's accounts of the expenses of the house came up to $\$ 45,500$ besides which I had still to pay for the cedar wood bought, as well as for the water pipes to be laid by Hart Brothers.

Saturday, $24^{\text {th }}$ of September. Dia de las Mercedes. I visited the ladies of this name, with whom I was acquainted. Doña Mercedes Riva Agüero was quite as silly as usual, Mercedes Canseco, the niece of Castilla's widow, married to Yrigoyen, did not receive, her husband being ill. As little was Mercedes Guise visible, she and the whole family having gone to Chorrillos. Mercedes Soyer, Elster's wife, was talkative and agreeable.

Saturday, $7^{\text {st }}$ of October. The whole week the discussions on the Dreyfus question had continued in the Chamber of Deputies. Ignacio Tavara, whom I always met on Thursdays at Garlands, Deputy for a town in the Interior, Ayabaca, where he had never been and a staunch partizan of Dreyfus, told me that in his opinion, several weeks would still elapse before the question could be settled, a great number of Opposition members being anxious to speak on the subject. The speech of José Maria Gonzalez of San Pedro, a little Cholo, though not without errors in his calculations, was much admired and applauded by the opposition. Notwithstanding all the efforts of this party, it was generally supposed that if Dreyfus in Paris were able to keep up the contract, here he would not lose it. Meanwhile, the Government found itself in a critical situation; the treasury was without funds, Dreyfus were not under the obligation to furnish any for the present $[\ldots]$ had advanced their monthly payments as far as November [...] [196] December, and even had they been willing to assist the President Balta they would have found great difficulty 
in placing their bills, for owing to the disastrous state of pecuniary affairs in France, nobody was inclined to take them.

The Directory of the Banco de Lima had their usual monthly meeting. Since Argumaniz's departure, the greatest harmony prevailed amongst us, and though of course it was impossible that we could always be of the same opinion, yet up to this day no violent or bitter word had been exchanged. The question, which we discussed, was whether another $121 / 2 \%$ of the Capital should be called in or not. Lembcke, Zuloaga, and I were in favor of this measure, but the majority being against it, it was resolved that the bank should raise the interest to $12 \%$ and limit its operations, refuse the making of any large loans, and be extremely careful in the discounting of pagarées and bills. The preceding, very prudent resolutions showed evidently that the bank was not flush of money, and this arose in some degree from a debt of S/130,000 owing by the Government, long overdue, and of the receipt of which there was for the present little probability. In a similar manner I also was rather hard up, and this I owed to my having entered into more speculations than my means strictly warranted. Antonio Garcia y Garcia had induced me about a month previously to take an interest of $15 \%$ in his share of $\mathrm{S} / 100.000$ in the railway from Eten to Ferreñafe, in which were interested amongst others Ruden, Canevaro, Candamo y Cia, J. M. Varela, Delgado, Bros. \& Sons, Althaus, said Garcia each for S/100,00o the total capital being one million. Garcia assured me that a long time would elapse before the money would be required, and now, all of a sudden, the Directory had decided that in order to remit to the South American Company established in London, the amount due to the same, $80 \%$ should be paid in before the end of the year. Secondly, I had taken 12,000 Soles of the 100,000 S. Obligaciones de preferencia - debentures - which the Cerro de Pasco Mineral Railway Company had resolved to issue, at $93 \%$, interest $8 \%$, annual redemption $4 \%$ - see page 193. The remaining S/88,0oo were taken by: Manuel Pardo S/20,00o. J. M. Varela S/20,00o. Alex Ruden for the South American Insurance Coy. S/20,00o. Nicolas Rodrigo S/18,00o and General Yturregui 10,00o S. Sixtyfive percent was to be paid in before the end of the year. Finally, the repairs of the house increased from week to week instead of decreasing; for this week [...] up to nearly $\$ 1500$. [197]

In the evening it became known that a telegram had been received from Payta. Rapidly did the Exchange Rooms in the Consulate fill with curious expectants, mostly foreigners, amongst whom the greater number were Germans, all anxious to have a glimpse at the few words which were lying upon the desk. The capture of the Emperor of France was a fact. Other advices were partly amplified, partly ratified by those brought by the steamer herself which entered Callao Bay on 
Monday, $3^{\text {rd }}$ of October. Marshal Mac Mahon as said above had marched from Chalons on Rheims, but instead of continuing his retreat towards Paris, he had turned to the right, his plan having been without doubt to take the enemy of Prince Frederic Charles between two fires, that is to say, whilst he attacked him from the Westward, Bazaine should make a desperate sally from Metz and thus crush the enemy between the two; but the fate which they were preparing for the Germans, awaited and overtook them on a terrific scale. The Crown Prince pursued the retreating Mac Mahon on his way to Paris, as far as La Ferté, where he was not a little surprised to find no vestige of him; he then sent out in all directions cavalry parties to reconnoitre; a regiment of Saxon Cavalry overtook and defeated a regiment of Chasseurs d'Afrique, from whom the direction taken by Mac Mahon was ascertained. Then the Crown Prince hastened his march, the French retreating to the N. E. towards Sedan. Prince Frederic Charles, having been made acquainted with the Crown Prince's movements, detached a large proportion of his army to his cousin's assistance, the troops which he kept with him being sufficient to surround Metz, and to beat back any sortie which Bazaine might make. Now these came from the East, the Crown Prince from the South and West; not far to the N. E. was the Belgian frontier. Step by Step Mac Mahon's army was driven onward. Towards Sedan they marched as a place of safe retreat. Early in the morning of the $1^{\text {st }}$ September the fighting commenced; the bravery of the Bavarians, who fought to the S. E. of the town, was particularly extolled. To the North the troops from Frederic Charles' army, commanded by the Crown Prince of Saxony, completed the iron girdle, shaking hands with their companions under the Crown Prince. The whole day long the battle raged round the walls; every sortie of the French, desperate as they were, was beaten back; the heavy artillery of the Germans was [...] into position upon the heights around and began to vomit $[\ldots][198]$ hail upon the town, and the French cooped in within its precincts. About 5 p.m. a white flag was hoisted from one of the towers, for Napoleon, to put an end to the useless shedding of blood, had authorized General Von Wümpfen (who had arrived a few days previously from Algeria, and who had taken the command of the army, Mac Mahon being wounded) to surrender on the best conditions obtainable, and these conditions were that the entire army, 120,000 men, should lay down their arms as prisoners of war; 600 pieces of artillery were found in the fortress. The Emperor himself wrote an autograph letter to the King of Prussia, in which he said that not having been able to die at the head of his army, he laid his sword at the feet of King William, with whom he had an interview on the $2^{\text {nd }}$, but not before the capitulation was signed and ratified. The next day, the $3^{\text {rd }}$ September, he was conveyed per train through Belgium, not to Berlin as my original says, but 
to Wilhelmshöhe near Cassel, and thus an old prophesy of mine was verified; years back I had told my wife over and over again - and she well recollected I had said so - that I entertained the firm conviction Luis Napoleon would not die a natural death on the throne of France, which meant that he would either be assassinated whilst on the throne, or that he would be dethroned - this latter had now come to pass. On the $4^{\text {th }}$ September, as soon as the disaster of Sedan became known in París, the Chamber of Deputies declared in a stormy meeting that the Empire had ceased to exist, and that henceforth France was a Republic, which was recognized as such on the $8^{\text {th }}$ by the North-American Ambassador, resident in the Capital; Jules Favre, Gambetta, Henri Rochefort, and perhaps a few more raised themselves or were raised to the head of the Government which called itself that of National Defence. On the $22^{\text {nd }}$ Septr. the headquarters of the Germans with King William himself were at Versailles. Paris was said to be provisioned and full of fighting men.

In Spain the Republic had been proclaimed in Madrid, Saragosa, and Tolosa. On the $20^{\text {th }}$ September Rome was occupied by the troops of King Victor Emmanuel. In Austria, Bavaria, and Wirtemberg the respective Governments had prohibited the proclamation of the Popes infallibility. In the Chinese Waters the Prussian man of war "Hertha" had been taken by the French squadron. On board of this Hertha [...] Donner one of the younger brothers of John, bookkeeper in [...] [199] Banco de Lima. Both from Hamburg and Altona, young men of the best families had been obliged to take arms as common soldiers, amongst others, of the family Reincke, two sons of Maria Knawer, married to Arthur Donner and a son of Andersen, married to Wilhelmina Reincke. Of the two Donners, George, the eldest, was severely wounded in one of the desperate battles fought in the environs of Metz and at the time of the last advices had been removed to a hospital; the other two had marched on towards Paris. The communication between this capital and London was stopped. Already before the last events occurred, the Chamber of Deputies had passed a law in virtue of which the payment of all acceptances falling due between $11^{\text {th }}$ August and $20^{\text {th }}$ Septr., might be deferred for 30 days.

Sunday, $9^{\text {th }}$ of October. The steamer, corresponding to the French one from San Nazaire, arrived without bringing advices of a later date than those come to hand by the last steamer. The Empress of France and the Prince Imperial had taken up their provisional residence in Hastings on the Coast of Sussex. In Paris the Chamber of Deputies had been dissolved, the Senate abolished. The Government consisted of the following: General Trochu, Minister for War, President of the Committee for national defence, Leon Gambetta, Minister for the Interior, Jules Favre for Foreign Affairs, Pierre Magne for Finance, Jules 
Simon, Public Instruction, and Emanuel Cremier, Justice. The Committee for national defence consisted of such as had been Deputies for Paris, amongst whom Rochefort and Jules Favre, Vice-President. The Republic had been acknowledged by the principal towns of France Marseilles, Bordeaux, Lyons, Rheims etc. The Capital, it was said, had been removed to Tours - what this expression meant I did not understand at the time.

Garibaldi had offered his services to the French Republic; they had been accepted and would probably consist in the reinforcement of the French forces by a few thousand Italian volunteers.

In Lima the debates relative to the Dreyfus Contract continued. Chinarro had distinguished himself on the Opposition Side, whilst the lawyer Luciano Benjanim Cisneros had harangued not less than four hours defending the contract, in Adolfo Alvarez's opinion excelling in unrivalled eloquence.

Saturday, $15^{\text {th }}$ of October 1870 . The debates in the Chamber of Deputies on the subject of [_] contract dragged on their wearisome length. The Minister $\mathrm{Pi}[\ldots][200]$ had been on his legs in defence of the same for four hours on two consecutive days. On the opposition side there were Puga, Gadea, two Gonzales, Velarde y Alvarez, Chinarro, a young Mariategui, and heaven knows how many more.

Of the repairs of my house I might say the same as of the debates - they never came to an end and increased weekly in amount. In my daily occupations I introduced no alteration; with the help of Mr. Rees, I made fair progress in the remodelling of my old diary. In the evening when my wife was not in the other house, where she went regularly in order to look at the work, we were generally by ourselves: Araos' and Limpricht's absence I much regretted.

Manuel Velarde looked in occasionally, not so frequently as formerly, owing to the pains he still felt in his foot.

In appendix under $\mathrm{N}^{\circ} 2$ will be found a cutting from the Panama Star \& Herald which gives a succinct account of political events in Europe from the abdication of Queen Isabel of Spain until the surrender of Napoleon and the French army at Sedan on the $2^{\text {nd }}$ September.

The "Nacional" of $9^{\text {th }}$ October contained a narrative translated from the French, purporting to give an exact account of an interview held in a certain barn between the victorious King and the fallen Emperor, but there being not a word of truth in it, I do not recopy it here. It was the fabrication of a spiteful Frenchman who, disappointed in his expectation of "la promenade militaire à Berlin", which was the fashionable phrase in the first days of the war, now attempted to place the character of King William in an unfavourable light, not warranted by anything he ever said or did. 
This evening the Exchange Rooms were once more crowded; all were eager to learn the meagre contents of the telegraphic dispatches just received from Payta - further down I shall give a summary of them.

Sunday, $16^{\text {th }}$ of October. In the evening the letters from Europe came to hand. I had as usual a long one from Juan, also one from Corina dated Brighton $16^{\text {th }}$ September, and Enriqueta hers from Rosa.

To judge from what they wrote us, a feeling of compassion for the sufferings of the French people had taken possession of the hearts of the bulk of the English nation. There it was asked: "why should the French people pay for the errors of the Emperor? he declared the war, the war was carried against him, and should cease when he is no longer at the head of the [_]nment". In my opinion this was the most ridiculous [...] [201] Those who are ruled have to suffer for the errors of him by whom they are ruled in the same manner as they reap the advantages of such measures as are crowned with success. Was it ever heard before that Napoleon I spared the Prussian or the Austrian people because the King and the Emperor had declared war and not the nation? has war ever been declared by a nation, can it be declared by a nation; must it not be declared by him or her who represents the nation? Moreover; in the present instance it was well known that the French people, with the exception of a few moderate men, hailed with delight the declaration of this war, which they expected would secure to them the natural limits of La Belle France, the banks of the Rhine.

Juan, owing to the communication between London and Paris being stopped, had not received mine of $13^{\text {th }}$ August, and he intended to apply for the same to the London Post Office as Mr. Schutte had done for his communications and received them; he was of opinion that even were the worse to happen Dreyfus would not allow either him or me to lose a cent of the capital which many months back we had placed into his firm. From Alejandro here in Lima I heard that Dreyfus in Paris was taking steps to have money placed at his disposal in London, for the funds which he might have in Paris were at the moment of no avail; for here nobody thought of taking bills upon Paris; only those on London were in request.

Monday, $17^{\text {th }}$ of October 1870 . The Dreyfus question was at last decided in the Chamber of Deputies; a majority of 63 against 32 approved the report of the Committee for Finance; which said that the Contract concluded by the Minister of Finance with the firm of Dreyfus Bros. \& Co. on the $17^{\text {th }}$ August 1869 was to be confirmed by the Chamber of Deputies in all its parts.

Mr. Rees not making his appearance at the usual hour, I availed myself of the time left at my disposal to climb up San Cristoval.

Here follow the details of the European news which went to the $28^{\text {th }}$ Septr. 
On the $27^{\text {th }}$ September Strasburg surrendered after having sustained a severe bombardment. The Commander was Ulrich, a native of Alsace: 17,000 men with 500 officers laid down their arms. Three hundred thousand men were said to form the army under the command of the Crown Prince which encircled Paris. Serious combats were daily occurrences; hitherto, the most bloody had been fought to the South of the [...] close to the villages of Villeiuif and Sceaux situated between [...] [202] ways, the one to Orleans the other to Versailles. Bazaine had attempted once more a sortie, but though the first advices stated that he had gained an advantage, he had once more been beaten back and forced to retire within the walls of Metz. Orleans was taken by the Germans (incorrect as by later advices). Tours was threatened, and the capital was to be removed to Limoges, which expression meant that the members of the Government were to retire thither.

If the French accounts were to be believed, the Prussian soldiers were making themselves guilty of the most atrocious cruelties. Negotiations of peace were being carried on between Jules Favre and Count Bismarck; the former, it was reported, had offered to pay a war indemnity of £ıoo,ooo, ooo to deliver up a considerable proportion of the French fleet, and to raze the fortifications of Strasburg and Metz, but the king of Prussia insisted upon much larger concessions. If I remember correctly, in 1815 the French had to pay 1,000,000,000 of francs which sum was raised by a loan contracted for by Hope \& Co. of Amsterdam, with the assistance of either Rothschild or Baring of London.

Rome was taken on the $19^{\text {th }}$ September by the Italian army by assault, which lasted ten minutes and at a cost of four men killed and a few wounded. The Papal army was made prisoner; the foreigners who formed part of it were sent to their respective homes, whilst the Italians were incorporated with the army of Victor Emmanuel. This sovereign would not permit Garibaldi to join the French Republicans; off Caprera a frigate was cruising to prevent his escape. His Holiness was deprived of his temporal, but was to preserve his spiritual power. The residence of the King of Italy was to be transferred erelong from Florence to the eternal City.

Russia was making great military preparations directed against the Mussalman power of Turkey. In the island of Martinique the negroes had risen against the whites and killed many of them.

Thursday, $20^{\text {th }}$ of October. Last night's Nacional contained the translation of a letter written by the King of Prussia on the $3^{\text {rd }}$ Septr. to the Queen in Berlin from a small place, Vendresse, at a short distance to the South of Sedan. This being an authentic document, I thought that its contents were worth preserving. On the $1^{\text {st }}$ September in the afternoon when part of Sedan 
and many villages around were in flames, and the united German army was gradually narrowing the circle in which [...] French were encl[_]d the King sent General Von Bro [...] [203] Staff to the Emperor Napoleon demanding the surrender of the town. Von Bronsart met on the road a French officer dispatched to the King with an offer to the same effect; nevertheless, the former proceeded, and when in presence of Louis Napoleon was told by him that the conditions of the capitulation had to be arranged with General Von Wümpfen, commander-in-chief of the army; he likewise delivered a letter directed to the king, with which Von Bronsart, accompanied by the French General Reilly returned to headquarters. This letter - so the King wrote to the Queen - did not contain the humiliating words "I place my sword at the feet of your majesty", but "in the hands of".

On the $2^{\text {nd }}$ the capitulation was signed between Moltke and Von Wümpfen; the second article was in my opinion of a very liberal nature; it said that all civil authorities and officers who would give their word of honor in writing not to serve against the Germans, nor do them any injury whatever during the war should be allowed to preserve their arms and their private property; such as would not agree to this would be disarmed and sent to Germany as prisoners together with the soldiers. On the same day, the $2^{\text {nd }}$, the King rode to Douchery where he had learned from Moltke that the Emperor was, and there being in this village a handsome country house with a park, the king fixed on this spot for their interview. The Emperor received him; they were together about a quarter of an hour, and the king added in his letter that he was much affected on meeting the Emperor, whom he had last seen three years previously in Paris in the plenitude of his power. Napoleon with several officers, amongst whom Prince Murat and Prince de la Muscowa - probably the grandsons respectively of King Murat of Naples and Marshal Ney - guarded by a German escort travelled by train through Belgium, the government of this kingdom having given permission to this effect. The prisoners arrived at the Castle of Wilhelmshöhe near Cassel, which place was to be their residence for some time, at 9.30 on the evening of the $5^{\text {th }}$ September. A correspondent who saw Napoleon in this castle wrote to a London daily paper that the Emperor had changed wonderfully in the course of the last three years; he now appeared an old man, broken down and overwhelmed by his late misfortunes.

Monday, $24^{\text {th }}$ of October 1870 . This being the birthday of Rafael Velarde, I went in the forenoon to congratulate him, when he invited me to come back at 5 O'clock [...] with him and so I did. At 6 O'clock we sat down to din [_] [204] which was very good, it having probably been ordered from one of the hotels, and I wondered that Rafael should have gone to this expense for a party consisting of such insignificant persons as those who were present. 
He placed Garland and myself opposite to each other in the middle of the table, which I thought in bad taste for these two seats ought to have been occupied by himself and wife. To my right I had Dr. José Maria Perez, Vocal of the Superior Court, married to Cora, one of Rafael's sisters-in-law, next to him a gentleman whose name I did not learn, father of the wife of Pablo Barrera, Rafael's brother-in-law, then another person unknown to me; to my left, old Aranivar, an Islay Custom-house employé, father of Balthazar Aranivar; next to him Diego Masias, the revolutionary character of former times, now the conservative man of property. To Garland's right was Manuel Velarde, to his left Baltazar Aranivar, Rafael and his wife at one extremity of the table, close to each other, and the remainder of the seats were occupied by a certain Vaca, an anti-Dreyfus deputy, a true Indian of the genuine brown color, by Vaca's daughter, Rafael's young daughter Zoila, Perez's daughter Alejandrina, married to the naval officer Lino de la Barrera, and perhaps two or three more. After dinner my wife, Enriqueta, and three of the young Garlands, old Mr. Elmore, and some nondescripts came in, and tea having been served I blessed my stars when we could leave about 1o O'clock.

Sunday, $30^{\text {th }}$ of October. To my great astonishment the Dreyfus question had not yet been decided in the Senate, this Chamber, as well as that of the Deputies having for a great part of the week been occupied with questioning the Minister of the Interior, Santa Maria, on the subject of the attempted arrest of Dr. Pazos, the responsible editor of the Nacional. In the lower chamber Chinarro, in the upper one Manuel Francisco Benavides took the lead; but they did not succeed in obtaining any other reply than the following: "Within 24 hours after the arrest of Pazos, I shall place him before a competent judge, and then I will give my reasons for what I have done, and not before". In the Senate the Minister of War, President Balta's brother, Juan Francisco, presented a letter to prove that Benavides was a Conspirator. It purported to be written by Prado from Santiago on Octr. $16^{\text {th }}$ and spoke of $\$ 20,000$ - the Minister said the sum was $\$ 200,000$ - which for certain purposes were to be placed at Prado's disposal in Valparaiso. More did not become known for the public session was immediately, by order of the President General Echenique, changed into a secret one. On the $13^{\text {th }}$ October died [...] [205] Valparaiso Mr. Bartholomew Browne, 69 years of age, for many years head of Huth Gruning \& Co.'s houses first in Lima, then in Valparaiso. Thus one after another those of that generation dropped off.

Monday, $37^{\text {st }}$ of October. The Senate approved the Dreyfus Contract by a majority of 26 to 10; the noes were Francisco de Paula Muñoz, Manuel Alvarez Calderon, Augusto Althaus, Vivanco, M. F. Benavides, Mesa, Usandivaras, Manuel Costas, Oviedo and Chavez. 
Tuesday, $7^{\text {st }}$ of November. On this day, All Saints, it has always been the custom of the Lima people to visit the pantheon; I did so early in the morning. Of this burial ground, extremely well and carefully kept, I gave a pretty exact description on a previous occasion; here I will only say that it was filled with all kinds of people, many of whom carrying with them garlands and flowers with which they adorned the last resting-places of their friends and relations. I saw the Althaus and the Ingunsas. The marble monument, erected to the memory of General Althaus, sculptured in Italy and sent hither by the daughter Grimaneza, is perhaps one of the prettiest. The female figure leaning against the cross is said to bear some resemblance to the said daughter. In the vault below the mausoleum of José Galvez, blown up in Callao on the $2^{\text {nd }}$ May 1866, mass was being said, and part of the family were present. I was much pleased with all I saw and was back with my wife for breakfast.

Last Sunday I spoke of the letter presented to the Senate by the Minister of War as an accusation against Manuel Francisco Benavides, who in one of the late sessions cleared himself of every imputation of treason or conspiracy; he acknowledged the authenticity of the letter and said that it solely referred to the encouragement which Prado's friends, he amongst them, had given him to return to Lima, and to aspire to the next presidency, to which Prado had replied that in order to do so he wanted money, and that the said $\$ 20,000$ was the sum which his friends had promised to place at his disposal. On the other hand, Benavides accused the Minister of the crime of having broken the seal of a letter not directed to him.

Thursday, $3^{\text {rd }}$ of November. The letters by the North Steamer were delivered; the only news of importance was that of the capitulation of Toul on the $24^{\text {th }}$ Septr. with some two thousand and odd prisoners. The number of Germans who sur[_] Paris and completely isolated this town was calculated [...] [206] to 400,000 men, nevertheless, even of St. Denis they had not yet been able to make themselves masters. A certain M. Tissander had made his escape from Paris in a balloon with a large correspondence. He descended at Dreaux, outside the German lines, and the 25,0oo letters which he carried with him were immediately dispatched to their respective destination by various trains.

On the $16^{\text {th }}$ October elections for the $75^{0}$ members who were to compose the Constituent assembly were to take place all over France. As yet there was no chance of peace. At the capitulation of Sedan an Emperor, 39 Generals, a great number of officers of all grades, and 84,500 rank and file fell into the hands of the victors. The Emperor Napoleon was perfectly well treated; King William had proposed to the Empress and Prince Imperial to join him at Wilhelmshöhe, which they had declined. The Pope continued in Rome, but without temporal power. 
Juan wrote me from Brighton - which place was filled with Peruvian refugees from Paris - that Dreyfus had established his provisional counting-house in London and that he believed his situation to be perfectly sound. Scheel, manager of his house in Lima, assured me that there was such a demand for bills that they were sometimes unable to satisfy all applicants. They drew upon Huth and Schroeder of London.

Limpricht wrote me on the $16^{\text {th }}$ Septr. from New York, immediately after his arrival, that Charles Duval was there, and that he was in hopes of catching him and squeezing some money out of him. I myself thought he was too sanguine, and so it turned out, for on the $3^{\text {rd }}$ October, after his return from his journey to the falls and other places, he informed me that he now entertained not the slightest hope of recovering anything, for Duval had not gone to the post-office, where a detective was on the watch, to apply for his letters as he had done heretofore; no doubt, he had received advice from his friends in Lima that Limpricht had gone to New-York in search of him.

From Monday, $7^{\text {th }}$ to Thursday, $10^{\text {th }}$ of November. Mr. Rees did not come to my office; he sent word that he was ill of a cold, but I suspected that the effects of intoxication obliged him to stay at home. On Thursday I myself felt unwell and continued so both on

Friday, $11^{\text {th }}$ and Saturday, $12^{\text {th }}$ of November. However, my occupations forced me to [...] [207] street. On Friday, a juez de paz, accompanied by the notary public Pedro Seminario, gave me possession in due form of the four shops in the Calle de Zarate below the balconies of my house, $\mathrm{N}^{\circ}$ 92, with a room behind, No 94 No $^{\circ} 8$ and 10o. These, many months back, had been bought by Dr. Lucio Barrios on my account, in public sale as then related, but the former owners of the same and their creditors had thrown so many difficulties in the way that not before the $28^{\text {th }}$ October the escritura of the sale had been drawn out in favor of Barrios, who at once transferred it to me. On Saturday I went to the office of this lawyer and handed him a cheque for $\$ 1000$ as remuneration for his trouble; also went to the Banco de Lima to fetch money wherewith to pay Villa's note of weekly expenses.

From Sunday, $13^{\text {th }}$ to Tuesday, $15^{\text {th }}$ of November. All three days I stayed at home.

On the $22^{\text {nd }}$ October a revolution broke out in Potosi, headed by General José Manuel Rendon, against the authority of the drunken president Mariano Melgarejo. Here in Lima people were always dreaming and talking of conspiracies and revolutions and of arrests made, or to be made.

Meanwhile, on the $11^{\text {th }}$ inst., the President had put his cúmplase to the contract with Dreyfus, approved of by the two chambers, and thus it became the law of the country. The only limit to the same was that the Executive was 
not permitted to make a new sale of guano to him, after the 2,000,00o tons were delivered, without special permission from the Congress. By this steamer Dreyfus received $\$ 300,000$ in gold from the United States, and even Emilio Althaus had told me two or three days previously that Dreyfus's bills might now be taken with all confidence.

The following was the principal news relative to the war in France: Amiens had been occupied by the Germans, and Metz had been surrendered by Marshal Bazaine on the $27^{\text {th }}$ Octr., with 150,000 men, of whom 20,000 were in hospital, which I believe to be much exaggerated In appendix under $\mathrm{N}^{\circ} 3$ will be found a cutting from the Times sent me by Juan, which gives a clear idea of the difficulties to be encountered in the siege of Paris. The palace of St. Cloud had been destroyed after the works of art had been removed, whether by the French or Germans I was unable to make out. George, the eldest son of Arthur Donner, grandson of Mr. and Mrs. Knawer [...] received at Mars la Tour I have already [...] [208] had his leg amputated; his parents had travelled to where he lay in hospital, but the limb could not be saved. For his bravery he received the iron-cross, a poor compensation for a lost leg. Of his younger brother Arthur, of three sons of Theodore Reincke, of whom one was employed as a medical man, and of Bernhard Elmenhorst, all with the army before Metz, no bad tidings had as yet been received by their relations in Altona. Arthur Heeren, to whom and his wife, Mariquita and I paid a visit, told me that he had already lost three of his schoolfellows during the war.

Friday, $18^{\text {th }}$ of November 1870 . This morning the funeral of Juan Mariano Goyeneche, 86 years old, and younger brother of the Archbishop, was solemnized in the Cathedral. I need hardly say that he was the richest man in Perú, and perhaps on the whole West Coast of South America. His fortune for the greater part consisted in landed property which was valued at \$20,ooo,ooo: nevertheless, his death was regretted by nobody, except, perhaps, by his children, for he was avarice personified. I was not present at the funeral on account of my cold.

Of late the two provinces of France, Alsace and Lorraine, which it was said King William insisted upon severing from France, were so much talked about by the foreigners in Lima, that I was of opinion a succinct historical account of them would be here in its right place; it will be found in appendix under $\mathrm{N}^{\circ} 4$.

By the steamer which came in this day from Panamá General Pezet and family, also Mr. and Mrs. Henry and two children arrived from Europe.

Sunday, $20^{\text {th }}$ of November. The papers said that Pope Pius IX, though he had protested against the occupation of Rome, had condescended to accept from Victor Emmanuel 50,00o Spanish dollars to defray the expenses of his 
civil list for the month of October; as yet he was in Rome. The next meeting of the Ecumenic Council was postponed for an indefinite period which meant in other words that all was over with it, and that the high dignitaries of the Church might return to their respective homes.

Also in France the meeting of the Electors for the National Assembly, which was fixed for the $16^{\text {th }}$ October, had been put off indefinitely by the selfnamed government of Paris. Gambetta, with a few of his friends in one balloon accompanied by another balloon with other individuals made his escape $[\ldots]$ though fired at when passing the Prussian lines [...] [209] to the north of them.

Monday, $27^{\text {st }}$ of November 1870 . My wife's birthday. For many years past it had been my custom to make her a present on this day, sometimes of a larger, sometimes of a smaller value. Today I did not do so, for I was of opinion that the state of my finances did not allow my incurring any unnecessary expense. It was true I had had an unexpected windfall of interest from C. W. Schutte, which I had long given over as lost; but, on the other hand, Charles Duval had robbed me of a considerable sum; \$10oo I had subscribed for the German wounded during the war; £2oo I had given as a present to my niece; the repairs of my house Calle de Zarate surpassed every calculation I had formed; the Telegraphic and the Huacho Railway Companies, in both which I had shares, would probably give no dividend, and the prospects of the Cerro de Pasco Mineral Railway Company, in which I was deeply interested, were by no means cheering. Under these circumstances I considered it prudent to diminish my expenses as much as lay in my power. From Garland, Enriqueta, the children, also the servants presents came in; likewise, from other acquaintances, ladies and gentlemen many nosegays and dishes with sweetmeats. We had invited to dine with us all the Garlands, Manuel, and Rafael Velarde, Dr. Middendorf, and Dr. Gervacio Alvarez; just before the dinner hour Dr. Ribeyro came in and remained at my wife's earnest request. Adolfo Alvarez came with his father without being invited. The dinner was very nice as everything turned out which my wife took in hand. The two Vocales sat to her right and left. I had my seat opposite to hers between Dr. Middendorf and Manuel Velarde, and to confess the truth was not much amused with my neighbours. We rose at past 8 , when our various receiving rooms gradually filled with the families of Ribeyro, Alvarez, Dr. Morales, and Dr. Carbajal. Dolores Puente came, but soon retired; and two rocambor tables were formed by those who usually met at Garland's on Thursdays: Manl. Francisco Benavides, Ignacio Tavara, Juan Baso, Col. Masias, Pedro Bernales, Dr. Barrios, Dr. Middendorf and Garland. Of course tea and chocolate, ices, sandwiches, wine etc. were handed round, but it was really 
surprising to observe how little the Peruvians drank. Past midnight all left, and at 1 O'clock I was quietly in bed, glad that all was over.

Friday, $25^{\text {th }}$ of November. I called on Edward Knauer in Store Calle [...] [210] Bodegones. He had just arrived from Europe, accompanied by his young wife. He told me that since his father had been struck by apoplexy, he was completely broken down; he hardly moved from his armchair, was in bad humour and took no interest in anything, not even in his garden, hothouse, and flowers, which had ever been his hobby-horses. Further, that though there was still much enthusiasm all over Germany for the war against France, yet the inhabitants of Hamburg and Altona were upon the whole downcast. There was hardly a family, high or low, which had not one or more relations in the army, and many of them had already to lament the loss of one member or other. The wound which young George Donner had received was in the lower part of the leg, and the bones were shattered; his leg was amputated about half way up by one of the first surgeons, Langenbeck - soon after it was considered necessary to amputate it again at the knee, but mortification ensued and the poor fellow died, 22 years of age; when the mother Maria, Knauer's eldest sister, was on her way to the hospital she met her husband coming back with the coffin. This misfortune had of course thrown a deep gloom over the whole family.

Saturday, $26^{\text {th }}$ of November Manuel Pardo, Nicolas Rodrigo, José de la Riva Agüero, and I were together an hour and a half conferring about the Cerro de Pasco Railway. Sagastabeytia was absent, owing to the death of old Mrs. Ramos, wife of the Chilian, owner of the sugar estate Hualcará in the valley of Cañete. Two bad pieces of news were made known: the one, the tremendous difficulty which the contractors encountered in forwarding the rails to the Cerro; this however would in my opinion at last be overcome by dint of money, and in the course of time. The second was worse; the locomotive, brought out from England in pieces and put together in the Cerro, did not answer; what the defects were I did not understand. It was resolved that Nicolas Rodrigo should write to the brother of Agustin Steele, who was his partner in the Cerro mine, to examine the locomotive and to write down without loss of time whether it could be repaired there or not.

Saturday, $3^{\text {rd }}$ of December To my great delight Riva Agüero came in to read me a few words of a letter just received from the Cerro, in which he was told that the locomotive was going backward and forward [...] wagons along with it. [211]

The news of the capitulation of Metz was confirmed; it was signed on the $27^{\text {th }}$ October in the evening, and on the $29^{\text {th }}$ the Germans took posession of the fortress. Three Marshals, 66 generals, thousands of officers, 173.00o rank and 
file - amongst whom 20.000 wounded - 3000 pieces of canion, and 60,000,000 francs fell into the hands of the victors. The French ascribed this terrible disaster to treachery on the part of Marshal Bazaine. Schlestat, a fortrees to the N. E. of Strasburg had also surrendered, and Dijon been occupied by the Germans. On the other hand, it was reported that about Orleans, and in the neighbourhood of Rouens and Amiens, the Germans had suffered some reverses. The sentence of death pronounced by Marshal Mac Mahon upon Genl. Failly, of which I spoke some pages back, was not carried into effect. The Prince Royal of Prussia and his cousin Prince Frederic Charles had been raised to the rank of FieldMarshal. Von Moltke when completing his $70^{\text {th }}$ year had been favoured by the King with the title of Count.

I received letters from Johannes Limpricht, my son Juan, and my niece Elizabeth. She and her husband were of course full of gratitude for the £2oo remitted to them. Her new son-in-law Fischer, husband of her daughter Maria, and her son Manuel had both escaped serving in the Prussian army, the former owing to his extreme shortsightedness, the latter on account of a rupture from which he had suffered ever since he served as apprentice in the machine manufactory in Güstrow. Limpricht wrote that my cousin Nelly Kramer, my junior by one year, kept up extremely well. When the Metz news reached Hamburg, he said that the enthusiasm passed all bounds; Rosa wrote the same from Münich. Two sons of Charles Willink of Hamburg had joined the army as volunteers, whilst on the other hand the widow of Bernard Donner had made an offer - which was of course not accepted - of half a million of Banco Marks, to have her son exempted from military service. This son, a young man, was the grandson of my old principal Conrad Hinrich Donner, and, in connection with a Mr. Jansen, an experienced merchant, and his sleeping partner, the head of the firm which under his grandfather's name was, and is well known all over the mercantile world; he now served as a sergeant in the Prussian army. The papers said that he had been slightly $[\ldots]$ which however turned out to be false. [212]

Juan thought of leaving Brighton for Lisbon, and thence for Palermo, where he intended to spend the Winter.

In Lima the Congress did nothing; and a new Municipality had been elected, a poor miserable set; whose Alcalde would probably be either Nemesio Orbegoso, protected by the Government, or Evaristo Gomez Sanchez who had many independent votes in his favor. How different was this body to that just dissolved over which Manuel Pardo had presided!

Monday, $5^{\text {th }}$ of December. At 4 O'clock in the afternoon died Doña Josefa Arauzo, probably more than eighty years of age, an unmarried cousin of my wife's. She had been living in the house of Don José Albarracin, a Callao 
port-agent, who by means of successful smuggling had made a fair fortune, and for many years she had been the faithful companion of his wife, a handsome woman in the prime of life.

Tuesday, $6^{\text {th }}$ of December. In conformity with the Municipal regulations at 10 p.m. precisely the corpse was carried to the Church de la Merced, thither as it was the custom, some gentlemen, I amongst them, accompanied the same.

Wednesday, $7^{\text {th }}$ of December. Again I was present at the funeral, which was more numerously and respectably attended than I had expected.

In the course of this my diary the name of the Velardes, with whom through my marriage I became related, has frequently turned up, but nowhere have I said anything about them, who they were, and whence they came. I now make up for this mission by affixing in appendix under $\mathrm{N}^{\circ} 5$ a succinct account of the genealogy of the family.

Thursday, $8^{\text {th }}$ of December. Dia de la Concepcion. Within the last few days a tribunal called el de Responsabilidad, known in the time of the Spaniards, but which had lain dormant for many years, was again called into life. Its object was to be a check upon the Vocales of the Supreme Court. Such litigants as had been cast in this tribunal if they believed that the sentence pronounced by the same was unjust, might appeal to the Tribunal de Responsabilidad which, if it resolved that the sentence of the Supreme Court was not founded on justice, made the members of that tribunal responsible for the injury they had done to the losing litigant. The following were named by the Congress to constitute this Tribunal: Francisco Javier Mariategui, who had lately retired from the Supreme Court, Dr. Loayza, a very clever lawyer, at present Minister for [...] [213] Affairs, Mariano Felipe Paz Soldan, José Aranivar, Minister of Justice, Santiago Figueredo, Antonio Saldaña, an astute lawyer without any particular reputation, and Mariano Loli, once employed in one of the Ministries. The adjuncts were: Carlos Lisson, unknown to me, Tomas Davila, he from Moquegua, and Juan de los Heros, formerly Juez de primera Instancia, then Deputy, a member of the Comision Permanente, now lawyer and my good friend. Fiscal: José Simeon Tejeda, Prado's ex-minister and a lawyer of very good name. Adjunct of the Fiscal: the lawyer Francisco Garcia Calderon.

Last night's papers published the following news from Europe to 18 Nov. received in New York by submarine wire: Paris had not yet been bombarded. Near Orleans on the $9^{\text {th }}$ Novr. the Bavarian General Von der Jann had been beaten by the French General Paladines and the army of the Duke of Mecklenburg-Schwerin had been ordered to march to Van der Jann's assistance, and he again was to be followed by the troops under the command of Prince Frederic Charles, set free by the surrender of Metz. Verdun surrendered on the $10^{\text {th }}$. New Breisach, another fortress in Alsace, had likewise capitulated; 
and Dijon, after having been retaken by the French, had again fallen into the hands of the Germans.

On the $17^{\text {th }}$ November, the Duke of Aosta, second son of Victor Emanuel King of Italy, was elected by the Cortes King of Spain, the votes having been divided as follows: for him 191, for the Federal Republic 6o, for the Central Republic 3, for the Duke of Montpensier 27, for Espartero 8, for Alfonso - son of Isabel II -2, for the duchess of Montpensier 1, in blank (the Carlists) 19, making a total of 311 Deputies present. About the middle of November rumours were afloat in Europe of the probability of a war between England and Russia:

Last night at 12 O'clock died Doña Mariquita, the wife of Dr. Manuel Morales, of fever. She had been a good friend of my Mariquita's. On the $21^{\text {th }}$ Novr. she was with us; this was the last time she had been out and the last time she had played her favourite game of rocambor.

Friday, $9^{\text {th }}$ of December. In the Huerta of Juan Rivera, Manuel Pardo the ex-Alcalde gave a splendid lunch to the hundred gentlemen who had with him constituted the late Municipality of Lima.

To celebrate Geraldo's birthday we dined at Garland's and at [...] [214] went to the house of Dr. Morales to accompany his wife's remains to the Church of La Merced. The small patio of the small house was crowded, and many gentlemen had to stand in the street; on

Saturday, $10^{\text {th }}$ I was also present at her funeral, and seldom had I witnessed a more numerous and respectable attendance; the following four gentlemen took hold of the black ribbons hanging down from the coffin: Dr. José Aranivar, Juan Antonio Ribeyro, Eusebio Sanchez, and Ignacio Osma, Dr. Morales's particular friend and landlord.

Friday, $16^{\text {th }}$ of December. We had telegraphic dispatches from Payta to the effect that the North Steamer had arrived, but that on her departure from Panamá neither the American nor the European steamer had made her appearance; consequently we were without any late advices from Europe.

Formerly the Supreme Court of Justice had consisted of 7 vocales; Prado increased the number to 9, which was again abolished when Canseco took the reins of government; now President Balta in order to reward two of his favourites, who had done him great service in the Chamber of Deputies and the Senate, say Manuel Cisneros - who was hardly known as a lawyer - and Dr. Oviedo, had again raised the number to 9. There were moreover two vacancies in the Supreme Court caused by the retirement of Mariategui and the death of Carpio, whose places were occupied provisionally by Drs. Vidaurre and Alzamora. The Constitution required that the Executive should propose for each vacancy six persons, from amongst whom the Congress was to elect. Dr. Blas Alzamora, who had served in the Judicature nearly the whole of his 
life, and frequently provisionally in the Supreme Court, was not even included in the number, which was done of course to punish him for the vote given by him in the Dreyfus question against the Government. The persons chosen turned out to be: Dr. Vidaurre, a very proper person in lieu of Mariategui, Dr. Arenas, who had only been "Juez de Alzadas", judge of appeal in Commercial cases, but a lawyer of great renown for more than 30 years, in lieu of Carpio, and the above-mentioned Cisneros and Oviedo. The old Vocales were by no means pleased with their new colleagues, with the exception of Vidaurre.

Saturday, $17^{\text {th }}$ of December. The Railway from Lima to Chancay, just completed, was inaugurated by a grand lunch given by the Director $[. .$. course at the expense of the shareholders - to the President [...] [215] his usual toadies and a great many other persons. Guillermo and Alejandro also obtained tickets through the influence of Oswald Pflücker, son of Julius, employed as engineer on the line. Alejandro told us that the company had been by no means select.

Sunday, $18^{\text {th }}$ of December 1870 . A Concert was given to celebrate the hundredth anniversary of Beethoven's birthday. I did not learn who was the original promoter of this festival, but it was Lembcke who had asked me to subscribe. The subscribers were 20 in number, viz.: Mr. Jerningham, Mr. Von Bunsen, Brauns, Lembcke, I, Garland as representative of a German house, Tate of Graham Rowe \& Co. - an amateur and first-rate musician - Heeren, Böhl, Otten, just arrived and head of Ph. Ott \& Co., the two Gildemeisters, Dr. Middendorf, Scheel and Dammert, both of Dreyfus's house, Crämer, Kast, and three more. At 7.30 Mariquita and I, Garland, Enriqueta, and little Antonio drove to the saloon where the concert was to be given, in the upper story of the Municipal building where on the $29^{\text {th }}$ July the Municipal schools had been assembled and prizes been distributed. It was spacious, without the slightest ornament, the walls white-washed, and the ceilings painted; our party was the first to arrive; rapidly the saloon filled, and more than 300 chairs placed in rows for the audience were occupied. Of course the German element prevailed in both sexes; there were however also some Peruvians, amongst whom Manuel Pardo, and the daughters of Felipe Barreda, Canevaro and his wife, and others. We had sent our spare tickets to the family of Dr. Jervacio Alvarez.

Opposite the audience on a low platform were the professional and amateur musicians, the German Band from on board the "Independencia" and the German singing club, one with another at least 400 persons; nevertheless, both windows and doors being kept open, we did not suffer from heat. Tate played on the piano, accompanied by a gentleman on the violin; a quartette was performed on two violins, a viola, and violoncello; both were applauded, but I preferred by far the various pieces played by the entire orchestra, two 
choruses by the singing club were in my opinion not much above mediocrity. It was over by 11.30, when we walked home, and I was glad when my wife told me that she had been well pleased.

From Monday, $19^{\text {th }}$ to Saturday, $33^{\text {st }}$ of December. The Concert in honor of Beethoven [...] [216] as my wife enjoyed it, had its bad consequences, which we might have anticipated, for we knew full well that the ascending of a steep staircase always did her harm, and so it turned out on this occasion; the tumours inconvenienced her more than usually, and though on Christmas day she received a great many visitors in the forenoon, immediately after dinner she felt so ill that she had to go to bed. On the $2^{\text {nd }}$ Christmas-day we dined at Garland's, much against her inclination, and as on the $27^{\text {th }}$ Dr. Middendorf and Dr. Macedo, recommended to us by the former in case of his absence, had both left the capital, we had to apply to another medical adviser, a young man, Dr. Romero, much praised by young Adolfo Alvarez, and who had been at Enriqueta's on the day of Corina's birth. He carefully examined the tumours and confirmed the opinion expressed by all who had been consulted till then, viz.: that they were of no dangerous nature, but according to him it was not unlikely that they would increase in size in course of time. The numbness in her feet, which gradually had extended as far as the hips, but which did not prevent her from walking, arose from the pressure ot the tumours upon some tendons extending to and corresponding to the lower limbs.

The cause of the absence of the two Doctors above mentioned was the inauguration of the railway from Mollendo to Arequipa, the construction of which had been conceded by President Balta to Henry Meiggs in 1868 and which had been concluded six months before the expiration of the term of three years allowed him. Both the President and the Contractor had invited perhaps 1000 persons - Guillermo and Alejandro were of the number - to be present at this solemnity, and they embarked on the $27^{\text {th }}$ in three men-of-war and one merchant steamer. Henry Meiggs took with him lots of eatables and drinkables, fireworks, a band of equestrian performers and Heaven knows what else. It was expected that the festivities, both in Mollendo and Arequipa, would be on a grand scale.

By this time the repairs, or, to speak more correctly, the reconstruction of my house Calle de Zarate, had so far advanced that in the Calle de Aldavas several stores and shops were completed; of these I succeeded in letting three; I also raised the rent of the four, Calle de Zarate, but one with another I was not satisfied with the revenue I $d r[\ldots]$ om them. [217] On the $30^{\text {th }}$ the Directors of the Banco de Lima, Zuloaga and Renner excepted, met. The Gerentes laid before them a statement of the profits of the now expiring year, which, amounting to nigh $15 \%$ on the paid up Capital could not otherwise 
but give satisfaction to all parties concerned. Lembcke proposed to give an extra remuneration to the clerks and to raise their salaries, which was unanimously agreed to. Zaracondegui proposed that the accounts should be submitted for inspection to two shareholders named by the Directory. Heudebert and I opined that the shareholders themselves should name those inspectors; others thought that the nomination was altogether unnecessary, because, according to the statutes the books lay open to every shareholder, who could examine them whensoever he pleased, and thus after a long and animated debate, the motion was lost by 6 to 5 , which result evidently annoyed Zaracondegui. Lembcke, Heudebert, Sagastabeytia, Muro, and I were against it; who was the sixth I could not distinguish owing to my bad sight.

In the forenoon of the $30^{\text {th }}$ the telegraphic dispatches arrived from Payta. Both steamers, that which had not arrived in Colon in due time, and the present one, had come in; nevertheless, as the cables were partly interrupted, the news went only to the $12^{\text {th }}$ December. There were many reports, but the authentic news was but few. On the $29^{\text {th }}$ and $30^{\text {th }}$ Novr., and the $1^{\text {st }}$ and 2 December the French shut up in Paris had made extraordinary efforts to break the Prussian lines, but were repulsed every time. The surrender of Thionville on the $24^{\text {th }}$ Novr. was certain; the occupation of Amiens and Rouen by the Prussians and the defeat of General Paladines, I considered probable, but as yet they were not established facts. It was even added that the Germans were marching upon Havre. The disagreement between England and Russia was likely to be amicably adjusted. [218]

1871

The following is a somewhat abridged, otherwise literal copy of what I dictated in my original diary on

Sunday, $7^{\text {st }}$ of January. "Eighteen hundred and seventy has been an eventful year, and will in all probability be the beginning of a new era in the history of nations. The charm of invincibility which ever since 1793 has surrounded the French eagles is broken, and the preponderance of the German over the French troops is established. Nobody can doubt these two facts who takes into consideration the extraordinary and continuous victories gained by the Germans during the last five months of the year. To enumerate them here would be superfluous, for they are still fresh in the memory of everybody; suffice it to say that the Emperor Napoleon III of France who on the 15 July declared war to King William I of Prussia had to deliver his sword to him on the $1^{\text {st }}$ September. Probably in the course of this year, perhaps in the first months, 
a peace will be signed which will put an end to the international strife and fix the boundaries of the two Empires.

Other events of great, thought of less magnitude than the Franco-German war, have been:

Firstly. On the $13^{\text {th }}$ July the declaration of the Ecumenic Council in Rome that the infallibility of the Pope is henceforth one of the dogmas of the Roman Catholic Church.

Secondly. On the $20^{\text {th }}$ September the occupation of Rome by the troops of Emmanuel, King of Italy.

Thirdly. The cessation of the Pope's temporal power, and

fourthly. On the $17^{\text {th }}$ November the election by the Cortes of the second son of the King of Italy as Amadeo II King of Spain.

In Peru, notwithstanding the apparent material progress of the Republic, the present government is in my opinion hurr[_] the country into an abyss of the most frightful financial [...] [219] barrassment, from which it will finally only be saved by a bankruptcy and the repudiation of all its debts. Loans after loans are to be raised until no European Capitalist will be inclined to invest his funds in Peruvian Bonds, and what is then to be done? - pay nobody. Meanwhile the railway from Mollendo to Arequipa has been finished; and the contract concluded by the Government with Dreyfus Bros. \& Co. of Paris for the sale of 2,000,000 tons of guano been sanctioned by Congress.

In our familly we have had the birth of Corina Garland on the $23^{\text {rd }}$ of July. My wife enjoys fair health, but the tumours inconvenience her more and more every day. As to myself, I have left off taking such violent exercise as I have done heretofore; it would appear as if I were not quite so strong on my legs as formerly. In my sight, heaven be praise, I note no particular deterioration.

As to my finances, though I have had the good luck to receive from Mr. Schutte $\$ 30$, ooo interest, due upon the old debt since August 1838, it has otherwise by no means been a good year for me. Charles Duval has robbed me of nearly $\$ 7000$ and there is not the slightest chance of my ever getting back a cent; the expenses in the repairs of my house calculated at first in from twenty to thirty thousand dollars, will probably rise to four times as much, which is an abominable outlay; then some investments have turned out well, other the reverse; for instance the S/5000 in the telegraph Company, and the S/10,00o in the Lima and Huacho Railway will never earn a dividend. In the Cerro de Pasco Mineral Railway Company I am far too deeply interested; perhaps ultimately it may answer, if only money can be got together to continue the work. To the Eten and Ferriñafe railway I have subscribed 15,000 Soles, and it is generally supposed that it will leave some profit, but time must show whether these expectations are well founded or not. On the other 
hand, the Banco de Lima, the Banco Hipotecario, the Cedulas issued by this bank, the South American Insurance Coy., the Lima Gas Coy., the Lima Water Coy., in all which I am interested to some extent, give a good interest. Of my shares in Dreyfus Contract I also entertain a good opinion."

Monday, $2^{\text {nd }}$ of January 1871. In the meeting of the Directors of the Banco de Lima I, Juan de Dios Calderon, and José Mu[_] [220] laid down our posts of President, Vice, and Secretary respectively, and were unanimously reelected.

Friday, $6^{\text {th }}$ of January. Some time back I spoke of a contract made by the Executive with the firm of Templeman \& Bergmann for the construction of a large dock, Muelle Darsena, in the Port of Callao. The carrying out of this contract met with great opposition by the merchants of Lima, and especially by the port agents of Callao; it was proved by many articles which appeared in the daily papers that both the vessels themselves and the cargo brought by them would be subject to considerably heavier expenses than those hitherto paid; nevertheless, the contract was approved in the Chamber of Deputies and would in all probability likewise pass the Senate. The Bergmanns, whose pecuniary means it was well known were very limited, had, as far as I understood, transferred this contract to some wealthy firm in London or Paris, reserving for themselves a small part for having obtained the concession.

Within these days the amnesty previously granted by the Chamber of Deputies, to Huertas, Bishop of Puno for the misconduct in his diocese, of which he had been found guilty, was confirmed by the Senate.

We received a letter from Guillermo who informed us of his and his brother's safe arrival in Arequipa. The merchant Steamer Panamá, in which they had taken their passage, had left Callao at 6 p.m. on the $27^{\text {th }}$ and reached Mollendo on the $29^{\text {th }}$ at 8 a.m. The men-of war which carried the President, Ministers, Suite, and hangers on came in in the evening of the same day. This large party remained in the Port, where at Henry Meiggs' bidding an hotel had sprung up, till the morning of the $33^{\text {st }}$. Immediately on their arrival in Arequipa they walked in procession to the Cathedral where a Te Deum was sung.

Guillermo further wrote that the enthusiasm of the Arequipeños was extreme, and well might it be so, for now they had an easy communication with the port, whilst until then a ride to and from Islay had always been a fatiguing journey, as I myself had experienced over and over again.

Sunday, $8^{\text {th }}$ of January. This morning I walked out along the Chorrillos Railway where I had not been for at least six months and [...] [221] the changes that I could hardly believe my eyes. The walls in this neighbourhood had been razed to the ground. The Guadalupe gate existed no more, as little as that apperture through which the railway used to run. On the other hand, on the same side as the Penitentiary, a large building destined for an Exhibition 
had been commenced and part of it been concluded; S/300,000 which the Government had destined for this edifice and which sum was included in the budget, had been disapproved by the Chamber of Deputies, and thus it was uncertain at the time, whether the work would be continued or not.

Two accidents had occurred on the railway to Chancay, at the perilous spot where from Ancon to the river Pasamayo the line runs along the side of the high sandy hills, which form the Coast for the distance of from three to four leagues; to the left you have the sea at a depth of from 200 to 300 feet, whilst to the right to the summit the height is about the same. The road itself is, I suppose, perhaps twice or three times the width of the line; on some places the sleepers rest on bags filled with sand, and short curves follow each other in rapid succession. On the $26^{\text {th }}$ December a wheel of one of the cars broke; fortunately the car turned over to the land side, and no further damage was done; but on the $31^{\text {st }}$ December a large mass of sand detached itself from above, fell upon one of the cars, and turned it over. I did not learn how many were injured; one passenger lost his life, and one well known landed proprietor near Chancay, called Castro, had his left collar bone and his right hand broken.

Last night's papers published the telegrams received from Payta; both the English Atlantic cables were broken, and only the French one was at work. The news from Europe, which went to the $19^{\text {th }}$ December, were very unfavourable for the French. The advices received by last steamer were all confirmed. Manteuffel had been marching upon Havre, but been recalled. The fortresses Phalsburg and Montmedy had surrendered. Belfort still held out. Paladine had been removed from command by order of Gambetta, in all probability on account of the defeats which he had sustained, and been replaced by Bourbaki. Not only had the Germans again made themselves masters of Orleans, but had also occupied [...] and as it was said, even Tours. The French Government [...] [222] removed to Bordeaux. On the other hand, the French had [_]ossessed themselves of Laon. Garibaldi, despairing of the French Republic, had returned to his island of Caprera. The relations between Russia and England were, it would appear, not on such an amicable footing as the last advices led us to believe. Prussia, it was added, had threatened the Grand Duchy of Luxembourg which had roused the opposition of England, Holland, and Austria.

Tuesday, $10^{\text {th }}$ of January 1871 . This day the President, his Ministers, the Diplomatic Body, and all those who had gone to Arequipa in order to be present at the inauguration of the railway, returned to Callao by the same steamers which had taken them to Mollendo. Alejandro, who as yet had not been able to obtain a situation in Lima, had remained in Arequipa at the earnest request of Mrs. Dolores Harmsen, whilst Guillermo came back not at all pleased with 
his excursion. He had suffered from sea-sickness, the rarefied air of Arequipa had not agreed with his weak chest and made his nose bleed frequently. Nevertheless, he confessed that he and his brother had been extremely well received by Col. Jimenez - nicknamed Polilla - with whom he and his brother had lived at the recommendation of Rafael Velarde, related to him through his mother, as well as by our own Arequipa acquaintances.

On the $2^{\text {nd }}$ January Meiggs had given a ball; on the $6^{\text {th }}$ the Arequipeños another in honor of President José Balta, of ex-President Pedro Diez de Canseco, who it will be recollected, made the contract with Meiggs for the construction of this railway, and of Meiggs.

The railway itself was described by all to be a really wonderful work. In its whole length there was not one single tunnel, instead of tunnels, cuttings of an extraordinary depth; not one single viaduct, all the quebradas through which it had to pass, being filled up to the necessary height; and only one bridge of small dimensions over the insignificant river el Prostrerrio, which at a short distance before the town falls at a right angle into the Arequipa river. On leaving Mollendo, the line, rising gradually in a Southerly direction, approaches the valley of Tambo which it overlooks from a height; thence onwards the windings and continual curves commence and continue through the "Lomas", [_] [_]pampa, more than 4000 feet above the level of the sea is reach [...] [223] gradient in this ascent is frequently 3 , sometimes even $4 \%$. From La Joya onwards the well known Tambo on the road from Islay to Arequipa - see Vol. 5 page 557 - where a terminus is erected, the line keeps more to the left, approaches the valley of Vitor, lying deep below, and winds around the formidable mountain La Caldera, of which I said a few words Vol. 1 page 95. Hereabouts are the deepest cuttings, and here is situated the valley of Huasamayo, with which I am not acquainted; further on, on the other, the right side of the Arequipa river - which river the line does not cross - lies the valley of Uchumayo, frequently mentioned in my trips to and from Quilca; the railway continues on the left bank, opposite Tiavaya, and finally by way of La Laja and Tingo (having previously crossed el Prostrer rio) reaches the terminus distant about three cuadras from the Merced Street.

During his absence the President had left his brother, the Minister of War, in charge of the Government, and nothing worth noting had occurred except the elections for the members of the Comision Permanente, in which the opposition boasted they had the majority.

Since the beginning of the year Geraldo had had the good luck to obtain a situation as clerk in the counting-house of M. G. Chavez. This Chavez only became known in Lima when Gordillo, his half-brother, placed him at the head 
of his mercantile establishment, which for several years had been managed by Anibal Gonzales, husband of Pepa Bazo, and who was at present in London as one of the Managers of the South American Company there established, and of which the principal shareholders were: José Canevaro, son, said Gordillo, the Luzzarragas, John Bryce, M. M. Cotes, and perhaps a few more. Chavez was the Lima correspondent of this company.

Sunday, $15^{\text {th }}$ of January 1871 . By the 12 O'clock train I went to Chorrillos. Often as I had travelled on this road, nowhere in my diary had I given a description of the same; now I made up for this omission.

This railway to the watering place of Chorrillos, about three leagues distant from Lima in a South - easterly direction, as well as that to Callao, the port of Lima, is owing to the enterprizing genius of Pedro G. de Candamo, whose death, which took place in January 1866, I noted page 728 Vol. VI [...] his partner José Vicente Oyague who was interested for one [...] [224] obtained the concession for the construction of the Callao Railway from President Castilla during his first administration, and that for the Chorrillos Railway when Castilla was President for the second time. Candamo offered to the public as many shares as they might wish to take, but the public, judging from the little traffic there was at the time between the two places, did not apply for a single share, and Candamo constructed the railway on his own account, disbursing, as it was rumoured, no more than $\$ 200,000$, for the ground is level, and the rails which he made use of were of light North American manufacture and comparatively speaking cheap. Not many years before his death Candamo sold the two railways to Antony Gibbs \& Sons of London for £60o,00o which left him a large profit. Gibbs and Joseph Hegan \& Co. who had bought from José V. Oyague his $1 / 3^{\text {rd }}$ of the Callao line, for one-third of a million of dollars formed a new company with a capital of $£ 800,000$ in which these two firms continued to be the principal shareholders; some shares, not to a large amount, were offered to and taken by the public, mainly by the friends and correspondents of Gibbs. A dividend of $10 \%$ it is true was paid, yet the shares could in 1871 be bought at a discount, owing to the circumstance that in 1876 the exclusive privelege of the Callao, and some years later that of the Chorrillos railway, would expire. Both lines run for some distance through the very streets of Lima; the terminus of that to Chorrillos is in the sixth cuadra of that long street which from the plaza runs to the gate of Guadalupe. When emerging from this street, it crosses an open place to the right of which stands the Penitentiary and the Exhibition, which in 1871 was still in its infancy, to the left the Church and Barrack of Guadalupe. When outside the town it has to its left, at a distance of a few yards, the high road to Chorrillos; it passes through the large farm of Santa 
Beatriz, which, once belonging to the noble family of Torre-Tagle, had not long before 1871 been sold by Dr. Manuel Ortiz de Zevallos, husband of Doña Josefa, the last descendant of that family, to the Government, which at the time intended to transform the same into a "model-farm". Somewhat further on at the "Balconcillo" - see Vol. II page 35 - the rails cross the high road, which now remains to the right, and gradually inclining more and more to the left, or inland, avoids in this manner [...] ravine of the Barranco. At some distance before [...] [225] Barranco is a station in front of the village of Miraflores, which lies to the right, close to the sea, distant perhaps ten minutes walk. On the other side of Miraflores the line again approaches the high road and exactly five minutes per train before reaching Chorrillos is another station, the prettiest spot on the whole line, where the passengers get out for the Barranco to the right, or the village of Surco to the left. The terminus in Chorrillos is in a street parallel to the high road, there called Calle de Lima. The country from Lima to Chorrillos is level; to the right, nor far from the railway, is the sea; to the left, at a distance of two or three leagues, several low ridges of hills are visible. Want of water is the cause of its not being so carefully cultivated as it otherwise would be; wheat or maize is hardly grown at all; of the latter I have seen a few fields close to Chorrillos - there are some potato and yuca, also some clover fields, but the greater part is, if I am not mistaken, pasture land.

Chorrillos itself had undergone considerable improvements since I gave an account of it in 1843 - Vol. II page 35/37 - in fact its appearance had entirely changed, many handsome and tasteful houses having been built in every direction; almost all the streets had now footpavements though only of bricks or wood, and in the Calle de Lima two rows of trees had been planted. Mr. Mathison had introduced gas, and the gasometer was erected close to the railway station.

Immediately after my arrival I took my bath, not in the usual place but outside the village, at Agua Dulce where I had been told the bottom was fine smooth sand; this however was not the case, and the customary old spot was certainly the better of the two. My calls were upon: Westphal, the Junior partner of Huth, whose wife, a North-American, was not visible; Mrs. Juana Guise, always agreeable; the family of Dr. Morales, with whom I condoled for the loss of their mother; General Pezet and his lady, in their palace-like house opposite the railway station; Melchor Velarde; and Doña Maria, the widow of Lino de la Barrera. I had done by 4 O'C. and was back in Lima for dinner.

The following was the principal political news received from Europe: the occupation of Blois by the Germans was confirmed, and it was not unlikely that also Havre would erelong fall into their hands. Of the many forts around 
[...] had as yet been taken; an entrenchment provisionally thr[_] [226] up by the French near a place called Avron, forming the only exception, and from this spot towards the end of December the Germans had begun to bombard Paris. The French general Paladine had been sent to Cherbourg to take the command of this important place. The Garibaldians and Franc-tireurs were said to be doing much harm to isolated German parties. The King of Italy had made his entry into Rome, the King of Spain, late Duke of Aosta, his into Madrid. General Prim had been assassinated; on the $29^{\text {th }}$ December, when leaving the Cortes in his coach, eight shots were fired at him by a party of Republicans, and on the $1^{\text {st }}$ January he died in consequence of his wounds. The difference between Russia and England was not in such a fair way of settlement as one had reason to expect judging from previous advices. The conference to be held in London was postponed for an indefinite period.

Saturday, $2{ }^{\text {st }}$ of January. This day the Government suffered a signal defeat in the Congress. The Ministers had sent in a note in which they demanded the cancelment of the election of Manuel Francisco Benavides as member of the Comision Permanente, founding this their request upon the intercepted letter from Prado, of which I have spoken above; it was unanimously rejected, with the only exception of the vote of Ricardo Palma, Balta's private secretary. On the other hand, both chambers had authorized the Executive to raise in Europe a new loan for $£ 15,000,000$ the object of which was to cancel all previous loans and to pay for the railways which President Balta, or rather those around him were planning on an extensive scale.

Sunday, $22^{\text {nd }}$ of January. Garland and Enriqueta, my wife and myself were invited by Juan Baso and his wife Irene to breakfast and lunch at the chacra of Mansanilla, the property of Antonio, Juan's younger brother. Accordingly, we, together with little Maria, Antonio and Geraldo, drove out thither at 9 O'clock a.m. The ground upon which the Hospital del 2 de Mayo, then in progress of construction, is built, a few hundred yards outside the Cocharcas gate, already belongs to Mansanilla, whilst the house itself is at the utmost ten minutes drive distant. It stands upon a small eminence - whether a natural mound or an ancient huaca I cannot say - and from its corredor one has an extensive view over the lower-lying land, belonging for the greater part to the chacra, wh [...] bought from the Conde Castel Bravo for $\$ 12,000$ a very [...] [227] considering its proximity to the town; the present owner would certainly not let it go for $\$ 50,000$. It produces neither corn nor maize, hardly any potatoes or yucas, the whole area being covered with clover fields and pasture lands. The number of horned cattle was considerable; there were not less than 40 milch cows, which enabled Don Antonio to send daily to Lima, milk to the value of $\$ 25$. 
The making of adobes, or sunburnt bricks for the "Hospital del 2 de Mayo" had likewise been the source of a handsome income, but now all the earth suitable for that purpose had been used up. Shortly after our arrival mass was said in a very small oratory, at which the inmates, my wife, and Enriqueta, attended. Meanwhile, Garland read to me a fulsome account given in the Nacional of the ceremonies at the marriage of Miss Whitting, an adopted daughter of Henry Meiggs, with a certain Backus, a North American engineer.

We, that is to say, Juan Baso and wife, his sister Pepa, his brother Antonio, my wife, Enriqueta, Garland, I, and the children, and Chavez, half brother of Gordillo, partook of a very good breakfast, which over - it was 12 O'clock Garland, Juan Baso, and Chavez, sat down to rocambor and played the whole day long. The ladies conversed. I was sometimes with the one, sometimes with the other, and at about $2 \mathrm{O}^{\prime} \mathrm{C}$. went out first by myself then with Antonio and climbed up a neighbouring height, part of el Cerro Agustino, the other extremity of which extends towards the pantheon. The prospect hence is very extensive; I myself could not distinguish so well as Antonio, who pointed out to me the Cerro San Cristoval, Lima, Callao, and Chorrillos, whilst inland lay the valleys of Ate and Surco, upon the whole a greyish-looking area, here and there a few trees and some green fields, intersected by high roads and the ugly looking "tapias", or low mud walls. At 4 O'clock we took lunch consisting mostly of fruit; I took nothing but half a palta and two tumblers of chicha, which latter did me much harm. At half past five the coach was at the door, and by 6 we were back in Lima, but hardly had I eaten a few morsels at Enriqueta's when I felt indisposed and hastened home, where I vomited, went to bed, and was not well again before the stomach was thoroughly cleared out.

Wednesday, $25^{\text {th }}$ of January 1871 . The various joint Stock companies lately established in Lima had upon the whole given good results for the last year.

The banco del Peru

declared a dividend of $15 \%$ upon $\$ 50,000 \quad$ paid up on each share [...] Banco de Lima declared a dividend $\quad$ of $16 \%$ upon $\$ 40,000 \quad$ paid up on each share [228]

The South American $\begin{array}{llll}\text { Insurance Coy. } & 30 \% & \text { on } \$ 100 & \text { paid up on each share } \\ \text { The Banco Hipotecario } & \mathrm{S} / 123 & \text { on } \mathrm{S} / 700 & \text { paid up on each share }\end{array}$

Of these companies none was better managed than the South American Insurance Coy. with Alexander Ruden as President of Directory, and Schmidt, 
a Frenchman, as manager. From the Telegraph and the Huacho Railway Company nothing was expected. The Directors of the Pasco Mineral Railway Company - of whom, unfortunately, I was one - had to overcome many and serious difficulties, the worst of which was the want of funds.

Wednesday, $25^{\text {th }}$ of January The proceeds of the loan of £15,00o,ooo - see page 226 - were to be employed exclusively in the construction of the new railways; and the previous loans, including that of $\mathrm{S} / 59,500,000$ for the railways to the Oroya, and from Arequipa to Puno, were to remain in force. If that of $£ 15,000,000$ could and would be raised in Europe, I for my part, was at a loss to comprehend how Perú would be able to pay the interest upon these enormous sums; the redemption of the principal I believed to be an utter impossibility.

This day the Minister of War, Juan Fco. Balta, embarked for the North to inaugurate the railway from Pacasmayo to La Magdalena, situated at the foot of La Cordillera Real, which, here of no great height, separates it from the valley and town of Cajamarca - see Vol. I page 637. Henry Meiggs, the Contractor, was to begin the building of this railway without loss of time; that from Ilo to Moquegua, originally conceded by the Government to Devés Frères for $\mathrm{S} / 6,700,000$ had been transferred by them to the same Meiggs, who promised that also here the beginning should be made within a few days.

The German merchants established in Lima had set on foot a third subscription for the Germans wounded in the present war, to which I contributed, as I had done to the first, S/80o; from the second I had kept aloof, whilst there were here in Lima five Germans who each time had subscribed S/10oo; they were: Arthur Heeren, John and Mathias Gildemeister jointly, Charles R. Pflucker, Scheel of Dreyfus' house, and Schutte \& Co. represented by Garland. Of Heeren I said a few words page 34 of Volume II. He was of a respectable family of Hamburg and related, though distantly, to the great historian Von Heeren. When at school he became acquainted with Carlos Candamo, whom his father always kept extremely short of cash. Heeren assisted him occasionally with the little he had [...] [229] intimacy sprung up, which to Heeren has borne rich fruits - for not only did Candamo, as mentioned Vol. II, place him at the head of his affairs in Lima, but even made him marry the eldest of his two sisters, whose fortune was about $\$ 5,000,000$. In 1868 he used to dine with us in Chorrillos every second day; now he hardly came near us. Of Charles R. Pflücker I have also spoken page 43 of Vol. II; as long as his wife lived, we were extremely intimate with him, but though I did everything in my power to keep up his acquaintance, for I like him well, he completely estranged himself from us. The other day however having been told that he had a stroke of apoplexy I went to see him. He received 
me with his usual kindness and told me amongst other things that he looked upon this attack as a warning to retire from active life, which he actually did about this time. His sons, if I am not much mistaken, allowing him annually a handsome sum upon which he and his new family could comfortably live. As a merchant Pflücker was always of unimpeachable integrity; $\$ 10,000$ which I lent him about the year 1840 he paid me gradually, together with part of interest as soon as his circumstances mended. With the firm of Gibbs of London, to whom he owed largely, he also settled, they making him a considerable abatement. Of his moral character as a husband, unfortunately, the same cannot be said; already during the lifetime of his wife Doña Gertrudes, he formed an illicit connection with the wife of the administrator of his mine in Morococho; this broke poor Getrudes' heart - under the pretence of seeing her children in Germany, she went to Breslau, where perhaps not 10 persons spoke Spanish, and there laid her wearied head to rest. Pflücker, after the death of Doña Gertrudes and that of the administrator, married the widow and by her he had the new family just referred to. Of Francisca, his eldest child and only daughter, I have spoken Vol. VI page 282/5, to which I refer. The next child, his eldest son Carlos Maria, was educated in Lima; for several years he, Pepe Izque, Corina and Amalia, Schutte, and some of the daughters of Julius Pflücker had their daily lessons from a German called Zyla, the same who for a year or so taught me latin. His three other boys Julio, Federico, and Leonardo were sent to Germany, where they remained for several years and received an excellent education, [_]lly in [_] and engineering; on their return this knowledge [230] was of the greatest use to them. They formed a partnership with their brother Carlos and jointly were, and still are in 1878 , working the sugar estate of Falcalá in the North, and the silver mines of Tuctu, and others in the province of Castro Virreyna, which their father had bought from Juan Salaverry. In 1871 the most brilliant prospects opened to them, which were realized in later years.

Of the elder Gildemeister, John, I have merely to say that his family belongs to the old patricians of Bremen. When he arrived here more than 25 years ago, he was a mere lad and consigned himself to the firm of Theodore Müller \& Co.; afterwards he established himself in partnership with another young man Mr. Cronsbrück, who after a few years died of consumption. He continued under the firm of John Gildemeister \& Co., did the usual consignment business and formed a branch establishment in Iquique for the purchase, and in later years for the elaboration of Nitrate of soda, which, notwithstanding the loss caused by the earthquake of 1868 , turned out a very extensive and extremely lucrative business. He married a woman with whom he had lived for some time; with this exception he is much esteemed in Lima. His cousin and partner Mathias I hardly knew. 
Scheel, native of the island of Fehmern, after having served as clerk in one or two second or third rate houses in Lima, was engaged by Agustus Dreyfus, who erelong made him a partner in his Lima-branch, where his yearly income was unquestionably very considerable.

Thursday, $26^{\text {th }}$ of January. In the evening we were as usually at Garland's; where the visitors brought the news of the total defeat of Melgarejo, hitherto president of Bolivia. On the $15^{\text {th }}$ inst., he, with what he called his invincible army, 1200 men strong, attacked the revolutionary party commanded by Col. Morales, intrenched in La Paz; the combat lasted till 9 in the evening when the assailants were beaten, and Melgarejo with a few officers fled to the Department of Puno. Of Morales a very bad character was given; it was said that when sober he was quite as bad as Melgarejo was when drunk. Many feared that a rupture between Perú and this new government of Bolivia could hardly be avoided.

Friday, $27^{\text {th }}$ of January. I was up before 7 and walked down the Santo Domingo Street, passed the Church of Santa Rosa [...] [231] and was not a little astonished to find that at the end a wall had been built right across, so that I had to turn to the left and take the other street, which runs parallel. When I reached what was formerly the Portada de Monseratte, what a change did I find there! The old wall was gone, except the isolated gate leading to the camal, or slaughter-house, also a little bit had remained of the wall along the river, joining the new wall drawn right across, with an immense wooden enclosure within the precincts of which was the establishment of Meiggs, where he kept the materials for his railroads, his locomotives and wagons, his forges etc. Through the midst of this area runs the railway issuing in the one direction towards Callao, in the other, descending to the bed of the river and thence to the sierra. Upon the open place close by, the station was to be built; the "muladar", or heaps of rubbish, sweepings, and all kinds of filth was about being cleared away with great rapidity, and in the same manner a deep ravine was being filled up with the earth of the old wall, of which a few remnants were still standing here and there. The Polish engineer Malinowsky, employed by Meiggs, told me last night that he had just come back from Coca Chacra 14 miles distant up in the quebrada of Matucanas; and that rails had been laid as far as there; further on, the road was levelled and ready to receive rails.

The European papers gave the news that the Mont Cenis tunnel had been completed; however, nobody took any notice of this wonderful enterprize, all thoughts being turned to the Franco-German war.

Sunday, $29^{\text {th }}$ of January. Mathias Gildemeister having in the usual manner informed me that he had contracted matrimony with a certain Miss Hoffmann, 
sister of the wife of Krämer, the East Frisian who had made a fair fortune here in Lima merely by the sale of German toys. I was in duty bound to pay my visit to him and his lady, which I did this day. She, they said, was good-looking of which however I could not judge, not only on account of my bad sight, but also because the visitors were received in a darkened room; her pronunciation of German was none of the best, from which I inferred that her education must have been neglected. Her husband was a nice genteel young man. There were several visitors of what, meaning no offence, I should call the second class of $[\ldots]$ in Lima. Wehrmann an excellent good [...] [232] man, but rather given to drink, and I think that even when there, he was a little in the wind. He was a native of Lubeck; many years back I knew him as clerk of Huth - then he went in the same capacity to Henry Moss of Callao, who erelong made him his partner, and since Moss' departure for Europe he carried on the business. The second was Sand, a German Swiss, married to one of the well known landed proprietors Montero; he carried on an insignificant import business, had a shop where he sold ribands, thread, needles, pins etc., and was always hard up for money; I occasionally made him loans upon security, which I got back, but never without trouble. The third was Leuthold, also a German Swiss, stout, rather insignificant, and fond of his glass of beer. When old José Canevaro sent his sons for education to Switzerland, he was their master in some science or other, they liked him so well that they persuaded him to come with them to Perú, where he first entered as clerk in the business of Canevaro and soon was made partner. He had been sent to China for coolies and was certainly well off. The fourth was Weiss from Kiel, port agent in Callao and Prussian Consular Agent, whose acquaintance I made after the death of Theodore Müller, and the fifth, Heynemann, a German Jew, established here since a few years under the auspices of the wealthy Bresani; him I saw here for the first time.

Thursday, $2^{\text {nd }}$ of February. Candlemas. I said above that in the question of the "desafuero" as it was called here, of the Senator Benavides, all the votes of the Senate, except one, were against the Government. The Government insisted on the Senate's reconsidering the same question, when they were again defeated, only two votes, those of Palma and Ruso, being in favor of the desafuero. This, no doubt, was a severe blow to the Government, but still more must they have felt the election of the same Benavides as President of the Comision Permanente, by 10, exactly $2 / 3^{\text {rds }}$ of the votes. Muñoz, the VicePresident, and Chinarro, the secretary, each chosen by nine votes, were also opposition men.

The differences which for a long time past had existed between the Government and Schutte \& Co. reached by this time such a point that a downright rupture seemed unavoidable. The former demanded the immediate 
delivery of $£ 200,000$ and odd in bills upon England, [...] was the exact amount to the credit of the Government [...] [233] Schutte \& Co.'s last account current. Garland as representative of the firm refused to deliver these bills, on the plea that the injury done to them by the unjust and illegal cancelment of the contract for the German Guano Consignment before its term had expired, exceeded the amount claimed by the Government, so that Schutte \& Co. were not debtors to, but creditors of the Government.

Letters from Puno said that the bishop Huertas on his arrival there had been received with great rejoicings. The North Steamer brought us no letters from the family in Europe; probably, they being in Italy their correspondence had not reached Southampton in time for the steamer. From my friend Sieveking I had a long epistle dated $29^{\text {th }}$ Decr., which contained many to me interesting details relative to my Altona friends and acquaintances. His brother-in-law Lucas Willink, 84 years old, who hitherto had kept up wonderfully well, was now nearly blind. His wife Ernestina, my senior by one year, was in good health. Mr. George Knaur, lately struck by apoplexy, had recovered his health in an extraordinary manner, and had, it would seem, taken a new lease of life. On the other hand, my good friend Charles Semper, 75 years of age, was much affected by the events of the war. Sieveking himself and his and my old chum Edward Reincke had as yet no reason to complain; they bore up manfully against the weight of years. The former had had with him on Christmas Eve all his children and grandchildren, a respectable number, nevertheless, both his letter and that written by Mrs. Knauer to her son Edward, gave evident proof that the war, popular as it was, did not fail to throw a damp upon the many families which had their sons or brothers engaged in the fatal strife. Hermann, the son of Wilhelmina Reincke, married to Andersen, had died of typhus in a small town of France; Leo Arnemann had one of his legs broken, Richard Semper had returned to Altona to get cured of a rheumatism, which had fallen upon his eyes; Vidal, the merchant, of Hamburg had lost his second son, who had risen to be an officer; the son of clergyman Ritter of Hamburg, who in the beginning of the war was stationed at the mouth of the Elbe in the army commanded by Von Falkenstein, which [...] likewise to march to France had been [...] [234] by the francs-tireurs. Anton Hugues, the son of my cousin Theodore, clergyman in Celle, who until 1866 had served in the Hanoverian Army and then refused to enter the Prussian service, was at the time military commandant of Altona, from which I inferred that he had changed his mind and at last donned the Prussian uniform.

The telegrams from Europe went to the $20^{\text {th }}$ January. Many balls and bombs had been thrown into Paris; damage had been done, but as yet no great impression had been made upon the defenders. On the $17^{\text {th }}$ the bombardment 
had ceased. The French armies upon the Loire had once more been defeated. Havre was not yet taken; Peronne had surrendered; Belfort still held out. Young Knauer read me from the German papers the following official returns: on the $30^{\text {th }}$ November the number of dead, wounded, and missing in the German army, exclusive of Bavarians and Wirtembergers, also without counting those who had died from sickness, amounted to 67,000 and odd; on the same day the French prisoners, not wounded, came up to 303,000 rank and file, and 15,000 officers. The cold was severe, in Hamburg about 12 below zero of Reaumur, the Elbe was frozen, and carriages came over from the other side. In Paris the cold was no doubt somewhat less; however, on both sides not a few died in consequence. The papers said that the German wounded, who occupied $5^{0}$ odd cars in a train, when arriving at their destination, had all died of cold. The Paris correspondent of the Comercio who signed himself "Nemo", an ultrarepublican, whose reports must be received with some diffidence, stated that the Bavarian Corps under Van der Jann, which at the beginning of the war numbered 30,000 and which had fought in 16 battles, was reduced to 7000 .

Sunday, $5^{\text {th }}$ of February. Mr. Rees being - as he sent me word - prevented by indisposition from coming to my office, I went per train to Chorrillos, bathed, and made many calls. From the original I copy literally the following notes: "Mrs. Riva Agüero was not less silly than she had been when I paid her my last visit", and, "how strange it is that such excellent ladies as Doña Paula Benavides and her daughter Candelaria should have such a wicked son and brother as the hypocrite Evaristo Gomez-Sanchez!"

At the earnest request of Melchor Velarde, I remained with him to dinner. We were he, his wife, 10 or 11 children, young Dañino from Callao, with his wife and mother-in-law, Eulogio Igueras nephew of Mrs. Velarde [...] [235] at Canevaro's, and myself. Dinner was good; Melchor and his wife were very attentive towards me, yet I was glad when it was time to break up, and I could return to Lima by the 8 train. My poor wife had been quite alone the entire day, "Como una alma en pena", as she used to say; only in the evening Adolfo Alvarez, and the two ladies Basagoytia, Senior and Junior, took tea with her.

Wednesday, $8^{\text {th }}$ of February 1871. In Bolivia Agustin Morales, who headed the last successful revolution against Melgarejo, had been proclaimed provisional president about the middle of January. The President of Perú, José Balta, had with his family removed to Ancon, where he would probably remain during the hot season. In Chorrillos there was no rancho adequate for him, for that which he had rented last year was now occupied by its owner General Pezet. The fleet had also left Callao for the bay of Ancon; the Ministers however had remained here; and probably one of them at least would every day have to take a trip to Ancon to consult with the Supreme Chief of the Republic about the 
affairs of the nation. In the Exchange Rooms, about 2 or 3 in the afternoon, there was a numerous gathering of the shareholders of a new joint stockcompany called "La Constructora" for the purpose of choosing the President and Vice-President. The broker Ricardo Marty had planned this company, though probably the original idea was not his own. The company was to purchase land and to build houses, which it was expected would easily find purchasers, because the purchase-money was not to be paid cash down, but in the course of 20 years, viz.: $12 \%$ annually, in the same manner as the Banco Hipotecario received the money which in the shape of Cedulas they lent to proprietors of immovable property, of which $12 \%$, $8 \%$ were looked upon as interest, and $4 \%$ as payment for the gradual redemption of the principal. Julian Zaracondegui and José Muro eagerly took up this idea and subscribed each 25 shares of S/1000 each. For several days I would take no interest, but allowed myself to be talked over by Marty and subscribed 10 shares. Zaracondegui not being present in the Exchange Rooms, I was literally forced into the chair to preside at the above elections. Every share had a vote, and as no less than 138 shares were represented, the scrutiny took a very long time. A great many left after having delivered their papers upon which the names were written; but I and the scrutators had to hold out to the very last. Zaracondegui, Mur [...] had [_] 136 votes; the others chosen were: Dr. Simon Gregorio P [...] [236] Dr. Emilio Solar, César Saco y Flores, Juan Martin Echenique, Emilio Pierola, Amancio Castillo, and Santiago Lanfranco. Whilst I was thus unprofitably employed, Mr. George A Coleman, to whom I had written immediately after the discovery of Duval's theft requesting him to rejoin me, had arrived in the steamer through the Straits of Magellan. At a later hour he again looked in, and I was really glad to see him; he looked much healthier and stronger than he had done a few years back.

I let this day the two large stores in the Calle de Aldavas to Mayne Crosby \& Co., dealers in eartheware, at $\$ 180$ monthly on a lease of five years.

Saturday, $1{ }^{\text {th }}$ of February. A new joint-stock company was set afloat, of which José Muro seemed to be the prime mover; at least it was he who came twice to me and tried to persuade me to take shares. It was to be a new Insurance Company. Shares in the South American having of late been sold at $150 \%$ premium, it was very natural that such an extraordinary result should call similar establishments into life. The manager or Gerente named beforehand was to be a certain Macgill, an Irishman, of whom I knew but little and of whom I entertained but a poor opinion. Moreover, to direct an Insurance-Company requires a man of great tact and caution, such as Ruden at the head of the South American, and for these reasons I resolved not to take any interest in it. The letters and papers by the North Steamer came to hand. The political news 
went to the $23^{\text {rd }}$ January. The Southern part of Paris - I suppose it must have been Le Quartier Latin - and the old aristocratic quarter of St. Germain on the left side of the river had suffered most by the bombardment; of the forts round Paris, a few had been silenced by the superior artillery of the enemy. Trochu had momentarily laid down the command, but been induced to resume it. We had also the particulars of the battle of Le Mans fought on the $10^{\text {th }}$ January; the French were commanded by Chanzy, the Germans by Prince Frederic Charles. The latter gained the victory after very severe fighting and made about 20,000 prisoners. On the $18^{\text {th }}$ of January King William issued a proclamation in which he accepted the title and assumed the functions of Emperor of Germany; the Imperial crown having been offered him spontaneously by the various sovereigns and Princes of Germany, with Louis the young King of Bavaria at their head. The conference in London on [...] iental question had opened its sessions; only the representative of [...] [237] was wanting.

Tuesday, $14^{\text {th }}$ of February 1871. This morning Mr. Rees bade me good by, and Mr. Coleman took his place; Rees had behaved very well since the beginning of the year; previously he had more than once absented himself not having been able to withstand the charms of a good glass of wine, or perhaps of brandy. At last I was talked over to take twenty shares of S/100o each in the new Insurance Company, and this day Muro and Castilla fetched me away to be present at the election of the Directors. I went with them to the Exchange Rooms, but left immediately after having given my power to Lembcke.

Pardo, Riva Agüero, Sagastabeytia, and I had a very long session on the subject of the Pasco Mineral Railway Coy., which looked by no means satisfactory. The railway would cost much more than Wyman and Harrison had calculated upon; the work proceeded very slowly, and the company was short of funds.

Wednesday, $15^{\text {th }}$ of February. In yesterday's meeting of the members of the New Insurance Company, called “La Limeña”, Lembcke was called to the chair; 31 voters were present, and the election for the Directors turned out as follows: Gustavo Heudebert, E. Moyna, and José Muro each 31 votes, I, William Brauns and José F. Canevaro each 30, J. F. Lembcke and Valentin Gil each 29, Arturo Heeren 28, Emilio Althaus 26, James Henry 25, and Manuel Pardo 21.

This day at 2 p.m. the ten Directors of La Constructora were cited to meet in the locality of the Banco de Lima; all came, with the exception of Dr. Paredes. There was a great deal of talk, much more than was necessary, owing to the presence of two lawyers, Drs. Emilio Solar and César Saco, of whom the former was by far the more agreeable. Emilio Pierola, the brother of Nicolas, the finance minister, was very quiet, and Martin Echenique made known that in a week's time he was obliged to leave for Europe. Zaracondegui was elected 
President, I Vice, Saco secretary; then two commitees were named, the first, consisting of Zaracondegui, Paredes, and Saco for drawing out the Statutes, the second, of Castillo and Solar to look out for a proper locality. Castillo told me that he would take provisionally one of my stores in the Calle de Aldavas. At 4 p.m. we broke up.

Thursday, $16^{\text {th }}$ of February At 2 p.m. the Directors of the new Insurance Company met in the Banco de Lima; only Heeren was wanting; I was introduced [...] of the house of Fox Sawyers \& Co., hitherto unk[_] [238] to me. Lembcke was chosen President by 7 votes, (I had 4) Henry Vice by 9. The name of the company was changed from "Limeña", to "de Lima". A commission was named to form the statutes, which would be probably a copy of the Statutes of the South American Insurance Company. Magill, who had been proposed as Gerente of the company, was quietly put aside, and each of us took upon himself to look out for a person fit to take charge of such a delicate post.

The Steamer from the North arrived. Paris and all the surrounding forts capitulated on the $27^{\text {th }}$ and $28^{\text {th }}$ of January; the capitulation was signed by Trochu, General Chanzy, and ratified by Gambetta. Longwy had surrendered. Genl. Bourbaki and his army, pressed by Manteuffel on the one side and by Werder on the other, had been obliged to cross the frontiers of Switzerland. The armistice was signed for three weeks, and a national convention was to meet in about a fortnight. The following were the conditions said to have been laid down by the King of Prussia, now Emperor of Germany, as the basis for peace: The payment of one thousand millions of francs; the delivery of twenty first-rate men of war; the cession of Alsace and part of Lorraine with Metz and Belfort, and of Pondicherry in India. Here in Lima a representation, in which the King of Prussia was congratulated on his being elected Emperor of Germany, had been set on foot by Von Bundsen, and signed by nearly all the Germans resident in Lima. I did not affix my signature, being of opinion that as Danish Consul it was not proper for me to do so.

I received a letter from Juan from Palermo dated $20^{\text {th }}$ December; he liked the place well; only in the evening for want of society he did not know how to pass the time. In order to reach Palermo, he had to go per steamer from Lisbon to Gibraltar, and from there to Malta, thence to Messina; whether he went from there to Palermo by land or sea he did not say.

Tuesday, $28^{\text {th }}$ of February. This being Guillermo's birthday, who completed his twentieth year, we dined at Garland's together with Rafael Velarde and Dr. Middendorf.

Wednesday, ${ }^{\text {st }}$ of March. Two "celadores" or policemen were placed at the street door of my house, as a coercive measure against Schutte \& Co., who, or 
rather Garland as their representative refused paying the £200,00o and odd to the Government, as explained page 232. I immediately went to the Minister for Foreign Affairs and requested that the guard should be removed from my street door and placed before the counting house [...] [239] Shutte \& Co., which was done without delay. By this steamer, Garland received advice from Hamburg that Saenz, the Peruvian Fiscal Agent, had obtained from the Hamburg Tribunal of Commerce a sentence in virtue of which he had embargued the stock of guano in the hands of Mutzenbecher \& Schön, as well as the proceeds of their sales. This Garland made known, and at the same time represented to the Government that they having now the property in hand, all coercive measure against him were useless; consequently the guards were withdrawn.

From Juan I received no letter. Rosa wrote on the $23^{\text {rd }}$ December from Naples, much displeased with the rain and cold of the climate. The political news was confined to a confirmation of that received by the last teamer. It was on the $19^{\text {th }}$ January that the French garrison with a force of 100,000 men and considerable artillery made their last attack on the German lines and were beaten back. On the same day the French army of the North was defeated at St. Quintin; these two disasters with the great scarcity of provisions were the immediate causes of the surrender of Paris. The correspondent of the Nacional, David Olinedo, said that the mortality in the capital had reached such a point that 4500 were dying per week, no doubt a great exaggeration; that on the $15^{\text {th }}$ the National Assembly was to meet in Bordeaux, and that on the $18^{\text {th }}$ the armistice would expire. Mariano Melgarejo, the ex-President of Bolivia who had arrived in Lima, was visited by the President Balta and returned the visit, going by train to Ancon, where his excellency resided, as above said. For the last week or ten days the heat had been excessive.

Thursday, $2^{\text {nd }}$ of March. By the steamer through the straits, Dr. Middendorf and Alfred Böhl, junior partner of William Gibbs \& Co. of Lima embarked for Europe. The latter had to be back by the end of the year; whether the Doctor would return was doubtful.

Mr. Ochsenius, agent of the firm of Erlanger \& Co. of Paris, who, whilst in Lima about a year back, had obtained from President Balta the concession for the construction of the railway from Tacna to the Bolivian frontier, had also about this time left Valparaiso for Europe. Of his drafts to a large amount on Erlanger \& Co., which were taken by some Lima firms, those to the order of Gildemeister \& Co. had been duly accepted, whilst £15,00o sold to Arthur Heeren had been protested for non-acceptance, no doubt solely owing to the war, which, when the advice of these drafts reached Paris, had [...] assumed a for France threatening aspect. [240]

Wednesday, $8^{\text {th }}$ of March 1871. Alejandro returned from Arequipa. 
Thursday, $9^{\text {th }}$ and Friday, $10^{\text {th }}$ of March. The Directors of the new society La Constructora had their meetings to discuss the statutes drawn out, nominally by Zaracondegui, Saco, and Paredes, in reality by the two latter only. We met in one of my stores Calle de Aldavas, which I had let to the company, but made little progress, for the opinions on many points were not unanimous, and this led to long, often unnecessary dicussions. Juan Martin Echenique was the principal debater; on

Saturday, $17^{\text {th }}$ they again met. I did not attend, having to settle my usual weekly account with the architect Villa and painter Palacios. Since the $1^{\text {st }}$ I was again Director de Turno of the Banco de Lima and had to go there everyday at about 3 O'clock.

The chief articles of the peace which was being negotiated between Count Bismarck, acting for the Emperor of Germany, and Jules Favre in the name of the French Republic, were not yet made public. It was only known that Paris and the surrounding forts had surrendered to the German arms, that the Municipality of the Capital had had to pay immediately 200,000,000 francs, and that the French army with the exception of 12,000 men was disarmed and had to remain within the precincts of the town. Belfort had surrendered. The National Assembly had met in Bordeaux. Thiers had been chosen head of the Executive of the French Republic, and had named his Ministry, amongst whom was Jules Favre, Minister for Foreign Affairs.

About this time we began making our preparations for our removal to the house Calle de Zarate. My wife packed up her china and earthenware and the innumerable nick-nacks of which she was so fond. The house Calle del Correo we let for $\$ 400$ monthly to Antonio Salinas, whose splendid and extensive mansion opposite the church de la Concepcion had been rented by Henry Meiggs. The day for our giving up to him the house Calle del Correo depended upon us.

Wednesday, $15^{\text {th }}$ of March. I was under the necessity of presenting myself this day before a Juez de $1^{\mathrm{a}}$ Instancia, demanding that my next door neighbour, Col. Leyva should close a big hole made by him in the [...] wall between his property and the garden behind [...] [241] which ran an open gutter, contaminating the air with its noisome effluvia.

Thursday, $16^{\text {th }}$ of March 1871. Much of my time was taken up by my regular attendance at the meetings of the various directories of which I was a member. In the Constructora little progress was made in the formation of the statutes for, as already said, there was a great divergence of opinions, and the discussions were consequently long and time consuming. In the meetings of the Directors of the new Insurance Company [_] went on orderly and pleasantly. Lembcke, in the chair, touched the bell as soon as he observed any irrelevant conversation 
without consideration of person, exactly as it should be. In a late meeting he made known that with the exception of a few, all shareholders had paid into the Banco de Lima the first $5 \%$ on the Insurance Company's shares, that Guiroy had accepted the nomination as Gerente of the Company, without his losing his situation as book keeper in the National Guano Company, that José Francisco Canevaro had given up to the Insurance Company, in the locality of the said National Company, a saloon for which he refused receiving payment, and that Emilio Althaus had not accepted his nomination as Director, he being otherwise too much engaged. Another Director was chosen; I proposed Chavez; Henry, Garland; others, Felipe Osterling and Bianchi, an Italian storekeeper who was doing a very extensive business. On comparing the written votes Garland had 3, Bianchi 7; consequently the latter was elected. Various points were discussed and quickly settled. Sylvestre Guiroy was a very proper person for managing an insurance company; he was a steady, elderly Frenchman, a married man, had in his younger days been captain of a merchant vessel and for many years been employed as book keeper in the guano business, first by Gibbs, then by the Government, and at present by the National Company.

Our Cerro de Pasco Mineral Railway Company had at last, after six months, repeated applications to the Finance Minister, obtained a decree in virtue of which the Government placed at our disposal $\$ 500,000$ in Vales de la Nueva Consolidacion, the company binding itself to pay the annual interest of $6 \%$ and to redeem of the 500,000 dollars $4 \%$ annually at par. In consideration of this service we released the government of their guarantee of $7 \%$ annually on the amount to be expended in the construction of the railway [...] was of opinion that the decree once being given the Vales [...] [242] shortly be in his possession, and then by disposing of them at the market rate we should have the funds necessary for continuing the work.

Within the last week or fortnight the rains in the Interior had been very heavy, so that not only all the rivers which come down from the mountains where much swollen, but torrents were formed in places where before there had no been a drop of water. Much damage had been done to many estates and sugar plantations in the various valleys of Perú both to the South and North of Lima; here the Rimac had destroyed the slender wooden bridge and carried away part of the wall made to secure Meigg's railway in the bed of the river. A little higher up than the Alameda de Acho it had overflowed much cultivated land and rendered almost impassible the road to Lurigancho. I went this morning to see how things looked and having gone so far, I thought I might as well ascend San Cristoval; so I did, and though I perspired profusely I was glad to find that I reached the summit with the same ease as hitherto. 
The Government made itself guilty of a very arbitrary act. My lawyer Fernando Palacios had for many years filled the situation of provisional Juez de Alzadas, whilst Dr. Arenas - who was the actual judge - was otherwise employed. Arenas being at present Vocal of the Supreme Court, Palacios expected that in consideration of his long services this post would now be secured to him for life, but learning on the contrary that the Minister of Justice José Aranivar, the lawyer opposed to him in my Sotomayor suit, intended to deprive him of the said employ, he preferred throwing it up; his resignation was accepted by the Minister in a decree countersigned by the President, drawn out in a manner extremely offensive to Palacios' moral character, not in direct and clear terms, but by insinuation. Palacios now directed a representation to La Comision Permanente claiming redress for the injustice done him, and this he did in strong terms. The Comision Permanente had not yet decided what to do, but in the meanwhile the Government had taken the affair into its own hands, and to-day when Palacios left his office, he was arrested in the street and was now locked up in the Barrack of San Francisco de Paula, irons to his feet and without any one being allowed access to him.

Friday, $17^{\text {th }}$ of March. The Steamer arrived; she brought the news that $[\ldots]$ Peace was signed, but its exact conditions were as yet unknown [...] [243] knew for a certainty was that Alsace would be given up to the Germans, and that they would keep the inmense material of war which they had taken - in Paris alone not less than nineteen hundred cannon had fallen into their hands. The amount of the war indemnity was differently stated, also what part of Lorraine would remain to France, and what would be ceded; of Pondicherry and the fleet no further mention was made.

Sunday, $19^{\text {th }}$ of March 1871. This being San José, the Saint's-day of the President José Balta, I found myself under the necessity of paying my respects to him; fortunately, at Doña Josefa Tagle's I met Mr. Basagoytia who had to go to the palace on the same errand; accordingly we went together, I in black, not in uniform. The President and his Ministers, also in black, stood at the upper end of the second long receiving room: we walked up to and shook hands with him, sat down for two or three minutes, repeated the ceremony, and departed.

Friday, $24^{\text {th }}$ of March. Though I had no actual occupation, it was really astonishing how my time was taken up. This day for instance I and my wife were at 7.30 a.m. in the other house, where we examined the keys, locks, and bolts of the various doors, and my wife gave her orders about papering. It was 10 O'clock before we were aware of it. Then Pietrosanti, the dealer in marble, kept me in conversation for more than half an hour about the marble slabs for the new staircase. I swallowed my breakfast, and Mr. Coleman had hardly read a few words when I had to go to José Antonio Garcia y Garcia to pay 
another $15 \%$ on my $S / 15,000$ for which I was interested in the Eten-Ferreñafe Railway, which, I was happy to learn, had hardly suffered anything from the late rains and swollen rivers, thanks to the precautionary measures which had been taken. From Garcia I went to José Muro who was desirous of deferring a little the payment of the $\$ 63,000[\ldots]$ due $1^{\text {st }}$ April, taken by me from Schutte \& Co. on account of the last $\$ 100,000$ due $28^{\text {th }}$ February last: from Bamberger I collected rent to the amount of $\$ 100$; and hardly had I recommenced my occupations with Mr. Coleman when architect Villa came to let me know how much I had to pay for the week. Now I had to fetch the money from the bank. I received a message from the "Constructora" that the Directors were expecting me; another from the New Insurance Company to the same effect. It was impossible for me to go [...] but after paying Villa's bill for the next day was a holiday [...] [244] as "Director de Turno" at the Banco de Lima, was there just in time to approve of what the Gerentes had done; and with Lembcke I went to the Insurance Company "Lima". Besides us two there were Henry, Moyna, Bianchi, Heeren, Muro, Gil, and the manager Guiroy. I was much astonished to see how many insurances against sea-risk had already been effected in the eight days since the establishment of the company. I was back by 4.30 when I found the painter Palacios waiting to be paid for his work; my wife and I dined by ourselves, after dinner I wended my way to San Francisco de Paula to see Dr. Palacios, whom, since the morning, when his fetters had been taken off, his friends were allowed to see. I was back by 7 O'clock, and now the day's work was over. Mr. Coleman read to me for an hour, and after tea I soon went to bed.

It was rumoured that the Minister of Finance, Pierola, had resigned in consequence of a dispute with the President about a large payment to be made for expenses for the construction of the Lima Exhibition buildings; according to the others for the two lions that had arrived. Pierola refused putting his signature to the order for payment, whilst the President said he was the master and must be obeyed.

Sunday, $26^{\text {th }}$ of March. Yesterday evening the German Club which for some time past had had its apartments over the way in the Altos where Campos formerly lived, celebrated the conclusion of peace, and I received an invitation from the committee for the dinner given on this occasion, which I accepted. I went at 6 O'clock, and was received by Lembcke, the President of the club. Besides myself, Von Bundsen, Charles Pflücker, Heeren and Renner were the only ones invited not belonging to the club. The two first named excused themselves under the pretence of indisposition. At 6.30 Lembcke took me by the arm and placed me to his right, he himself occupying the centre of the table; to his left sat Brauns, opposite, Wagner, Schutte \& Co.'s Clerk, 
belonging to the Committee; to his right Renner, to his left Heeren; to my right John Donner. Present were about 80, with few of whom I was acquainted. I noted the absence of John Gildemeister, who had gone to his establishment in Iquique, of Matthew, his cousin, and of Edward Knawer, who had preferred dining by themselves, and of Scheel and Dammert of Dreyfus' house, who had not come in from Miraflores. After the soup had been served, Lembcke rose and made a pretty speech, proposing the health of the Emperor of Germany $[\ldots]$ followed Donner who gave in a stentorian voice the health [...] [245] Crown-Prince and the other members of the Imperial family; another of the committee: The German Princes; Wagner, the "German Navy"; and the last official toast was the "German army". These various toasts were each prefaced by a short appropriate speech, in which, as inclination prompted the orator the Franch Nation was alluded to in a more or less hostile spirit. All were received with loud acclamations. Soon after, singing commenced, which pleased me very much. Again it was interrupted by toasts; Brauns gave "the German women"; another, "Counts Bismarck and Moltke"; and finally Donner; "the Minister of War, Von Roon", in a particularly pretty speech, which elicited hurrahs after hurrahs. Brauns and Heeren left before 9 O'clock; gradually the wine had its effect upon a few of those who remained; they became a little uproarious, and their singing less melodious. I left at 1o O'clock, well satisfied with the festivity, and particularly with the conduct of the young men.

In appendix under $\mathrm{N}^{\circ} 6$ will be found a song composed five years previously in Valparaiso; it has no great merit, but is worth preserving as a strange prophecy of what was to happen in after years.

From Monday, $27^{\text {th }}$ of March to Saturday, ${ }^{\text {st }}$ of April. A very busy week. Day after day there were meetings either of the Shareholders or of the Directories of the various joint-stock companies in which I had an interest. The Gas Company went on swimmingly; for the previous year it had paid a dividend of $15 \%$, and the value of the shares, all paid up, was raised from $£ 100$ or $\$ 500$, to $£ 100$ or Soles 500, and this was perfectly correct for the soles had in course of time superceded the old Spanish dollars. Many years back the exchange on London for the dollar of 8 rials was the same as at present that for the sol of 10 rials. At the "Constructora" we continued our discussions on the statutes, which I hoped would shortly be concluded. The business done by the Banco de Lima was extensive and lucrative; perhaps we went beyond our means, to remedy which I - backed by Zuloaga and Gil - proposed that a call of $15 \%$ should be made in the shareholders; the majority was however against us, being of opinion that as we were on the eve of obtaining a blank-credit for $£ 100,000$ from the South American Company in London, there was as yet no necessity for this new call. I delivered up the keys of the vault in which the 
bullion was deposited, to my successor Don Valentin Gil, Director de Turno for the month of $[\ldots]$. On the same day my turn commenced in the new Insurance Com[_] [246] The Telegraphic Company was in a very bad condition; for want of funds it could not go on. S/150,00o were required, which the present shareholders, each of whom had paid up his share, were not inclined to furnish, and accordingly at the motion of Cipriano Correa, it was agreed to make a petition to Government to lend the company this amount, which would then be considered the Government's share in the enterprize. My opinion was that the petition would be rejected, and then the company would have nothing else to do but to liquidate. Our Pasco Mineral Railway Company had also been in great straits and of late had only kept a going, owing to the personal efforts of Manuel Pardo, who, himself a shareholder for $\mathrm{S} / 50,000$, had placed various securities in the hands of the Banco Hipotecario, the Directors of which had accordingly authorized José de la Riva Agüero, who was at the same time Gerente of the Hipotecario and treasurer of the Railway Company, to furnish the latter with funds in proportion to the securities deposited. To Huth \& Co. of London the Company owed £ı.ooo, for which we, the five Directors, had made ourselves personally responsible. Thus, one with another, our prospects looked very black.

On Wednesday, Enriqueta with her servant girls, her children Antonio, Maria, and Corina removed to our rancho in Chorrillos in hopes that a change of air would benefit herself and Corina. Garland went there to dine and returned to town in the morning.

On Friday Dr. Palacios was placed at liberty, and I went immediately to see him in his study, when he gave me many thanks for the cakes my wife had sent him during his incarceration.

Sunday, $2^{\text {nd }}$ of April. At an early hour I went to Chorrillos, breakfasted with the Garlands, bathed, and returned by the 1 O'clock train, having to call upon several Vocales of the Supreme Court to thank them for the vote which they had given in favor of Lucio Barrios, who, it will be remembered, bought for me the four shops in the Calle de Zarate; he claimed the rent paid by tenants of these shops from the day the purchase was made until the day they were delivered up to me, because, as he very properly affirmed, he had had the money ready from the very first day, and that Montes, the former owners, did not receive it because they were disputing with their creditors. These Montes pretended, on the other hand, that the rent was only due to Barrios from the day that they actually received the money [...] [247] Juez de $1^{\text {a }}$ Instancia had sentenced in favor of the Montes, the Superior Court for Barrios, the Vista Fiscal had been for Montes, and in the Supreme Court Ribeyro, Muñoz, Alvarez, Gomez Sanchez, 
and the adjunct Dr. Barrenechea, consequently the majority for, Cosio, Oviedo and Cisneros against Barrios.

Tuesday, $4^{\text {th }}$ of April 1871. In the Insurance Company Lima we had a long discussion on the propriety of insuring goods against fire risk, deposited in stores in the street of Bodegones, and portal of Botoneros.

Wednesday, $5^{\text {th }}$ of April. By an early train I went to Chorrillos. The temperature had of late changed a little, and a slight fog hung upon the land. Corina had improved in health.

Thursday, $6^{\text {th }}$ of April. Holy Thursday. The Panamá Star and Herald was read to me, and I extracted from the same the following details: The treaty of peace was signed at Versailles on the $26^{\text {th }}$ February by Count Bismarck, since then created a Prince of the German Empire, on the one hand, and Messieurs Thiers, Jules Favre, and fifteen Deputies from the National Assembly sitting at Bordeaux on the other. The principal conditions were the following: France ceded to Germany Alsace, excepting the fortress of Belfort and one fifth part of Lorraine, including Metz, Thionville, Longwy and Saarbruck, but excluding Nancy, which was returned to France. France paid to Germany a war indemnity of five thousand million francs in three instalments, one thousand million in the first, two thousand in the second and two thousand in the third year - on which last interest was chargeable, but from which the value of the railroads in the ceded territory was to be deducted. Until this indemnity were paid, the German troops would occupy Champagne. On the $28^{\text {th }}$ February these conditions were approved by the National Assembly by 546 votes against 107, and on the $2^{\text {nd }}$ March the peace was ratified in Versailles by the Emperor, whereupon the usual exchange of documents took place. The same Assembly in Bordeaux voted the abolition of the Imperial Government. The $1^{\text {st }}$ of March was the day fixed on for what was in my opinion erroneously called the occupation of Paris by the German army; a line of demarcation was drawn from the Seine through the Place de la Concorde, up la Rue Royale to the Northern Enceinte, and only this small triangle; the most western part of Paris, including Les Champs Elysièes, l'Arc de l'Etoile, and some of the most fashionable quarters amongst which la Rue de Presbourg, where Mr. Schutte had his house, had been [...] ession of a small proportion of the German host from the $1^{\text {st }}[\ldots][248]$ the $3^{\text {rd }}$ of March. On the former of these days, between 7 and 8 in the morning a few Hussars with drawn swords appeared in the Champs Elysèes, at their head a young officer, Bernhardy, lieutenant of the $14^{\text {th }}$ Hussars, to whom this distinction had been conceded, to reward him for the great bravery he had always shown on the battle field. At a later hour the whole body, 30,00o men with 96 cannons, constituting the $11^{\text {th }}$ Corps, followed. The North American Reporters wrote 
that the troops were in excellent order and splendidly dressed, showing no signs of the hard service they had undergone; only their flags were riddled with balls. They made the Palace of the old ex-Queen of Spain Cristina their headquarters. The Emperor of Germany did not enter Paris; neither was Bismarck, nor Moltke particularly mentioned. The streets were almost deserted, the windows closed, and some of the statues in the Place de la Concorde covered with black drapery. On the last days of February there had been great excitement in Paris amongst the lower classes, and some policemen been killed. On the $1^{\text {st }}$ March, owing to the preventive measures of General Vinoy, military commandant of Paris, tranquillity was restored, only some Prussian officers dressed as Civilians who ventured to pass the line of demarcation, on being recognized were roughly handled and had to thank the police that they escaped with their lives. The Emperor of Germany had returned to Berlin; the ex-Emperor Napoleon was in London.

In the evening of this day my wife accompanied Garland and Enriqueta, who had come in the previous day, to Chorrillos where she intended to spend the easter-holidays.

From Good Friday, $7^{\text {th }}$ to Easter Monday, $10^{\text {th }}$ of April. These three days I spent with my wife and the Garlands in Chorrillos. Bathing and visiting took up the greater part of my time. On Sunday the architect Villa and Antonio Martinez - neither of whom I particularly admired - dined with us. On Monday M. G. Chavez and J. P. Escobar, the former Geraldo's principal, a very quiet man - the latter (hitherto Alex. Ruden's partner in Payta, and now resident in Lima) very talkative and agreeable.

Wednesday, ${ }^{2}{ }^{\text {th }}$ of April. In the Constructora the Statutes were at last approved; an amendment moved by Agusto Althaus that no Director [_]ld be gerente or manager having been lost by a great mayority [...]. [249]

Friday, $14^{\text {th }}$ of April 1871. Eight Directors of the Constructora - I of the number - met; we fixed the salaries of each of the two gerentes at $\$ 4000$ annually, and resolved that before the $1^{\text {st }}$ of May the first cuota of $5 \%$ on each share should be paid into the Banco de Lima. Juan Francisco Balta, the President's elder brother and Minister of War, of whom it had been said that being a candidate for the next Presidency of the Republic he had in conformity with the Constitution resigned his charge, entered unexpectedly the Council room and declared that he had given up the idea of aspiring to the Presidency, and would therefore remain in his ministry.

Saturday, $15^{\text {th }}$. Ricardo Marti was at this time the most active money broker, and I frequently made use of his services. This day through him I made a loan of $S / 22,000$ to Pablo Vivero for six months, deducting the discount at $9 \%$ p.a., 
and he placing in my hands as security one share of the Banco de Lima and two shares of the Banco Territorial. Having settled this with Marti, I looked in at Riva Agüero's office as I was in the habit of doing; he assured me that there was hardly any doubt but that Manuel Pardo would be chosen President of the Republic for the next constitutional period of four years, to begin on the $2^{\text {nd }}$ August 1872. Manuel Costas was at work for him in Puno, Francisco Garmendia in Cuzco, J. M. Goyeneche in Arequipa, and Iglesias in Cajamarca.

The last political news from Europe, reached per steamer to the $8^{\text {th }}$ per cable to the $26^{\text {th }}$ March. Shortly after the peace had been signed, an insurrection broke out in Paris, directed against the National Assembly and Thiers as President of the Republic. The more moderate daily papers gave it as their opinion that all Frenchmen should break off their social intercourse with the Germans resident in France, whilst the Ultras went so far as to propose that all German artizans and tradesmen at the time in Paris should be turned out without delay. Meanwhile the established Government had taken up its seat in Versailles, where it had 40,00o men under its orders, and it was reported, though probably without foundation, that no part of the German army would for the present leave the French territory.

Thursday, $20^{\text {th }}$ of April. Last night Mariquita and I slept for the first time in our spacious and airy bedroom in our new house Calle de Zarate, where I flattered myself we should live together happily and contentedly for [...] years to come. Our furniture we had been gradually rem $[\ldots][250]$ with the assistance of a French carpinter, who had placed at our disposal for a remuneration, both a spring van and the men he was in the habit of employing. We both did our best, but my wife worked much harder than myself. Architect Villa was now occupied pulling down the old staircase, which was of such a solid construction that this workmen had to make use of combas, a heavy hammer which serves in the mines for breaking rocks, and [_] thus armed they made but little progress in the work of destruction. Meanwhile a moveable staircase belonging to Enriqueta was put up, but it was so steep, and the steps so high that probably Mariquita would not venture down before the wooden scaffolding for the new staircase - afterwards to be covered with marble slabs - was put up

Thursday, $27^{\text {th }}$ of April 1871. This day at about 8 p.m. a terrible accident occurred on the railway between Lima and Callao; the usual passenger train left Lima at the fixed hour 8 p.m., stopped as it usually did at the Bellavista Station; not more than five minutes later another train was dispatched with merchandize, some said by order of the Government. It had a powerful locomotive, which the former had not, so that this was overtaken and run into 
before it had moved on to Callao. Many persons were wounded and several killed. I was surprised how this could have happened for it was a clear, bright, moonlight night.

Friday, $28^{\text {th }}$ of April. To John P. Gallagher I lent S/10,0oo at 9 1/4\% allowing Marti 1/4\% for his brokerage; the security consisted in thirteen shares of $\$ 1000$ each of the United States Guano Company.

The Constructora did not make much progress, and had I known beforehand that the family of Echenique, and those related with the same, would have had such a decided preponderance, perhaps I would have kept aloof. There were of them: J. M. Echenique, the second son of the General; Rufino his third son, brought up in England and a very genteel young man, who was elected one of the two gerentes having obtained all votes except mine; further: Agusto Althaus, nephew of Victoria Tristan, General Echenique's wife; Santiago Lanfranco, married to a sister of this Doña Victoria; César Saco y Flores, elected second gerente, after a long and protracted voting; Dr. Simon Paredes, and Emilio Pierola, all connected with the same family Amancio Castillo, who had counted on being chosen one of the two Gerentes [_] dissappointed in this his expectation threw up the five shares [...] [251] he had subscribed. Dr. Paredes, subscriber for an equal number of shares, did the same. The reason why, did not come to my knowledge. Of the cuotas to be paid in, one third was still outstanding.

Saturday, $29^{\text {th }}$ of April 1871. News from Europe per cable went to the $8^{\text {th }}$ April. Paris continued in the hands of the red republicans; other large towns, such as Rouen, Lyons, Bordeaux and Marseilles, had fortunately remained quiet, and adhered to the Government in Versailles. The forts round Paris had not yet been evacuated by the German troops.

In the course of the present week, the friends of Manuel Pardo, a very respectable body, presided over by General Medina, held a meeting and declared that Pardo was their candidate for the Presidency. Two other civil candidates presented themselves: Toribio Ureta, the Fiscal, and Melchor Vidaurre, member of the Supreme Court of Justice, this latter - it was said favoured by Government.

Tuesday, $2^{\text {nd }}$ of May It became known that the train on the Lima and Callao Railway, which had been the cause of the catastrophe spoken of on the $27^{\text {th }}$ April, carried 25 tons of powder belonging to Meiggs and destined for the railway from Arequipa to Puno. The Company was fined by Government S/25,000 for which sum Gibbs gave their acceptance at 15 days-sight, and this acceptance the Intendente discounted in the Banco de Lima. The money, he said, was to be handed to the President in person. 
Strange things happen when interest is concerned. It will be recollected that the so-called Nacionales, Althaus, Canevaro, Sancho Davila etc., who were the principal shareholders and supporters of the Banco del Perú, were also the principal opponents of Dreyfus' Contract of August 1869. At the time Althaus was twice arrested and put into prison. Government gave orders that the notes of the Banco del Perú should not be admitted in the treasury; and now the house of Dreyfus, though they, as well as Derteano, who was supposed to be a sleeping partner of the firm, had shares in the Banco de Lima, transferred its account from the London and Mexican Bank where it was hitherto kept, to the Banco del Perú which establishment to be sure granted to the same conditions, which were extremely favourable, and which the Banco de Lima would not concede. Scheel [...] to Europe and Ford, sometime back the manager of the Lond[_] [252] and Mexican Bank, occupied his place.

By the last steamer Juan wrote me from Nizza; he intended to leave for Paris as soon as tranquillity was restored. We learned by cable that on the $22^{\text {nd }}$ April Paris continued in possession of the Red Republicans - to whom the Bank of France, to save itself from greater loss, had paid 3,000,000 of francs - who had sacked the Church of Notre Dame, and done more or less damage to several public buildings; amongst which L'Arc de l'Etoile was particularly mentioned. The first five hundred millions of francs had actually been, or were about being paid, to the Germans by the Versailles Government.

Monday, $8^{\text {th }}$ of May. Though my wife and myself had for more than a fortnight been sleeping in the new house, yet hitherto things there had been in such disorder that in the day time Mr. Coleman and I still continued our occupations in the house Calle del Correo; this day however we also removed and took up our quarters provisionally in the large saloon, which was afterwards to be our drawing room, for my office was still under repairs.

Thursday, $11^{\text {th }}$ of May. Enriqueta having invited Mariquita and myself to spend this, my birthday, with her in Chorrillos, we went there by the ten O'clock train. We breakfasted and conversed a little, then I, to ascertain whether at the age of 72 my climbing powers had undergone any change for the worse, or not, ascended with Antonio to the highest point of the Moro Solar where the cross stands; we continued our walk to the end of the ridge of hills and ploughed our way back to Chorrillos through the heavy, sandy, high road, which last part of our promenade took us no less than one hour ten minutes. Bartolomé Araoz, Mariquita and I had invited; J. P. Escobar was Garland's guest; Manuel Velarde came with Enrique and Guillermo. Everything was very nice and pleasant, and I returned to town by the 8.15 train. 
Friday, $12^{\text {th }}$ of May. Mariquita came in, and I delivered the keys of the house Calle del Correo to Antonio Salinas' porter.

The news from Europe differed little from that previously received; the Red Republicans continued in possession of Paris; they sacked and plundered and destroyed, and had repeated combats with the troops of the Versailles Government. [253]

Thursday, $18^{\text {th }}$ of May 1871. Ascencion-day. My wife and I spent this day in Chorrillos with the Garlands. I came back in the evening.

Saturday, $20^{\text {th }}$ of May. This day died the wife of Nicolas Rodrigo, an excellent lady. In the evening the North Steamer arrived. European news per cable to Jamaica went to the $5^{\text {th }}$ May. There had been much fighting between the Parisians and the Versailles troops, but the capital was not yet taken by the latter.

On the $11^{\text {th }}$ inst. an attempt was made to take possession of the "Huascar" [_] "Independencia", Peruvian men-of-war lying at anchor in the Callao Port; however, as the Government had received previous information the conspirators were taken in-fragante, and many arrests were made accordingly. Amongst the persons now in prison was a certain Babilon, brother-in-law of Dr. Saavedra Prado's decided partizan; it was therefore supposed that it was for this latter that the conspirators had been at work. For the Presidency of the Republic many candidates were in the field; not only Manuel Pardo, Dr. Ureta, and Dr. Vidaurre as above said, but also Generals Echenique, Vivanco, Segura, Herencio Zevallos, and Pedro Diez Canseco.

The three Ministers Pierola, Loaiza, and Santa Maria had made themselves very ridiculous during the last few days. The so-called Catholic party in Lima at whose head figured Monseñor Garcia, and the eldest son of Bernardo Roca y Garzon, who was a clergyman, and whose organ was the paper "La Sociedad", had drawn up a protest against the invasion of Rome by the troops of the King of Italy, to which document they had been begging for signatures all over the place, and succeeded in persuading the said three Ministers to put their names to it; but as this document contained many expressions injurious to the King of Italy and his Government, the Italian Chargé in Lima had represented to the cabinet that though private individuals might sign the protest, he could not allow the signatures of three of the Ministers of the State to pass unnoticed; whereupon these three gentlemen published another declaration in which they stated that they had meant no disparagement to the Italian Government.

Sunday, $27^{\text {st }}$ of May. In the morning I climbed up San Cristoval, and though a little fatigued, reached the summit without resting for a moment. 
By the 2 O'clock train I went to Chorrillos, dined with the family, and returned in the evening, when to my great annoyance I found my porter [...] dead drunk, for which on Monday morning he made many ex [...]. [254]

Our servant Juan had been sick of late, and obliged to stay in his own house, there to be cured.

Tuesday, $23^{\text {rd }}$ of May. Mariquita came in from Chorrillos.

My house Calle de Aldavas I let to a French civil engineer Eugene Plazolles from the $1^{\text {st }}$ June, at $\$ 270$ monthly, the first month's rent to be paid in advance.

The following was my way of living. I rose about 7 a.m., either walked out a little, or looked on at what the work men were doing in my house. We breakfasted generally in company with Enrique, Guillermo, and Geraldo; then Mr. Coleman was with me till 4 p.m., our principal occupation being to remodel and rewrite my diary, for I was very desirous to leave a well written record of my life and travels, though perhaps in reality of little value. Every forenoon I had to go out for several hours; to my lawyer Fernando Palacios, on account of the suit against Col. Leiva, and to Dr. Lucio Barrios, who had occasionally to present an escrito relative to the four shops Calle de Zarate, for though I had taken possession of them, the former owners would not leave me at rest; to my different tenants, from whom I had to collect rents; to the meetings of the Lima Bank, La Constructora, the Cerro de Pasco Mineral Railway Coy. etc. We dined at 5 O'clock, always with Guillermo and Geraldo; where Enrique dined I did not know. Mr. Coleman read to me from 6.30 to $7 \cdot 30$, at this time the very interesting life of Frederic the Great by Thos. Carlyle, a thorough heroworshipper; when he left, Don Bartolomé Araoz came in, took tea, chatted, and stayed till near 10, if not daily, at least four times in the week. Frequently at that hour, I had still to go to the Notary Escobar, who, though perhaps the best of his tribe, was not so perfect as not to require an occasional stirring up.

Saturday, $27^{\text {th }}$ of May. Mariquita went out to Chorrillos, where it was her intention to remain a few weeks with her daughter, both she and I being in hopes that the change of climate, the sea air, and the bathing, would do her good and give new strength to her system.

Whitsunday, $28^{\text {th }}$ of May. I was up at an early hour; a fog covered both the plain and the hills; the ground was moist, and the sides of San Cristoval were slippery here and there, thus my ascent was not so ea [...] however, I reached the top, sat down for a few mo[_] [255] upon the big stone which lies there, and was back long before 10 O'clock, the breakfast hour. When Mr. Coleman was gone, I made a few calls, of which only two are specified; the one to Dr. José Gregorio Paz Soldan, the other to Dr. Jervacio Alvarez. At Paz-Soldan's I found 
Dr. José Aranivar, and hardly had I recognized him when I recollected that the last time I had exchanged a few words with him two or three years back, I had accosted him standing in the corredor of the Superior Court in a brusque even rude manner, saying "When will you return to me the autos which you have kept for such an unreasonable length of time?" to which he replied by cooly referring me to his procurador. Now Paz Soldan introduced us to each other, him by the name of Minister of Justice; we merely bowed. However, in the course of conversation there was no stiffness between us, and when we rose we shook hands. He spoke all the while with an air of authority and with a magisterial tone, so that even Paz-Soldan, usually so overbearing, gave way to what he said as if it were the law of the land. Dr. Muñoz, who also came, merely laughed and acceded to everything that fell from the lips of his superior, the Minister of Justice. Dr. Alvarez, to whom I next went, was in a poor state of health; here I again met Dr. Muñoz, who was now much more agreeable and independent than I had found him in the previous visit.

By the five train I went to Chorrillos, where we had at dinner Bartolomé Araoz, J. P. Escobar, and José Maria Costas, this latter a native of Puno, eccentric, but intelligent, well educated, agreeable, and upright to the back-bone. The 8 O'clock train took me back to Lima.

Whitmonday, $29^{\text {th }}$ of May 1871. In Chorrillos we had young Adolfo Alvarez with us at dinner. Hitherto, the exportation of the silver and gold coins of the country had been permitted on their paying a certain export duty; the consequence was that large quantities had been shipped both to Europe, and to the port of Guayaquil. A diminution of the circulating medium began to make itself felt and to put a stop to the same the Government had of late thought proper to prohibit the exportation of silver and gold in bars, and in Peruvian coins. This measure would without fail be followed by a rise in exchange, which was about this time 45 pence per sol, $90 \mathrm{~d} /$ st. on London. M. G. Chavez had drawn at 120 days sight and [...] the same figure. [256]

I saw by the papers that the Italian Government had made the following proposals, which I considered to be very favourable, to his Holiness Pope Pius IX. As the head of the Church, he was placed on a level with the King; he was to have his two palaces in Rome, the Vatican and the Lateran; his court, his cabinet, his ambassadors: he might receive Ambassadors from foreign Courts; any offence against his dignity and self was to be punished as if it were directed against the king himself. He might name bishops in Italy without their receiving the royal approbation, subject only to the condition that they were Italian; and finally he was to receive an annual stipend of 3,225,000 Lire wherewhith to defray his expenses including those required for the preservation of the national gallerie and museums. Should in after times the Italian Government 
take the care of these establishments on themselves, the annual payment above mentioned was not to be diminished.

Thursday, ${ }^{\text {st }}$ of June. In the beginning of this week took place the funerals of Enrique Armero and of Juan Centeno; the former died of a cancer in the tongue, the latter of apoplexy. Enrique Armero was the eldest son of Cristoval Armero, a native of Venezuela, and Jesus Campo a Guayaquileña, both of whom had departed this life a few years back. He was well brought up, had an agreeable comportment, and was a first rate dancer and expert at all games of cards and dice; to this expertness he owed the not inconsiderable fortune which he bequeathed to his sisters, who had to conclude the bridge across the Rimac, for the construction of which he had signed a contract with the Government. Juan Centeno was the only son of the rich Cuzqueño Don Anselmo, whose name has occurred now and then in this my diary. Juan spent several years in France where he acquired a good deal of book-learning so that he was a very agreeable gentleman and admitted in the very best society, notwithstanding his very dark Indian complexion. He married Margarita, a daughter of General Manuel Mendiburu whom he left penniless. It was said of him, and I believe with truth, that whilst in France he had cheated his father, or even robbed him, of a considerable amount of money, and this black spot stuck to his character to the very last day of his life. A bad cold prevented my being present at the funerals of either of the two; this indisposition, which had beco [...] [257] general all over the town, went by queer names "la Candidatura civil", "el abrazo de Pardo", both alluding to the probability there was that this gentleman would be raised to the Presidency of the Republic. About this time I saw him frequently at the repeated meetings of the Directors of the Pasco Mineral Railway Company. Nicolas Rodrigo, one of them, since the death of his wife never made his appearance; in lieu of him, two gentlemen interested in the railway, Francisco Bohorquez, in previous years a miner of the Cerro, and Cipriano Correa, had been named in a general meeting of the shareholders to join the Directors, which they did accordingly. A slight deference was always shown to Don Manuel Pardo, not only in expectation of what he was likely to be erelong, but also because he had really the clearest head of those present, besides being interested for $\mathrm{S} / 50,000$ in the enterprize. He was no fluent speaker, but what he said was generally well founded; I liked him well - he was very polite, and by no means overbearing, on the contrary, he listened to the observations made to him; he tried to convince, and allowed himself to be convinced. This railway, of which such great expectations were entertained when we formed the company in 1868, did not present at present the slightest chance of success, and it was thus easily to be conceived how delighted I was when I was told by Sagastabeytia, at first as a great secret, that there was 
someone willing to take the entire enterprize off our hands. Then it oozed out that this mysterious person was Juan Martin Echenique, but the conditions offered by him were as yet not made known to the Directory though, no doubt, Pardo was acquainted with them. Riva Agüero and Sagastabeytia were his, Pardos', intimate friends.

Friday, $2^{\text {nd }}$ and Saturday, $3^{\text {rd }}$ of June. My wife and daughter occasionally came in from Chorrillos, but never remained long in town. Garland went out every afternoon and stayed till next morning, whilst I kept a close watch on my new house Calle de Zarate. In the evening, when Mr. Coleman was gone, I was sometimes quite by myself and spent many a lonely hour especially since indisposition prevented Don Bartolomé Araoz from keeping me company.

Sunday, $4^{\text {th }}$ of June. In Chorrillos, where I made one or two calls, I [...] some news of importance: firstly that Antony Gibbs \& Sons of London [...] [258] representation of themselves, and the other parties who jointly with them formed the Callao, Lima \& Chorrillos Railway Company had disposed of the two lines to the Peruvian Government, through the medium of Don Toribio Sanz, Peruvian Fiscal-agent in Europe, for the sum of £80o,ooo. And secondly that the same firm had telegraphed to Arthur Heeren of Lima that they had received advices from Macao to the effect that the Chinese Authorities had prohibited the exportation of Chinese Coolies to Perú.

On the $15^{\text {th }}$ May Paris continued in possession of the Red Republicans, which party was also called La Commune. Their leaders held their meetings in the Town Hall, or Hotel de Ville, where they ruled with a despotic sway, having introduced a system of terror not inferior in atrocity to that of 1793 . Deadly and sanguinary combats between them and the troops in Versailles, which hitherto had led to no definite result, were of daily occurrence. My son Juan wrote from Geneva on his way from Nizza to London.

Monday, $5^{\text {th }}$ of June. Last night a marriage took place which gave great satisfaction to our whole family. It was that between one of the sons of Antonio Salinas and a young lady called Jesus Rabago. Guillermo Garland had been desperately in love with her, and we all feared that he would be foolish enough to offer her his heart and hand; not only was she his senior by several years, but what was worse, she was known to be a coquette of the first water, and of this she gave a proof that whilst dallying with Guillermo she married said Salinas. Guillermo however did not seem to take it much to heart, for he was now as gay and unconcerned as ever. This evening Rafael Canevaro was to contract matrimony with Inés one of the daughters of Don Mariano Laos, proprietor of a sugar estate. 
Monday, $12^{\text {th }}$ of June. Antonio Salinas returned to me the keys of my house Calle del Correo, paying, of course, the stipulated monthly rent of $\$ 400$. He had let the ground floor of his house opposite the Church of La Concepcion to J. P. Escobar, lately arrived from Payta, and as Escobar returned the keys to him, he did the same to me.

The construction of the new flight of stairs in my house Calle de Zarate progressed very slowly. Its plan had been drawn [_] not by the architect Villa, but by Geraldo Garland [...] [259] should not at all wonder, if Villa did not work with a very good will, because the idea had not been his. My neighbour Leyva, as was to be expected, availed himself of every chicane which the Peruvian law allows to a litigant, to protract the decision of my suit against him on the subject of the extinction of the open gutter in the garden behind my house. On the $9^{\text {th }}$ I wrote a detailed letter to my son Juan relative to the unfortunate Pasco Mineral Railway Company, to which he had subscribed and paid 10,000, I, 20,000 Soles. I explained to him the cause which had led to the ruin of this enterprize; I next told him that in the very nick of time when the Directors did not know whither to turn to obtain further resources, Juan Martin Echenique had made an offer to take the whole enterprize off our hands; and finally I gave him an idea of the conditions agreed to between the Directory and said Echenique and approved by a large majority of the shareholders. A press-copy of this interesting document will be found in appendix under $\mathrm{N}^{\circ} 7$. I may add that the escritura between Echenique and the Directors was signed in the office of the notary Francisco Palacios, and that he had sent money to the Cerro to continue the work, whilst on the other hand the interest due on the $1^{\text {st }}$ June to Riva Agüero for the Banco Hipotecario, to Felipe Barreda, Jr. and to myself, was paid us by Echenique not in cash but in his vales or promissory notes at three months date. Four hundred thousand Soles special bonds of the Internal debt, promised to us by the Government, were lithographed and signed by Don Nicolas Pierola, Minister of Finance, but were not yet provided with the signature of a Garcia, a subaltern employé of whom Riva Agüero suspected that he would not move, if he were not feed. It was a fortunate thing for me that in this affair I found myself in the same boat with Felipe Barreda and José de la Riva Agüero, the former Manuel Pardo's brotherin-law, the latter his intimate friend; and even as it was I did not feel at all certain that the 50,000 Soles disbursed by me would ever again find their way back into my chest. Enrique Marriott was named by Echenique as his agent in Lima.

Wednesday, $14^{\text {th }}$ of June 1871. The only event worth chronicling was a a crime committed by Silvestre Gutierrez, Colonel of the battalion Pichincha [...] of 
the wife of the Minister of War, Juan Francisco Balta [...] [260] was on bad terms with a certain Colonel Garrido; they met in the street, Garrido offended Gutierrez in some way or other, whereupon the latter called two policemen and had Garrido taken to the barrack of his battalion, where he received two hundred lashes and was then turned out. Gutierrez was arrested, together with two captains who had been present at the flogging, and Garrido laid his complaint before a Juez de derecho, but I much doubted that he would succeed in obtaining the justice due to him, for the four brothers Gutierrez, though much hated for their overbearing and cruel character, were men of great power and influence; Silvestre, Marcelino, and Marceliano commanded each a battalion; the fourth, Tomas, was inspector of the army, and their sister, as already said, wife of Juan Francisco Balta.

Friday, $16^{\text {th }}$ of June. The North steamer arrived, bringing per cable advices from Europe to the $3^{\text {rd }}$ June. At last the Commune had succumbed, and Paris was once more in the hands of the established Government, now Republican. It was on the $21^{\text {st }}$ or $22^{\text {nd }}$ of May that a Captain of the Versailles troops observing an uncommon tranquillity in the Western fortifications of Paris, ventured to approach; he entered and found them abandoned. He returned to Versailles and gave advice of what he had seen. Marshal Mac Mahon, the Commander-inchief of the Republican troops, then approached with about 80,00o men, and as far as I could make out from the more or less contradictory reports published in the papers, met with no resistance until he reached the Place de la Concorde where barricades were erected. Thenceforward the combats recommenced. To say that on both sides they fought with desperate valour would be but a tame expression. They met with a fiendish fury; no quarter was given on either side; the Parisians defended the ground inch by inch. At the Tuilleries they made an obstinate stand. Gradually they retreated to Montmatre and it was not before seven days of incessant fighting that the Versailles troops possessed themselves of the last strongholds of the Reds, Belleville in the N.E. corner and the Cemetery du Père de la Chaise, outside the Barrière du Trône. Then the insurgents, leaving about 20,00o dead and wounded in the streets of Paris, fled in all directions, except where the Germans had drawn an impassable cordon. The Governments of the neighbouring countries, Switzerland excepted, had promised to deliver up the [...] [261] unconditionally. Of the Versailles troops, who pursued their enemies without mercy, about 3000 were said to be wanting, in dead, wounded, and missing. Several of the Chiefs of the Commune, the Pole, Dombrouski and the Fenian general Clusseret, fell into the hands of the victors and were shot on the spot. The war minister of the insurgents - name not given - was killed by them. Before this, their final defeat, they had committed 
unheard of atrocities. The Archbishop of Paris, Darbois, and a considerable number of priests and Curates, the President of La Cour de Cassation, and the notorious banker Jecker (see Vol. VI pages 387/388) had been arrested on the pretence that they should be kept as hostagés; but were they kept as such? Certainly not. One or two days before the $21^{\text {st }}$ May they were removed from a place of detention to a prison, La Roquette, and when their cells were again opened, they were led out and shot down like dogs. Not only upon human beings, but also upon inanimate objects did the insurgents vent their lust of destruction; the column in La Place de Vendome, the trophy of Napoleon I's Austerlitz Campaign, and cast out of Austrian cannons then taken, was pulled to the ground, and in its fall broke into three pieces; to many public buildings they applied petroleum and the torch; amongst them were enumerated the Tuilleries, the War Ministry, the Hotel de Ville, the principal police office, the tribunal of accounts, the Palace of the Legion of honor, and the Lombard. The bombs and shells thrown from either side upon the unfortunate town increased the conflagration, to extinguish which it was said that fire brigades had come over from London, and others were expected from Belgium.

The foregoing is in a few words a summary of the last Paris occurrences. Enriqueta received her letter from Rosa, I mine from Juan. They were all in London. The Schuttes had taken a house in Berkely Square, Carlos Candamo his of course in a still more expensive quarter, in Belgrave Square.

Saturday, $17^{\text {th }}$ of June 1871. It turned out as I had expected. Garrido was unable to obtain justice against his powerful enemy Silvestre Gutierrez. No proof could be produced of the flogging. Gutierrez confessed that, as Garrido had insulted both him and the President, he had him arrested and not finding the sub-prefect in the police-office, he had taken him to the barrack; all the rest, he said, was false, and consequently he lodged a complaint against $[. .$.$] for$ calumny. On the $29^{\text {th }}$ May I gave an abstract of the [...] [262] made to the Pope by the Italian Government, but according to the last advices from Europe his Holiness Pius IX had declined to accept them branding them with the name of a tissue of deceptions. In Frankfort on the Maine the peace between Germany and France, the preliminaries of which were signed in Versailles about the end of January, was finally concluded.

The banking-houses of Rothschild, Erlanger \& Hahn, it was said, had come forward with an offer to the French Government to advance 2,000,000,000 of francs as part-payment of the war indemnity due to Germany.

Sunday, $18^{\text {th }}$ of June. This day left for Europe Anibal Gonzales, his wife Josefa Bazo, four children, a male companion, and two female servants. Gonzales, a 
native of Guayaquil, had some years previously been managing the business of Gordillo, then in Paris, and had given complete satisfaction; now he had been named one of the gerentes, or manager, of a joint-stock company which, under the name of the General South American Company, had just been formed in London, and of which the principal shareholders were M. M. Cotes, the brothers Luzarraga, Candamo, Gordillo, and Canevaro. To me it was an enigma why they had chosen for such a post a man who, though of an excellent character, did not understand a word of English.

Ernest Wagner who for twelve years had been clerk in the house of $\mathrm{H}$. Witt \& Schutte, afterwards Schutte \& Co., and who had always done his duty to the fullest extent of the word, left the firm for want of employment; he established himself on his own account and went to Europe to further his business. The business of Schutte \& Co. was now so reduced that Garland did not think it necessary to come to town every day. In the meanwhile, Government had again placed a policeman at the door of Schutte \& Co.'s office in hopes that Garland's obstinate refusal to make a payment to the Government would at last be overcome. Riva Agüero, owing to the last imprudent advances made by him to the Pasco Mineral Railway Company, found himself hard pressed for money to make the large payments due on the $30^{\text {th }}$ June partly for interest on Cedulas, partly for Cedulas which had been drawn six months previously, and had now to be redeemed at par. To extricate him from this difficulty, as far as lay in my power, I bought from him S/32,00o Cedulas at par, and paid him the money on condition that I might return them if I pleased, before the $30^{\text {th }}$ September, he repaying the money, with $8 \%$ annual interest.

Monday, $26^{\text {th }}$ of June. This day the apostolic Delegate Serafin Vanute [...] received by the President in solemm audience. Pedro D [...] [263] a native of Genoa died at an advanced age, leaving to his children, at it was said, a fortune of $S / 5,000,000$. I had known him since I first came to Lima when he was clerk to his future father-in-law Felix Valega, with a salary of $\$ 50$ monthly. Having married Miss Valega, he demanded either a higher salary, or an interest in the business, which was refused him, whereupon he established himself on his own account, and being well acquainted with all Valega's connections, they flocked to him, and in course of time he made his large fortune.

Tuesday, $27^{\text {th }}$ of June 1871. A strange scene took place this day in the palace. A few days previously a sentence was given in the Superior Court declaring that Dr. Fernando Palacios was not guilty of the offence of having calumniated the Chief magistrate of the Republic, which verdict was signed by young Mariategui, Mariano Alvarez, Domingo Mendoza, and Mariano Dorado, which number of 4 showed that the first three had not agreed, and that a fourth had 
been called in to give the decisive vote. The President Balta called Alvarez into his presence, and asked him why he had voted against the Government; he replied that he had done what he considered just; the President rated him soundly and told him that it was well known that he, Alvarez, had pocketed large sums when making the purchase of the monitors in the United States. Alvarez did not allow himself to be brow-beaten and said he would challenge Balta were he not protected by his Presidency. "Then", replied the latter, "I am no longer President." The Ministers were called together, Balta repeated his resolve, and the necessary documents were drawn out, even a letter written to Francisco Diez de Canseco, $2^{\text {nd }}$ Vice-president, placing the Government of the Republic into his hands, the $1^{\text {st }}$ Vice-president Herencio Zevallos being absent. This occurred between 2 and 4 p.m. The Gutierrez came, Balta's wife and family, Pierola and family; their joint entreaties and representations induced Balta to change his mind, and by 6 O'clock the storm had blown over.

Thursday, $29^{\text {th }}$ of June. San Pedro y San Pablo. The Garlands and my wife continued in Chorrillos. I of course went out every Sunday and holiday, sometimes sooner, sometimes later. This day, for instance, I had to make several calls, amongst which upon the Papal Delegate Vanutelli, who had sent me his card; I did not find him at home. In Chorrillos [...] was unwell in bed, and several visitors in our sala: Luis Be [...] [264] Cisneros, late Peruvian Consul in Havre, with his pretty young wife Cristina Bustamante, a grand-daughter of Dr. Jervacio Alvarez; Dr. José Gregorio Paz Soldan; J. P. Escobar, and Adolfo Alvarez. Paz-Soldan and Alvarez remained to dinner: the former finished his three bottles of wine and boasted of the capacity of his stomach and the power of his head to withstand such ample libations. The conversation turned on the change of Ministry - even the successors were named. The 8 train took me to town.

Friday, $30^{\text {th }}$ of June. Balta's momentary resignation of the Government of the Republic spoken of on the $27^{\text {th }}$ was the cause of a serious altercation between him and his Minister Santa Maria. The note to the $2^{\text {nd }}$ Vice President then referred to, was not only written but actually sent, and on Balta's changing his mind, Canseco addressed to him an official dispatch, in which he divested himself of his ephemeral Supreme power; and this dispatch Santa Maria, who certainly for these few hours could not have been Canseco's Minister, had been foolish enough to countersign. This was the motive of the quarrel between him and the President, which, of a violent nature whilst it lasted, did not endure twenty-four hours, for this day, I was assured, matters had been made up between them. 
Sunday, $9^{\text {th }}$ of July. According to the last advices received from Europe, tranquillity was restored in Paris. The Republican Government with Thiers as its President was acknowledged all over France. Of the Paris insurgents it was said that 20,000 would be banished to New Caledonia and 2000 be sent to the hulks in Cherbourg: the names of the leaders showed different nationalities, such as Germans, Italians, and Poles. My conviction was that Paris, though for the moment shorn of its glory and abandoned by thousands of foreigners, would soon resuscitate from its despondent state and be again, as heretofore, the point of attraction for numberless visitors. Juan wrote from London that he was about leaving for Kissingen in Bavaria. The family Schutte would go to Boulogne; their house in Paris, near L'Arc de l'Etoile, № 8 Rue de Presbourg had hardly suffered at all during the siege, whilst Luzarraga's, not far from theirs and newly furnished, had sustained considerable damage by shells.

Not only the capital, Lima, but the entire Republic was agitated by numberless intrigues for the election of the new President. Man[_] Pardo had the best chance next to him Ureta who publis [...] [265] newspaper the "Republica" solely for the purpose of advocating his own election; the ostensible editor was Antonio Martinez, who formerly frequently visited us, but had made himself scarce since the day he borrowed $\$ 200$ from me. I regularly attended the meetings of the Directors of the Insurance Company Lima and of the Constructora. In the former some business was always transacted, and premiums were paid in; Lembcke made a very good chairman; of the Directors Manuel Pardo, José Canevaro and Arthur Heeren were the most irregular in their attendance. In the Constructora only money was spent, and nothing was done which brought grist to the mill; the company had given up my store in the Calle de Aldavas, and subrented from J. A. Garcia y Garcia, in the house of J. M. Varela, Calle de Valladolid, part of the ground floor, more spacious and of course more expensive than the locality in Aldavas. At my recommendation José Pablo Escobar was chosen Director, and he again introduced as book-keeper a certain Arosamena from Panama, married to a Señorita Lopez, sister of Escobar's wife; we assigned to him a salary of S/200 monthly, upon which, he complained, he could not subsist - Alejandro Garland was named cash-keeper with S/10o monthly, but as yet neither the one nor the other had any thing to do.

To Escobar I let from the $11^{\text {th }}$ inst. my house Calle del Correo, at \$350 monthly.

In the course of last week I lost in the Superior Court one article of little importance in my suit against Leyva about the extinction of the gutter. The Juez de $1^{\text {a }}$ Instancia, Dr. Patron, had sentenced that guards should be placed at 
his street door till he pointed out where the title deeds of his house were to be found; he appealed to the Superior Court, where the three judges Alzamora, Rospigliosi, and Perez resolved that he, Leyva, had done all I had a right to ask from him, when he indicated to me the notary's office where I could find the escritura of the purchase he had made of the house. By Dr. Palacios' advice I appealed to the Supreme Court.

José Muro paid to me the sixty odd thousand dollars amount of his pagaré endorsed to me by Schutte \& Co., as above said.

This day a numerous meeting of the friends of Manuel Pardo was held in the place of public resort, called the baths of Altazar. Many speeches were [...] As long as they were within the precincts of the baths all was [...] [266] peacable, but on returning to town when their number, increased by the populace who joined them, might perhaps have run up to 3000 , they were interfered with by a few armed negroes, adherents of Echenique and headed by Otayza; they were however easily put to flight. I of course saw nothing of this, for I had gone out to Chorrillos, which I again did on

Thursday, $13^{\text {th }}$ of July. Antonio's birthday, when Garland had invited J. M. Costas to dine with us.

Friday, $14^{\text {th }}$ of July. In the office of the Banco Hipotecario Manuel Pardo, Riva Agüero, Felipe Barreda Jr., Sagastabeytia, and I had a private meeting with Juan Martin Echenique to arrange with him about the payment of the different amount owing by the Pasco Mineral Railway Company, viz.: to Riva Agüero for the Banco Hipotecario S/158,500, to Barreda S/100.0oo, and to me S/50,0oo. I had made a calculation how the $S / 400,000$ Bonds, signed by the Government, and which at last were in Riva Agüero's possession had to be distributed, to Riva Agüero S/205.000, to Barreda S/130,000 and to myself S/65,000, which sold at $77 \%$ would more or less cover the three creditors; this was found correct and approved, but as Echenique expected that he would be able to dispose of the Vales at a better price, Barreda and I conceded to him one years term to do so, at the expiration of which if no sale had been made, we were authorized to dispose of them at the best price obtainable, Echenique and the Railway remaining responsible to us for any deficit there then might be. The interest of $9 \%$, payable every three months as per escritura, we conceded to Echenique might be paid by him every six months. Riva Agüero, who had no escritura like Barreda and myself and who had made use of the funds of the Banco Hipotecario, with the consent of Pardo, one of the Directors, was promised by Echenique to be paid at the end of the year, with interest. Pardo was quite the same as he used to be in former meetings, and in my presence Echenique said to him "when you are President you will make me Alcalde of Lima, and we shall 
keep the town in good order", to which Pardo replied in very flattering terms. The great measure of the Government during the week had been the decree to disarm the whole fleet, save two of the smallest vessels.

In Chile Federico Errazuriz, brother of don Maximo, our fellow passenger from Europe in 1863 - see Vol. VI page 533 - was elected President [_] had been the Government candidate whilst his [...] [267] by the opposition, and who lost the election, called Urmeneta, must have been a relation of his, for I recollected that Don Maximo told me that his wife, whom he had lost, had been a lady of this name.

Sunday, $16^{\text {th }}$ of July 1871 . This was the last time I went out to Chorrillos there to dine, for on

Wednesday, $19^{\text {th }}$ my wife came in for good, and this she did with the more safety as the scaffolding, or rather the commodious wooden staircase, hereafter to be clad with the marble slabs contracted for with Pietro Santi, had been concluded, and the steep portable stairs again been removed. She complained of a pain in the waist which Dr. Bambaren attributed to the tumours, I to a mere cold.

Santa Maria the Minister for the Interior embarked this day for Pisco to inaugurate the railway from that Port to Ica. He was accompanied by José Francisco Canevaro, the contractor of the line, and many friends of the latter.

By the North Steamer neither Enriqueta nor I received letters from Rosa and Juan, but Schutte wrote Garland that he and the family would erelong remove to their old apartments in Paris. Mejsier \& Co. who sent me B/ Lading of the dining-room furniture bought by Juan for me, wrote that bating the damage done by the conflagrations, to which I have already referred, Paris bore the same aspect as before the siege. Fifty thousand labourers were said to be at work to repair the injury done. The German troops were returning in masses to their own country. Arthur Donner, brother of him who had died in a French hospital in consequence of the wound received in Mars la Tour, had amongst others rejoined his family in Altona, from which place I also learned that Mrs. Hesse, whether wife or widow of the rich Isaac I did not recollect, but whom I well recollected under the nickname of Countess Amalia, by which she was known and which she owed to the haughty airs she used to give herself, had in a moment of mental derangement thrown herself from the window of her house, and been killed on the spot. On the $1^{\text {st }}$ July the King of Italy had removed the capital from Florence to Rome and been followed thither by the foreign diplomats accredited to him.

Sunday, $23^{\text {rd }}$ of July. In the course of last week Nicolas Pierola the [...] resigned his post and was succeded by Camil [...] [268] Carrillo, hitherto 
commander of a Peruvian man-of-war, a particularly honest man, but certainly not versed in financial affairs.

From Monday, $24^{\text {th }}$ to Thursday, $27^{\text {th }}$ of July. A very severe cold in the throat prevented Mr. Coleman from coming to my office. I had thus many leisure hours at my disposal of which I availed myself to take long walks, and to ascend San Cristoval more than once.

Friday, $28^{\text {th }}$ of July. This day commenced the civic festivities to solemnize the fiftieth anniversary of the Independence of Perú. Many of the Diplomatic and Consular agents presented their respects to the President. I was not of the number.

Saturday, $29^{\text {th }}$ of July. Early in the morning I took a fatiguing walk, of which I may as well give the particulars. I walked as far as Amancaes, where I intended to cross over to Lurigancho by a pass in the hills, comparatively low, but missing the same I kept too much to the right and had to climb up a very steep and high ascent covered with prickly and stiff cactuses, which I had necessarily to avoid, and with many projecting grey stones, by taking hold of which I could swing myself up, but more than once I found the ground so slippery that I had to creep on all fours. Having reached the top after great exertions, I found myself on a level piece of ground, where all bushes and stones had been cleared away. Thence I continued my walk over the ridge of hills, strewn with enormous blocks, and descended one of the many stony gulleys into the Lurigancho Valley, where I walked at a very rapid pace along the sandy carriage road between the cultivated fields to the left, and the chain of hills to the right till I reached the other saddle behind the convent of the Descalzos, which route, so frequently trod by me, brought me back to Lima.

Horse races were held outside what was once the Juan Simon gate. All the young Garlands went and came home highly pleased; they said that it had been a grand affair, and that all the beau-monde of Lima had been out.

Sunday, $30^{\text {th }}$ of July. A review was held in Amancaes.

In the evening there was a dramatic performance by ama[_] in the German Club Rooms to which Lembcke the President [...] [269] me a ticket. I went at 8 O'clock; as soon as Mr. Otten, the successor of William Müller in the house of Ph. Ott \& Co., who was Vice-president, observed me, he conducted me to a room where many ladies and some gentlemen were assembled, of whom I only recognized Mr. Westphal and his lady. The large room, formerly the counting-house of Campo, was appropriated for the spectators, whilst the small adjoining one, the partition wall being removed, served for the stage. Otten gave me a seat in the fourth row, but when Lembcke came he called me to him and assigned to me an arm-chair close to his wife, at the left extremity 
of the first row, where I could see and hear extremely well. The performance commenced with the overture from William Tell, splendidly played on the piano by the two brothers Guzman; next came a short comedy by Kotzebue "Die Zerstreuten" - the oblivious, or absent - very amusing, and which was well represented. It was succeeded by two musical pieces, an Andante for the piano and Violincello, and a duet from Lucia, for bass and tenor, accompanied by the piano. In the Petite pièce, "Wie Denken sie über Russland" (what do you think about Russia?) the four performers, and especially a Mr. Thiessen, a shop-keeper in the portales, who acted the part of a lady, did extremely well, and were all called before the curtain. The same must be said of the last, a farce "Wer iszt Mit" (who dines with us) in which the actors imitated the Berlin dialect, committing most stupendous grammatical errors, for which the lower classes of the Berlin population are notorious; I could not understand all that was said, as little was I able to make out the plot. It was over at 12.15, when I walked home in a wet night. At Lembcke's solicitation I consented to be a member of the club; but made the stipulation that I should not be expected to attend except on extraordinary occasions.

Monday, $37^{\text {st }}$ of July 1871 . The integrity of the new finance minister was extolled to the skies, and was put in juxtaposition with the character of his predecessor Nicolas Pierola, of whom it was well known that whilst in office his financial operations had invariably had two objects, firstly, his own private advantage, and secondly, the interest of the State. The house of Dreyfus, I was told, had paid to the treasury in anticipation eight or ten months instalments and refused making any further advance, whilst at the same time - and this was certainly very strange - they had given acceptan $[\ldots]$ the Providencia had discounted to the amount of S/300.000 [...] [270] Canevaro had lent $\mathrm{S} / 100,000$, Valdeavellano another $\mathrm{S} / 100,000$ and thus the new finance minister had scraped together half a million, sufficient for the most urgent necessities of the day, but how he would get on hereafter surpassed my comprehension.

Tuesday, $7^{\text {st }}$ of August. This day was celebrated the funeral of General Iturregui of Trujillo; his widow, to whom he left a very handsome fortune, was a sister of the brothers Gonsalez, Agustin, Alfonso and Vicente. Of late he had been residing in Lima, and when he met me in the streets, hardly ever sober, used to stop me and talk a good deal of nonsense.

Wednesday, $2^{\text {nd }}$ of August. A dinner was given in the palace to the Diplomatic and Consular Corps, to which I went at 6 O'clock in uniform. I entered just at the same time with Escardó, and with him I went up to shake hands with the President. After a delay of twenty minutes the party adjourned from the reception room to the long and narrow dining apartment, well fitted up under 
Pezet's administration. We were about 60 odd; the dinner provided by Lecaros being exceedingly good I ate a little more that was my wont. Present were the President and the Ministry, the Diplomatic and Consular Corps, and the Chiefs of the various departments of the Administration, such as Muñoz, Vicepresident of the Comision Permanente, the President, Benavides, being absent in Arequipa; Ribeyro, President of the Supreme Court, with the two fiscales Ureta, and Paz-Soldan; the Chief of the mint; Osorez, Director de Rentas, the same whose acquaintance I had made when visiting Chota in 1842; Nemesio Orbegoso, Alcalde de la Municipalidad; Vanutelli, Delegate of his Holiness; Tordoya, Bishop of Tiberiopolis, and some more. I sat between Orbegoso to my left, and Jose Vicente Oyague to my right, and had thus an opportunity to converse a little; next to Orbegoso sat Osorez, next to José Vicente Oyague, Rafael Canevaro, Dutch, then George Elster Russian Consul; opposite to me Bernardo Roca y Garzon, Papal Consul. Oyague, as it was his habit, got very tipsy and talked a good deal, even in French; from the other side of the table José Gregorio Paz-Soldan, for whom it was difficult to keep sober on such an occasion, also made himself heard.

I was home by 9 O'clock, being I believe the first to leave after we $[\ldots]$ the table and coffee been handed round. [271]

Thursday, $3^{\text {rd }}$ of August 1871. The letter which I received from Juan was dated Kissingen. On his way thither he had passed through Paris; he spoke of course of the damage which many of the buildings had sustained, but dilated mostly on the ruinous state of the Hotel de Ville. Foreigners and French were already returning in great numbers. The Schuttes had found their house but little injured; only one shell had passed through it, broken some furniture, and burst in the dining apartment of the servants below, fortunately at a moment when they were not in the room.

All advices received from Europe agreed in stating that the French Govt. with Thiers at their head did not meet with the slightest difficulty in raising the loans required for paying off the German War indemnity. The terms upon which these loans were concluded did not come to my knowledge.

Agusto Althaus received a telegraphic dispatch via Jamaica from his sister Grimaneza, Mrs. Cotes, who informed him of the sudden death of her husband Don Manuel Maria, who at the time of the steamer's departure was apparently enjoying perfect health. Cotes had been in Lima the previous year about the same time with Mr. Ochsenius for the purpose of dissolving his partnership with his brother-in-law Emilio Althaus. We then saw him pretty frequently in our own house, and at Enriqueta's on Thursdays when he was full of life and prospects. 
Here in Lima Balta's brother Juan Francisco had withdrawn from the Ministry of War and Presidency of the Council. It was said that he wanted to be Deputy for Chancay to the next Congress; his place was taken by General Allende. The other ministers Santa Maria, Aranivar, and Loayza were also to go out, but the President was again talked over by General Echenique's clique.

Sunday, $6^{\text {th }}$ of August was the first Sunday for many months that I did not pay any visits. In the forenoon Manuel Pardo made a great display of his electioneering forces, and I was desirous to see something of what was going on. At about 1.30 Mr. Coleman and I went over the bridge and were just in time to see many of his partizans, some well dressed; others of the lower classes streaming in uninterrupted files to the Plaza del Acho, where he gave a bullfight at his own expense. Don Manuel had introduced amongst his partizans something like [...] subordination, and to this was owing the great order which [...] [272] all their proceedings. In each of the five parishes into which Lima is divided, one of his devoted friends, who resided in that quarter of the town and had some influence amongst his neighbours - for instance José de la Riva Agüero in Santa Ana, Juan Baso Basombrio in San Marcelo - took the lead. Under their orders were men, also of some standing in society who commanded 100 of the lower classes, and these again were divided in knots of 10, each with its Chief. To this day's gathering, the parish of Santa Ana had contributed above 2000, a still greater number the parish of El Sagrario. Callao furnished its contingent which came in an express train, of course paid for by Pardo. This vast concourse of people, in numberless bands each with its leader and a standard with an inscription, defiled in the greatest order and tranquillity before the windows of the palace, where the President, family, and friends looked from the balconies, then over the bridge to the bull-ring, where they arrived at about 3. This building which can hold about 12,00o was crowded; two or three thousand who could not obtain access remained outside. To each who asked for it, a draw of pisco and a small loaf with a slice of pork, or sausage, and onions, called in Lima a "butifarro", were handed gratis. In the Oval before the bull-ring some soldiers and policemen were drawn up, but as the multitude behaved in the most orderly manner there was no motive for their interference. At 4 O'clock all was over, and even Pardo's enemies acknowledged that it was a grand success. From the Paris paper "El Correo de Ultramar" of $30^{\text {th }}$ June, I took the following figures relative to French finances. The National Assembly having authorized the Executive to raise a loan to the amount of two thousand millions of francs, the Minister of Finance took the necessary steps to make it known all over the globe, and in an incredible short time four thousand five hundred millions were subscribed, viz. two thousand five 
hundred millions in Paris, one thousand millions in the rest of France, and nearly one thousand millions in foreign countries. The rate at which this loan was issued was $82 \%$, the interest, $6 \%$ p.a. Thiers, in his speech of $28^{\text {th }}$ or $29^{\text {th }}$ June stated that during the last two years of the second empire the budget had risen to 2,150,000,00o francs, and that the expenses of France in 1870 had run up to $3,474,000,000$; for 1871 the budget came to $26[\ldots]$ [273] francs, of which 930 millions were for war expenses, whilst the ordinary revenue was calculated at 1,660,000,00o.

Sunday, $13^{\text {th }}$ of August 1871. The only occurrences of some importance in the course of last week, were firstly: The sentence of the Supreme Court, of the $8^{\text {th }}$, which confirmed the sentence of the Judge of the first instance, and of the Superior Court, to the effect that Colonel Silvestre Gutierrez and several other officers accused of ordering the flogging of Col. Garrido were not to be placed at liberty on bail. Secondly: A circular from Santa Maria, Minister for the Interior, in which he ordered the prefects of the various departments of the Republic to have the elections for President and Vice-Presidents fixed for the first Sunday in March 1872, instead of May as hitherto ordained. The reason given for this alteration was that May was fixed on at a time when it was calculated that a new President would come into power in the month of October, as was the case with San Roman in 1862, but as the present President would go out on the $2^{\text {nd }}$ August, it followed that the elections had also to take place two months previously.

Emilio Duval, who, it will be remembered, together with Pinckernelli, was the first clerk who came out from Europe for the firm of H. Witt \& S. in 1852, who had afterwards in various capacities roved all over Perú, and lately gone on a visit to Europe, returned, of course I had some conversation with him, and it was his opinion that the damage done to Paris during the siege and the insurrection had certainly been great, but been much exaggerated in the papers.

Monday, $14^{\text {th }}$ of August. I rose early and was before 8 O'clock in the Callao Terminus to accompany my friend Bartolomé Araoz on board the steamer in which he intended to leave for Europe. He came a few minutes later, together with his son-in-law Rufino Torrico, and his relation José Maria Peña. On our arrival in Callao, instead of going at once on board, we went to breakfast at the Commercial Hotel, a very decent place, where I contented myself with a cup of tea and bread and butter; next to us sat the two Althaus, and Rufino Echenique who accompanied young Manuel Cotes, also going to Europe. When we were rowed on board the steamer "Arequipa" we passed under part of the skeleton woodwork of great breadth, which when filled up with stones was to form 
one side of the Muell [...] or dock the construction of which though so much opposed was [...] [274] last being carried into effect. The "Arequipa", a beautiful large new steamer, was lying high out of water. Don Bartolomé had taken one of the berths on the main deck, which are certainly cooler, but where the motion is more felt than in the berths below on a level with the dining saloon. I much regretted parting with Don Bartolomé, for during the last one or two years when in Lima, he had never failed to pass his evenings with me twice or three times a week; his conversation though not always very interesting was amusing and agreeable.

Tuesday, $15^{\text {th }}$ of August. Dia de la Asuncion. I received a note from the architect Villa in which he informed me that as the repairs of my house were nearly concluded, he thought it unnecessary to attend to them any further, to which advice, unexpected as it was, I merely answered requesting him to send me his account down to the $14^{\text {th }}$ of this month. The cause of this sudden rupture was ostensibly the complaint which I had made to Tomás Muñoz, the Sobrestante, or Villa's second in command, of the very high daily wages which had been paid to a carpenter, say $\$ 5$. The real motive was Villa's knowledge of our being dissatisfied with him and his consequent apprehension that we would turn him off, and thus he thought it more to his honor to break with us before we broke with him. For the moment we found ourselves in what is called a fix, for all the carpenters, many of them clever men, left me, the work they had commenced remaining unfinished; also the masons I should have to pay off on the following day.

Horse races were held this day, at which two riders were severely injured, both by running their legs against the wooden railing; the one, Gortsch, cashkeeper and cousin of the Bergmanns, was likely to remain lame for all his lifetime; the bone of his leg having been crushed into splinters; the other, a Peruvian, son of the late George Smith of Iquique, was less injured but would probably be obliged to keep his bed for seven or eight weeks.

Sunday, $20^{\text {th }}$ of August. At 12 O'clock Garland, three of his sons and myself drove out to the Chacra of San Isidro, the property of Don José Gregorio PazSoldan. We had made up our mind to pass a tedious day, but to offend Don Gregorio, the Fiscal of the Supreme Court, would have been [_] perilous affair, and thus we sacrificed our pleasure to our interest. Mari [...] [275] Enriqueta had found admssible pretences for staying away. A party of fifty persons assembled, of whom I knew but few, and none intimately. The host's wife, Doña Jesus, his daughter Petita with her husband Carlos, and his two brothers Pedro and Mariano Felipe were not there - certainly very strange! Of those present I recognized Malinowski, the Polish engineer; Gregorio Benavides, Bundsen, the German Chargé, Cipriano Correa and family, the Doctor's son, 
the "fat boy", José Luis with his wife, and not less than six Canevaros, José the head of the firm, Bernardo, Rafael, the Dutch Consul, Felipe, Octavio and Francisco an engineer. This large attendance from one single family I thought rather unusual, but a solution for it I found in the following circumstance. The Canevaros had a large share in the former consignment of guano to the United Kingdom where the company's correspondents were the firm of Thomson Bonar \& Co. in London. Against both the Company and this London house, the Government had commenced a suit for irregularities in accounts. Agents had been sent to England to bring the case before the Court of Chancery, but the Canevaros had given in an escrito to the effect that the case should be tried, not in England but by the Supreme Court of Lima, and about this time the Fiscal Paz-Soldan, no doubt very well remunerated, had given a vista advocating Canevaros' demand, and this was in all probability the cause of their temporary friendship. In the chapel belonging to the farm mass was said, at which some of the guests were present; next, a miserable procession walked around the yard. A few rocambor tables were set out, but as to me I knew not how to pass the time. At 2.30 we sat down to a lunch, in reality a complete dinner. The doctor sat in the centre of the table, to his right his colleague, the Fiscal Ureta, to his left the wife of Cipriano Correa, then I, and to my left Elvira, a very young girl, Correa's daughter. Opposite Paz-Soldan his daughter-in-law, to her right Bundsen. The banquet over the whole party, Paz-Soldan somewhat in the wind marched two by two over part of the grounds, I with my young partner, whose grandfather I could be. Then there was cockfighting, finally miserable horse racing. Fortunately however, I had brought my chessmen and board from Lima, and through the intervention of Rafael Canevaro, Bundsen, with whom hitherto I had never exchanged a word, and I, sat down to play a game, which he gained, being by far my superior. He gave me the King's gambit; at first I pushed him hard, but he got out of the scrape, and gained with King, knight and [...] which he made queen. At seven O'clock the party broke up and $[\ldots][276]$ drove home.

Monday, $27^{\text {st }}$ of August. The repairs of the house, which had been at a stand-still since my rupture with Villa, were again taken up. I having made an agreement with a certain Esquibel, who called himself architect, but in reality was nothing but a first-rate carpenter. I paid him 100 Soles monthly and had the firm conviction that I should spend with him less than with Villa, but in contracts for the building of houses, if one escapes Charybdis, one is sure to fall into Scylla. With Villa, to whom I paid a commission on the outlay, I ran the risk that he would spend more than necessary. With Esquibel, whom I paid monthly, it was likely that he would draw out the construction as long as he could. Others who paid a round sum were in danger of having the work badly 
done, and thus it always depended more upon the character of the architect than upon the conditions of the contract.

Esquibel had no sobrestante, and thus I had to rise somewhat past 6 to be ready at 7 O'clock when all the workmen came, whom I had to count one by one; at 10 O'clock they left off, returned at eleven, and then continued till 5 p.m.

Sunday, $27^{\text {th }}$ of August. Emilio Althaus and Maria Luisa Dartnell were this day married in the greatest privacy. I need hardly say that Althaus is the second son of the late Colonel, then General Clemente Althaus. Maria Luisa is the second daughter of the late John Dartnell and of Mercedes, daughter of Juana Valleriestra, widow of Admiral Guise.

Sunday, $3^{\text {rd }}$ of September. By the North Steamer I received a letter from Juan from Homburg near Frankfort on the Maine, from Johannes Limpricht from Marienlyst, a bathing place close to Elsinōer in Zeeland. The Schuttes wrote from Paris. The political advices merely confirmed those received by the previous steamer viz. that the first instalment of the war indemnity, say 1,500,000,000 francs, had been paid, and that accordingly the German troops had abandoned the neighbourhood of Paris.

Monday, $4^{\text {th }}$ of September. To my great surprise Juan Martin Echenique fulfilled the engagements which he had taken upon himself at the time that the Pasco Railway was made over to him with exemplary exactitude. The obligatory notes signed on the $1^{\text {st }}$ June for interest, say $S / 1552.50$ owing to me, and S/310 5 to Felipe Barreda Jr. were paid when they fell due. This day he made good the $2 \%$ on the S/100,00o [...] [277] Bonds of which I held S/12,00o, and consequently I received S/250. To F. Huth \& Co. of London he had made a remittance of $£ 2000$ somewhat more than the company had remained owing to this firm, and finally he sent up to the Cerro the funds required for the continuation of the railway work. This looked very well, but I had the conviction that his means were not sufficient to allow his going on in this manner, and that sooner or later he would be under the necessity of replacing the railway into the Company's hands. Moreover, up to this day he had not come to terms with the miners of the Cerro, and arranged with them the freight they had to pay for the conveyance by train of the ore from the mines to the smelting works; in this manner he had nothing but disburses and no revenue whatsoever.

Sunday, 10 ${ }^{\text {th }}$ of September 1871. This being Garland's birthday, Enriqueta without his knowledge had invited some friends and prepared a very nice supper. There came the usual rocambor players and of ladies Irene, Bazo's wife, the wife of Diego Masias, and her sister Tránsito, Adela, Manuel Velarde's daughter, two of Melchor's daughter's, Rafael's wife and daughter. However, as there was neither music nor dancing, the ladies must have found it rather 
tedious and been glad when at one supper was announced. Guillermo and Alejandro were the whole day and night in Chorrillos, which certainly showed something like a want of affection for their father.

Tuesday, $12^{\text {th }}$ of September 1871. In the evening there was in the German Club Rooms a meeting of the Committee of the German Relief and School association, and of a few gentlemen, viz. Mr. Von Bundsen, Lembcke, Gildemeister, Charles Pflucker, and I. The elder Brunswig was in the chair; he proposed to engage a German protestant clergyman for the German colony residing in Lima, and after a protracted discussion the Committee was authorized to take the necessary steps to obtain this object; a subscription was opened, to which W. Von Bundsen signed \$10o yearly, the other four mentioned gentlemen $\$ 200$ each.

Wednesday, $13^{\text {th }}$ of September. The Banco de Lima and the Insurance Coy. "Lima" of both which establishments I continued to be one of the Directors, progressed prosperously, the former with long and rapid strides. The same could not be said of the Constructora; several of the Directors were very irregular in their attendance, and though the Gerentes had laid before us more than one plan of greater or lesser importance for the construction of houses, none had as yet [_] accepted This day however he approved the contract concluded with [278] the Municipality of Lima for the building of a new market place for the sum of $S / 725,000$. This was to be built on the spot known as the Paseo de Aguas, to the right when going to the Alameda de los Descalzos. I had been there in the course of last week and been surprised at the alterations which had been made. The old ruinous structure had been razed to the ground, and further on many bushes and masses of rubbish been cleared away, so that there was now a large open place ready to receive the foundation of the new building. At the earnest request of the architect Esquibel, to whom I had complained that the work in my house did not proceed as quickly as it should, I made a separate contract with some masons, who signed themselves Pinto \& Co., and who for the sum of $S / 1800$ I furnishing the materials, obliged themselves to conclude all the masonry work, of which much remained still to be done. I had engaged as sobrestante a certain Don Gavino, a good kind of fellow, which precluded the necessity of my rising so early in the morning. Four carpenters were also at work, and the requisite number of common labourers - peones. Every Saturday afternoon I myself had to pay them all, which, whilst I employed Villa, he had been in the habit of doing.

We learned from Arequipa that the partizans of the different candidates for the Presidency had more than one bloody affray. It was said that the Echeniquistas were generally the assailants, but I will not affirm that this was 
really the case. After the resignation of the Prefect Chocano, Government had named my good friend Dr. Pedro José Bustamante, a man of the best intentions, but without sufficient energy, and who after a few days experience, no doubt aware of his incapacity, threw up the post, which resignation had not yet been admitted by the Lima Government. On the $20^{\text {th }}$ August, on occasion of my visit to Dr. Paz-Soldan's farm, I said a few words about the suit instituted by the Peruvian Government against the National Guano Coy. and their correspondents in London. I will give here some further details, which, though they may perhaps be repetitions of previous notes on the same subject scattered here and there in my diary, may serve to elucidate the question. When the President Castilla conceded the consignment of guano to a Peruvian company, this Company resided in Lima and consisted of the following: Carlos Delgado, Delgado Brothers and Sons, José F. Canevaro, F. S. Gordillo, Clemente Ortiz de Villate, Felipe Barreda and Manuel Pardo, who distributed their respective [...] [279] amongst their friends; thus for instance, my son Juan interested himself for 50,000 $\$$ under Villate's name. Manuel Pardo, about the time that he presented himself as Candidate for the Presidency of the Republic, made over his share by public document to José Francisco Canevaro. For some time the business went on smoothly, but after the lapse of years the Peruvian Govt. discovered in the accounts handed them by the company great irregularities, even frauds, which they affirmed came up to the enormous sum of $£ 2,000,000$ Stg. Fiscal agents were sent over to examine the accounts, both of the company and of their Correspondents Thomson Bonar \& Co. The first who went were: Dr. Manuel Ortiz de Zevallos, Col. Joaquin Torrico, and Juan José Araoz, accompanied by Guillermo Bogardus, the original denouncer. Erelong they quarrelled amongst themselves when they were replaced by Ruso and La Torrebueno, Bogardus always remaining, for without him they were at a loss how to proceed. On the $20^{\text {th }} \mathrm{I}$ already mentioned that the Fiscal Paz-Soldan had given a favourable vista to the petition of Rafael Canevaro, who in representation of the National Company very properly insisted upon the case being judged in Lima, where the original contractors resided, and not in London, where their agents or correspondents who depended from them, lived. José Aranivar, [...] Minister of Finance, who, it was said, also lent a willing ear to Canevaro's "weighty" arguments, was of the same opinion, and consequently a decree was signed by the President and countersigned by this Minister, which conceded everything, Canevaro had asked for; but hardly had it been published, when General Echenique and his friends bestirred themselves when Col. Torrico took up the cudgels, and in a day or two such a storm was raised that a new decree under the innocent 
name of an "aclaratoria", or explanatory document, in every respect reversed the previous one, and the case would now be pleaded in the London Court of Chancery.

Sunday, $17^{\text {th }}$ of September 1871 . The Ultra-Montane, or clerical party, which formed but a small proportion of the Lima population, made this day a rather unsuccessful attempt at a popular demonstration, by which they intended to prove to the Italian colony resident in Lima, and to their Peruvian sympathisers, that there existed in the Capital of Perú some men and women in whose eyes the incorporation of Rome with the Kingdom of Italy, and the despoilment of the Pope of his temporal power, were deeds [...] ecrable sacrilege. I went to see what was going on. At about [...] [280] 2 p.m. a procession started from the Church of San Pedro, and paraded through many of the principal streets of Lima. The portrait of the Pope, encircled by a wreath of flowers, and several standards with the inscriptions "Viva el Papa", "Viva la Religion Catolica", "Viva Jesu Cristo", were carried aloof. Around them crowded hundreds of colored women, black and brown, a dense mass, who occupied nearly a cuadra, and a number of ragamuffin boys who amused themselves with throwing stones at some gentlemen who were standing in the balcony of the "Club de la Union", and who had the imprudence not to take off their hats. All waved their handkerchiefs, shrieked, and shouted the words which were inscribed on their flags, and one with another made a tremendous uproar. Of decently dressed men there were perhaps 200, amongst whom I noted Enriqueta's compadre, the Col. Juan N. Vargas, Francisco de Paula Boza, formerly in Candamo's employ, and a few others known to me. The prime mover was Evaristo GomezSanchez, who had a peculiar object in view; he was one of the candidates for the Presidency of the Republic, and his adherents were exclusively those of the clerical party. When he passed our house, he walked to the left of the Pope's portrait and shouted himself hoarse with the various vivas. Of friars and clergymen I saw but few: I was however assured that the Bishop Valle of Huanuco was amongst them. To celebrate Enriqueta's birthday, Mariquita and I dined with the family Garland; the other guests were solely the Franciscan friar Zapata, ignorant and stupid, but good natured, and Emilio Duval above mentioned whom we must not confound with the thief Charles Duval, or with the North-American Alfred Duval, who with his plausible but unproductive schemes had caused to Garland the loss of many thousands of dollars.

Wednesday, $20^{\text {th }}$ of September. When this day dawned Don Bernardo Roca y Garzon, Papal Consul, found to his astonishment that the escutcheon of his Holiness had been daubed over with black paint, only the tiara had not been touched. 
It was the first anniversary of the Plebiscite which on the $20^{\text {th }}$ September 1870 proclaimed almost unanimously all over the Papal States that the population was in favor of an incorporation with the Kingdom of Italy. To celebrate this fortunate event [...] [281] meetings were announced in the papers. The one, of the Italians resident in Lima - the other of their Peruvian sympathizers. The former, who made this day a complete holiday by shutting up all their shops, stores, and mercantile establishments assembled in the garden de la Aurora in a quiet and tranquil manner. Very different was the result of the meeting of the Peruvians who in the very teeth of a prohibition published by the local authorities invaded in great numbers, some said even as many as 20,000 - which I looked upon as a tremendous exaggeration - the Plaza de Bolivar. Dr. Francisco Flores Chinarro, member of la Comision Permanente, and one of the editors of the daily paper "El Nacional" ascended a table, but hardly had he commenced his harangue to the populace when from all sides an armed force of the policemen, or celadores, who had been lying in ambush, rushed in. They dispersed the multitude, dealt blows right and left, inflicted some wounds and many contusions, and carried off to prison a considerable number of persons, amongst whom not a few of the higher classes. Polis, the Belgian Vice-Consul, for instance in whose favor José V. Oyague, Consul General, had to intercede before he was again let out, after a few hours incarceration.

In the evening the students of San Carlos assembled before the house of Santa Maria, Minister for the Interior, where they made a most infernal noise, which they styled a serenade. Of course, the police appeared, the collegians scampered away, and none was caught.

Saturday, $23^{\text {rd }}$ of September 1871. Within these last few days the printingoffice of "El Nacional" was more than once forcibly entered by the police, who were in search of the editors Chinarro, Chacaltana, Valle, and Aramburú, but all four having received timely advice, had made their escape and taken refuge in the Legation of the North German Confederation.

Wednesday, $27^{\text {th }}$ of September. Last night a dreadful crime was committed in the streets of Lima. Dr. John Gallagher was returning home at about 10.20, and was already close to his house in the Calle del Banco del Herrador, on the opposite side, when two tall men, whom by their looks he believed to be negroes, allowed him to pass by and at the very moment when he found himself between the two, one of them stabbed him in the right side, just above the ribs. The Doctor, who had just strength enough to reach [_] house and to give these particulars, said he had distinctly felt [...] [282] when the knife was drawn out the assassin gave a twist, so as to increase the size of the wound. The two men got off, and though it was a clear moonlight night, none of the policemen at the corners of the street had seen anybody run away. Alejandro 
Garland, who passed by on his way to a dance at Cipriano Correa's, heard the shrieks of the females of the family and immediately went off in search of medical assistance.

This morning I went to enquire how the Doctor was, when I was received by the unmarried daughter Alice, who, pale as death, told me that her father was as well as could be expected.

Thursday, $28^{\text {th }}$. The Doctor lingered on, and on

Friday, $29^{\text {th }}$ at somewhat past 10 a.m. he expired. Several people were taken up on suspicion, but I much feared that the perpetrators would never be apprehended, notwithstanding the reward of S/5000 offered for their discovery, coupled with a promise of secrecy, which was clearly set forth in the placards stuck up on the corner of the streets. There was not the slightest doubt, but that revenge had been the cause of this murder, for the Doctor who was always involved in lawsuits and hardly ever lost a case in the Supreme Tribunal, though the Inferiour Courts might have sentenced against him, had many many enemies. Only a few days previously he had gained a suit against the Pandos, who by the sentence of the Supreme Court were deprived of the house which the Doctor claimed; thus the Pandos were suspected of being concerned in the deed, whether justly, or unjustly I could not say. On me it made a deep impression. I had known the Doctor for nearly forty years and always been on very good terms with him. He used to come to our house, and I visited his family. On Sundays in the forenoon we frequently met at different houses; the Sunday before last I had seen him at Ribeyro's when he was low spirited, having received bad news of the state of the health of his son Archibald in England. Generally he was joyous, boisterous, full of life and spirits, of plans and projects. By my calculation he reached the age of 65 . In the evening at 10 p.m. I accompanied the corpse to San Francisco, and on

Saturday, $30^{\text {th }}$ of September in the morning, was present at the funeral. On both occasions the concourse of people was very great. Hardly an Englishman was wanting, and a great many Limeños of the best [...] [283] families attended.

In the course of this and the previous day the President José Balta and his elder brother Juan Francisco, both just returned - the former from an estate in the North, lately purchased by him, the latter from Iquique, where he possessed a salitrera - made several attempts to bring about a reconciliation between the various candidates for the Presidency of the Republic. Balta had cited to the palace Manuel Pardo, José Rufino Echenique and Toribio Ureta; he represented to them that their patriotism demanded that they should make some concession the one to the other, that the Republic suffered by their dissensions etc., but as might have been foreseen, none was inclined to give 
way, and the conferences led to nothing. The Minister of Finances Camilo Carrillo gave in his resignation, and his post was occupied by Felipe Masias - el sordo - who in Pezet's times had been oficial Mayor of the same ministry.

Sunday, ${ }^{\text {st }}$ of October 1871. This Sunday, for the first time since our removal to our new house, my wife had again her usual Sunday visitors, which to me was a real pleasure, for I knew that she liked to have somebody with her with whom to converse. Those who came were: Manuel Espantoso with his sons, old Mr. Basagoytia, Dr. M. F. Benavides, President of the Comision Permanente, and Dr. Bruno Bueno, ex-Vocal of the Superior Court. The latter related that he had seen the knife with which poor Gallagher had been stabled; it had a wooden handle, and the point had lately been sharpened on both sides. The murderer had been a tall man; his accomplice, of shorter stature, had also carried a knife, but had run off at the sudden appearance of a woman, who lived close by; this latter, the samba, had a sister with whom one of the brothers Pando cohabited. Dr. Ribeyro added that in the Comercio of the $26^{\text {th }}$, the same day of the murder, an article had appeared abusing the members of the Supreme Court in very unmeasured terms for their verdict in favor of Gallagher against the Pandos, which sentence had been given unanimously by the seven Vocales in conformity with the vista-fiscal.

Monday, $2^{\text {nd }}$ of October. By the steamer which arrived last night, Alfred Böhl returned from Europe. Juan wrote from Baden-Baden on the $26^{\text {th }}$ August, Sieveking on the $28^{\text {th }}$ from Altona; he informed me of the death of [_] Willink, my mother's cousin, and his brother-in-law at the age of [...] [284] Sofia Bergmann, the wife of Dreyfus, was suffering from dropsy and was not expected to live many months longer. Advice was also received of the death of Archibald Gallagher, who had expired in a village close to London, where he had been under the care of his aunt Mrs. Went.

Tuesday, $3^{\text {rd }}$ of October 1871. In a meeting of the Directory of the Insurance Company "Lima", Manuel Pardo, José Canevaro, and Arthur Heeren threw up their posts; and in lieu of them were chosen Rafael Canevaro, José Maria Peña, a native of the Argentine Provinces, married to the sister of the brothers Costas, and Pedro Noriega, of the firm of Valdeavellano \& Co.

Saturday, $7^{\text {th }}$ of October. I learned from Alfred Böhl, upon whom I called, and who had returned my visit, that Mr. William Gibbs, the Chief of the house, and till of late an extremely active man, my senior by about ten years, had lost the use of one of his legs, that he hardly ever came to town, and that he generally sojourned on his estate Tyntsfield near Bristol, where he was moved about in a rolling chair; his intellect remained unclowded. This was not the case with another partner, George Thomas Davy, of about my age, who also showed 
himself but seldom in the office; he was strong in body, but weak in mind. Neither did Henry Gibbs, the son of George Henry, who, the elder brother of William, died many many years back in Venice, trouble himself much about business; he resided in a splendid mansion in Regent's Park, where he saw the best and most aristocratic society, and in the Summer season never failed to make an excursion to the Continent. The active partners were: Edward Stubbs, late of Lima, and George Gibbs, son of the Revd. Joseph brother of George Henry, and William.

Böhl's only sister Antonia, a very young lady, had lost her husband Mr. Vogler of Brussels. Riva Agüero delivered to me S/65,00o in Government Bonds, as collateral security for the $\mathrm{S} / 50,000$ so often spoken of, lent by me to the Pasco Railway Company.

In celebration of Alejandro's birthday all the Garlands dined with us, which of late had been no uncommon occurrence owing to the illness of their cook.

Sunday, $8^{\text {th }}$ of October. About a week back S/6o,ooo more or less of bank notes were stolen from the Banco del Perú. The two managers Emilio Althaus and Vicente Espantoso, as well as the President [...] [285] Directory Alexander Ruden, had felt no inclination to write themselves their Signatures to a lot of new notes. They therefore had them lithographed in their own office by a French artist, who called in one of his workmen to assist him, and this latter managed to walk off with a considerable number of notes of $\mathrm{S} / 4$ each amounting more or less to the above sum. This day I learned in my round of visits that $S / 32,000$ had been recovered.

When I left my house for these my usual calls, I observed that the foot pavement on both sides of the street was occupied by an uninterrupted file of men of all descriptions, some in coats, others in ponchos who directed their steps towards la Plaza de Bolivar. I followed and was stopped by José de la Riva Agüero, who walking in the middle of the street close to a standard-bearer, told me that this was a great demonstration of Pardo's partizans, who were to meet in the quinta of Juan Rivera. I hastened to the corner of the street which leads to the quinta and saw them all pass by, perhaps five or six thousand in number, each of the five parishes of Lima distinguished by a different flag. I shook hands with Manuel Pardo, and J. A. Garcia y Garcia, who walked at the head of the procession; a little further on I conversed a few words with General Miguel Medina and Melchor Velarde, who belonged to Pardo's body-guard. I did not enter the quinta, but already in the afternoon of the same day it became known that a great many speeches had been delivered, Pardo's certainly of an inflammatory character; he had made use of these words "We are the majority, and must triumph, por derecho, ó por hecho." When the meeting had broken 
up, its members returned to their homes, they at the corner of San José came in contact with the partizans of Ureta, who had assembled in the Plaza de Acho; a scuffle ensued, but the combatants were soon dispersed by the police; also the Echeniquistas had had their meeting, but did not make themselves conspicuous.

Monday, $9^{\text {th }}$ of October 1871. Dr. Ureta's paper, the "Republica", of this day in its leading article contained severe and well merited strictures on Manuel Pardo's speech of the preceding day; it said, "he who threatens, the first time he meets with an obstacle in his political carreer, and who cannot govern his passions, is not a fit person for ruling a nation."

Saturday, $14^{\text {th }}$ of October. In the course of the week advices were received [...] Europe brought to Colon by the French Steamer. [_] were for the [...] [286] part only confirmations of those received by last mail. The French Chamber of Deputies continued to hold its sittings in Versailles, and Thier's lease of power had been prolonged for three years more. Here in Lima great excitement prevailed ever since Monday last. The municipality was continually beleagured by persons of all classes who asked for cards of citizenship, without presenting which no one had a right to vote, but as almost all the members of this body, including the Alcalde Nemesio Orbegoso, were staunch adherents of Echenique, the greatest partiality prevailed in the delivery of those certificates, and the partizans of the civil candidates Pardo and Ureta complained with justice that theirs were withheld from them. To revenge themselves for this decided hostility shown to them by Echenique and his party, the daily papers which wrote in the interest of the civil candidates published many violent diatribes against Echenique, and the "Nacional" distinguished itself particularly by reproducing a long correspondence which had passed in the years 1856 and 1857 between Echenique, then out of power, and his friend and partizan General Morote on the one, and Hermann Lohmer (in 1854 my wife's and my travelling companion) on the other hand, which treated on the latters recruiting four hundred North-Americans with whom Perú was to be invaded and Echenique restored to the Supreme power. The cuttings from the papers go affixed in appendix under No 8/9. As on the following day, Sunday, the elections for the Presidency were to begin, it was generally feared that the disorders which are never wanting on such and similar occasions, would this time be of so serious a nature as to deter the usual vendors of provisions from coming to the market-place, the consequence of which was that there were few families in Lima who did not on this day lay in their stock of eatables if not for 48 , at least for 24 hours. 
Sunday, $15^{\text {th }}$ of October. Being desirous to see with my own eyes what aspect Lima wore on this memorable day, I left my house between 8 and 9, though rather against the wish of my wife, who called it a foolhardy expedition; nevertheless, I was back before breakfast safe and sound, and even without being able to boast that I had noted anything out of the way. The streets, it is true, were more deserted than I had [_] seen them before; the plazas, where the polling-booths or "tabla [...] [287] were erected, were however crowded with people. The only street door which I found wide open was that of Mariano Felipe Paz-Soldan's house, others were half shut. When I came to the Plaza de Santa Ana, then in the power of the Pardistas, I was told that during the night they and the Echeniquistas had been fighting and that the latter had been forced to retire. San Marcelo was in the hands of the same party. Here I met a certain Valladares, a desperate fellow, a mason by profession and partner of Pinto \& Co., with whom I had made the contract for the work in my house; he offered to accompany me, which I declined with thanks, saying that I had no fear. Next, in San Marcelo I accosted a tall negro who carried a flag in his hand; this, I asked, "is Manuel Pardo's flag?" - "no", answered he, "it is one which we have taken from the Echeniquistas". In the Plaza Mayor there was loud huzzaing for Pardo, and a few minutes later he passed our house on his way to Santa Ana, preceeded by Correa y Garay, and accompanied by Malinowski the Pole, and a few others. I was told that about 3 or 4 a.m. a troop of Echeniquistas, joined by some partizans of Evaristo Gomez-Sanchez, had come in the direction of Santo Domingo with the object of making their way to the Plaza Mayor, but had been fallen on by a troop of Pardistas, and been scattered to the winds. The remainder of the day passed over quietly.

From Monday, $16^{\text {th }}$ to Wednesday, $18^{\text {th }}$ of October. The town continued in a state of great excitement; shops and stores were closed; the street doors of dwelling houses and of the banks stood half open, and no business whatever was done. In the night from Saturday to Sunday a Chilean called Galvez mounted on a fine white horse, had been dangerously wounded near the Church of San Sebastian. If I was not mistaken, the shot which struck him had parted from a crowd of Pardo's adherents. On Monday the "tabladillos" were exclusively in the hands of this party; however, few people walked up to deliver their vote. On Tuesday the friends of Ureta erected another polling-booth in the Plazuela of Santo Domingo; those of Pardo fell on it and destroyed it. On Wednesday morning a "bando" or proclamation was published, stating that thenceforth the military force would protect every tabladillo which might be constructed, and accordingly each [...] three candidates had his own mesa 
with his own friends who [...] [288] only vote for the electors of their party; these were technically called dualidad and trialidad; and the Congress would have to decide which election was legal, perhaps also, as it had happened in the last Congress, all might be annulled, and the Capital of the Republic again remain without its representative in the legislative body.

This same day, Wednesday, the students of medicine called here those of San Fernando, availing themselves of the permission given in the above proclamation, also erected a "tabladillo" where they went through all the forms of polling in the most approved and regular manner, but with the object, in which they completely succeededed, of ridiculing the Minister of the Interior Santa Maria.

Thursday, $19^{\text {th }}$ of October. The town was quiet as in normal times. The polling at the different "tabladillos" went on with regularity and without interruption.

Saturday, $21^{\text {st }}$ of October. The masons with whom I had made the contract as said some pages back, gave me a great deal of trouble, the more so as Esquibel, whose duty it was to direct all the repairs, was a stupid fellow and had no power whatever over them.

Sunday, $22^{\text {nd }}$. In my round of visits I always learned some news. This day I was told that José Aranivar, the Minister, and La Torre, Master of police, had given in their resignation, both being looked upon as friends of Manuel Pardo, whilst the other members of the cabinet, and the President himself, were hostile to him.

The Minister Santa Maria, who no doubt had a right to inflict some chastisement upon the students of San Fernando for the ridicule heaped upon him, had, I was assured, passed all bounds in his wrath. Such as the students as were caught had by the express order of the President been stripped of their clothes, conducted to different barracks, dressed in the uniform of common soldiers, and incorporated in the ranks of the army; it was added that their heads had been shaved, and that they had been compelled to discharge the lowest menial offices. Dr. Ribeyro, who besides being President of the Supreme Court was also Rector of the University, told me that he would make a strong representation to the Government demanding the liberty of the students.

Wednesday, $25^{\text {th }}$ of October. Rafael Velarde had a few month [...] [289] removed to a pretty new house owned by Dr. Patron, which he had neatly and elegantly furnished. Yesterday being his Saints-day, he had invited us to spend the evening with him, which we willingly did. Present were about 30 persons: his, and some of his wife's relations, the family of Colonel Diego Masias, Dr. Patron, Colonel Gamero, and others. At about 1o O'clock tea was served in 
an adjoining room with all kinds of cakes and sweetmeats. One rocambor table was formed, the young people danced with great animation to the music of the piano; at 1 O'clock an excellent cold supper was laid out. On both occasions I had to lead the hostess to the table. At 3 a.m. Mariquita, Enriqueta, Antonio, and I walked home; the dancers and cardplayers remained to a later hour. I did not amuse myself much, but must say that everything was in good style.

In Lima the elections were over. In Arequipa it was reported that the disturbances had been very serious.

This day died quite suddenly the Franciscan friar Zapata and Doña Carmen, wife of José Rey de Castro; the former I had often seen at Enriqueta's; he was certainly good hearted, but stupid and without any quality, which renders a friar worthy of respect. Doña Carmen, a native of Bolivia, was a very pleasant woman. Our family was well acquainted with her, and I used to visit her occasionally.

Scheel of Dreyfus' house, lately returned from Europe, confirmed to me the advices received regarding the dangerous illness of Sofia Bergmann, Augusto Dreyfus' wife.

Friday, $27^{\text {th }}$ of October 1871 . This morning I ascended San Cristoval. The sides of the mountain were still covered with the short green plants which always spring up in the rainy season. The thick fog concealed every object, and thus when descending I lost my way and came down a very rugged and stony gulley, where I had never been before, the consequence of which was that on

Saturday, $28^{\text {th }}$ I felt a stiffness and pain in my limbs.

Sunday, $29^{\text {th }}$. Aramburú, one of the editors of the "Nacional", was arrested, and it was said (though I did not give full credit to the report) had been treated in the same manner as the students of San Fernando. I did not know what had become of the other editors, at all events the [...] last night had a blank where the leading article was [290] usually printed. It was reported that when José Canevaro on leaving for Europe paid his farewell visit to the President, the latter said to him - "You do right in absenting yourself, for pretty things will turn up", by which expression he meant to allude to the defraudations said to have been committed by the National Guano Company in England, of which Canevaro was one of the principal shareholders.

Wednesday, $7^{\text {st }}$ of November 1871. After dinner I walked out to the pantheon where, as it is always the case on this, All Saints-Day, many people were walking up and down, and not a few adorning with flowers and garlands the niches in, and the marble monuments under which their friends and relations were resting from the troubles of this world. I noted that more than one new monument had been erected in the course of last year, and was particularly 
struck with that of an Italian, member of the brigade of voluntary firemen, who had fallen a victim to his self imposed duty, when jointly with his companions of his own and other nationalities, he had contributed to extinguish a fire in the Calle de Filipinas. The vault beneath the mausoleum of General Castilla was open; I descended into it and found that it was almost entirely occupied by a large coffin, in which no doubt his mortal remains were enclosed.

Thursday, $2^{\text {nd }}$ of November. Before breakfast I visited the Botanic-Garden, close to the fort of Santa Catalina, which was under the care of a German gardener, Klug, who, as far as the limited means placed at his disposal permitted, kept it in excellent order. It was far from being concluded, but what was done was prettily planned; there were hot-houses, which being locked, I could not enter, also a low hill with a rustic summer house on the top, which pleased me most of all. This day President Balta published under his own name a proclamation in which he, considering the animosity and violence with which the respective parties of the various Chiefs who were the acknowledged candidates for the next presidency strove for the preponderance, recommended Dr. Antonio Arenas, Vocal of the Supreme Court around whom all who had the welfare of the country at heart should range themselves in order to raise him to the Supreme ma [...] the Republic. It was seen at a glance [...] [291] that this was a machination of General Echenique who possessed great influence with Balta; he, seeing no chance for himself, put up Arenas, in hopes that if this man were elected, he would be the real ruler.

Saturday, $4^{\text {th }}$ of November 1871. A declaration was issued by General Echenique, which proved that the above supposition was correct; he said that his patriotism and disinterestedness were such that he did not hesitate a moment to do what the President had recommended, and that accordingly he and his party would contribute everything in their power to forward the election of Arenas. The students of San Fernando and Aramburú had by this time been placed at liberty.

Monday, $6^{\text {th }}$ of November. This morning the funeral honors of Mrs. Dreyfus, Sofia Bergmann, were solemnized in the church of Santo Domingo, advice of her death - which occurred in Paris on the $16^{\text {th }}$ Octr. - having been received by telegram to St. Thomas, thence per steamer hither. The walls and pillars of the church were so completely covered with black cloth, that notwithstanding the lighted torches and vases with flaming alcohol, of which it is true there were not a great many, the obscurity was such that I could hardly distinguish anything or anybody; however, when leaving I observed that the attendance was by no means so numerous as I had expected, which was no doubt owing to the anti-Dreyfus feeling which pervaded the higher classes of Lima society. 
Wednesday, $15^{\text {th }}$ of November. This day was fixed upon for the electors of the different provinces all over the Republic to assemble in the provincial capitals there to choose their Deputies and Senators for the Congress to assemble on the $28^{\text {th }}$ July 1872 ; also the members for the new Municipalities. The old Municipality of Lima refused to give up their apartments for the said purpose and assigned to the friends of Manuel Pardo a saloon in the convent of Santo Domingo - to those of Ureta one in San Agustin - to those of Echenique, or, as we might now say, of Dr. Antonio Arenas, one in San Francisco. Accordingly, the electors assembled, each party in its respective locality. Pardo's friends chose for Deputies for Lima: himself; Dr. Ramon Ribeyro son of the vocal J. Antonio, Dr. Emilio Solar, and Ignacio Osma; Ureta's, old [_] Francisco Javier Mariategui, Dr. Bruno Bueno and two [...] [292] persons, whose names were unknown to me.

Saturday, $18^{\text {th }}$ of November. Evaristo Gomez Sanchez, who no doubt had some partizans amongst the ultra-Catholics of the Lima population, likewise published a proclamation similar to that of General Echenique, in which he declared his adherence to Dr. Arenas, and placed the votes of his friends at his disposal.

Sunday, $19^{\text {th }}$ of November. Juan wrote me from Brighton, $11^{\text {th }}$ Octr.; he was doing well, for the seabathing agreed with him. My cousin Frances Cresswell wrote me under the same date and told me, in answer to a question I had put to her, that Mr. Hermann Willink, a cousin of my mother, whom I had visited more than once when he resided on a small farm called Stift near Kiel, as well as his wife, had died many years ago.

Political news was of no importance. The town of Chicago in the State of Illinois, U.S. had been destroyed by fire, and the loss sustained, though perhaps exaggerated, was estimated at $\$ 200,000,000$. A Mr. Tweed, Director of the Public works in New York, had been arrested, being accused of immense defraudations, amounting as it was said to $\$ 19,000,000$. He was placed at liberty on giving bail for $\$ 2,000,000$.

Whilst I was with the family of Dr. J. A. Ribeyro, upon whom I frequently called on Sundays, Manuel Pardo came in; this rather surprised me, for though he was hand and glove with the son Dr. Ramon, I knew full well that the father Dr. Juan Antonio was no great friend of his; however, he, who was likely to become the President of the Republic for the next term, could not otherwise but be received with much politeness. We all sat down, and the conversation ran on freely; of course, it treated only on the political occurrences of the day. The elections were over; Pardo's party had chosen as Senator for the province of Lima the landed proprietor Don Buenaventura Helguera, for the department 
of Ica Emilio Althaus. The Echeniquistas had elected for Deputies for Lima: Nicolas Piérola, the ex-Minister of Finance, Juan Martin Echenique, Pedro Calderon, Peruvian Minister in Berlin, and Juan Aliaga y Puente.

Monday, $20^{\text {th }}$ of November. Ever since the declaration of Peruvian independence, venality, corruption, and bribery had not been entire stra [...] in the offices of the Ministers and their dependents neith [...] [293] saloons of the President himself, nor in the apartments of his near relations. Under Echenique's administration at the time of the Consolidacion they, it was believed, had reached the highest pitch, but greatly did they deceive themselves who had thought so; never had those crimes stalked about with more unblushing effrontery than at the present period. To prove the correctness of my assertion, I will pick out one of the many instances which I could adduce. Some months back it was determined by the Minister of the Interior that a railroad should be constructed from Chimbote - a small port to the south of Huanchaco - to Huaraz, which line, it was affirmed, would be of the greatest utility to the district through which it passed. Sealed tenders were asked for; various persons came forward amongst whom Benito Valdeavellano and Dionisio Derteano, this latter, a very clever and unscrupulous man, who, first heard of at the time of the conversion of the Bolivian coin into silver soles, had gradually become known as the most efficient of Dreyfus partners in Lima; he was, moreover, very intimate with Doña Melchora, the President's wife. They asked a fabulous amount, if I remember correctly, thirty odd millions of Soles. The law required that a few days should elapse before the concession were granted for the chance of more advantageous proposals, and such were actually made, firstly by Meiggs, Montero, and Muro; and secondly, by a company of twelve individuals, one of whom was Garland. I also was requested to take a share, which I at last agreed to, but with the express condition that my name should not appear; from Bartolomé Araoz I obtained a promise that he would lend me the money required, in case I had not a sufficient amount to my credit in the bank, but after all it came to nothing, for the other parties interested insisted upon my signing jointly with them the petition to Government, which I would not do on any account. This company offered to make the railway for $\mathrm{S} / 21,000,000$, which did not answer the purpose of those in power; their object was not to have a cheap railroad but a heavy cost, so that there might be a large surplus to be distributed amongst them, consequently under the pretence that the difference between the various offers was too enormous, the previous proceedings were all annulled, and new tenders asked for; this was done only to give time for negotiations between the different parties. Meiggs [...] cause with Valdeavellano and Derteano [...] 
[294] of twelve was bought off, and their months stopped with S/6oo,ooo. How much of this sum fell to Garlands share I never learned, but what I know is that for a long time my wife would not forgive me for having allowed an opportunity to escape which, as she very properly observed, would have ensured me a considerable profit without risk or trouble, and in a short time, but on the other hand she could not know that this transaction was, as I looked upon it, of such a nature that it would have cast a slur upon the respectability of my mercantile character, had it become known that I had been implicated in it. How much Meiggs had to pay to Montero and Muro also remained a secret to me; it must have been a very handsome sum: $\mathrm{S} / 700,000$ came into Doña Melchora's pocket, and 24 millions were the sum for which Meiggs bound himself to construct the line.

Tuesday, $27^{\text {st }}$ of November 1871. My wife's birthday. Mariquita and I had resolved to spend this day in a quiet manner; she came to this decision because on the previous day she had been suffering more than usual from the numbness in her legs and feet. I, because I was never without many annoyances which troubled me, and kept me more or less in bad humour. My suit against Leyva, relative to the gutter, would soon be decided, but I feared not so favourably as I had expected. Dr. Lucio Barrios, who had still to take some steps for the purpose of ensuring to me the undisputed possession of the four shops Calle de Zarate, was either absent or ill, and nothing was done; the Frenchman Eugene Plazolles was behindhand with the payment of the rent of the house $\mathrm{N}^{\circ} 41$ Aldavas; to the repairs of my house I saw no end, and their amount passed all limits; my shares in the Telegraph company I had sold at 50\%, or with a loss of S/2500. Juan Martin Echenique, I was convinced, would not be able to go on with the two great undertakings which he had taken upon himself, the one the Pasco Railway, the other the enterprize for draining the Cerro mines - in which case the former of the two would again be returned to the unfortunate company. The Constructora did hardly anything. In the Insurance Company Lima we had suffered a heavy loss, viz.: on a cargo of timber insured by Dinegri for S/16,ooo from Orego[_] to Callao; the vessel by stress of weather had been obliged to take refug $[\ldots]$ and there the cargo was sacrificed at [...] [295] prices. Moyna and I had signed the policy. Only the Banco de Lima, the Banco Hipotecarío, and the South American Insurance Company were likely to show profitable res[_]ts at the end of the year; the Water Company would give $10 \%$, the Gas Company a trifle more.

My wife allowed herself to be talked over by Enriqueta and by the young Garlands, and whilst I was in the street my table, papers, writing materials, Mr. Coleman himself, etc., all was removed from the drawing-room to the two 
apartments which look to the roof of Leyva's house, and which henceforth were to serve as my office. The covers were taken from the furniture, and the necessary preparations made for receiving our friends, should any of them favor us with their presence, and this they did not fail to do. About 9 p.m there came Garland's usual rocambor players, Dr. Jervacio Alvarez with his daughter Asuncion, and his grand-daughter Aurora Santillana, (His son Adolfo, who had sput blood, had suddenly been sent off to the Sierra). Juan Bazo with his wife Irene, Rafael Velarde, wife, and daughter Zoila, who - thirteen years of age promised to become a pretty girl, Melchor Velarde with two of his daughters, Manuel by himself, for his daughter was expecting her confinement, Doña Juana Carbajal, a good kind of woman who might however be a little more refined, with two of her daughters. The young Garlands had invited a few of their friends; they began dancing, which they kept up with much animation till past one. First tea was served, then ices, jellies, wines, sandwiches etc. were handed round; finally, we sat down to a good supper, far too abundant, which being dispatched, the party broke up.

Friday, $24^{\text {th }}$ of November 1871. Last night again a horrid murder was committed in this capital of Lima. Sometime back a family Sanchez had come hither from Bolivia; one of them was a young woman, the mistress of the Bolivian ex-President Mariano Melgarejo, of whom it was said that when she was a girl of thirteen of fourteen he had her carried off forcibly from the streets of La Paz. When in one of his drunken moods he had ordered her to place herself upon an altar in his oratory, with uplifted hands and in a posture of adoration; revolver in hand he then threatened to shoot her, if she made the slightest motion, and meanwhile his chaplain had to say mass. To his mistress' brother he had given his own daughter in marriage, made him a general, and glutted him with all kinds of favors, honors, and money. For some [...] natural friendship lasted [_] they were at [...] [296] Melgarejo at about 7 p.m. presented himself at the house where the Sanchez resided in the Calle de Gallinacitos, in his hand a revolver which he had that day bought at Lasarte's, and taken great care that it was well loaded. The street door was closed. Melgarejo burst it open; the policemen were sent for, but did not come. Then Sanchez who had been in bed - leeches being applied to some part of his body - rose and encountered the General. The father and son-in-law had high words, and the latter shot the former through the head and through the throat. Melgarejo expired at 11 O'clock this night having completed his $55^{\text {th }}$ year.

Saturday, $25^{\text {th }}$ of November. Melgarejo was buried with all the honour due to a General. President Balta had expressed his willingness to pay the expenses of the funeral, which the Bolivian Minister Juan de la Cruz Benavente residing 
in Lima declined, and made the necessary disburses on account of his Government.

Once more did Don José Balta give a proof of his despotic and passionate character. I have already mentioned that on the spot of ground known as the Paseo de Aguas the Constructora was building for the Municipality a new market; the road leading thither was sufficiently wide, but Mr. Lopez Aldana, who had rented from Candamo the large building close by constructed originally for the manufacture of domestics, had made it a little narrower by enclosing with an adobe wall a small piece of ground alongside the building, where he had put up a steam engine. These few hundred square yards he pretended to be his property, whilst the Municipality of Lima asserted that they were theirs, and the tribunals were now to decide which of the two was in the right; but to Balta it sufficed that Lopez Aldana was a staunch adherent of Manuel Pardo, and accordingly he sent word to Nemesio Orbegoso Alcalde, ordering him to pull down the wall; the natural answer was that this could not be done because the case was pending in the Courts of justice, whereupon Balta dispatched a troop of soldiers who immediately began the work of demolition.

Monday, $27^{\text {th }}$ of November. This evening the Prussian Chargé Mr. Von Bundsen took tea with us; we played one game at chess, which I thought I should have gained for I had two pawns more than he, and to effect an attack Bunsen sacrificed his castle, but then my king and one cas [...] [297] assistance, and with his queen and castle after a great many moves he brought about the check mate.

Wednesday, $29^{\text {th }}$ of November 1871. This morning I ascended about one third of the height of San Cristoval, to a spot where nature has formed a small excavation with a stone bench. To reach it, one has to climb for several yards over live rock, without any grass or earth, and this had always been to me a somewhat difficult job, but this day, I confess, I felt something like a tremor, for owing to the increased weakness of my sight, I had to be particularly careful to pick out the spots where I had to place my feet, or where I had to hold on with my hands. One or two pages back I enumerated the annoyances of which I was then complaining, to which another may here be added. In 1855 when we paid a visit to the Berlin manufactory of porcelain, I bought for my wife a particularly handsome tea service, the cups of a peculiar shape, very richly gilt and artistically painted. My wife was so fond of them that she was the only one who washed them when they had been used; in our removal from the Calle del Correo, they were carefully packed up in a little box, and this we could not find anywhere; there was not a spot where we did not hunt after it, but it seemed lost. 
In the first week of October I omitted to chronicle the death of Theodore Gortsch, cousin and cashier of the Bergmanns; his death was not the immediate consequence of the fractured leg - which was not amputated - but his lying in bed for many weeks had caused the sore, the sore became a wound, mortification ensued, and death was the result.

Within these last days a great deal of Mr. Coleman's and my time was taken up with placing the library, and arranging my books in the same.

From Thursday, $30^{\text {th }}$ of November to Saturday, $2^{\text {nd }}$ of December. All three days I was at the meetings of the Directories of the Insurance Company "Lima", of the Banco de Lima and of the Constructora. Of the Banco de Lima nothing was to be said, for its business went on prosperously under the management of the two Gerentes, Lembcke and Zaracondegui. In the Insurance Company the loss upon Dinegri's timber cargo was discussed; as the supercargo who was on board the vessel had made himself quilty of many irregularities, sufficient to invalidate the Insurance, it [...] [298] interview with Dinegri, and endeavour to come to a friendly settlement with him, of course standing out for an abatement on the sum insured.

In the Constructora one of the Italians Larco presented himself with a grand plan which, it was well known, had its origin in the palace. He proposed that the entire block between the Portal de Botoneros, Bodegones, Plateros de San Pedro and Mercaderes should be bought, which he expected could be done for $S / 1,200,000$. Then he intended to cut two passages in the form of a cross right through, somewhat like the English "Arcades", or the French "Passage", and to build about 80 stores with a second and third story, which he proposed to the Constructora to do by contract for $S / 800,000$. He calculated that the rent for stores and dwelling apartments would give a handsome interest upon the money disbursed. The two cross passages were to be named "el Pasaje Balta". This sounded very magnificent, but from the first moment I had the firm conviction that nothing would be done. I left Larco in the midst of his harangue, for I had to go home to pay my workmen.

On the $1^{\text {st }}$ December in the morning I went out to Chorrillos to speak with the broker Mogaburu, who lived there, about a pagaré of Miguel Winder which he had brought to me for discounting, and which when due had not been paid. Juan M. Echenique was also in arrears with his payments; but on the other hand Plazolles had paid his rent for October and November; Sand \& Co. had at last cancelled a pagaré of $\$ 5000$ long overdue, and Melchor Velarde had paid a vale of his signed $31^{\text {st }}$ March for $\$ 500$ but without interest, because the interest he thought might go in compensation for the services he had rendered me by signing occasionally an escrito in my case, long decided, against J. M. Varela. 
Mariquita complained more than asual of the numbness in her limbs. From Juan I had a letter from Paris in which he wrote that he had gone thither solely with the object of being present at the funeral of Mrs. Dreyfus which had taken place on the $18^{\text {th }}$ October.

Tuesday, $5^{\text {th }}$ of December. In the morning I was present at the funeral of Don Pedro Salman, my senior by two years. He had for many years been administrador of the Custom-Houses in Islay, Arica, and finally Callao, and always been reputed a perfectly honest man. When in Islay in 1830 to [...] [299] to dispatch a lot of manufactured goods, he and I to gain time calculated the amount of duty, which was by no means incumbent upon him, but upon the "vista" Ciriaco Garcia, an extremely slow calculator.

In the forenoon of this same day Enrique Marriott paid to me on account of Juan Martin Echenique the interest upon my two loans of S/50,0oo and S/12,00o to the Pasco Railway Company; this was certainly a heavy weight taken off my mind.

Thursday, $7^{\text {th }}$ of December 1871 . This morning I was awakened with the words that our house was flooded, and surely so it was; the cook had omitted to shut the water-cock, and consequently the water had overflown our corredores, leaked through, and spoiled the "cielos razos" of the rooms below. The cook was immediately dismissed. Mogaburu paid Winder's pagaré.

I had the good luck to sell $\$ 50,000$ my son Juan's interest in the London Guano Company, through the broker Martí, to José Muro, at 8\% premium, with two months credit, from which were to be deducted $1 \%$ brokerage, and $2 \%$ discount for I discounted Marti's bill on Muro, without my endorsement at the Banco de Lima; consequently, the nett premium was $5 \%$ whilst Juan had authorized me to dispose of his shares even at $10 \%$ discount.

Friday, $8^{\text {th }}$ of December. La Concepcion. We saw by last nights papers that within the last few days two suicides had been committed here in Lima, the one by a major Lara, who had shot himself through the body, and died in consequence; the other by a certain Meneses, collecting clerk at Dreyfus, who might perhaps recover; the ball had entered just above the eye. With him it was supposed the cause had been a deficiency in the cash which he had under his charge.

It was further made known to the public that Tomas Gutierrez, a notoriously bad character, hitherto inspector of the army had been called by Balta to fill the post of Minister of War, resigned by General Allende. Also José Aranívar, Minister of Justice, had gone out, and his place been occupied by Melchor Garcia, hitherto Director of a college.

A new firm came into life, that of Bauer Kruger \& Co., which had rented a store more or less opposite my house Calle del Correo, and which was expected 
to do a large import business. Bauer, a disagreeable French jew, had for some time been partner of Dreyfus in Paris, and Kruger was at the present salesman in the Lima house, which would devote itself exclusively to the Guano business $[\ldots]$ had obtained the concession for the construction [...] [300] Arequipa to Puno for $\mathrm{S} / 25,280,000$; he had also purchased the walls round Lima, which were to be demolished; of course the earth of which they consisted was to be his, as well as the site upon which they stood.

From Monday, $11^{\text {th }}$ to Saturday, $16^{\text {th }}$ of December. In the course of this week nothing occurred worthy of note if I except two resolutions taken by the Directory of the Banco de Lima in an evening session on the $16^{\text {th }}$. We granted to the Government a loan of $\mathrm{S} / 400,000$ with the express condition that the interest were not below $1 \%$ monthly, and the money to be returned in monthly instalments of S/100,0oo each. To the brothers Montero we increased the credit which they already had in the bank, upon the security of their railways in the Province of Tarapacá to $S / 2,000,000$ with $1 \%$ interest, and the repayment of S/10o.ooo every month.

In the forenoon of the same day the Directory of the Insurance Coy. "Lima" had had a meeting, when Brauns gave an account of the interview which he and Rafael Canevaro had had with Aurelio Dinegri; after a long discussion, in which Lembcke, Henry, and Gil, refuted Brauns' argument in favor of Denegri, we determined that $S / 12,000$ cash down should be offered Denegri in full of his demand, or if he would not accept them to propose the settlement of the question by arbitration. From Andres Rey, manager of the Lima Water Company, I received a note in which he informed me that two of the Directors having gone out, the shareholders had named the Frenchman Mr. Schmidt, of the South American Insurance Company, and myself to replace them; I replied, accepting the nomination.

Our overseer, or sobrestante, Gavino Cabezas, resided with his family in Callao; we however had given him in the ground-floor of our house a room and a bed, so that he could be up at 7 in the morning and count the labourers who came to work. On Sundays and holidays he spent the day with his family, and did not come to Lima till next morning by the 8 train; thus, on these days I had necessarily to rise early, to do what, properly speaking, was the sobrestante's duty. Every day I convinced myself more and more that Esquibel, whom Manuel and Melchor Velarde had so emphatically recommended to us, was nothing but a good carpenter; the two masons Pinto and Valladares, whom he had brought to us, understood their work, but they were expensive, and the latter not without a spice of [...]. Every Saturday at 5 p.m. I paid all the workmen [...] [301] which I might easily have made some mistake, for every payment to twelve or fifteen men was but small varying from 6 or 7 to S/25 
per week; nevertheless, though down to this day more than $\$ 9000$ had passed through my hands, my cash was always correct.

In the remodelling and recopying of my diaries I was now about the year 1845 , and was thus fearful that I should never be able to bring them up to the day.

Monday, $18^{\text {th }}$ of December 1871. The shareholders of the Banco Hipotecario had a meeting, which was numerously attended. Firstly, two members were named to examine this year's accounts, and the choice fell on Sagastabeytia and myself. Secondly, it was unanimously resolved that as soon as the $100 \%$ of the present shares were paid up, the capital of $S / 1,500,000$ should be doubled, and this in a very simple manner, for instance, he who was now interested for S/10oo would be considered as a shareholder for S/200o with half of the capital paid up. Thirdly, Riva Agüero submitted to those present whether the Banco Hipotecario should make loans on railways or not, the first lawyers in Lima having given it as their opinion that railways are immovable property; this gave rise to an animated discussion. Lorente and Oyague took the lead against the grant; Garcia Calderon, the lawyer of the company, spoke in favor, but when the question was put to the vote, all were against it.

Tuesday, $19^{\text {th }}$ of December. In the forenoon a few of the shareholders of the Lima Water Company met; in this company everything went on so smoothly and nicely that there were never any discussions. Mathison was named to inspect the yearly accounts.

Wednesday, $20^{\text {th }}$ of December. In the preceding days I have given to understand more than once that Esquibel, the so-called architect, was by no means a man to my liking. This day he went so far as to tell me that it was not his duty to look out for some bricklayers of whom I stood in need. Then I told him to go about his business, and off he walked. We should now have been in some difficulty with regard to a proper person for directing the repairs of the house, if Don Gavino had not introduced to us one or two days before a Frenchman Baumann de Metz, who at all events was an architect for as such he gave lessons in the college of Arts and trades. He did not displease me, though as a true Frenchman he was very talkative.

Friday, $22^{\text {nd }}$ of December. At 7 p.m. a considerable number of the share [...] Banco de Lima assembled in the usual locality [...] [302] of electing Directors, the old ones who had been two years in office having to go out in conformity with the Statutes. I, as chairman, in the centre, with José Muro on one and Juan de Dios Calderon on the other side, stated in a few words the object of the meeting, when Pedro Bernales rose and moved a vote of thanks to the gerentes and the Directory, which was opposed by Brauns, representative of Andrés Alvarez Calderon, on the very proper plea, that the result of this year was not 
yet officially known, and consequently Bernales' motion had to lie over. We then proceeded to the election; each wrote the names of those for whom he voted upon a small piece of paper, and these papers folded up were thrown into a plated wine cooler which answered the purpose of an amphora. I then took them out, the secretary Muro read over the names, others noted them down, and the result was that with the exception of Amancio Castillo and José Herce, all the other Directors were re-elected. Lembcke had been intriguing for the elimination of these two, and the election of Pedro Bernales and José Maria Cantuarias in lieu of them. At 9 we broke up.

Saturday, $23^{r d}$ of December. A very numerous meeting of the Lima Huacho Railway shareholders took place in the large saloon of the Exchange. Hardly had the "informe", or printed message of the Directors, been read by the secretary, when the lawyer Pasapera rose to find fault with it; he was succeeded on the same tack, but with more violence and acrimony by Dr. Emilio Solar, who himself had been member of the Directory, and who having given in his resignation had been replaced by Emilio Pierola; he said amongst other things that the shareholders ought to be called together more frequently, that the Directory should make known the cause of his resignation. He asked how the money had been spent which the Government had contributed; more than $\$ 300,000$ were owing by the Company, to whom? and wherefore? He went so far as to say that neither plans nor estimates had ever been presented. I left him in the middle of his peroration, for it being Saturday and 4 O'clock, I had to attend to my own business. In the course of this week various persons had been arrested viz.: Chinarro and Aramburú, editors of "El Nacional", the printing office of which was shut and sealed; Francisco Andraca, Master of police in the time of Prado (these three staunch adherents of Manuel Pardo) and Echeandia and Lira, officers not in active service.

From Sunday, $24^{\text {th }}$, to Tuesday, $26^{\text {th }}$ of December. In the forenoon of these three [...] [303] much work upon my hands; not less than thirty visits were paid by me; some of those upon whom I called were not at home, otherwise, as I was always on foot and never availed myself of the hackney coaches easily to be had in the streets of Lima, it would have been impossible to accomplish the task. My wife on the other hand had on the first day not a single visitor, whilst on the second, first Xmas day, she held a complete levee in her drawing-room, which she used to throw open on great holidays, whilst on Sundays she received either in the parlor or in the small room, which she called the salita, which was her favourite apartment, and where we were always together in the evening until bed-time.

On the $24^{\text {th }}$ I noted that Enriqueta was unusually busy the whole day long and I had no idea what she was about, but in the evening it came to light. 
She requested us to enter the dining saloon which she had lighted up with many candles and lamps, and where for every one of us, the servants included, she had spread out presents, of course of no great value. Little Maria's joy and happiness knew no bounds; as to myself I was much affected and even pained with these reiterated proofs which dear Enriqueta, forgetful of herself and sacrificing her small savings, never failed to give of her kind feeling towards all around her.

On the $26^{\text {th }}$ at 8 p.m. I went to the German Club Rooms to be present at an amateur theatrical performance, similar to that previously described. I took the same seat which I had occupied last time, an armchair in the left corner of the first row, where I could see and hear well. Edward Knaur for some time had the seat next to me, which however when the performance began he ceded to Adelina, one of Lembcke's daughters, with whom I conversed a little and found her to be a nice young lady. Between three short comic pieces represented by some Germans, clerks of Lima mercantile houses, the members of the German singing club treated the audience with various songs. I was well pleased and was home by 12.30. A young man named Arévalo was pointed out to me; he had the complexion of a true indian, was born in the department of Amazonas, and when very young had been sent to Germany for education in a military school; when grown up he had entered the Prussian service, served in 1866 in the war against Austria, again in 1870/71 in that against France, had risen to be captain of cavalry, and been decorated with [...] cross. He had now returned to Perú and entered the Presid [...] [304] body guard.

Wednesday, $27^{\text {th }}$ of December 1871. Once more I ascended San Cristoval. I did so because I thought that exercise was indispensable, for of late, owing to the excellent and abundant cookery of our new Chinese cook I had partaken of his good things more than I strictly should have done.

Friday, $29^{\text {th }}$ of December. We had a death in our house, which, though it was only that of a dog, was regretted by all of us. He was a white terrier named Tippo, and had been presented several years back by General Wright to my daughter Rosa, who, when she left for Europe, had given him to Enriqueta; he was really an intelligent animal, and so clean in all his proceedings that he was allowed free admittance into all the rooms of the house. To cats, rats, and mice he bore an inveterate hostility, and though he was lame of one leg, for once when in the blind pursuit of a cat he had fallen down from the roof of Mr. Schutte's house, he never tired hunting them out in all the recesses. No doubt he was poisoned in the street by a policeman; when he came home the servants tried to save him by pouring oil down his throat, but in vain, he lay down on the ground, stretched his legs, and died after a few convulsions; we interred him in the garden. 
Saturday, $30^{\text {th }}$ of December. In the meeting of the Directory of the Banco de Lima a letter directed to me as President by Amancio Castillo was read. He complained that by intrigues, "maniobras", he had been deprived of his directorship, spoke of his being one of the founders of the bank, and asked whether he had done anything which rendered him unworthy of being a Director. Agustin Escudero insisted upon the letter being returned to him; I opined that the answer might say that as the elections had been made by all the shareholders, and not by the Directory exclusively, he should address himself to the former, and not to the latter. One said the one thing, the other the other, and finally Zaracondegui put an end to the discussion by proposing that he himself would return the letter to Castillo; thus we got over this difficulty. Next, the Gerentes, or rather Lembcke who was their mouthpiece, informed us that Wenceslao de la Jara and Eduardo Ponsignon, managers of the Bank lately established in Arequipa, in which the Goyeneches and Romaña, the richest men in Arequipa, were large shareholders, had written to them and expressed a wish to enter into mercantile relations with the Banco de Lima. We authorized the Gerentes to say in reply that we should be most [...] [305] to enter into such relations; and moreover, instructed them to open a credit of $\mathrm{S} / 100,000$ to the new bank, should it be asked for.

Sunday, $37^{\text {st }}$ of December 1871. Since the $27^{\text {th }}$ of this month the sun had not risen a single time over the Cerro of San Cristoval without finding me on its summit between the hours of 8 and 9 in the morning; the natural consequence of this my daily ascent was that I began to accomplish it without particular fatigue and even with comparative ease; from the moment I left my house until my return two hours passed more or less. This morning I noted that the volume of water in the river had increased materially since the preceding day, also that the canal, which separates the high road from the paseo militar and puts the mill, formerly Landaburu's, in motion, threatened to overflow its banks.

About this time, the end of the year, the Lima Municipality published a new list of the Predios Urbanos, a yearly impost, to be paid every six months by the proprietors of immovable property in the capital. The members of the commission named for the purpose raised this impost to about $100 \%$ above that hitherto paid, and in order to bring about this result, they had proceeded in the following manner. They had gone from shop to shop, from store to store, from house to house, and enquired from the tenants what rent they paid, and upon this rent they calculated $3 \%$. When the owner and tenant were the same person, then they estimated the rent, taking great care that if they erred, it was always in favor of the receiver. Chorrillos had hitherto been free from 
this impost, and so it ought to have been because the law said that Predios Urbanos should only be levied in the capitals of provinces; however, under Balta's absolute administration this impost was also extended to that wateringplace, and here they calculated $4 \%$ upon the rent; the difference between $3 \%$ in Lima, and 4 in Chorrillos was made because in the former place another contribution, "la patente", or licence for carrying on one's business, trade, or profession was paid, whilst this was not done in the latter. In my opinion this was a ridiculous and groundless distinction, because with very few exceptions all the houses or ranchos in Chorrillos were owned by Lima people. I was taxed as follows: for my Chorrillos rancho 30 Soles annually - a fair impost - for the shops and house Calle de Aldavas No 29 to 45 S/18o high, but not so exorbitant as to warrant my complaining of the same, for the four shops 92, 94, 98, 100, and the house 96 Zarate S/67.30, extremely low, undoubtedly the house itself had been omitted in the [...] for the house $\mathrm{N}^{\circ} 22$ Calle del Correo my own and [...] [306] shops 16, 18, 24 and 26, rented by me from the Convento de la Concepcion, S/153.18 which I thought to be out of reason high, and therefore presented a petition begging for a reduction, to which I received the answer

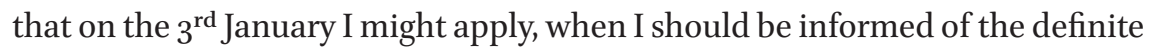
resolution taken by that time.

1872

Monday, $7^{\text {st }}$ ofJanuary. Till the arrival of the Papal Delegate Vanutelli Juan de la Cruz Benavente, the Bolivian Minister, had been the senior of the Diplomatic body in Lima; now however, the precedence was ceded to the said Delegate; and accordingly it was from him I received a circular note, in which I was requested to attend in the palace for the purpose of presenting, jointly with the other Diplomatic and Consular Agents, the customary new-year's congratulations to the Chief magistrate of the Republic. Bernardo Roca y Garzon and I, in full uniform, drove thither at the appointed hour, and at 2.15 the two bodies, a considerable number for some had come up from Callao, and only two, Leal, the Brazilian Charge, who had just received advice of one of his daughter's death and Beddy, the newly named Chargé for the Sandwich Islands, were wanting, marched two by two from the office of the Minister of Foreign Affairs to the long and narrow receiving room, at the other extremity of which stood as usual Balta with his Ministers. Vanutelli red his address, Balta answered a few words, and when the shaking of hands was over, we, contrary to custom in former years, were ushered to the dining saloon, where an excellent cold lunch was laid out. I had my seat between Antonio Souza-Ferreyra, several 
years older than I, Brazilian Consul General and Senior of the Consular Corps, very taciturn, and Gregorio Escardó, a native of the Argentine Provinces, and Consul General for that Republic, a very agreeable and talkative gentleman with whom the time passed quickly till 4.30, I having, as it was my custom, eaten little and drank still less.

Tuesday, $2^{\text {nd }}$ of January. In the Banco de Lima the Directory had their usual monthly meeting. Cantuarias attended for the first ti [...] [307] Pedro Bernales was prevented by his duties as Secretary of the Comision Permanente. After the acta of the last meeting had been read, I said the first thing to be done was to elect a new President, vice-president, and secretary, but by acclamation the old ones were reelected; I President, Juan de Dios Calderon Vice, and José Muro secretary. In the office of the Insurance Company "Lima", where this month I was Director de turno, I learned that Aurelio Dinegri had accepted our offer of $\mathrm{S} / 12,000$ in payment of his claim for the loss of the timber cargo.

Wednesday, $3^{\text {rd }}$ of January 1872. I went to the office of Enrique Guimaraes, employed in the Municipality, who told me that the committee to which I had to apply for a reduction on the predios urbanos was the Junta de Matricula; the letter which I had written to him on the same subject he returned to me.

Thursday, $4^{\text {th }}$ of January. One of the carpenters made known to me that the lintel over the door $\mathrm{N}^{\circ} 94$ Zarate, placed hardly a fortnight previously under the direction of Esquibel, had given way a little. Baumann de Metz thought that it threatened the safety of the entire superstructure, and did not move until under his own eyes it had again been sufficiently secured and propped up.

Saturday, $6^{\text {th }}$ of January. Garland and Enriqueta with Antonio and Maria, my wife, and myself, drove to the village of Magdalena, where Enriqueta was particularly desirous to have a look at a house which had been offered for sale to her husband. The road to this village, which is situated at a short distance from the sea, leads through what was formerly the Juan Simon gate, over a sandy road lined on both sides with the low mud walls behind which green fields and meadows extend right and left. The house, the largest in the place, occupied years back by the Spanish Viceroys, and situated on one side of the Plaza Mayor, was in good condition as regards its strong and massive walls, but the roof required repairs, and so did the "mirador" or "look-out". The large garden, filled with flowers and vines was well kept. In a house close by resided old Doña Carmen Lopez Aldana, upon whom we called, and who was very glad to see my wife, an acquaintance of hers of former years; both going and coming we suffered much from heat.

Sunday, $7^{\text {th }}$ of January. In my round of visits I called amongst others upon Mrs. Henry, when I entered into a long conversation with her husband who 
made me observe how the number of English import houses had decreased in Lima. Now there were only six, at the utmost seven, say: Wm. Gibbs \& Co., Huth Gruni [...] Bates Stokes \& Co., Graham Rowe \& Co. Fox Sawers \& Co. and F. S. Isa [...] [308] As to Templemann \& Bergmann it was doubtful, whether they could be called English because both Charles and Frederic Bergmann, the heads of the firm, were by birth Buenos Ayreans, and besides their business with the United Kingdom was fast decreasing. Within the last fifteen years, five English houses had liquidated, viz.: Myers Bland \& Co., Gemmels \& Co., Joseph Hegan \& Co., Naylors Conroy \& Co., and Dickson Colfer \& Co.; two had failed, Lang Pierce \& Co., and Green Nicholson \& Co.

From Monday, $8^{\text {th }}$ to Saturday, $13^{\text {th }}$ of January 1872 . In the course of this week we had meetings both in the Banco de Lima and the Insurance Company "Lima". In the former a dividend for last year of $25 \%$, in the latter of $41 / 2 \%$ was declared; from Riva Agüero I learned that the Banco Hipotecario would give S/140 per share, and from the South American Insurance Company $30 \%$ was likely to be received, all very satisfactory.

Leyva and I, both dissatisfied with the sentence given by the Juez de $1^{\text {a }}$ Instancia on the subject of the gutter, appealed to the Superior Court. To the Junta de Matrícula I gave in a petition requesting a reduction on the predios Urbanos imposed upon my property Calle de Aldavas, and that Calle del Correo. There was hardly a proprietor in Lima who was not dissatisfied making complaints, and presenting petitions, but whether they would effect anything was more than doubtful. Upon my house Calle de Zarate weighed some impositions known by the name of Censos, of which I was perfectly aware when making the purchase; they consisted of: $\$ 100$ to the College of San Carlos, $\$ 54$ to San Francisco de Paula, $\$ 30$ to Santa Rosa de los Padres. These could however be cancelled by paying to the Government a sum which at $10 \%$ interest would produce the above $\$ 184$; accordingly I proposed to pay $\$ 1840$ and my representation to this effect was at the present time lying in one of the Government's offices. The repairs of the house progressed under the direction of the new architect. On Friday the Steamer arrived, corresponding to the French one from St. Nazaire. From a firm in this last named port, I received a few words, requesting me in the name of my son Juan to suspend the sale of his shares in the London Guano Company which counter-order came too late.

Monday, $15^{\text {th }}$ of January. Last night the three eldest sons of Enriqueta $\mathrm{u}[\ldots]$ ent at the marriage of Julius Pflücker Jr., clerk at Gildemeister [...] [309] with a salary of S/250 monthly, and Rosalia Puente. The bride belonged to one of the most aristocratic families of Lima, her father having been Don Lorenzo, a thorough spendthrift, but son of the Marquis of Avellafuerte; his mother 
Francisca Risco was of a very respectable family; after Don Lorenzo's death she married a certain Madalengoytia of Trujillo. One of the sisters of Doña Rosalia was married to Juan Mariano Goyeneche, the other to Dr. Rosas, a physician. The bridegroom's parents on the other hand were of rather humble extraction; Julius, the father, was the son of a linen merchant in Waldenburg, Silesia, had for many years been cashier at Huth's, and from the very moment that he established himself on his own account had gradually become involved in pecuniary difficulties, from which he had never been able to extricate himself; his wife Doña Mariquita, a lady of excellent character, was of a completely unknown family. Thus, not one of the sisters of the deceased Don Lorenzo was present at the ceremony; as soon as this was over the young Garlands went to a ball given by Pedro Bernales, where the dancing was kept up till an early hour this morning.

My wife feeling much indisposed, not to say ill, we sent for Dr. Bambaren who however assured me that there was not the slightest reason for my entertaining any apprehension, for a lady who suffered from tumours as my wife did, could never be certain of uninterrupted good health.

This day at 1 O'clock Mr. Coleman bade me good by. I was really sorry to part with him, for though his deafness was a drawback, and he had more than one eccentricity, yet his extensive knowledge, his good nature, and his great uprightness were qualities much in his favor. The eleven months he had this time been in Lima he had continually been ailing; dysentery was the illness from which he suffered, and he had the conviction that whilst in Lima he would never get rid of it, for which reason he now embarked for Valparaiso.

From Tuesday, $16^{\text {th }}$ to Wednesday, $37^{\text {st }}$ of January. All this time I was without anyone to read to or write for me, and nevertheless the time did not hang so heavily upon my hands as I had feared. Some of my time was taken up by my looking after the workmen, and attending more or less to the repairs of the house. Sagastabeytia and I examined the accounts of the Banco Hipotecario, and together with Riva Agüero, Manuel Pardo, and Cipriano Correa we had more than one lon $[\ldots]$ ence with Juan Martin Echenique on the subject of the Pasco Railw [...] [310] none of which however led to any satisfactory result. On Saturday the $20^{\text {th }}$ my wife, thanks to the remedies prescribed by Dr. Bambaren, had so far recovered that she was able to go in the evening to a small party given by Mr. and Mrs. Frederic Marriott to celebrate the birthday of their little daughter Maria. I not being invited did not accompany her. On the $31^{\text {st }}$ the shareholders of the Insurance Company "Lima" assembled in the Exchange Rooms. Lembcke, pleading his manifold occupations, desired to be exonerated from the presidency, but was persuaded to remain in for one year longer. Three of the Directors had to go out according to statutes; lots were drawn, and my 
name, that of Rafael Canevaro, and Bianchi came out of the amphora. I was reelected, the two others not - instead of them Carlos Elizalde, port-agent in Callao, and a certain Juan Calderon, son of an Italian, formerly clerk to Pedro Dinegri and now partner of Schinoll of Paris.

From Europe we heard nothing of importance. Juan, tired of the monotonous life of Monaco had removed to Nizza. Laurie, the North-American for many years cashier with Gibbs, who had retired with a handsome competency, had suddenly died in Paris. I may also mention the death of Mrs. Barton, which took place in London some months back, and of Mr. and Mrs. Codecido, of whom I spoke detailedly page $741 \mathrm{Vol}$. 3, who both breathed their last in Santiago de Chile. On Saturday the $27^{\text {th }}$ I was the greater part of the day in Callao. The Captain of the Danish schooner "Margrethe", called Winge, presented himself in my Consulate and stated to me that he had sailed from Hamburg for Islay, there to discharge his cargo, and to proceed thence to Punta Arenas, in Central America. When in Islay, three of his men had refused to work; he had them taken on shore, where the Captain of the port had kept them in jail for some days, after the lapse of which he had again sent them on board and instructed the Captain to sail for Callao, there to deliver them up to me. Though this was a deviation from his voyage, he had had to obey and now came to me for my advice. I went to Lembcke to ask his opinion, and then by 12 O'clock train to Callao. Here I took the captain's declaration, having had the good luck to find some one who was willing to write English for me; in the office of the Captain of the port the three mutineers, who were brought from prison, gave their declarations; and finally I was rowed on board the "Margrethe" which was lying far out - here I called the rest of the crew before me and took their depositions. I was on the point of getting sea-sick, but [_]ately got over it. On Monday the $29^{\text {th }}$ I again went down. In [...] [311] office the three men were paid off, and the captain made his protest. Now I thought all was settled, but when on my way to the terminus the captain came running after me with a long face and told me that the Captain of the Port refused to give him his sailing licence; again we hastened to Higginson's, who agreed to take the necessary steps for dispatching the vessel, charging of course his customary commission. Now the Captain had not sufficient money to defray all the expenses incurred, and I had to lend him 55 Soles, for which he gave me a bill for one hundred and fifty banco marks on his correspondent in Randers, Carl Hassager, which I would have to remit to my friends in Altona, and so the affair ended.

Thursday, $7^{\text {st }}$ of February 1872 . Having advertized in the papers for a secretary and lector, various persons presented themselves, and I had come to terms with an elderly Frenchman, Mr. Victor Dupont, who, as far as I could judge from the one or two interviews which I had with him, was perfectly acquainted 
with his own language, knew a good deal of Spanish, and had a considerable knowledge of English; his handwriting was but middling. This day he came to me for the first time. The news of the day were, firstly, the removal of the President Balta to Ancon; he took with him all the troops, infantry, cavalry, and nearly fifty pieces of artillery - also some of the men of war had been ordered thither. What he intended doing in Ancon with such a force nobody could tell. Secondly, the union of the firm of Dreyfus with the Banco del Perú. The capital of the bank was four millions of dollars, of which one half had been paid up; Dreyfus Bros. \& Co. and friends entered with a similar capital, of which one half was to be paid in cash, and the other half in short instalments. As soon as found necessary shares of S/1000 each to the amount of 3,200,000 Soles would be offered to the public. If this project was carried into effect, the entire nominal capital of the Banco del Perú would not be less than twelve million dollars, and this would no doubt be very prejudicial to the banks whose capital was less considerable.

The repairs of the house went on with much activity under the direction of the architect Baumann; with another Frenchman, the painter Gauret, I made a contract for painting the entire house outside and inside.

By the North Steamer I received a letter from Juan, still dated Nizza; another from Sieveking of Altona, who informed me to my great surprise that the firm of C. H. Donner was about removing its office from Altona to Hamburg, leaving in the former place a branch under the management of Jansen [...] and import business whilst the Hamburg house would att[_] [312] to the banking and bill business; even Sieveking thought of following this example.

Friday, $2^{\text {nd }}$ of February 1872. Last night at 10 O'clock I was in the house of Rafael Velarde, whence jointly with some other gentlemen I accompanied the coffin which enclosed the corpse of his nephew Eduardo Robinson, to the Church de los Huerfanos, (foundlings) and this morning I was present at the funeral. Eduardo was one of the sons of Don Rafael's sister Rosalia and brother of the Doctor Don Jorge, of whom I have spoken once or twice, and of another Enrique, who all three brought themselves to an untimely end by hard drinking.

In the monthly meeting of the Directory of the Banco de Lima, Lembcke informed us that last month not less than 28,000 Soles had been made by the daily discounting business, and that of late shares had been sold the one with a premium of $\$ 6000$ the other of $\$ 7000$. No one alluded to the increase in the capital of the Banco del Perú.

Sunday, $4^{\text {th }}$ of February. I was up at 5.30 with dawn of day for I had to arrange my cash, which on the previous evening, when the paying of my workmen took 
up my time till 6.30, I had not been able to do. Juan Bazo, who lived in Chorrillos, had invited me to breakfast with him; thus I went out by the 8 O'clock train, bathed, walked over the hills, and was at about to in his house, or rancho, which, lately constructed by Villa might perhaps answer Bazo's purpose, but to me it appeared too small, and consequently uncomfortable. We were at breakfast: Don Juan, his wife Irene, his very agreeable brother Antonio, the latter's son Juan, adopted by his uncle, and myself. I remained a considerable while, for the time passed away quickly in lively conversation. I called upon various of my acquaintances, and walked over to the Salto del Fraile where I sat down for some time; my sight, weak as it was, roamed over the far stretching ocean, and over the ever rolling waves, which coming on in regular succession died the one after the other on the sandy beach; close to me I had the foaming surf, which breaking over a rocky islet formed cataract after cataract, and threw the spray high into the air. Before taking the train I looked in at General Pezet's, whose palace - for house or rancho it could not be called - was furnished and fitted up in an extremely elegant and comfortable manner. I was back in Lima for dinner, when I found my wife again indisposed.

Sunday, $11^{\text {th }}$ of February. Last night Mr. Dupont who since the [_] of the month had been reading to me a very am [...] [313] extracted from the Duc de Simon's memoirs, called "Louis XIV, et sa Cour", took up at my request the daily London paper called the Evening Mail, which contained amongst other things an official dispatch directed by Prince Von Bismark to the German Ambassador in Paris, Count Von Arnim, to be communicated by him to the French Government. It stated that in those Departments of France still occupied by the German troops, isolated German sentries had occasionally been found murdered. The perpetrators had been apprehended and placed before a French jury, but twice they had been declared innocent, once by the jury in Melun, another time by that in Paris; if, therefore, continued the dispatch, the French authorities had not the power to do justice, he, Prince Bismark himself, would look to the matter. These were more or less the contents of the official note written of course in a very polite style. According to the same paper the expenses of the French Government for the year 1872 would come to £1o9,500,ooo Stg., as per budget presented by the French Minister of Finance; this enormous sum included interest on the many loans raised during, and since the conclusion of the war. More or less $£_{3,000,00 o}$ devoted during the Empire to public works had now been carried to the increase of the army; for the navy the expenses were less than under the rule of Napoleon III, who by the by resided in Chiselhurst, and the Empress' diamonds, valued in $£ 80,000$ were to be brought to the hammer. Of the war indemnity one third had hitherto been paid. 
Though this was Carnival Sunday, I ventured out and had the good luck to return without being wetted. My wife and I being without a cook had for some time past been dining with the Garlands; I never objected to it for a day or two, but for a length of time I did not like to be under obligation to any one, not even to my daughter Enriqueta.

The Archbishop Goyeneche who had had a severe fall, which at his advanced age was likely to have serious consequences, was lying dangerously ill in the house next door to ours, whither he had removed from the Archiepiscopal palace, and which was occupied by his nephew José Sebastian and his nieces Carmen and Josefa.

Monday, $12^{\text {th }}$ and Tuesday, $13^{\text {th }}$ of February. Carnival days. I did not stir from the house. Mr. Dupont who had been complaining for several days, had on Monday such a violent attack of the fever and ague that he had to leave, and I was thus [...] my own resources, unfortunately very scanty. [314]

Wednesday, $14^{\text {th }}$ of February 1872. In the club-rooms a few Germans assembled; they treated on the necessity of having here in Lima a German clergyman. We however came to no decision as to the steps to be taken to procure one; the only thing really accomplished was the raising of the subscription from dollars to Soles, so that should we ever have a clergyman here, $\mathrm{S} / 200$ a year would have to be disbursed by me.

Saturday, $17^{\text {th }}$ of February. In a meeting of the Directory of the Water Company Andrés Rey, the manager, complained to us of the hostility which the company experienced from the Lima Municipality; the only advice we, the Directors, could give him was to recommend to him to proceed in future in all his transaction with the higher and highest authorities, with the same prudence and suavity as he had done hitherto. The fusion of Dreyfus with the Banco del Perú was at all events postponed for some time. Though the majority of the shareholders of the bank seemed to be in favor of the union, yet a few of them were violently opposed to the same, and thus Dreyfus had withdrawn his proposal; but now I learned from Zaracondegui and Lembcke that one or two of the bank's Directors had insinuated to Ford, who in this affair came forward as the representative of the firm of Dreyfus, that the bank would be glad if he would resume the negotiations.

Monday, $19^{\text {th }}$ of February died José Sebastian Goyeneche, Archbishop of Lima, at the age of 88 years and a few months; he had been not only the oldest but also the Senior of all the bishops on the face of the earth, at least of the Roman-Catholic Church. Already at the age of 32 or 34 he had been ordained bishop. He was a man of mediocre intellectual capacity, rigidly pure in his morals, but miserly in the extreme. By his death the large fortune of the three 
brothers Goyeneche, estimated by some at as high as forty million dollars, probably over-rated, concentrated in the children of the late Juan Mariano, viz.: the eldest, Count of Huaquí, residing in Madrid, married, but childless; Juan Mariano Jr., who had several children; José Sebastian, Josefa, and Carmen these three last unmarried.

Wednesday, $21^{\text {st }}$ of February. The corpse of the deceased in an open coffin placed on a bier was carried to the Archiepiscopal Palace at the corner of the "plaza mayor": it was preceded by two rows of persons, for the greater part friars, who carried lighted torches; it was a poor procession, nevertheless some of our acquaintances had come to our ba [...] [315] a look at it.

Thursday, $22^{\text {th }}$ and Friday, $23^{\text {th }}$ of February. These two days the body, which had been embalmed, was exposed to public view in a room of the said palace, which was lighted up with many candles, the walls were hung with black cloth sprinkled with silver stars, also the scaffolding upon which the open coffin stood was covered with black drapery. Many people, I among the number, went to see him - a few kissed the dead man's right hand.

Saturday, $24^{\text {th }}$ of February. The funeral took place in the cathedral, and in the vault below Don José Sebastian found his last resting-place. I saw nothing of the solemnity; when as usually at 3.30 I went to the Banco de Lima, the Plaza was so crowded that I could hardly make my way through the multitude.

Sunday, $25^{\text {th }}$ of February. In the papers of last night appeared the programme of a new bank called the "Nacional" in which Dreyfus Bros. \& Co. and their friends were mainly interested. Dreyfus contributed four millions of Soles and eight millions were offered to the public; each share represented S/10oo and every 10 shares entitled the holder to a vote in the general meeting of shareholders; these were to elect seven Directors, and the Directors to name two gerentes or managers. On subscribing, $2 \%$ were to be paid in, $13 \%$ ten days before the opening of the bank, and $10 \%$ one month after. Should the subscriptions for which fifteen days were allowed for such as resided in Lima and forty-five for those who did not live in the capital, surpass the eight millions, then all subscribers would have to submit to a proportional reduction, whilst on the other hand if the eight millions were not completed, Dreyfus would take the amount which might be wanting.

Monday, $26^{\text {th }}$ of February. I went to Dreyfus office and subscribed S/40,00o on Juan's account. In my letter to him I left it to his option whether he would take the whole sum, or two thirds, or one half; whatsoever he was not inclined to take, I would take on my own account. This letter, as well as as another to my cousin Mrs. Cresswell of Winchmore Hill, and a third to my niece Mrs. Bobertag I of course dictated to my secretary Mr. Dupont, who had however 
been so often indisposed that it had been out of his power to attend to his duty as I could have wished. I also made use of his services to index the remodeled diaries written in clean by Mr. Coleman, which he read to me aloud: I was [_] shed and at the same time displeased with the many oversights [...] [316] say errors I discovered in Mr. Coleman's writing. This day the subscriptions to the new bank came up to eleven million Soles; all descriptions of people hastened to the office to put down their name: capitalists, merchants, hairdressers, cigardealers, carpenters etc., from Henry Meiggs who subscribed for $\mathrm{S} / 2,000,000$ down to G. M. Valdeavellano, clerk in La Providencia, who signed for one share.

Wednesday, $28^{\text {th }}$ of February. Guillermo Garland's birthday, which we celebrated by our dining with Enriqueta and family upon a turkey; otherwise every thing was as quiet as usual.

Thursday, $29^{\text {th }}$ of February. All our carpenters left, their chief refusing to obey Mr. Baumann's orders. Miceno Espantoso threw up his situation as gerente of the Banco del Perú, which he had filled together with Emilio Althaus ever since the establishment of the bank; it was not yet decided who would take his place. The Government subscribed two millions of Soles to the new bank.

Nearly all with whom I came in contact, as well as myself, looked forward with dread and apprehension to the month of May; about that time, or perhaps a little later a crisis both monetary and political was imminent. The Banco del Perú had almost entirely ceased discounting and Lembcke, Zaracondegui and I also thought prudent to reduce the operations of the Banco de Lima. Everybody kept back his money, and the rate of discount had necessarily to rise. Whatsoever money I might get in within the next month or two, I was determined not to lend again, but leave it at the bank. Since two or three days the temperature had become cooler, and this morning when going out at half past seven I wondered to see a thick fog covering all the environs of Lima.

Friday, ${ }^{\text {st }}$ of March. In the course of last night I was called up by my wife, who suffered from indigestion. This morning she was really unwell; Dr. Bambaren was sent for and came twice in the course of the day.

In the monthly meeting of the Directory of the Banco de Lima, where all were present, except Sagastabeytia, absent in Chorrillos, and J. M. Cantuarias, who had sold his share, with a premium of $\$ 6800$, and thus de facto ceased to be a Director, we resolved that our operations should be curtailed, not entirely suspended - also that when we next met we would decide whether a new call should be made upon the shareholders. The Banco del Perú had ceased discounting and would probably give no dividend for 1871. Lembcke told me in strict confidence that its situat[_] was far from flourishing, and that its 
shares could be bought at par. The [...] Marti offered me one of the Banco de Lima with a premium of $\$ 50[\ldots]$ [317] great falling off from the premium of $\$ 6800$ paid by Narciso Velarde to Cantuarias. Money was extremely scarce; even I had no more than $\$ 17,000$ in the Banco de Lima - less than I ever had before; I did not at all like the look of things. Enrique Marriott paid me for Juan Martin Echenique the $2 \%$ interest for 3 months on my S/12,00o obligations of the Cerro de Pasco Mineral Railway Coy., which I had hardly expected.

Saturday, $2^{\text {nd }}$ of March 1872. Thanks to Bambaren's efficient remedies, my wife was this day again in her normal state of health. The architect Baumann procured new carpenters who took the place of the mutinous ones of the other day, and thus the work was again going on. With Gauret, the painter, I agreed that all the walls inside the house were to be painted with oil paint I paying him 8 cents the square vara for each coat. I also closed with a certain Dewerth to floor the corredor round the patio with artificial stone, all of one piece, at 19 rials the square vara, I furnishing the materials, mainly sand and portland cement, here called "cimiento Romano" and finally, with a certain Santiago O. Frilla for paving the patio with small stones, which he had to bring from the bed of the river, in pretty designs at 20 rials the square vara. The subscriptions to Dreyfus' Bank came up on this day to 20,000,000 Soles, instead of the 8,000,000 required. The two brothers Bergmann had put down their name for S/300,ooo.

Juan in his letter from Nizza, of $28^{\text {th }}$ January wrote that Corina Cordes had grown very thin, was suffering continually, and that the physicians who had been called to see her were completely at a loss what further remedies to prescribe.

Tuesday, $5^{\text {th }}$ of March. The Manager of the Lima Water Company informed the Directory that the Lima Municipality had decreed the cancelment of the contract which years back the Supreme Government had concluded with old M. M. Basagoytia to provide Lima with water, and which contract had been ceded to the present company. One need not be a lawyer to see that the Municipality had no right to cancel any contract concluded by the Government. In this we all agreed; we also were unanimous in the necessity of a lawyer being called to defend our interest; we passed in review the Lima lawyers most in repute, and some fault or other being found with every one of them I proposed mine, Fernando Palacios, whom nobody objected to. I went to fetch him. As soon as he was with us all the details of the case were placed before him and we were pleased with the case and quickness with which he mastered the $[\ldots]$ and demerits of our situation - also with the measures he proposed [...] [318] counteract the Municipality's decree. The salary we fixed on was $S / 200$ every 6 months. 
Friday, $8^{\text {th }}$ of March. In the meeting of the Constructora's Directory, the two gerentes César Saco and Rufino Echenique gave us a detailed account of the various buildings in the construction of which the Company was employed. At a later hour I subscribed in Dreyfus' office, on Juan's account, for 110 shares of S/100o each to the "Banco Nacional", so that with the previous 40, Juan had now 150 Shares.

Sunday, $10^{\text {th }}$ of March. In the course of the preceding week I had the good luck to collect a few thousand Soles amongst which the $31 / 2 \%$ from Enrique Marriott account J. M. Echenique, on the Pasco Mineral Railway Coy's shares. Common labourers, peones, could not be had at less than twelve rials each, per day; the number which I employed in my house was therefore very limited: only the carpenters and the artificial-stone maker - with whom I suspected that the architect himself was interested - made some progress.

The only important political news received from Europe was the rumour of a misunderstanding between England and the Unites States on the subject of the "Alabama". In my opinion the latter had not the least right to make any claim for indemnification for the damage done by the "Alabama" to the United States trade during the civil war. The Alabama was a private enterprize; it is true she was fitted out in England, but had a letter of marque from the Southern Confederacy recognized as a belligerent power, and if the Federal Government did not at an earlier date put an end to her depredations it was their own fault.

By the five O'clock train I went to Chorrillos to dine by invitation with Juan Bazo. We were: he and his wife Irene, his brother Antonio, Felipe Coz, Enrique Ayulo, one of his daughters, a Miss Roel (niece of Ayulo), and Alejandro Garland. Great pleasure could not be expected from such a party however I could not help noting the great attention shown to me by all the gentlemen and by Irene; the two young ladies were very quiet, my weak sight did not allow my distinguishing their features, Miss Roel was said to be handsome.

From Monday, $11^{\text {th }}$ to Saturday, $16^{\text {th }}$ of March. Having made up my mind to pay to the "peones" twelve rials a day I had no lack of them, and the work in my house proceeded very fairly.

In the Comision Permanente Pardo's party gained an unexpected victory. Emilio Althaus and Chacaltana were qualified by 8 votes aga [...] ven the former as Senator for the Department of Ica, the latter as his [...] [319] On Saturday I was called with great urgency to the Water Company's office where I found Rey, Rodrigo, Oyague, and Schmidt. The decree lately given by the Government to expropriate the company was considered by all as the best thing that could have happened, for before turning us out they had to pay the value of all the works according to an equitable valuation, and we flattered 
ourselves that we should find no difficulty in inducing the appraiser to make an estimate favourable to the company.

Sunday, $17^{\text {th }}$ of March. I was up by six, when it was not yet light enough to permit me to write the few words I wished to note down; I therefore went out into the street and ascended San Crístoval, which I had not done for two or three months. I did so from that side of the mountain which terminates at the extremity of the Paseo Militar. The first steepest part, which is perhaps one sixth of the whole height, I climbed up with a good will and had to rest for a few minutes, bathed in perspiration; the remainder I took more easily and reached the summit without any particular exertion. I then took my seat on the stone, well known to me, and returned by the new Alameda.

Tuesday, $19^{\text {th }}$ of March. San José. I availed myself with pleasure of an offer which Garland made to me to go with him per train upon the Oroya line as far as San Bartolomé, forty miles distant, the last point to which the rails were laid. Enrique, who was in the employ of Meiggs, had procured four tickets gratis, and thus by 8 O'clock Garland, Enrique, Antonio, and I were at the Monserrate station. The engine which pulled us up was a very powerful one nor could it be otherwise, for the latter part of the road ascended continually at the rate of 3 and $4 \%$. In the first class carriage we were - I suppose - somewhat more than forty persons, many of whom employes of Meiggs. In one corner was a small recess boarded off, containing the great convenience of a water-closet, in the other corner a deposit for potable water with a metal jug attached to it.

The road is in every respect highly interesting. Immediately on leaving the terminus we entered the bed of the river, the river itself, much swollen in the present season, flowing alongside of us; we passed under one of the arches of the bridge. To our left we had the Alameda and the Cerro de San Crístoval, to our right the houses of the town; we then passed close to the other bridge, still in progress of construction, and a little further on, leaving the bed of the river, we emerged more or less on the high road which leads up the quebrada of San Juan de Matucanas; the railway leaves it a little to the right and inclines to the left closer to the course of the [...] sometimes visible, sometimes concealed by intervening land and vegetati [_]. [320]

At first we found ourselves in a wide valley, well cultivated and divided into many haciendas, producing clover, camotes, yucas etc. To the right the plain extends without being confined by mountains; by and by a ridge of barren, sandy hills came in sight, which as well as an uninterrupted chain to our left, kept us company the whole day long. The distance between the two ridges might be a league, gradually they draw closer; at San Bartolomé the distance between them is perhaps not much above a mile. At 8.30 we stopped 
for the first time at an hacienda called Santa Clara; henceforward the valley narrowed considerably, and though the country was still cultivated, I often observed pieces of ground covered with stones and wild cane; the hills on both sides were invariably arid and sterile, without a single blade of grass. At 10.30 we arrived at a small hacienda called La Chosica where the quebrada widens a little; here a North American had established an hotel, and breakfast was waiting for the travellers, twenty five or thirty of whom sat down. The breakfast, consisting of broth, cutlets, beefsteaks, fish, tea or coffee, bread and butter, was indifferent. After a detention of half an hour we started afresh; again the quebrada narrowed, and henceforward the ascent was much more perceptible than hitherto, also curves followed each other in rapid succession. The line wound along the base of the ridge, crossed over a bridge to the right bank, remained there for a short time, and recrossed to the left side. At every turn it looked as if there were no outlet, so completely were we surrounded by mountains. At a place called Parachaca, 4000 English feet above the level of the sea, we came to the first encampment of engineers; the ground was covered with white tents, next we came to Cocachacra, the road continually ascending and the chains of mountains drawing near and nearer; at about 11.30 we arrived at San Bartolomé, another encampment, and the end of our this days' journey. I learned that here the engineers had met with a great difficulty; the gulley rises so steeply that it is impossible to follow its course, the line must necessarily return a considerable distance along the side (la falda) of the ridge to the right, and then take another turn, forming a complete zigzag. It was past 12.30 when we left San Bartolomé; the second class carriage was well filled; going it had been very warm, on returning it was much cooler, for the sea breeze blew right into our faces. At La Chosica the train stopped again, and passengers alighted to take lunch. At 3.30 we were back in the terminus in Lima, whence it took us more than a quarter of an hour to walk to our house; for the remaind[_] of the day I was very sleepy. [321]

Wednesday, $20^{\text {th }}$ of March. Mr. Dupont, who had been indisposed for several days, returned to his post; on the other hand Don Gavino, the sobrestante, was called to Callao by the sudden illness of his wife, and thus though Mr. Baumann, the Architect, was generally present I myself had to pay to the workmen each his two rials when he went for breakfast, and to attend to their many requests and wants, to do which was the special duty of the sobrestante. The political news which the steamer brought us was the following: The Pope, it was said, intended to convoke another ecumenic Council, but it was not yet certain where it was to meet; he had asked leave from the Emperor of Austria to hold it in the Tyrol, and from Queen Victoria to hold it in Malta. There had been an extraordinary 
gathering of Legitimists in the town of Antwerp, with the object to present their respects to the Count de Chambord, also to lay before him a manifest drawn up by his friends in the French Chamber of Deputies; in this chamber it had been voted that all the laws referring to new imposts should contain the words, "caused by the war of 1870 ", to which an amendment was moved by the left, and carried to the effect that to the word "war" should be added the words, "declared by Napoleon"; then the right moved another addition, "and continued by the September Government" (which meant of course the Republic) and this was lost. The voluntary subscriptions to contribute to the payment of the war indemnity had run up to 23 millions of francs; three thousand millions were still unpaid. The German Government had made the offer to allow a discount of $5 \%$ p.a. upon every anticipated payment. My son Juan was still in Nizza. Rosa wrote from Paris that the Countess Uribarren had given a great ball: Forbes, the son of old Forbes of the firm of Barron Forbes \& Co. of San Blas so well known to me during the time of my connection with Gibbs, another, a fancy ball, on the last Carnival-day. The jewelry displayed on this occasion by the rich Mexican and Peruvian ladies had struck the Parisians with wonder and amazement. The wife of Carlos Candamo, who represented Night and Day, had perhaps surpassed them all; on one side, representing day, she was covered with pearls - on the other, representing night, with diamonds; her pearl necklace was valued at \$10o,ooo. Carlos Candamo's sister, married to the son of John Bryce, had remained not much behind her sister-in-law. Of Doña Barbarita, Allier's step-daughter, Rosa also made particular mention. Amalia had worn a blue dress with silver stars, some diamonds in her hair.

We received from the port the stoneware flower-pots which Dreyfus had sent us at the request of Juan; they were beautiful indeed, and my wife was quite $[\ldots]$ with them. [322]

Sunday, $24^{\text {th }}$ of March 1872. Antonio Garland and I left our house at 6.30 to ascend San Crístoval. We crossed the river over a provisional wooden bridge constructed close to that not yet concluded, the building of which had been begun by the Contractor Enrique Armero, and was now continued by his sisters and heirs. We walked up the valley of Lurigancho, along the base of the mountain as far as where the road takes a decided turn to the right, and there where the ascent is longest, and consequently the easiest, we climbed up, and reached the summit without any particular fatigue. For a few minutes I rested on the big stone and descended exactly opposite to where we had come up. On reaching the saddle instead of turning to the left we descended to the right into the valley of Lurigancho when Antonio, not yet satisfied, begged me to extend our walk as far as the Chacarilla, the first farm in the valley; here we 
turned our faces townwards, and were home by 9.30 when I tried to sleep a little, but could not.

Monday, $25^{\text {th }}$ of March. La Anunciacion. By the twelve O'clock train I went as far as the Barranco where I called upon the family of the late Dr. Prada. Great improvements had been made here since my last visit; houses were springing up in every direction, for Chorrillos was getting too small for the many families desirous to spend the hot season in the country. The descent to the sea had been levelled and made very easy. At the Prada's I was received by Doña Isabel, an elderly lady, and intimate friend of my wife's; her daughter Josefa, Prada's widow, was unwell, and her two granddaughters Cristina, married to Dr. Domingo Mendoza, and the unmarried Isabel, never showed themselves to strangers; these two young ladies might perhaps be too strict in the observance of the religious rites prescribed by the Church, but if in this they erred, the error was amply made up for by their extraordinary charity; both, but especially the younger, spent all their time in Churches, in hospitals, and at the bedside of sick and dying persons. They were always dressed in black in the plainest manner and their clothes and shoes made of the coarsest materials.

My walk to Chorrillos along the sinuosities of the high coast took me half an hour. I called upon Mrs. Riva Agüero, Mrs. Frederic Marriott, and Dr. J. G. Paz-Soldan, who was over head and ears busy with the reconstrucion of the large rancho, formerly the property of old Doña Ignacia Palacios, lately bought by him. I dined quietly with Juan Bazo and Irene, looked in at Doña Jesus, the daughter of Muñoz, married to Manuel Panizo; and returned to Lima. At home I found Antonio with a very bad cold, for on the preceding da [...] [323] violent exercise he had had the imprudence to take a cold bath in the marble bath on Enriqueta's side of the house.

Wednesday, $27^{\text {th }}$ of March The Government gave a decree in virtue of which the pay of all persons in their services, whether civil or military, way raised from dollars to Soles, that is to say $25 \%$; the object they had in view was very clear, viz.: to gain popularity now that the elections for a new President were close at hand.

At last, after negotiations which I feared would never come to an end, Garland brought to a close the dispute which for such a long time had been pending between Schutte \& Co. and the Peruvian Government, the former claiming indemnification for having been despoiled of the Guano Consignment to Germany, before the expiration of their contract, the latter pretending that in one or two instances Schutte \& Co. had not complied with the orders given them. I need hardly say that it would never have been concluded had 
Garland not resorted to those means without which nothing could be obtained under the present administration, that is to say, he had to pay heavy sums as gratifications; whether they went, and who received them, I never learned; I should however not wonder if part of the money found its way into the pockets of Doña Melchora, the President's wife. Once or twice, perhaps even three times, Dr. Francisco Garcia Calderon, Garland's lawyer, had gone to Ancon where he had personal interviews with the President; he certainly had rendered Garland great services, whilst I was told that the Minister of Finances, the deaf Masias, and Jose Felipe Izcue, an influential employé, the same who, when a child had jointly with Corina and Amalia Schutte been under the tuition of Zyla, had done all they could to retard the settlement. However, notwithstanding their intrigues the escritura de transacion was finally drawn out in the office of the Notary public Claudio Suarez, and signed by Garland for Schutte \& Co., by said Izcue for the Government. The exact conditions of this friendly arrangement never came to my knowledge; there was however no doubt that they were much to the advantage of the firm of Schutte \& Co., whose partners were C. W. Schutte of Paris, who had an interest of 70, and G. Garland of Lima who had $30 \%$ in the business.

Friday, $29^{\text {th }}$ of March. Good Friday. Mr. Dupont did not come, and seldom have I spent a more tedious day. Garland sent to the lawyer Garcia Calderon as a remuneration for his services a cheque for a sum, which Enriqueta and I thought would not satisfy him, and so it turned out; he returned it, and we [...] from other persons that he claimed an enormous sum, which Garla[_] [324] was not authorized to give; now all friendly relations with him were at an end, which I much regretted, for in a country like Perú, such a man as Garcia Calderon, who had been minister of finances, was very clever, and enjoyed a great and deserved reputation, might be a dangerous enemy, or an influential friend.

Sunday, $31^{\text {st }}$ of March. Easter Sunday. Antonio's illness turned out be the measles; in order that Maria and Corina might not be infected, his bed was removed to our side of the house, where at Enriqueta's request Clementina Frias, a particular friend of hers, attended and nursed him.

Monday, ${ }^{\text {st }}$ of April. Easter Monday. This morning I was up at 6, and again up to San Crístoval. On my reaching the summit, I found there 7 or 8 persons; this was by no means a pleasant surprise, for I could not guess who they were, and what was their object in being there at such an early hour; to return, would have indicated fear; I therefore saluted them with the words "buenos dias, que, están trabajando aquí?", "no trabajamos, estamos mirando, y Ud.?” "Voy á bajar", and without even throwing a glance at my usual resting-place, the big stone, 
I descended on the other side with winged speed; they seemed to be labourers, but I apprehended that if I had remained they would have either asked me for money, or offered me their bottle of brandy, both which I was desirous to avoid.

Sunday, $7^{\text {th }}$ of April. In the first days of the preceding week the Directories of the Banco de Lima and the Insurance Company "Lima" had their usual monthly meeting; both establishments were doing little business about this time, and consequently the gerentes had nothing of particular interest to lay before us. Very different were the proceedings in a meeting of the shareholders of the Huacho Railway Coy., who had been convoked to assemble in the exchange rooms in the first story of the Consulado, but on account of the crazy state of this building we, at least fifty in number, removed to a saloon in an hotel close by. Of the Directors only two were present: Pedro Telmo Larañaga, who presided, and Emilio Solar, the only one of the Directors who enjoyed the complete confidence of the shareholders; Graña did not attend, fearful no doubt, that questions might be put to him, which he would be unable to answer; the company's engineer was absent probably for the same reason. The President of the Directory Fabian Melgar had sent in a note to excuse himself; it was read, and no notice taken of it. Solar in a long speech gave a detailed account of the present state of the compan[_] affairs. The monthly gross income was about $\mathrm{S} / 15,000$ - the monthly ord[_] [325] expenses came to the same amount - one million of Soles were immediately required to pay the debts and to enable the company to go on with the necessary works; if this sum could be procured, and the administration were completely changed, he was of opinion that the railway would still be a good enterprize, he being certain that the carriage of produce, particularly sugar, would vastly increase owing to the great augmentation of sugar plantations in the neighbourhood. From all he said one could clearly infer that he inclined to accept the proposal made by the Government which, it must be borne in mind, owned half of the shares. They, the Government, proposed to take the railway on their own account, paying of course the debts. Those of the shareholders who were inclined to continue as before, but in company with the Government might do so, without their being allowed any right to interfere; those who preferred, might exchange their shares at par for Government Bonds bearing $5 \%$ annual interest, and with a redemption of 2 or $4 \%$ annually. If the shareholders accepted neither the one nor the other, the company would have to declare itself in bankruptcy. Aurelio Dinegri first rose and spoke in favor of the Government's proposal; next, Dr. Fernando Palacios who took a diametrically opposed view; of his observations the most weighty one in my opinion was that the Congress 
could annul these bonds, and then we should find ourselves without shares or bonds, and in fact without anything. The lawyer Pasapera, whom I asked for his opinion, said that in such a case, by no means probable, though possible, the shareholders would naturally resume their original rights. Many gave their opinion: young Tenaud, Pasapera, Dr. Pasos ex-editor of the "Nacional", Solar for the second time, who said that on his own accord he had been to the President explained to him the miserable state of the country, and asked for the assistance of the Government. By and by the noise became great, many spoke at the same time; it was hardly possible to understand what was said, and the President had no bell near him to restore order. Lembcke however and Agustin Escudero were listened to with some attention, and finally a great majority resolved that a commission of three or four of shareholders should be named for the purpose of soliciting the President to place the bonds to be issued in payment of the shares on better terms than those hitherto offered. Solar and Lembcke were named, and accepted the nomination. I left before the number of the members of the commission was completed, for it was late, and I had to pay my workmen at home.

Last night the rancho of Dr. Mariano Dorado in Chorrillos was [...] by fire; it was caused by the negligence of Chinese servants who had fall[_] [326] asleep whilst smoking opium.

Tuesday, $9^{\text {th }}$ of April 1872. I had a great fright. As one of the Directors de Turno I at half past three was going to the office of the Insurance Company "Lima", Calle de la Coca, when at the corner of Bodegones a passer by pointed out to me a column of smoke clearly discernible in the direction of the Calle del Correo; I ran across the plaza, and soon saw the flames burst out of the door of the pulperia situated between the corner house, occupied by Conde-Marin, and my own, let to Escobar. As yet there were but few people on the spot; no engine had come, and several men were endeavouring, though fruitlessly, to put out the fire by throwing in buckets-full of water. I ran up the stairs of my house; Escobar was not in, his wife of course in great consternation. With the young men of Bamberger's house I took my station on the roof, assistance we could not render, but carefully did we watch the wind which fortunately did not blow the flames towards that balcony between them and the balcony of my house. Quickly did the engines arrive the French, Italian, and Peruvian Volunteers - that of the "celadores" was the last. The volume of water which they poured in was such that the fire was soon got under and at 4.15 all danger was over. I then went to my house calle de Zarate leaving the street still crowded with people, and the engines at work. The Interior of the Pulperia was entirely destroyed; Conde-Marin's rooms above the same, as well as the 
balcony, had suffered. Close by at the corner was the shop in which Kast was interested, and which was insured by the South American Insurance Coy. in $\$ 50,000$; it escaped unscathed. I may add that for two or three years previously I had my house insured in the said South American, but fires being of such rare occurrence in Lima, I at the end of the preceding year had allowed my policy to expire without renewing it.

Saturday, $13^{\text {th }}$ of April. In the forenoon both my lawyer Dr. Fernando Palacios and Leyva's, J. M. Varela, pleaded in the first Chamber of the Superior Court before the Vocales, Blas Alzamora who presided, and with whom I was on rather indifferent terms since he had sentenced against me in the case against J. M. Varela Sr., Dr. J. M. Perez, married to the sister of Rafael Velarde's wife, and Dr. Mariano Dorado, who was intimate with my wife and myself. The case to be decided was that carried on by me against my neighbour on the subject of the "servidumbre" (the extinction of the gutter in my garden).

The Commission named by the shareholders of the Huacho Railway Company (see $7^{\text {th }}$ April) had been with the President [...] [327] obtained some trifling amelioration in the terms offered by Government. The bonds to be given to the shareholders in payment of their shares would bear $6 \%$ p.a. instead of $5 \%$, and the redemption fund was to be $S / 8000$ every three months.

Sunday, $14^{\text {th }}$ of April 1872. This morning I was again up to San Cristoval. The Cathedral struck half past seven when I reached the summit; at that very moment the sun, hitherto hidden by clouds, shone out, a thick fog concealed the valleys and the sides of the hills; only the tops stood out, like islands from a surrounding sea.

By the steamer for Panamá several Peruvian families left for Europe: Arthur Heeren, wife, and child, John Gallagher, his wife, and his sister Mrs. Evans, Benito Valdeavellano, wife, and numerous family, and perhaps several more.

From Monday, $15^{\text {th }}$ to Thursday, $18^{\text {th }}$ of April. Mr. Dupont, prevented by indisposition, did not make his appearance in my office. On Monday some of the shareholders of the Lima Gas Company met, and in the absence of José V. Oyague, who always presided when present, I was called to the chair. When Marriott, the Gerente, had read the annual report, I observed that the waste of 800,000 cubic feet, equal to $161 / 2 \%$ of the quantity produced appeared to me enormous, to which Marriott replied that in 1871 it had been less than in 1870 , and that it was caused partly by a natural evaporation, and mainly by the continual injury done to the pipes by the labourers employed in constructing the sewers in the streets of Lima. Marriott further proposed that Silvestre Guiroy, who for many years past had examined the accounts of the Company, should do so again at the end of the present year. And finally informed us that three new Directors had to be named in lieu of Arthur Heeren, and 
Mr. Prentice, who had both left the country, and Domingo Castañeda, who wanted to retire on account of his advanced age. On Thursday the Directory of the Constructora assembled, and this time the meeting was better attended than usual, we were: Zaracondegui, Escobar, Dr. Emilio Solar, Santiago Lanfranco, Granda, Emilio Píerola, Juan Martin Echenique, I, and the two gerentes R. Echenique and C. Saco. After an animated discussion we approved with some slight alterations a very advantageous contract which Juan Martin Echenique, who in the last meeting had been empowered for that purpose, had drawn out with Nemesio and Serapio Orbegoso for the irrigation of vast tracts of land, close to the river Santa. The Comercio in one of its numbers gave an account of a fraud committed by a certain Ramos of a Callao firm, to the extent of about S/50,00o. On Saturday the $13^{\text {th }}$ he bought of certain Lima [...] on Chile for which he paid by giving cheques on the bank [...] [328] established in Lima; the drafts he resold in Callao for cash, got the money, and on Sunday the $14^{\text {th }}$ embarked on board the steamer for Panamá. On Monday the cheques were presented and dishonoured, for in none of the banks stood there any money to his credit.

Friday, $19^{\text {th }}$ of April. At 2 p.m. died in Chorrillos Mr. William Brauns, head of the firm of Huth Gruning \& Co. of Lima. He and I had frequently met and always been on good terms, never intimate. Brauns was a native of Bremen; when a young man he had entered the counting-house of Huth's house, where he had worked to the satisfaction of his superiors; being well educated, very industrious, and sufficiently clever in mercantile affairs, he gradually rose to be the second managing partner, as long as Hermann Rodewald was the first; when this latter left for Europe Brauns took his place, and Alexander Westphal, a Hamburger, stepped into the vacancy left by Brauns. When clerk he had offered his hand and heart to Carolina, General La Fuente's eldest daughter, and received a negative answer. Many years later he made a like proposal to Sofia Bergmann, and was again rejected. In his third attempt he was more fortunate, his choice had now fallen upon an extremely handsome young lady Carmen Becherel, of an obscure family, who readily accepted him. Her father was a Frenchman who for some time had kept a shop in Guayaquil.

He was dotingly fond of her and overwhelmed her with presents. In her company he visited Europe where he minded no expense if he could but please her, and yet it was generally said that the lady did not requite his love as She ought to have done; their only child had died an infant. The fortune Brauns left was not very considerable, and thus Doña Carmen would now have to relapse into the obscurity from which her husband had raised her; the first thing to be done by her was to leave in a few days the house of the firm, where she had reigned as queen paramount, and cede her place, which was perhaps the most 
galling to her, to Mrs. Westphal, upon whom she had always looked down with a kind of disdain. Previous to the events of 1866 Brauns had been Hamburg, in later years Austrian Consul General.

Saturday, $20^{\text {th }}$ of April. I went to Antonio Sousa Ferreira, Senior of the Consular Corps, and asked him whether he had taken any steps to request the attendance of the Consuls at Brauns' funeral which was to take place on Monday. As it was his habit he had done nothing, and pretending to suffer from [_] looseness in his bowels begged me, next in Seniority, to [...] [329] necessary steps to do whatsoever might be necessary; accordingly I had to run about nearly the whole morning in order to obtain from the Ministry of Foreign Affairs a list of the Consuls residing in Lima, and from Mr. Westphal the details of the arrangements made regarding the funeral; he took upon himself to send round the letters of invitation.

Monday, $22^{\text {nd }}$ of April 1872. I was up at an early hour, and by 7 O'clock stood in the street door of my house expecting the bricklayers and common labourers; none came - they had, as was sometimes the case, made Monday half a holiday. In uniform I drove at 9.30 to what was formerly the Church de San Juan de Dios, and where the Lima firemen now kept their engines; as yet few gentlemen were assembled; one of them was Leal, the Brazilian Minister, who complained to me with some bitterness that I had sent no invitation to the Diplomatic Body. Besides him, Jerningham, Gauldrée Boilleau - the French Chargé, and a few other Diplomats were present; also Dr. Loayza, the Minister for Foreign Affairs. At my request the latter headed the cortége, Lembcke and I walked behind him, and after us the remainder. At the Callao station a special train paid for by Huth's house was waiting for us. In the Government carriage Dr. Loayza and a few of us took our seats. The corpse, which had come from Chorrillos by the 9 O'clock train, went by the same conveyance. We stopped at the Bella Vista station whence we proceeded on foot and in solemn procession under an unclouded sun to the Protestant Churchyard, a band of military music leading the way; next came the coffin borne by eight stout porters; the ribbons hanging down from the same were taken hold of by Dr. Loayza, myself, Lembcke, Escardó, Rafael Canevaro, and one or two others; then followed all the mourners perhaps 200 in number. At the entrance to the churchyard the coffin was placed upon a bier and carried to the chapel where the Revd. Mr. Henry in a white surplice was waiting; he read the funeral service in English, whereupon the coffin was again lifted up, and carried to where the clergyman close to the grave had taken his post.

He read the funeral service, the coffin was lowered, some earth and flowers - of which an abundance had been procured - were thrown upon 
it, and the sad ceremony closed with some pretty singing performed by the amateurs of the German Club. Pell-mell we hastened back to the Bellavista station, entered the train when it passed by from Callao, and returned to Lima where each of us resumed his daily avocations, little thinking of his late companion whom he had left in [...] dwelling cold and dark, six feet below ground there $[\ldots]$ until $[\ldots]$ [330] into a heap of rich fertilizing earth. I had merely time to change my dress, in order to attend a numerous meeting of the shareholders of the National Bank, convened by Dreyfus' house, for the purpose of choosing the Directors. We met in a very large saloon in a building adjoining the Church of San Pedro, the same in which about a year back the Concert had been given to celebrate the anniversary of Beethoven's birth. Scheel made a short speech, in which he said that the subscriptions including those from the departments amounted to 32 million Soles, and as 8 million was the amount required, all the subscriptions had necessarily been reduced in proportion. S/150,000 subscribed by me for Juan and myself were brought down to 32,000 . José V. Oyague was called to the chair to preside, whilst the votes were given in, but this election was a mere farce, for as the Government, Dreyfus' house, their friends, and Meiggs had an overwhelming majority of shares those only were chosen whom they had fixed upon, viz.: Frederic Ford, William Scheel, Dionisio Derteano, all three partners of Dreyfus' firm, John Meiggs, Miceno Espantoso married to Augusta Bergmann, and thus Dreyfus' brother in law, Alexander Westphal, and Vicente Gonzales y Pinillos.

Tuesday, $23^{\text {rd }}$ of April. Our architect Baumann required some flag-stones to be placed in our patio, from the street door to the door of the principal room in the ground floor, with a branch to the foot of the stairs; Albarracin in Callao, I was told, had some such stones for sale; accordingly I went down to have a look at them, but did not find them to my liking.

On board of the steamer which left this day for Panamá embarked Amandus Möller, clerk of Schutte \& Co., and C. W. Schutte's confidential adviser, an extremely clever but at the same time dissolute young man.

Wednesday, $24^{\text {th }}$. A meeting of the shareholders of the Huacho Railway Company was held in the Consulado, not upstairs in the Exchange Rooms but below in the very handsome hall, the entrance of which fronts the street door. Its walls are covered with the names of all the Priors and Consuls, each three in a small square compartment, who have presided this Commercial tribunal for several centuries, probably beginning shortly after the foundation of Lima. Benches run alongside the walls, whilst in front two of three steps lead to a small elevation, with a table, and some chairs around, covered by a canopy; here the three members of the commission took their seats. Lembcke, as 
president in the centre, to his right Dr. Emilio Solar, to his left Manuel Irrigoyen. Lembcke spoke but a few words, but the two others [...] [331] Solar, made long and excellent speeches, in which the late Directors and the subalterns were not spared. Everything done by the commission was approved by all present and thanks were voted to them. When the meeting was already drawing to a close a motion was made by Dr. Fernando Palacios, Agustin Escudero, and José Luis Bernales, to the effect that a commission should be named to investigate who were those who had been the cause of the heavy loss sustained by the company, and if the guilty were discovered to make them responsible. This also passed by a large majority; a few however were against it, and I was of this number, because I was convinced that such an investigation would, after all, lead to nothing.

Thursday, $25^{\text {th }}$ of April 1872. Early in the morning died Mr. John Renner of Hamburg at the age of 66. The cause of his death was fever, aggravated by exposure to the sun, particularly on Monday last at Mr. Brauns' funeral, by improper use of the remedies prescribed, and by imprudence in eating. He was known to be a jew, but was allowed to pass for a protestant. He arrived in Lima in 1833 in the same vessel with Julius Pflücker and old Fleischmann the musicmaster. When in 1836 my wife and I lived in the first story of the house in Calle de Mantas, at present owned by J. M. Varela, Renner occupied the ground floor as hatter, which was his original calling; this however he soon abandoned, and with the tact which is peculiar to his race commenced lending money, first to the Government, then to private individuals, in which description of business he was very fortunate; being unmarried, and very close he in the course of years amassed a large fortune. About six years ago he returned to Europe, where he remained a considerable time travelling about and amusing himself. Part of his capital he left in the hands of Julius Pflücker to employ for him in the manner which he might deem most profitable, and, who should have thought it? Pflücker swindled him out of the whole. On his return to Lima about two years back he was made aware of what had occurred during his absence; the loss he had suffered was great; however, to no one did he ever state the real amount, nor did he take any judicial steps against Pflucker - perhaps because he had the conviction that do what he might, never would he get anything back from his debtor, who really had nothing; perhaps also, as he sometimes gave to understand, he forebore out of consideration for the family, especially Mrs. Pflücker, whom he said he much esteemed. He recommenced his former business as moneylender, in which he was again successful; he also invested part of this capital in the purchase of the stock in [...] shop, which enjoyed a great reputation for fashionable [...] [332] articles. His character was a compound of strange contradictions; for himself he spent hardly anything, and 
was a thorough miser; at the same time he was charitable, was active member of the institution called the Beneficencia, and to more than one Peruvian, as for instance Antonio Salinas, he lent a helping hand when they stood in need of pecuniary assistance.

Saturday, $27^{\text {th }}$ of April. The funeral took place in Bellavista. It was a counterpart of that of Brauns, with the exception that the cortége was less numerous, that there were no uniforms, no music, and that the funeral service was read in Spanish by Mr. Henry. When we were ranged round the grave a native, whom I did not know, frequently blew his nose and wiped his eyes - no doubt he was weeping. Pedro Landaburu said in a trembling voice, "ha sido mi benefactor, que descanse en paz", and threw a little earth into his grave. Woldt, the eccentric one legged German who resided in Callao, also contributed his mite - "When I was dying, he took me to Miraflores, where I was cured" were the words which he directed to the bystanders.

Wednesday, $7^{\text {st }}$ of May. The Directors of the Banco de Lima had their usual monthly meeting. Lembcke laid before us the monthly statement and informed us of the heavy sums they had discounted of late: $\mathrm{S} / 500,000$, three five, and six months acceptances of Dreyfus, in favor of H. Meiggs; S/100,000 a pagaré Montero \& Meiggs, and other pagarées of some respectable firm or other with the endorsement of Juan Ugarte, all which transactions were unanimously approved.

Thursday, $2^{\text {nd }}$ of May. Anniversary of the victory over the Spanish fleet in 1866, was of course a civic holiday, but was not celebrated by any demonstration on the part of the Government. Mr. Dupont did not come, and to me it was a very heavy day.

Friday, $3^{\text {rd }}$ of May. Owing to the large transactions of the Banco de Lima, of which I gave an account on the $1^{\text {st }}$, hardly any notes were left in this establishment; all those of 1 and 4 Soles, Meiggs had carried off and sent to the North, particularly to Chimbote, where he was constructing the railway to Huaraz. The Gerentes were busy signing new notes; cheques, the value of which the holders would readily have taken in notes, had to be paid in hard silver. This day, as well as

Saturday, $4^{\text {th }}$ of May we were without an architect for Mr. Eugène Baumann de Metz, the greatest scamp and the most barefaced liar whom the [...] shone upon availed himself of a difference of opinion bet [...] [333] my wife, and myself, to tell the pavior and the carpenter that he would no more put his foot into a house where everybody wanted to be an architect. When I made him the last payment, which he begged and prayed me to do in order to purchase a piano for his daughter, he signed a receipt, in which he obliged himself to remain with me until the house was concluded, but of course it was not to be 
expected that he would keep his word. The house of Dreyfus in Lima returned to the shareholders in the National Bank the difference between the $2 \%$ paid on the amount originally subscribed, and the $2 \%$ on the amount to which the shares were reduced. To the same firm the Bergmanns made over with the Government's consent, their contract for the construction of the new Dock or Muelle Darsena in Callao. The last streamer from Europe brought advice that of the new Peruvian loan of £15,000.00o paying 5\% annual interest, and with annual redemption of $2 \%$, part had been placed al $771 / 2 \%$, but to how many millions this part amounted, was not known; Juan wrote me from Paris that no more than three or four millions had found purchasers.

Sunday, $5^{\text {th }}$ of May 1872. This was the day fixed upon by Government for the elections all over the country of the President and two vice-Presidents for the next Constitutional period of four years to begin on the $2^{\text {nd }}$ August next. Here in Lima they went off with great order and tranquillity. The one party, the most numerous and influential, chose Manuel Pardo, President, Manuel Costas first, and Francisco Garmendia Second Vice. The second: Toribio Ureta, old Fco. Javier Mariategui, and Pedro Balta. The third, which might be called that of Javier Balta's friends: Dr. Antonio Arenas, the Vocal Eusebio J. Sanchez, and the lawyer Luciano B. Cisneros.

Pardo, when the elections were over, treated his friends to a lunch in the garden of Juan Rivera.

Monday, $6^{\text {th }}$ and Tuesday, $7^{\text {th }}$ of May. The sobrestante did not come up from Callao, in consequence of which I had to attend continually to the various wants of the labourers, who were always asking for some trifle or another. Also Mr. Dupont played the truant for one day, all which put one much out of humour.

Wednesday, $8^{\text {th }}$ of May. We engaged a new architect, recommended to us by a Roman clergyman Valerí, who was in great repute amongst the devout ladies of Lima. I liked neither him nor his protegé called Bernard Jeckel [...] Munich who like Valerí walked about in the [...] [334] catholic clergyman, and had to me the appearance of a jesuit; fortunately there remained little to be done and for this little I hoped he would answer.

The Directors of the Insurance Company Lima met; we had nothing of particular importance to transact. Alexander Westphal of Huth's house was chosen Director, in lieu of Williams Brauns deceased. The meeting over: I went to Pardo's house to congratulate him, but he not being at home, his mother Doña Petita who heard my voice called me upstairs, and I stayed with her more than half an hour, waiting for her son, who however did not come.

Thursday, $9^{\text {th }}$ of May. Ascension-day. At 10 p.m. I with many others accompanied to the church of San Francisco the corpse of Maria Josefa 
Moreira, who had died on the previous day. Though of a very dark complexion, like all her sisters and brothers, she on her mother's side belonged to one of the first families of Lima; she was unmarried and had passed the prime of life, the natural consequence of which was that her former visitors had gradually fallen off. I however occasionally called on her on Sundays and holidays, found her very agreeable, and it was evident to me that she was always glad to see me.

Friday, $10^{\text {th }}$ of May. I was present at the funeral of the Señorita Moreira.

Saturday, $11^{\text {th }}$ of May. I was still in bed, for having been up very early on the previous mornings, I thought of taking a little more rest on this my birthday, when the door opened, and in came Antonio and Maria, even little Corina not yet two years old, with nosegays in their hands, and shouting Viva Papá Witt. In the course of the day I received small presents from my wife, Enriqueta, and the four eldest sons of Garland, otherwise it was by no means a holiday for me; on the contrary I had more to do than usually. With Rehder, of the firm of Rehder \& Co., I had a long conference; the head of the establishment, Gustavus, a native of Kiel, ran away from his home many years back in order not to serve in the Danish army; he safely reached Hamburg, where he embarked on board a merchant vessel bound for Callao. Shortly after his arrival here he came in contact with Wilder, book-keeper of Huth Grüning \& Co., who having some money of his own, proposed to Rehder to put up on joint-account a shop for the sale of such articles as were not to be had either in the stores in the Calle de Bodegones or at the dealers in French fashionable articles. They intended to confine themselves to ribbons, tape, needles, pins, thread, lace, ornaments for ladies' dress chemisettes etc., etc. They carried out their plan, and erelong did a very [_] business so much so that when after the lapse of a few [...] [335] went home, Rehder paid him $\$ 50.000$ remained with the stock on hand, and continued on his own account. It is not at all unlikely that at that time he, not having the entire $\$ 50,000$ at his command, received a loan from Renner; at all events when this latter Rehder \& Co. owed him $\$ 30$,ooo for which sum they apprehended Renner's heirs or executors would make a sudden call upon them, and for this reason they now came to me, and asked me whether I would lend them the said amount, they giving me as security the pagareés of the purchasers with their endorsement, which I discounted at $1 \%$ monthly; when the pagareés fell due they engaged themselves either to pay them, or to replace them by other pagareés again to be discounted. I liked the proposal, we soon came to terms, and I paid them this very day several thousand dollars.

Tuesday, $14^{\text {th }}$ of May 1872. This was the day fixed upon for the departure of Garland and family for Europe. The motive for this voyage was the every day increasing short sightedness, not to say blindness of Garland; with one eye he could not see at all owing to a cataract which had completely developed itself. 
The other eye was not yet in such a bad condition, but was likely soon to be so; an operation became therefore indispensable; in the Lima occulists he had no faith, nor was there perhaps a single one who could take upon himself to couch a cataract. The voyage was therefore decided upon; Enriqueta went with her husband to take care of him; Antonio was to be placed in Schülers boardingschool near Hamburg; Maria and Corina went because Enriqueta would not leave them behind, and two servants girls, Aurelia a most trustful samba woman, and Marcelina, made up the party. The passage money on his side by the Pacific steamer and on the other side by the Bremen line to Cherbourg, Southampton, or Bremen was for Mr. and Mrs. Garland S/346 each for Antonio one half, 173 - for the two little ones each one quarter, again 173 for the two servants girls each one third, together 231 - total 1269 Soles upon which an allowance of one sixth was made.

We were all up at an early hour; I need not say how mother and daughter wept when they parted; Antonio was also much affected, Maria made a long face, and tears stood in her eyes, whilst Corina of course did not know what all this was about. At 7.30 three carriages ordered by Garland were at the door; in them the travellers, the four eldest sons; and I drove to the Callao terminus where a great many friends were waiting for us to accompany us to the port. Garland had been under the necessity of engaging an entire coach for [...] [336] persons. There were: Baso, Irene, Rafael Velarde, and Zoila, Manuel Velarde, Col. Masias, and his sister-in-law Tránsito, the lawyer Garcia Calderon, Col. Juan N. Vargas, Ml. Alvarez Calderon, the architect Villa, and I don't remember who else. As soon as we alighted from the train we went to the mole, I of course leading Enriqueta; here some bade good by; others were rowed on board the steamer "Caldera", which as usual lay far out. Carlos Ferreyros, who commanded the "Chalaco", had put one man-of-war boat at our disposal, also another boat belonging to the capitania del puerto. The cabins on board the steamer were not on deck, but below, on the same level with the dining saloon; I thought them rather small; each of them had two berths, and a sofa, with a window towards the sea; two of these cabins Garland had taken. There were few passengers, amongst them Vicente Camacho with wife and daughter; I left Enriqueta with the children in her berth and returned to Lima by the 11 train.

Saturday, $18^{\text {th }}$ of May. Since the departure of the family Garland, many ladies called upon my wife their kind intention being to divert the thoughts of my good Mariquita, who they very correctly supposed was very sad in the absence of her daughter and grand-children. In this they succeeded, but when they were gone my wife relapsed into her low spirits; above all in the morning when 
she awoke she missed the two little ones, who used to come to her bed to caress and play with her.

The repairs of our house still continued, but I had every expectation that all would be concluded by the $30^{\text {th }}$ June. I had purchased it on the $15^{\text {th }}$ February 1864; on the $23^{\text {rd }}$ June 1869 I took possession of it, and on the $30^{\text {th }}$ September of the same year the work of demolition and reconstruction began; I have omitted to mention that the house 41 Aldavas was let by me ever since the Frenchman Plazolles left, to Sigismund Sattler, cousin and partner of John Gildemeister and husband of Beatriz, Julius Pflucker's eldest daughter; also that in my suit against my neighbour Col. Leyva, the Superior Court had decided against him; the sentence was that everything should be replaced in the same state as it had been before he had made the hole in the partition wall through which ran the gutter which carried all the filth from his house into my garden. He appealed to the Supreme tribunal.

Our next door neighbour in the Calle de Aldavas, Dr. Flor, had suddenly died; also General Frisancho had departed this life.

The dissolution of the firm of Schutte \& Co. was advertized in th [...] [337] papers, with the addition that Guillermo Garland remained with full power from C. W. Schutte, and from Geraldo Garland, each separately.

Saturday, $25^{\text {th }}$ of May 1872 . Since Saturday last nothing worth noting down had occurred. Mariquita continued sad and felt no inclination to go out. Yesterday the enormous stone which formed the threshold of our street door was removed, and a new one placed in its stead; the old one was not taken away - which would have cost much trouble and money - but merely turned over so as to strengthen the position of the new one; it was a tremendous job, at which seven men worked half the day.

Wednesday, $29^{\text {th }}$ of May. Once more Mr. Dupont did not make his appearance. I availed myself of the leisure hours to ascend San Cristoval, always a healthy exercise.

Friday, $3^{s^{s t}}$ of May. I received a letter from Dr. Lucio Barrios, claiming a commission of not less than $\mathrm{S} / 4000$ for having purchased for me the four shops under my house Calle de Zarate. This letter of his was a reply to mine, in which I had requested him to return to me the rent which he had collected of these four shops since the day of the purchase, until the day that I myself received the rent. I was determined rather to be sued by him in a court of justice than give way to his exorbitant pretension.

I for the first time attended a meeting of the shareholders of the Banco del Perú, where I represented my son Juan's share, and that of Schutte \& Co., which Garland had done hitherto. I believe I was acquainted with all present, but 
could not recognize them. José Maria Sancho-Davila presided; Emilio Althaus as gerente made known that the object of the meeting was to elect another gerente in lieu of Meceno Espantoso who had resigned. The question arose whether the new gerente should be elected for three years, or merely for the time wanted to make up the three years for which Espantoso had been elected; I left at 3 O'clock when the matter was still under discussion and requested Espantoso to give in my written vote, which was for José Pablo Escobar as provisional gerente for the few months which still remained of Espantoso's term. On each share of the Banco del Perú $80 \%$, say $\$ 80,000$ had been paid up; the last 10,000 on account of Juan I had advanced out of my own funds, he not having anything to his credit in my books.

Saturday, $7^{\text {st }}$ of June. In the course of the forenoon I had a long and disagreeable session in the office of the Lima Water Company, together with the other Directors [...] J. V. Oyague, Nicolas Rodrigo, José Basagoytia, the Frenchman [...] [338] Schmidt, another gentleman name not known to me, and the gerente Andrés Rey. The two commissioners named by the Government and by the company to fix the amount which the former should pay to the latter for a total cession of the enterprize, say Rafael Velarde, and Mariano Felipe Paz-Soldan, had put it down at $S / 1,550,000$, but the payment of this sum had not yet been decreed by the minister of the Interior. Rodrigo said that for the last two months he had done nothing else but take the steps which he thought necessary to obtain this indemnification for the company, but that the gratifications paid and to be paid came up to no less than S/250,00o. Oyague, Basagoytia, Schmidt, and I cried out against this enormous sum; Rodrigo was piqued and said he would have nothing more to do with the affair; then we begged Basagoytia and Oyague to take it in hand, and try to carry it through; the latter refused, saying that he was on bad terms with the Government; the former was willing, but would not act alone, and thus it was impossible to come to any result; we broke up at 4 and resolved to meet again on Monday at 2 O'clock.

From the Water Company's office I went to that of the Banco Hipotecario where the question to be treated on was of a nature quite as disagreeable as that I had just been discussing. The Directory of the Pasco Railway Company Manuel Pardo, José Riva Agüero, Sagastabeytia and I, together with the adjunct Cipriano Correa, were present; the last mentioned informed us that Juan Martin Echenique had left on the $23^{\text {rd }}$ ulto. for Europe, and that his brother Pio who held his full power had directed a letter to the commissioners, Correa, Bohorquez, and Sagastabeytia, in which he informed them that the railway in conformity with the original agreement between him and the Company was 
again at the Company's disposal; this was a bad piece of news. After conferring on the subject we resolved that a meeting of all the shareholders should be convened for Wednesday next, for the purpose of proposing to them that a confidential and competent person should immediately be sent to the Cerro, there to examine and to investigate whether the railway actually yielded a revenue of $\$ 8000$ monthly as the Echenique's asserted. Now there was no probability of my receiving any more interest either on my S/12,00o preference obligations, or on my loan of $\mathrm{S} / 50,000$.

Monday, $3^{\text {rd }}$ of June. The Directors of the Lima Water Company again met. Rodrigo and I did not attend, but I learnt afterwards from Basagoy[_] after long discussions they had resolved that $S / 160,000$ should [...] [339] to be laid out, if necessary, in Gratifications.

Tuesday, $4^{\text {th }}$ of June 1872. In the meeting of the Directory of the Insurance Company "Lima", when Alexander Westphal attended for the first time, we resolved unanimously to insure against fire risk in $\mathrm{S} / 100,000$ at $1 \%$ p.a. the recently concluded and solidly-constructed house at the corner of the Calle de Carrera owned by the National Bank. Underground were the vaults for keeping coined silver and gold, bars, bank-notes etc. On the ground floor were the offices for the transacting of the bank business, upstairs the dwelling apartments for the gerentes. The regulations of the Company said that to all such as paid annually a thousand Soles or more in premiums, an abatement of $10 \%$ was to be made, and this we had also to allow the bank.

Wednesday, $5^{\text {th }}$ of June. In conformity with the statutes of the Pasco Railway Company, the presence of $2 / 3^{\text {rds }}$ of the number of the shareholders was required to form a quorum on the first convocation, and this number not being assembled at the fixed hour in the office of the Banco Hipotecario, we resolved to call a new meeting for Saturday next, and then separated.

Friday, $7^{\text {th }}$ of June. In a session of the Directors of La Constructora the number required to form a quorum did not attend; nevertheless, Escobar and I pointed out to the gerentes some gross irregularities in the company's accounts.

Saturday, $8^{\text {th }}$ ofJune. This time a sufficient number of the shareholders of the Pasco Railway Company assembled. Pio Echenique, representing his brother Juan Martin, spoke first; he said that he had been negotiating with another party (supposed to be Vicente Gonzales y Pinillos) to take the railway off his hands, that these negotiations had led to nothing, that in conformity with the original agreement his brother returned the said railway to the company, and demanded that the company should recognize him as their creditor for a considerable amount which he said he had invested in the construction of 
the railway in the course of the twelve months he had had it under his charge; as was to be expected, to his pretension nobody would listen. The one or the other said a few words; upon the whole great silence prevailed. I begged Manuel Pardo, who sat next to me, to give his opinion, his words being always listened to with great deference; he answered that he had various reasons why he did not wish to stand up, and make himself conspicuous at the [...] moment; nevertheless, he said a few words also little to the [...] [340] Once more all were silent, and the upshot was that the commissioners Sagastabeytia, Bohorquez, and Correa were authorized to make with Juan Martin Echenique the best arrangement they could.

About this time the "Comercio" published an agreement, made between Juan Martin Echenique and the Government two months previously, which stipulated that only those vessels which said Echenique would charter should be allowed to load in Europe the materials which might be used in Perú for public works as well as all the articles which the Government might order to be purchased there; moreover, only Echenique was to furnish the coals required for the Peruvian navy; still more concessions were made to him, which however my original does not specify. As soon as this contract became known the outcry against it was so general and so violent that Balta thought proper to annul it, the consequence of which was that the entire family Echenique was now on bad terms with the Government; the father, the General, was absent in Chile; Juan Martin, the most intriguing of them all, had gone to Europe; Pio and Rufino had little influence. The printing-office of the daily paper "El Nacional", which had been closed for six months, was reopened in virtue of a sentence of the Supreme Court, and it immediately recommenced writing in the usual style in opposition to the Government and all its measures which were certainly far from constitutional; amongst other infractions recruiting was carried on. The offices of the daily papers "La Centinela" and "El Comercio" were shut up; the editor of the latter, Amunategui, was arrested for a night.

Tuesday, $11^{\text {th }}$ of June. Again the Directors of the Water Company, except Rodrigo, assembled; Rey observed that though the Directory was authorized by the statutes to sell the entire establishment they were not empowered to spend any money in gratifications, whereupon I gave it as my opinion that the safest plan would be to obtain from all the shareholders their written authorization to spend as much as $10 \%$ upon $S / 1,550,000$, the amount fixed upon by the appraisers, in order to procure from the Government the signature of the decree, and the payment of the money; this was agreed to, the authorization was drawn out and signed by the Directors present. Basagoytia said that he was ready to do all in his power to further the views of the Company, but did not wish either to receive or pay mone[_] and for this object I was chosen. [341] 
Thursday, $13^{\text {th }}$ of June 1872. The Directors of La Constructura had a meeting; we had only time to decide two points; the one, a proposal made us by Rütte, Feliz Dibos, and a certain Basadre, who had obtained from the Government the co[_]sion of the railway from Lima to Magdalena: this proposal was that the Constructora should construct the railway as well as the breakwater, which was required to secure the safety of the bathers and to build small houses; the guarantee which they offered was nothing but some ground which they had bought in the neighbourhood of Magdalena; in other words, we should lay out all the money, we should run all the risk, if the undertaking turned out a profitable one, they would take it on their account, if otherwise, they might leave it on our hands. Our refusal was styled in the following words: "We do not admit the proposal because the guarantee is insufficient". The second point upon which all agreed was the necessity of naming a superintendant, an honest man and well paid, whose only business should be to be continually on the move for the purpose of counting the workmen at the different works, so as to render it impossible, or at least very difficult, to the sobrestantes to charge the wages of more workmen than they actually employed.

Friday, $14^{\text {th }}$ of June. There was another meeting at La Constructura, at which I could not be present, being occupied with Mr. Gauret, the French painter, measuring all the walls, columns, balustrades, roofs, doors etc., which he had finished painting.

Saturday, $15^{\text {th }}$ of June. Though the work done by Gauret had not turned out either to my wifes or my own satisfaction, yet as the contract with him was binding I had necessarily to pay him the amount of his heavy account.

In the course of this week I had been to J. P. Escobar, Peter Gallagher, Henry Prevost and obtained their signature to the authorization spoken of on the $11^{\text {th }}$ inst. Rey had procured the signature of Nicolas Rodrigo, Schmidt that of Prentice with his 200 shares, and thus we had now the authorization from holders of more than 1000 shares, whilst according to statutes 1001 sufficed to carry any measure.

Monday, $17^{\text {th }}$ of June. D. Bartolomé Araoz returned from Europe, and I immediately went to see him; he had been absent less than a year, and this time he had not at all been pleased, the weather having been two raw and cold. Except three months residence in Paris, he had spent all the time in Spain, mostly in Valencia, and he was now determined to pass the remainder of his life in Perú. I was very glad that he was back for the reasons given more than once $[. .].[342]$ now sure of having a pleasant companion in the evening, twice or three times a week.

Thursday, $20^{\text {th }}$ of June 1872. The shareholders of the Eten-Feriñafe Railway were called together. Juan Antonio Garcia y Garcia as manager presided and 
laid before us a statement of the affairs of the railway; according to his account the actual proceeds were very satisfactory, and he expected splendid results for the future, but in the meanwhile there was not one single rial in the chest, and money was immediately required in order to pay interest on the money borrowed, to pay what was due to the South American Company in London, and to proceed with the work of the railway and of the mole in Eten, neither of which was concluded. When Garcia had finished his long speech, in which he endeavoured to present things as favourably as possible, various questions were asked him by Mortier, of the house of Thomas Lachambre \& Co., and Aurelio Dinegri, whereupon I asked whether the real state of the enterprize was not the following: "the shareholders had actually paid 675,00o Soles, and $S / 850,000$ were now required"; Garcia answered in the affirmative. Various modes were discussed how to raise this sum; in the discussion, besides those mentioned, Ruden, and particularly Emilio Althaus and Dionisio Derteano took an active part. At last it was determined to raise the $S / 850,000$, if possible, by issuing preference shares, which after the interest on the loans were paid, should, as the name indicates, have a preference of receiving $10 \%$ interest before the original shares received anything, but I feared that even this attempt would fail. We knew that J. M. Varela, who was a shareholder for 100,000 Soles, would not give one rial more; Althaus himself as representative of Cotes \& Althaus refused contributing, Manuel Candamo before deciding had to receive the authorization of his brother Carlos, absent in Paris, and shareholder for 100,000 Soles; I, shareholder for S/15,00o, would not bind myself for more than 8000 Soles, whilst the remainder present agreed to pay their proportion of the $S / 850,000$ that is to say 126 Soles for each 100 originally contributed. Now another difficulty arose. Garcia declared that before the $1^{\text {st }}$ July he wanted S/50,000 whereupon Dinegri proposed that each present should pay 5000 Soles, which would give more than the $S / 50,000$ asked for, to which my neighbour Irrigoyen and I objected. I said that each should contribute to the $S / 50,000$ in proportion, for I considered it unjust that I who was interested for no more than $\mathrm{S} / 15,000$ should contribute as much as Candamo, whose interest was S/10o,ooo. I then went away leaving the remainder discussing the matter, I supposed they would succeed in [...] [343] the money required, by paying a very high interest; the last word I heard was Escobar's speaking of $15 \%$. The affairs of the Water company did not proceed as quickly as one could wish; to expedite the Government's expropriation decree Basagoytia and Oyague suggested that we should present the Minister Santa Maria with a Vale for a considerable amount signed by Basagoytia and myself; to this I made no objection but made it a condition that the vale should be drawn out in the most guarded form to 
secure Basagoytia and myself against any personal responsability; and so it was done: Basagoytia took upon himself to deliver it.

Rumours, for the authenticity of which I would not vouch, were afloat, very prejudicial to the Government's credit; it was said that heavy drafts of theirs on Dreyfus of Paris, had been protested, viz.: S/2,000,000 with which Ferreyros was to purchase some monitors, and $S / 1,000,000$ or thereabouts wanted for the construction of the new Custom House in Callao.

Sunday, $30^{\text {th }}$ of June 1872. On Monday last Basagoytia in person handed the above spoken of Vale to the Minister of the Interior Santa Maria, having enclosed it in a very well written letter. A few days later he again called upon him, was received with great civility, but had the vale returned to him, though at the same time he was requested to draw out the decree, which he did, and showed to me.

On the $24^{\text {th }}$ Dia de San Juan, and the $29^{\text {th }}$ San Pedro I paid the usual ceremonial visits to the Juans and Juanas, to the Pedros and Petronilas of my acquaintance. It was a fact that the Government's drafts on Dreyfus' firm in Paris in favor of Bluhme for the Paita-Piura railway had been protested for non-acceptance.

Monday, $7^{\text {st }}$ of July. Ever since the $28^{\text {th }}$ July 1869 when we had here in Lima the first Exposition of Peruvian produce in the Colegio de Artes y Oficios it had been the desire of the Government to have a permanent Exposition building, and as during Balta's administration the word economy was unknown to the inmates of the palace, a decree was given that an Exposition Palace should be constructed, and an extensive park be laid out round the same. General Vivanco was named Director of this work, and under him Dr. Fuentes, nicknamed "El Murcielago" (the bat). The cost of the whole ran up to more than 1,000,000 Soles, and as this large sum had passed through Fuentes hands, it was supposed that not a few Soles had stuck to his fingers. This day the Exposition was opened to the public. Many entrance tickets [...] cost was 4 Soles each, were distributed gratis, amongst others to the [...] [344] Diplomatic and Consular Bodies, and consequently one was also sent to me by the Minister for Foreign affairs. Though it was a wet and disagreeable day Don Bartolomé Araoz and I walked out thither. An extensive area close to the Penitentiary, and stretching some distance outside the town to the right of the Chorrillos road, had been enclosed by a low brickwall surmounted by iron railings. The entrances, the one called "la Portada Balta" and the other "la Portada Vivanco", though only of brick and plastered over, were very handsome and bore some resemblance to the Arc de l'étoile in Paris. We entered through the Portada Balta, whence a well kept gravel walk covered over with red and white striped awning, and 
adorned with many Peruvian colors, led in a straight line to the Exposition building; half way was an artificial rock, with a basin around, which was to serve for water-works, hitherto not concluded. The Exposition building is a very large and handsome structure. A few steps lead up to three arched doors, the largest in the middle; the two wings of the building recede a little. The groundfloor is one wide hall, sustained by columns; two wide flights of stairs of wood lead up to the first story, of the same size as the ground-floor; in each of the four corners is a large square room, carpeted, exquisitely furnished and fitted up, each in a different style. I, and I believe everybody present, must have been of the same opinion as Don Juan Baso, who said to me "El Continente no puede ser mejor, el contenido no vale nada" Anglice, "The shell is beautiful, the contents are good for nothing". What were the articles exhibited? A pretty large collection of stuffed birds, not amiss, in my opinion, especially the eagle and the Condor; oil paintings, which my sight did not allow me to examine, a few of them were said to be very fair. On the first landing-place of one staircase hung a large painting by a Peruvian artist, Montero, considered to be of great value, and representing the funerals of Atahualpa. Several marble statues, others of gypsum; of the same material the busts of Castilla and Salaverry, also that of Columbus. Beautiful fire arms of North American manufacture; a small brass gun cast in the Bellavista foundry, various descriptions of carts, ploughs, and agricultural implements; cloth from Garmendia's manufactory in Cuzco; samples of sugar, a tremendous array of liquors; shoemakers, and tailors work, many articles from the plumbers Kemish \& Melson, and I do not know what else. On the ground floor a recess was devoted to old Indian pott [...] Indian mummies all in a sitting posture found in the Peruvian [...] [345] which interested me much. Though, as already said, the weather was very unfavourable we went into the park, which of great extent is very tastefully laid out, much in the style of the London Zoological gardens, and which in course of time if well taken care of, and the trees increase in size, was likely to become a beautiful promenade. There were a few wild beasts well worth the visitor's notice, a jaguar, or South-American tiger, not so large as the Bengal tiger, nor striped, but spotted like a leopard, otherwise as restless as its prototype; a brown bear, continually moving about, a small elephant, very tame, a camel, and above all some lions and lionesses not inferior in any respects to those I had seen in London and París: the keeper, a North American, stirred them up with his whip, when they roared and jumped about in a frightful manner. At a short distance we saw an artificial lake and a bridge, but the weather was too bad, and we were anxious to get home. The concourse was far from numerous; perhaps not above 2000 people, amongst whom the President Balta, incognito, in whose stead the Minister for the Interior, Santa Maria, who 
came accompanied by the members of the Superior Court of Justice, made a speech relative to the opening of the exposition. I neither heard this speech nor the musical performances, the sound of which was drowned by the roaring of the lions close to whose cage we were at the time.

Wednesday, $3^{\text {rd }}$ of July 1872. Last night I, together with Don Bernardo Roca y Garzon, went by invitation to Don Evaristo Gomez Sanchez, a well known political character, and with whom, since he had removed to a new house close by in the Calle de San José, which was formerly occupied by General Cisneros, we had renewed our acquaintance. When we entered Don Evaristo received us at the door in a very cordial manner; a few gentlemen were already assembled, amongst whom General La Fuente. Gradually his suite of apartments, three or four in number, not large, but furnished with great elegance and taste became well filled; of ladies there were no more than 8 or 10, his wife's best friends, and nearest relations. In a small adjoining room, separated by glassdoors, was a military band which played occasionally. First tea was handed round, afterwards ice and jellies, wines stood on a side table - and in one word nothing could be better arranged. At about 9 O'clock many gentlemen went to the card-tables. At ten dancing commenced to the playing of the piano; I left at eleven very well pleased - again the host was at the door to bid me good by. It was as late as six this morning when the last guests drove home. Of the ladies I only knew Doña Dominga Zelaya, the daughter of Dr. José Luis Gomez Sanchez with her two grown-up daughters, Mrs. Evaristo Gomez-Sanchez, and [_] José Maria Sancho-Davila. To enumarate the gentlemen would be a [...] [346] job; there were of course many Arequipeños, to my surprise none of Balta's cabinet, not even Antonio Arenas - one of the candidates for the Presidency. General Rivas died a few hours after he had left the party owing to the bursting of a blood vesel close to the heart.

At the usual hour 3.30, the Directors of the Banco de Lima had their monthly meeting. The customary statement laid before us by Lembcke was very satisfactory. He and his co-gerente Zaracondegui wished to know to what extent they could discount the signatures of Dreyfus and Meiggs respectively; we authorized them to go with Dreyfus as far as one and a half million Soles, whilst with Meiggs we told them to go not one rial further than they had already gone.

Thursday, $4^{\text {th }}$ of July. In the meeting of the Directory of the Insurance Company "Lima" the only thing worth noticing was that nobody seconded a motion made by me. It occurred in the following manner. Hitherto on Coolies from China we had not insured more than 20,000 Soles in each vessel. We now authorized Guiroy to go as far as 25,000 ; but Henry proposed that on the "Clotilda" exceptionally we might take 40,000 , and as this did not seem 
acceptable to anybody, I to mediate between the two extremes, moved that we should insure S/30,00o per "Clotilda", when to my no little mortification nobody rose to second me. In the evening, all the Directors except Zuluaga, who was unwell, held a meeting in the Banco de Lima from 7.30 to 10.40. A very important question was discussed, viz.: that of raising a loan of not less than five million Soles upon the Montero Brothers' railways in the province of Tarapacá. Juan de Dios Calderon was the only one opposed to the plan; all others took an active part in the discussion, and the conditions were fixed upon which were to serve as a basis for Lembcke and Zaracondegui when concluding the business with the Monteros.

Sunday, $7^{\text {th }}$ ofJuly. The Exposition was for the first time opened to the public at two rials a head, and it was calculated that no fewer than 15,00o persons had visited the park and the palace in the course of the day.

Monday, $8^{\text {th }}$ of July. Not one workman made his appearance.

Wednesday, $10^{\text {th }}$ of July. The shareholders in the Eten Feriñafe railway were called together, but only the following attended: J. A. Garcia y Garcia, Ruden, Mortier, Manuel Candamo, Derteano, Escobar, Varela, and myself. After a good deal of needless talk it was decided that preference shares should be issued, if possible to the extent of $\mathrm{S} / 485,000$. If this amount could not be got together $[\ldots]$ satisfied with what we could obtain. Though I had as [...] [347] of the original shares, I did not take more than $\mathrm{S} / 8000$ preference shares, for the plain reason that the state of my finances did not allow me to subscribe for more.

Friday, $12^{\text {th }}$ of July 1872 . In the morning I was present at the funeral of Adelina Barrera, one of the younger sisters of Rafael Velarde's wife who had died of consumption.

Saturday, $13^{\text {th }}$ of July. The repairs of my house were, Heaven be praised, drawing to a close; in the course of the week the garden walls were painted.

The Senators and the Deputies held their first preparatory sessions; in that of the latter President Macedo, who as second vice-president of the last Congress had closed its sessions in February 1871, and now opened those of the new Congress, named three persons who were wanting to complete the number of the members of the "comision calificadora", a committee which was to decide upon the legality or illegality of the late elections, and, as Melchor Velarde told me, the three named were Government people. Macedo, who in February 1871 belonged to the opposition, had since then been bought over by Balta, who had conceded to him the construction of the railway between Huacho and Sayan. In the Senate, three Senators were qualified: General La Fuente for Tarapacá, a partizan of Arenas, Lizardo Montero, husband of Rosa Elias for Piura, and Emilio Althaus for Ica, both friends of Pardo. 
Monday, $15^{\text {th }}$ of July. The Directors of the Banco de Lima were called together. All the conditions upon which the loan of 5,000,00o Soles was to be raised on Montero's railways in the province of Tarapacá were at last fixed upon, and the gerentes were authorized to close the business with Montero as soon as a person dispatched to Iquique for the purpose of examining the actual state and revenue of the railways returned and gave a satisfactory account. We flattered ourselves that this advantageous affair was now brought to a conclusion, but on

Thursday, $18^{\text {th }}$ of July Lembcke told me that Ramon Montero had received a telegraphic dispatch from London, advising him that his brother had succeeded in raising there the money required, and that consequently he stood no more in need of the assistance of the Banco de Lima.

Saturday, $20^{\text {th }}$ of July. At 9.30 p.m. I went to the German club where a meeting had been convened to treat on the subject of the German Protestant clergyman required for the German Colony in Lima. It was agreed that if we were certain that the German relief association would give the money wanted for the clergyman's passage out, and for the purchase of his furniture in Lima, further steps should be taken to procure a proper person. A committee was also named to serve as a Directory for the manag [...] German church association in Lima. Twenty voters were present Lemb [...] [348] not attend had all the votes, Charles Pflucker 19, all, except his own; John Gildemeister, F. Brunswick and I, each 18; the remaining three to complete the number of the eight directors had fewer votes; they were Krumdieck, a turner, Behr, a smith and the third I do not remember. It was nearly 11.30 when I came home. There was now hardly any doubt as to the election of Manuel Pardo for President of the Republic, and this would be brought about in a quiet, legal manner. In the beginning of the week he had a very small majority in the Chamber of Deputies and in the Senate, but this majority sufficed for the qualification of only those Deputies and Senators who were of his party, and thus - from day to day the majority increased. The barra (audience) in both houses consisted almost exclusively of Pardo's partizans, and in more than one instance General Echenique, President of the Senate, Evaristo Gomez-Sanchez, and other Arenistas were treated by them with very little respect.

The North steamer brought us letters advising the safe arrival of Garland and family in Paris; my wife had one from Enriqueta, Guillermo one from his father, and I one from Juan. In Colon they had embarked on board the German steamer bound for Bremen; of the excellent qualities of the vessel as a sea-boat of her good accomodation; of the equally good eating and drinking, (for instance, twice a week they had had ices at dinner) and above 
all, of the amiability of the captain, they spoke in high terms. The passage from St. Thomas to Cherbourg had lasted fifteen days, owing to continual contrary winds, and the last two or three days the temperature had become cold. It was on the $11^{\text {th }}$ June when they went ashore, but owing to indisposition of Garland and Camacho, they remained one day [_] Cherbourg, and arrived in Paris on the $12^{\text {th }}$ where at the terminus they re[_] received by Schutte, Rosa, Juan, and Corina. The recently married couple Mr. and Mrs. Shattuck were in Fontainebleau, there to spend their honeymoon; they were second cousins, for Mr. George Shattuck, a native of Boston, W. S. by profession a physician, was a grandson of an uncle of Mr. Schutte, Mr. Bruhne, who when a youth had gone to the United States, and formed a respectable mercantile establishment in Baltimore. At her marriage Amalia had received from her father a dowry of 1,000,000 francs, from her mother an expensive trosseau and from all her friends valuable presents. Corina, who stayed with the two little Lavalles in St. Germain en Laye, returned thither, taking Antonio with her. Garland and the remainder of the family had taken apartments in an hotel. [...] thought of consulting a French oculist, but before having the operat [...] [349] would first pay a visit to his mother in Liverpool, whom he had not seen for many, many years, and then another to the Mutzenbechers in Hamburg.

Monday, $22^{\text {nd }}$ of July 1872. The President Balta had fixed upon this day to celebrate the wedding of one of his daughters, Daria, with Estevan Montero, and a great number of persons, I amongst them, had been invited to witness the ceremony at 8 O'clock in the evening. I had already written a note excusing myself from attending when the servant Juan rushed into my room with the news that the President had been made prisoner. I went out into the street to enquire what had occurred, and learned that what the servant had said was but too true. Tomas Gutierrez, one of the four brothers, whose sister was the wife of Juan Francisco Balta, and who himself was Minister of War, had previously taken the necessary steps to secure the adherence of the troops; his brother Silvestre, the same whose cause about the flogging given by his order to Col. Garrido was still pending in the Superior Court of Justice, entered the President's apartment, revolver in hand, accompanied by a few soldiers, arrested him, and sent him as prisoner to the barrack of San Francisco, where a battalion commanded by another of the Gutierrez, Marcellano, was quartered. This done, Tomas Gutierrez proclaimed himself Supreme Chief of the Republic.

When the news of the arrest reached the Congress, which was sitting at the time, a protest was drawn out declaring the authors and abettors of the "execrable deed" "fuera de la ley", and was signed by all present, even by 
General Echenique, who as president put his name at the head of the list. Before all present had time to sign, an officer with some soldiers entered and turned them out.

Tuesday, $23^{\text {rd }}$ of July. A "Junta Gubernativa, to consist of Ureta, Evaristo Gome [...] nchez, and Dr. Manuel Ortiz Zevallos, was spoken of, but it seemed to ha $[. .$.$] en a mere rumour for already in the forenoon it became known$ that the [_]preme Chief had named the notorious Dr. Fernando Casós, his Secretary-general. In the morning I, for safety's sake, withdrew my money from the Banco de Lima, and kept it with me; hardly had I done so when this bank as well as all the others closed their doors, and ceased to transact any business. The night to

Wednesday, $24^{\text {th }}$ did not pass in the usual quiet manner; there was much noise in the streets, and we heard firing. The battalion "de la Marina" had dispersed; one of its soldiers came to our house, and begged us to allow him to remain for some time, to which we did not object. Gutierrez' proclamations spoke of course of his purest patriotism and of his saving the country from the abyss into which it was about being plunged [...] of Balta and the tortuous policy of another party which them [...] [350] consisted of an insulting nobility, and which lavished the corrupting gold - these words referred of course to Pardo's adherents. At the same time the proclamations held out threats against all such as should venture to oppose the new state of things. It became known that the fleet commanded by Aurelio Garcia y Garcia had left Callao, and did not recognize Gutierrez' authority. A great many of Pardo's friends took refuge in the different Legations. The house of Dreyfus was requested to pay a million of Soles within a few hours, which the active partners Scheel and Ford refused to do, and found an assylum at Mr. Jerningham's. The SecretaryGeneral sent round circulars dated the $23^{\text {rd }}$ to the Diplomatic and Consular agents, requesting them to let him know who were those who had taken refuge with them, and promising to send passports for foreign countries. My note I received on the $24^{\text {th }}$ at 4.30 p.m. and answered it at 6.30 in the very driest manner. A copy I affix in appendix under $\mathrm{N}^{\circ} 10$.

In the evening in the barrack of Guadalupe, the two battalions $\mathrm{N}^{\circ} 69$ № 8 fought against each other; many lives were lost, and a great number of soldiers dispersed.

Thursday, $25^{\text {th }}$ of July. Though the policemen had been removed from their usual posts the streets were still safe, and I ventured as far as Doña Mercedes Riva-Agüero's house to enquire about her husband; neither he nor she were in. Next, I went to Irene's house near San Marcelo; she was not in either, having gone to see her husband, who had taken refuge in the house of Mr. Leal, the 
Brazilian Minister, a few yards off; thither I directed my steps, and found there not only Mr. and Mrs. Baso, but also Juan Mariano Goyeneche, and a certa[_] [_] eres. Manuel Pardo I learned had made his escape; from Leal's house [...] across the street to an acquaintance of his, and then over the roofs of the entire block to another house, where he had descended, and in the disguise of a carter driven himself a cart, some said laden with furniture, others with coal, to the Chorrillos gate, where some friends had been waiting with a led horse, which he had mounted, and then started off. When walking home I met Alejandro who told me that the Directors of the Banco de Lima were holding a meeting; I hastened thither, and found that his information was not quite correct. Not the Directors, but the Gerentes of the four banks together with Henry Meiggs were assembled in the first story above the offices of the Banco de Lima, and had agreed together with the house of Dreyfus, to pay to the Government each 50,000 Soles [...] a total of S/300,000 one half payable the same the other half the ne [...] [351] Dreyfus' house was to give its acceptances for the $\mathrm{S} / 300,000$ but each party to run its own risk in case another government refused to recognize the loan. In the evening of this day we learned that Callao had risen against [_]tierrez, that part of the rails had been taken up, and the telegraphic wires been cut: also that the protest spoken of on the $22^{\text {nd }}$ had been published in the South Pacific Times as well as a declaration made by such members of the Congress as had not been present, or had not had time to sign, to the effect that they adhered to it in all its parts; only Evaristo Gomez Sanchez and General Vivanco made an exception, and it was not at all unlikely that the former had been cognisant of Gutierrez' plan.

Friday, $26^{\text {th }}$ of July 1872. At 11.30 I went to Guillermo's counting-house to fetch some copying ink, when all was apparently quiet. About half an hour later Silvestre Gutierrez, who in the morning had come from Bellavista in the engine to ask for more troops, his own battalion having dispersed, went to the terminus, accompanied by a single officer. Some people shouted "Viva Pardo"; Silvestre drew out his revolver and fired at them whereupon a young officer dressed as a civilian shot him through the head, then jumped upon the engine and forced the engine driver to steam off towards Callao. Hardly had Silvestre fallen when the populace dispatched him with sticks and stones. As soon as this piece of news reached Marcellano Gutierrez in San Francisco, he entered the room where the President Balta, a defenceless prisoner, was still in bed; "my brother has died, thou must die", with these words he shot him four times through the head, then passed his sword through the body. (This was the version given at the time; afterwards it became known that another officer had done the deed by order of Marcellano.) Hereupon he with his battalion marched to reinforce his brother in the palace. A few compassionate persons 
carried the body of the President to the sanctuary of Santa Rosa de Viterbo. At about 2 O'clock cavalry, infantry, and several pieces o artillery, without beat of drum; passed our house quietly and very slowly; the infantry did not occupy the carriage road but walked two by two on the foot pavement. The Supreme Chief, a stout man with a big-belly, in black, with a white waistcoat, a crape round his black hat, was on foot; he like all the other officers had a revolver in his hand. They marched to Santa Catalina where they joined the garrison of this fort. Meanwhile the people had risen; few were armed, but their number was great, and all enthusiastic in favor of Pardo; in some streets barricades were thrown up, the refugees left the respective Legation, some soldiers and celadores passed over, Lizardo Montero, Baltazar La Torre, and [...] tizans of Pardo showed themselves on horseback - so did the first and [...] [352] Vice-Presidents Herencio Zevallos, and Francisco Canseco - and at about 4 O'clock the palace was taken, the assailants having made their way in through the Prefectura. Now all their [efforts] were directed against Santa Catalina, but against its strong walls they could not do anything. Marcellano Gutierrez with a few soldiers arrived in Callao at about five; here he was soon overcome and killed. In a cart his corpse was paraded through all the streets, and interred by order of Lizardo Montero who of his own accord had taken command of the port. In the meanwhile great disorder prevailed in Santa Catalina; the soldiers refused to obey, the chiefs fired at them. Tomas Gutierrez placed himself at the head of a small body, probably with intention to make his way out of town; after having marched a few cuadras the soldiers abandoned him; he then addressed himself to a Col. Ayarza and begged him to save his life. Unfortunately for him he was recognized, when to save himself from the fury of the mob, he ran into the shop of an apothecary at the corner of Lescano and Espaderos; the apothecary shut the door; it was forced open, Gutierrez threw himself into a bath, begged those who entered to pardon him, but in vain, he was killed in an atrocious manner. At about 9 O'clock his corpse and that of Silvestre were suspended from two lamp posts in the plaza, more or less in front of the Archiepiscopal palace; during the night they were taken down and carried to the palace, but on

Saturday, $27^{\text {th }}$ ofJuly early in the morning the mob was already besieging this building, and did not cease clamoring until the corpses were again delivered up to them; then they were suspended, each from one of the steeples of the Cathedral, close to the dials. At a later hour they were allowed to fall down and then thrown into a lighted pile made of the wood brought thither from a bakehouse owned by one of the Gutierrez. At this moment a procession of Dominican friars carrying the high-cross aloof appeared in the plaza, with the laudable purpose of persuading the populace to desist from their atrocities, 
but in vain, they were beaten back with caps and hats, and with the shouts of "no queremos frayles, no queremos las coronas". The burning continued, and when the corpses were consumed the ashes were thrown into the winds, and some of the populace, it was asserted, had even tasted the flesh of their victims. The body of Marcellano was exhumed in Callao, thrown into a box, brought by rail to Lima, and dragged to the nearly expiring fire, which it was necessary to rekindle with turpentine and spirits. The cruelties of the brothers Gutierrez whilst in power had exceeded all bounds, and this only could explain though not excuse the barbarities committed by the populace. The $[. .$.$] of the$ "Nacional", "Comercio" and other papers was [...] [353] and published the names of the members of the new ca[_] et formed by Herencio Zevallos, first Vice-President, who took into his hands the [_] of Government in conformity with the constitution. They were: Dr. Ribeyro of the Supreme Court, for Foreign Affairs, and President of the Council, Dr. Morales, Fiscal of the Superior Court, for the Interior, or "del Gobierno" (these two I went to congratulate) Eusebio Sanchez, President of the Superior Court, for Justice, Riva Aguero, Director of the Banco Hipotecario, and Pardo's most intimate friend, for Finances, and Francisco Canseco, second Vice-President, for War.

Manuel Pardo landed in Callao and reached Lima by train at about 2 O'clock. Wheresoever he showed himself he was received with the greatest enthusiasm. Negroes embraced him, calling him "el lindo mozo", "el bello Limeño"; he went to his house and then rode through the streets accompanied by some friends. On the $25^{\text {th }}$ I gave an account of his escape as far as the Chorrillos Gate; thence, he, accompanied by a few friends galloped off. In the fog they lost their way however reached the port of Chilca in safety, and there Pardo, whether alone or accompanied I do not know, was rowed in a fishing boat to the fleet which was anchored at some distance from the coast. The sea ran high, and the danger to which Pardo was exposed during the short passage was not trifling.

All the while the Congress was sitting, and qualified senators and deputies, of course only Pardistas. For Lima, Senator Buenaventura Elguera, by an overwhelming majority, against Dionisio Derteano, who did not venture to show himself; deputies, Manuel Pardo, Emilio Solar, Ramon Ribeyro, and Ignacio Osma. It was said that of the whole army, five or six thousand strong, splendidly equipped and armed, hardly one thousand had kept together, a great saving for the nation, and a really fortunate circumstance for Pardo. The Banks, Meiggs, and Dreyfus actually paid S/150,00o on Thursday; the other half was not paid owing to the turn events took on Friday.

Sunday, $28^{\text {th }}$ of July 1872. Anniversary of the Independence. "Misa de gracias" was said in the Cathedral, and the Congress was opened by the second Vice- 
president, Francisco Diez Canseco, in the usual manner. Amongst others I called upon Doña Petita, Pardo's mother, who was still dressing. In the evening we had a visit from Dr. Morales, as kind and good-natured as ever, he told us that he had returned a fortnight ago from Jauja, where he had left his eldest son Manuel very consumptive, and his two daughters Antonia and Francisca.

Monday, $29^{\text {th }}$ of July. The body of the late President Balta [...] [354] was removed from the house, formerly the property of Sayan, and lately purchased by his wife for $\$ 100,000$, to the Church of la Merced where it was laid out in state, watched by friars, and [_]vided by lighted tapers. I went to see this so called "Chapelle ardente", but all was so dark that I could not distinguish anything.

Wednesday, $3^{\text {st }}$ of July 1872 . The body was removed from "la Merced" to the Cathedral, where the funerals were celebrated with due solemnity. Neither the Diplomatic, nor the Consular body being properly invited, I did not attend. It was nearly 5 p.m. when the Cortege passed our house. General Segura on a white charger was at its head; then followed a numerous military band; next, the hearse, the coffin, the body on a bier, uncovered and in uniform, the President's carriage drawn by four horses, another carriage drawn by four horses, with the Ministers, a few companies of soldiers, the Peruvian, Italian and French firemen, who in their gala dress and their respective apparatus made a very good show, and finally twenty or thirty carriages, the greater part of which hackney coaches.

Thursday, ${ }^{\text {st }}$ of August. Manuel Pardo was declared by the Congress President of the Republic, having been elected by an overwhelming majority of votes.

Friday, $2^{\text {nd }}$ of August. As Don Manuel Pardo was to take this day his oath as President of the Republic in the Congress Hall, I was desirous to witness this solemnity, but the Consular body not having been invited, under the pretence that the building was not sufficiently large, I availed myself of the offer of the Senator J. A. Garcia y Garcia, to procure me a place. He called upon me, and with him I went, but the seat which he got me was by no means to my liking, being in the very gallery where the members of the Diplomatic body were seated. I squeezed myself into a corner where I hardly could be seen, but was able to see pretty well. The house was crowded to excess. After the usual routine business had been dispatched, a commission of several individuals was named to fetch Pardo from his house: for a short time nothing was done and all was quiet, then the first Vice-President Herencio Zevallos took his place under the canopy and spoke a few words; soon after Manuel Pardo made his appearance, and was received with universal cheering and clapping of hands. He knelt down before the table and took the oath, which being done he and the President 
of the Congress, Manuel Francisco Benavides, walked to the two chairs under the canopy. Benavides delivered a short speech and invested Pardo with the Presidential scarf; finally, Pardo read his answer, which was rather long. I recollect [_] of the principal points: he said it was necessary to [...] [355] the Municipalities and in the elections, also in the judicial proceedings; to bring to condign punishment the military men who had taken part in Gutierrez' mutiny, and to entrust the army exclusively to those chiefs on whom confidence could be placed; finally, to introduce economy into the budget. The enterprizes once begun would be continued, but no new ones undertaken; he said also that the hostility of those who had been opposed to him during the elections, should find no place in his memory. On leaving the hall he was cheared in the same manner as when he had entered, and the crowd which surrounded him was such that I could not make my way through it, and to reach my house had to make a considerable circuit. Here I found all the balconies filled with perhaps 60 or 70 persons, many of whom had come uninvited, and some were even unknown to us: Six or seven ladies of the Meiggs family, with Mr. John Meiggs, an equal number of the female Delgados, accompanied by a certain Gregorio Lamas who threw medals to the crowd, and introduced by J. A. Garcia y Garcia, various of the Lastres, together with Enrique Solar, in their company a daughter of the Portuguese Minister, the Ayulos and Roels, Mrs. Higginson and daughter brought by Guillermo, Mr. and Mrs. Henry, Macandrew and Böhl, José Rey de Castro and his daughter Eliza, two daughters of Dr. Carbajal, several of the family of Dr. Gervacio Alvarez, Catalina, daughter of Dr. Ribeyro, Col. Masias and wife, Rafael Velarde, and daughter Zoila, Adela, Manuel Velarde's daughter, and many more whom I could not distinguish. Fortunately, my wife had prepared a very nice and abundant lunch. Though the table was pretty large, all could not sit down round it; nevertheless, my servants assured me that justice had been done both to eatables and drinkables, and it seemed to me that all left quite satisfied.

Saturday, $3^{\text {rd }}$ of August 1872. I drew out my fiftieth planilla of the expenses incurred on account of the repairs of my house, which I expected would be the last; this number did not include those of the architect Villa. Don Gavino, the sobrestante, had left us on the $31^{\text {st }}$ of July. For painting and papering I knew that I should still have to pay many a dollar, and I feared that a dispute with Pietrosanti would be unavoidable, for the marble steps he had laid were not at all to my wife's and my satisfaction.

Sunday, $4^{\text {th }}$ of August was a very busy day for me. In the morning I had to attend the funeral of a son of José Maria Peña; the mother being a sister of Manuel Costas, who was likely to become first Vice-president, a great many 
people were [...] Mr. Dupont was gone I, as it was [_] custom, went out [...] [356] my Sunday visits; firstly, to those whose name was Domingo, it being this Saint's day; to Dr. Domingo Mendoza, where I met several of his colleagues in the Superior Court, to Admiral Domingo Valle-Riestra, not at home, and to Doña Dominga Selaya, daughter of Jose Luis Gomez-Sanchez. I also called upon Riva-Agüero, upon the mother, and upon the wife of Manuel Pardo, which two latter were not ready to receive. At General Medina's I heard of the formation of the new cabinet; the Ministers had just been sworn in: Medina himself, Minister for War, and President of the Council, a medical man, Dr. Rosas, whose wife was daughter of the late Lorenzo Puente, and sister of Mrs. Juan Mariano Goyeneche, Minister for the Interior - all his acquaintances spoke very highly of him and of his capacity - La Jara, once C. W. Schutte's clerk, and lately vista in the Callao Custom-house, Minister of Finances, Eusebio Sanchez for Justice, and José de la Riva Agüero for Foreign Affairs. Juan Baso had been made Prefect, also the Municipality consisted of decided Pardistas, viz.: José Antonio Garcia y Garcia Senator for the department of Amazonas, Alcalde, Frederic Marriott, Vice-Alcalde; Dr. Bambaren one of the Municipals.

At 7 O'clock in the evening I had to go to a dinner party which the Germans in Lima gave to the officers of the German man-of-war "Hertha" now in Callao Bay and to which most reluctantly I had subscribed $5^{0}$ dollars. We met in the house of Gildemeister, and then walked to Maury's hotel, where the dinner was spread in the dining hall. I suppose we were 60 who sat down, of whom at least 15, if not 20, were officers. Charles Pflücker and Alfred Böhl, though they had subscribed, were not present. The captain Köhler sat in the middle of the table, I to his right, Lembcke to his left; opposite to him the first lieutenant Hasenpflug. Many speeches were delivered by Sattler, Lembcke, Solf, and others, to which the Captain, the first lieutenant and the doctor replied; the military band from on board the "Hertha" was in attendance, and singing hardly ever ceased. No doubt the dinner was good, but I did not eat, nor did I drink a drop. Champaigne was in abundance. To my right sat a young German from Hamburg, called Averdieck, now in Gildemeister's employ, who gave me an account of the many adventures he had had at Singapore as clerk, as gold-digger in Australia, then in New-Zealand, and having come to Callao, with one million and a half of leeches, which he had been obliged to sell at a ruinous price, he had thought himself very fortunate in obtaining a situation at Gildemeister's [_] hose timber business in Callao he superintended. The [...] [357] please me; he appeared to me vulgar, there were two midshipmen, natives of Altona, the one, a young Donner, brother of John, late book-keeper in the Banco de Lima and a young Kirchhof, son of a teacher in the gymnasium. I was 
glad when we rose at near midnight, for to me it had been a very dull party; not a few were much in the wind. Pfaff, partner of Knawer, and Hartmann clerk at Huth's, insisted upon accompanying me to my street door.

Friday, $9^{\text {th }}$ of August 1872. In the course of the week I had been present at a meeting of the Directory of the Insurance Company "Lima", and of that of the Banco de Lima. In the Insurance Coy. everything went on satisfactorily, whilst in the bank, for the first time since its establishment, the members who attended were not in sufficient number to form a quorum; also, for the first time a large sum overdue was outstanding on the $1^{\text {st }}$ of the month, owing of course to the disturbed state of the capital in the last week of July. It was doubtful whether the present government would acknowledge the $S / 25,000$ paid by the bank to Gutierrez' Secretary-General, who by the by had been accused in the criminal court of justice of having stolen $\mathrm{S} / 180,000$ out of the treasury immediately after the fall of his principal; he was believed to be on his way to Europe. Of the whereabouts of Manuel Eugenio Velarde, my wife's cousin, and a staunch partizan of the Gutierrez, nothing was known; no doubt he lay concealed somewhere. Marcelino Gutierrez had been arrested in Callao.

Saturday, $10^{\text {th }}$ of August. Doña Mercedes Riglos, wife of José de la Riva Agüero had said many months back that if Manuel Pardo were elected President, she would give a grand ball. Now she kept her word, and for yesterday the $9^{\text {th }}$ when Pardo completed his $38^{\text {th }}$ year, she had sent invitations all over the town. My wife preferred staying at home. I went at 10 O'clock and had the good luck to find the new president in the ante-room, where I congratulated him on his election; he shook hands with me in his usual friendly manner, saying that he was convinced of the sincerity of my good whishes. As yet not many people were assembled, but by and by the rooms - not particularly large - became crowded, so much so that for the gentlemen it was almost impossible to move. I of course could not distinguish who the ladies were, but learned this morning at breakfast from the three eldest Garlands, who had also been there, that there had been more than fifty ladies with few exceptions the very élite of Lima society: the Orbegosos, Elespur [...] Riestras, Dartnells, the daughters of Pedro Paz-Soldan, Fort[_] [358] Nieto, wife of José Maria Sancho Davila, Inez Laos, wife of Rafael Canevaro, who was the most elegantly dressed and made the greatest display of diamonds, Irene, wife of the Prefect Baso, Teresa Lastre, wife of Aurelio Garcia y Garcia, Mariana Barreda, the President's wife, and many others. Carolina Sotomayor had the good luck to be seen in this society, because her husband Juan José Araoz was Senator for Cuzco and an eager Pardista; in the same manner Mrs. Lembcke and daughters owed their invitation to Lembcke's being Swedish and Norwegian Consul, and at the same time gerente of the Banco de Lima. Gentlemen there were perhaps three hundred, of course 
the members of the cabinet, and the greater part of the foreign diplomatic and consular agents, but to my surprise not one of the Supreme Court, and of the Superior Court only Dr. Manuel Morales, a thorough Pardista, and Eusebio Sanchez, Minister of Justice. I exchanged a few words with the one and the other, took a cup of tea, and left at about midnight. When looking for my greatcoat and hat, another gentleman, who was similarly employed, addressed me; I did not recognize him, but he told me that he was La Jara, the present Minister of Finances, late "Vista" in the Callao custom-house. He put me in mind of our ride from Islay to Arequipa in company with C. W. Schutte in January 1846, of which I have given the particulars page 777 Vol. III, and though he lived at the other end of the town, near Belen, insisted upon accompanying me to the door of my house. We conversed on many topics, on the present state of the Peruvian Finances, on the difficult position in which Pardo was placed for want of money etc. We also spoke of former times, and he complained of the conduct which his then principal C. W. Schutte had observed towards him. After I was gone the tables in the dining room had been covered firstly with all kinds of refreshments, at a later hour with an excellent supper; everything had been first rate; the last guests left between 5 and 6 in the morning.

The Consular Corps, with Sousa Ferreyra its Senior, at the head presented their official felicitations to Pardo. All did not attend-Roca y Garzon and Oyague amongst others, were absent owing to indisposition. We assembled in uniform in the Ministry for Foreign Affairs; at about 2 O'clock Riva Agüero ushered us into the receiving-room, and as soon as Pardo had entered, dressed in black as usual, we ranged [...] a half circle [_] Sousa Ferreyra read his short speech [...] [359] replied ex-tempore in a very obliging manner. He then requested us to sit down, and commenced the conversation with the remark that some of the Consuls were more Peruvian than he, by which he meant to say that they were more years in the country than he was old. Sousa Ferreyra, Lembcke and I kept up the conversation, which however did not last more than five or ten minutes; we again shook hands, and marched out. At a later hour I was present at a meeting of the shareholders of the Eten Railway Company, when it became quite clear to me that the holders of the original chares, of which I held S/15,000 would for a long time to come receive no dividend whatever, whilst the holders of the preference shares, to which I had subscribed $8000 \mathrm{~S} /$ had a chance of receiving something in the course of time. Dionisio Derteano bade us good by; he left for Payta, there to have an interview with Dreyfus, who was expected by the first steamer, together with Ferreyros, whom Balta had dispatched to Europe for the purchase of men-of-war and who returned, without having been able to execute his commission. I suspected that Derteano would proceed to Europe, for it was well known that during Balta's administration he had made 
an immense deal of money in a not over honourable manner. It now became known that the house of Dreyfus of Paris had advanced to the Government of Balta, twenty three million Soles, besides having paid regularly the monthly instalments of I believe 800,000 Soles; moreover, every branch of revenue was mortgaged for the next eight months to various creditors, and I could form no idea how Pardo would manage to get on. During the few days that Riva Agüero had been Minister of Finance the two banks, del Perú and Lima, had lent each $S / 75,000$ without interest to the Government to be returned on the $31^{\text {st }}$ August. Rey, manager of the water Company, had seen Pardo in his own house on Thursday night, when he was received in the kindest manner, and told that there was no chance of the Government taking the enterprize off his hands, for there was no money in the treasury wherewith to pay the same.

The Cerro de Pasco Mineral Railway Coy. was in a dreadful state of confusion, and I saw no way how it could be disentangled. Felipe Barreda Sr. came yesterday to me and proposed that we two - he in the name of his son founding our claim upon the mortgage in our fav [...] jointly embargo the railway and its proceeds I however persu[_] [36o] him still to wait a few days, as a proposal made by Wyman might perhaps be acceptable.

Sunday, $11^{\text {th }}$ of August 1872. I called upon La Jara, and he paid his visit to my wife. By telegram from Payta news came of the death of Juarez, President of Mexico.

In the Chamber of Deputies various members had signed the proposal that the greater part of the Ministers of Balta's government be accused before the Senate for having infringed the Constitution. Santa Maria, Nicolas Pierola, Felipe Masias, Dr. Loayza, Dr. José Aranivar, Melchor Garcia, General Allende, and Col. J. F. Balta were included in the list.

Wednesday, $14^{\text {th }}$ of August. The shareholders of the Eten Railway again assembled. The plan of the preference shares was likely to fall to the ground for the Delgados, who had promised to take more than S/100,00o, had withdrawn their signature. Irrigoyen proposed another way to raise money which appeared very acceptable to the majority of those present, but as it was still doubtful whether it would be carried out, I did not give the details.

Thursday, $15^{\text {th }}$ of August. Dia de la Asuncion, was at the same time the Saint's day of the ladies called Tránsito, and consequently the Arequipeño Col. Diego Masias gave a ball in honor of his sister-in-law, Transito Llosa, a very agreeable young lady who lived in the same house with him and his family. We were invited, and my wife feeling well enough, accepted the invitation. We called first upon Mrs. Sancho Davila and upon Mrs. Carmen Barreda and arrived at about 9 O'clock, when as yet there were but few guests. Gradually the rooms - more spacious than those of Riva-Agüero - became filled, and dancing 
was commenced and kept up with great spirit. The company was not the very cream of Lima society as at the Ministry for Foreign Affairs, but of course very decent people for the greater part natives of Arequipa; amongst others the widow of the president Ramon Castilla, but on the other hand also the French engineer Plazolles and his brother, the latter lately married to the youngest daughter of Dr. Tomás Davila, to which circumstance they in all probability owed their invitation. I knew very few of the party, and was glad when my wife thought of going home at one O'clock. She would have remained longer for she was very much pleased, had it not been for the sudden dre [...] pain caused her by a cramp in the leg. [361]

Friday, $16^{\text {th }}$ of August 1872 . The steamer from the North arrived, on board of which came Dreyfus together with Manuel Ferreyros from Europe and Derteano from Payta, which latter was on

Saturday, $17^{\text {th }}$ of August present at a meeting of the shareholders of the Eten Railway Coy.; there was now some probability that the plan proposed by Irrigoyen would be carried out, and the Company thus saved from the necessity of declaring itself bankrupt.

Lerdo de Tejada was the successor of Juarez as President of Mexico which Republic was in a dreadful state of anarchy. In the capital itself banditti kidnapped respectable and wealthy persons, carried them off, and did not restore them to liberty until a ransom had been paid.

In Madrid an attempt had been made to assassinate King Amadeo and his queen Maria Victoria; at midnight when returning to their palace in a carriage, they were fired at by five ruffians, fortunately without the slightest injury being done them. One of the five was killed on the spot by the King's attendants, the four others were made prisoners. It seemed that they were mere instruments hired for the deed by the members of a vast conspiracy. The arbitrators, who for a long time had been sitting in Geneva to decide on the claim made by the United States Government, on that of Great Britain and Ireland, for the injury done to the United States trade by the Alabama and other privateers during the last civil war, would shortly give their sentence regarding which the opinion prevalent at that time in all political circles was that it would turn out less unfavourable to the British interest than had hitherto been expected.

From Enriqueta we had letters to the $16^{\text {th }}$ July from Paris. Schutte, as one might have foreseen, pretended to be dis-satisfied with the manner in which Garland and the lawyer Garcia Calderon had settled the differences between the firm of Schutte \& Co. and the Peruvian Government. Garland had been over to England and visited his mother whom he had found in good health; though 93 years of age she was still able to read English papers without spectacles and to walk without a stick. Towards the end of August the cataract upon one 
of Garland's eyes was to be couched. Ricardo and Juancito had arrived from Hamburg, the former plain, diffident, and bashful, the latter a handsome lad, full of life, and desirous to learn. Together with Corina, Enriqueta and family intended to visit the bath of Nerts, Dr. Acosta being of opinion that [...] in the ferruginous waters of that place would give strength to En [...] [362] debilitated system. Juan was still in Kissingen.

Monday, $19^{\text {th }}$ of August. Once more the shareholders of the Eten Railway Company assembled, and I took an active part in the discussion on the subject of Irrigoyen's plan, which was approved. Its details were the following: Bonds should be issued by the Company to the amount of one million Soles, or less, if the total sum were not required, paying $9 \%$ annual interest, and with $4 \%$ annual redemption. These bonds, guaranteed not only by the company but by each shareholder personally in proportion to his original share in the enterprize - not de mancomun et insolidum - it was hoped could be disposed of without difficulty, or if this was not the case at all events if deposited as security at any of the banks; money could easily be raised upon them.

Tuesday, $20^{\text {th }}$. In a meeting of the shareholders of the Banco del Perú I took no share in the debate. It was resolved that the capital of the bank hitherto $\mathrm{S} / 3,200,000$ all paid up, should be raised to eight millions, in 8000 shares of 1000 Soles each, with a paid up capital of $50 \%$. Of these $S / 8,000,000, S / 3,200,000$ should be offered to the public with a premium of $5 \%$, on condition that $50 \%$ of the same, or $S / 1,600,000$ should be paid before the end of the year, the remaining $S / 4,800,000$ or in reality only $50 \%$ of the same say $S / 2,400,000$ the original shareholders kept, and as they had already paid up S/3,200,000, the surplus of $S / 800,000$ was to be returned to them. It was my intention to subscribe for Juan $40,000 \mathrm{~S}$. part of the $S / 3,200,000$ offered to the public, leaving it to his option whether he would keep them all on his own account, or take only part, in which latter case I was ready to take the remainder for myself.

Saturday, $24^{\text {th }}$ of August. This evening at 8 O'clock I went to the German Club Room where the committee met which had to treat on the coming out of a German protestant clergyman. We were Lembcke, whom we named our president on my proposing him, Charles Pflücker, I, (Gildemeister did not come), F. Brunswick as secretary, and three artizans. Brunswick assured us that the German Relief Association was willing to pay the expenses of the clergyman's voyage out, as well as the cost of the first necessary furniture; his monthly pay was fixed at 125 Soles, besides which he would have the fees for christening, marrying etc. The rent for his apartment was to be paid by us. On these conditions there was a chance of an unmarried clergyman being procured, and we agreed that a letter should be written to this effect to a 
certain Dr. Burchard of Solingen, [...] llent man with whom Brunswick had already been $[. .].[363]$ time.

About three weeks had now elapsed since Don Manuel Pardo had been elected President, and he had named his Ministry; hitherto however they had hardly given any signs of life. It was of course the want of money which hampered the new President's actions. Besides these financial difficulties against which he had to contend, another serious question had presented itself. According to the Constitution, in order to elect a new Archbishop the Government must propose three persons to the Congress, of whom the latter choses one, and presents his name to the Pope for his approbation. Balta had not done so, but of his own accord had chosen a Bishop whom the Pope had already approved of. Now the Congress insisted upon its right, and on the other hand it was not to be expected that the Pope could recede from what he had done. This day I made a verbal agreement with Feliz Dibos, husband of Ernestina Pflücker, to let him the ground floor of my house with the garden at $\$ 340$ monthly, the rent to begin from the 15 September.

Sunday, $25^{\text {th }}$ of August 1872 . In the course of last week the Congress elected the first and second Vice-president for the Constitutional period of four years. With regard to the election of the president and vice-presidents the Constitution says that an absolute majority of all the voters in the country, or in other words one half of their number, and at least one more, is required to elect president or vice-president. If none of the candidates obtains this absolute majority, then the deputies and Senators united in full congress have to decide between the two candidates who have the greatest number of votes, and then the relative majority of their votes suffices. Manuel Pardo was chosen by the absolute majority of the voters in the Republic, whilst of the candidates for the two vice-presidencies, none had obtained his majority. These candidates were: for the first vice-presidency Manuel Costas, and J. A. Ribeyro, for the second Francisco Garmendia, and Luciano Benjamin Cisneros. Costas, a native of Puno, and of respectable parentage had belonged to the cabinet under Pezet's administration and had great influence in his department; he possessed various estates, and his business was that of purchasing wool - both sheep and Alpaca - and consigning it to London, where for many years past A. Gibbs \& Sons had been his correspondents. J. A. Ribeyro, probably born in Lima and of an unknown family, had dedicated himself to the law, and, certainly a clever man, had gradually risen to be vocal, and more than once president of the Supreme Court of Justice. [...] had filled the post of Minister for Foreign Affairs. [364] Francisco Garmendia, of Cuzco, was the owner of a large cloth manufactory which he had established in that capital; his 
influence in the department was considerable, though not to be compared to Costas' in Puno. Luciano Benjamin Cisneros sprang from the province of Conchucos; he, as well as his two brothers Manuel and Luis, are illegitimate, their father being a clergyman, Cartagena, their mother a sister of General Pedro Cisneros. None is deficient in intellectual capacity and acuteness, and Luciano, the eldest, is perhaps the cleverest lawyer in Lima; he belonged hand and foot to Dreyfus' party. Of these four candidates the two friends of Manuel Pardo, Manuel Costas and Francisco Garmendia were chosen, the former having a majority of 33 , the latter one of thirteen votes. Immediately after his election Garmendia embarked from Callao, via Panama for France, there to purchase new machinery for his manufactory.

In the evening, Mariana, the only daughter of the late Stanhope Prevost, was married to the Chilian Chargé d'Affaires, Godoy, much against the wish of her mother Mariquita Moreyra. On the $28^{\text {th }}$ of last month Julius Pflücker, one of the sons of Charles, married his cousin Hortensia, daughter of his uncle Julius, who had been brought up in France in the family of her brother-in-law Dibos. This Julius, junior, had formed a partnership with his two brothers Federico and Leonardo, who like him had received an excellent education in Germany, and with his eldest brother Carlos Maria brought up in Lima. Jointly they worked a sugar estate and silver mines, which latter situated partly in the province of Castro Vireyna, partly near Tucto, close to the copper-mine of Morococho, are their Father's property. The sugar estate called Falcalá situated in the neighbourhood of Trujillo, is the property of Doña Francisca Risco, to whom they paid a heavy rent; besides, they had had to make good to the late tenant, a certain Albrecht, a very large sum (perhaps S/400,000) for the improvements which he had made on the estate. This amount through the medium of Chavez they had borrowed from the South American Company established in London, and already in the short time elapsed since then they had been able to make shipments of sugar in part-payment. Julius attended mainly to this estate, Leonardo to Tuctu Federico to Castro-Vireyna, and Carlos Maria was the head-manager in Lima, counselled no doubt when necessary by his father.

Wednesday, $28^{\text {th }}$ of August. This day embarked for Eu [...] [365] licence for two years absence, the Fiscal, Dr. Toribio Ureta. The pretence was ill-health, the real motive a desire to absent himself for some time from the political Arena; he had been an unsuccessful candidate for the presidency and in all probability not been ignorant of Gutierrez' plans. Just before leaving he played me one of his usual shabby tricks - in my suit against Leyva, about the gutter in my garden, which I had gained in the Superior Court, he gave the most unfavourable vista imaginable, which was not to be wondered at, as Leyva was 
one of his staunchest political adherents. This day he accompanied him on board the steamer.

Friday, $30^{\text {th }}$ of August 1872. Santa Rosa. I visited all the Rosas of my acquaintance, viz.: Rosa, widow of Conroy, her mother Rosa, widow of Robinet, who did not show herself, being occupied with nursing another daughter of hers, Emma, just confined, Rosa, the wife of Cipriano Correa, Rosa, the widow of Manuel Mur, and again married to the music master Francia, Rosa Lacharrière, who excused herself on the plea of indisposition, in her absence I conversed for some time with her son Adolphus, port-agent, a very pleasant man, Rosa Elias, the wife of Lizardo Montero, who was with her mother, being dangerously ill of a pulmonary attack, her husband and sisters received the numerous visitors, Rosa Beltran, wife of Pio Echenique, Juana Rosa Ribeyro, one of the Vocal's daughters, Juana Rosa Moreira, wife of General Freyre, who together with Ribeyro and another gentleman unknown to me were criticizing some of Pardo's measures in military matters, and lastly, Rosa Osma, an elderly unmarried lady, sister of Felipe Barreda's wife.

Monday, $2^{\text {nd }}$ of September. At early hour I called upon Dr. Oviedo somewhat later upon Dr. Arenas, on

Tuesday, $3^{\text {rd }}$ upon Dr. Vidaurre, all three of the Supreme Court, and explained to them the merits of my case against Leyva; they were polite, but their opinion it was impossible for me to discover. To Drs. Gomez-Sanchez, Alvarez, Muñoz, and Ribeyro with whom I was much more intimate than the three others, I had previously been. This day the two lawyers pleaded before the tribunal. Leyva's, young J. M. Varela, founded himself exclusively upon the right of prescription, more than ten years having elapsed since 1857 when Leyva made the hole in the wall, and 1871 when I presented myself demanding its closure. My lawyer on the other hand maintained that there was no prescription, because Juan Aliaga, the father who gave permission [...] the hole was not the real owner of the house, but merely an "usufruct[_] [366] or in other words that he had the use of it during life-time, and that accordingly with his death the permission given by him expired, and as he died only two or three years ago there could be no prescription. On this point he insisted over and over again, and beat it as flat as a pancake. The pleading being over I called upon Cristina Bustamante, the grand daughter of Dr. Gervacio Alvarez, married to Luis Benjamin Cisneros, and begged her to interest herself with her brother-in-law Manuel Cisneros, another judge of the Supreme Court; the result of all these steps was that on

Wednesday, $4^{\text {th }}$ of September the seven judges: Cosio the president, GomezSanchez, Alvarez, Vidaurre, Arenas, Oviedo and Cisneros, in spite of Ureta's vista, pronounced in my favor, confirming the sentence of the Superior Court that the hole was to be shut up. 
Manuel Pardo had made known that every Wednesday of the first and third week of the month he would receive his friends at 9 O'clock in the evening in the saloons of the palace. An invitation had also been sent to me, and accordingly this evening I went, accompanied by Mr. Westphal, for owing to the weakness of my sight I did not like to go by myself into any large party. When we arrived the saloons were already pretty well filled; an aide-de-camp at the door showed us in - the first acquaintance whom I saw was Riva Agüero now Minister; at the other extremity Pardo, dressed in black like everybody else, stood talking with some near him. We walked up to him, when I introduced Westphal, whom he hardly knew; we shook hands and I saw no more of him during the evening. It was rather a dull affair, for the time was to be whiled away merely with talking; there was no card playing. Present were a great many deputies and Senators, of whom I knew but a few, various members of the diplomatic and consular corps; of ministers I only saw Riva Agüero; Manuel Costas was hovering about in the neighbourhood of the President. Besides tea and cakes ices were handed round, in an adjoining room stood wines and spirits, of which I, of course, took nothing; and towards 11 O'clock Westphal and I quietly made our exit.

Sunday, $8^{\text {th }}$ of September. Since the $1^{\text {st }}$ of this month I was again Director de turno in the Banco de Lima, and accordingly every day at about half past three O'clock I was there to consult with the two gerentes, whether the documents presented to them should be discounted or not; this was in fact hardly anything better than a mere formality, for, as might well be supposed, Lembcke and Zaracondegui by their long experience were well acquainted with this char [...] [367] solvency of the persons who had accepted and endorsed the bills, pagarees, and other documents presented to them. In the course of the week, with the exception of Friday, there had been meetings daily, and perhaps even two on the same day. Those of the Directors of the Banco de Lima presided by me and of the insurance Company Lima went off as satisfactory as usual. The Bank had settled with Montero Bros. the large debt which these gentlemen owed; all the mortgages had been cancelled, and instead of them the bank had taken in payment four acceptances of Canevaro, drawn by Valdeavellano \& Co. in favor of Montero, and endorsed by these in blank, to the amount of about one and a half million Soles, all payable before the $1^{\text {st }}$ November. In the two meetings of the shareholders of the Pasco Mineral Railway Coy. we treated on our reassuming the same. Pio Echenique demanded that we should acknowledge his brother Juan Martin as creditor for various sums which he affirmed had been laid out in the construction of the railway, and on this being proved there was no reason why we should not concede to him his just claim. On Saturday Felipe Barreda was present, also Echenique and Wyman, Varela, 
Jimenez, Correa, Bohorquez, Sagastabeytia - representing besides himself Pardo, Riva-Aguero, and Lavalle - Peter Gallagher, Marti, Agustin Escudero, Aurelio Dinegri, Ascarrate, Puente, Dr. Julian Sandoval, myself - representing my son, and Manuel Mendoza - and perhaps one or two more. As far as I could judge, there were now no difficulties in the way, and all who were acquainted with the Cerro agreed to the following: "if the pumps put up by Wyman \& Harrison succeeded in draining the mines of the water which at present prevented their being worked, of which all seemed certain, then, they said, nobody would lose by the enterprize, on the contrary, if the pumps did not answer their purpose, then it would be a dead loss."

This day I went round to the seven judges who had sentenced in my favor but did not find a single one at home, as little as Dr. Blas Alzamora, whom I wanted to congratulate on his being elected by the Congress, Fiscal de la Corte Suprema, instead of Ureta. He, Alzamora, had obtained 64 votes, Dr. Manuel Morales 62. At Dr. Gervacio Alvarez' I was received by his daughter Asuncion, married to a certain Santillana, a lady whom I liked very well; at Gomez Sanchez' by his daughter Dominga, married to the Arequipeño Telaya; and at Dr. Manuel Cisneros' - in whose house I had not been before - by his wife, the niece of Bishop Valle; she was very friendly, and I [... ch pleased with my new acquaintance. [368]

Saturday, $14^{\text {th }}$ of September 1872 . The Juez de $1^{\text {a }}$ Instancia Dr. Patron had been indisposed the whole week, and it was therefore only this day that he ordered Leyva to shut the hole in the partition wall within ten days, counting from the $16^{\text {th }}$ when this order would be notified to him. This evening the Directors named for the purpose of bringing out the German protestant clergyman, met in the German club rooms. We were: Lembcke, who presided, Gildemeister, I, (Charles Pflücker was wanting) and the three artizans Eisenloh, Behr, and Krumdieck, together with Brunswick, the secretary who informed us that the attempt made by him and Lembcke to obtain some pecuniary assistance from the German Relief Association, which had a fund of about \$6ooo, had failed. To this coming of a protestant clergyman there had been a violent opposition, which arose from the German Catholics, from the German jews, and even from some of the German protestants. A commission however had been named by the association, one of whose members was Lembcke, and some hopes, though faint ones, were still entertained of our coming to an understanding, for which purpose we chose Lembcke as a mediator between the contending parties.

Pardo had named a commission of various individuals, to whom he and the Minister of Finance, la Jara, had made manifest in what a deplorable condition the late administration had left the finances of the country. Sagastabeytia, who 
was one of the commission, gave me the following details: To the Consignees of Guano to the United States the Government was owing such a large sum that the sales of the next four years were required to work it off, consequently from that quarter no money was to be expected. With Dreyfus the Govt. found itself in the same situation; the proceeds of the guano sold and to be sold as per contract of August 1869 would only suffice to pay the interest on and the redemption of the different European loans, and to cancel gradually the 23 million Soles advanced by them; thus from the guano nothing was to be obtained. The annual expenses of Perú were not less than 17 millions of Soles, whilst the ordinary revenue, guano of course excluded, was between 8 and 9 millions, consequently 8 or 9 millions were wanting annually; how was this enormous deficit to be covered? The plain answer was, by raising export and import duties, and by imposing new taxes; but, would the people bear it, this was the question.

Monday, $16^{\text {th }}$ of September. The soldier, an indian, from the department of

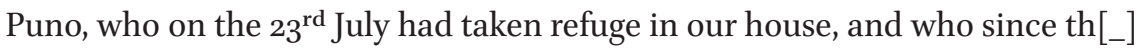
for a small remuneration, had assisted our two other servants with the [...] [369] willingness went into the street to fetch a new pair of pantaloons which my wife had presented to him, and did not return; in all probability he had been recognized for a deserter, and again been forced to enter the ranks.

Wednesday, $18^{\text {th }}$ of September 1872. The shareholders in the Pasco Railway Coy. had a long meeting which led to nothing, except the nomination of the new directory consisting of Sagastabeytia, Correa, Bohorquez, Azcarraga, and me.

Mr. Felix Dibos, to whom I had let the apartments on the ground-floor of my house, took possession of the same; his family consisted of his wife and three children, the eldest, Ana, seven or eight years old, and two younger boys Eduardo and Jorge besides servants.

Thursday, $19^{\text {th }}$ of September. The President gave a dinner in honor of the Diplomatic and Consular Bodies, to which I was invited, and went by myself in uniform at 6.30. Fortunately, when I ascended the steps in the Palace I was joined by Elster, the Russian Consul, who guided me to the upper end of the second saloon where Pardo had taken his post. When saluting him, and shaking hands with him he was quite as friendly as he had been on previous occasions. At 7 O'clock we went to the long narrow dining saloon where a splendid dinner was served furnished by Lecaros, since many years succesor of Maury. My seat was the seventh or eigth to the left of the President, who on one side had the Brazilian Minister Leal, on the other the Pontifical Delegate Vanutelli, opposite, the Vice-President Costas. I had to my right the postmaster-general, Salmon, nephew of the late Pedro Salmon, whom I found to be a rather pleasant man; 
to my left the Portuguese Consul General Narciso Velarde, of whom nothing favourable was to be said; opposite to me sat Lembcke, Sweden and Norway, and Rafael Canevaro, Netherlands. We were about 80 at dinner; besides the numerous members of the Diplomatic and Consular bodies, and the two Presidents there were the five Ministers: Cosio, President of the Supreme Court, Ribeyro, rector of the University, Manl. F. Benavides, president of the Senate, and Simeon Tejeda, president of the Chamber of Deputies, Frederic Marriott, Vice-Alcalde of the Municipality, Juan Bazo, Prefect, General Freyre, Inspector of the Army, the Aides-de-camp of the President, the Oficial Mayor of the Ministry for Foreign Affairs, and perhaps a few more whom I did not know or did not notice. Ramon Castilla had introduced the custom to take wine with all present, four or five at a time; his successors had followed his example; Pardo did not, neither did he give any toast. At 9.30 we rose; when in the same saloon where we had first assembled coffee and pousse-café we [...] us. In Balta's time I had always run away immediately after dinn[_]. [370] On this occasion I remained about half an hour, for I was acquainted with all present. At 10 O'clock I was home, well pleased with the entertainment.

Friday, $20^{\text {th }}$ of September. Rodrigo, Oyague and I had a conference with Rey, the Administrador of the Lima Water Company. There was now some chance that the company by making some trifling concessions to the Municipality who were well inclined, very different from the previous one, the company would remain in the quiet possession of all its rights.

Saturday, $27^{\text {st }}$ of September. The five new Directors of the Pasco Railway Coy. met in the rooms of the Banco Hipotecario, where we were joined by Pio Echenique and after an earnest discussion, which threatened to become a dispute, Echenique hit upon the expedient that for the amount due to his brother Juan Martin, to be fixed after his account with Wyman were liquidated, he should be considered in the same light and with the same rights as the shareholders; we were pleased with this idea, and accordingly an agreement was drawn out and signed by all of us, of course on condition that it were approved of by the shareholders, whom we resolved to convoke for Thursday next.

Pardo and his Ministers presented themselves in the Congress, when the former read a message in which he explained the miserable state of the finances more or less in the same terms as I did on the $14^{\text {th }}$. A translated extract of the same is affixed in appendix, under $\mathrm{N}^{\circ} 11$.

In the evening of this day were married in the house of Mr. Francis Bryce his only daughter Ellen and Rufino Echenique, the youngest son of the General, who, one of the gerentes of the Constructora had sent me an invitation, and I went accordingly at 8 O'clock in a dress coat with a white cravat. Francis 
Bryce and his elder brother John who since many years resided in England, had made their large fortune as extensive ship-chandlers in Callao, and particularly as exclusive purveyors of the Peruvian navy for a long series of years. The handsome house which Francis had bought from General Torrico with the greater part of the furniture for $\mathrm{S} / 100,000$ was the same which I had purchased from the Spanish Brigadier Morales in 1852, and of which I spoke in Vol. II page 570. The large saloons, beautifully furnished and brilliantly lighted up, were crowded to such a degree that it was difficult to move. Gentlemen there were perhaps 300 , of all grades of society; of ladies there were about 30 , not all of them of a unexceptionable character, as an instance of which I will only mention the [_]fe of Dr. Lucio Barrios. On the other hand there were the two B[_] [371] married to Pio Echenique, and to Carlos Elias respectively, Rosa, a sister of Clementina, Mr. Bryce's wife, married to the music-master Francia. A daughter of Pio Tristan, married to Santiago Lanfranco, and others. Of the marriage ceremony, performed by the Canon Garay, it was impossible for me to get a glimpse. Tea and ices were handed round; I addressed a few words to at least twenty different gentlemen, and at past 9 left the house unperceived.

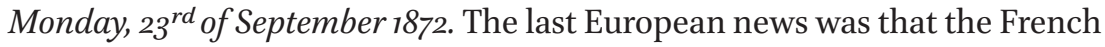
Government in order to pay the 3000 millions of francs, remainder of the war indemnity due to Germany, had been under the necessity of raising a loan for this amount; accordingly, subscriptions were opened in the principal mercantile places of Europe, and the result was surprising: about twelve times as much as the original sum required was subscribed, the greater part of which of course in France itself, but even the Berlin bankers took a fair share. The arbitrators on the Alabama question, who for a long time had been sitting in Geneva, had come to a decision, and awarded £2,00o, ooo to the Government of the United States.

Tuesday, $24^{\text {th }}$ of September. This being the dia de las Mercedes, when ladies of this name had to be visited, I called upon Mercedes Valle Riestra, widow of John Dartnell, upon Mercedes Soyer, wife of George Elster, upon Mercedes Riglos, wife of José de la Riva Agüero, and upon Mercedes Canseco, wife of Manuel Irrigoyen who did not receive, her grand-aunt, the mother-in-law of the late Don Ramon Castilla, having lately died. On

Wednesday, $25^{\text {th }}$ took place the funeral of Juan José Pinillos, who, blind for a number of years, had died at the age of 79 .

Thursday, $26^{\text {th }}$ of September. Last night I accompanied to the Church of Santo Domingo, the corpse of Don Manuel Ferreyros, a man highly respected, who in the course of his long life had filled many important posts in the service of the Republic, and this morning I was at his funeral. A few hours later I went to the Banco de Lima, where the gerentes laid before the Directory a proposal 
made by Henry Meiggs. He asked from the four banks "de Lima", "Perú", "Nacional", and "La Providencia" a loan of S/6,0oo,ooo giving as security the certificates of the work done by him on the different railways, and the amount of which already due, was to be made good to him by the Government out of the proceeds of the loan of $£ 15,000,000$; we discussed the matter, and resolved not to lend the money. The establishment of another bank [...] El Garantizador was advertized; as yet I was ignorant of its real [...] [372] Its principal promoter was Barrenechea, and its capital was to be $S / 1,000,000$ in shares of $S / 1000$ each. At the head of the list stood Emilio Althaus with S/50,0oo, next Barrenechea with $\mathrm{S} / 30,000$.

Sunday, $29^{\text {th }}$ of September. After a long interval I again climbed up San Cristoval, but I must confess it was the most difficult ascent I had ever made. Perhaps this was owing to my having lost the habit, for at least three months had elapsed since I was last up, perhaps it was owing to my being so many months older; but more probably the cause was the unfavourable state of the weather - for it was very foggy, and it had rained the night before - and above all the bad state of the ground itself. The entire side of the mountain, except where the live rock precluded the possibility of vegetation, was covered with grass and plants about half a foot high, which obliterated the path, clearly seen in dry weather; now I had to wade through them - in a minute or two my feet were thoroughly wet - I often slipped, though I did not once fall, and when I was near the summit I was so completely tired that for at least ten minutes I had to sit down on a large stone. I feared I should faint, my bowels became loose, a sign of debility; however, this exigency of nature being satisfied, I was strong enough to start afresh, reached the top in a few minutes, redescended with comparative ease, and was home before 9 O'clock when I lay down on my bed and slept half an hour. My wife was pretty well, but not yet in such a state as to allow her to pay visits - some friends, male and female, always came to see us.

Monday, $30^{\text {th }}$ of September. Guillermo, who with some of his friends had been on horseback out to Amancaes, was thrown by his horse on their return, and had fallen upon some stones, which inflicted a severe wound just above the left eye. He was brought home, bathed in blood, and the doctors were with him till early in the morning of

Tuesday, ${ }^{\text {st }}$ of October. I went to see him, and found him extremely pale and with an occasional shivering all over his body. At breakfast I told my wife of what had occurred.

At the usual hour the Directory of the Banco de Lima assembled, when nothing of importance was transacted.

Wednesday, $2^{\text {nd }}$ of October. The shareholders of the Pasco Railway Company approved in a general meeting the arrangement made by the Directory with 
Pio Echenique representing his brother Juan Martin and of which I ga[_] the details on the $21^{\text {st }}$ September. In order that hereafter their consent [...] [373] not be called in question, everyone of them put his signature to the protocol, or acta, which generally is only signed by the chairman and secretary. The minuta for the escritura or public document drawn out before a notary, which gives the necessary validity to any agreement, was signed on the one hand by the Directory, on the other by Echenique.

Thursday, $3^{\text {rd }}$ of October 1872 . Guillermo was so much better that he was allowed to leave his bed, and already on

Friday, $4^{\text {th }}$ he went into the street.

Saturday, $5^{\text {th }}$. Again the Directory of the Pasco Railway Coy. met, but waited in vain till 3.30 for Wyman, who on the preceding day - when I was not present - had promised to attend and to give his answer on the subject of a rough draft which was the work of Sagastabeytia, and in which it was said that the company resumed the railway with Wyman's consent. From the office of the Banco Hipotecario I walked to the Exposition park, in hopes of being in time for the distribution of prizes made by the President Pardo to all those who had distinguished themselves by the articles which they had exhibited in July last; however, when I arrived all was over, the park was deserted, and I remained by myself walking about for an hour or so.

Monday, $7^{\text {th }}$ of October. Alejandro's birthday, passed over quickly; Bartolomé Araoz dined with us.

Tuesday, $8^{\text {th }}$. The Directory of the Insurance Coy. "Lima" had their usual monthly meeting; nothing worth particular notice was laid before us by the gerente. For this month I was one of the two Directores de turno.

Wednesday, $9^{\text {th }}$. Augustus Dreyfus took tea with my wife and myself. He pleased me much better than when I had known him about 10 years back; he was certainly less forward. I coincided with Enriqueta's expression in one of her late letters; she said that his having been married for several years to Sofia Bergmann had done him much good by refining his manner. In the course of conversation he told us that since September 1870, that is to say within two years, he had paid to Henry Meiggs fifty four millions of Soles, also that of the late loan of $£ 15,000,000$ only $£ 4,100$, ooo had been actually disposed of, but that if Perú remained but quiet, he expected to place the remainder at about $75 \%$.

Within the last few days a motion passed the Congress which certainly did no honor to its members; it was Juan Salaverry who moved that the daily stipend should be raised from ten dollars to twelve Soles; this was approved in the Upper House by the majority of one vote, in the Lower by the majority of nine. For the greater part [...] last week Manuel Pardo had been obliged 
to keep his house and to [...] [374] himself up in a darkened room owing to a severe inflammation of his eyes, probably similar to that from which he was suffering at the time he was Prado's Minister of Finances. My wife had likewise been ailing more than usual, the cause were the unfortunate tumours so frequently spoken of.

Saturday, $12^{\text {th }}$ of October. The five directors of the Pasco Railway Company held their meeting in a nice light room which a clerk, Enrique Carrera, whom we had engaged at $\mathrm{S} / 40$ per month, had placed at our disposal in the public library, where he and his family occupied some apartments. We now seriously commenced our work; we named Sagastabeytia our chairman - he was to draw out all judicial documents which might be required, and keep them under his care. Bohorquez, who had recommended his correspondent in the Cerro, a certain Ygnacio Bao, to act as our agent there, was to draw out the instructions for him, which we discussed this day, and which were to be sent to him by the post of Monday; he was to attend to the traffic on the line, pay the expenses, collect the fare, and remit us the surplus. With Wyman \& Harrison we had come to terms that they should attend to the draining of the mines, and keep the railway under repair. Ascarraga was named our secretary, I the cashkeeper. Some of the shareholders had sent in the $1 \%$ on their original shares, which in the last general meeting it had been resolved should be paid to the Directory, in order to defray the most indispensable expenses, such as paper, pens, ink, books, the salary of a clerk etc. Correa had no special branch to attend to; he was a tremendous talker, but occasionally had a good and sound idea. Advice was received of the death of Rosa Quiroz, married to her cousin Pelegrin, which had taken place in Tarma. All who had known her much regretted her; she was one of those young ladies who, a year or so before the marriage of my daughter Enriqueta, used to come to the Sunday evening parties which we were then in the habit of giving, and which were for a long time remembered with pleasure by all who had taken a share in them. With her husband she had led no happy life. Another occurrence caused the greatest surprise in the Lima circles; it was the marriage of an excellent lady, Josefa Ulloa, widow of Dr. Prada, with a deaf, elderly, not to say old man, Andrés Zavala, one of the many brothers of that name, sons of the Marquis Valle-Ombroso.

Monday, $14^{\text {th }}$ of October. The Directors of the Pasco Railway Company met, and signed the instructions for Bao, drawn out by Bohorquez and [...] ied by Carrera; they were sent [_] by this day's mail. [_]rth [...] [375] that every day in the week, from Monday to Friday, one of the Directors, by rotation, was to show himself in our office, and listen to what Carrera had to lay before him, and that on every Saturday all five should meet, without any further citation. The North steamer brought me two letters dictated by Garland to Enriqueta, 
and dated Paris $30^{\text {th }} / 3^{1}$ st August, which gave me much to do. There existed in London a bank called "The London Banking Association" with a nominal capital of $£ 2,000,000$ - half of which was paid up. One of its Directors was Lazky, a very clever man, who called himself a Frenchman and was probably a Polish jew. At the time he was connected with Thompson Bonar \& Co. of London, he had been in Lima, and become very intimate with Manuel Pardo. This man, considering that the various banks established in Lima left good results, persuaded his fellow-directors to establish a branch-establishment in Lima, the capital of which was to be nominally $S / 5,000,000$ - half of which the London Banking Association was to contribute, whilst the other half was distributed between five shareholders each for half a million of Soles. Four of them were: Carlos Candamo, whose representative in Lima would be Manuel Candamo, Lescau, his representative Graña, the third José Canevaro, Senior, his representative, his son Rafael, the fourth, a Frenchman, name unknown to me, and the fifth share - Garland wrote - had been offered to C. W. Schutte, who however would only take the half, say $\mathrm{S} / 250,000$, but was willing to place the entire S/500,00o in Garland's name, on condition that this latter procured the other half. In order to make up this amount Garland addressed himself to me; in the very last case he said that he himself would take S/125,00o; but that it would in the highest degree inconvenience him, and then he expressed a hope that I would take the other $\mathrm{S} / 125,000$. On the $3^{1^{\text {st }}}$, however, probably after having received a letter from Juan, he added that as it would most likely not be convenient for me to take such a large share, I might apply to some of my friends, and propose to them to take an interest in these S/125,000. I neither could, nor would subscribe myself for such a sum as $\mathrm{S} / 125,000$ - the very utmost would be $\mathrm{S} / 40,000$; consequently I had to go round, and look out for participators.

Tuesday, $15^{\text {th }}$ of October 1872. I went to José Vicente Oyague, who agreed to take S/10o,ooo. The second to whom I addressed myself was Bartolomé Araoz [...] clined, but could not give a decided answer until the [376] arrival of José Maria Peña, shortly expected from Arequipa. Lastly I went to Patrone, the Italian, brother of the rich Lázaro Patrone, at this time in Europe. He listened attentively to my proposal, and replied that he was more or less acquainted with all the details which I gave him, his brother having written on the $12^{\text {th }}$ September from Genoa, that he would probably take an interest with one of the original great shareholders, and that he, the Lima brother, could therefore not comply with my request; he told me another thing which made me rather uneasy, viz.: that Don Lazaro spoke of only four shareholders, and made no metion whatever of Schutte. On the other hand, we had a letter from Enriqueta of $16^{\text {th }}$ September from Paris (four days later than Don Lazaro's from Genoa) 
and as she did not even allude to what Garland had written on the $30^{\text {th }} / 3^{\text {st }}$ of August, I inferred that no change had taken place. On the $18^{\text {th }}$ September died the King of Sweden, Charles XV, grandson of Bernadotte; as he left no male descendant - his daugther was married to the Prince Royal of Denmark - he was succeded on the throne by his brother Oscar Frederic. As per last census London had 3,200,00o inhabitants; it covered 122 English square miles.

The President Pardo had removed to Chorrillos, and his Ministers had to go out daily, there to work with him.

Thursday, $17^{\text {th }}$ of October. At 2.30 in the morning we were awakened by the shaking of the earth; two shocks were distinctly felt, the second much severer than the first. The walls trembled, the woodwork creaked, but fortunately no actual injury was done. It seemed to me that the earthquake of $20^{\text {th }}$ April 1860, had been more violent than this; on the $13^{\text {th }}$ August 1868, when Arequipa was nearly destroyed, we here in Lima had certainly felt less than we did this night. J. V. Oyague sent word to me that in the new bank to be established he could only take an interest of $\mathrm{S} / 50,000$, instead of $\mathrm{S} / 100,000$ as he had led me to expect on the $15^{\text {th }}$ inst.

Saturday, $19^{\text {th }}$ of October. As soon as the Directors of the Pasco Railway Coy. were assembled, Sagastabeytia read to us an excellent letter drawn out by him, in answer to one received from Wyman, and which we approved without any alteration. It was on the following subject: Wyman \& Harrison had a long time back made an agreement with the Cerro de Pasco miners, in virtue of which these latter had to deliver to them $10 \%$ of all the silver ore which was extracted from such of their [...] [377] as were drained by Wyman \& Harrison's newly erected pumps. These $10 \%$ Wyman \& Harrison had made over to the late Directory as a security for the surplus they had received over and above the amount due to them for the construction of the railway; but at a later time they being hard up for money, had applied to the said Directory, and obtained fm. them the cession of half of these $10 \%$ - and now they had requested the present Directory to confirm in clear and explicit terms this cession, which we however for various reasons, which it was not necessary to detail here, were not inclined to do; and to make known to them this our resolution was the object of Sagastabeytia's letter.

Monday, $27^{\text {st }}$ of October 1872. Again I made various attempts in order to procure the money which I still required for completing S/250,00o, Garland's half of the one share which Mr. Schutte of Paris intented to take in the new bank to be established in Lima, but had the ill-luck to meet with three repulses. Aurelio Dinegri said that the parties interested in Europe were not to his liking; Zuloaga, that he had no funds disposable, and Felipe Barreda that in his opinion this new bank was not likely to give a remunerative result, and above all that he 
was averse to enter with any new speculations, because he was of opinion that a monetary crisis in the course of the next three or four years was unavoidable. When I came home and told my wife of the bad result which had attended all my steps, she said "I am sure Dreyfus will help us, I shall send for him"; "dicho, hecho" as the Spaniards say. Dreyfus came, my wife told him what she wanted, I gave him the necessary explanations, and without a moment's hesitation he declared himself willing to interest himself for $\mathrm{S} / 50,000-\mathrm{On}$

Wednesday, $23^{\text {th }}$ of October I wrote Garland by the steamer corresponding with the French one from Colon to St. Nazaire, that the S/250,000 were brought together in the following manner:

$\begin{array}{lr}\text { G. Garland } & \mathrm{S} / 70,000 \\ \text { J. V. Oyague } & \mathrm{S} / 50,000 \\ \text { Augustus Dreyfus } & \mathrm{S} / 50,000 \\ \text { Bartolomé Araoz } & \mathrm{S} / 40,000 \\ \text { H. Witt } & \mathrm{S} / 40,000 \\ & \mathrm{~S} / 250,000\end{array}$

[...] also sent him a telegram through some one in Panamá - m [...] [378] does not give the name - with the words "Banking affair arranged", and as a submarine cable had been lately made between Colon and Jamaica I calculated that this advice would be with him on the $1^{\text {st }}$ or $2^{\text {nd }}$ November.

Saturday, $26^{\text {th }}$ of October. The Directors of the Pasco Railway Coy. met at 12.30 and remained together for two hours. Ygnacio Bao's answer was read; he accepted our offer of a salary of 200 Soles monthly, and $4 \%$ upon the Nett proceeds, should their be any, and added that he met with much opposition from all sides, principally from the late employés, but that he was determined to carry the matter through, and that he was convinced he would succeed. On Moday $21^{\text {st }}$ the railway was to be thrown open to the public. Many shareholders had refused to pay the $1 \%$ spoken of on the $12^{\text {th }}$ inst. S/30oo were however collected, quite sufficient for our wants and I deposited them in the Banco de Lima, where they gained $4 \%$ annual interest.

I saw by the papers that a certain Mr. Stanley, whom a year or eighteen months ago the editors of the New York Herald had dispatched in search of the renowned African explorer Dr. Livingstone, of whom at the time it was not known whether he was still alive, and if alive, where he was, had actually discovered him in the interior of Africa. The two explorers had been together for some time, and Stanley had then returned to Zanzibar. On his arrival in England he was much fêted; he even dined with the Queen at Balmoral. 
The remuneration received by him for his enterprize was fifty thousand American dollars.

About this time Mr. Dupont was reading to me a book presented to me by Enrique Garland "Hall's Artic Research Expedition". In the year 186o Mr. Hall, a North American, left the United States in the whaler "George Henry", moved, it would appear, by uncontrollable desire to explore the Artic regions, and particularly anxious to discover some relics of Frobisher's expedition in the $16^{\text {th }}$ century. He did not proceed further north than 65 or $66^{\circ} \mathrm{N}$. latitude, to FieldBay, Rescue Harbour, Frobisher's Straits - or rather Bay - etc. Nevertheless, he speaks of cold of $59^{\circ}$ Farheinheit below freezing point, whilst in the two or three summer months the plague of mosquitoes was insupportable. Innumerable were the dangers and hardships to which he was exposed during his stay of more than twelve months among the Esquimaux, with whom he had been living; with them he fed upon whale skins, upon [_] flesh of seals, raw and cooked, upon their blood, and as a great delic [...] [379] upon reindeer meet, ducks, and flesh of polar bear. He speaks of measurements which he had taken, from which I inferred that he had fixed the exact situation of many places hitherto unknown.

Sunday, $27^{\text {th }}$ of October 1872. I started at 6 O'clock, and crossed the river over the provisional wooden bridge; that made by Enrique Armero was concluded, but not yet thrown open to the public. It was a very handsome structure quite level, and consisted of five arches, the widest in the middle, two on each side somewhat smaller, and the two smallest nearest to the land; under that on the left side of the river runs the railway to the Oroya. The marble Statue of Colon which stood in the round place between the two Alamedas had of late been removed to the neighbourhood of the Exhibition, not far from the Chorrillos gate. The morning was foggy, but not wet, the ground dry. I made my ascent from the Lurigancho side where it is longest, and consequently least steep. Since I was there last the vegetation had dried up, so that the path was clearly marked, and though I was not able to climb up so quickly as I had done a year ago, I reached the summit without resting a single time, sat down on the big stone, and then returned through the Lurigancho valley, so that it was 8.30 when I reached my house, and lay down for an hour. My wife, who of late had been rather unwell, felt so far recovered that she could sit down with me to breakfast.

Tuesday, $29^{\text {th }}$ of October. In the meeting of the Directory of the Pasco Railway Company, Wyman was present. Steele, hitherto the agent of Wyman \& Harrison on the line, and Bao, our agent, had had a violent dispute on the $22^{\text {th }}$ October, the second day after the line had again been placed at the disposal of 
the public. Bohorquez defended what Bao, Wyman what Steele had done; the altercation became a dispute, finally a quarrel; nevertheless, before we broke up both had cooled down, and were apparently on friendly terms. Wyman requested us to meet again next Tuesday, as he wished to have our consent to the conditions upon which he expected he should be able to form a Company in London for the conclusion of the railway and the draining of the mines.

Wednesday, $30^{\text {th }}$ of October. A newly born babe of Mr. and Mrs. Dibos was christened Maria Theresa, in celebration of which they gave a lunch, to which I and the four young Garlands were invited. I went down at 2.30 and half an hour later a party of at least thirty sat down in the dining room. A sister of Dr. Lucio Barrios, married to Rütte, who was interested with Dibos in the Magdalena [...] was the god-mother and distributed among the guests gold and silver [...] [380] about the size of a medio, attached to a silk ribbon, upon which the name of the child and the date of her birth was printed. I neither knew nor recognized all who were present. There were of course Mrs. Julius Pflucker, some of her sons and daugthers, Mr. Charles Pflücker, Dr José Santos Chavez, who had baptized the child, Rütte, and Sattler, this latter husband of Beatriz Pflucker, and my tenant - between these two I had my seat - Yrrigoyen, Villemars the Belgian, secretary of the Maritime Company, old Larrañaga, very intimate with Dibos, and many others. Everything was excellent. I ate a little ham and ice-cream, and listened to the talk of my neighbours, especially Sattler's. At 5 O'clock I left.

Friday, ${ }^{\text {st }}$ of November. Todos Santos. I rose early and ascended San Cristoval; this time up the steep, sandy slope which rises from the valley of Lurigancho. I managed to climb up, but had to rest half way. On former occasions I could do it without stopping. When on the opposite side I had again descended as far as where the saddle is, I reascended to the hill close by, and reached the pretty cave, of which I have spoken many another time; further on I descended a path unknown to me, which gave me a good deal of trouble, walked as far as La Chacarilla, and then returned. It was as late as 9.30 when I reached my house, and had only a quarter of an hour to rest in order to be ready for breakfast. I was sleepy the whole day long, but not stiff in the limbs.

The letters from Europe which my wife read to me, from Juan to myself, and from Enriqueta to her, dated $29^{\text {th }}$ September, brought me disagreeable intelligence. Most probably Garland would not obtain the share in the projected Anglo-Peruano bank; the cause seemed to be that Carlos Candamo had told Lazky that he would not enter into any business in which C. W. Schutte was interested. Lazky, though he had promised the share to Schutte, would on no account break with Candamo who was of more importance to him than Schutte. Now I had the unpleasant task to go round to the three persons who 
had done me the favor to take a share in Garland's half, and tell them what had occurred; fortunately they took it in good part, seeing clearly that it was no fault of mine.

Saturday, $2^{\text {nd }}$ of November. At 3 O'clock the monthly meeting of the Directory of the Banco de Lima took place. Nothing of particular importance was communicated to us by the Gerente Lembcke - merely a considerable falling off in the business, since the establishment of the National or Dreyfus' Bank. In September 1870 the discount gained had come up to $S / 80,000$, in October [...] S/50,000, in October 1872 to hardly S/40,00o. Also the circulat [...] [381] billetes had decreased.

Sunday, $3^{\text {rd }}$ of November 1872. I was again up San Cristoval, and reached the top, slowly it is true, but without resting a single time. It was a wet, foggy morning.

Monday, $4^{\text {th }}$ of November. Having received an order from the Municipality to shut up the gutter in my garden, of which so much has been said, threatening me with a fine if it were not done by the $5^{\text {th }}$ inst. I gave instructions to my servant Juan to do this work. This day he together with two labourers set to in good earnest: they opened the ground in the small inner patio and discovered the tube through which the water rushed in; everytime they closed it it was reopened from Leyva's side. At last they succeeded in blocking it up; and no more water came in; hereupon on

Thursday, $7^{\text {th }}$ a notary presented himself with an escrito directed by José Sebastian Goyeneche, owner of the last house in the cuadra, from where the water came, to the Juez de $1^{a}$ Instancia Yañez, in which he asserted that he had a right to this "acequia", which he would prove, and that the Municipality could not take it from him; in the second place he begged the judge would order that everything should remain in "statu quo", or, as the Spaniards say, "que no se innove", the judge consented to his petition, and the Municipality, Leyva, and I were notified accordingly. On

Friday, $8^{\text {th }}$, at 4 p.m. appeared in my house the judge Yañez, the Notary Escobar, two witnesses, somebody from the Municipality, and Leyva, "para practicar la vista de ojos".

Sunday, $10^{\text {th }}$. This morning the servant Juan told us that there was again water in the acequia, which proved that Leyva must have made another hole in our wall.

The entire previous week the Pasco Railway Company had given me much to do. Both in the Lima and Callao papers we had advertized for engine drivers and mechanics. A good many presented themselves, all English, and I being the only one of the five Directors who could speak this language fluently had to treat with them. One, to serve as engine-driver was 
finally engaged. I also carried on the correspondence with Bao, who advised us that the first week the line had been reopened to traffic 1400 Soles had been received, and as the expenses had come to $S / 500$ there was a surplus of $\mathrm{S} / 900$.

Enriqueta wrote us from Paris that on the $24^{\text {th }}$ September the cata[_] [382 ] on one of Garland's eyes had been couched, that the operation had been successfully performed, and no inflammation ensued. The cataract upon the other eye was to be removed on the $8^{\text {th }}$ and as soon as the state of Garlands eyes would permit it, it was their intention to pass over to England, and to return to Perú in the month of Decr.

There was a remote possibility of Perú getting involved in difficulties with Japan. In September last a Peruvian vessel, the "Maria Luz", Capt. Herrera, left Macao with a cargo of coolies destined for Callao; the vessel having suffered some damage the Captain touched in Yokohama, there to make the necessary repairs, when one of the Chinese escaped on shore, went to a Japanese Judge, and complained of ill-treatment and want of food. The judge, instigated, as the "Comercio" said, by the English Chargé Mr. Watson, ordered all the Chinese on board to appear before him; some declared that they had been put on board by force, others that they were often beaten, others that they would not go to Perú; the captain defended himself against these imputations, and the judge gave his sentence to the effect that he, the captain, was to be imprisoned for 100 days, or to receive 100 lashes. Almost all the European Consuls and Chargés, excepting the English, protested against the proceedings of the judge, and so the affair stood.

Saturday, $16^{\text {th }}$ of November. The Pasco Railway Coy. continued to take up a great deal of my time. With the engine driver, of whom I spoke on the $10^{\text {th }}$, who resided in Callao, and whose name was Morgan, I made a contract. He was to start for the Cerro without loss of time, the expense being paid by the company, there to take charge of the engines, and to place himself under the orders of our agent Bao. We made him an advance of S/50. Enrique Higginson, my Callao agent, rendered me much service in this affair, without claiming or receiving a remuneration. This day's meeting of the Directory lasted three hours, which were taken up by our debates with Wyman relative to his project of forming a company in London for the objects spoken of on the $29^{\text {th }}$ October. Sagastabeytia and Bohorquez were the spokesmen, Ascarraga and I interfered occasionally, Correa said nothing. I left at 3.30 when the discussion had not yet come to an end.

Wednesday, $20^{\text {th }}$ of November. At last Sagastabeytia and I dispatched the engineer Morgan; he went together with the contingent of money 
which the Government was in the habit of sending up every month to the Cerro. The accounts which we received from our agent continued favourable; the traffic, and consequently the income, went on increasing; seldom less than [_] 1500 were received weekly. On the other hand, the extra expenses [...] [383] considerably more than we had counted upon; we had to send up Russian tallow and oil for lubricating the machines and wheels - also new springs were required which could only be made here in one of the foundries.

Thursday, $27^{\text {st }}$ of November 1872 . My wife's birthday, we spent in a very quiet manner. At dinner we had only Manuel Velarde and Doña Manuela Zubiaga, widow of Pedro Salmon and sister of the notorious Doña Pancha, president Gamarra's spouse, both dead long ago. In the evening Doña Dolores Puente, Josefa, Rafael Velarde's wife, with her two daughters, and Doña Juana Carbajal with her daughter Josefa, took tea with us; by 10 O'clock they were all gone.

Our European letters came to hand; on the $8^{\text {th }}$ October Garland's other eye had been operated with the same good success as the first. In a very short time he expected to be perfectly well, and able to see better than he had ever done before.

The topic of the day was the formation of the National guard, which seemed to be a hobby-horse of Manuel Pardo; here in Lima it would certainly be carried through, but I much feared that in other parts of the Republic this measure would meet with great opposition.

Friday, $22^{\text {nd }}$ of November. Mr. Dupont finished reading "Hall's Artic Expedition" in $1861 / 62$. This book is written in a heavy style, and the English is none of the purest, full of Yankeeisms; it contains however many facts worth knowing. The winter lasted 9, and the summer hardly three months, and the dangers to which he was frequently exposed were certainly quite out of proportion to the little, which after all he seems to have contributed to a correct geographical knowledge of these parts, for his explorations did not extend very far in any direction. The people, whom we know by the name of Esquimaux, which, according to Hall means raw-flesh eaters, call themselves "Innuits", "inu" being in their language a man, "innuit", the plural, men, or people. Their number is fast decreasing, which is easily accounted for; they often are exposed to famine, and subject to many hardships, nay dangers. Seals are their principal food, both raw and cooked, and their patience in catching them passes all belief; they are also eager hunters of reindeer - in their language "tuktoo" - of Walrus, of polar bears (Ninoo) and of ducks, and duck eggs during the short summer season. Their inseparable companions are dogs which pull their sledges, and feed with them upon the same meat and out of the same pots, which, as Hall observes, they wash by licking all round with their pliant tongues. In summer 
the "Innuits" reside in tents made of reindeer skins, called [...] in winter in their snow-huts or "igloos". They have some vague id [...] [384] Supreme Being, of Heaven, and Hell - their wizards (Angekos) make use of incautations to cure the sick when they act as physicians, to assuage the evil spirit and to keep off calamities when they present themselves as priests. Hall speaks of their mild character, murder and theft being crimes hardly known among them. One of his objects in making this expedition was to acquire some information relative to Frobisher's visit to these parts in the second half of the sixteenth century, and in this he succeeded in some measure. As he lived with the "Innuits" more than a year, and obtained some knowledge of their language, he learned from them that many many years back foreigners (Kodlunas in their language) had come to that part of the coast erroneously called Frobisher's strait, being in reality a bay. In this vicinity he picked up what he called his relics, such as glass, bits of pottery, bricks, tiles, coals etc., which he supposed could only have been left there by Frobisher's men. From this result he drew the conclusion that in a similar manner it would by no means be difficult to acquire some information respecting Sir John Franklin's expedition, if any one would devote himself to that purpose with the same resolution and perseverance as he had done respecting Frobisher's.

In the beginning of this week I had more than one long visit from John Donner, who, first book-keeper to the Banco de Lima had afterwards been named gerente of the Piura Bank, and in this capacity had gone to Europe to have the billetes made, which was done in Leipsic and, as he assured me, to his entire satisfaction. Of his father Otto, whom I recollected as a bold harumscarum boy about the years 1820,1821 , he told me that the state in which he had found him had affected him deeply. He was, he said, an idiot in mind and paralytic in body. After having risen to the rank of rear Admiral in the Prussian Navy, for some reason or other unknown to me, he had fallen into disgrace, and been deprived of his post. About the same time he had lost his wife, and one of his sons had gone to the bottom in the Baltic on board of a Prussian Man-of-war; to these different causes his son attributed his mental and physical decrepitude. Of my Altona friends he gave me upon the whole a good account. Sieveking, Edward Reincke, and Semper kept up extremely well. Knauer, though struck by apoplexy some time back, was still in a fair state of health. Theodore Elmenhorst had become very stout, and was a hypo-condriac. Altona was fast increasing in size and population, not so much as a commercial but as a manufacturing town. The business done in Hamburg was enormous [_] very large fortunes were daily being made. [385] 
Wednesday, $27^{\text {th }}$ of November 1872 . The ordinary Congress which had lasted one hundred days closed its sessions. The two principal laws which it had given was the one relative to the formation of the National Guard all over the Republic. The other regarding the accusation of nearly all the Ministers under Balta's Administration, of whom however only J. F. Balta would be accused before the the Supreme Court, whilst, contrary to every expectation it had been resolved that there was no just cause for the accusation of the ex-Minister Nicolas Pierola, or in Spanish "que no habia lugar para formacion de causa". The following were chosen to form la Comision Permanente, which it will be remembered holds its sessions when the Congress is in recess - Senators: Manuel Fco. Benavides, Francisco de Paula Muñoz, M. Alvarez Calderon, Dr. Pedro Emilio del Solar, Francisco Chavez, Manuel C. Torres, José Feliz Garcia; suplentes: Rafael Salazar, Manuel Daza, Benigno La Torre; Deputies: José Simeon Tejeda, Francisco F. Chinarro, Agustin R. Chacaltana, Ricardo N. Espinoza, José Maria Gonzales, Manuel F. Basurto, José Ygnacio Távara, Pedro Bernales; suplentes: Juan Barreto, Federico Huidobro, Agusto Althaus, and José M. Garcia.

The Congress Extraordinary would open its sessions on the $9^{\text {th }}$ December, and according to the Constitution it could only occupy itself with those objects which the Executive laid before the same; these various topics were enumerated in the decree for the convocation, but there were so many of them, that it was impossible they could all be discussed. The two principal ones were the budget and the Municipality law.

Sunday, ${ }^{\text {st }}$ of December. From Mac Millan's Magazine I copied the following figures, which give the amounts of the debts of various European powers in 1870. England £800,700,ooo; France £550,00o,ooo; Germany £170,ooo, ooo; Russia $£_{300,000,000 ;}$ Austria £310,000,00o; Italy £285,000,00o; Spain £237,000,000; Turkey £104,ooo,ooo. The debt of the United States before the civil war was no more than $£ 18,000,000$; after its conclusion it had risen to $£ 551,000,000$; and on the $1^{\text {st }}$ January 1871 , after $51 / 2$ years of peace it had again been reduced to $£_{4} 66,000,000$. After the conclusion of the Franco-German War in 1872 the indebtedness of France had reached the stupendous sum of $£$ 1,100,0oo,ooo. Of these countries the credit of Spain and Turkey was by far the worst. England, Germany, and the United States paid off their debts year by year, England very slowly, the two other countries with great rapidity. The remainder gradually increa [...] debt annually. [386]

Saturday, $7^{\text {th }}$ of December. The whole forenoon till dinner-time was taken up by meetings at which I had to be present. In the first place I went to that of the shareholders in the Banco del Perú, where the Directory proposed to 
the shareholders the establishment of a branch, "sucursal", in Iquique, and requested their authorization to that effect. After a short silence Cipriano Correa and José Maria Peña were the first to make some objections to the plan, which were answered by Mortier, the Vice-President of the Directory, and the two gerentes Escobar and Graña. After some further talk I proposed to name three shareholders, who jointly with the Directory should study the question, and decide whether the establishment of a branch in Iquique were convenient or not. This, my idea, was eagerly taken hold of by Graña, who brought it to paper: Aurelio Dinegri opined that the nomination of the three members was unnecessary, whereupon we were requested to give our votes, when a very respectable minority voted with Dinegri, but the majority was in favor of my idea. Now the question was who were to be the three members; my neighbour Alexander Ruden suggested Macandrew, I, Peña and Dinegri, and these three were chosen. Secondly, the meeting of the Directory of the Insurance Company "Lima" took but little time, as nothing of importance was laid before us by the gerente Guiroy; and finally, in that of the Directory of the Pasco Railway Company our agent Bao, who had come to Lima on private business, was with us; he was of a very dark complexion, probably a pure indian, but seemed to be well educated and of sufficient capacity. He advocated strongly the prolongation of the line for one mile, which in his opinion, the necessary rails and sleepers being already paid for, would cost about 30,000 Soles; by these means many valuable mines would be brought in contact with the line, and the gross daily produce would not fall short of $S / 300$. We all agreed with him that this would be a very desirable thing, but where was the money to come from? I insisted, and was determined not to give way on this point, that as soon as we had any disposable funds they should be employed in reducing the debts of the company. In course of conversation Bao related to us that on the previous Saturday his younger brother, whom he had left in his place, had met with a dreadful accident. He had been told that ill-intentioned people were continually placing stones on the line; he was in one of the carriages, and in order to ascertain whether the road was clear of every impediment, leaned with his head and part of the bod [...] [387] out of the window, forgetting at the moment that a stone pillar stood but a few inches distant from the line. Against this he was knocked with all the impetus of the train at full speed, and of course dreadfully mutilated. The first advice received was that there was not the slightest chance of his recovery, the second that the medical men held out slight hopes. The making of the springs, as well as of several other articles required for the locomotives, Sagastabeytia and I entrusted to Mr. Sterling, an engineer who was at present at the head of the Lima, Callao and Chorrillos' Railways, and who promised to get them made in his own foundry; these 
railways by the by had been sold not long ago by the late company, of which A. Gibbs \& Sons were the principal shareholders, to another company established in London, whose bankers in Lima were the London Bank of Mexico \& South America; the price at which the sale was effected was, as Mr. Henry told me, $92 \%$ on the nominal capital. In the course of the week the Government and Dreyfus' house had been on the point of rupture; the former had asked for the accounts of the house over and over again, and as often Dreyfus had postponed their delivery under some pretence or other; at last Pardo's patience was worn out, and the finance minister peremptorily ordered Dreyfus to present his accounts of the guano business within twenty-four, those of the loan within forty-eight hours, or the loading of guano would be stopped. This had the desired effect, and within the terms fixed the accounts were given in. Gradually steam navigation on this coast had increased in an extraordinary manner: Not one day passed without one steamer at least arriving in and leaving the port of Callao; four steamers arrived monthly at Colon from Europe, viz.: two English, one French, and one from Bremen, and this had of course their corresponding steamers from Panamá to Callao; four steamers, belonging to the Pacific Steam Navigation Company, left Liverpool monthly, which after touching at various ports, passed through the Straits of Magellan, touched in Valparaiso, and finished their voyage in Callao. An old established steam Company in Liverpool called the "White Star" began to compete with the P. S. N. Coy., the first steamer of which, four-masted, the "Republic", arrived in Callao a few days back, and a lunch was given on board, for which the agent, Norman Evans, Dr. Gallagher's son-in-law, sent round invitations, none to me. Also in Hamburg a line of steamers through the straits to Callao had been formed, and the first of them had arrived; moveover, there existed a steam-navigation company in Valparaiso; and Petrie, the efficient manager of the Pacific Company, had many smaller steamers for the [...] between Callao, and the minor ports, as far as Panamá northward [...] [388] Valparaiso southward. All those which came from Europe through the Straits were filled with Merchandize, and returned laden with produce, the natural consequence of which would be a corresponding decrease in the number of sailing vessels.

Sunday, $8^{\text {th }}$ of December 1872. La Purisima Concepcion. This was the third time I ascended San Cristoval in the course of one week.

Wednesday, $11^{\text {th }}$ and Saturday, $14^{\text {th }}$ of December. On both days four Directors of the Pasco Railway Company (the fifth, Bohorquez, being absent in Chile) met, jointly with Bao. Various topics were discussed and decided. I informed my colleagues that I had received from the Banco del Perú a small balance of 76 Soles, 65 cents, which stood to the credit of the company in the books of the bank. Sagastabeytia presented the Account-Sales of some Roman cement 
belonging to the Company, and deposited in the stores of José Gregorio Garcia in Bellavista; he, Sagastabeytia, was commissioned to collect the amount due by Garcia, and I took upon myself to effect the sale of 362 barrels of cement still on hand. When we had broken up Sagastabeytia and I went to several shops in the town in order to purchase a steam-gauge and some emery-cloth, which after a great deal of trouble we found, the former at Schwalb's, the latter at Menchaca's. Bao told us that his brother was likely to escape with his life, and that he intented to leave for the Cerro on Monday the $16^{\text {th }}$.

There existed in Lima a medical practitioner, by name Meliton Porras, who about twenty years ago was mostly employed in vaccinating children, and for which purpose he had more than once come to Enriqueta's house, satisfied with a fee of a doubloon of $\$ 2.1$ or $\$ 4.2$, a coin which at that time was current here. During Balta's administration a sudden turn took place in his affairs. He was intimate with Doña Melchora Balta, whose acquaintances were not those of the higher circles, and through her influence obtained a commission to be one of those who contracted the last loan in England, and who signed the bonds. When he returned it was well known that these operations had produced him a good deal of money, and shortly after Manuel Pardo had taken the reins of Government, Meliton Porras was arrested and placed before a criminal judge, accused with having illegally kept back $£_{3} 6,000$, a commission charged by him. The judge however sentenced that he was guiltless, and within these last few days he had been placed at liberty.

From Arequipa advices were received of some trifling disorders $[\ldots]$ [389] who were not well disposed towards the present administration called a revolution, and it was generally believed that tranquillity was not yet restored, which supposition was founded upon the sudden departure of the "Independencia" with a battalion on board.

Guillermo and Alejandro had entered the National Guard in that battalion of which Antonio Salinas was Colonel, and Rafael Canevaro second chief, the former as lieutenant, the second as aide-de-camp.

In the month of November the town of Boston, United States, had suffered from a fire which had destroyed a great many warehouses, in which hides, cotton, wool, and other produce was stored; the loss was calculated to amount to eighty-five million American dollars.

Monday, $16^{\text {th }}$ of December 1872 . I called upon our good friend Pedro José Bustamante just arrived from Arequipa, and on

Wednesday, $18^{\text {th }}$ he returned the visit to my wife. He told us that though perhaps the entire Arequipa population was not satisfied with Pardo, the discontented had no chance of bringing about a rising, and that the late 
disorders had been extremely insignificant; I had not the slightest doubt but that he was correct in the opinion he expressed, the more so as it became known that the "Independencia" had not gone Southward, but Northward to Payta. At this port La Cotera and a few other ill-disposed persons had disembarked from on board the merchant steamer, but hardly had they landed when the Prefect, who had received a telegraphic dispatch from the Government, laid hands upon them, and sent them back to Callao, where they were safely lodged in the casemates. On this day, Wednesday and on

Saturday, $27^{\text {st }}$ of December the Directors of the Pasco Railway Coy. assembled in the usual manner. The Roman cement was not yet sold; neither had Jose Gregorio Garcia paid the amount of the A/Sales. On the other hand, I had received from the Municipality S/500 for 100 barrels, and S/40 from Escudero for 8 barrels. The majority resolved that the $1 \%$ on the original capital which I had collected in October last, should be returned, together with $1 \%$ monthly interest.

From Europe nothing new of importance. Juan wrote from Algiers under date $11^{\text {th }}$ November. Enriqueta said that she and the family would leave Paris on the $22^{\text {nd }}$ of the same month, and in all probability embark in Southampton on [...] December on board the Bremen Steamer for Colon. The ocul[_] [390] had charged Garland for his two operations 15,00o francs.

Sunday, $22^{\text {nd }}$ of December. This morning Geraldo left Lima as attaché to the Peruvian Legation for Japan and China. I was confident that of the various young men who went in the suite of Aurelio Garcia y Garcia, the Ambassador, and Frederic Elmore, the Secretary, he would be the most efficient. The Legation was to go all the way by merchant steamers, firstly, hence to Panamá, thence to San Francisco, Yokohama, and Canton. Gerardo counted upon an absence of ten months, and hoped to meet his parents in Panamá. His brothers accompanied him to Callao.

Monday, $23^{\text {th }}$ of December. I was for a short time in a state of great anxiety. Nearly a fortnight back Mr. Scheuermann, who in the absence of Bamberger was at the head of his business, informed me that a wooden pillar which sustained a big beam, upon which the ceiling of the store rested, occupied by them in my house Calle del Correo, had bent a little, apparently unable to sustain the weight which pressed upon it. I applied to various carpenters and smiths requesting them to prop up the beam, but none was inclined to do the job; this morning Scheuermann came to tell me that in his opinion there was imminent danger. I now applied to Pinto, the negro bricklayer whom I had employed in my house, and who was still at work at the corner, at Goyeneche's; I borrowed two beams from Valentin Gil who was building over the way, and in 
less than hour's time the ceiling in the store was secured, so that at least for the moment there was no danger.

Wednesday, $25^{\text {th }}$ and Thursday, $26^{\text {th }}$ of December. Christmas. Though I was rather indisposed I could not avoid making a great many calls "para dar las pascuas". My original specifies them, and for once I will copy this enumeration. The first I went to see were Messrs. Henry and Böhl of Gibbs, and Mr. Joseph Macandrew of Graham Rowe \& Co.'s house; thence I directed my steps to Dr. José Luis Gomez-Sanchez, Vocal of the Supreme Court, who always received me with much kindess, his poor wife was paralytic all over. Also at Gervacio Alvarez', Vocal of the Supreme Court, the entire family, particularly the married daughter Asuncion, was always very friendly to me, Doña Mercedes Riglos, wife of José de la Riva Agüero, Minister for Foreign Affairs was an excellent, good-natured, wonderfully talkative lady; this day I found a visitor with her unknown to me, whose tongue was still more voluble than hers, and who thus had the advantange over her. Doña Manuela Portillo was an [...] [391] so lively and agreeable in her conversation that I always stayed with her with much pleasure for an hour or so; this day her granddaughter Amalia, a pleasant young woman, and her husband Manuel Ferreyros, also Dr. Manuel Ortiz de Zevallos were with her. Ferreyros was for a short time Minister of the Interior during Balta's administration; he was one of the best naval officers in the Peruvian service, a steady, upright man, and a staunch friend of Pardo; of Zevallos I hardly need say anything; he was a clever lawyer, but otherwise a good-for nothing character. At Dr. Muñoz', another Vocal of the Supreme Court, his agreeable daughter Jesus married to Manuel Panizo was still dressing; in her stead a friend of hers, a Señorita Menacho, came out to receive me. She related to me the following, which, though it seems incredible is however an authenticated fact: for some time owing to a local paralysis she had been so completely lame in both legs, as to be unable to walk a single step; she called in one physician after the other without however experiencing the slightest relief from their prescriptions, which she strictly observed. She then thought that sea-bathing would do her good, removed to Chorrillos, and was carried day after day in an arm chair down to the beach, and into the water, for move she could not; the baths had as little effect upon her lameness as the medicaments had had, and at last a friend of hers advised her to try the miraculous water of the Virgin de Lourdes, of which some one here in Lima - I believe Bernardo Roca y Garzon - had received a small supply from France. She confessed, took the holy sacrament, drank a tumbler-full of the said water, and ... was cured! When she gave me these details she enjoyed perfect health, had the free use of her limbs, and moved about with the same ease as myself. Of the apparition of the Virgin at Lourdes in the Pyrenees in $185^{8}$ I said a few words 
Vol. V, page 491, to which I refer. From Dr. Muñoz' I went to Dr. Ribeyro's, also Vocal of the Supreme Court, next to Doña Estanislaa Bergmann, and Alexander Westphal, none of whom I found at home. José Pablo Escobar was the last upon whom I called; he was rather pompous, otherwise agreeable: his wife Doña Emilia Lopez pleased me well. Escobar, a Panameño, was formerly partner of Alexander Ruden in Payta; about two years ago their firm liquidated, and Escobar continued the business in his own account, together with his brother-in-law Carlos Lopez, who remained in Payta, whilst Escobar came hither, where he succeeded in being named one of the two Gerentes of the Banco del Perú, where he attended to his duty with the greatest [...]; at my recommendation he was also named one of the Directors [...] [392] La Constructora, and was perhaps the one who took the greatest interest in this enterprize. The second day my calls were quite as numerous. I commenced with Doña Josefa, the widow of Prada, lately married to Andrés Zavala, who was not yet visible. A little further down the street I looked in at Carlos PazSoldan's, where, to my surprize, Petita, his wife and cousin, the daughter of José Gregorio, came out to receive me. She was the best-hearted creature in the world, but unfortunately rather deaf, which prevented her mixing freely in society. Moreover, her father, though rich, did nothing for her, and her husband Carlos, the founder of the telegraph-Company, the shares of which were at $50 \%$ discount, did certainly not prosper in the world. Don Carlos' father, Dr. Don Mariano Felipe, whom Castilla made Director of Public Works, though at the time he knew nothing of engineering, being brought up for the law, directed the building of the penitentiary, when evil tongues said, he made some illegal profits, which enabled him to build a house, now his own. He occupied the altos, where I called upon him and his good wife Francisca Benavides of Arequipa. The ground-floor, more extensive than the upper story, he had let to Vicente Gonzales y Pinillos, my old friend from on board the "Vicar of Bray", whose eldest daughter Luisa, still dressing when I called, was engaged to Agustus Dreyfus, the marriage with whom was to take place in the first days of January after the return of her mother Emilia Orbegoso, and her younger sister from the baths of Yura, near Arequipa. At José Vicente Oyague's, all was shut up, the entire family having removed to Chorrillos. The most agreeable visit which I paid was to the wife and daughters of Alvarez Calderon, the Senator, brother of Don Andrés who made such an enormous fortune merely by the contract for loading guano vessels, which he had obtained from President Castilla, and who was spending his money in Paris. At Cipriano Correa's I found his wife Doña Rosa, with whom I remained but a short time. At General La Fuente's where I had not been perhaps for a year, his eldest daughter, past the bloom of youth, was as kind and friendly as I had always found her; her 
father, who, at least 80 years of age, kept up wonderfully well, came in, accompanied by Dr. Loayza, a clever lawyer, who was the Minister of Finances under Pezet, and of the Interior under Balta. This latter I again met in the house of Dr. Manuel Morales, Fiscal of the Superior Court, who was not visible, an operation having been performed a few days before on a big tumour which had appeared on his arm. In the house of Dr. Domingo Valle-Riestra, Admiral not in active service, nobody was in. Doña Dolores [...] [393] was the lady whom I visited with the greatest regularity, at least every second Sunday. She was the sister of Doña Manuela, widow of Don Juan Aliaga y Calatayud, of whom and family I gave a short account Vol. IV page 143. Doña Dolores, unmarried, looked younger than she really was; her features were marked, and aristocratic; she knew that she belonged to the first families of Lima, and many believed her to be haughty and proud. With my wife she was on very friendly terms, and with me she talked on many subjects without the least reserve; she had no shining intellect, but a great deal of good common sense, and a small fortune left to her, I believe by an aunt, she managed with such prudence as to be able to live in a very respectable manner. My last call was upon Doña Manuela Mendoza y Boza, who lived over way in the house of her eldest son Don Manuel. She was a widow, and the most simple lady imaginable. By chance our conversation turned upon her son's property, one of the few topics on which she was capable of speaking, and thus she gave me a detailed account of all the estates, farms, and houses which he, her first-born, possesed. In the family of the Mendoza's there existed the right of primogeniture, and thus the eldest, Manuel, was one of the richest proprietors in Lima, whilst the younger brother Domingo owned only one estate and having devoted himself to the law, was at present Vocal de la Corte Superior and had the reputation of being an honest, upright judge. Catalina was one of the daughters, if possible still more simple, candida, than her mother; she had been married to one Quintanilla, Conde de Monte Blanco, who at his death left her a very extensive landed property in the vicinity of Pisco; her second husband was General Manuel de la Guarda, who for the last two years had been lying ill of dropsy, and whose death was daily expected.

Mr. Dupont and I, who about this time were revising my diary of 1847 for curiosity's sake, compared the names of my acquaintances then mentioned with those just enumerated, and found that a great change had taken place; by far the greater part of those of 1847 had either died, left the country, or become estranged from us. As regards the disorders in Arequipa I learned as a fact that some disturbances had actually occurred in the night from the $15^{\text {th }}$ to $16^{\text {th }}$ November, and that the Prefect had availed himself of this pretence to arrest the eternal conspirators Domingo Gamio, and the ex-president Herencio Zevallos, and to send them off to Callao, where at this moment they were imprisoned 
in the casemates. On the $16^{\text {th }}$ there had been a great demonstration of Pard [...] 3000 for the greater part respectable people [...] [394] upon which the words "Pardo, peace, and tranquillity" were inscribed, marched to the house of Don Juan Mariano Goyeneche y Gamio, and insisted upon his taking charge of the Prefectship, he having repeatedly been named Prefect of the Department by the Supreme Government, and as often declined the nomination; he now promised to comply with the wishes of the people, only on condition that the next steamer from Callao were to bring no counterorder. The multitude then huzzaed for him, next for the Prefect Corales Melgar, and dispersed.

In the night from the $25^{\text {th }}$ to $26^{\text {th }}$ a fire broke out in a carpenter's shop, situated between the two streets of Sauce and Guadalupe. The tolling of the bell of San Pedro awoke me about 2 in the morning, and though I had taken a sudorific the night before, I rose and went out, to convince myself with my own eyes, bad as they were, whether the fire was making any alarming progress or not. When I arrived the engines were already on the spot, and the fire had been got under; towards morning it was extinguished.

Tuesday, $37^{\text {st }}$ of December 1872. The political news of this last week was of the greatest importance. I have just said that Herencio Zevallos and Domingo Gamio had been arrested in Arequipa by order of the Prefect, and been brought to Callao. On the $23^{\text {rd }}$ the Executive gave them the commission to proceed without delay to the frontiers of Perú and Brazil, there to examine the localities, the one on the North, the other on the south side of the Amazon, and to report to the Government which spots they considered most proper for the construction of fortifications. Zevallos presented a petition, praying to be separated from the military service, to which Medina, as Minister for War, replied that as soldier it was his duty to obey, and that he might afterwards at the place of his destination present himself to the competent authority and demand a separation from the service. On the $27^{\text {th }}$ it became known that the President Pardo had narrowly escaped being assassinated. The papers " $\mathrm{El}$ Nacional, and "Comercio" published the details. On the $26^{\text {th }}$ several individuals were arrested: Guillermo Bogardus, and an officer, José Segundo Heredia, in the house of the former close to the theatre; the others, amongst whom Pedro Beausejour, and Dolores Valiente, a woman of bad repute, in the dwelling of the latter, a house opposite the penitentiary. From their respective declarations it was evident that Bogardus was the head of these conspirator [...] of course being merely the agent of some other person who furnished the [...] [395] and this latter person was Emilio Píerola, who had been sought for, but had escaped, and lay somewhere concealed. Emilio, with whom I was acquainted, he being like myself one of the Directors of La Constructora, was no doubt the tool of his elder brother Nicolas, the ex-Minister, who, after having been 
declared innocent by the Senate had left Lima a fortnight or three weeks ago. The plan was to blow up the train in which Pardo went to or came from Chorrillos. The barrel, with powder, together with the electric wires wherewith to fire it, were found in the rooms of the Valiente. The $24^{\text {th }}$ had been fixed upon for the deed, but as Pardo, after having received his friends in the palace, remained in town that night and did not return to Chorrillos by an extra train, the plan was frustrated. The opposition papers "El Pueblo", "La Nacion", La Patria and "El Cascabel", affected to treat this conspiracy as a mere invention of the Government in order to get rid of Bogardus, who, it will be remembered, about five years ago presented a document to the Congress, in which he, a native of Perú, denounced all the guano consignees - see Vol. VI page 788 and demanded that all their accounts should be re-examined, he offering to prove the truth of his asseverations. A denouncer, according to the laws of Perú has a right to a considerable part, the third or fourth, of the sum which may be recovered owing to his denunciation. Manuel Pardo had for some time quite in the commencement of the guano consignment to Great Britain after Gibbs had given it up, been the manager or gerente of the company which still existed in 1872, and thus he was in some manner, though indirectly, involved in this accusation of Bogardus, but not satisfied with this Bogardus in the same document hinted at frauds which he said had been committed by Pardo at the time when - I do not recollect the year - Pardo had something to do with the purchase made in France of two vessels for the Peruvian navy the "America" and the "Union", the former of which was lost on the $13^{\text {th }}$ August 1868 at the time of the earthquake in Arica; the other, the "Union", was still in the service. This Bogardus was a known bad character, and generally believed to be the same who on horseback and with his face muffled, fired at General Castilla, without however hitting him many years back. [396]

1873

Wednesday, $7^{\text {st }}$ of January. At 8 a.m. the President laid the first stone of a new college in which he took great interest. It was to be built on shares, of which Garland - who thought of placing his son Antonio in the same - had taken one.

The teachers were exclusively German Catholics, clever men, and well paid.

For a short time previous to this date they had occupied the large house called de Micheo, where some young men had been instructed by them.

At a later hour a deputation came up from Callao to congratulate the President on his late escape, and to assure him of the fidelity of the Chalacos. 
He also received many visitors, amongst whom all the officers of the various battalions of the lately formed National Guard. The Diplomatic corps went in a body - the Consular did not. I went by myself in a black frock-coat; as far as I could distinguish not many persons were present just at the moment. Pardo sat at the extremity of the second long saloon, in a common arm chair; he, of course rose, shook hands with me; I congratulated his Excellency and added, "deseo que en el año venidero Ud. tenga menos trabajos y disgustos que en aquel que acaba de espirar." He begged me to sit down on a chair close to him, but as he continued his conversation in French with two or three sisters of charity, I soon rose and took my leave, when he said with his usual winning smile "Ud. viene á verme una vez cada año." I replied that I should see him in his own house, and then made my bow. Pardo had not made the Palace his residence; he only went thither in the morning to attend to business; at night he returned to his private dwelling, where he slept. Up to this day, as far as I knew, his wife Mariana, the second daughter of Felipe Barreda, had not crossed the threshold of the palace. This evening many of his friends and partizans went to see him in his house; I was not of the number.

In the forenoon of this same day I called upon the President's mother who lived upstairs in the same house with her son. She, an agreeable old lady, received me in her bed-room, and I should willingly have remained with [...] longer than I actually did, if other visitors had not been announced [...] [397] and took leave. With her and her late husband Don Felipe, completely paralytic for the last years of his life, I had always kept up my acquaintance, though never intimate. At old Mrs. Elias', nobody was at home; she had removed to Chorrillos, and her eldest daughter Rosa, with her husband, the well-known Lizardo Montero, had gone thither to pay her a visit. Juan Bazo, Prefect of Lima, since Pardo's Presidency was reclining on a sofa; having hurt his leg he moved about with difficulty; his wife Irene was always friendly, nevertheless I was not much pleased with my call - as little as with my next upon their neighbour Jesus Beltran married to Carlos Elias. She and her sister Rosa, the wife of Pio Echenique, had undoubtedly seen the best society in Europe. When some years ago they lived with their mother in Paris they became acquainted with the Empress Eugénie; who frequently invited them to spend some days with her in Fontaínebleau. The mother was at present again in Paris and the two daughters, who lived together and who strange to say had no children neither the one nor the other, were generally very agreeable; this day however Doña Jesus seemed to think only of the arrangements of a dance she intented to give in the evening and therefore I did not trouble her long. Mrs. Lacharrière, née Telleria, the widow of a Frenchman, who lived close by was very amiable, and her son Adolfo, Callao port agent, was quite as agreeable as she. At 
Dr. Bruno Bueno's I only found one of his daughters; the Doctor was a staunch adherent of Prado, and in 1865 brought about the revolution in favor of this latter whilst he was Vocal of the Superior Court of Trujillo; to reward him for this service Prado made him Vocal of the Supreme Court of Lima, but he fell with his protector; during the last electional strife he had adhered to Ureta, and, as might be expected, was now without employ. Opposite to where Bruno Bueno dwelt stands the fine mansion of the Marchioness of Torre-Tagle, the wife of the always dirty Don Manuel Ortiz de Zevallos; she and her nice daughter Elena were at home. The last I did was to leave my card with Don José Santos Chavez, for many years secretary of the late Archbishop Goyeneche, at present Curate of the Díocese del Sagrario.

The man-of war "Mairo", on board of which Herencio Zevallos and Domingo Gamio had embarked on the $24^{\text {th }}$ ulto., returned from Chancay, and her captain reported to the Government that the two said gentlemen had been safely landed, and were already on their journey to the Brazilian frontier.

Saturday, $4^{\text {th }}$ of January 1873. In the course of the last week the Directors of the Banco de Lima met twice, without transacting any business of particular [...] Juan de Dios Calderon sent in his resignation in conseq [...] [398] an altercation he had had with the Gerente Lembcke. In the meeting which we of the Pasco Railway Coy. had this forenoon I was enabled to tell my colleagues that I had received a remittance from Bao of $\mathrm{S} / 3360.20$ which would enable me to return the $1 \%$ paid in some time back by several of the shareholders.

Monday, $6^{\text {th }}$ of January. I had quite recovered from my slight indisposition but now my wife suffered from a bad cold and cough.

At 4 p.m. we had the pleasure to receive a telegraphic dispatch from Payta dated the same day, in which Garland informed me of his and his family's safe arrival; another telegram to the Exchange rooms stated that the steamer "Arequipa" had left Payta at 1 p.m. thus, she being a fast steamer, we expected her in on Wednesday, before noon, and Carlos Ferreyros, Captain of the transport steamer "Chalaco" moored in the bay, having invited me to breakfast on board of his vessel, on

Wednesday, $8^{\text {th }}$ I went down to Callao with Enrique, Guillermo, and Alejandro by the 10 O'clock train. Ferreyros, in a man-of-war boat was waiting for us, and we were rowed on board. The "Chalaco", formerly the "Quito", bought under Pezet's administration for $\$ 500$, ooo from the Pacific Steam Navigation Company, looked exactly the same as when she had been a merchant steamer. In the saloon there were still the portraits of Queen Victoria, Prince Albert, the Prince of Wales, the Princess Royal, and her husband the Crown Prince of Prussia. We had a nice breakfast in the saloon, and as no Arequipa made her appearance, we, to pass away the time, paid a visit to one of the Monitors, 
the "Manco Capac". Everybody knows that Monitors are constructed of iron only; this, the "Manco Capac" and her companion the "Atahualpa", bought by J. A. Garcia y Garcia in the United States, were built for river service, and are consequently almost without any keel. She lay about one foot above water, so that we could easily step on board from the boat without the help of a staircase; there are no bulwarks, no mast: the big funnel and a tremendout tower are the only two objects which rise from the deck. The tower is an enormous mass of iron - its height I do not know, its diameter about 16 feet, and its walls are eleven inches thick; inside the same stand two immense cannons, the weight of the balls which they project is at least 500 pounds. As soon as one of the cannons is discharged, the aperture in the tower, of the size of a door, is closed, which can be done by one man; the entire tower, together with the cannons, stands upon an iron platform, and such is the wonderful mechanism that this enormous weight can be [...] [399] ease in every direction. In an action nobody is seen on deck, the crew is below, and air is mostly admitted through the tower, open at the top; frequently, in the course of the passage from the United States to Callao, which was an extremely dangerous one, the weather was so bad that for several days consecutively nobody could venture on deck without running the risk of being washed away. This monitor is about 200 feet long, and uncommonly broad in the beam. We returned to the "Chalaco", as yet no "Arequipa" in sight; the whale boat was got ready, a mast was put up, a sail fastened to it, and for full half an hour we cruised about in the bay; the boat, impelled by the wind, glided through the waters with an almost imperceptible motion. By and by the weather cleared up; at 3.30 the "Arequipa" could be seen through the spy glass, and in about half an hour she was anchored in the bay. Again we went off in a boat, but had to wait a few minutes because nobody was allowed to step on board of a vessel before the arrival of the Captain of the port. The deck was crowded, not so much with passengers as with all kinds of fruit and vegetables taken in at Guayaquil and Payta. There were Garland and Enriqueta, who looked extremely well, Ricardo, Antonio, Maria - who immediately came up to me - and Corina, who did not recollect me. After some detention owing to the luggage, we were rowed on shore in Ferreyros' man-of-war boat and returned to Lima by the 5.45 train. My wife, I need not say, was overjoyed to see Enriqueta and the little ones again. All dined with us.

Thursday, $9^{\text {th }}$ of January 1873 . Besides the family, for Enriqueta had as yet no cook, we had at dinner with us Dr. Pedro José Bustamante, lately arrived from Arequipa, his son Enrique, and Carlos Ferreyros. The Doctor was so taciturn as to make himself almost disagreeable, whilst his son Enrique was a tremendous talker. Many visitors came in to see Garland and his wife, and when all were gone Enriqueta kept us up till a late hour, relating of Paris 
and her acquaintances there; many of the South Americans residing in that capital, [_] said, lived in great style, and spent much money. At the head of them stood, of course, Carlos Candamo, whose wife threw money away as if it were water; next followed Andres Alvarez Calderon, Francisco Luzarraga, the Canevaros, Aquilles Allier, Grimaneza Althaus, the widow of Cotes, who had been extremely kind towards Enriqueta, C. W. Schutte, and others unknown to us. On the other hand, Dolores Alzua, the widow of Dorn, who had been the partner of her brothers, was almost reduced to poverty; one of her brothers, Liberato, had committed suicide in Mazatlan [...]. Of Duquenne, to my surprise, Enriqueta had [...] [40o] During the time of their residence in Paris they had lived in a house by themselves [_] 15 Rue Pressbourg; one of their windows looked in the direction of the Bois de Boulogne and from about 1 or 2 in the afternoon till late in the evening an almost uninterrupted row of carriages used to pass by. In London they had been but a short time, and during Garland's absence Enriqueta had taken up her quarters in the Great Western Hotel, a building of enormous size, close to the Paddington Station. Here she had had a visit from Mr. Clay, many years back North American Chargé in Lima, from his wife, and her sister, still Miss Crawford. From their appearance Enriqueta inferred that they were living in actual poverty, and Mrs. Clay so sprightly, so coquettish, whilst in Lima, had now the looks of an elderly lady who had suffered much; she told Enriqueta that they had taken up their residence in London because there they could live cheaper than in their own country. What Grimaneza Althaus had been to my daughter in Paris, Josefa Bazo, the wife of Anibal Gonzales was to her in London. Garland had been to Liverpool to take leave of his mother. Ricardo and Antonio he had brought back with him; the former had been with old Mrs. Garland, whilst the latter for a short time had been staying in a boarding-school, where his father did not venture to leave him, because he was suffering from an organic defect of the heart. Juan, on the other hand, remained in this college, whither he had been removed from Schüler's establishment near Hamburg. Ricardo, 17 years of age, was in every respect different from his brothers, weak in body and mind; and incapable of any exertion, either mental or physical, but good natured; he had learned but little, wrote a shocking hand, and had not made much progress in cyphering.

Here in Lima the only news worth noting was the liquidation of the firm of Templeman \& Bergmann; this was an evident proof of the want of mercantile capacity. The house was established immediately after the war of Independence under the very best auspices, at the same time with Huth, Gibbs, and Alsop. These three had made lots of money in the course of the half century which had elapsed since, and continued to be of the highest respectability, whilst Templeman \& Bergmann, managed for many years by Mr. Frederic Bergman, 
no great commercial genius, and since his death by his two sons Frederic and Charles, very inferior to him, had, it was true, done much business, effected many sales, but never been able to make large profits, and now at last they $\mathrm{w}[\ldots]$ their business. [401]

Saturday, $11^{\text {th }}$ of January 1873. Of the Directors of the Pasco Railway Coy. also Ascarraga had absented himself, and thus only Sagastabeytia, Correa, and I met in the course of the forenoon. Money had come in for the cement sold before, we had taken charge of the direction, with which we now bought three cedulas of the Banco Hipotecario, of S/1000 each.

Saturday, $18^{\text {th }}$ of January. In the course of the last week I was present at two meetings, the one, of the Directors of the Insurance Coy. Lima, the other of the shareholders of the South American Insurance Coy. Both companies had done very well during the last year; the latter, established eight years, had a reserve fund of $\$ 300,000$; besides $\$ 200$, ooo paid up, and though it had had to pay $\$ 40,000$ for maritime losses, it gave a dividend of $60 \%$. The Insurance Company "Lima", established hardly two years, had S/200, ooo paid up, a reserve fund of $S / 72,000$, had paid for losses during the year a little more than $S / 1000$ and gave $9 \%$ dividend. I heard from Ruden that the Eten Railway Company was at its last gasp, that in all probability it would declare itself bankrupt, and that the shareholders would lose every rial.

This day at 12 O'clock Augustus Dreyfus was married to Luisa Gonzales y Orbegoso in the chapel of Belen; after the ceremony the party removed to the house of the father, where a lunch was waiting for them, and at about 5 or 6 p.m. the newly married couple went per train to Chorrillos, there to pass the few days of their residence in Perú, for on the $28^{\text {th }}$ they intented leaving via Panamá for France. Present at the marriage were all the relations of the bride, and the most intimate friends as well as the partners of Dreyfus; also Böhl, Riva Agüero, Minister for Foreign Affairs, and Dr. Rosas Minister of the Interior.

Sunday, $19^{\text {th }}$ of January. This morning I left my house at 6 O'clock, and crossing the river, which was much swollen, over the provisional wooden bridge, thought of ascending San Crístoval from its furthest point, but the road was so overflown with water that I had to climb up where I had never done it before; it was very steep, and on my reaching the first range I was thoroughly tired and had to rest; thence I continued my ascent very slowly, and the sun being concealed by the thick fog I did not suffer from the heat so much as I had feared. I was home by 8.30 and slept till 10. At 1 Sagastabeytia came to me, and we occupied ourselves with some affairs referring to the Pasco Railway Company.

Monday, $20^{\text {th }}$ of January. The following scandalous story made much noise [...] Lima circles: A certain individual whose name was unkn [...] [402] me but no doubt a very contemptible character, went, perhaps four weeks back, to 
the house of Mr. Francis Bryce when he was not at home. He asked for his lady Doña Clementina Lopez Aldana, and showed her a few verses in manuscript, in which her honor was attacked in terms which could not be misunderstood, and told her that if she did not pay him 1800 Soles, they would be published in the papers; she threatened to have him thrown out of the house by her servants; he left, and the verses were published in the "Nacional". Rufino Echenique, lately married to Bryce's daugther Elena, kept on the look out for the slanderer; a few days ago he got sight and took hold of him; in a retired place he had his breeches pulled down and I do not know how many lashes inflicted upon him.

Page 363 I spoke of the difficult situation in which Pardo found himself, arising from the illegal nomination of an Archbishop for the Republic of Perú. He however got out of it in a clever manner. Pedro Galvez, Peruvian Minister in England and France, presented himself before his Holiness Pius IX, and arranged with him that the illegally named Archbishop Valle remained Archbishop, not for Perú, but in partibus infidelium, and thus the Archbishopric of Perú remained vacant and could be filled up by him whom the Executive and the Congress named. Their choice was likely to fall upon Urueta, Bishop of Trujillo, of whom Don José Gregorio Pas-Soldan once spoke to me as being a particularly well instructed man.

Tuesday, $27^{\text {st }}$ of January. The shareholders of the Eten Railway Coy. met, when notwithstanding José Antonio Garcia y Garcia's attempt to prove the contrary, all were of opinion that the affairs of this enterprize could not be in a worse condition than they were. Ruden, Aurelio Dinegri and I declared our willingness to lose every rial of what we had paid in, if we were but released from the guarantee which each of us had taken upon himself, to do the service of a part of the late loan of 1,00o,ooo Soles. Jose Maria Varela did not know his own mind; he saw that he was losing a great deal of money, but could not decide what steps to take. Felipe Barreda proposed that a commission of 3 should be named for the purpose of laying before us some plan or other how to extricate the Company from its difficulties. This was objected to, because several of us opined that we all knew perfectly well how the affairs stood, and that only a declaration of Insolvency could put an end to the matter. At last however it was agreed that Derteano should draw up a plan of a new company, and that we should meet again on

Friday, $24^{\text {th }}$ of January. When I went at the appointed hour I met [...] [403] Manuel Candamo, and Aurelio Dinegri who told me that the meeting was put off till Wednesday next.

In the evening at 7 O'clock the shareholders of the Banco de Lima met in the office of the bank. At about 7.45 a sufficient number were present, and I as President in an arm chair before a long table, with Pedro Bernales to my 
left and José Muro, the Secretary, to my right, made a short speech in which I said that the object of the meeting was, in the first place, to have the account (memoria) of the transactions of the last year read aloud, secondly, to discuss the project of an increase of the capital of the bank considered indispensable by the Directory, and thirdly, to choose three new Directors to make up the number of eleven required by the Statutes, John Renner having died in the course of the year, José Maria Cantuarias having sold his share in the bank, and Juan de Dios Calderon thrown up his Directorship. I got through with my speech pretty fairly, though I am always nervous when I have to speak in public; about fifty persons were present. Lembcke, as gerente, read the memoria, as well as the plan for the increase of the capital. Nobody spoke against it; nevertheless, Amancio Castillo, Focion Mariategui, and especially J. M. Cardenas, rose, and gave it as their opinion that the formalities prescribed by the Statutes had not been observed; they were refuted by various members, particularly by the two gerentes and by Dr. José Aranivar, the bank's lawyer. I, also, gave Cárdenas a few raps on the knuckles, and at last the project for the increase of capital was unanimously adopted. Then came the election of the Directors, which took a long time. Sixty-five shares were represented, of which Nicolas Rodrigo obtained 63 votes, Jose F. Puente of the firm of Juan Ugarte 53, Manuel Mandoza y Boza 21, Manuel Ortiz de Villate 19, Amancio Castillo 13, and a few others 2, 3, or 4 each. When I was about proclaiming the first two as duly elected Amancio Castillo made us observe that according to the statutes the elections were null, because in the first place Ignacio Távara, who was no shareholder, had voted for Luciano Benjamin Cisneros, a shareholder who was absent, and secondly because Gustavus Heudebert had voted for six shareholders, whilst according to statutes nobody was allowed to vote for more than four. Consequently another meeting was indispensable for the purpose of choosing new Directors.

Saturday, $25^{\text {th }}$ of January 1873 . Sagastabeytia told me that he intended [...] to Chorrillos for some time. Ascarraga was absent in the Cerro [...] [404] Bohorquez, just returned from Chile, pretended that his own business took up all his time, Correa did nothing, and thus I alone had to attend to the affairs of the Pasco Mineral Railway Coy.

For some time past there had been a scarcity of bills on Europe, and this scarcity went on increasing. The firm of Dreyfus was almost the only drawer and their bills were not sufficient for the demand. Though the exportation of silver-bars, of gold ingots, and of gold and silver, Peruvian coin was prohibited by law, he house of Dreyfus obtained from the Government a special permission for shipping a certain quantity of silver bars for Valparaiso, which bars, if an arrangement to that effect could be made, should be coined in the Santiago 
mint, the Lima mint being out of order. If this arrangement was impracticable then Dreyfus might ship the bars to Europe with the express condition to offer to the Lima merchants bills on London or Paris for an amount equal to the value of the bars shipped.

About this time the Congress passed an important law; it resolved "El Estanco del Salitre", that is to say the Government monopolized from the $17^{\text {th }}$ March onwards, all the Nitrate of Soda produced in the Province of Tarapacá they paying the producers $S / 2,40$ for each quintal placed alongside the vessel's launch.

Tuesday, $28^{\text {th }}$ of January. Dreyfus and his young wife left for France via Panamá. They were accompanied on board by numerous friends, amongst whom Dreyfus' partner Dionisio Derteano, who availed himself of this as an excuse for not presenting to the Directors of the Eten Railway Coy. the plan which he had promised in the meeting of the $21^{\text {st }}$ inst.

The shareholders of the Insurance Company Lima had their annual meeting in the Exchange Saloon; few were present. The annual report was read by Lembcke the President, and three Directors were chosen, Moyna, hitherto Director having left Lima, and Henry \& Zuloaga having lost their Directorship, their names having been drawn; Henry was reelected - besides him M. G. Chavez and Aurelio Denegri. In the evening at 8 O'clock the shareholders of the Banco de Lima met, to elect three Directors; the meeting was not so well attended as last time, and in less than an hour Nicolas Rodrigo, Puente, and Manuel Mendoza y Boza were elected almost unanimously.

Saturday, ${ }^{\text {st }}$ of February. The Directory of the Banco de Lima asse [...] it was the custom to do on the $1^{\text {st }}$ of each month. Gust [...] [405] was chosen VicePresident in lieu of Juan de Dios Calderon.

Sagastabeytia, Correa, and I discussed for more than an hour various measures, the adoption of which we considered necessary for the Pasco Railway Coy.; articles such as lard-oil, copper in sheets, copper-tubes, oakum, and various pieces required for the locomotives, which were about being cast in the Callao foundry, would be sent up in due course.

My wife and daughter had a long visit from Manuel Costas, first VicePresident of the Republic, who told them in the course of conversation that those persons who were of opinion that the differences which had lately arisen between the Government and the house of Dreyfus, were about being amicably settled, laboured under a gross mistake; on the contrary, these differences were of so serious a nature that had he been in the place of Manuel Pardo he would not have allowed Augustus Dreyfus, the head of the firm, to leave the country.

The North steamer brought no European letters; the steamer from Southampton not having arrived at Colon when that for Callao left Panamá. 
Via the United States we received advice of the death of the ex-Emperor Napoleon III, which had taken place in Chisselharst on the $9^{\text {th }}$ January.

Sunday, $9^{\text {th }}$ of February 1873. I made it a rule to ascend San Crístoval every Sunday morning. I started a little past six, was back by 8.30, again lay down for an hour, and was ready for breakfast at 10. Afterwards I took the train for Chorrillos, bathed, returned by the 4 O'clock train, and dined at home. This Sunday I went out at 12 O'clock. After the bath I made several calls in Chorrillos, none of which was much to my liking; first, I looked in at Rafael Velarde's who had rented the rancho, or rather house of Lazurtegui, which has a very pretty view upon the sea, for four months at $\$ 250$ monthly. At Henry's, who having sold some time back his own rancho to Dreyfus, now lived in another recently built by Swayne, I found nobody at home. José Maria Costas played at cards with two of his friends, and, of course, I did not remain long. His was the rancho formerly Went's, then Stubb's, the very last in that direction, for which he, Costas, had paid £20oo. My fourth visit was to Mrs. Guise, where I found them likewise playing rocambor - she, her daughter Mercedes, the widow of John Dartnell, and Dr. Manuel Morales their very intimate friend. Dr. Ribeyro and family were by themselves; not so Doña Mercedes Riva Agüero, who, surrounded by a number of gentlemen, was holding forth on the subject of the enormous work which her husband, Minister for Foreign [...] especially he being, as everybody knew, the intimate [_] [406] of the President. Riva Agüero himself was absent, having rode out to his chacras, to which it is true, he could now only attend on Sundays and holidays. They occupied the first story of the very handsome house which of late Francis Bryce had bought from the widow of Losternau, for somewhat above $\$ 50,000$. This first story had for some time been occupied by Manuel Pardo, who had lately removed to another house in the outskirts of the village, the property of the Italian Tenderini. My last call was the most agreeable, upon Doña Juana Tirado, wife of General Pezet.

Saturday, $15^{\text {th }}$ of February. In the course of these last two weeks I had been present at several meetings, none of which was of much importance. In that of the Directory of the Insurance Company Lima, Garland, proposed by Henry and myself, was unanimously chosen Director in lieu of Aurelio Dinegri, who had declined the nomination. In the Lima Water Company nothing was done, the sufficient number of shareholders not being present. In the Banco del Perú I believe seven new Directors were chosen, all such as were proposed by the Gerentes. My name was not upon their list, nevertheless, to my surprise, I had several independent votes. In the Banco Hipotecario the lawyer Garcia Calderon, Gerente since Riva Agüero's nomination to the Ministry for Foreign Affairs, presided the meeting of shareholders; a dividend of $17 \%$ was declared for last year, and a cuota of $5 \%$ was asked for. The three new Directors chosen were: Agustin Escudero, Carlos Delgado y Moreno, and José Maria Sancho Davila. 
The prospects of the Pasco Railway Company did not improve. Ascarraga had returned from the Cerro, and would take the correspondence off my hands. Bohorquez very seldom attended at our meetings, which we held every Saturday, at present in my office since our clerk Enrique Carrera had been obliged to abandon his apartments in the public library building. The house of Dreyfus did not draw on Europe and the want of bills was severely felt by all such as had to remit funds home. The rupture between the same and the Government had as yet not been soldered up. The Executive had been authorized by the Congress to raise a loan in Europe to the amount of 36,800 , ooo pounds sterling, annual interest $5 \%$, and annual redemption $2 \%$. The President had put his cúmplase to this law. All the previous Peruvian loans in Europe were to be refunded in this new one; and as far as I understood the quarrel between Dreyfus and the Government had arisen in the following manner. Pardo ins [...] [407] a certain figure, some said $771 / 2 \%$, below which Dreyfus was not to sell the new bonds, whilst this latter demanded that "Carte blanche" should be given him. This account did not appear to me quite correct, for Pardo knew quite as well as everybody else that if you want to sell you must take the price which is offered, and that to stand out for unattainable rates is tantamount to a declaration of unwillingness to sell. On Tuesday last a sad piece of news reached us from the Interior; Colonels Herencio Zevallos, and Domingo Gamio, on the way to their destination, the banks of the Amazon, had reached an estate called Mercedes situated in the department of Huánuco; here, if the official dispatch of Manuel Cornejo who commanded their escort, could be believed, in the night from the $1^{\text {st }}$ to the $2^{\text {nd }}$ February about two in the morning, whilst he was lying asleep on a mattress, the two said Colonels, who someway or other had possessed themselves of arms, fired at him, without however hitting him; he quickly rose, and seeing that the two Colonels were on the point of effecting their escape, ordered the gens d'armes who formed the escort to fire - so they did, and in an instant or so Zevallos and Gamio lay dead on the spot. This news, of course, caused great indignation, and the enemies of the present administration availed themselves of the same to throw grave suspicions not only upon the Ministers, but even upon the President. On Wednesday the attack commenced in the Chamber of Deputies. Ignacio Tavara and Federico Luna were the first to speak; the lawyer Luciano B. Cisneros followed in their truck, and moved a vote of censure against the Ministry. His speech was much applauded, and at 6 O'clock the chamber rose without having come to a decision. On Thursday the scene had changed; the friends of Pardo had taken their measures. Cisneros was hissed, insulted, and on his way home even threatened, so than on the following day he directed a long, and in my opinion ridiculous, letter to the chamber, asking security for his life, which, he said, was exposed. The 
Chamber addressed itself to the Minister of the Interior, Rosas, who ordered the Prefect to place at Cisneros' disposal as many gens d'armes as he might ask for. In one of the opposition papers a telegraphic dispatch from Daniel Ruso, the President of the Fiscal commission which was investigating the accounts of the firm of Thompson Bonar \& Co., late consignees of guano in England, was published and then copied in the other papers. This dispatch said that the two new Commissioners, Dr. Mesones and José Maria Rey de Castro had stopped the proceedings against Thompson Bonar \& Co., dismissed the lawyer hitherto employed, and engaged another, Mr. Southgate [...] to Ruso had hitherto defended the Canevaros implicated in [...] [408] accusation against J. B. \& Co. This news had also a bad effect, but since the arrival of the last mail, the letters from Mesones and Rey de Castro, and other documents published in the papers, showed that they had suspended, not stopped, the proceedings, because they and Ruso could not agree on a single point, and according to the instructions given to the commission, the three members were not allowed to act without being unanimous. The Peruvian Minister Pedro Galvez had taken the same view as they, and as regards the lawyer they said that Mr. Scarborough hitherto employed by Ruso, had failed for somewhat more than $£ 160,000$ and that for this reason they had taken the business out of his hands; they did not say whom they had engaged in his stead. To a letter directed by them to the firm of Dreyfus, they received the answer that Dreyfus had already paid to the Fiscal commission not less than £20o,ooo say £19,ooo, and odd for salaries, and $€ 180,000$ and odd, for expenses.

Sunday, $16^{\text {th }}$ of February 1873. I went to Chorrillos, bathed, looked in at our rancho occupied by Doña Manuela, widow of Salmon, and when returning in the train had for neighbour Agustin Escudero, who gave me much information on various subjects. The Government, and the firm of Dreyfus, he told me, were agreed as to the price to be asked in Europe for the bonds of the new loan. The difference between the two parties arose from the following: Pardo insisted that if the price asked for could not be obtained, then in future the sale should be effected by the Government's agents, whilst the firm would not allow the sale to go out of their hands. In the second place, Escudero informed me that the Minister of Finance La Jara had asked and obtained leave of absence for a fortnight, and in the meanwhile Dr. Rosas, Minister for the Interior, would also take charge of the Finance Department, and finally that a commission named in the Chamber of Deputies to report on the notion for the censure of the Ministers, had given their opinion in the negative. One of the members of the commission was the lawyer Perez, who in August 1869 defended in the Supreme Court the rights of the so-called "Nacionales" against Luciano Benjamin Cisneros, Dreyfus' lawyer - see page 111. He and my lawyer Fernando 
Palacios had been candidates for the Deputation of Chincha; both had been elected, each by his party, but, as might have been expected, Perez, a partizan of Pardo, was qualified in the Congress.

From Europe we learned that the Belgian Princess Char [...] [409] Maximilian, late Emperor of Mexico, had died. [...] She had been insane over since her husband's death. Also the famous novelist Sir Edward Bulwer Lytton had departed this life. In Lima the small-pox was committing great ravages, especially among the lower classes. Within the last fortnight had died here: Cristoval Conroy, of small-pox and drunkenness - he was one of the sons of Thomas Conroy of Callao, and married to one of the daugthers of the late General Raygada; secondly, Manuela Molina, Mrs. McCall, of a chronic disease of long standing; and thirdly, the mother of Doña Carmen Lopez Aldana 95 years of age, who had lived to become a great-great-grandmother.

Tuesday, $18^{\text {th }}$ of February 1873 . The Directors of the Banco de Lima were cited to meet at the usual hour of 3 p.m. The object was said to be urgent, thus all except Muro and Zuloaga, both unwell, were present. Lembcke informed us that on the preceding evening the gerentes of the five banks established in Lima, had been called by the President to the palace, where he represented to them that as he could not come to terms with the firm of Dreyfus about the disposal of the loan in Europe for various reasons which he explained, he saw himself in the necessity of applying to the banks for a loan of 6,ooo,ooo Soles, which sum would be exclusively laid out in payment to Meiggs, so that the work on the railroads might not be stopped. The gerentes, of course, replied that they could not do anything without being authorized by their respective Directories. We empowered them to take for our bank a share in this loan to the amount of 600,000 Soles more or less, payable in monthly instalments.

Wednesday, $19^{\text {th }}$. I went to the bank to enquire what had been the result, and learned that nothing had been done, because though the banko del Perú, and La Providencia, besides that of Lima, had declared their willingness to advance some money to the Government; the Gerentes of the Banco Nacional, and of the London Bank of Mexico \& South America had refused to do so.

Thursday, $20^{\text {th }}$ of February. Our Directory again met at 2 O'clock without my being present, for though the letter which cited me was delivered in my house in good time, I did not receive it till 3.30. Heudebert had been in the chair; besides myself, Manuel Mendoza, Zuloaga and Bernales had been wanting. The other nine, sufficient to form the quorum, gave ample authorization [...] who for a second time had been applied to by Pardo. [410]

Friday, $27^{\text {st }}$ of February. Zaracondegui told me that on the previous evening the three gerentes of the three banks, Escobar, Lembcke, and Moscoso Melgar had agreed with the President to lend him 6,00o,0oo Soles in six monthly 
instalments of 1,000,00o Soles each. The Banco del Peru took three millions and odd, the Banco de Lima two millions, La Providencia, the balance: $21 / 2 \%$ commission Pardo allowed to the Banks upon this amount, and bound himself to return the same in bills on England at the exchange of $451 / 2 \mathrm{~d}$.

Saturday, $22^{\text {nd }}$ of February. In last night's Nacional appeared a letter from the Gerentes of the Banco Nacional, and another from those of the London Bank of Mexico \& South America, in which they said that they had been quite willing to lend money to the Government, but that in the later transaction they had been excluded by the other banks. Bills all at once became abundant; not long ago some one paid to Dreyfus for drafts at 180 days sight, 42d; to-day Gibbs drew at 43 1/2 $90 \mathrm{~d} /$ st., and Dreyfus readily at 45d.

From the Comercio of the $5^{\text {th }}$ inst. I took the following: - of the war indemnity of 5,000,000,00o francs due by France to Germany, hitherto 2,868,00o,ooo had been paid, viz.:

in gold
in five franc silver pieces
in German coins
in Drafts on Berlin
in Drafts on Frankfort
in Drafts on Hamburg
in Drafts on Amsterdam
in Drafts on London
in Drafts on Belgium
in French bank-notes
in Part of railways in Eastern France,
$\quad$ now Western Germany

whilst according to the "Comercio"

the total paid comes to fcs 109,000,000

fcs 73,000,000

fcs $88,000,000$

fcs $743,000,000$

fcs $117,000,000$

fcs $265,000,000$

fcs $250,000,000$

fcs $265,000,000$

fcs $147,000,000$

fcs $125,000,000$

fcs $325,000,000$

fcs $2,507,000,000$

2,868,000,000

which proves that somewhere there must be a mistake in the figures.

From Sunday, $23^{\text {rd }}$ to Tuesday, $25^{\text {th }}$ of February. Carnival.

On Sunday, as it was my habit, I was on the top of San [...] [411] at an early hour. After my return home I rested for a short time, took a light breakfast, and by the 12 O'clock train went to Chorrillos, where I bathed, and paid a few visits. At Dr. José Gregorio Paz-Soldan's I met Frederic Bergmann from whom I learned that the construction of the Muelle Dársena, or Dock, in Callao, was at present carried on on account of La Société Générale of Paris, the firm of Premsel of the same place, John Henry Schröder \& Co. of London, and the Bergmanns of Lima; each party being interested for one fourth. Derteano of 
Dreyfus' house held the power for La Societé, Ford and Scheel for the two other firms, and Bergmann, as he said, presided, when the four who formed the Directory held their sittings. In my opinion it was utterly impossible that the Bergmanns could contribute the fourth of the outlay, because everybody knew that they had not got the means, and I was almost certain that this fourth was in reality Dreyfus. It will be remembered that during Balta's administration, notwithstanding the most violent opposition, the firm of Templeman \& Bergmann obtained the concession to build this dock, they after its conclusion receiving as a remuneration for their disburse, the dock-dues for a long series of years, I believe 99 - and this, it was calculated, would turn out a splendid business. Many thousands of Soles were spent by the Bergmanns in bribes to obtain the contract, but having once obtained it they had not the funds required for carrying it out, and then, it was generally believed, they had transferred it to the firm of Dreyfus, who again had made their arrangements with the above named houses.

Monday I spent by invitation with the family Masias in Ancon. The terminus is on the other side of the bridge, whence I started at about 9 O'clock the fare being on feast-days fifteen rials first-class, on working days double, and in about two hours I alighted in Ancon. Of the road I gave a detailed description on the $4^{\text {th }}$ September 1870 , since the place had somewhat increased in size and improved in appearance. The streets were wide, and ran parallel to each other; the houses were built of wood, many of them with corredors in front. The row nearest to the sea was by far the best; here stood the hotel in which Mr. Masias and family had their comfortable lodgings. The largest and bestlooking houses were those of Scheel and Derteano; the former was offering his for sale for the half of what it had cost him (22,00o Soles). The streets were not paved, and here and there planks and canes were placed over the deep-lying sand. Masias was extremely friendly; he accompanied me to the bathing-huts [...] like those in Chorrillos and I then took my bath. I walked stra[_] [412] into the sea, which deepens very gradually; there were no violent waves, nor any surf, and the ground was smooth hard sand, nothing could be more agreeable. Four vessels were lying at anchor in the ample and glassy bay; two were loading sugar, one was landing machinery for Graña's sugar estate. On my return to the hotel they gave me a very nice breakfast, which being dispatched I hardly knew how to while away the time; however, it being carnival-day, several young men came in, the brothers Bresani, Luis Roca y Boloña and one or two others; they commenced playing, that is to say they on the one side, Mrs. Masias, her sister Transito, her young daughter, and another lady on the other, wetted, and actually drenched each other with water in an unmerciful manner till the 
ladies were dripping and had to change their dresses, and the rooms had to be swept out. As regards myself I was a mere spectator and escaped with being wetted with a little scented water. I then called upon the family of Don Manuel Basagoytia who had here a house of his own, also upon Don Manuel Rodriguez de la Rosa y O'Phelan, and took a walk through the place, wading ankle-deep in the heavy sand, and over some of the ashy hills which surround it. By the 5 O'clock train I returned to Lima where I arrived at 6.30 and dined with the Garlands and my wife.

Ancon had as yet no fresh water, though wells had been dug about three varas deep, which gave a scanty supply, a little brackish. All kinds of provisions brought thither by train, as well as the water, could be obtained in the market place; there were butchers, and the beef was good; fish was sometimes very cheap, and fruits brought from Chancay not so dear as in Lima. According to the original Escritura Publica signed by the shareholders of this railway, it should have been prolonged as far as Huacho, but owing to an erroneous estimate of the probable cost, and particulary to gross-mismanagement, the entire paid-up capital was already spent before the line reached Chancay, halfway between Lima \& Huacho. Then, to the great relief of the shareholders, as I have already said at the time, the Govt. under Balta's Administration stepped in, took the railway on its own account and paid for each share the same amount in bonds of the Internal debt; mine I had the good luck to sell at $75 \%$, escaping thus with a loss of $25 \%$. The distance from Ancon to the river Pasamayo is not great, but the line runs over an unsafe and dangerous ground, as I have explained page 191, and accidents were of no unfrequent occurrence, though but seldom connected with loss of life or limbs. The line after [_]cending from the heights [...] [413] over a solid bridge, and terminates at Chancay.

On Tuesday I remained quietly at home expecting Mr. Dupont, but as he did not come the day would have passed very heavily if Ricardo Garland had not read to me for several hours a history of Germany written by Kohlrausch.

Wednesday, $26^{\text {th }}$ of February 1873. In the morning of this day a pretty numerous cortege accompanied the mortal remains of poor Mrs. Gallagher to their last resting-place in the Bellavista protestant cemetery. This good lady had not been able again to lift up her head since the foul murder of her husband, the doctor. Shortly after his death she had gone to England; there the climate, she said, did not agree with her; she returned to Lima, where, upon my calling on her I found her in a very delicate state of health, and now she followed her husband to the grave. Amongst the mourners were Messrs. Henry and Böhl, with both of whom I exchanged a few words; the latter told me of the death of his mother, which had occurred in Hamburg, not long ago. 
She, and the entire family of Böhl had been particularly attentive towards my wife and myself when in 1854 and 1855 we made a stay of several months in that Hanseatic town.

In the course of the forenoon I learned from different sources that during the three carnival days the President, jointly with Dr. Rosas, Minister for the Interior, and provisionally for Finances, had been negotiating with the partners of Dreyfus' firm on the subject of the late loan, and that there was every probability of their coming to a satisfactory understanding. These rumours gained strength from hour to hour until the morning of

Friday, $28^{\text {th }}$ of February when it became known that on the previous night at the very last moment, when the signatures were about been affixed, a difference had arisen which was insurmountable. The friends of Government said that Derteano had inserted a clause which previously discussed and rejected he again tried to introduce under a different form. Dreyfus' people, of course, told a different tale.

Saturday, $7^{\text {st }}$ of March. Dreyfus paid to the shareholders in his guano contract, and consequently also to Juan and myself on our joint 100,000 $\mathrm{S}$. last year's dividend at the rate of $5225 / 1000$ ths $\%$. With Ascarraga and Correa I had the usual Pasco Mineral Railway meeting, but nothing of importance was transacted; Bao's remittance for the month of January amounted to no more than S/2155.31c. Sagastabeytia was absent in Chorrillos, and [...] never attended. We had again to look out for an [...] [414] driver, for Morgan whom we had engaged and sent up two months back, had turned out unfit for the situation, and come back to Lima.

Sunday, $2^{\text {nd }}$ of March. The South steamer brought news that in the afternoon of Carnival Sunday some of the lower classes in Arequipa, numbering at the utmost 40o, had committed some disorders, without knowing exactly what they wanted; they called themselves the friends of the deceased Gamio, and erected a barricade on the right side of the river, at the end of the bridge. The police on foot and on horseback were sent against them; they crossed the river over the railway bridge a little further down, took the mutineers in flank, where they were not protected, and in less than half an hour these latter were dispersed; they fled, and tranquillity, which had hardly been disturbed, was completely restored.

Monday, $3^{\text {rd }}$ of March. The Electric wire brought us the news of the abdication of King Amadeo of Spain on the $12^{\text {th }}$ February, which had been admitted by the Cortes, who had thereupon resolved that Spain was to be a Republic. The new Minister of Foreign Affairs Emilio Castelar, some years back the correspondent of the Lima newspaper "El Nacional", immediately made known to the various European powers this change in the government of Spain. The ex-King was 
honorably exorted as fas as the frontier of Portugal whence he continued his journey to Lisbon, there to embark for his native country. The daily papers informed their readers that the rioters in Arequipa on Carnival Sunday had been stirred up by a few ringleaders who had distributed small sums of money amongst them, and this money they had received from Gibbs' firm, to whom a considerable amount had been remitted from Chile with orders to hand it to certain individuals pointed out to them. "El Nacional" added that $S / 15,000$ still in Gibbs' hands for the same purpose had been embargoed by the Arequipa authorities.

At Mrs. Gallagher's funeral Mr. Henry said to me: "do you know why the rising in Arequipa on Carnival Sunday had no serious consequences?" On my answering in the negative he replied: "because those who were ordered to distribute the money kept the greater part for themselves". These few words proved that the statements in the papers were not without foundation.

Johannes Limpricht from whom I had a long letter of $28^{\text {th }}$ January wrote me that William Müller, late partner of Ph. Ott \& Co. of Lima, had d [...] consumption leaving a wife and four children in [...] [415] which he believed to be far from affluent. When he left the house and his account was liquidated, a great many bad, irrecoverable debts were found, which accounted for the poor state of his fortune. Müller was an excellent man for the counting-house; such he proved himself to be when clerk at Lembcke's, and afterwards when in the employ of H. Witt \& Schutte, but already when with us I found him to be no good salesman, for he was too ready and too easy in giving credit to purchasers.

Hardly had the steamer of the $28^{\text {th }}$ February left when the negotiations between the firm of Dreyfus and the Government were again taken up, and brought to a satisfactory conclussion on

Wednesday, $5^{\text {th }}$ of March. The details were not yet known, but I learned from Nicolas Rodrigo that, according to Riva Agüero, Pardo had obtained everything he wanted, and given way in nothing. It was further said that one of Dreyfus' three partners had refused to sign the contract. Scheel had left for Europe. As yet there was no money in the treasury, and of the many people, especially in Lima, who lived exclusively upon the Government, such as the employés in the public offices, all the members of the judicial body, the widows who received pensions, military men not in active service etc., none had been paid for the last month. I was once more Director de Turno in the Banco de Lima in lieu of Sagastabeytia, who had begged me to act in his stead, whilst he resided in Chorrillos; we were doing very little and refused many documents offered for discount, for the very simple reason that we were short of funds. Even the Lima Water Company was hard up; the house of Bates Stokes \& Co. of Liverpool, who had for many years back been their correspondents and 
supplied them with iron pipes and everything else they required, had suddenly asked for a considerable remittance on account of the amount due to them by the Company. Accordingly, Rey, the Manager, called together the Directors. On

Thursday, $6^{\text {th }}$ only Rodrigo, young Prevost, and I met, and we came to no decision because José V. Oyague, the most considerable shareholder, was not present. On

Saturday, $8^{\text {th }}$ I went again and found Rey, Rodrigo, Oyague and José Basagoytia in earnest consultation. Oyague had presented a written project, which after some sound discussion was admitted, with a few modi[_] and which on the next general meeting of shareholders was to [...] [416] submitted to them. It was in substance the following: the present capital of the Water Company was $\$ 1,000,000$ in two thousand shares of $\$ 500$ each. Now the capital had to be increased to $\$ 1,500,000$ and consequently 1000 shares of $\$ 500$ each would be issued; of these, one half, say 500 shares, would be distributed gratis among the shareholders in proportion to the quantity of shares which each held; and these shares were given gratis, because much additional work had already been concluded, and the capital in fact been increased, but in order to procure the money which was wanted to make a remittance to England, and for other purposes, the shareholder who received shares gratis, had necessarily to take an equal quantity of these shares, and pay for them. Applying this project to myself, I who held 44 shares of 500 dollars each or $\$ 22,000$ would receive 22 shares more, say $\$ 11,000$ - $\$ 5500$ gratis, and $\$ 5500$ to be paid for in cash. We hoped that all would enter into this combination but should some not be inclined to do so then there was not the slightest doubt but that Oyague and other Capitalists would take on their account all such shares as might have remained indisposed of.

In the Pasco Railway Company we had been mostly occupied with endeavouring to obtain an engine-driver, and we were likely to come to terms with a certain Crimmins, a North American, recommended to us by Mr. Charles Williams, formerly owner of the English college, now superintendent of the Lima-Chancay railway.

Sunday, $9^{\text {th }}$ of March. The ascent of San Cristoval, an hour's rest, my breakfast, my dictation to Mr. Dupont, the drive per train to Chorrillos, a bath, this time in an agitated sea, and finally two calls, one upon Mrs. Barreda, the other upon the widow of Mr. Stanhope Prevost, took up the whole day from 6.30 a.m. till 5 p.m. at which hour I was in the rancho of Juan Bazo, who had invited me to dine with him. At 6 we sat down: Don Juan, his wife Irene, his brother Antonio, Colonel Felipe Coz, Oficial Mayor in the War Ministry, a young Pardo-Zela, employed in the same office, son of the late General of the 
same name, Alejandro Garland, and two or three children. Everything was very nice; I merely felt the want of boiled potatoes, which to me are indispensable at dinner. Moreover, we had only Bordeaux wine which I had to mix with water, a beverage I dislike. Hardly had we risen when it was time for me to return by the 8.15 train.

Saturday, $15^{\text {th }}$ of March. In the course of this week La Jara [...] [417] Minister of Finances, had presented a project, of course Pardo's own work, to the Congress, the purport of which was to consolidate in one internal debt all the various sums due by the Government, such as the floating debt amounting to at least six million Soles, and arising from money borrowed by the previous administration before the $2^{\text {nd }}$ August 1872 , and not paid when Pardo took the reins of Government. For the total of these debts it was proposed to issue bonds with an increase of $331 / 3 \%$, that is to say, for 75 Soles owing by the Government, a bond would be given for 100, paying 6\% annual interest. The Vales de la Nueva Consolidacion, the Lima-Chancay Railway bonds, and others, would merely be exchanged for the new documents. Seventy thousand Soles to be paid by the Callao Custom House would be employed monthly for the redemption of this new debt, at par, and by lot. The small amount of the old Deuda Consolidada, hitherto unpaid, would be paid to the respective holders in cash and at par. When this project was read to me I observed to my great astonishment that of the Pasco Railway Bonds, 400,00o Soles, of which 205,000 in the hands of the Banco Hipotecario, 130,000 in the hands of Felipe Barreda y Osma, and 65,000 in my own, no mention whatever had been made. I therefore went this day to Riva Agüero in his office, and called his attention to this omission. His answer was vague though not unsatisfactory. He said that everything which Pardo intended to do could not be made public, that I should not forget that he, Riva Agüero, was much compromised in the Cerro de Pasco business, that Pardo himself was interested for S/80,00o, that the two, together with Felipe Barreda, who, for his son Felipe Barreda y Osma, was interested in the railway to a very large extent, had had more than one conference on the subject, and that therefore I might be certain that something or other would be done for the benefit of us all, and I believed that this would really be the case, if the present administration were not overturned, of which, fortunately, there was not much probability at the time.

The Directors of the Insurance Company "Lima" met, and two questions of little importance were treated on. The clerk who assisted Guiroy had asked for an increase of his salary from 100 to S/125 monthly, which was denied him. Gil, Westphal, and Garland voted for the increase - Chavez, Henry, Lembcke and I, against it. The other question was whether a transfer of 10 shares 
made by the firm of Duncan Fox \& Co., successors of Fox Sawyers \& Co., to Charles [...] lock lately married to a lady of the family of the Delgados should $[\ldots][418]$ admitted or not. Lembcke voted in the negative, the other six in the affirmative.

The shareholders of the Lima Water Company assembled, when the plan for raising the capital from one, to one and a half million, was submitted to them. Since I gave the details of it on the $8^{\text {th }}$ inst., it had undergone a considerable alteration, the work of a private conference between Oyague, Sevilla, and Basagoytia. Now it was proposed that of the 1000 Shares of $\$ 500$ each, even those shareholders who were not inclined to disburse any money should receive a considerable proportion, say $20 \%$ gratis, whilst those who were ready to disburse $25 \%$ in cash were not to receive above $25 \%$ gratis. I was decidedly opposed to this change because in my opinion those who disbursed nothing were too much favored. I was over-ruled, and the project passed as it now stood. When Basagoytia and I were by ourselves he confessed to me that I was certainly in the right, but that he had voted against me, because it had been for his private interest to do so.

The scarcity of money was greater than I had ever experienced in Lima. The Banco de Lima with the exception of S/40o,ooo an acceptance of Dreyfus discounted to Meiggs, and some unavoidable prolongations, did little business with the public in general, and what it discounted was at short sights. Bryce Grace \& Co. from whom I held a pagaré for $\mathrm{S} / 21,000$ due $21^{\text {st }}$ inst., had written me a note requesting me to prolong it, which I could not do, for I had promised the money to Garland who had given a Vale to the Banco del Perú, in part payment of bills remitted by him to C. W. Schutte at $441 / 2 d$ the sol. From Miceno Espantoso I received a note beginning thus ¿Querido patron, hay plata? I had to answer in the negative. Even John Gildemeister came with the same object; he required money he said, not for his own business, which I verily believed, but for the hacendado in the North, Mr. Albrecht, who, he assured me, was incessantly in want of money. He further told me that the machinery for Albrecht's sugar-estate, just received from Europe through his medium, cost not less than £1oo,ooo; also, that Montero's railway in Iquique did not suffice to transport all the Nitrate from the Interior to the Coast. He, Gildemeister, had 120,000 quintals ready in the interior which he could not bring down, and thus he had to pay lay-days to the vessels which were waiting for their cargo.

Monday, $17^{\text {th }}$ and Tuesday, $18^{\text {th }}$ of March. The Pasco Railway Companny took up $\mathrm{m}[\ldots]$ of my time. The muleteer Valderrama refused to take the [...] [419] Crimmins with him; Wyman and Harrison could render me no assistance, and 
at last I learned that in a tambo in the street of Malambo a muleteer had put up who might perhaps accomodate me. Thither I went in the heat of the day. The muleteer was a certain Bao, uncle of our agent, who agreed to take Crimmins with him. Now I had to fetch this man and his luggage and to go with him in a coach to Malambo, where I delivered him to said Bao. The remittance from the Cerro for the month of February came to less than S/2000 with which sum, through the medium of the broker O'Phelan, I bought two Cedulas at 97 1/2. We all considered this a cheap purchase, which we could only attribute to the scarcity of money, which every day became more perceptible in the market.

Wednesday, $19^{\text {th }}$ of March 1873. In Chorrillos from 2 till 4 I got through with as many as eight calls. Riva Agüero was very communicative and agreeable; the reverse I had to say of Dr. Manuel Ortiz de Zevallos with whom I remained but a few minutes in the absence of his agreeable wife and daughter. Dr. J. M. Perez of the Superior Court, Rafael Velarde's brother-in-law, was the only one who invited me to stay for dinner, which I thankfully declined. He had of late built in Chorrillos a pretty house of his own, where it was his intention to reside winter and summer.

Thursday, $20^{\text {th }}$ of March. After a long interval the Gerentes of La Constructora C. Saco and R. Echenique convened the Directory. Though there was no quorum. Zaracondegui, Emilio Solar, J. P. Escobar, the two Gerentes and I talked over several weighty matters. Amongst others were solved that the books should be balanced, not on the $31^{\text {st }}$ December 1872 , but at the end of March, in order to be able to include in the same the result of a favourable arrangement made with Meiggs regarding the expropriation of a property possessed by the Constructora near the Gas manufactory, and now required by Meiggs for the boulevard which he was about constructing all round Lima.

Friday, $27^{\text {st }}$ of March. Bryce Grace \& Co.'s pagaré which I held, fell due this day, but was not paid. In the Banco de Lima the only thing we did was to prolong a pagaré signed by the Hacendado Geronimo Sanchez, in favor of Juan Ugarte, and endorsed in blank by the latter.

From Europe we learned that Amadeo, ex-King of Spain had not yet left Lisbon, and that English men-of-war were placed at his disposal to convey [...] Italy. In Spain the Carlists had risen against the Repu[_] [420] Government; troops had been sent against them. The two branches of the Bourbons, the elder represented by the ex-queen Isabel, the younger by the Princess Luisa, her sister, married to the Duke de Montpensier, had, it was said, united for the purpose of overturning the Republic. My son Juan wrote from Naples where he seemed to be very well pleased; he took a great interest in the excavations made at Pompeii. On the $14^{\text {th }}$ February had died in Placencia, Northern Italy, 
Don Francisco Garmendia, second Vice-President of Perú; he was born in 1820 and married to a Miss Nadal, sister of the young Nadal who in 1856 was our fellow-passenger from Europe. In Lima we had the death of General Morote, a very insignificant man; some weeks back occured that of General Vigil, an old champion of the Independence.

About a fortnight back a daring and ingenious robbery was committed in the second shop in the Calle de Mantas on the left hand side going from the large square, owned by an honest Swiss Jeweler. The burglars were supposed to have entered the high and roomy sewer which runs under the streets, at Monseratte, where it was open, and on reaching the spot opposite the shop to have dug upwards as far as the shop itself, where they had come to light, filled their pockets with everything which was lying about, and then returned the same way they had come. Fortunately the iron-chest containing the most valuable articles they had not been able to open.

Sunday, $23^{\text {rd }}$ of March. Up San Cristoval I climbed, but felt more fatigued than I had done a year ago.

Tuesday, $25^{\text {th }}$. La Anunciacion. I went per train to Chorrillos but instead of calling upon any of my acquaintances preferred taking a good long walk, which I did, without feeling at all tired, a proof that my stamina were not yet giving way. I walked from Chorrillos to the Barranco along the high coast, under the rays of an unclouded sun. When in the Barranco I descended to the beach, where I convinced myself that bathing there must be very uncomfortable, returned to Chorrillos along the rails, and back to Lima per train.

Friday, $28^{\text {th }}$ and Saturday, $29^{\text {th }}$ of March. On Friday died here in Lima Doña Rosa Rabago, aunt of Mrs. Riva Agüero and her two sisters, a lady who in her youth had a great name for her good looks, and still more so for her extreme liveliness and for the many freaks which she, relying upon her station in society did not hesitate to play off [...] [421] whom she looked upon as her own and rightful laughing-stock. The Government had resolved that the handsome furniture with which the apartments in the Exhibition Palace were fitted up, should be brought to the hammer, and therefore both these days I drove out thither with my wife and daughter that they might point out to me those things which they liked best. My wife took a great fancy to a set of furniture consisting of 2 sofas, 6 arm-chairs, and 8 common chairs, gilt, and with red damask covers. On Saturday after our return I had a conference in my office with Ascarraga, on the subject of the Pasco Railway. He was of opinion that the railway in the Cerro should be prolonged as far as Bao had proposed some time back; and that we should settle our accounts with Wyman \& Harrison, to which I replied that I was quite as anxious as he to bring about these two disiderata, but that 
the former was impossible because we had not the money, and that the latter was equally impracticable at the present moment because J. M. Echenique was absent, and before Wyman had settled with him he was unable to come to an arrangement with us.

Sunday, $30^{\text {th }}$ of March 1873 . The furniture in the Exhibition Palace was sold by auction, and as my wife wished me to purchase the set above spoken of I bade for it, but the auctioneer himself, Igarza, overbade every bid of mine till at last I gave up the competition when he had offered S/1115. Afterwards, I learned from him that Westphal of Huth's was the real purchaser.

My wife's half sister Ciriaca Sierra had died in Arequipa, more or less at the age of 68; as far as I recollected, I had never seen her.

Monday, $33^{\text {st }}$ of March. The political news which the telegraph brought us from Payta was the resignation of the Gladstone Ministry in England and a fearful gathering of the Carlists in Spain. When Gladstone had given in his resignation Queen Victoria called for the purpose of forming a new cabinet, firstly, Mr. D'Israeli, and secondly the Earl of Derby, but as both declined, it was by no means unlikely that Gladstone and his friends would resume their posts.

Several months back it will be remembered the Juez de Derecho with a great accompaniment came to my house, and ordered that the gutter in my garden spoken of usque ad nauseam should not be touched by me because a suit was pending about the same between the Goyeneches \& the Municipality. Instead of the former, Leyva had carried it on and though the sentences of the Juez de $1^{a}$ Instancia and the Superior Court had been in his favor, the Supreme Court resolved that the gutter should be shut up, [...] at last got rid of this annoyance. [422]

Tuesday, $7^{\text {st }}$ of April. The Directors of the Banco de Lima assembled as was their custom, when the gerentes informed us that the funds of the bank had gradually been reduced to such a point that they were unable to do any extensive business, and that the discounting was limited to such documents as had at the utmost one month to run.

The Banco del Perú also did very little, and as Escobar told me it was his intention to raise the rate to $11 / 4 \%$, which example the Gerentes of the Banco de Lima were determined not to follow. In order to prevent the exportation of coined gold, which of late had been sent out of the country in large quantities owing to the great scarcity of bills, and the consequent high exchange, the banks had made known in the daily papers that they received gold coins in payment and changed them for notes or silver at the following rates: Peruvian twenty-sol pieces at $\mathrm{S} / 21.80$, American twenty dollar pieces at $\mathrm{S} / 22.60$, English sovereigns S/5.50, Chilian Condors S/10.40. 
Wednesday, $2^{\text {nd }}$ of April. I had the satisfaction to be able to tell my wife that I had obtained not only the set of furniture above spoken of, which Westphal had ceded to me, but also the red damask curtains corresponding to the furniture, which the upholsterer Stahl had given up to me at cost price. Both the one and the other were brought to my house; their cost was $\mathrm{S} / 205^{\circ}$ odd Soles besides S/6o which Stahl charged me for the carriage and the putting up of the curtains. (At this present day, $20^{\text {th }}$ May 1878 the curtains and the furniture still adorn my now but too desolate drawing-room).

Saturday, $5^{\text {th }}$ of April. In the forenoon the exequies of the Second VicePresident Francisco Garmendia, were celebrated in the church of Santo Domingo. Amongst the troops which were ordered out to be present at this ceremony was the battalion $\mathrm{N}^{\circ} 10$ of the National Guard, of which Antonio Salinas was Colonel, Cesar Canevaro second in command, and Alejandro first Aide-de-camp. It was at present this battalion's turn to be in barracks or "acuartelado", firstly at Guadalupe, then at San Lazaro for one month. This gave Alejandro much to do; in the day time he had to be in his office in La Constructura, early in the morning, in the evening, and at night in the barracks, and all the while he neither slept, nor breakfasted, nor dined at home. Enrique and Guillermo had taken rooms in Chorrillos and we saw little of them; the latter did a good deal of business of his own. Some [_] the hackney coaches in the town were his and jointly with some Dr. [...] [423] he had tried a rather strange speculation, which apparently left some profit. These two young men purchased from the importers of Chinese coolies those which were sick and infirm, and whom they obtained at a comparatively low price; they then took them to a house in the Cercado which they had hired for the purpose, where the Doctor attended to them with great care, and as soon as they were cured they disposed of them at their market value. About six months back Enrique had made a very fortunate hit. Ph. Ott \& Co. held a quantity of dynamite which Hamilton had brought hither on his own and C. W. Schutte's account; it was deposited on the island of San Lorenzo. Ott \& Co. could find no purchasers and had even received orders from C. W. Schutte to throw it into the sea rather than to continue incurring the expenses of storage. Then Enrique, through his connection with Meiggs, succeeded in selling the whole parcel to him at 6 months credit. The price he obtained I did not learn, but it was considerably above that which he paid to Ott. Meiggs' pagaré he discounted in the Banco del Perú, paid cash to Ott, and as Meiggs in the course of last month when his pagaré fell due paid it, Enrique realized several thousand dollars by the transaction. Alejandro owned various carts and mules; a certain Gil, son of an Englishman and to all appearances an honest man, was interested with him, and did the material part of the business. In the beginning it left him a 
handsome profit; of late it had fallen off, because the building of houses had somewhat diminished in Lima, and consequently carts to convey the materials were in less request.

Sagastabeytia, Bohorquez, and Correa came at the usual hour to my office, and we discussed very seriously the plan of prolonging the railway in the Cerro as far as, and across the river Santa Teresa, a distance of about $11 / 2$ miles, which according to two estimates in my possession, the one drawn out by Ygnacio Bao, the other by William Steele, would cost S/35,000 according to the former, 44,240 according to the latter. We determined that by the first post a letter should be written to Bao ordering him to make the following proposal to the miners. The company declared itself ready to furnish the sleepers and the rails, besides the money which might be wanted for doing the work over and above the sum of $\mathrm{S} / 40,000$ on condition that they procured these $\mathrm{S} / 40,000$ for which outlay they would be reimbursed by the freights chargeable on their ores conveyed by the train.

Saturday, $12^{\text {th }}$ of April 1873. This had been a very dull week, especially [...] Thursday and Good Friday when Mr. Dupont withdrew at 1.30 [...] [424] Ricardo who occasionally read to me a little German spent the time in the Churches to see the various religious ceremonies, and my wife and daughter were occupied with their devotions. It was to cold to bathe in Chorrillos, and too hot to climb up San Crístoval in the middle of the day; write, or read I could not, and how was I to while away the long hours? I walked to the Alamedas, and at home I sat in my arm chair, thinking, and when tired of thinking making multiplications in my head. Ascarraga had not written the letter to Bao in the manner which we others had determined on, because he was convinced that an application to the miners for money wherewith to prolong the Line, would lead to no result whatever. With him and Bohorquez I was for some time in the house of the latter when we resolved to convene the Directory for Wednesday next, when Bohorquez would lay before us various questions, the immediate discussion of which he considered to be indispensable.

From Europe we learned that the Ministry of Gladstone was again at the helm in Great Britain, also that the ex-king of Spain, Amadeo, had safely arrived at Genoa on board the Italian man-of-war "Roma", and intended to take up his residence in Turin.

Easter Sunday, $13^{\text {th }}$ of April. This morning I was in the street at a little past six before it was full day light, crossed the river over the bridge constructed by Enrique Armero, not yet completely finished, and for this reason not thrown open to the public, and ascended San Crístoval from the Lurigancho side, at the end of El Paseo Militar. After Mr. Dupont was gone I paid some visits, which I had not done for several Sundays. Firstly, to the judges of the Supreme Court 
Dr. Bernardo Munoz, Dr. José Luis Gomez Sanchez, and Dr. Jervacio Alvarez, whose acquaintance I had made in the course of my many law-suits, and with whom both Mariquita and I continued on friendly terms though the law-suits had all been brought to an end. Next, to the family of Col. Diego Masias, to Doña Petita, the mother of the President, and to the Minister of Finance La Jara, with which three calls I was much pleased. In the house of Don Jorge Pinto, lately made Chargé d'Affaires of the Republic of San Salvador, I for the first time showed my face. He and his two eldest daughters Eleonor and Rosa had been in our house more than once, and of course I could not otherwise but return the compliment. The two girls, very neatly and plainly dressed, received me, and I liked them very well. Whilst I was with them Henry Meiggs came in and was introduced to me: he seemed quite [...] [425] and well might he be so, for at his expense part of the family had made a voyage to Europe, visited many countries, even the Holy Land, whence they had returned in the beginning of this year.

Easter Monday, $14^{\text {th }}$ of April 1873. I went to Chorrillos to bathe. Villemars, the Belgian, secretary to La Sociedad Maritima, got hold of me and took me to his rancho, where I remained so long that I had hardly time to call upon the two Velardes, Rafael and Manuel, and upon Sagastabeytia, who told me that he could not be present on Wednesday at our meeting of the railway Directors, because on that day he, together with Pedro Puente, the widower of Doña Rosa Rabago, and Francisco Garcia Calderon, named by her as her executors, had to take up the inventory of her chattels.

Saturday, $19^{\text {th }}$ of April. In the course of this week I as Director de Turno had gone occasionally to the office of the Insurance Company "Lima" where, however, my presence was hardly necessary, for we effected but few insurances.

Bohorquez and Ascarraga were with me, but in the absence of Sagastabeytia and Correa we were unable to take any decision in the affairs of the Pasco Railway. About a fortnight or three weeks ago a small party of montoneros headed by a well known mulatto Luis Carrera from the neighbourhood of Chancay showed itself about Obrajillo and Canta. They were easily subdued by a small force sent against them, and Carrera was killed.

The commercial news, which caused great surprise in Lima, was the failure of the firm of Antonio Salinas in Liverpool. Two or three years back the rich hacendado Don Antonio, the father, established his son in said place, principally for the purpose of selling his (the father's) cotton. Afterwards Pedro Beltran, brother of Mrs. Carlos Elias and Mrs. Pio Echenique, formed a partnership with young Don Antonio and established himself in Lima. Not many months 
back he made known that he withdrew from the firm, and that Don Antonio, Senior, would liquidate the accounts of the house. Before retiring he had drawn considerably upon the Liverpool firm; his drafts were duly accepted but about $\mathrm{S} / 100,000$ worth of them were now expected back under protest for nonpayment. Guillermo Garland had taken £200o of them for Schutte \& Co.; other sufferers were: Gildemeister, Ayulo, the nephew of Renner, old Salinas, etc. In a meeting held by these creditors, Garland, Senior, represented the interest of Schutte \& Co. He was of opinion that old Salinas would come forward with a $[\ldots]$ to pay the entire debt in a certain number of years which would [...] [426] doubt be accepted by the creditors, for otherwise they would not get a rial. Beltran had not a cent, and young Antonio Salinas had been living in Paris in the most extravagant manner.

About this time Guillermo brought up my commercial books to the $28^{\text {th }}$ February last; when trying to balance them he could not make them agree. He tried it over and over again, but not being able to find the error I set to work with the assistance of Ricardo; for a day or two we were occupied in this manner which greatly injured my sight; then Dupont and Ricardo continued the work under my supervision, but up to this day they had not discovered where the mistake lay.

Sunday, $20^{\text {th }}$ of April. This morning I accomplished my usual task, the climbing of San Cristoval, with uncommon ease.

In Chorrillos I called upon old Don Mariano Blas de la Fuente, who was reading; he told me that his eyesight was fast failing him, and to judge from his looks I did not believe he could live two or three years longer. From him and afterwards from Dr. Ribeyro I learned that particularly in the houses of Malinowski, J. A. Garcia y Garcia, and one of the Elguerás, rocambor was being played at extremely high stakes, say 20 or $\mathrm{S} / 24$ the point; one person had lost 45,00o Soles during this season. After the bath I looked in at the two Velardes. Rafael and his wife were both in bed; he, the most apprehensive of creatures, complained of a cold; she, who had been brought to bed hardly 24 hours previously of a boy, looked as well as if nothing had happened to her. At Dr. Ribeyro's both he and his wife were particularly friendly. At Doña Mercedes Riva Agüero's I met various visitors: Francis Bryce, John Gallagher, Felipe Barreda, who introduced young Lord Cochrane, the grandson of Lord Cochrane who at the time of San Martin contributed materially to the Independence both of Chile and Perú. This young man not many months back had been invited by the Chilian Government to be present at the inauguration of a statue erected in Santiago to the memory of his grandfather; he had come, was at present on a visit in Lima, and would leave on the $7^{\text {th }}$ May via Panamá. He was tall, very 
thin, and spoke Spanish sufficiently to make himself understood. I returned to Lima at 4 O'clock.

From Monday, $27^{\text {st }}$ to Wednesday, $23^{\text {rd }}$ of April. Nothing was done to my commercial books, I myself did not venture to look into them for my sight had in reality suffered much by my late i[_]dence. [427]

Thursday, $24^{\text {th }}$ of April 1873. All the Directors of the Pasco Railway Coy. met in my room, and after a long and friendly discussion we agreed to make an attempt to raise from forty to fifty thousand Soles by offering to the lender a high interest and a good guarantee, viz.: the nett income of the present line and of its prolongation, until both capital and interest were paid. We calculated that $S / 40,000$ would suffice to prolong the line for a mile or a mile and a half to and across the river of Santa Teresa. Now there came another consideration: we, the Directors, could not mortgage the proceeds of the railway to the new lenders, without the consent of the old privileged creditors who were: Felipe Barreda y Osma for $\mathrm{S} / 100,000$ and I for $\mathrm{S} / 5^{0}, 000$ secured by the first mortgage. Secondly, the Banco Hipotecario for nearly $\mathrm{S} / 200,000$, represented by Riva Agüero, who had no security, and thirdly, the S/100,00o privileged obligations, which were issued by the late Directory, and of which the holders were: Manuel Pardo S/20,000, José Maria Varela S/20,000, the South American Insurance Coy. S/20,000, Nicolas Rodrigo S/18,00o, I S/12,000, the late General Iturregui $\mathrm{S} / 10,000$. I told my colleagues that I would see these privileged creditors, and endeavour to obtain their consent; accordingly, on

Saturday, $26^{\text {th }}$ of April I went first to Riva Agüero in his Ministry, who immediately agreed to my proposal, but added that being at present Minister for Foreign Affairs he could not sign as Gerente del Banco Hipotecario the document which had necessarily to be drawn out, and as he expected to leave the Ministry on the $5^{\text {th }}$ or $6^{\text {th }}$ of May he begged me to wait until then. Nicolas Rodrigo agreed at once. Varela was in Chorrillos. With Ruden, President of the South American Insurance Company, I had a long talk which led to no result, for, as he said, he could take no determination on such an important question without the consent of the other Directors, and requested me to return on Tuesday when they would be all united. Early this morning I was awakened by my wife who told me that the fire-bell was tolling. I immediately rose and went out, when I learned that a fire had broken out in the store of Mr. Salamon in the Calle de Bodegones. The engines were already on the spot, and in a short time the fire was extinguished. At a later hour I went to the office of the Insurance Company "Lima" when I learned from Guiroy that we had insured the goods in the store for $\mathrm{S} / 35,000$. Whilst I was there, Lembcke, the President of the Directory, entered as well as Mr. Salamon, by whom I was told that hardly anything had been destroyed by fire, but that considerable 
damage had been done by the water; this damage would [...] paid for by the company. [428]

Monday, $28^{\text {th }}$ of April 1873. The Directory of the Insurance Company "Lima" met, to treat on the Insurance we had effected on the goods in Salamon's store. Gil had examined the damaged articles, and had offered him in settlement of his claim S/900o; he had asked S/11,300, whereupon Lembcke, authorized to arrange the matter, had offered S/10,00o cash down; which Salamon had accepted, and with this settlement the Company had in my opinion every reason to be satisfied. From the company's office I went to Heudebert, who, I believed, held full power from the widow of the late General Iturregui; I explained to him what we of the Pasco Railway Coy. had resolved; his answer was that he held no such power as I supposed, but that he was convinced that the widow would not hesitate to put her name to a document which was headed by the signatures of Felipe Barreda, Nicolas Rodrigo, and others.

Tuesday, $29^{\text {th }}$ of April. In the meeting of the Directors of the South American Insurance Company I represented to them what I had already stated to Ruden, their President, and the result was that they did not accede to my request, but though preferable that every privileged creditor of the railway should contribute in proportion to the amount of obligations he held. I knew that Riva Agüero could not make the payment which would correspond to him, but this of course I did not tell them. Meanwhile we had received a letter from Bao in which he informed us that Villate, the manager of the branch establishment of the Banco del Perú in the Cerro, had told him that this bank might perhaps advance the money required at $1 \%$ monthly interest, they reimbursing themselves for this their outlay by one half of the freight which five or six of the principal miners would have to pay on their ores. This proposal seemed acceptable to Bohorquez, Ascarraga, and myself; not so to Sagastabeytia who was averse to any transaction with the Banco del Perú.

Wednesday, $30^{\text {th }}$ of April. In the meeting of the Directors of the Water Company, Andrés Rey, the manager, expressed a wish to be allowed to withdraw from his post, to which request none of us was inclined to listen, because we knew full well that it would be extremely difficult to find a man so well adapted for this situation as Rey was. My private opinion was that Rey would have been much disappointed, if we had conceded to him what he asked for.

Thursday, $7^{\text {st }}$ of May. I got quite tired of the Pasco Railway affair. [...] Director came at one hour the other at another [...] [429] done. Before we could come to any decision we had always to meet over and over again, and when it was taken then for a certainty so many obstacles were thrown in our way that its execution was rendered impossible. 
Friday, $2^{\text {nd }}$ of May 1873 . Yesterday evening at about 7 O'clock when Westphal of Huth's house, Marshall his junior partner, and Ryder, partner of Hetcher of Arequipa, who a few moments previously had arrived from Liverpool, were taking their coffee after dinner, eight or nine ruffians well muffled up entered the street door which was open, pushed aside the porter, entered the gate of the iron railing, both which gates they closed behind them, and then forced open the door of the first room which was shut. Mrs. Westphal, in an adjoining apartment was the first to see them, locked the door, and gave the alarm; Westphal ran for his carabine and revolver; on his return he fired at them, they at him. Marshall, a stout young Englishman, without arms attacked them with his fists, and these two succeeded in putting them all to flight. Two escaped over the roof, the others through the street door, firing through the railway as they fled, and Westphal pursued them about half a cuadra along the street which led from his house towards the river.

This being the anniversary of the victory over the Spaniards in 1866, a grand review was held. On the boulevard, which Meiggs was constructing all round Lima, three or four battalions of infantry, the artillery, the cavalry, and 19 battalions of National Guards, say 15 from Lima, 4 from Callao, ranged themselves from the Hospital del 2 de Mayo, between the gates of Barbones and Cocharcas, as far as where the Chorrillos gate formerly stood. Between 11 and 12 O'clock I walked out to the open place to the left of the Exhibition, and saw battalion after battalion make its appearance, marching on to take its respective station. I entered the Exhibition Park, and strolled about in every direction; page 345 I have said a few words about it. This day it seemed to me as if sufficient care were not bestowed upon it; the paths were not kept clean, the plants were covered with dust, and more than one cage stood empty. At 4 O'clock when I left the park Pardo with his suite, consisting of General Medina, Riva Agüero, and Rosas, Costas the Vice-President, the Prefect Bazo, General La Fuente, young Lord Cochrane in his red English uniform, and a few others, who had ridden along the line commanded by General Freire, just returned and took their station near the statue of Colon. I met young Enrique Prevost and Mariano Moreira, and mixed up with the crowd we saw all the troops, between 7000 and 8000 [...]. The National Guards looked uncommonly [_]ll [...] [430] especially if one considered that they had been formed between the last six or seven months.

In the evening there was a grand reception in the Palace. I had received a note of invitation from Riva Agüero, and went accordingly at a little past 9 in my black coat, not in uniform. When I entered the saloon I saw nobody whom I knew, and walked up to the other end, when Pardo, who was conversing 
with two or three gentlemen and who probably remembered that I cannot see anything even at the shortest distance, stopped me and gave me an uncommonly friendly reception. He slung his arm round my body, and chid me that I, one of his old friends, did not see him more frequently. I, calling him Usted, only once Vuestra Excelencia, congratulated him upon the splendid success which had attended the formation of the National Guards and the fine appearance they had presented this morning; I then withdrew and finding but few with whom I was acquainted merely took a good cup of tea and soon left the saloon.

Saturday, $3^{\text {rd }}$ of May. Last night several houses in Callao in the Calle del Comercio, were destroyed by fire, and the loss sustained was said to be very considerable. As far as I could ascertain no part of the property had been insured by either of the two Insurance Companies established in Lima.

This being once more a holiday Mr. Dupont did not come, and I to while away the time went out to see what was going on. I followed the direction which I saw many coaches take, and came to the Callao Gate, which at the time stood quite isolated, the walls on both sides being completely demolished. A little outside the same, to the right I saw a scaffolding covered over with Peruvian flags, close by many carriages, amongst which that of the Government, troops, guns, and many spectators all on the alert. I heard the report of the guns and on enquiry learned that the President had laid the first stone of a monument to be erected in celebration of the Victory of the $2^{\text {nd }}$ of May. Thence the multitude moved to another solemnity, viz: to the inauguration of a primary school, which owed its existence to the efforts of José Antonio Garcia y Garcia, and to voluntary contributions. I having refused to contribute did not avail myself of an entrance ticket sent me by Garcia. It was a fine building, a little inside the Callao Gate. The children were to be taught on the Lancastrian system.

Sunday, $4^{\text {th }}$ of May. The assault of Huth's house the other day had $[. .$.$] she$ would not allow [...] [431] my favourite hill for fear that I might be attacked by highway men.

When Mr. Dupont was gone I called upon Mr. Westphal whom I found still in bed, but otherwise well and without fever. He gave me all the particulars of the attempted robbery, and from him I learned:

Firstly, that he had been wounded by a shot in the arm, and that up to that moment the ball had not been extracted.

Secondly, that Mr. Marshall's right arm had been grazed by a ball, and that he had received a tremendous blow in the face, which had obliged him to let go his hold on one of the wounded robbers, whom he had firmly clenched. 
Thirdly, that the head-servant had been shot right through the body, without any vital organ having been touched.

Fourthly, that an underservant had been wounded in the arm by the same ball which had passed through his companion, and that the arm would probably have to be amputated.

Fifthly, that the porter was still suffering from the contusions received.

Sixthly, that a policeman had been shot dead right through the throat; and

Lastly, that one of the robbers had been found dead on the railway in the bed of the river; probably, having been wounded in the affray and unable to keep up with his accomplices, he had been killed by them.

Tuesday, $6^{\text {th }}$ of May 1873. In the meeting of the Directors of the Pasco Railway Company, Correa absent, we again conferred on the prolongation of the line, to which Sagastabeytia was much opposed, and we finally resolved not to take any decisive step on the subject, until the arrival of Bao, who was daily expected.

Wednesday, $7^{\text {th }}$ of May. Two employés of the railway, Anderson the platelayer, and Petersen the mechanic, appeared in my office. They bitterly complained of Bao, and said that they had been turned off by him; of the railway itself they gave a most disheartening description. In the course of the forenoon I received a note written by Felipe Barreda and dated Chorrillos $30^{\text {th }}$ April; he enclosed the rough draft of a petition which in his opinion I, in the name of his son, of Riva-Agüero, and of myself, all three holders of the provisional bonds issued by Government, should present to the Minister of Finances, requesting him to have these bonds included in the new consolidated debt. Before giving in this petition Barreda thought it advisable that I should consult with Riva Agüero, and accordingly I went to his office in the Palace, which he had already left, when I arrived. On

Thursday, $8^{\text {th }}$ of May Riva Agüero [...] pied with two foreign Chargés and [...] [432] could not see me.

The Directors of the Water Company merely met for the purpose of authorizing the manager Rey to give to Bates Stokes \& Co. of Liverpool the order for the purchase of a considerable quantity of iron-pipes indispensably required.

Friday, $9^{\text {th }}$ of May. The meeting of the shareholders of the Eten Railway Coy. was extremely disagreeable. Present were: Ruden, Derteano, Candamo, Emilio Althaus, Puente of Ugarte's house, Irrigoyen, I, and the gerente Inojoso. Ruden stated that the company was in such a state that if $\mathrm{S} / 200,000$ could not be brought together immediately wherewith to satisfy a demand which was threatening with execution, the Directors would find themselves in the necessity of declaring the insolvency of the Company, to avert which only two ways still remained open, the first, that the shareholders should make up the 
S/200,ooo each paying the proportion corresponding to his original share; the second, that each shareholder should pay cash down his proportion of the $\mathrm{S} / 1,000$, ooo bonds which were voted about a year back, and to the service of which, that is to say to the payment of $9 \%$ annual interest, and $4 \%$ annual redemption, all of us had made ourselves responsible, with the exception of Althaus and Meceno Espantoso, who at the time decidedly refused to take this new obligation upon themselves, and of Felipe Barreda, who, though he signed the escritura, had added a clause which in all probability would release his son from his obligation. I told those present that let the consequences be what they might I would not disburse a single rial more; I knew that my original shares of S/15,00o were not worth a cent; I knew that I had been foolish enough to bind myself to the payment of $9 \%$ and $4 \%$ on S/30,000 annually, and that of course I should always honor my signature, but that I could not pay at the moment the $\mathrm{S} / 30,000$ and that I would not pay a rial more. Very naturally this declaration was not well received, but no one had a right to say anything against it. Irrigoyen and Candamo were more or less of my opinion, but did not speak out so clearly. The debates continued, and I left, just at the moment when J. A. Garcia y Garcia entered. Hence I went to Riva Agüero's office, and waited full an hour, till 4 O'clock, when he came from the President, and told me he was so busy that he could not see me on the subject of the Pasco Railway till Sunday evening.

Saturday, $10^{\text {th }}$ of May. Soon after breakfast Felipe Barreda was with me, [...] I told that until then Riva Agüero had not been [...] [433] interview for which I had asked him several times, whereupon he requested me to hand him the above spoken of draft, and added that he would himself speak with Pardo, his son-in-law, on the subject and let me know the result. A few hours later the Pasco Railway Directors were again assembled, and approved various entries in rough which Ascarraga had made, and which had to be copied in the journal.

Sunday, $11^{\text {th }}$ of May 1873. This morning when I ascended San Crístoval it was very foggy, and the streets were wet, rain having fallen during the night. On my return I again lay down for a short time, but was soon disturbed by the two little girls who came to my bedside bringing me flowers for my birth-day, also the one a cravat, the other some chocolate. My wife and Enriqueta then came; also Enrique, Alejandro, and Ricardo made me presents. In the evening as per appointment I went to the house of Riva-Agüero, where I found him and his wife by themselves; they were both very agreeable, and I remained nearly an hour. He told me that he had seen Felipe Barreda's draft of the petition to be presented by me and that he approved of it. Moreover, he entertained hopes that the Pasco Railway would after all not leave so very bad a result as I and the greater part of the shareholders apprehended. 
Tuesday, $13^{\text {th }}$ of May. Felipe Barreda came to see me, and told me that his son-in-law had advised some small alteration to be made in the draft, which had been done accordingly.

Wednesday, $14^{\text {th }}$ of May. I presented my S/50,00o of the bonds mentioned more than once to the "Direccion de Contabilidad y Credito" to have them exchanged for bonds of the new consolidated debt, but they were not admitted, which refusal we had all anticipated. At a somewhat later hour the Directors of La Constructora met; present were: Saracondegui, I, Escobar, Lanfranco, Granda, Muro, and Dr. Solar, besides the two gerentes. The balance sheet till $31^{\text {st }}$ March 1873 was presented; it showed a gain of $S / 28,000$, a poor result for two years, $9 \%$ on $\mathrm{S} / 300,000$ paid in, or at least which ought to have been paid in, for some shareholders were still in arrears with their cuotas. Every item was commented upon, and the examination of the books entrusted to Granda and Escobar. We decided that in the next general meeting of shareholders we would declare the dividend of $9 \%$, but make its payment dependent on the recovery or non-recovery of $S / 73,000$ due by Henry Meiggs, which debt arose from the forcible expropriation of our wood deposit, the ground upon which it was built being required by Meiggs for his [_] ard [...] Lima. This expropriation had saved the company [...] [434] without it there would have been hardly any gain. In the course of the two years La Constructora had only concluded the following works: for the Lima Municipality the new market in the paseo de aguas, the construction of which had left no profit, secondly, a market in Ancon, thirdly, a number of sewers in the streets of Lima, and fourthly, a contract had been made for widening the bridge across the Rimac, which work had been stopped after the fall of Balta; for the Government it had also laid the ground-wall of a church in Ancon, but this had likewise been discontinued, and the money for its cost not yet paid. Many private individuals had applied to the gerentes for the construction of the one building or the other, but with none had they been able to come to terms. In this meeting Rufino Echenique informed the Directors that he could not continue as Gerente. Alejandro who had been aware of this had spoken to all the Directors, and requested them to name him instead of Echenique; all had promised him their votes, and it had been agreed with Zaracondegui, the President, to propose him, which however he did not do; it had become late, nearly 6 O'clock, we were anxious to get home for dinner, and thus we rose without a determination being taken regarding the acceptance of Rufino's resignation and the nomination of his successor.

Friday, $16^{\text {th }}$ of May. I personally presented to the Minister La Jara the petition I had signed for Barreda, Riva-Agüero and myself, and gave him a succinct account of how this debt $\mathrm{S} / 400,000$ in favor of the said persons had 
been incurred by the Government. He listened very attentively, said he would consult with the President, and requested me to return on Monday next when he would give his answer. The Pasco Railway Coy. took up my time from 1 to 5; Bao explained to the satisfaction of the Directory why he had dismissed the plate-layer Anderson and the mechanic Petersen; also made clear to us the causes why it was utterly impossible for him to satisfy all the miners who wanted to have their ore forwarded by the train; "they must go by turns", he said, "and of course I give the preference to such as are my regular customers and who send ore every week". He however confessed that the two locomotives were not sufficiently powerful; on their return with empty cars they made the passage without any hindrance, but uphill they stopped more than once in the short distance of seven miles, and he was therefore of opinion that a new locomotive of at least double the power was indispensable; he also required several pieces to repair the two old engines, and I agreed to go with him in a day or two to the fou[_] Staunton \& White in the Alameda del Acho, to see whether they [...] [435] would do the work. For a considerable while the other four with Bao, I taking no part in it, were occupied with calculating how much the rates could be raised for conveying the ore per train, and a new tariff was accordingly delivered to Bao, who presented to us his account for April, accompanied by a remittance of $\mathrm{S} / 2183.66$.

Sunday, $18^{\text {th }}$ of May 1873 . The political news from Europe was that the Carlists had been defeated, and that Don Carlos had taken refuge in France. In all probability before the end of the year the total of the war indemnity would be paid by France and the eastern departments be evacuated by the German troops.

As regards the Peruvian loan nothing certain was known; the "Comercio" said that there was little doubt of the house of Dreyfus having acceded to the conditions laid down by Pardo, and the particulars of which Scheel had taken with him. This agreed with what Juan wrote me from Paris, where it was rumoured that Dreyfus had given way to the pretensions of the Peruvian Government. Juan had dined with Dreyfus on the $16^{\text {th }}$ April, when he had hoped to learn the truth, but as there were other guests besides himself he had no opportunity of a private conversation with the master of the house. Juan, after several weeks residence in Rome, had visited Turin, which place he had left on the $2^{\text {nd }}$ April at 9 a.m. and had arrived in Paris on the $3^{\text {rd }}$ at 7 a.m; his route had taken him through the tunnel of Mont Cenis, the traversing of which occupied twenty-seven minutes. He did not feel the slightest inconvenience either from want of air, or from smoke; only the temperature was considerably warmer than outside. The coaches were brilliantly lighted up. Juan himself said nothing about his health, but Rosa wrote to Enriqueta that though her brother 
was not so weak as she had feared, his head and face often became all of a sudden very red, from which she inferred that the circulation of his blood was not as it should be, and that he was exposed to a sudden fit of apoplexy. Corina was so extremely weak that for a fortnight she had not left the room, and only exchanged the bed for the sofa and again the sofa for the bed. These advices, which Enriqueta communicated to us last night, much affected my wife, as may well be conceived, and she thus spent a very bad night. Amalia's little girl was born in Boston on the $18^{\text {th }}$ March and christened Corina on the $15^{\text {th }}$ April in accordance with the protestant rites. This day the marriage between Serapio Orbegoso and his cousin Zoila Elespuru took place here in Lima. Irrigoyen was named Peruvian Chargé in the Brazils, Uruguay, and the Argentine Provinces. The daily papers published [...] dispatch received by Dreyfus' house in Lima from their head [...] [436] París, who advised them that he agreed to the conditions laid down by Pardo. There had been no time as yet to take any steps with regard to the disposal of the last loan. The Peruvian bonds of 1872 paying $5 \%$ interest, were quoted at $65 \%$. Garland had a letter from his son Geraldo, who wrote from Jeddo that all the members of the Embassy had for some time past been extremely busy with drawing out the documents required for establishing the claim which the Peruvian Government intended making on Japan for the injury done sometime past to the captain of the Peruvian vessel "Maria Luz". Geraldo added that they were about leaving the Imperial Palace and taking up their residence in an hotel.

Monday, $19^{\text {th }}$ of May 1873. This morning at 7:30 Ignacio Bao was with me; together we went across the new bridge to the foundry of White \& Co., where he ordered the pieces which he required - thence to the store of Menchaca \& Co. to purchase various articles, and finally to Bao's lodgings, where we met Teodolfo Morales, a pupil of the Lima "Colegio de artes y oficios" who had been dismissed from this establishment with the most satisfactory certificates regarding his proficiency as mechanic, and whom Bao considered to be a very proper person for the Cerro. We engaged him accordingly, and I left the two to draw out the contract. It was past 10.30 when I came home. Two hours later I went to the ministry of finances, where La Jara, not so friendly as on Friday last, told me that my petition had been referred to the Direccion de Contabilidad y Credito, which was to give its opinion, or "informe" as it was called, and that I should return next Thursday. There was a meeting of the shareholders in the Eten \& Ferriñafe railway, from which I purposely absented myself.

Tuesday, $20^{\text {th }}$ of May. Quite unexpectedly Sagastabeytia, Bohorquez and Ascarraga entered, accompanied by Mr. Harrison, who in his own name, and that 
of his partner Wyman declared that they had no objection to our constructing in the Cerro a short additional line, which Bao considered necessary, and to make use for the same of the rails, sleepers, etc., existing there. At the very moment these four gentlemen left, Inojoso, the clerk of the Eten Ferriñafe Railway Coy., walked in, and informed me that on the previous day it had been decided in the general meeting of shareholders, to authorize the Directors to effect the sale of the line for the sum of 1,700,000 Soles, of which amount 1,130,000 would be required within a few months to pay the debts incurred, and the remaining $S / 570$, ooo would not be required in cash $[\ldots]$ the purchasers would have to make themselves answerable for [...] [437] payment of interest and redemption of obligations to the same amount of $\mathrm{S} / 570$, ooo held by various persons. If this sale could be effected, all the original shares were lost, but at all events those who had taken upon themselves the service of the last 1,00o,00o S. bonds, would be released from their responsibility, and this would be a great gain. I myself doubted that the sale could be made. The document authorizing the Directors was signed by many shareholders, but I refused putting my name to it until I saw the signatures of many more, particularly that of Felipe Barreda. Now it was 3.30 and I had to go to the Constructora where Zaracondegui, Augusto Althaus, Escobar, Granda, Lanfranco, Muro, Solar, I, and the two gerentes took their seats round the table. The discussion was not the most pleasant. Solar, Zaracondegui, and Althaus affirmed that they had been opposed to the gratification of $\mathrm{S} / 25,000$ which many months back had been given to Jose Peña, the Alcalde in Balta's time, in order to obtain the work of the enlargement of the bridge, which work had been stopped by the present Government. Escobar and I were of opinion, and stated it very clearly, that this was not the proper time to make such declarations, and that if they had been opposed to the gratification, or not been present at the meeting as Solar pretended, it could be proved by the "acta" or protocol of that day; but where was the book of "actas"? Emilio Pierola who had been our secretary, and who had of late absconded, had taken the book with him, and it was even said - I was one of those who were of this opinion - that many actas had never been written, and that Pierola had read them as if they were written, perhaps even from a blank paper. Next, Escobar made some observations on the balancesheet examined by him; some shareholders had not yet paid up their cuotas. Muro read the article of the statutes treating on this point, and we decided that if the cuotas were not paid at the time of the next general meeting of shareholders, the names should be made known, and their shares forfeited for the benefit of the company. Then Lanfranco confessed that he was one of those who were in arrears; Escobar also made known that he had seen by the books 
that the two gerentes had returned their salaries amounting to no less than $\mathrm{S} / 12,000$ which donation the majority refused to accept, but they persisting we determined to lay the case before the general meeting of shareholders. These $S / 12,000$ were included in the profits of $S / 28,000$ so that without them the gain would be reduced to a little more than $5 \%$, say $S / 16,000$ on an outlay of $\mathrm{S} / 300,000$.

Wednesday, ${ }_{21}^{\text {st }}$ of May 1873. I was at home for the greater part [...] [438] forenoon. Mr. Dupont and I occupied ourselves with remodelling my old diary of September 1848, which took up the greater part of our time. The dictation and writing of my letters formed another part of our daily work. If time permitted, Mr. Dupont read a little to me, at present the history of England by Lord Mahon, a work in which I take the greatest delight; the style is not so smooth and polished as that of Macaulay; in his politics he is a moderate Conservative, which he cannot conceal, though he makes no display of his political bent. What I much admired were the noble and elevated moral principles which he ocasionally expresses, and which proves that he must have been a good, upright man.

Thursday, $22^{\text {nd }}$ of May I was awaked at about 2.30 by the tolling of the fire-bell, but it not being repeated I thought I was mistaken, and lay down again; about ten minutes later I heard and felt a repeated shaking; I rose, dressed, and called my wife; the shaking continued, it was at our door; we called out, Enriqueta and our servant Juan were there to tell us that over the way at Mendoza's a fire had broken out. Our street door was already open. I went into the street with Juan; Dibos, our tenant, Antonio, Ricardo, the celadores, and perhaps forty or fifty people more were on the spot. A policeman walking his round had observed volumes of smokes issue from the cigar-shop in Mendoza's house, had given the alarm, roused Mendoza, and as the owner of the shop did not live there, broken up the door. The fire, which fortunately had not extended far, was discovered, and quickly extinguished before any engine arrived. By four O'clock I was again in bed.

Sunday, $25^{\text {th }}$ of May I was occupied with finishing a dispatch to my Government, in which I gave an account of the death of a Danish subject, Captain J. J. F. Borre, which had taken place in the hospital of San Andrés on the $20^{\text {th }}$ April last.

Monday, $26^{\text {th }}$. Some of the shareholders in the Eten Railway met; the authorization for its sale was signed by all, including Felipe Barreda and myself, but excluding Unanue, absent in Cañete, whose signature Ruden thought he could easily procure, as well as Emilio Althaus and Miceno Espantoso which two latter, it must be recollected, had refused to take upon themselves their share in the service of the $S / 1,000,000$ bonds. Without their signature the 
authorization would not be valid, and therefore two of their friends were co[_] missioned to do their best in order to obtain these signatures. [439]

Tuesday, $27^{\text {th }}$ of May 1873 . I was cited by the old Roque Chalons, the architect, to appear before the Juez de Paz Alfaro, to answer a demand which he made for some repairs in my house Calle de Zarate as far back as the year 1865, and which, as I proved by a receipted account, I had already paid in December 1868. Chalons not being in attendance, for he had sent somebody else to represent him, I was cited to reappear next Thursday.

Wednesday, $28^{\text {th }}$ of May. Two meetings were held in the same house; the one, of the Eten Railway Company's shareholders, at which I did not attend, but learned from Escobar that no resolution had been taken, as Althaus and Espantoso decidedly refused to sign the authorization for the sale. The general meeting of the shareholders of the Constructora was sufficiently attended, more than two thirds of the 1000 shares of which the company consisted, being represented. Zaracondegui, President of the Directory, should have presided, but he excused himself with his correspondence, and thus I as Vice had to take the chair, which I did not like at all. I sat in the centre, a table before me, to my right Augusto Althaus and Santiago Lanfranco, at the extremity of the table Cesar Saco, gerente; to my left Escobar and Muro, at the other end of the table Rufino Echenique, gerente, then Emilio Solar, and finally Zaracondegui, who came in when the discussions were nearly over. When Saco had read the Memoria, and the balance-sheet had been handed to Emilio Althaus and Calderoni, who sat exactly opposite to me in the first row of the shareholders, these two made many observations, not of the most pleasant nature, and, I must confess, not without foundation; for instance on the $31^{\text {st }}$ March, the date of the balance-sheet, all the shareholders had not paid up their cuotas, which was certainly incorrect, and for which the Directory was blamed. Then they found fault with the Directory for having submitted to the shareholders the question relative to the $S / 12,000$ ceded by the gerentes, and the majority voted that the Directory should decide what to do. They required an explanation on the subject of the $S / 25$, ooo gratification to Peña, which could not be given in public; and they then passed to another point, the $S / 63,000$ due by Meiggs for expropriation; they argued, and the Directory agreed with them, that no dividend should be paid until this amount were collected. Solar, Escobar, the two gerentes, and I - on one occasion also Augusto Althaus defended the steps taken by the Directory; Lanfranco, Muro, and Zaracondegui were mute. The last to be done was the election [_] four new Directors, viz.: instead of Emilio Pierola and Juan Martin [440] Echenique, absent, and of Zaracondegui and myself who went out by lot. According to statutes we could be re-elected, but were not; each of us had a little more than 100 votes, Garland 
somewhat more than 200; but those elected by vast majorities, which had been arranged amongst themselves beforehand, were: Emilio Althaus, Calderoni, Graña, and Rufino Echenique.

Juan Bazo, Prefect of Lima, and José de la Riva Agüero, Minister of Finances, had given in their resignation; the former's was accepted by Pardo, and a certain Soria named in his stead, the latter's not.

Saturday, $3^{{ }^{s t}}$ of May. The new Archbishop Urueta, hitherto bishop of Trujillo, had been consecrated in due time; this I omitted to mention in its proper place. I received a letter from Bao, who informed the Directory of his safe arrival in the Cerro de Pasco; the post from the Cerro had not been stopped on the roada proof that the Montonero parties, of whom much was said in the papers, were not of a very dangerous nature. They consisted mostly of indefinidos officers not in active service - were headed by a certain Col. Escobar, and infested the vicinity of Huancayo. In persecution of them the President had sent up a small detachment of picked men, commanded by a valiant officer Latorre. Ascarraga and Correa came, to whom I communicated that I had laid out the money which was in cash, belonging to the Pasco Railway Coy., in the purchase of two cedulas of S/1000 each, through the broker Malagrida, at $97 \%$.

From Alejandro Ilearned that the newly elected Directory of the Constructora had held several nocturnal sittings, with great secrecy; nevertheless, it had oozed out that it was their intention to bring about a complete change in the said Company.

My son Juan's usual fortnightly letter informed me that the firm of Dreyfus, and the Peruvian Government were at the time on very good terms; but of the disposal of the new loan he did not say a word.

Sunday, $7^{\text {st }}$ of June. My habitual ascent of San Cristoval turned out this day very fatiguing; it was a foggy morning, and thus on descending I lost my way, and had to climb down a steep gulley covered with rollingstones. On my return home I had necessarily to rest for a short time. Enriqueta was the whole day in the house of my wife's cousin Manuel Velarde, who on Wednesday last had suddenly been taken ill, owing to his having caught cold the previous night; already on Thursday his physician declared that he was suffering from an inflammation of the lungs; and that he was in a very dangerous state. On friday his life was despaired of; yesterday [...] [441] made his confession to Fray Cortés from the convent of the Descalzos; this day he was a little better, and hopes were entertained of his recovery.

Tuesday, $3^{\text {rd }}$ of June 1873. Enriqueta, who had remained in the house of Manuel Velarde until this morning, told us at breakfast - for we being without a cook took our meals with the family Garland - that the sick man had copiously 
perspired, and that she believed him to be a little better. At 4 p.m. I went to his house to enquire, when I received a vague reply, and hardly had I come home when advice was sent us that he had expired, ten minutes after I had left. This was the $3^{\text {rd }}$ of June; on the $2^{\text {nd }}$ he had completed I cannot say exactly whether his $67^{\text {th }}$ or $68^{\text {th }}$ year. Our whole family grieved for his loss for he had always been a good friend of ours, and as long as my wife and I had been living in the Calle del Correo he was one of our most regular visitors in the evening; our present house, he said, was too far for him to come at night. His father was Jorge Velarde, brother of my wife's mother, his mother Javiera Echevaria. His grand-parents were: Agustin Velarde and Catalina de la Torre. When a lad, his father, residing in Arequipa, sent him to the college of Bergara in the North of Spain, there to conclude his education; he went under the charge of a particular friend of his father's, Espartero, then an insignificant Colonel in the Spanish army, in later years Regent of Spain, and Prince de la Victoria. When Manuel returned to his native place he first entered as youngster the Counting-house of John Jack, but soon left the mercantile, and devoted himself to the military career, in which he rose to the rank of lieutenant-colonel of engineers, with the grade of Colonel. Like every other military man in Perú he took his share in the civil dissensions, but unfortunately always fought on the losing side. On the $20^{\text {th }}$ January 1839 he, a warm partizan of Santa Cruz, was present at the disastrous battle of Ancachs and on his flight was made prisoner by the enemy. In 1843 he sided with Vivanco, and was beaten by Castilla at San Antonio, near Moquegua. His last campaign was that of 1854 under Echenique, which concluded with the defeat of Echenique's forces by Castilla, near Lima in the battle of the Palma, on the $5^{\text {th }}$ January 1855 . On other occasions he had been employed by the Government as Director of Public Works, also as Director of the Powder Manufactory; however, for the last ten or fifteen years he had lived very retired, and received his pension from the Government as an indefinido. His widow is an excellent woman, [_]oria Gomez, who has some property inherited from her parents. Their [442] daughter Adela married about four years back Baltazar Aranivar, of whom I have already given my opinion; at the time he was in the service of the lawyer Francisco Garcia Calderon.

Wednesday, $4^{\text {th }}$ of June 1873. At 9 p.m. several gentlemen assembled in the darkened sitting-room of the house of the deceased; at 10 precisely the entire party, walking two by two, Don Baltazar and I at the head immediately behind the coffin, accompanied the corpse to the Church of La Merced, partly lighted up, where it was received by the singing monks, and placed behind the highaltar. The two brothers of the deceased Melchor and Rafael, to whom Don Baltazar had refused the precedence to which they were entitled, declined to be present at this solemnity, as little as on 
Thursday, $5^{\text {th }}$, at the funeral. At 9.30 I was in the Church, and took the second seat on the bench to the right of the high Altar, occupied by the chief mourners; Baltazar took the first seat, the third, a young medical man Ricardo, a natural son of Don Rafael, who however had to cede it to the Minister La Jara, whom Baltazar had espied among the gentlemen present. President Pardo had sent one of his aides-de-camp to represent him, also the Government's coach, in which, the service being over, Don Baltazar, the aide-de-camp, Ricardo Velarde and I drove to the pantheon, following close behind the hearse, behind us some infantry and artillery, which however returned before reaching the pantheon. At the gate of the cemetery the coffin was lowered and carried through the chapel to one of the niches, which, the coffin being placed into it, was immediately walled up by the bricklayers waiting for the purpose; this was to me the most affecting part of the ceremonies. We then returned to town, the four already named in the Government carriage, the remainder in their own, and the hackney coaches in which they had come out. On Monday the $2^{\text {nd }}$ had died Francisco Calderon, quite suddenly, owing to the bursting of an artery; he was a Guayaquileño, brother of Doña Balta, Vicente Rocafuerte's wife. I had known him about forty years ago as a robust young man; captain of a merchant vessel, after which I entirely lost sight of him until his reappearance in Lima with a moderate fortune, and a young woman from the Mauritius as his wife. He was made one of the Gerentes of the Banco La Providencia, afterwards President of the Directory of La Socíedad Maritima, in both which capacities he was much esteemed; as far as I knew he left his widow and child a very fair [...]. [443]

Friday, $6^{\text {th }}$ of June 1873. Early in the morning expired Manuel Espantoso, perhaps seventy years of age; he was a Guayaquileño, but had settled over to Lima many years back in consequence of the political convulsions which troubled his native country; he was a merchant, not rich, but well-to-do in the world; in former years he was an inveterate gambler, but with advancing age this passion diminished.

Saturday, $7^{\text {th }}$ of June. This day died Admiral Forcelledo, a very insignificant man, of whom I will only say that his mother was one of the Maldonados from whom in 1840 I bought my house Calle del Correo, and his wife, Josefa, daughter of Don Pio Tristan.

Friday, $13^{\text {th }}$ of June. More or less since the beginning of the month the Lima winter had regularly set in; the mornings were foggy, the streets wet and dirty, and thus for the present I had given up the ascent of San Cristoval.

On the $19^{\text {th }}$ ulto. my petition referring to the conversion of the special bonds held by me and my two colleagues in this transaction, into bonds of the internal 
debt was left by me in the office of the Minister La Jara, with whom I had since then been more than once, had always met with a kind reception, and been assured of as quick a dispatch as circumstances would permit; nevertheless, the affair dragged on from day to day, from week to week, and at the present moment the expediente was in the hands of the fiscal Don José Gregorio PazSoldan. On Monday and Wednesday last Dupont was prevented from coming, so that these two days would have been extremely tedious to me, if Ricardo had not read to me for several hours an account of the late Franco-German war, which was very interesting, as it gave all the details, with which hitherto I had not been acquainted. This book, called the War Chronicle, embellished with many wood-cuts was presented to me by Alejandro on my birthday; the narration is quite as impartial as can be expected in such a compilation.

The night from Tuesday to Wednesday last my wife was suddenly taken ill of a strange nervous attack; she awoke in a state of great nervous debility, a torrent of tears relieved her, and after having taken a little wine she felt somewhat better, and again fell asleep. Dr. Bambaren however ordered her to remove to Chorrillos without delay. She remained in bed on Wednesday and Thursday and this day, Friday, had so far recovered as to be able to get up.

The last news from Europe were not satisfactory; the true Republicans were gathering strenght in France, and were not satisfied with the late concessions made by Thiers [...] Monarchical party. In Spain the Republicans and Carlists were conti[_] [444] fighting; sometimes the one, sometimes the other, had the upper hand. Several failures had taken place in Vienna, and the Bank of England had raised the rate of discount to $6 \%$, in consequence of which the Peruvian loan of 1872 which had been quoted at 65 , had declined to $62 \%$; this, the Minister La Jara himself told me. Here in Lima the firm of Dreyfus drew generally every fortnight about £ıoo,ooo, not sufficient for the demand, last steamer at $441 / 2 \mathrm{~d}$ the sol, $90 \mathrm{~d} / \mathrm{st}$.

Saturday, $14^{\text {th }}$ of June. A telegram from Payta brought the advice that Thiers had resigned the Presidency, and that Marshal Mac Mahon had been named in his stead. The Imperial palace in Jeddo, it was said, had been destroyed by fire; that Boston in the United States had suffered from a great conflagration was certain. I was present at three meetings; the first, of the shareholders of the Banco del Perú, for the purpose of electing a new gerente - Emilio Althaus having resigned his post - was not sufficiently attended, and therefore nothing was done. In the office of the Water Company all the members of the board were present viz.: Andres Rey, the manager, José V. Oyague, Nicolas Rodrigo, Iguirre, José Basagoytia, Enrique Prevost, and I. The agreement, or new contract, drawn up by the Municipality of Lima for the purpose of adjusting 
and settling the different claims and disputes which for a considerable while past had interrupted the good understanding between this body and the Water Company, was approved in all its parts, and Rey was authorized to get the escritura signed without delay. In the Banco de Lima the Gerente Lembcke made known to the Directory that the bank had been called upon by the President to take a share in a company which was to be formed for realizing the "estanco", or monopoly of the Iquique nitrate; its capital was to be 5,000,000 Soles, its object to furnish the funds for the purchase of the nitrate produced in the salitreras, which nitrate was then to be sold by the Company, all, purchase and sale, on account of the Government; the sales commission to be $21 / 2 \%$, commission for chartering vessels $21 / 2 \%$, interest, pro and contra, $9 \%$ annually. Pardo expected that the Banks established in Lima would subscribe jointly for $25 \%$ of the five millions, that the salitreros themselves would take another $25 \%$, and the remaining $50 \%$ should be offered to the public, with the additional condition that the amount not taken by the public should be taken by the banks. The Directors who were present were unanimously of opinion that the Banco de Lima should not take an interest in this Company for the simple reason that it had not the means required for the first immedia[_] outlay. [445]

Sunday, $15^{\text {th }}$ of June 1873. I was present this morning at the funeral of General Manuel de la Guarda, who had died of dropsy on the $13^{\text {th }}$, early in the morning, after very long and severe sufferings. Though I had been personally acquainted with him, I knew but little of the particulars of his political and military career, in the course of which he had always preserved a fair reputation for integrity and consistency in the political opinions he had once adopted; sprung from an obscure Lima family he entered into the service of the Peruvian army probably after the victory of Ayacucho; already at the time of the PeruBolivian Confederacy, he had risen to the rank of General, but after the fall of the Protector he necessarily retired into obscurity. He was not present at the invasion of Bolivia by General Gamarra, but a few years later we find him actively engaged in the conspiracy which led to the Dictatorship of General Vivanco; after the defeat which this latter sustained at Carmen Alto near Arequipa, Guarda once more disappeared from public life; afterwards, I do not recollect under which administration he was for a short period Minister for War. At the time of the Prussian-Austrian war, he was in Europe; whether his absence was voluntary, or the consequence of banishment I cannot say. He was married twice; the first time with a lady of a very respectable Arequipa family, la Señorita Landazuri, the second time with a lady of the bluest blood of Lima, Catalina Mendoza y Boza, widow of the highborn Carrillo, Conde de 
Monte Blanco, with whom however she did not lead such a happy life as she did afterwards with the low-born Guarda.

Wednesday, $18^{\text {th }}$ of June. I attended a meeting of the shareholders of La Constructora presided by Emilio Althaus who stated that the object of the meeting was to lay before the shareholders a plan for liquidating the old Company, and for establishing another society upon its ruins, but that at the very last moment Henry Meiggs had made them a verbal proposal to take a share in the Constructora for the sum of one million Soles, and that he, Althaus, was of opinion that this proposal of Meiggs should be carefully discussed before any other determination were taken, to which all gave their consent, and next Wednesday was fixed upon for our again assembling, then to hear from the Directory the result of their negotiations with Meiggs. Emilio Solar, one of the Directors, moved that in meanwhile the judicial proceedings against the same Meiggs for the payment of his debt of sixty-odd thousand Soles should not be stopped; I, and two or three more voted with Solar, the majority against us, and thus Meiggs again gained a respite for the payment of his debt, of at least 8 days. I enquired of the Directory what they had decided upon on the subject of the $S / 12,000$ ceded by the [...] [446] the reply was that they had accepted the donation, with thanks to the givers; I again enquired whether the market place built by the Constructora on the Paseo de Aguas had been delivered up to the Municipality, and was answered that it had not.

Sunday, $22^{\text {nd }}$ of June. A telegram received from Payta, and published in the Nacional, said that the Empress Eugénie had arrived in Paris, that the Emperor of Germany was very ill, that the well-known Italian demagogue Ratazzi had died, and that the Bank of England had raised the rate of discount from 6 to $7 \%$, which last news augured very unfavourably for the realization of the Peruvian loan of 1872 .

Monday, $23^{\text {rd }}$ of June. Dr. Bambaren having, as above said, strongly advised my wife to remove for a month or so to Chorrillos, where in his opinion the change of air would do her much good, we this day followed his advice, and went by the 2 O'clock train to the said place, accompanied by Enriqueta, Ricardo, and the two little girls. Our servant Juan was to have come with the luggage by the same train, but did not make his appearance till 6 O'clock, when Enriqueta and children had already returned to Lima; thus, dinner was not ready till 8; we had a short visit from our old friend Don Mariano Blas de la Fuente, and retired to rest at about 10. The servants we had brought with us besides Juan, were: our old Chinese cook Achipe, another Chinese Ayao, whom in October of 1872 I had bought from Guillermo, the black servant woman Peta, and another black woman, Virginia, who in case of need was an excellent nurse. 
Tuesday, $24^{\text {th }}$ of June. Dia de San Juan. A great deal was to be done, the strawmats to be placed in the corredor, the curtains to be fastened, trunks to be opened, the pantry to be put in order etc., but to our great surprise much was wanting, both of our earthen and glass-ware, keys did not fit, or were lost, the gas did not burn, in short nothing was in such good order as it should have been. When on my way to the Gas Company to call some one to arrange our gas I met the Arequipeño Mariano Olazabal, with whom I went all over the place, and was surprised to see the palaces which had of late been built, especially in the Calle de Lima, which street was fast extending towards the Barranco, there were: that of Tenderini, abounding in marble and inhabited by the President Pardo, who, it was said, paid \$10oo monthly rent, that of José Antonio Garcia y Garcia, that of Heudebert, that of Manuel Irrigoyen and that of Estenós; others were in progress of construction, amongst whi[_] that of José Gregorio Paz-Soldan, which occupied the site of the ranch [...] [447] the property of Doña Ignacia Palacios; it would be a tremendous structure when finished - towards the sea it was to be four stories high, and the ground floor of the third story was on a level with the street. On my return we breakfasted, and at about 12.30 I started for one of my usual long rambles. I crossed over the ridge of hills towards the well-known spot el Salto del Frayle, then along the beach, where I found Chorrillanos digging with their hands in the wet sand for crabs and mussels, until a protruding headland stopped my progress; this I climbed up, no trifling job, and when I had reached the summit a sudden cold mist drew up from every side, it concealed the highest point where the cross stands, and which I looked out for as my landmark. I entirely lost my bearings, but following the path which I chose at random, it fortunately took me down to the high road which leads from Villa to Chorrillos. I met five or six labourers, all Chinese, not a single negro or cholo. By 3 O'clock I was back in my rancho. The first who paid us a visit was Dr. Bernardo Muñoz, and whilst I went to see the family of General Pezet, José Vicente Oyague called upon my wife, afterwards Manuel Alvarez Calderon, and Enrique Ayulo. We dined and spent the evening by ourselves. My wife was talkative, and in very good spirits, but in the middle of the night of

Wednesday, $25^{\text {th }}$ of June, she called me, and complained of extreme debility. I fetched her some wine, and some cold meat, which did her good; later on she took a little water and cognac, and when I left by the 9 train this morning she felt somewhat stronger and better. There was no doubt that the climate of Chorrillos was more agreeable than that of Lima; it was drier, and less cold.

In the meeting of the shareholders of the Constructora, the Directory communicated to us that Henry Meiggs had declared his readiness to join the 
present company and to contribute a capital of $S / 1,000,000$ but of this million, S/300,00o were to be taken by the Company in the ground which was his, which extends all round Lima, and which he had purchased with the object of transforming it into a handsome boulevard; for that part extending from the Chorrillos Gate to the right, as far as the Camal, he asked S/4 for that to the left as far as the Hospital del 2 de Mayo, S/3 the square vara. Pedro Tello Larrañaga and the Italian architect Tenderini proposed the Directory should offer him the same price per square metre, which would make a difference of $40 \%$, and this the majority consented to, though not a few, I of the number, had their misgivings as to the advantages which would accrue to the Company from such a union [...] Meiggs. Ever since Henry Meiggs' appearance in Lima I for my [...] [448] had never entertained a particularly good opinion of him. I dined with the family Garland, and took the 9 p.m. train for Chorrillos.

Thursday, $26^{\text {th }}$ and Friday, $27^{\text {th }}$ of June 1873. Both days I availed myself of the 5 p.m. train, so that I took my dinner with my wife in Chorrillos. It seemed to me that the few days stay in this village had already done her some good; she was certainly a little stronger than she had been in Lima of late; some of her acquaintances, particularly Doña Trinidad, wife of General Cisneros, occasionally came to see her, but upon the whole she was much by herself, and of this she complained; she was always fond of society, and solitude was not made for her.

On Friday died, after an illness of 27 hours, Ernest Wagner, a native of Silesia, a man not of refined education, but of a straightforward honest character. For twelve years he had been clerk of H. Witt \& Schutte, afterwards Schutte \& Co, for a long time cash-keeper, and whatsoever work was entrusted to him he always performed it with exactness, and to the satisfaction of his employers. When the house liquidated he went to Europe, married, and on his return established himself for the sale of wooden-gilt lists, and mouldings, engravings, pictures, and the like, but soon discovered that these articles did not find many purchasers. He then added all kinds of preserves to his stock, took a baptized Jew, Brunswick, from Lubeck for his partner, but the business did not prosper, and - I say so in May 1878 - a small loan which Mr. Schutte made to him has not been entirely paid off. Wagner had also the misfortune to lose both wife and child.

Saturday, $28^{\text {th }}$ of June. Once more I remained in town till 9 p.m.

Sunday, $29^{\text {th }}$. San Pedro y San Pablo. I was up early. My wife had prepared for me a light breakfast, and by the 7.15 train I went to Lima where I merely crossed over from the Chorrillos to the Callao Station. Hence a considerable number of Germans accompanied in an extra-train the mortal remains of poor 
Wagner to his last resting-place in the Cemetery of Bellavista. Few of them were known to me, and I only recognized Charles Pflucker, Sass formerly clerk at Lembcke's, now in the firm of Baur Krüger \& Co., Kast, partner of Castillo Kast \& Co., and the two Brunswick's, the elder owner of a cigar-shop, the younger, Wagner's partner, which latter told me that the cause of Wagner's death had been a colic; the intestines, he said, had actually been twisted, so that he could not ease his bowels, neither upwards nor downwards. When we had arrived in Bellavista, the coffin, placed on a bier, was [...] [449] in the chapel, where the Revd. Mr. Henry read the funeral service in English; at the open grave he pronounced a few prayers in German, which he did very fairly, then nine young Germans sang a funeral hymn, and finally another German, Welsch, pronounced a discourse, from which we learned that Wagner was born in Silesia in 1832, and that before coming to Perú he had been secretary to a Prussian Chargé d' Affaires in Central America; the discourse was extremely well spoken, and when it was over more than one eye was wiped, more than one nose was blown. Above sixty persons were present, amongst whom a little German boy, Emil, ten or twelve years of age, who having lost his father and mother at the time of the earthquake in 1868, had been adopted by Wagner, who a few hours before his death bequeathed to him S/100o which sum would no doubt be held at the boy's disposal. At 9.30 we were back in Lima. At a later hour I went to see the Pedros and Pablos, the Petronilas and Paulas of my acquaintance. My first, longest, and most agreeable call was that upon Doña Petita, the President's mother; my other visits were very short, for I had not much time at my disposal, as I had to return to Chorrillos by the 5 O'clock train - they were to Doña Paula Benavides, the old mother of the well-known Evaristo Gomez-Sanchez, he a hypocritical fanatic, she a fanatic by conviction, to Pedro Paz-Soldan, the owner of a sugar estate in Cañete, to his niece Petita, married to her cousin Carlos, not in, to Petita Lapuente, Frederic Marriott's wife, to Pablo Vivero, not at home, and finally to Pedro Bernales.

From Monday, $30^{\text {th }}$ of June, to Saturday, $5^{\text {th }}$ of July. With one exception I dined every day in Chorrillos, and only one evening were we by ourselves; old Don Mariano Blas de la Fuente was our most regular visitor. In the course of this week various people known in Lima society died: General Allende, probably more than eighty years of age, Doña Paula Cortés, notorious for her litigious propensities, and, on the $2^{\text {nd }}$ July, at 8 a.m. Doña Estanislaa Bergmann, at an advanced age; she was a Buenos Ayrean by birth, her maiden name Rubio, and had come to Lima about the year 1822 with her husband Frederic Bergmann, a Hanoverian, who having been a clerk of the firm of Britain of Buenos Ayres, was 
sent hither to establish a house under the name of Templeman \& Bergmann. He was a very good, and amiable gentleman, not of a shining intellect, she at that time a dashing, handsome, young lady; both were fond of seeing company [...] I believe that for a quarter of a century no house in Lima had been visit $[\ldots]\left[45^{\circ}\right]$ and frequented more than theirs. Their Saturday evening parties were always crowded and not a Sunday passed without some friends dining with them. They had 6 children: Sophia, Federico, Carlos, these three born in Buenos Ayres, Isabel, Estanislao, and Augusta. The first blow which fell upon them was the death of Isabel, the loveliest girl in Lima, in $185^{2}$ at the age of 24. Eight or ten years later died Mr. Bergmann, then Estanislao, who drank himself to death, and in October 1871 in París, Sophia as Mrs. Dreyfus, who from her childhood had hardly ever known what it was to enjoy good health for a single day, her complaint having been asthma. For the last three or four years of her life Doña Estanislaa was almost continually by herself. Of her many acquaintances Dr. Maclean and I were the only ones who still called upon her, and when I went to see her on Sunday forenoons, she always seemed to be glad to see me and to have a chat with me. Three children survived her: Federico, married, Carlos ummarried, both very insignificant, and Augusta, the best creature in the world, wife of Meceno Espantoso. On Thursday night, near 10 O'clock, I went to the house of the Bergmanns to accompany the body to the Church of San Francisco, many people were present. I went arm in arm with Juan José Moreira. The church was lighted up, and, as usual, the coffin was received by singing friars; I however had no time to wait till the ceremony was over, for I had to hasten to the terminus to take the 10.45 train to Chorrillos. On Friday I was at the funeral.

On Wednesday the Directors of the Banco de Lima met, and we had a very animated discussion. Lembcke read an official note from the Minister of Finances La Jara, in which he asked the bank to make a loan to the Government, the Government placing into its hands as security, Vales de la nueva Deuda Consolidada, about being issued. It was a service which was asked. Rodrigo and I said at once that we should not again answer in the negative as we had done the other day when the Government had asked our assistance in the Nitrate monopoly business; several were of a different opinion, but at last it seemed to me that all had so far come round as to be willing to lend a small sum. Then Lembcke spoke decidedly against it: "our means", he said, "do not allow us to make this loan; if we do so, we must ask the shareholders for a new cuota", to which measure, all present, I excepted, were opposed, on account of the scarcity of money in the market. Then I had to put it to the vote whether we should make a loan to the Government [...] [451] and the majority was against 
it; Muro, Sagastabeytia, the two gerentes, Pedro Bernales, and Heudebert, I myself saw stand up, which means that they voted for the refusal; how Puente and Mendoza opined I could not distinguish. Rodrigo, Escudero, and I were of the contrary opinion. This being settled, a proposal of the Monteros was read, who asked for a loan of S/10o,ooo, which they promised to cover by making shipments of sugar to the consignment of the bank from their estate of Caucata; I had to run away in order to be in time for the 5 O'clock train, before any resolution was taken.

On Saturday I came to town by the 11 O'clock train, not by the 9, as usual. My detention was owing to the bad night I had passed. When on Friday night my wife retired to her bedroom at about 10 she found that the rain had passed everywhere through the roof, and that her bed was wet; her bedstead had to be removed; she lay down in mine, and another was made up on the sofa in the parlour for me. Everywhere the rain came through, and all kinds of vessels, earthenware, glass-ware, and wooden were put in requisition to receive the dropping water. Also upon my couch the rain fell; which was received in a spittoon placed upon the same whilst I was fast asleep. At half past three I was awakened by the pattering noise which the big drops made upon the roof, and at 5 O'clock a complete torrent broke through the cielo raso, which of course was completely spoiled; this was the climax, and shortly after the rain ceased. For many many years such a fall of rain had not been experienced in Chorrillos; the streets were nearly intransitable. The greater part of the day was taken up by meetings. At one O'clock my four colleagues in the Directory of the Pasco Railway Company came, and we talked on various subjects, expecting Juan Martin Echenique, who in the course of the week had settled his accounts with Wyman \& Harrison, and with whom we had now to arrange the amount due to him by the Company. He came as late as 2.30 and as at this very hour Sagastabeytia and I were cited to a meeting of the Directory of the Banco de Lima, we requested him to return on Monday, which he agreed to. In the Banco de Lima all the Directors except Zuloaga, always ill, and Muro the Secretary, were present. The resolution of our last meeting was to be reconsidered. Lembcke gave a detailed account of the many conferences which he had had with the President of the Republic, and with the Gerentes of the other banks, between whom the greatest harmony had prevailed, and whom, to put a seal to their new fraternity, Derteano had invited, as well as the Minister [_] Jara to a breakfast in his house on the next day at 10 O'clock. All [...] [452] Directors were now unanimous in authorizing the Gerentes to take some part, of course as small as possible in the loan of $\mathrm{S} / 10,000,000$ to be made to the Government against Vales de la Nueva Consolidacion at $75 \%$, whilst these vales were offered 
to the public at $80 \%$, the payment to the Government to be made in the course of one year, either in monthly or three-monthly instalments. On enquiry I was told that on the $2^{\text {nd }}$ inst. after I had left, the loan of S/10o, ooo asked by the Monteros had been denied to them. From the Banco de Lima Lembcke, Gil, and I went to the monthly meeting of the Directory of the Insurance Company "Lima", where nothing of importance was transacted. Twenty five shares had been sold by Enrique Perez de Velazco to Ford of Dreyfus' house at the premium of $75 \%$, and Carlos Elizalde told us that for $\$ 2000$ disbursed by him on his 20 shares in the South American Insurance Coy., $\$ 7200$ had been offered him, and not been accepted. About 5 O'clock a horrible crime was committed not many streets distant from our house. Close to each other in the same story lived an Italian Swiss, a glazier by trade, and an Italian woman, the widow of a "pulpero" with her four little children. She was, according to all accounts, an honest, and pretty woman. The glazier, even during the lifetime of her husband, had pursued her with his addresses, to which she had not listened and after her husband's death he became from day to day more pressing. This day he entered her room with the question "Will you marry me or not?" When she answered in the negative he drew out his knife and cut her right across the face, then inflicted other wounds upon her, of which the most dangerous one was that which pierced one of her lungs. The eldest boy, a mere child, who beat the assassin with a stick was wounded by him in the hand. When the police came he barricaded the door; he then put a ladder to a small balcony, and the first policeman who mounted was shot dead on the spot; other policemen fired at him, when he being wounded first set fire to some loose powder, and then shot himself through the head. The fire engines were soon on the spot, and the fire was quickly extinguished.

Sunday, $6^{\text {th }}$ of July 1873. In Chorrillos I took an extraordinary walk. I left my house a little before twelve, and ascended the range of hills behind the village from that side most to the right, and then up-hill, and down hill to the summit where the cross usually stands, but which now had been taken down to the Church, there to be reblessed, thence down to the other extre[_] of the ridge where I was at 1.30; here, a fine circular beach called "la Ch [...] [453] before me, the crossing of which, to the next headland which impeded further progress took me a quarter of an hour's quick walking. I had to reascend, but was stopped by a crevice or gulley, not very deep, but so abrupt and steep that I hardly think a cat could have ventured to descend into it. I had to retrace my steps down to the beach, and to climb up from another side; and after great toil I once more reached the summit. I was home at a quarter to four, having been on the move without resting a second nearly four hours. I then dressed, and paid 
three visits: to Ayulo, Manuel Alvarez Calderon, and Jose V. Oyague. During my absence several gentlemen had called upon my wife; Melchor Velarde and Ricardo Garland dined with us. In the evening we were by ourselves.

About two months back I gave in this diary a short extract of a book I was then reading, called "Artic Researches", by Charles Francis Hall. The New York Tribune of $12^{\text {th }}$ May 1873 gave an account of the death of this Artic explorer. On the $29^{\text {th }}$ June 1871 he left New York in a vessel called the "Polaris" fitted out by the United States Government with the object of reaching the North Pole if possible, and at all events of ascertaining the existence or non-existence of the open water round the Pole, reported by Kane, and supposed to exist by other scientific men. In August 1872 news had been received nearly one year old; the "Polaris" had touched at Tossac in Greenland, the most Northern civilized settlement on the globe. In September 1871 the "Polaris" wintered in latitude $81^{\circ}$ 38', whence Captain Hall made an excursion on sledges, probably to a latitude exceeding by a few minutes that reached by Parry by way of Spitzbergen, say $82^{\circ} 45^{\prime}$. The explorers saw before them a strait calculated to be fifteen miles in width, hitherto supposed to be Polar Sea; this they crossed, and on the other side, that is, still further North, there was again appearance of open water. From this point Captain Hall returned to the "Polaris" on board of which he soon after died. After his death another attempt was made to proceed further North by water, which having failed, the return voyage was decided upon. On the $15^{\text {th }}$ October 1872 when in latitude $77^{\circ} 35^{\prime}$, nineteen persons left the vessel - probably deserters. According to their statements they were ordered to store provisions on the ice, because the "Polaris" was expected to go to pieces, and that when on the ice, the floe, about five miles in circumference at the time, broke loose; for six months they drifted Southwards through the Artic night until in April 1873 when the floe had melted away to twenty yard [...] meter they were picked up by a vessel called "the Tigress" about fort[_] [454] miles from the Coast of Labrador, more or less in the latitude of Liverpool.

Monday, $7^{\text {th }}$ of July 1873 . I was called to a meeting of the shareholders of the Banco del Perú, which was convened for the purpose of determining what was to be done in the Nitrate monopoly business. I had no time to remain, being cited to a meeting of the Directory of the Banco de Lima, and learnt afterwards that the shareholders had empowered the Directors to take the steps which they might think proper. In the Banco de Lima we had an animated discussion, of which it is unnecessary to give the particulars, because the Gerentes remained authorized to do what they thought most advantageous for the bank, always taking an interest corresponding to our capital in the loan, or to speak 
more properly in the purchase of the bonds of the new internal debt, which were about being issued by the Government at $75 \%$.

Wednesday, $9^{\text {th }}$ of July. The shareholders of the Lima Water Company assembled, and the remainder of the new shares (the capital being augmented $50 \%$ ) not yet distributed, were apportioned to those who were willing to take them. I had counted upon 13 to make up the number of 70 , but received only 10, so that I now held 67 of $\$ 500$ each. At 3 p.m. it commenced raining; when I went at 5 O'clock to Chorrillos the rain had nearly ceased, then it rebegan, and lasted till past midnight with a violence entirely unknown in Lima. The result was that it passed through the roof of every house in the town, and the "Comercio" valued the damage done to furniture and carpeting at half a million of Soles, which might perhaps be an exaggeration. In our house we escaped, comparatively speaking, with little damage, thanks to the activity of Enriqueta, who having the keys to our rooms, and assisted by Garland, Alejandro, and the servants placed every description of vessel under the spots where, the cielos rasos being pricked with a big needle, the water came down, sometimes in drops, sometimes in torrents.

Thursday, $10^{\text {th }}$ of July. All day long the rainfall of the previous night and the measures to be taken to prevent in future a similar inroad of rushing water into our saloons and upon our carpets and furniture, formed the topic of conversation. It was the general opinion that the best thing to be done was to cover the roof with sheets of zinc placed in a somewhat slanting position, so that the water collecting in narrow canals, or gutters, might run down into the street; but as this was a very expensive expedient I felt convinced that very few proprietors of houses would have recourse to it [...] [455] that they would go on in the same manner as hitherto, in hopes that as a similar rainfall had not occurred for many years a like period would elapse before its recurrence. In the forenoon of this day, as well as on

Friday, $11^{\text {th }}$ and Saturday, $12^{\text {th }}$ of July my colleagues in the Directory of the Pasco Railway Coy., as well as myself, Juan Martin Echenique being also present, spent many hours in fixing the amount due to this latter by Wyman \& Harrison, for outlays made by him whilst the railway was under his charge, and which amount the Coy. had to place to the debit of Wyman \& Harrison, and to pay to Echenique in spares of the Pasco Railway Company, in accordance with the authorization given to us, the Directors, by the shareholders in the meeting on the $2^{\text {nd }}$ Octr. 1872 - See pages 370 and 372.

From Sunday, $13^{\text {th }}$ to Saturday, $19^{\text {th }}$ of July. This week was a very quiet one. My wife remained in Chorrillos enjoying very fair health. I went to town every morning, and was back for dinner; only on Friday I stayed till 9 p.m., being 
detained by a meeting of the shareholders of the Constructora, which lasted till nearly 5 , and in which much was spoken and nothing done, owing solely to the want of formality of Henry Meiggs, who made one day one verbal proposal, and the other, gave in a different one in writing. Another term of eight days was allowed to the Directors, of whom by the by only Emilio Althaus and Rufino Echenique were present, to close with Meiggs, and if they did not come to terms to break off all negotiations with him.

The decree referring to the Estanco del Salitre was published. It was to come into force on the $1^{\text {st }}$ September; the Government bound itself to purchase from the producers of Nitrate of Soda, 4,500,000 quintals per annum, to be delivered in monthly instalments, at the rate of $\mathrm{S} / 2.40 \mathrm{cts}$ the quintal, if the nitrate was of a pureness of $95 \%$, if less the price was to vary in proportion. In order to find the funds for making these payments it was the intention of the Government to form a company with a capital of $S / 4,000,000$ of which the three Banks "Nacional", "Perú", and "Providencia" had taken jointly 1/4; the salitreros might take $1 / 4$, and the remaining half would be offered to the public; in case the salitreros and the public should not be inclined to subscribe for the $3 / 4$ allotted to them, then the three banks were bound to take the amount which might be wanting to make up the four millions. The Salitreros who should prefer $[\ldots]$ themselves of the quantity of Nitrate which fell to their share [...] [456] the total of four millions and a half of quintals annually might do so, and dispose of it as they thought proper, paying to the Government an export-duty of 15 centavos the quintal, of which 3 centavos went to the company. The sales commission allowed to the Company was $21 / 2 \%$, interest $9 \%$ per annum.

From Sunday, $20^{\text {th }}$ to Saturday, $26^{\text {th }}$ of July 1873 . A week like the previous one, and void of interest. On Friday a few of the shareholders of the Constructora, I one of them, assembled, but there not being a sufficient number to form a quorum, we soon separated.

On Saturday I was detained in town till a later hour than usual with paying off the labourers who, under the direction of our servant Juan, had been employed in covering the roof of my house with a thick crust of earth to prevent the passing of the rain, as it had done on the $9^{\text {th }}$. In Bolivia, José Balivian had been elected President, I believe a nephew of that Balivian who was President of Bolivia about the year 1840 .

Sunday, $27^{\text {th }}$ of July. After having been occupied with Dupont till past one I, instead of taking the train for Chorrillos, went to the Exposition Palace, where a concert was given by the members of the literary club, and to which one of them, Luis Benjamin Cisneros, had given me a ticket. The hall on the ground floor was filled with the audience, whilst the platform was occupied by the performers, 120 in number according to programme. The concert, which 
satisfied nobody, and much disappointed me, began with the National hymn, with variations by Claudio Rebagliati; I liked best the singing by Mrs. French, of which connoisseurs thought little, the march from the Opera Tannhäuser by Wagner, by the whole orchestra, and some playing on the piano by Guzman, accompanied by some of the other musicians. It was over by 4.30 and I in time for dinner in Chorrillos.

Monday, $28^{\text {th }}$ of July. Anniversary of the Declaration of the Independence of Peru in 1821 was, I was told, a very dull day in Lima; the President being unwell was not even present at high mass in the Cathedral. In Chorrillos it was equally dull; I, to while away the time, began my ascent of the Moro Solar from the beach, and climbed up a sandy slope, which, though with great difficulty, brought me up to near the summit; but here I came upon some hard ground with rolling stones, and ledges of rock projecting the one over the other; further ascent was to me impossible, the descent very diffi[_] I had to lie down and slide three or four times the length of my body [...] [457] again reached the sand; in doing so I had however to take great care not to lose the power over my motions, for had I not kept my limbs under my control the impetus increasing every second might have carried me down hill much too rapidly, endangering, if not my limbs, at all events my trousers.

Tuesday, $29^{\text {th }}$ of July 1873. A great civil procession paraded the streets of Lima, the different nationalities of America being represented by a few of their countrymen carrying their respective banners; the first place was assigned to the Cubanos libres; there was also a car with the Goddess of Liberty, further, the Lima firemen in their red uniform with their ladders and engines. I saw nothing of it, but Alejandro told me that the whole had turned out a miserable affair. By the steamer for Panamá many passengers left for Europe; General Echenique with leave of absence for one year, and his son Juan Martin, George Elster and wife, the two Misses Goyeneche, and their two brothers José Sebastian and Juan Mariano, the latter with his wife and some of his children - the two youngest he left under the care of his wife's aunt Joaquina Puente - and in their company, to the great surprise of all who knew her, Doña Manuela Subiaga, widow of Pedro Salmon.

Thursday, $31^{\text {st }}$ of July. Mr. Dupont being unable to come before 12 I also remained in Chorrillos till 11 ; I had previously taken a walk with Mr. Alexander Ruden, who was desirous to point out to me a Dane, whom he believed to be somewhat crazy, and who had taken up his abode a little outside Chorrillos where the ground was very uneven, and rent by gullies and crevices. Here he had shaped two places for himself, the one, a narrow bit of a cave with a mat answering the purpose of a door; the other, the inner most recess of a crevice, with a mat on the open side, and another for a roof, both affording 
him some shelter against the inclemency of the weather. His bed consisted of a mat, all his utensils a black earthen pot and a wooden spoon. We met him carrying a bundle of sticks to his abode, and accosted him; he spoke English, German, and Spanish fairly, more than sufficient to make himself understood. On another occasion he had told Ruden that it was a sin to kill any animal and that therefore he only lived upon bread, potatoes, and apples; to me he said that all languages were alike, and that the only language was "not to steal". He was extremely fair, and his age at the utmost I should think 35 . He further told me that he was born in Lundby, between Roeskilde and Copenhagen, that [...] was Andrés Petersen his father's Peter Sören; he had been in [...] [458] country about twelve years, and had not come out as a sailor, but how he came hither he did not tell me. When I asked him why he did not work he answered that he could not; he lived upon alms, and as his wants were very few he was satisfied with a trifle. His dress was much worn out.

In the evening of this day the weather in Chorrillos was dry and pleasant and my wife felt well; we therefore ventured out, and paid three visits, the first to the wife of Manuel Costas who occupied the house of his brother José Maria. The lady was unwell in bed; her daughters received us, and with them was the widow of Brauns who kept up the conversation. Next, we went to Henry and his wife, with whom we remained a long while; he told me that the telegraphic correspondence between the London house and the WestCoast establishments was carried on in cyphers, which it would be utterly impossible for anyone to understand. He showed me one; even the date was a cypher - instead of it stood the Spanish word "Alabanza" - the word "Nefando" meant wheat, and thus every word had a meaning impossible to be guessed at. He further said that since 1842, when I had separated from the house, their business had increased on a gigantic scale, and on my observing that the loss of the guano business must have caused a great difference in their profits he answered, "Well, I can tell you; William Gibbs \& Co. have had the best year since they lost the guano". In London the firm of A. Gibbs \& Sons consisted at the time of seven partners: Mr. William Gibbs, more than eighty years of age, who lived generally at his country seat Tyntesfield, near Brístol; Mr. Henry Gibbs who resided in the mansion in Regent's Park; it was he whom we used to call young Mr. Gibbs, son of George Henry, elder brother of William; a son of this Mr. Henry, who had been in the Lima counting-house and with whom I was not acquainted, was the third Gibbs in the firm. The fourth partner was G. T. Davy, formerly of Valparaiso, perhaps four years younger than I. The fifth, Edward Stubbs, who had been a long time on the coast, and of whom I have spoken on previous occasions; he was at the head of the Lima house until he was succeeded by Henry; he was now the active manager in London, 
but on important occasions had to consult Mr. Henry and finally Mr. William Gibbs. The sixth partner was Augustus Sillem, Chef de bureau; in 1857 he was established with his brother, both sons of Hermann Sillem of Hamburg, once partner of Mr. Grautoff; the crisis of that year upset the two brothers, when Augustus had the good luck to find a rep[_] in Gibb's offices. The name of the seventh partner escaped [...]. [459] Our last visit was to Mrs. Ayulo, whose husband was indisposed, and in bed.

Friday, ${ }^{\text {st }}$ of August 1873 . The usual monthly meeting of the Directory of the Banco de Lima took place. Nothing of importance occurred. The purchase from the Government of the ten million Soles Bonds de la nueva consolidacion, was not yet finally settled; it seemed that Don Manuel Pardo had at last come to and agreed to sell them at $75 \%$, allowing the bank a commission of $21 / 2 \%$, whilst hitherto he had insisted upon $771 / 2$ and $21 / 2 \%$; but now the banks were of opinion, and very properly so, that the new Anglo-Peruvian bank which was on the point of being established, and which, it was said, had already done some business, ought to take its respective share of the ten millions bonds, and so the affair stood. This day I made a proposal to the proper government office, to redeem S/10,00o of my Lima-Huacho Railway bonds, and 2400 Soles Bonos de la nueva consolidacion, at $75 \%$. My proposal was accepted and I got the money. I lost of course upon the original cost, but gained $5 \%$ upon my valuation of $28^{\text {th }}$ February 1873 .

The news from Europe was unimportant; the Republicans in Spain had gained a battle or two over the Carlists. The Shah of Persia had been received in London with much pomp and magnificence; also in Paris, where he was expected, great preparations were being made. The famous German historian Friederich Von Raumer, the author of the History of the Hohenstauffen, had died in Berlin. The dispute between Perú and Japan relative to the "Maria Luz" had been referred to the arbitration of the Emperor of Russia.

Saturday, $2^{\text {nd }}$ of August. The second daughter of Vicente Gonzales, sister of Dreyfus' wife, was married to a North-American, Dubois, engineer in Meiggs' service.

Sunday, $3^{\text {rd }}$. In order to celebrate the anniversary of Manuel Pardo's accession to the Presidency, a review was held in the Alamedas round the town. I received from the Minister for Foreign Affairs an invitation and ticket for the Exhibition Palace, but did not go.

Monday, $4^{\text {th }}$ of August. My wife being desirous to consult Dr. Bambaren, she and I went to town together, were we remained till

Friday, $8^{\text {th }}$. This day the usual monthly meeting of the Directors of the Insurance Company "Lima" took place, in which nothing of importance was transacted. In the beginning of the week advice was received of the death of 
Pedro José Bustamante, my wife's compadre, in Arequipa; to his widow, Doña $[\ldots]$ I without loss of time penned a letter of condolence. From Ay [...] [46o] we learned that a revolutionary movement had broken out, at the head of which stood a certain Col. Bedoya, who had proclaimed a Junta, consisting of General Vivanco, Dr. Ureta, and Nicolas Pierola, the first and last at present in Chile, Ureta on his way from Europe. Immediately Don Manuel Pardo dispatched per steamer two battalions and a few pieces of light artillery under the command of Col. Silva to Pisco, thence per rail to Ica, and across the Cordillera to Ayacucho, where, I was in hopes, the movement would quickly be suppressed. Another piece of news, which for a few days caused some apprehension here in the Capital, was that about twenty leagues from here, between San Juan de Matucanas and San Mateo, an entire mountain, 2000 feet high, had tumbled over, covered part of Meiggs' railway, and entirely blocked up the river Rimac; now some people feared that the river, stopped for several days, would finally break over like a cataract, carry every thing before it, and even endanger the safety of the suburb of San Lazaro, which lies on the right bank of the river, somewhat lower than the part of the town on the left side.

Saturday, $9^{\text {th }}$ of August. Advice was received that on the previous night the waters of the Rimac had reached the summit of the mountain which was lying in their way, had overflown the same, and we now saw the river, of a brownish color, carrying with it a somewhat greater volume of water than usual, quietly flow along its bed, without doing any damage on either side.

My wife had caught a bad cold when going to Lima, and she had now again to keep her bed.

Monday, $17^{\text {th }}$ of August. A considerable number of the shareholders of the Banco del Perú assembled in a saloon of this establishment. The object was to elect a new gerente, in lieu of Graña who had temporarily filled the post since Emilio Althaus' withdrawal. Three candidates were in the field: Cesar Canevaro, Alexander Ruden, and Carlos Prevost; the first named was chosen, by 380 or 390 votes out of 610 ; Ruden had 112, my votes, those of the two Costas, José Maria Peña, Goyeneche, Dibos, and perhaps one or two more; Carlos Prevost had 90, amongst which Oyague's; Chacaltana and Carlos Elizalde had also each 12 votes.

Tuesday, ${ }^{\text {th }}$ of August. By the 7 O'clock train my wife and I, together with the servant Peta, came to town, intending to return to Chorrillos in a day or $\mathrm{t}[$ ]. We therefore left there our clothes, our plate, and many other things, and the ra[_] itself in charge of our two Chinese, of the black girl Virginia, and our $\operatorname{ser}[\ldots][461]$ 
Friday, $15^{\text {th }}$ of August 1873. When I awoke, a cold from which I had been suffering for several days, had increased to such a degree that I thought proper to send for Dr. Bambaren. His remedies were very simple: hot milk with a spoonful of cognac and another spoonful of orange water, to make me perspire, and now and then a teaspoonful of a certain syrup to assuage the cough. I remained in bed this day, as well as

Saturday, $16^{\text {th }}$. The one and the other who called upon me during these two days, told me as a fact that Don Manuel Pardo, the President, had of late been more than usually low-spirited, and that the view which he took of the financial prospects of Perú was a very desponding one. As per advices received from Europe the late Peruvian loan enjoyed but little credit on the London and Paris Stock Exchanges. The last quotation was as low as $59 \%$ and not a few ascribed this their gradual decline to the intrigues of Dreyfus' firm, but whether there was any truth in this assertion, I was unable to say.

Sunday, $17^{\text {th }}$ of August. I felt well enough to rise from my bed, and remained in my bedroom well wrapped up. The letters received in the evening, by myself from Juan, and by Garland from Mr. Schutte, brought excellent news for Garland; his nomination as one of the two gerentes of the Branch, established in Lima, of the London South American Company, had been resolved upon his companion was to be young John Gallagher. There was also every probability, though as yet no absolute certainty, that he would be one of the Directors of the Anglo-Peruvian Bank, the capital of which was to be nominally

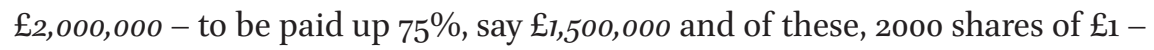
each as a donation to the original founders, and the remaining £1,498, ooo partly to be subscribed by the same founders, partly to be offered to the public.

I may say in anticipation that neither of the two posts was ever filled by Garland.

Tuesday, $19^{\text {th }}$ of August. I was again well enough to attend to my usual occupations. On going into the street I learned that on Saturday last a meeting of the shareholders of the Constructora had been held, but been poorly attended. In opposition to the opinion of the two Althaus, members of the Directory - Emilio, President - the majority had resolved not only to admit Henry Meiggs as shareholder for $S / 1,100,000$ but even to take in part-payment of this sum a considerable proportion of the ground which he owned round Lima, and for which he had paid the Government four rials the square metre, at comparatively speaking [...] high prices; to the amount of S/400,000. Emilio Althaus had [...] [462] a motion, which was carried by a majority, not unanimously, that the entire Directory, as well as the Gerentes should resign. 
I much approved this step, because it would free us from the Gerente César Saco, whom I looked upon as one of the main causes of the want of success which had attended the Constructora.

This being the birthday of little Maria Garland - who completed her fifth year - her mother, in celebration of the same, invited a large number of little girls and boys, perhaps seventy in number, to witness a puppet-show, or titeres, which gave great delight not only to the little folks, but also to the grown-up people, some of their papas and mamas. Enriqueta's large saloon, with its new carpet, new chandelier, and new furniture looked extremely well; to save her handsome chairs, covered with delicate silk, she had hired a great number of common cane-bottomed ones, but notwithstanding this precaution she had the mortification to find that some of her own had been soiled, and somewhat damaged. It was near midnight when the party broke up. In case in after years one or other of the family should look into this my diary, curious to learn who at this period were the acquaintances of his parents and grandparents, I, that he or she may not be disappointed, specify the names of the guests; they were: Doña Dolores Puente, my wife's particular friend, her sister Petita with her husband Frederic Marriott and two children; James and Lily, Mr. Henry's children; Pedro and José Bernales, each with a being of little ones; José Basagoytia with I do not know how many of his progeny; Felix Dibos, wife and three children; two children of Sattler; Rebeca Montero, grand-daughter of Julius A. Pflücker; Mariano Felipe Paz-Soldan, wife and one grand-daughter; José Vicente Oyague, with two or three of his children; Manuel Mendoza with two boys; Rafael Velarde, wife, Zoila, and other children; Melchor Velarde, and five of his; Jesus, wife of Colonel Masias, her sister Tránsita, and one or two children; Asuncion Santillana, daughter of Jervacio Alvarez, her grown-up daughter Aurora, and two little ones; M. Alvarez Calderon and children; Baltazar Aranivar, by himself; and for a certainty many more whom I did not recollect.

Friday, $22^{\text {nd }}$ of August. My wife and I having changed our mind, and resolved not to return to Chorrillos for the present; Enriqueta and I with two of our servants went out by the 10 O'clock train. The whole day was taken up with putting things in order, and picking out what we required for our Lima household. We returned per 4 O'clock train. [463]

Saturday, $23^{r d}$. I had again to go out to look for some keys which we had forgotten.

From Ayacucho we learned that Col. Silva had entered the town without striking a blow; the insurgents had fled to the province of Cangallos and would probably disperse. Of a less favourable nature were the advices from Iquique. Here the lower classes were decidedly opposed to the Nitrate monopoly, and it 
was said that they had threatened to destroy every estanco office which might be established. Mr. Williams, who had been named one of the Government employés, returned, not liking, as he said, to expose his life for Manuel Pardo's sake; Fabricio Cáceres, another employé, had also met with a bad reception.

Sunday, $24^{\text {th }}$ of August 1873 . Early this morning, or rather at 12 O'clock last night, died at the age of $5^{0}$, Dr. José Simeon Tejeda, a native of Chuquibamba, one of Manuel Pardo's staunchest adherents and best friends; hardly three or four weeks previously he had been chosen Alcalde of the Municipality of Lima, and it was said that Pardo wished him to be his successor in the Presidency. When Prado was Dictator he was Minister of Justice and Pardo his colleague, as Minister of Finances. In the last Congress he was president of the Chamber of Deputies and after its closure was chosen one of the members of la Comision Permanente. His profession was that of a lawyer; as such he enjoyed a good reputation; it was he who gained for the family of the Uretas their suit against the Ugartes, both parties claiming the large property left by the rich miser Miguel Ugarte. The fortune which he left to his widow, a sister of the auctioneer Igarza, with five children, was inconsiderable.

Tuesday, $26^{\text {th }}$ of August. The funerals of Tejeda were celebrated in the Church of La Merced with great pomp, and the number of coaches which accompanied the hearse to the pantheon was unusually great. About this time advice was received of the death of a valiant chief, Colonel Baltazar de la Torre, Prefect of Cuzco, who on an exploring expedition into the montaña had been killed by the Indios Bravos. The revolutionary movement in Ayacucho was at an end, its chief, Col. Bedoya, killed.

Saturday, $30^{\text {th }}$ of August. In last night's "Nacional" a great many documents relative to the last sale of Peruvian Bonds to the amount of nine millions and a half of pounds sterling at $60 \%$ effected by Dreyfus, and approved of by Carlos Gonzales Candamo, named by Pardo Financial-Agent for Perú, [...] published. A few of them were read to me and I gathered from them th[_] [464] following which I believe gives a correct idea of this transaction. At the time when Meliton Porras, who under Balta's administration was sent to Europe

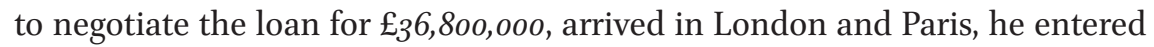
into negotiations with a group of merchants, probably Dreyfus Brothers \& Co., John Henry Schroeder \& Co., la Société Générale, B. Premsel, and others, who formed "le Syndicat". One of their first steps was to buy up, and to take out of circulation all that remained of the Peruvian loan of 1865 , this being one of the conditions of the new loan. For this their outlay Porras agreed with them that they should be reimbursed before the $33^{\text {st }}$ December 1872 out of the proceeds of the new loan, and if they were not, they might themselves sell the 
quantity required at any price obtainable. This term of $31^{\text {st }}$ December 1872 was first prorogued to $31^{\text {st }}$ March 1873 and again to the $30^{\text {th }}$ September of the same year, after which date the Syndicat would on no account whatever submit to any further prorogation. Under these circumstances Candamo, seeing that the credit of Perú was declining daily, a sale having actually been effected at $58 \%$, and fearing that if the Syndicat were not paid before the last mentioned date, they would in order to cover themselves sell at any price, thought it advisable rather to submit to a certain, but known loss, than to run the risk of still greater sacrifices when after the expiration of the term the syndicat - as already said might dispose of the bonds at any price; consequently, he authorized Dreyfus to sell $£ 9,500,000$ at $60 \%$, which was done accordingly. By means of this sale the debt to the Syndicat had been cancelled, and a balance of $£ 1,900$, ooo remained in the hands of Dreyfus, which had been applied by them to the account of Public Works, and against part of which the Lima firm I supposed drew by last steamer, for when I applied to them for £1ooo which Garland wanted for Schutte, their reply was that they could not give them to me, they having drawn very largely in favor of Meiggs.

This being the day of Santa Rosa I paid my respects to eleven Rosas which was pretty hard work, and just at $5.30 \mathrm{p}$.m. I got through with it. They were: Juana Rosa Velando, wife of José Basagoytia; Rosa Elias, Mrs. Lizardo Montero; Rosa Lopez-Aldana, wife of the Italian, Francia, who, formerly a music-master, turned merchant, and had just suspended payment; Mrs. Cipriano Correa, Rosa Veyan; Rosa Beltran, Carlos Elias' wife; the widow of Lacharrière, Rosa Telleria; Rosa Osma, an elderly, unmarried lady; Maria Rosa Dartnell; Juana Rosa Moreira, the wife of General Nicolas Fr [... [465] Juana Rosa, one of the daughters of the Vocal Ribeyro.

Sunday, $37^{\text {st }}$ of August 1873 . We had in the evening a visit from our tenants Mr. and Mrs. Dibos; the former told us a story, which, if true in all its details, redounded little to the honour of the parties interested - Dreyfus, and his brother-in-law Frederic Bergmann. The wife of the former, Sofia Bergmann, having died without issue, and intestate, her property, according to Peruvian and I believe also according to French laws - reverted to her mother. During the time of her marriage with Dreyfus he entered into the guano business, and in all probability at the time of her death already possessed a considerable fortune, to prove which would however be no easy matter. Accordingly, this one half was by rights to be Mrs. Bergmann's or her heirs', which Dreyfus foresaw when he was last in Lima, and in order to forestall such a claim, came to an understanding with Mrs. Bergmann; he paid her S/30,000 (which sum even included the $\$ 13$, ooo which he was said to have received at the time of his marriage with Sofia) and she signed an escritura, in which she renounced every 
claim on Dreyfus which she might have as heir to her daughter; but Federico, a short time before his mother's death, made her sign her will - whether she was acquainted with its contents nobody could say - in which she declared that Dreyfus had obtained by fraud her signature to the escritura just spoken of, which accordingly was null and void; she further declared that one fifth of what might be recovered from Dreyfus was to be set aside for the natural daughter of her deceased son Estanislao. Federico has now commenced or would commence a suit against Dreyfus for half of the gain made during the time of his marriage with Sofia.

Monday, ${ }^{\text {st }}$ of September. We had our usual monthly meeting in the Banco de Lima. Heudebert told me he knew for a certainty that it was the intention of the Banco del Perú to ejecutar the Eten Railway Company, which means, to rebegin judicial proceedings and to carry them on until, if meanwhile their claim were not settled, the railway and everything belonging to it were brought to the hammer. Another bad piece of the news was that the Minister of the Interior claimed from the Constructora the amount of the two monthlyinstalments paid to this company during the time of Balta's administration, on account of the contract for the widening of the bridge, which contract had been annulled since Pardo came into power, and in order to obtain this contract, as previously stated, a bribe had been paid to the then Alcalde, Peña, of $S / 25,000$, which sum was of [...] irretrievably lost. Still further news came to my knowledge. [466]

The firm of Ramos Roel \& Co., who for some time had carried on their business at the corner of Santo Domingo, in the house which was formerly occupied by Solari Schmidt \& Co., had stopped payment. Their debts amounted to S/300,00o amongst which S/63,00o to Pedro Noriega, Roel's father in law, and partner of Valdeavellano, who for this sum had given his guarantee to the Banco del Perú. Francia had in a similar manner let in his brother-in-law Francis Bryce for S/6o,ooo.

Dr. Bernardo Muñoz, Vocal of the Supreme Court of Justice, above sixty years of age, had just taken for his second wife a dashing and handsome young woman about thirty years of age, Irene, sister-in-law of the Criminal Judge Ponce. Muñoz's daughter Jesus, at least of the same age as her stepmother, had some time previously, knowing probably what was going to happen, left for Ica, where her husband Panizo possessed an estate. Manuel Morales, Fiscal of the Superior Court, not quite so old as Muñoz, but also advanced in years, was said to be on the point of following his colleague's example.

Wednesday, $3^{\text {rd }}$ of September. Last night the headless body of a white man was found in the suburb of San Lazaro in the street which turns off to the left after passing the bridge. In the evening of the same day, Antonio, brother of 
Cosme Ugarte of Callao, lost his life by his own imprudence; he having been in the habit of jumping upon the train whilst in motion, tried it again this evening, but slipped, fell, and the train passed over him.

Thursday, $4^{\text {th }}$ of September. Yesterday being Garland's birthday Enriqueta had invited several friends to spend the evening at her house, they were: Rafael Velarde with wife and daughters; Melchor Velarde;José Pablo Escobar and wife; Felix Dibos and wife; a certain Seminario from Piura; M. Alvarez Calderon; Ignacio Tavara; Malinowski the Polish Engineer; Da Ponte, Secretary to the Brazilian Legation; Carlos Ferreyros, Alejandro's friend; Mesquita a Portuguese, late captain of a merchant vessel, and a certain Taboada, Guillermo's friends; Jose Vicente Oyague and José de la Riva Agüero. The two last mentioned, who were no great rocambor players, were the first to leave at about midnight. Various gentlemen had declined coming for different reasons, such as Manuel Costas, José Maria Sancho Davila, Manuel Mendoza, Rafael Canevaro, Meceno Espantoso, Sagastabeytia, Chavez, and perhaps a few more. Between 10 and 11 tea was handed round, afterwards ices; at one we went to supper, which, I should say, was too good, too abundant, and the preparing of which had given too much tro [...] [467] daughter. Before supper three rocambor tables had been formed; after supper again some inveterate players sat down, whilst the younger folks tried to dance a little, which however did not answer, as Ricardo played the piano very badly. It was nearly 4 O'clock when I went to bed, much too late to my taste; the last did not leave till 5 O'clock.

Monday, $8^{\text {th }}$ of September 1873. Natividad de Nuestra Señora. Horse races were held on the race ground. In the evening Henry Higginson, to celebrate his wife's birth-day, gave a ball, at which all the young Garlands except Ricardo were present. It lasted till 6 or 7 O'clock in the morning of

Tuesday, $9^{\text {th }}$, and they said that everything had been exquisite, but according to the account given by the young Garlands the families present could not be numbered among the first society of Lima.

Wednesday, $10^{\text {th }}$ of September. Last night came off a most splendid entertainment in the Club de la Union; it was a fancy-ball, for which preparations had been made for the last six months, many of the ladies' dresses having been ordered from Paris, where they had been made by the first milliner, Worth, Rue de la Paix. Alejandro, to whom Manuel Candamo had lent a beautiful costume of a page of the XVI century was present, and told us that it had in fact been a magnificent affair. The two daughters of Manuel Costas had attracted general attention, and were much admired, the one as a Greek, the other as an Indian Princess; Fortunata Nieto, the wife of José Maria Sancho-Davila, representing Margarita of Valois, sister of Charles IX of France. Rosa Elguera, the wife of 
Mariano Laos, and her daughter Inez, married to Rafael Canevaro, which latter in a dress representing Night, was the Patroness, and received the guests, were resplendent with diamonds. A witch, in which character appeared one of the Delgados, was much spoken of; the daughter of José Maria Peña, whose dress had been sent out by Rosa Schutte, attracted much attention by her genteel appearance. One of the daughters of Cipriano Correa represented a butterfly with wings attached to her body; her sister, "la folie"; Maria Rosa Dartnell a nereu in a light green vestment, and so on. This morning some of the last who left, amongst whom Mesquita, who on the $3^{\text {rd }}$ inst. supped with us, went to take a cup of coffee in an hotel, unknown to me, the Lima Hotel, Calle de Plateros de San Agustin. Whilst the coffee was getting ready Mesquita rose and walked out into a passage; suddenly two shots, and shrieks of "Policia" were heard. The young men got up [...] Mesquita dead, two balls having passed through his head. [468]

In this hotel lived two Frenchwomen of easy virtue, with one of whom Mesquita was well acquainted; he knocked at the door, which was locked; for inside was a Frenchman, Henry Grafar. What occurred in the next two or three minutes did not transpire, and was likely to remain a secret for ever. It was said that Mesquita was warned not to enter, and that he had some high words with the Frenchman, which if true would go far to exculpate this latter, who, it was supposed, had fired the shots. Alejandro assured me that the second shot was fired when Mesquita was already on the ground, and dying.

In the forenoon the Portuguese Minister Vasconcello, and the Portuguese Consul Narciso Velarde were in Mesquita's rooms occupied with making an inventory and putting the official seals upon his effects. His fortune amounted to forty of fifty thousand Soles, and not a month back he had rented a chacra in the vicinity of Lima.

During the day I had a visit from M. G. Chavez, who at my own desire had come for the purpose of examining my mercantile books, and to whom I readily explained everything which he wished to know regarding the one or the other entry. A week or so previously I had made a petition to the Minister of Finances in which I asked for a reduction on the amount of S/80o which I was ordered to pay for my "patente", a real income tax of $4 \%$, levied upon the income of every individual who gained his livelihood by some profession or other. The minister of Finances had named a commission consisting of Messrs. G. Heudebert, J. Gildemeister, and M. G. Chavez, who had to examine the various claims made for reductions, and to determine whether any reduction was to be made or not; from their decision there was to be no appeal. I had been with them, and they had readily acceded to my proposal that one of them should inspect my books. 
Thursday, $11^{\text {th }}$ of September. The funeral of Mesquita was celebrated in the Church of La Merced, at which three of the young Garlands were present. At the same hour the exequies of Baltazar de la Torre were held in the Church of San Agustin. About this time General Nicolas Freyre, hitherto inspector of the Army, was named Minister of War instead of General Miguel Medina, since whose resignation Riva Agüero had attended to this Ministry, as well as to his own, that of Finances. Col. Silva, just returned from his successful expedition against the Ayacucho insurgents, filled now General Freyre's place as Ins [...] the $\operatorname{Ar}[-]$. [469]

Saturday, $13^{\text {th }}$ of September 1873. I went to see Gildemeister, who told me that from the examination of the memoranda which Chavez had taken when with me on Thursday last, and which he had laid before the Commission, they had come to the conclusion that I had no right to ask for a reduction, because my own books showed that the gains which I had made, exclusive of those arising from immovable property and from my shares in Joint-stock companies, came to a sum which warranted the patente of $\mathrm{S} / 800$; or, if there existed a difference, it was so trifling that it could not be taken into consideration; moreover, if last year had been a bad one, the present one, he said, might leave a better result. This last was for a certainty a very poor argument; however, in reality I had not to complain. José Vicente Oyague, whose patente had been fixed at S/2000 annually, far too little compared to mine, had also petitioned for a reduction, and received the same answer as that given to me.

Sunday, $14^{\text {th }}$ of September 1873. I affix in appendix under $\mathrm{N}^{\mathrm{o}} 12$ a cutting from the Nacional which gives a description of the fancy ball on the $9^{\text {th }}$.

As regards the murder of Mesquita, there was no doubt that the Frenchman Grafar had killed him, but he who was locked up with the Frenchwoman was believed to have been a married man, a deputy, and not unknown in Peruvian politics. As to the other murder, spoken of on the 3 inst., it came to light that the headless body was that of Juan Antonio Olmus, a native of Caracas, according to all appearances a man of some property; he had taken his lodgings in room $\mathrm{N}^{\circ} 12$ in the first story of the house $\mathrm{N}^{\circ} 4$ Callejon de Romero, and in a chest of drawers were linen shirts exactly similar and marked with the same number as that he had on his body; in an open trunk were found two bills on London to the amount of more than £200o and on the floor bloodstains, partly washed away. The porter had been taken up on suspicion, and some other persons residing in the same house were suspected of being implicated in the murder.

Monday, $15^{\text {th }}$ of September. A few days back Mr. Dupont had given me warning that he wished to leave Lima and to remove to San Francisco, where 
he expected that the climate would agree better with his constitution than had been the case in Lima. I was far from regretting his departure, for though I could put up with his general slowness, his morose and lachrymose character was not to be borne. This day he went to Callao to make there some arrange $[\ldots]$ and I availed myself of the three hours before di [...] clim [...] [470] San Cristoval accompanied by Ricardo. Seldom before had I seen the sides of the mountain so completely covered with a short green plant and innumerable delicate flowers, lilac and yellow. The paths were completely overgrown, and moreover, being somewhat slippery owing to the late rains, the ascent was not quite so easy as it used to be in the dry season.

Tuesday, $16^{\text {th }}$ of September. This morning at about 2 a.m. died Doña Manuela Puente, married, after the death of her first husband Juan Aliaga, to Clemente Ortiz de Villate, at present in Paris.

At about 3 p.m. there was a meeting of the shareholders of the Lima Gas Company. Frederic Marriott, the Gerente, stated that the Company owed to Bates Stockes \& Co. £53,ooo for coals and all kinds of gas apparatus, and as about the same amount was required for increasing the Gas Works, not sufficiently large for the present demand, and for the laying of the pipes to carry the gas to a few streets hitherto without it, and to the boulevards round the town, he was of opinion that $S / 75^{\circ}, 000$ should be raised, which could easily be done by issuing fifteen hundred new shares of $S / 500$ each. José Vicente Oyague, member of the Directory, then spoke, and said that the remittance to the Liverpool house was to be first attended to, and secondly, the enlargement of the works; but that the company should not think of laying pipes to the boulevards where as yet there were no houses, for this would be causing a great expense without a corresponding remuneration, and he opined that one thousand new shares of S/500 each would suffice, these to be offered, firstly, to the shareholders, at par, and if all were not taken by them, the remainder to the public. The debates were animated. Manuel Candamo, Dionisio Villate, Francis Bryce, Carlos Delgado, and a gentleman from Callao, unknown to me, spoke a good deal, though not much to the purpose; Ruden and I also said a few words. When on the $3^{\text {st }}$ March a dividend of $71 / 2 \%$ had been paid to the shareholders, which, with $71 / 2 \%$ previously paid, made a gain of $15 \%$ for the year 1872 , these large profits had actually been made, as was manifest by the books; but, the money wherewith to pay this dividend did not exist in cash, and thus the company borrowed $\mathrm{S} / 100,000$ at $1 \%$ monthly interest form the Banco del Perú, which loan had also now to be returned. All present blamed the Directory for having done so; "when there is no money in the chest, no dividend is to be paid." This had always been my opinion which I had clearly expressed on more than one 
[_]. Final [...] [471] agreed to the issuing of one thousand new shares of $S / 500$ each. Whilst we were here together it was whispered by the one to the other that Bianchi, the Italian, who had of late been doing a very extensive business in import and export articles and who, having no fortune of his own, had been a continual applicant to the banks for assistance, had clandestinely made his escape from Lima.

Wednesday, $17^{\text {th }}$ of September 1873. The rumours which were afloat on the previous day regarding Bianchi were but too true. On Monday night he had gone off to Guayaquil in a steamer belonging to the Pacific Steam Navigation Coy. expressly chartered by him. Last night a meeting of his creditors was held at Gustavus Heudebert's; fortunately I was not of the number; for a long time past I had given orders to the various Lima bill-brokers not to present to me any document bearing the signature of Bianchi, Marcone, Mazzini, and other Italians.

Bianchi's debts came up to S/3,200,00o. Joaquin Ortiz, the Spaniard, was said to be a creditor for S/500,0oo, Errequeta, Heudebert \& Co. for S/200,ooo, Marquet \& Co. for S/200,00o; of smaller creditors the number was legion. It was further said that on Saturday last he had bought from Dreyfus bills on London to some extent for which he had promised to send a cheque on Monday, which he had not done. This morning César Canevaro and a few others intended to go in pursuit of him in another steamer; whether they actually left this very day I did not learn.

In the forenoon the Directors of the Lima Water Company met, when Rey, the Manager, laid before us a very clear statement which showed the difficulty which the company would have to supply the town with the sufficient quantity of water in the course of the ensuing warm season. After discussing the matter it was agreed to adopt the plan which he suggested, and if the Municipality did not throw any obstacle in the way, which this corporation did but too often, there was every probability that we should be able to procure the water required.

Thursday, $18^{\text {th }}$ of September. Having advertised in the Callao "South Pacific Times" for a lector and secretary, various persons presented themselves and this day I engaged Mr. Edward Deeble, hitherto in the office of the said paper; he promised that on the $1^{\text {st }}$ October he would be with me without fail.

Friday, $19^{\text {th }}$. Lembcke showed me the list of the pagarées and acceptances with the name of Bianchi upon them, discounted by the Banco de Lima; they amounted to nearly $\mathrm{S} / 400,000$ of which, if I remembered correctly, S/63,00o [...] ned [_] Bianchi and endorsed by others - the remainder signed by oth[_] [472] and endorsed by Bianchi. Though the greater part of the co-signatures were good, I feared that the bank would lose at least S/50,000 and I could not 
help reminding Lembcke how often I had warned him and Zaracondegui not to involve themselves too deeply with Bianchi. On one occasion Zaracondegui had said to me boastingly "what a deal of discount we should have lost had we followed your advice" and now the result lay before us.

From Sunday, $27^{\text {st }}$ of September to Wednesday, $7^{\text {st }}$ of October 1873 . The short interval between these two dates the $21^{\text {st }}$ Septr. when Mr. Dupont was with me for the last time, and the $1^{\text {st }}$ October when Mr. Deeble made his first appearance, passed rather heavily, for though Ricardo did his best to while away my time by reading to me the chronicle, written in German, of the Franco-German war, yet I missed my customary occupations, the remodelling of my old diaries, and the listening to Mr. Dupont's reading of two interesting works - Lord Mahon's History of England from the accession of the first George till the peace of Versailles in 1783, and the History of the Sepoy war in 1858.

In a meeting of the shareholders of La Constructora, which was held on the $22^{\text {nd }}$, the propriety of liquidating the Company was discussed. The debates were very animated. Opposed to the liquidation were, above all, Don César Saco, the Gerente, the Italian Tenderini, also Garland, his sons, and some of their friends; in favor of the liquidation were: the two brothers Althaus and their circle; I voted with them, and they gained by as small a majority as possible, 405 against 400 . It was nearly 5 when we broke up.

On the $24^{\text {th }}$, Dia de las Mercedes, I merely called upon Mercedes Guise, and Mercedes Riva Agüero, which latter saw a few friends with her in the evening; amongst them were Garland, Enriqueta, and two or three of her sons. Dancing was kept up with great animation till an early hour in the morning.

On the $25^{\text {th }}$ the shareholders of La Constructora were once more assembled. César Saco did his utmost to invalidate the decision of the $22^{\text {nd }}$, but did not succeed; thereupon two shareholders were named to liquidate the business, and the choice fell upon Garland and Augusto Althaus. They were to have no fixed salary, but a percentage on the sums they might collect viz.: $5 \%$ jointly on the first 100,000 [...] [473] upon everything between 100,000 and S/200,000 and $25 \%$ on any amount above $\mathrm{S} / 200,000$.

On Friday the $26^{\text {th }}$ the Directory of the Banco de Lima met, when Lembcke read to us a circular directed by the Minister of Finances to the various banks, by which two Directors of each bank were requested to meet the Minister at 7 O'clock the same evening, for the purpose of consulting on the measures to be taken in order to remedy the present monetary crisis. We named Lembcke and Escudero to represent the Banco de Lima.

On Sunday the $28^{\text {th }}$ by the 2 O'clock train I went to Chorrillos to have a look at our rancho, also to pay a few visits, to Mariano Blas de la Fuente, Doña Goya Velarde, and General Pezet, which latter, his son Federico and wife, an 
English lady, were particularly friendly; and conversing with them I missed the 4 O'clock train. They then invited me to dine with them at a quarter past five, which I did, and was not a little surprised at the elegance of their dining saloon, of their table-service and glass-ware, and of the gentility which pervaded the whole establishment. Don Federico had brought out with him for his children as teachers, a Frenchman and an English lady, man and wife. Besides myself, Mrs. Henry, and her little daughter Lilly, only the family sat down to dinner, nevertheless we were as many as sixteen. I had also time to look in at Kast's, who had rented Luna's rancho, close to ours, and at Doña Trinidad Cisneros'. By the 6 O'clock train I returned to Lima.

In the forenoon of the $1^{\text {st }}$ October I went to the Banco de Lima to enquire how things were going on there since Bianchi's stoppage, when Lembcke told me amongst other things that on the previous day a pagare for $\mathrm{S} / 30,000$ signed by Errequeta, Heudebert \& Co. and endorsed by Bianchi Hermanos \& Co., which latter had discounted the same at the bank, had fallen due, and that when it was sent to Heudebert's office for payment he had refused honoring his signature on the plea that he held a counter-document signed by Bianchi, of which the bank had not the slightest knowledge. This unaccountable conduct of Heudebert spread like wildfire through the commercial circles of Lima, and there was not a single one who understood anything about business, who was not surprised at Heudebert's proceeding. In the course of the day I learned that he, having probably taken the advice of some of his friends, had gone to the bank, and placed into the hands of the gerentes as a security for the [...] payment of his document acceptances and pagarées [...] [474] solvent people, and endorsed by him in blank. So the affair was satisfactorily settled, but the mere attempt to avoid payment could not fail to injure the credit and mercantile character of Heudebert.

Thursday, $2^{\text {nd }}$ of October. In the meeting of the Directory of the Banco de Lima the Gerentes informed us: Firstly, that Joaquin Ortiz has sold his share in the bank to José Vicente Oyague at $12 \%$ premium. Secondly, that considerable payments had been made on account of Bianchi's debt. Thirdly, that Meiggs had asked for a loan of $S / 100,000$ which we unanimously declined making to him. Fourthly, that the hacendado Geronimo Sanchez who owed to the bank about $S / 200,000$ had declared his inability of fulfil his engagements. We resolved that as the principal was well secured by mortgages on his estates there was no necessity for pushing him for the payment of the same, but that the gerentes should insist upon the payment of the interest as soon as due.

Finally, Lembcke laid before us a plan of Manuel Pardo's for bringing coined gold from Europe hither in order to remedy the scarcity of the gold and silver 
circulating medium, which every day made itself felt more and more. He proposed to lend to the banks established in Lima, jointly, Anglo-Peruvian Bonds of the year 1872 , paying $5 \%$ interest, to the extent of $£ 2,500,000$. These were to be placed into the hands of some London Banker, who was expected to advance upon the same, and to send hither, one million sovereigns. With the exception of Lembcke, my colleagues believed this to be a splendid idea; I was of a contrary opinion, but my remarks were not well received. I understood that the banker was to keep the bonds in his possession, but that without the consent of the banks he was not allowed to dispose of them. How could it then be expected that anyone would be so rash as to make an advance without any available security? And, Secondly, when the banks had to cover the banker for the advance made by him, how was this to be done? Bills, it was known, were always scarce, and to be had with difficulty; if silver or gold, in bars or coin were sent to the banker, then Pardo's object, to augment the quantity of gold and silver, circulating in this country, would evidently be frustrated.

Saturday, $4^{\text {th }}$ of October. My colleagues in the Directory of the Pasco Railway Coy. came as usual, also Henry Wyman. The compa[_] [475] account with Wyman \& Harrison carried down to the $30^{\text {th }}$ June of the present year, was examined and found correct. We separated at 3.30 when I went to the monthly meeting of the Directory of the Insurance Company "Lima", where nothing of importance was transacted.

Sunday, $5^{\text {th }}$ of October 1873. In the course of the preceding week Bianchi had returned from Guayaquil, and some people were of opinion that it would be advisable to render him pecuniary assistance to enable him to continue his business, for, were he to declare himself bankrupt, they said, other firms might be carried along with him and the injury done to the Lima commercial world would be incalculable.

From Garland I learned that he and Augusto Althaus, the two liquidators of La Constructora, could not agree in anything, and that hitherto nothing had been done by them. The Gerente, César Saco, had refused to acknowledge their authority, and Emilio Althaus, the President of the Directory, had not interfered as he ought to have done.

From Monday, $6^{\text {th }}$ to Saturday, $11^{\text {th }}$ of October. The only meeting which I attended was that of the Directory of the Banco de Lima, when the President's project above spoken of was once more discussed, and I had now the great satisfaction that all except Escudero had come over to my side; accordingly, it was resolved that the Banco de Lima should take no share in the same. The three other banks, La Providencia, El Nacional, and Perú, it was said, were inclined to meet the President's wishes, as far as it lay in their power. 
On the other hand, we resolved to assist Bianchi with a loan of S/300,0oo one third of which to be contributed by each of the three banks if this loan would enable him to liquidate his business, without his being under the necessity of declaring himself bankrupt - I did not relish the idea, but as it was strenuously advocated by Lembcke, and all present concurred in his views, I withdrew my objections.

The weather was unusually cold for the season, and it seemed to me as if during my residence in Lima we had never had such a wet, raw, and inclement winter as the present one. My son Juan had written to me a long while back that it was his desire to liquidate his inscription in the Chile Porvenir de Familias, in favor of the six eldest sons of Garland, and that the proceeds of this liquidation I should pay over to his sister Enrique[_]. With some trouble and after considerable delay the amount about $S / 2500[-] ~[476$ ] was paid to me by the Porvenir's agent in Lima, Mr. Anderson, whom Elster had entrusted with the management of his affairs during his absence, and I handed it to my daughter.

About this time three deaths had occurred. In Chile, that of General Manuel Ignacio Vivanco, who in Peruvian politics had been a conspicuous character during his lifetime; not less than three times had he headed revolutionary movements against the established government, the second time with partial success, when for a twelvemonth or so he styled himself Dictator of the Republic. Secondly, that of Doña Micaela Cañete, the mother-in-law of Don Pablo Vivero; she, a native of Trujillo, had resided for many years in Lima, where she was well liked and respected by all who were acquainted with her. Thirdly, that of Doña Petronila Soto-Vallejo Entre-ambas-Aguas, a Bolivian by birth, a good friend of my wife, and godmother of my daughter Enriqueta. She was the mother of Candelaria, Mrs. W. Möller, and aunt of Dolores, William Harmsen's widow, both of Arequipa, in which place she had resided for the greater part of her life; for many years she had been paralytic, and, to her, death had certainly been a release from her many and severe sufferings.

Wednesday, $15^{\text {th }}$ of October. The two liquidators of La Constructora, Augusto Althaus and Gerard Garland Sr., had had a violent altercation, in consequence of which the latter in a huff, without telling me a word about it, threw up his post, whereupon Althaus, always a disagreeable man to deal with, without the slightest consideration ordered Alejandro to deliver the cash to him, and then told him that he no more required his services. This violent step I could only attribute to the circumstance that a few weeks previously Alejandro had had some high words with him; not only was Alejandro now without a situation but his business with carts and mules had ceased to be a lucrative one, and at present actually left a loss. 
Thursday, $16^{\text {th }}$ of October. We dined with the Garlands, in company with young Enrique Bustamante, son of the late Don Pedro José of Arequipa, and with a certain Tamayo, an engineer in Meiggs' employ and husband of a daughter of W. Möller of Arequipa. From him I learned that the Railway from Arequipa to Puno might be considered as concluded, only seven leagues perfectly levelled, being without rails, which were daily expected to arrive. On the other hand, the working of the railway from Juliaca to Cuzco was stopped for the present and would in all probability not again be take [...] [477] It was also said that Meiggs had been under the necessity of discharging not less than five thousand labourers, Chilians, Peruvians, and Chinese, who were at work on the line from Callao to the Oroya, and I was not at all surprised at this, because we all knew that the treasury, which had to supply Meiggs with the necessary funds, was empty, and that with the exception of the soldiers only a few of those who lived upon the Government, such as widows, the judges, the employees in Government offices, military men not in active service, and many others, had received anything in the course of the present month. Money continued scarce, and Cedulas of the Banco Hipotecario were down to $85 \%$.

For the last six or eight weeks Garland and Enriqueta had recommenced giving on Thursdays their evening party. I being no rocambor player attended but seldom; this evening however I went. Besides the customary players who formed one table there were Mr. and Mrs. Henry, and Mr. and Mrs. Dibos; with them, my wife, and daughter, I conversed, and it was as late as 1.30 before we broke up.

Friday, $17^{\text {th }}$ of October 1873. At last, after long negotiations, and through the intervention of Francisco Sagastabeytia, who was well acquainted with Juan Aliaga y Puente, I brought to a close a purchase which I had had in my mind's eye for a long time past. At the time that I carried on the law-suit with my neighbour Col. Leyva about the acequia or gutter which he refused to fill up, I by chance discovered in the title $\mathrm{d}[$ [] eds of his house, close to mine, that in the purchase of this house, the "Aires", that is to say the superficie of the roofs was not included, for it was stated in clear words that they belonged to Juan Aliaga the father; and from the son, Juan Aliaga y Puente, I now bought them, I running the risk of the lawsuit which would no doubt arise from Leyva's opposition to my taking possession of the same.

Saturday, $18^{\text {th }}$ of October. I lent Sagastabeytia $\$ 3500$ which he required for Doña Isabel Elias to make up the purchase money of a rancho just bought by her in Chorrillos; I only did so to render him a service.

As far as I knew the creditors of Bianchi had not yet come to any arrangement. 
My son Juan wrote me from Paris on the $15^{\text {th }}$ September that France had been completely evacuated by the German troops, the last two hundred and fifty millions of francs having been paid in the beginning of the month.

Tuesday, $27^{\text {st }}$ of October. José de la Riva Agüero whom I by chance [...] [478] this day, assured me that within the last few days the various persons depending for their livelihood upon the Government - and whom I ennumerated on the $16^{\text {th }}$ - had for the greater part been paid, but that from two to three hundred thousand Soles were still owing for the month of September. He further told me that the report of the discharge of five thousand labourers by Meiggs, mentioned on the same day, was one of the usual exaggerated rumours so frequently afloat in the Lima society; the number was hardly five hundred, and these had not been discharged, but merely transferred from the Oroya to the Chimbote line.

This day Manuel Rosa O'Phelan from Arequipa, our old friend and a very respectable man, applied to me for the loan of $\mathrm{S} / 6000$ which he required to make up a payment of $S / 13,500$ to M. G. Chavez; he found himself in the greatest straits, but the utmost I could do was to lend him S/300o. With much difficulty he obtained the remaining $\mathrm{S} / 3000$ from another friend.

Wednesday, $22^{\text {nd }}$ of October. In the meeting of the shareholders of La Constructora Emilio Althaus as President of the Directory made known to us that Garland had resigned his post as liquidator, and that another was to be chosen in his place. I was the first who spoke, and said in an angry tone that in my opinion the shareholders should beg Garland to withdraw his resignation, for his interference was of incalculable value to them; also that we should be made acquainted with the cause of the disagreement between him and his colleague. After a few words from Don Emilio and Rufino Echenique I declared my willingness to fetch Garland, which was agreed to; fortunately I found him in the club and he returned with me. He gave an account of his dispute with Augusto Althaus, and to Emilio Althaus' question whether he would withdraw his resignation, he answered in the negative and left the room. Thenceforward I took no further share in the discussions, the result of which was that Augusto Althaus by an overwhelming majority, only Alejandro and I voting against it, was chosen sole liquidator with a half of the remuneration which had been fixed on the $23^{\text {rd }}$ September. Thus, I did not attain my object, but had the satisfaction of having told them my mind.

Thursday, $23^{\text {rd }}$ of October. Garland was present at the marriage of Manuel Candamo with one of the daughters of Manuel Alvarez Calderon which was celebrated in Nicolas Rodrigo's rancho in Miraflores.

In the evening my wife who was again suffering from a cold [_] [479] not go over to Garland's apartments; neither did I. 
Friday, $24^{\text {th }}$ of October 1873. In the morning I gave in to the notary Escobar my first escrito requesting the judge Quiroga to grant me judicial possession of the "Aires" of Leyva's house, bought by me from their rightful owner Juan Aliaga y Puente. He at once decreed that this possession should be given me within the legal term, that is to say, after the lapse of three days, counted from the day on which this his decree were made known to Juan Aliaga y Puente, and to Colonel José Segundo Leyva.

It being Rafael Velarde's Saint's-day I went in the afternoon to congratulate him; my wife and daughter sent him presents. In the evening Rafael Canevaro gave a ball, José Maria Cantuarias another; Garland and Alejandro went to the former, Enrique to the latter.

Here follows in my original a detailed account of the manner in which I passed my time; I copy it verbatim. "I rise between seven and eight, then either take a walk with Ricardo, or, which is more frequently the case, he reads to me in German an interesting account of the Prussian-Austrian War 1866. At 10 my wife and I sit down to our solitary breakfast; at 10.30 Mr. Deeble comes and remains with me to four O'clock; our principal occupation is the remodelling and recopying of my old diary; some of our time is also taken up with writing letters to my son Juan and other friends, and if time can be found one hour is devoted to reading; we are now finishing Lord Mahon's History of England from the accession of George I to the recognition of the Independence of the United States in 1783 . This is a favourite work of mine, and I consider it a master-piece. Lord Mahon's style is perhaps not so polished as that of Macauley; when I listen to its reading I find it does not run on quite so smoothly and glibly as the latter's History, but for that very reason I believe it impresses itself more upon the reader's memory; occasionally the author, when warmed by the subject rises to a heart-stirring eloquence, whilst now and then he makes queer and sly observations, and introduces little anecdotes which illustrate the subject he treats on and make the reader smile. His delineation of public characters cannot be surpassed; his description of the Highland rebellion of ' 45 is more interesting than the most interesting novel. Seldom am I at home the whole forenoon; I have to collect money, to go to the banks, and be present at the one or the other [_]ting. Now and then I am also interrupted by some person [480] wants to borrow money. From 4 to 5.30 Ricardo is again with me; he reads aloud, or we walk out together; at $5.30 \mathrm{my}$ wife and I sit down to dinner by ourselves; perhaps once a week we dine with the Garlands. The short interval till 7 passes away quickly; then again Mr. Deeble reads to me till 8; we are now perusing Prescott's Conquest of Mexico, highly interesting. Prescott is also a first-rate writer; I however prefer Mahon's style, not so flowery as that of the North-American author. At 8.30 we take tea; Ricardo is always with us, 
Enriqueta generally; Enrique, Guillermo, Alejandro, and Antonio are seldom at home. Garland frequently goes out to play rocambor. Visitors seldom drop in, which is very natural, for my wife and daughter owe at least fifty visits, and with difficulty can make up their mind to pay these debts. Sometimes however they drive out, when they are absent from 7.30 to 9.30. In this quiet manner the week passes; on Sundays and holidays Mr. Deeble is with me from 11 to 1.30; and from 2 to 5.30. I am invariably on the move making calls. At present we have four servants: Juan, the Mayordomo, as they say here, who has been with us for about ten years; though he is somewhat spoiled, and must always have his own way, we could at present hardly do without him, so accustomed are we to him; he is a bit of a carpenter, of a mason, a painter, tailor, in fact he is good for everything, a jack-of-all-trades; we pay him $\$ 40$ monthly. For cook we have again, after the interruption of a few years, our old Chinese Achipe, who came to us in 1852 . At present his fierce temper has abated a little, owing perhaps to old age, perhaps to the experience which he has made whilst not under our roof; he is however sickly, which is a great draw-back; his wages are six soles weekly. The third is the black servant woman Peta, very deaf, who besides attending to my wife's wants, washes; she is very vulgar, and many a time gives reason for complaint; however, we do not turn her off for fear that her successor might be worse, she gets $\$ 24$ monthly. The fourth is a Chinese, Ayao, whom we have bought, and who as yet receives no more than three or four Soles monthly. He does not understand a word of Spanish, does everything which is bid him, and is more our servant Juan's assistant, than our servant. In 1833 and the next eight or ten years we used to give our cook for providing our breakfast and dinner twenty rials, which included the cost of fuel; now we pay him double, besides paying for the coal used in the kitchen. Thus if not in a still greater proportion everything has [...] [481] Lima, house-rent above all, which, I being now proprietor of two houses, is of course in my favor - also sugar, meat, fruits, and wearing apparel; only the price of bread had remained stationary. When I came out to Gibbs in Arequipa in 1824 my annual salary was $\$ 500$, which in a few months was raised to 800 ; in 1829 when I arranged the confused books and accounts of Gibbs in Lima, which, without vaunting, few in Lima at that time would have been able to do, I was paid in six months $\$ 750$. Now 100, 120, even 200 Soles are paid monthly. My opinion is that this great rise in prices all over the world is caused by the discovery of the enormous gold riches in Australia and California."

Monday, $27^{\text {th }}$ of October 1873 . Last night at 7 p.m. Garland and I went by invitation to the house of Evaristo Gomez-Sanchez, to be present at the marriage of his young daughter Rosa to Hermann Alvarado y Aparicio, no 
relation of General Aparicio, a native of the Canary Islands, but as far as I could learn related to that Aparicio a "Mantequero", dealer in lard, who at the time of the "Consolidación", under General Echenique's administration was the first whose claim for $\$ 120$,000 for damages done to him and to his fortune during the War of Independence, was acknowledged and paid for in Vales Consolidados; also from an uncle of his, the Curate of Santa Teresa, this young man had inherited considerable immovable property; thus, one with another he was certainly a wealthy man, but his family connections were not first rate. Of the ladies who were present I of course could not recognize a single one, but I knew that there were Doña Manuela, the wife of Judge Rospigliosi; Don Evaristo's sister; the daughters and grand-daughters of José Luis GomezSanchez, and Doña Fortunata Nieto, wife of José Maria Sancho-Davila: the remainder were unknown to me. Great was the number of gentlemen; they filled the five or six apartments, handsomely fitted up and well illumined. All nations, all political parties in Perú found here their representatives: the two ministers Riva Agüero and La Jara, the ex-minister Ignacio Elguera, General La Fuente, Dr. José Luis Gomez-Sanchez, Dr. Manuel Morales, Dr. Mariano Felipe Paz-Soldan, the ex-president General Pezet, with his son Federico and his relation Blume, an engineer, native of St. Thomas, Sancho Davila, the rich landed proprietor, Nicolas Hurtado, who owed me money, and who was the Government's creditor for more than S/40o,ooo for money paid by him to the Prefect and other Government employées in the Department of Amazonas, Barrenchea, in former [...] Minister for Foreign Affairs at present Gerente de la Pater [...] [482] Banco Garantizador, and of the Salitrera in Iquique which bore his name, Antonio Sousa-Ferreyra, Brazilian, Lembcke Swedish and Norwegian, and I, Danish Consul General, José Vicente Oyague, probably at the present day the richest man in Lima, Manuel Francisco Benavides of Arequipa, member of the Comision Permamente, a political character of some weight and great friend of Pardo, etc.

The ceremony was performed by Dr. Fuentes Chavez, curate of the church in the Barranco, near Chorrillos. I stood close by, heard both the bride and bridegroom answer in the affirmative the questions put to them by the clergyman, but could not distinguish anything. Don Evaristo made an excellent host; he neglected nobody, to everyone he had a word to say. At about 9 O'clock the card-players sat down to rocambor and professional artists played the piano. I took French leave at about 9.30, and found Doña Dolores Puente, with my wife, and, as it was my custom, accompained her to her house. Garland came home at about 1 , and the dancers kept it up till 5 this morning, at which hour the newly-married couple started for Chorrillos. 
Mr. and Mrs. Henry having invited us to dine with them this day, Garland and Enriqueta, Mariquita and I, drove to their house at about 5.30. When ascending the stairs I recollected how many times I had run them up and down in the nine years from 1833 to 42 . Since Went's time I had not dined in Gibb's house. We were but few, but everything was extremely nice, genteel, and agreeable. In the middle of the table sat Mrs. Henry, Anita Went, I to her right, then Enriqueta, at the bottom of the table Böhl, round the corner Mr. Ford, Mrs. Westpal, Henry, my wife, Mr. Westphal; at the other end of the table Mr. Swift, partner of Graham Rowe \& Co.; round the corner Mrs. Ford, Garland, and again Mrs. Henry. Dinner was neither over abundant nor extravagant, but very good; conversation was carried on in both languages. When the ladies had risen we remained a short time over our wine. On rejoining them we found there two young men, both Germans: Ulrich, head clerk, and a Mr. Schroeder, clerk at Candamos, belonging to the rich Hamburg family of Schroeder. Ulrich was very clever at sleight of hand, with which he amused us all, and whiled away the time. Schroeder told me that he had served in the war against France, as officer in the Uhlans, that he had been in the bloody battle of Mars la Tour and Gravelotte, and thence been ordered Northward when he had again fought at St. Quintin; he had not been wounded, but the fatigues he assu [...] had been great indeed particularly at the siege of Metz. It was [...] [483] night when we walked home, very well pleased with this little party.

I already said, about a fortnight ago, that Alejandro had lost his situation as cashkeeper of the Constructora, and within these last few days Enrique was dismissed by Meiggs who told him that he had been well satisfied with him, and that he had saved many a rial, but that as the Government was much behind hand with their payments to him he was under the necessity of curtailing his expenses. I need hardly say how sorry I was that both these young men were now out of employ.

Business was extremely dull; both shop and storekeepers complained that their sales had fallen off 50 , and in some instances $75 \%$; and many failures were expected. Bryce Grace \& Co. paid me with interest S/10,50o due since the $9^{\text {th }}$ and within a quarter of an hour I had placed through Fernando O'Phelan S/6ooo for four months deducting $11 / 4 \%$ monthly interest.

Saturday, $7^{\text {st }}$ of November 1873. All Saint's day. I thought I might as well rise early, and climb up San Cristoval. I left the house before six, and though slowly I reached the summit without stopping; about a month ago the sides were covered with vegetation - now it was all dried up. The big cross had been removed and provisionally replaced by a small one made of reeds. I returned my usual way by the new Alameda, and was at home at 7.30. 
Sunday, $2^{\text {nd }}$ of November. Besides my customary letter from Juan, I received one from Henry Sieveking dated $29^{\text {th }}$ September, which informed me of the death of George N. Knauer, husband of Emily Reincke; he had expired in his country house in Eppendorf on the $27^{\text {th }}$ at 1 in the morning, and on the $29^{\text {th }}$ an extremely numerous cortége accompanied the body to the new cemetery in Altona.

Friday, $7^{\text {th }}$ of November. Last night I went over to Garland's usual evening party where I found amongst others Lizardo Montero, husband of Rosa Elias, a lively, rather pleasant, but I should say very forward man, of which he gave a proof by his insisting on my wife's giving a large party to celebrate her Saint'sday on the $21^{\text {st }}$. I made my escape about half past ten, and was in bed by eleven; but when Mariquita came at about one, she told me that Montero had been so pertinacious, that it had been almost impossible for her to avoid giving an affirmative answer. To me nothing was more disagreeable than a numerous assembly in my apartments, but this time, I feared, I should not be able to escape.

Bianchi had made an extremely favourable arrangement [...] [484] his creditors; they left him at the head of his business without anybody's interferance; they allowed him an indefinite term for the payment of his debts, without charging him any interest. He promised to make a repartition every time he had collected $10 \%$, and upon each collection he received a commission of $2 \%$; moreover, for the maintenance of himself and partners $\mathrm{S} / 1400$ were put aside monthly.

Saturday, $8^{\text {th }}$ of November. In the monthly meetings of the Banco de Lima and the Insurance Company Lima, held in the course of the week I had attended, as it was my custom. Nothing was transacted worth noting. Sagastabeytia, Correa, and I had a long and disagreeable interview with Henry Wyman. Felipe Barreda y Osma informed me - Sagastabeytia also knew of it - that Wyman had sold of the rails belonging to the Pasco Railway Company, to Enrique Canaval, to the amount of $\mathrm{S} / 10,000$. Sagastabeytia taxed him openly with his sale; he did not deny it, but alleged that as the amount of the rails had been charged him in account, he had a right to dispose of them; I made him observe that there was a great difference between any amount being debited to a person, and a person having paid for it, and that as he was indebted to the Company for a very large sum, it was self evident that any sum which might arise from the sale of the rails should be paid over to the Company. There was now a great deal of talk in which Correa took hardly any part; but finally Wyman agreed to bring me the money on Tuesday or Wednesday.

At a later hour two important pieces of news became known in town; the one, that the Finance-Minister La Jara had resigned, and that his post had been 
filled by Camilo Carrillo, a naval officer who for a short time had the same portfolio under Balta; the other, that Government had given orders to suspend Dreyfus' shipment of guano, until "measures were taken to secure the interest of the Republic."

I said some pages back that I had given in an escrito to the Juez de primera Instancia, Dr. Quiroga, who, consenting to my request, had ordered that possession should be given to me of the Ayres of Leyva's house, and that this, his decree, should be notified to said Leyva; as I had expected he opposed himself, and to my great surprise and vexation the judge's sentence was entirely in his favor. He, in my opinion, gave a forced and erroneous interpretation to the words: "con todos los ayres que corresponden a Don Juan Aliaga" founded upon which interpretation as well as [...] [485] circumstance that I had not produced title deeds; which proved that the said Ayres were Don Juan Aliaga's - and in this my lawyer Dr. Palacios said he was right - his sentence was "Que la causa Se haga ordinaria", whilst my lawyer had insisted upon it being "ejecutiva".

Sunday, $9^{\text {th }}$ of November. This morning before six O'clock I was in the street and when I heard it strike seven I was already descending San Cristoval; before 8 I was home.

Tuesday, $17^{\text {th }}$ of November. I presented my escrito, extremely well drawn out by Dr. Palacios, to the Juez de primera Instancia, who admitted the appeal. Now, according to law, as soon as the judge's admittance was notified to me and to Leyva, the papers had to be sent up to the Superior Court, which is divided into two chambers. Till the end of the month the first chamber consisting of Drs. Leon, Chacaltana, and Rospigliosi received the appeals, but as I was not acquainted with any of the three, whilst the second chamber consisted of Drs. Mariategui, Julio Corso, and José Maria Perez, with the latter of whom - Rafael Velardes brother-in-law - I flattered myself I had some influence, I promised the escribano Escobar a gratification if he could keep back the papers until the $1^{\text {st }}$ of December when it was the second chamber's turn.

Thursday, $13^{\text {th }}$ of November. Felipe Barreda came to my office, and told me that Riva Agüero had informed him that the decree which ordered the conversion of the Pasco Railway bonds held by the Banco Hipotecario, by Felipe Barreda and myself, had at last been signed by the President. Repeatedly I went to Riva Agüero's office in the palace, but as he was never to be found I requested Garland who on Friday evenings always went to his house to play rocambor, to tell him that I wished he would appoint me an hour when I could see him, and accordingly on 
Saturday, $15^{\text {th }}$ of November I was with him at 11 a.m. when he promised that he would send the decree to Pepe Izcue, who was the first clerk in the Finance Ministry. With him I was at 5 p.m. but the decree had not yet reached his hands; however, from the manner in which he expressed himself it seemed to me that he would facilitate as much as lay in his power the conversion of the bonds. This Pepe Izcue, son of J. F. Izcue and Inéz Gutierrez, both dead, had been about twenty-five years previously the fellow pupil of Corina, Amalia, and the Pflückers, under Zyla's tuition; his sister Delfina, a very agreeable young lady, married Toribio Sanz, the well-known Peruvian fiscal-agent in Europe, and he himself had taken for [...] tner in life the daughter of old Agustin Garcia, the lawyer whose [...] [486] Don Toribio's sister. Izcue of course must have known me; though I did not recognize him.

The Government and the house of Dreyfus had been negotiating with the object of making up their differences, but it would appear that they had not come to an amicable settlement. On the previous day the mail steamer for Panamá had been detained by Government until a late hour, and this day the Peruvian Man-of war "Union" was dispatched after her no doubt with the only object to communicate to the Peruvian Minister in England and France by means of a telegraphic dispatch from Panamá, the decree of the $14^{\text {th }}$, of which the following was the substance: The loans of 1870 and 1872 had for their security the proceeds of the guano sold by Dreyfus, secondly, Dreyfus Bros. were bound "de hacer el servicio", which meant to pay the interest on the said loans, and the annual redemption of a certain proportion of the bonds on the $3^{1^{\text {st }}}$ December of the present year, as well as on later dates, and thirdly, that from the surplus of the proceeds of their sales of guano bought by them, which would remain in their hands after having "hecho el servicio" of which the second article spoke, any amount up to one million pounds sterling was to be kept at the Government's disposal for other objects, probably for public works.

Sunday, $16^{\text {th }}$ of November. Last night my wife and daughter went to see the family of our good friend the Vocal Don Jervacio Alvarez. His youngest son Adolfo, who about two years previously had removed to the Sierra to recover his health, particularly the strength of his lungs, had, whilst there, nobody knew the cause, become deranged. Consequently he was sent back to Lima, where I called upon him; it is true that he recognized me, but a minute or so later his thoughts wandered completely, he did not note my presence, and began to sing a ditty like a little child. Since then he had become worse, been furiously mad, had beaten his mother, and tried to do bodily harm to his niece Aurora, who only escaped by knowing the ins and outs of the house with which he was 
not so well acquainted as she. It may easily be conceived in what a state of sad distress the entire family was at the time.

Thursday, $20^{\text {th }}$ of November. I went to a certain Cáceres, chief of that section in the Finance Ministry which goes by the name of Direccion de Contabilidad, who had to carry into effect the decree signed by the Finance Minister relative to the conversion of the special Pasco Railway bonds - see $13^{\text {th }}$ inst. - to enqui $[\ldots]$ what was the reason that the bonds of the Internal Debts [...] [487] Riva Agüero, Felipe Barreda, and myself were not yet drawn out, when his answer was that in his opinion and that of his subaltern Tur, this could not be done until the Pasco Railway Company had mortgaged the Railway with all its appurtenances to the Government, and made itself responsible for the payment of interest and redemption on these bonds of the Internal Debt, to be handed to the above named persons; whereupon I observed to him that the Government had guaranteed to the holders of the bonds which were to be exchanged for the Internal Debt, the interest on, and the redemption of the same; "can you call that a guarantee if the Government will only pay the holders if they received from the company wherewith to make the payment? certainly not"; "you are correct", he replied, and called Tur to tell him in my presence that on the following day he might exchange the bonds of the Pasco Railway, for bonds of the new Internal Debt, in conformity with the decree of $5^{\text {th }}$ Novr. signed by La Jara and provided with the rubrica or flourish of President Pardo. Tur told me that on Friday he could not be in the office, being prevented by family affairs, but that on Saturday I might present myself at 11.30 with all S/400,00o bonds.

Friday, $27^{\text {st }}$ of November. Dr. José Gregorio Paz-Soldan was the first who came in the forenoon to congratulate Mariquita on her Saint's-day. I sat down to converse with him, when he told me that of the three partners of Dreyfus here in Lima, Derteano and Scheel were generally inclined to meet the wishes of the Government as much as lay in their power, whilst Ford's views were generally opposed to those of the two others. This house and the Government were once more at loggerheads; on the $15^{\text {th }}$ I gave the substance of a rather conciliatory decree of the Minister of Finance, to which Dreyfus' house acquiesced in a polite note which was published in the papers of the $17^{\text {th }}$, and in which they expressed the hope that Government would now again give the customary license for vessels to sail from Callao to the Guañape Islands for the loading of guano. I thought that the storm was blown over, when once more the Government came forward with a fresh claim on Dreyfus for $£ 533,000$ due to them in conformity with the liquidation of accounts made out by a commission consisting of J. V. Oyague, Emilio Althaus, and Nathaniel Sanchez, to whom 
Pardo had submitted for examination all the accounts of the firm. Dreyfus immediately published their answer, showing how and in what manner they had paid this money; now it was said that the Government would place guards at the street-door of their house.

I [...] the birthday. In the course of the forenoon a good [...] [488] presents were sent to my wife; visiting cards in abundance. Besides Paz-Soldan, a few other intimate friends came in the forenoon. In the evening a small party assembled, all uninvited; the large ball Lizardo Montero had insisted upon was not thought of. We had with us: Rafael Velarde, wife and daughters, Doña Dolores Puente, Doña Juana Carbajal with her daughter Manuela, Dibos, and his wife Ernestina, Carlos Ferreyros with his cousin Carlos Zevallos, Böhl, and perhaps a few more. Tea was served, afterwards ices; we went to Enriqueta's large saloon where the young folks danced a little, and by 1 O'clock all were gone.

Saturday, $2^{\text {nd }}$ of November. At the appointed hour I was in Tur's office with the object of exchanging Barreda's and my Pasco Railway Bonds, S/195,00o together, (Riva-Agüero said he would himself present his $S / 205,000$ ) for a similar amount of Bonds of the Internal Debt, but great was my surprise when Tur, who 48 hours previously had in my presence been ordered by his superior, Cáceres, to make this exchange, told me that he could not do so, because the expediente was in the hands of the new Minister of Finances Carrillo, who would make himself acquainted with its contents before he could authorize the issuing of the $\mathrm{S} / 400$,ooo bonds of the new Internal Debt, and when Sagastabeytia came to my office, as he was in the habit of doing on Saturdays, he informed me that on the previous day he had been notified by a notary of the Government that he, as representative of the Railway Coy., should draw out the escritura in virtue of which the Company made itself responsible for the above payments and mortgaged to the Government all its rails, locomotives, cars, the road itself, etc., which done, the Government was ready to exchange the bonds. This being entirely contrary to the spirit of the decree, we two resolved that I should go to Riva Agüero to speak to him on the subject, and that he, Sagastabeytia, should present an escrito saying that he was not the only representative of the Company, but that its Directory consisted of five individuals. Wyman, as might have been expected, had not paid the $\mathrm{S} / 10,000$; he now promised faithfully to do so before the $27^{\text {th }}$ inst. Harrison, who was also present, gave us to understand that in his opinion we had no right to claim the money from them.

From Sunday, $23^{\text {rd }}$ to Friday, $28^{\text {th }}$ of November. With the conversion of the bonds no further progress was made. Riva Agüero told [_] that Carrillo had 
applied to the President for instructions wh [...] [489] had been that he having been interested in the Pasco Railway, this conversion was a very delicate matter for him, in which he did not wish to interfere, and that he, Carrillo, might call a Council of Ministers at which he would not be present and in which the propriety or non-propriety of the conversion might be discussed. This Council had been put off from day to day, and, notwithstanding Carrillo's promise to the contrary, would I feared be postponed for some time. Wyman \& Harrison did of course not pay the money; now they offered the former's bill on London, which we, the Directors, declined to receive.

The Government had again given license to Dreyfus' vessels for loading guano, but only as long as the firm of Dreyfus in Paris paid the interest on, and the redemption of the loans of 1870 and 1872. In the meeting of the Directory of the Lima Water Company the only thing we did was to raise the salaries of the two engineers, Wilkinson present in Lima and Prentice about leaving for Europe.

Saturday, $29^{\text {th }}$ of November 1873 . The meeting of the Directory of the Banco de Lima was of some importance. Lembcke informed us that Graña and Emilio Althaus had come to him and Zaracondegui in the name of the President for the purpose of explaining to them a request made to the different banks by the Government to the following effect: The banks established in Lima were to pay for two years the interest on, and the redemption of the Peruvian internal-debt. As soon as Lembcke had done speaking I asked: "how much will be annually required? have all the other banks agreed to the proposal? and how much will fall to our share?" The reply was that $\mathrm{S} / 2,000,000$ were required annually, that as far as he knew the Bancos "del Perú", "Nacional", and "La Providencia" were likely to give an affirmative answer, and that if the Banco de Lima were to take its share, we should have to pay $\mathrm{S} / 25,000$ monthly for two years. As security for our outlay the Government would place into our hands "Bonos de Tesoreria" which the Congress had authorized them to issue, bearing $8 \%$ annual interest, and payable at the end of 1875 . Lembcke added that he and Zaracondegui were decidedly opposed to the plan, mainly because the bank was established to lend a helping-hand to the public in general, and not to make loans to the Government with whom there was no sufficient security, and from whom no sufficient advantage was obtained; I immediately replied that upon the whole I agreed with everything he had said, but that I considered it highly impolitic always to give a negative answer to the Government's proposal, and this was [...] third time we would do so. Nicolas Rodrigo and [...] [490] view of the question as I; Heudebert wavered between the yes and no, whilst Pedro Bernales, José Muro, Francisco Sagastabeytia, and Valentin Gil were decidedly 
of the contrary opinion; Puente, of Ugarte's house, said little if anything at all.

Lembcke went so far as to exclaim that if the Directory decided upon rendering this assistance to the Government, he would be under the necessity of giving up his post as gerente of the bank. All present looked upon this threat of Lembckes as highly improper, and certainly it was so; still the discussion continued, and he agreed to Rodriguez' motion not to give at once a decided answer, but to ask for further particulars, which was a half-measure not worth anything - it merely put off the evil-day. This being disposed of, Lembcke made known that Puente had formed upon the island of San Lorenzo an establishment for smelting all descriptions of ore, that it went on satisfactorily but that Puente now required assistance from the Bank; it was resolved that some of us should have a look at the establishment before coming to a decision: I felt little inclined to make him a loan, nor were my companions disposed to do so.

Sunday, $30^{\text {th }}$ of November. This morning I ascended San Cristoval from the side of the new Alameda; the rock, owing to the rain and fog, was very slippery. I slid frequently, but did not fall, and reached the top with some difficulty.

Monday, ${ }^{\text {st }}$ of December. At 8 O'clock I was in the Church of Sto. Domingo at the funeral of the wife of Bamberger, Erlinda Cosio, the ninth or tenth of the vocal's children who had died of consumption. The funeral was pretty well attended; the greater part of Cosio's colleagues, Vocales of the Supreme Court, were present and four of them took hold of the black ribbons which hung down from the coffin, Gaspar Puente and José Condemarin the other two. Next to me sat Charles Pflücker with whom I had some talk; he told me that the last telegraphic dispatch had brought the discount in London at $9 \%$, a universal lightness in the money market, and nitrate of soda at 11 shillings the hundredweight, lower than which figure it had probably never been. This funeral was followed by that of Juan Figari, a well known rich Italian merchant. I did not attend, but was told that the concourse had been extremely numerous. For some time past he had been suffering from a chronic hoarseness which hardly allowed him to speak. Dr. Alarco promised to cure him, and performed some extraordinary operation on his throat, the consequence of wh[_] hemorrhage which suffocated him. The Directors of the Ban [...] [491] Lima met; again we treated on the service to be rendered to the President Pardo, but as the gerentes had already sent into the Government a written answer, in which they said that if the bank could meet the President's wishes he should again hear from them; we decided to let the affair drop, and then our silence would be taken for a negative. From the Bank I went to the Palace where I spoke with Tur, the head 
clerk in the Direccion de Contabilidad, who told me that the Minister Carrillo had decided that the conversion of the bonds could only be effected after the document of the mortgage of the Railway to the Government had been drawn out and signed; I immediately went to Riva Agüero in his office, who confirmed what Tur had said; consequently, on

Tuesday, $2^{\text {nd }}$ of December the Government's decree of $5^{\text {th }}$ November, with the interpretation given to the same by the Direccion de Contabilidad was notified to Bohorquez, Correa, and myself.

Wednesday, $3^{\text {rd }}$ of December. At about three in the morning my wife called me, and said that she had a severe pain in the stomach. I got up, roused the servant woman Peta, who called Enriqueta and lighted the gas; water was heated, and - as Dr. Bambaren had advised my wife to do on such occasions - three drops of laudanum were poured into a small quantity of tepid water, which she took, and nine or ten drops in a larger quantity were injected. The pain ceased about 5 O'clock, and we went to sleep.

Thursday, $4^{\text {th }}$ of December. My wife remained unwell and kept her bed; Bambaren was called, and about 8 p.m. she was so poorly that I went again to fetch the Doctor. She complained of a dreadful "fatiga"; this word I heard frequently but as I myself had never suffered from the complaint, I could not say exactly what it meant. I believe it is the feeling caused by the great debility of the stomach. Dr. Bambaren was not at his house and not to be found; with his servant I went to all the iceshops in the plaza, but nowhere was he; at last at half past ten he came; then I had again to run for the medicine, and for full two hours I was continually on the move; my wife said she was very ill, but as she had no fever the Doctor assured us there was not the slightest danger; every half-hour she had to take a spoonful of medicine, which made her vomit a good deal, and at the same time had a calming effect, so that at 1.30 a.m. on

Friday, $5^{\text {th }}$ of December her dreadful headache was gone, and she was fast asleep. Then Enriqueta retired to her room, and I to bed. This morning [...] ok some castor-oil which had its due effect, she was certainly [...] [492] and delicate. In the forenoon Cipriano Correa came to see me, and said that he was determined not to sign the document of the mortgage without being authorized to do so by all the shareholders, of whom the Directory ought to convoke a general meeting. Some hours later came Don Felipe Barreda to enquire of me how the conversion of the bonds stood; I told him all the particulars. "Well", said he, "we must then present another petition to the Government, demanding the immediate conversion." He drew it out in rough; I submitted it to Riva Agüero, next to Garcia Calderon, who acted as the Gerente of the bank all the time that Riva Agüero was Minister, and 
both approved it. It was copied by Mr. Deeble, and on Saturday at a late hour I took it to the Ministry of Finances; I again saw Riva Agüero, told him that in the meeting which an hour previously the Directors of the Railway had had in my house, Bohorquez and Correa had insisted upon the necessity of a general meeting of shareholders, and that notwithstanding all Sagastabeytia's arguments they were not to be diverted from their purpose. He told me that he had read to Pardo the petition above spoken of, drawn out by Barreda, who had said it was quite right and well founded; nevertheless, I apprehended that as Pardo would not interfere directly in the matter, the Minister Carrillo would not give way and would insist upon the necessity of the previous mortgage.

Within these last few days died José Santos Castañeda, who during his life time had occupied many a high situation in the Peruvian Administration, amongst others he was Minister of Finance in the time of San Roman's Presidency and towards the end of 1862 prolonged to Schutte the guano consignment to Germany for four years.

From Europe we learned by the last steamer that the King of Saxony, John, had died on the $28^{\text {th }}$ October; he was born in 1801, and succeeded his brother in 1854. The death of Capt. McClure, who discovered the north-west passage, was also advised. From Gerald Garland, Junior, his father had a letter from Japan dated $28^{\text {th }}$ September; in company with other members of the Embassy he had made a short, but pleasant trip into the interior, and was then on the point of embarking for Shanghai. From Juan I received a very long letter dated Paris, $29^{\text {th }}$ October; he thought of embarking in Bordeaux for Madeira, where he intended to spend the winter; he further informed me that his speculation in Peruvian Bonds had caused him a loss of no less that 75,00o francs, and he requested me, in order to pay for this loss, [_] him a remittance of £2000 Stg. but as he knew I had no fun [...] [493] he wished me to sell his shares of the Banco del Perú, of which he entertained a very bad opinion, without having, as I thought, any sufficient reason; also his shares of the Gas Company, Cedulas - everything he wanted to sell. I did not intend to do so for the present; at all events I would first receive the dividends due at the end of the year, and then see what was best to be done.

Sunday, $7^{\text {th }}$ of December 1873. This morning I was in the street long before six. I ascended San Cristoval from the side of la Piedra Liza; the ground was dry and my thoughts being occupied with the Pasco affairs I reached the top without being aware of it. I descended into the Lurigancho valley, and walking very fast was home at a quarter to eight, when I immediately turned in, for I wanted some repose. 
From Monday, $8^{\text {th }}$ to Saturday, $13^{\text {th }}$ of December. Owing to the indisposition of which I spoke the previous week, Mariquita remained in bed all these days and consequently on Thursday night we did not go to Enriqueta's evening party, from which I always readily absented myself. Dr. Bambaren assured me more than once that though my wife was certainly weak, danger there was none.

The Pasco Railway business was to me a source of continual annoyance. Bohorquez and Correa persisted in their resolution not to sign the document, which mortgaged the Pasco Railway with all its appurtenances to the Government unless the three holders of the special Pasco-Railway bonds solemnly declared that they would cancel the mortgage they held on the railway as soon as they were in possession of the bonds of the Internal Debt which the Government had promised to give in exchange for the said special bonds. Sagastabeytia opined that the said two gentlemen were quite in the right, and I told them at once that I was willing to meet their wishes and to cancel my mortgage for $\mathrm{S} / 5^{0}, 000$ - as soon as the Government gave me for my $\mathrm{S} / 65,000$ special bonds, the same amount of the Internal Debt. Riva Agüero also agreed to receive the Internal Debt in exchange for the special bonds, and well might he do so for the debt due to the Banco Hipotecario was not secured by any mortgage; but I feared that Felipe Barreda would not be induced to follow our example; Riva-Agüero however promised me that he would speak to the President, and thought that this latter might perhaps succeed in convincing his father-in-law. Meanwhile, Bohorquez had a long conversation with Riva Agüero on [_]ay and on Saturday we four Directors decided not to present [494] any escrito to the Minister of Finance in reply to the notifications which had been served us, until Bohorquez had again seen Riva Agüero.

The lawsuit with Leyva did not wear a favourable aspect; notwithstanding all we had done to keep the "Expediente" in the lower tribunal till the end of the month, we had been unable to attain this end, and it had been sent up to the Superior Court, where it was the turn of the first chamber to receive appeals. It was well known that the President was forming one plan after another to improve the monetary condition of the country; these he was in the habit of submitting to some of his friends in whose mecantile capacity he had confidence, such as Emilio Althaus, José V. Oyague, his father-in-law Barreda, and Sagastabeytia, from which latter I learned all the details, but as it was not in Pardo's power to overcome the difficulties which presented themselves, without the assistance of the banks, I much doubted that he would attain his object. The Government required monthly $S / 1,300,000$. The revenue, exclusive of the sales of guano, the proceeds of which were absorbed by the service of the external debt, came to S/80o,ooo monthly, thus there remained 
a deficit of $\mathrm{S} / 500,000$ which Pardo said he might possibly be able to reduce to S/350,00o but how would these be made up? I did not believe that the banks would come forward and lend such a heavy sum, for the security which Pardo offered, say £2,00o, ooo of bonds of the late loan of 1872, was in my opinion no good available security.

On this same day, Saturday, Captain Miguel Grau of the "Huascar" gave a party on board of his vessel, it was said in honor of the President's wife, but perhaps also as a farewell to Mr. George Petrie, for many years the very successful agent in Callao of the Pacific Steam Navigation Company who was on the eve of leaving the country. Alejandro, who had been one of the party, had not been much pleased; he particularly complained of the smallness of the vessel compared to the number of guests, about fifty ladies and one hundred and fifty gentlemen.

Sunday, $14^{\text {th }}$ of December. This morning I was again up San Cristoval. Mr. William Möller of Arequipa, husband of Candelaria, and formerly partner of William Harmsen, had died of late. Several years back he had been struck by apoplexy, which had affected his intellect and incapacited him from doing anything for the maintenance of his family. [...] was also told that the famous Arab chief Abdel Kader had died. [495]

Wednesday, $17^{\text {th }}$ of December 1873. We, the Directors of the Pasco Railway Coy., met in my office, when Bohorquez confirmed to us what Riva Agüero had already told me, that Felipe Barreda would not give way, whereupon we decided to write a few words to Enrique Barreda, the real creditor, and to beg he would favor us with his presence on Saturday next.

Thursday, $18^{\text {th }}$ of December. My wife had so far recovered her health and strength that she was able to go over to Enriqueta's apartments, where a few friends were assembled, as it was their habit; I went with her. Garland had merely three rocambor players: Nicolas Hurtado, Senator for Loreto; Ignacio Távara, one of the nephews of Don Santiago, and a Frenchman, Picard, of whom I knew nothing. The remainder, amongst whom Mr. and Mrs. Dibos played at vingt-un. I retired at eleven; my wife came perhaps two hours later for she was always fond of a little game at hazard.

Saturday, $20^{\text {th }}$ of December. Enrique Barreda was with us at our meeting, but notwithstanding the most rational reflections made to him by all of us, especially by Bohorquez, he left us saying very decidedly that he would not take the S/130,0oo Pasco Railway bonds, even were they converted into bonds of the International Debt in cancelment of his claim for 100,000S/ and interest; he preferred, he said, to make effective the mortgage which he and I held upon the Railway. This stubborness of his was highly injurious to my interest 
and made nugatory my willingness to come to a friendly arrangement. The Directors of the Pasco Railway Company would and could not give a mortgage to the Government before the previous mortgage were cancelled; Barreda would not cancel this mortgage, and the Government would not convert the bonds until the mortgage were signed in its favor - thus I was bound hand and foot, and saw no possibility of extricating myself from these difficulties. S/50,00o of mine were at stake. In the course of the week I had paid my respects to the three judges of the first chamber who had to decide my suit against Leyva. Rospigliosi and Leon, whom I had seen previously on similar errands, were civil, but nothing more; Chacaltana, perfectly unknown to me, to whom I was introduced by an acquaintance of Enriqueta's, a certain Bartolo Urive, a very insignificant man who kept an earthenware store, was more polite and appeared at least desirous to make himself acquainted with the merits of the case.

At last Pardo's decree respective the banks was published. But [...] [496] it was hailed with delight, because they understood very little about it; but for the banks it was of the most oppressive nature, the principal feature being that of the amount of notes which a bank issued not less than $90 \%$ had to be employed in the purchase of treasury bonds, and Vales de la nueva consolidacion, three-fourths of the former, one-fourth of the latter; the treasury bonds given by the Government at $92 \%$ bore $8 \%$ annual interest, payable every three months, and although they did not fall due before the $31^{\text {st }}$ December 1875 , the Government promised to pay them before the $30^{\text {th }}$ June of the same year by means of the Callao customhouse revenue; the vales de la nueva consolidacion bore $6 \%$ interest payable every three months and were worth now 60 to $65 \%-\mathrm{S} / 85,000$ were set aside monthly for their redemption. The Banco de Lima for instance might issue $S / 1,000,000$; accordingly before the $30^{\text {th }}$ June, so the decree prescribed, the bank had to disburse $S / 700,000$ three-fourths of which would certainly not be repaid before the $30^{\text {th }}$ June, latest $31^{\text {st }}$ December 1875 , and then it was very doubtful whether the Government would be able to keep its promise. The object of this decree was clearly to oblige the banks to lend to the Government a considerable amount of money; if they refused to do so, their notes would not be admitted in the public offices. There were many other conditions, one of which that each bank should have paid up $50 \%$ of its nominal capital; this did not effect either the Banco de Lima, "Perú", or "La Providencia", who all three had paid up one half of their nominal capital, whilst the Banco Nacional on its capital of twelve million Soles had as yet called for no more than $30 \%$. In a meeting of the Directory of La Providencia the matter had been discussed but no resolution come to. 
Monday, $22^{\text {nd }}$ of December. In the forenoon the second chamber of the Superior Court confirmed the sentence of Dr. Quiroga, which declared that my demand against Leyva was "causa ordinaria", not "ejecutiva". At the usual hour the Directory of the Banco de Lima met, and discussed the Government's bank decree; the result of our debates was similar to that of the Providencia nothing was decided.

Wednesday, $24^{\text {th }}$ of December. I gave in my escrito of appeal to the Supreme Court.

Thursday, $25^{\text {th }}$ and Friday, $26^{\text {th }}$ of December. Christmas days. As in duty bound I paid a great many visits, at least twenty in number. At Dr. Munoz', whom I congratulated on his having been named President of the Supreme Court of Justice, I [_] met Felipe Barreda; we left together, when he told me that he had instr[_] [497] his son Enrique to sue the Pasco Railway Coy. for their debt of S/10o,ooo due to him, as soon as the tribunals were re-opened, say on the $7^{\text {th }}$ January. I was uncertain whether this was a mere threat of his, or whether it was his intention to carry it out.

On Friday a great number of gentlemen came to see my wife; when I came home from my calls she always gave me an account of those who had been with her, who had been the most agreeable, what news she had learned from them, and so on, whilst I did not fail to enumerate the names of all whom I had visited.

Henry Higginson, my Callao Port-Agent, was lying ill, suffering from an inflammation of the liver, and it was feared that his life was in danger.

Political news were few, and of little importance. For some time the monarchical party in France was generally believed to have had a chance of triumphing over the Republicans, but quite of late these latter had decidedly preponderated, and Mac Mahon's authority as President was prolonged for an indefinite term. Prince Alfred second son of Queen Victoria was about marrying one of the daughters of Czar of Russia.

Sunday, $28^{\text {th }}$ of December. A general meeting of the shareholders of the Banco de Lima had been convened by the Directory for we were desirous to hear their opinion on the late bank decree. It was about half past one when I took my seat in the arm chair, to my left and right the other Directors, Muro, the secretary, next to me, before me a narrow table with writing implements, at its one end, to the right, the two gerentes, and all around on chairs, the shareholders. The Nominal capital of the bank consisted of two hundred shares of $S / 25,000$ each, say $S / 5,000,000$ of which 157 shares were represented, and consequently the absolute majority, that is to say one more than the half, was 79 . As soon as all were seated and everything quiet, I said in a loud, distinct voice that the object of the meeting was: 
Firstly, to deliberate on the Bank-decree, which I supposed everybody to be acquainted with. "We either do, or do not accede to it; in the first case we have to disburse a considerable sum of money - in the second, the Government does not receive our notes in the various treasuries of the Republic; both are evils, we must choose the lesser."

Secondly, to elect a new Directory for, in conformity with the statutes, every two years all the Directors had to go out, and

Thirdly, I had to inform the meeting to my great regret that the $[\ldots]$ ntes Zaracondegui and Lembcke had thought proper to re[_] th [...] [498] in consequence of some articles published in "La Sociedad", unjust, unfounded, and injurious to their honor. I then sat down, and the protocol of the last general meeting was read by Muro, which ought to have been done before I spoke. It being approved, without any observation I requested Lembcke to read the document drawn out by him, which he did. He said in the same that three courses lay open to us; the first, to ask Government's permission to issue notes to the extent of $S / 2,500,000$ or half of our nominal capital; the second, to ask this permission for a smaller amount, say $\mathrm{S} / 1,000,000$; the third, to ignore the decree altogether, which would expose us to the nonadmittance of our notes by the Government's offices. He then gave his reasons why in his opinion the second plan should be adopted. All agreed with him in so far that two millions and a half were too large an amount to be asked for, but as to the exact amount suitable to the bank's business opinions differed. I from the very first observed that one million was too large a sum; Pedro Bernales reduced it to the half, which was again looked upon as too little. Correa, Perez Tudela, Amancio Castillo, and Pedro Tello Larrañaga said each a few words; and at last, two or three excepted, all acceded to the motion of Manuel Ortiz de Villate, that we should ask for permission to issue notes to the extent of $\mathrm{S} / 800,000$ exactly the amount at the time in circulation. Next, the question regarding the gerentes was discussed. I proposed that they should be re-elected by general acclamation, which was done; then the lawyer and ex-minister Aranivar moved a vote of thanks and confidence to the Gerentes, which was in a similar manner acceded to. Now came the most troublesome job, the election of the new Directors; Lembcke had formed his list, many copies of which had been drawn out by his son and the cash-keeper, and distributed amongst the shareholders; this of course gave the majority to those whom he wished to be elected, and though a few, I of the number, voted independently without being influenced by him, those upon his list were chosen. They were: José V. Oyague, a new Director, Sagastabeytia, Gil, Muro, Bernales, and I, old Directors, who had more or less the same number of votes from 129 to 135 each; next followed 
Manuel Mendoza, a few votes less, and Puente of Ugarte's house, hardly above a hundred, both belonging to the old Directory; and finally Manuel Salcedo, a respectable landed proprietor from the North, a new Director with a few votes above the half. M. A. Zuloaga and Pedro Helguero had a considerable number of votes, but [_] than the half; consequently only nine were and two had still to be [...] [499] the number of Directors being eleven, besides the two gerentes. The examining the votes and noting them down occupied some of us till past five; Muro read them, Pedro Bernales, Valentin Gil, and James Henry noted them down; I also made an attempt to do so, but my want of sight did not allow me to continue. Of the old Directors Escudero, Rodrigo, Heudebert, and Zuloaga lost their seats, owing to the intrigues of Lembcke, as far as the three first were concerned; Zuloaga was not chosen, because it was well known that his ill-health did not allow his leaving the house.

Monday, $29^{\text {th }}$ of December 1873. The shareholders of the Banco del Perú had their meeting; I was present, but did not open my mouth. We acceded to the decree, and asked permission to issue notes to the amount of two million Soles.

Tuesday, $30^{\text {th }}$ of December. The Banco Nacional, La Providencia, and El Garantizador, followed the example given by the two other banks, the first for $\mathrm{S} / 1,800,000$ the second for $\mathrm{S} / 500$, ooo the third for $\mathrm{S} / 100,000$. The Bank of London, Mexico, and South America kept aloof; Mr. Dawson, the principal manager, being absent, those who acted in his stead did not consider themselves authorized to take such an important step without the sanction of the Directory in London. The amount of notes, for the issuing of which, permission had been asked from Government, came to $S / 5,100,000.70 \%$ of which had to be deposited in Government papers, say three-fourths in Treasury bonds, to be purchased from Government at 92\%, and the other fourth in Vales de la nueva consolidacion, which, no doubt in consequence of this bank-decree, had risen to 65 and $66 \% ; 15 \%$ of the $70 \%$ had to be delivered in before the $10^{\text {th }}$ January, that at least Pardo would have some money, though not so much as he had counted upon, wherewith to pay his employees, the widows, officers out of service etc.

Wednesday, $3^{\text {st }}$ of December. About this time we of the Pasco Railway Coy. seriously thought of throwing up our Directorship. We were convinced that we could do little good to the Company, and at the same time we were determined not to defend the suit, should Barreda sue the Company for the S/10o, ooo due to him. I, above all, was in a very false position; as creditor I had to be the plaintiff, as Director I had to be the defendant, both which characters could not be united in one person. [500] 
Thursday, ${ }^{\text {st }}$ of January. The same as in previous years the members of the Diplomatic and Consular Corps, each of whom had received a note from the Minister for Foreign Affairs José de la Riva Agüero, assembled in his office, the greater part in uniform, thence, ushered in by the Minister we walked two by two to the receiving room, at the other extremity of which stood under a canopy Manuel Pardo, in black, the Presidential sash thrown over his shoulder. Leal, the Brazilian Minister and Senior of the Diplomats, read his congratulatory address, quite common-place; Pardo answered a few words, in which he took no notice whatever of the Consular Body. This omission struck all as quite uncommon, for on former occasions the Consular Body had always been included in the President's reply. Hereupon we went to an adjoining room, sat down for a few minutes, rose, shook hands with the President, and made our exit. I availed myself of this opportunity to tell him in a low voice, that I counted upon his assistance; he well knew that I referred to the Pasco Affair, and answered "No tenga Ud. cuidado", which may be translated by "do not fear"; but I could not help fearing that as soon as I had turned my back he would no more think of what he had said to me.

As soon as I had come home I changed my dress, and continued the round of visits which I had commenced making on the two Christmas-days. In the evening at Enriqueta's there were more or less the same persons as on the previous Thursday; one table for rocambor; and a few vingt-un players. My wife and I retired at 11 O'clock.

The principal European news was that Marshal Bazaine had been placed before a court-martial presided by the Duc d'Aumale, one of the younger sons of Louis Philippe, to account for his unwarrantable surrender of Metz to the German forces; he was sentenced to be degraded and to be shot, which punishment the President Mac Mahon commuted into twenty years imprisonment.

The Lima local news was the marriage of Doña Carmen Becherel, the very pretty widow of William Brauns, with Adan Melgar, a physician of no great repute. Everybody wondered that she should have made [...] [501] choice. The second was the disappearance from the mercantile world of the well-known firm of Alsop \& Co., a North American house, established in Lima since the first years of the Independence of Perú. Alsop \& Co. (then called Alsop \& Wetmore), Huth Gruning \& Co., Gibbs Crawley Moens \& Co. (now William Gibbs \& Co.), and Templemann \& Bergmann were the first four foreign houses which established themselves in Lima about the year 1821 or 1822 . From Iquique 
we learned that on the $29^{\text {th }}$ December at 1 in the morning a fire had broken out which destroyed nearly two blocks; amongst others the house of the branch of the London Bank of Mexico \& South America had been burnt down.

Monday, $5^{\text {th }}$ of January 1874 . Once more the abominable Pasco business took up my time. With Don Felipe Barreda I looked over the instructions which he had given his lawyer, who was to present his first escrito on the $7^{\text {th }}$. It must be borne in mind that the mortgage to Barreda and myself was secured in the same escritura, without any preference being given either to the one or to the other, and thus we had necessarily to act jointly. On the other hand, Bohorquez and Correa were as determined as ever to present on the same day, the $7^{\text {th }}$, their escrito in which they refused to give the mortgage asked for by the Government. Thus we had now reached the climax. I went to Riva Agüero's office, and told him how affairs stood; he was taken aback, for he was more interested in this affair than anybody else, and told me that he would immediately see Pardo as perhaps by this latter's influence Barreda might still be induced to stop his proceedings, but I was quite sure nothing would come of it.

From 4.30 to 5.30 six of the Directors of the Insurance Company "Lima" and Lembcke, their president, were assembled. After treating on various points the pecuniary state of the Company was laid before us; it was very satisfactory. Upon a paid-up capital of $\mathrm{S} / 200,000$ we had made $30 \%$ say S/60,00o and this after deducting from the gross gains $\mathrm{S} / 12,000$ for general expenses, salaries, and $5 \%$ to the gerente Guiroy. Three of us were of opinion that we should give a dividend of $15 \%$; four, who formed the majority, with whom I voted, that the dividend should be only $121 / 2 \%$, and that the surplus should be carried to reserve fund.

This day, after long sufferings, died from a cancer in the breast, Doña Isabel La Rosa O'Phelan, about the same age as my wife, and one of her [_] friends. Mariquita and Enriqueta drove in the evening to see the [...] [502] family, especially Doña Josefa, the daughter of the deceased, widow of Dr. Prada, lately remarried to Andres Zavala. The members of this family distinguished themselves by their extreme, one might say fanatic devotion, by their unbounded charity, and by their selfsacrificing abnegation; of their number was the late Dr. O'Phelan, the excellent Bishop of Ayacucho, who before being raised to the episcopal dignity when still a Canon of Arequipa, blessed my union with my wife on the $10^{\text {th }}$ October 1831.

In lieu of the firm of Alsop \& Co. a new house had formed itself, under the name of Prevost \& Co., with, as the circular said, a capital of S/500,0oo. The partners were:Julian Zaracondegui, José Muro, Enrique Prevost, Carlos Prevost, 
and Eduardo Lembcke; the three last named were the active partners and the only ones allowed to use the signature. A decree of the Minister of Finances prohibited the admittance of the notes of the London Bank of Mexico \& S. A. by the public offices.

Tuesday, $6^{\text {th }}$ of January. I left my house before six when the atmosphere was extremely foggy - even the Cerro of San Cristoval was hardly visible. When I began my ascent the sun gradually shone out; it became very warm. The vegetation, dried up by the mid-day sun, was moist and slippery owing to the late mist, and thus I reached the summit not so easily as on other occasions. When descending, the fog again came on; it was so dense that it concealed my usual land-marks. I lost my way completely, and when below found myself to my great surprise not near the Alameda de los Descalzos, but on the other side in the valley of Lurigancho.

At 10 p.m. I accompanied the corpse of Doña Isabel O'Phelan to the Church of La Merced, and on

Wednesday, $7^{\text {th }}$ I was present at the funeral. Bohorquez and Correa presented an escrito, not signed by Sagastabeytia or myself to the Minister of Finances, in which they declared that the Pasco Railway Company would not sign the escritura which mortgaged the railway and appurtenances to the Government. We decided to convene a meeting of the shareholders for next Wednesday.

At 7 p.m. there was once more a meeting of the shareholders of the Banco de Lima merely for the purpose of electing the two Directors not chosen last time. No more than 79 shares were represented. Zuloaga obtained 45 and Manuel Helguera 41 votes. [503]

From Thursday, $8^{\text {th }}$ to Saturday, $10^{\text {th }}$ of January 1874 . Every morning form 9 to 10 I had Enrique Carrera with me, to whom I dictated the informe, or account, of the proceedings of the Pasco Railway Company Directory, to be presented in the meeting of shareholders.

On Friday my suit against Leyva detained me with my lawyer and the notary so that when I reached the Banco de Lima I already found the Directory assembled with Sagastabeytia in the chair. In the absence of myself and two or three others they had elected new presidents and secretary, and their choice had fallen upon José Vicente Oyague for President, F. Sagastabeytia for Vice, and Pedro Bernales for secretary. I had filled the first named post since the establishment of the bank, say for four years, Heudebert, the second, for less than twelve months, Muro, the third, for four years. This over Lembcke communicated to us that two landed proprietors, Geronimo Sanchez and a certain Guimet, were considerably in arrears with their payments, both of interest and capital; he at the same time suggested some measures, which 
in his and his colleague's opinion would oblige the said two debtors to fulfil their engagements. The Directory authorized them to do what they thought most convenient to attain the desired end. I was struck with the silence which Zaracondegui generally observed; he hardly ever opened his mouth, and my opinion was that he actually did quite as little as he spoke; all the work fell upon Lembcke.

Monday, $12^{\text {th }}$ of January. At 7.30 p.m. I went to Dr. Domingo Mendoza's to pay him the usual visit of condolence on the death of his wife's grandmother. I found there only himself, his brother Manuel, Fernando O'Phelan, and a young Vermejo, these two latter closely related to the deceased.

Wednesday, $14^{\text {th }}$ of January. At between two and three O'clock a meeting of the shareholders of the Pasco Mineral Railway Coy. took place in a room belonging to the Banco Hipotecario. Those present represented about one hundred or two hundred votes, more than the half, required to form a quorum; thus there was no impediment whatever to our proceeding. Sagastabeytia took his seat amongst the shareholders, whilst at a table placed in the middle of the room Bohorquez, Correa, and I sat down. The first thing to do was to read the last protocol of Septr. 1872, which was approved of. Then Bohorquez read the Memoria, or statement, drawn out by me, and considerably altered by him with my consent, which gave a detailed account of all the Directory had done for the benefit of the [...] during their administration. I learned that at first the [...] [504] of shareholders had been very ill-disposed towards the Directory, and even expressed a wish that they should immediately be removed, and others named in their place. The reading of the "Memoria" completely changed their ideas. The thing which most occupied their thoughts was the emission of the $S / 400,000$ bonds; what they wanted to know was how they had come into the hands of three individuals, Rivagüero, Barreda, and I. A voice - I was told afterwards it was that of the lawyer Felipe Varela - asked me how I got them; my answer was, "they were delivered to me in this very saloon." Who gave them to you? "A clerk." By whose order did he give them to you? I gave no answer, for I feared to commit Riva-Aguero if I mentioned his name. Much animation prevailed, and in the meanwhile several of those present retired to an adjoining room and returned with a motion written on paper, and signed by Agustin Escudero, Dr. Sandoval, and F. Panizo - the grandson of the notorious Countess Fuente Gonzales - the contents of which were more or less the following: They had listened with pleasure to the reading of the memoria; they thanked the Directors for what they had done; they did not admit their resignation, but proposed that a fifth should be named in lieu of Ascarraga who had left Lima; and finally proposed that the shareholders should authorize the Directors to 
make known to the holders of the above-mentioned bonds, that the Company would only consent to give to the Government the mortgage upon the railway which it demanded, in case those who held the mortgage for S/150,00o (that is to say Barreda and I) would consent to cancel our mortgage, and content ourselves with the bonds which we held. If the mortgage-holders would not consent, then the Directors were to make known to the Government that the Company would not give the mortgage. This motion was put to the vote and approved of unanimously, though to say the truth I remained sitting, by which I indicated that I was against it, no notice was taken of this my isolated vote, nor did I think it judicious to insist upon it, for it could not be denied that the course proposed was the only one which the company could pursue; even Riva-Agüero, who was in a much worse plight than I, approved of this resolution. The young lawyer Felipe Varela was chosen to make the fifth of the Directory which was also authorized to employ the money which it held, to defend the suit which the holders of the original mortgage might institute against them; and thus ended the meeting much better than I had expected. The only reason why I kept my seat in the Directory was because I wanted to have the management of the cash for were the money to fall into other hands I feared th [...] [505] proper account would be given of it.

From Thursday, $15^{\text {th }}$ to Saturday, $17^{\text {th }}$ of January 1874 . The greater part of the forenoon of these three days was taken up with my listening to Dr. Palacios' dictation of his escrito to the Supreme Court in my case against Leyva. On Saturday I personally delivered it, copied in clean, to the Secretary of the Supreme Tribunal. At 2.30 Felipe Varela, Bohorquez, Correa, and I met in my rooms; the principal thing done was to discuss a letter to Felipe Barreda y Osma, communicating to him the resolution taken in the last meeting of shareholders, and requesting his answer within forty-eight hours. It was drawn up by Varela and signed by him, Bohorquez, and Correa, not by me; it was also sent for signature to Sagastabeytia, who, I much regretted, could no more attend to the Cerro de Pasco business, he having been named provisional gerente of the Banco de Lima during the absence of Julian Zaracondegui, who had gone to Iquique there to look after his nitrate of soda establishments. I feared that Zaracondegui's affairs were much entangled, and his finances not in so flourishing a state as in former years. About 5 p.m. on the same day, Saturday, died suddenly Eduard Mac Call. I believe the oldest foreign resident in Lima, nearly eighty years of age. At the said hour he entered one of the baths in the Calle de Nuñez; an unusual long time having elapsed without his coming out again, the door was broken open, and he was found lying dead in the water, having probably been struck by apoplexy. Of late I had sometimes met him, 
walking about in the neighbourhood of the Exhibition, when we used to exchange a few words; he then appeared to me strong and active considering his advanced age. He was a North-American, an agreeable and clever man. Shortly after the Independence of Perú he established himself in Lima under the name of E. Mac Call \& Co., his partner being then the late Stanhope Prevost; after some time this firm merged into that of Alsop \& Co., of which latter house Mac Call had been for great number of years a sleeping partner. In former years he was much addicted to gambling, which vicious habit he had given up in later times. His wife was the well known Manuela Molina who had died in the course of last year; he left two grown-up step daughters, Mercedes and Rosario, by his wife's first husband Domingo Tristan.

By the steamer through the straits I received two letters from Juan, from Madeira, the last of the $5^{\text {th }}$ December; he was delighted with the climate, which, he said, did him much good, but displeased with the extreme dullness of Funchal, $[\ldots]$ he had taken his lodgings in an hotel. The streets, he wrote, were [...] [506] badly paved, and so dimly lighted up that he did not venture out at night; went to bed early, having nothing wherewith to occupy himself, and rose betimes to enjoy the beautiful mornings. The Paris dates were of the middle of December. Rosa wrote to her sister that Schutte was very poorly; his head was very weak, his memory fast going, and his legs faltering. Two letters from him to Garland, as confused as they could be, were dictated by him to Corina, and merely signed by him. I much feared we should soon receive advice of his death. His late speculations in Peruvian Bonds had cost him a great deal of money.

Sunday, $18^{\text {th }}$ of January. I went to Chorrillos by the 2 O'clock train, took a seabath, and returned at four; my companions in the coach were amongst others Mr. Lührsen, the German Chargé d'Affaires, with his wife. He was a Hamburger, stout and fat, without any ceremony or pretensions about him; his wife, by birth an Austrian, was extremely fair, and equally unpretending. At about 10 p.m. Garland and I went to the house of the family Prevost, whither the corpse of Mac Call had been conveyed after his sudden death. Between forty and fifty gentlemen assembled who accompanied the coffin to the deposit in the Lima railway station. I noted amongst others Charles Pflücker, Lembcke, Henry, General Freire, Juan José Moreira, and Muro. On

Monday, $19^{\text {th }}$ more or less the same persons went per train to the Bellavista station; thence they walked, the coffin being carried by porters, hired for the purpose, to the chapel in the English cemetery where the Revd. Mr. Henry read the funeral service; a few steps thence it was lowered into the grave. We were all back in Lima before breakfast-time. About five in the evening Felipe Barreda y 
Osma sent me an open letter to the Directory of the Pasco Railway Company, in which he declared that he was willing to cancel with the S/130,ooo special bonds, his claim for $\mathrm{S} / 100,000$ on condition that these bonds were converted into Vales de la nueva consolidacion, and that the company would pay to him the amount of the cupons on these bonds for 1872 and 1873 , which, twice $6 \%$ upon $S / 130,000$ would come to $S / 15,600$. I added a few words to this letter, in which I said that as regards my claim of S/50,00o, I adhered to Barreda's proposal. This letter I hold my servant Juan to take to Bohorquez as soon as he had dined.

Tuesday, $20^{\text {th }}$ of January. I was invited to be present at two [...] [507] the one in Santo Domingo of the mother of the Canon Bandini; the other in San Francisco of the mother of Gaspar Puente. I went to both, but in San Francisco I was only present at the end of the ceremony, which concluded by 9 O'clock. At about 12 Bohorquez came to me in high dudgeon; he told me he had received a letter from Barreda and from me at 7 O'clock the preceding evening, and that an hour before, a notary had come to him in a coach, with the object of notifying to him - he having done the same to Correa and Sagastabeytia - a decree of the Juez de $1^{\text {a }}$ Instancia, ordering the Company to pay within three days the amounts claimed by Barreda and by me. He insisted that this was done on purpose, that such conduct was "indigno, y poco decente etc." Of course I replied rather angrily, told him that such words were not to the purpose, and that as regards myself I knew nothing whatever either of the escrito, or the providencia, or the notificacion. As soon as Bohorquez was gone I went to Varela, and Barreda y Osma, which latter I told what had just happened with Bohorquez, and gave it as my opinion that he, Bohorquez, had certainly much reason to be displeased - to which Barreda answered that it had been a mere casual, not intentional coincidence, that the hostile notification had been made, and the friendly letter been delivered more or less at the same time. With some difficulty I persuaded him to be present at the meeting of the Directory which would take place about two O'clock; at this hour all five were assembled in my room, Bohorquez still towering with indignation. At 2.30 Barreda came; he insisted upon his $S / 15,600$. We proved to him that the Company could not pay such an amount; he remained inflexible - altogether it was a disagreeable affair. At last, to put an end to the dispute I said that for my $S / 7800$ Cupons I would satisfy myself with six Cedulas of the Banco Hipotecario of S/10oo each at par, say $S / 6000$ and at Varela's request came down to $S / 5500$. Now this latter, who acted as mediator, offered Barreda for his $\mathrm{S} / 15,600$ amount of cupons, S/60oo in Cedulas at par, and S/5000 a debt of Escudero and Roca, due in May next. The Directory's proposal was conditional, to be referred to the meeting of 
shareholders for approval, or disapproval. At last Barreda said he would give an answer within twenty-four hours, when Bohorquez very properly insisted upon Barreda's giving a solemn promise to stop meanwhile all judicial proceedings, and this he did. We then separated at 4 O'clock.

Wednesday, 21 ${ }^{\text {st }}$ of January 1874 . At an early hour Varela brought [508] a letter from Barreda in which he acceded to the proposal made him; whereupon I also wrote one regarding my claim in terms similar to those used by Barreda. The Directory again met, without Sagastabeytia. Barreda's and my letters were replied to, saying that their contents would be submitted to the next general meeting of shareholders, and another was written to the Gerente of the Banco Hipotecario, in which he was asked whether he - like Barreda and Witt - would take in cancelment of his claim the S/205,00o Pasco Railway bonds which he already held, and requested to give an answer within forty-eight hours. I myself took this letter to Riva Aguero in his Ministry, and insisted upon the necessity of his immediate reply, and of his and his friend's attendance at the general meeting. Thence I went to the Exchange saloon, where a few of the shareholders of the South American Insurance Coy. were assembled; when I entered the "memoria" had already been read, and a dividend declared for 1873 of $60 \%$ upon the paid up capital. The Directors whose turn it was to go out - Ruden, Ayulo, and Carlos Delgado y Moreno - were re-elected. For "suplente" Henry Higginson was chosen; for inspectors of the books at the end of the present year Alfred Böhl, and Bartolo Figari.

Friday, $23^{\text {rd }}$ of January. In the morning I wrote a few words to Riva-Agüero, putting him in mind of what I had told him the other day and again insisting upon his answer.

Saturday, $24^{\text {th }}$ of January. Only Bohorquez and Correa came, with whom I was now on less friendly terms than heretofore. We only looked at what the book-keeper had done, and ordered him to have the balance-sheet and profit and loss account ready by Monday next. No answer having come from Riva Agüero, at 4.30 I once more went to his Ministry; he being with the President I wrote him, as well as I could in the office of the "Oficial Mayor", a note pressing him for an immediate answer. Just when I had done, he came, but in a great hurry, in order to be in time for the 5 O'clock Chorrillos train; he told me that hitherto he had not had a moment's leisure to write the letter, but that he would do so, without loss of time.

Sunday, $25^{\text {th }}$ of January. This morning it was past 6 when I left the house and was back from the summit of my favourite mountain at a little past 8 . By the 2 train I went to Chorrillos to take my bath; the [...] more than usually agitated and though the water was uncomm [...] [509] I remained in so long 
that it was nearly 4 O'clock before I was dressed; I then called upon Dr. José Maria Perez, Vocal of the Superior Court, married to Cora, daughter of the late Lino de la Barrera, one of whose sons, the younger Lino, had taken for wife Alejandrina, Perez' daughter by his first wife. The younger Lino was during Balta's administration captain of the "Sachaca", and continually employed in trips up and down the coast. When Manuel Pardo took the reins of Government, one of the first things he did was to deprive him of his command, whereupon, on account of Henry Meiggs, he went in a large sailing vessel, purchased in the United States, to Macao with the object to bring thence to the coast of Perú, a cargo of Chinese Coolies, but not being able to obtain a single one he had proceeded to Manilla, where he took in a cargo of tobacco for the NewYork market. These particulars I learnt from his wife and sister, who also confirmed to me what I had heard before as a mere report, that the Portuguese Government had prohibited from the month of March of the present year onwards, the exportation of Chinamen, and this it was generally supposed they had done at the request of the English Government, which had always been averse to the importation of Chinese into Perú, this traffic being in their opinion nothing better than a simulated slave-trade in a mitigated form. From Perez' I went to Riva Aguero's; he had gone to Lima. His lady, Doña Mercedes, was in; Böhl was with her, and we remained a pretty long time. I then strolled about in the village until six, when the train took me to Lima, where I fell so sleepy that I merely ate a trifle, and immediately went to bed. At a little past 9 I was awakened with the words that part of the battalion "Zepita" in the barrack of San Francisco had mutinied, and that the firing was clearly heard; I rose, and together with Dibos kept for a long time watch at our street door, but nothing certain could we ascertain; the streets were as quiet as if not quieter than usual, and at 10.30 I again lay down.

Monday, $26^{\text {th }}$ of January 1874. In the course of the previous night an attempt had certainly been made to bring about a revolution, but it had failed. At about 9 the signal had been given by a rocket let off by a person standing upon the new bridge, whereupon somewhat more than 100 soldiers with their sergeants, without any officer to take the command, had taken up arms, and tried to make themselves master of the barrack; but the captain who commanded the guard at the door immediately ordered it to be shut to prevent a com[_] nication between the mutineers and the discontented who might be [...] [510] and then ordered his men to fire volley after volley upon those inside. Twenty, more or less, were killed and wounded; some made their escape over the roofs of the houses, and the remainder surrendered. When succour arrived from the police and other battalions, tranquillity was already restored. Col. Elias Suarez, 
not in active service, teacher of the $1^{\text {st }}$ and $2^{\text {nd }}$ battalion of the NationalGuard, accidentally passed by, and being a staunch Pardista ascended the roof to render assistance, but was shot by the mutineers. The Colonel of the Batallion, who contrary to his duty had been absent from the barrack, was this day deprived of his command, and named instructor in lieu of Suarez, whilst the other three chiefs who had been on the spot and did their duty, were each promoted one grade. The President Pardo, who about a week back had removed to Chorrillos, on receiving advice by telegraph of what had occurred, had immediately come to town on horseback, accompanied by one or two of his ministers and his escort; he visited the various barracks, and when he saw that all was quiet returned to Chorrillos by extra train at 3 in the morning. This day advice came from Cañete by telegraph that there also some disorders had taken place. Part of battalion No 10, of the National Guard, of which César Canevaro was second chief and Alejandro, Adjuntant-general, was ordered thither; the men were told that those who did not wish to go might remain at home - only four availed themselves of this permission. With the greatest alacrity did they march to the station but when on the point of leaving they received counter-orders.

Sagastabeytia sent me a letter received by him the night before from RivaAgüero dated the $23^{\text {rd }}$ in which he declared his willingness to cancel his, or rather the Banco Hipotecario's claim, on the Pasco Railway Company with the special bonds amounting to S/205,00o which he held in his possession, because, as he pretended, the former Directory of the Company, viz.: Manuel Pardo, Nicolas Rodrigo, Sagastabeytia, I, and Riva Agüero himself, had signed a document, by which, de mancomun et insolidum, they made themselves responsable to Riva Agüero, in case the proceeds of the bonds when sold did not cover the amount claimed by the bank. Without loss of time I went to Sagastabeytia, who like myself had the firm conviction that no such document had been signed by the late Directory; but as this was quite indifferent to the other shareholders, I went to the meeting which was convened for 2 O'clock. After waiting for at least an hour, no sufficient number I say one above the half of the shares I was represented by those [...] [511] We therefore separated, after having resolved to convene another meeting for the third of February.

Wednesday, $28^{\text {th }}$ of January 1874. The shareholders of the Banco del Perú were called together. The message of the Directory was read by the President, José Maria Sancho Dávila; it was proposed in the same to pay besides the $41 / 2 \%$ interest already paid in the course of the year 1873 , another $41 / 2 \%$ interest, and $5 \%$ dividend; it also stated that instead of valuing at a certain discount the various documents held by the bank, it had been thought proper to write off 
to the credit of reserve fund a round sum of $S / 140,000$. Two observations were made, the one by Felipe Varela, ably supported by an individual unknown to me, but whom I took to be a foreigner - the other by myself. The first was to the effect that upon these S/140, ooo the Gerentes were not entitled to the $5 \%$ which was their due upon the profits of the establishment, $9 \%$ interest being first deducted; this was undoubtedly correct, however, the motion was withdrawn out of consideration to the gerentes. I said that I thought it more prudent only to pay to the shareholders the $41 / 2 \%$ interest and not to distribute any dividend, because it was well known that many heavy amounts were due to the bank, some of them of a rather doubtful nature. Ruden and Emilio Althaus, both Directors, confessed that more or less they had been of my opinion, but that the majority had been against them. Calderoni, ex-Director, opined that as the debt in the Cerro de Pasco, which he believed to be the only doubtful one, had been decreased S/10o,ooo in the course of the year, even a larger dividend than $5 \%$ might be distributed. Then the question was put whether the $41 / 2 \%$ interest and $5 \%$ dividend should be paid or not, and, as might be expected, all, I excepted, gave their assent by rising from their seats.

This day a sad misfortune befel Col. Juan N. Vargas, a particular friend of Enriqueta's. He and his elder daughters had gone to mass; a son, perhaps 16 years of age was left by his father to take care of his little brother, and two younger sisters; whilst he was reading the paper; the former had gone into a neighbouring room, taken out some matches and sealing-wax with which he had begun playing. When the father returned he found his child in flames running from one room to the other; he threw himself upon him and extinguished the fire by means of blankets, but it was too late, and in a few hours the child expired, strange to say without crying or complaining; he only said "lacre" (sealing-wax.)

We also received advice of the death of our good old friend Don Santiago [_] ara who had breathed his last in Piura in the house of his widowed [...] [512] Jacoba; he had probably reached his $80^{\text {th }}$ year.

Thursday, $29^{\text {th }}$ of January. On the previous day the term had expired which according to law was allowed to Leyva, or rather to his lawyer, for keeping the "expediente" relative to my suit, and I therefore presented this day an escrito to the Supreme Tribunal, requesting that the autos should be sent to the Fiscal whose turn it was to give his vista on judicial affairs. In the evening Mariquita and I walked to the house of Dr. José Gregorio Paz-Soldan, who, just risen from dinner and a little in the wind, received us with great kindness. I told him of the escrito which I had presented, because as it was his turn this month I was desirous to have his opinion or "vista"; and not Ureta's; of course he replied in 
the usual manner that he would do what he thought right and just. When we came home Mariquita went to Enriqueta's party; I preferred going to bed early.

Friday, $30^{\text {th }}$ of January. The Supreme Court acceded to my request.

Saturday, $33^{\text {st }}$ of January. Bohorquez came to my office accompanied by his faithful satellite Cipriano Correa. I begged the former to examine the books written by our book-keeper, which he did, and found everything in order; I then told them that I had to go to the Constructora, and thus they remained but a short time. Augusto Althaus had convened a meeting to communicate to the shareholders what he had done in the liquidation of the establishment; as was always the case only a few came, and another meeting was fixed for the $10^{\text {th }}$ inst.

Thus my time passed; these meetings took up many hours, and my wife was in the right when she complained that I spent my life in the banks, and that I was never with her. When at home I remodelled my old diary, now that of 1850, which Mr. Deeble copied in clean; now and then we read in the forenoon one of Walter Scott's novels, Anne of Geierstein, no master-piece. The scene is laid in the year 1474 about the time that the Swiss Cantons, still in peace, with Charles the Bold of Burgundy, were preparing for a rupture. The evening hour from 7 to 8 was to me the pleasantest time in the whole day; Mr. Deeble then read; we had just finished Prescott's interesting life of Philip the Second, and were now engaged with Motley's Rise of the Dutch Republic, also an able author, though I thought him less impartial than Prescott. William of Orange is of course his hero. After 8 O'clock we usually sat down in our corridor, and took tea in the open air. Now that the heat was so great in the day time, the evenings, especially as we had moonlight were very pleasant. Visitors we had ha[_] [513] Doña Juana Carbajal was the most constant. Between 10 and 11.30 we used to go to bed.

Sunday, $7^{\text {st }}$ of February 1874. This morning I was up San Cristoval, but the steep ascent from the Lurigancho side fatigued me beyond measure.

I did not go to Chorrillos, and preferred to call upon the four Vocales of the Supreme Court, with whom we were on good, not to say intimate terms. Firstly, on Dr. Juan Antonio Ribeyro, where nobody was in; next, on Dr. Gervacio Alvarez, his wife, the little-body Doña Mariquita, and the very rational daughter Doña Asuncion, were at home. With them was an apparently agreeable young man, Solar, brother of the Doctor Don Emilio. Dr. José Luis Gomez-Sanchez was conversing with Dr. Corso, an Arequipeño, Vocal of the Superior Court, who had hardly left when José Vicente Campo came in; this latter was a very old acquaintance of mine. Three or four years ago he went with his lady and children to France for the education of the latter; they were in Paris during the siege, and he returned hither about a month ago to look after his mercantile 
affairs which he had entrusted during his absence, to an old cashkeeper of his, Perez, and a young man, Valencia. According to Campo they had conducted themselves shamefully, and he was now involved with them in a lawsuit, of which he gave a confused and intricate account to Dr. Gomez-Sanchez and myself. Dr. Muñoz was on the point of starting for El Barranco, there to dine with his daughter Jesus, Panizo's wife; when he was gone I remained at least half an hour with his new wife Doña Irene, who might have been his granddaughter, so young was she. I also looked in upon a neighbour of ours, Pedro Noriega, partner of Valdeavellano, who had lately rented the very pretty altos in Gil's new house over the way.

The steamer brought me several letters, one from Diederich Willink of London of $31^{\text {st }}$ December, which contained nothing of interest; another from Juan, dated Funchal Decr. $17^{\text {th }}$, who complained bitterly of his great weakness, caused by the loss of blood owing to an old complaint of his, the piles. An English Doctor, whose acquaintance he had made, had assured him that he would never get cured, if he did not submit to an operation; after his return to Europe he would consult on the subject both London and Paris physicians. The third letter, from Mrs. Knauer, dated Altona $30^{\text {th }}$ December, was a reply to my letter of condolence on the loss of her husband. It was written in such a kind and affecting manner that Ricardo who read it to me could hardly refrain his tears; her husband, [_] said had been struck by apoplexy the first time about the year 1870 [_] [514] which he partly recovered. He had another stroke towards the end of 1872 , and this rendered him a helpless being; he died on the $23^{\text {rd }}$ September 1873. A few days after his death her son William, as yet unmarried, fell into an open sewer, and dislocated his leg to such a degree that when she wrote he was still tied up with bandages, and could hardly limp about. A Grandson of my good old friend, the dear Emily, a youth nineteen years of age, the son of her daughter Emily, who was studying in Munich at a polytechnic institution, had died of cholera, after an illness of six hours. This had quite broken the heart of his mother; the unmarried sister of the young man, an accomplished paintress engaged to an artist like herself, was fortunately on the spot to tend her brother in his last moments. Mrs. Knaur likewise referred to her other grandson George Donner who, as I well recollected died in a hospital in France in consequence of the wound received in the murderous battle at Gravelotte, near Metz.

Henry Sieveking's letter of $29^{\text {th }}$ December was as pleasant as his letters always were, but he also communicated bad news, viz.: that his sister Ernestina was lying dangerously ill, with little chance of recovery. The new imperial coin had been introduced all over Germany; even in Hamburg the change had been brought about with very little difficulty. Three Imperial Marks were equivalent 
to two Banco Marks, or one Prussian Thaler; one Mark had one hundred Pfennig. The exchanges, he wrote me, were quoted as follows:

$\begin{array}{lll}\text { One pound Sterling } & \text { equal to } & \text { Mks 20.36pf, more or less } \\ \text { One hundred francs } & \text { equal to } & \text { Mks 80.10pf, more or less } \\ \text { One hundred florins } & \text { equal to } & \text { Mks 167.50pf, more or less }\end{array}$

Monday, $2^{\text {nd }}$ of February. Last night we had visitors with us till nearly midnight: Rafael Velarde, wife and daughter, and Dibos and wife. The former, by no means a friend of the present President, was always certain that a revolution would break out erelong and upset the Government; now this month of February was the time fixed upon by him for this event. He was also of opinion that the intention of Col. Suarez, killed in the night of the $25^{\text {th }}$ January, had been, not to suppress the mutiny, but to place himself at the head of the mutineers. Dibos related that the orders on Dreyfus given by Pardo to Henry Meiggs had been protested, and that accordingly this latter, last Thursday night, had called together a great number of his employees, and stated to them that he felt obliged to dismiss them all [...] [515] works. Two escritos were drawn out by his lawyer Garcia Calderon, the one to the Consulado informing this Tribunal that he was under the necessity of stopping payment, the other to the Government making them responsible for the consequences which might arise from their not furnishing him with the necessary funds; at the very nick of time, whether on Thursday or Friday I cannot say, some friends interfered, and Pardo placed at Meiggs' disposal at the rate of $50 \% £ 275,000$ - in Peruvian bonds of the loan of 1872 reserved in Europe for public works, which sum would suffice for two months. In the course of the preceding week Pedro Marcone presented himself before a Juez de $1^{\text {a }}$ Instancia, giving in a long escrito in which he stated that he considered it for his own interest, and for that of his creditors to suspend payment for the present; he said that if he were to realize his property just now, he himself would be a ruined man, and his creditors would also be the losers; he therefore asked "esperas" for three and four years, and promised to pay meanwhile interest at $1 \%$ monthly, every three months. His assets by his statement came to $\mathrm{S} / 2,100,000$, more or less.

Tuesday, $3^{\text {rd }}$ of February 1874. We had a meeting of the shareholders of the Pasco Railway Coy. Sagastabeytia did not attend, his presence being required in the usual monthly meeting of the Directors of the Banco de Lima at which of course I could not be present; moreover, he was no more a shareholder, having, as he said, disposed of his shares to Carlos Elias. The protocol of the previous meeting being read and approved, Pio Echenique rose, and observed that he insisted upon a document being presented, which, of great importance, 
he had delivered to the Directory. Bohorquez replied that he recollected the reading of such a document, and that as all the papers had been taken to my house it should be in my possession, to which I replied very warmly that he was mistaken: "not I, the whole Directory was responsible, that from my room nothing was lost or taken away, that I did not deny the existence of such a document, but that I had not seen it; and that whosoever wanted it might come and look for it." Bohorquez replied; Felipe Varela, the little Doctor-at-law, and very useful man, said that Echenique's observation would be noted down in the acta of this day, and the subject dropped, whereupon Varela made a short statement of all that had occurred between the Directory and the two priveleged creditors Enrique Barreda y Osma, and myself. He read the letters written by us two to the Directory, and said that the object of the meeting was to ask the shareholders whether they [...] disapproved the [...] Barreda and $[\ldots][516]$ and that in his opinion the settlement was an advantageous one for the Company, as it would save it from a lawsuit which would be its ruin. Then Bohorquez read all the actas of the Directory relative to this question. Echenique, who was clearly against the amicable settlement, proposed that the Directors should each give his opinion. Varela declared that nothing better could be done; I abstained from giving my own opinion and added that Sagastabeytia had authorized me to declare that he agreed in every respect with Varela. Bohorquez and Correa likewise approved of the arrangement, but spoke in such cautious terms and in such a manner as gave us to understand that they would have preferred the lawsuit. I then proposed that the vote of the shareholders should be taken, but at that very moment Echenique again objected; I, much annoyed, withdrew to my seat, when Varela got up and asked those present one by one whether they were in favor of, or opposed to the settlement above spoken of, and the ayes having the majority we gained our point. Now Bohorquez and Correa declared that they resigned their situation as Directors, and two or three presented a written motion to the effect that a new Directory should be named, from which Varela and I were excluded, and Bohorquez and Correa included. This side blow was fortunately warded off by some one, who referring to the statutes shewed that in an extraordinary meeting only the object for which it was convened, and no other, could be treaded on. We then separated.

Wednesday, $4^{\text {th }}$ of February. Meetings were convened of the shareholders of the Gas Coy., and of the Directors of the Water Coy., but neither the one nor the other met in sufficient number, and nothing was done.

Friday, $6^{\text {th }}$. The customary annual meeting of the shareholders of the Insurance Coy. "Lima" took place in the Exchange saloon; few of them and all 
the Directors attended. Everything went off quietly and peaceably. Lembcke, Muro, and Heudebert went out, but were re-elected; Lembcke begged to be excused, but his excuses were over-ruled. Carrol and Böhl were chosen Inspectors of the accounts at the end of the present year.

There was also a meeting of the shareholders of the Banco Hipotecar[_] the gerente Garcia Calderon in the chair, contrary to usage and rule, because the chairman of the Directory is the proper person to preside at the meeting of shareholders, and the Gerente is the subaltern of the Directory. Riva-Agüero, though Minister, was present as shareholder. The balance-sheet [_] read; the debt of the Pasco Railway to the bank was stated to amount to [...] [517] $\mathrm{S} / 200,000$. This item was very naturally taken up by some one, and it was a certain Col. Perez who asked where the debt arose from. Now it was Riva Agüeros turn to speak. He said that at the time he had been authorized by the Directory to make this loan - which by the bye I believe to be false - and that the debt would be cancelled in the course of six months, for not only did the bank hold Government Bonds for S/205,00o but also a document of the previous five Directors, in which they made themselves personally responsible for any deficit. This was again an untruth. Rodrigo and I, two of the five to whom Riva-Agüero referred, ought to have contradicted him in public, which we did not do, but when the meeting was over I accosted him and said that I did not recollect having signed such a document as he had spoken of, and that I should like to see it. He replied angrily that the document was drawn out in the manner he had stated, and that he had now no time to look for it. On my return home from this meeting, which had been to me quite as disagreeable as that of Tuesday last, another annoyance awaited me; from last night's "Comercio" was read to me a long letter directed by Bohorquez and Correa to Sagastabeytia, president of the Directory of the Pasco Railway Company, in which these two gentlemen not only threw up their Directorship, but entered into long details, with many bitter allusions to me for having continued Director, being at the same time a creditor of the company. The original, Sagastabeytia forwarded to Varela and myself, the only two remaining Directors, for he, Sagastabeytia, since his nomination to the gerencia of the Banco de Lima, had also retired.

Sunday, $8^{\text {th }}$ of February 1874. As it was my custom, at an early, hour I was up San Cristoval. When going out to Chorrillos by the 2 train I met Alejandro in the carriage, who read to me a short article from the paper called "El Cascabel", in which I was spoken of in anything but flattering terms. As far as I recollected I was called an "enredista", an "avariente"; it referred in a malicious manner to my having been the cash-keeper of the company for such a length of time, and gave me the advice to continue accumulating money. I cannot say that it made 
the least impression upon me; the paper was too well known for its slanderous character. After taking my bath I made four calls: upon Doña Juana Guise, who was more than usually agreeable; upon young Lino de la Barrera, who gave me an account of his late voyages in the vessel which more than a year ago was constructed in New York under his direction; upon Mrs. General Pezet; and finally upon Mrs. Morales, the young wife of the Fi [...] [518] la Corte Superior. I returned to Lima by the 6 O'clock train, just in time for dinner.

Monday, $9^{\text {th }}$ ffFebruary. I called upon José Gregorio Paz-Soldan, who received me in a very kind manner, but assured me that it was utterly impossible to give a favourable vista; the only thing he could do was to give it as his opinion que era "improcedente", which means to say that the Supreme Court had nothing to do with such an appeal as I had made, which was by no means so severe a sentence as the other, when it was said "no hay nulidad". I hastened to my lawyer and as soon as his study was opened an escrito was drawn out in which I desisted from my appeal to the Supreme Court. The case had now to be returned to the Superior Court, and thence to the Juez de $1^{\text {a }}$ Instancia.

I was too late for the meeting of the shareholders of the Banco Nacional and merely witnessed the re-election of the three Directors, Fort, Meiggs, and Westphal. Rufino Echenique, one of the gerentes, had however the attention to sit down for a few moments near me, and to give me a short account of the proceedings. The "memoria" of the Directory had been approved of; a dividend of 33 Soles on each share had been declared, which jointly with 18 Soles previously paid, made a dividend of $17 \%$ upon each $S / 300$ paid up. The outstandings he told me were strictly valued, and S/140,00o carried to reserve fund.

The reports as to the pecuniary difficulties in which Julian Zaracondegui found himself, gained ground from day to day. They were believed to be of so serious a nature that he could not avoid presenting himself to the Consulado. It was well known that he had invested large sums of money in his Tarapacá Salitreras, and that as yet they had not produced one single cent. A visit to them was therefore of the greatest importance to him; this visit had also served him as a pretence for transferring the "gerencia" of the Banco de Lima to Sagastabeytia - and still he was in Lima! Within the last few days sentries had been placed at the street door of Dreyfus' house, because they had refused to pay for their patente, or trading licence, the enormous sum of S/20,0oo every half year. However, as the soldiers had afterwards been removed they had probably thought proper to pay.

Tuesday, $10^{\text {th }}$. The shareholders of the Constructora had again been cited by Augusto Althaus. I myself forgot everything about it, my mind being entirely 
taken up with the Cerro de Pasco Affairs. Rodrigo, Sagastabeytia and I called upon Riva Agüero in the Banco Hipotecario to obtain [...] [519] a decisive answer, on the subject of the promissory note which he had referred to in the meeting of the shareholders of the Banco Hipotecario; we were interrupted by other persons, and thus come to no understanding with him.

Wednesday, $11^{\text {th }}$, Thursday, $12^{\text {th }}$, and Friday, $13^{\text {th }}$ of February were comparatively quiet days. I merely had several conferences with Dr. Felipe Varela consulting with him how to ensure a majority in the next general meeting of shareholders, which was held on

Saturday, $14^{\text {th }}$ and which went off much more quietly than I had expected. Before the session commenced, Rodrigo called me, and requested me to make my peace with Bohorquez, who made some advances to me, to which I replied that I was satisfied. At about 3 O'clock little Varela took his seat at the table in the middle of the room, our clerk Enrique Carrera near him. I sat down amongst the rest. The first thing to be done was to ascertain whether the necessary number was present, either personally, or by representation. About two-thirds turned out to be present. Next, Varela read the last acta in which the arrangement with Barreda y Osma and myself was approved. I much feared that observations would be made, for I knew that several had given it as their opinion that on that occasion the votes had been taken in an irregular manner by Varela, and that consequently the said arrangement was not yet approved. Nothing of the kind occurred; the acta being read, a profound silence ensued; "Señores, la acta está aprobada", said Varela; nobody replied, and the acta was approved. Hereupon Varela read the letter from Bohorquez and Correa to Sagastabeytia, referred to above; he also renounced his post as Director, and so did I. The new Directory was to be elected; it was done by slips of paper, upon which each wrote five names, and the number of votes he represented; these slips of paper were folded up, and thrown into a hat. Manuel Mendoza, my neighbour over the way and a good friend of mine, was named to take out and read the votes; scrutators were: our clerk Enrique Carrera, a certain Alvarez, and myself. At the first election, Nicolas Rodrigo and young Peter Gallagher were chosen by a great majority; a second election took place - the battle was between Dr. Sandoval, Escudero, Dr. Felipe Varela, and Bohorquez. I had some votes; so had the said Alvarez; even Manuel Pardo had a few. The votes being counted Varela and Escudero turned out to be elected; Bohorquez had not a sufficient number but he stood next, and in order not to lose any more time he was chosen by acclamati [...] Directors were: Nicolas Rodrigo, whom they named President [520] Dr. Felipe Varela, Don Agustin Escudero, Francisco Bohorquez, and young Peter Gallagher, who was to be their secretary. We 
were just on the point of separating when Agustin Escudero said that if I did not continue to keep the cash, he would not remain in the Directory. Rodrigo insisted upon the same; I answered, "I cannot, I am not a Director." "True, but you will be cajero ad-honorem, you will continue to keep the documents, and you will even allow us to meet at your house." I acceded, for I was persuaded that nowhere would the money be in such safe keeping as in my hands. Whether the others were of the same opinion I did not know; I rather thought that they did it partly in order not to have the trouble, and partly in order to show the confidence which they placed in me. Finally, the new directors received full authorization to do anything they thought proper, with the only condition to inform the shareholders of what they did. I was also instructed to pay the printing office of the "Comercio" for the insertion of Bohorquez' and Correa's letter, which hitherto I had refused to do. Whilst this took place in the saloons of the Banco Hipotecario, my wife had other troubles in her house. Several weeks back she had observed that a pretty considerable quantity of her jewelry of inferior value had disappeared, though she kept them under lock; having satisfied herself that they were nowhere to be found she mentioned the loss to our two servants, Juan and Peta the blackwoman. Both took this observation of my wife in high dudgeon, and protested their innocence. We of course could not fix the guilt upon either the one or the other, but Peta thought herself so much offended that she said she would leave the house which she actually did, and thus my wife was now without a female servant. Juan also began to talk; I told him in a few words, and in an angry voice, "if you want to go, go, the door stands open; if you will remain, remain." I did not believe he would leave us, for nowhere could he get a better situation.

Saturday, $14^{\text {th }}$ of February. This day Gaspar Puente, a batchelor of about sixty years of age, married a girl eighteen or nineteen years old, the daughter of Mariquita Panizo, and one of the brothers Savala.

Sunday, $15^{\text {th }} .1^{\text {st }}$ Carnival day. Early in the morning I was up San Cristoval, and by the 2 O'clock train I went to Chorrillos. Both in Lima and Chorrillos I did not escape without water being thrown upon me. I bathed, made a few calls, and strolled about in the handsome Calle de Lima, until it was Henry's dinner hour, Doña Anita having previously invited me. In the said street, towards the sea side the houses, the one $\mathrm{m}\left[\_\right]$handsome than the other extended already as far as the desc[_] to that [...] [521] sea-beach called Agua-Dulce. The last house, still in progress of construction, and an enormous pile, was that of Don Mariano Laos; a few steps from it was that of José Antonio Garcia y Garcia, nicknamed "El Lord Inglés" on account of the airs which he gave himself; he showed me all over it, and it was certainly very well arranged. Heudebert, it was 
said, was desirous to sell his, a particularly handsome villa, for S/6o,ooo though it had cost him more. At 6 I was at Henry's, who had rented one of Swayne's new houses. A quarter of an hour later we sat down to dinner; we were, Dona Anita at the head of the table, I to her right, next to me Mr. Swift of Graham Rowe \& Co.'s house, to her left, Macandrew, then Böhl, at the bottom of the table Henry, to his right Alice Gallagher, a very nice girl. There were two other gentlemen, whose names I did not learn. Dinner was nothing particular; in fact, provisions had become so horribly dear that to give anything out of the usual way cost heaps of money. Only English was spoken, and the time slipped away very pleasantly until 8 O'clock, when I had to say good bye; and returned to Lima.

Monday, $16^{\text {th }}$ and Tuesday, $17^{\text {th }}$ of February, $2^{\text {nd }}$ and $3^{\text {rd }}$ Carnival day, were beyond measure tiresome. I did not stir out of the house, and as these days were looked upon as holidays, Mr. Deeble was with me only part of the usual time.

Wednesday, $18^{\text {th }}$ of February was a quiet day. I merely went to see some of the new Directors of the Pasco Railway Coy., Rodrigo, Varela, and Escudero, who gave me clearly to understand that they would not pay anything, either to Barreda or to me, and that the small amount which had gradually accumalated should be employed in paying the interest for six, or at least three months, on the $S / 400,000$ Government Bonds, and on the $S / 100,000$ priveleged obligations. I told them I should not make the slightest objection to any resolution of theirs, but I insisted upon their not placing me in a worse situation than Barreda, and also observed to them that the money would not suffice "para hacer el servicio."

Thursday, $19^{\text {th }}$. The Administrative board of the Water Coy. met at Rey's office. Here I was a mere cypher, partly because my interest in the Company was but small, partly because I was by no means well acquainted with all the details of the company. Rodrigo, Oyague, Basagoytia, and Rey were on the other hand large shareholders, and perfectly understood what ought to be done. I therefore only affixed my name to what they had previously signed. Thence I went [...] the Directors of the Insurance Coy. "Lima" where I was not [...] [522] a cypher as in the Water company. Chavez proposed to insure the house which belonged to his half brother Gordillo in the Calle del Correo, occupied by the firm of Dreyfus, against fire, even were the fire the work of an incendiary or caused by popular frenzy. In a previous meeting we had treated on the same subject. This day it was decided in the negative; I did not oppose the majority, though my private opinion was that we might well have taken the risk at $21 / 2 \%$ annual premium, which Chavez was willing to pay. Our president, Lembcke, communicated to us that the gerente, the Frenchman Guiroy, intended to leave 
Lima for his native country by the first steamer in April. This was a great loss, for a fitter person than he could not easily be found. Both this day, and

Friday, $20^{\text {th }}$ of February, when we again met, we treated on the choice of his successor, but came to no decision.

Saturday, $27^{\text {st }}$. The five new Directors of the Pasco Railway Coy. met in my office; I was not present all the while they were discussing, but I learned that the result of their meeting was to present an escrito to the Government declaring themselves ready to give the mortgage required, as soon as the previous mortgage, which still existed in favor of Barreda and myself were cancelled. This in reality was saying nothing, for if Barreda did not give way, our mortgage would not be cancelled, and a new mortgage would not be given. Rodrigo was sanguine that he would be able to persuade Barreda to change his mind, which I doubted. All present promised me on their word of honor that they would never place me in a worse situation than Barreda. It was near four when they broke up. Rodrigo, Sagastabeytia, and I addressed a letter to Riva Agüero requesting the favor of another interview in order to confer with him on the subject of the promissory note.

Sunday, $22^{\text {nd }}$ of February. On the first Carnival-day a murder similar to that of the Portuguese Mesquita had been committed. A Chilian, Vargas, Secretary to the Legation, visited some girls of easy virtue, where one of them, a Chilian, Enriqueta Godoy, whether in fun, or in anger, or in drunkeness, stabbed him with a small, three-edged dagger, and down he fell, dead on the spot. The inmates of the house were arrested and their declarations taken three or four days after the deed had been done. Now the papers said that the assassin was a man, name unknown, who had already made his escape, having embarked on board a guano vessel.

In the course of the week Zaracondegui received assistance from the bank which lent him S/300,00o. An Italian Mazzini stoppe [...] [523] asked "esperas" for five years. Various tenants of my shops and stores were much in arrears; even two shops Calle de Zarate stood empty, as well as one store in Aldavas, one of the two hitherto rented by a certain Mayne, a dealer in earthenware. A few thousand dollars I laid out about this time in the purchase of shares in the "Providencia" at par, and at a small discount, also of five shares in the Water Company which I bought at $3 \%$ discount from José Basagoytia, who was in want of money for the reconstruction of the house in the Calle de Baquijano, formerly inhabited by the family of Schutte, and which his father had lately purchased. The latest advices from Europe were: the death of the famous African explorer Livingstone, also that of the Siamese twins, and the marriage of the Duke of Edinburgh, Alfred, second son of Queen Victoria, with Mary, the 
daughter of Alexander, Emperor of Russia; it was celebrated in St. Petersburg on the $23^{\text {rd }}$ January, and the young couple were married in conformity with the Anglican and Greek rites. President Mac Mahon had given a grand ball in the Palais Elysée; about 6000 persons were present; of the Peruvians resident in Paris the following were named: Andrés Alvarez Calderon, and one of his daughters, for whom he had bought in her own right the title of Condesa de Saint-Ander, with her husband Felipe Canevaro, also Toribio Saenz, with his wife Delfina Izcue, who wore a necklace of pearls, of great value. Alvarez Calderon was a notorious gambler, and a disreputable character; he had made his enormous fortune by the loading of guano vessels. Saenz was likewise very rich: he owed his wealth to his situation as fiscal of the guano consignees in Europe; twenty or twenty-five years back he was contador in the Callao Custom House, acted also in the same capacity in the Consulado, whence he was removed by Castilla, owing to discoveries being made which gave rise to some doubts as to his immaculate integrity.

I had made it my rule on Sunday mornings to climb up San Cristoval and at two O'clock to take the train to Chorrillos to bathe, if I had time, to make a visit or two, and to return by the 4 O'clock train. This day I did not deviate from the rule.

Tuesday, $24^{\text {th }}$ of February 1874. The Directors of the Pasco Railway Coy. met in my rooms. Rodrigo had not succeeded in convincing Barreda; nevertheless, the escrito to the Government was drawn out as they had agreed upon on Saturday; all five signed it, and Rodrigo took it upon himself to deliver it to Riva Agüero, who had promised to present, and to recommend [_] to the [_] nce Minister. Riva Agüero was as [_] Minister [...] [524] Foreign Affairs and at the same time attended to his duty as Gerente del Banco Hipotecario. With him Rodrigo, Sagastabeytia, and I had our interview on

Tuesday, $25^{\text {th }}$. He was very, very angry, or at least feigned to be so, about the letter, which we had addressed him, and which he said offended his honour, worth to him more than any amount of money. Rodrigo tried to assuage his choler. Sagastabeytia spoke very rationally, and assured him that it had never been our intention to offend him; I said but a few words, perhaps, without boasting, most to the purpose. I observed that the promissory note in RivaAgüero's possession was not exactly of such a nature as he had represented it to be in the last meeting in the Banco Hipotecario. At the time that Wyman and Harrison, the contractors for the Pasco Railway, gave various orders to the firm of Huth in London, their representative in Lima asked a guarantee of the five Directors, which was given, for £1o,ooo. When Wyman and Harrison had spent all their funds, and the Banco Hipotecario paid to Huth the balance due 
to the same, the guarantee hitherto given to Huth was transferred to the bank, but as this payment to Huth was the very first made by the bank, it followed as a natural consequence that out of the proceeds of the bonds, the first sum received should be applied to the cancelment of the Directors guarantee, and not, as Riva Agüero pretended, pay first the later advances made by the bank to the Railway Company, and make us responsible for the last deficit there might be, or, as I expressed myself in Spanish "echarnos á la cola". This train of reasoning Riva Agüero strenuously opposed. A great deal was said on the one side and the other, in which long discussion I hardly took any further share, and at last it was resolved that each of the five Directors should pay that part of the ultimate deficit which might correspond to him. This being so far arranged, I touched on another point, viz.: that the said promissory note, signed by us five jointly, ought to be divided into five separate notes, each being responsible for his proportion; now another difficulty arose: should each of the five signers be responsible for one fifth of the $£ 10,000$ or in proportion to the shares which he had in the Company? This would make a considerable difference; if the first principle were acted upon, then each would be responsible for £2000, if the second, then:

$\begin{array}{lllr}\text { Manuel Pardo for his } & \text { S/50,00o shares } & \text { would be responsible for } & £ 4348 \\ \text { Nicolas Rodrigo for his } & \text { S/30,00o shares } & \text { would be responsible for } & £ 2609 \\ \text { Enrique Witt for his } & \text { S/20,000 shares } & \text { would be responsible for } & {[\ldots]} \\ & & \text { Brought forward } & £ 8696 \\ \text { [525] } & & \text { would be responsible for } & £ 869 \\ \text { F. Sagastabeytia for his } & \text { S/10,00o shares } \\ \text { Riva Agüero for his } & \text { S/5000 shares } & \text { would be responsible for } & £ 435 \\ & & & £ 10,000\end{array}$

These two questions were left undecided, and when we parted with Riva Agüero our difference was apparently made up.

Thursday, $26^{\text {th }}$ of February 1874. My wife and I were present at Enriqueta's usual tertulia; Manuel Francisco Benavides, Diego Masias, Ignacio Távara, and Garland firmed the rocambor table: for the ladies, Masias' wife, sister-inlaw, and daughter, Rafael Velarde's wife, and two daughters, and my wife and Enriqueta. Enrique kept the bank at vingt-un, but I advised him not to do so again, for if he lost he had to pay, and if he gained he could not be quite certain of being paid. My wife and I were just on the point of going to bed when the fire bell tolled; I hurried on my clothes; it had just struck one. In the street of Plumereros a fire had broken out in an eating-house kept by a Frenchman, and for a short time the flames made rapid progress. I went as far as the Calle de 
Mantas; the fire-engines were already on the spot; the Intendente came, and when I saw that every measure was taken to extinguish the fire I went home; at about two the sky ceased to be illumined, and I turned in. The Companies of firemen were all volunteers, Italian, French, Peruvian, and English; another company had lately formed itself, called "La Salvadora" whose only object was to save the articles and to carry them to a secure place, thereby putting a stop to the robberies which had hitherto been committed on these occasions. Within the last fortnight or so there had been two other fires, the one in the Church of San Pedro, the other in the coal and timber deposit of Pingel \& Co. close to the Callao Railway, still within the precincts of the town; both were quickly extinguished.

Saturday, $28^{\text {th }}$ of February. The Directors of the Pasco Railway Coy. did not meet. A meeting of the shareholders of the Water Coy. was convoked for two O'clock. I went, but no sufficient number had assembled. Then I had to be present at the meeting of the Directors of the Insurance Coy. "Lima"; only Carlos Elizalde was wanting, owing to illness. A new Gerente, in lieu of Guiroy, was to be chosen, but nothing was decided. A certain Haza, of Callao, who had hitherto examined the vessels for the Company, and who was a very proper person for that purpose, was strongly recommended by Guiroy; José Pablo Escobar, a relation of his [...] though no Director also spoke much in his favor, but as [...] [526] I learned he was not capable of keeping books and accounts, nor could he be trusted with lending money. Henry recommended Calixto Pfeiffer, to whom I was ready to give my vote if he could be here in time. He was absent in the north, where he and his partner Lauezzari, who had lately stopped payment, were liquidating their affairs. Muro proposed the eldest son of Lembcke; as soon as this motion was made, Lembcke, the father, left his seat and withdrew; Henry as Vice, taking his place. It being Guillermo's birthday, my wife and I dined with the Garlands.

Sunday, ${ }^{\text {st }}$ of March. This morning I left my house before 6 O'clock. From the side of the new Alameda I reached the summit of San Cristoval with great ease, but when descending on the opposite side to the Paseo Militar the fog lay so thick that I entirely lost my way; I kept too much to the right and found myself surrounded by rocks and stones, so much so that more than once I knew not whither to turn; I sat down, thinking I might wait till the sun came out, but this lasted too long; I rose, sat down again, rose once more and with much difficulty reached a trodden path, well known to me, which quickly brought me to the bottom; it was nearly half past eight when I reached my houses completely knocked up; nevertheless, at two I went as usual to Chorrillos. Conspiracies, and attempts at revolution were much spoken of, perhaps not entirely without 
cause; at all events a lot of rifles had been discovered somewhere, and taken possession of by the police.

I again bought fifteen shares of the Banco La Providencia at 99 1/2\%. The seller was Bernardo Roca y Garzon, who, as Fernando O'Phelan the broker told me, wanted money in order to assist his son Lewis, who, jointly with his partner Agustin Escudero, was, I believed, sorely pressed for want of funds.

Monday, $2^{\text {nd }}$ of March. I received a note from Doña Manuela Portillo, the highly respectable and agreeable old lady, whom I sometimes visited, and with whom I was on very friendly terms. She recommended to me as Gerente of the Insurance Coy. "Lima" Manuel Ferreyros, husband of her grand-daughter Amalia Alayza; this gentlemen was the eldest son of the lately deceased Manuel Ferreyros, and one of the best officers in the Peruvian navy. Under Balta's administration he was for a short time Minister of the Interior and being superceded by Rafael Velarde, left the Ministry to bring the Monitors from Rio Janeiro to Callao [...] [527] most perilous voyages ever made. Though a schoolfellow of President Manuel Pardo, whom he addressed with the familiar "thou", he was at present not in active service, and acted as President of the Commission in Callao which examined the vessels before loading guano. I sent word to him by Alexander through his younger brother Carlos who commanded the "Chalaco" that he might address a letter to me expressing a wish to obtain the said situation. On

Tuesday, $3^{\text {rd }}$ of March he came to me, told me that he preferred not to write such a letter, but that in the course of the day he would endeavour to secure some votes. He returned in the evening, and told me that he had succeeded quite as well as he had expected. At about 10 Rafael Velarde came, merely with the object to beg Garland and myself to give our votes in favor of Haza; Garland said "yes", I "no", because I had promised my vote to Ferreyros.

In the forenoon of this day José $\mathrm{V}$. Oyague presided for the first time in the Directory of the Banco de Lima. Manuel Salcedo, Manuel Elguera, and Julian Zaracondegui did not attend. Lembcke made known that one of the clerks, Salmon, had defrauded the bank of nearly S/13,0oo - but that the bank would probably not lose anything, for $\mathrm{S} / 10,000$ had been refunded by his friends, and for the remaining $S / 3000$ a pagare at three months date had been signed by his father, the postmaster. This question having been settled, Oyague, the President, spoke; he referred to the difficulties in which Zaracondegui found himself, and added that he had assisted him with a loan of S/10o,ooo; next that the Salitera "Esperanza" in the province of Tarapacá, in which by the by several of the Directors of the Banco de Lima, Zaracondegui, Lembcke, Muro, Gil, and perhaps one or two more were interested, had applied for a new loan 
of $\mathrm{S} / 200,000$ over and above the $\mathrm{S} / 800,000$ already lent to this establishment; these $S / 200,000$ were required to complete the railway; the construction of which it was said had just been begun; when finished, the nitrate produced in the establishment could easily be conveyed to the coast for shipment, whilst without the railway the carriage on mule-back would be much too expensive, consequently the railway was indispensable, from which followed that without the $\mathrm{S} / 200,000$, now asked for, the $\mathrm{S} / 800,000$ already advanced, might be looked upon as thrown away. Under these circumstances Oyague advocated the new loan; so did Lembcke, and finally it was unanimously conceded; though as to myself I did it with a heavy heart. By the North steamer I had no letter from Juan; Rosa $[\ldots]$ sister that she, her husband, and Corina $[\ldots]$ for some $[\ldots]$ [528] in Nizza, whilst Mr. and Mrs. Shattuck, and children had remained in Paris. Schutte was in a poor state of health; he was unable to walk, and with difficulty did he sometimes collect his thoughts; he was however able to dictate his letters, which Corina wrote. From England we learned that the Whigs, with Gladstone at their head, had gone out, and that a Conservative cabinet had been formed. D'Israeli was named First Lord of the Treasury, or what in other countries is called Prime Minister, Earl Derby for Foreign Affairs, Cairns, Lord Chancellor, Sir Stafford Northcote, Chancellor of the Exchequer, Caernarvon, Colonies.

Wednesday, $4^{\text {th }}$ of March 1874. In a meeting of a small number of the shareholders in the Constructora, Augusto Althaus, the liquidator, in a short speech made manifest to those assembled, I being of the number, that he had discovered more than one roguery committed by César Saco, one of the two ex-Gerentes of the Constructora; he also showed that the late Directory, to which I had belonged, had on more than one occasion made itself guilty of gross negligence. These statements were listened to without leading to any discussion. Next, Althaus was authorized to receive from the Municipality in payment of the new market-place built by the Constructora on the spot called el Paseo de Aguas, their municipal bonds, and to distribute them proportionally amongst the shareholders, also to discontinue the lawsuit against Henry Meiggs for the S/60,00o and odd which he owed, in case he could come with him to a friendly understanding, of which there was every probability. From this meeting I went to another, that of the Directory of the Insurance Coy. "Lima". At 3.30 the twelve Directors were assembled, viz.: Lembcke, in the chair, Henry, Vice, J. M. Peña, Pedro Noriega, G. Heudebert, A. Westphal, M. G. Chavez, Valentin Gil, José Muro, G. Garland, Carlos Elizalde, and I. Our object was to choose the new gerente. We resolved that the absolute majority, seven votes, should decide. The three candidates were: Lembcke's 
son, the naval officer Haza, and Manuel Ferreyros. The first time, the first of the three had four votes, the second, three, the third, five. Again we had to vote; now Ferreyros obtained eight, for the three who had favored Haza passed over to his side. The four who had steadfastly voted for young Lembcke were: his father, Muro, Gil, and either Chavez or Westphal.

In the evening Ferreyros went to Manuel Pardo's in Chorrillos to obtain from him permission to retire altogether from the naval servi[_] which was [...]. Early in the morning of th [...] [529] Adolfo, son of the vocal Jervacio Alvarez, in the lunatic asylum in the Cercado.

Thursday, $5^{\text {th }}$ of March 1874. Ferreyros' nomination was officially communicated to him in a letter, not signed by the President Lembcke as it should have been, but by Guiroy, the present Gerente, who also informed me by a few words that I was again Director de Turno, and had consequently to attend daily in the office. The shareholders of the Water Company who assembled in Rey's office merely re-elected the old Directors, and chose Enrique Prevost to examine the accounts at the end of the year.

In the evening I went to see the family of Dr. Jervacio Alvarez. The mother, whose idol Adolfo had been, did not yet know of his death. All were extremely sad.

Friday, $6^{\text {th }}$ of March. Early in the morning, Garland, his three eldest sons, and I were present at Adolfo's funeral in the Church of La Merced; I was requested to take hold of one of the black ribbons hanging down from the coffin; the three others were held by the three Vocales of the Supreme Court Cosio, Muñoz, and Ribeyro. I also drove out to the pantheon, where with little ceremony the coffin was shoved into one of the open niches; a clergyman in a white surplice mumbled a few Latin words, the bricklayers stood ready with their mortar, and by 9.30 we were back in Lima.

Saturday, $7^{\text {th }}$ of March. I met Henry in the Insurance Office, who read to me a letter addressed to him by Lembcke, in which he advised him that he had ceased to be shareholder, Director, and President of the Directory, having sold his shares, which, as I learned afterwards, had been bought by Juan José Araoz at $86 \%$ premium, $4 \%$ below their market value.

From Bolivia, advice was received of the death of the President, Adolfo Balivian, which was generally looked upon as a misfortune, not only to his own Republic, but also to that of Perú, to which during the time of his Presidency he had shown himself well disposed. Frias, President of the Council of Ministers, had provisionally taken the reins of Government into his hands, in conformity with the Constitution of the Country. 
Sunday, $8^{\text {th }}$ of March. Mr. Deeble having expressed a wish to attend divine service in the English Chapel I did not object to his leaving me somewhat earlier than usual; and I myself went to Chorrillos by the 12 O'clock train. When I was undressing in order to take my bath, I could not undo my cravat, a new fangled French invention, and had to tear it; this would [...] vented my customary calls had I not got it mended quite [...] [530] I was on my way over the hills to the Salto del Fraile, when I was called by Villemars, the stout and big Belgian; I entered his rancho, told him of my mishap, when he ordered a servant girl of his to sew the cravat, and whilst she was occupied with it, I stayed with him about half an hour; he was very tipsy, as I had never seen him before. On my leaving his rancho I met Lembcke who on the malecon was talking with Fernando O'Phelan about the Insurance Company Lima. I addressed him in Spanish, and told him that he had done wrong in separating from us, and that I was very sorry he had done so, because as he well knew I had a great opinion of his capacity; he replied that he had taken the step because he considered himself slighted by the Directory, the more so as he was convinced that his son was a fitter person than Manuel Ferreyros for Gerente of an Insurance Company. We parted as good friends as ever. Of the visits which I paid I will only mention that to Isabel Soyer, José Vicente Oyague's very agreeable lady, who made me a present, in her opinion of great value, and which she hoped would perfectly cure my wife of her tumours, viz.: a small phial filled with the true and veritable water of the well, known Virgin of Lourdes, of which her sister Luisa, José Francisco Canevaro's wife, who had bought it on the spot, and who as well as herself had been cured of an ulcerated throat, had sent her several bottles.

Monday, $9^{\text {th }}$ of March. All of a sudden, at about 10, I felt a severe and acute pain, which extended from the left shoulder-blade towards the chest. Had it lasted any length of time, I could not have borne it. I immediately went to bed; my wife rubbed me with some spirituous liquor and the pain decreased, though it did not leave me altogether.

The Directory of the Insurance Company "Lima" met. Lembcke, no more a shareholder, and José Maria Peña were wanting. In the first place we chose a new Director, and the choice fell upon Mr. Michael Carrol, partner of Bates Stokes \& Co.; next, a new President, and Carlos Elizalde was elected. Henry had three votes, one of which was mine. He of course continued as Vice.

Saturday, $14^{\text {th }}$ of March. I felt no more the pain of which I complained on Monday last, but just over the right hip a pain had settled which inconvenienced me a good deal. In all probability I had caught cold when bathing on Sunday. 
In the course of this week the Insurance Company Li[_] [531] effected some pretty considerable insurances upon property belonging to Julian Zaracondegui; in all probability the Banco Nacional, which had advanced him S/10o,ooo on his immovable property, had insisted upon its being insured against fire risk,

Viz.: $\quad$ S/50,000 on his house Calle de Mantas, occupied by the Bco. de Lima

$\mathrm{S} / 25,000$ on his tanyard; these two at $1 \%$ annually. And

$\mathrm{S} / 25,000$ on his candle manufactory, at $2 \%$, of which one half was taken by the South American Insurance Company.

Some months back the Insurance Company Lima, and I had lent to Marguet \& Co. S/10,0oo, the Company $3 / 5^{\text {ths }}, \mathrm{I} 2 / 5^{\text {ths }}$. This firm had suffered much by Bianchi's stoppage, and it was feared that they would not be able to weather the storm; we were thus very glad to hear that Manuel Ferreyros, the new gerente, had bought of them twenty shares in the company, say S/200o. Capital paid up, at $88 \%$ premium, together $S / 3760$ which sum he had paid in to Guiroy who handed to me the amount corresponding to my $2 / 5^{\text {ths }}$. My tenants LopezHurtado \& Co., who occupied two stores, 92 and 94 Calle de Zarate, had not yet paid their rent due $\mathrm{s}^{\text {st }}$ inst., and I heard that they had pagarées overdue, for which their creditors had cited them before the Consulado.

In the course of the forenoon a clerk from the establishment of Pingel \& Co., came to advise me that a Danish subject, the architect Albert Bernstein, was lying dangerously ill in the Hospital of Guadalupe, which was under the charge of the French sisters of charity; I immediately went thither, and found the sick man suffering from a disease of the heart; his groans, for want of respiration, were pitiful to hear. His room, bed, and all the surroundings were very neat and clean; he paid for the same S/5 daily. I sat down near him, and addressed him in German, which he understood, but was hardly able to answer; with him were two friends of his, an Englishman and a Dane, who made him sign a paper which I dictated in Spanish, and in which he requested the Gerentes of the London and Mexican Bank, in the unexpected event of his death, to hold at my disposal as Danish Consul the balance of his account in their books, this balance to be remitted by me to his relations in Denmark.

This day death put an end to the existence of Carlos Aliaga y Puente, one of the children of the late Juan Aliaga y Calatayud, a young man, of whom not much good could be said. On Sunday, the $8^{\text {th }}$ he had been [...] Pun [...] Call[_] with some of his friends. He mounted a splendid [532] horse of his brother 
Juan's, and, probably much in the wind, for he was given to hard-drinking, boasted that he could ride as fast as the train ran; those with him tried to dissuade him from such a mad freak, but in vain; off he started, and erelong the train had knocked him down, cut his horse in two, fractured his arm, cut off one of his calves, and severely injured his skull; as far as I understood he bled to death.

Last Sunday died in Chorrillos the old lawyer Don Agustin Garcia, an Ecuatorian by birth, with whom I had been but slightly acquainted, whilst many years back I had been a pretty regular visitor of his late sister Doña Ramona when she had still with her her daughter Rosa Zevallos, and her granddaughters Pola, and Margarita Egusquiza.

Sunday, $15^{\text {th }}$ of March. My wife, who for some time past had enjoyed pretty good health, again began to complain of the numbness which had first made itself felt in her toes at the time we were travelling about in Germany and Italy in the year 1855, which had gradually extended as far as her feet and legs, and now began to invade her thighs; fortunately it did not prevent her walking; it inconvenienced her when she was in a sitting, or reclining posture. Enrique and Alejandro continued without employ; the latter wrote up my commercial books to the $28^{\text {th }}$ February, which, under my direction, he did to my complete satisfaction.

Tuesday, $17^{\text {th }}$ of March. An Englishman, Barwise, informed me that his friend Albert Bernstein had died in the hospital. I went thither, and two sealed envelopes were delivered to me, in which I found the receipts given to the deceased by the National Bank; and the London Bank of Mexico \& South America, for money amounting to $S / 2100$ deposited by him. I applied for these sums, which were delivered to me without difficulty; and placed them in the Banco de Lima on my account.

Wednesday, $18^{\text {th }}$ of March. By order of the Consulado the stores of Lopez Hurtado \& Co. $\mathrm{N}^{\circ} 92$ and 94 Calle de Zarate, were locked and sealed. Lopez Hurtado had absconded and his affairs looked extremely bad. Julian Sandoval, the physician, who had advanced him money to carry on his business, was a creditor for a very large amount, and it was believed that this loss would nearly ruin him; his, the Doctor's signature, had even been forged by the said Lopez-Hurtado, and the pagarées provided with the same had been readily discounted by the Nation[_] Bank by Simon So [...]. [533]

Thursday, $19^{\text {th }}$ of March 1874. San José. I went with Barwise, who belonged to the Society of Odd-fellows, of which Bernstein had also been a member, by the 10 O'clock train to Chorrillos, there to take the inventory of the effects left by the deceased. He, in the employ of Pingel, had been superintending 
the building of several houses in Chorrillos and until he fell ill had occupied there a small room, one of a row of rooms owned by Estenós; his next door neighbour, Scott, in the employ of Hart Brothers of Lima, had the key to his apartments; to him I applied, and we three, Barwise, Scott, I busied ourselves for some time with taking the inventory, Barwise acting as secretary. When done, I locked the trunk and box, with their contents, and placed them under the Charge of Scott, against his receipt.

Friday, $20^{\text {th }}$ of March. I asked Hart about Scott, and was told that the articles placed by me under his charge were there as safe as they possibly could be.

Saturday, $27^{\text {st }}$. I to went the Consulado, and spoke to Lecca, one of the Consuls, on the subject of the rent due to me by Lopez Hurtado \& Co.; he replied that this was a priveleged debt, and that it would be paid me as soon as the Sindico were named. The Directors of the Cerro de Pasco Railway Company met as usual on Saturdays in my rooms, and to my great surprise I learned that the decree to convert the Pasco Railway bonds into Vales de la Nueva Consolidacion, of which Rodrigo told me over and over again, "ya está hecho", had not only not yet been signed, but the Minister of Finances Carrillo was averse to take the responsibility upon himself, and had called together a Council of Ministers to treat on the matter; thus I was much afraid that in my valuation of debts on the $28^{\text {th }}$ February of the present year I had valued the S/50,00o lent by me to the company, much too high, at $40 \%$, whilst I should perhaps have put them down at $100 \%$ discount. Were it not for these valuations, which I always made at the end of my financial year, the result of my last years business would have been a splendid one.

About this time a very dangerous conspiracy was discovered; several sergeants of the artillery in the fort of Santa Catalina had been gained over, by whom, and for whom I did not learn; fortunately one of them got tipsy, blabbed, and all came out.

Sunday, $22^{\text {nd }}$ of March. At 10 p.m. I went to Sagastabeytia's house in the plazuela de Bolivar, whence a number of gentlemen accompanied the coffin in which were enclosed the mortal remains of his mother Doña Josefa, an [...] had died at the age of 80 to the Church of La Mer[_] [534] where, on

Monday, $23^{\text {rd }}$ I was present at the funeral, but did not drive out to the pantheon.

Tuesday, $24^{\text {th }}$ of March. This day appeared, cited by me, before a Juez de Paz, one of my tenants, a shoemaker, Ramirez, who was much in arrears with his rent; he begged and prayed to be allowed one week, at the expiration of which he would pay me $\mathrm{S} / 20$ and I granted him this new respite. Other tenants were also in arrears, though not to such an extent as Ramirez. More than one of my 
shops and stores stood empty, and in order to let them I found myself in the necessity of lowering the rent considerably. In short, the poverty of Lima was very great; many of the persons who lived upon Government had not been paid for several months, and the President himself confessed that he did not know whence to get money; he and the whole country were now suffering the consequence of Balta's extravagant administration. Navarro y Mesa, who for a long time had been established in the Calles de Bodegones y Judios, and who till of late had enjoyed and excellent mercantile character, stopped payment. Their debts amounted to $\mathrm{S} / 600,000$ and in the list of their creditors the names of all the foreign importing houses were to be found. Geronimo Sanchez, an hacendado, or landed proprietor, somewhere to the North of Lima, found himself more or less in the same situation as the just mentioned firm. He owed $\mathrm{S} / 1,300,000$ of which a considerable sum to the Banco de Lima; he had ceased paying interest for some time past, and frequently had this debt been treated on in the meetings of the Directory.

Thursday, $26^{\text {th }}$ of March. Only Escobar and his wife Emilia Lopez came to Enriqueta's soirée.

Friday, $27^{\text {th }}$. In the evening it became known that a small number of Montoneros, forty or fifty, had shown themselves on the road to Lurin, and troops had been sent against them. This news caused such a fright amongst the pussillanimous part of the Lima population, which was very numerous, that they thought the revolution was at the door. Whilst I had gone to the Post Office, and found the streets as quiet as usual, Rafael Velarde out of breath, hardly able to speak, came running to our house, and fetched away his daughter Zoila, "not a second", he said "was to be lost", and yet, as might have been foreseen, nothing out of [...] occured. [535]

Saturday, $28^{\text {th }}$ of March 1874. Every day in the course of the week I, as Director de Turno, had gone to the office of the Insurance Company Lima, where I found the ex-gerente Guiroy, and the present one, Ferreyros, the former instructing the latter in the duties of his new office, and what I saw gave me the conviction that Ferreyros would never become so efficient as Guiroy had been. This latter was a very respectable elderly Frenchman. During his long stay in Lima he had made a small fortune, working as book-keeper with Gibbs, with the Government, and one or other of the guano Companies, and he was now on the point of leaving for France with his wife and son there to spend the remainder of his life on a small farm of his, near Bayonne.

My claim on the Pasco Railway Company continued to be a source of annoyance to me. I now learned that upon the first escrito given in by me, and the rough draft of which was made out by Felipe Barreda, approved of by 
Riva Agüero, Sagastabeytia, and even by Manuel Pardo, one of the subalterns in the Finance Ministry had written a very unfavourable note, "informe" as it is called here, and that it was now Riva Agüero's intention to substract from the document, this my escrito, and to supplant it by another, to be drawn out by him and to be signed by me.

Carlos Wheelock was named Sindico of the bankrupt estate of LopezHurtado \& Co., and without loss of time I presented to him my claim for the rent due to me.

Sunday, $29^{\text {th }}$ of March. For the last fortnight my wife had been without a female servant; the black woman Peta had left as above said, and another whom she had engaged had been ill for about a fortnight, for which reason, not to leave her by herself I had abstained from going out early in the morning. However, as the latter had recovered I once more made my ascent of San Cristoval, which this time fatigued me a good deal.

Wednesday, $7^{\text {st }}$ of April. My tenants remained in arrears with their rents. On the other hand I had been fortunate enough to recover S/10oo with interest from Tomas Solar Reyes, whom I had looked upon as a very doubtful debtor. Also with Marguet \& Co., the Insurance Company Lima, and I settled accounts. In payment of the balance of their debt, we took from them shares of the Banco Nacional, each with 300 Soles paid up capital, at a discount of $12 \%$. I saw by the papers that the telegraph Company, hitherto managed by Carlos Paz-Soldan [_] shares had not paid to the Government the sum of [...] [536] it had received in loan from the former administration, and that consequently Manuel Pardo, who was displeased with Carlos' father Mariano Felipe, had laid an embargo upon the assets of the Company, and placed its management under the charge of Nataniel Sanchez. Carlos advertized that henceforward he had nothing to do with the forwarding of telegrams. The reason of the President's displeasure with Mariano Felipe Paz-Soldan was the following: The Government had been on the point of concluding, or perhaps had actually concluded a contract with an English Company for laying a cable from Panama to Payta, but on application through the Columbian Minister resident in Lima, to his Government, for permission to land the cable in Panamá, the reply was that this Government had already made a contract with Mariano Felipe Paz-Soldan for establishing a submarine telegraphic communication between Payta and Panamá, touching at the mid-way port of Buenaventura; this last part of the contract, the sinequa-non condition of the Columbians, the English Company with which Pardo was treating, would not accede to, and thus in all probability some years would still elapse before the desired communication would be effected. 
From Europe we learned that the Emperor of Austria had paid a visit to the Emperor of Russia, on which occasion toasts had been given to the firm alliance of the four great powers, Russia, Austria, Germany, and England. In the German Parliament a strange scene had occurred; the Deputies for Alsace and Lorraine, amongst whom the Bishops of Strasbourg and Metz, had appeared to the first time in the German Parliament. Such as were graced with the ribbon of "la Legion d'honneur", wore this insignia of French nationality; one of them read in German a motion to the effect that the Parliament might order a plebiscite to be held in Alsace and Lorraine, as to whether the inhabitants wished to be subjects of France or Germany; he also gave it as his opinion that the treaty of peace of Frankfort could not be binding upon them. As was to be expected, the motion was lost by an immense majority; only the Deputies for Posen, Slesvic, and Holstein voted with Alsace and Lorraine. On the other hand, the Bishop of Strasbourg declared in his own name, and in that of all the Catholics of Alsace, that they considered the Frankfort treaty as binding upon them and that they left the future to a kind Providence. This unexpe[_] [537] declaration was received with shouts of applause by the true German members. In another meeting the far famed Count Moltke, chief of the staff in the French-German war, delivered a speech in which he explained and gave very good reasons, why the peace establishment of the German army ought never to be less than 400,000 men. On occasion of the marriage of Prince Alfred to the Princess Marie, daughter of the Czar Alexander, the officers of the British Navy and Marines had made her a present of a dessert service consisting of sixty pieces of massive gold. Denmark had conceded to Iceland a liberal constitution, upon the model of the Danish, of 1849, which, an English paper said, was one of the most liberal in Europe; the king however denied to the Icelanders their demand for an entirely seperate Government; so as to be united to the Danish crown merely by the person of the sovereign.

In Chisselhurst there had been a great gathering of the adherents of the Napoleon dynasty, to congratulate the Prince Imperial on his attaining his majority, for according to a law given by the Senate during the reign of Napoleon III, the Prince was to attain his majority at the age of 18 , which age he now completed, having been born on the $16^{\text {th }}$ March 1856 .

Thursday, $2^{\text {nd }}$ of April 1874. This day being Holy Thursday all good Catholics considered it their duty to "Andar las estaciones", that is to say, to visit if possible seven different Churches, and to repeat at the foot of seven Altars in each of these seven Churches, the same prayers. In the evening the churches were brilliantly lighted up; in the one or the other a table was placed before 
the Altar; upon it stood eatables, and round the same sat thirteen Statues, representing Christ and the twelve apostles, Judas Iscariot frequently redhaired, and with an "aji" in his mouth. My wife and daughter went out in the forenoon, but contented themselves with saying their prayers in two or three Churches. Deeble was with me in the forenoon; at 2 I went to Chorrillos, bathed, and returned at 4. Through Alejandro, whom I had requested to confer with Riva Agüero on the "vexed question", I learned that it had certainly been Riva Agüero's intention to substract my escrito as said above, but that he had changed his mind when he saw that the informe given by Cáceres, Tur's superior in the office called "la Direccion de Contabilidad", had been the very reverse to the unfavourable opinion expressed by Tur. Riva Agüero now expected that the conversion [_] the Special bonds, held by him, Barreda, and myself into bonds [...] [538] Internal Debt, would erelong be decreed.

Saturday, $4^{\text {th }}$ of April. We had our usual monthly meeting in the Compañia de Seguros "Lima", Carlos Elizalde presiding, and Manuel Ferreyros taking for the first time his place as "gerente", or manager. Nothing of great importance was transacted. Elizalde presented a proposal to insure merchandize to the amount of S/60,ooo in the Callao Custom-house Stores, for the firm of Dorca and Ayulo; it was resolved not to effect this insurance, because a few months back under Lembcke's presidency the Directors had decided not to exceed the sum of $\mathrm{S} / 400,000$ in the said stores, and the risks insured in the same came already to $\mathrm{S} / 384,000$. Elizalde said he would himself examine the Customhouse Stores, and give his report at the next meeting.

Sunday, $5^{\text {th }}$ of April. Easter Sunday. Before six I was in the street. The sun shone from an unclouded sky, and I accomplished my ascent of San Cristoval without stopping, but reached the top, bathed in perspiration. When Deeble was gone, I made a great many visits viz.: to Dr. Bandini, canon of the Cathedral, a very agreeable and well instructed man; Francisco Sagastabeytia, provisional gerente of the Banco de Lima; Dr. José Gregorio Paz-Soldan, fiscal, and Dr. Bernardo Muñoz, Vocal of the Supreme Court of Justice; Dr. Teodoro de la Rosa, Vocal of the Superior Court; Col. Diego Masias and family, Dr. Rafael Velarde, for a short time Minister under Balta's administration now without employ, and consequently no great friend of the present Government; Doña Josefa Ulloa, widow of Prada; Doña Goya Gomez, widow of Manuel Velarde, with her daughter Adela, and son-in-law Baltazar Aranivar; José Maria La Jara, ex-Finance Minister, now again "Vista" of the Callao Custom-house; and finally, the three vocales of the Supreme Court, José Luis Gomez-Sanchez, Jervacio Alvarez, and J. A. Ribeyro. The Government had not paid them their appointments for the last five or six months, and it was thus very natural that 
they were not well disposed towards President Pardo; whilst the judges of the Superior Court, and Primera Instancia, who now depended on the Concejo Departamental were paid up to the day, and consequently quite satisf[_]. A considerable number of the persons just enum[_]ted I [...] [539] find at home, with them I merely left my card.

About this time José Maria Sancho Davila had a stroke of apoplexy. He was however recovering and would probably escape this time.

Monday, $6^{\text {th }}$ of April. Easter Monday. Having taken my usual sea-bath in Chorrillos I looked in upon some of my acquaintances residing there. Old Dr. Don Mariano Blas de la Fuente was not at home; he, a native of Arequipa was a gentleman in every respect; after having served his country for many years mainly in the judicature, also in the political administration, he now led a quiet and retired life, partly upon his small income which he derived from some immovable property he possessed in Arequipa, partly upon his pension, with which however he did not fare better then many others similarly situated he had not been paid for the last three or four months. Dr. José Maria Perez, and his brother-in-law Lino de la Barrera, were at home, with their respective wives, and so was Doña Juana Tirado, General Pezet's lady. General Pedro Cisneros, generally "half seas over", also so on this occasion, and his excellent wife Trinidad de la Fuente, niece of the above Don Mariano, Luis Cisneros, nephew of the General Don Pedro, and his wife Cristina, grand-daughter of Dr. Jervacio Alvarez, with whom I found her cousin Aurora, and old Anselmo Centeno believed to be nearly one hundred years old - all received me with politeness and kindness. Only Mrs. Riva Agüero, lady of the world as she was, was not so polite as she used to be; perhaps the rocambor-playing of some of her guests attracted her attention so much that she had none left to bestow upon me. I returned to Lima by the 6 O'clock train.

Tuesday, $7^{\text {th }}$ of April. The Directory of the Banco de Lima had their monthly meeting; we were assured by the Gerentes that the debt of Geronimo Sanchez to the bank, of more than S/30o,ooo was quite safe. To my particular enquiry about the debt of the Monteros, and about that of Manuel Maria Perez, at present in Iquique, amounting to $\mathrm{S} / 50,000$ and arising from Bianchi's stoppage, I received the answer that neither of the two was as yet paid. The shares of the Banco de Lima had of late somewhat declined in their market value; Mr. Henry of Gibbs' house, who at the end of last year had bought two shares at a premium, had now resold them at a discount.

Wednesday, $8^{\text {th }}$. At Don Nicolas Rodrigo's particular request the Dir[_] [540] of the Pasco Railway Company met in my rooms, when he informed them that the Minister of Finance Carrillo had sent for him on the previous day, and 
told him that though he knew full well who were interested in the business, he, defending the interest of the country, could not decree the conversion of the bonds, whereupon, after some conversation Rodrigo had proposed to him the purchase of the railway, which, as he explained to him, would be the best thing the Government could do. The Minister, according to Rodrigo, was well pleased with this idea, and he, Rodrigo, now took with him several documents and accounts, to lay before the Minister. I was convinced that the Government would not buy the railway; the President Pardo, out of delicacy, would not do anything in the matter, neither pro nor contra, and Riva Agüero I saw clearly had neither energy nor influence. He had obtained two months leave of absence, during which time Eusebio Sanchez Minister of Justice, took provisional charge of the Ministry for Foreign Affairs; it was, to be sure, high time that he should recollect that before being made Minister he had been "Gerente" del Banco Hipotecario, and that not having thrown up his post it was his duty to look after the affairs of this establishment. Had he not done so, a motion for his deposition would probably have been made by one or the other of the many discontented shareholders.

Saturday, $11^{\text {th }}$ of April. During the whole of this week Government had been negotiating with the firm of Dreyfus; the former required a monthly advance of $\mathrm{S} / 500,000$ for fourteen months, which the latter were willing to make, but as to the conditions they had not yet come to terms.

Mr. Dibos paid me the rent due $15^{\text {th }}$ March, and gave me warning that he would leave my house, because his circumstances did no more allow him to pay the rent which I asked for the apartments he occupied. The Government owed him a very large amount of money - about a million of Soles - for military uniforms and accoutrements which he had furnished for the army, but though his account had been recognized as correct and part payment of the same been ordered, yet he found great difficulty in obtaining the money; moreover, a clerk of his, who had left him some months previously, had presented himself to the Government with copies of Dibos' books and accounts, and accused him of having defrauded the Government of several hundred thousand Soles; if he cou[_] prove the correctness of his charge he was entitled according to [...] [541] of the country, to one third of the amount.

Sunday, $12^{\text {th }}$ of April 1874. I made my usual ascent of San Cristoval, this morning from the side of the new alameda, descended on the opposite side to the paseo militar, and was back in my house in two hours; in a shorter time I could not accomplish it. After Mr. Deeble had left me I paid a few visits. I first went to my next door neighbour Enrique Ayulo, who had recently rented the house of the Goyeneches; I recollected him many years back as clerk of Benito 
Dorca, when this latter had a store in the Calle de Bodegones. They afterwards formed a partnership, and though their means could not be great they enjoyed a fair credit. Their business lay mainly in the importation of French manufactured goods; they had also been large speculators in nitrate of soda, in which it was known that they had been successful. Both Ayulo and his wife Doña Santos were agreeable people; she was the sister of a certain Mendibil, port-agent in Callao, and a notorious smuggler. From Ayulos, I went to the house of Dr. Bruno Bueno, a native of Arequipa, of very dark complexion, but agreeable comportment; he had risen and fallen with Don Mariano Ignacio Prado, whose staunch partizan he was; when Manuel Pardo and Dr. Ureta were striving for the Presidency of the Republic, he sided with the latter, and on Pardo's accession lost his post as Vocal of the Superior Court. Next, I went to the house of Jorge Tizano Pinto, where his wife Leonor, related to the Riveros of Arequipa, and her two grown-up daughters Leonor and Rosa received me in a very pleasant manner. Seacomb was the next upon whom I called; several years back he was clerk at Graham Rowe \& Co.'s, and was employed by them as their confidential agent when they, together with José Vicente Oyague, obtained the contract for the conversion of the Bolivian coin into silver soles. Afterwards he went home with his wife, a Señorita Estenóz, and had of late returned hither being a relation of the rich Brassey, who had contracted for the construction of the Callao Muelle Darsena, and it was he who now attended to the money transactions relating to this enterprize. My two last calls were upon Doña Pancha Castañeda, Melchor Velarde's wife, and upon Doña Dolores Puente.

Monday, $13^{\text {th }}$ of April. The Directors of the Insurance Coy. "Lima" met, [...] specially cited by the President Carlos Elizalde. The principal [...] [542] was to confer on the steps to be taken with regard to the debt of fourteen or fifteen thousand Soles owing by the Italian Mazzini, who had stopped payment, and was kept in close confinement by his creditors; he had placed into the hands of the company as security a sufficient amount in shares of the Banco Hipotecario, but these shares were endorsed in blank not by himself, but by a lady who had deposited them with him, and he had consequently committed a criminal action when he pawned them to the Insurance Company. It was resolved that the Gerente should inform the Consulado that we were creditors of Mazzini's estate, and that we held the above security. Insurance against fire and sea-risk proposed by the parties interested, were agreed to.

Saturday, $18^{\text {th }}$ of April. The most notable event in the course of the week was the signing of an agreement between the Government and the firm of Dreyfus, subject to ratification by the Paris house. 
Dreyfus bound themselves to pay the interest on, and the redemption of the External debt on the $1^{\text {st }}$ July 1874 , $1^{\text {st }}$ January, and $1^{\text {st }}$ July 1875 , as well as to make the customary payments to the diplomatic and other Peruvian agents in Europe. It was calculated that after Dreyfus had sold the 800 and fifty thousand tons of guano still wanting to complete the two millions for which he had contracted in August 1869, and after he had made the above-mentioned payments, there would remain a balance in favor of the Government of about seven million Soles, which sum the Government was allowed to dispose of, drawing upon the Lima firm every month at four months sight for S/40o, ooo the first installment on the $15^{\text {th }}$ April excepted, when S/80o,ooo were drawn for. Some clauses stipulated what was to be done if on liquidating the accounts after these seven millions had been paid, the balance was either in favor of the Government or in favor of Dreyfus; these however were of no great importance.

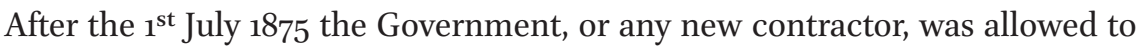
ship guano, but not to sell, before the $31^{\text {st }}$ October 1876 . Dreyfus also bound themselves to "hacer el servicio" of the external debt, on the $1^{\text {st }}$ January 1876 if requested by the Government to do so, in which case they would be allowed to ship over and above the two millions of tons; a quantity of guano sufficient to cover this new outlay; and then th [...] [543] prohibition of selling, by other parties, would be prolonged till the $30^{\text {th }}$ April 1877 . Dreyfus were allowed to lower the price from $£_{13}$ at which they had hitherto been selling to £12.10/per ton, and a corresponding deduction was made to them in the purchase price; they were further permitted to "manipulate" the guano, that is to say to mix it up with sulphuric acid and other ingredients, by which means the fertilizing and stimulating effect which the guano when used as manure has upon the earth, is much augmented.

Sunday, $19^{\text {th }}$ of April 1874. I mentioned a few pages back that in the German Parliament Count Moltke had shown the necessity of keeping up the peace establishment of the German army at 400,000 men, but when the corresponding motion was made by the Government, the majority was opposed to it.

Tuesday, $27^{\text {st }}$. The firm of Castillo Kast \& Co., successors of Plenge \& Kast called a meeting of their creditors, by which step they hoped to escape the necessity of presenting themselves before the Consulado. Their debts amounted to more than one million Soles, and in their assets appeared S/500,00o advanced by them to various landed proprietors in the North of Perú.

Barrenechea, hitherto gerente of the Banco Garantizador, had resigned his post, knowing full well that if he had not done so, he would have been deposed. He, the son of a Spaniard, had devoted himself at an early age to the Diplomatic career, he married Amalia, the daughter of General la Fuente, 
who died, after having borne him several children; his second wife was one of the daughters of the late General Raygada. For several years he was Peruvian Chargé in Brussels, rose twice to be Minister for Foreign Affairs, and went out, under Balta, jointly with Teodoro de la Rosa and Rafael Velarde, on the subject of the contract with Dreyfus, of which they did not approve. Since then he had thrown himself into mercantile affairs; he was made gerente of "La Paternal", an institution similar to the Porvenir de Familias in Chile, of the Banco Garantizador and of the Salitrera called by his name. He held a patent from the Peruvian Government, which secured to him the privelege for producing the Nitrate of Soda in a manner different from that generally in use in the Province of Tarapacá. The "Caliche", which means the earth which contains the nitrate, is mixed up with water on the spot where it is found; then the water is boiled, allowed to evaporate, and the crystalized nitrate remains. This is more or less the $[\ldots]$ in all the Tarapacá Salitreras. The conveyance on [_] back [...] [544] per train, from the Interior to the Coast, is [_] heavy item in the cost of the article, and to avoid this expense, Barrenechea's plan was to dissolve the "caliche" on the spot, with a sufficient quantity of water, and to allow this impregnated water to run through subterranean iron-tubes to the coast, when the nitrate was then produced in the same manner as in the other salitreras. The principal objection raised to this plan was that the impregnated water would quickly deposit in the tubes a large proportion of sediment, so much so that the tubes would be blocked up, and the running of the water impeded. Whether there was any foundation in what I have just said I knew not, but there was no doubt that the shares in the Salitrera Barrenechea were at a very heavy discount, and the Directors of the Banco Garantizador who had guaranteed to the South American Company, established in London, the payment of about $\mathrm{S} / 400,000$ cost of the iron tubes and other articles which the Salitrera Barrenechea had received from the said London Coy., now saw clearly that the salitrera could not pay, and that they would have to make good the said sum to the London firm. Thus circumstanced they made a scapegoat of Barrenechea, because whilst he was gerente they had taken the guarantee upon themselves, forgetting that with the exception of Rafael Velarde and Manuel Ortiz de Villate, who had protested against giving the guarantee, they had all voted in favor of it.

Wednesday, $22^{\text {nd }}$ of April. Last night at 2 a.m. my wife awoke me with the words that the fire-bell of San Pedro was tolling. I hurried on my clothes, and went into the street, where I already found my servant Juan. The policemen told us that a fire had broken out in the neighbourhood of the Chorrillos railway station. Thither we hastened, and found that it was the Church de la 
Encarnacion which was in flames. The fire-engines [_] the brigade of Salvadores, the President, and some of the Ministers were already on the spot; by 2.30 I was back in my house, and soon after in bed: the fire burned till daylight when everything in the interior was destroyed. The roof, and one of the steeples had fallen in, and it was believed that not a few valuable trinkets, jewelry, gold, and silver, which had adorned the Altars and the Saints, were buried under the ruins, for which reason guards were placed all around, and nobody was allowed to enter. Fortunately the fire had not passed through the thick wall which separat[_] the Church from the Convent where the nuns were and who had not left [...] [545] during the fire. This convent was the first founded in Lima in the year 1588, and was originally destined exclusively for ladies of the highest rank.

Thursday, $23^{\text {rd }}$ of April 1874. Oyague, Rodrigo, Basagoytia, and I, Directors of the Lima Water Company, assembled in Rey's office, when the two last named agreed to a proposal made by Oyague and Rodrigo, to raise Rey's salary from six to seven thousand dollars annually. We also discussed the propriety of providing that part of Lima with water, which on the other side of the bridge extends towards the Alameda del Acho by means of tubes placed under the pavement of the new bridge, that of Balta, not over the old bridge as Mr. Prentice, the engineer and great shareholder absent in England, had proposed.

Saturday, $25^{\text {th }}$ of April. Castillo Kast \& Co. were obliged to present themselves before the Consulado; their debts amounted to $S / 1,800,000$. The Banco Nacional was creditor for $S / 100,000$, Dreyfus for $S / 30,000$ cost of bills which Kast had taken, solemnly promising to pay for them on the following day. This way in every respect contrary to mercantile rule, and Scheel, partner of Dreyfus, allowed Kast to take away the bills without paying for them, solely in consideration of their intimate friendship. Kast once in possession of the bills disposed of them, and thus Dreyfus became creditors of the firm for the above sum. Failures of smaller shop-keepers followed each other in rapid succession; the last two were Lebian \& Co., and a certain Thiessen, amongst whose creditors appeared the name of Rehder \& Co., a firm which was always my debtor for from 25 to 30,000 dollars; partner of Lebian \& Co. was a German, Meyer, whom I remembered many years back as clerk of Montané \& Co.; he was of a respectable family of Hamburg, and before coming hither had been in Singapore; after leaving Montané \& Co. and trying his fortune here in Lima various ways, he established himself in Ayacucho, where he failed, when my nephew Johannes Limpricht was sent up thither by Meyer's Lima creditors to look after their interest. He never prospered and had gradually, as one might say, gone to the dogs. 
Monday, $27^{\text {th }}$ of April. On the previous day a regatta had been held in Chorrillos, which had drawn out thither a large number of Limeños of both sexes. The burning sun, for the sky was cloudless, had been the only inconvenience; otherwise all had been much pleased. The greatest [_]erest had been excited by the rowing-match between two Peruvi[_] [546] manof-war boats, each manned by six men and the coxswain, in this instance Captain Carlos Ferreyros of the "Chalaco", and a certain Govian of the MancoCapac respectively. Considerable bets were made; at first Govian had a slight advantage, but finally Ferreyros gained. His victory was attributed by all to the lesser weight of his boat, and of the oars; he had accomplished the distance of one mile in 6 minutes 10 seconds.

From Tuesday, $28^{\text {th }}$ to Thursday, $30^{\text {th }}$ of April. Mr. Deeble did not come, owing to a slight attack of pleurisy. In the day time the heat was too great to take violent exercise and thus I did not know what to do with myself. On Tuesday I had a few words conversation with Riva Agüero, whom I found in the office of the Banco Hipotecario. His opinion was that, notwithstanding all Rodrigo had told me, the Government would never purchase the Pasco Railway, but that on the other hand the conversion of the special bonds into bonds of the internal debt could not be far distant. On Thursday when returning from Chorrillos, where I had taken my customary bath, I had Mr. John Farmer for my neighbour in the train; he immediately began to speak about spiritualism, in which he was a firm believer. Amongst other things he related to me that there existed at the time in New York a certain Dr. Mansfield who was a first-rate medium for communicating with spirits or the souls of the departed; "write", he said, "to him, a letter directed to a deceased friend of yours; he receives the letter, does not open it, merely places his hand upon it, and through his medium the spirit of the deceased to whom you have written communicates the answer, which he again transcribes to you." Franklin, in farmer's opinion, continued his studies on electricity in the other world, and imparted his discoveries to his chosen friends on this earth. Another idea of the spiritualists, which I did not at all think out of the way, was that there exists no heaven, no hell, but that the punishment or reward of the deceased, whose souls, or spirits, are endowed with memory lies solely in their own conscience, and that the earth is filled with these spirits, which float continually around us.

With Dibos, who intented to remove at the end of May, I arranged that I would allow him for the improvements made by him in my hou[_] S/400 to be deducted from the amount of rent he might be owing [...] [547] day he left. From the Concurso of Lopez Hurtado \& Co., three months rent was due, but not yet paid, though Wheelock, the Sindico, repeatedly assured me that he would pay it as soon as he had any funds belonging to the estate. The 
Stores for which Hurtado had paid me $\$ 240$ monthly I let to a certain Sagastegui at $\$ 200$.

Friday, $7^{\text {st }}$ of May 1874. Enriqueta's soirée of last night was a little more animated than usually. Garland had at his rocambor table the Pole Malinowsky, and the two Senators Nicolas Hurtado, and Manuel Alvarez Calderon. The Frenchman Picard soon left, and the ladies, the two Emilia Lopez - one married, the other unmarried - Mariquita, and Enriqueta, and Rafael Velarde's wife and daughters amused themselves with Monte and Vingt-un, at which Enrique was the banker, till past midnight. By the steamer of the $28^{\text {th }}$ I ordered Gibbs of London to buy for me £2000 of the Anglo-Peruvian Bonds of 1872, if they could be had, expenses and commission included, at $52 \%$, and before twentyfour hours had elapsed after taking my letter to the Post-Office a telegraphic dispatch from Payta brought the advice that they had risen $7 \%$; consequently my order would probably not be executed. From Europe we received the news that the Archbishop of Posen had been arrested by order of Prince Von Bismark for not complying with one or the other article of the German Constitution. In appendix, under $\mathrm{N}^{\circ}{ }_{13}$, I affix a cutting, which contains a very interesting letter written from Japan by Fred Elmore, secretary of the Peruvian Embassy, in which he gives the details of what he had seen on a short tour through part of Japan.

Saturday, $2^{\text {nd }}$ of May. The anniversary of the Victory over the Spaniards in 1866 was celebrated by a review in the plain of Amancaes; otherwise it was a dull day both in Lima and Chorrillos, where I took my bath.

Sunday, $3^{r d}$. Of the various calls which I made, the most agreeable was that to the family Basagoytia; the father, perhaps not so old as I, was however completely worn out by disease and age. In the course of his life he had filled more than one situation under Government, and always given satisfaction. Once he was sent to England to examine the accounts of A. Gibbs \& Sons relating to the Guano Consignment which they had had for a number of years; it was also he who obtained from the Government the [...] the establishment of the Lima Water Company of which he [...] [548] in reality the founder. His son José was a very active man, notwithstanding his extraordinary stoutness; their respective wives were good-natured women, but more could hardly be said in their favor. At Mrs. Riva Agüero's, always talkative, always a little silly, I met General Nicolás Freyre, who on the previous day had commanded the troops at the review in Amancaes, and who now complained bitterly of the great heat from which he had suffered; what would such a Peruvian hero have said of the fatigues undergone by men and officers in the FrancoGerman Campaign of 1870/71? My last call was upon the Brazilian Minister 
Leal, who was somewhat indisposed, and with whom I found Mrs. Ayulo and her daughter Rosa; conversing with them, the time passed quickly, and ere I was aware it was 5 O'clock, nigh time for me to take my leave, and to hasten home, where half an hour later my wife and I, as it was our custom on Sundays, sat down to dinner with the family Garland.

Monday, $4^{\text {th }}$ of May. In the usual monthly meeting of the Directory of the Banco de Lima, Lembcke read a letter he had received from the post-master Salmon, in which he, in consideration of the poor circumstances in which he was, begged to be released of the responsibility which he had taken upon himself when signing the pagaré of 3000 and odd Soles, of which I spoke on the $3^{\text {rd }}$ March. José Vicente Oyague, the President, Pedro Bernales, the Secretary, Valentin Gil, and Manuel Mendoza were of opinion that we should accede to his request; Manuel Elguera, the landed proprietor from the North, and I were of the contrary opinion, because, as I said, we Directors had no right to be generous or charitable with the money of the shareholders; "we must be just, and nothing else." Elguera went further, he said the Directors should rather pay the $S / 3800$ out of their own pockets than throw them upon the shareholders. Sagastabeytia said nothing, Lembcke but a few words; it was however clear that he rather sided with Elguera and me; nevertheless, at the end we had to cede to the majority. Though it was not my turn I agreed to be "Director de Turno" for this month.

Wednesday, $6^{\text {th }}$ of May. The Directory of the Insurance Coy. "Lima" met; we were Carlos Elizalde, President, Manuel Ferreyros, Gerente, Valentin Gil, Pedro Noriega, Chavez, Garland, Carrol, and I. We decided not to increase the fire risks in the Callao Custom House now amounting to S/340,000 and gradually to redu[_] them to $\mathrm{S} /[\ldots]$. [549]

Thursday, $7^{\text {th }}$ of May 1874. The ground-floor of my house which Dibos would shortly vacate I let to Henry Meiggs for the new society for building houses which he was about forming, at 300 Soles monthly.

Saturday, $9^{\text {th }}$ of May. In the course of this late week Deeble was prevented by indisposition from attending to his duty with due regularity. In the evening he came but seldom, and even in the forenoon he could not remain all the time.

Sunday, $10^{\text {th }}$ of May. At $2.15 \mathrm{I}$, in full uniform, drove by appointment to the Brazilian Minister's, and jointly with him and a few others to Mr. Garon, the Italian Minister, in whose apartments the young Duke of Genoa, nephew of the King of Italy, and officer on board an Italian Man-of-war just arrived from the north, was ready to receive the Diplomatic and Consular Corps; the room was well filled - Mrs. Garon and her daughters were also present. One after another we had to shake hands with him, Garon mentioning the 
name of each, and the country he represented. We then took our seats, and the one or the other of the Diplomats sat down near the Duke on the sofa, and conversed a few words with him. To me it was beyond measure tedious, being unable to distinguish anyone. I merely talked a little with Lembcke, Leal, and Jerningham. I was anxious to get away, but etiquette did not allow us to leave the Duke; he had to leave us, which he did at about three O'clock when the Government coach was waiting for him to take him to the bull-fight. He was a very young man, hardly 21 years of age, spoke several languages, even German his mother, the spouse of Duke Ferdinand, being the daughter of John, King of Saxony. Some said that he was shy and reserved, others that he was agreeable, and well educated. I hastened home, changed my clothes, and called upon Dr. José Gregorio Paz-Soldan to congratulate him, for the previous day, the $9^{\text {th }}$, when I had also been in his house without finding him at home, had been his Saint's-day. A certain Ureta, son of the little Pedro Ureta, formerly shopkeeper, now Vista in the Callao Custom-House, had lately married Angelica Palacios, daughter of Don Manuel who failed many years ago as storekeeper in the Calle de Bodegones; they had advised us of their marriage, and accordingly I went to pay them a visit but did not find them in, which I was not sorry for. I looked in at Doña Paula Benavides to enquire after the health of her daughter Candelaria [...] continued very ill. Then went to Doña Dolores Puent[_] [550] and finally to Doña Josefa Tagle de Zevallos who was a very good lady, her daughter Helena a nice young girl.

Monday, $17^{\text {th }}$ of May. I was still in bed when my wife came to congratulate me; then came Enriqueta with the little girls, who brought me their presents; Enrique's consisted of a pretty little revolver; which was very welcome. I disliked giving dinner parties, for the inconvenience and trouble it cost my wife; nevertheless, there was no help for it, this day something had to be done. Mariquita prepared a very nice dinner, to which besides us two and the family Garland - except Guillermo who was absent in Callao - the following sat down: Dr. Muñoz, President of the Supreme Court of Justice, to the right of my wife, Francisco Sagastabeytia to her left, and Rafael Velarde to my left; Enriqueta to my right, Garland at the one, Enrique at the other end of the table. At 8.30 when we rose Enriqueta begged us all to go over to her side of the house to see the pretty roulette table just received from Paris; nobody knew anything of the game except Alejandro, who explained it, and we then amused ourselves playing at it for counters. Dr. Muñoz left at nine, Sagastabeytia at ten, Rafael Velarde with his family who had come in the evening, half an hour later. I believe all had been well pleased.

Tuesday, $12^{\text {th }}$. In the morning our Chinese cook Achipe informed us that he was unwell and could not cook, which was rather annoying for though we 
could take our meals with the Garlands we did not like doing so for any length of time. A long time ago I had lent through the medium of the broker Malagrida S/10,00o half mine, half Juan's, with a security of S/20,00o Noml. Shares in one of the Salitreras of Iquique, to Pablo Vivero. To the same, Garland had lent previously to my loan $S / 21,200$ with the security of shares in the Company for loading guano, and this pagaré of Vivero's I again discounted to Garland about twelve months back, when he had considerable remittances to make to Schutte. Repeatedly we had urged Vivero to pay us the principal, which he had put off from month to month; and on Tuesday he came to Garland with the unwelcome news that he was not able to pay the monthly interest, which at $11 / 4 \%$ came to 390 Soles, but proposed to give as further security the mortgage upon a large and valuable estate of his wife's, upon which he [...] already to the Banco Hipotecario S/100,00o. [...] [551] be the second one. I of course agreed to this proposal, though I was fully aware that the mortgage on a married woman's property is in reality no security at all, for if she is unwilling to pay she can always say that her husband forced her to sign, and this excuse is admitted by the tribunals. Garland of course remained responsible to me for the $S / 21,200$ and interest until paid. This was in every respect a disagreeable affair, and S/39o less in my monthly income was a perceptible falling off.

The promoters of the new building Society, to which I had let the ground floor of my house were: Henry Meiggs, his relations, his engineers, and his legal adviser, the lawyer Francisco Garcia Calderon. The nominal capital was to be five million Soles, divided in 30,00o Shares of 100 Soles each, and 200,000 Shares of S/10 each. The ten sol shares had to be paid immediately on subscribing. Of the one-hundred sol Shares only $30 \%$ would be called in for the present. One of the principal conditions was that land at a certain valuation was to be taken in part-payment, which condition clearly showed that Meiggs' object in forming this society was to get rid of the extensive tract of land which he had purchased all round Lima, and to obtain from the public money wherewith to construct houses. To the holders of the ten-sol shares an annual interest of $10 \%$ was guaranteed.

Riva Agüero who for some time had attended to the gerencia of the Banco Hipotecario again took charge of his own Ministry, that of Foreign Affairs, probably for no other reason but that Dr. Eusebio Sanchez, who provisionally had filled his post, was not exactly the person for showing to the Duke of Genoa all the attentions due to his elevated station, whilst on the other hand Don José de la Riva Agüero, himself the son of the Princess de Loos, whose ancestors had belonged to the Sovereign princes of the Holy Roman Empire, well knew how to demean himself towards royal and other high personages. 
Thursday, $14^{\text {th }}$ of May 1874. Ascension-day. The horse races which were held this day were probably the cause that of the various persons upon whom I called many were not at home; for instance Carvalho, Secretary to the Brazilian Legation, just arrived. As little did I find in the family of Dr. Bruno Bueno, who himself, for a considerable while out of employ, had just been named by Manuel Pardo, Prefect of Ica, and had already left for [...] tion. [_] Enriqueta's [_] they [...] [552] in the evening playing at roulette. I however did not join them; also Mariquita came to our rooms as early as 10.30.

Friday, $15^{\text {th }}$ of May. Ricardo had for some time past been reading to me in German, a chronicle of Hamburg by a certain Clemens, written in a heavy style, and upon the whole not particularly interesting. I was, however, much pleased when we came to modern times, especially to the year 1813 when the author gives the details of the evacuation of Hamburg by the French, and the occupation of the town by Russian troops, which I compared with the account of the same events given in my diary Vol. 1. He also gives the details of a horrible murder committed in Hamburg in 1803. I recollected that when a child I occasionally had heard grown up people speak about it, but the particulars had been no doubt kept a secret from me. There lived in Hamburg about the end of the year 1803, a certain Rusau, a native of Riga, and son of a poor goldsmith. With the aid of his friends he was enabled to pursue his academical studies in the university of Erlangen, came to Hamburg, gave lessons, established a school, married a very good young woman, and for some time prospered in the world, but his character was always sombre and melancholy; he was fond of sleeping, of eating, and drinking well, and addicted to gambling. He had to give up his school, tried his luck in several ways, and never succeeded, owing I should think to his own fault: from day to day he became more recluse, more melancholy, more taciturn. It was clear to those who knew him that he revolved in his mind some dark deed or other; a few feared that he would commit suicide. In the month of August he dined with his wife and some of his children at his father-in-law's; he was more silent than ever, and stared and glared in an extraordinary manner. "In a short time you will all be happy," said he, to which his wife replied "I am always happy if you love me," and took no further notice of this expression. At ten O'clock they returned home, went to bed, and all fell asleep except Rusau who awake till four in the morning rose, and with a razor cut his wife's throat with one stroke, did the same to a favourite son of his, went up-stairs in search of his eldest daughter, a pretty girl of 18 , who resisted, but was overcome by her murderous father, then to the next room where another daughter $[\ldots]$ with some girls $[\ldots]$ his wife's charge, $[\ldots]$ [553] children of his all met the same fate. This done he awakened the servant 
girl, told her he had to go out, and ordered her to shut the street door after him. He went to the banks of the Elbe to drown himself, but too many people were already stirring, and he could not carry out his purpose. Then to a ditch which was too shallow, and finally he took out a knife, not the razor, which he had left in his wife's bedroom, and inflicted upon himself many wounds, none of which was mortal. In this state, not dead, he was found lying on the ground by two individuals, who had gone out to shoot ducks. To them he gave himself up, confessed all he had done, and spoke so rationally that when his lawyer in his defence pleaded insanity as an excuse for the perpetration of the crime, the judges of the inferior tribunal found it impossible to absolve him on this plea, and sentenced him to be beheaded; both the public accuser and the lawyer who defended him appealed, the former for the aggravation, the latter for the mitigation of this sentence. The Supreme Court condemned him to be broken on the wheel, which sentence was carried out in February 1804. The same chronicle gives some details of the origen and gradual rise of Altona. Already in the $12^{\text {th }}$ century there existed a small chapel devolved to St. Otto, and a few huts around it went by the name of Ottendorff, or Ottenheim, the present Ottensen. In the $16^{\text {th }}$ century, about the time of the reformation, a few Catholics left Hamburg, where the new creed rapidly gained ground, and settled in the vicinity to the west of the town. The Dukes of SchaumburgPinneberg, on whose territory this new settlement arose, granted the same many priveleges amongst which that of universal toleration. The Hamburgers now gave it the name of Al-to-na, which means in low German much too near. In 1547 it was destroyed by a casual conflagration, but was rebuilt. In 1640 the last Count of Schaumburg-Pinneberg died, and his territory, amongst which Altona, was incorporated with Holstein, and consequently fell under the Danish dominion. The Danish kings always favored Altona in every possible manner; it was made a free port, and by receiving such signal protection was enabled to exist and to prosper, though so near its mighty rival Hamburg. In 1713 it was burnt down for the second time by the Swedish general Stenebock, and but few houses then escaped destruction. When I was a child I learned that its population was from 24 to 25,000 souls, now it is 80,000 . Next to Copenhagen it was always considered [...] in the Kingdom of Denmark. [554]

Sunday, $17^{\text {th }}$ of May 1874. I left the house at a quarter past six, ascended San Cristoval with great ease from the side of the new alameda, and without resting a single instant descended on the opposite side, which brought me down to the Paseo Militar.

Of the calls which I made this forenoon, or rather in the hours between two and five, only two deserve any special mention - the one to Mr. Dominguez, 
Buenos Ayrean Minister, who had lately arrived with his wife and grown-up sons and daughters, and to whom, as Consul, I had to pay my official visit; of the young folks I could not form any opinion, but the father and mother I found to be agreeable off-hands people. The other was to Mrs. Escobar, where I met Enrique Ayulo, my conversation with whom treated exclusively on the great event of the day, the failure of Julian Zaracondegui, who on the previous day had presented himself to the Consulado, and given in a statement of his affairs, by no means satisfactory to this Tribunal. Zaracondegui had for many years been established in Lima, and always been looked upon as one of the most upright and respectable merchants of the place. Riches he was not believed to possess, but nobody doubted of his being an opulent man, and of having the means to carry on the extensive business he did. Now it became evident that the public opinion had erred in every respect. If ever he had had any fortune of his own it had been but small, and at all events disappeared long ago; and for a very long time his credit alone had kept him up. He allowed $9 \%$ annual interest on the money placed into his hands and paid the interest with the greatest regularity. Thus all kinds of people took their money to him; they would rather leave it with Zaracondegui than deposit it in the Banco de Lima. He now saw himself in possession of large sums of money; necessarily he had to employ them, for it would not do to pay interest for nothing. He confessed that in the year 1873 he had paid not less than S/200,ooo interest. Then he entered into speculations, took shares in three salitreras in Iquique, which cost immense sums and as yet produced him nothing; he established a stearine candle manufactory, and a tan-yard, the result of which was equally unprofitable; he built the house which the Banco de Lima occupied and which lately he had mortgaged to the very bank for S/50,ooo; and finally he was the part-proprietor of a large [...] [555] called Cayalti, of which C. G. Schutte was in the habit of relating wonders, and his half of which he had also been forced to make over to his partner in the estate, Ramon Aspillaga. Thus time wore on; the machine was kept in movement as long as there was oil with which to lubricate it, but when the supply failed the wheel stopped, and then came the crash. The amount he owed for money lent him, and for balances of accounts current came to about two millions and a half of pesos, against which he presented assets of somewhat more than one million one hundred thousand pesos; moreover, he owed $\$ 446$, ooo to various persons, but as these held security he had not thought it necessary to include the amount in the statement handed to the Consulado. It was, however, very unlikely that this tribunal would pass over such an irregularity. At the head of the list of creditors for money lent, appeared a certain Rojas with $\$ 112,000$, next to

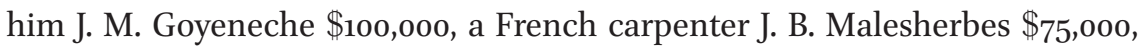


José Davila Condemarin $\$ 75,000$, José Vicente Oyague $\$ 66,000$; thence the amounts decreased gradually till the last creditor was for $\$ 200$. In this list appeared some of the fair sex; the two sisters-in-law of Melchor Velarde, Juana and Matilda Castañeda, Rosa and Manuela Osma, together for $\$ 50,000$; the wife of José Luis Bernales for 20,000. Also an Italian was his woman who regularly every week had taken her hard earnings to him. Emilio Althaus, the Prior del Consulado, told me that in his opinion the estate would not give $5 \%$.

Thursday, $27^{\text {st }}$ of May 1874. On Tuesday Rafael Canevaro gave a ball, on Wednesday there was a dance in the apartments of the Club de la Union, and fireworks in the plaza mayor, and this day a lunch was given by the Municipality of Callao, all to celebrate the Duke of Genoa, who embarked on board the Garibaldi. I was told by various persons who had come in contact with him, that his intellect was not of the most shining.

It was rumoured that the Banco Garantizador had stopped payment and though there was no truth in the statement the Banco de Lima, and the Banco Nacional refused taking their notes. On

Friday, $22^{\text {nd }}$ the panic had partly subsided.

Saturday, $23^{\text {rd }}$. The opposition paper "La Patria" spoke of the conversion of the so often mentioned special bonds into Vales de la Nueva Consolidacion, [...] that it was I who appeared as demandant and that persons of hi[_] [556] station in the political world were interested in the business.

Riva Agüero having as above said returned to his ministry, the Directors named Agustin Escudero provisional gerente of the Banco Hipotecario, whereupon the lawyer Francisco Garcia Calderon threw up his post as lawyer of the bank, and I was assured that when at Rafael Canevaro's party of last Tuesday, Riva-Agüero addressed Calderon in his usual polite manner, this latter turned his back upon him.

In the forenoon of this day a few shareholders of the defunct Constructora met in the office of the liquidator, Augusto Althaus, in the first story of the house formerly the property of old Doña Ignacia Palacios. He told us that the Municipality of Lima had paid him what they owed to the Constructora, but that he had been under the necessity of receiving Municipal Bonds, which gained an annual interest of $8 \%$, and of which $4 \%$ were redeemed every year. After deducting his commission, the amount he had to distribute came to $S / 163,200$ equal to $S / 163.20 c t s$ on each share. There being no municipal bonds of less than $\mathrm{S} / 100$ we discussed for some time how the odd sums should be paid, and to cut short the matter, Dr. Aranivar, Emilio Althaus and I agreed to pay the difference there might be at the rate of $80 \%$; for instance, Alejandro and I had to receive jointly $\mathrm{S} / 3264$ - consequently $\mathrm{S} / 36$ were wanting to make up $S / 3300$ and for these $S / 36$ wanting, we paid Althaus $S / 28.80$ in cash. This 
was saved out of the fire, but bad news awaited me. In the Banco de Lima Nicolas Rodrigo told me that on Tuesday next there would be in his house a meeting of the creditors of the late Juan de Ugarte. Juan de Ugarte, a Spaniard like Rodrigo, had been looked upon as one of the Capitalists of Lima. It was said that he could not have a sound sleep if he had not at least $\$ 100$, ooo in his chest. After his death, which had taken place exactly four years previously, the business was carried on by a countryman and clerk of his Gonzalez Puente, a devotee of the first water, whether a sincere one I cannot say - I was but indirectly interested in this stoppage. On the $14^{\text {th }}$ July 1873 I had lent to the firm through the intervention of the broker Malagrida the sum of S/ro,ooo. When it fell due, and was not paid I felt so[_]what uneasy and insisted upon the immediate ca [...] [557] pagaré, when Puente offered me the guarantee of J. M. Zuloaga, which I accepted, on condition that 2000 Soles were paid on account, which was done. Zuloaga, when signing jointly with Puente, made use of the expression, "Esto se llama miel sobre bunuelos." He was a man of delicate health, but of an excellent character, and some property, though about that time he had made an unfortunate speculation, when he entered with Zaracondegui and one or two others in the purchase of the Salitrera "La Alianza" in the province of Tarapacá, in which he had invested a good deal of money, without hitherto having received any returns.

Sunday, $24^{\text {th }}$ of May 1874. This morning before six I ascended San Cristoval together with Alejandro and Antonio. At one point of the ascent I made a strong effort, and strange to say, all at once a debility came over me as if I were to swoon; I lay down flat on the ground, and after having rested two or three minutes commenced climbing till I reached the summit. In the forenoon I paid my first visit to the German Chargé d'Affaires, Dr. Lührsen, a native of Hamburg, married to a lady from Vienna; before coming hither he had resided for some time as German Consul General in Smyrna. Both were without any pretensions, and the lady lively and talkative; she was in high spirits, having, as she told me, been present in the course of the week at no less than three balls, viz.: at Rafael Canevaro's, in the Club de la Union, and at Alexander Westphal's who was in the habit of giving a small party every Saturday evening. Mrs. Francisco Benavides, wife of Mariano Felipe Paz-Soldan, upon whom I next called, was a very different kind of woman, good natured, but quiet, and without having much to say for herself; her husband was at this time quite in the back ground, and I hardly knew how he could make the two ends meet. My third visit was to the family of Dr. Tomas Davila, whose acquaintance I had made when I was in Arequipa in 1859. He had been judge de $1^{\text {a }}$ Instancia, then Vocal of the Superior Court. Now he lived retired from public life upon the income he derived from some houses he possessed in Lima, and 
especially from a valuable estate producing wine and brandy in the valley of Moquegua.

In these my visits I heard of an accident which on the previous [...] some North-Americans when returning to Lima [...] [558] hand car from their encampments on the Oroya line. A stone had been placed upon the rails, the hand-car was upset, and when those in the car lay on the ground they were fallen upon by robbers, who took from them the money they had, probably not a great deal, because it was the balance which remained in their hands after paying their workmen, and wounded them so severely that the one or the other would perhaps not survive. In Lima on the same day a young man called Villarán, clerk in the London Bank of Mexico \& South America, was sent by his superiors with $\mathrm{S} / 52,000$ in bank-notes to make two payments, the one of $S / 37,000$ wrapped up in paper and carried by the porter of the Bank to the Banco Nacional, which were duly delivered; the remaining $S / 17,000$ he had to pay to the Banco del Perú, which is hardly two cuadras distant from the Banco Nacional. He was seen to pass the auction mart, a few houses distant from said bank, but from that moment he had disappeared, and nobody knew what had become of him.

The following interesting statements I took from the Panama Star \& Herald of $16^{\text {th }}$ May. In 1872 the exports from Hamburg amounted to nearly 571 millions of Prussian dollars, say 317 and odd millions seawards, 253 and odd millions landwards, showing an increase of nearly 200 millions upon the exports of 1868. The war indemnity of $£_{212}, 640$,ooo due by France to Germany, was paid in the following manner:

In notes of the Bank of France

French gold and silver coins

$£_{5,000,000}$

German coin and bank notes

$£ 20,480,000$

Railways of Alsace and Lorraine

$£ 4,200,000$

Bills on England, Germany, Belgium and Holland

$£ 13,000,000$

$£ 169,960,000$

$£_{212,640,000}$

Queen Victoria reigned over 234,752,593 souls, of whom lived in the United Kingdom and Ireland 31,000,000; in the East Indies 191,327,000 the remainder being distributed over the four quarters of the globe. As to their religion they were divided as follows: Christians 40,000,000. Mahommedans 36,000,000. Hindoos 98,000,000. Budhists 2,000,00[_] and heathens of all descriptions $58,000,000$. The census of England and Wales was taken on the $3^{\text {rd }}$ April 1871 in one [_] ni [...] [559] showed the number of inhabitants to amount to $22,856,164$. 
Tuesday, $26^{\text {th }}$ of May 1874. Some of the creditors of the firm of Juan de Ugarte met in the house of Nicolas Rodrigo; present, as far as I remember, were: Lembcke, for the Banco del [Pe]rúa, which was deeply interested, Bartolo Figari, Aurelio Dinegri, M. G. Chavez, Felipe Barreda y Osma, my neighbour the Col. Segundo Leyva, I, and perhaps one or two more. After some friendly discussion, it was agreed that Chavez and Barreda should draw out a plan how the affairs of the house were to be liquidated, with the assistance of an interventor, which project should then be laid before all the creditors, and if approved of, be confirmed by the Consulado. It was calculated that the creditors would, besides interest, not lose much, perhaps 20 , perhaps $10 \%$, perhaps nothing; the result would depend on the prices which the houses in Lima and three vessels belonging to the firm might fetch. The assets came to about 1,300,000 Soles including the capital of 400,000 Soles, the debts to $\mathrm{S} / 900,000$. When Juan Ugarte died he left somewhat more than 6oo,ooo Soles, of which 100,000 were bad debts, and 100,000 were paid to the widow of one of his two sons deceased. Zuloaga, who was unable to pay me the pagaré of 8000 Soles spoken of on the $23^{\text {rd }}$, begged me not to urge him for payment, and meanwhile placed into my hands as collateral security 16 shares of La Salitrera Alianza, of 1000 Soles each.

Thursday, $28^{\text {th }}$ of May. My wife being in excellent health we drove out in the evening to pay our visits to Mr. and Mrs. Dominguez who had taken apartments in the house of General Francisco Diez de Canseco, Calle de Boza, and to Mr. and Mrs. Lührsen who occupied the house formerly Juan Bazo's, near the church of San Marcelo. My wife was much pleased with both families, and delighted with the frank and kind demeanour of Mrs. Lührsen, who spoke Spanish sufficiently to be understood. They insisted upon our taking tea with them which we did, whilst the Doctor and John Donner, the manager of the Piura bank, preferred drinking their beer. Donner told me that the Piura Bank was doing a very fair business.

Saturday, $30^{\text {th }}$ of May. To the funeral of Doña Hermenejilda, a very old lady, mother of the ex-President Rufino Echenique, which was solemnized in the Church de la Merced, I came just too late; when I entered [...] coffin was about being carried to the hearse. [56o] The whole week long the hall of the Consulado had served for the meetings of the creditors of the various firms which had stopped payment of late. For Sindicos of Zaracondegui's estate were named; Joaquin Osma, whose two sisters were interested for S/50,00o, José Luis Bernales, whose wife's dowry $\$ 20,000$ had been deposited in Zaracondegui's hands, and José Davila Condemarin, Creditor for 75,000 . 
The advices received from Europe per cable spoke of defeats suffered by the Carlists in Spain, and of differences having arisen between Germany and France owing to the President Mac Mahon continuing to fortify the frontier places of the latter country. I was certain there would be no outbreak, the French not being as yet ready for the fight.

Sunday, $33^{\text {st }}$ of May. This morning I attended in the Church of San Francisco the funeral of Candelaria Gomez-Sanchez daughter of Doña Paula Benavides, whose dangerous illness I mentioned not many pages back; she died unmarried; her character had been irreproachable.

Saturday, $6^{\text {th }}$ of June. This week everything had gone wrong with me. Mr. Felix Dibos who had left the ground floor of my house had not paid the balance of his rent, though for the improvements which he said he had made, I had allowed him more than what they really were worth. To Henry Meiggs new building company I had let the ground-floor, two stores 92 and 94 in Zarate, and two shops in Aldavas, one with another for S/540 Soles monthly; but the tenants of the stores and shops I could not get rid of, and moreover two of them, a saddler and a shoemaker, were far in arrears with their rent. To Charles Wheelock, Sindico of Lopez Hurtado \& Co.'s estate, I had repeatedly applied for what it owed me, but hitherto in vain. Finally, the emission of the bonds of the internal debt, for Riva-Agüero, Barreda, and myself seemed to have fallen into utter oblivion; and notwithstanding all these drawbacks to my income I saw by the "Patria" that my patente, or trading licence for the present year, had been raised from 800 to 1200 Soles annually. Of course I intended to apply for a reduction.

In Rodrigo's house the creditors of Juan de Ugarte had another private meeting. The plan drawn out by Chavez and Barreda for liquidating the [_] of the firm was approved and several [...] [561] left by them in blank were filled in, viz.: to Gonzales Puente, who was to wind up the business, S/300 monthly were allowed for his expenses, besides the house in which he lived, rent free, and $2 \%$ upon the amounts collected, which were to be distributed amongst the creditors as soon as they came up to $10 \%$. Ugarte's widow and daughter were to receive each monthly $\mathrm{S} / 250$ and their rent being paid.

Sunday, $7^{\text {th }}$ of June 1874. Mr. Deeble, who on the previous day had been prevented by indisposition from coming to my office, neither made his appearance this morning, and I availed myself of the hours thus left at my disposal to ascend San Cristoval; I started at 11 and was back by 1 O'clock.

Monday, $8^{\text {th }}$. At an early hour died a cousin of my wife's, Juana, sister of Manuel, Melchor, and Rafael Velarde, whom I had but seldom seen in our house. In Arequipa she had married a good-for-nothing drunken English 
physician, who at his death left her one daughter, Isabel, and not one cent. She then came to Lima, where she had lived at the expense of her brothers, mainly Rafael, who would in all probability now take the orphan daughter to his house.

The members of the Directory of the Insurance Company "Lima" met. We were: Carlos Elizalde, President, James Henry, Vice; Garland, Carrol, Chavez, Peña, Gil, and I, Directors; Manuel Ferreyros, Gerente. In these meetings everything went on exactly as they should; there was no one who exercised a domineering influence over the others; everyone gave his opinion in a quiet manner to the best of his knowledge and ability. When the question laid before us by the Gerente was sufficiently discussed, we came to a resolution, generally unanimously; when we differed, of course the majority decided. In Lima, another firm, that of Maron \& Co., had declared its insolvency; the stoppage of José Maria Gonzales Veliz in Tacná was of more importance. His business had been the guaranteeing of Bolivian purchasers to the import-houses; he had also some interest in one or two Iquique Salitreras. His debts amounted to S/80o,ooo; his principal creditors were George Hellmann of Tacna, and Alsop \& Co. of Valparaiso, each for about S/80,ooo.

On Wednesday of last week a [...] and [...] [562] same time for the perpetrators, little profitable burglary, was committed in the Calle de Belen, in the house of Suarez Valdez, more or less opposite that of Pedro-Paz-Soldan; sixteen or twenty men entered, killed a police inspector and a policeman - also a poor bricklayer with his wife, who lived close by, and made off with no more than 6oo Soles; several of them, it was said, had been apprehended.

Tuesday, $9^{\text {th }}$ of June. I handed to Gustavus Heudebert, President of the commission named for receiving the petitions for reductions of patentes, mine which I had drawn out for this object. His colleagues were John Gildemeister, M. G. Chavez, and another Peruvian, whose name I did not learn.

Wednesday, $10^{\text {th }}$. Early in the morning the funeral service of Juana Velarde was solemnized in the Church del Sagrario. Rafael Velarde, without asking permission either from Garland or myself, had made use of our names and those of the young Garlands in the advertizement of her funeral inserted by him in the papers, and thus several persons were present who certainly only attended for our sake, as for instance: Sattler, and Escobar, both my tenants, and Charles Pflücker. Rafael and the nearest relations as chief-mourners occupied the first bench, to the right of the high altar; the second he had left empty for myself, Garland, and sons, but as he had not told me a word about it, I took my seat as everybody else did; and, though we also drove out to the pantheon, Rafael, I heard, was somewhat offended at what he called a want 
of sympathy on our part - nevertheless I put on mourning. Enriqueta did not open her roulette table on

Thursday, $11^{\text {th }}$. Present at her tertulia were: four rocambor players, Vicente Hurtado the gerente of the United States Guano Company, a pleasant and talkative man, and Carvalho, the Secretary to the Brazilian Legation, as yet not much versed in the Spanish language. These two gentlemen and I kept my wife and Enriqueta company, and we broke up at a little past eleven.

Two mutinies had of late broken out in Arequipa, but been quickly suppressed. Of the one, Diego Masias had been the prime mover. The other had been caused by the introduction of a new school-book, call[_] "El Educador Publico" into the primary schools the A [...] [563] notorious for their religious fanaticism, found in the same some doctrine or other opposed to the pure Roman Catholic faith. Masia, a barefooted friar from Lima, present from Arequipa on a mission, thundered against it from the pulpit, and the populace rose and demanded its suppression, whereupon the prefect, Javier Osma, Pardo's uncle, had nothing better to do than to collect the obnoxious books, and to promise that they should not be used in future, which being done, tranquillity was restored.

About this time the Lima Municipality, with its Alcalde Aurelio Dinegri, resolved that the Church de la Encarnacion, partly destroyed by fire, should be bought by this corporation and then be razed to the ground by doing which the open place, or plazuela already existing, would gain in extent, whilst at the same time the chapel forming part of the convent might also be enlarged. On the other hand a subscription was opened, headed by Manuel Pardo with 100 Soles, with the object to raise the necessary funds for repairing the damage the church had suffered. This was clearly in direct opposition to the resolution of the Municipality, and to me it appeared that they would have to rescind it, and that the repairs of the Church would be proceeded with as quickly as the funds subscribed were paid in.

Saturday, $13^{\text {th }}$ of June 1874. To my great joy I received a note from Riva Agüero, who communicated to me the unexpected news that the Council of Ministers had come to the decision to sign the decree, which was to order the so oft spoken of conversion of special bonds into Vales de la Nueva Consolidacion, to be handed over, when signed, to the Banco Hipotecario, to Barreda, and to myself.

Sunday, $14^{\text {th }}$ of June. Mr. Jerningham, for many years British Chargé, and his wife, embarked for Europe, probably not to return.

Monday, $15^{\text {th }}$ ofJune. In the meeting of the Directory of the Banco de Lima, at which all except Manuel Elguera were present, Manuel Salcedo made himself 
very troublesome, and wasted much time with his ridiculous questions, remarks, and motions. José V. Oyague, who was in the chair with great patience and forbearance, gave him all the explanations he required, and if he did not succeed in satisfying, at least silenced him, which being accomplished we proceeded to the business of the day, for the [...] which we had been convened. Firstly, We authorized the [564] gerentes to lend to the Banco Hipotecario $\mathrm{S} / 100,000 ; \mathrm{S} / 200,000$ in Cedulas being placed into their hands as prenda pretoria, and on condition that these $S / 100,000$ should not be disposed of before the $1^{\text {st }}$ July, and be returned before the $31^{\text {st }}$ of the same month. Secondly, We allowed the Directors of the Salitrera Esperanza not only to borrow from the London Bank of Mexico \& S/America S/25o,ooo, but also, and this was the main point, to concede to the same as guarantee for the loan, the first mortgage upon the salitrera, hitherto held by the Banco de Lima as a security for the million Soles owed by the "Esperanza". This step, which placed the Banco de Lima in a worse situation than that which it had hitherto held, could only be excused for two reasons, the one, that the "Esperanza" absolutely wanted funds, the other that the Banco de Lima could, or would not furnish them. The London Bank would be covered for these $\mathrm{S} / 250,000$ by shipments of nitrate to England, on which, when receiving $\mathrm{B} /$ Lading, the bank advanced $80 \%$ of the market value, $2 / 3^{\text {rds }}$ of which $80 \%$ would be paid to the Salitrera wherewith to continue their operations, and $1 / 3^{\text {rd }}$ kept back by the bank to cover themselves gradually for the $\mathrm{S} / 250,000$ advanced. The surplus which the Account Sales would leave over and above the advance of $80 \%$ would be divided in the same manner. Of the S/250,00o the Directors of the Salitrera required S/150,00o to finish the railway which they were constructing, $\mathrm{S} / 70,000$ to pay off a debt already owing to the London Bank, and the remaining S/30,0oo to pay interest to the Banco de Lima. The new Escritura in favor of the London Bank, of which the minuta was read, would be due in six months, to which I made the observation, that six months appeared to me by far too short a period, because it would be impossible to pay off the $S / 250,000$ within that time, and that one year ought to be at least the credit allowed them. Gil, since Zaracondegui's failure the principal man in the Directory of the Salitrera, answered that this my observation would be attended to.

Tuesday, $16^{\text {th }}$ of June. The creditors of the firm of the late Juan de Ugarte met in the Consulado; it was near four when the sitting commenced, and we did not break up till six when gas was already lighted. Emilio Althaus made a very good prior. Of the creditors, Lembcke as representative of the Banco de Lima interested for more [...] [565] S/400,00o was the principal, if not the only spokesman. Manuel Candamo and I said a few words. The agreement, which about a fortnight previously was drawn up in a private 
meeting of creditor's in Rodrigo's house, was confirmed, with the only addition that if at the end there were a surplus, $6 \%$ interest annually should be paid to the creditors. It was I who made this motion, which was then enlarged upon by Lembcke. As Interventores were named Chavez, one of the principal creditors, who promised to look in now and then, and Garland wo was no creditor, with a salary of S/300 monthly, and the obligation to be continually on the spot in Ugarte's counting-house, to look after what Puente might be doing.

Wednesday, $17^{\text {th }}$ of June 1874. The Directors of the Water Company had their meeting; I understood little about the matter, but always learned something for Rey's explanations were clear and intelligible. This day it was resolved to suspend some excavations outside the Maravillas gate until an answer were received to a letter addressed by Mr. Wilkinson, the Engineer resident in Lima, to Mr. Prentice, chief-engineer and shareholder, absent in England. The daily consumption of water in Lima was above five millions of gallons.

Thursday, $18^{\text {th }}$ of June. Our Lima winter had set in, some weeks later than last year. It rained the whole of last night, and this morning the streets were wet and muddy. The North Steamer brought Garland the advice of the death of his sister Mariana. In European politics nothing of particular importance had occurred. In France there had again been a change of ministry, and in Spain the Carlists had had the advantage in several combats. On the $14^{\text {th }}$ May the Peruvian Bonds were quoted on the London Stock Exchange as follows: the $6 \%$ of 1870 , at 74 to $741 / 2 \%$ - the $5 \%$ of 1872 at 62 to $63 \%$.

My tenants, of whom I spoke a few pages back, had at last left my Stores and shops, and since the $16^{\text {th }}$ inst. Meiggs' building company occupied them. On the other hand, as yet I had no answer from the Patente commission, or from the Consulado, to which I had addressed myself regarding the rent of Lopez Hurtado \& Co., and the decree about the conversion of the bonds, though written out in clean, as Pepe Izcue told me, the Ministers had not yet found time to sign.

Saturday, $20^{\text {th }}$ of June. J. P. Hague, to whom I had lent S/6ooo paid [...] amounts the very day it fell due. Also from Pablo Viver [...] [566] obtained some payment, though not so easily as from Hague. After long and continued dunning he authorized me to sell S/20,00o Noml. Shares in the Salitrera Rimac, which I held as security for S/10,ooo. I disposed of them through the broker Malagrida at $60 \%$, and after covering myself for capital, and about S/1000 interest, I handed over the balance to Vivero. The S/10,00o were half mine, half Juan's. In the interest was included some due on the pagare of $S / 21,200$ I held with Garland's endorsement, and for which in my opinion the shares in the guano-loading Company were not sufficient security. 
Tuesday, $23^{\text {rd }}$ of June 1874. There was a meeting in the Consulado of the creditors of Lopez Hurtado \& Co. I went, because my just claim for rent had not yet been attended to; it was nearly 4 O'clock before the session commenced, not in the large hall, but in the adjoining room. The Prior, Emilio Althaus, the two Consuls, Calderoni, and Lecca, together with the notary Mosquera, sat around the table, whilst the creditors, hardly more than twelve in number, took their seats on the sofas which stood round the walls. Charles Wheelock, the Sindico, read the statement drawn up by him, in which he made his observation on each claim; my rent he mentioned as a debt immediately to be paid; then Althaus said that the meeting was not convened to quality or classify the debts, but merely to decide by majority of votes whether the respective claims were true debts or not. All went on fairly, few remarks being made, until we came to the claim of Dr. Julian Sandoval for S/45,00o which Wheelock had considered as no just claim, because according to him Sandoval had not lent the money on interest, but for the purpose of receiving his share of the profits, as a proof of which he read an agreement between the two parties, which said in clear terms that $S / 45,00 o$ had been paid in by Sandoval in order that Lopez-Hurtado should trade with them, "para partir utilidades" - to divide profits. Now Dr. Sandoval and his brother-in-law, Serapio Orbegoso, rose and attacked Wheelock in severe terms, charging him with partiality and with having done everything that lay in $\mathrm{h}[\ldots]\left[5^{6} 7\right]$ to prejudice their interest; Wheelock defended himself. Sandoval read a long statement, certainly drawn up by a lawyer - perhaps by Dr. Palacios - in which he endeavoured to prove by many expressions in the same agreement with Lopez Hurtado, that he was not a partner, and that the money was lent on interest; at the end of the year 1872 he had received $24 \%$. It was now as late as 6.30 ; no decision had been come to, the altercation continued, and Böhl and I left. At 10 in the evening I went to the house of Doña Petronila Saavedra de Puente, the mother of Doña Manuela, Dolores, Petronila, and Joaquina, who had died a day or two before, and accompanied the body to the Church of San Francisco. On

Wednesday, $24^{\text {th }}$, day of San Juan, in the morning, I was present at the funeral.

When my lector was gone I paid my customary visits to the Juanas and Juans of my acquaintance; to Doña Juana Carbajal, to Doña Juana Valle-Riestra, widow of Admiral Guise, whose drawing room on her and her daughter's birthdays was like a bee-hive; gentlemen continually going in and coming out; to her niece Juanita, a pleasant young lady, daughter of Don Domingo Valle-Riestra. A few gentlemen were there. Thence I went to Dr. Juan Antonio Ribeyro, Vocal of the Corte Suprema, where I met Pedro Paz-Soldan, General Medina, and other gentlemen of weight in Lima Society; from his house to that 
of Juana Rosa Moreyra, the wife of General, at present Minister Nicolas Freyre, and finally to a Roman Canon, Dr. Juan Bautista Valeri, though a clergyman quite a man of the world, with whom we thought prudent to be on good terms, in order to obtain through his influence with the abbess of the Concepcion a renewal of my lease of the five shops Calle del Correo.

Thursday, $25^{\text {th }}$ of June 1874. In the evening Garland had his usual rocambor, and Enriqueta's friends amused themselves at the roulette table, at which my wife, who was very fond of the game, lost $\mathrm{S} / 5$. I ceased playing when my losses came to four rials.

Saturday, $27^{\text {th }}$ of June. The Directors of the Pasco Railway Company did no more meet in my rooms, for Agustin Escudero, one of them, lately chosen gerente of the Banco Hipotecario, could in the day time not leave [...] there they now assembled. In the course of the day [...] [568] occupied with my law-suit against Leyva, and in the evening when Garland and Enriqueta went to Rafael Velarde's to congratulate his daughter Zoila on her birthday, my wife and I remained at home by ourselves. It became known that Agustin Gonzales y Pinillos, husband of Enriqueta Elespuru, had declared his insolvency; he lived separate from his wife, and his moral character was held low in general estimation. There was also some talk about the solidity of Valdeavellano \& Co., as well as their partner Graña, individually. This latter was looked upon as a particularly clever man, not so Benito Valdeavellano, the head of the house, which, it was well known, had lost much money in the Bolivian guano, exported from Mejillones, lately bought by them from Henry Meiggs.

Monday, $29^{\text {th }}$ of June. This being the day of San Pedro y San Pablo I had once more to make indispensable calls, viz.: upon Doña Paula Benavides, whom I found very low spirited, owing to the recent death of her daughter Candelaria; neither was Don Pedro Paz-Soldan so cheerful or talkative as was his wont, whilst on the order hand his son Pedro - known by the pseudo-name of Juan de Arona - as well as his cousin Carlos Paz Soldan, husband of Petronila, who preferred remaining in her inner apartments, were both more agreeable than I had found them on other occasions. Doña Petita Puente, Frederic Marriott's wife, whose mother's death I noticed some pages back, did not receive her friends; and at Pedro Bernales' where the drawing-room was filled with gentlemen, hardly a word was spoken. I also paid my visit to Doña Petronila, the President's mother, who however I did not find at home, she having gone out to Chorrillos.

Tuesday, $30^{\text {th }}$ of June. In the saloon of Frederic Marriott, Manager of the Lima Gas Company, there was a strong gathering of the shareholders, all displeased with the bad result of 1873, and with the management in general. The dividend had not exceeded $7 \%$, of which the last two, due since December, had only just 
been paid. There was a general desire to remove Marriott, but of its being done, there was not the slightest chance; his family connections were too powerful; moreover, he had the protection of José Vicen[_] Oyague the largest shareholder [_] he held 600 shares of $S / 50$ [...] [569] who, as usual, was called to the chair, and communicated to us that a considerable amount of money was required to pay the debts of the Company, mainly to Bates Stokes \& Co. of Liverpool, and to lay new pipes, the old ones being for the greater part much damaged, partly by the corroding influence of time, partly by the labourers who had been working at the recent canalization of the streets; and to this their bad condition, the great waste of gas in the course of the previous year, viz.: one-third of the quantity produced was attributed. Oyague proposed to raise the money by issuing new shares at a discount of $10 \%$, with the condition that the persons who at the end of the previous year had taken shares at par, should be allowed the same discount if they again took shares. This motion, though opposed slightly by Manuel Candamo and M. M. Galvez, passed by a great majority; neither was any objection made to Dionisio Villate's amendment, seconded by me, that this taking of new shares should not be obligatory. Hereupon two new Directors, instead of George Petrie and Manuel Candamo, were chosen, and the choice fell upon Garland, who represented C. W. Schutte, owner of 375 shares which he had lately bought in Paris at a premium from Arthur Heeren, and the physician Dr. Arosemena, who in the course of this meeting had dilated in a very proper manner on the improvements and economies which might be introduced in the fabrication of the gas. I now left, having to attend the meeting of the creditors of Lopez Hurtado \& Co., which was held in the Consulado. Dr. Sandoval's claim was discussed, and the creditors present unanimously decided that he was no creditor, but partner of Lopez Hurtado. Then Serapio Orbegoso's claim came on, and after I had gone, met, as I was told, the same fate as that of his brother-in-law Sandoval. To both, the appeal to the Superior Court lay open.

Wednesday, $7^{\text {st }}$ of July 1874. A great part of the day I was occupied collecting money: $2 \%$ for the last three months on my Cedulas of the Banco Territorial and Banco Hipotecario, $2 \%$ for the same period on the Municipal Bonds lately received from the liquidator of the Constructora, and $20 \%$ dividend for six months from the South American Insurance Company. [...]. The 2 $1 / 2 \%$ [...] [570] months dividend from the Water Company, was sent me to my house as it was Mr. Rey's custom.

Thursday, $2^{\text {nd }}$ of July. In the monthly meeting of the Directory of the Banco de Lima Manuel Salcedo was as tiresome, and José Vicente Oyague quite as patient as both had been at the last session. The former now harped on the 
loan of $S / 1,000$, ooo made by the bank to the Salitrera "Esperanza", of which all present knew as well as he that we should have acted more prudently had we made no such loan. When Salcedo had done speaking, and Lembcke had read the customary monthly statement, this latter urged the necessity of convening as soon as possible a general meeting of shareholders for the purpose of choosing two new Directors, and a gerente, Sagastabeytia's nomination being but provisional. I observed it would be advisable that we, the Directors, should be agreed as to the new ones to be recommended by us to the shareholders. Oyague then requested me to name such as I considered proper persons. Gustavus Heudebert was the first whom I named, and who was approved of; the second, M. G. Chavez, was rejected, Oyague remarking that he might be an excellent person, but that he never opened his mouth. The third, Manuel Ortiz de Villate, again rejected because he was one of the Directors of La Providencia: the fourth, Amancio Castillo, though not much liked, passed in silence. When the election of a new gerente came on, Sagastabeytia said that he was desirous to throw up his post. We all knew full well that he was not sincere when he expressed himself in this manner; nevertheless, in order to be prepared in case he should actually leave us, Oyague proposed for his successor, Garland, to whom nobody objected. In the evening Garland had his customary rocambor, Enriqueta her roulette, at which latter Enrique and Gregorio Benavides, the bankers, gained, and my wife, as always, lost a few Soles.

Friday, $3^{\text {rd }}$ of July. Juan's letter, just received, was dated end of May; it contained a resumen of the complaints of the Paris holders of Lima Gas Shares as to the bad administration of this Company, and their unanimous desire to see Frederic Marriott removed; it was an exact counterpart of what I [...] [571] subject on the $30^{\text {th }}$ ulto. José Sevilla, Juan added, was the most conspicuous grumbler; he, Mrs. Cotes, and others wanted to see Garland in Marriott's place. Juan gave me peremptory orders to dispose of his cedulas del Banco Hipotecario, which I had to comply with, though much against my inclination; they stood at $75 \%$. He further wrote that the agreement between the Peruvian Government and the House of Dreyfus in Lima dated $14^{\text {th }}$ April, and a copy of which Ford, partner of the firm took with him to Europe, was not yet ratified, and that on the very day he wrote, at five in the afternoon another conference on the subject would take place between Dreyfus, Carlos Candamo, Peruvian Financial agent in Europe, Pedro Galvez, Peruvian Minister, and Mariano Lino de la Barrera, Peruvian Fiscal.

This day the "Inspeccion ocular" of the "aires" of Leyva's house was held. The architect whom I had named, Jacobo Lopez Castillo, did not attend. Present were: Dr. Quiroga, the Judge, Manuel Escobar, the notary, Leyva, his "perito", 
the architect Cabiezas, and I. We climbed up a ladder to the roof, where Leyva made the judge observe:

Firstly, that from my first story no door opened to his roof.

Secondly, that on his roof were two old "ventanas teatinas".

Thirdly, that upon the partition wall between his house, and that of La Campanita, he had erected a low adobe wall.

Fourthly, that his servants had always been in the habit of drying linen on his roof - when I remarked that I had never seen it done; and

Fifthly, that in former times he had a ladder by which he ascended to the roof, but that for various motives he had of late removed it.

As to the measuring of the rooms of my property built upon part of the roof of the ground-floor of his house, it was put off to another day when both architects could do it jointly. Of the foregoing the protocol or acta was drawn out, signed by the judge, Leyva, and myself, and certified by the notary. Leyva and I were polite towards each other; he had beer brought in, of which I did not partake.

Saturday, $4^{\text {th }}$ of July 1878. I went to the office of Pepe Izcue, who told me that the decree for the conversion of the special bonds was not [...] Elguera, who had of late succeeded Carrillo [572] Minister of Finances.

A few days previously Mariano Ignacio Prado had arrived from Chile, and been received by the populace of Lima, which had turned him out on the $6^{\text {th }}$ January 1868, with great demonstrations of joy. He had been named Peruvian Minister at the court of St. James by Manuel Pardo the President, in 1865-6 Prado's Minister of Finance.

Sunday, $5^{\text {th }}$ of July. I called amongst others on Dr. Mariano Ignacio Prado, who lived at Pablo Vivero's. When I entered I found him conversing with a circle of gentlemen who were on the point of leaving; after they were gone he took me into the next room, where we talked on indifferent subjects for about three or four minutes. In all probability he would take his seat in the chamber as Deputy for Callao, and then be elected President of the Chamber.

Wednesday, $8^{\text {th }}$ of July. In the evening the shareholders of the Banco de Lima met. Oyague presided, I to his left, next to me Salcedo, then Mendoza; to his right Bernales, Gil, and the Gerentes. Many shareholders were present. Sagastabeytia, who has declared his willingness to continue gerente, was re-elected by 111 votes, I voting for him; Agustin Escudero had 32, Garland 11, a certain Larabure, who was about marrying a daughter of Cipriano Correa, 8. Then came on the election of the New Directors. Manuel Cucalon had 131 or 141 votes, not mine, Heudebert 96, Amancio Castillo 92, a certain Castro Zaldivar, unknown to me, was next in number. When we were about breaking up, this man, who seemed to be much dissatisfied, demanded a new meeting 
of shareholders, and the naming of a commission to examine the accounts of the bank. Nothing was determined, for it was getting late, but undoubtedly some shareholders were displeased with the proceedings of the Directory. I was home by 10 O'clock, when the family, which had counted upon Garland's nomination, was much disappointed at Sagastabeytia's re-election.

Thursday, $9^{\text {th }}$ of July. A considerable part of the day was taken up by the declaration of witnesses, both Leyva's and mine, which were taken in the office of the judge Quiroga, by the notary Manuel Escobar. Leyva more than once availed himself [...] [573] right which he had of counter-questioning my witnesses, without however eliciting any answer which could favour his pretensions. In the evening I suffering from a bad cold went to bed at 9 whilst Mariquita went across to Enriqueta's apartments.

Saturday, $11^{\text {th }}$ ofJuly 1874. Leyva presented an escrito demanding that I should present the title deeds of my house in order to ascertain the dimensions of the rooms belonging to me, built upon his. Quiroga acceeded to his request, and I presented the same afternoon an escrito refusing to come forward with the deeds because there was no connection between them and the case in dispute between Leyva and myself. At 1 p.m. the shareholders of the Providencia met. I attended for the first time. The lawyer Garcia Calderon presided. The statement of the affairs of the bank was read aloud by one of the gerentes, and proved very satisfactory. Thereupon the Directors, who went out by rotation, were re-elected. Moscoso Melgar, and Joaquin Bolivar were the gerentes.

Sunday, $12^{\text {th }}$. In the Exhibition palace a concert was given under the patronage of Doña Petronila, the President Pardo's mother. The Net proceeds being destined for the construction of a church in Chorrillos, which this lady had much at heart. At the same hour there was a bull fight in the Plaza de Acho in honor of Prado, and thus the concourse of people being divided, was not great at either place.

Monday, $13^{\text {th }}$. A telegraphic dispatch was received from Paris, which said that Dreyfus had approved the contract between his firm and the Peruvian Government, dated $12^{\text {th }}$ April.

Tuesday, $14^{\text {th }}$ of July. In the evening Mariquita and I paid a visit to Dr. Muñoz, and his young and handsome wife Irene. They were very friendly and showed us all over their apartments in the first story, which they had just concluded, and which were fitted up with much elegance.

Wednesday, $15^{\text {th }}$ was San Enrique. Neither Enriqueta nor Enrique Garland, nor I minded our saint's-day, but Doña Rosa, wife of Cipriano Correa, never omitted to send her card; Don Cipriano himself came in the evening and remained with us for an hour. 
Thursday, $16^{\text {th }}$. We passed the evening in Enriqueta's apartments $[\ldots]$ was only one rocambor table, but a good many round the roul[_] [574] Rafael Velarde and family, Gregorio Benavides and wife, a certain Corso from Arequipa, brother of the Vocal, Carvalho, the Secretary of the Brazilian Legation, Mariquita, Enriqueta, Enrique, and I. Don Rafael was the banker, Antonio his assistant. I hardly played at all, my wife lost.

Friday, $17^{\text {th }}$ of July 1874 . We received the letters from Europe. Juan wrote that he had at last resolved to submit to an operation, for which reason he had been obliged to put off his voyage to Perú.

Garland had a letter from Geraldo from Hong-Kong in which he informed him that he had thought proper to leave the Peruvian Embassy and that he was on his way home via Suez and Marseilles, Aurelio Garcia, the Minister, having furnished him with the necessary funds. I was much displeased with this step of his.

Saturday, $18^{\text {th }}$ of July. In the course of the week I encashed $41 / 2 \%$ interest for six months both from the Banco del Perú and the Banco Nacional, from the former for Schutte, Juan and myself, I being interested for only $\mathrm{S} / 5000$ from the latter for Juan and myself, he owning 16, I 42 shares, on each, 300 Soles paid up.

This day the Directory of the Banco de Lima met, present were: Oyague in the chair, Bernales, Secretary, Gil, Salcedo, and I, and the three lately elected: Heudebert, Castillo and Manuel Cucalon. Also the two gerentes, Lembcke, and Sagastabeytia. Absent: Muro, Elguera, and Mendoza. After the last acta had been read a Vice-president was elected in lieu of Sagastabeytia. I was chosen by seven votes; Heudebert, Gil, and Cucalon had each one vote, Heudebert, mine. Then came the great question, the convening of a general meeting of Shareholders. The discussion was long, and I was much pleased with what Cucalon said. At last it was resolved that such a meeting should be convened under the pretence of treating on the reform of the Statutes, when all the discontented would have an opportunity of coming forward with their complaints, and state what they wanted. The next point of great importance to be discussed was that relative to the Salitrera Esperanza which owed to the bank not less than a million of Soles. To my regret I could not remain for I had necessarily to go to Chorrillos to [...] [575] old lady, the widow of the saddler Agreda, who for a number of years had lived in the house now owned by Leyva, and of whom a black woman called Santos had told my wife that she could give us some particulars regarding the "Ayres" of Leyva's house. This Santos had been the favourite servant of Doña Juana Querejazú, marchioness of Avellafuerte, who until her death had occupied a room in the house now mine. Jointly with Santos I went per train to see the widow who resided in Chorrillos, 
and who told me on my questioning her that her late husband had frequently said in her presence that the "Ayres" in dispute did not belong to the house at present Leyva's, but formed part of that of Querejazú, now mine, and that she was willing to give a declaration on oath to this effect, if requested to do so. With this satisfactory result of my visit I returned to Lima, to communicate it to my lawyer.

Tuesday, ${ }^{2}{ }^{\text {st }}$ of July 1874 . I went to see a certain Miguel Rotalde, a man of very dubious character, with whom however I had been acquainted for a number of years, even since the time that he was clerk to Cristoval Armero. I asked him about the ayres of Leyva's house, and strange to say his answer was the very reverse of what Doña Jacoba had told me. He was quite certain, he said, that those Ayres belonged to Leyva.

Wednesday, $22^{\text {nd }}$. At 7.30 in the evening the shareholders of the Banco de Lima met. A great number of them were present. Castro-Zaldívar, the leader of the opposition, sat exactly opposite to me, my seat being to the left of Oyague, Bernales to his right. The Presidents opening speech was not much to my liking. After the acta of last meeting was approved, Oyague proposed the reform of the statutes, which being unanimously agreed to, he named a commission, consisting of two Directors, Sagastabeytia and Cucalon, and three Shareholders, Agustin Escudero and two others, to make the alterations they might think necessary and then to present the result of their labours in the next general meeting. This over Castro-Zaldivar came forward with his motion that a commission should be named to investigate closely everything which had been done by the Directors. I was the first to answer him, and said that though I was not opposed to such a commission, I thought it quite unnecessary, [...] the [_]atutes allowed every shareholder to examine the ac [...] [576] and the portfolio, and to question the gerentes on every possible subject. Hereupon, Escudero said that such a commission would be prejudicial to the credit of the bank, and begged Zaldivar to withdraw his motion, which he refused to do. Now, at the request of various persons the President put the question "Should Zaldivar's motion be admitted to discussion, or not?" and even this was denied him by a great majority, which I myself thought very wrong. In my opinion it ought to have been discussed, and then thrown out. Zaldivar now got up, very choleric, and said he would publish in the papers how the bank stood, he would ruin it though it cost him $\$ 25,000$. Then Lembcke rose, and having asked the President's leave, read a long and very proper document, in which he gave a detailed account of how the affairs of the bank stood, which in a great measure pacified Zaldívar. The loan of one million Soles made to the Salitrera "Esperanza", was of course the most objectionable part, and the worst was that this company wanted $S / 200,000$ more to conclude the railway. Lembcke 
expressed a wish that the shareholders should at once decide whether this new loan was to be made or not, but they would say neither yes nor no. I also took my share in the discussion, and the result was a middle course, which I disapproved of, viz.: the nomination of a commission to investigate the affair, and then lay their "dictamen" before the Directors. This was only putting off the evil day. It was half past ten before I came home. Dr. Jose Aranivar, who was the bank's lawyer, was of great assistance to the directory in these disputes with the shareholders.

Friday, $24^{\text {th }}$ of July. I gave in my escrito, in which I appealed to the Superior Court from the sentence of Judge Quiroga, who complying with Leyva's request, had ordered me to present the title deeds of my house. In the evening I went to Chorrillos, accompanied by Enrique and Alejandro. In my pocket I had a letter addressed by me to Doña Jacoba Oliva, widow of Agreda, in which I begged her to give a written answer to the questions which I put to her in the same. She was ready to do so. Alejandro put her answers in the proper form, and dictated them to Enrique. On

Saturday, $25^{\text {th }}$ of July I presented an escrito to Dr. Quiroga, accompanying this my letter with Doña Jacoba's replies, toget[_] with another letter from architect Jacobo Lopez Casti [...] [577] said that the word "Ayres" was never applied to the vacuum over the first story of a house, and was solely used when speaking of the vacuum over the roof of the ground-floor. This declaration I required, to invalidate an assertion made by Leyva in one of his escritos, viz.: that the Ayres which in the title deeds of his house were excluded from the purchase, referred to the Ayres upon the Altos erected on part of the roof of his house, and belonging to me - and not to the open space upon the roof of the ground floor of his house, as I affirmed.

Sunday, $26^{\text {th }}$ of July 1874 . Thermometer in my office at noon, $61^{\circ} \mathrm{F}$. Hitherto we had had but little rain this year.

My wife, who had suffered for the greater part of the week from a bad cold, was this day well enough not only to leave her bed, but even to go to Chorrillos on a particular errand. On the previous evening I had sent to the Señora Jacoba through Enrique, who frequently went out to Chorrillos to spend the evening with the family Farmer, $\mathrm{S} / 20$ as a gratification for the trouble I had given her. This morning when he returned he told my wife that Doña Jacoba had looked as if she were not satisfied, and my wife now proposed to me that she and I should without loss of time pay a visit to the said woman, to which I of course gave my willing assent. We dined by ourselves, took a cab to the terminus, and thence per train to Chorrillos, Mariquita well covered up. Doña Jacoba, whose house was close to the terminus, seemed much flattered 
by our visit. Mariquita was very friendly to her, to her daughter, the widow of Francisco Lagomarsino, and to her grandson, a farmer. I gave her another S/20 - she now seemed well pleased, and I was confident that I could now count upon her for the future.

The Executive had given two decrees, which I trusted Pardo would be able to carry through; the one, in which the Prefect of Junin was ordered to expel from his department a few jesuits who without leave from the Government had established their House in Huanuco; the other, which directed the Supreme Court of Justice to proceed criminally against Huerta, Bishop of Puno, for having abandoned his diocese, and given up his episcopal dignity into the hands of the Pope, both the one and the other without leave or consent of the Government. To make assurance doubly sure I sent my servant Juan [_] [578] a dozen wine as a present to Doña Jacoba.

Tuesday, $28^{\text {th }}$ of July. This being the day when the Congress opened its sessions, we had some bustle in our street, that of Zarate. The Government coaches drove more than once from the Congress Hall to the Palace, and back again; soldiers lined the foot pavement, the President walked on foot to the Congress, and so on. All this, insignificant and unimportant as it was, had been seen over and over again; nevertheless, such is the propensity of the "Limeñas" "a la noveleria", in other words, so eager are they to witness what is going on, let it be ever so trivial, so as to have an opportunity of seeing and being seen, that gradually the balconies of our house, which belonged to Enriqueta's apartments, became filled with ladies of our acquaintance, invited and uninvited. I neither knew nor could distinguish them all. A few however I can enumerate: Mrs. Riva Agüero, the wife of Dr. Muñoz, and her sister, married to the judge Ponce, the two grand-daughters of Dr. Alvarez, Cristina Bustamante, married to Luis Cisneros, and Aurora Santillana, two daughters of the fiscal Morales, and a relation of theirs, Virginia La-Torre, wife of Domingo Valle Riestra, with some of her daughters, Mercedes Dartnell, with her daughter Maria Rosa, Jose Vicente Oyague, wife, and number of children, Mr. and Mrs. Henry, Alfred Böhl, José Pablo Escobar, his brother-in-law Carlos Lopez, Electro Corso, his wife a native of Guayaquil, Doña Pancha, wife of Mariana PazSoldan, young Pedro Paz-Soldan, and little ones, I do not know how many. The President's procession to the Congress was the principal attraction. Military music was heard. Shortly after appeared the pupils of San Carlos, then Manuel Pardo, the bi-colored scarf over his shoulder, surrounded by his ministers and a few generals. Behind him walked the members of the Supreme and Superior Courts of justice and some other civic dignitaries; battalions of the standing army and the national guards brought up the rear. When they had 
passed Enriqueta requested her guests to partake of a nice lunch which she had laid out, and now I committed a very great blunder. I led in the wife of Dr. Muñoz and placed her at the head of the table not recollecting at the moment that before her marriage she [...] [579] hardly ever have been seen in decent society, besides, that Mrs. Riva Agüero, the wife of a Minister, and in her own right belonging to the first families of Lima was present. It is true that Garland took in this lady; but she has never forgiven us what she considered to have been an insult (This last sentence I add in July 1878.) Just about the time that we rose from the table the procession returned from the Congress; then also several gentlemen looked in: Frederic Marriott, who came for his daughter Maria, Manuel Francisco Benavides, the Senator, Seminario, Senator for Piura, in search for his wife, Ignacio Tavara, Deputy, Pinto, Chargé for San Salvador, to fetch his two daughters - Piedrahita, Chargé for Ecuador, introduced by Pinto, and perhaps a few more.

Already in the evening we learned that in the election of the Presidents the opposition, though led by the clever lawyer Luciano Benjamin Cisneros, had been completely defeated. In the Senate were chosen: Francisco de Paula Muñoz, President; Buenaventura Elguera, Vice; Pedro de Solar, secretary. In the Chamber of Deputies: Genl. Prado, President; Ramon Ribeyro, son of the Vocal, Vice; Emilio Solar, secretary. All six, except General Prado, were staunch friends of Pardo, and also Prado was not believed to be exactly hostile to him. That this last named would be chosen constitutional President of the Republic for the next period of four years from the $2^{\text {nd }}$ August 1876 was the general opinion.

Wednesday, $29^{\text {th }}$ of July 1874. The monument which had been erected on the spot where formerly the Callao gate stood, and which was to commemorate the repulse of the Spanish fleet on the $2^{\text {nd }}$ May 1866, was unveiled and inaugurated. The number of people who flocked thither, on foot, on horseback, and in carriages, both from Lima and Callao, was great indeed, and I was in the very midst of them. The procession, which I saw marching towards the vast circle round the monument, kept clear by soldiers, was headed by the brigades of firemen in their gala uniform, and carrying with them their engines and other implements, the Italians first, then the French, Peruvian, and the English: followed the girls and boys of the Municipal schools, a number of officers of the National guards, and other military men; next, a number of North Americans carrying their stripes and stars, a few [...] from the Island of Cuba with their banners; Equatori[_] [580] Bolivians, and Chilians resident in Lima, each nationality with its standard, the pupils of San Carlos, the President with his cortége, and the members of the two Courts of Justice. From another quarter came the members of the Municipality, also some battalions 
of soldiers, but neither the one nor the other did I note. After a short pause the cover which had concealed the monument fell down, the music struck up, and cannons were fired but there was not the slightest enthusiasm, no shouting, no huzzaing. The President Pardo, and General Prado delivered each a speech, which I did not hear, being too far off, but a sound as of clapping of hands reached my ears. Now all was over the crowd dispersed, and I was home by five, little pleased with what I had seen.

Thursday, $30^{\text {th }}$ of July 1874. At Enriqueta's earnest entreaties my wife and I agreed to drive with her, Garland, and the two little girls in an open carriage to the race ground; the sun was not out, the temperature was cool, and we had done right in covering ourselves well up. For a long time I had not been on this the Callao road, and I was much surprised at the great improvements which I noted everywhere. Instead of the bad road of former times, the present one, La Carretera, constructed by George Elster in virtue of a contract made by him with the Municipality, was as hard, smooth, and level, as one could wish. On each side of the carriage road, lined with trees, was a wide footpath, and then extended the open country, here cultivated there barren, the race ground was about halfway between Lima and Callao on the right side of the Carretera. Here we ordered our coachman to turn off, and to halt more or less opposite the grand-stand. About us were other carriages with their occupants, horsemen and spectators on foot, but the space between our carriage and the stand, which was part of the race-ground, was kept clear. After a short time four or five riders galloped by at full tilt, not in one heap, but the one a few yards behind the other; at the utmost one minute elapsed from the moment they came into, and were again out of sight. Some gentlemen came to the side [...] [581] carriage to converse a few words; I felt cold, alighted, walked about, and thus nearly an hour passed when again some horsemen careered along, again and again others flitted by; I could see, but not distinguish them, and was heartily glad when all was over, and the horses' heads were turned Lima-wards, fully resolved, never again to grace a race-ground with my presence. The drive home was pleasant; the carretera was filled with those who returned from the races, and others who came from Lima to meet them.

Whilst this was going on on the race-ground, in the Exhibition-palace prizes were distributed by the President to such of the pupils in the Municipal schools, who had distinguished themselves by their industry and good behaviour. There were but few at Enriqueta's soirée. Garland, Enrique Ayulo, Manuel Francisco Benavides, and Gregorio Benavides played at rocambor. At roulette Alejandro was the banker, Antonio his assistant; Mrs. Gregorio Benavides, her two sons, Carvalho, Carlos Lopez, my wife, Enriqueta, and I 
were the only players. For the first time I gained a trifle, my wife lost double. J. P. Escobar looked on at the rocambor table. By half past twelve I was in bed.

Friday, $33^{\text {st }}$ of July 1874 . In the message which on the $28^{\text {th }}$ inst. the President Pardo read to the assembled Congress, he slightly touched on the various subjects to which he had given his particular attention during the two years of his administration. At the conclusion he recommended to the Congress

Firstly - the improvement of the judicial proceedings in criminal affairs.

Secondly - the formation of two funds, the one for promoting European immigration, the other for increasing and improving primary education.

Thirdly - the reform of the electionary laws and those referring to military men not in active service, and

Fourthly, the budget, jointly with a law for regulating the sale of guano. He likewise stated that in the year 1873, of the Anglo-Peruvian Debt of 1872, $£_{7} 82,000$, and of the Interior Debt $S / 1,469,000$ had been redeemed; further, that the budget for the said year amounted [_] 23 millions, and the actual expenditure had come to 17,389,00[_] [582] viz.: balance of the preceding year: $S / 1,181,000$ - actually spent in the course of the year $S / 15,883,000$. The floating debt not yet cancelled, amounted to $S / 1,505,000$. After the President had left, the Congress continued its sitting, and Prado made a motion for granting a general amnesty to all political offenders; this motion was followed by two, relative to the Nitrate of Soda business, the one made by M. A. Oviedo, the other by Constantino Duarte, both demanding the cancelment of the law which had ordered the "estanco" or Government's monopoly, as per decrees of $17^{\text {th }}$ and $18^{\text {th }}$ January 1873; the first wanted the export duty to be reduced to five cents per quintal, the second to have it taken off altogether. At about two O'clock, when I had done dictating my answer, Mr. Deeble left me to see the horse races with which and the firing at a target in Amancaes, the festivities to celebrate the Peruvian Independence concluded, and I having nothing better to do ascended San Crístoval, which this time I did with the greatest ease. I was absent from my house exactly two hours. On my return my wife communicated to me a piece of news of very sad import. Guillermo, more than a year back, bought in China a vessel which he called the "Guillermo", for which he obtained the money on very onerous conditions from Chavez, the manager of the Lima branch of the South American Company. In Macao she was chartered to Bresani for Chinese coolies; she arrived here safely, and Guillermo rechartered her to Serdio, to bring wheat from Chile; the vessel had been insured for a year, which year had elapsed, and Guillermo neglected to renew the policy. His excuse for this culpable oversight was that once or twice he had applied to Ferreyros, Manager of the Insurance Company Lima, who had declined effecting the Insurance; and now advice was received that the 
vessel was totally lost on the Coast of Chile. This loss of about $\mathrm{S} / 20,000$, and other speculations in some of which he had gained, in others lost, entirely ruined him, and even his father did not yet know how his affairs stood. I in the meanwhile thought it my duty to tell him that for the present he need not trouble himself about the repayment of $S / 10,000$ due by him to me. Of these S/10,00o I in reality only had lent him S/450o for which I held some though not sufficient security. The balance of $S / 55[\ldots]$ [583] originated in a peculiar manner. Some time back Guillermo borrowed from Rafael Velarde S/25,000 at $1 \%$ monthly interest. Before the pagare fell due, Rafael wanted money, and applied to me for S/2500 which I let him have against his pagaré. A few weeks later he again stood in need of the "nervus rerum", and now asked Garland for S/3000, which this latter had not, and in order not to disappoint Rafael I had again to come forward with the amount required; Garland signing me his promissory note. Meanwhile, Rafael's pagarées to Garland and myself had fallen due, but on our demanding payment, the answer was: "Get the $S / 5500$ from Guillermo, this being exactly the balance he still owes me". To save Guillermo's credit we could not tell Rafael that he was unable to pay; Garland had not the means either, and thus, as it was often the case, I had to bear the brunt, and Guillermo became my debtor for $\mathrm{S} / 10,000$ without my seeing the slightest probability of his ever being able to pay me.

Sunday, $2^{\text {nd }}$ of August 1874. Ricardo read to me Seume's walk to Syracuse in the year 1802 and 1803 very prettily written. I then paid my visits as I was in the habit of doing. To the Canons Bandini, and Valeri, neither of whom I found at home; also Mrs. Prevost had gone out, and her sister Mariana, the wife of Hülsenbeck, as a true Moreyra, was still dressing at 2.20 in the afternoon. Mrs. Dibos, Ernestina Pflücker, showed me all over her new house in the Calle del Corcovado, formerly Codecido's, now Oyague's. The ground-floor which she occupied was certainly more extensive than the one she had in our house. I further called upon the four vocales of the Supreme Court who had always favoured me with their votes, and with whom my wife and I had become rather intimate. They were: Drs. José Luis Gomez-Sanchez, Gervacio Alvarez, J. A. Ribeyro, and Bernardo Muñoz. With the first of these four I was in the habit of conversing in a very confidential manner, so I did this day, but whilst we were in the midst of our confabulation the Minister of Justice, Dr. Eusebio Sanchez entered, when I rose, and took my leave. Of Dr. Alvarez my original merely gives the name, whilst of Dr. Ribeyro it says that we hardly talked on any other subject but the triumph which his son Dr. Ramon [...] ained by being elected President of the Chamber of Deputies [...] [584] Dr. Luciano B. Cisneros, an extremely clever lawyer, backed as he had been inside the house by all the members of the opposition, outside, by the influence and money of the firm of 
Dreyfus. I now recollected that I ought to present my congratulations to Don Ramon himself, went to his house, but not finding him in had to transmit them to him through the medium of his lady. Dr. Muñoz was not at home either, as little as his dashing, young wife Irene, who, now in the first year of her married life, enjoyed in full draughts all the pleasures and comforts which her amorous husband had placed at her disposal: she had driven out in her own "coupé". In the evening a letter was brought me from Johannes Limpricht dated $30^{\text {th }}$ June; it contained good and bad news, the latter by far preponderating. Maria, 17 1/2 years old, the eldest daughter of my nephew Henry Limpricht, Professor of chemistry at the university of Greifswalde, was engaged to Dr. Wellhausen, Professor of Oriental languages in the same university. Their marriage would not take place till next year. On the $24^{\text {th }}$ June died at Ratzeburg of asthma, Bobertag, the husband of my niece Elizabeth Limpricht, without leaving her a cent; on the contrary, debts amounting to more than $\$ 1000$ which would just be cancelled by the proceeds of the insurance effected on his life. The Government allowed her a pension of 190 Prussian Dollars annually. I resolved to make her a remittance of $£ 200$ by the first steamer. The second bad piece of news was the death of the young wife of Edward Knawer. She, in the family way, left Callao with her husband and children towards the end of May last; she expired on board the German Steamer, two days before reaching Cherbourg. Limpricht had not learned whether she had been confined before her time or whether her death had been caused by a fall from her berth immediately after her confinement.

Monday, $3^{r d}$ of August. By last steamer from Panamá arrived J. A. Lavalle, married to Mariana, the President's sister, and without loss of time took his seat in the Senate for the department of Apurimac, also Oscar, brother of Arthur Heeren, who was likely to be named one of the gerentes of the Banco Anglo Peruano. In the Senate the Finance Minister J. J. Elguera read his message, probably drawn out by the President himself in which he gave a det[_] [585] account of the financial operations of the last two years. Of the conversion of the Pasco Railway Special Bonds into bonds of the Internal Debt he spoke as of an "fait accompli".

Tuesday, $4^{\text {th }}$ of August 1874. Within these last days it had rained a little, which accounted for a slight improvement in the temperature, Fahrenheit's thermometer marking at 2 O'clock $62^{\circ} \mathrm{F}$.

Dr. Aranivar asked in the Senate for all the documents relative to the Pasco Railway, which the Minister could not deny him.

In the meeting of the Directory of the Banco de Lima, the discussions were of no importance, for the commission named to report on the Salitrera "Esperanza", had not yet finished its labours. 
Wednesday, $5^{\text {th }}$ of August. I went to see Felipe Barreda and Riva Agüero, and asked them whether they could tell me what had been Aranivar's object when on the previous day he had demanded that the Pasco Railway documents should be delivered to him. His exact intention they of course knew not, but nothing good did they anticipate, for Aranivar had a grudge against Pardo, and against Riva Agüero, "and", thought I to myself, "when he discovers that I also am interested in the affair, matters will not be mended." Pardo had tried to thwart him in his election; Riva Agüero had contributed to deprive his intimate friend Garcia Calderon of his post as lawyer for the Banco Hipotecario, and I it was against whom he had lost the suit when he defended the Sotomayors.

Thursday, $6^{\text {th }}$ of August. Of the Directors of the Lima Water Company at a meeting held this day, only Rey, Oyague, and I were present, consequently we were too few to come to any decision. Rey told us that he had the money required to make a remittance of $£_{3} 000$ which were due to Bates Stokes \& Co. for iron tubes, but that on the $30^{\text {th }}$ Septr. he would be without funds to pay the dividend; "Then", said I, "if you have no money, don't pay the dividend." but as I had always found it to be the case, both he and Oyague were of opinion that it would be more advisable to take up money at interest; the next meeting would decide it, but I knew beforehand that I should be over-ruled.

Monday, $10^{\text {th }}$ of August. The Directors of the Insurance Coy. Lima had [...] usual monthly sitting; the only subject of importance which we [586] treated on was the following: Many months back when Lembcke was President, and Guiroy manager, a brother of the Italian José Alberto Larco, who held this latter's power during his absence in Europe, applied in his brother's name to the company for a loan of S/20,00o giving as security two shares of the Banco de Lima, of $\mathrm{S} / 25,000$ each, $50 \%$ paid up, which he omitted to endorse. The loan was granted him. The pagaré had now fallen due, and José Alberto who meanwhile had returned made difficulty about its payment, because the power given to his brother did not say in clear terms that he authorized him to take up money. This was clearly a miserable subterfuge to avoid payment, because the money was made use of for his benefit; the two shares, nominally S/25,00o, were in reality worth no more than S/20,0oo. These, José Alberto proposed the company should keep for their nominal value of $S / 25,000$ and return to him the surplus of $S / 5000$. As soon as the power was read to me, and I learned that the shares were not endorsed, I gave it as my opinion that we should accept Larco's proposal, disadvantageous as it was. Carlos Elizalde, the President, sided decidedly with me, also Peña did not like to go to law; Gil spoke very properly on the subject without giving his opinion; Carrol said we should go to law at all hazards; Henry took more or less the same view as Carrol, Heudebert thought it advisable to come to some arrangement; 
Garland, Muro, Chavez, Noriega, and Westphal were absent. The matter was discussed for a long time, and at last Henry proposed that we should empower Elizalde and Gil to settle the matter in the best manner possible, and to this we all agreed. From Arequipa advices were received that there had been a rising of the populace, when the decrees ordering the expulsion of the Jesuits from Huanuco and the institution of a criminal suit against the Bishop Huerta had become known. The monk Masia, belonging to the barefooted friars of Lima, who was on a mission in Arequipa, contributed to stir up his audience by a sermon, which he concluded with saying that this would be the last time he could address them. The Prefect Javier Osma, it was said, had shown a want of energy on this occasion and accordingly the Government sent a battalion of troops of the line under the command of Col. Rivarola to Arequipa, there to restore order. [587]

Thursday, $13^{\text {th }}$ of August 1874 . My wife and I dined with Enriqueta and Garland who had invited some friend, viz.: a young Rafael Möller by birth a Chilian, whose father, many years established in Valparaiso, and mother, Carolina Garcia afterwards residing in Hamburg, had shown great kindness to the young Garlands when at school at Mr. Schüler's; secondly, Carvalho, the Brazilian, Alexandro's friend; thirdly, Fitzroy Cole, an English engineer, just come from Iquique, introduced by Guillermo, and fourthly Rafael Velarde. I sat near Mr. Cole, with whom I talked a good deal. We had not yet risen when my wife and I were told that Dr. Lührsen, the Chargé for Germany, and his lady, had come. Of course we had to receive them, and after a short while took them over to Enriqueta's where they remained till past nine. Rafael Velarde's wife and daughters came, also Mr. and Mrs. Escobar, thus there was no lack of roulette players at which game my wife and I lost as we usually did. Garland had no rocambor, for Malinowski was the only one who came. The party broke up at midnight.

In the chamber of Deputies to my great surprise the Government had not been able to prevent the qualification of the son of Herencio Zevallos, whose father, it will be remembered, together with Domingo Gamio was shot in an obscure village when on the road to their banishment on the frontiers of Brazil. The young man would of course be a most violent member of the Opposition. His mother, the widow, a very clever woman, daughter of Santo Domingo, a merchant in Cuzco, who many years back committed suicide, was our next door neighbour, she occupying the ground-floor of Goyeneche's house, rented by Ayulo.

Saturday, $15^{\text {th }}$ of August. Dia de la Asuncion, for many years, as long as the Napoleons were in power, a great feast-day with the French people. I climbed 
up San Cristoval, which took me nearly two hours, from 12 to 2. Mr. Deeble was gone to a cricket match. I merely paid my visits to Transito Lloza, Asuncion Santillana, and old Bartolomé Araos with whom I remained chatting an hour and a half.

In the course of the week the Superior Court of Justice, consisting of Drs. Teodoro de la Rosa, Bernardino Leon, and Julio Corso, confirmed Dr. Quiroga's sentence that I should present the title deeds of my house. Both $[\ldots]$ and indirectly I had tried hard to influence them in my [...] [588] but, as just said, it had been of no avail.

Monday, $17^{\text {th }}$ and Tuesday, $18^{\text {th }}$ of August. I called upon James Hayne, partner of Gibbs firm in Chile, and he returned my visit; both times we had a long talk, and he gave me many interesting details relative to the business of the house. His wife, Carolina Pfeiffer, and their numerous family, the eldest a girl, nineteen years of age, resided in London. On

Wednesday, $19^{\text {th }}$ of August, Hayne embarked for Iquique where Gibbs had extensive saltpetre establishments. In the evening my wife and I had a long visit from J. A. Lavalle who was particularly agreeable; he related to us a great deal about his residence in St. Petersburg and the intense cold from which he had had to suffer there. In October next he thought of returning to his post as Peruvian Minister in Berlin, when he hoped that Geraldo would be willing to accompany him as second secretary, for Aurelio Garcia, the chief of the late embassy to Japan and China, had spoken to him of Geraldo as of the most useful of the young men whom he had had with him; also his conduct had been irreproachable.

Thursday, $20^{\text {th }}$ of August. Garland and Enriqueta had invited to dinner Oscar Heeren, brother of Arthur, Candamo's brother-in-law, from whom he had brought us a letter of introduction. He had also been very friendly towards Geraldo in Japan when he passed through there with the Peruvian Embassy, and for these reasons Garland had thought it proper to show him some attention. The other guests were: Mr. and Mrs. Henry, Manuel Francisco Benavides the Senator, Electro Corso, who frequently came to play at rocambor, and Melchor Velarde. I sat near Heeren, and but a few seats from Henry, so that I conversed very pleasantly during dinner-time. Heeren told me that he spoke and understood Japanese, but could not write it. The Japanese make use of the same characters for writing as the Chinese, but pronounce them differently, so that they do not understand each other when speaking, but in writing yes. Meanwhile, in the saloon a great many boys and girls, perhaps 50 in number, had assembled to witness the performance of Punch and Judy, in Spanish "Titeres" which diversion Enriqueta had devised for the celebration of 
little Maria's birthday who on the previous day had completed her [...] [589] year. All were anxiously expecting the arrival of the Titiritero, who had been duly engaged, but who now sent word that he was prevented from coming. This was a disappointment, not only to the little folks, but perhaps also to some of the grown up people, of whom not a few had come, for instance:Vasconcello, the Portuguese Chargé, with wife and daughter; Gregorio Benavides, wife, and niece Rosaura Cardenas, José Vicente Oyague; Jose Basagoytia, Dibos, Vicente Hurtado, Baltazar Aranivar; Carvalho, Rafael Velarde and family, Asuncion Santillana, Mrs. Masias and Transito; Emilia Mendoza, Cox, whom Alejandro had brought, and many more whom it was impossible for me to distinguish. What was now to be done? Mrs. Henry, afterwards Ricardo, played the piano, the children danced and ate sweetmeats; also the grown up young people, waltzed and polked, so that one with another all were in very good spirits and amused themselves, notwithstanding the non-appearance of the Titiritero. It was about midnight when we were again by ourselves. I learned that Oscar Heeren would for a certainty remain in Lima, and be one of the Directors of the Anglo-Peruvian Bank, whilst Manuel Candamo, jointly with Rafael Canevaro would be gerente in lieu of Graña, who had of late entirely retired from public life, probably owing to the bad state of the affairs of Valdeavellano \& Co., of which firm Benito Valdeavellano, Pedro Noriega and Graña were partners.

By last steamer arrived from Europe John Gallagher with his wife, also Jameson, who it was said had come to look after the interest of the Company formed in London, which had bought the Iquique railways from Montero Brothers. I knew Jameson well; many years back he had been clerk in the firm of Allison Cumberledge \& Co. of Tacna. When they failed he was engaged by John Hayne as salesman in Lima, in lieu of Charles Pflücker; he rose to be partner, married Enriqueta, the youngest daughter of Thomas Conroy of Callao, and was afterwards removed to Valparaiso, where being too speculative a character he did not give entire satisfaction to the London House, and was consequently dismissed.

Friday, $27^{\text {st }}$ of August 1874. From noon till 3 O'clock I was in the [...] lawyer Palacios for Dr. Quiroga had once more senten[_] [590] against me in my suit against Leyva. On the $25^{\text {th }}$ July I said that I had presented an escrito to this judge, accompanying two letters written by me, the one by Jacoba Oliva, widow of Agreda, the other to the architect Jacobo Lopez-Castillo, together with their written answers, but I omitted to mention that at the same time I requested the judge to order the judicial recognition of their signatures. This he now declined to do, because the article $\mathrm{N}^{\circ} 1809$ of El Codigo de Enjuiciamientos does not permit witnesses to be acquainted beforehand with 
the questions which the one or the other of the litigants may put to them, which prohibition would be eluded by means of such letters and answers I had presented. My lawyer thought proper to appeal from this sentence to the Superior Court notwithstanding the opinion expressed by Dr. Simon Paredes, an ex-judge who at the time was present in the office, and who said he was certain that the Superior Court would confirm Quiroga's sentence, because though in former times such letters and answers had been frequently admitted by the judges the custom had of late fallen into desuetude. From Dr. Palacios study I hastened to the office of the Insurance Company "Lima" where Carlos Elizalde reported to the Directory the arrangement made by him with Alberto Larco, much more favourable than we had expected; Larco acknowledged the debt incurred by his brother in his name, allowed the shares of the Banco de Lima to remain in our hands, and had solely insisted upon a reduction of the interest to $7 \%$ annually, to which Elizalde had consented. We next discussed the insurance of a vessel, the "Agustina", the property of Juan Ugarte's estate, on her voyage from Hong Kong to San Francisco, thence round the Cape to Great Britain. The instructions we gave to our gerente Manuel Ferreyros, were, to ask the following premiums: for the first part of the voyage $3 \%$, for the second, $4 \%$, should Ugarte's firm prefer to insure by the year, $10 \%$, at the very lowest $9 \%$. Our Insurance Coy., as well as the South-American, established in Lima, insured only against total loss, and general average, not against particular average. Elizalde, Henry, Heudebert, and I were the spokesmen, Westphal, Peña, and Chavez, said but little.

Saturday, ${ }^{22}{ }^{\text {nd }}$ of August. When Deeble had left and Ricardo was on the point of reading to me from an extremely interesting Germ[_] book called "Mines \& Counter-Mines" written by a Han[_]ian [...] [591] we heard the shutting of street doors, the customary signal that something is out of joint in Lima. I went out and met Rafael Velarde, who coming from the Congress told me that the President Pardo had been fired at, but had escaped without being injured. In the Senate the Government's party had once more triumphed over the opposition; Salazar, brother of the Oficial Mayor in the Ministry for Foreign Affairs, had been qualified as Senator for the Department of Junin, his opponents having been the lawyer Ramon Patron, and the physician Dr. Saavedra, a clever and dangerous man, the same who at the time of Prado's revolution in 1865 arrested Melchor Velarde, then Sub-prefect of Huancayo. In the Chamber of Deputies they were discussing the law of amnesty moved by Prado, to which motion some imprudent person had attached a rider that the amnesty should extend to a pardon for malefactors imprisoned in the Penitentiary. This latter part, cleverly defended by the lawyer Luciano Benjamin Cisneros, was refuted by 
other members, and whilst treating on this subject the news of the attempt to assassinate the President was brought in, and the debates were of course suspended.

At 7 p.m. when I went to the Banco de Lima where the Directory had been cited to an extraordinary meeting, I found the street-door locked and two sons of Lembcke waiting for the comers, to tell them that as one could not know whether the attempt upon the President's life had any ramification or not, it had been thought advisable not to be out in the street at a late hour, and that consequently the meeting had been put off for another day.

Sunday, $23^{\text {rd }}$ of August 1874. The night passed over quietly.

The Nacional gave an account of the previous afternoon's occurrence, of which the following is an abstract. At 4.30 p.m. Don Manuel Pardo, as it was his custom, left the palace on foot through the lateral door which opens into the Calle de Palacio. Two of his aides-de-camp, Santa Maria and Huguet, accompanied him. When passing the corner of the Calle del Correo a man who stood close by, fired his revolver at the President, but was struck down by a policeman with his baton; when on the ground he managed to fire off his revolver five times more, one of the balls passing close to Pardo's head, none however hitting him. The would-be assassin [...] then [_]wered by Col. Santa Maria and when disarmed [...] [592] to confess everything; he said that he had fifteen accomplices, five of whom had been with him; these however fled, fired off their revolvers, and shouted "Viva la religion, muera Pardo". Meanwhile, another aide de camp Alaiza, not on duty, had pushed the President almost by main force, into the shop of Messier, at the corner of the portal, whence after a few minutes he, Pardo, walked to the Palace, entered the Government's coach, and drove home. Crowds of people collected before his house and called out for him. He presented himself at the balcony, and said a few words to the multitude. At a later hour the saloons of his house were filled with gentlemen who congratulated him upon his escape. The name of the culprit was Juan Boza, a native of Ica who some years back had served in the battalion of Paucarpata commanded by Tomás Gutierrez. The barefooted friar Masia, who had contributed to the late disorders in Arequipa, arrived in Callao by the last steamer.

At 2 O'clock Garland and I went to Pardo's house where many gentlemen were assembled. We walked straight up to him; I offered him my congratulations without giving him the title of Excellency and was received in his customary off-hand manner, "Como Va Don Enrique - Sientese Ud.", pointing to the sofa; but there was no time for sitting down. He and all who were below went upstairs to the rooms occupied by his mother; he had to present himself at the window, and listen to a speech delivered by Aurelio Dinegri, the Alcalde 
Municipal, who had come with a crowd of people from the principal square, where a meeting had been convoked. Pardo replied; some of those present, I of the number, spoke a few words with Doña Peta, and when going below we were stopped on the staircase, for the patio was filled by the Callao firemen whose chief was again speechifying; the President replied.

Sagastabeytia, who was also there, said "let us go to see Doña Mariana, Pardo's wife"; she was, however, not visible, and we merely addressed ourselves to her aunts, Manuela and Rosa Osma. Garland and I left without saying good-by to the President, and then directed our steps to the house of Pardo's father-in-law, Don Felipe Barreda, who, at first taciturn, as it was his habit, gradually thawed a little, but merely to expatiate on the melancholy aspect of public and private [...] [593] By myself I went to Ribeyro's; the Dr. I met in the street, on his way to Pardo's, the family was not visible; then to Escobar, whose wife and sister-in-law were still dressing, and finally to Doña Dolores Puente. At 7 p.m. all the members of the Municipality in a body went to Pardo's house to present their congratulations, and in the evening he showed himself in the theatre where he was enthusiastically cheered. Various persons, mostly military men, were taken up; General Vargas Machuca who had been at the head of the conspiracy was searched for, but could not be found. His wife was an Arequipeña, a Vermejo; of the family of the O'Phelans, and thus by marriage related to Domingo Mendoza, brother of Manuel, married to Isabel Barreda, sister of the President's wife.

Monday, $24^{\text {th }}$ of August 1874. Also from Callao a numerous deputation came up to congratulate the President. In the Chamber of Deputies the opposition party was once more signally defeated. The motion which had been made a few days previously to extend the amnesty for political offenders to malefactors in the penitentiary, which would include, if it was not particularly intended to apply to, some of the sergeants who had fired upon the officers in the barracks, was lost.

At 7.30 the Directors of the Banco de Lima met. Oyague not having come, I as Vice took the chair. Some insignificant business was got through with, also a letter from José Muro was handed me, in which he resigned his place as Director; then Oyague came, to whom I gave up my seat; present were he, I, Bernales, the Secretary, Valentin Gil, Manuel Cucalon, Amancio Castillo, Manuel Elguera, Manuel Salcedo, and the two gerentes; also the bank's lawyer, Aranivar, who explained to us how the affair of the bank stood with regard to the last $\mathrm{S} / 50$,ooo lent to Zaracondegui upon his house occupied by the bank. He endeavoured to make clear to us that notwithstanding the mortgage we held, the creditors of Zaracondegui's estate would certainly endeavour to invalidate our claim, and that the only way to prevent their doing so, 
or to anticipate them, would be to demand judicially the sale of the house. I could not follow his reasoning, and most likely nobody else could. However, we authorized the gerentes to demand the sale, and take the lawyer's advice in all their proceedings relative to this question. Then came another [...] great importance, viz. a new loan of S/200,000 which the Salitre[_] [594] "Esperanza" asked from the bank; there was a great deal of debating, in which Cucalon and Aranivar took the principal part, the former complaining of, and pointing out great irregularities committed by the bank in their loans to the Salitrera, which Aranivar would not confess, and tried hard to invalidate Cucalon's assertions, in which he but partly succeeded. All present took more or less a share in the discussion, but as Gil and Lembcke being interested in the Salitrera, were excluded from voting, only eight remained who could vote on the subject of the loan, and as nine formed a quorum according to the Statutes, no decision could be come to and all promised to meet again the next evening.

Tuesday, $25^{\text {th }}$ of August. In the Senate the election of Dr. Mesones, of the Government's party, as Senator for the Department of Loreto, was declared null, and instead of him Arevalo Villacis, who belonged to the opposition, was qualified as having been duly elected. The session in the Chamber of Deputies was of an uncommonly turbulent character. In February 1873 or thereabouts the labourers on Meigg's Oroya line, who were quartered in the encampment of Ocatara, Chilians and Peruvians, quarrelled, came to blows, and lives were lost. According to the laws of the country they should have been judged in Perú, but this was not done, and by Pardo's express order, given by him to Bazo, Prefect of Lima, the Chilians were shipped off to their country. Pardo knew perfectly well that this was an unconstitutional act on his part. He confessed it in his message to the Congress and gave his reasons for having done so. This day the Minister of the Interior, Dr. Rosas, was interrogated on the subject by various opposition members, and especially by Dr. Luciano Benjamin Cisneros, whereupon the Minister mounted the tribune, and speaking with great deliberation, and in the calmest manner imaginable, expressed himself more or less in the following terms: "If amongst the persons who have listened to Dr. Cisneros' speech, there were some one not acquainted with the country and its politicians, I am certain he would ask, "who is this energetic accuser of the Ministry? who is this defender of the law, who demands the chastisement of those who infringe the law? What would be his surprise if he were told that $[\ldots]$ person who presents himself here in such a decided manner [...] [595] of those unfortunate beings who have prospered under the shade of stupidity, of extravagance, and of crimes." At these words, which created general sensation, Cisneros interrupted the orator, requesting the President of the chamber to 
call him to order, which he did; the agitation became general. Of those outside the bar some applauded, others hissed; some members left the hall, Cisneros and Rosas had a few words in private, with some difficulty the hall was cleared of strangers, and when they were allowed to reenter, the President Pardo declared that Rosas had given full satisfaction to Cisneros, and the session broke up.

At 8 p.m. we were again assembled in the Banco de Lima. Gil was absent, Mendoza and Heudebert present, but as this latter was, like Lembcke interested in the Salitrera Esperanza, they left the apartment during the debate. In the same manner as in the previous evening Cucalon and Aranivar were the principal spokesmen, the latter having, as it seemed to me, this time the better of the argument. Castillo asked for the book of actas of the meetings of the shareholders, and read that in the last meeting they had demanded that a commission should be sent to Iquique to examine the railway, the machinery, and everything relating to the Salitrera, and as this had not been done we could in his opinion not come to a decision; I seconded him. Again Aranivar and Cucalon took up their debate, and it was near 10 when Bernales put an end to these useless disputes by moving that a commission should be sent to Iquique for the above purpose, and secondly - as Aranivar had counselled that the Company of the Salitrera, or rather its present members, should sign a new partnership, drawn out before a notary, because the previous one might be considered as dissolved by the bankruptcy of Zaracondegui, one of the principal shareholders. This motion was unanimously approved of, and I was home at about half past ten.

Wednesday, $26^{\text {th }}$ of August 1874. At 2 O'clock the members of the Diplomatic and Consular Corps assembled in the office of the Minister for Foreign Affairs, about one half in black, the other half in uniform. Riva Agüero ushered us into the saloon where Pardo was in the habit of receiving, and where he stood at the extremity of $[\ldots]$ apartment dressed in black, the bi-colored scarf over his sh[_] [596] Leal, as Senior of the Diplomatic Corps stepped forward, all the others ranged themselves in a half circle behind him, and he delivered a short congratulatory speech, to which Pardo answered a few appropriate words, whereupon he went round to all of us, and shook hands. We remained standing, and conversed one with the other for about ten minutes, again there was shaking of hands and we left. The whole had taken up hardly three quarters of an hour.

Whilst this occurred in the palace, important events took place in the Supreme Court of Justice, and in the Chamber of Deputies. In the former the last will of Mrs. Ramirez, aunt of the Osmas, in which she left the bulk of her 
property to her nephew Ygnacio, and which his brother Mariano had attacked as being null and falsified, was declared to be neither the one nor the other. The Superior Court had on the contrary sentenced in favor of Don Mariano, and of the Supreme tribunal only Dr. Oviedo had concurred with the inferior one. I for my part was convinced, and I believe it was also the general opinion, that this time Mariano had justice on his side, but he was a disreputable character, whilst his brother Ygnacio was rich and had at least a fair reputation, and thus there was little chance of the former getting what was really his due.

In the Chamber of Deputies the election of the Deputies for Huancayo was debated. Garcia Calderon and Carlos Elias were the candidates for the opposition; the names of the Government candidates were unknown to me. The result was quite unexpected. In the first place the electoral college which had chosen the Government's candidates was declared illegal; then the friends of Garcia Calderon thought they had gained and sent word to him to that effect; a quarter of an hour later all their expectations were blasted; the electoral college which had chosen Calderon and Elias, was likewise declared illegal by a majority of 46 to 37, and accordingly there was no Deputy for Huancayo.

After what had occurred on the $25^{\text {th }}$ in the Chamber of Deputies, Dr. Rosas tendered his resignation which was accepted by Pardo, who named Riva Agüero Provisional Minister for the Interior.

Friday, $28^{\text {th }}$ of August. The Banco de Lima had a long sitting. Mendoza and Gil did not attend. After the reading of the last ac[_] Cucalon and Salcedo took up the time with many super[_] [597] observations. When at last they had come to an end Lembcke made known the object of the meeting. The Government wanted a loan of S/800,00o from the banks. It gave to the banks eight drafts of $S / 100,000$ each, dated, the first, $1^{\text {st }}$ November, the second, $1^{\text {st }}$ December, and so on till $1^{\text {st }}$ June 1875 , at 4 months date on Dreyfus Bros. \& Co. which firm only accepted the drafts at their respective dates. Consequently the last payment would be due on the $1^{\text {st }}$ October 1875 . As a further security the Government placed into the hands of the banks $S / 1,600,000$ Vales de la Nueva Consolidacion; the conditions were $1 \%$ monthly interest and $1 \%$ commission. The Banco Nacional and the Banco del Perú took each S/30o,0oo and we were requested to take $\mathrm{S} / 200,000$. I was the first to speak, and gave my vote in favor of the loan; Bernales and Cucalon were of the same opinion. Oyague, as President expatiated on the advantages and disadvantages of the operation, in his somewhat prosy, but upon the whole not improper manner; he was also in favor of the business, and Castillo, Elguera, and Salcedo, followed in his wake. Lembcke however did not seem much pleased. We were all of opinion that we did not run any risk in making this loan as long as there were no change 
of Government; nevertheless, we instructed the gerentes to reduce our share in the loan, if possible, to $\mathrm{S} / 150,000$.

Saturday, $29^{\text {th }}$ of August 1874. Being cited by Andrés Rey, the manager of the Water Company, I went there at the appointed hour, but found nobody but him. He gave me some particulars regarding the affairs of the company. The gross yearly income was hardly $\$ 200,000$. The annual dividend hitherto paid $\$ 150$, ooo the annual expenses $\$ 40,000$ accordingly there was every year a surplus of $\$ 10,000$. Extra pipes were to be laid, extra work was to be done, which would require $\$ 100,000$. Where was this money to come from? Oyague and Rodrigo generally opined that money should be taken up at $1 \%$ monthly interest. I was decidedly opposed to this method of meeting the difficulty, and told Rey that in the next meeting I intended to propose that the annual dividend should be reduced to $5 \%$ until the state of the company were such as to be able to return to the $10 \%$ without taking up money at interest.

Sunday, $30^{\text {th }}$ of August. Santa Rosa. I called upon the Rosas of [598] my acquaintance, of which visits I have nothing particular to say, but Muñoz, where I also looked in, told me that the above loan of S/800,00o was not yet concluded with the banks, because the Minister of Finances, Elguera, objected to the $1 \%$ commission. I also learned that Dr. Garcia Calderon and Carlos Elias had asked in the Chamber of Deputies a reconsideration of the resolution of the $26^{\text {th }}$ August, which had declared their election for Huanuco illegal. The reconsideration had been granted them, but the majority against them had this time been still greater than on the previous occasion.

Monday, $3^{7^{\text {st }}}$ of August. Alejandro returned from a short trip which he had made on board the Peruvian transport "Chalaco" commanded by his friend Carlos Ferreyros. On board of her had been the President, who stood in need of some relaxation after the excitement of the last few days, accompanied by some of his friends. They had left Callao on Thursday. Alejandro suffered much from sea-sickness during the night. On Friday morning they arrived at the Port of Supe, where horses were in readiness to take them to he Sugar estate San Nicolas, belonging to Don Domingo Laos; here they breakfasted, and proceeded to the valuable property of Enrique Canaval, married to Amalia Bolivar, the President's cousin. They remained here till the $30^{\text {th }}$, proceeded to Huacho, re-embarked, and reached Callao this morning. Alejandro had been much pleased with his excursion. Everywhere they had been sumptuously entertained, and the President had been affability personified. He had talked and chatted with everyone, the word "Excellency" had not been heard, only "Señor don Manuel". 
Tuesday, $7^{\text {st }}$ of September. Within these days the Congress had abolished the Comision Permanente, an Institution which was in fact altogether superfluous. Its object had been to watch the proceedings of the Executive during the recess of the Congress, but it had no power to enforce its mandates. It consisted of 7 Senators and 8 Deputies who received a daily stipend of $\mathrm{S} / 10$ each. Whensoever this body opined that the Executive had infringed the constitution, it made a representation requesting the same to retrace its steps; the Executive in reply made its observations, and defended what it had done. Then the Com[_] Permanente made two other [...] [599] consecutively, but as the Executive was seldom inclined to undo what it had done, it contented itself with saying that it would account for its proceedings to the Congress, and thus the matter rested.

In the Senate, a motion of M. F. Benavides to the effect that only such citizens as could write and read should be permitted to vote at general elections passed unanimously.

At 4 p.m. the Shareholders in the Chilete Mining Company assembled in the Exchange Rooms. Of late I had taken two shares in the same of S/10oo each, at the earnest representation of Malinowski and Escobar, who assured me over and over again that the riches which this mine contained surpassed everything ever heard of, and that in two years at the very utmost the original outlay would be reimbursed. This mine is situated not far from Chimbote, where one of Meiggs railways to terminate at Huaraz, was in progress of construction. Present were: the two Directors, Escobar, President, and Malinowski, the third, Emilio Althaus, had to attend to his duties in the Senate, and shareholders: Raymondi, the Italian naturalist, Meceno Espantoso, Rufino Echenique, Climaco Basombrio, Polis the Belgian head of the firm F. S. Isaac \& Co., a certain Villanueva, unknown to me, and perhaps two or three more, also Guillermo Lembcke, two shares, J. L. Bernales, one share, and I, two shares; these last three named had no right to vote, for according to statutes five was the smallest number of shares which entitled their holder to one vote. A very interesting report on the state of the mine was read by Malinowski; 40,000 Soles were required immediately, the greater part of which was to be invested in the purchase of machinery for separating the light from the heavy ore, the light to be thrown away as useless, the heavy, containing silver, and a large proportion of lead, to be shipped to Europe. The selected ore was calculated to contain about $5^{2}$ marks silver per cajon of 60 quintals. In the Cerro de Pasco the miners are satisfied if their cajon gives seven marks. It was affirmed by the Directors that at present by manual labour, four tons could, and by the machinery twenty-five tons of ore would be daily picked and separated. Escobar 
wished the shareholders to authorize the Directory to issue, if necessary, 140 new shares of $\mathrm{S} / 1000$ each, which was agreed to, though Malinowski inclined to have the $[\ldots]$ limited to $S / 40,000$. Jose $\mathrm{V}$. Oyague had already taken $S / 10,000$ $[\ldots][600]$ the new issue.

Wednesday, $2^{\text {nd }}$ of September 1874. Twenty-two thousand Soles was the amount which on this day stood to the credit of my account in the Banco de Lima, S/200o I had promised Garland, who wanted them for his son Guillermo, who had not yet been able to extricate himself from his pecuniary difficulties, and S/20,00o I thought prudent to have always at my disposal, so as not to be unprepared in case of any sudden and unexpected emergency. The remainder of my property was so completely locked up that though on the $28^{\text {th }}$ February of this year the Stock Account in my books showed $S / 781,200$ to its credit, it was impossible for me to continue the business which I had been doing for the last few years, viz.: that of lending money on interest and discounting acceptances and pagarées, and thus my mercantile occupations were limited to the collection of the interest and rent. The loans made to J. N. Hurtado, Pablo Vivero, J. G. Garcia, Manuel Rosa O Phelan, and Agustin Escudero and Luis Roca, I considered to be safe, but saw no chance of encashing them for a length of time. S/24,00o were due to me by the U. States Guano Coy. upon their simple pagaré, but such a good opinion did I entertain of its solidity that I had told its manager, Vicente Hurtado, over and over again that he might keep the money as long as he liked. Together with Juan I was interested for S/100,00o, he $2 / 5^{\text {ths }}$, I $3 / 5^{\text {ths }}$, in Dreyfus Guano Contract with the Peruvian Government, which had hitherto given us from 14 to $15 \%$ annually. Smaller amounts were owing to me by the Vocales J. Alvarez, J. Luis Gomez-Sanchez, and the lawyer Fernando Palacios, all three very doubtful. As security for Dr. Munoz's small debt I held cedulas del Banco Hipotecario. Juan owed me about S/10,0oo of course as safe as if I had the money in my pocket; also Limpricht and Becker the balance of their account, which I expected to receive in course of time. Guillermo Garland, or his father in his stead, was indebted to me for $\mathrm{S} / 10,000$ besides the above $\mathrm{S} / 2000$; perhaps they would be paid after the lapse of some years. The bulk of my property consisted of my two houses, Cedulas del Banco Hipotecario \& Territorial, and shares in different banks and Insurance Companies, of which the best was undoubtedly the South American Insurance Company. T[_] S/15,00o invested by me in the Eten and the $S / 20,000$ in the Pasco Ra [...] [601] Company, I had long ago given over for lost, and hardly ever thought of them. Whether I should ever receive the $S / 50,000$ lent to the latter, and the $S / 12,000$ preference obligations of the same, became to me more uncertain from day to day. The worst of all was that two guarantees of mine were still pending, the 
one for $\mathrm{S} / 30,000$ arising from the Eten Railway, which however, according to the opinion of Felipe Varela, the lawyer, could never be exacted, the other for S/50,00o jointly with Pardo, Rodrigo, Riva Agüero and Sagastabeytia, who as Directors gave their signature for this amount to the Banco Hipotecario, which guarantee I much feared would turn up some day or other. A great deal of my time was, as it will have been seen, taken up by the meetings of Directories of which I was a member, and of the shareholders in the different jointstock companies. When absent in these meetings Deeble copied for me my remodelled diary with which we had come as far as October 1851. When I was with him in the morning and we had leisure, he read the History of Scotland contained in Walter Scott's Tales of a Grandfather, in the evening Macaulay's History of Europe, Ricardo, as said above, Mines and Counter Mines, which gives an excellent idea of the political intrigues of 1867 when the Luxembourg question threatened to disturb the peace of Europe.

Thursday, $3^{\text {rd }}$ of September 1874. At the usual hour the Directory of the Banco de Lima met, and though owing to the absence of Gil, Elguera, Salcedo, and Mendoza we formed no quorum, for which 9 were required, we thought advisable to deliberate on the subject which Lembcke laid before us, viz.: the loan of $S / 150,000$ to the Government. He had all along been opposed to it, and now he stated that in the opinion of both gerentes the Banco de Lima was not in a condition to disburse such a considerable amount; he made us observe that the exportation of coined and bar silver was augmenting from day to day, that our fund of the precious metals was decreasing in proportion, and that therefore it was prudent not to increase the circulation of our notes.

We knew that Chavez, the agent of the South American Company in London, had opened a floating policy with the Insurance Company Lima for bar silver, to the amount of S/100,00o, and consequently there was some truth in what Lembcke said. Nevertheless, it was against my wish when the majority resolved that the loan should not be made to the Government. This being disposed of, Cucalon brought forward his old motion, in which I seconded [...] viz.: that in future pagarées with two signatures and without secu[_] [602] should only be prolonged at the rate of $11 / 4 \%$ monthly discount, not $1 \%$ as hitherto.

This being Garland's birthday, the tertulia was more numerously attended than usual. He had two rocambor tables; at the one, four soles the point, sat down: Malinowski; Vasconcello, the Portuguese Charge; M. F. Benavides, and Electro Corso, both from Arequipa; at the other, two soles the point: Garland, Picard the Frenchman, James Henry of Gibbs, and Gregorio Benavides; this last named, a not very respectable character, had rented a small farm near La Magdalena, but, as it was well known, derived his principal income from 
playing cards and gambling, at both which he was an adept. Round the roulette table were my wife - who this evening neither gained nor lost - my daughter, whose losses came to two Soles, her sons, Mr. and Mrs. Seminario from Piura, the wife of Gregorio Benavides, her son and her niece Rosaura Cardenas, a very pretty girl, Rafael Velarde and family, Carvalho, the Brazilian Secretary, Carlos Zevallos, Carlos Cox from Trujillo, and Carlos Ferreyros, captain of the "Chalaco"; besides these, all of whom tried their luck, Enrique Ayulo, a young Canaval, and I, were lookers on. At past midnight the play was over, when Enriqueta begged her guests to walk into the dining room, where, contrary to the general rule she, in celebration of her husband's birthday, had laid out a nice supper. At 2 O'clock the party broke up.

Friday, $4^{\text {th }}$ of September. Deeble, who had lately taken a wife to himself, sent words that owing to the indisposition of his better half, a young girl from Callao, he was prevented from coming to me, and I had thus to while away the time as well as I could. Two hours were killed by my ascent of San Cristoval, one by two visits; of the former I have merely to say that the sides of the mountain were partly covered with young green plants, and tiny yellow flowers, of the latter, that John Gallagher was not at home, and that Diego Masias, just returned from Arequipa, did his best to persuade me that he had never taken a share in any political movement though I knew full well that not one had occurred in his native place without his having been mixed up with it, and that even at the present moment Pardo suspected him. The following is a extract from Macaul[_] History of England. It was on the $15^{\text {th }}$ December 1692 under the [...] [603] of William and Mary, that the house of Commons for the first time authorized the Executive to raise a loan of 1 million pounds, which was done by means of long annuities. At the time of the Peace of Utrecht the debt had risen to fifty million pounds; at the conclusion of the war of the Austrian succession it came up to 80 millions; under the administration of the first W. Pitt, Lord Chatham, it rose to 140 millions. In 1786 when at the Peace of Versailles Great Britain had to acknowledge the Independence of the United States, another hundred millions was added to the debt, and in 1815 at the conclusion of the revolutionary wars, and the wars against Napoleon, it had swelled to the enormous amount of $£ 800,000,000$ - so far Macaulay - which cipher has little changed since then to the present day, 1874. It is true that during the Crimean War the debt again increased several millions, but these had been paid off, and at the present day it is the plan of all English statesmen, whensoever the revenue surpasses the expenses, not to decrease the debt, but to diminish the impost. The debt goes by the name of Consols, pays $3 \%$ annually, and is almost exclusively held by British subjects. 
Saturday, $5^{\text {th }}$ of September 1874. The Directory of the Lima Water Coy. met. The request of the engineer Mr. Wilkinson to have his salary raised, was unanimously rejected without discussion. Next Rey laid before us the state of the Company's finances. All the money collected he had had to remit to England to pay Bates Stokes \& Co., thus on the $30^{\text {th }}$ September he would be without a rial to pay the dividend. Moreover, he required money to pay the workmen, and to make further remittances to the Liverpool house. I said, "if there is no money, pay no dividend", but neither Oyague, nor Rodrigo, nor Basagoytia would listen to such a thing. Enrique Prevost did not say a word. Rey then proposed to raise the money by taking it on interest, which I decidedly objected to, or to issue new shares of $\$ 500$ each and reduce the yearly dividend from 10 to $8 \%$. I proposed the reduction to $6 \%$ but was again overruled. The following was finally resolved: 300 new shares of $\$ 500$ each should be issued, if the entire sum were required, meanwhile for the 30 Septr. 70 should be offered to the shareholders at $20 \%$ discount, but with the proviso that he who took these had likewise to take an equal number [...] those to be issued at $\$ 410$, $31^{\text {st }}$ December and at $\$ 420$, $31^{\text {st }} \operatorname{Mar}\left[\_\right]$.[604] By this means Rey would have sufficient money to go on for some time. The dividend was to be $8 \%$ annually. I was averse to such palliatives; if you have no money do not pay, and in a year's time the state of the cash must right itself.

Sunday, $6^{\text {th }}$ of September 1874. This being the first Sunday of the month Mr. Deeble as per agreement did not come in the forenoon, and I again climbed up San Cristoval. On my return I felt somewhat tired and thus made but few calls; upon José Gregorio Paz Soldan, and Doña Dolores Puente, neither of whom was at home. To Rafael and Melchor Velarde, and to Mrs. Dr. Bueno, whose husband was absent, having been named Prefect in Ica.

Monday, $7^{\text {th }}$ of September. This evening my wife and daughter paid a few visits, on their return they found our servant Juan dead drunk in his room, and of course he could not serve tea.

Tuesday, $8^{\text {th }}$. Natividad de Nuestra Señora. I rose early, and as soon as I saw Juan told him that I did not require his services any further. His wife came to my wife, and begged her to keep him, but we would not, for though useful in many respects, his defects outweighed his good qualities.

Wednesday, $9^{\text {th }}$. Juan left us, and we had now only the Chinese Ayao to do the work of both. At 8 in the evening some of the shareholders in the unfortunate Eten Railway had their meeting. Present were: Alexander Ruden, President; José A. Garcia y Garcia, who having returned from his voyage to Europe stated that he had found it impossible either to sell the Railway or to make any other arrangement with European Capitalists so as to extricate the company from its difficulties; Manuel Candamo, Oscar Heeren, J. P. Escobar, 
Dionisio Derteano, Carlos Delgado y Moreno, Felipe Varela, Felipe Barreda y Osma, and I. That the company was insolvent, could not pay its debts, and might every moment be declared a bankrupt, everybody present recognized as a fact; the yearly gross income was about $\mathrm{S} / 200$,ooo expenses $50 \%$. Garcia was of opinion that the one might still be increased and the other diminished. All were of course very desirous to get rid of the guarantee which more th[_] a year ago they had taken upon themselves "para hacer el servicio" [...] [605] bonds amounting to $S / 1,040,000$. The escritura drawn out at the time said that the various parties made themselves responsible to the company, not to the holders of the bonds, and from this condition the lawyer Felipe Varela drew the conclusion, a legal one I should say, though not a fair one, that the holders of the bonds had no right to sue the persons who had taken the guarantee upon themselves, and that this, the sueing, could only be done by the company. Candamo was the only one who frankly declared that all those who had signed the escritura must, if the worse were to come, hacer el servicio in conformity with the obligation which they had taken upon themselves. After a great deal of discussion the Directors were authorized to make if possible some arrangement with the different creditors, of which the outlines will be given hereafter if carried into effect.

Sunday, $13^{\text {th }}$ of September 1874. Pablo Vivero had declared to Garland that it was out of his power to pay even the smallest trifle on account of the $S / 21,200$ amount of his pagaré to Garland, which in an evil hour I had discounted to the latter. An escritura would now be drawn out to be signed by him and his wife, in which they mortgaged some valuable landed property somewhere in the North, near the river Santa, belonging to the lady. The Banco Hipotecario had the first mortgage for S/10o,ooo, Francisco Garcia Calderon, and General La Puerta the second for another S/100,00o and then came ours. The interest was settled at $1 \%$ payable every three months; the shares in the Guano loading Coy. which Garland held would not be given up till the debt were cancelled.

Monday, $14^{\text {th }}$ of September. The shareholders of the Lima Water Company held an extraordinary meeting. At my suggestion Jose Vicente Oyague was called to the chair. The last acta, or protocol, being read and approved, Rey informed them that $\$ 50$, ooo were required, and that the Directory had proposed to raise this sum in the manner explained by me on the $15^{\text {th }}$ inst. Meliton Porras, who had lately purchased some shares from José Basagoytia, required explanations and made observations, to which Oyague replied. In the discussions between him and Oyague, others took a share, but they could not agree; when I, availing myself of a momentary pause said in a loud and clear voice, "the difficulties raised by the one side and the other can easily be overcome; when there is no money, no dividend [_] be paid." Porras answered 
"that is exactly what I thought." [606] Francisco Garcia Calderon, who represented the interest of Goyeneche, coincided with me. José Basagoytia took the same view; so did Barrenechea and Mathison, whilst Oyague always insisted upon the necessity of a dividend being paid. Rodrigo and Rey said little, but inclined rather towards Oyague. I took no further part in the discussion; the other persons present were silent. Notwithstanding the general opposition Oyage was unwilling to yield, and he then proposed that as hitherto, every three months a dividend of $21 / 2 \%$ should be declared, that it should not be paid in money, but that every shareholder should receive new shares at par, equivalent to the dividend corresponding to him. In this manner all were placed on the same footing, none had the preference, and his proposal was unanimously agreed to. Meanwhile, all the money which the Company collected, was to be laid out in the necessary works. This being now settled, Oyague turned to me and asked "ahora está Ud. contento Don Enrique?" Enrique Prevost says "Ud. ha ganado", and Basagoytia squeezed my hand.

Thursday, $17^{\text {th }}$ of September. Enriqueta's birthday; her sons made her pretty presents; I presented her with an étagère which cost me about $S / 400$; my wife gave her six gold ounces, each worth $\mathrm{S} / 21.80$. We dined with her together with Conrad Möller, one of the sons of the unfortunate William Möller of Arequipa. In the evening there was rocambor and roulette as usual. I went to bed early. In the forenoon of this day I, after at least ten fruitless attempts, had at last an interview with José de la Riva Agüero in the Ministry of the Interior; he was less friendly, and gave himself greater airs than he had done on previous occasions. He gave it as his opinion that it would be advisable that I, in the name of Felipe Barreda and myself, and Agustin Escudero as gerente of the Banco Hipotecario, should present an escrito to the Ministry of Finances demanding the payment of the cupons overdue on our joint $\mathrm{S} / 400,000$ bonds issued by the Government in favor of the Cerro de Pasco Mineral Railway Company. On this subject I had several interviews on

Friday, $18^{\text {th }}$ and Saturday, $19^{\text {th }}$, both with Barreda and Escudero, and in the ensuing week something would probably be done. Felipe Varela the young lawyer [...] [607] taking steps to induce all the creditors of the Eten Railway to take this railway on their J/Account for the amount of their claims, amounting more or less to $S / 1,400,000$ or $S / 1,500,000$, whilst it had cost at least $S / 720,000$ more, amount of the original shares, which were all lost. My loss was $S / 15,000$, but if Varela succeeded in bringing this about, all those fools, I of the number, for $\mathrm{S} / 30,000$ who guaranteed the second series of obligations would be released from their guarantee. Juans letter of the middle of August was still dated from the Rigi, but as the weather was getting rainy and foggy he thought of returning 
to Paris via Vevay and Ouchy, close to Lausanne. In the former of these two places he thought of paying a visit to Mr. Federico Barreda, in the latter to Juancito Garland. Geraldo, Junior, of whom I said some time back that he had separated from the Peruvian Embassy in China, had reached Europe, been in Paris, where he had had high words with Mr. Schutte, and now wrote from London.

Monday, $27^{\text {st }}$ of September 1874 . The Directors of the Lima Insurance Company met. This Company held S/10,00o of the original priveleged obligations of the Eten Railway Company. Felipe Varela's proposal, explained above, was laid before us by Carlos Elizalde, the President. Henry who came in latest and who had had a long conversation on the subject with Alexander Ruden was inclined to accept it: Carrol, Gil, and especially Chavez, were against its acceptance; at last all agreed in authorizing Carlos Elizalde to make the best arrangement he could with Varela.

My suit with Leyva progressed very slowly. After a delay of more than three weeks the Superior Court had confirmed Quiroga's sentence that the recognition of signatures to such letters as I had received from the widow Agreda, and the architect Castillo, in reply to my questions, was against law. Dr. Quiroga hitherto Juez de $1^{\text {a }}$ Instancia had provisionally been raised to the rank of Vocal of the Corte Superior in lieu of Teodoro La Rosa who had been chosen Deputy to the Congress; his place was meanwhile filled by a certain Dr. José A. Goitisola, with whom it was now indispensable I should become acquainted either directly or indirectly.

Thursday, $24^{\text {th }}$ of September. Dia de las Mercedes. I made two short calls, on Mercedes Riva Agüero and Mercedes Guise. With Bartolomé Araos, and afterwards with Augusta Bergmann, wife of Meceno Espantoso, I stayed a [_] iderable while. In the evening there was a dance at Riva Agü [...] [608] to which of our family only Alejandro went, who came home at 5 O'clock on

Friday, $25^{\text {th }}$ of September, well pleased. The Directory of the Pasco Mineral Railway Company bought S/10,0oo Cedulas del Banco Hipotecario at 80\%, and I sold, of my son Juan's shares in the Banco del Perú, 7 at 10\% discount.

Sunday, $27^{\text {th }}$ of September. Agustin Escudero and I presented in due time the escrito in which we two, I for myself, and Barreda y Osma, as holders of the $\mathrm{S} / 400,000$ Noml. amount of the Pasco mineral railway bonds demanded from the Ministry of Finances payment of the cupons already due, as well as redemption of part of the bonds themselves, but hitherto the Minister had merely passed our escrito to the Direccion de Contabilidad, ordering the same to give its report on the subject.

Monday, $28^{\text {th }}$ and Tuesday, $29^{\text {th }}$ of September 1874. Mr. Deeble being considerably behind-hand in the copying of my remodelled diary, I had 
necessarily to leave him for some time, to bring up his arrears; I had no collections to make, neither had I to attend any meeting, and thus to while away the heavy hours I had nothing better to do but to walk about in the environs of Lima. On Monday I came to the open place called the Paseo de Aguas, in former years a receptacle of rubbish, and further on overgrown with brushwood, all which had been cleared away; and the site was now occupied by the new market-place built by the Constructora for the Municipality. This building was shut up, because being too far distant for the bulk of the inhabitants of the suburb of San Lazaro, it had not answered the purpose for which it had been intended; also several stores close by likewise the work of La Constructora, were closed for the same reason; of the high walls, perforated both above and below, which in the time of the Spanish dominion one of the Viceroys had ordered to be constructed to please a favourite mistress of his, and through which water was to rush so as to form cataracts - whence the name of El Paseo de Aguas - only one row was still in existence. Also further on, on the lower ridge of San Cristoval, I observed a change: ever since my first coming to Lima, a single arch, said to be the remnants of an old chapel, was standing there, now only one pillar remained. When reaching my house at 5.30 p.m. I was received with [...] [609] intelligence. My wife, when walking up and down the corridor, had suddenly been seized by a cold fit, so much so that her whole frame felt like ice, and her fingers were benumbed. She was immediately led to her bed, bottles of hot water were applied to her feet, and her body was rubbed by Enriqueta and the servant girls. I found her in bed, and considerably better; her natural warmth had returned. Bambaren who was called in was of opinion that this indisposition was caused by want of exercise, and of sufficient nourishment.

Wednesday, $30^{\text {th }}$ of September 1874. Mariquita was well enough to leave her bed. In the suit against Leyva, active steps had been taken. Rafael Velarde had spoken to the new judge de primera instancia, and had found him willing to serve me. To the architect I wrote a polite note enclosing $\mathrm{S} / 40$ in consequence of which he came to see me, and promised to give the declarations which I required, viz.: that the word "aires" is applicable only to the space upon the roof of the ground-floor, not to that on the top of the second or third story.

A meeting of the shareholders of the Gas Company was held, which lasted from near one till about five. The Company paid a dividend of $21 / 2 \%$, and on the other hand received the value of 98 lately emitted shares, of which not a single one had been bought by the shareholders resident in Paris, and which were now distributed amongst the shareholders in Lima. I being one of them had to pay S/9oo for two, of S/50o each. Nominal, at $10 \%$ discount. The 
object of the meeting was to discuss the new statutes drawn out by the new Directory. More than once I took an active part; I proposed that in proportion as the number of shares held by one individual increased, the number of votes should decrease, thus from 1 to 100 shares, each share should be entitled to a vote, from 100 to 200 each two shares should have a vote, from 200 to 300 each three shares should have a vote, and so on progressively. I did not expect I should carry it, as the interest of all the big shareholders was opposed to me; nevertheless, I had the satisfaction that Manuel O. de Villate and Dionisio O. de Villate, which latter sat next to me, were of the same opinion as I. I was opposed by Juan Gallagher who represented José Sevilla, owner of more than 300 shares. Oyague who, as always, [...] President, said that I was right in principle if a new co[_] [610] were to be formed, but that I could not expect that any of the large shareholders would give up their "derechos adquiridos", and thus my motion was lost without being voted. Another question I gained, as I had done in the Water Company. The Statutes said that dividends of $21 / 2 \%$ should be distributed every three months; I insisted that the words should be added "habiendo fondos disponibles". Then it was proposed that the Directors should have an annual remuneration jointly of $2 \%$ on the profits. I rose and added "yes, after the shareholders have received their interest of $9 \%$ on the capital disbursed." Here I was beaten, but after I had left, this remuneration was again voted, and negatived. John Gallagher tired out the patience of those present with the alterations proposed by Sevilla, which with few exceptions were unanimously thrown out. Oyague, the two Villates, Carlos Elizalde, Alexander Ruden, Francis Bryce, and Jose Albarracin were the other speakers; also Carrol defended the interest of Bates Stokes \& Co., violently attacked by Dionisio Villate and myself. The following Directors were chosen: J. V. Oyague, Garland, Ruden, Bryce, Carrol, John Gallagher, and Mathison.

Thursday, $7^{\text {st }}$ of October. I was busy encashing the interest on the Cedulas of the Banco Hipotecario. Geraldo arrived per Steamer from Panamá, apparently in good health, but very thin; with Japan, and his stay there he had been much pleased; not so with his protracted residence in Pekin. The French steamer in which he had taken his passage had left Hong-Kong on the $17^{\text {th }}$ May; on her way she had touched at the French colony in Cochin-China, Saigon, at Singapore, at Point de Galles in the island of Ceylon, at Aden, the English settlement in Arabia, at Suez, then through the newly built canal, at port Said in the Mediterranean, at Naples, and finally reached Marseilles after a voyage of 42 days. The train from Marseilles to Paris had taken fourteen hours.

Friday, $2^{\text {nd }}$ of October. Geraldo presented himself to Riva Agüero, Minister for Foreign Affairs, who told him that he had been named second secretary to 
La Valle about leaving as ambassador for Berlin, to which he gave the answer that he was as yet uncertain whether the state of this health would permit him to accept the appointment.

I went to the Direccion de Contabilidad where I enquired w [...] [611] become of the escrito presented as above said by Escudero and myself on the subject of the S/40o,ooo bonds, and was told that one of the employees, Tur, who had to give his report on the same, was sick, had not been to the office, and consequently nothing had been done. At a later hour, as recommended by Dr. Bambaren my wife and I took a walk to the Inquisition Square; on our return we met Deeble in the patio of the house, who told me that when trying to shut a window above the book-case in my room he had fallen with the chair and much hurt his arm.

Saturday, $3^{\text {rd }}$ of October 1874. Not having Deeble with me, I went out and climbed up San Cristoval. In the morning and evening Ricardo read to me a book which my son Juan had just sent me; it was the first of a series of political novels written by Von Meding, and was entitled Crown and Sceptre. The Mines and Counter - mines spoken of a few pages back, the second of the series treats as then said on the events of 1867, whilst Crown and Sceptre opens with 1866, and of course includes the Prussian-Austrian War. The author however does not expatiate on battles and warlike deeds; what he delights in are long political discussions which he puts into the mouth of the Emperor Luis Napoleon, of his Ministers, and other statesmen. He also introduces a great many imaginary characters in the humbler ranks of life, and alongside the weighty matters of state runs the narration of their domestic and love affairs; each of these forms a pretty novel by itself, always interesting, generally natural, and life-like, sometimes verging on the improbable, if not the impossible, once or twice passing the bounds of decency. Of these imaginary characters the Count Rivero excels by the sublimity of his views, whilst his tool, the beautiful marchioness of Palinzona is the quintessence of corruption, of wickedness, and of expertness in amorous and political intrigues; her husband, Balzer is the vilest of the vile. Whensoever the blind ex-king of Hannover is introduced, he speaks of him in terms of the most loyal affection, and at the same time does not conceal his dislike of the ex-king's prime Minister, the count Von Platen-Hallermund.

Sunday, $4^{\text {th }}$ of October. I went to Chorrillos by the 12 O'clock train, where I first looked in at the old woman's Jacoba Oliva de Agreda, whom I told that the tribunals had declared illegal the recognition of signatures to letters similar to that she had written me, and that therefore I wished to know if she was willing to make $[\ldots]$ bal declarations, to which she applied in the affirmative. I also learned [612] from her that she was about removing to Lima, where she would 
occupy a room in the hospice for old indigent women. I next called upon José Maria Perez, the Vocal of the Superior Court, and his wife; then upon Manuel Costas, the Vice-President, who was not in, and was back in the station just before two where I learned that no train would leave before four; how was I to while away the two hours? I climbed up to the highest point of El Moro Solar, in my opinion not so high as San Cristoval, and at half past three was with General Pezet and his lady, with whom I remained until the train started for Lima. Here I had still time to look in at Dr. José Blas Alzamorra's, whom I congratulated on his having been chosen by the Congress Vocal of the Supreme Court in lieu of José Luis Gomez-Sanchez, who had retired on a pension. In conformity with the law of the country six individuals had been proposed by the Executive to the Congress. Of 140 voters, 80 had given their votes for Alzamorra, 42 for Teodoro de la Rosa, 4 for Chacaltana, and 3 for Manuel Morales - the house three stories high, the uppermost empty, as President Castilla used to say - and 1 in blank.

Tuesday, $6^{\text {th }}$ of October. The Directory of the Banco de Lima met; the choice of a new Director in lieu of José Muro, fell upon Nicolas Rodrigo. Felipe Cucalon and the engineer Thierry had given their reports on the Salitrera Esperanza, which were to be read by all of us, before our next meeting on the $15^{\text {th }}$. The bank had already advanced to the Salitrera one million Soles, and two-hundred thousand more were required to complete the work.

Wednesday, $7^{\text {th }}$. This being Alejandros's birthday; Oscar Heeren and Zoila Velarde, also my wife and myself, dined with Garland and family. Our cook Achipe had been ill for some time, and thus we always took our meals with the Garlands.

My son Juan's letter of $27^{\text {th }}$ August urged me to sell his shares of the Banco del Perú, and his Cedulas and shares of the Banco Hipotecario. Accordingly, I sold this morning to Gabriel Saco, thirteen Cedulas of S/100o each, at $773 / 4 \%$, which was the price of the day, viz.: 78 , less $1 / 4 \%$ to the broker.

Thursday, $8^{\text {th }}$. Deeble returned to his work.

Sunday, $11^{\text {th }}$. This morning at an early hour I was prese [...] [613] in the Church de la Merced, at the funeral service of Doña Jesus, daughter of Dr. Bernardo Muñoz, with whom my wife and I had been well acquainted. She was the wife of Manuel Panizo, owner of an estate in the neighbourhood of Pisco, and died a few days back of consumption in the town of San Juan de Matucanas.

In the course of the preceding week no progress whatever had been made in the various affairs in which I was interested. The finance minister had not yet returned the petition presented to him by Escudero and myself. The judge Goitisola had not decided whether the verbal declarations of my witnesses 
should be admitted or not. For Juan I had effected no further sale; and about $\mathrm{S} / 5000$ of my own, of which I could dispose, I had not yet been able to place, though I had spoken about it to the four money-brokers with whom I was acquainted.

Monday, ${ }^{\text {th }}$ of October 1874 . The only object of this day's meeting of the Directors of the Banco de Lima was to choose a provisional director instead of Nicolas Rodrigo, who had not accepted his late nomination. Two candidates were in the field; the one, Dr. Aranivar, proposed by Lembcke; the other, Dr. Luis B. Cisneros recommended by me. I objected to the former, because he being the banks lawyer was in reality in the employ of the Directors, and if some day or other we were dissatisfied with him, it would be as I said an incongruity that he as Director should sit in judgement upon himself as the bank's lawyer. Cucalon was of my opinion; nevertheless it was as close a division as could be. Cisneros had 6 votes, probably Oyague's, Salcedo's, Elguera's, Mendoza's, Cucalon's and mine; Aranivar five, those of the two gerentes, Gil, Heudebert, and Bernales.

Wednesday, $14^{\text {th }}$ of October. The judge Goitisola sentenced that the objections raised both by Leyva and myself against the admission of the witnesses brought forward by the opposite party, were groundless, and consequently fixed upon the days from $19^{\text {th }}$ to $24^{\text {th }}$, for the taking of their declarations in his juzgado.

Thursday, $15^{\text {th }}$. The Directory of the Banco de Lima met once more, this time on an important question, viz.: whether the $S / 200,000$ asked for by the Salitrera "Esperanza" should be lent or not. Though Gil, Heudebert, and Lembcke were interested in this establishment, they did not [...] as on other occasions they had done, but took a share in the de[_]. [614] It became evident that none of us was inclined to make a new loan without a personal and individual guarantee of some of the shareholders in the "Esperanza". Oyague gave it as his opinion that our ultimate decision should be postponed until it were known what export-duty Congress would impose upon Nitrate of Soda. This was agreed to, though I myself saw no use in such a postponement. Castillo and I insisted upon the indispensable necessity of ascertaining whether there existed, or could be found, water sufficiently free of salt to be used in the boilers without corroding them. Cucalon and Cisneros agreed with us that without such water the whole enterprize was not worth a rap. Lembcke said that the engineer Thierry was almost certain that by digging still deeper than done hitherto, water sufficiently sweet would be found, to which we answered "yes, nearly certain, but no certainty as yet". The two engineers, Felipe Cucalon and Thierry, who had examined the Salitrera Esperanza, valued the railroad, as far 
as constructed, the locomotives, wagons etc. together with the buildings and machinery of the Salitrera, the one in about $S / 1,200,000$ the other $S / 1,300,000$. To complete everything, Cucalon had calculated 120 odd., Thierry S/130,00o were required. This latter spoke of two to three thousand quintals of nitrate which the Esperanza was likely to produce daily, as soon as everything was put in proper order. Cucalon on the other hand reduced the daily production to one thousand quintals. Moreover, he had written to his brother Manuel that if the whole were brought to the hammer, it would fetch above S/500,00o. As already said, we rose without having come to a final resolution.

Saturday, $17^{\text {th }}$ of October. The Editors of La Opinion Nacional, the President's organ, said that the sale of guano had been materially interfered with by that of Nitrate, both articles being used for the same purpose, that of manure, and that therefore, in order to do away with this interference it had become indispensable to subject the Nitrate to such a high export duty as to precludethepossibilityof theholdersofthisarticlesellingatapricecomparatively lower than that fixed upon by the Government for the sale of guano. The paper further stated that since the year 1864 the sale of guano had progressed until 1870, when it exceeded 500,000 to[_]. Since then the sale had declined rapidly; in 1873 hardly 340,000 tons [...] [615] disposed of. In this year, 1874, the sale would hardly reach 300,000 . On the other hand, the exportation of Nitrate of Soda had increased wonderfully; in 1870 it came up to 4,000,000 quintals, in 1871 to $4,500,000$; in $1872,5,000,000$, in $73,6,000,000$, and in 1874 the writer expected that it would reach $8,000,000$. This last figure was however decidedly wrong, for another paper said that up to the $30^{\text {th }}$ Sept. 1874 only 3,900,00o quintals had been exported, half a million less than during the same period of the preceding year.

The "Nacional" made known to its readers that the Austrian Artic explorers had returned to Vienna; only one had died during their long absence. The Winter from 1873 to 74 they had passed in $79^{\circ} 51^{\prime}$ North, and $59^{\circ}$ East. On the $9^{\text {th }}$ March they set out in sledges, and reached latitude $82^{\circ} 5^{\prime}$; they descried mountains rising to 5000 feet in Lat. $83^{\circ}$. On the $4^{\text {th }}$ May they returned to their vessels. The greatest cold they experienced was $31^{\circ}$ below zero Reamur. The same Nacional spoke of a proposal made by the Prussian Government to that of Denmark, to form a part of the German Confederation, which, as might have been expected, was declined by King Christian.

In the forenoon I went to the office of Pepe Izcue, Oficial Mayor of the Finance Ministry, who on my asking him, replied that the Minister had not yet dispatched Escudero's and my escrito, so frequently referred to. With this news I hastened to Escudero in the Banco Hipotecario, where to my great surprise I 
found him and Felipe Varela in an earnest conversation with one of the clerks of the treasury, who held in his hands an order from Elguera, the finance minister, to the effect that the Cerro de Pasco Railway Company should within three days pay in S/10o,ooo to enable the Government to pay the interest on, and the partial redemption of the $\mathrm{S} / 400$, ooo bonds, held by Felipe Barreda, the Banco Hipotecario, and myself; the clerk was requested to return in an hour or so, when all the Directors would have met; and when he was gone Escudero and Varela said that they were much inclined to give a rather strong answer, which I begged them not to do until I had seen Riva-Agüero, to whom I again went, and insisted upon being admitted. He told me that the order of the finance minister had been given in conformity with M. Pardo's, and his own ideas, and that the railway company should merely answer that they had not the funds, when the result would then be satisfactory. With this message I returned to the Banco Hipotecario, where Escudero told $[. .$.$] than an answer would be given$ corresponding to Riva Agüero's wish. [616]

Sunday, $18^{\text {th }}$ of October 1874. Juan's letter received this day from París informed me that in all probability he would leave Europe in November to pay us a visit and that therefore I should cease writing to him. From Sieveking I learned that Hannchen the last of the Willinks of my mother's generation had died, at the age of 86 , she having been born on the $25^{\text {th }}$ September 1788 . Here in Lima we had the death of Antonio Salinas, and of Doña Calista Thwaites, both at an advanced age; the former was a very respectable man, and landproprietor; the latter, a native of Buenos Ayres, was, to say the least of it, a very eccentric woman; her husband, Mr. Thwaites, a North American, died many years back, and it was then said that her ill treatment of him had contributed to his untimely end. In her later years she had turned usurer. For Juan I had succeeded in selling seven of his Cedulas of the Banco Hipotecario of S/1000 each at $771 / 2 \%$. Of my own disposable funds, I had not been able to place any on interest.

Monday, $19^{\text {th }}$ of October. Deeble came as usual both in the morning and evening, but was suffering from a bad cold.

Tuesday, $20^{\text {th }}$. He did not make his appearance, as little as on

Wednesday, $27^{\text {st }}$. In the Juzgado of Dr. Goitisola I presented my two witnesses, the widow Agreda, and the architect Castillo; the former, notwithstanding the malicious questions put to her by Col. Leyva declared in clear terms that the Ayres of his house did not belong to him but to the neighbouring house of Querejazú, mine at present. Castillo, when asked the meaning of the word Ayres confirmed what he had said on the subject in his letter to me. 
The answer given by the three Directors of the Pasco Railway Coy.: Felipe Varela, Francisco Bohorquez, and Peter Gallagher had by no means been such as Riva Agüero and I had wished it to be. They said that they could not recognize the Government's right to demand their paying the interest on and redemption of the $\mathrm{S} / 400,000$ Bonds, as long as the mortgage on the railway, to the amount of $S / 150,000$ in favor of Felipe Barreda and myself, was in existence. "Let the Government cancel this mortgage", they said, "and then we shall see what we can do."

Thursday, $22^{\text {nd }}$ of October. I went to Deebles lodgings, where I was received by his young wife, a nice little woman who told me that [_] [617] husband felt so ill of a pain in his side that he could not again return to my office. This I much regretted, for I had been well pleased with him, and I was convinced that he would not have left me had it not been for his wife, who, born and bred in Callao had there all her friends and acquaintances, whilst in Lima she led a solitary life.

Without loss of time I put advertizements in the Comercio and South Pacific Times, in consequence of which several young men presented themselves.

Saturday, $24^{\text {th }}$ of October 1874 . This being Rafaels birthday, Mariquita and I, Enriqueta, and Garland went to his house in the evening, where only his usual visitors were with him: M. F. Balta, the older brother of the late President, a quiet, taciturn man, Col. Gamero, the governor of the Palace, and José Basagoytia. All was rather dull, though the news of the day, the departure of Nicolas Pierola from Valparaiso in the steamer "Talisman", with cannons and rifles on board, destined for the coast of Perú, gave something to talk about. Gamero assured me that the President had known of this intended expedition many weeks back, that the necessary precautions had been taken, and that there was nothing to fear. This Gamero was the son of Santiago Gamero, an Arequipa shop-keeper, who occasionally bought of me when I was at the head of Gibbs' house, but who was never punctual in his payments; my wife recollected him by his sobriquet of El feo Gamero, I on account of his red face marked by the small-pox, and his always brilliantly blackened shoes.

Sunday, $25^{\text {th }}$ of October. Last evening the creditors of Valdeavellano \& Co. had a private meeting in Don Benito's house; according to some the affairs of this firm, presented a very gloomy aspect, in the opinion of others the creditors might perhaps receive $40 \%$ which I feared was taking rather too favourable a view. In the forenoon I ascended San Cristoval, which this time I did more slowly and with greater difficulty than hardly ever before; owing to the little rain we had had this year, the vegetation which covered the mountain was scanty. 
At 8 O'clock in the evening, I, accompanied by Garland, went to the house of Don Cipriano Correa, whose eldest daughter was to be married to Laraburre y Unanue, whose mother was the sister of [...] rich José Unanue of Cañete, and he consequently the nephew of [618] Pedro Paz-Soldan. In the saloon, well lighted up, perhaps twenty or thirty ladies - the nearest relations and intimate friends - occupied the chairs ranged along the wall, whilst the gentlemen (whose number was very great) were crammed together so that they could hardly move. I by chance stood foremost; near me were Emilio Solar, Manuel Seminario, Manuel Mendoza, Manuel Candamo, Vicente Hurtado, and Moscoso Melgar. I saluted many others, and after all perhaps I did not see one third. It was nearly 9 O'clock before the bride and bride-groom appeared; then came the clergyman - there was a general rush forward, and I, knowing but too well that I should not be able to distinguish anything, retired to the background. In a few-minutes the ceremony was over; a great many looked for their cloaks and hats, and I, one of them, was home by half past nine.

Monday, $26^{\text {th }}$ of October 1874 . This morning I rose early, for I had to go to Bellavista, there to be present at the interment of a little girl of the German Chargé Dr. Lührsen. A special train left the terminus a little past eight. Dr. Lührsen himself was with us; frequently did he wipe his eyes. There were: Riva Agüero, Minister for Foreign Affairs; of the diplomatic body, Leal for Brazil, and the Secretary Carvalho, Garon for Italy, Vasconcello for Portugal; of the Consular corps, Oyague, Lembcke, and myself; and finally, a great many Germans, Gildemeister, Charles Pflücker, Constantine Rehder, with his clerk Bodmer, etc. On arriving at the Bella-vista station, the small coffin, adorned with flowers, was lowered; it was carried by four young men, and the wide silk ribbons hanging down from same, were taken hold of by Oyague, Lembcke, Gildemeister and myself. Thus we walked in slow procession to the Chapel, where the Revd. Mr. Henry read the funeral service; thence again to the grave which was standing open to receive its little inmate. By ten O'clock I was back in my house in time for breakfast.

Of the persons who towards the end of the preceding week had presented themselves in my office, it was with Mr. James Bryson, a native of Glasgow, with whom I came to terms; and this morning at the appointed hour of 10.30, he came for the first time to act as my secretary and lector. Besides being well acquainted with [...] [619] language he knew the Spanish tongue, and could thus write and read in both. I at once told him that what I had most at heart was the correcting and copying in clean of my old diaries, with which at the time I had not progressed further than October 1851. The evening hour, I said, was exclusively devoted to reading. 
From Tuesday, $27^{\text {th }}$ of October, to Sunday, ${ }^{\text {st }}$ of November 1874 . Bryson came regularly, and the work went on nicely.

I was only present at two meetings, in neither of which anything of importance was transacted; the first was that of the shareholders of the Gas Company. The new Statutes were again read, some articles discussed, and all, except one, unanimously approved. Hitherto if one of the shareholders sold a share, the company had the preference of purchasing it, which is called in Spanish "el derecho de retracto"; it was now proposed that this right of preference should be taken from the company and that every shareholder might sell as he liked, merely advising the gerente of the sale, who would then have to make the transfer in the company's books. All except Oyague, Garland and I voted in favor of this alteration, and of course the majority was against us; but then Oyague insisted that in order to alter the statutes, two-thirds of the votes of all shareholders were required, whilst his opponents said that twothirds of the shareholders must be present, and that the majority of these twothirds decided the point. I had to go to the Courts of Justice, and left them discussing the matter. The second was that of the Directors of the Banco de Lima. All were present except Gil and Lembcke, who retired to the adjoining room. The "Esperanza", as mentioned more than once, required pecuniary assistance. We were of opinion that a written proposal should be made out and laid before us in our next meeting. My law-suit with Leyva progressed slowly; both he and I were still producing our proofs, and the judge gave sometimes a sentence in my, sometimes in his favor. I was assured that the President had received from Paris advice of the intended expedition of the "Talisman". At a dinner party given by Genl. Torrico to various Peruvians, General Echenique who was cognisant of the enterprize, after the wine had freely gone round, could not keep the secret, and blabbed. As soon as the [...] broken up, Torrico went straight forward to Pedro Galvez [_] [620] the Peruvian Minister, told him what he had learned, and a telegraphic dispatch carried the news to Perú. On the $23^{\text {rd }}$ October at 2 O'clock in the morning the Talisman made her appearance in the Port of Pacasmayo, in the neighbourhood of which place a few troops had been drawn together. When day broke, the Captain of the vessel, an Englishman, together with a few sailors, came on shore under the pretence of having a piece of machinery repaired. The Captain of the Port went on boards the Talisman, where he was detained, whereupon a launch with armed men left the shore, and was received by the enemy with a discharge of musketry, which fortunately hurt no one. The launch returned to where she had come from, and the "Talisman" departed, her captain and sailors remaining prisoners on Shore. Several Peruvian men-of-war steamers were watching the entire 
Coast; in Arequipa a revolutionary rising took place on the $22^{\text {nd }}$ at 8 p.m. It was headed by Captain Vargas Machuca, son of the General. The Prefect Javier Osma, uncle of Manuel Pardo's wife, stated in his official dispatch that after a combat of an hour and a half the insurgents had been dispersed; on both sides some were killed and wounded; Captain Vargas, dangerously, was not likely to recover.

On Thursdays, Garland and Enriqueta continued their evening parties; some gentlemen played rocambor, the ladies and the young folks roulette - I also tried my luck at the latter, but very moderately. Juan wrote in his letter from Paris, dated $30^{\text {th }}$ September, that having consulted his medical adviser he had thought prudent to postpone his visit to Lima till next year, as the great heat of the West Indies and Panamá might relax his entire system, and augment the piles from which he suffered. Geraldo's nomination as second secretary to the Peruvian Embassy to Berlin and St. Petersburg was published in the papers. Ricardo read to me from some paper or other that the debts incurred by the Prince of Wales amounted to $£_{3}, 000,000$ Stg. and that his mother had made herself responsible for this immense sum. It seemed to me that probably there was some exaggeration in the figure.

Monday, $2^{\text {nd }}$ and Wednesday, $4^{\text {th }}$ of November. The Directors of the Banco de Lima met - all present except Valentin Gil and Manuel Mendoza [...] [621] Cucalon, who was decidedly opposed to any further assistance being rendered to the Salitrera "Esperanza", and Lembcke, interested in the same, looked upon the new advance asked for in a very different light. In the heat of the argument neither the one nor the other kept within the limits of moderation, and more than one offensive word passed between them. Manuel Salcedo spoke a great deal, but hardly anything to the purpose. Luis Benjamin Cisneros and Pedro Bernales expressed themselves in a very sensible manner. Amancio Castillo, though rather prolixly, gave it as his opinion that we could not help assisting the Salitrera. Oyague, the President, with a great deal of unction and too frequent reference to his own person, as it was his habit, was of the same opinion. I took little part in the debate, and finally it was resolved by all, except Cucalon, that a further advance, at the utmost of S/200,00o should be made to the Salitrera, on condition that both the dominion over and the administration of the Salitrera passed into the hands of the bank. Cisneros and Castillo were commissioned to draw out the contract to be submitted to the Directory for approval at the next meeting.

Thursday, $5^{\text {th }}$ of November 1874. The "Talisman", with part of her crew and part of her cargo consisting of arms and ammunition, was brought into port. She had been captured by the "Huascar" in the cove of Pacocha, a trifle to the 
south of Ilo, but not before forty or fifty of the revolutionists on board, with Nicolas Píerola at their head had landed, overcome twenty or thirty soldiers, and started by train for Moquegua, together with a quantity of arms and ammunition.

It has been said in previous pages that in the first months of the year 1872, the differences which for years had existed between the firm of Schutte \& Co. and the Peruvian Government arising from the German guano consignment, had been brought to a satisfactory and amicable conclusion, due mainly to the personal exertion of Mr. Garland, also to the assistance rendered by the lawyer of the house Francisco Garcia Calderon. Garland handed to this latter as a remuneration for what he had done, a cheque for $S / 15,000$ which he thought proper to decline receiving, but still continued with Garland on such friendly terms that when he and his family embarked for Europe, Calderon accompanied them to the port. After Garland's return in the beginning of 1873 he offered Calderon S/20,00o which were once more rejected, and Calderon instituted a suit against Schutte \& Co. for a [...] S/100,000 and not satisfied with this [_] demanded [_] [622] Garland should give a satisfactory guarantee for the payment of this sum, should it be awarded to him. The Juez de $1^{\text {a Instancia }}$ Dr. Olivares, sentenced in favor of the plaintiff the Superior Court confirmed this sentence; Garland appealed to the Supreme Tribunal. The fiscal J. G. PazSoldan gave his vista in favor of Garland, by which he was so much elated that he thought it unnecessary to speak on the subject to the Vocales of the Court, though I repeatedly begged him to do so. More than once he told my wife and myself: "It is quite impossible I can lose"; and what did happen? This day the Supreme Court of Justice confirmed the sentence of the inferior tribunals as regards the guarantee.

Friday, $6^{\text {th }}$ of November. The Government dispatched some troops for the South under the command of Col. Rivarola, on board the "Panama", a fast steamer of the Pacific Company. The defence of the capital was entrusted to the police and to the National Guard, of which latter five or six battalions were called out to active service; Alejandro, with his battalion. According to latest advices, the departments of Puno, Arequipa, and Tacna, including Tarapacá, were quiet, and obeyed the established Government.

Saturday, $7^{\text {th }}$ of November. A telegraphic dispatch was received from the South, which brought the advice that Nicolás Piérola - the Supreme Chief as he styled himself - dressed in full uniform, had reached Moquegua with his few adherents, and had succeeded in raising a small force of from three to four hundred men. With him were: his brother Emilio, whom I had known as co-Director of the Constructora; the notorious William Bogardus; Federico 
Larrañaga "el Cojo" - the lame man whose reputation was nothing better than Bogardus'; a certain Colonel Escobar who some time previously had headed a revolutionary movement in the Sierra; a Captain Arevalo who had served with distinction in the Prussian army, and afterwards returned hither where he mixed himself up in a conspiracy against Pardo, besides many others, whose names were not familiar to me. It was the said Cojo Larrañaga who towards the end of 1867 contributed a great measure to the downfall of the then President Mariano Ignacio Prado, who at the time was besieging Arequipa, whilst in the North Mariano Pio Cornejo held up his authority against José Balta [...] [623] revolutionists. Cornejo stood in need of armament for his soldiers, Larrañaga was dispatched to him from Lima with a quantity of rifles; the rifles he delivered; the fulminatory caps he held back, which of course rendered the rifles useless.

Monday, $9^{\text {th }}$ of November 1874. The Directors of the Banco de Lima met and the draft of the contract with the Salitrera "Esperanza" made out by Cisneros and Castillo, was read, modified in some parts, and upon the whole approved. Cucalon again opposed every further assistance to the Salitrera; he and Lembcke had once more high words; the former even went so far as to say that on a previous occasion Oyague, the President, had not done his duty in not checking Lembcke; at these words, Oyague took fire, and defended his conduct; by and by satisfaction was given by the one to the other, they cooled down, and we continued our debate. There was one point of importance, viz.: whether the interest due by the Salitrera to the Banco de Lima should be included in the $\mathrm{S} / 200,000$, and consequently diminish the amount to be paid, or whether this amount should be debited the Salitrera in account, over and above the $S / 200,000$. Oyague was of opinion that the interest should be deducted, because the shareholders in their last general meeting had limited the advance to the Salitrera to $\mathrm{S} / 200,000$ and that we, the Directors, were not authorized to exceed the sum, which we would do, if we paid the S/200,0oo and over and above debited the Salitrera with the interest. He was certainly correct in the view which he took, and all except Cucalon, the eternal opposer, and Sagastabeytia, who owing to his deafness had not been able to hear the debate, followed in his wake. I also acceded, but added that by deducting the interest from the $S / 200,000$, the amount to be placed at the Salitrera's disposal would not suffice for its most necessary expenses; when I was answered - and certainly with perfect correctness - that in that case we would require to call another general meeting and ask for a further authorization; in this manner the affair was finally settled and the gerentes were empowered to draw out necessary documents, with the assistance of our lawyer Dr. Aranivar, and to make the payments. 
Tuesday, $10^{\text {th }}$ of November. The government ordered the two battalions of the National Guard $\mathrm{N}^{\circ} 10$ and 11, to embark for the South; the Colonel of the former was Cesar Canevaro, whose adjutant was Alejandro, who for some hours [...] what to do he having of late entered into extensi [...] [624] in Vales de la nueva Consolidacion; considerable sums he had to pay, similar amounts to receive. At last he determined upon going, gave detailed instructions to his brother Geraldo, bade us good-by on

Wednesday, $11^{\text {th }}$ and left on

Thursday, $12^{\text {th }}$ at 10 a.m. on board the "Valdivia". Besides the two battalions already mentioned, a body of young men, for the greater part Indians from twelve to fourteen years of age, well drilled and educated by Antonio Bazo, to serve as non-commissioned officers were embarked; they were armed with the rifles found on board the "Talisman".

Friday, $13^{\text {th }}$ of November. Geraldo, who as Lavalle's second secretary, had been instructed to get ready for to-morrow's steamer for the North, but who had, as just said, been entrusted by his brother Alejandro with the management of his business, went this night to his superior, and requested him to allow him to remain one fortnight longer in Lima but as Lavalle would not take upon himself to grant him this respite, Geraldo went below to where the President was with several of his friends, stated his case, was received with the greatest kindness, and immediately obtained the leave which he asked for.

Saturday, $14^{\text {th }}$ of November. The Judge Goitisola with the notary Manuel Escobar, accompanied by Leyva, came to our house to take the declarations of my wife and daughter. The substance of the questions laid before them by Leyva was, whether at the time of our repairing our house, he, Leyva, had not opposed himself to any alteration being made in the windows, and that my wife and daughter had abstained from making these alterations, because they considered Leyva to be the owner of the Ayres. My wife answered far too decidedly in the affirmative, whilst Enriqueta qualified her reply, and added that her compadre, José Maria Sotomayor, had frequently stated to her and to her husband that as soon as he made himself owner of the house, now mine, he would immediately commence building upon the Ayres, because they did not belong to Leyva, but to Aliaga. Leyva had left, before Enriqueta concluded her declaration. Both the judge and Escobar were very polite and before they left, we offered them some wine, of which they partook.

As per advices published in this night's Nacional, Rivaro[_] with his troops was still [_] Ilo on the $12^{\text {th }}$, but [...] [625] moving upon Moquegua, the locomotive, partly destroyed by the revolutionists having been repaired. Pierola and his party were said to have left for Tarata; all the Southern departments 
were quiet. Anjela the Chola, for many years Enriqueta's servant, wrote from Arequipa that every moment a rising was expected.

Sunday, $15^{\text {th }}$ of November 1874. News were received that on the morning of Thursday last the populace of Cajamarca headed by the ex-prefect Iglesias had risen against the Constituted authorities, and that shots were being exchanged between them and the soldiers. The advice had been carried by a propio across the low Cordillera, to Magdalena; thence per train to Pacasmayo, and per electric wire hither. Also in Lambayeque a momentary discontent had shown itself, and this for the following reason. The Congress had given a law, in virtue of which a new department was formed which included both Lambayeque and Chiclayo; and this latter place, the new upstart and rival of Lambayeque had been declared the capital, which naturally gave umbrage to the Lambayecanos, who considered themselves far superior to the Chiclayanos.

Monday, $76^{\text {th }}$ of November. Late in the evening of this day the President Don Manuel Pardo embarked for the South on board the "Panamá" taking with him national guards from Lima and Callao, half a battalion of infantry of the line, some cavalry, and two pieces of light artillery.

Saturday, $27^{\text {st }}$ of November. A Steamer from the South arrived, bringing the advice that Pardo had touched in Mollendo, and that Arequipa being quiet he had continued his voyage to Ilo, where the troops had been disembarked. Between Rivarola and the revolutionists, who, it appeared, occupied Moquegua, as yet no serious encounter had taken place.

On this, my wife's birthday, I made her a present of a handsome and valuable diamond cross, upon which about a year ago I advanced to a broker, J. A. Garcia, S/2000 and which he - being unable to redeem it - sold to me at this price with twelve months interest at $2 \%$ monthly upon it. Garland, Enriqueta, the children, the servants, all made my wife some present or other. In the evening only Rafael Velarde, wife and two daughters and Goyo Benavides, wife, son, and niece came to congratulate Mariquita. We took tea, had the roulette table brought over from the other side, and, played [...] midnight I losing a trifle as always. In the dining-room [...] [626] wife had laid out sweetmeats and jelly, a present from Enriqueta. Wine also stood on the table. Our guests partook of all, and left at past one O'clock.

In the course of the week the Directory of the Banco de Lima met once. All were present except Mendoza and Cucalon. Dr. Aranivar came in, took his seat, gave us his legal advice, Gil defended the interest of the Salitrera, and finally the agreement drawn out by Cisneros and Castillo was approved with trifling modifications. I had also been present at two funerals; the one, that of Rafael Saco, father of Alejandro, many years back assistant lawyer in Dr. Palacios' 
study, and of Gabriel at present money broker; the other, that of a sister of the Paz Soldans, widow of a Frenchman Rouaud.

Sunday, $22^{\text {nd }}$ of November. My money transactions were reduced to a mere nothing. I had no more than 9050 Soles in the Banco de Lima and contented myself with receiving my rents and interest.

I saw from the papers that the revolutionists of Cajamarca had left the town and fled to Chota; those in the South under Pierola had abandoned Moquegua for Torata; and Rivarola occupied "El Alto de la Villa". During Pardo's absence from Lima the executive power had remained, not in the hands of the VicePresident Manuel Costas, but in those of the Ministers. About this time Bryson read to me Walter Scott's History of Scotland, and Alison's History of Europe; in the former we had come as far as the Scotch Rebellion of 1745 ; in the latter we had just concluded the first rising of the Vendéens. From these Histories I copied a few details relative to the seven men of Moidart, and the seven leaders of the Vendéens in 1793, which will be found in appendix under $\mathrm{N}^{\circ} 14$.

My wife had this day more visitors than usual, for several gentlemen who had not been with her on the previous day came to congratulate her. We dined by ourselves, Garland and Enriqueta having at an early hour in the morning started for an excursion on the Oroya line, to which they, together with other gentlemen and ladies had been invited by the engineer Malinowski. When they returned in the evening, Enriqueta was as knocked up that she was not inclined to go to José Canevaro's [_] to which both she and husband had [...] [627] invitation. With the little trip they had been much pleased. After crossing the wonderful viaduct called De Verrugas, they had stopped for a short time in San Juan de Matucanas, where in the hotel an excellent breakfast had been provided. Further on, the line passed through tunnel after tunnel. On the other side of San Mateo the train stopped before the last tunnel, for though the sleepers had been laid, the rails were not; when walking through it in utter darkness, Garland had a bad fall. Here they had reached the height of about 13,000 feet above the level of the sea. On their return they again stopped in San Juan de Matucanas for another meal, not inferior to the breakfast.

Monday, $23^{\text {rd }}$ of November 1874. I presented an escrito to Judge Quiroga in which I demanded that though Leyva had not yet adduced all his proofs, the documents should be delivered up to me in order that my lawyer might draw out an important escrito called "de buena prueba". The judge at once decreed that Leyva should produce within two days his witness Muñoz, and that the architect Cabiezas whom Leyva had named as his perito - appraiser? - should without loss of time present his written opinion; and finally, that the two notaries, Orrellano and Yparraguirre, the former named by Leyva, the latter 
by me, should on Friday next appear in the office of the Notary Terrazas, and there compare the certified copy produced by Leyva, of the purchase of his house, with the original document drawn out and deposited with this Terrazas.

Tuesday, $24^{\text {th }}$ of November. The above decree of the Judge was notified to me and I most earnestly recommended Luis Orbegoso, the notary Escobar's clerk, to do the same to the parties above mentioned.

Thursday, $26^{\text {th }}$ of November. The famous Italian tragedian, La Ristori, whom in 1856 we had seen in Paris, was at this time in Lima, where, though already fifty years of age she was much admired, and caused great sensation. Last night she performed in Italian the part of Maria Antoinette in the tragedy of the same name, at which Garland and Enriqueta, Mariquita and myself were present, in the box belonging to José Pablo Escobar, who had had the attention to place it at Enriqueta's disposal for this evening. For many years my wife and I had not $[\ldots]$ the theatre, the last time at [...] request to witnes [...] [628] performance given for the benefit of the French Beneficencia. To me it seemed that the interior of the house was more prettily painted, and cleaner than it had been then. The box being exactly opposite the stage my wife and daughter could see everything that was going on there, and though they understood but little, if anything of the language more than once they were much affected, especially by that scene when the sans-culottes tear the Dauphin from his mother's arms. As for my part I passed a few tedious hours; I could not distinguish the least, and though I did my best to make out what was spoken, yet I only caught occasionally a few words uttered by the male actors; of what the women said I could not catch a syllable. The performance was over at 1 this morning, when we walked home.

Saturday, $28^{\text {th }}$ of November. Geraldo embarked for Europe, there to place himself under the orders of J. A. Lavalle, Peruvian Ambassador in Berlin and St. Petersburg. He, as second secretary, had an annual salary of $S / 2000$ Silver, and for his first instalment $\mathrm{S} / 1000$ were allowed him. For these, and the half of the first year's salary he received a bill of $£_{400} 90 \mathrm{~d} /$ st., Dreyfus on Premsel of London. His father and his three brothers Enrique, Guillermo, and Ricardo accompanied him on board. The Steamer did not get under weigh until seven or eight in the evening, and Geraldo had just time to shake hands with his brother Alejandro who arrived in the mercantile steamer from Mollendo. The Col. of his battalion, Cesar Canevaro, had given him leave of absence for a short time to attend in Lima to his mercantile business. He told us that the Lima and Callao national-guards had been very badly received by the Arequipa male population; with the reception given to the officers by the fair sex, they had been extremely well pleased. On the $9^{\text {th }}$ the President Pardo had arrived 
in the train from Mollendo; the Arequipeños had thronged round to see how he looked, but not one viva, no cheering had made itself heard. In Alejandro's opinion Pardo had but few if any friends in Arequipa; the inhabitants took no active part whatever, neither in favor of nor in opposition to the revolution; they were quietly in expectation of what the result would be. The President had alighted in the Prefectura, and having taken upon himself the direction of the campaign the Executive [_] hitherto entrusted to the Council [...] [629] Ministers, now devolved upon the Vice-President Manuel Costas. Alejandro was further of opinion that Pierola would finally succumb. He with about 800 men had taken up his position in Torata, where erelong he would be surrounded by the Superior forces of the Government, 3000 in number, who in three divisions were commanded respectively by Col. Rivarola, Admiral Lizardo Montero and Col. Manuel Velarde. Andraca continued Prefect in Lima, the environs of which place, at least so it was said, were infested by montoneros, in other words bands of mounted banditti.

Monday, $30^{\text {th }}$ of November 1874. To expidite my law-suit I engaged another notary de diligencias called Barrantes, whom I paid well, and who without loss of time notified Leyva. When in search of the architect Cabiezas his neighbour said that he had gone with the national-guard to the South; then Leyva produced in his stead the architect Quesada, whom judge Goitisola ordered to present his written informe within three days.

I received my usual letter from Juan who wrote me under date $31^{\text {st }}$ October, that having consulted with Dr. Acosta he had determined upon leaving Europe on the $17^{\text {th }}$ November and that therefore we might expect him here on the $17^{\text {th }}$ inst. I at once resolved to give up to him the apartments hitherto occupied by me and to remove to two inner rooms looking to the garden.

Tuesday, $7^{\text {st }}$ of December. The Directors of the Banco de Lima had their customary monthly meeting; nothing of particular importance was transacted. Lembcke made known to us that he and Sagastabeytia had been applied to to contribute to the funds which were being raised by subscription for the families of the soldiers of the national-guard of Lima who had left for the south. Oyague spoke first, and said that in his opinion four or five hundred Soles should be given. I observed that this was too much, "for", said I, "La Providencia, which is cited as a precedent for having given $\mathrm{S} / 500$ is in a brilliant situation, whereas the Banco de Lima is in a different position and consequently ought to give less." Oyague replied, Mendoza sided with him, Cucalon - who was of my opinion - did not open his mouth, the remainder kept silent, and finally it was decided that the Gerentes should give the same as the other banks, which turned out to be $S / 500$ each. 
Wednesday, $2^{\text {nd }}$ of December. Alejandro returned to the South after having [...] [630] a considerable amount of his Vales de la nueva consolidacion, which had been the principal object of his coming hither; he had also made other arrangements, so that he could quietly resume his military duties. The Minister of War, General Freyre, likewise left for the South taking again a few troops with him. The news from Torata and Moquegua, the former occupied by the revolutionary, the latter by the Government forces, was as yet of little importance. There had been some skirmishing between the outposts of both parties; much powder and many balls were spent, but not much damage had been done.

Saturday, $5^{\text {th }}$ of December. Between two and three in the afternoon about thirty individuals, nearly all officers not in active service, indefinidos, also two clergymen, the one a presbyter from Ecuador, the other the Inter of the Chapel of Guadalupe in Callao, were discovered in the Custom-House armed with revolvers, and as it was supposed that their intention had been to possess themselves of the castle, they were made prisoners and marched off to the Casas-matas, notwithstanding the slight resistance offered by the one and the other, especially by the Ecuatorian clergyman.

Tuesday, $8^{\text {th }}$ of December. La Concepcion. Bryson remained with me till 1.30 and at 2.30 I started for an ascent of San Cristoval, which I accomplished with great ease though I perspired profusely; for the heat was great.

Wednesday, $9^{\text {th }}$. Though this was the fiftieth anniversary of the battle of Ayacucho it was hardly kept as a civic holiday; even some shop-keepers kept their doors open.

Thursday, $10^{\text {th }}$. Enriqueta's evening tertulia was well attended; the Velardes were wanting, but instead of them there were Col. Diego Masias, wife, and sister-in-law, José and Rafael Canevaro with their respective wives, Goyo Benavides and wife, who seldom failed to come, and several rocamboristas, Malinowski, Nicolas Hurtado, and Ignacio Tavara etc.

Friday, $1^{\text {th }}$ of December. The news spread, brought by the man-of-war "Union" that on the $7^{\text {th }}$ Pierola and adherents had been beaten and dispersed. Garland received a letter from Alejandro written on the same day from El Alto de la Villa, who said not a word about the fight, whilst El Nacional gave a long and detailed account of an attack execu[_] on [...] [631] by Rivarola's men upon the height called de los Angeles. After a combat which lasted six or eight hours they had been recalled, without any advantage having been gained, and owing to this advice not a few, I of the number, began to doubt of the truth of the victory.

At 3.30 p.m. the Directory of the Insurance Company "Lima" held their usual meeting. The insurances effected were inconsiderable; however, as we had 
no losses, and our capital made a good interest I calculated that at the end of the year we would have made a clear profit of S/50,00o which upon S/200,00o paid in, was an excellent percentage. The firm of Dreyfus paid the dividend for $1873-10139 / 1000^{\text {ths }}$ which, added to $5 \%$ interest, received in March last, was a handsome return for the outlay. On the other hand, I contributed S/5o to the above spoken of subscription for the families of the national guards. This day, as well as

Saturday, $12^{\text {th }}$ of December Ricardo and I were occupied with carrying over to my new apartments all my books and papers, some of the furniture having been previously removed.

Wednesday, $16^{\text {th }}$ of December. I once more presented an escrito to the judge Goitisola, reiterating my demand for the immediate delivery of all the documents "todo el expediente" to my lawyer Palacios, that he might draw out, without loss of time the escrito Alegato de buena prueba, to which Leyva had to reply previously to the judge giving his sentence. I knew that Quiroga looked upon the ayres in question as the property of Leyva; what Goitisola opined I knew not, but at all events I had with him some chance in my favor, and it was for this reason that I did my best to accelerate the suit, because as soon as the Congress closed, Teodoro de la Rosa would return from the Chamber of Deputies to his seat in the Superior Court, and Quiroga again occupy his post

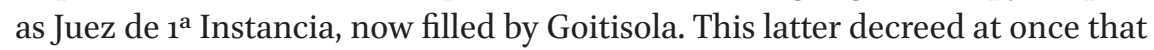
the architect Quesada should present his informe within two days.

Thursday, $17^{\text {th }}$ of December. By the two O'clock train, when I knew that the North Steamer was in sight I went to Callao. Juan had already landed and dispatched his luggage, thus without loss of time he, Garland, Enrique, and I, returned together. He looked extremely well [...] enjoy good health though he [_]sionally suffered [...] [632] rheumatic pains. He had had a good passage, and only complained of too many passengers, bad living, and extreme heat. The Steamer from Southampton touched at present in Barbadoes, Jacmel, and Santa Marta. On board the same steamer arrived Aurelio Garcia y Garcia, the Ambassador of Perú to Japan and China, and Ford of Dreyfus' house. We all dined with Enriqueta. In the evening Manuel Costas, the Vice President, came, accompanied by an aide de camp; he was as off hand as he always was. With Juan he had a very long private talk.

Sunday, $20^{\text {th }}$ of December. The Nacional gave the news that Pierola with some of his adherents was known to be in a place called Tarata, still in Perú, forty leagues distant from Tacna in the direction of Bolivia, and that troops had been sent in pursuit of him. This proved that the victory of $7^{\text {th }}$ was no myth as I had thought, but a fact. In Tarapacá a certain Albarracin was in arms against the Government; about Cajamarca, Iglesias caused disturbances; troops were 
sent against both; all this cost money, and money there was nowhere; even the Senators and Deputies were without their daily stipend. President Pardo, by latest advices, was still in Tacna.

In the course of the last week the Directors of the Water Company had had a meeting, all present. Mr. Rey made known to us that the engineer, Wilkinson, had proposed a plan to procure a greater supply of water, which was certainly wanted; at present Lima consumed daily six million gallons, and Mr. Wilkinson was confident that if the excavations were continued, where, and in the manner he proposed, one million and a half more would be obtained daily; at the same time he asked for an increase of salary, because, as he said in his letter, he did not act as a sub-engineer, in which capacity he had been engaged, but that he was now first engineer; he both made the plans, and carried them out. Oyague took the lead in the debate, if debate it could be called, and we agreed that the salary asked by Wilkinson should be granted him, on condition that he succeeded in procuring the above increase in the daily supply of water.

Thursday, $24^{\text {th }}$ of December. Early in the morning our Chinese cook Achipe came to my wife and told her that he was unable to cook any [...] [633] being too old, and completely worn out. He brought with him a countryman of his to take his place, whom however we did not engage, but prefered taking our meals with the Garlands until another cook to our liking could be found. I in the meanwhile paying, of course, our share of Enriqueta's expenses.

Since the beginning of this week I had continued to urge on my suit against Leyva, and this day Judge Goitisola allowed to the architect Quesada, a new, but peremptory term till the $28^{\text {th }}$, when he had to present his so often spoken of informe.

Friday, $25^{\text {th }}$ of December. Christmas-day. In the morning a steamer arrived from the South, with battalion $\mathrm{N}^{\circ} 10$, and part of $\mathrm{N}^{\circ} 7$ of the Lima Nationalguard. It was nearly 1 O'clock before they disembarked; a train conveyed them the greater part of the road, and they then made their entrance on foot, walked through many streets, passed the Palace, where the Vice-President Costas was at the window, and finally went to the barracks, where they were disbanded. Alejandro, now captain of company $\mathrm{N}^{\circ} 6$ of the battalion $\mathrm{N}^{\circ} 10$, who came at about 6 O'clock p.m. looked much thinner than he had done when he left on the $2^{\text {nd }}$ of this month, and though his battalion had not come to blows with the enemy they had undergone much fatigue, slept more than one night in the open air on the hard ground, and marched many a dreary league. He told me that Rivarola's attack had been badly managed; the original plan had been merely to divert the attention of the enemy as the principal attack was to be 
made on the following day from the opposite side, by the forces commanded by Lizardo Montero; but instead of skirmishing, all the troops of Rivarola took part in the combat, spent their ammunition and had to be recalled. Alejandro was of opinion that had there been a good officer on Pierola's side, Rivarola's troops might easily have been defeated. They returned to their encampment on El Alto de la Villa where Alejandro with his battalion had arrived on the evening of the same day. On the $7^{\text {th }}$ they had heard the firing of guns, which they knew must have been Montero's, who easily put to the rout a few hundred men commanded by General Segura; he, the General, it was firmly asserted, had been the first to run away under the pretence of bringing reinforcements. In the $[\ldots]$ of the $7^{\text {th }}$ from Rivarola's side, bombs were thrown with precision [634] into Pierola's intrenchments, which had been raised at the head of the gulley or Quebrada de los Angeles. On the $8^{\text {th }}$, at two in the morning, the troops under Rivarola, the battalion $\mathrm{N}^{\circ} 10$ included, put themselves in motion, and after a march of seven hours, continually ascending, without anything to eat or to drink, reached Torata at 9 a.m. tired to death.

On the road they had found muskets and other accoutrements thrown away by Pierola's soldiers; they smelt the stench of the corpses just interred, but no enemy was to be seen, all were gone. They met Montero's troops, remained a few days in Torata, returned to Pacochas, embarked for Arica, went per train to Tacna where they remained some time, and returned with the President to Mollendo, whence he went up to Arequipa, and the troops returned to Callao. Moquegua and Torata were, Alejandro said, completely in Pierola's interest. Arequipa was hostile to Pardo, though not favourably inclined to Pierola, whilst in Tacna and Arica, all the inhabitants were Pardistas. For a few days Pierola with his followers, perhaps two or three hundred in number, was completely lost sight of; he reappeared at Tarata, as above said, and, driven away from this place, the last news was that he had moved towards Puno. We also heard that in La Noria, close to Iquique in the Province of Tarapacá, the Chilian labourers there employed in the Nitrate of Soda works, had mutinied, committed many disorders, and plundered the shops.

William Scheel, of the firm of Dreyfus Bros. \& Co. had given on the previous evening, Christmas Eve in his country-house in Miraflores a numerous party to which my wife and myself had been invited, but declined going. I learned this morning that all who had been there, grown up people and children, had been much pleased, especially with the high pine-tree, which, as it is the German Custom, Scheel had erected in the middle of the saloon. It had been lighted up with innumerable small wax candles, and hung with toys of all descriptions, which were distributed in great profusion amongst the infantile world. The 
extra-trains to bring his guests, and to convey them home, had been of course at Scheel's expense.

This day, Christmas-day as well as

Saturday, $26^{\text {th }}$ and Sunday, $27^{\text {th }}$ of December I made many calls I will enum[_] [635] the various persons whom I went to see, with a short appendix to each name.

On the $25^{\text {th }}$ : 1) Jose Santos Chavez, curate of the Parish El Sagrario, for many years secretary of the late Archbishop Goyeneche, a man of no bright intellect, but apparently good natured; he had baptized the greater part of Garland's children, whence our acquaintance with him. 2) The Brazilian Minister Leal, the Señior of the Diplomatic Corps, a particularly agreeable, elderly man, who intended leaving Lima within a few days; he was not in, but his successor was, and with him I conversed a few words, first in Spanish then in French. 3) Dr. José Gregorio Paz-Soldan, one of the two fiscales of the Supreme Court, a very clever man; his exterior was far from prepossessing, his integrity doubtful, and the good opinion which he had of himself beyond measure; also his morals were very lax; he had a number of natural children. His present, third, wife, was Jesus, daughter of the late Pepe Rivero of Arequipa, nicknamed Soliman. 4) Doña Irene, the pretty young wife of the Vocal of the Supreme Court, Dr. Bernardo Muñoz; she talked so much, so rapidly, sense and nonsense that I was glad when good-breeding permitted me to take my leave. 5) Mercedes Riglos de Riva Agüero, not in, having gone to the club in the plaza to see the troops pass by; she was a very good natured, though somewhat silly woman, and I really believed that nobody could find any fault with her except her husband, who must more than once have wished that his better-half were less devoted than she was to the latest Parisian fashions. In her soirées, the best company of Lima was to be found, where she gave herself the heirs of a lady of the highest rank, not forgetting that the mother of her husband, a Belgian lady, was the Princess de Loos, whose father, at the latest grandfather, had been a sovereign German Prince, whose small principality, like that of many others, had been swept away towards the end of last century by the treaties consequent upon the first revolutionary wars. 6) General Miguel Medina, Minister of War in the first months of Pardo's Presidency, now an anti-Pardista, because his son-in-law, More, captain of the "Independencia" had been placed before a Court-martial for having allowed the "Talisman" to escape at the Port of Pacasmayo, when it had been in his power to capture her. More, a good naval officer, excused himself with saying that he had not had [...] coal to put on steam. This More's mother was or is [_] [636] certain Bustamante from Ayacucho, his father, that John More with whom in the last months 
of 1827 and the first months of 1828 I made a journey from Lima to Cuzco; I then went on to Arequipa; he returned and in Ayacucho fell in love with her who afterwards became his wife. He did not prosper in the world, and went afterwards to Spain to look after some property which his wife's family was said to possess there, and there he died. 7) Mrs. José Vicente Oyague; though mother of a numerous family she still preserved remnants of the good looks of her youth; in her comportment she was agreeable and lady-like. By her mother, the sister of the President Pardo's mother, she belonged to the first families of Lima, whilst her father, a Frenchman, Soyer, came to this coast in the first years of the Independence in a humble situation of life; he took service with the patriots, rose to become Colonel, and always behaved like a gentleman. With her I found a Chilian, whose name, La Marca, was not new to me; neither was mine unknown to him. When a boy he had been brought up in Hamburg, and had become acquainted with the two Misses Schutte at the time they were at Mrs. Rücker's, and in the summer of 1855 whilst we were travelling about in the picturesque mountainous country in the vicinity of Dresden, which goes by the name of the Saxon Switzerland, he overtook us, and remained a day or two in our company. He had now come from Chile, and was, as he said, on his way to Europe. 8) Mr. Dominguez, Minister of Buenos Ayres in Perú; of him, his wife, his grown up sons and daughters, I knew nothing, and have only to say that they had arrived in Lima hardly a year ago, and that they were pleasant people to converse with 9) Dr. José Luis Gomez-Sanchez. He, a native of Arequipa, was brought up for the law, and had passed through all the grades of judicature, until he reached the summit by becoming Vocal of the Supreme Court of Justice in Lima; a few months ago he retired with a pension pretending that his infirmities and advanced age did not allow him to attend to his duties; he was born on the $19^{\text {th }}$ August 1799. Also in Peruvian politics he has taken an active part; he has frequently been deputy to the Congress, and more than once Minister. In 1854 when I embarked for Europe it was he who, as Minister for Foreign Affairs under Vivanco's rule, provided me with my passport [...] [637] long law-suit with Sotomayor was the cause of my becoming intimately acquainted with him, and I continued to visit him pretty frequently, but nevertheless I did not trust him in the least, and his continual smile, or rather smirk, was to me the sign of a want of frankness. In the course of our law-suits he hardly ever rendered us a real service, and in that with the Sotomayors took care to come to the tribunal at an hour when his colleagues had already commenced treating on its merits and demerits, and consequently did not vote, when their sentence was given in my favor; he owed me some money, which probably he would never pay. 91/2) The wife 
and daughter of Jervacio Alvarez, another Vocal of the Supreme Court; of his uprightness and integrity I had no great opinion either, but at all events he had served me, and we were on the very best terms. With the exception of Paz-Soldan, he was without fail the best instructed of all the Vocales; when conversing with him on history I had been astonished at his extensive learning. He was writing a universal history, which, as far as I could judge, for now and then he had read a few lines of it to me, would be a mere compilation. His wife Doña Mariquita was an insignificant little woman, who could not forget the death of her favourite son Adolfo. Asuncion, one of their daughters, a married woman, whose husband, Santillana, was always absent, and who, Asuncion, was my very good friend, was in fact the mistress of the house. 10) The German Chargé d'Affaires, Dr. Lührsen, a native of Hamburg, and his accomplished lady, a Hungarian by birth, brought up in Vienna. Though they had their house in Lima, they had for the present removed to Miraflores, where they resided in a house belonging to Scheel. I was but little acquainted with them, but liked them well.

On the $\left.26^{\text {th }}: 11\right)$ Dr. Bandini, a canon of the Lima Cathedral, more a friend of my wife and daughter than of myself. 12) Dr. Wenceslao Rospigliosi, Juez de $1^{\mathrm{a}}$ Instancia del Callao. Of him I knew very little; his wife was Doña Manuela, a nice young woman, sister of Dr. Evaristo Gomez-Sanchez, who, as Minister of Pezet during the President's absence in 1865 ruled in Lima with an iron rod. His mother, and consequently Rospigliosi's mother-in-law, was Doña Paula Benavides, whom I visited occasionally and of whom I have spoken more than once. 13) Doña Maria Moreira, widow of the late highly respected NorthAmerican merchant, Mr. Stanhope [_]ost. The Moreira's were a numerous family and much este[_] [638] on account of their integrity. By their mother's side they were connected with the aristocracy of Lima, whilst I suppose it was to their father they owed their somewhat dark complexion. She, as it was her custom, was not yet ready to receive visitors. 14) Her brother Juan José, unmarried, who attended to the cultivation of a farm close to Lima, was still shaving, and of course I remained with him but a few minutes. 15) Colonel Diego Masias, a native of Arequipa; he was an agreeable man, and pleasant talker, but to all he said, implicit belief could not be given. From his youth he had been mixed up with all the revolutionary movements in Arequipa. In the beginning of 1868 by his influence with the then President Pedro DiezCanseco, he contributed a great deal to the concession which was made to Henry Meiggs for the construction of the railway from the Coast to Arequipa, and for this he was well remunerated by Meiggs, who paid him, as some said, \$10o,ooo others $\$ 200,000$. Since then he had become more steady, had 
removed to Lima, purchased a house, and lived now in a decent, though not extravagant style. His wife Doña Jesus, and his sister-in-law Transito Llosa were good natured women. 16) Rafael Velarde, my wife's cousin; the best hearted man in the world; he had been Deputy several times, even Minister under Balta, and nevertheless, I was of opinion that he was very deficient in sound judgement, and good common-sense. The poor fellow was in great trouble owing to the imprudent conduct of his wife; his eldest daughter Zoila was a very good girl, and people said that she had a pretty face. 17) The wife of José Maria Peña. All I could say of her was that she was the sister of Manuel Costas, Vice-President of the Republic. Peña a native of the Argentine Provinces was a pleasant, intelligent, and wealthy man who had made his fortune mainly by purchasing sheep and Alpaca Wool, which he consigned to A. Gibbs \& Sons of London; of late he had settled over to Lima, where he had bought and repaired the house which for many years was owned by General Castilla. 18) Godoy, Chilian Chargé in Perú, who was not visible, as little as his wife Mariana, the daughter of Mr. and Mrs. Prevost. She was generally considered to be a goodlooking young lady, and no doubt she had been well educated. She had married her present husband after her father's death against the wish [...] [639] and all her family. Her brothers were: Juan, weak in body and mind; Enrique and Carlos, who under the firm of Prevost \& Co. continued the business of Alsop \& Co., of which firm, extinct for about a year, their father was partner for a very long time, and lastly, Luis, an insignificant youth. 19) Basagoytia, father and son, with their respective wives, all natives of Arequipa, and in every respect very estimable people. The father, at present completely broken up, had in the course of his life time filled many situations under government, and always given satisfaction. At the time, I do not remember the year, when the Congress decreed that commissioners should be sent out to examine the accounts of the guano consignees - Gibbs in London, Montané in Paris, and Barreda in New York - he was named for England, and, as might be expected, found nothing wrong in the books laid before him by Gibbs. Soon after his return he was made Director of the Lima mint, and now, a complete wreck, enjoyed a pension. Without being rich he was well to do in the world, and what he possessed he owed in a great measure to his having been one of the founders of the Lima Water Company. Being unable to attend to any business, his only son José did everything for him. José, a married man, perhaps forty years of age, was an uncommonly stout person; you need only look at him to be convinced of his good nature, but with him good nature did not go hand in hand with stupidity; he was wide awake, of which I had seen many a proof in our meetings as co-directors of the Water Company. About a year ago he 
bought the house in the Calle de Baquijano which for many years had been occupied by Mr. C. W. Schutte and family; it was completely rebuilt, under his sole direction, and it was in this new house that I paid him my visit. 20) The wife of José Pablo Escobar, who occupied my house Calle del Correo. The lady's name was Lopez; she was a native of Piura, where her father had once been prefect; her mother was insane. She was rather stiff in her demeanour, but half an hour or so passed quickly in conversing with her. Her husband, and his elder brother Emilio, born in Panamá, had come to Payta when young, where they entered the mercantile establishment of Alexander Ruden and Charles Higginson. In course of time Emilio became partner of Ossa in Chile, and José Pablo, after Garland had separated from Ruden, took his place. A [...] [640] back Ruden gave up his business, and Escobar continued it in his own name, under the management of one of his brothers-in-law, whilst he himself came to Lima, where he succeeded in being named one of the gerentes of the Banco del Perú. He was certainly an intelligent man, knew what he was about, had an insinuating address, was intimate with all the monied men of Lima, also a great friend of President Pardo; but no one placed any confidence in what he said, for sincerity and frankness were qualities alien to his character.

On the $27^{\text {th }}$ :21) Doña Manuela Mendoza y Boza, a true specimen of the old Spanish nobility to which she belonged by father and mother; she was a very silly creature, and had learned but little, otherwise good hearted in the extreme. She had four children: Catalina, twice widow, her first husband having been El Conde de Carrillo, the second, General Guarda; Emilia, badly married to a Chilian, Soto; Don Domingo, Vocal de la Corte Superior, and Manuel, who was believed to be very rich, for, as eldest brother, he had by thelaw of primogeniture, been the only heir. 22) Manuel Mendoza, who lived in the same house with his mother; his wife, Isabel Barreda, was absent in Paris. He was an agreeable man, and he and I were on friendly terms, but a bright genius surely he was not, and of this I had seen many a proof in the meetings of the Directory of the Banco de Lima, of which he was a member. 23) Bartolomé Araoz, a native of the Argentine Provinces, a man of about my age, with whom, as said on other occasions, I was more intimate than with any other of the male inhabitants of Lima. As long as he resided in the house called de Pilato, situated opposite the Church of San Francisco, and bought by him from the heirs of the late Francisco Quiroz, he used to keep me company in the evening, three, perhaps four times a week, and as he had travelled much, topics of conversation were seldom wanting. Now and then he paid a visit to his valuable sugar estates in the Province of Abancaes, from which he derived a considerable income, and his absence was always a source of regret to me. Whilst on one of these journeys 
his wife, Doña Carmen, for whom it seemed to me he had no gre[_] affection, died and within less than a year's time he more [...] [641] seventy years old, took another companion to himself, Doña Tomasa Gonzales, a Cusqueña. The house of Pilato he ceded to his daughter Maria, married to Rufino, one of the sons of General Torrico, and removed with Doña Tomasa to a house not far from the Callao gate, sold to him by Dr. Fernando Palacios, and since then, for our respective dwellings, in Lima estimation, were rather distant from each other, I saw less of him than formerly. 24) Rufino Echenique, the youngest son of the General, very different in every respect from his father and two elder brothers. The only fault people found with him was that his name was Echenique. He had been educated in England at the expense of his cousin Mrs. Cotes, and for a year or so had been student in the University of Cambridge. Shortly after his return to Perú, though quite a young man, he was named one of the two gerentes of La Constructora, and though this company turned out a losing concern, no blame was attached to him; the fault lay with the other gerente César Saco, also with the Directory, of whom I was one, who were not sufficiently energetic to stop in time the ill-doings of Saco. Rufino married Elena, the daughter of the rich Francis Bryce, and when the Constructora broke up, obtained the situation of one of the two gerentes of the Banco Nacional, in which capacity he had an annual salary of $\mathrm{S} / 10,000$, besides a small percentage on the gains. 25) Vasconcello, the Portuguese Minister in Perú; of him I had only to say that I had met him and his wife several times at Enriqueta's evening parties, and that his uprightness was very doubtful. 26) Dr. Dorado, an excellent little fellow, Vocal of the Superior Court of Justice; once he was raised to the rank of Minister, I forget under whose administration though certainly he was no fit person for such a post. Twice I had lent him money, and both times he had returned it! 27) Doña Carmen Osma de Barreda, who, though no more young, still retained the traces of her former good looks; she was the eldest sister of a numerous family; her father, a native of Spain, had come to Perú like many of his countrymen here to try his luck, and by a marriage with a wealthy lady, una Señorita Ramirez, laid the foundation of his temporal prosperity. Doña Carmen was generally considered to be rather proud of her station in life; my wife and I had however always found her to be very agreeable. Don Felipe [_] her husband born in Lima had been brought up in Spa [...] [642] and returned to his native country when an Independent Republic, well educated, and with a clear head. I first knew him when in partnership with Nicolas Rodrigo, an astute Spaniard, he was established in the Calle de Bodegones, where the two partners kept a store. They remained together for several years, and when they separated, both had made some money. In after times however, though Don Nicolas also made a handsome fortune, Don Felipe 
outstripped him in the acquisition of riches, which may perhaps be attributed to the circumstance that part of the money belonging to Ramirez was placed into his hands at a low interest. Not many years back he divided half his fortune (the other half he kept for the maintenance of himself and wife) between his seven children, to each of whom he gave $\$ 210,000$. Previous to his period he was considered one of the richest men of Lima; he had also the credit of being very reserved and taciturn; however, whensoever I had come in contact with him I had never found the slightest reason to complain of his comportment towards me. His three eldest daughters were: Rosa, Mariana, and Isabel, who when twelve or fourteen years of age sometimes came to my house Calle del Correo, where they played with Corina and Amalia Schutte, and when I also joined them occasionally in their games. Rosa resided at present in Paris, with the one or the other of her younger sisters, because the climate of Lima did not agree with her constitution. Mariana became the wife of Manuel Pardo, and mother of many children. Isabel, as already said, married Manuel Mendoza. 28) Doña Carmen, the wife of Manuel Alvarez Calderon; of her, a native of Ica, I could only say that she appeared to be a good-natured, talkative woman. Her husband, Senator, and a staunch adherent of Manuel Pardo, was brother of the notorious Andrés Alvarez Calderon, who at present in Paris, squandered away the large fortune made by loading guano vessels, the contract of which he had for many years. One of the daughters of Don Manuel was married to Manuel Candamo. 29) Doña Francisca Benavides of Arequipa, wife of Mariano Felipe Paz-Soldan; she was a very old acquaintance of ours, and a very excellent woman; her husband, who in former Governments was seldom without a situation and her son [...] [643] who for a long time had been the manager of the Telegraph Company, were now on bad terms with the present Government, which demanded the repayment of a sum of money lent to the Company at the time of Balta's presidency; thus it was quite natural that this family was not well disposed towards Manuel Pardo. 30) Vicente Gonzales y Pinillos and lady, both from Trujillo; she, Emilia, daughter of the President Luis Orbegoso, was a really well educated and highly accomplished lady; her husband Don Vicente had been my fellow passenger in 1843 to Europe, on board the Vicar of Bray. He was a wealthy man, and one of the Directors of the Banco Nacional, which situation be owed to the marriage of one of his daughters with Augusto Dreyfus of Paris, another daughter was the wife of Dubois, a North American engineer; and his grown up sons, my son Juan told me, were very good young men. 31) The family of Melchor Velarde, brother of Don Rafael and one of my wife's cousins. He was a Colonel, not in active service, and was always doing some business or other, by which means he was able to sustain his wife and eleven children, several of whom grown up daughters, in a respectable and decent 
manner. His wife, Doña Pancha, was daughter of José Mercedes Castañeda, who died at a very advanced age two or three years ago. 32) Juana Rosa, and Mariana Moreira. Of the Moreiras I have spoken above. The former was wife of Nicolas Freyre, Minister of War, at present absent in the South; the latter of Hülsenbeck, a German, who lived in Europe, and to whom she would probably not return. For several years she had resided with her mother-in-law in an estate near Düsseldorf, but as the one did not understand Spanish, and the other was ignorant of German, it was not likely that they could have spent a particularly pleasant life in their mutual society, the less so as Hülsenbeck was frequently absent in Paris. 33) Dolores Puente, my very good friend. She was by no means young, and unmarried; extremely prudent and rational, she knew how to manage her small income, which enabled her to live quietly and very decently. She belonged to one of the old aristocratic families of Lima, in which the right of primogeniture had prevailed, and thus the brother Lorenzo got the whole fortune, which was quickly spent, and the sisters nothing; they were: Manuela, dead, first married to Juan Aliaga, secondly to Clemente Ortiz de Villate; Dolores unmarried; Petita [_] of Frederic Marriott, and Joaquina, unmarried. [644]

Monday, $28^{\text {th }}$ of December 1874. Judge Goitisola did not come to his office under the pretence of indisposition.

Tuesday, $29^{\text {th }}$ of December. I gave in an escrito, in which I said that the term which had been allowed to the architect Quesada for presenting his informe having expired, he, without loss of time should return the Expediente to the Juzgado. On the same day Leyva delivered his escrito, in which he alleged that Quesada being unwell the term for the presentation of his informe might be prolonged. Goitisola was again absent from his office. In the evening I learned that he had thrown up his post owing to some severe article published against him in la Gazeta de los Tribunales. From the foregoing I see that this year the Tribunals were not closed as formerly from the $24^{\text {th }}$ December to the $6^{\text {th }}$ January Epiphany, but that the Vacations - El Punto as it was called - were now transferred to another period of the year say, from Carnival, until Tuesday after Easter.

1875

Friday, ${ }^{\text {st }}$ of January 1875 , I continued, and on

Sunday, $3^{\text {rd }}$ as well as

Wednesday, $6^{\text {th }}$ of January, Epiphany, concluded my round of visits commenced on the Christmas days of the previous year. The nomenclature of the persons, on whom I called, follows: 34) Francisco Sagastabeytia, a highly 
respectable gentleman, of about the same age as Garland, this is to say more or less ten years younger than I. His father, a Spaniard, must have died many years back, for I never heard of him. He himself when a lad entered the countinghouse of Hegan Hall \& Co. Afterwards he was for many years with Domingo Elias, who placed the greatest confidence in him. On his own account he did some business with the Cerro de Pasco, where he established a younger brother of his. Also in Lima he had a shop, not under his own name and thus by dint of perseverance and economy he succeeded in making a small fortune. When the Banco de Lima was founded he was one of the first to take a share in the [_] was immediately [...] [645] Directors, and after Zaracondegui's failure chosen gerente. He sustained his mother, and several sisters, who relied solely upon him, and it was generally believed that he had not married, because had he done so, his means would not have sufficed to sustain the increase of family. He was always seen in the best circles of Lima, and was everywhere well received. 35) Colonel Juan Nepumuseno Vargas, with whom we had become acquainted whilst he was a fellow lodger with the Garlands in the house, which now mine, was then rented by the Sotomayors. He, not in active service, belonged to the ultra-clerical party, and was thus no friend to the present President Pardo. The two mothers of his children had died; by the second, his legitimate wife, he had two little girls, to one of whom Enriqueta had stood godmother, whilst the others, grown up men and women - one of the latter a professed nun - had for their mother a very pretty, not over-virtuous, Limeña, Carmen Quintanilla with whose husband, Vallarino, an elderly gentleman, I was well acquainted in Arequipa about the year 1830. Vargas was at present much esteemed for his upright character. 36) Valeri, a native of Rome, who though a clergyman did not stand in the best repute as to his morality. However, he was considered to be one of the best pulpit orators in Lima; and he drew no inconsiderable revenue from his sermons. We availed ourselves of his influence with the Abbess of the Convent of the Concepcion, to obtain from her the prolongation of the lease of the five shops under my house Calle del Correo, but though Abbess and secretary had signed the Minuta, or rough draft of the contract, the Archbishop had thrown some impediments in the way which Valeri had not been able to overcome. 37) Doña Josefa, daughter of Anselmo Centeno, and widow of Fermin Miota, who died in 1868 of the yellow fever, and whom Miss Flora Tristan has saved from oblivion by mentioning him in her book "Les perégrinations d'une Paria", as having been her fellow-passenger on board a vessel from Bordeaux to the West Coast. Centeno's name has frequently been mentioned in my diary; I knew him first in 1828 in Cuzco, where he had been Prefect and master of the Mint. He seemed to be a pure Indian, and in one 
respect was a wonderful man: he himself confessed to be 87 years old, and I believed him to be at least five years older; he walked about by [_] read without spectacles [...] shaved himself. 38) [_] [646] Peta the daughter of José Gregorio Paz-Soldan, and the wife of Carlos Paz-Soldan, her cousin. Of the Paz-Soldans, I have already said more than enough. Of Doña Peta I will only add that she was a good woman, that she was very deaf, and mother of many children. 39) Doña Josefa, the widow of Dr. Prada, and married for the second time, to the surprise of all who knew her, to a wealthy man Zavala, whom, strange to say, she had never presented to me, though I had frequently called upon her. She belonged to the O'Phelans, one of the most virtuous families in Lima. 40) The wife of Dr. Ramon Ribeyro; of her I only knew that she was the niece of the wife of Vicente Pasos, for many years resident in the United States; her husband, a young man, son of J. A. Ribeyro, Vocal of the Corte Suprema, was a clever lawyer, and to all appearance a decided adherent of Manuel Pardo; as such he was second in command of a battalion of the National Guards; moreover, he was elected vice-president of the Chamber of Deputies, having had the majority over the Candidate of the Opposition Dr. Luciano Benjamin Cisneros; and as the president of the Chamber, General Prado, had absented himself, Ribeyro presided, no small distinction for such a young man as he was. 41) The second wife of Charles Pflucker. This is a strange story. Charles Pflucker, at the same time as I partner of Gibbs, was very intimate with my wife and myself as long as his first wife Doña Gertrudes, belonging to one of the first families of Guayaquil, Rico y Roca Fuerte, was alive. When he separated from Gibbs, and devoted himself entirely to the working of his copper mine at Morococho, his presence there was frequently required, and it was then that to his shame he formed too close an intimacy with the wife of the Administrador of the Mines; by her he had several children. Poor Gertrudes died in Breslaw in Silesia whither she had gone under the pretence of seeing her sons, who were being educated there. They, now young men, turned out extremely well and the four: Carlos Maria, Julio, Federico, and Leonardo, were doing jointly an extensive business as miners and as lessees of a sugar-estate called Falcalá, near Trujillo. The father, a very agreeable, jovial man, robust and strong for his age, and whom I occasionally saw at long intervals had retired [...] [647] from affairs, for having had a slight attack of apoplexy he was not allowed to exert himself. At the earnest request of the sons by the first marriage, he at last married the woman after her first husband had died, and it was she upon whom I called to return the visit which he and she had paid my wife several months back. Contrary to my expectations she knew how to keep up a conversation; her mother was an old Indian woman, whilst the children whom 
I saw were nice little girls very neatly dressed. 42) Mr. and Mrs. Henry, excellent people, and very good friends of mine; I need hardly repeat that Mrs. Henry's maiden name was Anna, the daughter of my good friend, the late Samuel Went, and his wife, Juana Chocano. 43) Mrs. Jose Canevaro Jr. an extremely pretty, and agreeable young lady; her maiden name was Luisa Soyer. She had many brothers and sisters, the eldest, Isabel, José Vicente Oyague's wife, another, Mercedes, married to George Elster, at present in Paris, Victoria, widow of one of the sons of the Chilian Ramos, owner of a sugar estate in Cañete, Simon, Cashier of the Banco Hipotecario, Manuel, first secretary to José Antonio Lavalle, Ambassador to the Courts of Berlin and St. Petersburg, and the last, Salvador. 44) The family Ayulo, our next door neighbours. Enrique, the father, a very agreeable man, I recollected as clerk of his present partner Benito Dorca, resident in Paris, then owner of a store in the Calle de Bodegones. Ayulo's wife, Santos Mendibil was a dashing, and probably expensive lady; her family was only known, in so far as that her brother, a Callao Port-Agent, had years back been one of the first and most successful contrabandists. Dorca and Ayulo were importers of French goods, and exporters of Nitrate of Soda. 45) The wife of Henry Higginson. Him I had known since his boyhood when he entered the counting house of Dalton and Butters, who were then, about the years 1833 and 1834, Port Agents of Gibbs. In the beginning of 1846 on my return from Europe I gave him then shortly established on his own account my port-agency, worth little at first, but very profitable to him when I was associated with Mr. Schutte: since then he had always acted for me in Callao, and I looked upon him as a very good and trustworthy man. His wife, Mariquita, seemed to be goodhearted, and had a few words to say [...] she used to [_] in a really scandalous manner [...] [648] her reputation before her marriage was such that the less I say of it the better. 46) The wife of Manuel Francisco Benavides, both natives of Arequipa; she appeared to me stupidity personified; he, one of Pardo's friends, was Senator in the last Congress, and had again been named for that which was now sitting; during the recess he was even president of the Comision Permanente, and he enjoyed some reputation as a Statesman; however, my opinion of him was none of the greatest. On Thursdays he frequently came to Garland's to play at rocambor. 47) Domingo Valle-Riestra. He entered the Peruvian navy at an early age, and rose to the rank of Admiral. He had certainly not distinguished himself by any great naval deeds, but he was both a good man, and an experienced mariner. Having been struck by apoplexy he retired on a pension, and from day to day the paralysis made palpable inroads upon his constitution. Doña Virginia, his wife, a very clever woman, and a great favourite of mine, was the daughter of La Torre, Minister of Finances many 
years back, and of a daughter of Lorenzo Vidaurre, who in the first years of the Independence acted a prominent part. 48) Doña Juana Valle Riestra, sister of Don Domingo, and widow of Admiral Guise, who, a Captain in the Peruvian Service under Lord Cochrane, passed to the service of the Republic of Ecuador, where he was made Admiral, and killed by a cannon-ball on board "La Prueba" in Guayaquil river. Her daughter Mercedes, now widow, married John Dartnell, a few months before Enriqueta married Garland. She had three daughters: Maria Rosa, the eldest, Jorgina, the youngest, both unmarried, and Maria Luisa, married not long ago to Emilio Althaus, the second son of the Colonel, who in 1825 accompanied me in my ascent of the Misti near Arequipa. Emilio and his elder brother Augusto received their education in France; the first rudiments of trade, Emilio learned in Chile in the counting-house of Cancino; when he returned to Perú, his rich brother-in-law Manuel Cotes made him his partner. When the Banco del Perú was established he was made one of the Gerentes, the other being Meceno Espantoso. When he separated from Cotes he entered into partnership with his half-brot[_] Julio Tenaud. Last [_] he was Prior del Consulado [...] [649] Senator, a great friend of the President, and looked up to as a man well versed in financial affairs. In his social comportment he was rough and uncouth. 49) Pedro Paz-Soldan, the best of the three brothers, owner of a large sugar estate in Cañete. His wife, an Unanue, was in the highest degree insignificant; I never heard her open her mouth; the children on the other hand were well brought up and intelligent; the eldest, Pedro, husband of Cipriana, daughter of Domingo Valle Riestra, was an occasional writer in the papers under the name of Juan de Arona; another, Francisco, was an expert engineer; with the daughters, single and married, I was but little acquainted. 50) Carolina, the eldest, and unmarried daughter of General La Fuente; of him I have often spoken in my diary, for in Peruvian politics he had acted a conspicuous part; he was now a very old man, but kept up wonderfully well; with the family we had been well acquainted as long as Mrs. La Fuente, Doña Mercedes, was alive; two of her daughters soon followed her to the grave: Isabel, single, and Amalia, married to Barrenechea. Narcisa, the youngest, was badly married, and Carolina upon whom I called, was no more in the bloom of her youth, but a pleasant lady. 51) Doña Petita Puente, the wife of Frederic Marriott, the younger sister of Doña Dolores, of a very delicate constitution. She was an excellent woman, perhaps too good for her husband; he was her younger by several years, and suffered from asthma and a weak chest. They had two children, Maria and Federico, doted upon by their Aunt Dolores. 52) Gustavo Heudebert, and his lady Maria Gonzales, not at home. He was partner of Errequeta, who resided in Paris, and though the firm had suffered 
severely by the failure of Bianchi, it had been been able to weather the storm. As co-director in the Banco de Lima he had there his seat next to me, and in our ideas we frequently coincided. His wife was the daughter of the once beautiful Benjamina Elespuru, and of a Gonzales, a great rogue, brother of Don Vicente. 53) Robert Jameson, and Polis, with his wife Emilia Conroy, daughter of Thomas Conroy of Callao, I did not find at home. Jameson was many years back salesman at Gibbs, at the time that Samuel Went was head of the house here. He married Enriqueta, the eldest daughter of Thomas Conroy, afterwards joined the house of Gibbs in Chile, [...] which he separated. He then returned to England and was again [_] [650] out by the parties interested in Europe in the Banco Anglo Peruano. Of Polis a Belgian, I knew little; after having been clerk at various houses, he was now, since the decease of Richard Eggert, who died in 1868 of the yellow-fever, head of the firm of F. S. Isaac \& Co. 54) Mrs. Garron, wife of the Italian Chagé d'Affaires; the last time I had seen her was when the Diplomatic and Consular Corps paid their respects to the Prince of Genoa. Both she and her daughter received me in a very friendly manner, notwithstanding the long time which had elapsed since my last call. 55) Melchor Vidaurre, one of the few, if not the only, strictly upright Vocal of the Supreme Court; he was the son of the above mentioned Lorenzo Vidaurre, and consequently uncle of Virginia La Torre. I only went to see him once a year on twelfth-day, Melchor, Gaspar, and Baltazar being the names, as it is said, of the three kings who worshipped our Saviour in the cradle. He never came to our house, but whensoever I met with him he was always particularly polite. 56) Doña Josefa Torre-Tagle, wife of Dr. Don Manuel Ortiz de Zevallos. Of the Doctor I have spoken more than once. The lady was first married to one of the Moreyras, after whose early death she became involved in a law-suit with her father-in-law. She called in Zevallos, a clever lawyer, to defend her interest, when he knew how to ingratiate himself with her, and, to the surprise of everybody, for it was well known that the Zevallos were of an obscure family of Quito, was accepted when he offered her his hand. Besides the daughter Elena, very well educated, they had four sons: Ricardo a lawyer, married to Carmen, the only daughter of Melchor Vidaurre, Carlos, without any fixed occupation, Teodocio, employed in the Banco Nacional, and Fausto, still in college. 57) Agustin Puente and wife, who were not in, and with whom I was but little acquainted. Agustin was one of the sons of José Puente and Paula Cortes, both dead, who carried on, and lost the law-suit against me when they pretended that the house which Juan Aliaga sold me was not entailed property according to the laws of primogeniture, but belonged to the entire family, of which José Puente was a member. His wife was one of the [...] Demetrio Ola $[\ldots][651]$ 
Thursday, $7^{\text {th }}$ of January 1875. Mariquita, who had been taken ill in the night from Tuesday to Wednesday, did not yet feel well enough to be present at Enriqueta's as usual evening party; neither did I attend, for I also was somewhat indisposed.

In the course of this day I attended the meetings of three Directories of which I was a member.

Firstly. Of that of the Insurance Company Lima. The principal question which we discussed was how the profits of 1874 , which, without any deduction being made for doubtful debts, amounted to about S/64,00o should be distributed. Muro, who sat next to the President Carlos Elizalde was first asked, and replied that in his opinion about the half of the profits, or $15 \%$ on the paid up Capital of S/200,000 should be divided amongst the shareholders, and the balance carried to reserve fund. Next came I, who answered that instead of 15 , only 12 or $121 / 2 \%$, the same as last year, should be distributed, and consequently a larger sum be added to Reserve fund. Carrol and Westphal voted with Muro; Chavez, Peña, Henry, Gil, and Elizalde, with me, and $121 / 2 \%$ or S/25,000 was consequently declared as the dividend for the last year.

Secondly. In the office of the Water Company nothing was transacted, for the number of Shareholders present was not sufficient to form a quorum.

Thirdly. In the Banco de Lima, where Mendoza, Salcedo, and Cucalon were wanting; Mendoza, because he did not like to show his face, several pagarées of his, discounted by the bank being overdue, and as yet unpaid; Salcedo because he having accepted the post of trustee of Julian Zaracondegui's estate, with which the bank was involved in a law-suit; Lembcke, with the consent of Oyague, had not cited him, and the secretary Bernales was now directed to address a letter to Salcedo, representing to him the incongruity of his filling both situations. Cucalon was absent on account of the death of his brother Felipe.

The Gerentes informed us that the contract which on a previous occasion we had instructed them to conclude with a certain Mr. Stirling, who had previously been employed by the Callao Lima Railway Company, to act as Administrator of the Salitrera Esperanza, had been drawn out and signed.

Page 634, it was said that Pierola was on his way to Puno [...] [652] he was, perhaps he was not; certain it is that he suddenly reappeared in the village of Puquina twelve leagues from Arequipa, which I passed on the $30^{\text {th }}$ November 1828 on my return from Tacna. According to Pardo's bulletins he was here completely surrounded, but again succeeded in giving his enemies the slip on the $29^{\text {th }}$ November, favoured by a thick fog, and on the $30^{\text {th }}$ he was, at an early hour in the morning within the precincts of Arequipa, at a spot called "La Rancheria", where the road from Sabandia enters the town; close by, a little 
to the South, is the Pampa de Miraflores, which one has to cross on going to the Sierra; fortunately Pardo was in Arequipa, and he immediately ordered part of his troops to occupy the steeples of the various churches to keep down Pierola. Col. Rivarola marched with a few soldiers under his command, against Pierola's forces, and beat them. Pierola himself again escaped, whilst Escobar was said to have been killed, General Segura wounded. Of Bogardus nothing was known.

Whilst these occurrences took place in the Southern Departments, also in the Northern, Pierola's party still lifted up its head. In the province of Huarochirí, contiguous to that of Lima, Montoneros had reappeared, and killed the Sub prefect of San Juan de Matucanas. In Cajamarca, Iglesias and his adherents were not yet completely put down. Also in the Department of Ayacucho some disorders had arisen, which were however quickly suppressed, thanks to the energetic measures taken by the Prefect Manuel Velarde y Alvarez. During these disturbances, of short duration as they were, two young men lost their lives, or, as the Anti-Pardistas said, were foully murdered. The one was the nephew of General Vargas Machuca; the other, Felipe, a younger brother of Manuel, my co-director in the Banco de Lima, and son of Antonio Cucalon, who, a native of Ecuador, had many years back come to Lima where he had made a considerable fortune, owing, as evil tongues said, to the clever use he knew to make of dice and cards, by which expression I do not mean to imply that cheating was ever imputed to him. His son Felipe, a young man of a restless spirit, was brought up in Europe for engineering and had [_] inscribed under Baltas Adminis[_] [653] in the list of Engineers paid by Government. One of the first acts of President Pardo was to erase his name from the list, which sufficed to make him one of his most inveterate enemies. The father strongly advised him not to mix himself up with politics, but in vain; he first went to Pisco, where he was immediately arrested, and released, bail being given for his future pacific conduct, but as soon as he found himself at liberty he went to Ayacucho where he joined the rebels, who, as already said, were put down, and he himself came to an untimely end.

In the first days of this year I was present at the funeral of two ladies, who had died at an advanced age; the one, the widow of the late Don Manuel Ferreyros; the other, the widow of Juan Ugarte, who, one might say, expired just at the right moment, for owing to the failure of her husbands firm, of which I have already spoken, she and her daughter Dolores, who had been accustomed to live in affuence, had been reduced to very straightened circumstances.

Saturday, $9^{\text {th }}$ of January 1875 . The shareholders in the Lima Water Company assembled to choose Directors for the present year, re-elected those of the previous, with the exception of Enrique Prevost, whose place was taken 
by Meliton Porras, once a needy medical practitioner, at present a rich capitalist.

Sunday, $10^{\text {th }}$ of January. This morning arrived from Mollendo, the "Huascar" and "Independencia", with about fifteen hundred men on board, viz.: The battalion Pichincha of the line, two or three battalions of the National Guard, the body of sergeants, and a few more. They entered Lima preceded by Manuel Pardo, Manuel Costas, Riva Agüero, and other men of importance. Colonel Rivarola had the command. Lizardo Montero, the War Minister, General Nicolas Freyre, and Colonels Velarde and Suarez also came on board of the same vessels, whilst General Buendia had remained in Arequipa with nearly fifteen hundred men. The President did not proceed to the palace, but to his private house, where a considerable number of his friends was expecting him. From Arequipa he had been up to Puno per train, where the Prefect San Roman had given a banquet in his honor. On his return to Arequipa, the foreign Merchants had fêted him with a ball.

Monday, $17^{\text {th }}$ of January 1875 . Tranquillity was now restored in the [654] Southern Departments. Pierola, as already said, had been finally defeated in Arequipa on the $30^{\text {th }}$ November, and Albarracin, who had raised the Standard of rebellion in the Province of Tarapacá, had met with a similar fate in Tacna. With about 200 men, for the greater part Chilians, who were working in the Salitreras, he had approached the said town and summoned the Prefect Sapata to surrender. On receiving a negative answer he entered, and penetrated as far as the Plaza Mayor, where Sapata with his gens d'armes fell upon him, and forced him to retreat, with the few men who still adhered to him.

Wednesday, $13^{\text {th }}$ of January. Though I had not yet recovered from my indisposition, for some opening medicine which I had taken, with the advice of Dr. Bambaren, had much affected my bowels, I could not help being present at the funeral of my wife's and my own very good friend, Dr. Mariano Blas de la Fuente, a very respectable man, who a few days previously had breathed his last at the age of 87 . The attendance was very numerous; I particularly noted many of the Vocales of the Superior Court, with their insignia, a medal attached to a white and red ribbon hanging down over the breast.

Don Mariano Blas, his brother Basilio, several sisters, his cousins Manuel Baltazar, and Eusebia - of all of whom, only the last named, General Pedro Cisneros' mother-in-law, survived - belonged to the highly esteemed family of the La Fuentes of Arequipa, which for many years had derived a large income from their silver mines of Tarapacá; but when the rich veins in these mines were either exhausted or lost, the male members in this family had necessarily to look out for other means to gain their livelihood. Don Mariano Blas studied law, and more than once the Arequipeños chose him for their Deputy to the 
Congress; he had also been Counsellor of State, but in the Judicature he did not rise higher than to the Vocalia of the Superior Court, whence at an advanced age he retired upon a pension. He left a moderate fortune to his widow and to his son, the former a good woman, deaf as a post, the latter a thorough scamp.

I have hitherto omitted to mention the death of Federico Malagrida which occurred very suddenly on one of the last days of December. [_] was a money broker [_] did some business in publ [...] [655] As such, I had sometimes made use of his services, and always found him to be an honest man. He was born in France, and came to Perú many years back quite a boy, with his father, an Italian, Antonio Malagrida, who had a China and earthenware store. After his father's death, young Malagrida married his step-mother! who survived him.

Thursday, $14^{\text {th }}$ of January 1875 . My indisposition still prevented me from taking a part in Enriqueta's Soirée, neither could I comply with the request of the notary Manuel Jesus Escobar to attend at the funeral of his sister Mercedes Escobar de Castañeda, his elder by perhaps forty years. When we lived in the Calle de Mantas, in the house now J. M. Varela's, my wife was well acquainted with this lady, who occupied the house opposite to ours. At last a new Juez de $1^{\mathrm{a}}$ Instancia was named to supply the place of Dr. Adolfo Quiroga; his name was Manuel Antonio Puente Arnao. Ricardo Zevallos and a certain Yañez had previously been named, but both had declined accepting the appointment.

Friday, $15^{\text {th }}$ of January. The members of the Club de la Union gave a dinner to those of their number who, serving in the National Guard had taken a share in the operations against Pierola. Of course Alejandro was one of the guests. Manuel Pardo, and José de la Riva Agüero were also present, the former invited, the latter one of the inviters. Pardo had not yet resumed the Supreme Command, though Manuel Costas, the Vice-President, was very desirous to get rid of it. This latter, Juan, frequently met at Ruden's in Chorrillos, whither he had removed, and taken a room in Cucalon's hotel, whilst he regularly breakfasted and dined with Ruden; sometimes, though not often, he came to town. On one occasion he, Ruden, paid a visit to Pardo, who had treated him with the same cordiality as he used to do before his elevation to the Supreme power.

The resignation of Espinosa, Minister for the Interior, was admitted by Costas.

Two deputies, Emilio Luna, the notorious deputy for Acomayo, and his near relation, the son of the late General Zevallos, when on the road to Huanuco, were arrested by the prefect of the department of Junin; the persons of deputies, whilst deputies, are inviolable, according to the Constitu [...] was thus an infringement $[\ldots]$ and the government $\left[6_{5} 6\right]$ had informed the 
Congress of what had occurred that they might decide on the measures to be taken.

Iglesias and his adherents had been completely defeated and dispersed by a battalion of troops of the line, and № 2 of the National Guard.

Sunday, $17^{\text {th }}$ of January. Though not yet quite well I went out to make some calls, and at last got through with all the names which I had upon my list, with the exception of F. Ford and S. Sattler. Ford was an Englishman, in former years manager of the London Bank of Mexico and South America, at present, partner of Dreyfus, and consequently on the high road to make a fortune. Sattler, a native of Bremen, cousin and partner of Gildemeister, and husband of Beatriz, the eldest daughter of Julius Pflücker, was no doubt a good merchant and a good man, but to my taste too talkative to be agreeable.

58) The first visit I made, was to Asambuja, Brazilian Minister, the successor of Leal, to whom I returned the official visit which he had made me a few days ago. I did not like him at all, and his wife, whom he introduced to me, spoke a language which I could hardly understand, neither Spanish nor Portuguese, but a mixture of both. 59) Demetrio Olavegoya, and his wife Manuela Iriarte. He, a native of the Argentine Provinces had all his life time been a hard working man, and success had crowned his exertions. He was now very wealthy, being the owner of mines and estates in the Sierra in the neighbourhood of Yauli. His wife, a Limeña, about the time of Enriqueta's marriage - then, though a young woman, already the mother of a numerous family - frequently came to us to take a share in the small dancing parties we then gave; her younger sister was Antonia, the widow of a German, Dubocq, whose loss I believe she had no cause to regret. 6o) Manuel-Rosa O'Phelan and his wife Manuela Benavides, both natives of Arequipa, and excellent persons. He had in the course of his long life - for he was now more than seventy years of age - filled many situations under Government. He had been postmaster in Arequipa, Administrador of the Islay Custom-House, and finally one of the members of the Tribunal de Cuentas, an office established in Lima for the examination of all Government's accounts including those given [...] the guano consígnees $[\ldots]$ every $[\ldots][657]$ he had given satisfaction. He and his wife lived in a quiet manner upon the income which they derived from a house of their own in Lima, from an estate which they possessed in Tambo or some other valley in the vicinity of Arequipa, and from some Cedulas del Banco Hipotecario. He had also a pension from the Government, but upon its regular payment he could not count in the present state of Peruvian Finances. 61) Climaco Basombrio and his wife Carmen Carrasco; he was the cousin of our stout friend Juan Bazo, his father, and Baso's mother having been brother 
and sister. I first became acquainted with him when the Banco del Perú was established, where he filled one of the most responsible positions, whilst Emilio Althaus and Miceno Espantoso were gerentes; when the Banco de Lima was established he was engaged by this bank, and paid a higher salary than he had received in the Banco del Perú, and again at the establishment of the Banco Nacional he passed over to this bank, where he was now one of the gerentes, with an annual salary of $S / 10,000$, a small percentage upon the net gains, and a fine suite of apartments, rent free, in the first storey of the bank. His second wife, the first having been the sister of that Lopez Hurtado who failed at the time that he occupied one of the stores in my house, was the daughter of Dr. Antonio and Carmen Carrasco, whose names have been mentioned more than once in this diary. Carmen was a very good woman, her elder sister Manuela, who lived with her, so devout, that she never would show her face to visitors, whilst their two brothers, Antonio, and Feliz were downright rogues. I called upon several other persons, but as they were the same whom I had seen on the previous holidays, it is superfluous to repeat their names.

Monday, $18^{\text {th }}$ of January 1875 . About this time we had some trouble with our servants. Ayao, our Chinese, fell ill, and we had thus to take our meals with Garland's family; the Chinese cook, not our trustworthy Achipe, was no great proficient in the culinary art. The black woman Peta had left my wife to set upon her own account as a washerwoman, and only this day we had engaged a young black-woman in her stead, Ecsequiela, who had that recommendation that she was related to Enriqueta's Aurelia and Virginia, both honest to the back-bone.

Manuel Pardo again took the reins of Government into his own hands, and $[\ldots]$ the Vice-President retired [...] private life. José de la Ri [...] [658] Minister for Foreign Affairs, was provisionally entrusted with the portfolio of the Interior, lately resigned by Rospigliosi, which measure caused some surprise, a rumour having been afloat that both he, and Sanchez, Minister for Justice, would resign. In the Chamber of Deputies one of the members had called upon Riva Agüero, to justify the arrest of the two Deputies, Luna and Herencio Zevallos, an arrest the more unjustifiable, as the order for the same should at all events have emanated from the Minister for the Interior, at that time Rospigliosi, and not from the Minister for Foreign Affairs Riva Agüero. I had no conception what this last named gentleman would do with regard to the Banco Hipotecario, of which he was the original gerente, for Escudero, the provisional gerente, had assured me a few days previously that he would without fail throw up the post within a few days, and if Riva Agüero did not go to the bank, who would be there to take care of the establishment? Moreover, 
the same Riva-Agüero had promised about a year back in the general meeting of shareholders that the S/200,00o owing to the bank by the Pasco Railway Company would be paid or at all events satisfactorily settled; nothing of the kind had as yet been done, and how would it be possible for him to defend himself in the next meeting when called upon to explain how the matter stood, by the one or the other of the shareholders not friendly inclined towards him?

At 2 O'clock I went to the Exchange Rooms in the Upper story of the Consulado, were a meeting of the shareholders, of the Insurance Company "Lima" was convened; a very small number was assembled, of the Directory, only Elizalde, Henry, Carrol, and myself; of the other shareholders, Juan Martin Cardenas, Russell Dartnell representing Castagnini, Narciso Velarde, and at the utmost two or three more. According to statutes we proceeded to business half an hour after that fixed for the meeting, that is to say, at 2.30. The statement of the proceedings of last year was read, and Cardenas moved a vote of thanks to the Directory, which passed. Six new Directors had to be elected in lieu of Garland, who had sold his shares, Westphal, who had resigned, Robertson, who had left Lima, and Gil, Peña, and I who went out by rotation. The six Directors now elected were [659] Gil, Peña, and myself, Dionisio Villate, Narciso Velarde and Moscoso Melgar. This being done, a written motion signed by Carlos Elizalde and Narciso Velarde was read, the object of which was to reduce the number of Directors from twelve to seven, and to draw lots, so that chance should decide who of the twelve Directors were to remain in. I opposed this motion, and gave it as my opinion that seven were too few, and that at least there should be nine, but the majority was against me; not so in the second, more important, point. I said it would be improper to leave to chance the nomination of seven Directors, and that they ought to be chosen; after very short debate, all agreed with me. Finally, Cardenas proposed that the Directors should receive a small remuneration for their trouble, viz. $5 \%$ of the profits; this again I opposed; the greater part were silent, and the final decision on all three points stood over till the next general meeting. I had then to attend the meeting of the Directory of the Banco de Lima. All were present except Salcedo, Castillo, unwell, and in bed, and Mendoza, said to be indisposed. In the first place, Salcedo's answer to the letter written him by Secretary Bernales was read: he said in the same that we had separated him from the Directory, which was not true, and then continued the letter in an ironical style, in reality ridiculing the Directory, and concluding with the request that his letter might be read in the next general meeting of shareholders. Bernales was authorized to return the letter to him, accompanied by a few words to the effect that the Directory had not separated him, and that we did not choose to become the 
conduct for communicating his ideas to the shareholders. Next, Lembcke gave his usual account of the state of the bank, which in truth was lamentable. Montero Brothers and Henry Meiggs owed large amounts and did not pay; and $S / 1,200,000$ the bank had advanced to the Salitrera "Esperanza"; Stirling however wrote that there was every probability of obtaining a sufficient supply of water, though somewhat brackish, from a well, the digging of which had been begun, and that to bring the fresh water from a distance by means of tubes as had been proposed, was not to be thought of, for the expense, owing to an intervening low ridge of hills, would be very heavy. Then came the main question, what dividend was to be declared? Oyague, Lembcke, Cucalon, and I [...] convinced that in reality nothing should be given to the sharehol[_] [660] but we also knew that this would have a very prejudicial effect upon the shares, which already could be had at $40 \%$ discount, and thus, after some talk on the subject it was decided to declare an interest of $9 \%$, of which $4 \%$ on the paid up capital of $S / 2,500,000$, say $S / 100,000$ should actually be paid to the shareholders, and the other $5 \%$, or $\mathrm{S} / 125,000$ be added to the respective shares, so that the paid up capital would come to $55 \%$, instead of $50 \%$ as hitherto.

Wednesday, $20^{\text {th }}$ of January 1875 . Edward Knauer came to see me; he had just returned from Europe, where he had left his two little children with his eldest sister Maria, married to Arthur Donner, in Altona. He told me that trade both in Altona and Hamburg, was carried on upon an unsound footing, that the great bankers, and old established houses did still a good business, and made large profits, but that the smaller houses stood, in his opinion, upon a volcano, and that the crisis would ere long overwhelm them. Altona, he added, had certainly wonderfully increased in population, but it was after all, a very poor place, owing to the circumstance that a large proportion of the inhabitants consisted of the poorer classes of society who preferred to reside in Altona, where living was cheaper than in Hamburg,

Friday, $22^{\text {nd }}$ of January. Last night the rocambor players in Garland's soirée were: at the one table where they played four or five Soles the point if not higher: Nicolas Hurtado and Manuel F. Benavides, Senators, Jose Canevaro, Deputy, and Dr. Corso, a native of Arequipa, married to a rich lady of Guayaquil. At the other table where the stakes were, I believe, not above one Sol the point, played Garland, Picard, Col. Masias, and Gregorio Benavides. Round the roulette the ladies were: my wife and Enriqueta, Luisa Soyer, the pretty wife of José Canevaro, Gregorio Benavides' wife, two daughters of Melchor Velarde, and Zoila, Rafael's daughter. Alejandro and Enrique Cox were the bankers, and I believe gained handsomely. My wife lost her S/4. I did not play, and went to 
bed at eleven, but by making difficult multiplications in my head kept myself awake till one, when my wife came.

This morning before breakfast I took a walk as far [...] [661] Alameda de los Descalzos; then to the right, passing the new market-place which was shut up, over the lower ridge of San Cristoval descended where the broken arch stood, and returned over Balta's bridge; this proved that I was recovering my strength, though my bowels were still out of order.

In the remodelling and copying of my former diaries Bryson and I made quick progress, which was owing in a great measure to the few alterations we had to make in what Richard Bullen had written under my dictation.

In the forenoon Bryson read to me occasionally the Lives of Foreign Statesmen in Lardner's Encyclopedia, written in a heavy style, and sometimes even in Faulty English. The hour from seven to eight in the evening was, I might say, the pleasantest time of the day. I was now for the second time listening to the reading of the highly interesting work "Alisons History of Europe from 1789 to 1815 ".

In the Senate the Government met with a rebuff. Pardo had been desirous to reward some of his military friends who had served in the South, by giving them higher grades in the army, and a motion was made accordingly. However, the Senate only consented to raise Lizardo Montero to the rank of "ContraAlmirante", and Velarde and Suarez from brevet Colonels to real Colonels.

For more than a year, perhaps for two years, Guillermo, Garland's Second son, had paid his addresses to Eliza, Henry Higginson's eldest daughter, who had readily given her Consent; so had her father and mother, but Garland and Enriqueta, my wife and myself, though we had no objection to the bride herself, who was a very good girl, were averse to the match, firstly, for the reason which may be inferred from the few words said on the $6^{\text {th }}$ January under $\mathrm{N}^{\circ} 45$, and secondly, because we considered that Guillermo had not the means to sustain a wife, and family. He was partner of two Italians in a coal business, which did certainly not leave large profits, and even were there any, according to contract none of the partners was allowed to withdraw any money until their capital had reached a certain sum. Further, owing to the loss of the vessel "Guillermo", of which I have spoken above, and the bad result of various imprudent speculations into which Guillermo [...] tered during his father's absence [_] latter had been under [_] [662] necessity of making heavy payments for his son, for which he would not be reimbursed for a length of time. Father and son jointly owed me about S/22,00o upon which I charged no more interest than $4 \%$ annually, and even this small disburse of $S / 73.33$ cts monthly would fall heavily upon Guillermo's purse. These were certainly sufficient reasons why 
Guillermo should not marry, but what could be done? he would be twenty-four years old within a few days and, as already said, he had the consent of Eliza and of her parents. In the morning, Higginson, the father, had spoken to Garland on the subject; in the evening he came to my wife and myself rather low spirited, and begged us to be present at the marriage which would be celebrated next evening in his house. Mariquita begged to be excused, because her delicate health did not allow her to go out in the evening, and in this she was not altogether wrong, whilst I at once acceded to Higginson's request.

Saturday, $23^{\text {rd }}$ of January 1875 . The Senate thought proper to reconsider the resolution taken on the previous day; in other words, in the twenty-four hours which had elapsed, a good many of them had been influenced by Manuel Pardo; they acceded to his wishes, and the Republic had now the following new generals: Freyre and Buendia, generals of division, Rivarola and Javier Osma, also Leyva and Barredo, Generals of brigade. My opinion was that Pardo had done wrong in having insisted on these promotions, and the Senate in having granted them, for, what had they done who had gone to the South? nothing but their duty; 5000 regular troops and national guards had overcome 1000 armed men collected and equipped in a fortnight's time; surely this was no great deed of arms. Alejandro said that fidelity ought to be rewarded, a poor compliment to the Peruvian Army.

At about 8 p.m. Garland and Enriqueta, Enrique and I drove to Higginson's house, Calle de Gremios. Enriqueta did so very reluctantly and only at the very last moment had she given way to her husband's and son's earnest entreaties. On our arrival we found a large party assembled; I was immediately lost in the crowd, and was glad to meet Gre[_] [663] Escardó, whom I had not seen for a length of time: we sat down on a sofa and I listened to a long account which he gave me of his illness, and how the Chinese Doctor had cured him in a fortnight, whilst the best doctors of Lima had carried him to the very brink of the grave. So the time passed away, which was all I desired; I also spoke a few words with Thomas Conroy of Callao, José M. Cantuarias, José P. Escobar, and Melchor Velarde. There were a good number of gentlemen, amongst whom Manuel Pardo, the President, and José Antonio Ribeyro, Vocal of the Supreme Court of Justice, but neither of them did I see. As soon as the bride and her mother came from inner apartments, the ceremony took place, of which I saw nothing nor did I wish to see anything. Sitting on the sofa, between me and the bridal couple stood a cordon of gentlemen five or six deep. I merely heard the clergyman murmur the service, and the clear, distinct "si" which Guillermo answered to the various questions asked him. I then begged Melchor Velarde to conduct me to Mrs. Higginson and the bride; I shook hands with each, and 
presented my congratulations in a few words; I did the same to Guillermo, looked for, and found my hat and stick, and walked home. Garland and Enriqueta came in a carriage hardly ten minutes after me. Enrique, Alejandro and Ricardo came home at midnight, about which time an express train conveyed the couple to Higginson's country house in Chorrillos. The families of Ayulo and Mendivil, intimate friends of the Higginsons, were the only ladies present at the ceremony not belonging to the family.

Sunday, $24^{\text {th }}$ of January 1875 . As soon as Bryson had gone, with whom I made fair progress in revising my diary written in German when in 1855 on my travels with my wife and grand-daughters, which Ricardo read aloud, and I then translated, I took the two O'clock train for Chorrillos though I felt weak, having suffered during the night loose bowels. I alighted in Miraflores, where I had not been for twenty years. An avenue leads from the station to the village, a distance of about a quarter of an hour's walk, to the left a row of houses with a foot pavement made of wood, to the right, fields, partly barren, partly cultivated. In the village itself I noted great improvements; for instance, formerly water was brought $[\ldots]$ the houses by water carriers; now by means of pumps it was rais [...] [664] from the beach, where sweet-water springs gush from the hills, and then distributed by subterranean pipes to the different houses. The cost varied according to the quantity consumed, but for a moderate family it was about six Soles monthly. I asked my way to the house of William Scheel, partner of Dreyfus, who was the great man in Miraflores. He received me in a friendly manner, and showed me all over his extensive establishment. The area it occupied was 11,0oo square varas; the house, very neatly furnished, had every possible comfort; the garden was crossed by straight paths cutting each other at right angles; they were overshadowed by high trees, which already existed when Scheel bought the ground, and by dense luxuriant shrubs planted by him; the most interesting was the menagerie, no doubt very expensive. He had six horses, two for himself, two for his wife, and two for Mr. and Mrs. Lührsen; several donkeys, two beautiful cows, which provided him and family with abundance of milk; poultry, wild and tame ducks, a peacock, various small birds in a large cage of iron wire; in another, canary birds; in a third, birds belonging to the parrot species, two white cockatoos, several green loritos, and a steady, formal-looking huacamayo with its rich plumage and hooked peak, a vicuña; deer, male and female, disporting themselves on two small meadows, and so tame that they approached the railing in expectation that Scheel had brought them something to eat; two land turtles, two foxes in a cage by themselves, and a black bear, which, on seeing its master approach, came to the iron-grating and showed its disappointment at 
not receiving its customary lump of sugar. There was moreover in the garden a ground for playing at ninepins, and a billiard-room; in this latter I rested a little and requested Scheel to let me have a little wine and water, for I felt extremely weak. At a quarter past three Scheel showed me the way through the garden, to the house, his property, which was occupied by Dr. Luhrsen and wife. It was smaller, but otherwise quite as neat and pretty as that in which Scheel lived. Mr. and Mrs. Lührsen were at lunch; both, particularly she, were nice people, with them were O'Connor of Cal[_] I could not conceive how Lührsen picked up such acquain[_] [665] and his secretary, Captain Oldenburg. I remained till near four O'clock, when Mr. Lührsen accompanied me to Scheel's garden, where he, his lady, and several gentlemen took their lunch in a shady bower. I bade them good by, and returned to the station, where we were on very good time for the train which had left Chorrillos at 4 O'clock. Capt. Oldenburg told me that he belonged to the Prussian army, which he had entered voluntarily as a common soldier, and been quickly promoted to his present grade, that of Captain. He had served both in 1866 in the war against Austria and 1870/71 in that against France; in the former he escaped unhurt; in the latter he was twice wounded, the first time at Saarbruck, a mere flesh wound, which was quickly cured, so that in four weeks he had been able to rejoin his battalion; the second wound, a more serious one in the leg, he received at Lemans towards the end of the war, and in order to get perfectly cured of the same he obtained leave of absence, of which he had availed himself, and entered the service of Mr. Lührsen as his secretary. He had also been present at the siege of Metz, and confirmed to me what I had already learned from other sources, viz.: that quite in the beginning of the siege, say for four or five days, Marshal Bazaine might perhaps have been able to break through the besiegers at some point or other, though, he added, the effect which repeated defeats such as the French had suffered, have upon an army, is inconceivable; moreover, the discipline, never very strict amongst the French, was much relaxed, and thus Bazaine might have found some difficulty in bringing the soldiers to the scratch. Afterwards, the Prussian General-in-Chief took such measures that every sally would have infallibly been beaten back. When I reached my house I felt extremely weak, and continued so the remainder of the day. In the meanwhile, whilst I had been absent in the country, there had been a numerous gathering of the partizans of General Prado, the ex-President of Perú, who on the $27^{\text {th }}$ Decr. 1867 had been miserably beaten by the Arequipeños, and on the $6^{\text {th }}$ January 1868 ignominiously expelled by the Limeños. In this meeting, a committee was named for the purpose of using all their efforts to bring about the election of said Prado for Constitutional President of Perú, after the expiration of Pardo's period on the $2^{\text {nd }}$ August 1876 . Amongst the members of this com [...] the 
names of: General Luis La Puerta, president, Pedro Pa [...] [666] Pablo Vivero, M. F. Benavides, Buenaventura Helguera, Rafael Velarde, Alberto Elmore, etc.

Our good friend, Don Bartolomé Araoz came to inform us that on the $16^{\text {th }}$ of this month, his grand-daughter Micaela had been married quietly and privately to a certain Flores, a shop-keeper. She, the pet of her grand-father, was an agreeable young woman; her father was Antonio, Don Bartolome's second son, who died about a year back; her mother, Don Antonio's first wife. She had a fortune of her own, and great expectations, for Don Bartolomé was a rich man and had only three children besides the late Antonio; and thus I thought she might have made a better match, for though Flores, whom I did not know personally, was for aught, I knew, a good man, I did not like his connections. His mother, widow of Col. Flores, was married for the second time to Julian Zaracondegui. From Europe we had the news that Don Alfonso, Prince of Asturias, eldest son of the dethroned Isabel, had been named King of Spain, taken possession of the throne, and formed a cabinet.

Tuesday, $26^{\text {th }}$ of January 1875. A motion made in the Chamber of Deputies to pass a vote of censure on the Minister Riva Agüero for having ordered the arrest of the two Deputies, Luna, and Herencio Zevallos, was negatived, the noes being 47, the Ayes 37. The papers published an official note directed by the Minister of Finances J. J. Helguera to the Chamber of Deputies, in which he said that on account of the five millions of Soles which the Congress had authorized the Executive to borrow in order to defray the expenses which might be incurred in the suppression of Pierola's revolt, S/774,6oo had been received, viz.

From the United Estates Guano Company

$\mathrm{S} / 125,000$

From Jose V. Oyague, purchaser of guano for Havana and Porto Rico S/249,600 From Mr. Champeaux, Agent of the Société Générale to be repaid out of the proceeds of the first loan or guano contract which might be made

$\mathrm{S} / 400,000$

And of these

$\mathrm{S} / 774,600$

about $\mathrm{S} / 500,000$ had $[\ldots]$ extraordinary expenses caused by [...] [667] revolution.

Thursday, $28^{\text {th }}$ of January 1875. I was present at the meeting of the shareholders of the South American Insurance Company. With the exception of the Directors not many attended. Alexander Ruden presided. Enrique Ayulo read the statement of the proceedings of the year 1874. They were very satisfactory, though the profits not quite so large as those of 1873; then each shareholder received 60\%, and I of course \$1200 upon my \$2000 paid up capital, whilst this year, $1874, \mathrm{~S} / 40,000$ had been distributed between the 
shareholders on the $30^{\text {th }}$ June, and an equal amount would now be given, corresponding to $31^{\text {st }}$ December, total $S / 80,000$ or $\$ 100,000$ equal to $50 \%$ on a paid up capital of $\$ 200,000$. In the course of the year the insurances against sea-risk amounted to about three and a half millions, the premium upon which to $S / 49,407.39$ [ct]; insurances against fire risks to $S / 3,900,000$, premium upon the same, $S / 48,372.73$; interest gained $S / 43,600$. The losses paid in the course of the year had come to the trifling sum of $S / 832$. Besides the capital actually paid up, of $S / 160,000$, there was a reserve fund of $S / 240,000$; and moreover, the Directory had thought proper to open two other accounts, the one for the purpose of paying losses already known, but the exact amount of which was not yet as certained, with $S / 22,000$ to its credit, the other, to meet the depreciation of Shares in other companies, held by the Insurance Company, with S/34,029.72. The last named amount was in my opinion insufficient, otherwise everything seemed to be well done. Three Directors went out: Polis, Manuel O. de Villate, and Leuthold. The first two were re-elected, instead of Leuthold, Bartolo Figari. In the evening my wife and I were on the point of paying a visit to Doña Tomasa Gonzales, Bartolomé Araoz' second wife, which visit my wife had put off for an unpardonable length of time; but at the very last moment I felt so weak that I had to go to bed. Mariquita remained with me an hour or so, then went over to Garland's side of the house where this evening the Soirée was very poorly attended.

Friday, $29^{\text {th }}$ of January. Our Chinaman Ayao had recovered his health; the cook did his duty, and Ecsiquela turned out a very good girl. Thus, for the moment we had no reason to complain of our servant[_] except of the stupidity of Ayao, who made not the slightest progress in learni [...]. In the course of the forenoon [...] to the Banco Nacio[_] [668] where the meeting of the Shareholders had been called together. Derteano, the President, made a few appropriate remarks; then Rufino Echenique one of the gerentes, read the informe. The amount of cheques drawn upon the bank in 1874, came to more or less $\mathrm{S} / 42,000,000$ and about an equal amount had been paid in. In 1873 the bank discounted eighteen million Soles, in 1874, nine millions. The gross gains in 1874 amounted to nearly one million Soles, of which about S/140,0oo were left to the credit of the Iquique branch, and another sum - how much I did not recollect - to reserve account; next, expenses, including patente, salaries, etc., $20 \%$ of the gains to the Directors and $5 \%$ to the gerentes and clerks, were deducted, and there remained at net profit of $\mathrm{S} / 540,000$ for the shareholders, say $15 \%$ upon the paid up capital of three million six hundred thousand Soles. Of these, $41 / 2 \%$ have been paid in the course of the year and $101 / 2 \%$ would now be distributed. 
At 3.30 I was in the Banco de Lima; of the Directors, Salcedo, Castillo, Mendoza, and Gil were absent. In the first place the answers to Salcedo's letter which had not yet been sent, was once more discussed; as this was of little interest to me, I took no share in the debate. Next, Lembcke read the report on the truly sad situation of the bank. The $9 \%$, interest, which according to Statutes the bank was obliged to pay to the shareholders, should, as previously be determined, be divided in the following manner: $4 \%$ to be actually paid, and $5 \%$ to be added to each share as an increase of the paid up capital. This last, being an innovation, for the statutes did not authorize the Directory to make the distribution in this manner, I insisted upon the necessity of our taking the consent of the shareholders before doing so. Pedro Bernales sided with me, with his assistance I carried the point, and the gerentes were instructed to convene a general meeting of shareholders for the $4^{\text {th }}$ February. In my lawsuit against Leyva we had progressed one step. The two architects whom Leyva and I had respectively named, he Quesada, I Castillo, to examine the Ayres, had not agreed in their opinion; accordingly, the judge Puente Arnao, had to name a third to decide the question. Dr. Palacios had flattered himself that the not[_] [669] Escobar, by means of his influence with the judge, could have induced him to choose one of three whom the Doctor had proposed, but he was mistaken, for the judge's choice fell upon a certain José Castañon. This morning I was out early to make the choice known to my lawyer and Rafael Velarde, and both assured me that they were well acquainted with him, and expected to be able to influence him in my favor. So the matter stood.

Saturday, $30^{\text {th }}$ of January 1875 . This day the sessions of the ordinary Congress closed, and by a proclamation, "bando", the Congress Extraordinary was convened for the $3^{\text {rd }}$ February.

In the Banco del Perú, the shareholders who assembled were not in sufficient number to form a quorum, and accordingly it was resolved that we should again meet on the $11^{\text {th }}$ of next month.

Sunday, $3{ }^{\text {st }}$ of January. I took the two O'clock train for Chorrillos, but got out at the Barranco, where I called upon the family of J. A. Ribeyro, and upon J. P. Escobar and wife. At both places I met with a very friendly reception and Ribeyro was very jocose, as he sometimes was. He told me amongst other things that one day when conversing with Riva Agüero about J. A. Garcia y Garcia being admitted into the cabinet, Riva Agüero merely observed: "los Monitores pesan demasiado", referring of course to the enormous gain which, as everybody knew, Garcia y Garcia had realized for himself when purchasing in the United States for the government, the two monitores which were now uselessly moored in the Bay of Callao. The village of Barranco was fast 
improving and increasing in size; many houses were large and comfortable, but hardly a single one had a view upon the sea, which was a great drawback. I returned by the 4 O'clock train.

Monday, $7^{\text {st }}$ of February. In the forenoon I called upon José E. Castañon, named by the judge as Umpire in the question relative to the Ayres of Leyva's house. I had to make myself known to him, which being done he was very polite. We sat down on the sofa; he told me that both Dr. Palacios and Rafael Velarde had interested themselves in my favor, that Leyva had done the same through his friends, and that he believed I was in the right. In the course of the day he went to the Tribunal, and took the requisite oath.

Tuesday, $2^{\text {nd }}$ of February. Candlemas. I went by the 2 O'clock train to the Barranco, there to bathe. The descent to the sea is long and gentle $[\ldots]$ and bushes, sometimes plantains [_] upon the sides of the ab[_] [670] sandy hills which confine the descent on both sides. On two spots the road was shaded by vines drawn over trellis-work. On reaching the beach I found that the conveniences for bathing were still in their infancy; the hut into which I was shown for undressing was more or less like those in Chorrillos fifteen years back, consisting of mats, and a narrow wooden bench to sit down upon, instead of a wooden staircase to descend into the sea, the steps were formed by big stones, in my opinion impassable for ladies; the entire beach was covered with stones, and so was the bottom of the sea. On the other hand, the water was beautifully clear, and the big waves came rolling in so that I had to make an effort in order not to be overthrown. After all I enjoyed the bath, and then walked to Chorrillos; the fields were irrigated everywhere, so that I could not follow the path along the high coast, had to make many circuits, to jump over more than one pool of water, and at last emerged into the railway at a short distance from Chorrillos. Here I called upon Mrs. Henry, who, suffering from a violent headache, was not to be seen, upon Manuel Costas, General Pezet, and Dr. J. M. Perez; everywhere I had to leave my card, for nobody was at home. I was back in Lima before five.

José de la Riva Agüero at last had left the cabinet and returned to his old post in the Banco Hipotecario; with him went out José Eusebio Sanchez, Minister of Justice, and in lieu of these two the President Pardo named Aurelio Garcia y Garcia, Geraldo's late Superior as Ambassador to Japan and China, for the interior, and provisionally for Foreign Affairs until the arrival of Anibal La Torre, at present Peruvian Minister in Bolivia. Many years back I had known his father, and I knew his sister Virginia, both intelligent persons, which made me conclude that the son and brother would not be inferior to his father and sister. 
Dr. Odriozola, a medical man, Pardo entrusted with the portfolio for Justice and Ecclesiastical affairs.

Wednesday, $3^{\text {rd }}$ of February. Early this morning Enriqueta, Garland, and all in our house whose bedrooms looked toward the street were awakened by a violent knocking at the street-door [...] [671] wanted him to come to their aid, for the father Don Enrique had had a stroke of apoplexy, and immediate medical assistance was to be sent for. Alejandro was at the time paying his addresses to a Miss Roel, niece of Mrs. Ayulo, and this accounted for their intimacy with him. In the course of the day I attended the usual monthly meeting of the Directory of the Banco de Lima, in which nothing of importance was transacted. I was requested to join on the following day a commission of four members who had been previously named to revise the statutes of the bank, and to introduce alterations where they might be wanted.

Thursday, $4^{\text {th }}$ of February 1875. I went accordingly at a little past three and found at their work, Francisco Sagastabeytia, Julio Armero, Luis Benjamin Cisneros and Manuel Cucalon. I sat down with them. At the other end of the table Lembcke had taken his seat, whom we occasionally asked for this opinion. Considerable changes were made in the statutes; hitherto each share consisted of S/25,000 They were now subdivided into five of S/50oo each; instead of eleven Directors, and two "Directores Gerentes", there should be henceforth twelve Directors, and two Gerentes; seven should form the quorum instead of nine as hitherto. The Director whose pagaré in the hands of the bank was overdue and unpaid, ceased de facto to be a director: the Gerentes were not allowed to take a loan from the bank, in any shape, or under any pretence; the shareholders were not permitted to examine the books whensoever they liked, but at the end of the year they were laid before them and they might then make any observation they thought proper; the reserve fund of $10 \%$ upon the net profits, before $9 \%$ interest was deducted, was to go on accumulating from year to year until it reached the amount of $20 \%$ upon the paid up capital.

From Enriqueta's tertulia in the evening I withdrew to my side of the house before the party broke up, for I still felt somewhat indisposed. After having suffered from loose bowels I had been troubled for a few days with dyspepsia, so that I had thought best to apply to Dr. Bambaren who prescribed some pills to strengthen my digestive organs. Garland, as said above, was liquidator of the late Juan de Ugarte's estate, thus he knew all that was going on there, and from him I learned that the rich [...] [672] Valladolid, belonging to the estate, for S/50,000, the other, Calle de San José from Serdio, for S/70,000; this latter, Serdio, had taken from the estate in cancelment of his claim on the same, and 
sold it to Varela, with the condition that if he returned the purchase money within two years, the house was again to be delivered to him.

Friday, $5^{\text {th }}$ of February. The Architect José Castañon came to examine the Ayres of Leyva's house; Alejandro went with him in my stead. When he had done he came to see Mariquita and myself, conversed a short time, and as far as I could judge was favourably inclined towards us. On the same day when I looked in at the Insurance Company Lima I learned to my great sorrow from Carlos Ferreyros, the naval officer, that his eldest brother Manuel, Gerente of the said Insurance Coy. who had of late expressed a wish to be allowed to go to Europe, there to be cured of a serious illness from which he was suffering, was in fact somewhat deranged in his mind, and that for the present he could not return to the office. In the Banco de Lima I was for this month Director de Turno instead of Manuel Mendoza, who had requested me to take his place as he was staying in Chorrillos, consequently I had to go there every day between 3 and 4 p.m.

Saturday, $6^{\text {th }}$ of February. This day, the Tribunals closed, excepting the Criminal Court, and would not reopen until Wednesday after Easter. For the next judicial year Melchor Vidaurre was chosen President of the Supreme, Bernardino Leon, of the Superior Court.

In the evening of this day my lawyer Fernando Palacios married Josefina, one of the daughters of Manuel Palacios and Mariquita Mendiburu. The ceremony was performed in the house of Bishop Huertas, where I was told that many persons had been present, and was therefore rather surprised that he had not told me a single word about it.

From Sunday, $7^{\text {th }}$ to Tuesday, $9^{\text {th }}$ of February. These three Carnival days I spent this year in a less tedious manner than I had done in previous years. At 12 O'clock I went per train to Chorrillos, bathed, made some calls, and was back in Lima for dinner. The so-called carnival-play was c[_]ied on with little spirit, and though [...] [673] means I escaped wetting, yet I regretted that it was so on account of little Maria who had promised to herself much fun, and who now passed the day almost as quietly as any other day in the year. Even of her brothers none was at home. Twice Bryson read to me in the evening; Alison's History of Europe became the more interesting, the further we proceeded. We had now come to the time when Napoleon was first Consul, when the Prince D'Enghien was shot in the ditch of Vincennes, and when Pichegru, Captain Wright, and Toussaint-L'Ouverture were found dead, each in his respective prison, whilst no one could, or would say whether they had died a natural death, whether they had committed suicide, or whether they had secretly been done away with. Of these three presumptions the last is the most probable. 
Of my visits in Chorrillos I will only enumerate two or three: that to Mariano Felipe Paz Soldan, with whom I conversed a long time about the quechua language, which in its grammar is very complete: the Indians conjugate their verbs and decline their nouns, without however knowing the art of writing in their own language. With Heudebert, in his palace-like rancho I had a long talk on the subject of the Statutes of the Banco de Lima; and finally, when entering the large house, formerly Carolina Losternau's, at present Francis Bryce's, I made a blunder, which however I was not sorry for. I wanted to see Rufino Echenique, who with his wife, Helen, Bryce's daughter, occupied the upper story, but by mistake I knocked at the saloon on the ground-floor, where I was received by Bryce, who immediately introduced me to his elder brother John, just arrived from Europe. I enquired of him for my old acquaintances, for instance for Samuel Lang, of whom he could give me no particulars, for the two brothers Jack, alias Fletcher, with whom he was not even acquainted. Of Henry Dalton, many years ago port-agent in Callao, with whom he himself had been apprentice, he could only tell me that he had gone to California. This elder Bryce had come out in all probability to look after the affairs of his firm Bryce Grace \& Co., of whom it was known that they, as well as Francis Bryce individually, were frequently hard up for money. Moreover, Francis had laid out much money - probably more than he should have done; in the purchase of Houses in Lima and Chorrillos, [...] in a Sugar Estate Santa Clara situated on the Oroya li[_]. [674]

Wednesday, $10^{\text {th }}$ of February 1875 . Last night little Corina was very ill, so much so that my wife could with difficulty be persuaded to lie down in her bed; she wanted to watch the little girl, which however Enriqueta would not allow on any account, whilst she herself had not a wink of sleep the whole night. In all probability Corina had eaten too much during carnival.

Thursday, $11^{\text {th }}$ of February. The Shareholders of the Banco del Perú had their usual annual meeting. Emilio Althaus, who presided, read the statement of the transactions during the past year, and declared a dividend of $12 \%-41 / 2 \%$ already paid seven or eight months ago, $71 / 2 \%$ now to be paid. One entry of S/200,00o for bad debts, carried to the debit of Profit and Loss was found fault with by two small shareholders, the one said that these debts had been made before the last increase of capital when new shares were issued and sold to the public first at 5 then at $21 / 2 \%$ premium (when I myself bought ten shares at the latter price), and this being the case, it was in his opinion improper to throw the loss of the $S / 200,000$ upon the present shareholders; the other opponent opined that it was hard that the present year should bear exclusively the loss

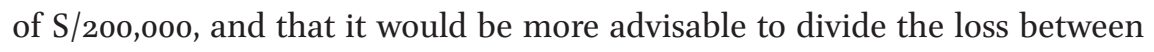


1874 and 1875 . Althaus and other Directors replied with great forbearance, and gave the reasons why they had acted in the manner they had. As regards the heavy amount of $S / 600,000$ owing in the Cerro, Calderoni affirmed that this debt was by no means so decidedly bad as it was generally believed, and that the Cerro de Pasco branch was always of advantage to the bank, firstly, because a large amount of notes was put there into circulation, and secondly, because the Banco del Perú received thence a supply of silver bars, which the other banks did not. Polis, the manager of F. S. Isaac \& Co. adverted to the S/60o,0oo due to the bank by the Eten Railway Company, but did not insist on detailed explanations, on the contrary, appeared satisfied with an evasive answer given him by Althaus. This debt of the Eten Railway was the sorest point in the affairs of the bank. The Directors who went out were re-elected with the exception of Carlos Delgado y Moreno, whose place was taken by the rich José Unánue, owner of a Sugar estate in Cañete, and [...] [675] intellectual capacity.

In the meeting of the Directory of the Insurance Company Lima, the President, Carlos Elizalde, acceded to our unanimous request to attend with more than usual care to the affairs of the company, whilst the illness of Manuel Ferreyros lasted; of the remuneration he said he wanted nothing for himself, but that he intended to divide it between Ferreyros, and the principal clerk Valdivieso.

Saturday, $13^{\text {th }}$ of February 1875 . I was occupied in the Banco de Lima together with Francisco Sagastabeytia, in looking over the list of debtors. I found that nearly $S / 3,000,000$, not exactly irrecoverable, would at all events take a very long time before they were paid; such were the $S / 1,000,000$, increased by $\mathrm{S} / 200,000$ since the $1^{\text {st }}$ January, by the Salitrera "Esperanza", and many hundred thousands due by the landed proprietors Geronimo Sanchez, Belisario Eysaguirre, a certain Jimet, a certain Alzamora, and others; not much better than these were thousands and thousands which stood to the debit of Henry Meiggs, Montero Hermanos, José Muro, M. M. Perez, Arizola, who made his fortune during Balta's administration, and others. Thus a very heavy amount was locked up without the bank being able to dispose of it; consequently the business the bank could do was trifling, and the profits, if any at all, could only be insignificant.

In the morning, a fire broke out in Callao, and destroyed, as the papers said, property to the amount of $\mathrm{S} / 400,000$. At about 5 a.m. heavy columns of smoke had been observed to issue from the store of Bryce Grace \& Co., or, as others said, from that of O'Connor \& Co. The alarm was given, the fire engines were on the spot, and assistance was rendered from on board, but water was scarce. In Lima the fire-bell tolled at 7.30, and when the Lima engines arrived 
at somewhat past 9 , the fire was already got under. The following property had been destroyed: the store of Bryce Grace \& Co., insured in the Royal-North

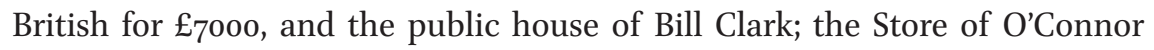
\& Co., and the St. James Hotel, property of Cantuarias, O'Connors premises insured for S/25,000 in the Imperial; house of Sancho-Davila, with the store of the gas fitters Taylor and Macintosh; also the store of Aguirre, insured for [_]5,00o in the Imperial had suffered considerably. The [...] [676] Insurance Companies fortunately escaped without loss.

Sunday, $14^{\text {th }}$ of February 1875 . I went to Chorrillos by the 2 O'clock train, took my sea-bath, and returned at four O'clock.

Monday, $15^{\text {th }}$. Juan came in from Chorrillos to be present at the funeral of Juana Canaval, Benito Valdeavellano's wife. I did not attend having to look after a sudden inundation in the store 45 Calle de Aldavas, which had not been let for several months and consequently been shut up all the while. I called in the plumbers Hart Brothers who were of opinion that the waste pipe was obstructed, that therefore the water could not reach the main sewer, retroceded, and spread everywhere. Without loss of time they set to work to make the necessary repairs. Benito Valdeavellano was left with ten children, the eldest 12 years, the youngest fifteen days old; he had lost the use of one of his eyes and his entire fortune. The estate, with the liquidation of which Carlos Elizalde was entrusted, would probably not give more than $10 \%$. In the course of the day I was with the Directors of the Pasco Railway Coy:: Felipe Varela, Agustin Escudero, and Francisco Bohorquez. The first named said that he had been with Riva Agüero, who had told him that the decree for the conversion of the S/400,00o Pasco railway bonds into Vales de la Nueva Consolidacion, had not yet been signed by Pardo, but there was not the slightest doubt that it would be done ere long. Until the debt owing by the Railway Company to the Banco Hipotecario were cancelled, Riva Agüero, the manager of the latter, could not possibly call together a general meeting of the shareholders, and the time fixed upon by the statutes for this meeting was now fast approaching. Varela added that whilst on the one hand the Government had not yet done its duty to the Railway Company, on the other it had already embargoed some rails belonging to the same company, and deposited somewhere in Chancay.

In the evening the usual annual meeting of the shareholders of the Banco de Lima took place in the locality of the bank. At half past seven, half an hour after the time fixed upon for our meeting, Oyague had not come, and I, as Vice, had to take the chair, which I did very reluctantly. To my right sat Dr. Luis B. Cisneros whose seat was afterwards taken by the secretary Pedro Be[_] [677] to my left Heudebert, Manuel Mendoza y Boza, and Manuel Cucalon; Valentin Gil, 
Helguera, and the gerentes were also present; thus the Directory was complete, with the exception of Oyague, Castillo, unwell, and Manuel Salcedo. Cisneros read the acta of the last meeting, which was approved; next, the names of the shareholders present were called over and noted down, and Oyague not having come yet I had to make a short speech, which I did, but I was by no means satisfied with myself; I spoke badly and became confused. I said however that the two commissions, named in the last meeting, had done their duty, the one in reforming the statutes, which, if the shareholders were willing, might be read and discussed this very evening. The other commission had examined the accounts of the Salitrera "Esperanza"; engineers had been sent thither, who had given in their reports; and finally, that the Directory had placed at the disposal of the said Salitrera $\mathrm{S} / 200,000$ from which $\mathrm{S} / 30,000$ interest due had been first deducted, all in conformity with the authorization given them by the shareholders. I also said that the Banco de Lima had taken possession of the Salitrera, which was now administered by the same, on account of the Company. Hereupon Lembcke read the memoria of the gerentes, in which he stated amongst other things that the Directory declared a dividend, or rather the interest of $9 \%$ for last year, but that the state of the finances was such that it would be highly inconvenient to pay the $9 \%$ cash down. It was now again my turn; I said the Directory had thought of paying $4 \%$ cash, and of adding $5 \%$ to the value of the shares, that is to say, $5 \%$ upon the paid up capital, which would be equal to $21 / 2 \%$ upon the nominal capital; but that we submitted this to the shareholders, not being permitted to do so by the Statutes, which said that when making a call on the shareholders for a percentage on their shares, thirty days had to be allowed them for paying in the money. Escudero replied in moderate and proper terms that he was decidedly opposed to this manner of disposing of the $5 \%$, because by increasing the nominal value of the shares, each shareholder would in reality lose 30 or $40 \%$ upon this increase, for the shares were actually at this discount in the market; moreover, the increase of the nominal amount would augment the difficulty at the end of the present year, to pay $9 \%$ on $[\ldots]$ and he therefore proposed that $4 \%$ should be paid now and [_] [678] remaining $5 \%$ in the course of the year, whensoever the bank could conveniently do so. I answered that I considered his observations to be well founded and that I agreed with him. Now, Juan Martin Cardenas, the same who some weeks back had eulogized the Directors of the Insurance Company Lima, rose and spoke for a considerable while, but all he said was to the disparagement of the Bank, of the Directors, and of the Gerentes; he insisted upon the $9 \%$ being paid in conformity with the Statutes, when I broke out in these words: "if you insist upon receiving $9 \%$ the Directory will 
make a call for $10 \%$, which you must pay, or your shares will be confiscated"; to this he did not reply. Now Oyague came and I ceded him my seat. Again Cardenas spoke, and this time he attacked still more the management of the Gerentes, and of the Directory. Lembcke stood up, but was persuaded not to speak by those near him; Cucalon and I tried to make Oyague say something, but he would not. I could not contain my ire, and directing myself to where Cardenas' voice came from, for see him I could not, I said in a bond voice "you speak, and speak, and say nothing; do you think it is pleasant to be a Director? move a vote of censure against the Directors and the Gerentes, and be yourself Gerentes and Directory all in all." By this time Oyague roused himself and made a long speech; he poured oil upon the troubled waters, and at last the proposal made by Escudero was put to the vote, and unanimously carried, Cardenas himself included.

The choice made by the Directory of Luis B. Cisneros as provisional Director was approved, and a new Director was chosen instead of Manuel Salcedo. John Gallagher was chosen with 80 votes, Escudero had 26, amongst which my 4, Cardenas 17, and Castro Zaldivar, the great talker in the last general meeting 3 , perhaps those of Cárdenas.

Thursday, $18^{\text {th }}$ and Friday, $19^{\text {th }}$ of February 1875 . The Directory of the Banco de Lima held long sittings from 2.30 to $5.30 \mathrm{p} . \mathrm{m}$. The second day we were joined by Agustin Escudero and Julio Armero, who, together with Dr. Aranivar, Manuel Cucalon, Luis B. Cisneros, and Francisco Sagastabeytia, the three last named members of th[_] [679] Directory, formed the commission named by the shareholders for the remodelling of the Statutes of the bank. Every article was read aloud, eagerly discussed and many of them altered. Of course, the opinions were frequently divided, nevertheless both sessions went off and closed in the most friendly spirit, and with the [_] harmony. Mendoza did not attend either the one or the other day; Helguera was present the first day, and say little.

Monday, $22^{\text {nd }}$ of February 1875. At an early hour I attended in the Church of La Trinidad the Misa de Gloria, accompanied by instrumental music, which was sung at the funeral of a little child of the Chilian Minister Godoy.

Tuesday, $23^{r d}$. At 2 p.m. in the office of the Eten Railway Company, some of the shareholders assembled. It was about two years back that they had had the rashness to guarantee in a public document, or escritura, "el Servicio", that is to say the payment of $9 \%$ annual interest and $4 \%$ annual redemption on bounds amounting to one million Soles deposited in the Banco del Perú as guarantee for a loan of $S / 600,000$ and interest at $1 \%$ per month made by the said bank to the company. This Company could not pay the S/60o,ooo, and 
various proposals had been made to the bank, to come to some understanding or other. Alexander Ruden, one of the Directors of the Banco del Perú, at the same time one of those who had guaranteed the servicio, was in favor of such a friendly arrangement; two or three of his colleagues in the Banco del Perú went hand in hand with him, whilst he was violently opposed by Peña, Ayulo and Chavez, who insisted upon the bank proceeding judicially against those who had guaranteed. The meeting was convened in order to hear the opinion of everyone interested; present were: Felipe Varela, representing his father Jose Maria, J. A. Garcia y Garcia, Manuel Candamo, Ruden, Aurelio Dinegri, J. P. Escobar, who soon left, Le Maitre, Jose Canevaro, José Unánue, Manuel Yrigoyen, an individual unknown to me, and myself. The debate was very animated; all except myself took a part in it, and I only gave my opinion when I was asked for it, and then said that I agreed with Yrigoyen, who declared in clear terms, that he would comply with what he had signed, viz.: "para hacer el servicio de los bonos", not to the Banco del Perú, which had no claim upon him, but to the Eten Railway Coy. [...] the escritura decidedly expressed. Moreover, it was to be bo [...] [680] mind that those who had guaranteed were not responsible for the entire "ser[_]o", but only for the part which the railway might be unable to pay. Candamo was more or less of the same opinion, whilst Varela declared in a firm voice that he would not pay a cent of the guarantee, that he would allow himself to be sued in the Courts of [_]e, and defend himself to the last extremity. Unanue sided with him; the remainder did not say what they intended to do, and the meeting broke up without having come to any resolution.

Friday, $26^{\text {th }}$ of February The Shareholders of the Banco Hipotecario had their usual annual meeting, which this year had been postponed to a very late date. Riva Agüero was present as gerente; of the Directors only Escudero. John Gallagher animadverted very properly and in strong terms upon the absence of the two others, Manuel Mendoza y Boza, and Felipe Barreda y Osma. Riva Agüero read the Memoria, also the opinion given by Lucas Oyague and Peter Gallagher named to examine the accounts of the bank. The profits, according to Riva Agüero, came to $10 \%$, which he proposed to pay, $5 \%$ on the $15^{\text {th }}$ March, $21 / 2 \%$ on the $15^{\text {th }}$ June, and $21 / 2$ on the $15^{\text {th }}$ August. Various shareholders, particularly Dr. José Aranivar, required explanations; the latter asked what security the bank held for the $S / 200,000$ owing by the Pasco Railway. Riva Agüero answered that the security held consisted in above S/200,00o Pasco Railway Bonds given by the Government, and in an escritura for £10,ooo given by several capitalists; and that he gave his word that within a few days this debt

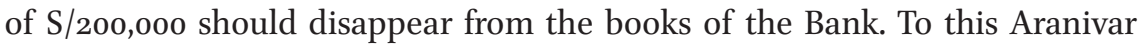
replied that if the debt were not paid, he made the Directors responsible for the 
payment of this sum, lent in opposition to the Statutes of the Bank, whereupon Riva Agüero said that he considered himself responsible; as gerente, for the fifth or sixth part corresponding to him of the said loan. Now John Gallagher rose, and gave it as his opinion that in the straightened circumstances of the bank, it would be more prudent not to pay any dividend at all, but to place all the profits, if there were any, to the credit of a reserve fund. I said that I adhered to his opinion. Jose Vicente Oyague spoke against our suggestion, so did other shareholders; again [...] [681] rose, but it being now as late as half past four, when many present had to go to Chorrillos, the meeting broke up to reassemble at an early date.

Sunday, $28^{\text {th }}$ of February 1875 . This being Guillermo's birthday, part of our family had been invited to dine with Mr. and Mrs. Higginson in Chorrillos. Only Garland, the two little girls and Antonio went; my wife, Enriqueta, and I, preferred staying away. I however did not lose my sea bath.

Monday, ${ }^{\text {st }}$ of March. This being Juan's birthday, he by Enriqueta's invitation came to town to dine with the family. I however had to rise before the others, as I had to be at 7:30 in the Banco de Lima where a meeting of the shareholders had been called together for the object of discussing the new statutes. Oyague not being present I presided. Mendoza and Heudebert were also wanting. Of the shareholders but few attended; amongst them, Juan Martin Cardenas, and Pedro Castro Zaldivar, who from the very first manifested the same spirit of hostility against the Directors, which they had shown at the previous meetings. When the acta of the last meeting had been read by the Secretary Bernales, Cárdenas made a long speech to prove that it was incorrect; much time was lost, many angry words were exchanged, but the acta remained as it was. The list of those present was read over, and the discussion relative to the statutes commenced, in which Cardenas, Zaldivar, Escudero, and all the Directors except Helguera - who did not know what to say - and Sagastabeytia, hard of hearing, took a share. The Bank's future business was henceforth to be confined exclusively to banking operations; its duration was fixed at 30 years from the date of its establishment. Both alterations, proposed by the opposition, were unanimously agreed to; next, came the point whether the present shares of $\mathrm{S} / 25,000$ each were to be reduced to shares of 5000 or of 1000 Soles each. This was an open question, and gained by those who were for the $S / 5000$, by a small majority. The next question was of vital importance; hitherto, as it is the custom in all banks, the Directory had fixed the day when calls for new cuotas were to be made, and to make these calls as little burdensome as possible, we had never asked for more [_] $5 \%$ at a time, with an interval of at least thirty days [...] [682] each call, now Cardenas and Zaldivar proposed and insisted that this attribute should be taken from the Directory, and that the shareholders in 
a general meeting should determine when the calls were to be made. This we strenuously opposed, and it was on this occasion that I said to Zaldivar, who sat opposite to me: "If we are bad Directors; if you have no confidence in us, it is your own fault, why have you chosen us? if you wish to take my seat, do so and I will take yours", to which he replied "no, I am very well where I am." It was now getting late, many had to go to Chorrillos, by the last train, no decision was come to, and it was near 11 O'clock when I reached my house.

Tuesday, $2^{\text {nd }}$ of March. This morning at 7.30 I went out to have a look at the Hospital, solely for male sick, called "Del 2 de Mayo" inaugurated on the preceding Sunday, to which solemnity I had been invited, but had not gone. The construction of this edifice was decreed under the Presidency of Pedro Diez de Canseco in 1868 when Dr. Bernardo Muñoz was Minister for the Interior. Its cost came to 830,000 Soles, part of which was found by the Beneficencia, part by the Government. Its Architect had been the Italian Trefogli, and Gaspar Puente and Juan Valdeavellano, members of the Beneficencia, had superintended the building. It stands just outside where formerly the Cocharcas gate was, upon a piece of ground belonging to the Chacra Manzanilla, Antonio Bazo's property. The area it occupies, is I should think nearly equal to that of a block of houses or "Manzana" in Lima. The height of the walls does in my opinion not correspond to the dimensions of the edifice; were they one, or perhaps two feet higher, it would no doubt have a more striking appearance. The façade turned towards the town has an iron gate on the centre; the two corners are flanked, each by a turret somewhat higher than the walls. The walls of the three other sides have not the slightest ornament. When I had made my circuit and stood again before the railing where the main entrance is, a gentleman on horseback, Juan Valdeavellano, asked me whether I should like to walk in. I answered in the affirmative, and entered. The first patio, or yard, is more or less of a qua[_] [683] shape, surrounded by wide porticoes, which are sustained by massive square columns, not of marble, probably of brick, and whitewashed. From the porticoes, many doors open into apartments of various dimensions. From this first patio a wide and vaulted passage leads to another yard, large, of a circular shape, again surrounded with porticoes; it is filled with shrubs and flowers, in the centre a large basin with water, with a fountain, and filled with small fishes. On the other side, exactly opposite the passage, is the chapel, the interior of which is very tasteful; the pavement is of marble, the altar of the same material. Without a guide I wandered about for more than an hour, through the labyrinth of saloons and rooms, along the passages, and through many gardens, all of a triangular shape. At last, as good luck would have it, I met Juan José Moreyra, one of the members of the 
Beneficencia, named Inspector of the Hospital; under his guidance I formed a clear idea of this splendid establishment; there are twelve saloons for the sick who are received and cured gratis; these saloons are of various sizes - in one of them stood fifty-nine iron bedsteads, in another fifty-five; in another thirty nine; each iron bedstead with its mattress, two clean cotton sheets, two pillows, with clean covers, and a woollen coverlid, the color of these coverlids different in each saloon, in the one red, in the other red and white, in the third green and white. About the middle of each of these saloons is a door, which through a short passage leads into one of the many gardens. At one extremity of each saloon is a corredor, from which doors, many of cedar wood, open into two rooms inhabited by the sister of charity who has this particular saloon under her care; all these sisters are Frenchwomen. Water closets and marble baths are to be seen in every direction. It is calculated that 600 sick can be accomodated, but Moreyra thought that in case of need, the number might be increased to one thousand. There are also saloons and private rooms for such as are willing to pay for admittance to the hospital. Moreyra showed me to the two rooms where meat is kept, to the kitchens, to the servants hall, to the washing establishment, to the place where linen is hung out for drying in summer, to another where in winter it is dried under shelter; he showed me to the rooms of the two chaplains, to the extremely neat apothecary shops, where the presses are of [_]lished mahogany, and finally to the tower on the left on entering [_] [684] hospital, where the dead are to be deposited, and through a side door to be carried to the cemetery; in the ceiling is a large hole, through which the corpses, which the physician should be desirous to dissect in order to discover the cause of the disease and death, are hoisted up to the upper room, which, rather low, is of course of the same size as the lower one. The platform on which the corpses are to be placed is of marble, with a small hole in the middle for the blood to run off. The only apartments which I did not see, were those allotted to the sisters of charity of whom, including the superior, there were twenty one. I was home a little past ten O'clock much pleased with my visit.

In the course of the day the Directors of the Banco de Lima had their usual monthly meeting, when, to my great surprise, a letter was read, directed by Jose V. Oyague to the Gerentes, in which he requested them to inform the Directory that his many own affairs, and the attention which he had necessarily to bestow upon them did not leave him the necessary time to act as a Director of the Banco de Lima, and that consequently he resigned the Directorship, and Presidentship of the Directory. He added in the letter, as a proof of his entertaining no bad opinion of the present condition of the bank, that he had 
bought a few shares over and above those he already held, so that at present he was the largest shareholder. The Directors who were present agreed that a commission should be named to wait upon Oyague, and to beg him to alter his resolution; Heudebert Castillo, and Cisneros were named.

Wednesday, $3^{\text {rd }}$ of March 1875. Once more a meeting of the shareholders of the Banco Hipotecario, present: Riva Agüero Gerente, Escudero and Manuel Mendoza Directors, Felipe Barreda y Osma had sent in his resignation, having to absent himself from Lima. Of the shareholders the principal orators were: Clemente Noel, Sebastian Lorente, who once had a college in Jauja and was now one of the professors in the University of San Carlos, Dr. Forero, Senator in the Congress, Manuel Candamo, Diego Lopez Aliaga, procurador of the Superior Court, and John Gallagher. After a very long and animated discussion the following resolution was come to, viz.: That of the profits of 1874 only [685] a proportion as the Statutes allowed should be carried to a reserve fund, whilst the entire balance should be distributed amongst the shareholders as soon as the funds of the bank would allow the Directors to make the payment; this last proviso was the point upon which Gallagher insisted and which was carried at last unanimously, though I was sure not to the satisfaction of all present. Now came the election of new Directors; Mendoza said he also resigned, but whether all considered his resignation as valid was doubtful, for some gave their written votes for five, others for four Directors. I gave my vote for Escudero, Gallagher, Candamo, and Felipe Varela; only a few remained to learn the result of the scrutiny. There were 300 votes, thus the majority was 151; only two obtained this majority, viz.: Agustin Escudero 160 odd, Jose V. Oyague 152, Simon Soyer, hitherto Cashier, known to be extravagant in his expenses, also an inveterate gambler, and of whose strict integrity some doubts began to be entertained, had as many as 140 votes, which in all probability he owed to such of the shareholders as were desirous that the mismanagement, of which it began to be rumoured, he had made himself guilty, should not come to light. He was the cousin of the President, their mothers being sisters, also brotherin-law of Jose V. Oyague, but I was convinced that neither of the two had taken any step to favor his election. I, to my great astonishment, had between fifty and sixty votes.

Saturday, $6^{\text {th }}$ of March 1875. The Commission, named on Tuesday last, informed the Directory of the Banco de Lima that though they had seen Oyague more than once, he had remained inflexible, and would not return as Director to the Bank. Our opinion was, that though there was some truth in the large business which Oyague urged as the reason for his not being able to attend, the main cause of his resignation was the annoyance to which the President 
of the Directory was exposed in the general meetings of shareholders, and of which of late he himself had once or twice made the experience. Now a new president and Vice-president had to be chosen, and though I did my utmost to induce my colleagues that their choice should not fall upon me, I was again elected by eight, out of nine votes. The first time, none had the absolute majority for the Vice-Presidency, the second time, Heudebert [_] five of the nine. At a later hour a few shareholders of the [...] [686] Pasco Mineral Railway Coy., assembled in the premises of the Banco Hipotecario. The "Acta" of the last meeting was read and approved, and after some desultory talk we agreed that another extraordinary meeting should be convened for Saturday next, for the sole purpose of naming one person who alone should be authorized to treat with the Government, which had already laid an embargo upon the railway itself, and the rails which lay scattered about in various places, from the coast to the Cerro.

Sunday, $7^{\text {th }}$ of March. This being the first Sunday in the month Mr. Bryson did not come in the forenoon, and I availed myself of the leisure time to go to Chorrillos by the 12 O'clock train. By 2 O'clock I had taken my bath, and the two hours till 4, when the train returned to Lima, I spent in making five pleasant visits; to Mrs. Juana Guise, where I met her agreeable sister-in-law Virginia de la Torre; to Doña Dolores Puente, who resided with her sister and her brother-in-law Frederic Marriott; this latter, who, he told me, frequently spent the evenings in the house of Don Manuel Pardo, assured me that it was the President's desire to purchase all the Salitreras in the Province of Tarapacá, and that a European house, or company, was ready to advance a very large sum of money on condition that the Salitreras were mortgaged, and the consignment of the Nitrate secured to the same. The project which about this time was presented by Chinarro in the Chamber of Deputies relative to the Salitreras, contained, Marriott said, Pardo's own ideas. From Marriott's house I went to that of José Maria Sancho Davila, where Doña Fortunata not yet being ready to receive, a young lady, unknown to me, took her place. In course of conversation I learned from her that she was one of the orphan children of Enrique Perez de Velazco who, an extremely clever man, had first come to Lima in 1860 or 1861 as Chargé for the Republic of Venezuela; shortly after, a revolution broke out in that Republic, he lost his situation, and, as he said, all he then possessed, whereupon he settled over to Lima with his wife and various young children. He gained a livelihood as teacher in various sciences, formed a mercantile establishment under the auspices of Nicolas Rodrigo in which he did not prosper, for [...] [687] thrive under the close cutting shears of Don Nicolas. He had died almost in poverty about a year ago, his wife 
having preceded him to the grave. My last two calls were upon Jose Vicente Oyague and José Canevaro; at the former's were his wife, two or three of his daughters, and one or two visitors; at Canevaro's only gentlemen, eight of whom sat round two rocambor tables. It was said that José Canevaro aspired to one of the Presidencies of the Republic, and that for this reason he showed great attention to the Senators and Deputies, whom he not only frequently invited to his houses in Lima and Chorrillos, but to whom, and this was the main point, he advanced their stipends, with which the Government was in arrears, he knowing full well that though there might be some delay he would finally be reimbursed. Little Corina was very ill, and had been so for the last few days. My wife even feared for her life.

Thursday, $11^{\text {th }}$ of March 1875. I was present at two meetings. In the forenoon at that of the shareholders of the Banco Hipotecario. Riva Agüero, the Gerente, presided, contrary to the rules of all other banks, with which establishments it is the duty of the President to be in the chair; to his left sat Escudero; Mendoza, who had given in his resignation as Director, took his seat among the shareholders. The last acta was read and approved not without several remarks; next, two propositions made by Dr. Aranivar in a former meeting, and still pending, were discussed. The one was that, without any distinction, the gerente should in future judicially proceed against every debtor who was in arrears with one single three-monthly payment; the other, that the penal interest of $3 \%$ per month should be levied upon every one behind hand in his payments. Animated debates ensued, in which took part: Diego Lopez Aliaga, Jose V. Oyague - less prosy than usual - John Gallagher, Manuel Candamo, Clemente Nöel, and one or two more unknown to me. I merely said that in my opinion the $3 \%$ penal interest monthly was ridiculous, preposterous, and ruinous for the debtors, and that the highest rate which ought to be charged should be $11 / 2 \%$. Finally, the following resolutions were taken, viz.: the penal interest was to be henceforth $11 / 2 \%$ monthly, $3 \%$ as soon as judicial proceedings should be instituted against an urban proprietor as soon as he were two, against a rural proprietor as soon as he were three three-monthly instalments in arrears. To the latter, in the last case, even [_] days mo [...] race were allowed. We then proceeded to the elect [...] [688] Directors. Escudero's late election was null, because he, not being owner of forty shares, required two-thirds of the votes and one more, and these two thirds he had not obtained. Oyague admitted his nomination; Mendoza's resignation was not accepted, and thus three new Directors and two Suplentes had to be chosen; John Gallagher for Director, and José Jimenez, a common cholo who had made his large fortune by usury, for Suplente, were the only ones who had the number of votes required - the half, and at least one more. Simon Soyer and I came closely up to the number for 
Directors, Melchor Velarde for Suplente; consequently a new meeting had to be convened. In the evening I had to preside in the meeting of shareholders in the Banco de Lima. We took our seats at a quarter to eight. Of the Directors all were present except Mendoza and Helguera; of the shareholders not many: I noted the two eternal opponents of the Directory, J. M. Cardenas, and Pedro Castro Zaldivar, Jose Basagoytia, Dr. Aranivar, who spoke much to the purpose, Antonio Baso, and Camogli, married to a daughter of the deceased Pedro Dinegri, who appeared to me a vulgar Italian. These last named voted upon the whole with the Directory. When the acta had been read, Cárdenas made his observations; they were replied to by Pedro Bernales, the Secretary, and at last the acta was approved, not unanimously, but by a majority. Then the names of those present and those represented were called over. I made known the resignation of José V. Oyague and then said we might continue with the discussion of the remodelled statutes, which I begged would be done with calmness and moderation. Pedro Bernales left in the meanwhile, and John Gallagher took his seat to my right and rendered me great assistance in the course of the evening. The first thing proposed was to reconsider whether the shares were to be divided into shares of 5000 or 1000 Soles each. The reconsideration was carried, as well as the division of the shares into $\mathrm{S} / 1000$ by a considerable majority, several Directors voting also in its favor. I was against it, so was Lembcke. The next important point was whether the calling in of a quota of $5 \%$ should depend upon the Directory or upon the general meeting of shareholders. Cardenas [...] [689] with much animation; they were opposed more or less by all Directors, most efficiently by Lembcke and Gallagher. When brought to the vote the opposition lost by a large majority. Other alterations were of little importance; the principal one proposed by Cardenas, and immediately agreed to by me, was that not only the election of the Directors, but also their removal, should be done secretly, that is to say, by papers, and not publicly, which means that those in favor of a measure rise, and those against it, keep their seats.

When I came home, nearly at 11 O'clock, a small party was assembled in Enriqueta's saloon; there was only one rocambor table, and ten or twelve persons round the roulette. I hardly played at all, and we broke up at midnight.

Saturday, $13^{\text {th }}$ of March 1875. At a meeting of the shareholders of the Pasco Railway Company, only the following few were present: the four Directors, Escudero, Bohorquez, Felipe Varela, and Peter Gallagher, also I, Col. Joaquin Torrico, a in every respect wicked man, and Dr. M. M. Galvez, brother of Don Pedro, Peruvian Minister in France, who (M.M.G.) represented the interest of Don Nicolas Rodrigo, whose youngest daughter, the widow of Herce, he was about marrying. Considering the scanty attendance we thought proper not to 
enter into any discussion, but to convoke another meeting. Hereupon Galvez proposed and Bohorquez and Torrico insisted that the advertizement for the convocation should say that the Government had embargoed the railway; I said that I was decidedly opposed to such an advertizement and that I begged that my opposition would be noted down in the acta. Escudero sided with me, Gallagher and Varela said nothing. Galvez however altered the advertizement in so far as merely to say that matters of great importance would be discussed.

Sunday, $14^{\text {th }}$ of March. By the two O'clock train I went to Chorrillos, and after my bath searched in vain for the house of Dr. Anibal V. de la Torre, who, just arrived from Bolivia, had accepted his nomination as Minister for Foreign Affairs. In the evening my wife and I on foot paid three visits, the first to the wife of the Brazilian Minister, the second, to the wife of Dr. Manuel Morales, married for the second time, and the third, to Doña Carmen Montero, widow of a certain Argüellas. The two first [...] [69o] acquainted in Chorrillos in the year of the yellow fever, 1868. Since then she had lost her husband, had been twice to Europe, travelled about a good deal, and had thus something to say for herself.

Tuesday, $16^{\text {th }}$ of March 1875. There was a numerous gathering of the shareholders of the Insurance Company Lima for the purpose of electing seven new Directors, all the previous ones having gone out. Carlos Elizalde, the President of the Directory, who acted at the same time as Gerente since the illness of Manuel Ferreyros, had drawn out a list with the following names: Elizalde, Henry, Carrol, Witt, Gil, Peña, and Moscoso Melgar; such lists were distributed amongst the shareholders, and every one of the seven was elected by the number of voted required, say at least one more than the half of the votes, of which there were 147 , consequently 74 formed the majority. Elizalde had by far the greater number, nearly all the 147 ; next to him came Henry, then I, if I mistake not with 111, the remaining four more or less the same. It was however clear that another party had been intriguing against us; there were many lists which had the names of Escobar, Leuthold, Ford, Meceno Espantoso, and Derteano. I met here Juan Martin Cardenas, the great opponent in the Banco de Lima; he overwhelmed me with civilities, assured me of his esteem, and added that against me personally he had no ill-will, but certainly against the statutes of the bank, which stood in need of reform. In the evening once more the shareholders of the Banco de Lima met to continue their discussions on the subject of the statutes. It was nearly eight when I took the chair, Pedro Bernales, the secretary, to my right, John Gallagher, my faithful aidede-camp to my left. Of the Directors, the following were wanting: Mendoza, Helguera, Heudebert, Castillo, and Luis Cisneros, the latter excusing himself with indisposition. The debates were animated, Cardenas talked a great deal; Focion Mariategui, Escudero, Manuel Cucalon, Gallagher, P. Bernales, also took 
a share. I believe Lembcke spoke only once, when he gave up the right which was secured to him by escritura, to be gerente for life. I myself lifted up my voice many a time, but not once did I venture on a long speech. Upon the whole every thing went off in a friendly spirit and we [...] [691] the satisfaction to conclude our work. The two main points which were decided were: firstly, that Lembcke's resignation as gerente for life was accepted by all the shareholders who were not Directors, and who formed the majority, whilst the Directors present, Cucalon, Gallagher, I, Bernales, Gil, and Sagastabeytia, did not admit it. Henceforth the Gerentes were so for 3 years only, but could be re-elected; the second point of importance was whether there should be a reserve fund or not; there was a strong opposition to it. The majority however, of which I was one was in favor of such a fund. It was near 11 O'clock when I came home, and found all in the house asleep.

Thursday, $18^{\text {th }}$ of March 1875. A well attended meeting of the Banco Hipotecario took place. Riva Agüero, the gerente, again presided, on one side of him sat Escudero, on the other Mendoza. Oyague and Gallagher had their seat among the shareholders. After the "acta" of the last meeting had been read, and the names of those present been called over, there was some desultory conversation, which lead to no result; whereupon, before proceeding to the choice of the two Directors who were still wanting, as also the one Suplente, Riva-Agüero asked whether the election should be confined to those four who last time had had the greatest number of votes, or be extended to all shareholders. Now it was my turn to rise, and I said that everyone of the shareholders ought to be eligible. Soyer said that, as it had been rumoured, that he sought the Directorship in order to escape his responsibility as cash keeper, he declared that he wished not to be chosen. The absolute majority was 172 votes, and on the votes being called over Manuel Candamo had 259, I 249, Derteano and Canevaro less than the required-number, and others a few. Aurelio Dinegri, who had 16 votes, gave his for Candamo, not for me, which accounted for the 10 votes which Candamo had more than I. For Suplente the procurador Diego Lopez Aliaga had by far the greater number 159, Melchor Velarde had also a fair number, and as only 13 were wanting for the requisite 172 Aliaga was chosen by acclamation without again going to the trouble of writing his name upon slips of paper; two commissions were now named, the one to investigate the state of the cash, the quantity of cedulas on hand, and in short everything where a defraudation might have been committed; the other, for the purpose of modifying the statutes. For the first were chosen: Henry, Forero, Senator for Tacna, and Lorente, considered [...] clever man; for the second Lorente, Cesar Canevaro and Mosco [...] [692] Now Aurelio Dinegri rose and delivered a violent philippic against the gerente, the cash-keeper, 
the Directory, and even Oyague - why he included him I cannot tell - for not having answered several articles published in "La Patria", to the discredit of the Banco Hipotecario. I rose and said that they being anonymous, and accordingly without any responsible signature, they in my opinion merited no reply; but I immediately observed that the sense of those present was opposed to the view which I took. Riva Agüero was much offended at what Dinegri had said; he declared that if one single shareholder was dissatisfied with his management, he was ready to throw up his post, and with these words he left the room. Dinegri explained, Oyague conciliated and Riva Agüero was brought back by Gallagher; soon after we broke up.

Friday, $19^{\text {th }}$ of March. Dia de San José, and that of La Virgen de los Dolores, an unusual coincidence. I went to Chorrillos by the 12 O'clock train; the water was considerably cooler than the last time I had bathed. This time I found the house occupied by the Minister for Foreign Affairs, Aníbal V. de la Torre; he had gone to Lima, and I left my card with the eldest son of his sister Virginia. Next, I went to see Doña Dolores Puente, to congratulate her on her Saint'sday. Marriott told me that the President was very unwell and had sent to Lima for his physician Arosemena. José de la Riva Agüero was as yet by himself, Doña Mercedes dressing; I left as soon as other visitors came in. At Jose Gregorio Paz Soldan's all was shut up. At Felipe Barreda's nobody visible, but at Vicente Gonzales' I was very kindly received by his wife Emilia Orbegoso, who showed me all over their new house, recently finished, and extremely pretty; the furniture not splendid, but the neatest and most adequate for a country residence which can be conceived; everything - even the paper hangings - had been sent them from Paris by their son-in-law Dreyfus. The floor of the three principal rooms was inlaid in wood made here, waxed over, so as to render it a little slippery. I returned by the four O'clock train. The temperature had become somewhat cooler, thermometer $79^{\circ} \mathrm{F}$. For the last two or three days there had been a guard of soldiers in the patio of Dreyfus' house; the reason was that they would not pay the patente of S/40,000 annually to which [...] [693] of $\mathrm{S} / 10,000$ had been added. I heard from Juan that Ford, one of the partners, was not confined to his house, but this solely owing to a strong representation from the English Chargé, who declared that he could not allow an English subject who had committed no crime to be under arrest. How Derteano and Scheel fared I did not know.

Saturday, $20^{\text {th }}$ of March 1875. At about one O'clock I was by appointment with Riva Agüero in his office in the Banco Hipotecario. For some time past he had assured me that he had come to an arrangement with the Government regarding our joint Pasco Railway Bonds, and in fact this day he gave me a 
document, in which the Government bound themselves to issue $S / 26,000$ Vales de la nueva Consolidacion, or Internal Debt. The calculation had been made in the following manner: I had S/65,00o Pasco Bonds, upon which the Government had to make good to me, interest for the three years 1872,1873 and 1874 at $6 \%$ annually $=18 \%$, and three year's redemption at $4 \%$ annually $12 \%$, jointly $30 \%$ on $S / 65,000=S / 19,500$ for which sum the Government gave Vales de la nueva Consolidacion at $75 \%$, that is to say with an increase of $331 / 3 \%$, and accordingly $331 / 3 \%$ upon $S / 19,500$ are $S / 6500$ together $S / 26,000$ which I resolved to redeem if possible on the $1^{\text {st }}$ April, and I hoped to get for them $65 \%$. Whilst I was with Riva Agüero, some of the shareholders of the Pasco Railway Company had assembled in the next room, where I joined them. They were: Escudero, Felipe Varela, Bohorquez, Peter Gallagher, Dr. Sandoval, Joaquin Torrico, and Dr. M. M. Galvez. Torrico and Bohorquez made very unpleasant remarks on the subject of the four hundred thousand Soles bonds; really I did not know what to say and how to defend their emission. Fortunately at this moment Riva Agüero, who in the neighbouring room had overheard on what subject the shareholders were treating, entered, and he being shareholder, and ex-Director of the Railway Company, Gerente of the Banco Hipotecario and holder of $\mathrm{S} / 205,000$ nominal of said bonds, and as such the most proper person to give an exact account of all that had occurred on the subject, did so in a very quiet and lucid manner, which, if it did not entirely satisfy those who were present, al least, silenced them. With Bohorquez he had a few sharp words. The object of the meeting was to name one person who in the name of all the shareholders should exclusively understand with the Government, which had embar [...] way and much "materiel". Riva Agüero proposed [...] [694] as the fittest person, who was unanimously named, with the condition that he should give an account of his doings to the Directory. The number of Directors, as per statutes, should be five; there were only four for Rodrigo had thrown up the post many months ago, and we now named Dr. Galvez in his stead. In the evening, the Concejo Departamental of Lima chose its President, which elevated situation was eagerly canvassed for by José de la Riva Agüero, and by his intimate friend José Canevaro. There were 70 voters, of whom 34 voted for Canevaro, 26 for Riva Agüero, and 10 for various persons; a second choice took place between Riva Agüero and Canevaro. There were now 69 voters, 36 for the latter, who was chosen, 33 for the former.

Sunday, ${ }_{21}^{\text {st }}$ of March. I took my customary sea bath in Chorrillos.

Lizardo Montero presented himself this day as Candidate for the Presidency of the Republic for the next constitutional period to commence on the $2^{\text {nd }}$ August 1876 . 
Monday, $22^{\text {nd }}$ of March. The Directors of the Lima Water Coy. met; we were: Rey, the Manager, Oyague, who was called to the chair, Rodrigo; the new Director Dr. Meliton Porras, apparently an intelligent man, and myself. Nothing of importance was transacted; José Basagoytia sent in his resignation on the plea of ill-health, and his manifold occupations - in his stead we chose Enrique Prevost. Rey made known that the excavations had so far proceeded as to give nearly a million gallons daily more water than hitherto, whereupon Porras observed that this was the season of the year when springs give most water, and that in the course of a few months this supply might considerably decrease, to which Rey replied that he was correct. New shares, amounting together to $S / 1,320,000$ in 3300 shares of $S / 400$ each would shortly be issued, to be exchanged against the old ones. They were to be signed by all seven Directors, but Oyague and I expressed the wish that our signatures should be lithographed, which was granted us. One of the employees, Manuel Palacios, brother of my lawyer Fernando, Rey said, was not satisfied with his salary of $\$ 2500$ annually, and wanted $\$ 3600$. Oyague thought that we should pay this in[_], Porras and I were opposed to it [...] [695] Unanimously we agreed to cease our payment of $\mathrm{S} / 200$ every six months to the lawyer Fernando Palacios, hitherto employed, because this company had no law-suits, and ought to have none. The soldiers were still at the door of Dreyfus' house; everything was shut up. I was assured that not even provisions were allowed to enter through the street door, and that they were introduced from the neighbouring house over the roof. Dr. Lührsen, the German Chargé, had, it was said, obtained Scheel's liberty; only Derteano remained shut up. The building of the chapel of Santa Sofia, on account of Augustus Dreyfus was stopped for the present; four hundred labourers hitherto at work there had been discharged by Derteano.

Tuesday, $23^{\text {rd }}$ of March 1875. At 2.30 I went to the Banco Hipotecario for the first time as one of the Directors. We were: Riva Agüero, the Manager, Manuel Mendoza, Manuel Candamo, John Gallagher and I. In order not to be overheard we removed to an inner-room. Riva Agüero read two letters, the one from Oyague, the other from Henry, both refusing to admit their nomination, the first as Director, the second as one of the members of the commission for examining the accounts. In lieu of Henry we took it upon ourselves to choose Peter Gallagher, and it being the general opinion that Oyague would enter the Directory as soon as the accounts of his brother-in-law Soyer, the cash keeper, were examined, we decided on not calling in one of the suplentes. A President was now to be named; I pointed out Mendoza for this post, Gallagher Candamo, Candamo and Mendoza, me; and at last I was elected Vice-President, though 
much against my inclination. The Presidency was left open for Oyague. Now graver subject were laid before us by Riva Agüero. On the $1^{\text {st }}$ of April the interest of $2 \%$ on the Cedulas was to be paid, and only S/20,00o were in Cash; a sum which by no means sufficed. Money of course had to be procured, and Riva Agüero and Gallagher were of opinion that we could easily obtain it at $1 \%$ per month from the one or the other of the banks established in Lima. What was then discussed, I at the time abstained from noting down.

Wednesday, $24^{\text {th }}$ of March. We again met in the Banco Hipotecario. As regards the money wanted, Riva Agüero told us that he had obtained the [...] from the bank of London, Mexico \& S. A. and from [...] [696] Banco de Lima. This was satisfactory; but as to the second point, the particulars of which I again refrained from committing to paper, the information he gave us was far from being so. At 5.30 we were again assembled in the Counting house of Candamo, and the advices which were communicated to us by Riva Agüero were again as unfavourable as the previous ones, and we therefore agreed to meet again at 8 p.m. in the premises of the Concejo Departamental, on the ground-floor of Salinas' house, opposite the Church de la Concepcion. We four Directors were there at the appointed hour, and waited till ten. Riva Agüero, the manager, and accordingly our dependent, did not make his appearance; we therefore addressed him a note, in which we requested his attendance on the following day at 2 p.m. in the Banco Hipotecario.

Holy Thursday, $25^{\text {th }}$ of March. We the Directors were in the Banco Hipotecario at the hour we had fixed upon; once more Riva Agüero did not come. We drew out on acta, and took other steps which we considered requisite with regard to Simon Soyer. We broke up somewhat before 5, when my three colleagues had to take the train for Chorrillos. At 6 I received a letter from Riva Agüero from his chacra, in which he said that our last night's note had not reached him till this day at 3, and added that next day he would go to Chorrillos by the 10 O'clock train, to which I replied that I should go by that of 2 .

Friday, $26^{\text {th }}$ of March. Good-Friday. When I alighted from the train Gallagher met me, and took me to his house, where I found Mendoza and Candamo. Riva Agüero was sent for, and until he came we signed the acta drawn out the previous day, to which we affixed his note to me, above spoken of. When he came, the statement he laid before us was satisfactory if it could be relied upon. We authorized him to engage a new cash-keeper instead of Soyer and to call in for the next meeting the two Suplentes José Jimenez and Diego Lopez Aliaga, for Oyague had not yet joined us, and Candamo was shortly to leave for Europe. After Riva-Agüero had gone, and we four were again by ourselves Candamo proposed as cashkeeper a certain Muelle who had hitherto been in 
[...] [697] capacity in the counting-house of Valdeavellano \& Co. I myself was not acquainted with him, but as both Candamo and Gallagher spoke of him in the highest terms we at once resolved to engage him, with the same salary as Soyer had received. It was 4 O'clock when we separated. I then took my bath, walked up and down the streets of the village and returned by the 6 O'clock train. In Lima I did not sit down to my light dinner before 8 O'clock; meanwhile Doña Dolores Puente kept my wife and Enriqueta company.

Saturday, $27^{\text {th }}$ of March 1875. For more than a week Alejandro had been occupied before breakfast in writing up my books till the $28^{\text {th }}$ February 1875 ; and Mr. Bryson made good progress in copying the remodelled diary of 1858 . When in the forenoon we had half an hour's time he read to me "The March to Magdala", which gives a good account of the Abyssinian Expedition in 1867. The British forces, commanded by Sir Robert Napier, had, according to the author - a correspondent of one of the London newspapers - to contend with and overcome, not the enemy, who hardly showed himself, but the difficulties of the roads. In the evening he read Alison's History of Europe, always extremely interesting.

In the forenoon John Gallagher and I were occupied in counting the Cedulas of the Banco Hipotecario kept in the iron chest of the bank; we found there, the receipt given by a person for a Certain number which he had taken away, and considering those mentioned in the receipt as on hand, the total agreed with the account of the Cedulas kept in the books of the establishment.

Easter Sunday, $28^{\text {th }}$ of March. Manuel Candamo embarked for Europe. It was said that the President had entrusted him with a financial commission in Paris. By the same steamer left the mother and daughters of an Italian, Marconi, of whom it was known that he owed in Lima a large sum of money; whether he himself accompanied his family was doubtful, but that his son-in-law, a certain Caivano, also Italian, a very clever lawyer, at the same time a great rogue, had gone with them, was a fact.

By the 12 O'clock train I went to Chorrillos, bathed, and paid a few visits. The first to Anibal de la Torre, Minister for Foreign Affairs, whom I found to be a very agreeable man; to my surprise he recognized me when I entered and asked with great interest for all the members of my family; his wife $[\ldots]$ Fidelia appeared to me to be an insignificant woman [...] [698] the Vocal of the Superior Court, José Maria Perez, always taciturn, whilst his brother-in-law, Lino de la Barrera, kept up the conversation. Thirdly, I called upon General Pezet, very polite. The ladies I did not see. Dr. Manuel Ortiz de Zevallos came in, and hardly saluted me, for which want of civility I could not account. I for my part spoke with him as I had been in the habit of doing. For a few 
moments I looked in at Melchor Velarde's, and then took the four O'clock train for Lima.

Monday, $29^{\text {th }}$ of March. I went by the two O'clock train to Chorrillos. At John Gallagher's he and I waited in vain for Manuel Mendoza. Hitherto, with the previous Directories Riva Agüero, though merely the gerente, had been in the habit of doing everything he liked, and he could therefore hardly understand how the present Directors could have taken upon themselves to name a clerk for the establishment without even taking his opinion. It now came to light that there had existed something like a promise to Carlos Zevallos that he should be named cash-keeper, and as this had not been done I thought I discovered the reason for his father's strange behaviour on the previous day. I bathed, and returned to Lima by the Six O'clock train.

Tuesday, $30^{\text {th }}$ of March. I had a visit from Doña Eulalia, the wife of the Vocal Dr. Ribeyro, and her daughter Catalina, who begged me to use my influence with the Directory to have her son Eduardo, for a long time clerk in the Banco Hipotecario, named cash keeper instead of Simon Soyer. Of course I had to tell them that the situation had already been given to another person, and they left, by no means pleased.

Thursday, $7^{\text {st }}$ of April. I made an offer for the redemption of the S/26,00o Internal Debt received the other day from Riva-Agüero, at $63 \%$, which was not accepted, because the $S / 85,000$ employed by the Government every month for the redemption of the Internal Debt, had been absorbed by lower offers, the highest of which had been $621 / 2$.

Saturday, $3^{\text {rd }}$ of April. Marconi was really gone. His power of attorney he had left with the lawyer Fuentes, El Murcielago. The telegraphic wires to Payta, it was said, had been cut by his order, to prevent his being stopped in this port. In the course of this [...] [699] telegrams had been received by various houses in Lima; which brought the news of the stoppage of the South American Coy. (Limited) which for some years had been established in London. It had been formed by various capitalists, both Ecuatorian and Peruvian, residing in London and Paris, such as Carlos Candamo, the three brothers Luzarraga, the Canevaros, John Bryce, Doña Grimaneza, the widow of Cotes, C. W. Schutte, who had lately purchased shares to the extent of £20,000 at a high premium, Gordillo, who had had the good sense to sell the greater part of his, and had now only $£_{5000}$ of them. Others of lesser note interested in the same were: Emilio Mora, José Antonio Lavalle, Ventura Marcó del Pont, and no doubt many more, with whose names I was not acquainted. For some time one of the managers was Anibal Gonzales of Guayaquil, brother-in-law of Bazo. When he fell out with the Directors they put in his stead Thomas Wheelock 
and Schwank, a Swiss, who in former years was Cordes' clerk, and afterwards partner. Here in Lima, since the beginning of the establishment in London M. G. Chavez, half-brother of Gordillo, managed the branch house, and only quite lately he lost his situation, and Manuel Ortiz de Villate and John P. Gallagher, had been placed in his stead. For one or two years the South American Coy. gave good dividends, and the suspension of payment, which must have taken place about the $16^{\text {th }}$ March, was, as the rumour went, solely owing to the want of remittances from their debtors on this coast, landed proprietors, who owed them very heavy sums. Amongst them were named: Althaus and Tenaud, Francis Bryce, the Delgados, José Muro, Antonio Garcia y Garcia, El Banco Garantizador, which within these last few days had paid in to the Lima Directory $S / 100,000$ and probably still others whose names had not come to my knowledge. To several firms and banks in Lima, the said South American Coy. in London had granted blank credits, against these credits they had drawn, and many of the drafts which would now be returned protested, either for non-acceptance or non-payment, had to be taken up by the drawers, who would perhaps find some difficulty in procuring the necessary funds for these large and unexpected payments.

The United States Guano Coy. was one of those in this predicament. On my enquiring from the gerente, Vicente Hurtado, when the dividends [...] due would be paid his answer was that there was no [...] [700] of this being done for some time to come, for they found themselves under the necessity of keeping their funds together in order to meet their drafts on the South American Company, which by the first steamer they expected back under protest. The Directors of the Banco de Lima had twice been assembled, when I noted that Lembcke was very low spirited, and well might he be so, for not only the affairs of the bank, but also the commercial and financial prospects in Lima were at the time a very gloomy aspect. I find in my original the following words which I copy literally:

"The commercial world of Lima stands upon a volcano; there is but a thin crust between the same and the abyss below; but a slight push is wanting, a hole is made, and we are all precipitated."

From the broker Fernando O'Phelan I learned that the public and private securities, and the bank-notes in circulation amounted to 70,000,00o Soles, whilst coined silver and gold did not surpass the sum of 4,000,000 Soles. In our meetings, letters were read from Stirling, Administrador de la Esperanza, which held out hopes that in the course of a few weeks Nitrate of Soda would actually be produced there. As to our principal debtors we resolved that to Geronimo Sanchez, a certain Guimet, and the brothers Montero, some indulgence should still be shown, but that against Henry Meiggs and Arizola, judicial proceedings 
should be instituted without loss of time. Gallagher brought me a message from Dr. Zevallos to the effect that he, the Doctor, had not the slightest illfeeling towards me, for as I had given no promise to his son Carlos he could not be offended with me for the non-election of his son as cash-keeper of the Banco Hipotecario.

Sunday, $4^{\text {th }}$ of April. For some time past my wife and my son Juan had urged upon me the necessity of having the corredor in our Chorrillos rancho floored with marble slabs instead of with bricks as hitherto; and as Garland, who was still employed in the late Ugarte's counting-house, told me that they had some marble slabs for sale, which I might perhaps obtain at a rather low price. I complied with their wish, and this day I went out to Chorrill[_] with an Italian bricklayer to have the corredor measur [...] [701] order to judge how many slabs were required. We found that including a small cabinet at its extremity it measured go square varas. It was past three when we had done. I took my bath and on looking at my watch when again dressed, only five minutes were wanting to 4 O'clock. I ran to the station as fast as my legs could carry me reached it in six minutes, and was just in time to have the door slammed in my face. I now ascended to the top of the Moro Solar, was back in an hour and a half, and by the 6 O'clock train returned to Lima.

Tuesday, $6^{\text {th }}$ of April 1875. At last the firm of Dreyfus was forced to give way to the Municipal Council, who threatened that if they did not pay the $S / 40,000$ for patente, besides $\mathrm{S} / 10,000$ fine and $\mathrm{S} / 57$ gratification to the soldiers who had kept watch in the house for six days, all three partners would be sent to prison; accordingly Derteano delivered two Treasury Bonds of S/50,00o each, which were to be sold in auction and the Surplus returned to the firm.

The gerentes of the Banco de Lima having sent me a message to the effect that they wished to see me, I went, when we had a long consultation relative to the steps best to be taken when our drafts upon the South American Coy., London, came back protested, as they undoubtedly would. From three till half past four Gallagher, Manuel Mendoza, and I were with José de la Riva Agüero. Though the affairs of the bank were in great confusion, there now seemed to be a probability of order being restored. John P. Gallagher, whose office for the London and American Company was on the same ground-floor with the premises of the Banco Hipotecario, was quite as much in the latter as in the former; he allowed Riva Agüero hardly any rest, and looked into every thing, also the commission named, Forero, Lorente, and Peter Gallagher, had commenced their investigations. In the evening Lembcke was with me for about an hour conversing about the affairs of the bank.

Wednesday, $7^{\text {th }}$ of April. The Directors of the Banco de Lima had been convened, but as nine of us, the number required to form a quorum, were 
not present, Mendoza and Cucalon being wanting, we had merely a [_]dly consultation no regular meeting. Lembcke gave an [...] [702] of his interview with Mr. J. Anson, manager of the Bank of London Mexico \& S. A., who had promised assistance, as soon as the bank should require it; he further told us what had been the result of his last interview with Henry Meiggs, which was not satisfactory. This day died Frederic Bergmann Jr. in consequence of a cancer in the tongue.

Friday, $9^{\text {th }}$ of April. I was present at his funeral in the Church of San Francisco. In Paris had died about a month back Gustavus Duval, nephew of Auregan, and younger brother of Emil, many years back clerk of H. Witt \& Schutte. In the course of a few years he had made a handsome fortune in Lima as importer of boots and shoes, and ready made clothes.

By the steamer before last advice was received of the failure of the firm of J. C. M. Thurn \& Co. of London, a Swiss house, whose liabilities amounted to $£ 2,000,000$ Stg.

In Lima, things looked very black; the Banco Nacional had made a call of $5 \%$, in consequence of which I had to pay S/400o on my, and S/80o on Juan's account; very inconvenient at the moment. A pagaré of Miranda \& Co. of Callao, due 5 inst., which I had discounted through the intervention of the broker Gabriel Saco, was not yet paid. J. M. Zuloaga, my guarantee for the S/80oo owing to me by Juan de Ugarte, had had a slight stroke of apoplexy; and I heard this morning that his confidential clerk Quiñones, whom he had looked upon as his "alter ego", had robbed him, of how much I knew not.

Mendoza, Gallagher, and I, Directors of the Banco Hipotecario, and Forero, Lorente, and Peter Gallagher, members of the investigating commission, met, Riva Agüero, the gerente, being also present. Part of the large amount of which the bank had been robbed by Simon Soyer was gradually recovered, owing in a great measure to Riva Agüero's exertions; however, in a short speech made by Forero he plainly said that Riva Agüero was not so frank and open as he should be, which very naturally offended the latter.

Saturday, $10^{\text {th }}$ of April. Garland's sons brought the report that Simon Soyer had fled. I caught Riva Agüero when [...] [703] came from Chorrillos at half past eleven in the morning, and told him what I had heard. In the course of the day I received two notes from him advising me that there was no truth in the report.

This day Alejandro balanced my books. I made the final entries, and for the first time since I had entered into business, in 1830 when I became partner of Gibbs' houses on the coast, and again on the $30^{\text {th }}$ April 1843 when I opened my own books with a capital of $\$ 172,694.2$ I had to make an entry to the debit 
of Profit and Loss, of S/10,00o which arose from the low valuation which I put upon the various items which constituted my fortune, and even low as these valuations were, I feared they were not low enough.

I learned that Juan Aliaga y Puente, who owed me S/7200 due $31^{\text {st }}$ July 1875 , had fallen from his house and broken his leg.

Sunday, $11^{\text {th }}$ of April 1875. I did not go to Chorrillos, but made a round of indispensable visits. Cipriano Correa, upon whose wife I called, had lost with Marconi S/23,000 and Dr. Jervacio Alvarez, Vocal of the Supreme Court who owed me S/80o - of course irrecoverable - complained bitterly that Marcone had cheated him out of $\$ 23,000$. Micaela, the grand-daughter of Bartolo Araoz, lately married to Manuel Flores, stepson of Zaracondegui, seemed quite happy in her new state.

Tuesday, $13^{\text {th }}$ of April. This being the last day of Juan's stay in Lima, he, my wife, and I dined with the Garlands. At a later hour Rafael Velarde and family, also Alfred Böhl, came to bid him good by; to his mother, sister, and the little ones Juan told me he would not say farewell; he therefore went quietly to bed without saying a word. In the forenoon also Manuel Costas had been with us to take his leave of Juan, and I had on this occasion a long talk with him on the state of the country. I told him that in my opinion - and that of many others - the only thing which Pardo could do to save the whole mercantile community from certain ruin, was to give a decree which would exempt all such banks as had deposited an equivalent to the amount of their notes in circulation into the hands of the government in conformity with the decree of January 1874 from the obligation to pay their notes on presentation in coined silver or gold. In short I counselled a tempora[_] [_]pension of cash payment but I much feared that Pardo [...] [704] not take such a responsibility upon himself; however, Costas promised to speak to him on the subject.

Wednesday, $14^{\text {th }}$ of April. I was up early. Juan, Garland, Alejandro, Enrique, and Ricardo drove to the terminus. I walked thither on foot, and met them there. We reached Callao about 9 O'clock. Here everything was so much changed that I could hardly recognize it. The old rickety mole; the wooden steps where we used to embark, and many other objects familiar to me had disappeared, and a large piece of the sea, filled up with earth and stone had been converted into firm ground. Enrique conducted me over a long bridge to one of the walls which enclosed the Muelle Darsena, or Dock, just concluded. Alongside, lay a small steam launch, with Carlos Ferreyros, Captain of the "Chalaco", and a few marines of the Peruvian navy. We were joined by Juan, who had his luggage with him, and the others already named. The luggage was taken to the "Islay", bound for Panamá, and we then cruised about for some time in 
the beautiful bay. The walls of the Muelle Darsena were constructed of blocks of artificial stone made in Callao. To the left on entering stood a lighthouse, and the entire structure had a grand and solid appearance; inside the same, as Don Carlos told us, an unusual heavy swell, "resaca", was experienced, which, very injurious to the shipping, was in all probability the cause of the few vessels, only two in number, which were lying inside the dock discharging their cargo, an English merchant vessel, and a steamer. We breakfasted on board the "Chalaco"; the meal was excellent, too abundant. I had been last on board of this vessel in January 1873 when the Garlands returned from Europe. From the Chalaco we steamed to the Islay, the decks of which were crowded with people, passengers and their friends. Here was Lizardo Montero, the Admiral, and candidate for the Presidency of the Republic; he was in high spirits, and apparently certain of success. Here was Edward Bodmer, a German Swiss, who returned to his native country with a small fortune, after having been for many years confidential clerk of Rehder \& Co., Lima shopkeepe[_] indebted to me for more than $\mathrm{S} / 20,000$. Here was Adriano [...] [705] whom perhaps thirty years ago I had under my charge when he was in college in Lima, and when his father Don Juan of Islay had entrusted him to my care. He, married to a daughter of J. F. Johnston of Arequipa formerly, now of London, was about sending to Europe for his education a son of his, twelve years of age. There was on board a Miss Wilson, whose father and mother I had known in Tacna in 1846. Her mother, then a very interesting lady in the prime of life, now a widow residing somewhere in England, had written for her daughter, who of late had been staying in Tacna, with her sister Mrs. Jefferson; Jefferson, portagent had been previously married to Juanita, one of James Gibson's daughters. At about noon we left the steamer; when I embraced Juan I could could not speak, so affected was I; his last words were: "muchos cariños á mamita." On shore Carlos Ferreyros showed me all over the ground gained from the sea. I was surprised at its extent. It comprised several blocks; the houses were not yet built, but the streets were marked out, the flagstones for the foot pavements were laid, and the posts for the lamplights were put up. I was back in Lima by 2 O'clock when my wife told me that she had sent for Dr. Bravo to ask his opinion about a certain numbness, not pain, which she felt in her feet and legs, and which sometimes extended above her knee.

My law-suit against Leyva did not progress, which was entirely the fault of the judge Puente Arnao. The architect Castañon, whom he had named as umpire, had given in his opinion. Leyva had demanded an amplification of the same, to which I had not opposed myself, and though there was now not the slightest difficulty in the way, the judge did not sentence. About this time 
the well known firm of Delgado Brothers \& Sons, originally from Lambayeque, was liquidating; the pretence was ill-health of some of the partners - the real cause, perhaps, want of disposable funds. Also the jeweller Meyer, a Jew, had suddenly decamped; he owed considerably, and was unable to pay; his shop in Felipe Barreda's house was locked up, and the keys his clerk had delivered to the Consulado. News was received of the death of John Hamilton, who had expired somewhere on the Chimbote line. Several years back he had been clerk of H. Witt \& S. I liked him well, for the was frank, well educated, good- [...] and a useful clerk. Unfortunately he could not always [...] [706] from drink, and this propensity was probably one of the causes of his early death. He was a native of Scotland, but his parents had settled over to Hamburg, when he was an infant; his mother belonged to the influential family of the Schröders. We also heard of the death of Juan Crisostomo Torrico, which had taken place in Paris where for some years together with his wife he had led a quiet and retired life. More than once he and his actions have been spoken of in this my diary.

Friday, $16^{\text {th }}$ of April 1875. The Directors of the Banco Hipotecario, John Gallagher, Manuel Mendoza, José Jimenez, Diego Lopez Aliaga and I, had a very long sitting, together with Riva Agüero, the gerente, and the three members of the investigating commission. Riva Agüero always gave a pretty satisfactory account of the money which was coming in, and even Gallagher was of opinion that the loss which the bank would sustain owing to the defraudations of the late cashkeeper Simon Soyer, would not be very considerable. Soyer's place was now filled by Muelle.

Saturday, $17^{\text {th }}$ of April. I had a long conversation with Lembcke who who thought that the Bank Directors would find themselves under the necessity of making a new call upon the shareholders; otherwise, he feared, it would be impossible to pay all the bills which would come back protested from the South American Company.

Sunday, $18^{\text {th }}$ of April. At 8 O'clock Bryson and I went by train to Chorrillos, where in my rancho we busied ourselves for some time with fitting the keys to the various doors. I took a dip in the sea and at a later hour arrived from Callao three carts with 660 marble slabs bought by me from the estate of Juan de Ugarte. It was twelve before they were stowed away, when we returned to Lima, and breakfasted together in my house.

Monday, $19^{\text {th }}$ of April. This morning I again went to Chorrillos by the 8 O'clock train, merely for the purpose of securing the iron railing of my rancho with an additional padlock.

Thursday, $22^{\text {nd }}$. In the course of this week the Directors of the Banco de Lima met twice. The first time Lembcke laid before us a statement of the affairs of 
the bank which were certainly [...] [707] most disheartening condition, so much so that I thought proper to make the motion for a call of a new quota from the shareholders. Only Cucalon seconded me; at Gallagher's request the discussion was put off to our next meeting. The second time Lembcke gave a detailed account of the interview which he had had with Juan Martin Cardenas, the leader of the opposition amongst the shareholders. Cardenas had behaved in every respect like a gentleman, but had given it as his opinion that he looked upon the calling in of a new quota as the most impolitic measure imaginable, and that he and his friends would oppose it by all the means in their power. This induced me to withdraw my motion of last meeting; then Cucalon made the same motion, but after a long debate he was persuaded to allow it to stand over till the arrival of the next steamer from Europe, when we should probably hear something from the South American Coy. Before going to the Banco de Lima I was with the other Directors of the Water Coy., and here Mr. Prentice, lately arrived from England, who was our principal engineer, read in a low and indistinct voice a long statement, the object of which, as far as I could understand, was to find fault with everything that Mr. Wilkinson, our Lima working engineer, had of late been doing, to procure a greater supply of water. I left, because I had to go to the Banco de Lima; also because I did not understand what Prentice read, and even if I had understood it, I should not have been able to decide which of the two was in the right.

Friday, $23^{\text {rd }}$ of April. The same persons as on the previous Friday met in the Banco Hipotecario, and did not break up till three O'clock. The landed proprietors who owed the bank were much behind-hand with their threemonthly payments; little money came in from them, and quite as little on account of the deficit in the cash caused by Simon Soyer. I began to doubt that Riva Agüero was the proper person for the post he filled; he talked much, and did little. When Torrero, Lorente, and Peter Gallagher were gone, he read to us a letter from the Banco Anglo-Peruano, and another from La Providencia, both demanding payment of the amount due to them by the Banco Hipotecario. I was charged by the other Directors to accompany Riva Agüero in a call to the gerente [...] the first of the two banks and did so on [708]

Saturday, $24^{\text {th }}$ at half past one, when both Oscar Heeren and Rafael Canevaro, received us much better than I had expected. Heeren especially said that it was by no means their idea to inconvenience the Banco Hipotecario; they only wished that the amount due should be paid off gradually, and this we promised to do in monthly instalments.

Sunday, $25^{\text {th }}$ of April. I did not go out to Chorrillos, for the temperature was getting cool, and I no more required sea-bathing. A regatta was held, to 
witness which I had given the keys of the corredor in my rancho to my lawyer Fernando Palacios. In the evening there was a ball at General Pezet's. In Lima I paid several visits; many upon whom I called had gone out. Dr. J. Alvarez again spoke to me of the S/23,00o which Marconi had cost him, and of which he feared he would never see a rial; a long time I was with Bartolomé Araoz, who intended to embark for Europe on the $28^{\text {th }}$, on a pleasure trip, together with his newly married wife; they expected to be back by the end of next year. General Prado, one of the candidates for the Presidency of the Republic, arrived this day from Chile; his friends, especially those who formed a committee to work in his behalf all over the Republic, were much excited; they had gone to Callao to meet him, where, according to Zoila Velarde, whose father was one of his staunchest adherents, he had been enthusiastically received. Rafael was hardly to be found in his house the whole day long. General La Puerta was the President of the Committee; members were: Ceferino Elguera, Manuel Fco. Benavides, Rafael Velarde, Fuentes (el murcielago), Pablo Vivero, in whose house Prado took up his quarters, and others, with whose names I was not acquainted. In the Nacional $N^{\circ} 3028$, the list of "Patentes" for the present year was published. The amounts put down were for the half, consequently the double for the whole year. The sum opposite Dreyfus' name was left in blank, not having been fixed as yet. Followed Meiggs with S/1500, Candamo S/1400 José V. Oyague with S/100o, I S/400, José Muro, whose affairs were in a very bad state, S/500 a great injustice. I myself wa[_] taxed to the very utmost for in 1874 the interest gained incl[_] [709] that upon Cedulas, came to a mere trifle above $\mathrm{S} / 20,000$. The Banks as follows

$\begin{array}{lr}\text { Nacional del Perú } & \mathrm{S} / 11,924 \\ \text { Perú } & \mathrm{S} / 9933 \\ \text { Lima } & \mathrm{S} / 4500 \\ \text { Londres Mejico y Sud America } & \mathrm{S} / 4602 \\ \text { Anglo Peruano } & \mathrm{S} / 4500 \\ \text { La Providencia } & \mathrm{S} / 4448 \\ \text { Garantizador } & \mathrm{S} / 500 \\ \text { Hipotecario } & \mathrm{S} / 5700 \\ \text { Territorial Hipotecario } & \mathrm{S} / 3260\end{array}$

The Gas Company S/280o, the Water Company S/1728, the United States Guano Coy. S/4500, the Insurance Coy. Lima S/500, the South American Insurance Company $\mathrm{S} / 1600$. Under the heading of Consignatarios, or Importers of the first class, only four houses appeared: W. Gibbs \& Co., F. Huth Gruning \& Co., 
Graham Rowe \& Co., \& Duncan Fox \& Co.; they paid no more than S/680 half yearly each. Of the store keepers by retail in the Calle de Bodegones, only one firm ranked in the first class, that of Knauer \& Pfaff, who paid S/104 every half year; it seemed that not one trade was omitted; even washerwomen were included.

Wednesday, $28^{\text {th }}$ of April 1875. Thermometer in my office at 10 O'clock $70^{\circ} \mathrm{F}$. It commenced raining a little both in the morning and the evening. In the day time the sky was overcast. There had been no meetings and as after the $23^{\text {rd }}$ of every month none of my rent or interest fell due, I had just now hardly anything to do. I however dictated one letter to my son Juan, and another to Johannes Limpricht. In the evening Bryson still read to me Alison's History of Europe; in the forenoon, we had just finished the March to Magdala. Magdala, the fortress of King Theodore, considered impregnable, was taken on the $13^{\text {th }}$ April 1868. When the gate had been blown open, Theodore was found dead on the ground - he had committed suicide. A few days previously, a combat outside the walls had taken place: the Abyssinians commenced by rushing down upon the English, but were repelled with great ease, and considerable slaughter. What could they do against Snider rifles, rockets, and steel [...]? Their loss was calculated at 500 whilst of the English [...] [710] died of his wounds. The Europeans of various nations whom Theodore had kept prisoners, and whose delivery had been the only object of the expedition, had been given up several days previously. The great difficulty of the expedition consisted in the march, and the transporting of so many men and beasts, of provisions, ammunition, provender, etc. over an inhospitable country, over mountains, and through ravines, where many a time the road had to be made by parties sent on ahead, and where water was always scarce. This morning I received a few words from my son Juan, dated Payta $16^{\text {th }}$, in which he informed me of a disagreeable loss he had suffered. The very first night he had been on board, his toilette-bag had been stolen out of his cabin. He had in the same all his brushes and shaving apparatus, his sleeve links, diamond pins, some sovereigns, and Napoleons, also first of a bill for $£ 1000$, Dreyfus on Premsel, but this being to his own order, would be of no use to the thief.

The law regulating the sale of Guano passed both houses of Congress. It was plain and short. The Executive was authorized to sell guano in the best way it could. The only limitations were that any contract made was not to be valid for more than four years, and that the utmost amount to be sold annually was for four millions pounds sterling. The "service" of the external debt was to be attended to, and the Executive might take an advance of three million pounds sterling. 
Thursday, $29^{\text {th }}$ of April. Enriqueta's tertulia was somewhat better attended than usual; there were two rocambor tables. To the one sat down Malinowski, M. F. Benavides, a certain Quevada, and José Luis Bernales. At the other table played Garland, Corso of Arequipa, Seminario of Piura, and Picard. The last named had been established in Tacna, where, if his words were to be believed, he had been doing a very good business, but was ruined by the earthquake of 1868; what he did in Lima, I knew not. At the roulette table Gregorio Benavides and Enrique were the bankers. Rafael Velarde did not come; no doubt he was with Prado, but his wife and two daughters were present. There were also Carlos Ferreyros, and two new faces Oscar Heeren and Jose Basagoytia, it was past two O'cl[_] [711] before I was in my bed.

Friday, $30^{\text {th }}$ of April 1875. We had again one of our disagreeable meetings in the Banco Hipotecario, viz.: the four Directors, Riva Agüero and of the investigating commission only Lorente. For more than six weeks we had been flattered with hopes, and deceived by promises. The enormous deficit in the cash had not decreased, and severe measures had to be taken against Soyer. At a later hour I made in the same bank a transfer of Juan's ten shares, upon which $95 \%$ were paid up, to Evaristo Barrios, owner of a large store of ironware in the Calle del Arzobispo, to whom I had sold them at 50\%.

Saturday, $7^{\text {st }}$ of May. In the morning I withdrew from the Banco de Lima above $S / 15,000$, by which I reduced the amount to my credit to $S / 14,000$. $S / 10,000$ I paid to Dreyfus on Juan's account, say $S / 5000$ in general account, and $S / 5000$ on account of the rancho in Chorrillos of which my wife and myself had made him a present the very day I bought it from Pfeiffer, and which when he was last here I purchased from him for S/14,00o, four hundred Soles I paid for my patente of the first half year of 1875 to the Concejo Departamental, a municipal body for the department of Lima, of which Riva Agüero was President, whilst that body which in the time of the Spaniards was called Cabildo, afterwards Municipality, now went by the name of Concejo Provincial, and its President or Alcalde was Dr. Rosas, late Minister of the Interior, an energetic and intelligent man. Some said that he might perhaps be the civil candidate for the Presidency of the Republic; I did not believe it, though I considered him more capable than either Riva Agüero or Pedro Galvez, at present Peruvian Minister in London and Paris which two were also put forth in contraposition to the two military men Mariano Ignacio Prado, and Lizardo Montero. The last payment I made was that of $\mathrm{S} / 4800$ to the Banco Nacional, amount of the call of $5 \%$ above spoken of. I withdrew such a large amount, because I counted upon the redemption of $S / 26,000$ Vales de la nueva consolidacion received the other day from Riva Agüero. I entrusted Alejandro with the redemption; his offer was 
at $611 / 2 \%$, and to my great disappointment of the amount redeemed at this figure only $S / 10,406 \mathrm{Noml}$. equal at $611 / 2$ to $S / 6400$ corresponded to me, and of this last named sum another deduct [...] have to be made for the Government paid in drafts on the Call [...] [712] Custom-House, and these the port-agents purchased at from 2 to $3 \%$ discount; one with another I calculated $60 \%$ net would remain and as I had received them from Government at 75 , the loss upon them was exactly $20 \%$.

Sunday, $2^{\text {nd }}$ of May. Anniversary of what was called the great victory gained in Callao on the same day 1866, when Prado ruled the country as Dictator, when he shut himself up in a solid tower in Callao, and when José Galvez, then Minister of War, with those around him, was blown up. Prado's friends in Callao had invited him to a grand lunch; and thither he went with a great accompaniement by the 2 O'clock train. In Lima it was the quietest day imaginable; I made many calls, four of which were very agreeable; to Col. Diego Masias, to the Buenos Ayrean Minister Domínguez, to the Basagoytias, and to Augusta Bergmann, Miceno Espantoso's wife. From her I learned that a lad, Eduardo, a natural son of her husband's, and who was in England at the same college as some of the sons of J. A. Lavalle, had written that the young Lavalles had just received a telegraphic dispatch from their father, informing them of the death of their mother Mariana, sister of the President Pardo, which had occurred in St. Petersburg. Geraldo had not written by this steamer; from Juan I had a few words of $21^{\text {st }}$ April from Colon. The South American Company in London wrote to the Banco de Lima that they had suspended payments on the $17^{\text {th }}$ March, that the remittances received would be credited in A/current, and that two liquidators had been named by court - one of the two, Schwank. Protests had been received by many houses, but whether actually bills on the South American Coy. had already come back, did not come to my knowledge. Lembcke had called the Directors together, to consult with them whether the bank should pay on receipt of protest, or wait for the bills; he inclined to the former; I was of the latter opinion. I took Henry's advice, who agreed with me, and so did, of the Directors, Bernales, Heudebert, and Cisneros. For want of the sufficient number of nine, we had no formal session, and we were cited to meet again on Wednesday. [713]

Tuesday, $4^{\text {th }}$ of May 1875. The same who met on Friday last came again together in the office of the Banco Hipotecario, Forero, of the investigating commission instead of Lorente. The lawyer Felipe Varela, who jointly with Dr. Ramon Ribeyro was employed by the bank as their Council, was also present, and after some talk, which, as usual, led to nothing, Forero proposed to the Directory in writing that they should without loss of time institute legal 
proceedings against Simon Soyer, late cash keeper of the bank for defraudation and abuse of confidence, both criminally and civilly. Mendoza pleaded hard that another respite till the end of the week should be granted him, to which I was decidedly opposed, and to cut matters short I took the opinion of the Directors present. I commenced with Lopez Aliaga, who sat to my left; he voted for "no respite", Felipe Varela and Forero, not being Directors, were passed over; then Gallagher, "no respite", Riva Agüero, who sat next, and who as gerente had no vote, was passed over, Mendoza now said that he adhered to the opinion of the others, José Jimenez, and again I, "no respite", and thus, the resolution being unanimously taken, Riva Agüero was charged to carry it into effect, and Felipe Varela being rather intimate with Soyer, Ribeyro was to be the lawyer in this case. We agreed to meet again on Monday. When the others were gone, Riva Agüero laid some trifles before the Directory. A certain Gomez, a broker, had requested the bank for a subvention to a weekly paper which he intended to publish on commercial affairs; Riva Agüero spoke in favor of such an assistance being rendered him, also Gallagher and Mendoza; nevertheless, it was refused by the majority, Diego Lopez Aliaga, Jimenez and myself.

Wednesday, $5^{\text {th }}$ of May. By the ten O'clock train my wife and I went to Chorrillos to have a look at our rancho, and to come to an agreement with some one about the laying of marble slabs in the corredor. A North American, and an Italian bricklayer presented themselves, and after an immense deal of haggling, which took several hours, we at last came to terms with the latter, at two dollars the square vara. My wife had a long visit from Doña Dolores Puch, the widow of General Alejandro Deustua, whilst I had much to do with picking out keys, and making them fit into the locks. At 3:30 we left our rancho and looked in for a [...] [714] at Doña Petita's, daughter of José Gregorio PazSoldan. I calculated upon reaching the terminus in ten minutes with great ease, but we arrived at the very last moment, five seconds more would have been too late. My wife was completely knocked up on our arrival in Lima, and we went to bed immediately after dinner.

Thursday, $6^{\text {th }}$ of May. My wife remained in bed the whole day. I, remembering that I would complete within a few days my $7^{6}$ th year, thought I might as well make a trial whether I could still ascend San Cristoval, and I was glad indeed when I found that I could accomplish the ascent with great ease, even from the side of Los Descalzos.

Friday, $7^{\text {th }}$ of May. Mariquita was again well enough to rise at the usual hour.

Saturday, $8^{\text {th }}$. I went to the Banco Hipotecario to have a look at the cash book written by the new cash-keeper Muelle. It seemed to me in good order, 
but what did not please me was that as soon as I entered, Riva Agüero also came in, as if he did not wish me to be alone with the cash-keeper.

At 3 the Directory of the Banco de Lima met; all were present except Cisneros and Heudebert. Lembcke stated that he had borrowed from the London Bank of Mexico \& South America S/120,ooo for three months, and that Mr. Champeaux, agent of La Société Générale of Paris, had placed in the bank in account current $S / 150,000$ so that we could now pay the bills which the South American Company in London had accepted and not paid; and we resolved to do so even if the protests came unaccompanied by the bills; but with the express condition that every party when paid should give a document to the bank, binding itself to return every rial which it might receive on account of these bills from the South American Company. This obligatory document was drawn out in the most binding terms, and I therefore withdrew my previous opposition to pay without the bills being themselves presented. The damages for redraft, in former times $25 \%$ were now reduced to $10 \%$, including of course interest protest hefty exps. and loss on exchange. All this was $[\ldots]$ [715] enough; the only difficulty I saw was how the $S / 120,000$ were to be returned to the London Bank.

Sunday, $9^{\text {th }}$ of May 1875. I paid, as was my habit, several visits one of which to General Prado, at Pablo Vivero's. I entered at the same time as Dr. German Tejeda. The General, who sat down on the sofa, made me take a seat near him, and was particularly polite. There were four or five besides me; amongst whom Cipriano Correa. In the evening whilst Rafael Velarde and family were with us, Garland had a sudden and violent attack of colic. Both Ricardo and Don Rafael went for Dr. Bravo who came immediately; and his prescriptions gradually assuaged the pain; however, for an hour or so Garland suffered much. On

Monday, $10^{\text {th }}$ he kept his bed.

The Juez de $1^{\circ}$ Instancia, Olivares, sentenced against Garland in the suit which Dr. Francisco Garcia Calderon had instituted against him, or rather Schutte \& Co., claiming a remuneration of one hundred thousand Soles for having contributed to the settlement of the dispute which had existed several years back between the Peruvian Government, when José Balta was President, and Schutte \& Co., guano consignees in Germany. The Directors of the Banco Hipotecario had their meeting. Of the investigating commission only Peter Gallagher was present. In the proceedings against Soyer not one step had been taken; and not a rial had been received from him.

Tuesday, $11^{\text {th }}$ of May. I completed my $7^{\text {th }}$ year, Heaven be praised, except my want of perfect sight, in excellent health, and with an unbroken constitution. The Government had bought within these days the entire establishment 
belonging to the telegraphic society. The debt due by the said company was cancelled, and it received over and above $S / 200,000$ in treasury bonds, worth about $70 \%$. Also with the Unites States Guano Coy. Pardo had come to terms. Bonds to the amount of three millions, six hundred thousand dollars (American) were to be issued, guaranteed by the guano existing in and to be shipped to the United States, the interest and redemption to be paid [...] the same Company; and upon these bonds placed in the [...] [716] hands they were confident that they would be able to obtain money wherewith to pay themselves for the heavy advance made by them to the Peruvian Government. Should the 200,000 tons of guano, which the Government was authorized by Congress to sell for the United States, find purchasers, then half the proceeds was to be for the Company, the other half for the Government. Another feature of this contract - and for Pardo no doubt of the greatest importance - was that the Guano Company advanced to the Peruvian Government £100,0oo Stg.

Thursday, $13^{\text {th }}$ of May. For the first time since the establishment of the roulette, my wife gained at the same a trifle, say four or five Soles. José Basagoytia was present, also Muelle, the cashkeeper of the Banco Hipotecario, whom Alejandro had brought with him as well as Rafael, his wife and daughters.

Friday, $14^{\text {th }}$ of May. Several months back a certain J. A. Garcia had placed into my hands a diamond necklace, consisting of 36 stones, upon which I had advanced him $S / 12,000$; with interest on the same, this loan ran up to $S / 13,080$. On the $11^{\text {th }}$ it fell due, but Garcia could not pay; hereupon I wrote him a letter, in which I said that in virtue of the literal tenor of the pagaré, the necklace was now mine, and a receipt given by me for it, had to be returned to me. Garcia did not answer; I went to see him. He confessed that I was quite right, but that he was merely the broker, and that the owner of the necklace refused giving up the receipt. Unfortunately I had no copy of the same, and without seeing it, my lawyer Dr. Palacios could give me no advice what steps to take. In my suit against Leyva I had now progressed so far that Dr. Palacios had to draw out the escrito called "alegato de la buena prueba"; this, Leyva, would have to answer, and the judge then to give his sentence.

Saturday, $15^{\text {th }}$ of May. The Directors of the Banco Hipotecario met at 4 O'clock, having been called together by Riva Agüero who said in his note that the case to be treated on was an urgent one. Jimenez did not attend; Varela the lawyer did; also José Canevaro, married to Luisa, Simon Soyer's sister, was present [...] [717] last mentioned gentleman made some proposals, which, if accepted by us would probably materially contribute to diminish the deficit in the cash. We did not at once give an affirmative answer, but held out hopes that we would do so in our next meeting. 
Sunday, $16^{\text {th }}$ and Monday, $17^{\text {th }}$ of May. Whitsuntide. On Sunday the only visit my wife had, was that from Dominguez, the Buenos Ayrean Minister, a very agreeable gentleman. At dinner she ate nothing. When we had risen, a sudden cold came all over her; she hastened to bed, and did not rise on Monday. On

Tuesday, $18^{\text {th }}$ she was again somewhat better.

Wednesday, $19^{\text {th }}$. Last night by the 7 O'clock train I went by appointment to the rancho in Chorrillos, in which Dr. Palacios resided with his young wife. He had promised me that the escrito in my suit against Leyva would be concluded; he had however only begun. For the 8.15 train I was too late, and, as I did not like to remain with the Doctor till ten O'clock, I went to Henry's rancho, where I found him, his wife, Böhl, Calixto Pfeiffer, and Dawson, manager of the London Bank of Mexico and South America. Talking on various subjects the time passed quickly. I learned that by this steamer the firm of Gibbs had received confirmation of the telegraphic dispatch which had brought them the advice of the death of Mr. William Gibbs, who had nearly completed his $85^{\text {th }}$ year, having been for 62 years partner, and for 32 years head of the house of Antony Gibbs \& Sons of London; formerly so active and agile he had been paralytic for the last few years of his life. George Thomas Davy, another partner of the firm, often mentioned by me in the course of this diary, at the time that he was head of the Valparaiso branch, had died last year or the year previously. The number of the present partners in London was reduced to five: Henry Gibbs, son of George Henry, elder brother of William, who died in Venice in the year 1842 or 1843, two younger Gibbs, Stubbs, long in Lima, the principal manager of the business, and Sillem, one of the two brothers Sillem who failed in the crisis of 1857. It was a pleasant moonlight night; Mr. Dawson and I returned to Lima by the 10 O'clock [...]. This morning I recei [...] [718] letters; one from Juan, dated St. Thomas $28^{\text {th }}$ April who complained bitterly of the numerous and mixed company on board the steamer. He had had to pay $£_{34}$ extra, in order to keep his cabin for himself from St. Thomas onwards. Johannes Limpricht, his sister Elizabeth, and Henry Sieveking, all congratulated me on my birthday. Limpricht wrote that Bismarck and the Pope were at daggers drawn; two bishops and three archbishops were in prison, and he thought that the total separation of the Catholic Church in Germany from the Pope would probably be the result. Both he and Sieveking apprehended that there would be a war between Germany on the one, and Austria and France on the other side, within two years. Limpricht wrote moreover that by that time France would be able to put under arms one million six hundred thousand men. Kochen, married to Julia, the youngest daughter of Mrs. Emily Knawer, had again failed, under the firm of Lorent \& Co., owing to heavy losses sustained in his business with the commercial towns in the North of Norway. 
Saturday, $22^{\text {nd }}$ of May. In the course of the week John Gallagher, Diego Lopez Aliaga and I, as Directors of the Banco Hipotecario, conferred three times with Riva Agüero, on the subject of Soyer's debt, amounting to about S/210,00o and we flattered ourselves that there was now some probability of its being cancelled - though of course the bank would always sustain some loss - owing to the interference of his two brothers-in-law José Canevaro and José Vicente Oyague.

Yesterday, at 3 in the afternoon the clerk of my lawyer Palacios handed me the escrito, Alegato de buena prueba. Enriqueta read it to my wife and to me in the evening; we thought it very well drawn out, and this day I handed it to the notary Escobar, at 9 a.m., when to my utter surprise an escrito of Leyva was notified to me, in which he said that owing to a sudden illness of a member of his family he had left Lima, without giving his power to anyone, and that therefore he begged that during his absence no notification might be made to him [...] ans of [_]uelas, or notes left by the not[_] [719] in his house. The judge Puente Arnao merely ordered that it be made known to me; and Palacios in his answer said that in such and such a place a power existed, given by Leyva to the procurador Munar, and that therefore Leyva having an "apoderado" in Lima, the notifications should be sent to this procurador.

At 2 O'clock I went out to Chorrillos to see how the Italians were getting on with the laying of the marble slabs. They had not yet finished, but what was done was well done. I measured the length and width, in order to know what I should have to pay, as I had settled the laying of each square vara at $\$ 2$; and had just time to take a bath and return by the four O'clock train. The Nacional said that by the first steamer Emilio Althaus and Dr. Rosas, the ex-Minister, would be sent to Europe by Government, to treat for the sale of guano. The same papers gave the ages of the following notable characters: Prince Bismarck, 60 years in April last, Von Moltke, 75 in October next, Gortschakoff, 77, Thiers 78 years in this year, Disraeli, 70, Gladstone 66, Victor Hugo 73. The Emperor of Germany had completed his $78^{\text {th }}$ year on the $22^{\text {nd }}$ March.

Wednesday, $26^{\text {th }}$ of May 1875. In appendix under $\mathrm{N}^{\circ} 15$ will be found a cutting from the Nacional of Tuesday the $25^{\text {th }}$ which gives the conditions upon which the Government of Perú was willing to sell, or to send on consignment two million tons of guano for the next four years, the first shipments of which might be made on the $1^{\text {st }}$ July, 1875 , the first sales on the $1^{\text {st }}$ November 1876 . Le Maître, Chief of the house of La Chambre Gautreaux \& Co. of Lima, had left for Europe by the steamer three or four days ago, so that he would be in Paris a short time before the arrival of Althaus and Rosas.

My wife and I went by the two O'clock train to Chorrillos. She was satisfied with what the Italians had done. We returned by the 4 O'clock train. I 
immediately hastened to the notary Escobar when I found that the judge Puente Arnao had not only ordered that the procurador should be, but that he had actually been notified. This unusually quick dispatch I owed to the kind interference of Rafael Velarde.

Thursday, $27^{\text {th }}$ of May. Corpus Christi. I started at 1.30 [...] [720] ascent of San Crístoval and reached the summit without being tired. I was back by 3.30, rested, dressed, and had still time to pay three visits, viz.: to Doña Manuela Boza de Mendoza, who belonged to the very "Sangre azul" of the Lima aristocracy, but was at the same time one of the silliest women under the sun; then upstairs to her first-born Manuel Mendoza y Boza, certainly no bright genius either; and thirdly, to José Pablo Escobar and his wife Emilia Lopez, of Piura, who, not of such a high caste as the Mendozas, made up for their humbler birth by agreeable conversation and pleasant demeanour.

Friday, $28^{\text {th }}$ of May. The Procurador Munar gave in an escrito requesting not to be notified in my suit against Leyva - which was flatly refused by the judge. This sentence should have been notified to him on

Saturday, $29^{\text {th }}$, but was not.

Sunday, $30^{\text {th }}$ of May. We had a visit from the Minister for Foreign Affairs Anibal de la Torre, an old acquaintance of the family, though I did not recollect having been previously acquainted with him. He was particularly agreeable, and without the slightest pretensions. I made many calls, amongst others upon the family of Dr. Ribeyro and upon Doña Dolores Puente, both returned from the sea side.

The decrees respecting the Tarapaca Salitreras were published. The one imposed an export duty of thirty cents, or three rials upon each quintal of nitrate of Soda, such cargoes as were actually loading, paying only half a rial, or five cents. The second decree ordered that all Salitreros who were desirous of disposing of their establishments to the Government should give in before the fourth of July next an exact account of the details which the Government had asked for and specified. Those who did not do so by the said day were looked upon as unwilling to sell their establishments to the Government.

Wednesday, $2^{\text {nd }}$ of June. Quite unexpectedly arrived per Steamer from Panamá, Geraldo and Juan Garland, the la[_] from his board [...] school [_] L[_]anne whence he had [...] [721] by train to Paris in about eighteen or nineteen hours, and from Paris to London in ten or eleven. Geraldo came from St. Petersburg and brought dispatches with him from the Peruvian Embassy to the Government; his route had been the following: from the Russian Capital via Wilna to Königsberg, thence to Berlin, to Cologne, and to Ostende, all this distance of course by train; in Ostende he had taken the steamer for Dover, 
again by train to London, and from London to Southampton. As far as London he had accompanied the younger children of Lavalle. Juan was by far not so good-looking as when he left in 1868; he was quiet, modest, and by no means so full of pretensions as I had been led to believe by the letters received from Paris. With the same Italian bricklayer who had done the work in Chorrillos I made an agreement for repairing the roof of my Lima house, Calle de Zarate, wheresoever it might be required, to prevent the water from passing should we again have such heavy rains as we had two years back.

At 7 p.m. I went to the Banco de Lima, but as two Directors were wanting to form the quorum, we had no regular meeting, merely a friendly conference. Dr. Aranivar, the lawyer of the bank, was also present. The questions laid before us were of importance. A short time before the stoppage of Julian Zaracondegui the bank had lent him $\mathrm{S} / 50,000$, secured by a second mortgage upon the house in which the bank had its offices, which was Zaracondegui's, and to whom we paid a monthly rent of $\mathrm{S} / 400$. Ever since his stoppage the trustees of the estate carried on two lawsuits against us; the one demanding the cancelment of the mortgage, on the plea that it had been imposed upon the house hardly a month or so before the stoppage, which was contrary to law, the other claiming payment of the monthly rent - in which they were quite correct, for the law of the country says that from the moment an individual stops payment, interest upon the loans made him ceases. Now it was proposed to purchase the first mortgage of $S / 8000$ in favor of a certain Carolina Bolivar; because both mortgages being once in our hands it was believed that it would be an easy matter to bring the house to the hammer. We $[\ldots]$ ined that it would be advisable to make this purch [...]. [722] The second question was the following: The Salitrera "Esperanza" greatly indebted to the bank, as mentioned more than once, was not the owner of the ground from which the nitrate was extracted, and upon which the different edifices, machinery railway etc., were constructed. The "Esperanza" was merely the lessee for twelve years. The owner was a certain Almonte who was carrying on two lawsuits against the Esperanza; the one, the object of which was to annull the lease, because, as he said, the Company La Esperanza had been dissolved through the bankruptcy of Zaracondegui, one of its principal shareholders. The object of the other was to invalidate the loan made by the Bank to La Esperanza, because, as he pretended, the "Esperanza" had no right to mortgage the property. He now applied to the bank for a loan which we thought prudent to concede to him upon the Sine qua non condition that he desisted from the above two suits. The third question was how to procure funds to make remittances to F. Huth \& Co. and the International London and Hamburg Bank, both creditors of the 
bank, for about fifty thousand pounds each. It being considered unadvisable to call upon the shareholders for further quotas, we decided that the Gerentes should apply to the Government, requesting the same to return to the bank one half of the Government papers which at the beginning of 1874 had been placed into their hands as a guarantee for the solvency of the bank, and for the notes in circulation. It was past nine when I came home. At a still later hour Rafael Velarde came with his family to salute the just arrived young men. Don Rafael was in high spirits, for this very day he had been elected by the Congress one of the nine members of the Tribunal de Responsabilidad, a tribunal placed above the Supreme Court of Justice. The sentence of the Supreme Court once given, was irrevocable, but the litigant who considered himself prejudiced by an unjust sentence might apply to the new, or rather resuscitated tribunal and demand the responsibility and punishment, of those Vocal[_] of the Supreme Court whom he considered to ha[_] given [...] [723] sentence contrary to law. The nine members were: Dr. Pino, formerly Vocal of the Superior Court of Justice in Puno, Dr. Loayza, a very clever lawyer, Minister of Finance, I do not remember in whose time, Dr. Lizarraga, an insignificant man, once Peruvian Minister in Bolivia, Dr. José Antonio Garcia y Garcia, he of the Eten railway and Monitors bought in the United States, Evaristo GomezSanchez, ex-Minister of Pezet, Manuel Francisco Benavides, Tomas Gadea, a clever Deputy, Francisco Garcia Calderon but too well known to our family, and Rafael Velarde. Fiscal was Dr. José Aranivar, one of Balta's Ministers. Adjuncts were: Fernando Palacios, my lawyer, Manuel E. Ingunza, native of Huanuco, Dr. Manuel M. de Aparicio, a son of the general, and Ramon La Fuente of Arequipa, son of Basilio and nephew of Blas. This last named had of late come once or twice to Enriqueta's parties on Thursday evenings. Adjunct-fiscal was Juan Martin Cardenas, the same who in the meetings of the Banco de Lima gave so much annoyance to the Directory.

On the $1^{\text {st }}$ an authentic document was presented in the Congress, from which I took the following details:

On the $20^{\text {th }}$ April 1868 , President Canseco contracted with Henry Meiggs for the construction of the railway from

Mollendo to Arequipa, for

$\mathrm{S} / 12,000,000$

President Balta contracted on the $18^{\text {th }}$ June 1869 for that from

Arequipa to Puno, for

$\mathrm{S} / 32,000,000$

and for that from Callao to La Oroya, for

On the $10^{\text {th }}$ Dec. 1870 for that from Ilo to Moquegua

$\mathrm{S} / 27,600,000$

On the $13^{\text {th }}$ Dec. 1870 for that from Pacasmayo to Magdalena

$\mathrm{S} / 6,700,000$

$\mathrm{S} / 5,850,000$ 
On the $17^{\text {th }}$ July 1871 for that from Payta to Piura

$\mathrm{S} / 1,945,000$

On the $31^{\text {st }}$ Oct. 1871 for that from Chimbote to Huaraz

$\mathrm{S} / 24,000,000$

On the $2^{\text {nd }}$ Dec. 1871 for that from Juliaca to Cuzco

$\mathrm{S} / 23,959,144$

On the $3^{\text {rd }}$ Jan. 1872 for that from Salaverry to Trujillo

$\mathrm{S} / 3,400,000$

Besides these

$\mathrm{S} / 137,454,144$

the purchase of the railway from Lima to Chancay cost the Govt. S/4,000,000

Moreover, the railway from Trujillo to Huamachuco, and that [...] La Oroya to Ayacucho had been decreed in 1871 and [...] [724] that from Tacna to the frontiers of Bolivia; so that in my opinion the thirty million Soles, which the commission which presented this document - and which consisted of J. A. Garcia y Garcia, Nicolas Hurtado, and others - calculated to be sufficient for completing all the above railways, would not be enough.

Thursday, $3^{\text {rd }}$ of June 1875. The procurador Munar having appealed to the Superior Court against Dr. Puente Arnao's sentence that during Leyva's absence notifications should be made to him. I went this morning at an early hour to Dr. Mendoza, one of the Vocales, and begged him to dispatch this appeal of Munar's as quickly as possible, which he promised to do. I was at 3.30 in the Banco Hipotecario with Gallagher, Diego Lopez Aliaga and Jimenez as Directors, and Riva Agüero, Gerente. Gallagher stated that several shareholders with whom he had spoken were highly dissatisfied with the arrangement we were about making with Soyer, and was of opinion that as hitherto it had not been carried into effect, we should consider it as annulled. This, Aliaga thought could not be done. I, knowing the idea of my colleagues, proposed a meeting of all the shareholders to whom we might present the whole affair. This was violently opposed by Riva Agüero, who said that this would be the ruin of the bank, and that it would then be out of his power to borrow the money necessary on the $30^{\text {th }}$ June, and that in short, were the Directory to insist upon it, he would throw up his post. In the discussion some disagreeable words passed between him and Aliaga, and after a great deal of talking, one way and the other, I proposed that Saturday should be the very last term given to Soyer to conclude the arrangements previously proposed, and that if not completed on said day, criminal proceedings should immediately be commenced against him. This was unanimously agreed to. The Gerente laid before us proposals made by several debtors of the bank as to the manner in which they wished to cancel their arrears, some were inadmissible others were accepted. To the number of the former belonged one of Mariano [...] [725] Paz-Soldan, who proposed to cancel his debt of $\mathrm{S} / 8000$ by means of Cedulas at a higher price than they were actually worth; this proposal was rejected as ridiculous and absurd. 
The Consulado had declared the bankruptcy of the Salitrera Barrenechea. They who had demanded this declaration were: el Banco Garantizador, La Compañia Sud Americana and M. G. Chavez.

Sunday, $6^{\text {th }}$ of June 1875. In my usual round I called amongst others on the Minister for Foreign Affairs Anibal de la Torre, and his wife Fidelia, the niece of General Buendia. He was quite as agreeable and friendly as I had found him to be the two or three times that I had previously seen him. Also his wife knew how to say a few words. They had a numerous family, of whom the eldest were two grown up girls. Lembcke came in whilst I was there, and to both of us La Torre repeated the invitation which on the previous day he had sent round in a circular to the Diplomatic and Consular Corps, to take tea with him in the evening. Accordingly I went with Garland, and was not a little surprised not to meet with any one of the Diplomatic body; also of the Consuls only Oyague and I were there. The former took his seat close to the lady of the house, and kept her in conversation, Garland and others went to play rocambor, and I, not knowing, or not distinguishing the other guests, took French leave as soon as tea had been handed round.

Monday, $7^{\text {th }}$ of June. At 3.30 the Directors of the Banco Hipotecario, as usual without Mendoza, met once more on the subject of Soyer's affairs. Soyer himself was present, and begged us earnestly to give him another respite till Thursday, for, as he assured us everything was ready for signature, and that the documents were not signed solely owing to the want of stamps, to buy which he had not the money, but that this would infallibly be arranged, if not before, at least by the said day. We acceded to his request. Riva-Agüero made known to us that he had paid Puccio S/40,0oo which the bank had owed him, and we instructed him to proceed without loss of time, judicially against several debtors, who had not made regularly their three-monthly payments, of the number of whom were: Pio Echenique, Juan Martin Echenique, and Carlos Elias, the representati [...] the two former being their brother Rufino. [726]

Tuesday, $8^{\text {th }}$ of June. The members of the Directory of the Water Company had a meeting. Prentice, the chief-engineer, who had a great name in Lima, but whom I did not like in the least, made bitter complaints of the sub-engineer Wilkinson, who, he said, had not obeyed his orders. I asked him whether the works which had been concluded were badly done, "no", he said "but they have cost more than they ought." Again I asked, "are they to be undone?" "no". Again I: "what use is it then to speak so much about them, what we want is water, and if we get water we must be satisfied." Afterwards I enquired how much would be the daily increase of water by means of the new works, but neither Rey nor Prentice would, or could give me a definite answer. I was glad to learn that Prentice purposed leaving for England on the $14^{\text {th }}$ July. The other subjects 
on which we treated were of little importance, such as the probability of a dispute with the Lima Municipality relative to some tracts of land close to where the company was at work digging for water.

The great mercantile news of the day was that the firm of F. Huth Gruning \& Co. of Lima would liquidate in the course of the next two months, and that everything, the stock on hand and outstandings included, would be transferred to the house of Graham Rowe \& Co. This arrangement had been made by the Liverpool branch of Huth's with Mr. Joseph Macandrew of Graham's house, and been approved of by the London firm. Westphal, the head of Huth's house in Lima, was extremely annoyed with this sudden liquidation; he expected that it would have been entrusted to him, and at least six months been allowed. Mr. Macandrew by the by had got married in England; his wife was one of the daughters of the late Henry Read who was twice married, first, with Antonia Cossio, next, with her sister Manuela, still alive, and whom my wife and I once visited in Torrington Square London.

Ricardo came in to tell of the death of Dr. Francisco de Paula Vigil, an extremely clever man, a great heretic, excommunicated by the Pope.

Thursday, $10^{\text {th }}$ of June. At the appointed hour all the Direct [...] [727] Banco Hipotecario assembled. The escritura by which Soyer transferred to the bank a large building in Callao, for which he was to be credited S/80,0oo though in reality it was not worth more than $S / 60,000$, was drawn out, but another difficulty arose. Soyer had promised to deliver to the bank $S / 20,000$ in his drafts on Francisco Garcia Calderon accepted by the latter. Calderon had withdrawn from his original promise, and merely proposed to guarantee Soyer's signature, not de mancomun et insolidum, which ridiculous offer was unanimously rejected, and a new term conceded to Soyer. Riva Agüero again laid before us several petitions made by such as were in arrears with their payments. One, of the widow of the late President José Balta, praying for some concession, was acceded to, others were rejected. In the evening at Enriqueta's, Rafael Canevaro and his wife Inéz Laos made their reappearance, after a long interval, caused by their absence in the country. Rafael Velarde and family were present as usual.

Friday, $11^{\text {th }}$ of June 1875. The funeral of Dr. Francisco de Paula Gonzales Vigil, for many years librarian of the Lima library, took place. He had reached his $83^{\text {rd }}$ year. His charity had been great. It was said that of $S / 80$ amount of his monthly salary as librarian he had been in the habit of giving $\mathrm{S} / 6$ o to the poor. I was not quite certain whether he had actually been excommunicated, as said above. There was no doubt however that several of his works against the abuses of the Roman Catholic Church, or, as others said, written against the religion itself, had been prohibited by the Pope; accordingly the clerical authorities of Lima would not permit his corpse to be deposited at night in any of the 
churches; they even attempted to prevent its being interred in the pantheon, which was considered to be holy ground. This however they could not carry through for the pantheon was under the management of the Beneficencia, and there the majority decided that the body should be admitted. About 9 O'clock a.m. a great number of people assembled before the house in the Plaza de la Inquisicion, where Vigil had died, and where his relations resided. I hastened to the street which leads to the Maravillas gate where the procession passed. It seemed [_] me a poor affair. I only distinguished the "Bomberos" or fire [...] [728] the different nations, who had certainly a stately appearance in their gala dresses. Between their two files I saw a great many people in black, some with blue, others with red sashes. Behind them more and more gentlemen in black, then the hearse, the Government's carriage with four horses, and the public and private coaches. My weak sight, however, must have deceived me, for by all accounts, especially those published in the papers, it had been a splendid demonstrations of the love and esteem felt for the deceased by a large proportion of the Lima population. All the way from the house to the pantheon the coffin was carried on the shoulders of various parties who relieved each other. The first were young men related to him, or sons of his intimate friends: Leandro Mariategui, son of old Francisco Javier, Francisco Paz-Soldan, son of Don Pedro, Carlos Ferreyros, son of the deceased Don Manuel, Arístides and Francisco Vigil, and Carlos Pimentel this last unknown to me. The ribbons which hung down from the coffin were held by General Lafuente, head of the deputation sent by the Senate, by Dr. Ureta, fiscal of the Supreme Court of Justice, by Pedro Paz-Soldan, and by one of the President's Aides-de-camp. A band of music belonging to the Italian Bomberos led the procession; it was followed by the "bomberos" of different nations, both of Lima and Callao, also by the Salvadores. The freemasons mustered in great number; these were the wearers of the red and blue sashes noted by me. There marched in due order, deputations from the Senate and Chamber of Deputies, from the Departamental and Provincial Councils, from many associations, of whose existence I had hitherto been ignorant, from the Clubs "Nacional", and "Union", even from the German Club, though the papers did not mention it. The pupils of San Carlos and San Fernando also made themselves conspicuous and of private individuals, of whom the number was great, the Nacional particularly mentioned General Prado, Dr. Ureta, Dr. Eusebio Sanchez, Dr. Quiroga of the Superior Court, José de la Riva Agüero, the English Minister etc. It was 1 O'clock before the cortege [...] [729] were assembled; and with difficulty a way could be made through the crowd. A funeral hymn was sung by a corps of young Limeños, and after the coffin had been placed in its niche, not less than ten speeches were delivered. No clergyman was visible, no prayers were said. 
The Congress had declared the day to be one of general mourning; it did not meet. The tribunals were closed, so were the greater part of the shops, stores, commercial houses, and banks. The Banco Garantizador, where Bernardo Roca was Gerente, and a shop of another brother in the Calle de San José were open; they belonged to the clerical party whose organ was "La Sociedad", of which one of the brothers, a clergyman, was an active member.

Sunday, $13^{\text {th }}$ of June 1875. The various clubs of Pradistas met in the Plaza de Armas, and marched out to the Plaza de Acho where Prado delivered a discourse, and then went by train to Chorrillos, where he resided. He of course had walked at the head of the procession accompanied by the members of the committee whose object it was to secure his election as President of the Republic, amongst whom Rafael Velarde; M. F. Benavides, who called himself one of the Prado's great friends, preferred remaining in the balcony of the Club de la Union. Garland, who with Enriqueta's and Rafael's family had likewise been in the balcony, told me that it was a very poor assemblage, consisting almost exclusively of the lowest classes of people. Alejandro counted them, and told me that when marching out they were not more than 2000, which number might have gradually increased to its double. I called in the morning upon the Minister La Torre, but found nobody at home. Garland went in the evening, when the party had been better attended than last Sunday.

Tuesday, $15^{\text {th }}$ of June. I was present at a meeting of the shareholders of the Chilete Mining Company, which was numerously attended. J. P. Escobar as President communicated to us that more funds were required than the Company hitherto possessed. He then read the report, which accounted for this unexpected call. It said that the machinery which was expected from France, and the object of which was to separate the heavier from the lighter metal, had not yet arrived, that perhaps one [...] [730] months more to put it up. In the meanwhile the separation of the different ores was done by manual labour, which proceeded very slowly and thus the quantity of ore shipped, and the advance received upon it from Gibbs' house, to whose firm in London it was consigned, did not suffice to cover the daily expenses.

One of the violent attacks of migraine from which Enriqueta suffered regularly once, if not twice a month, obliged her to keep her bed, and she therefore did not appear at table, where since Tuesday last owing to our cook Achipe's illness my wife and I had also sat down. We had not yet done when Garland suddenly rose, and I heard him tell Ricardo to go immediately for Dr. Bravo. All got up, and hastened to Enriqueta's bedroom. I did not approach the bed, but heard her groan and weep, and was told that she was lying in dreadful convulsions. Bravo soon came. Alejandro went for the medicines, which consisted in a great measure of ether and musk. They had their due effect, 
the convulsions decreased, and when we retired to rest at about eleven, they had ceased. Though Bravo assured me that such nervous convulsions were not fatal, yet Enriqueta I believe thought differently. She sent for Guillermo, who immediately came, and all her sons, Antonio excepted, behaved extremely well. Enrique was absent having gone on Saturday up the Oroya line. I begged Bryson to excuse me for the evening, but somewhat later my wife and I had a long visit from Doña Francisca, Melchor Velarde's wife, and one of her daughters, who, much against our inclination, kept us tied to our room till 10 O'clock when they left.

Wednesday, $16^{\text {th }}$ of June. This morning Enriqueta was somewhat better, but extremely weak.

The Lima winter had regularly set in. Thermometer at 11 a.m. within doors, $64^{\circ}$ F. The sun seldom came out, and it rained a good deal, though as yet not so much as to pass through the roofs. I was in the habit of rising about 8 O'clock. Sometimes, but very seldom, Ricardo read to me in German at present the [_] lent us by Mr. Diez called "1812" crowd[_] [731] with incidents arising from the occupation of Germany by the French and from the invasion of Russia by the Grande Armée in the same year 1812. When Ricardo did not read I frequently took a walk, and often had to go to the notary's office in the Consulado or to the office of the notary Escobar in the justice-hall. At ten we breakfasted; at 10.30 Bryson came, and remained till past four. Our grand work was the remodelling and copying of my former diaries in which we were up to October 1858; there was however a great chasm to be filled up from October $185^{2}$ to June 1856, which included the travels of my wife and myself, Corina and Amalia in 1855, and as all this was written in German I translated it in the forenoons of Sundays and holidays, when Ricardo read the German and Bryson wrote down my English translation. In this however we did not make such quick progress as I could have wished. An hour or so we generally devoted every forenoon to reading; it was now Sir Samuel Baker's journey in search of the sources of the Nile, an extremely interesting work, to which I now listened for the second time; frequently I had however to absent myself to be present at the different meetings. When Bryson was gone I usually took a short walk. Dinner was served at 5.30; from 7 to 8 was to me the most pleasant hour in the day; Bryson read to me Alison's History of Europe from 1789 to 1815 . Towards 9 we took tea in our small parlour - La Salita - where we were generally joined by Garland, Enriqueta, Ricardo, Juan, and the two little girls. Our hour for retiring to rest varied from 10 to 11; Enriqueta's tertulia on Thursdays formed of course an exception to the general rule. On Sundays and holidays Bryson left at 1.30 and did not come after dinner. The hours from 2 to 5 p.m. on these days I generally employed in making calls. 
The Directors of the Banco de Lima, Elguera excepted, assembled at 1 O'clock, and did not rise till half past three. Many important points were discussed and decided. Manuel Cucalon for instance insisted that a certain Guimet, a landed proprietor, much in arrears with his payments, should immediately be sued; Castillo and Mendoza replied, and showed the impropriety of taking such a step at the [_]ent moment as Guimet was just ab [...] tting up his [...] [732] for making sugar. The majority decided that two months or thereabouts should still be allowed him before proceeding judicially. It was further agreed, though opposed by Cucalon that some latitude should be given to the gerentes as to where to insist upon the payment of $11 / 2 \%$ interest, and where to make concessions. The gerentes were also authorized to make such arrangements as they might think proper relative to the amounts owing by Zaracondegui's estate to the bank; further, Lembcke made known to us that the Government, the Banco Territorial, and the Banco Hipotecario wanted loans; the first and the last were denied, because the repayment of the sums lent them could not be counted upon within a month's time, the longest term we could allow them. To the Banco Territorial we offered S/50,000 at 1 1/2\% monthly, to be held at their disposal on the $1^{\text {st }}$, to be returned by the $31^{\text {st }} J u l y$ at latest. From the Banco de Lima, Gallagher, Mendoza, and I went to the Banco Hipotecario, where we found Lopez Aliaga and Jimenez, also Riva-Agüero. In Soyer's affair not the slightest progress had been made. José Canevaro had excused himself with his parliamentary duties, which for the moment did not allow him to occupy himself with anything else. We remained together till half past five, but nothing of importance was determined. At 7 O'clock I had again to go to the Banco de Lima where the shareholders were called together to listen to the reading of the new Statutes which had been agreed upon in former meetings, and to approve or disapprove of the manner in which they were drawn up. Instead of this there were a few who wanted to open a new discussion, with the object of disapproving what they themselves had approved of in a previous meeting. Octavio Tudela was the leader; with him sided Focion Mariategui, and a certain Serdio, who, without having been present at a single previous meeting, now came for the first time as representative of some other shareholder. Cipriano Correa, who had neither attended a single previous meeting, flung out of the room with the words, "what is the use of my remaini[_] if nothing is to be discussed?" To the opposition belonged [...] [733] J. V. Campo, Toribio Escurra, one of the sons of Julius Pflücker, and two or three more. The Directory was by no means complete; present were: Gallagher, Luis Cisneros, I, Gil, who acted the part of secretary in the absence of Pedro Bernales, Castillo, Mendoza, and the two Gerentes. With us voted: Diego Lopez Aliaga, Antonio Bazo, representing the deceased J. C. Torrico, J. V. Oyague, young Lembcke, 
representing Salaverry in Europe, and perhaps one or two more; so that we had always the majority, and the statutes were finally approved. I was home by 10 O'clock. Whilst we were here assembled the Congress Extraordinary held its last session; probably it would not be reopened, and if so, Leyva by his manoeuvres would have gained his object. The judge Quiroga, whom we knew to be in his favor, would give his sentence, for he returned to the Juzgado de $1^{a}$ Instancia from the Superior Court, where he occupied the place of Dr. Teodoro de la Rosa who had been called to the Congress, whilst I, on the other hand, had done everything in my power to have the suit sentenced by Dr. Puente Arnao, who in the meanwhile had taken Quiroga's place, and upon whom I flattered myself to have some influence through Rafael Velarde's acquaintance with his brother-in-law Villarán.

Thursday, $17^{\text {th }}$ of June 1875. The lawyers Loayza, Garcia Calderon, and Aparicio, Vocales, and J. M. Cardenas, adjunct-fiscal of the Tribunal de Responsabilidad, declined their nomination; the Government however insisted.

In the evening Garland had two rocambor tables. At that where they played for high stakes sat down: himself, Anibal de la Torre, Malinowski, and Corso, the brother of the Vocal of the Superior Court of Justice. At the other table played Carlos Ferreyros, Geraldo, and two more. At the roulette table Alejandro and one of the two brothers Cox were the bankers; and for the first time two young girls, Juanita and Margarita, daughters of Domingo Valle Riestra, were present. They had come with their uncle Don Anibal, brother of their mother Virginia. It was past one when we broke up, and for a wonder my wife rose winner of a few Soles.

Friday, $18^{\text {th }}$ of June. A "bando" or [_]tion made [...] [734] that on the $21^{\text {st }}$ a second Congress Extraordinary was to assemble. The three principal points which the Executive submitted to its deliberation were:

Firstly, how to obtain the funds required for the deficit in the budget for the two years 1875 and 1876 , amounting to between seven and eight million Soles.

Secondly, how to obtain the thirty million Soles wanted to conclude the railways already begun, and

Thirdly, how to obtain the funds for the establishment and maintenance of public schools. The last Congress, just before closing its sessions had voted a subvention of $S / 160,000$ annually to the line of steamers which might be established between Callao and Hong-Kong, for the purpose of bringing to this coast free Chinese emigrants.

Now I was again all right as regards my suit against Leyva, for Teodoro de la Rosa would remain in the Congress, Quiroga in the Superior Court, and Puente Arnao in Quiroga's place as Juez de $1^{\text {a }}$ Instancia. 
In a letter from my nephew Johannes Limpricht of the $22^{\text {nd }}$ February, he told me amongst other things that one hundred and twenty million Imperial Marks, or six million pounds sterling, were deposited in gold in the fortress of Spandau to serve on an emergency, and that in order not to lose interest upon this large sum, bank notes were issued for this amount.

Tuesday, $22^{\text {nd }}$ of June 1875 . When at the appointed hour, say 3 O'clock, I went to the Banco Hipotecario, I was again received with a piece of bad news. A certain Barrios, son of a natural daughter of the late Domingo Castañeda, who had been as clerk in the establishment since its foundation, and whose business it was to collect money, and when collected to take it to the bank with which the Banco Hipotecario kept its account, had decamped with about 10,000 Soles. On the previous day at about 2 O'clock a cheque of S/60oo on the Bank of London and between three and four thousand [...] [735] in billetes had been handed him by the cashkeeper for the purpose of taking these two sums to the Banco Anglo Peruano. He did not come back; neither did he make his appearance this morning, Riva Agüero became alarmed, enquiries were made, and it was discovered that he had cashed the cheque, made no delivery, and not slept in his mother's house. Riva Agüero now applied to the Prefect, who sent telegraphic dispatches to all quarters in order to stop Barrios' escape. I myself much feared that all these steps would be useless, and the money be lost. With Soyer's debt no progress had been made, and now Riva Agüero himself was of opinion that Canevaro was humbugging us, and that at once we ought to proceed criminally against Soyer.

Wednesday, $23^{\text {rd }}$ of June 1875. We again met. As regards Barrios, nothing new. Canevaro had had a long conference with Gallagher, made new proposals and again solicited a term of three days, which Diego Lopez-Aliaga, José Jimenez and I, would not concede to him. Mendoza was absent. Gallagher declined to vote.

Thursday, $24^{\text {th }}$ of June 1875. San Juan. I went to see Doña Juana Carbajal, who bitterly complained to me of the conduct observed towards her by her husband, the Doctor, and her eldest daughter Josefa. Then to Juanita, one of the daughters of Domingo Valle Riestra, to Doña Juana, widow of Admiral Guise, to Doña Juana Rosa Moreyra, wife of General Freyre, and to the family Ribeyro to congratulate the father Juan Antonio, and one of the daughters, Juana Rosa. At Mrs. Freyre's I met a stepson of hers, lately married, who told me that he had been ordered to leave for Panamá with one of the Peruvian gunboats under his command, for the purpose of returning hither immediately, as soon as the telegraphic dispatches expected from Althaus and Rosas on the subject of the new guano contract were received. I also looked in at Rafael Velarde's, and old Anselmo Centeno's, which latter told me that in Cuzco a young lady, Teresa 
Maria Enriquez, had been received in the University as a student at law. The Cuzco authorities had first refused admitting her, whereupon she applied to the supreme government in Lima, and after a vista-fiscal given by Paz-Soldan in favor of her $[\ldots]$ ssions the President had ordered the Cuzco University to $[\ldots][736]$ as one of its members.

In Enriqueta's tertulia there were again some new faces: Jorge Pinto, Chargé d'affaires for Honduras with his two daughters Leonor and Rosa, not handsome, but extremely well educated. This was the family which Henry Meiggs had overwhelmed with presents. He had furnished them with the means to travel all over Europe as far as the Holy Land, also with the funds required for the total repairs of the house which they occupied. Carlos Elias did not remain long, neither did the Minister Anibal de la Torre, who had to spend the remainder of the evening at his sister's Virginia. From Rafael Canevaro, who was present with his wife Inéz Laos, I learned that at the desire of Manuel Pardo, the banks established in Lima would send by the steamer of the $28^{\text {th }}$, their agents to Europe, in order that these Peruvian establishments might if possible also obtain some share in the guano contract to be concluded in the first weeks of August. For the Providencia, one of their Gerentes, Joaquin Bolivar, would go; for the Nacional, Rufino Echenique, for that of Perú, Cesar Canevaro. Don Rafael added that Lembcke for the Banco de Lima had declared that the bank had not the necessary funds to enter into such a business; and the Anglo-Peruano had already its representatives in Europe.

Friday, $25^{\text {th }}$ and Saturday, $26^{\text {th }}$ of June 1875. The Directors of the Banco de Lima met. Two new Directors were elected: Evaristo Barrios, a respectable ironmonger, and I believe a good, but very insignificant man; I did not vote for him; and secondly, unanimously, the procurador Diego Lopez Aliaga. The choice for the Vice-president fell upon Luis Benjamin Cisneros, who had five votes, John Gallagher, and Pedro Bernales, each two. These elections were however things of minor importance. Lembcke made known that the balance of $\mathrm{S} / 30,000$, which a few weeks back still existed in the hands of the Banco de Lima being the remainder of the $\mathrm{S} / 200,000$ which the shareholders authorized the Directory to advance to the Salitrera "Esperanza", had been totally absorbed by the expenses of June and that [...] [737] present there was not a rial on hand belonging to this establishment wherewith to pay further expenses. Lembcke thought that as there were about 8000 quintals of nitrate actually produced, though not yet carried to the coast, ready for embarkation, the bank might make a further advance, and cover itself out of the proceeds of the nitrate, when sold. I spoke first, and decidedly opposed this plan. The bank, I said, could not disburse a single rial more, in hopes of being reimbursed hereafter 
and added that the nitrate might be sold where it lay, though at a distance from the coast, and that in the price, a deduction might be made corresponding to the expenses of carriage. This, Lembcke said, was impossible, for nobody would buy nitrate if not placed on the beach. Now animated debates ensued, with after all led to no result, except that the shareholders in the "Esperanza" should be informed of how things stood, and be called upon to come forward with the money required. Their answer, it was calculated, could be received before Monday. On Monday, $28^{\text {th }}$ as well as

Wednesday, $30^{\text {th }}$, the Directors of the Banco de Lima were again called together. I went at 7 p.m.; so did various others, but the requisite number of nine to form a quorum, was not there. We talked a good deal on the subject of which I spoke above, but nothing could be determined. When I left, together with Cisneros, Bernales begged us to come with him. We were joined by Gallagher and Aliaga, and for more than a quarter of an hour we five, like a knot of conspirators, stood in the open air in the Plazuela of San Agustin. Before we separated we had come to the mutual engagement to be unanimous in our votes on the "Esperanza" question, at the next meeting. On Wednesday Diego Lopez Aliaga and I were about an hour with Riva Agüero, who told us that the escrito against Soyer, which the two lawyers of the bank, Varela and Ribeyro had declined signing, and therefore been signed by a third, Alzamora, had been presented to the criminal judge Ponce, who had refused to receive it, under the pretence that it was not his turn, and that it had now to be presented to another judge Carrillo. Somebody had told Soyer that the criminal proceedings against him had commenced, and since that moment he was not to be found. I felt convinced [_] his relationship with the President, with José Canevaro and [...] [738] Jose Vicente Oyague, had influenced both Riva-Agüero and Ponce. The former had unduly postponed the criminal proceedings, the latter had refused to admit the first escrito.

Thursday, $7^{\text {st }}$ of July 1875. At 12 O'clock the following Directors of the Banco de Lima, Gallagher, Bernales, I, Aliaga, Mendoza, Barrios, and Cisneros, together with the two Gerentes were assembled. The answer from the Salitrera Esperanza was that they could not procure the funds required, whereupon our debate was long and animated; and finally it was resolved that Lembcke should embark for Iquique by the Saturday's steamer, and act in conformity with the instructions given him by the Directory which were the following: If he found that the value of the nitrate on hand sufficed to pay the expenses for the month of July, he might incur them; if not, give immediate advice to the Directory. Twice I observed that in this manner we should always come under a new advance, and that if by some unforeseen casualty, for instance 
an earthquake, fire, or any other event, the nitrate were destroyed before sold, the advance would be lost, and the Directory would be responsible. Nobody however entered into my views, and I said no more on the subject. Lembcke was of opinion that it would be more advisable not to sell on the spot, but to consign the nitrate on account of the Esperanza to F. Huth \& Co. of London, and for the bank to make an advance upon it to the "Esperanza". Gallagher and I opposed this because the main object was for the bank to get money wherewith to pay the expenses without making a new outlay, and, without this our opinion, which prevailed, being inserted in the written instructions, Lembcke was told to bear it in mind when disposing of the Nitrate.

At last Riva-Agüero handed me in exchange for my $\mathrm{S} / 57,000$ Pasco Railway Government Bonds, the same amount in Vales de la nueva Consolidacion, that is to say one thousand Soles of the one, for one thousand Soles of the other paper, whilst I had hitherto understood that the exchange was to have been ma[_] S/10oo Railway Bonds for S/1333 Internal debt. This [...] [739] Riva Agüero assured me he had not been able to obtain. I calculated that my loss would be very trifling, if anything at all, upon the capital, but that the interest was lost since November 1871 , for the $S / 15,600$ which the other day I received from Riva Agüero under the denomination of interest, merely served to cover me for the capital.

Erelong a beginning would be made with the laying of a submarine telegraph-cable from Chorrillos to Caldera, which, if accomplished, would place us in telegraphic communication with Europe. The "International" was in Callao with 467 miles cable, weighing about 800 tons. Mr. Henry told me that she had the Islay shore end, and that the Dacia was expected shortly with the Chorrillos shore end. His house, Gibbs, had just received advices from London in 9 days, say in twenty-four hours to Valparaiso thence per steamer hither.

Friday, $2^{\text {nd }}$ of July 1875 . The shareholders of the Gas Company were called together. A dividend, of $2 \%$ was paid, and nothing else done, for there was no quorum. Afterwards the Chilete shareholders met. I did not go, but learned afterwards that in order to raise the funds required for putting up the machinery, it had been resolved to emit new shares, that is to say, as many as $40 \%$ upon the shares already issued, and these should be offered to the shareholders at as low a rate as $60 \%$. I took one share, for which I had to pay S/60o in the course of the month, so that I now possessed five shares, and was entitled to one vote, which hitherto I had not been. In the Banco Hipotecario, Gallagher, Aliaga, and I met. José Canevaro was with Riva Agüero, and both requested us to suspend the criminal proceedings against Soyer, for Oyague had now come 
forward and was inclined to do something in order to save his brother-in-law. It was agreed that we should meet in my house on Monday next.

Saturday, $3^{\text {rd }}$ of July. The Directors of the Banco de Lima were once more together at about 1 O'clock. The previous acta was approved, a copy of the same, certified by Bernales as Secretary, was handed to Lembcke to serve as his instructions, and Luis Cisneros was chosen provisional gerente during his absence. Through the mediation of Gallagher, the two Gerentes, with the consent [_] the Director de turno had made a loan of S/50,000 to the Banco Hip[_] [740] on the same terms as that to the Territorial. No doubt it would have been more in order, if the consent of the Directory had been taken, and Cucalon made very severe observations on the subject. He was answered by Lembcke and Gallagher, and a violent altercation ensued, which however led to nothing. What was done could not be undone. Lembcke left in the afternoon for Iquique.

Sunday, $4^{\text {th }}$ of July. At 1.30 I started from my house for an ascent of San Cristoval, and without stopping or resting was back in my office in two hours, less two or three minutes. The sides of the mountain were covered in many places with verdure, not with grass, but with a plant about an inch above ground.

The only visit I paid was to Anibal de la Torre and his wife.

Monday, $5^{\text {th }}$. Between 3.30 and 4, José V. Oyague and José Canevaro, José de la Riva Agüero, Gallagher, Diego Lopez Aliaga, José Jimenez, and I assembled in my house in the room lately occupied by my son Juan. As soon as we were seated Oyague made his and Canevaro's proposals how to cancel Soyer's heavy debt to the Banco Hipotecario, which were however of such a nature that we could not accept them. I was the first to speak, and said in a few words that I considered them as such. Gallagher followed in my track, and dilated on the subject, in very proper terms, and with great judgement. Now the discussion began, and after some time I begged Aliaga to give his opinion, which he did in a neat speech, and completely in accordance with the ideas of Gallagher, Jimenez, and myself. We proposed the one and the other alteration, and at last, without coming to any decision, for Canevaro wanted first to see Soyer and to hear from him whether he still had any property and what it consisted of, all agreed to meet again in my house on Wednesday.

Tuesday, $6^{\text {th }}$. This morning when walking out before breakfast I came as far as a building which was in progress of construction and which was to be called Santa Sofia, situated a short distance outside of what was once the gate of Santa Catalina, on the other side of the Boulevard, an avenue with four rows of Estrapeas with which it was Henry Meiggs' intention to encircle that 
part of Lima which lies on the left bank of the Rimac. Of the wall which formerly $[\ldots][741]$ the town few vestiges were left. Santa Sofia was being built by order, and on account of Augustus Dreyfus in commemoration of his first wife Sofia Bergmann. Its object was to serve as a refuge for poor young women. A good deal was already done, but a great deal still remained to be done. A large square yard was in the middle; round the same ran a wide portico into which opened many apartments of different sizes, none so small as to fall under the denomination of a cell. Exactly opposite the main entrance the building receded a little, and there the chapel was to be. An overseer, to whom I applied for information, told me that the coffin with the corpse of Mrs. Dreyfus, hitherto kept in a convent in Lima, would be interred in the centre of the yard.

Wednesday, $7^{\text {th }}$ of July 1875. By last steamer advice was received of the stoppage of Anibal Gonzáles of London, which had already been foreseen for some time. When Juan was last here he told me that before he left Europe, Gonzales had stood in great need of assistance; he had then applied to Mr. C. W. Schutte for a heavy loan, he did not recollect whether of twenty or forty thousand pounds, which however had been denied him. We were sorry for this misfortune, mostly on account of his good wife Josefa, sister of Juan Bazo. Gonzales was a native of Guayaquil, for a long time in Lima clerk of Gordillo, who like Bernardo Roca y Garzon in former and J. V. Campo in later times, was in the habit of making considerable purchases of goods for Guayaquil, Quito, and other Ecuatorian markets. When Gordillo left for Europe, Gonzales remained at the head of the house, and about that time married his present wife. When the South American Company was established in London by various American capitalists resident in Europe, the management was entrusted to him, which was certainly very strange as he did not understand a word of English. About two or three years back he fell out with the Directors, and then another company similar to the South American was to be formed under his management, but I believe it was not carried into effect, and I was ignorant what was his actual business at the time of his stoppage. At about 3.30 all the Directors of the Banco Hipotecario, Mendoza included, were assembled in my house, together with Riva Agüero as Gerente, and Oyague and Canevaro. The balance of Soyer's debt was S/66,ooo for the cancelment of which [742] various methods were proposed from both sides; some were rejected by the Directors, others by the two brothers-in-law. At 4.30 Canevaro, who was indisposed, left, and authorized Oyague to act for both. The discussion became very animated. Oyague's choler rose, and he made use of some rather offensive expressions, for which, after all had been settled, he begged pardon. Jimenez proposed that the $S / 66,000$ should be paid by Oyague and Canevaro in Cedulas 
at par, which Oyague qualified as preposterous. Mendoza acted as mediator, and thought that $2 / 5^{\text {ths }}$ might be paid by Oyague, $2 / 5^{\text {ths }}$ by Canevaro in Cedulas at par, and for the $1 / 5^{\text {ths }}$ in money, payable within two years, Soyer might sign an escritura. Oyague offered $S / 40,000$ for both, leaving $S / 26,000$ to be paid by Soyer, which I decidedly rejected; and at last it was agreed that the two should deliver within a few days $\mathrm{S} / 5^{0,000}$ in Cedulas at par, and Soyer make himself responsible for the balance of $S / 16,000$ within the said two years. It was past six O'clock when we separated.

Thursday, $8^{\text {th }}$ of July. The protocol of the preceding days proceedings drawn out by Riva Agüero in a very detailed manner, exactly as it ought to be, was read by him to Gallagher and myself. In the evening at 7 O'clock I was in the Banco de Lima, but it was near 8 before I took my seat. Of the Directors there were besides me only Cucalon, Evaristo Barrios, Castillo and Bernales, which last soon withdrew, and the two gerentes, Sagastabeytia, and Cisneros, who acted as secretary. Also the number of shareholders was somewhat smaller than on former occasions; I noted Escudero, Antonio Bazo, Julio Armero, Octavio Tudela, two sons of Lembcke, a son of José V. Oyague, Henry Higginson, and a few more. After the names had been called over, and the last "acta" read, I said that the object of this meeting was to discuss four articles of the new Statutes. The first article, which treated on the object of the bank, was but slightly altered; as it now stood, it confined the bank's business exclusively to banking transactions, a wording which conveyed in an indirect, but not to be misunderstood manner, a censure on the Directory for having made loans to the Salit[_] [743] "Esperanza", and to landed proprietors on the mortgage of immovable property. In another article a mere mistake had crept in; hitherto it had been said that if a shareholder had but one share of 1000 Soles he might be elected Director with $2 / 3^{\text {rds }}$ of the votes. The alteration we now made was that at all events he must have five shares of S/1000 each. The third, which permitted the gerentes and Directors of the Bank to lend money upon one sole signature, was unanimously annulled; and at the motion of Evaristo Barrios, it was further resolved that the amount lent upon security with one signature, could not exceed $5 \%$ of the paid up, capital of $21 / 2$ millions, say $S / 125,000$. The fourth, and last alteration, which we made on Cucalon's motion, was the following: Hitherto one article of the Statutes had prohibited a Director from taking a share in any discussion, and from giving his vote on a question in which be himself personally was interested; now this prohibition was extended to the Directors, who were at the same time Directors of another establishment in case this establishment were to ask a loan from the bank, or was already indebted to the same. 
The object of this motion was clearly to exclude the Directors of the Salitrera Esperanza from the discussions in the Directory of the Banco de Lima, which might have any reference to the Salitrera. I opposed it, but was beaten by a vast majority. I then proclaimed that the new Statutes were approved, and would enter into force on the following day. It was 10.30 when I was back in my house.

Sunday, $11^{\text {th }}$ of July 1875. John Gallagher having requested me to be in the Banco Hipotecario at 1.30 for the purpose of examining the cash, I went there at the appointed hour; he was already on the spot. Diego Lopez Aliaga came a few minutes later, and we then set to work assisted by the book-keeper, a Frenchman, and by the cash keeper, Muelle. Gallagher did most, for I was impeded by my want of sight, and Aliaga, though otherwise a very intelligent man, did not understand much about books and accounts. The accounts and the cash were found correct; the examination of the portfolio we put off to another date, and we resolved that after this was done, a statement of the affairs of the bank, down to the $30^{\text {th }}$ June, signed by [_] as Vice-president of the Directory should be published in the dail [...] [744] When we had concluded our work I had still leisure to call upon Dominguez, the Buenos Ayrean Minister, upon Oscar Heeren, and upon Mrs. Riva-Agüero, which last visit was by no means to my liking. She had all the talk to herself, praised her husband as the cleverest of men, and spoke in terms the very reverse of laudatory of all those who were supposed to wish for her husband's removal from the Banco Hipotecario, and did not even seem to relish the idea of a second being named to act in concert with him.

Tuesday, $13^{\text {th }}$ of July. Once more all the Directors met in the Banco Hipotecario. We instructed the gerente to proceed judicially, and without loss of time, against all those debtors who were in arrears with their three-monthly payments.

Wednesday, $14^{\text {th }}$. Within these last few days Alejandro had informed the various members of the family that he intended marrying a Miss Röel, niece of Enrique Ayulo's wife. Her mother was a Mendibil, and hitherto she had been under the charge of Ayulo.

Thursday, $15^{\text {th }}$. At the request of Enrique Perla, Gerente, of the Banco Territorial, I went at 12 O'clock to the office of this establishment, to be present at the sorteo, or drawing of the numbers of the Cedulas to be redeemed at the end of the year. There were, besides myself: Perla, some clerks, José Vicente Oyague, called in as second inspector, Enrique Cox, the broker, who came in by chance, and several of the Directors, of whom I knew J. M. Cantuarias, Bartolo Figari, and a certain Espinosa, in former years clerk to Julius Pflücker. The whole proceeding was carried on in the most orderly manner. There stood a chest of drawers, each drawer consisting of a board, each with two-hundred 
small round holes, and each containing half of a small round ball upon which a number was written, beginning with one, and concluding with the number of the cedula last emitted. The number of all such Cedulas as were redeemed in previous drawings, were taken out, as they of course had not to be drawn again. The remainder of the numbers were thrown into a large round barrel which could be [...] [745] round, and at one side of which was a small hole, shut for the moment, out of which, when opened, one number fell at a time. We now took our seats at a table, the Directors, Oyague, and I, each ready to note down the numbers redeemed. Now Perla referred to his books, and said the first emission of Cedulas included the numbers (I will say, to make the matter clear) $\mathrm{N}^{\circ} 1$ to 200 . In the last six months a certain number of Cedulas, say 5 , had been paid in by debtors, who had cancelled their loans, consequently there remained 195, or $\mathrm{S} / 195,000$. Of these, $21 / 2 \%$, according to the regulation of the bank, had to be redeemed every half year; $21 / 2 \%$ on $S / 195,000$ are equal to $\mathrm{S} / 4875$. Thus 5 Cedulas had to be redeemed, and consequently drawn, due note being taken for next half year that $\mathrm{S} / 125$ were achially redeemed more than should have been, which could not be remedied, as it was necessary to make a round sum. If the odds came to less than $S / 500$, then these odds stood over till next drawing. Now the round barrel was turned several times, the small shutter opened, and a number fell out. This was repeated five times, the numbers handed to those round the table, called aloud, and noted down. In this manner we proceeded with the various emissions taking each half year by itself. We had finished by four O'clock. In the evening I was so sleepy that I did not go to Enriqueta's tertulia.

Friday, $16^{\text {th }}$ of July 1875. At 5 a.m. a fire broke out in Callao in the mill of an Italian called Serdio situated in that part of the port called Chucuito. It was entirely destroyed, and the loss was calculated to come up to S/150,00o.

Saturday, $17^{\text {th }}$ of July. I attended a meeting of the shareholders of the Banco La Providencia. Besides me there were only six shareholders, four or five Directors, E. M. Cardenas, Aurelio Dinegri, José Albarracin, Francisco Garcia Calderon, and the Gerente Moscoso Melgar. The report of the proceedings of the bank for the last mercantile year concluding on the $30^{\text {th }}$ June was read by Melgar in a very indistinct voice. Amancio Castillo and I asked a few questions of the Directory, but the whole affair was in the highest degree insignificant. A dividend of $8 \%$ was declared, which, together with the $4 \%$ paid on the $31^{\text {st }}$ December made a total of $12 \%$ for the year.

In the course of this week the two steamers "Dacia" and "Int[_] [746] had been occupied laying the submarine telegraphic cable between Chorrillos and Islay, but had not yet concluded the operation. 
Sunday, $18^{\text {th }}$ of July 1875 . Of the visits which I paid this day, I will only mention that to Col. Diego Masias who had arrived from Islay a few days ago, having been sent hither by Javier Osma, Prefect of Arequipa, who suspected him of being implicated in the revolutionary movements which had again shown themselves in the South of the Republic. A certain Captain Arevalo, for instance, who had taken a part in Pierola's late revolt, had collected a few men, and occupied the ports of Islay and Mollendo. To suppress this rising the Government dispatched this day at an early hour, the man of war "Union" with a few troops on board. Col. Masias, as soon as he had landed in Callao, was placed at liberty by order of the President, but for the present prohibited to return to Arequipa.

At 9 p.m. Garland and Enriqueta went to the tertulia of the Minister Anibal la Torre, who on Sundays was in the habit of seeing some friends with him. Mariquita and I stayed at home, and went to bed at an early hour.

Monday, $19^{\text {th }}$ of July. After one or two unavoidable delays, Gallagher, Aliaga, and I were once more in the office of the Banco Hipotecario for the purpose of examining the portfolio, in doing which, Gallagher as usual took the lead. We found it correct, as far as it was in our power to revise it, for a considerable amount in Cedulas and in documents of the Internal debt were wanting, without a receipt existing for the same. They had been given as security for a loan to the London Bank, which had merely noted on the pagaré signed by the Banco Hipotecario that such and such documents were in their possession, without having given a separate receipt. I now, as Vice President, signed the balance sheet dated $30^{\text {th }}$ June. At a later hour I went to a meeting of the creditors of Agustin Escudero, and Luis Roca y Boloña who owed me S/10,00o overdue, for which I held as security S/12,00o in Cedulas del Banco Hipotecario, worth at $60 \% \mathrm{~S} / 7200$ and some shares [_] the Telegraphic Com[_]ny worth at the utmost $S / 800$ [...] [747] principal creditors were: The Banco de Londres, represented by its manager Dawson; and F. S. Isaac \& Co., for whom appeared their active partner Polis. Aurelio Dinegri was likewise present. Escudero and Roca explained to us what their assets consisted of. Morales Brothers, owners of a sugar estate in the vicinity of Trujillo, of whom I knew that they were also indebted to the Banco Hipotecario for a considerable amount, were their principal debtors. They also possessed a small estate of their own called Chicamita in the valley of Santiago de Cao. As neither Dawson nor Polis made any proposal as to the measures which were to be taken, I went away, determined to make my own arrangement with the debtors.

For the evening I was cited to a meeting of the Directory of the Banco de Lima, but did not go, because I was not inclined to lose the hour from 7 to 8 when Bryson read to me Alison's History of Europe. 
Tuesday, $20^{\text {th }}$ of July 1875. The Directory of the Banco de Lima was once more assembled; all were present, except Lembcke, absent in Iquique, Gil, who never made his appearance when he knew that the "Esperanza" would be brought on the tapis, and Mendoza, upon whose regular attendance we could not count. Letters were read, received from Lembcke, from F. Huth \& Co., and from the International Bank of London; the two last named urged the bank to make remittances, even holding out threats if their request was not complied with. We agreed that these remittances had above all to be attended to. Lembcke had drawn $S / 20,000$ from Iquique to pay various accounts left unpaid by Stirling and Quiroz, and to take the balance with him to the "Esperanza", there to defray the necessary expenses. Stirling, who for a short time had been the Administrador, had by no means answered the expectations which we had entertained of him. In fact he had given no satisfaction whatever, and thrown up the post under pretence of ill-health. Quiroz, the son-in-law of Lembcke, by profession an engineer, had for a long time been employed in the Esperanza and attended to the management after Stirling's departure. I gave my opinion to the effect that for the credit of the bank we could not refuse accepting Lembcke's draft, but as we would do it against the express will of the shareholders, it was on our own responsibility, and therefore, if the 15,000 quintals nitrate said to be ready, and which I counselled should be consigned to one of the two [...] mentioned firms did not suffice to [_] the S/20,00o then the Di[_] [748] would be responsible for the deficit. J. M. Cardenas and Gallagher, voted with, the remainder, as I had expected, against me. Then Pedro Bernales moved that the bill should be accepted, and placed to the debit of Lembcke's private account until he could give satisfactory explanations on the subject. This, all agreed to, except Cardenas and Gallagher. Many other motions were made and withdrawn, much was talked, much discussed, but no particular result come to. At three we broke up. I looked in at the Banco Hipotecario to ask if there was anything new, and received for answer from Riva Agüero, "cosa muy grave". Oyague, Manuel Candamo just returned from Europe, John Gallagher and I were present. The serious matter was the following: About three months back Simon Soyer, in order to cancel part of his debt, had given to the bank in part payment of his debt, two drafts of his, of $S / 15,000$ each, accepted by Dionisio Derteano. Riva Agüero endorsed the drafts for the bank, in blank to the Banco Anglo Peruano, which accordingly cancelled an equal amount due to the same by the Hipotecario; we the Directors knew of this transaction, and had at the time been satisfied with it, but now it turned out that Riva Agüero, whether inadvertently or purposely, had given a counter-document to Derteano, relasing him from his responsibility, and now Derteano, notwithstanding his acceptance, very naturally said that not he but the bank had to pay the bills. As 
Riva Agüero had not kept a copy of this counter document, we the Directors could not form an opinion whether the bank was actually responsible or not, and we therefore agreed to meet again on the following day. Manuel Candamo had brought with him from the London Directory of the Banco Anglo Peruano, stringent orders to the Lima Gerentes to show no further mercy to their debtors, and accordingly these latter had written a strong letter to the Banco Hipotecario demanding immediate payment of the amount due by this to that bank, and, as might have been expected, the Hipotecario had not the means to pay.

Wednesday, $27^{\text {st }}$ of July. Somewhat a little before the time appointed for the meeting, I received a note from Riva Agüero, holding out hopes that Derteano would pay and postponing the meeting [...] [749] next day.

Thursday, $22^{\text {nd }}$ of July 1875 . Again Riva Agüero wrote me, and again he put off the meeting, always holding out hopes of Derteano's paying. Nevertheless, I went to the bank, and was joined there by Candamo, Gallagher, and Diego Lopez Aliaga. Riva Agüero did not come till half past three, when he brought with him a copy of the counter-document given to Derteano, which was drawn out in so binding a form that the bank could not escape paying the $S / 30,000$. Riva Agüero's excuses were ridiculous; he said that his own rough draft of the document had been in quite different terms, and that on the $1^{\text {st }}$ April when the other was laid before him for signature he had been so occupied signing cheques, attending to the payment of interest, and to other indispensable business, that he put his name to it without reading it. As to the repayment of the $S / 30,000$ by Derteano he said that this depended upon the transfer of a certain share which Soyer had in the theatre, and which Derteano intended to take from him, and in payment of which transfer he could then pay the S/30,000. Pedro Telmo Larrañaga, who had also some interest in the theatre, had written a few words to Riva Agüero, telling him that the necessary arrangements would at least take three or four days. I proposed that before proceeding any further we should wait till Monday next, but was overruled, and the hour of eight, the following evening was fixed upon for our next meeting.

The cable between Chorrillos and Mollendo was laid, and telegraphic communications were being received. The revolutionary movement above referred to had been quelled. On the $15^{\text {th }}$ July Arevalo, the captain who served in the German army, and who came hither after the peace with France covered with medals, had collected about fifty men in the valley of Vitor, moved with them upon Islay where he had taken the money belonging to the Custom House, thence to Mollendo, where he possessed himself of a small cannon, and obliged the chief of the railway station, Mr. Flint, to put a train at his 
disposal. Towards morning of the $16^{\text {th }}$ he arrived at Tingo, crossed the river, and barricaded himself in the village of Sachaca. From Arequipa he did not receive the assistance which he had expected, was attacked by the forces brought against him by Javier Osma, beaten, wounded [...] carried to the hospital, where he died. [750]

Friday, $23^{\text {rd }}$ of July. At the appointed hour all the Directors of the Banco Hipotecario were again on the spot. As was to be expected, Riva Agüero had not progressed a step with Derteano, and after a great deal of conversation, Candamo at last came to the point declaring that Riva Agüero was responsible for the $S / 30,000$. The ice once broken we all concurred, and Riva Agüero himself acknowledged his responsibility, and promised us an escritura to that effect. Another important question was mooted. How had the debt owing by the Pasco Railway Coy., amounting originally to from 150 to 160,000 Soles, and with interest, to the present day, to about S/225,000 been paid? Riva Agüero was forced to make a clear statement. The $\mathrm{S} / 205,000$ Government Bonds, relative to the Pasco Railway, and which had been placed into the hands of the Banco Hipotecario as security for the debt, had been converted into Vales de la Nueva Consolidacion in the following manner: $12 \%$ of the capital, and $18 \%$ interest, say 3 years at $6 \%$ from $30^{\text {th }}$ Novr. 1871 to $30^{\text {th }}$ Novr. 1874 , together $30 \%$, of the $\mathrm{S} / 205,000$ say $S / 61,500$ had been converted at $75 \%$, that is to say, for the $S / 61,500$ Pasco Bonds,

Vales de la Nueva Consolidacion had been received to the amount of S/82,000 whilst the remaining $88 \%$ capital, or $\mathrm{S} / 180,400$ had been received at par; thus the bank had received in payment of the $S / 205,000$ $S / 262,400$

Vales de la Nueva Consolidacion, which at their present value in the market say at the utmost $60 \%$, would of course not suffice to pay the debt. Who was to be responsible for the difference? We all agreed that the responsibility should fall upon the Directors who had made the loan to the Pasco Railway Company, contrary to the Statutes of the Banco Hipotecario. In the acta it was entered: The responsibility to fall upon those who are responsible. Riva Agüero was anxious to get away for, as he said, on Friday he had always an evening party in his house. We however made him stay until we had determined how the sorteo of the Cedulas, to be redeemed at the end of the year, was to be made on the following day. In the Statutes there were two articles on this subject, the one contradicting the other. The first, which was the [_] correct one said: "every year such an amount is to be redee $[\ldots][751]$ corresponds to that year, 
whilst the other says, $5 \%$ are to be redeemed every year. During the first years the second article was erroneously taken as the rule by which to proceed, and consequently much more was redeemed than actually corresponded to the year. This was discovered by Garcia Calderon, when gerente, and accordingly the redemption was diminished in accordance with the first of the two articles, and we unanimously agreed that also this half year the redemption should be made in this manner. It was eleven when we broke up.

Saturday, $24^{\text {th }}$ of July 1875 . At 2 p.m. I was there once more to witness the sorteo, or drawing. Besides me, several shareholders, owners of Cedulas, Gallagher the Director, who soon left having to attend a meeting in the Gas Company, José Jimenez, who looked on very attentively at what was doing, Luis Cisneros, gerente of the Banco de Lima, Selaya the Notary, and his clerk, were present. In the same manner as in the Banco Territorial, the numbers belonging to the emission of each year separately were throw into the round barrel, which was turned round making an abominable squeaking noise. A young fellow who by chance was there, was called to draw out one by one; he called it out and Riva Agüero repeated it, Jimenez keeping his eyes upon them. When all were drawn they were again called over; the notary Selaya put his rubrica to the list of numbers written by his clerk, and it was 4 p.m. when we had done. Not one of my Cedulas was drawn.

In the evening of this day, at about half past six, when my wife and I were sitting by ourselves on the sofa in the Salita, Alejandro came in, and after speaking on different subjects told me, without addressing himself to Mariquita: "ésta noche es la ceremonia", referring to his marriage. I asked, "will your father be present?" to which he answered "I see no reason why he should not; he will be the padrino." Garland and Enriqueta I had not seen the whole day long. They came to our salita at 9 p.m. when they told us that they had not been present at the ceremony.

Sunday, $25^{\text {th }}$ of July. Rafael Velarde who called upon my wife gave us the following particulars of Alejandro's marriage with Miss Roel, which had been celebrated in the house of our neighbour, the bride's uncle, Enrique Ayulo. The Canon Bandini had officiated. For some time they had been waiting for Garland, but he not making his appearance [...] [752] had taken his place and acted as padrino. The number of persons present had been very considerable: Rafael and Melchor Velarde, without their families, the President Manuel Pardo, the Vice-President Manuel Costas, the two ex-Ministers Riva Aguero and Eusebio Sanchez, J. P. Escobar, the lawyer Espiritu Cisneros, and many other friends of Alejandro and Ayulo, Henry Higginson with his wife, Enriqueta Bolivar, Enrique Marriott with his wife Rosa Escardó and two of her sisters, and of 
course the numerous families of the Ayulos, Roels and Mendibils. In appendix under $\mathrm{N}^{\circ} 16$ goes affixed a cutting from the Nacional relative to this marriage.

Mr. Seacomb paid me his farewell visit as he thought of embarking by the first steamer for Europe, together with his wife Carmen Estenós. He had been here for the last five years attending to the pecuniary affairs connected with the construction of the Muelle Darsena, his mother being the sister of the wife of Mr. Brassey whose firm, he himself having died, had contracted for the building of the said Muelle Darsena for one million pounds with the Société Générale of Paris. Many law-suits were pending between some Chilians, the original projectors, Templemann \& Bergmann who obtained the concession from Balta's administration, Dreyfus Bros. \& Co., to whom the concession was transferred by the Bergmanns, the Société Générale who had found the funds and perhaps also J. H. Schroeder \& Co. of London much befriended by La Société. It was a complete legal labyrinth. According to Seacomb, Mr. William Gibbs had left a fortune of four million pounds Sterling, which, I thought was rather an exaggeration.

Tuesday, $27^{\text {th }}$ of July. At my request the Directory of the Banco Hipotecario was called together. Candamo had begged to be excused on the plea of his many occupations for the steamer. Riva Agüero did not make his appearance, pretending that he had to collect funds, and had begged Gallagher to act in his stead as secretary. José Jimenez observed that Riva Agüero ought to give a mortgage upon some property of his to secure the $S / 30,000$. We were all of his opinion, and the following acta was drawn in[_] in rough: "Riva Aguero must give a mortgage. Steps must [...] [753] immediately be taken to remove from the present locality to the ground-floor in Varela's house, for two rents ought not to be paid at the same time." From this Gallagher disagreed, because, he said, that ground-floor was not suitable for the purpose. Thirdly, that the clerks should give security as previously ordered; and finally that the Directory was to meet again on the $29^{\text {th }}$ at 9 in the morning. Gallagher promised to have the acta drawn out in clean, and to send it to me in the evening.

Wednesday, $28^{\text {th }}$ of July 1875 . I received it this morning, and enclosed it with a note to Riva Agüero, which I myself saw delivered by my Chinaman Ayao, to the porter in Riva Agüero's house. The note in which Manuel Candamo was cited, was delivered in the same manner.

From the Minister for Foreign Affairs I received a note in which he informed me the president would receive in the palace immediately after High Mass. In my uniform I went thither at $2.30 \mathrm{p} . \mathrm{m}$., and was told that I came too late, the Diplomatic corps having been there at half past twelve. I returned home, changed my dress, and though it was rather late ascended San Cristoval from 
the steepest side, from the new Alameda. By mistake I came down the same way, which was very difficult, not only owing to the nature of the ground, but also to its being overgrown with slippery young plants, and to the lateness of the hour, for it was already getting dusk.

Thursday, $29^{\text {th }}$ of July. At 6.30 p.m. I received a note from Riva-Agüero written in a very cool style, in which he said that owing to indisposition arising from the anxiety which the Banco Hipotecario had caused him of late, he could not come to the meeting fixed upon at 9 p.m. At 9.30 Gallagher, Jimenez and I were there. A note came in from Manuel Candamo in which he resigned his post as Director, and again an acta was drawn up in which a new meeting was fixed for the following day, and in which I, as Vice-president was authorized to apply to José Vicente Oyague requesting him to attend the meeting, also to obtain from Riva Agüero an answer whether he would give the mortgage or not.

Friday, $30^{\text {th }}$ of July. Early in the morning I received a note from Oyague in which he said that he did not object to join us, not at the inconvenient hour of 9, but at 4 p.m. I immediately hastened to the houses of Lopez [_] and [_]menez neither of whom made any objection. Galla [...] [754] gone to the races; I left word with his wife, and then wrote him. To Riva Agüero I sent at about half past two with Ricardo Garland, a clean copy of the acta made in Gallagher's office, together with a few words of mine. Ricardo delivered it to the porter.

At 4 p.m. Oyague, Gallagher, Diego Lopez Aliaga, myself, Jimenez, and the Gerente were assembled in the patio of the Banco Hipotecario, where, it being a holiday, all the rooms were shut up, and we had thus to remove to Gallagher's house. Oyague presided. At my request the two last actas, the clean copies of which, enclosed by me to Riva Agüero, he had brought with him, were read, whereupon he declared in clear and decided terms that he did not consider himself responsible for the repayment of the $S / 30,000$ amount of Derteano's acceptances, and this his refusal he founded upon the enmity against him which had made itself manifest in the late proceedings of the Directory, who, as he said, had insisted upon his paying an interest of $11 / 2 \%$ monthly upon the $\mathrm{S} / 30,000$ until cancelled - which high rate by the by, had not come to my knowledge - and secondly, upon our demand to have the payment secured by a mortgage, to be given by him upon his immovable property. He concluded with the words that the tribunals would decide whether he was responsible or not. This tergiversation of a man who, but a few days previously had made a diametrically different declaration annoyed me in the extreme. I was the first to speak, and gave, as clearly as I could, the reasons why Riva-Agüero was responsible. By and by I worked myself up into a violent passion, and most probably whilst it lasted said the one thing or the other which it would have 
been more prudent I had not said. At all events I told Riva Agüero everything that I had upon my mind. When I had done I sat down, tried to collect myself, and took no further share in the discussion. Then Lopez Aliaga made a long, very proper, and conciliatory speech, showing that we had asked for a mortgage, not to offend Riva Agüero, but to shelter ourselves against any inculpations which the shareholders might make. I had said the same, but not in such a quiet manner. Jimenez followed in the track of Lopez Aliaga; so [...] [755] Gallagher, entering into many details; and finally Riva Aguero said he would give a decided answer on Monday next. This over, the state of the finances of the bank was treated on, in which discussion Oyague took a share. The fact was that the bank was over head and ears in debt, without having the means to pay. On the next day $S / 23,000$ were due to the Banco de Londres, 46, ooo to the Banco de Lima, whilst there was in cash a mere trifle. Riva Agüero held out hopes that Canevaro would pay $S / 21,000$, and that a considerable amount would come in in a day or two. He refused to draw out the acta; Oyague dictated and Lopez Aliaga wrote it. All the while Gallagher and I conversed together in English. We agreed to meet again next Monday. It was past six when I came home.

My wife, Garland, Enriqueta and the little ones went by invitation to Basagoytia's, who gave a small party, under the pretence of seeing the fireworks which were let off close by, in celebration of the Saints day of General Mariano Ygnacio Prado, who resided a few houses off with Don Pablo Vivero.

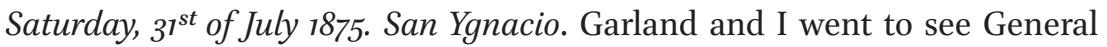
Prado, to congratulate him on his Saints day.

Sunday, ${ }^{\text {st }}$ of August. There was a numerous gathering of the partizans of Prado. Many clubs assembled in the Plaza, a great number, on horseback came in from the environs, and all directed their steps to the open place round the monument "2 de Mayo", where years back the Callao gate stood. The leader speechified, and the multitude shouted, but after all, this, which was meant to be a popular demonstration, did not turn out such a splendid affair as Prado's friends had expected. The clubs of the Monteristas were also on the move, and some blows were exchanged between the two parties. A telegraphic dispatch received from Arequipa and dated this very day, brought the advice that there things had not gone off without the shedding of blood. The two parties had fought, and the Monteristas had had the advantage. In the afternoon I called amongst others upon Mr. Richard Gibbs, North American Minister, lately arrived, successor of Mr. Thomas. He was an agreeable, off-hand gentleman, and I remained with him a considerable while conversing with him on various topics, but mainly on the financial and political condition of the Republic of Perú. At the French Minister's I only found his lady, who took my card, which 
[_]nded her and as she did not even ask me to take a seat I [...] [756] bow, and left.

Monday, $2^{\text {nd }}$ of August. When still in bed a card was handed me from Sagastabeytia "urgentisimo", calling me to a meeting of the Directors of the Banco de Lima at 9 O'clock. I was there before the hour. The object was of the greatest importance. During the whole night the Gerentes of the four banks: Basombrio of "El Nacional", Escobar, "Perú", Moscoso Melgar of "La Providencia", and Sagastabeytia of "Lima", had been conferring with the President on the necessity of suspending cash payments. Part of the acta, drawn out for this purpose, which the gerentes had to sign, was in Pardo's own handwriting. Basombrio and Escobar had been authorized by their respective Directories to affix their signatures, and had done so. Moscoso Melgar and Sagastabeytia had signed with the proviso "if approved by the Directory". For this purpose we met, and unanimously gave our consent, because, though a most perilous step, it was the only one which could stave off the ruin of all the banks. I was told, but could not vouch for the truth that the Banco Nacional owed to the Banco de Londres at the end of last month S/800,00o, which of course they could not pay in cash, and consequently they had represented to Pardo that they would be under the necessity of closing their doors if the Government did not interfere and release them from the obligation to pay their notes in cash. Accordingly, a decree to this effect was given, which appeared in all the evening papers.

In the forenoon we again assembled at two in the Banco de Lima, which was our usual monthly meeting; nothing of importance occurred. Thence I went to the Banco Hipotecario, where Riva Agüero once more put off his definite answer till Wednesday. He however acknowledged his responsibility for the $\mathrm{S} / 30,000$.

Tuesday, $3^{\text {rd }}$ of August. I was by no means quite easy in my mind as to the effect which last night's decree about the suspension of cash payment might have in the market: I feared the vendors of provisions would refuse the bank notes. However, fortunately, nothing of the kind happened, and our cook Achipe came as usual carrying the basket containing the purchase [...] [757] had made.

Wednesday, $4^{\text {th }}$ of August 1875. At 2 again in the Banco de Lima where motions were made by Cucalon and Cárdenas the object of which was to increase the circulation of our notes, which we could now do without danger as we were no more under the obligation to exchange them for hard cash on presentation. Cárdenas proposed that we should rebegin discounting. Cucalon that we should now pay to the shareholders the $41 / 2 \%$, the remainder of the interest for last year. This I decidedly opposed, and the solution of both 
questions was put off till Saturday. It was now 4 O'clock, I ran to the JusticeHall, where after a good deal of urging the notary Escobar gave me the good news that the judge Puente Arnao had decided in my favor the suit against Leyva about the Ayres of the house; that the sentence was written out in rough, but that there was no clerk to copy it. I proposed that one of the sons of Garland might do it, to which Escobar agreed, and accordingly he was with me in the evening at eight, and dictated to Juancito till half past ten.

At 5 p.m. the Directors had once more been assembled in the office of the Banco Hipotecario, when Riva Agüero gave us his promise that he would pay the $\mathrm{S} / 30,000$ before the next meeting of shareholders.

Thursday, $5^{\text {th }}$ of August. The notary Escobar again came to me at 9 a.m. and took with him the sentence written out in clean, ready for signature. For this trouble I gave him a gratification of forty Soles. In the course of the last two months several of my friends had at my request used their influence with Puente Arnao, viz.: Rafael Velarde, intimately acquainted with his brother-inlaw Villarán, Amancio Castillo, friend of Julian Guimet, his son-in-law; and I had even ventured to apply to Prado, who without loss of time had sent to the judge his aide-de-camp Col. Noya. The sentence was, as already said, in my favor, but very badly drawn out, and not well founded.

At about 3 p.m. a large number of shareholders assembled in the Banco Hipotecario. José V. Oyague took the chair, to his right sat I; next to me Col. Joaquin Torrico, one of the most virulent of the party opposed to Riva Agüero, before me at the table, Manuel Mendoza another Director, opposite to him Riva Agüero the Gerente, to the left of Oyague, Gallagher, [_]enez and Lopez Aliaga the three other Directors. [758] Riva Agüero called over the names of those present as well as the number of shares they represented, and there being above the half, the proceedings continued. The last acta was read and approved. Oyague read a few words to give an idea of what was to be done in this meeting, and then requested me to give an account of the proceedings of the new Directory, he having joined it only a few days previously. I said I had drawn out a short report which, with the permission of the shareholders, would, on account of the weakness of my sight, be read by Mr. Gallagher. This he did and I had the satisfaction that afterwards several persons came up to me and told me that they had been much pleased with my report, of which, by the by, one or two sentences towards the end had been somewhat altered by Gallagher. A copy of the same will be found in appendix under $N^{\circ} 17$. The first thing the Directory did was to submit to the shareholders for their approval or rejection our late agreement with Oyague and Canevaro. Before they would come to a decision they thought it advisable to hear first the informe of La Comision 
Investigadora, the reading of which document, containing many truths and some exaggerations, took up much time. When it had been concluded Dr. José Aranivar rose and impugned in very severe terms a measure taken by a previous Directory, which consisted in having paid a bribe to some one in the Congress, with the object of facilitating the passing of a law which favoured the Banco Hipotecario and similar establishments. Hitherto immovable property if brought to the hammer could only be sold if it fetched $2 / 3^{\text {rds }}$ of its valuation; in virtue of the new law the $2 / 3^{\text {rds }}$ were reduced to one half. When Dr. Aranivar had done speaking, Aurelio Dinegri rose, and said a few words, not much to the purpose. Then the two Gerentes Riva Agüero and Francisco Garcia Calderon expressed a wish to be heard in their own defence, for which reason, as it was getting late, the meeting was adjourned till next Saturday. Escudero the last gerente before Riva Agüero resumed his post, and he whom I believed to be the most culpable, did not say a word. After all, the meeting went off in a more quiet manner than I had anticipated. We broke up near six. In the eve[_] [759] Enriqueta's tertulia was very numerously attended. There were two rocambor tables, and round the roulette Mrs. Leonor Pinto, Mercedes Dartnell, Inéz Laos, Rafael Canevaro's wife, Pancha, wife of Gregorio Benavides, and Mrs. Rafael Velarde. They left off playing at about half past one, whilst the young folks continued dancing till half past three when my wife came to our bedroom. The girls were: two daughters of Pinto, Maria-Rosa and Georgina Dartnell, two daughters of Domingo Valle-Riestra, two daughters of Melchor Velarde, Zoila, Rafael's daughter, and Eliza Higginson, Guillermo's wife. The young men I hardly knew, amongst them three or four North American naval officers, together with their Admiral from on board the "Richmond".

Friday, $6^{\text {th }}$ of August 1875. At 2 p.m. the Directors of the Banco de Lima met. The gerentes made known that Derteano had been with them, and told them that the Government wanted a loan of $11 / 2$ million Soles, in which it was expected that the Banco de Lima would take a share. The discussion lasted till past four, and it was resolved that the gerente Cisneros should go to the Minister of Finances and treat directly with him, not through the intervention of a third person. In the Banco Hipotecario I found all the Directors assembled, but owing to the eternal talking of Oyague and Riva Agüero, little progress could be made. The latter had neither paid the $S / 30,000$ not given any security for them. In the evening the Directory of the Banco de Lima was again together till 11 O'clock. Three resolutions were taken, viz.: to lend $S / 150,000$ to the Government, if the terms granted were satisfactory; to recommence discounting to the extent of $\mathrm{S} / 120,000$ (This was merely done to quiet the everlasting talker Cardenas), and thirdly, to pay to the shareholders $41 / 2 \%$ interest due to them since last year, 
which last measure was carried by the majority, the two Gerentes, Valentin Gil and I being opposed to it.

Saturday, $7^{\text {th }}$ of August. Immediately after breakfast Oscar Heeren, one of the gerentes of the Banco Anglo Peruano, came to me in the belief that I was still President of the Directory of the Banco Hipotecario. He told me that his bank could no longer wait for the payment of the large debt - between one hundred and thirty and one hundred and forty thousand [...] and if the Hipotecario did not pay immediately the Anglo P [...] [760] required an authorization to sell at the best price obtainable the Cedulas which they held as security, and if this were not done they would apply to the tribunals. He added that in the course of the forenoon a letter to this effect would be sent by the Anglo Peruano to the Hipotecario. When I went to see Oyague, Riva Aguero was already there with the letter itself. They were opposed to grant the authorization asked for. Oyague wished me to go with Riva Agüero to the Anglo Peruano, which I declined, whereupon he said he would go himself.

Sunday, $8^{\text {th }}$ of August. In the forenoon I drove with Rafael Velarde to give my thanks to the Judge Puente Arnao who was not in, and to the judge's brotherin-law Villaran, who had rendered us great service in the suit against Leyva. For half an hour or so we remained with him and his wife.

Mariquita had in the forenoon an unusual number of visitors: the Minister for Foreign Affairs, and his brother in law General Buendia, Dr. Muñoz, Vocal de la Corte Suprema, Dr. Lührsen German Chargé, Vicente Gonzales, and José Pablo Escobar. In my round of visits I called upon Doña Panchita, daughter of Dr. Morales, recently married to Manuel Medel, who lived with her father and mother-in-law in the Calle de Mestas $\mathrm{N}^{\circ} 233$ a great distance off. The gentleman knew me, and we conversed on the great news of the day, the arrival of the gunboat "Pilcomayo" from Panamá, with telegraphic despatches from Althaus and Rosas in Paris, who asked for new instructions, because the parties inclined to enter into the guano business demanded the purchase of four million tons, instead of two millions, a term of eight years instead of four, and the sanction of the Congress; nothing more was known with certainty. The Man of war "Union" had started last night for Panamá with the answer.

Monday, $9^{\text {th }}$ of August. This morning appeared with us unexpectedly, Doña Manuela Salmon, who had been absent for about two years. She, an elderly lady, without a male companion and understanding no other language [...] [761] Spanish, had ventured on a voyage to the Holy Land and Egypt, which she had accomplished, together with a number of other travellers, male and female, who had formed a kind of caravan. They had embarked in Marseilles 
on board a steamer, and returned to the same port. Amongst other news she brought that of the death of Octavia Vigil, wife of Federico Sotomayor, which had occurred in Paris. About this time died in Lima Santiago Lanfranco, an Italian, married to one of the daughters of the late Pio Tristan. The very day of his death I received a letter from one of his sons, asking for a loan of S/20oo to defray the funeral expenses, which I very naturally refused. An urgent message of Sagastabeytia called together the Directors of the Banco de Lima. By 1 p.m. they were assembled. The Government required $11 / 2$ million Soles. The banks Perú and Nacional were ready to lend each $\mathrm{S} / 550,000 ; \mathrm{S} / 200,000$ were asked from La Providencia, and the same amount was expected from the Banco de Lima. We separated without having come to a determination. At a later hour I, and the other Directors met in the Banco Hipotecario, Riva Aguero had merely signed a provisional pagaré for S/30,0oo without giving any security, which was by no means to our satisfaction.

Tuesday, $10^{\text {th }}$ of August 1875. In the Banco de Lima yesterday's debate continued, and after some conferences between Luis Cisneros, one of the gerentes, on the one hand, the President and Minister of Finance Helguera, on the other, the upshot was that the Banco de Lima gave nothing. We offered S/150,000 at $1 \%$ with prenda pretoria, which was declined, the President's answer being that he did not require the co-operation of the Banco de Lima. Lembcke, who had arrived in the morning, was present at this meeting as well as at another which we had in the evening. According to him the production of the Nitrate in the Salitrera "Esperanza" sufficed to pay the expenses, but a gain there would not be. Besides the $\mathrm{S} / 20,000$ drawn by him, and paid by the bank, $\mathrm{S} / 25,000$ more were wanted, part of which outlay of $S / 45,000$ would be covered by the sale of fifteen thousand quintals Nitrate, which might be considered as ready for shipment.

This day Leyva presented an escrito, in which he tried to prove that Puente Arnao had given the sentence after he had ceased to be a judge [_] oga who had reoccupied his post as Juez de $1^{\text {a }}$ Instancia ord [...] [762] notary Escobar to state what he had to say on the subject.

Wednesday, $11^{\text {th }}$ of August, was comparatively speaking a quiet day. Nearly two hours in the forenoon I was occupied comparing the various securities held by the Insurance Coy. "Lima", with the list of them. The documents, together with the list, were deposited in two drawers inside an iron chest. The keys of the drawers were delivered to me; the key of the door of the chest, Carlos Elizalde President, and provisional Gerente, kept; whilst the duplicate keys were to be sent to the Providencia, there to be preserved. In the afternoon the negotiations between Manuel Pardo and the Banks Nacional and Perú 
for the loan of a million, and odd Soles, were broken off; the reasons had not transpired, but it was known that the President was in a great passion at not having obtained any money, and to revenge himself he gave the decree which is affixed in appendix under $\mathrm{N}^{\circ}{ }^{18}$. It said, amongst other things, that the payment of their quotas had to be made by the shareholders in cash, or in good bills on London, a downright impossibility. Should all the banks in which I was interested have asked quotas, I at least could not have paid.

This day was solemnized the funeral of the Fiscal de la Corte Suprema, Toribio Ureta, a very intelligent man, well acquainted with the laws of his country, and yet notwithstanding his capacity and knowledge, in the various suits carried on by me since February 1863 , all which I had gained in the Supreme Court, this tribunal had generally sentenced in opposition to his vista, or written opinion.

On Thursday last, as then said, Admiral Collins of the North-American Manof-War Steamer "Richmond" was present at Enriqueta's tertulia. He seemed to be in good health, and well pleased with the entertainment. The following day, as it was his habit, he gave a small party on board of his vessel, when he felt something like an oppression about his heart, which he thought to be of so little moment that he even promised to his officers to give a party, larger than usual, on the following Friday. Already on Saturday he felt worse, and on Monday he breathed his last, much regretted by all who were acquainted with him. [763]

Thursday, $12^{\text {th }}$ of August 1875 . The Directory of the Banco Hipotecario, myself excepted, who had not received timely advice, had their meeting. At 8 p.m. I was in the Banco de Lima, with seven of my colleagues, sufficient to form a quorum; however, at the request of Pedro Bernales we did not proceed to business, because Cucalon and Cardenas, always opposed to make advances to the "Esperanza", had not come, and we therefore thought it prudent to hear their opinion whensoever the advances made to this establishment were to come under discussion. Pardo's last decree formed of course the topic of conversation. It was clear to us that it had been given solely because the banks had refused lending pecuniary assistance to the Government, and I now learned that the Banco del Perú before giving their money had insisted upon the signing of the contract which would secure to them the consignment of guano to Mauritius and other islands. This, Pardo had refused to do, and thus the negotiations had been broken off. On the $31^{\text {st }}$ July the notes of the Banco de Lima in circulation came up to $\mathrm{S} / 500,030$ which amount as per Government's decree, was not to be exceeded, and yet the present circulation surpassed it. I was home at half past nine, dressed, and went over to Enriqueta's, where the party was uncommonly small. 
Friday, $13^{\text {th }}$ of August. This morning the funeral of Ramon Aspillaga took place. $\mathrm{He}$, a Chilian by birth, of rather low extraction, commenced life as a common sailor; he rose gradually, and became Captain of a merchant vessel, the "Hector", which for many years traded along the Coast. He became acquainted with Don Domingo Elias, who at first rendered him some assistance, which afterwards was amply repaid. At a later period, he, jointly with Julian Zaracondegui, was owner of the valuable estate in the North, called Cayalti.

Henry Meiggs, I learned, had been struck by apoplexy, and was lying dangerously ill.

Some pages back I spoke of the failure of J. C. im Thurm \& Co. of London. I now affix in appendix under $\mathrm{N}^{\circ} 19$, a list of the London firms who had stopped payment in the course of the last two months.

As had been previously arranged, the Directors of the Banco de Lima met. Again Cucalon and Cardenas did not make their appearance. [...] who were assembled resolved that the money which the sale of [...] [764] already produced might fetch, should be employed in paying the expenses for July, and that on no account whatever the expenses of the following month should exceed the proceeds of the Nitrate sold, so that the twenty thousand Soles advanced over and above the $S / 1,200,000$ should be considered as a floating capital, to be debited a new account, "Saltpetre", and never be exceeded by a cent. Upon this last condition I insisted with unrelenting pertinacity.

Saturday, $14^{\text {th }}$ of August. Again the Directory was assembled with Cucalon, but without Cardenas. The resolutions of the previous day were now brought to paper, without a dissentient voice. This being over by half past one I went to the Banco Hipotecario, where by half past two a great many shareholders were assembled with Oyague in the chair. The acta of last meeting was approved with some trifling alterations, whereupon Garcia Calderon and Riva-Agüero read their respective defences. That of the latter was attacked by Aranivar, on three vulnerable points, viz.: he asked whether S/6ooo more or less which had been spent secretly, in order to obtain from the Congress the law which favoured the interest of the Banco Hipotecario, had been voted by the then Directory. On Riva Aguero's answering in the affirmative, the next question was, "Where is the acta?", answer: "there is none". "Where is the acta which proves the payment?", answer: "there is none". Secondly, Aranivar showed the incorrectness of Riva Agüero's calculation, who had made an attempt to prove that the loan of $S / 150,000$ to the Pasco Railway Coy. had been a profitable transaction; and thirdly, he asked for the counter-document, signed by Riva Agüero, and which, as said above, released Derteano from his obligation to pay the S/30,0oo. Col. Torrico said that the shareholders had a 
right to see this document, in which, no doubt he was correct. Riva-Agüero demurred, and said it was sufficient, if he declared himself responsible for the S/30,000; and made a very improper observation, viz.: I doubt whether Dr. Aranivar could do so in my place. This of course was a gratuitous insult, which Aranivar could not otherwise but resent. Oyague observed that he thought it was sufficient if Riva Agüero declared himself [_]ble [...] [765] signed a pagaré. Col. Torrico - perfectly so, if the Directors take the responsibility upon themselves. Then I turned towards the spot whence the voice came, without knowing who was the speaker: "No Señor, yo no admito responsibilidad alguna"; the Colonel: "pero no dice el Señor Riva-Agüero que dara prenda pretoria", I: "y si no la da? no puedo ponerlo en la carcel." Now Riva Agüero jumped up: "Agradezco al Sr. Witt la confianza que tiene en mi." I: "no digo que Ud. no la dará, pero si Ud. no la da, no puedo, ni quiero ser responsable." So this incident ended. Lorente made a pretty speech, in which amongst other things he said he could not agree with the opinion of one of the Directors who refused to be responsible. Gallagher said a few words to the effect that he believed he spoke the sense of the entire Directory, if he admitted the responsibility in case the Directory acted contrary to the Statutes. Forero, the principal member of the Comision Investigadora, spoke, and Oyague read a paper which contained the conclusions drawn from the report of the Commission. The first was, "se debe hacer una reforma radical en la administracion." Aranivar: "what does that mean? I understand it to be, una reforma radical de todo el personal." When he had said these words I left the room, and whilst I was speaking a few words with José Maria Sancho Davila, who had also gone out, Aranivar came running after me saying "Don Enrique do not go, come back, responsibilities are never made effective." "No Doctor, I do not admit any responsibility." To let me out, the counter was opened by Muelle, the cashkeeper, and I went to the Justice hall. On the way I met Lembcke, who gave me another bad piece of news. The Banco de Londres, he told me, asked immediate payment from the Banco de Lima of $S / 87,000$ due by the latter to the former, being balance of a loan made at the time that the Banco de Lima had to pay the bills which came back protested by the South American Company in London, and as this loan had fallen due before the decree of $1^{\text {st }}$ August, Mr. Dawson the manager, asked payment either in silver or gold, or in notes of his own bank. The former, the bank would not, and the latter it could not give. Our opinion was that Dawson might do what he liked, and the Banco de Lima would pay when it could. In the office of the notary Escobar the [...] was [_]rable. Escobar had given a detailed account of $[\ldots][766]$ why the sentence of the judge Puente Arnao, given in proper time, say on the $31^{\text {st }}$ July, had not been notified till the $4^{\text {th }}$ August, 
which statement Quiroga had ordered to be added to the expediente. Leyva's appeal to the Superior Court, he had of course admitted and on Monday, or Tuesday, all the documents would be sent up to the second chamber, whose turn it was this month, and whose members were: Dr. Corso, Dr. Mendoza, and Dr. Galindo. In the office I met Guillermo who wrote for me a few words to Oyague, President of the Directory of the Banco Hipotecario, in which I resigned my post as Director of the said bank. I myself took the note to Oyague's house, who had not yet returned from the meeting. It was rumoured that in the Banco Territorial a large deficit in the cash had been discovered, and that there the culprit was not the cashkeeper, but the gerente Enrique Perla, a very nice young man, whom I for a certainty should not have believed capable of such a crime.

Sunday, $15^{\text {th }}$ of August 1875 . La Asuncion. I paid my visits to Transito Llosa, and Asuncion Santillana. On my way to the wife of the Minister Anibal de la Torre I met Vicente Oyague, who said that he was on the way to my house, merely for the purpose of dissuading me from giving in my resignation as Director of the bank. We talked at least a quarter of an hour, standing in the saguan of a house, and I determined to withdraw the letter written by me to Oyague, not at all because he had convinced me, but because I thought that my remaining in the Directory would be of use to Garland who about this time had made up his mind to present himself as candidate for one of the gerencias in the Banco Hipotecario. Hitherto the affairs of this establishment had been managed by one single gerente, but the sad experience which the shareholders had made, and of which the details given in the preceding pages have been a sufficient proof, made them come to the conclusion that this had been an ill-judged economy, and that henceforward the affairs of the bank should be managed by two gerentes. That Gallagher would be one of them was a certainty, but as to the other, the opinions were much divided. [767]

Monday, $16^{\text {th }}$ of August 1875 . The Directory met without Mendoza. Oyague, prosy and consequential as it was his custom, gave us the good news that Riva Agüero had resigned his post as gerente of the Banco Hipotecario, which resignation we readily admitted, and named John Gallagher provisional gerente in his stead. Riva Agüero was requested in writing to come the following day to the office, there to deliver up the portfolio, and all other documents.

Tuesday, $17^{\text {th }}$ of August. Riva-Agüero did not come to the office. This day, as a rare exception to the general rule, I was not present at the meeting of the Banco de Lima Directory, and this was owing to my time having been completely taken up by the steps which I had to take to obtain from the Municipality a licence for breaking up the pavement in front of my street door, without 
which the Water Company could of course not examine the water pipes laid underground, nor discover the obstruction which had been the cause of my not having received my regular supply of water. I went several times to the office of the Water Company in the Calle de Plumereros, to its establishment in San Jacinto, and to the Municipality in the Plaza, and after all I did not get the necessary document for though it was drawn out, the alcalde did not come to affix his signature. A telegraphic dispatch from Payta brought the news that on the $6^{\text {th }}$ inst. Gabriel Garcia Moreno, President of Ecuador, had been assassinated by a captain of the army Rayo, who in his turn was shot down by a common soldier.

Juan did not write me by last steamer, but in his letter to Enriqueta he said that as far as he could judge, the Peruvian Government would not obtain any loan from European capitalists, upon the security of the Nitrate establishments which they thought of purchasing in the Province of Tarapacá, and as little would any one take the guano contract on the conditions proposed by the Peruvian commissioners whom Pardo had sent out for the purpose. My opinion was that Dreyfus would keep the guano business, and this my opinion I founded upon the intimacy which about this time seemed to exist between Dionicio Derteano, to whose influence, he being one of the Directors of the [_]co Nacional it was no doubt owing that this establishment [...] [768] lent to the Government $S / 300,000-S / 200,000$ of which for paying the troops, S/100,00o due to Chile.

Thursday, $19^{\text {th }}$ of August. Between two and three O'c. a considerable number of the shareholders of the Banco Hipotecario were again assembled. Oyague presided. John Gallagher acted as Gerente and consequently as secretary. After the usual forms had been gone through with, Riva Agüero's resignation was made known. Next, Forero, Lorente, Noel, and several others, gave their opinion on various subjects. Manuel Candamo called upon Escudero who had been gerente before Riva-Agüero had resumed the post, to explain more than one irregularity. He defended himself, asserting that the $S / 5^{0,000}$ paid by the Anglo Peruano, though not entered to the debit of the cash, had certainly been received, for otherwise it would have been impossible to have paid on the $2^{\text {nd }}$ January the interest on Cedulas, and the redeemed Cedulas. Though, as it is always the case in such large assemblages, many speeches were made which led to no result whatever, yet upon the whole a good deal of work was actually done.

It was resolved that a lawyer should be engaged to examine all the title deeds of the property which had been mortgaged to the bank for the advances made upon the same, also, a bookkeeper to examine the accounts of the 
bank since its establishment. This latter I opposed as unnecessary but as Lorente, one of the investigating commission, affirmed that in his opinion there were still many frauds undiscovered, I had to withdraw my opposition. The agreement which the Directory had made with Oyague and Canevaro on the $10^{\text {th }}$ July was approved. Also a proposal of Oyague that henceforth there should be two gerentes instead of one, each giving a guarantee of $S / 20,000$ or be owner of at least thirty shares in the bank, passed unanimously; not so his next motion that the shareholders should have one vote for each five shares, whilst according to the present statutes even the largest shareholder could not have more than five votes. Aliaga and I had [...] [769] told Oyague that we were opposed to this innovation and from the shareholders there broke forth such a storm of opposition, that it would certainly not pass. Oyague closed the meeting without a decision having been come to, and convoked a new one for Saturday the $28^{\text {th }}$.

This was the birthday of little Maria, who completed her $9^{\text {th }}$ year. In the evening Enriqueta had her usual party, which was well attended. Before joining them I went to congratulate Dr. José Luis Gomez Sanchez, whose birth-day it was.

Saturday, $21^{\text {st }}$ of August 1875. Once more at 1.30 the Directory of the Banco de Lima met, when Lembcke made known that he had had a long conference with the President, who, though very polite and friendly had decidedly and peremptorily refused to allow the bank to increase its circulation above the $\mathrm{S} / 500,030$ which were in the street on the $31^{\text {st }}$ July. Lembcke had represented to him that when the decree limiting the circulation was published it had nearly reached $S / 600,000$ and that it was literally impossible to stop it, because the Bank had necessarily to pay its cheques with its own notes, in default of notes of other banks; but Pardo was not to be moved. What was now to be done? Many remedies were proposed, found impracticable and rejected. At last it was resolved that without loss of time, Government securities which the bank held, Treasury bonds for instance, should be disposed of, and with their proceeds it was expected that the surplus of the circulation over and above the President's limit might be cancelled, and thus the government's order be obeyed. I myself did not anticipate any good result from this step. It was nearly 4 O'clock before I could join the Directory of the Banco Hipotecario. Riva Agüero had of course not delivered in the securities he had promised for his pagaré of $\mathrm{S} / 30,000$. This document of his I looked upon as of very little value. The only measure of importance which we agreed to, notwithstanding the strenuous opposition of Jimenez, and the reluctance of Aliaga, was to authorize the Anglo-Peruano, to which the Hipotecario owed more than S/100,00o to dispose 
of $\mathrm{S} / 5^{0,000}$ in Cedulas part of the security which they held, at the market value. If this authorization were not [...] the gerentes had threatened - so Gallagher stated - to [...] [770] judicially against the Banco Hipotecario and this, Oyague, Gallagher and I, were of opinion should be avoided at all hazard. Commercial affairs in Lima became worse from day to day and I much feared that a dreadful crash was close at hand.

Sunday, $22^{\text {nd }}$ of August. I made my usual calls.

Monday, $23^{\text {rd }}$ of August. I took Soles 10,000 from the amount which I had to my credit in the Banco de Lima, and paid them into the Banco La Providencia, where I opened an account. Whilst I woas thus occupied, Lembcke passed by and observed what I was doing.

Tuesday, $24^{\text {th }}$ of August. The Directory of the Banco de Lima met. The Government securities, as I had expected, could not be sold; accordingly, I proposed as a saving measure to make a call of $21 / 2 \%$ upon the shareholders, allowing a discount to those who would pay before the $31^{\text {st }}$ August, and a small premium on payments made in the notes of the Banco de Lima. Gil considered this the only true measure, but it was hardly discussed, because the general opinion was that the greater part of the shareholders would refuse paying. Then Lembcke entered, who had to communicate great news, but before doing so he said more or less the following words: "it was not to be wondered at that the credit of the Banco de Lima declined in the public opinion, when the President of the Directory himself took money out of the bank to place it in other Banks." This of course was a direct thrust at me, and I told him very angrily that I did not recognize in him any right to find fault with what I thought proper to do with my money, that other Directors had a balance of ten, twenty or thirty Soles to their credit, and that he had never said a word about it, that I had had continually from sixteen to twenty thousand Soles to my credit, and that I should never have thought of withdrawing any part of them if he himself in the last meeting had not enquired in writing from the Directory, whether the Gerentes should continue paying the cheques drawn by those who had balances in the $[. .$.$] and$ by so doing take no heed of the [...] [771] of the Government's limitation of notes. This enquiry, made by one of the gerentes had shaken my confidence, and I had therefore thought prudent to take part of my money out of the bank. We then continued with the affairs of the bank, and Lembcke informed us that the Government had made a proposal the particulars of which will be found in appendix under $\mathrm{N}^{\circ}$ 20. It was discussed, but I took no share in the debate, being entirely occupied with my own thoughts, and with writing a note to the gerentes, in which I gave in my resignation as Director and President. I had laid down my pen for a few moments, because my weak sight did not allow me 
to write uninterruptedly, when Bernales took away the paper saying "do not write". Various copies were made of the project which the Directors were to take home, think over, and again meet on the following day. Bernales, Castillo, and others begged me to make up matters with Lembcke. I refused. Lembcke said "I respect Mr. Witt"; but I interrupted him with "I do not require any respect, we are here all equals." The others begged me not to resign; Lembcke said, "that would be the last blow to the bank", which already had suffered from Oyague's withdrawal; and very reluctantly I at last said "me quedaré." Thence I hastened to the Banco Hipotecario, where again bad news was awaiting the Directors. Riva Agüero had of course not delivered in the prenda pretoria nor even answered Gallagher's letter, in which he had asked for the same, and another sum now appeared to have been made away with by Soyer. In the first deficit of three hundred and odd thousand Soles were included between nine and ten thousand paid in, so the cash-book said, by Orbegoso and Puente. In the second statement the deficit had been diminished by these nine or ten thousand Soles, because, as Riva Agüero assured us, the entry to the debit of the cash had been false; Orbegoso and Puente had not paid the sum and still owed it. Now Orbegoso had come to Gallagher and told him that this was not true, and that they had paid the nine or ten thousand Soles, but could not show a receipt for it; as a proof of what he said he presented a bill drawn [...] same amount by Escudero upon [_] accepted by him [...] [772] discounted by the Banco de Lima, and paid by him. Gallagher was ordered to write RivaAgüero and ask for particulars. It was near 6 O'clock when I came home. News had been received of the stoppage of Denegri Bros. London, whose liabilities amounted to £120,0oo.

Bryson finished reading to me Alisons History of Europe, which is carried down to the fall of Napoleon in 1815. We now took up the "Defence of Paris" presented to me by Enrique on my last birthday; it is written by a Mr. Bowles, special correspondent of the Morning Post, in a flimsy, meant to be a funny style, and, as far as I could judge, beyond measure partial to the French. He had been in Paris all the time the siege lasted.

Wednesday, $25^{\text {th }}$ of August 1875. I did not go to the meeting of the Banco de Lima, on the plea of indisposition; neither did I go on

Thursday, $26^{\text {th }}$ to this bank, as little as to the Hipotecario and was of course ignorant of what was doing in either of them. Bryson read to me in the daytime from the Eclectic Magazine, to which I was a subscriber since the beginning of the year, a very clever article written by Thomas Carlyle in his peculiar, quaint style, treating on the old Kings of Norway, beginning with Harald Haarfagr. From the same Magazine astounding articles were read to me relative to the 
Universe, which they described as infinite, both as to extent and duration. The earth is at present in its life-sustaining period, of an infinitely small duration compared to the period whilst it was in progress of formation, and the period which will follow when, like the moon, it will be in its decrepit state, unable to sustain life. During its present period the earth is gradually cooling, and when the warmth is gone, life will go with it. Jupiter is considered as being in progress of formation; Mars is supposed to have passed its life-sustaining stage. There are, according to these articles, Solar-systems without number, systems of these solar-systems and galaxies of these solar-systems compri [...] [773] A German Philosopher has said: "the centre of the Universe is everywhere, its circumference nowhere."

In the evening we were at Enriqueta's party, not so numerous as on other occasions.

Friday, $27^{\text {th }}$ of August 1875. In the evening at 8 O'clock I went to the office of the Banco de Lima, where my colleagues Bernales and Castillo received me with marked civility. Manuel Pardo's project had undergone some modifications; its basis, however, remained the same and it was now submitted to the Directors. The Tarapacá Salitreras were likewise offered as security to the Banks, but coupled with conditions, which in my opinion were inadmissible. Lembcke, Bernales, and others thought however that this was a great advantage gained by the banks. The loan required by Government was now $S / 12,500,000$ of which the last monthly instalments reached to the end of 1876 . Interest allowed on the loan, $6 \%$ per annum. The guano to Mauritius was now valued at $S / 30$ instead of $S / 27.50$ as per former project; in the exchange of the bills, an improvement was granted to the banks, from 41 to $421 / 2$ d. The Providencia had as yet refused to take a share, whilst the Nacional, Perú, and Lima were inclined to enter into the business, each in proportion to its paid up capital: Lima, $50 \%$ of five millions $=$ S/2,500,000; Nacional, $35 \%$ of twelve millions = S/4,200,000; Perú, $50 \%$ of eight millions; equal to $S / 4,000,000$; La Providencia, were it to take a share, $50 \%$ upon $S / 3,200,000=S / 1,600,000$. Our discussions, in which Gallagher took a prominent part, lasted till eleven. The Anglo Peruano, and Londres Mejico \& S/A, kept entirely aloof. I was told that on Thursday night Riva Agüero had gone to the Banco Hipotecario, been let in by the porter, and remained there by himself for some time. Gallagher also told me last night that he had just discovered that on the $2^{\text {nd }}$ July Riva Agüero had asked and received from the cash keeper Muelle S/30oo for which he, as gerente, had given a receipt on account of profits due to him in the course of the present year, and very strange to say, Muelle had not entered this payment in the Cash, but considered it at the end of the month as so much cash on hand. The [_]co del Perú through the 
medium of César Canev [...] [774] Agent in Paris, had made an offer for the consignment of guano to Belgium, which had not yet been accepted, neither by their commissioners in Europe, nor by the Government in Lima.

Saturday, $28^{\text {th }}$ of August. I went at one O'clock to the Banco Hipotecario, but it was late before Oyague came, he having been detained in the Banco del Perú, where they had required his advice on the subject of the Government's proposal. The Directory of the Banco Hipotecario was but a short time together. The affairs of the $S / 3000$ taken out by Riva Agüero was communicated by Gallagher; the cashkeeper Muelle was called in, and I told him in clear terms that he had acted very improperly in not entering the sum to the credit of the cash, notwithstanding Riva-Agüero's order not to do so. Oyague and Gallagher defended the cashkeeper on the plea that he had to obey his superior's orders. Manuel Mendoza, Riva-Agüero's near relation, begged us not to lay this affair before the shareholders, and that he would endeavour to get the money back from him. It was about three, when the shareholders had assembled in sufficient number. The taking out of the S/300o could not be kept secret, and caused general indignation; it was resolved by an overwhelming majority that not only these $S / 3000$, but also the $S / 20,000$ or $S / 22,000$ taken out by the gerentes Riva Agüero and Escudero, their joint $5 \%$ on last year's profits, should be returned by them. As regards the $S / 3000$ all were unanimous, but respecting the profits of last year, nominal to be sure, which the Gerentes had appropriated to themselves, whilst the shareholders had not received a cent, there were a few, but only a few, who voted against the restitution; amongst these latter was I, but I coupled my vote with the words "porque no se sacará nada". Dionicio Ortiz de Villate, only just returned from Chile, made himself conspicuous by the strong expressions of which he made use. At his request, the acta dated many years back, in which the Directory assigned to the gerentes $5 \%$ of the profits was brought in, and it being signed, not by the President of the Directory as the Statutes prescribed but by [...] [775] Gerente Riva Agüero only, he declared this acta to be null, and upon this he founded his vote for the restitution of last years profits. In my opinion this motive assigned by him was ridiculous, for if it held good, all the $5 \%$ of the years previous to 1874 would have also to be reformed, and nobody thought of making such a demand. It was already getting dark when Oyague proposed the second approval required by the statutes of the alteration resolved in last meeting to the effect, that henceforth two gerentes, and not one as hitherto, should manage the business of the bank. Then José Canevaro made a speech proposing that one of the two gerentes should be, not a lawyer, but at least versed in law. This was rejected, and the nomination of two gerentes without any condition, unanimously 
approved. Then came another point, their remuneration; the debates on the subject did not last long and it was agreed that each should receive monthly S/400 and annually $21 / 2 \%$ upon the net effective profits after deducting $10 \%$ interest to the shareholders. Gallagher was not satisfied; he thought the salary ought to have been $S / 500$. When we broke up at past 6 I was met by Cucalon, afterwards by Lembcke who told me that on the following day, the $29^{\text {th }}$, there was to be in the premises of the Banco Nacional a general meeting of the Directories of the four national Banks, excluding of course the Anglo-Peruano, and that de Londres Mejico etc.

Sunday, $29^{\text {th }}$ of August 1875. I went at 1 p.m., and a little before two, all were assembled in a large saloon in the said bank. It had a very respectable appearance. At Gallagher's suggestion Derteano was called to the chair, he sat by himself on a sofa, at one end of the saloon under the window, before him, a table with papers, at which Climaco Basombrio, Gerente, took a seat, acting as Secretary. To his right along the wall were ranged on sofas and chairs the Directory of the Banco del Perú, then that of La Providencia; opposite to Derteano the Directory of the Banco Nacional, to his left, along the wall, the Directory of the Banco de Lima. The Gerentes also attended. Derteano opened the meeting, stating that its object was to discuss the project presented by the Government, which was read by Basombrio. Lembcke rose, giving the reasons why the Banco de Lima had accepted [...] with modifications. Ruden corrected him saying that [...] [776] del Perú had not rejected the project, but merely postponed their decision. Pedro Bernales presented a counterproject which was read. Several rose and spoke some in favor, some against the project; against it those of La Providencia, Garcia Calderon in a very pretty and well founded speech; Aurelio Denegri spoke in the same sense, so did J. M. Cardenas, this latter very diffusely and I thought little to the purpose. On the other hand, in favor of the project spoke: Derteano, several times, and very plausibly at least, Escobar and Lembcke, each a few words, Luis Cisneros in a set speech attempted to refute Garcia Calderon, but I hardly think that he succeeded in obtaining his object. Garcia Calderon had said that at the end of next year all the resources of the country would be entirely eaten up, and that then we would be still worse of than at present. Cisneros thought on the other hand that if not the guano, the monopoly of the nitrate would save us, also that next Congress would diminish all salaries, pensions etc., and impose heavy contributions; then only, and not before then, the revenue would equal the expenses. At Fords suggestion a Commission, two of each bank, was named to deliberate on the subject, for as many as forty, or more, who were present, could never come to any result. The Banco de Lima named almost without 
deliberation Luis Cisneros and Pedro Bernales; La Providencia, Francisco Garcia Calderon, and Albarracin; the Nacional, Ford and Westphal; the Perú took a long time before it had named Ruden and Chavez. Of these eight, Chavez and Albarracin were in my opinion little to the purpose. We separated at five.

Monday, $30^{\text {th }}$ of August. Santa Rosa. I called upon some of the Rosas of my acquaintance: Juana Rosa, wife of José Basagoytia; Rosa, Mrs. Correa; Rosa, Mrs. Francia; Rosa Osma, an elderly lady; upstairs lived in the same house Augusta Bergmann, married to Meceno Espantoso; she was an excellent woman, and I remained with her a considerable while. Thence to Doña Juana, the widow of Admiral Guise, one of whose grand-daughters was Maria Rosa Dartnell. From General Freyre, mar [...] [777] Juana Rosa Moreyra I learned that at that very moment the eight commissioners were conferring with the President in his own house, and this was confirmed to me by Rafael Canevaro, whom I met at the Pintos, where the second daughter was Rosa. Jose Basagoytia had invited us to spend the evening at his house. Garland and Enriqueta went. Mariquita had made up her mind to accompany them, but at the last moment she felt so unwell that she could not go out and of course I did not stir either.

Tuesday, $3^{\text {st }}$ of August 1875. General Freyre and Rafael Canevaro had been mistaken when they told me on the previous day that the eight commissioners of the four banks had been with the President in the middle of the day; not they, but the three gerentes Escobar, Lembcke and Moscoso Melgar, respectively of the banks Perú, Lima, and Providencia, and Derteano, the leading Director of the Nacional had been with him. Pardo had said that he was not at all satisfied with the turn which the project laid by him before the banks had taken; that in this manner no resolution could be come to for a length of time, and that he had therefore determined to give a decree which was to be his ultimatum, the sketch of which he would however present to the different banks that they might determine before the $7^{\text {th }}$ September, whether they would submit to it or not; consequently, the Directory of the Banco de Lima met on this day as well as on

Wednesday, $7^{\text {st }}$ of September, but no decision was come to.

Thursday, $2^{\text {nd }}$ of September. At 8 p.m. the Directories of the four banks again united in a saloon of the Banco Nacional, when the counter-project drawn up by the eight commissioners was read aloud by Dr. Francisco Garcia Calderon, who further stated that the commissioners had not continued their labours, not thought it necessary to do so, because they had learned that Pardo intended giving the ultimatum decree, of which I have spoken above. After a few minutes silence Gallagher was the first to rise, but I did not remember what he said. 
Lembcke said repeatedly that the Govt.'s decree was an ultimatum; Escobar, that the Banco del Perú would call their shareholders together.

Garcia Calderon in a long speech made manifest that the [...] [778] Securities offered by Government were hardly worth anything at all. Ford, who was evidently somewhat tipsy, spoke a great deal of nonsence, in very bad Spanish, and more than once made the whole assembly laugh. J. M. Cardenas' discourse was confused and, as he spoke rather low, not entirely intelligible. He proposed that those present should vote whether the Government's decree was acceptable or not. Notwithstanding great opposition it was put to the vote, but I could not distinguish whether the greater part of those present rose, or remained sitting, the latter meaning that it was not acceptable. I kept my seat so did my neighbour Lembcke; Bernales, who sat to my left, rose. The only practical motion made, was that of Diego Lopez Aliaga, who proposed that the eight Commissioners should continue their labours. I voted for it, but it was lost by a great majority. Garcia Calderon finally proposed that the labours of the Commission should be published. This was agreed to unanimously, on condition - and this was Lembcke's idea - that this publication should only take place after the Government's decree were given. It was nearly half past eleven when I came home, where I did not go to Enriqueta's saloon, but turned in.

Friday, $3^{\text {rd }}$ of September. In the meeting of the Directors of the Banco de Lima Lembcke said only two ways lay open for us, either to liquidate, or to submit implicitly to Pardo's will. I asked for some further explanation, and having received it, gave it as my opinion that we ought to liquidate. Nobody adhered to or opposed what I had said. After some desultory conversation it was unanimously resolved that for Monday evening the shareholders should be called together in order to learn their opinion, and take our determination that very evening still in time for the $7^{\text {th }}$.

Oyague, Jimenez and I, Directors of the Hipotecario, were together for more than an hour and a half when the most important item which Gallagher communicated to us was a letter dated $28^{\text {th }}$ August written by Riva Agüero to Oya [...] [779] the President, and received by the latter on the $29^{\text {th }}$, in which Riva Agüero claimed $5 \%$ of the profits made by the bank till the $30^{\text {th }}$ June, which according to him amounted to much more than S/200,000, and that accordingly he had a right to about $\mathrm{S} / 13,000$, viz.: $\mathrm{S} / 3000$ which he had taken out in the beginning of July, and $S / 10,000$ to be placed against his pagare of S/30,00o. This evening Garland went to Riva Agüero's Friday party, where they behaved towards him with their customary politeness. 
Saturday, $4^{\text {th }}$ of September. At 8 p.m. I was in the office of the Banco de Lima, where of the Directors Cardenas, Gallagher, and Mendoza were wanting. Lembcke communicated the details of a project which had emanated from the Banco Nacional, and to which the adhesion of the Banco de Lima was solicited. It offered to the Government a loan of $S / 18,000,000$, the last monthly instalment of which would have to be paid in April 1877. It demanded more, better, and more tangible securities than the Government offered, and finally, that the banks should have on the $3^{\text {st }}$ December in their vaults, in gold or silver, an amount equal to $10 \%$ of bank notes in circulation on that date, and that this metallic deposit should be increased every six months by $5 \%$; as soon as it came up to $40 \%$, then cash payment should be resumed. I disliked the first and third clause: the first, because I considered the issue too large, the third, because the metallic deposit was in my opinion too small; however, as I knew Derteano to be the author of the project, and as I believed Manuel Pardo to be acquainted with its contents, I agreed to all its parts, which were discussed one by one. So did the other Directors, and the answer to the Banco Nacional was written, in which that of Lima gave its adhesion on condition that the shareholders approved of what we had done. "La Providencia" had adhered unconditionally.

Sunday, $5^{\text {th }}$ of September. The shareholders of El Banco del Perú had a meeting, which lasted from two till five. I was present, listened, but did not say a word. The first thing I learned, to my great surprise, was that the Government had published the decree early in the morning of this day, the Council of Ministers with the President having deliberated [...] the subject till a late hour the previous night. This pu [...] [780] manifest that the president was opposed to the project. Both project and decree were discussed in the meeting; in favor of the former spoke Garcia Calderon and Lembcke, against it, and in favor of the decree, Canevaro at some length, Candamo, Escobar, and Oyague. Others also gave their opinion, but these mentioned were the principal spokesmen. However, no decision was taken, and a new meeting was convoked for Wednesday next.

Monday, $6^{\text {th }}$ of September. In the meeting of the shareholders of La Providencia my occupations did not allow me to be present, and I therefore gave my power to Amancio Castillo. In the evening the shareholders of the Banco de Lima met, and before eight a considerable number were assembled. The last acta was read, names called over, upon which I opened the session saying that the object was to decide whether the Banco de Lima should obey the decree, or adhere to the project, which latter, I added, I myself had approved of when under the impression that the President of the Republic had been cognisant of it, and even tacitly approved it, but that the publication 
of the decree proved that this had not been the case. Then Lembcke rose, and in a long memorandum which he read extolled the advantage of the project; in the same track he was followed by Derteano. Under what pretence he came to this meeting, I did not know. Oyague was present, so was Henry; neither opened his month. Correa said a few words; also Escudero, Dr. Aranivar, and Focion Mariategui. I again spoke, not much, but gave clearly to understand that in my opinion the project should be rejected and the decree accepted. Gallagher entered into an analysis of the decree, and showed its disadvantages. Derteano again rose, and explained that in his opinion La Providencia and Lima could not withdraw from the adhesion they had given to the project; finally, Mariategui moved that the shareholders should approve what the Directory had done and authorize them to act in future as they thought best. This motion, its redaction somewhat improved by Aranivar and Aliaga, was accepted [_] all Cardenas excepted, who said that he could not vot $[\ldots][781]$ the motion, not being acquainted with the details of the project. Lembcke rose, and accused Cardenas of having purposely abstained from attending the Directory everytime he knew that the loan demanded by the Government was to be discussed. Cardenas denied that this was the case; they had some high words, and the consequence was that Cardenas verbally resigned his post as Director.

Tuesday, $7^{\text {th }}$ of September 1875. When the Directory of the Banco Hipotecario was together, Gallagher read an answer from Riva Agüero, in which, as might have been expected, he differed from everything Gallagher had said in his letter. He had even presented himself against the bank, before a Juez de $1^{\text {a }}$ Instancia, but Gallagher had not yet been notified. I proposed that the bank should without loss of time proceed judicially against Riva Agüero. Oyague opined that we should endeavour to settle the dispute by arbitration, which milder course was agreed to; however, when in the meeting of the shareholders, which succeeded that of the Directory, this plan was proposed, it was unanimously rejected, and the Directory ordered to take judicial measures against him without loss of time. Then the election of the Gerentes came on. Those present had $35^{1}$ votes, consequently the majority was 176 . John Gallagher was elected by 196 votes; Garland had 111, Jose Luis Bernales 96, Emilio Forero 92, Ruperto Delgado 60 odd, Diego Lopez Aliaga 50, some others, a few votes, not worth mentioning. The election of the second gerente was put off till next meeting. Aranivar still proposed that the Directors should be paid, and their responsibility clearly defined. Oyague begged him to postpone this measure for better times, and nothing was decided on the point. Cardenas confirmed in writing his verbal resignation of his post as Director of the Banco de Lima. 
Some of the Directors of El Nacional, La Providencia, and Lima, also Escobar, Gerente of El Perú, assembled in the saloon of El Nacional. Derteano presided; Calderon proposed some material alterations in the project; Moscoso Melgar, Lembcke, Escobar, also Derteano, gave their opinion more or less approving the modifications, and without much discussion it was decided that the commission should go to the President and do their best to come with him to a friendly understanding. Derteano $[\ldots]$ the persons who should $[\ldots]$ Garcia Calderon for [...] [782] Lembcke for Lima, John Meiggs for Nacional, and Escobar for Perú, which latter excused himself on the plea that he did not know the opinion of his Directory. This meeting was immediately succeeded by one of the shareholders of the same bank, for which I did not remain.

Wednesday, $8^{\text {th }}$ of September. Rafael Velarde came last night at a late hour, and told us that he knew for a certainty that the commission and the President had come to terms. The editors of the daily paper El Nacional gave the same information in a loose sheet sent round this morning.

Thursday, $9^{\text {th }}$ of September. The Directories of the four banks were once more convened to meet in the saloons of El Banco Nacional. I was there at twelve, but it was one O'clock before proceedings commenced. Of the Banco de Lima were present: Lembcke, Luis Cisneros, Pedro Bernales, Valentin Gil, Diego Lopez Aliaga, Amancio Castillo, and I. I could not distinguish who were there of La Providencia and Nacional; Escobar, the only one of Perú. Derteano as President opened the meeting, and Garcia Calderon read the modifications, in which the three commissioners and the President had agreed. They differed from the project only on two or three points, but these were vital; the Government admitted the loan of $S / 18,000,000$, but limited the circulation of notes to $S / 14,000,000$; secondly, instead of metallic existency of $10 \%$ of the circulation of notes on the $3^{\text {st }}$ December 1875 the President insisted upon $30 \%$ of the circulation on the $1^{\text {st }}$ August, and thirdly, amongst the securities to be given by Government, the consignment of guano to Belgium was excluded, instead of which the Government offered bills on Europe for S/3,500,00o Soles, or in default of these drafts an equal amount of the proceeds of the guano sold in Belgium. Escobar said that the Banco del Perú had directed an escrito to the Government, in which they had declared their adhesion to the decree, with the modifications agreed upon. Amancio Castillo found fault with the conduct of the Banco del Perú, which he considered to have been not straightforward that they had been made acquainted with the modifications [_] [783] before the Directors of the Banco de Lima had known of them, and that the Banco del Perú, which had always hung back had now been the first to give in its adhesion. Escobar defended himself saying that he had thought it necessary 
to do so before the expiration of the $9^{\text {th }}$ September, the day fixed upon by the Government in the decree published last Sunday. After some conversation it was decided that the Directories should withdraw, and discuss the matter, each by itself. "Lima" went to an adjoining room. I took the chair. We all saw clearly the great inconvenience which might arise from a loan of eighteen and a circulation of 14 millions; nevertheless, with the exception of Bernales, the other six submitted to the decree. We then returned to the saloon, and Derteano in a speech, in which he explained at great length the two drawbacks which he found in the modifications $\mathrm{N}^{\circ} 1$ and 2 also inveighed in very strong terms against the conduct observed by the President of the Republic in all his financial operations ever since his accession to the Presidency, finally wound up with saying that notwithstanding all the difficulties which the banks would have to encounter, the Banco Nacional accepted the decree and its modifications. He said that for the next three months Dreyfus would not be able to give any bills to the public, for they required them all in order to procure silver bars; also, that the Banco Nacional adhered, in order to act in unison with the other banks. Garcia Calderon, who sat opposite to me, asked for the decision of the Banco de Lima. I answered that the Banco de Lima accepted the decree and its modifications on condition that the other banks adhered, "porque el Banco de Lima no tenia la fuerza suficiente para llevar adelante, solo, un tal negociado." La Providencia, through Moscoso Melgar, spoke in the same terms. Cardenas rose, and observed very properly that each bank entered if the others did, and that in fact everyone wished to get out if he could. Derteano made an attempt, in which he was seconded by Bernales, to return to the original decree with a loan of $S / 12,500,000$ but did not succeed, and when I left at four it had just been resolved that the gerentes of the respective banks should sign the acceptance of the decree with its modifications. Hardly had I reached the Banco Hipotecario, where Oyague, Mendoza, Aliaga and [_] with the Gerente Gallagher were already assembled [...] [784] Canevaro came in, who talked a great deal, and begged that the Directory would clearly understand that he did not consider himself bound to comply with the arrangement made by him and Oyague with the bank for the payment of $S / 15,000$ cash and $S / 5^{0,000}$ in Cedulas, if the various property belonging to Soyer such as coaches and horses, a rancho in Chorrillos, a huerta I do not know where, etc. were not made over to him and to Oyague. Aliaga opposed Canevaro, and observed that though this might have been the idea of Canevaro from the very beginning, and he did not doubt it was, it had not been expressed anywhere, and the Directory had considered the agreement as binding, whether the said property was made over to Canevaro or not. This gave rise to a very animated altercation, not to 
say dispute, and Gallagher wrote at once a letter to Riva Agüero, in which he demanded that the cession made by Soyer to Riva Agüero of this property should without loss of time be made over to the bank. It was past six when I came home. In the evening I did not go to Enriqueta's party. My wife did.

Friday, $10^{\text {th }}$ of September 1875 . At 2 O'clock I was in the Banco de Lima where Lembcke told me that he had just come back from the President with whom he had had a long conference, and, he hoped, had at last convinced him to allow the circulation of the banks to be raised not only to fourteen, but to fifteen million Soles. When they had separated, Pardo said he was going to the Palace to have the decree drawn out. This same day the two banks Lima and La Providencia already paid in some money to the Treasury.

At 2.30 there was again a numerous gathering of the shareholders of the Banco Hipotecario, for the great question was to be resolved who was to be the second gerente. Before the election took place Oyague was anxious to have an alteration in the Statutes passed, viz.: that the article were annulled which did not allow any shareholder to have more than ten votes. He proposed, and the motion was carried, notwithstanding a strong minority, amongst which was myself, that every five shares should have one vote up to 100 shares, after which each ten shares should have a vote. B [...] [785] alteration the large shareholders obtained a great influence which hitherto they had not had. Now the election came on; three hundred and eighty votes were registered, thus one hundred and ninety one were required to be elected. Garland obtained 168, J. L. Bernales 158, Emilio Forero, the lawyer and Senator, and Ruperto Delgado the remaining few. None had the majority required, and the election was again put off. Garland had had in his favor the Directory, Aliaga excepted, who, I believed, voted for Forero; a great many of the smaller fry, the principal opponents of Riva Agüero, collected by Melchor Velarde, and several highly respectable men, Pedro Paz-Soldan, Manuel Mendoza, Nicolas Rodrigo etc.; Garland had against him the powerful influence of Garcia Calderon, of José Antonio Garcia y Garcia, against both of whom he was carrying on law suits on account of Schutte \& Co., the personal friends of Bernales, and finally Felipe Varela and José Canevaro, who, friends of Riva Agüero, acted by his instructions, which were to oppose Garland because he was related to me, who on two occasions had not treated him with the deference which he thought was due to him. None of these took into consideration the welfare of the establishment; they were actuated by private motives. Even José Maria Sancho Davila, who the first time had voted for Garland, and who towards me had expressed himself unfavourably to Bernales, had at last been gained over by his relation Riva Agüero, and mainly by the latter's wife, Doña Mercedes. The next struggle 
would, I expected, be a very severe one, and I feared that Garland would be beaten, though Forero was now decidedly in his favor, because he wanted to be named lawyer of the bank; on the other hand, the Delgados were entirely under the thumb of José Antonio Garcia y Garcia.

Our family dined with Guillermo and his wife Eliza, to celebrate the birthday of the latter. They occupied at the time some apartments, not extensive, in the first story of a new house, built by Dr. Titus Melgar, more or less opposite to General Lafuente's. The marble stair-case, steep and narrow, led up directly from the street, and proved rather inconvenient for my poor wife. The vestibule, covered with an awning carpeted and furnished, served as ante chamber, it was very cold $[\ldots]$ had to wait long till Higginson and his wife came; we [...] [786] the dining room where a numerous party sat, or rather crowded round the well covered table. Everything was very nice, in my opinion too good and too expensive for Guillermo's straightened circumstances. We were: our entire family, not less than ten - Alejandro and his wife came after dinner - of the Higginsons I do not know how many, Enrique Cox, a clerk of Meiggs, another clerk of Sawers Woodgate \& Co., and a few more, whom I neither saw nor distinguished, in all twenty one. Eliza was at the head of the table, to her left Enriqueta, Higginson, and my wife; to her right Antonio, Ricardo, I, Meiggs' clerk, a Chilian, very agreeable, with whom I conversed a good deal, and Garland; at the foot of the table Guillermo, opposite Garland, Mrs. Higginson.

This day the Tribunal de Responsabilidad of which I gave an account some months ago, was installed. The two first causes brought before it were that between Mariano and Ignacio Osma, and that between Bonas Hermanos and the Government.

Monday, $13^{\text {th }}$ of September 1875 . The whole family, the two Velardes included, worked hard to obtain votes for Garland so as to ensure his election as one of the two Gerentes of the Banco Hipotecario.

Tuesday, $14^{\text {th }}$ of September. None of us slackened in our exertions. We even procured by telegraph two votes from Trujillo, those of the Father-in-law of one of the Figari's.

Towards four O'clock I went to a meeting of the Directory of the Banco Hipotecario. We dispatched a great many items which Gallagher laid before us. We also chose for examining all the title deeds, the lawyer Forero, for the second revision of the accounts the book-keeper Fromont, and for our umpire in the arbitration case with Riva Agüero, Alfred Böhl. We Directors, Oyague excepted, left at six; he and Gallagher remained to examine the contents of a box containing a number of documents, pagarees, receipts, letters, shares, all belonging to Soyer, and ceded by him to the Bank, but one 
with another, worth little if anything at all. In appendix will found under $\mathrm{No}_{21}$ a copy of the Governme[_] decree relative to the banks so often referred to. $[787]$

From Wednesday, $15^{\text {th }}$ to Friday, $17^{\text {th }}$ of September. I was for the greater part of the forenoons in the study of my lawyer Fernando Palacios, who commenced his reply to Leyva's escrito de Agravios, but so continual and incessant were the interruptions caused by people who came in, that very little progress was made. Dr. Puente Arnao when giving his sentence on the $31^{\text {st }}$ July made himself guilty of great neglect. The law says that the sentence must be proclaimed in the juzgado itself and in the presence of witnesses, and this formality he had not observed. Very naturally Leyva's lawyer availed himself of this culpable neglect to demand the nullity of the sentence; but Palacios, on referring to the Codigo de enjuiciamiento, found that in the article which treats on the causes which invalidate a sentence, the informality referred to is not included, and I flattered myself that in this manner we might get over the difficulty. On Wednesday I was cited to a meeting of the four Directories in the Banco Nacional, but for the reason already given could not attend. I was told that the object was to choose one person from each Directory, which four were to form a committee considered indispensable in order to defend the interest of the four associated banks in the pecuniary and other transactions which would necessarily arise between them and the Government in consequence of the late decree and contract. For the Banco de Lima the two candidates for this post were: Pedro Bernales and Luis Cisneros. I did not know as yet who was elected.

On Thursday, the eve of Enriqueta's birthday, the tertulia was very numerously attended. I went in, but unable to distinguish anybody soon left again. There were three rocambor tables; the young folks danced till two in the morning, and roulette was not neglected either.

On Friday the shareholders of the Banco Hipotecario once more assembled. Oyague's favourite plan to increase the number of votes for large shareholders viz.: one vote for every five shares up to one hundred and one vote for every ten above one hundred was thrown out. According to Statutes, any alteration of them, which this measure would have been, required at the second reading two thirds of the votes, whilst on counting them it turned out that the opposition numbered more than one third [...] motion that no shareholder should in future be allowed to [...] [788] more than 10 votes not his own, passed unanimously; thus no shareholder could ever have more than 20 votes, ten for himself, ten for others. Then the election of the second gerente came on; 392 votes were registered, consequently the majority was 197. I represented not less than 34 votes, say 8 for myself, 8 for Dionisio Villate, 6 for Camogli, 
2 for the Chilian Minister Godoy, 3 for the Eldridges, which I had obtained through Vicente Hurtado, 4 for Sand, which I got from Leuthold, 2 from the testamentaria of Ramos, and one from Josefina Ramos. These latter, as well as Camogli's, Enriqueta had procured. On the other hand there came down for Bernales, Francisco Garcia Calderon, mainly for the Goyeneches, and Felipe Varela with 30, viz.: 10 for his father, 10 for Riva Agüero, and 10 for José Maria Sancho Davila. Four or Five noted down the numbers of votes, Oyague taking out of an urn the folded up slips of paper. I was one of the escrutadores as they are called. Garland obtained 216 votes, José L. Bernales 176, accordingly, the former was elected, to the great joy of the family and the two Velardes. My wife and I, and Rafael dined with Enriqueta; otherwise, though it was her birthday, the day passed over as quietly as any other. This very day the Directory of the Banco de Lima had a very long session from near three till half past five. Many questions were settled. The resignation of Cardenas we refused to admit. For the committee of the four banks above referred to, two members, not one as above said, were to be chosen by each bank. With us the election fell upon Luis Cisneros and Pedro Bernales. Lembcke, Armero, Cucalon, Gil, and I had struggling votes, no one above two, I but one. We resolved to rebegin discounting documents at no longer date than three months, at $1 \%$ monthly, the penal interest to be raised to $11 / 2 \%$ at the option of the gerentes. Silver was to be bought at the current premium of 10 to $11 \%$, for the present to the extent of S/50,00o wherewith to purchase bills to remit to F. Huth \& Co. and the International bank of London, to whom the bank was largely indebted. The discussion relative to the Salitrera Esperanz[_] was put off until the receipt of the estimate of expenses for [...] [789] month; and finally, at the urgent request of Castillo, backed by Cucalon, the payment of the $41 / 2 \%$, remainder of the dividend for 1874, was ordered to be made. I was opposed to it, but gave in.

Large sums had already been delivered to the Government by the four associated banks. Exchange on London, for silver, not for paper, varied from 40 to $42 \mathrm{~d} 90 \mathrm{~d} / \mathrm{st}$.

Sunday, $19^{\text {th }}$ of September 1875 . On the $19^{\text {th }}$ June 1859 I gave a short account of the manner in which I then spent a Sunday here in Lima. This day I did the same, and it will be seen that things had altered very little - with me at least in the course of the 16 years elapsed since then.

I rose very late, later than usual. Our breakfast hour, in 18599 O'clock, was now nearly half past ten. My wife and myself sat down by ourselves; occasionally, but very seldom, little Corina Garland joined us. When I rose from breakfast Bryson was generally waiting for me. On Sundays the first thing we did was to 
balance the cash, which being done Ricardo Garland read aloud the diary of 1854, 5 and 6, which, written in German under my dictation, was now translated by me into English, and written down by Bryson. At 1 Ricardo sometimes went to mass; this day Bryson read to me from the Eclectic, Thomas Carlyle's history of the old Norwegian Kings. We had just done, when a letter was brought me from J. F. Lembcke, Gerente del Banco de Lima, in which he informed me, as President of the Directory, that "motivos de dignidad personal" induced him to resign the gerencia. I hurried to his house, and gathered from him that he was offended at our not having immediately admitted the resignation of Cardenas; this however he did not give as his only motive; he also complained of Cucalon's "foul mouth". This call, and dressing, kept me till nearly 3 O'clock.

The first visit which I made was upon Doña Inéz Laos, the wife of Rafael Canevaro; she was a nice young woman, and when I entered her well furnished drawing room I found her in conversation with a gentleman of Callao, to all appearance a man of some importance; he called me by my name, though I did not know him. Next, I went to the house of Dr. Muñoz. His young wife, the showy and elegant Irene, was, as always, out in her carriage. At [...] I found of the family only the sister-in-law Transito [...] [790] other ladies, amongst whom Doña Pancha, the widow of General Castilla whom I had not seen for many years. At Rafael Velarde's I did not remain long with his wife and daughter. At Melchor's nobody was at home. Doña Fidelia, the wife of Anibal de la Torre, Minister for Foreign Affairs, was by herself. She, as well as he, were always very friendly towards the members of our family. We were soon joined by a gentleman from Trujillo, José Feliz Ganosa. My last call was upon Doña Dolores Puente, with whom I was very intimate; if I did not go at least every second Sunday I was sure of a scolding. Our dinner hour was between half past five and six. On Sundays and holidays we usually dined with Garland, but as this day they had gone out to Chorrillos to spend the day with José Canevaro and his wife Luisa Soyer, my wife and I took the meal in our own dining room, together with a certain Canon Dr. Mora, whom I did not admire; he was rather vulgar. After dinner my wife and I were alone for some time. At half past eight tea was brought in, and whilst we were taking it, Mr. Sattler, the partner and cousin of John Gildemeister, who occupied my house Calle de Aldavas, came with his wife Beatriz Pflücker. He was a loud and continual talker, she quiet and modest. They left past ten, and above half an hour later Garland and Enriqueta returned from Chorrillos.

Monday, $20^{\text {th }}$ of September. I learned to my great sorrow and surprise that Guillermo had been deprived of his situation as book-keeper in La Sociedad Maritima. The Directors had resolved to reduce expenses to the very lowest 
point, and consequently both he and Escudero, the liquidator, had been dismissed. What was the poor fellow now to do to pay the rent of his house, and sustain his wife, and children, who no doubt would come in course of time?

Of course I had now no chance of receiving any further the monthly interest of $1 / 3 \%$ upon the $S / 22,000$ which some time back I had to pay for him, and for which I held his pagaré de mancomun et insolidum with his father. Garland had neither been able to pay me the rent for last year, due $31^{\text {st }}$ May, though only $\$ 120$ monthly. On Saturday last I had transferred to him thirty of my shares of the Banco Hipoteca[_] which he as Gerente had to deposit as guarantee; consequently [...] [791] shares remained to me, and as no shareholder, owner of 10 shares could be a Director without uniting $2 / 3^{\text {rds }}$ of the votes, and I when elected had only the majority, I this day gave in my resignation as Director, which however was not admitted, and I was again cited for a meeting at 3 O'clock, the same hour at which I had convened the Directors of the Banco de Lima for the purpose of laying before them Lembcke's letter above spoken of.

Tuesday, $22^{\text {nd }}$ of September 1875 . The majority of the Directors of the Banco de Lima, without the gerente Lembcke, met at half past three. All unanimously agreed that his resignation could not be accepted on any account. Bernales, the secretary, was instructed to write him a letter to that effect, and a commission, consisting of myself, Gallagher, Cucalon, and Castillo was named to wait upon Lembcke on Thursday and to request him to withdraw his resignation.

In the Banco Hipotecario neither Mendoza nor Jimenez attended. Present were: Oyague, I, Diego Lopez Aliaga, and the two gerentes. As yet Garland was merely a listener. Nothing of particular importance was discussed. There being more than S/100,00o to the credit of the Banco Hipotecario in the Banco de Lima, we did not hesitate to order the payment of the interest due on the $1^{\text {st }}$ October on the cedulas. This time it was true the bank had not been obliged to borrow money to make this payment, as had been the case under the late gerentes, but it still owed considerably to the Banco de Londres, to the AngloPeruano, and the Paternal.

Wednesday, $23^{\text {rd }}$ of September was a quiet day.

Thursday, $24^{\text {th }}$. At somewhat past twelve Gallagher, Castillo and I - Cucalon did not come - went to see Lembcke in the office of the Banco de Lima. We took him into an inner room. I began, Gallagher dilated on what I had said, and Castillo spoke also a few words, though not much to the purpose. Lembcke was somewhat moved, vacillated, but gave no decided answer. Afterwards Oyague, Rodrigo, Yguren, the Gerente Andrés Rey, and I were for some time together in the locality of the water Company. Several trifling matters were disposed of, which being done it was resolved to resume the payment of dividends on 
the $1^{\text {st }}$ October at the rate of $8 \%$, upon the original, $10 \%$ upon the newly issued shares; further $[\ldots]$ the surpluses or deficits arising from the provisional $[\ldots]$ [792] in the course of the last twelve months, and now to be exchanged for shares of $\mathrm{S} / 400$ each should be reciprocally sold or bought by the shareholders themselves at a discount of $12 \%$, but in case there were more sellers than buyers, then the company itself should buy up at the same discount the surpluses for which there might be no purchasers. I was in a situation either to sell a surplus of $\$ 100$ or to purchase $\$ 400$ to make up another share of S/400 and agreed with Rodrigo to purchase $\$ 400$ which he had more than he wanted. In Enriqueta's tertulia there were of ladies only my wife; Eliza, Guillermo's wife; Pancha Cardenas, wife of Gregorio Benavides, and her pretty niece Rosaura.

Friday, $25^{\text {th }}$ of September. Dia de las Mercedes. I did not pay my respects to Mercedes Riglos de Riva Agüero, to whom in former years I never failed to go, but merely sent my card. After having made some other calls I looked in at Doña Mercedes Guise, widow of Dartnell, where Oyague was the only visitor. When Riva-Agüero came in Oyague left. I shook hands with the new comer, otherwise we were rather cool towards each other. The principal topic of conversation was the gran feria to be held on Sunday next in the Exhibition Palace. There would be eighteen or nineteen stalls or tables, each presided over by a married lady with two or three, or four unmarried girls to assist. The President's wife Mariana Barreda de Pardo was to preside at one stall. Enriqueta had also been requested to lend her services, but declined. On one table gloves were to be sold, on another, cravats; on a third counting-house utensils, on a fourth, pastry, on a fifth, liquors (this, Bella Gallagher, married to Evans, had taken under her charge). The proceeds, after deducting the cost, were destined for contributing to the construction of a new church in Chorrillos, which the president's mother had particularly at heart. A committee of young men had sent round nearly to every house five entrance tickets, each one sol, and I, of course, had to contribute my share. At $6.30 \mathrm{p}$.m. I went by invitation with Garland to the house of J. V. Oyague, who, as he told us, gave [...] dinner in honor of the two new Gerentes of the Banco Hipot [...] [793] At the last moment, Gallagher begged to be excused, as he was detained by a cricket match. Anibal de la Torre was prevented by a diplomatic dinner given by the English Minister Spencer St. John, thus there were besides us two, only: Elguera, Minister for Finance, who in 1846 and thereabouts was clerk in the Treasury, and with whom I then made many calculations when I was in the habit of discounting Custom-house pagarées duty being then paid not cash down, but by pagarées at 3 and 6 months credit; and the Chilian Lamarca, for one or two days our companion when my wife, Corina and Amalia were travelling in 1855 in the Saxon Switzerland. 
Elguera had to give his arm to Mrs. Oyague, I to the eldest daughter Elvira whose birthday it was. At dinner I sat to the left of Mrs. Oyague, and to my left the eldest son Vicente; to her right the Minister; opposite to her her husband, to his right Garland, to his left Lamarca, to Lamarca's left Elvira; the remaining seats were filled by the children. Dinner was splendid, far too good for so few guests. Mrs. Oyague was very agreeable, Oyague himself by no means so pompous as he often was in the meetings of the Directories. The conversation, though not very animated, was general, and the time passed away quickly till nine when we rose. The other gentlemen went to an adjoining room to smoke. I sat down for some time on the sofa near Doña Isabel; coffee was served, we joined the gentlemen, and after tea had been handed round, Garland and I left, both well pleased. The Minister had gone before us, being summoned to a council of ministers, the object of which was kept secret, though afterwards Oyague told Garland in strict confidence that it was convened to treat on the subject of bills drawn by the United States Guano Company in virtue of the arrangement lately made when young Hurtado was here from the United States, and which bills had now been protested. Not long ago news had been received from San Francisco that the Californian Bank, established there, had stopped payment; its liabilities amounted to fourteen million North American dollars. By last steamer we learned that the Shannon, the splendid vessel belonging to the Atlantic Steam Navigation Coy., on board of which I took my passage in March 1863, had struck upon a rock just before entering Kingston. The date of the occurren $[\ldots]$ took place at 4.30 in the morning I did not learn she had $[. .$. [794] Colon on the $6^{\text {th }}$ September. The captain being sick in bed she was under the charge of the second in command. All on board, as well as the mail were saved. To-day my lawyer's escrito replying to Leyva's "Espresion de agravios" was handed into the secretary's office of the second chamber of the Superior Court. Palacios merely refuted every argument of the other party, without entering into any further particulars.

Sunday, $26^{\text {th }}$ of September 1875 . The grand feria in the Exhibition Palace came off. It was well attended, the saloon nearly crowded. However, of the young men known in the Lima circles hardly any one was present, whilst on the other hand a great many shopkeepers were there; also many foreigners, amongst whom the North Americans were said to have been the most liberal. The President spent at each table S/5. The amount collected, some said, had come up to nearly $S / 15,000$, others to $S / 12,000$ and both statements might be correct, $S / 15,000$ gross, $S / 12,000$ after deducting all expenses and the original cost of the articles sold.

Monday, $27^{\text {th }}$ of September. Last night Anibal de la Torre gave a ball to celebrate the Saints day of his eldest daughter Cipriana. Enriqueta and Garland 
went. Less than a hundred persons were present, of course the greater part of the diplomatic body, Lührsen and his lady not, she being prevented by her late confinement; neither a single one of the Minister Latorre's colleagues, which was rather strange. Enrique, Guillermo, and his wife, Geraldo and Juan, who had been invited, came home this morning at 3 O'clock. In the forenoon I went to see Lembcke, who at last ceded, and declared his willingness to continue as gerente. From the Banco de Lima I went to the office of the United States Guano Company; Vicente Hurtado was not in, but John Bryce, the elder brother of Francis, one of the Directors, was there, and he gave me more or less the details of the difficulties in which the company found itself. Several months back when Hurtado, cousin of Vicente, and partner of the firm of Hurtado Hobson \& Co. of New York, had been in Lima, the company had made a new arrangement with the Government in virtue of which the Government issued bo [...] [795] to the amount of more than three million North American dollars, the servicio, that is to say the interest and redemption of which was to be paid out of the proceeds of the guano consigned by the United States Guano Company established in Lima, to the said new York firm, on account of the Peruvian Government. Upon the security of these bonds the North American Hurtado had been confident that the banks in the United States would readily make advances, and relying upon this, his assurance, the company here accepted bills drawn upon the same by the Government in pounds sterling, £100,000 or more, divided in $£ 10,000$ monthly. According to the terms of acceptance the company had to give in payment drafts on London, which they expected they could have done, had Hurtado obtained from the United States bankers the advances upon which he had counted, but he did not obtain any, and had gone over to England in hopes of meeting there with better success. His telegraphic dispatch was now momentarily expected by the company; if favourable, they would be able to take up the first £10,00o in the hands of Graham Rowe \& Co. as well as the second $£ 10,000$ in the hands of the Banco de Londres, both which two acceptances had been protested for non-payment. Should Hurtado be as unsuccessful in England as he had been in the United States, then the company would have to call its creditors together, one of whom I was unfortunately for $\mathrm{S} / 41,000$. The principal, if not the only debtor of the company, was the Peruvian Government, for at least four million Soles.

I saw by the Nacional that the committee, named by the four banks for treating with the Government, consisted of the following members: Schell and Basombrio for the Banco Nacional, Calderoni and Chavez for Perú, Luis Cisneros and Pedro Bernales, for Lima, Garcia Calderon and Moscoso Melgar for La Providencia. Garcia Calderon had been named President, Cisneros secretary. The work had been distributed as follows: Scheel and Calderoni had 
to attend to the guano business; Garcia Calderon, Moscoso Melgar, and Bernales to the Nitrate, and Cisneros, Chavez, and Basombrio to the organization and branch establishments.

Tuesday, $28^{\text {th }}$ of September 1875 . Of this days meeting of the Directory of [_] Banco Hipotecario little was to be [_]aid. Garland was [...] [796] but as yet took hardly any share in the discussions. Gallagher made known that according to instructions, he had disposed of a considerable quantity of the Internal Debt, which the bank had received some time back in exchange for the Pasco Railway Bonds, at $641 / 2 \%$ and it was resolved that he should continue selling the remainder, as the market was gradually rising. Secondly, in a previous meeting it had been determined that $S / 50,000$ should be paid to the Banco Anglo Peruano, on account of the large amount due to the same. Now, as we had expected, the Anglo Peruano refused accepting payment in bank notes at their nominal value. Their reasons, not without some show of justice, were the following: at the time that the pagaré for the amount borrowed by the Banco Hipotecario fell due, and even at a later period when the pagare had been prolonged and the bank ought to have paid, the exchange upon London was 43d. Now, the bank, against the wish of El Anglo-Peruano delayed the payment for several weeks, if not months, and finally when it declared its willingness to pay, the exchange was $37 \mathrm{~d}$, consequently, the sol at present offered to the Anglo-Peruano was in reality not the same Sol which it would have received if paid at the proper time, and it was only just that the Hipotecario should pay so much more as to make up for the difference between the exchange of 44 and $37 \mathrm{~d}$; nevertheless, the Anglo-Peruano declared its willingness to bear part of the loss. Against this argumentation the only objection which could be made was that the Government had declared the bank notes as legal tender, and that therefore everyone had necessarily to receive them at their nominal value.

Thursday, $30^{\text {th }}$ of September 1875 . There was a poorly attended meeting of the shareholders of the Gas Company, which paid a miserable dividend of $2 \%$ for three months. However, sufficient shares were represented to enable us to proceed to business. The first thing to be done was to name a person to examine the accounts at the end of the year, which in former years had been done by Guiroy, last year by Calixto Pfeiffer. Mr. Henry proposed Guiller[_] Garland who was unanimously accepted. Then [...] [797] nomination of a Director instead of Francisco Bryce, who had gone out, and of two suplentes. Oyague, who always presided these meetings, proposed me as Director, and Manuel Ortiz de Villate and Manuel G. Chavez as Suplentes, to which nobody made any objection.

Friday, $7^{\text {st }}$ of October 1875. This day the Banco Hipotecario commenced paying interest on Cedulas. They had risen within a few weeks from 57 to 
$70 \%$; Vales de la nueva Consolidacion from 46 to nearly $70 \%$. Money, that is to say notes, was plentiful in the market, a natural consequence of the millions the banks had paid to the Government and the Government to its creditors.

The $S / 15,000,000$ which as per decree of $13^{\text {th }}$ September the four banks were allowed to issue, were distributed as follows: $S / 5,122,500$ fell to the share of the Banco Nacional, S/4,878,00o to the Banco del Perú, S/3,048,750 Lima, and S/1,950,750 La Providencia.

Saturday, $2^{\text {nd }}$ of October 1875 . At 3 p.m. I went to the Banco de Lima where I presided the Directory as usual; few were present. Absent were: Sagastabeytia, one of whose sisters had just died, Cucalon, Gallagher, Gil, and Cardenas. Hardly anything of importance was discussed. No estimate of expenses had been received from the Salitrera. Manuel Mendoza, notwithstanding his repeated promises, had not given a mortgage upon one of his estates for the amount due by him. From Julian Guimet, a landed proprietor, much indebted to the bank, and whom Manuel Rosa O'Phelan, another of his creditors, was pushing hard to make him declare his insolvency, no money had been forthcoming. The only resolution worth noticing was the authorization given to the gerentes to discount a bill amounting to between eighty and ninety thousand Soles drawn by the Bolivian on the Peruvian Government, accepted by the latter in favor of Valdeavellano \& Co., indorsed to Derteano, and offered by him to the bank for discount at $1 \%$ monthly. This bill was drawn on account of the annual subvention paid by Peru to Bolivia for the latter country's share of the duties levied in the port of Arica. From the "Lima" I went to the Banco Hipotecario, where all the Directors, the two gerentes, and the lawyer Emilio Forero were present. This latter proved by the Codigo [...] that before a pagaré falls due the creditor must receive the [_] [798] amount if offered by the debtor; after the document has fallen due the creditor is not permitted to refuse a partial payment, or if he does refuse, interest can no longer be charged on the amount offered. On the other hand Forero told us that though capitalisation of interest was prohibited by Peruvian law, yet this practice had of late been introduced into commerce, and been generally accepted; he himself had gained in Tacna a case where compound interest had been charged. It was resolved to borrow from the Banco de Londres $S / 100,000$, and if this loan could be obtained, then, adding to this amount $\mathrm{S} / 50,000$ which the bank had still disposeable, to propose to the Anglo Peruano the cancelment of the debt. A letter was read from Felipe Barreda relative to the Cedulas which were held by persons resident in Paris, and upon which the bank, when Riva Agüero was gerente, had bound itself to pay the interest and redemption at an exchange equal to $45 \mathrm{~d}$ per Sol. Now that exchange was at $37 \mathrm{~d}$, the bank suffered a heavy loss which of course made us 
desirous to annul the arrangement, but whether we had a right to do so was the question. Forero, before giving his opinion, wanted to see the advertizement which at the time had been inserted in the Lima papers. In Soyer's account new deficiencies turned up at every step.

Riva Agüero had taken in payment twenty-two shares of the Banco Hipotecario to the order of Pedro Telmo Larrañaga, without any transfer having been made in the books of the bank of these shares from Larrañaga to Soyer and from Soyer to the bank, and now Larranaga claimed ten of them as his own, he presenting a paper signed by Soyer which said that they were merely deposited with him by Larrañaga.

Sunday, $3^{\text {rd }}$ of October 1875 . In the forenoon I made some calls, of which the most agreeable was that upon Ernestina Pflücker, wife of Felix Dibos, with whom I remained about an hour, and talked on a variety of subjects. At Dr. Lührse[_], the German Chargé, I made the acquaintance of the Engl [...] [799] Chargé Mr. Spencer St John. Mrs. Lührsen, whose babe was only three weeks old, was quite well, and in her usual good spirits. This day the first trip was made on the railway to Magdalena; one of the passengers was General Prado, accompanied by some of his friends.

Monday, $4^{\text {th }}$ of October 1875. Once more a meeting in the Banco Hipotecario, at which the lawyer Forero and Diego Lopez Aliaga did not attend. Gallagher made known that he had borrowed between ninety and one hundred thousand Soles from the Banco de Londres, and cancelled the debt to the Anglo Peruano interest being capitalized at $1 \%$ at the end of each year. Oyague proposed and advocated that the bank should take on its account a house in Valladolid, the property of Señora Comparet, who owed to the bank and was much in arrears with the payments. Gallagher seemed inclined to have a house owned by the bank in order to arrange it to his liking. I was decidedly opposed to this idea, because, firstly, we wanted money to pay debts, and not to buy houses; secondly, because we had rented the bajos we now occupied at S/400 monthly for five years, bound by escritura, and thirdly, because in the meanwhile we should make a miserable interest upon the money laid out, even were we fortunate enough always to let the house which it was intended to purchase. Jimenez sided with me. Garland opined very properly that we could make no purchase without the authorization of the shareholders. Mendoza was silent. Finally it was resolved that before coming to any decision Gallagher and Jimenez should examine the house.

Thursday, $7^{\text {th }}$ of October. At noon I went to the Secretaria of the second chamber of the Superior Court of Justice, and enquired whether the "relator" had already returned all the documents belonging to my suit against Leyva, together with his "relacion". To my great surprise I was told that they had not 
yet been delivered to him. For an hour and a half I waited for Dr. Palacios in his study, and when at last he came, the only advice he gave me was to complain to Dr. Leon, President of the Superior Court, of the Secretary's neglect. This, I was loath to do, and spoke to the secretary himself, who promised me faithfully $[\ldots]$ all the papers should this day be handed to the relator $[\ldots][800]$ At somewhat past three the Directory of the Insurance Company Lima met, Carlos Elizalde President, Mr. Henry, Vice, Mr. Carrol, Valentin Gil, Moscoso Melgar and I, also the Gerente Manuel Ferreyros, lately returned from Europe in perfect health. An insurance, and a loan of money S/24,000 to J. G. Garcia of Callao, were approved of, and the state of the monthly accounts of the company read. Elizalde informed us that the company had lost in the Superior Court the suit against the widow of a certain Abril. The case was the following: some years back, the company had lent to an Italian Mazzini, who since then had failed, $S / 13,000$ as a security for which loan he placed into the hands of the Company shares of some joint-stock company endorsed by the deceased Abril in blank. After the failure of Mazzini, the widow of Abril presented herself with a paper signed by Mazzini, but of a later date than that on which he had borrowed the money, in which it was said that he had received the shares in deposit from the deceased Abril; and founding herself upon this document she now claimed the shares as hers. She had gained in the first instance, and this sentence had now been confirmed by the Superior Court. From the Insurance Company's office I crossed over to the Banco Hipotecario, both on the same ground-floor of the house which I inhabited together with my family from ${ }_{183} 6$ till 1842 when we removed to the house bought by me in the Calle del Correo. We had to wait a long time till José Vicente Oyague came. All were present except Mendoza; Dr. Forero attended. The house of la Señora Comparet had been examined and found unsuitable. The gerentes had sold $S / 5^{2,000}$ of the Internal Debt to Alejandro Garland, at $67 \%$. José Canevaro refused to carry out the agreement to which he and Oyague had bound themselves when we met in my house, and to which I have referred more than once. The reason which he gave was that the various property which Soyer was to have delivered to him and his brother-in-law, was not in existence and what existed was for the greater part worthless. He [...] [801] He had been requested to be present at this days meeting of the Directory, but did not appear. Forero said that he had examined the advertizement inserted in the Lima daily papers, of which I spoke on the $2^{\text {nd }}$ October, and he had found it drawn out in so binding a manner that in his opinion as long as the bank had a representative in Paris it had necessarily to remit to this representative the funds required para hacer el servicio of the Cedulas transferred to Paris at the exchange of fs 4.65, equal to about $45 \mathrm{~d}$ per Sol. The exchange being now $37 \mathrm{~d}$ there was naturally 
a loss to the bank upon this transaction, which loss would still increase should the exchange continue to decline. What was to be done? Forero gave his advice - that of an astute lawyer. He counselled us to annul without loss of time the power which Ventura Marcó del Pont held of the bank as its representative in Paris; then the holders of the transferred Cedulas would necessarily have to apply to the bank in Lima, when the gerentes should refuse payment, availing themselves, amongst others, of the plea that the transfer to Paris had been made in opposition to the Statutes of the bank, and that consequently it was illegal; probably, Forero continued, some of the holders of the Cedulas when they saw the attitude taken by the bank might be inclined to "transar", that is to say, content themselves with receiving cash down, and without trouble, part of their just claim, rather than sue the bank for the total, incur the certain expense of a lawsuit, and run the risk of the result.

At about one in the day-time, telegraphic dispatches were received from Iquique stating that a fire had broken out at two in the morning, that it was making great progress, that the premises of the Banco Nacional had much suffered, and that Gibbs' establishment, the Banco Anglo-Peruano and the Banco de Londres had as yet escaped. The Salitrera "Esperanza" lay so far distant as to be out of the reach of the conflagration.

My wife was in bed the entire day with a bad cold, thus neither she nor I went in the evening to Enriqueta's tertulia.

Friday, $8^{\text {th }}$ of October 1875. Telegraphic dispatches from Iquique announced that the fire still continued.

Saturday, $9^{\text {th }}$ of October. The Government ordered the Company which collected the export duty on Nitrate, to place $S / 5000$ at the disposal [...] Municipality of Iquique. In General Prado's house a [...] [802] was opened for the Iquique sufferers. Prado headed the list with S/10oo; followed, José F. Canevaro, S/10oo; Pablo Vivero, for the Guano loading Company S/100o. Others subscribed according to their means and inclinations. Various persons were named to go round and solicit subscriptions. Past four we met in the Banco Hipotecario, Mendoza absent, the lawyer Forero present. José Canevaro came in, and explained that the convenio so often referred to was illegal, and could therefore be easily annulled. He proposed that Soyer's various property, a rancho in Miraflores, another in Chorrillos, and a quinta, also a coach and horses, should be taken by the bank at the reduced valuation given to them, for according to him he and Oyague, Soyer's brothers-in-law, would find much more difficulty than the bank in making him deliver up the said property, and if once in the bank's possession it could also be disposed of more easily than if it were in the hands of the two brothers-in-law. After Canevaro was gone Forero declared that he had been in the right when he had said that the convenio could 
easily be annulled. Taking this declaration as our starting point, Canevaro's proposal was discussed by all present, Forero and Aliaga, more versed in law than the others, taking the lead, but no resolution was taken.

Sunday, $10^{\text {th }}$ of October 1875. At Somewhat past two O'clock I went out with Garland, firstly to Dr. José Luis Gomez Sanchez, who was a great friend of Dr. Antonio Arenas, Vocal of the Supreme Court. Garland represented to the Doctor the injustice done to him in the suit of Garcia Calderon against Schutte \& Co. Olivares, the Juez de $1^{\text {a }}$ Instancia had assigned to Calderon for his remuneration $10 \%$ upon the two hundred and odd thousand pounds allowed by Balta's administration to Schutte \& Co. in cancelment of all their claims as Guano Consignees to Germany. The Superior Court had reduced the $10 \%$ to $4 \%$ and Dr. Villarán, one of the adjunct fiscals to the Supreme Court since Ureta's death, had given his vista that there was no nulidad in the sentence of the Superior Court, and that consequently Sc[_] [803] had to pay to Garcia Calderon $4 \%$ on $£ 200,000$. The Doctor promised to speak to Dr. Arenas on the subject, but I doubted he would do so. Next, we went to Melchor Velarde's house, from the balconies of which we saw several of Prado's Clubs walk out to the open place near the Exhibition where his friends and adherents intended to make a grand display of their numerical strength. They waved their banners, and huzzaed now and again, but enthusiasm there was none. With Melchor was Rafael, his wife and children; he, Rafael, prevented, as he said, by a violent headache had thought proper to stay at home instead of accompanying his chief. Zoila, Prado's god-daughter, an enthusiastic Pradista, had brought with her flowers and garlands to be showered down upon the hero of the 2 de Mayo, on his passing by. Melchor was displeased with this show of party feeling. After leaving Melchor's house Garland and I looked in at Pedro Paz-Soldan's, where nobody was in; next called at Anibal de la Torre's, and at José Vicente Oyague's, with whom we remained a considerable while, conversing solely about the Banco Hipotecario. We then separated; I went to the Masias, where Doña Transito Llosa told me that Mr. Henry of Gibbs' house had suddenly been taken ill. I immediately went to Gibbs, and found Böhl, Isaacson, and Gallagher in the drawing-room. Böhl did not clearly tell me what was the matter with Henry; it was an irritation of his nerves he said. Henry had looked rather strange and spoken somewhat incoherently. The remainder of the day we were quietly at home. In various places the Monteristas had come in contact with the Pradistas; they had had their scuffles, some had been wounded, one or two killed.

Monday, $11^{\text {th }}$ of October 1875 . Ricardo brought word that Mr. Henry was somewhat better. By last steamer Grimaneza Cotes wrote Enriqueta that Mr. 
Errequeta of Paris, partner of Heudebert, had committed suicide, which act was generally attributed to the bad state of his business. It had been known in Lima by telegraphic dispatch about three weeks previously, but then I gave no credence to the report.

Tuesday, $12^{\text {th }}$ of October. The Directory of the Banco de Lima met at $3 \cdot 30$. Our number was very reduced: the two Gerentes, Aliaga, Bernales, and I, Luis Cisneros, Gallagher, who was soon called off to [...] Banco Hipotecario, and Julio Armero. Absent were: Gil [...] [804] Mendoza, Cárdenas, Barrios, and Castillo. Lembcke asked the opinion of the Directory as to two loans which the bank was requested to make; the one, of a large amount to an hacendado Silva, lessee of the state of San Pedro, Lurin, which was refused almost without any discussion; the other, of $S / 50,000$ to the firm of Pedro Dinegri é hijos. Don Aurelio Denegri required S/450,00o to pay his drafts on his London firm, accepted by them, protested for non-payment, and shortly expected back. The Banco Nacional had refused assisting him, because this establishment did not think it prudent to put any more of their notes into circulation; Perú, and La Providencia after a close examination of the books of the firm had come to his aid with loans of large amounts. Don Aurelio now wanted S/50,00o more to make up the $\mathrm{S} / 45^{0,000}$ as security for which he offered the mortgage of a valuable house owned by the Dinegri's in Callao. Aliaga gave it as his opinion that the lawyer of the bank should examine the security offered, which being done the Directory would decide on the subject. We all agreed with him; only Julio Armero was decidedly opposed to lend money on immovable property. It was also discussed how much the bank should contribute for the Iquique sufferers. I proposed S/50o but the majority voted S/1000.

Thursday, $14^{\text {th }}$ of October. This morning I took a walk to that part of the open country behind the penitentiary and the exhibition where the ground was very uneven, and so much covered with rubbish and sweepings from the town that I could hardly make my way through them. When I came home, just before ten, I was received with the news that the Curate of the Sagrario, Dr. José Santos Chavez had been assassinated in his bedroom. This man, a foundling of Arequipa, had gradually made his way in the world owing to his good conduct. For many years he was the secretary and most confidential servant of the Archbishop Goyeneche, to whom he owed his valuable curacy. He [...] two rooms on the ground-flo [...] [805] Goyeneche's large house in the corner of Zarate and Trapitos. This morning he had been found dead in his bedroom, having, according to all appearances, been suffocated, wool having been forced into his mouth, into his nose, and even into his ears. The object of the perpetrators, in all probability the porter, a Spaniard, 
and some of his countrymen who had all disappeared from Lima, had been to rob some valuables which belonged to the Goyeneches, and which Chavez was known to have had in his possession. At 4 p.m. the Directors of the Banco Hipotecario, except Mendoza, and with the lawyer Forero met. Oyague opined that the bank should not contribute anything for the Iquique sufferers, and though I agreed with him it was resolved to send S/200. Jose Canevaro's proposal as to the manner in which he wished to cancel his debt to the bank arising from the frequently mentioned convenio, was accepted with some modification. Aliaga voted against it.

In the evening nobody came to Enriqueta's tertulia, for fears were entertained that there might be some disturbances owing to the ill-feeling between the Pradistas and Monteristas. Moreover, owing to the death of the curate Chavez, Enriqueta's good friend, who had christened the greater part of her children, she at least would not have received her friends had they come.

In the course of the day died José Maria Varela, one of the richest men of Lima. His fortune, which he had made by great economy, bordering on parsimony, consisted for the greater part in houses.

Friday, $15^{\text {th }}$ of October 1875. A meeting, very-poorly attended, of the shareholders of the Banco Hipotecario, took place. The sole object was to choose two Directors, for which post the two suplentes Aliaga and Jimenez were recommended by Oyague, and chosen by a great majority, not unanimously. We were then about to proceed to the election of two suplentes, when a difficulty arose. The statutes say that in an extraordinary meeting of shareholders, no other subject can be treated on but that for which the meeting is convened. The advertizement in the papers had said: "para ele[_] Directores", and nothing about [...] the suplentes wh[_] [806] could therefore not be done. A few minutes before 10 p.m. Garland Ricardo, and I went to Goyeneche's house where Chavez had been assassinated, and, together with a pretty numerous cortege, accompanied the corpse to the Church of El Sagrario, between the archiepiscopal palace and the cathedral. The high Altar was brilliantly lighted up. To everyone who entered, a lighted taper was handed, which he held whilst prayers were sung, and thus, we were kept there fully half an hour.

Saturday, $16^{\text {th }}$ of October. Early this morning I was present in the Sagrario at the funeral service of Chavez; the small church was crowded. At nine the service was over, when the hearse, followed by many carriages, drove out to the pantheon. I, with three other persons, one of whom, Ricardo Garland, occupied one coach. When we arrived, the coffin was carried to the niches destined to receive it; also here more prayers were said than on similar occasions, and it was near half past ten before I again reached my house. The accomplices in 
the murder were: a cousin of the porter, and the Mayordomo of Goyeneche's estate of Villa, both Spaniards, the latter had taken some horses with him. After breakfast I went to the church of La Merced to attend the funeral of Varela. In the Plaza Mayor a platform was being constructed for the elections, which were to begin on the morrow. At about 1 O'clock Rafael Velarde and family came to our house, where he wished to remain a day or two, for in his own residence, he, a decided Pradista, feared for his personal safety. We assigned to them the rooms occupied by my son Juan when in Lima. This day passed over quietly; the shops were however closed at an early hour; our street door was shut a little before the usual time, and at about eleven we all retired to rest.

Sunday, $17^{\text {th }}$ of October. This was the much dreaded day of the elections, and to me individually it was beyond measure tedious. Bryson did not venture out, Ricardo only read to me an hour, and thus the time passed very heavily. By Rafael's Advice we only opened the small not the large street door [...] [807] Achipe our cook, nor the baker came. The latter had brought the usual supply of bread on the previous day, Achipe the provisions, which the female servants now cooked for the family. The milk women were the only ones who made an exception to the general rule; they never feared, and at about half past nine ours was at the street door, and her shrill voice made known her arrival. Rafael, as well as Enriqueta had slept little during the night, having been kept awake by continual firing. In the Plaza de Santa Ana the two parties of Prado and Montero had been firing the whole night through; the former had had possession of the buildings, formerly the hospital of San Andres, whilst on the opposite end those of Montero, amongst whom was the notorious La Valiente at the head of a gang, had possessed themselves of the steeple of Las Descalzas. Not before ten or eleven in the morning the Pradistas gained the upper hand, made themselves masters of the mesa - a small platform destined for the elections - and the Monteristas retired. One of the chiefs of the latter, a certain Arciniega, had fallen into the hands of a Pradista, called Prado, who however had the generosity to allow him to escape. In the other parishes El Sagrario, the mesa in the Plaza de Armas, San Lazaro, the mesa in the open place before the church of this name, San Sebastian, the mesa before the Church, and of San Marcelo, mesa in the plazuela de la Salud, the resistance of the Monteristas had been either trifling or none at all. It was calculated that 24 or 25 lives had been lost, of which 17 fell in Santa Ana; and perhaps a hundred wounded, amongst these latter - very severely - a certain Raygada, nicknamed El Negro, a natural son of the late General and Minister. Neither Montero, not his great friend Simon Soyer were seen anywhere. Prado, with some of his adherents, on the other hand, showed himself in the streets; also the President Pardo was 
out in the course of last night, and the general opinion was that it was due to the effectual measures taken by the Minister of the Interior, Aurelio Garcia y Garcia, by the Prefect Francisco Andraca, and by the police in general that no greater disorders had occurred. As soon as the mesa was secured, what is called La Mesa Momentanea - that is to say, the [_]bers who had formed the board at the time of the last [...] [808] four years ago - met on the platform; then the victorious party gave in their votes for the members of la mesa permanente, which being done, the affair closed for the day; the platforms were abandoned and everybody went home, for now the members of la mesa permanente being named, the government would decidedly interfere if anybody else but they were to take their seats round the table placed upon the platform. Of course all were decided Pradistas: Joaquin Osma was President of la mesa permanente del Sagrario; one of the escrutadores Rafael Velarde: President of Santa Ana, Ramon Ribeyro, one of the escrutadores José de la Riva Agüero: of San Sebastian, Manuel Francisco Benavides: of San Marcelo, Ulises Delboy: of San Lazaro José Mateo Espiel.

The family breakfasted in Enriqueta's dining-room where however there was no room for all the children, five of Rafael, and Enriqueta's two. Ricardo read to me, and at one O'clock I went out, and until three, walked over the town in every direction. All was quiet; many streets without a human being but myself. In the plazuela of San Pedro I found a small piquet of policemen, and near San Sebastian a group of members of a political club, from whom I kept at a respectable distance. In the street leading from our house to the plaza of Santa Ana, many loose stones were lying about, and the flagstones of the foot pavement broken up, which had served to form a strong parapet at the corner. Nearly all the street doors, all the shops and stores were closed; here and there the small street door left open. Only the house of Pablo Vivero, where General Prado resided, was not shut up. Rafael Velarde went to see his compadre, who, he said, was on the point of lying down to rest after the fatigues of the day. We again dined with the Garlands. Rafael, who was not the most valient of men, and who, I thought, ought to have returned to Prado in the evening, went to bed under pretence of indisposition. Garland amused himself playing rocambor; my wife and I retired to rest at a ver [...] [809] hour.

Monday, $18^{\text {th }}$ of October 1875. Anniversary of battle of Leipzic, fought in 1813. Contrary to my expectation, stores and shops continued closed; also the banks. No business was done; the elections commenced. Bryson came as usual. Ricardo read my diary in German, which I translated, and dictated to Bryson.

The Mail from England brought the news of the death of Irene Vasquez, wife of Juan Bazo, at the age of $5^{2}$ or thereabouts. A fleshy-excrescency had 
threatened to cover one of her eyes; she consulted the best surgeons, both in France and England, who assured her that it could easily be cut out. She preferred submitting to the operation in London where she counted upon the assistance of her husband's sister Pepa, but when the surgeon began operating he discovered that the excrescency had grown upon an artery; then to stop the effusion of blood, he had to cauterize, which caused the poor woman excruciating pain. Chloroform was then administered probably in too large a dose, the consequence of which was lock-jaw and death; perhaps, the medical men said, it had been owing to the extreme irritability of her nervous system. She had always been intimate with our whole family, and been a particular friend of Rosa.

Juan, who was again suffering from his old complaints, dyspepsia and piles, also informed me of the death of Miguel Montani, in former years Peruvian Guano Consignee in Paris, who had reached the age of 77 .

A certain Captain Webb had performed the extraordinary feat of swimming across the channel: he had been 22 hours in the water, boats always in attendance, and coffee, cognac, and other stimulants occasionally administered to him. A young girl, 14 years of age, Miss Beckwith, had swam the distance from London Bridge to Greenwich in 1 hour 7 minutes, 45 seconds; she was cheered all the way, and on her arrival received by a band of music playing, "See the conquering hero comes". I have hitherto omitted to mention that my friend Sieveking of Altona informed me in his letter of $3^{\text {rd }}$ September of the dangerous illness of Charles, son of Hermann Willink, my mother's first cousin. For many years he was a partner, and since Mr. Schon's death, head of the firm of J. [...] \& Co. of Hamburg. [810]

Tuesday, $19^{\text {th }}$ of October 1875 . Shops were open, and everything in its normal state. At 3 O'clock the Directors of the Banco de Lima had a meeting, and at Lembcke's suggestion it was resolved without much discussion to send S/30,00o in paper to the Salitrera Esperanza, and to order Prevost \& Co. to effect the sale in Valparaiso of 20,000 quintals of Nitrate, which were ready for embarkation.

Friday, $22^{\text {nd }}$ of October. For the first time I was present in a meeting of the Directors of the Gas Company; besides myself: Oyague, President, Garland, Mathison, Carrol, Directors, and Frederic Marriott, Gerente. Nothing of great importance was discussed. After the last acta had been read, Marriott laid before us the various questions upon which he wanted our opinion. Amongst other things he told us that Bates Stokes \& Co. of Liverpool had reduced the credit open to the company from $£ 15,000$ to $£ 9000$. Further, that he had remitted to them $£ 400090 \mathrm{~d} /$ st., which he had obtained from the Anglo Peruano at $36 \mathrm{~d}$; 
also that the two English engineers in the employ of the company could not agree, the one finding fault with what the other was doing. Carrol, of the firm of Bates Stokes \& Co., seemed to me the most intelligent of all present.

Saturday, $23^{\text {rd }}$ of October. The Directory of the Banco Hipotecario met. Gallagher as usual was the mouth piece. Oyague had paid the half which corresponded to him in virtue of the arrangement made between him and Canevaro on the one, and the bank on the other hand; otherwise hardly any progress had been made in reducing Soyer's debt. Canevaro had not paid his half. Riva-Agüero had not given security for his pagaré of S/10,0oo; for the remaining $\mathrm{S} / 20,000$ no conclusive arrangement had hitherto been made, nor had Forero drawn out the arbitration document to be signed by said Riva Agüero and the bank. The elections, which had lasted the whole week, served as an excuse for this complete stagnation.

Sunday, $24^{\text {th }}$ of October. San Rafael. My wife and Enriqueta went to Rafael Velarde's in the forenoon, I in, the even[_] to congratulate him. [811]

Monday, $25^{\text {th }}$ of October 1875 . The elections closed in Lima. The general opinion was that Riva Agüero and Pardo had outwitted Prado and Buenaventura Helguera. The Vice Presidency was considered secure for Riva-Agüero, and not a few thought that he might even be chosen President, in which case he would be nothing but an instrument in the hands of Manuel Pardo, the real ruler.

Tuesday, $26^{\text {th }}$. The temperature had much changed; it had become considerably warmer; thermometer at $3.30 \mathrm{p} . \mathrm{m}$. in my office $71^{\circ} \mathrm{F}$.

Thursday, $28^{\text {th }}$. By last steamer arrived from Europe General Rufino Echenique with his two sons, Juan Martin and Rufino, the latter of whom, it will be remembered, went to Europe several months back in the expectation to secure for the Banco Nacional de Perú the one or the other of the guano consignments, in which however he had not succeeded. In the Eclectic Magazine I found an article taken from the Quarterly Review which gives very interesting details about Balloons, Aeronauts, and Carrier-pigeons, an extract of which will be found in appendix under $\mathrm{N}^{\circ} 22$.

Somewhat past two O'clock the Directors of the Banco Hipotecario had a meeting; Aliaga did not attend. Mendoza was present, so was Dr. Forero, who read his draft of the arbitration document to be signed by the gerentes and José de la Riva Agüero, which, with some modifications was approved of. To the arbitrators would be submitted, firstly, whether Riva-Agüero had a right to take for himself S/300o in July, on account of profits which could only be ascertained and liquidated at the end of the year; and secondly, whether he and Escudero were entitled to about S/22,00o which they had appropriated to themselves on account of the profits of last year, whilst the shareholders had 
not received a cent. In the second place, a letter directed by Col. Torrico to the Directors was produced, in which he asked for a copy of the report drawn out by a commission named for the purpose, on the state of the bank, about the time that Riva Agüero gave up his situation, and of which informe I have given an account in its place. I insisted that Torrico, being a shareholder, had a right to receive the copy, on the express condition that he should not [...] it [_] I knew as everybody [_] did that Torrico intended [812] publishing it, thereby to injure Riva Aguero's character, and to render more difficult his election as President or Vice President of the Republic. The three other Directors, and the lawyer, were however against me, and it was resolved to refuse the copy to Torrico on the plea that the publication of the informe would do great harm to the good name of the bank.

Friday, $29^{\text {th }}$. The earthquake which in the preceding Century destroyed Lima and Callao occurred on the $28^{\text {th }}$ October 1746 at 10.30 p.m. According to the Nacional of $26^{\text {th }}$ inst., the register kept for inscribing the names of the citizens residing in Lima itself, and its environs, showed that their number was 17,080 whilst only 4912 had presented themselves to receive their "Cartas de ciudadania", or documents proving their citizenship, and of these 4912, only about 3000 had voted for the electors.

Saturday, $30^{\text {th }}$ of October. A telegraphic dispatch was received and published in the papers, stating that a contract for the sale or consignment of guano had been signed by the Peruvian Commissioners; when, with whom, and on what conditions, was not said.

This day General Prado left for Chile, whither as he said, his own private affairs called him.

In the evening Dr. Ricardo Zevallos, who resided with his wife and children in the house of his father-in-law Dr. Melchor Vidaurre, President of the Supreme Court of Justice, gave a fancy ball to between eighty and ninety little girls and boys, from four to nine or ten years of age. Maria and Corina were also invited, and, accompanied by the black woman Aurelia, drove there at past seven, and came home somewhat past eleven highly pleased. All agreed that Corina had been one of the prettiest, if not the prettiest of all. Bryson read to me an essay of Macaulay on Gladstone's work "The State in its relations with the Church", in which essay the author referred to several hetorodox sects amongst the Catholics. We were not acquainted with the [_] aming of their names, referred to [...] [813] Encyclopædia, and the result of our researches was the following: The Arians believed Christ to be the most perfect creature created by God Almighty, but that he was inferior to God the Father; the Sabellians believed that the Trinity meant Father Almighty, possessing three attributes, 
and that the Holy Ghost, similar to a ray from the sun, passed from the Father through the Son; the Monothelites - also called Maronites - who wear a green turban, and who still at the present day inhabit Mount Lebanon, believe that Christ had but one will, not two, a divine and human as the Orthodox Church says; the Monophysites maintained that Christ had but one nature, not two; and finally, the Nestorians, whose remnants still exist somewhere in Asia, refuse to call Mary the Mother of God, though they acknowledge that She is the mother of Christ.

Sunday, $37^{\text {st }}$ of October 1875 . I paid many visits, amongst others one to Mrs. Henry, who told me that her husband was somewhat better though certainly not well. On the $8^{\text {th }}$ or $9^{\text {th }}$ November he and she, with their children James and Lily and a servant girl, intended to leave for Valparaiso thence to proceed to the baths of Cauquenes, where the mountain air would, it was expected, give some tone to his shattered system. Serious thinking was decidedly prohibited him.

Monday, ${ }^{\text {st }}$ of November 1875. At 8 I left our house, passed the new bridge of Balta, and climbed up San Cristoval. It was a pleasant morning, the sky overcast, the ground not at all slippery, neither too dry nor too wet, merely a little moist, so as to give a firm footing; nevertheless I got tired before I reached the summit. It was nearly 10.30 when I came home. In the forenoon I felt very sleepy, which prevented me from making so many calls as usual. I merely went to José Maria Costas, lately come from Valparaiso, who was not in. Next, to Joseph Macandrew who had just arrived from England, together with his newly married wife; he was the head of the firm of Graham Rowe \& Co., many years back Maclean Rowe \& Co. She was the daughter of the late Henry Read, once active partner of Tailleurs \& Co. of Lima, and of his second wife Manuela Cossio. Mrs. Macandrew was an agreeable young lady, and I remained with her nearly an hour conversing in English, though, as she told me, she was also perfectly acquainted [...] the Spanish language. Before I left Polis, the Belgian of [814] F. S. Isaac \& Co.'s house came in. I here learned that not long ago J. I. Rowe had died. He had come out to Lima about the year 1835, when he took charge of the establishment of Graham Rowe \& Co. His younger brother Charles, who arrived a few years after him, entered the house as clerk, became partner, and married Emilia Pfeiffer, was still alive, though paralytic for many years. He and his family resided in or near Liverpool.

By telegraph, advice was received of the death of Benito Dorca of Paris, partner of Dorca Ayulo \& Co.

A discovery, said to have been made in Santiago de Chile, about this time became known in Lima, which I thought might in course of time lead to great 
results. Two small tubes, a few inches long, of wood, reed, or any other material, are taken; they are left open on the one extremity; on the other end they are closed, and through this closed end a small hole is bored. A piece of common thread is passed through the hole, of both tubes with a knot at each end so that it cannot slip through. Then one of the small tubes is taken hold of by a person who speaks in a low voice into it on the open side; the open side of the other tube another person applies to his ear and distinctly hears what is said, at a distance of I cannot say how many yards. Thus it is very clear that any thread or cord is a conductor of sound.

Tuesday, $2^{\text {nd }}$ of November 1875 . At the Basagoytia's I enquired about the health of Doña Juana Rosa, wife of the son José, who had met with an accident. An acquaintance of theirs, Federico Palacios, in former years Intendente of Lima, drove her out on Sunday last in his open carriage to see the troops come in from a review held in Amancaes. In the carriage sat with her her young daughter Filomena, another lady, and another young girl. In the street of Copacabana the carriage stopped to let the troops pass by, when a hackney coach with a negro driver came on at a furious rate, ran the axle tree into one of the wheels of Palacios' coach, dragged it along, and upset it. Doña Juana Rosa, rather sto[_] fell on the stones and broke her left arm in two places [...]. [815] attended her, and was in hopes that he would be able to set the arm right again.

At 3.30 the Directory of the Banco de Lima had their usual monthly meeting. It was resolved to send another $\mathrm{S} / 35,000$ in paper to the Esperanza, and this was done because the production of nitrate in that salitrera was, according to all accounts, sufficient to pay the expenses, and might also leave a small surplus. Some months back in Lembcke's absence it had been resolved not to admit Cardenas' resignation of his Directorship. The secretary Bernales had been ordered to write a letter to that effect, which letter, I now heard for the first time, had not been sent, and it being clear to all of us that Lembcke and Cardenas could never agree with each other, the latter's resignation was reconsidered and accepted.

Wednesday, $3^{\text {rd }}$ of November 1875 . The "Nacional" made known that my good friend Bartolomé Araoz had departed this life in Paris, at the age of 85, whilst other advices said that he had died in Viariz, whether he had gone with his wife, his son Juan José and his daughter-in-law Carolina Sotomayor. In my opinion he could at the utmost have been 74 or 75 years old.

Friday, $5^{\text {th }}$ of November. The Directory had a meeting in the Banco Hipotecario, all present except Mendoza. A great many things were discussed of more or less importance. The question whether the shareholders had a right to inspect the actas of the Directory and the actas of the general meetings, 
and to take copies of them occupied us for a long time. As to the actas of the Directory we were all inclined to decide in the negative, but at last resolved to submit the case to the lawyer of the bank. As to the actas of the general meetings I gave it as my decided opinion that the shareholders had a right to inspect and to copy them. The other three took a middle course not to my liking. They decided that if a shareholder came to the bank for the purpose the gerentes should first ask permission from the Directory. Riva Agüero objected to the arbitration document drawn out by Forero. The twenty-two thousand Soles taken out by him and Escudero on account of profits of last year, he would not submit to [...] tion; and as regards the $S / 3000$ taken by him in July last [816] and S/10,0oo more which he considered due to him for profits of last year, and by means of which he intended to cancel S/10,00o part of the S/30,0oo which he owed for the counter-document given to Derteano, so often spoken of, he would submit not to "Arbitros Juris", from whom appeal lay open to the higher tribunals but to "Arbitros Arbitradores y amigables componedores", from whom there was no appeal. We acceded to his wishes. Canevaro had paid the whole amount for which he had made himself responsible to the bank as per agreement so often referred to. Now began the difficulties of the gerentes with regard to some immovable property which belonged to Soyer, and had been ceded by him: firstly, a rancho in Chorrillos, half finished, for which he had paid to Baltazar Aranivar S/500o on condition that if Aranivar could return the sum within a certain period the rancho had to be returned to him; moreover, this rancho was mortgaged for several thousand Soles to a carpenter who had done all the work, and not been paid. Secondly, a house in Miraflores, mortgaged for several thousand Soles, and thirdly, a very valuable huerta called de Jimenez situated behind the Church del Prado. The rights which he pretended to have to this latter were of so dubious a nature that I for my part was unable to decide whether they were founded on justice or not.

Telegraphic dispatches were received from Europe, confirming the previous ones as regards the guano contract; consequently the Internal Debt had again risen a little, to $671 / 2 \%$. Cedulas Hipotecarias were up to 74 or $75 \%$. Coined Silver $19 \%$ premium.

Saturday, $6^{\text {th }}$ of November. Meeting of the Directory of the Banco de Lima. Cucalon, who had not been present at the last meeting when we accepted Cardenas' resignation, was much annoyed at our having done so, called it "una destitucion", despoilment, not a reconsideration, and requested that this his opinion were inserted in this days acta. We refused lending Aurelio Dinegri the S/50,00o upon a house in Callao; I had been [...] [817] to the loan from the very beginning; now it was resolved that it could not be made because 
the statutes say "the bank can only lend upon the security of two signatures, or upon "prenda pretoria", and Dr. Luis Cisneros said that in law a house was no prenda pretoria. Only Aliaga opined that we might lend not fifty, but thirty-five thousand Soles upon the said house, because according to statutes the Banco de Lima did the same business as other banks, and the banks La Providencia, and del Perú had lent Dinegri upon houses. To this observation some one replied, "if other banks have not kept within the limits prescribed by their statutes, there is no reason why we should follow their example." It was further resolved, at Cucalon's request, and rather against Lembcke's opinion, that the judicial proceedings against Geronimo Sanchez suspended for some time, should again be taken up; of late he had been paying $S / 4000$ monthly by which payment he had nearly cancelled the interest with which he was in arrears, but nothing on account of the principal of about S/260,00o for which we held mortgage upon several estates, as well as the "mancomunidad" con José Basagoytia. Besides this large debt he owed S/80,00o pagarées signed by him and taken by the bank when the bank settled its accounts with Juan de Ugarte's estate. According to "El Nacional", a company, in which La Société Générale was likely to take an interest, was on the point of being formed in Paris with a capital of five million pounds Sterling with the object of contracting with the Peruvian Government for the guano consignment. Shares were to be offered to the public. Lembcke told me that the Banco del Perú, and the Canevaros were intriguing with Pardo in order to secure this business for Peruvians, and that for this reason he the President had not yet affixed his signature to the contract made by his commissioners in Europe. I could not understand upon what capital the Peruvians counted.

Monday, $8^{\text {th }}$ of November 1875 . In the evening letters received by North steamer were brought in. I had none, but Garland and Enriqueta had letters from Mrs. Cotes and from Rosa, who gave a deplorable account of the state of her husband's health. She wrote [_] Schutte had lost the use of his legs and that his mouth was [818] somewhat awry, owing no doubt to the paralytic stroke from which he had suffered some time back. Rosa went so far as to express her apprehensions that her husband would soon be taken from her. Mrs. Cotes wrote Garland in the strictest confidence that Marcelino Hurtado had told her brother Emilio, that if he did not obtain a loan of five hundred thousand francs, his firm in New-York to whom the United States Guano Company consigned their guano would be obliged to suspend payment.

Tuesday, $9^{\text {th }}$ of November. I went to the office of Vicente Hurtado, Gerente of the said United States Guano Company, who told me that he was completely ignorant of the straightened circumstances of the house of Hobson \& 
Hurtado of New York, confessed to me however that if Marcelino Hurtado did not succeed in getting some money upon the Peruvian Bonds amounting to three million six hundred thousand North American dollars issued by Pardo and guaranteed by the guano in the hands of the said company, he was sure that they could not meet their engagements, which here in Lima were very considerable. Dividends upon the shares, of which I held $\mathrm{S} / 8000$, were not to be expected for some time. Six hundred Soles, interest for three months at $11 / 4 \%$ upon $S / 16$,ooo owing to me were, however, duly paid on the $8^{\text {th }}$.

Wednesday, $10^{\text {th }}$ of November. We had a meeting of the Directory of the Insurance Company "Lima", at which were present: Elizalde, President, Carrol, of Bates Stokes house, Jose Maria Peña, Valentin Gil, I, and the Gerente. Some routine business was gone through with, and Moscoso Melgar was chosen provisional Vice-President during the absence of James Henry of Gibbs' house, who on the previous day had left with his family for the baths of Cauquenes in Chile.

At the usual hour of 3.30 the Directory of the Banco de Lima was assembled. Lembcke made known that Aurelio Dinegri had offered shares of the Banco del Perú as guarantee for the $\mathrm{S} / 50,000$ which he wanted. It was resolved not to lend him the money; firstly, because it did not answer the bank's purpose to lend such a large sum to [_] person [...] [819] secondly, because we were of opinion that the shares in the Banco del Peru were not sufficient security. After the meeting had broken up we conversed for a few minutes on the topics of the day, as it was our custom. Luis Cisneros said he knew for a certainty that M. Champeaux, who represented La Société Générale in the Muelle Darsena, had received a telegraphic dispatch from this society, which said that the Peruvian Government might draw upon La Société as soon as the contract made in Paris were ratified by Pardo, but I knew that this Pardo had not yet done. Now the rumour was that the Anglo Peruano was making proposals for the guano consignment or purchase, and that this was the cause of Pardo's irresolution. Luis Cisneros also called the attention of all present to an acta signed on the $29^{\text {th }}$ October by the principal merchants of Tacna, and agreed to by the Prefect Zapata, to the effect that henceforth the said merchants bound themselves not to pay or to receive any notes of the Lima banks, and the Prefect had promised to do the same in the offices of the Government, Municipality, and Beneficencia. Cisneros finally observed that he feared there existed a great tendency in the Departments of Perú, extending from Moquegua to the frontiers of Chile, to separate from the North, because within their territory exclusively were situated the riches of the Republic, the Guano and Nitrate of Soda deposits. 
Thursday, $11^{\text {th }}$ of November 1875 . The Directors of the Pasco Railway Company having convened a meeting of the shareholders; at a little past the appointed hour I went to the office of the South American Company where we were to meet, and to my great surprise found none of the Directors, and only three of the shareholders, Colonel Torrico, José Jimenez, and Augusto Althaus, who were of course much displeased at this want of common civility on the part of the Directors. I went in search of Felipe Varela, but only found the amanuensis Enrique Carrera, who returned with me. Varela, he said, was too busy to come. Pedro Gallagher had been called to Callao on urgent business, Agustin Escudero was not to be found anywhere, Dr. Galvez, Rodrigo's son-in-law, never came, and Francisco Bohorquez was [...] ed with the Directorship, and would have nothing more to $\mathrm{d}[\ldots][820]$ with the Pasco Railway.

Friday, $12^{\text {th }}$ of November. In the evening we had an agreeable visit from Mr. Corso, brother of Dr. Corso, Vocal of the Superior Court, with his wife and daughter. Two young naval officers of the North-American War Steamer "Richmond" also came in. Their object, however, was not to see my wife and myself, but to present themselves after their return from a cruise, to Garland and Enriqueta with whom they had been acquainted before their departure, and before the sudden death of Admiral Collins, spoken of a few months back.

Saturday, $13^{\text {th }}$ of November. Meeting of the Directory of the Banco Hipotecario. Oyague gave himself wonderful airs; he spoke as if he were the only one who could direct and save the bank from impending ruin. Money came in very slowly. The arbitration document with Riva-Agüero was not yet signed. Another S/300o which Toribio Calmet said he had paid, and for which he produced a receipt from Soyer had again not been entered in the cash, and we resolved not to admit the validity of this receipt, because it was without the signature of the Gerente Escudero, with which it ought to have been provided.

Sunday, $14^{\text {th }}$ of November. It was $7 \cdot 30$ before I left my house to climb up San Cristoval. I did so from the Lurigancho side, but really had some difficulty in reaching the summit. It seemed to me as if my strength was waning. Owing to the bad make of the boot of my right foot I felt great pain in the big toe, and thus when I came home at about ten I immediately went to bed to sleep a little, but could not. I breakfasted in bed, dressed, went out to get shaved, and on my return, as Bryson had not come, lay down on my sofa till near two, when it was time for me to start. I found General La fuente conversing with my wife, and I remained some time with them. He looked very old, notwithstanding his wig and blackened moustache; his head shook a little, and he could not recollect names, a clear sign of a failing memory. I lea[_] [821] from him that the London Bank of Mexico and South America had instituted judicial proceedings against all the shareholders in the Salitrera Esperanza, who several years back borrowed 
from the bank, all de mancomun et insolidum S/300,000. I knew the names of the greater part: Zaracondegui, Lembcke, Valentin Gil, Narciso Velarde, José Basagoytia, Muro, and General La fuente. They very naturally tried to shirk the payment, but I had no idea how they would manage it.

Yesterday having been the day of San Diego, I went to Masias house to congratulate the Colonel, but only found his sister-in-law Transito. Thence to Rafael Velarde, to do the same to his wife Josefa on her birthday. With Doña Manuela Portillo and her grand-daughter Amalia Alaiza, married to Manuel Ferreyros, I remained a long time, both were very agreeable ladies. I was also well pleased at Dr. Jervacio Alvarez, where his wife Doña Mariquita, a very simple old lady, and his grand-daughter Aurora Santillana, this day particularly talkative, received me. In the evening we had the visit of another nice lady, Manuela Iriarte, married to Demetrio Olavegoya. Enriqueta had to go out to Don Rafael's and Anibal de la Torre's, which latter received every Sunday evening.

Monday, $15^{\text {th }}$ of November 1875 . In the Banco de Lima I had a short conversation with Francisco Sagastabeytia and Evaristo Gomez Sanchez. The former said he knew that La Société Générale not satisfied with the security of the guano depôts, had asked for as further guarantee the Salitreras in the Province of Tarapacá, and the latter affirmed as certain that the contract concluded by the commissioners in Paris had been disapproved, and consequently not ratified by Pardo.

At 8 p.m. I went to the Banco Nacional where the Directories of the four banks, "Nacional", "Perú", "Lima", and "Providencia" had been invited to meet. I think forty or fifty gentlemen were present. Dr. Garcia Calderon presided, in the absence of Derteano, who had gone to his large sugar plantation in the vicinity of Santa. The last acta was read and approved, which being done Garcia Calderon said $[\ldots]$ the object of the present meeting was to lay before the Director[_] [822] for their approval the agreement which the commissioners named for the purpose by the four banks had concluded with the Government relative to the consignment of guano to Mauritius and other islands. Now the question arose how the approval should be given, whether individually, that is to say, each person present to give his vote, or whether each bank was to have one vote. This latter was certainly the fairer way, but then Calderon proposed that if three banks agreed the fourth should necessarily accede to what the three had determined. This I thought quite right and so did many who were present; nevertheless, Cardenas of La Providencia, who, as usual, wasted much time, with his speeches, was opposed to it, founding himself upon the Statutes of his bank. Also Calderoni of the Banco del Perú was in the opposition, because 
of this bank only four Directors had come, and four Directors were insufficient, according to their statutes, to decide on any question. Unánue, of the same bank, said a few words, not at all to the purpose whilst from the Banco de Lima, Lembcke, Bernales and Aliaga expressed themselves very properly. Finally, it was resolved that a copy of the agreement with the Government should be sent to each of four banks, there to be discussed by each Directory, and the resolution of each to be communicated to another general meeting, which was at once convoked for next Wednesday night. I was home by 10 O'clock.

Tuesday, $16^{\text {th }}$ of November. Meeting of the Directory of the Banco de Lima. Lembcke informed us that La Salitrera-Esperanza had received from Prevost \& Co. of Lima S/68,ooo in bills on Chile on account of nitrate sold, that the Banco de Lima had bought them at $14 \%$ premium, and remitted them to a house in Valparaiso, which had to buy with them bills on London to be remitted to F. Huth \& Co. and the International Bank, both of London, and creditors of the Banco de Lima. This was satisfactory. The very reverse was a letter received from an Interventor sent to a sugar estate, the property of a certain Guimet, largly indebted [...] [823] the bank, and far in arrears with his payments. According to this letter the estate itself was valuable, but everything upon the same, machinery, boilers, carts, Chinamen etc., were all insufficient. Then Lembcke left the room because the affair with Cardenas was to be discussed. Present were: Pedro Bernales, Luis Cisneros, Manuel Cucalon, Francisco Sagastabeytia, Julio Armero, Diego Lopez Aliaga, Amancio Castillo, and I. The letter received from Cardenas was extremely long. He spoke of the great services rendered by him to the bank, of the injustice done to him by accepting his resignation after having in a previous meeting resolved not to admit it, and called this a despoilment - una destitucion - and concluded with saying that the Directors had no right to despoil one of their members of his post. He also asked for a copy of several actas which he pointed out. I said that this was such a weighty matter that it was impossible to decide it on the spot, and that it would be advisable to name a commission who should give their report. Luis Cisneros said that it was no doubt a serious affair, and that we should limit ourselves to two points: the despoilment, and Cardenas' demand for the "actas"; and take no notice of the remainder of the letter. Cucalon opined that we should immediately resolve to readmit Cardenas. I replied that this would be acting too hastily, and that I on my part would on no account agree to such an immediate resolve. Then Cucalon demanded that his motion for the readmittance should be put to the vote. Bernales said that my motion had the preference; Cucalon, that I had only given an opinion, and made no motion; nevertheless, what I had said was looked upon as a motion, put to the vote, and agreed to by all except 
Cucalon, whose motion for the readmittance of Cardenas was not even taken into consideration. To form the commission I named Bernales and Aliaga. Cucalon said that they ought to give the dictamen within two days, and left the room because he had to go to Chorrillos. I then submitted to the two named whether they could give their report by next Friday; they only promised to do it as soon as possible. It was five when we rose, thus too late for Aliaga and me to go to the Banco Hipotecario where Oyague and Jimenez had been waiting for us.

Wednesday, $17^{\text {th }}$ of November 1875 . We were again called together [...] [824] the Banco de Lima; only six were present: the two Gerentes, Aliaga, Barrios, Armero, and I; thus no Directory could be formed, seven being required for that purpose, and we contented ourselves with listening to the reading of the contract, which, subject to the approval of the four banks, the Government had concluded with them through the medium of their commissioners. The principal articles were: that the four banks enjoyed for four years the exclusive consignment of guano to the Islands of Mauritius, La Union, Barbadoes, Jamaica, Martinique, Guadeloupe, etc. Charters might be concluded and shipments made immediately; sales not to begin before the $1^{\text {st }}$ November 1876 , commission for sale and guarantee $21 / 2 \%$, for all expenses including freight, but excluding the loading expenses, £.5.10/ to be charged per English ton of 2240 lbs. Interest upon expenses $5 \%$, upon advances $6 \%$; the contract to last for four years; but if at the expiration of this period the banks are not covered for their outlay of $S / 6,000,000$ viz. 200,000 tons at $S / 30$, the Government had to pay them any difference there might be. We approved of it, but thought that some trifling alterations might be made, which, I agreed with Lembcke, he should propose in the evening at the general meeting. This being Enrique's birthday my wife and I dined with Garland and Enriqueta. All the children were present except Alejandro. Guillermo had been invited with his young wife, also Gregorio Benavides. It was half past six when we sat down, and I left them still round the table when I at eight O'clock went to the general meeting in the Banco Nacional. All four banks were represented. By chance I got my seat between John Meiggs and Scheel, next to Scheel sat Lembcke. Garcia Calderon presided. After some desultory conversation, in which took a part Unanue, very stupidly, Cardenas diffusedly and not to the purpose, Ruden, Scheel, Calderoni, Luis Cisneros, and I, it was decided that each bank should have a vote, and that the resolution of the majority should be binding upon the minority. Ruden represented the Banco del Perú, Scheel, in the absence of Derteano, El Nacional, I, Lima, Albarracin, La Providencia. Lembcke then requested the reading of the agreement, and [825] the course of the lecture noted the few alterations which we had made in the forenoon. Two or three were found correct, and 
made accordingly. Garcia Calderon then again directed himself respectively to the four above mentioned persons, and each gave his approval. It was not yet ten when we broke up. At home I found in Enriqueta's parlour Böhl and Dr. Middendorf, which latter had returned from Europe after an absence of four and a half years. I had called upon him in the forenoon. For the present he lived with Böhl at Gibbs. Contrary to all expectations, in the Colegio Electoral the party of Buenaventura Elguera gained this morning a decided victory over that of Riva Agüero. The Mesa calificadora which was formed this day contained for the greater part friends of the former; Dr. Saavedra was named President. This was the same man who in 1866 arrested Melchor Velarde who at that time during Pezet's administration was sub-prefect of Huancayo. Saavedra then acted for Prado whose partizan he now was. When Rafael Velarde was Minister under Balta he had to order the arrest of this same Saavedra, for what reason I did not know. Now their common friendship for Prado made them work together, and they sat round the same board, for Rafael was escrutador, and Saavedra president.

Thursday, $18^{\text {th }}$ of November 1875 . In the Municipality a violent dispute arose between the Electors; the partizans of Elguera, and of José de la Riva Agüero ranged themselves in direct opposition to each other. The former had the majority; but the latter, a formidable minority. Ignacio Osma, Emilio del Solar, Espiel, and other well known persons at the head, seceded, and withdrew to the club de la Union, corner of plaza and Bodegones where they protested against the proceedings of those who had remained in the Cabildo, and these in the meanwhile voted that the electors chosen in the Parish of San Marcelo at the board where Ulyses Delboy had presided, had been duly elected; these were Elgueristas. In the dispute referred to, insulting words had been used by both parties; they threatened each other with their fists, and some said that a few drew their revolvers. Mr. Corso, who was one of the many in Enriqueta's tertulia, said that Elguera had spent within the last [_] days S/11,0oo to secure the majority. I also went over to En[_] [826] but hardly remained an hour.

Friday, $19^{\text {th }}$ of November 1875. A meeting of the shareholders of the Pasco Railway had been called together for the second time. The Statutes said that at a second meeting any number of shareholders, even one or two, formed a quorum, and what they resolved was binding upon all. We met in the locality of the Eten Railway Company, present were the five Directors: Dr. Felipe Varela, Francisco Bohorquez, Agustin Escudero, the lawyer Galvez, and Peter Gallagher; Shareholders Col. Torrico, Augusto Althaus, and I. I took hardly any part in the discussions, and listened merely to the mutual recriminations, to the high words which passed between them, three or four spoke at the same time, but finally all settled down in pretty fair harmony, and they resolved that 
every document, every book, everything, should be placed at the disposal of Col. Torrico, that he might examine and investigate all to his heart's content. I merely told him that nobody could give him better data than Riva Agüero, and these words did not seem to be much to his liking; he rose, and said that he never looked to individuals, but to their doings.

Saturday, $20^{\text {th }}$ of November. When I went to my lawyer's office he told me that the court had asked for all the autos in my suit against Leyva which he had in his study, for the purpose of comparing and verifying "la relacion del relator", but as Palacios knew that two of the judges upon whom I believed I could rely, viz.: Corso and Mendoza, were indisposed, and did not go to the tribunal he had put in an escrito, which he expected would cause a delay of a week. I learned in the course of the day that Mendoza was getting better, and would shortly return to the Tribunal. Corso had received licence to absent himself for a month. At somewhat past three we met in the Banco Hipotecario, the two Gerentes, Oyague, Aliaga, I, and the lawyer Forero. More and more receipts signed by Soyer turned up, of which the money received was never entered in the cash, but as these receipts were without the signature of the respective gerentes, Riva-Aguero, Garcia Cald[_] and Escudero we resolved not to recognize them as valid. [827] Agustin Escudero came in to reply verbally to a letter directed to him by the gerentes, in which they had requested him to return the $10 \%$, or $S / 11,000$ which he had improperly received as his share of $5 \%$ upon the gains supposed to have been made, and not made, in 1874. He answered that he had left the bank on the $30^{\text {th }}$ January 1875 , that until that day he had not taken any share of the gains, but that after he had left the money had been sent to his house by Riva Agüero, and that consequently he was not to be blamed if an improper division of supposed gains had been made. Another strange thing came to light. The first time that Gallagher and I examined the contents of the cartera we found a receipt which Simon Soyer had given for 80 cedulas withdrawn from the cartera. Escudero asserted that when he delivered the cartera to Riva Aguero, which he had done without taking a receipt, the cedulas were complete, and no such receipt of Soyer existed. The receipt was produced and found to be dated $14^{\text {th }}$ Novr. 1874, when Escudero was gerente, from which the natural inference was drawn that either Escudero said an untruth, or Soyer, with the connivance of Riva Agüero had ante-dated the receipt.

Bad news came from Europe. As far as it was known at the present moment, nobody would pay the interest on the Peruvian Bonds in Europe, due $31^{\text {st }}$ December, say $21 / 2 \%$ for six months, as little as the half yearly redemption of $2 \%$. I had been under the impression that when Manuel Candamo had 
lately been sent by Pardo to Europe; he had arranged with the Anglo Peruano that they would pay the interest and redemption if nobody else did. Now, when the commissioners had concluded the contract with La Société Générale and others, they informed the Anglo Peruano that they did not require their service; the contract was disapproved, and very naturally now neither the one nor the other would make the payments. In the Comercio appeared an editorial article on this subject, which was in my opinion highly improper. The writer expressed himself more or less in the following manner: "The low quotation of the Peruvian Bonds in the London and Paris money markets is a proof of the little or no credit at present enjoyed by the Peruvian Government. There is no motive for [...] a want of confidence because hitherto we have paid [...] [828] interest and redemption with the greatest exactness; consequently, we are treated with great injustice, and therefore if no confidence is placed in us whilst we have fulfilled our engagements, there is no use for our doing so in the future."

Sunday, $27^{\text {st }}$ of November. It being my wife's birthday, many of her friends sent in presents; others sent cards to congratulate her, others came personally. In the forenoon I for the first time called upon Enriqueta's intimate friend Isabel Coloma, widow of Carlos Canseco, and found her quite as agreeable as my wife has told me she was. I also went to the family of the Buenos Ayrean Minister Dominguez who had removed to the fine altos near San Marcelo, formerly occupied by the widow of Lacharière, and to the widow of Frederic Bergmann, from whom I learned that she had seen the vocal Corso on our behalf, that he was very well inclined towards us and that therefore he wished that we could throw some impediment in the way so that our cause against Leyva were not decided until he returned to the Court. To celebrate my wife's day we had resolved to give a small party. All our apartments were thrown open, and lighted up by gas they looked very well. Dolores Puente with her niece Maria Marriott was the first who came, a little past eight, then José Basagoytia with his young daughter Filomena, his boy Enrique, fifteen years old, two little girls more or less of Maria's age. Gradually came in: Isabel Coloma, with two daughters and a son, Diego Masias with his wife and young daughter, accompanied by a very nice, and pretty North American lady, hitherto known to me as Doña Catalina; young Maria's teacher, Rafael Velarde, wife, and daughter, Melchor Velarde with wife and two daughters, Gregorio Benavides with his wife, and his wife's handsome niece Rosaura, Guillermo and his wife Eliza. The stronger sex was numerously represented by: Mr. Corso, John and Peter Gallagher, Malinowski with his secretary Cudlip, Nicolas Hurtado, Vicente Hurtado, Carlos and Fernando Ferreyros, Enrique and Carlos Cox, Böhl, Dr. Middendorf, four North American 
naval officers, a young Valle, and variou [...] [829] whom I hardly knew, or if I knew I did not recognize. Mr. and Mrs. Macandrew had declined coming, it being a Sunday when it was against their religious principles to be present at a party. Rocambor was played at three tables. Ricardo played the piano nearly the whole time and thus they danced with great spirit till nearly two in the morning. We gave no supper; first tea was handed round by the three Chinese, two of Enriqueta's and our own. Enriqueta herself attended to the making of it; and her two black servant girls Aurelia and Rosalia made themselves very useful. Afterwards ices were served, and just before breaking up, chocolate. In the dining saloon stood upon one table sweetmeats, upon another port, sherry and cognac, of which the consumption was pretty considerable; the port was best liked. The whole went off extremely well, and I was sure that all had been well pleased.

Monday, $22^{\text {nd }}$ of November 1875. Agusto Althaus had called together the shareholders of the Constructora, of which he was liquidator. Hardly any one came and nothing could be done. All in our house were extremely sleepy and went to bed early.

Tuesday, $23^{\text {rd }}$ of November. There was a numerous gathering of the shareholders of La Constructora to whom Althaus made known that he had collected S/12,00o in cash and S/50,000 in Treasury Bonds - these latter from Meiggs - and that he was ready to divide them amongst the shareholders, but that he was pursued by a notary who was ordered to notify to him that for some reason or other which I did not understand, Meiggs had embargoed these S/50,00o in bonds. Hitherto Althaus had been able to avoid the notification; nevertheless, everything being taken into consideration, it was resolved with the advice of the lawyer José Aranivar that the shareholders should at once give Althaus a receipt for the $\mathrm{S} / 12,000$ and the $\mathrm{S} / 5^{0,000}$, that the $\mathrm{S} / 12,000$ cash he should immediately divide between them, and that the bonds should meanwhile be placed in deposit with Aranivar in order to secure Althaus if against all probability Meiggs were to gain the suit and Althaus were ordered to return the bonds to him. In the meeting of the Directory of the Gas Company a few hours later only Oyague, Mathison, Garland, Carrol, I and the gerente were present. The subject treated on did not affect me. Garcia Calderon, in the name of José Sevilla and Juan Mariano Goyeneche, both resident in Paris, had judicially protested against the members of the former directory in which of course I was [_] [830] included, for the loss which might accrue to the company owing to their improper management. They resolved, with the advice of the lawyer Ricardo Zevallos, who had come in, to reply to this protest, and Zevallos having left the room Oyague informed us that he, having been personally 
insulted by Garcia Calderon's protest, had inalterably resolved to renounce the Directorship at the end of the year.

Wednesday, $24^{\text {th }}$ of November. From 11 to 1 I was occupied with Bryson in delivering to Carrera by order of Peter Gallagher, secretary and director of the Pasco Mineral Railway Company, all the documents which I held belonging to the said company.

Thursday, $25^{\text {th }}$ of November. At 3 I went to the Banco de Lima. Hardly had we sat down when Oyague was announced and requested to enter. He begged us to reconsider the loan to Aurelio Dinegri, which we had hitherto declined to make; he said that Dinegri now only required $S / 40,000$ of which he, Oyague, would lend $S / 10,000$ if the bank would lend $S / 30,000$. When he was gone I was the first to speak, and said that I persisted in the refusal, because, we having twice said no, it would be ridiculous now to alter our mind; "we would be like a weathercock moving at every change of wind." Cucalon immediately agreed with me. Luis Cisneros said my reasoning was not correct, because if circumstances had altered, one might well say yes on third consideration though one had said no twice before. However, as nobody could prove that either the affairs of the bank or those of Dinegri had of late changed for the better, I, on taking the votes nominally had the satisfaction that all were of my opinion. Then Cucalon moved that a commission should be named, consisting of two or three of the Directors to examine all the accounts of the bank, and present a report with the least possible delay. Lembcke raised no objection, nor was the motion opposed by anyone. Accordingly it passed unanimously, Gallagher having taken the place of Cucalon who had withdrawn his name on observing that Sagastabeytia had been much offended, and spoken of a "fiscalización", for which he, Sagastabeytia, had given no cause. Another commission [_] named to reform the "reglamento interior", and put it in [831] with the statutes. Enriqueta's tertulia was very numerously attended. I retired and went to bed a little past eleven; my wife did not come till near two in the morning.

Friday, $26^{\text {th }}$ of November 1875 . The heat had actually set in. I wore light clothes. Thermometer at noon, $70^{\circ} \mathrm{F}$.

Within the last few days one of the accomplices in the murder of the Curate Chavez had been arrested in Mollendo, and been brought to Lima. All the articles found in his possession had been deposited in the Banco La Providencia, of which Moscoso Melgar, who with Garcia Calderon held Goyeneche's power of attorney, was one of the gerentes; they were: gold-coins, banknotes, a few Spanish dollars, three Cedulas del Banco Hipotecario, a bill for £8o drawn by an Ica firm on a Liverpool house, a dagger; revolver, old clothes etc. In the 
course of the present year had died in England Lady Franklin, widow of Sir John who in the year 1845 commanded an expedition from England to discover a N. W. passage, and was never again heard of.

Saturday, $27^{\text {th }}$ of November. Meeting of the Directory of the Banco Hipotecario. When walking thither I overtook Oyague, and on our way represented to him the necessity of some efficient measure being taken against Riva Agüero, not that I had the least ill-will against him, but because I wanted to cover my responsibility towards the shareholders. After a long talk he at last came out with the truth, viz.: that owing to his intimate connection with Pardo, protector of Riva Agüero, he, Oyague, could not proceed judicially against Riva Agüero, to which I answered that we were all in the same situation, because nobody liked to be on bad terms with the President. Nevertheless, when the three Directors Oyague, Aliaga, and I formed a quorum, the same question was mooted by Aliaga. It was first resolved that judicial proceedings should be instituted against Escudero for the $S / 10,000$ improperly received by him on account of last year's supposed gains, as well as against Riva Agüero for his S/12,00o of the same, and S/300o taken by him in July of the present year; afterwards this decisive measure was postponed till next meeting when lawyer Forero would be present. We further resolved and authorized the gerentes to suspend the judicial proceedings against Enrique [_]aval, Gallagher's brother-in-law, to whom the bank had [...] [832] S/6oo,ooo and who was much in arrears with his three-monthly payments of $S / 18$,ooo but who had lately solemnly promised to pay henceforth every month $\mathrm{S} / 8000$ in billetes, and deliver in S/7000 noml. in Cedulas to be taken by the bank at their nominal value.

On the $2^{\text {nd }}$ October I spoke of the heavy loss which would accrue to the Bank from the transfer of a certain amount of Cedulas to Paris, and on the $7^{\text {th }}$ of the same month I said that the lawyer Forero had counselled us to cancel the power of attorney given by the bank to Ventura Marcó of París. This was done accordingly, but before the cancelment of the power had reached him, he for want of remittances had been under the necessity of discontinuing his payments for interest as well as for the redeemed cedulas, and accordingly various holders of these Paris Cedulas, amongst others Gibbs, acting for the I knew not whom, had applied to the Gerentes for the said payment. They received the interest at the current rate in billetes, but not the difference arising from the exchange and for the non-receipt of this difference they levied protest. Moscoso Melgar claimed, besides the interest upon the Cedulas, an interest of $8 \%$ p. annum for the time which had elapsed from the day that the interest on the Cedulas should have been paid in Paris and the day it was actually paid in Lima, moreover $1 / 2 \%$ which had been charged by the bank 
at the time the Cedulas were transferred. The Directory resolved to accede to his claims, on condition that he did not demand the difference in exchange. Hardly had this been dispatched when the hacendado Domingo Laos entered, and complained bitterly of the conduct of the gerentes, who, he said, had refused to credit him in account for somewhat more than $S / 2000$ which he had paid, and for which he presented a receipt signed by Soyer. It was in vain that the gerentes and Oyague represented to him that we could not admit the validity of the receipt because it was not signed by the gerente of the establishment. He was not satisfied and left grumbling, saying that he would speak to Riva-Agüero on the subject. Finally we were informed by the gerentes that they had necessarily to proceed judicially against Rufin[_] [833] Echenique who had not paid his acceptance for $\mathrm{S} / 30,000$ long overdue which before his voyage to Europe he had given to the bank for his elder brother Pio who was then far in arrears with his three-monthly payments.

Sunday, $28^{\text {th }}$ of November 1875 . A very quiet day. I made a few calls. Mariquita was much indisposed, and was in bed or resting on the sofa the whole day. Last Friday a regatta came off between the cutter rowed by part of the crew of the North American man of war Steamer "Richmond" and that of the Peruvian "Huascar", both anchored in Callao Bay. The distance rowed was two miles. The captains of two English vessels were the umpires. The amount of the bet was $\mathrm{S} / \mathbf{2 0 0 0}$, deposited by the North Americans in Silver Soles, by the Peruvians in bank notes. The two boats started at 4.12, and 30 seconds, and to the great surprise of all the Peruvians reached the goal at 4.29, one and a half minutes before the Americans. The race over, the North American Admiral and part of the officers went on board the "Huascar" to partake of a lunch to which they had been invited.

Tuesday, $30^{\text {th }}$ of November. In this days meeting of the Directory of the Banco de Lima, at which all were present except Mendoza, Gil, and Cisneros, a good deal of business was dispatched. The opinion given by Bernales and Aliaga on Cardenas' letter was read; their reasoning was well founded; they made a nice distinction between "renunciacion" and "destitucion". The Directory they said had a right to accept the resignation, but not to deprive one of their members of his post, and concluded with saying that the whole affair ought to be laid before the general meeting of shareholders. The Directors had undoubtedly made themselves guilty of a great irregularity in their conduct. During Lembcke's absence they had first resolved not to admit Cardenas' resignation. The letter had been written by the secretary Bernales, but not been sent by the gerente Sagastabeytia; and after Lembcke's return solely in consideration of him we had admitted the resignation. This error committed by us had been 
carefully eluded by Bernales and Aliaga and I therefore jumped at Gallagher's hint to ignore the premises of the opinion given, and solely to approve the conclusion. I made my motion accordingly, and all except Cucalon resolved to lay the matter before [_] shareholders in the next general meeting. Next it was [...] [834] at Cucalon's request that at every meeting of the Directory before the proceedings commenced, the gerentes should inform them of the various questions which they wished to be discussed in the course of the session. It was further resolved to make a remittance of $S / 35,000$ in paper to the Salitrera "Esperanza", and that the proceeds of twenty thousand quintals nitrate ready for sale should not be remitted to Europe, but come hither in bills upon Chile, the proceeds of which, sold here should then be paid over to the Banco de Londres, our creditor for sixty-odd thousand Soles. Finally the gerentes were authorized to purchase at a premium all the notes of the Banco de Londres which they could possibly obtain.

Thursday, $2^{\text {nd }}$ of December 1875. In the office of the Insurance Company Lima I, who had been one of the two Directores de Turno for November, delivered over to Valentin Gil, one of the Directors for December, all the documents belonging to the company deposited in two small iron drawers of an iron chest, the key of the chest being in the possession of Manuel Ferreyros, Gerente, the keys of the drawers being kept by one of the two Directores de Turno. This operation kept me till nearly four, when I was called to the Banco de Lima, where the meeting was poorly attended. Lembcke laid before us the usual monthly statement of the affairs of the bank, and then made known that the interventor whom, as I said a few days ago, the bank and other creditors of Julian Guimet had sent to his estates, wanted money for the most necessary expenses, for he had not a single rial disposable. All except Lembcke agreed that no money could be given by the bank, and the meeting broke up.

Friday, $3^{\text {rd }}$ of December. Died Telesforo Llerena, brother of the wife of Anibal de la Torre, who not long ago had married one of the daughters of the rich José Maria Varela. When I passed the Banco de Lima I was called in. The two gerentes Gallagher, Cisneros, and the Interventor in Guimet's estates, Iglesias, were in an eager discussion. The latter stated that he did not get money wherewith to pay the Chinese, 85 in [...] [835] whose wages were in arrears for several months, if not all, at least many of them would run away. To prevent this, we saw the necessity of providing Iglesias with a little money, and we therefore took it upon ourselves to let him have from the funds of the bank $S / 800$ which would enable him to make a partial payment to the Chinese, and also cover a few other indispensable expenses. We calculated that the bank would be 
reimbursed for this outlay by the sale of 104 quintals of sugar which were lying ready, and of a few more which the machinery, small and incomplete as it was, would probably produce.

Saturday, $4^{\text {th }}$ of December 1875. At 4 p.m. Rafael Velarde accompanied me to Dr. Galindo, Vocal of the second chamber of the Superior Court of Justice, who was one of the three who had to decide my suit against Leyva on the subject of the ayres of the latter's house. He received me in a very friendly manner, and told me that he had known me for many years, for he had begun his career as clerk to the notary J. A. Menendez, of ill repute, whom I occasionally had employed about 35 years ago. From him I went to the Banco Hipotecario, where as usual Mendoza was wanting, and Dr. Forero was present. After the acta of last meeting had been read, approved of, and signed by Oyague as President, he gave us a circumstantial account of a long interview which he had had with Riva Agüero, who had refused to submit to the arbitration "juris" and preferred that the bank should institute against him a judicial demand. I regretted that Riva Agüero had anticipated me, for I had intended to move, and I did move, that on Monday next the bank should sue Riva-Agüero before a Juez de $1^{a}$ Instancia; firstly, for the repayment of the $S / 22,000$ taken by him out of the bank as supposed gains due to him, for 1874; secondly, for the repayment of S/3000 taken by him in July of the present year, and thirdly, for the delivery of the securities promised by him for his pagare of $S / 10,000$ balance of the $S / 30,000$ arising from the counter-document for that sum, so often spoken of. Aliaga and Jimenez agreed with me; neither did Oyague oppose my motion; nevertheless, he "salvó su voto", under the pretence that he had always advocated the arbitration; but in reality because he was afraid of breaking with Riva-Agüero. This was in my opinion no straightforward [...] [836] of a conversation which on the previous night he had had with Soyer and from which we drew the inference that for years back the Banco Hipotecario had been a den of thieves. Many other topics were treated on, which, though of more or less importance, required no particular notice. At 6 I came home, dined, Bryson came, read to me, and at 8 I went to the Banco Nacional, where the Directories of the four banks Nacional, Perú, La Providencia, and Lima were represented by part of their members. Dr. Garcia Calderon presided, and stated that the negotiations with the President regarding the Salitreras in the Province of Tarapacá were far advanced, and that Pardo wished that the Directories would authorize the eight Delegates definitely to conclude the contract without submitting it for approbation to the Directories. A short silence ensued, which I was the first to break, saying that such a weighty matter could not be decided at once, and that each Directory ought to consult separately and then give its reply. Garcia 
Calderon acceded to this idea, when Aliaga said he thought it more advisable to discuss the matter previously between ourselves and in our own office. Then Cardenas rose and in a long, diffuse speech declared that he was opposed to such an authorization because the last contract with the Government relative to the advance of $S / 15,000,000$ proved that Pardo did with the Delegates what he liked. This he did not say in clear terms but at all events he gave it so to be understood. Against this inculpation Garcia Calderon, President of the Commission of Delegates, defended himself and his colleagues. Lembcke rose and spoke against the authorization; the Guano contract for Mauritius and other islands having been submitted to the Directories for their approval, this nitrate contract, of more importance, should also be submitted to them. Aliaga was likewise against it; he said the shareholders had not authorized the Directories to delegate their power to two members of their body. Only Moscoso Melgar and Garcia Calderon attempted to defend the authorization. Garcia Calderon then put the question to the vote. I took the opin[_] of the Directors [...] Banco de Lima Bernales, Cucalon, Ba [...] [837] Aliaga, Cisneros, Lembcke, and I. All were unanimous in not giving the authorization to the Delegates. It lasted some time before the members of the Nacional resumed their seats. Garcia Calderon addressed himself first to me, and my answer was, in the name of the Directory, in the negative. Scheel for the Nacional was also for the negative, whilst Ruden for Perú, and Albaracin for La Providencia, gave an affirmative answer. We were now two against two, and as this case had not been foreseen, or at all events nothing had been resolved what to do in such a dilemma, we for the moment were brought to a stand-still. Bernales now proposed that full power should be given to another commission of twelve persons, viz.: the President and the two Gerentes of each of the four banks. This did not seem to please the generality. Then Scheel and Miceno Espantoso came forward, with more or less the same idea, viz.: that on the evening of the day that the Delegates had to close with the President, the four Directories should again meet in the Banco Nacional, and not separate until a definite resolution were come to. This was agreed to by the four banks; it was 10.30 when I came home.

In the course of the week Riva-Agüero had published a manifest in which he declared that he withdrew his pretensions to the first Vice-Presidency of the Republic. Rumours were afloat that Pierola was preparing in Chile a new expedition against Peru.

Sunday, $5^{\text {th }}$ of December 1875. I was on the point of starting on my usual round, when Dr. Manuel Antonio Puente Arnao, the same who had decided in my favor the suit against Leyva, and declined to accept the plaque tea service, came in, and remained with us till half past three. On both sides all was politeness, and he 
expressed a wish that we should use our influence to procure him the situation of agente-fiscal, vacant by the death of Telesforo Llerena. My wife promised him that we would do our best. Accordingly we spoke to Rafael Velarde, who would see Fuentes, (El Murcielago) who was very intimate with Dr. Odriosola, Minister of Justice, on whom the nomination depended. When I went out I called upon Dr. Muñoz, who himself received me, tears in his eyes, for his last child by his first wife, a grown up young man, was lying dangerou [...] the last stage of consumption. I [...] [838] wife of Manuel Flores, and granddaughter of Bartolomé Araoz, her deceased father having been Don Antonio. The widow of Araoz, Tomasa Gonzales, just returned from Europe in company with Juan Jose Araoz, resided with her, as she had done before her voyage. Both ladies were sad, the grand-daughter more than the widow, who attributed in a great measure her husband's death to their having alighted in Biaritz, in an hotel just finished, where everything had felt damp and moist. The finishing blow however had been given by a cold caught by Araoz when witnessing a regatta. The family was now busy with dividing the property, for which purpose Juan José had started for the estates they possessed in Abancaes, and on his return to Lima it was their intention to sell the houses they had here. Only a small one in the Calle de Polvos Azules - one of the many bought from Dr. Palacios by Don Bartolomé - stood in the name of his widow.

Monday, $6^{\text {th }}$ of December 1875. At 8 a.m. I was in the church of San Francisco at the funeral of Llerena. Though the season was far advanced it had rained during the night, and the streets were very wet. By the twelve O'clock train my wife and myself with our Chinese servant Ayao, and Serapio, the husband of our servant woman Isabel, whom we had engaged for the day, went to Chorrillos. We walked to our rancho, and had much trouble with the keys, otherwise, though several things were wanting, it was in very good order. We had the corredor, and every apartment swept, and returned to Lima by the four O'clock train. At 10 p.m. Garland and I went to the house of Francisco Sagastabeytia, to accompany to the Church of San Francisco, the corpse of his brother Manuel. This Manuel had in every respect been the very reverse of Francisco, and his death was in a great measure attributed to his dissolute life.

Tuesday, $7^{\text {th }}$ of December. This morning I was again in San Francisco, at the funeral of Manuel Sagastabeytia. [...] [839] Anglo Peruvian Bonds, due $31^{\text {st }}$ December would not be paid, and it was quite as certain that the Peruvian Government intended to come to some arrangement with the bondholders, so as to reduce wither the capital of the debt, or the rate of interest and redemption. Last nights Nacional made a calculation which showed that were the capital reduced from $£_{34,000,000}$ to $£_{20,000,000}$ the redemption to remain 
at $4 \%$ and the Interest to be raised to $6 \%$ annually, the quantity of guano which was calculated to exist, about nine million tons would be sufficient, taking the annual sale to be 350,000 tons, and the net proceeds of each ton $£ 5.10 /$, to pay both interest and redemption. At 3 O'clock I went to the usual monthly meeting of the Directors of the Insurance Company Lima. Present were: Carlos Elizalde, President; Michael Carrol; Jose Maria Peña; Valentin Gil; I, and the Gerente Manuel Ferreyros, whose intellect in my opinion had not completely recovered from his late mental derangement. The only thing of importance on which we had to treat was the pagare for $\mathrm{S} / 70,000$ signed by the United States Guano Company, and by its Directors, de mancomun et insolidum, which fell due on the $25^{\text {th }}$ December. We were all of opinion that it would not be paid; also that if we were to sue them we would gain out little by doing so. We therefore came to the resolution not to renew the pagaré, but to leave it as it was, so that if anything were to happen to the Company we might have a document already due upon which we could proceed at a moment's notice. The Directors of this guano company were, as far as I recollected, the two Bryces, Andres Alvarez Calderon, resident in Paris, Raynuso, Miceno Espantoso, and two more, none of whom at present in a flourishing condition. We rose at about four when I went to the Banco Hipotecario under the same roof where I found the two Gerentes, Oyague, Mendoza, and Jimenez. The "reglamento interior", if I mistake not, drawn up by Garland, was read, a few insignificant alteration were made, and one of great importance, which I pointed out, viz.: hitherto the key of the case, in which the archives, consisting of the most important tittle deeds were kept, was in the hands of a clerk called "El Archivero". I insisted that the key should be kept by the gerentes, and very naturally all coincided with me. At 8 p.m. I was cited with the greatest urgency to the Banco de Lima. Present were: [_] les and Cisneros [...] [840] Barrios, Castillo, Lembcke, and I. The Delegates laid before us the project relative to the Salitreras, handed by the commission to the government, not yet approved of, but very likely to be approved. They further stated that the President Manuel Pardo in order to be able to purchase the small establishments worth a few thousand Soles each, also coals, barley, provisions, mules, etc., which might be in existence, wanted from the banks a further advance of one million soles, of which one-sixth corresponded to the Banco de Lima. The discussion lasted long, everyone saw the necessity of this further outlay, but Lembcke explained in a very clear manner that it would be utterly impossible to make all the payments which we still had to make to the Government, and which would be further increased by these fresh S/166,00o, if the Government did not allow the banks to increase their circulation. With this proviso, he, like the rest, voted in the affirmative. The two 
Delegates were confident that before the end of the year the decree relative to the expropriation of the salitreras would be published. I called the attention of my colleagues to the difficulty which I apprehended the expropriation of the Salitrera "Esperanza" would meet with, owing to the circumstance that the ground belonged to a certain Almonte, who was hostile to the "Esperanza", which had merely the use of the land for ten years. Cucalon was glad that I touched on this point, whilst Lembcke observed, and with justice, that this had nothing to do with the present question whether the advance was to be made to Government or not. The contract of the banks with the Government for the consignment of guano to Mauritius had been signed by Pardo. We finally resolved that the lawyers of the four banks should be ordered to draw out a project of the partnership which the four banks formed, in as far as the guano consignment and the Nitrate of Soda business were concerned. It was half past ten when I came home.

Wednesday, $8^{\text {th }}$ of December 1875. Dia de la Concepcion. Holiday. At the usual hour, say two O'clock, I went [_] to make [...] Dr. Manuel Morales [_] [841] de la Corte Superior. With him and his wife I remained but a short time, whilst on the other hand I was detained nearly an hour by the wife and mother-inlaw of Dr. Puente Arnao, to whom I went with the bad news that there was no chance of his obtaining the situation of "agente fiscal", the Government having already determined to give it to Dr. Castellanos, for many many years secretary of the Supreme Court. Puente Arnao's wife was the daughter of the hacendado Guimet, of whom I have spoken more than once as being indebted to the Banco de Lima for above S/180,0oo for which he had hypothecated to the same his estate called Esquivel, and the moveable property, "capitales" which he possessed on the estates of San Lorenzo and Copacabana, rented by him from their owner Vitorero; to this latter he was in arrears with his rent, to the bank he paid neither principal nor interest, to Manuel La Rosa O'Phelan he owed S/50,000 and interest, and besides these he had still more creditors, all of whom, most naturally, had presented themselves in order to be paid, and to bring the property to the hammer. This would of course be the ruin of the family and thus Mrs. Puente Arnao knowing me to be one of the Directors of the bank, tried to persuade me that it would not be to our interest to proceed to extremities. I listened attentively, and told her I would mention what she had said to my colleagues. At Dr. Muñoz's, where his son was fast approaching his last hour, I met Dr. Corso who said that on the $10^{\text {th }}$ his leave of absence expired, and he would have to return to the Superior Court, whereupon I hastened to the Basagoytia's of whom I had the firm conviction that the son Jose would willingly avail himself of the intimacy which he had with the said Corso, to 
make him look with a favourable eye, upon my suit with Leyva. Unfortunately he was not in, when I had to tell my tale to his father, who promised me that he would faithfully repeat to him every word I had said. Next, to the widow of Frederic Bergmann, who assured me that she had recommended my suit to Corso.

Thursday, $9^{\text {th }}$ of December 1875. Anniversary of the battle of Ayacucho. No holiday.

This being Geraldo's birthday, his mother requested [...] and me to dine with [...] Dr. Midd[_] [842] and Julio Benavides, son of Manuel Francisco who had been a colleague of Geraldo's in the Embassy to Japan and China, and Federico Pflücker, one of the sons of Charles with whom Enrique on one of his late trips to the Sierra, had for some time been staying at his establishment in Morococha. I had not seen him since his childhood and of course should not have recognized him. We sat down at half past seven, and it was nearly nine when we rose. Garland related that he had been told an individual from the firm of Morgan \& Co. of London was expected shortly here in Lima accompanied by Pedro Galvez, the Peruvian Minister in London and Paris, and that his object in coming was to make some proposal relative to the Guano business. My wife went over to Enriqueta's tertulia; whilst I took some sudorific medicine, and turned in at about 10 O'clock.

Friday, $10^{\text {th }}$ of December 1875. I was much better, not yet quite well. My wife, unwell, kept her bed. The cook Achipe did not make his appearance, being indisposed, and we therefore took our meals with the family Garland. At 3:30 p.m. I went with Jose Basagoytia to Dr. Corso by whom I was received with great politeness, and who attentively listened to the succinct account which I gave him of my suit against Leyva in which I particularized such points as I thought of most importance.

From Saturday, $11^{\text {th }}$ to Monday, $13^{\text {th }}$ of December. Very quiet days. On Sunday I for the first time called upon Dr. Ramon Fuente, an elderly man, nephew of my late friend Don Mariano Blas. Don Ramon gave me a detailed account of a painful operation which two days previously his brother Mariano had undergone. A cancer had shown itself in the tongue, and to prevent its spreading, a large piece had been cut out. The operation had lasted an hour and a half.

Tuesday, $14^{\text {th }}$ of December. Our cook had not yet returned. [...] declined [...] [843] Cedulas del Banco Hipotecario to about 69, Exchange on London for drafts of the Banco Nacional 90 d/st. 38d; others drew at from 35 to 36 Silver bars, ley 11.22 had been sold at $\mathrm{S} / 12.30$ the mark. The Banco de Lima bought yesterday $S / 20,000$ coined silver at $181 / 2 \%$ premium. The Directory of the 
Banco Hipotecario met; near four O'clock all were present, except Mendoza. The only question of importance which was discussed was in what manner the nominal gain of 1874 should be disposed of. Oyague proposed that some dividend should be paid to the shareholders. Gallagher and I jointly argued against this idea, and succeeded; consequently, it was resolved not to give any dividend for this year and to carry the nominal gain to the credit of reserve fund, which fund would be entirely absorbed by the losses caused by Soyer, by several decidedly bad debts, and by the depreciation on the value of other debts. In the evening my wife and the Garlands went to Basagoytia's weekly tertulia. I remained at home, but stayed up till past one, when they returned.

Thursday, $16^{\text {th }}$ of December 1875 . Meeting of the Directory of the Banco Hipotecario. Oyague presided. Besides him were present: Jimenez, Aliaga, I and the two gerentes. Jose Canevaro took up a great deal of our time with the proposal to pay the $S / 63,000$ with which the brothers Montero were in arrears for their three-monthly payments, either in Cedulas at par or with a very heavy discount. No resolution was taken; I for my part felt no inclination to submit to such a sacrifice as Canevaro's proposal involved. Another irregularity, committed at the time that Garcia Calderon was gerente, but when, as he asserted in a letter written to the bank, Riva Agüero, though Minister, still interfered was discovered. Henry Swayne in the beginning of 1873 applied to the bank for a considerable loan, which being conceded him, he ordered the bank to make payments in cash on his account to Dinegri, which was done, though the Statutes say that the bank is only allowed to make its payments in Cedulas and not in cash. Cedulas stood then at $87 \%$, and consequently Swayne made an undue gain of $13 \%$, perhaps with the connivance, perhaps owing only to the negligence of the gerente, whosoever he may have been. Next, a beginning was made with reading aloud the reformed statutes, and after having read a few articles we discovered that the original statutes, after having read a few articles [...] [844] were included in a law given by the Congress, and therefore it did not behove us alter them. Whilst I was in the bank, in the second chamber of the Superior Court before the Vocales Corso, Mendoza and Galindo, the relator read his "relacion" of my suit with Leyva. Dr. Palacios and Guillermo Garland were present. In the evening I was not at Enriqueta's tertulia; it was near two when my wife came to her bedroom.

Friday, $17^{\text {th }}$ of December 1875 . Meeting of the Directory of the Insurance Company Lima; Carlos Elizalde, President; Moscoso Melgar, Vice; Peña, Gil, Carrol and I, Directors. Valdivieso, the clerk, took the place of Ferreyros, the gerente, who was absent. At my suggestion Elizalde had requested Vicente Hurtado, Gerente of the United States Guano Company, whose pagaré of 
$\mathrm{S} / 70,000$ fell due on the $25^{\text {th }}$ inst. to be present. Hehad proposed to the Insurance Company to give as security Bonds of the Peruvian Government, amounting to 140,000 American Dollars (nominal). He explained to us that these bonds paid $7 \%$ annual interest, that they would be redeemed in five years, and that the company itself "hacia el servicio", out of the proceeds of the guano sold in the United States. When Hurtado had withdrawn, we resolved to renew the pagare for six months, discounting the same at $1 \%$ and taking, besides the signature of the company and all its Directors, de mancomun et insolidum, this new prenda pretoria. Then a letter from Manuel Ferreyros was read, in which, on account of bad health, he gave up his situation as gerente. Unanimously Carlos Elizalde was chosen in his stead, whereupon it was found necessary to choose one other Director, because we were now only five in number. Elizalde thought that Chavez would be a proper person. I proposed Böhl of Gibbs house who was preferred, and chosen accordingly. By the North Steamer I received three letters, each of a different character. Johannes Limpricht's of $13^{\text {th }}$ November from Hamburg treated on general topics, mostly on the miserable state of Peruvian Finances. He also informed me that the Hamburg [Bank founded in 1619] [...] closed by the [_] of the [845] year, and its place be taken by a branch establishment of the Imperial German Bank, which was founded on 40,000 shares of 3000 Imperial marks each, making a total of 120 million marks; of these, 20,000 shares were reserved for the shareholders in the old Prussian Bank, whilst the remaining 20,000 were offered to the public at a premium of $30 \%$, and were eagerly taken; instead of sixty millions required, nine hundred millions were subscribed. At the date of his letter they stood at $153 \%$. The second letter was from my cousin Frances Cresswell from Winchmore Hill, in which she gave one an animated account of her short residence with the family Siemssen in Eppendorff, where she seemed to have been extremely well pleased. The third was from my son Juan from Nizza, written in a very different strain from the previous ones. Rumours had already reached him of Pardo's disapproval of the contract concluded by Althaus and Rosas with La Société Générale. He, like the entire Peruvian Colony in Paris, had speculated on a rise in Peruvian Bonds; he himself had bought at $395 / 8^{\text {thso }} \%$, and his loss, he apprehended, would be so heavy, as nearly to ruin him. Rosa wrote in the same strain to her sister Enriqueta; she stopped the payment of all the alms hitherto given here on her account. Schutte, Corina, and Shattuck, who had all speculated in Peruvian Bonds, were losers to a large amount. Shattuck and Amalia with their four children were about leaving Paris for Boston, there to join Shattuck's family. The Canevaros had been the only ones who had gained, in the same proportion as the others had lost. César, who was in Paris, knew 
of the disapproval of the contract two or three days before anybody else, speculated on the fall of Peruvian Bonds, and realized in this way large profits. My opinion was that Pardo was interested with the Canevaro's. (Not so, $23^{\text {rd }}$ January 1879).

Saturday, $18^{\text {th }}$ of December. This morning at 1 O'clock died Dr. José Gregorio Paz-Soldan, Fiscal de la Corte Suprema. Only yesterday we learned that he had been taken ill the previous night. I went this morning to his house at 8.30, to enquire how he was $[\ldots]$ the porter received me with [...] [846] quite sudden. The whole day of yesterday he had been pretty well. Only his brother Mariano Felipe was in the house with the widow Doña Jesus Rivero of Arequipa, not even his own son José Luis, who, the porter told me, was on bad terms with his stepmother, was there. Paz-Soldan was a very clever, but to say the truth, also a very bad man. Everybody knew that the large fortune left by him he had not acquired in a strictly honest manner. He had many children, the greater part of whom illegitimate. His first wife, who had a fortune of her own, was a Martinez of Arequipa, by whom he had two children, José Luis, married to a cousin, and Petita, married also to a cousin, Carlos, the son of Mariano Felipe. To neither of them had the father during his life time given a rial of the property to which they had a right, as being their mother's. The second wife was a Zavala of Lima, who bore him no children; she died soon after her marriage, and left him on her deathbed the large house which he inhabited. His third wife, who survived him, was Doña Jesus, daughter of José Rivero of Arequipa, of very limited capacity, and who certainly did not love him. From this marriage four or five children were alive.

The vistas which Paz-Soldan gave as Fiscal, and which he wrote with extraordinary facility, are upon the whole considered to be excellent compositions; but I was convinced that though they had generally been founded on justice and law, on more than one occasion, if temptations were held out to him, which he was unable to resist, he knew how to twist the laws, to suit the views of the party he wanted to favor. He was a great eater and drinker, and for many years was in the habit of lying down immediately after dinner, and sleeping till nine or ten; he then rose, worked till two or three in the morning, and again went to bed.

In the course of the present week the long expected decree, relative to the expropriation of the Salitreras in the Province Tarapacá, was published in the papers; it was a very long, and complicated [_]ent. Those who did not [...] [847] sell, might go on working on their own account; but the nitrate they produced and exported, would be subject to an export duty of six rials per quintal. Those who wished to sell, might do so immediately, or give their promise to sell in 
the course of two years. The Salitrera "Esperanza" which had cost the company nearly two million Soles was valued at $\mathrm{S} / 900,000$ - three hundred thousand Soles less than the one million two hundred thousand, due by the Esperanza to the Banco de Lima. As yet I was ignorant what the shareholders in the said Esperanza would do. Neither had the Directors of the Banco de Lima come to any decision with regard to the Salitrera.

This forenoon I was more than an hour in the Superior Court, where I listened to the pleading, el informe, of Leyva's lawyer Aramburú. My lawyer Palacios assured me that it would be an easy matter to refute all his arguments.

Sunday, $19^{\text {th }}$ of December 1875. I left my house before six, and made my usual ascent of San Cristoval from the side of Lurigancho, very slowly it is true. I descended on the other side to the Alameda de los Descalzos, and was home by 8, when I lay down, and rested till ten. Mr. Bryson and I remodelled the diary; Ricardo read to me in German for more than an hour. We were now occupied with a novel called the Imperial Countess Gizela, written by a lady under the pseudo name of Eugenia Marlitt. She was decidedly hostile to aristocracy, and the religious party known by the name of Pietists. I was pleased with her style, and her stories are certainly interesting, but to me it appeared that the characters she introduces bear an extraordinary family likeness to each other; the heroine Felicitas, in the "Secret of an old Spinster", and Elizabeth in the "Gold Elze" are both pretty young girls, of an energetic, indomitable character, merely placed in different situations. In the same manner, the professor in the former, and Mr. Von Walde in the latter, are men of a stern, abrupt, somewhat rough, but noble mind. The visits which I made in the forenoon, I already looked upon as Christmas and New Year [...] In [_] original the [...] We dined [848] with the Garlands. After dinner I was very sleepy; fortunately Doña Dolores Puente kept my wife company for more than an hour. I accompanied her home, and then went to the house of Don Gregorio to form one of the numerous cortége which followed the corpse to the Church of Santo Domingo, where he, one of the most decided scoffers and sceptics, was received by the friars, with more than their usual chanting, and thus it was as late as half past eleven before I was home.

Monday, $20^{\text {th }}$ of December. At eleven I went to Santo Domingo. The interior of the Church, hung with black drapery, and illumined with wax tapers and other lights, was crowded and had it not been for a friar who took me by the hand, I should not have got a seat. The Government Coach, drawn by four horses, and more than fifty carriages followed the hearse to the pantheon, where Dr. Melchor Vidaurre, the President of the Supreme Court of Justice, and other gentlemen, delivered the customary laudatory speeches. All courts of Justice were closed on account of this funeral. 
The shareholders of the Banco Hipotecario were convened for the purpose of choosing two merchant shareholders to examine the accounts of the bank at the end of the year. The number required by the statutes - the half, and one more - not being present, Oyague requested those who attended, to come again on the $22^{\text {nd }}$.

Tuesday, $27^{\text {st }}$ of December. At 12.30 I went to the second Chamber of the Superior Court, in the Hall of Justice, where Aramburu, Leyva's lawyer, was already on his legs. When he had done, Dr. Palacios rose and pleaded, very much to the purpose, without taking up so much time as the other had done. When we left together before two O'clock, he told me in strict confidence that he had been told by José Basagoytia that Dr. Corso had expressed himself rather unfavourably to my side of the question and therefore, as soon as I came home, my wife and I drove to the widow of Frederic Bergmann, who pretended [...] [849] much influence with Corso, and who promised she would again speak with him in our behalf. Thence, with the same object to Doña Manuela Mendoza, the mother of the Doctor Don Domingo, one of the three judges in the second chamber. Here I left my wife and hastened to the meeting of the Directors of the Banco Hipotecario, of whom all were present except Mendoza. More receipts of money received by Soyer in the latter half of 1874 , and not entered in the cash, turned up. This time one for about $\mathrm{S} / 2000$ handed in by Dr. Wenceslao Rospigliosi of Callao. None of us doubted of the exactness of the payments, and I proposed that we should at once recognize them, but on Aliaga's motion it was resolved first to take our lawyer's opinion. Dr. Ramon Ribeyro having declined to carry on the suit against Riva Agüero, I proposed José Aranivar in his stead, which all agreed to, but when I mentioned Fernando Palacios in case Aranivar should also decline, the preference was given to a certain Fernandez, proposed by Aliaga. When I came home my wife told me that Dr. Don Domingo Mendoza had come in whilst she was with his mother, and that he had been very civil, but that was all. In the evening we two drove to Rafael Velarde, with whom my wife again spoke extensively on the same subject, to us of vital importance.

Wednesday, 22 ${ }^{\text {nd }}$ of December 1875. Before nine, just when Ricardo commenced reading to me, as he was on the habit of doing till ten, Rafael Velarde came and told me that he had just been with Dr. Galindo, the third of the three judges, who had received him well, and said he had been pleased with Dr. Palacios' pleading of the previous day. At 1 p.m. my wife and I drove to our good friend Doña Josefa, widow of Dr. Prada, and mother in law of Dr. Domingo Mendoza, our object always the same.

In the meeting of the shareholders of the Banco Hipotecario, where at the second convocation any number present sufficed to form a quorum, the 
examiners of accounts were chosen: Francisco Sagastabeytia, and Manuel O. de Villate; and, should one of the two, or both, decline, Briganti, Dinegri's book keeper, and Manuel Cucalon. During my absence from my house, my wife had received a note from Julia Cavenecia, who wrote her that she had seen Dr. Corso, who [_] promised to examine the autos, and who said that the [...] [850] would not be given till next week. José Basagoytia, who came in in the evening, confirmed the same. Advice was received of the death of the poet Clemente Althaus. Here in Lima he had become deranged, whereupon his brothers sent him to their sister, Mrs. Cotes of Paris, who had placed him in lunatic asylum, where he died.

About this time died in Lima Hermann Woldt, a native of Lubeck, who had come to this coast, I think in 1825 when I made his acquaintance in Arequipa; he then brought with him a small invoice of goods, which he disposed of, I do not remember whether in Tacna, or Arequipa. He was of a good family, and well brought up; nevertheless though he tried his luck all over the country, and in all ways and manners, he never prospered. For the last ten, perhaps twenty years, he resided in Callao, where he married, and did his best to flight his way through the world as Port Agent, but again without success. He put up a house of refuge for destitute Germans, and declared himself their defender. Owing to his own imprudence he had his leg broken when he tried to get on the train whilst in motion. His leg was amputated, and during his illness his wife robbed him; he commenced a suit against her, they separated and for the last two or three years he could be seen limping about the streets of Lima, with his long white beard, in his blue blouse held together by a black leathern waistband, a crutch under one arm, a stick in the other hand. In the printing office of "El Comercio" Amunategui, the owner, lodged and boarded him. Occasionally he made translations for the paper. Though we had never been intimate he now and then addressed me with the familiar "thou", as if we had been great friends in our youth. His last request was that he might be buried in the Island of San Lorenzo, without any funeral rites; and this was done accordingly.

Thursday, $23^{\text {rd }}$ of December. By the advice of Isabel Coloma, Enriqueta's intimate friend, I went to Pedro Bernales, one of my colleagues in the Banco de Lima, and who, as well as Dr. Corso, was a tenant in the large house of Panizo, formerly that of La Condesa de Fuente Gonzales. I waited for him in his win[_] store Calle de [_] and when he came and I had exp [...] [851] to him what I wanted, he promised to speak to Dr. Corso. In the evening Enriqueta's tertulia was numerously attended. I preferred staying on our side of the house, and went to bed at 10.30, but as usual had to rise at half past one, when my wife came, to bar the doors and extinguish the gas. 
Friday, $24^{\text {th }}$ of December 1875. At 7.30 p.m. my wife and I drove to the house of the late Don José Gregorio Paz-Soldan, para dar el pesame, that is to say, to condole with the widow for her recent loss. We were ushered into the large ante saloon, where, after having given our names, Don Daniel Rivero of Arequipa, who, it was said, had been sent for by his sister when she noted the declining state of her husband's health, and another lady, unknown to me, came to meet us. They were very polite, and all the while we were there I kept up a lively conversation with Don Daniel, hardly taking any notice of another gentleman who came in, and who being called Doctor, I believed to be a physician, and thus, as soon as we were in the coach my wife asked me: "why were you so cold and reserved towards Dr. Corso?" My answer was that I had not recognized him. Having still time to spare we ordered the coachman to take us to the house of Don Mariano Felipe Paz-Soldan, where however we found nobody in.

Saturday, $25^{\text {th }}$. Christmas Day. I was up by 5.30 with the intent to climb up San Cristoval, but, when in the street, I recollected that my wife had lately had some dispute with the servant woman. I feared she might have another squabble, also thought of the recent murder of the Curate José Santos Chavez, and both ideas made me hasten home. I again went to bed, and when all in the house were stirring, though my wife was suffering from an irritation in the belly, owing to the shaking of the carriage on the previous evening, I started for the second time, and accomplished the ascent, though not with the same ease as twelve months previously.

After breakfast Ricardo read to me, and having this day a great many calls to make, I left as early as 1.30. My first call was on Guillermo's young wife Eliza, not yet ready to receive; the second, to her mother, who was as behind hand as her daughter. The third visit was [_] Dr. Corso to whom I wanted to make [_] excuses for [...] [852] of politeness on the previous night. He had gone out, and his wife did not show herself. Fourthly, the wife of General Freyre begged to be excused under the pretence of indisposition. Fifthly, the widow of General Salaverry received me jointly with her sister, and one of her granddaughter; to me she was of course polite, but to her companions, as stern and despotic as was her custom. Sixthly, to the family of the vocal J. A. Ribeyro; three of his daughters were in the drawing-room, neither pretty, nor young, but talkative and agreeable. Seventhly, to J. V. Oyague, the drawing room was open, no one to be seen. Eighth, to the family of Manuel Andres Calderon, brother of the notorious Andrés; their unmarried daughter Teresa received me, and I thought this the most agreeable call I made in the course of the day. Ninthly, at the Minister's Anibal de la Torre, his silly wife Doña Fidelia spoke to me 
all the while of the dishes she was in the habit of ordering for breakfast and dinner. I was glad when the entrance of Garron, the Italian Chargé, put an end to her garrulity. $10^{\text {th }}$, at Rafael Velarde's I saw only his wife, Zoila, and little ones, no inducement to remain long. $11^{\text {th }}$, on the other hand I was well pleased with Macandrew and his young wife, very nice people. $12^{\text {th }}$, Isabel Barreda, Manuel Mendoza's wife, just returned from Paris, was not in her drawing room; whilst, $13^{\text {th }}$, I had to remain more than a quarter of an hour with her mother-in-law, Doña Manuela, and her sister-in-law Emilia, very good natured, but shockingly silly people.

Sunday, $26^{\text {th }}$ of December 1875 . I continued my yesterday's calls, commencing with the most distant, Bartolomé Araoz's widow, Doña Tomasa, and his grand-daughter Micaela, who had not yet returned from mass. Secondly, at Dr. Dorados' all was shut up. Exactly opposite was the house of the Minister, Aurelio Garcia y Garcia; his wife, Teresa Lastre had of late reproached me for having entirely forgotten her. I therefore thought it my duty now to call, and th[_] I did not see the lady was well pleased with the rec [...] [853] Don Aurelio gave me; Pio Echenique was with him. Mr. Francis Bryce, and his wife Clementina were likewise very civil. $5^{\text {th }}$, Doña Josefa, Prada's widow, whom I was very desirous to see, was not in her drawing room, though the door was open. $6^{\text {th }}$, of the Basagoytias I can only say that they were as friendly as was their habit. At Melchor Velarde's I saw his wife and his two eldest daughters; the education of her sons, Jorge, midshipman, on his way to Europe, Melchor, and Ernesto, on board of a naval school in Callao, was the favourite theme of the mother's conversation. Thence it was a great distance to the house of Dr. Puente Arnao, with whose wife I remained but a short time. My ninth call was on Doña Dolores Puente, from whom I learned the great news of the day, that on Friday Rufino Echenique had received a telegram from his brother Juan Martin in Paris, stating that a respectable firm had made a proposal for the guano contract on the same terms as those lately offered by the Société Générale, but with the notable addition that it would make an advance of $£_{1}$ Stg. on each ton of guano, on shipment, of course to be deducted from the ulterior met proceeds, and as this was exactly the point Pardo had insisted upon, this new offer would in all probability be accepted. My last visit was to Doña Emilia Lopez, married to José Pablo Escobar, who confirmed the information which I had received from Doña Dolores. At home Garland told me that he had also heard of the above news.

Both this and the previous day many persons had paid their respects to my wife, amongst whom Pedro Bernales who had come merely for the purpose of telling her that he had seen Corso, but that he counselled us to address 
ourselves to Doña Manuela Orbegoso, wife of Federico Panizo, who had great influence with her tenant, Enriqueta, Corso's lady. Bernales even promised to send a rough sketch of the letter to be written by Mariquita to Doña Manuela.

Monday, $27^{\text {th }}$ of December 1875 . The letter promised by Bernales came whilst we were at breakfast; it was immediately copied, dispatched, and elicited a favourable answer.

The news from Paris about the guano business [...] [854] all over the town, and believed to be true.

Tuesday, $28^{\text {th }}$ of December. At 2.30 I was in the office of the Water Company, but could remain only a short time, for at 3, Doña Manuela Orbegoso de Panizo had cited me to be with Corso's lady, Doña Enriqueta. She was very polite; however, two expressions of hers gave me little hope as to her husband's sentence. She said, "Corso is so strict that the other day he sentenced against a cousin of mine in Huancayo"; and again: "in the last call the appeal to the Supreme Court lies open to you." At 3.30 the Doctor came, and listened with the greatest attention to all I had to say, but all I could draw from him were the words: "I shall bear in mind everything you have told me." Mendoza, he added, has asked for the autos after he had done with them. In the Banco Hipotecario only Oyague, Jimenez, and I, with the Gerentes, were present. Dr. Ramon Ribeyro, the lawyer of the bank, had been asked for his opinion whether receipts given by Soyer were binding on the bank, and whether those holding his receipts had a right to demand that such amounts should be credited them in account. His written answer was that such receipts were not obligatory on the bank. Dr. Ricardo Zevallos had on the contrary given his verbal, not official, opinion, in direct opposition to Ribeyro's. Oyague agreed with Ribeyro; Jimenez again with Oyague, whilst I was opposed to them, and thus the case stood over till Diego Lopez Aliaga could attend our next meeting. This was the only question of importance treated on. A letter, directed by Col. Torrico to the Directors, was also read, in which he demanded that a general meeting of shareholders should be convened. We resolved unanimously that in the answer it should be said that in conformity with the statutes the signatures of twenty shareholders were required to ask for a general meeting. In the evening my wife with Enriqueta and Garland went to Basagoytia's weekly tertulia. I stayed at home.

Wednesday, $29^{\text {th }}$ of December 1875. Both my wife and Enriqueta kept their beds; the latter suffered from her customary migra[_].

In the office of the Gas Company the Directory had a meeting. All were present, viz.: [_] President, Ruden [...] [855] Mathison, Garland, Manuel O. de Villate, I, and the Gerente, Frederic Marriott. We resolved to pay a dividend of $3 \%$ 
at the end of the present month. When all were gone I had a long conversation with Ruden about the South American Insurance Coy., in which he was the leading director. The capital was 200,000 dollars; the reserve fund amounted to $\$ 300,000$ and a second reserve fund, under the name of "depreciation fund", would at the end of 1875 amount to about $\$ 60,000$. The dividend for the present year would probably be 50\%. Ruden however confessed that the company had made many bad investments, the depreciation on which other Directors had insisted upon writing off at once at the end of the present year. This, Ruden had resisted, and carried his point, so that the loss upon their value would be spread gradually over several years. I asked for these details because J. M. Polo offered me for sale twenty shares, upon which $\mathrm{S} / 1600$ had been paid up, and for which he expected to receive more than $100 \%$ premium, this years dividend being for the seller. I resolved not to make any purchase whatever at such a high premium.

Thursday, $30^{\text {th }}$ of December 1875. Enriqueta was up; my wife continued in bed, having one of her feet a little swollen. Dr. Bravo prescribed a liquid wherewith to rub it, the swelling of which, he said, would soon go down. On the other hand, he declared that every time he came to see my wife he found her weaker; she had less than sixty pulsations per minute. This her debility I could only attribute to her great disinclination to take any substantial nourishment. At the request of Manuel Cucalon the Directory of the Banco de Lima was called together. Lembcke left the room, for he knew that the debt owed by the "Esperanza" to the bank would be treated on, of which Salitrera he and Valentin Gil were shareholders. Gil was not present either, as little as Mendoza, or Castillo. Cucalon asked whether the gerentes, the Director de Turno (Luis B. Cisneros), or the President of the Directory (I) had taken any step with regard to the said "Esperanza" since the date of the publication of the Government's decree, relative to the expropriation of the Salitreras; and as in fact nothing had been done, Cucalon's motion with some slight alterations was unanimously agreed to, viz.: that the $[\ldots]$ should address a letter to the Direct $[\ldots]$ the Espe $[\ldots][856]$ them whether they would sell their establishment to the Government at the valuation fixed upon by the latter, and how and when they intended to pay their debt to the bank. They were further requested to send their answer at latest on the $5^{\text {th }}$ of January. When Lembcke returned to the room, a letter directed to me by Garcia Calderon, President of the 8 Delegates, was read aloud. It was a circular to the four banks, in which it was proposed that they should each name one of its Directors, and that these four Directors should form the administration of the guano business, they again choosing their gerente. 
Against the proposal itself we had nothing to say, but we all were of opinion that the first thing to be done was to draw out a public escritura which would establish the partnership of the four banks; and before this were done we thought no other step should be taken. We then resolved to ask for a meeting of the four Directories, when we would give our opinion. This settled, Lembcke begged to know what had been resolved upon during his absence; it was communicated to him, whereupon he said that as in all probability the "Esperanza" would not admit the Government's valuation, and as in that case the bank had to proceed judicially against the Salitrera, he could not at the same time be the "demandante", as gerente, and the "demandado", as shareholder of the Salitrera, for which reason he gave in his resignation as Gerente. It was past five when we separated. In the evening there was a large party at Enriqueta's. All the ladies came to our side to enquire for my wife's health.

Friday, $3^{1^{\text {st }}}$ of December 1875. At 9.30 a.m. I was in the house of Dr. Don Domingo Mendoza to speak with him about the suit against Leyva. The servant girl told me he had gone out, but I suspected that he was in, and did not wish to see me. Afterwards I went to the Tribunal where I learnt that the sentence had not yet been given, and from Doña Julia, Bergmann's widow, my wife received a note which again gave me some hope as to the final result. Near 4 O'clock only seven members of the Directory of the Banco de Lima, the two gerentes included, were assembled. Of Lembcke's resignati [...] [857] a word was said; it remained in suspense. Privately, we other Directors had resolved not to accept it. The object of the meeting was to hear what the gerentes had to say of various debtors; for instance Geronimo Sanchez who of late had paid with the greatest regularity S/60oo monthly, viz.: S/2700 interest, and S/3300 account capital, in consideration of which we resolved not to resume for the present our judicial proceedings against him. The affairs of Julian Guimet, largely indebted to the bank, wore a gloomy aspect; they were much complicated, owing, it was said, in a great measure to the improper interference of his other creditors, amongst whom Manuel R. O'Phelan was particularly mentioned. Dr. Aranivar had thrown up the sindicatura, and not a rial was forthcoming. In the evening Rafael Velarde, wife, and daughters kept us company. My wife still in bed. When they were gone, Enriqueta read aloud the letter received from Juan, dated Nizza, Novr. $28^{\text {th }}$, in which he gave a sad account of the losses suffered by all those who had speculated in Peruvian Bonds; he had purchased at 39 5/8 and sold at $273 / 8 \%$ and calculated his loss at fcs 100,000; whilst the fortune of Schutte who had speculated to the extent of millions, would probably be reduced to fcs 500,000 . Schutte's temper was not to be borne, and in order not 
to witness what the family had to suffer from him, Juan had preferred returning to Nizza. He had gone to Paris, in order to dispose of his bonds, and Dreyfus, who was his creditor for more or less the same amount which he had lost by their sale, had told him that he might pay when convenient to him, he, Dreyfus, charging him in the meanwhile interest at $5 \%$ p.a. Another bad piece of news, which also interested me, was that Dreyfus would not pay the dividend to the parties who had shares in his contract with the Government; not because, as Juan said, no dividend had been earned, but because, their outlays being enormous, they preferred borrowing the money from the shareholders at $8 \%$ p.a. rather than take it up from other persons. [858]

1876

Saturday, $7^{\text {st }}$ of January. I was in bed, not yet asleep, when last night the clock struck twelve.

In the forenoon of this day I made numerous calls. More than one of my acquaintances whom I met in the street greeted me with the words: "May the year 1876 be a better one than 1875 ." Dionisio Villate added, "I much doubt it will." My first visit was to Francisco Sagastabeytia, not in. Next, to Doña Juana Carbajal who had lately lost her son Pedro, who, a doctor by profession, died in Huancayo of consumption. Whilst I was with her, Joaquin Osma came in, a gentleman with whom I was but little acquainted, but of whom I had hardly expected that he would visit such poor people as Doña Juana, from whom he could certainly not draw any advantage. It seemed however that I had formed too bad an opinion of him. Thirdly, to Dr. Muñoz, where nobody was visible; fourthly, to the Col. Diego Masias; fifthly, to Doña Manuela Portillo. She told me that Manuel Ferreyros, the ex-gerente of the Insurance Company Lima, husband of her grand-daughter Amalia Alayza, had on Wednesday last left for Puno where he expected his health would be benefitted by the cold climate. At the President's I merely left my card. Three aides-de-camp who attended in the drawing-room told all who called that his excellency was in bed; so was his wife Mariana Barreda. But a few days ago they had lost their youngest child, thirteen months old. When I passed the house of Constantine Rehder, of the firm of Rehder \& Co., to whom I was in the habit of lending money, he was standing at the door, and begged me to come in, and of course I could not refuse. He and his wife lived in the house Calle de Bejerano, the same which several years back was occupied by Mr. and Mrs. Cordes. There were in the drawing room [_] his [_] a native of Rostock his brother [...] [859] with his lady from Offenback, and her mother. The ladies I did not much admire; vulgar I 
would not call them, but of a refined education they certainly could not boast. At Don Felipe Barreda's I was at twenty minutes to five, and the porter told me that Doña Carmen, the lady of the house, had not yet dressed to receive visitors. I suspected that she had been much affected by the bad news lately received from Paris, and that it was for this reason that she did not show herself. It was well known that her son Enrique, and her two daughters resident in Paris had deeply speculated in Peruvian Bonds and lost a considerable proportion of their fortune. Not many years back, Don Felipe, the father, distributed between his seven children half of his fortune, giving to each of them $\$ 210,000$. I now intended to pay a visit to Doña Francisca, the wife of Don Mariano Felipe Paz-Soldan, but by mistake entered the next house where several ladies and gentlemen were assembled. I did not immediately find out my mistake, though the lady, also dressed in black as Doña Francisca would have been, did not seem to me the identical person. I told them of my mistake, and fortunately was known to the lady, the wife of Domingo Laos, and to two of the visitors Carlos Ferreyros and Gallagher. My last call was a very pleasant one, viz.: upon Doña Virginia, the sister of the Minister La Torre, and wife of Domingo Valle Riestra. I was with her full half an hour; she was by herself, and I had the firm belief that she was one of the cleverest, and best educated ladies in Lima. I still recollected her father, Pedro Antonio, who was Finance Minister, I believe in the time of Gamarra. My wife, who at my earnest request had got up, had received a great many visitors; she was however by no means well, and went to bed before we had got through dinner.

Sunday, $2^{\text {nd }}$ of January 1876 . This morning at 7 O'clock, a young Englishman Holcombe, clerk of Sawers Woodgate \& Co., was waiting for me in the patio of our house, and we two, taking our way over the new bridge, slowly ascended San Cristoval. We rested for a short time on the big stone upon the summit, and descended on the other side, but instead of coming back by the [_]da de los Descalzos, we ret[_] through the valley [...] [86o] Lurigancho, so that it was as late as 9 O'clock when we reached my house.

Once more at half past one I continued my visits. $1^{\text {st }}$, to the Brazilian Minister, nobody at home. $2^{\text {nd }}$, to Doña Manuela Olavegoya, ditto. $3^{\text {rd }}$, to the U.S. Chargé Mr. Gibbs, who told me that on the previous - new-year's-day - he had kept open house, as was the habit in the United States. More than ninety persons had been with him, North Americans and others; he had treated them to champagne-punch, and it had been as late as ten in the evening before the last left him. In the same house where he resided, another suite of apartments was occupied by the Bolivian Chargé Terrazas, who, like Garland, had gone to Ancon to pay a visit to Rafael Canevaro. His wife, a stout chola woman, by 
no means disagreeable, received me. Her last journey from La Paz had taken her no more than seven days: five hours per coach from La Paz to the lake of Titicaca, less than twenty-four hours on the lake, per steamer to Puno, twentyfour hours per express train from Puno to Arequipa, one night's rest in this town, less than twelve hours from Arequipa to Mollendo, and the rest of the seven days per steamer from Mollendo to Callao. My fifth call was upon Isabel Coloma, widow of Carlos Canseco, who was kept in bed by a headache. Her two daughters, Juana and Maria, received. Old Basagoytia was there, and I remained nearly half an hour. At Dr. Zevallos', the ladies, indisposed, did not show themselves. I remained some time with Mrs. Juana Guise, and closed the round with a visit to Emilia Orbegoso, married to Vicente Gonzales; a headache kept her out of sight also, and her place was taken by Emilia, her daughter, married to the North American Engineer Dubois. My wife, to my great regret, had again been obliged to keep her bed. I was very sleepy in the evening, and in bed by ten.

Monday, $3^{\text {rd }}$ of January. Of the many disagreeable meetings which the Directory of the Banco de Lima had had of late, this day's was one of the worst. It commenced with Cucalon's unreasonable [requ] est that the gerentes should demand [...] [861] lawyer Aranivar a written answer to every question put to him by them, and quite as unreasonably Lembcke instead of answering coolly that this could not be done, flew into a passion, and said he would not do it. Next, Cucalon moved that of everything which in the book of actas treated on the Salitrera Esperanza, a copy should be drawn out and be ready by the fifth of this month. I proposed that instead of doing so, the gerentes might make a list of the dates, and of the pages in the book where this question was treated on, which might then be referred to in our meeting of the $5^{\text {th }}$ and thus the great labour of making out all these copies would be saved. Gallagher, however, sided with Cucalon, and the corresponding orders were given to the Gerentes. With the concession which in our last meeting we had made to Geronimo Sanchez, Cucalon, as might have been expected, was dissatisfied. As regards the affairs of Guimet, Lembcke stated that besides the $\mathrm{S} / 800$, advanced some time back, $\mathrm{S} / 1200$ more were asked for by the Interventor in order to pay the wages of the Chinese labourers, and to buy indispensable provisions. I was utterly at a loss what decision to take. On the one hand I feared that our advances would never be got back, and on the other hand I saw that if we did not pay the money, the Chinese would run away, and all would go to the devil. At last, after Aliaga had spoken on the subject in a very rational manner, all, except Cucalon, resolved that the $S / 1200$ should be paid. He gave it as his opinion, and begged it to be noted down in the acta that the Banco 
de Lima would never recover a rial of these $S / 2000$ advanced or of the entire debt of Guimet.

It was further resolved to send another $S / 35,000$ in notes to the Salitrera "Esperanza", and to order Prevost \& Co. of Iquique to sell the 45,00o quintals of nitrate which were disposable, at the best price obtainable. A draft for more than S/80,000 of the Bolivian on the Peruvian Government, accepted by the latter, to the order of Valdeavellano \& Co., endorsed by these to Derteano, and discounted by him six months ago to the Banco de Lima had fallen due within these last few days. Lembcke enquired whether he should insist on the payment, or take another draft for the same amount, with the interest added, due in the beginning of July. I was the first who said it would be better to get the money, and all went with me. Hereupon Lembcke read the usual statement of the affairs of [...] by no means satisfa[_] and this being done he said [862] decidedly that from this very moment, he threw up the gerencia, and then left the room. Aliaga gave an account of his want of success in getting money from Manuel Mendoza. He said that Mendoza was bitterly complaining, but surely without reason, of the severity with which the bank was about to proceed against him. Bernales proposed we should make another attempt to come to some friendly understanding, before proceeding judicially, and to this all agreed, out of consideration to Mendoza, none willingly. As regards Lembcke's resignation it was resolved that he should give it in writing, and I, accompanied by Cisneros, told him so. This month I was Director de Turno. It was a quarter past six when I came home. My wife was up, and well enough to go out with Enriqueta in the evening. Whilst they were absent I had a visit from José Maria Peña, wife and daughter.

Wednesday, $5^{\text {th }}$ of January 1876. At 2.30 I was in the office of the Water Company. Of the Directors only Rodrigo and Eguren were present. José Basagoytia, holder of many shares, came in by chance. Rey stated to us that the overflow of water which had occurred on the $31^{\text {st }}$ December at about 10 at night, and with which all of us were acquainted, had done some injury to the furniture in two houses, and to the effects in a shop in the vicinity of the Church of San Francisco. The owners claimed an indemnification amounting one with another to S/1020 from the Water Coy. to whose neglect, they, in a well written letter, attributed the loss which they had sustained. Rey explained to us how it had happened. No doubt the engineer had made himself guilty of some oversight, and we therefore instructed Rey to settle the affair quietly and as well as he could, without any noise being made about it, and taking particular care that our present concession should not serve as a precedent on a future occasion when the Company might not be culpable. 
In the Insurance Company "Lima" I merely looked in, and told the Directors assembled that they might consider me present, for without my presence there would have been no quorum.

In the Directory [_] the Banco de Lima Lembcke [...] [863] did not attend; neither did Mendoza, Gil, and Aliaga. The first thing we did was to read a letter directed to me by Garcia Calderon, in which he said that the other three banks having each named one of their Directors to form the administration board of the guano consignment to Mauritius etc., he expected that we would do the same. We did so, and the choice fell upon Pedro Bernales, who had seven votes, Cisneros one, the ninth in blank. In our answer to Calderon it was resolved to insist upon the necessity of a public document, or escritura, being drawn out, which was to set forth that the four banks had formed a company for the above purpose. Now Dr. Aranivar entered. The answer of the Salitrera "Esperanza" was read; it was vague and evasive; in fact, it merely said that they requested the Government to reconsider the valuation, which in their opinion was too low. Now a long discussion ensued, in which Aranivar took an active part, and we decided to make a petition to Government, which Aranivar dictated in an adjoining room, and in which it was said that the bank being in reality owner of the Esperanza, which owed S/1,200,00o Capital, and S/140,000 interest was quite willing to accept the $\mathrm{S} / 900,000$ which the Government had offered, and requested the Government to consider this their offer binding upon them. Whilst Aranivar was dictating this petition we occupied ourselves with Lembcke's resignation. I was the first to speak, and said that in my opinion we must admit it, though con "el mayor sentimiento", and that we having already resolved to convoke a general meeting of the shareholders for Monday next, then to treat on the "Esperanza", there was no necessity for naming a provisional gerente for these few days. After some observations of no importance all agreed with me. Next, Sagastabeytia said that he also was determined to retire from the gerencia, but on our begging him unanimously not to do so he ceded to our desire. Finally, we resolved to meet again on Saturday.

In the evening Rafael Velarde came to our house, and told us he knew for a certainty that the Superior Court in my case against Leyva had resolved this day to return all the documents to the "perito dirimente", Castañon, in order that he should amplify his opinion as to the meaning of the word "ayres", which he had given in writing, and which existed in the autos. Leyva and his fatherin-law had been with Col. $[\ldots]$ the father of the architect $[\ldots]$ him to make [...] hi[_] [864] influence with his son in their favor. Without loss of time the Colonel had informed Rafael that he had had such a visit; and now Rafael advised me, in the first place to go to the son, the architect, and speak with 
him on the subject, and secondly to make my lawyer Palacios bring his ideas to paper, which he, as if emanating from himself, would then take to the younger Castañon to serve as a basis for his scientific superstructure. Middendorf also looked in, and Enriqueta secured the votes of this gentleman, shareholder in the Banco de Lima, for Alejandro, who had started as candidate for the gerencia of this bank left open by Lembcke's resignation.

Thursday, $6^{\text {th }}$ of January. Holiday. Before breakfast I was in Dr. Palacios house, in the Calle de Gallinacitos; he was not in. I returned at 11.30, had to wait till he had done breakfast, and when I communicated to him what I had learnt from Rafael Velarde on the previous evening, he said he would at once go and see the architect Castañon. So he did, and it was nearly half past one before he came back. He said he had had a very long conversation, and that Castañon seemed to be well inclined towards me, of course for a remuneration, and that he intended to give a detailed and very scientific opinion. Palacios then wrote a few words which he said I might give to Rafael Velarde, but which in my opinion were good for nothing. On my return home it was near two O'clock. José Basagoytia, Manuel Mendoza, Dr. Bandini, Malinowski, came in one after the other, and detained me so long that I had merely time to call upon Dr. Melchor Vidaurre, President of the Supreme Court, where I met many visitors, upon Melchor Velarde, and upon Gaspar Puente, who, his young wife said, was indisposed. Finally, upon Doña Dolores Puente. Enriqueta's tertulia was more numerously attended than usual. I went over for about an hour, had a long conversation with José Maria Peña, handed the above paper written by Palacios to Rafael Velarde, and was in bed by half past eleven. My wife came two hours la[_].

Friday, $7^{\text {th }}$ ofJanuary. For the Gerencia of the Banco de Li[_] four candid[ates] [...] in the [_]ield Alejandro, Luis B. Cis [...] [865] J. M. Cantuarias, and Norman Evans, Bella Gallagher's husband. When Alejandro came to me, and asked me for my vote and assistance I answered that though Luis Cisneros had been with me beforehand, I would do for him what lay in my power, and so I did.

Saturday, $8^{\text {th }}$ of January 1876. Before breakfast I was with Castañon, who was very friendly, and to whom I gave to understand that his services to me would not be unrequited. He read to me his rough draft, which I told him was in my opinion not sufficiently clear. The paper handed him by Rafael was, he said, too straightforward, too naked, without any argumentation. I went to Dr. Palacios, who promised that he would see Castañon, and examine what he had written. At near 4 p.m. the Directory of the Banco de Lima met. Lembcke of course no more attended. Mendoza and Gil had for some time back withdrawn from our meetings, and Aliaga, Sagastabeytia had omitted 
to cite. Sagastabeytia, it was clear to me, was not the man for his situation; his partial deafness was also much against him. We agreed on the points to be be laid before the shareholders on the ensuing Monday. Cucalon as usual made himself remarkable by his loud talking, and his incessant observations. Gallagher was neither a quiet discusser; his opinions were however very sound, and well founded, and I generally agreed with him.

Sunday, $9^{\text {th }}$ of January. Before breakfast I was in the Church of the Merced at the funeral of Doña Rosa Garcia, widow of Wm. Robinet and mother of Rosa, Peter Conroy's widow. She was nearly related with the family of the Garcias, and Garcias y Garcias, had many friends, and thus the church was well filled.

In the course of this forenoon, I concluded my long list of visits. I went to see Doña Pancha Cardenas, wife of Gregorio Benavides, who lived over the way in the house formerly Juan de Ugarte's; upstairs I saw a sister of the Coxes, daughter of the late William Cox of Trujillo and widow of a German, Charles Minks, who had resided in Lima a few years back. I was quite surprised to find her such a pleasant woman as she was. Thirdly, to Augusta Bergmann, Meceno Espantoso's wife, who was already now as stout as her late mother was at [...] of [_] decease [...] not so [...] Doña Estani[_] [866] but I preferred her character. Fourthly, to Antuca Morales, the unmarried daughter of the doctor. She was bathing, and I spoke a few words with her youngest brother, clerk in the Banco del Perú, who complained that this year the bank did not give the usual yearly gratification to their clerks. Fifthly, to Rosa, the wife of Manuel Francisco Benavides, where the servant told me that her mistress was not in. Sixthly, to Dr. José Luis Gomez-Sanchez, who was beyond measure polite. Whilst I was with him two gentlemen came in; they remained but a few minutes, and when they were gone I learned that the one was Dr. Galindo, whom, to my regret, I had not recognized. Next, Dr. Lizarraga entered, who, an intimate friend of the late J. G. Paz-Soldan, corroborated what I have said above, that his death was owing to his irregular way of living, and to his great gluttony. Seventhly, at Manuela Orbegoso's, the wife of Federico Panizo, whom I intended to thank for the interest she had taken with Dr. Corso in our behalf, the drawing-room was open, but nobody was to be seen. The very small room at General Freyre's was nearly filled with the few persons present; he, his wife, Juana Rosa Moreyra, his sister-in-law Mariana, married to Charles Hülsenbeck, a German who resided near Düsseldorf, and whom probably she would never rejoin; his son, a Peruvian naval officer, and wife, and myself. Finally to Dr. Morales, who was always very friendly; fortunately Galindo and his companion entered, and I could make my excuses to the former, for not having recognized him at Gomez Sanchez'. Now, of all my acquaintances the only one whom 
I had not visited was General Miguel Medina. Being Sunday, Mariquita and I dined with Enriqueta. Six little girls sat down with us: the two Garlands, three Basagoytias, and a little friend of the latter, Maria, daughter of a certain Palacios who once upon a day was Intendente de Policia, and of his wife Mercedes Villacampa. After dinner these little creatures made me play with them at hide and seek.

Monday, $10^{\text {th }}$ of January. There was to be a [...] [867] meeting of the shareholders in the Water Company, but as usual the requisite number did not appear, and nothing was done. For a short time Rey, Garcia Calderon and I were by ourselves, when Calderon, who had full power from the Goyeneches, complained that in the new house of the Goyeneches, in the same street as mine, they had not a sufficient supply of water, whereupon Rey very politely but distinctly told him, and at the same time me, that in reality neither the Goyeneches nor I were entitled to have water upstairs. In the time of the Spaniards the noble owners of several large houses in the town had a right to a certain quantity of water gratis, but as at that time no house had an upper story, the right to the water was limited to a certain height above the ground. When the water company was established all the old conducts were destroyed, but the water company bound itself to furnish the same houses with the same quantity of water which they formerly had had. Nothing was said about the height to which the water was to be carried. Calderon acknowledged the justice of these observations, and would consider them. When I was with Rey by myself he said "go on in your house as hitherto, and say nothing more about it." From the Water Company I went to the Banco Hipotecario where I waited till Oyague and Aliaga came. Various questions were laid before us by Gallagher, none of great importance, and all were quickly and easily dispatched.

At somewhat past 7 p.m. I was in the Banco de Lima where the gathering of the shareholders was numerous. About 8 , I took the chair. To my left sat Gallagher, then Luis Cisneros, to my right the secretary Bernales. When the names of those present were called over, which Bernales did, and the Concurso of Zaracondegui was mentioned, a dispute arose between Aurelio Dinegri, who pretended that Zaracondegui's shares were his, in virtue of a judicial award, and José Luis Bernales, the Sindico of the Concurso. I proposed over and over again to leave the decision of who was right to the shareholders who were present, but this Bernales decidedly opposed because he, as Sindico, had a right to represent the shares, which [_]ight nobody could take from him. This dispute took up more [...] hour till at last Dinegri with [...] Then [_] [868] acta of last meeting was read, and signed by me without any observation being made. I then said that only three points were to be discussed 
in this extraordinary meeting; firstly, the debt of the Salitrera "Esperanza"; secondly, the resignation of the gerente Lembcke; and thirdly, the difference between the Directory and Dr. J. M. Cárdenas. José Luis Cisneros read from the actas of the Directory various extracts relative to the Salitrera, our late correspondence with the said company; and the petition which the Directory intended to present to the Government. The question which I put to the shareholders was "did they approve our petition?" A long discussion took place, in which L. B. Cisneros, Gallagher, Derteano, Cardenas, and Dr. Aranivar took an active part. Pratolongo asked whether any shareholders in the Esperanza were still in the Directory. I answered him that Gil and Lembcke, the two shareholders, had both retired. Basagoytia, shareholder of the Esperanza, counselled an understanding between the bank and the Salitrera; Pedro Bernales was similarly inclined, and finally two motions were made, the one by Derteano, to the effect that the ulterior management of this affair should be left exclusively to the Directory; the other by Cardenas, who proposed that the shareholders should first decide whether the petition to the Government should be presented or not. Derteano's motion was carried by a majority of about three to two. Of the Directors only Cisneros voted, and in the negative. It was eleven when we broke up, after a meeting of the Directory had been convened for the next day.

Tuesday, $11^{\text {th }}$ of January 1876. At about 4 p.m. seven of the Directors of the Banco de Lima, the number requested to form a quorum, sat down, viz.: Bernales, Cisneros, Aliaga, Armero, Barrios, the Gerente Sagastabeytia, and I. Dr. Aranivar joined us and without much discussion we resolved that a letter should be written, of which Cisneros made the draft, to the Directors of the Salitrera Esperanza, and be dispat[_] without lo [...] which we requested the [_]sence [...] [869] them at the session of the Directors of the Banco de Lima, which would take place next day at 7.30 p.m. We decided that the Salitrera should accept the price of expropriation which the Government offered for their establishment, say S/900,000 at the exchange of $44 \mathrm{~d}$, and as at the present exchange this would amount to more than one million Soles of the present paper currency, the bank would content itself with the million, cede the surplus to the Salitrera, and thus be a loser for $\mathrm{S} / 200,000$ besides $\mathrm{S} / 144,000$ interest of last year. If the Salitrera would not consent to this very rational proposal, we were resolved to continue our judicial proceedings, and bring the Salitrera to the hammer.

Wednesday, $12^{\text {th }}$ of January 1876 . Garland and Enriqueta went to the tertulia of the Basagoytias where the wife of the vocal Corso, whom Enriqueta had never seen before, sat down near her, spoke about the lawsuit against Leyva, 
and assured her that her husband was very well inclined towards me, but that everything depended upon Castañon's definition of the word "ayres". Enriqueta heard also some one, very likely a certain Barrionuevo, Vocal of the Superior Court of Puno, speak of the previous nights meeting in the Banco de Lima, and complain of the President - that is to say of me - "who was not fit for his situation, who had not sufficient energy to impose silence on the two malcriados" - Aurelio Dinegri, and José Luis Bernales. The wife of my lawyer Dr. Palacios was on the point of being confined, and thus this day he could not attend to any business, either his or mine, which was very annoying.

I went to Rafael Velarde, who told me that I need not make myself uneasy, and that Castañon's written opinion would be exactly as I could wish it to be, this, he said, he guaranteed to me.

My wife, without my knowledge, went to see Castañon's wife, and on her return told me that she had been extremely well received. Dr. Palacios, the whole day long, was with his wife, and not in his office.

In the evening at about eight the same whom I enumerated yesterday met in the Banco de Lima. We were joined by José Basagoytia and a Frenchman, who had the full power of Errequeta and Heudebert which two were commissioned by the Directors of the Salitrera, to treat $[\ldots]$ They agreed to the condition detail $[\ldots]$ the previ $[\ldots][870]$ to which was added, after a short discussion, that if the Salitrera were to receive hereafter more than the $\mathrm{S} / 900,000$ offered by Government, of such amount, up to $S / 500,000,50 \%$ were to be paid to the bank, and of any amount above $S / 500,000,15 \%$, of course only up to the amount due by the salitrera to the bank for capital and interest. Amongst the Directors the great debate was whether the representation to the Government, to be given in before the $15^{\text {th }}$, should be drawn out by the Salitrera or by the bank. Bernales insisted with great energy, and with much show of reason upon the latter; Dr. Aranivar, Cisneros, and Gallagher were for the former, which was finally resolved. I took no part in the debate, because I was unable to decide. Another condition of the agreement was that if the government finally did not pay the $\mathrm{S} / 900,000$ in good drafts at $44 \mathrm{~d}$ on London, then the bank would resume all its previous rights upon the Salitrera. If the Salitrera did not present its petition to the Government on the $14^{\text {th }}$ the bank would present its recurso on the $15^{\text {th }}$. A new meeting was convened for next evening to read the minuta drawn out by Aranivar. I came home at about eleven O'clock.

Thursday, $13^{\text {th }}$ of January 1876 . About noon I met Basagoytia in the street, and went with him to the Banco de Lima when he told Sagastabeytia and myself that the Directors of the Esperanza had approved the agreement made on the previous evening, with one exception, which was that of the S/900,00o, 
S/100,00o they wanted for themselves, so that only $S / 800,000$ would remain for the bank. I requested Sagastabeytia to call a meeting of the Directors for 3 O'clock. At home I made a calculation, which showed that S/800,000 at $44 \mathrm{~d}$ and reduced to Soles again at the present exchange of $34 \mathrm{~d}$ were equal to $\mathrm{S} / 1,035,294$ that is to say, the bank would gain $\mathrm{S} / 35,294$. If the exchange were to fall to $36 \mathrm{~d}$ the result would be $S / 97,777$ or a loss to the bank of $S / 22,223$. At 4 od the $S / 800,000$ would give $S / 880,000$ or a loss to the bank of $S / 120,000$. This calculation I showed to several of the Directors, and all, Gallagher $[\ldots]$ Sagastabeytia excepted, resolved that [...] [871] should be made to the Salitrera. Cisneros wrote a draft of the letter to that effect. Cucalon and Castillo voted with the majority. Aliaga did not attend; Dr. Aranivar did. In the evening I did not go to Enriqueta's tertulia, which, I heard from my wife when she came to our bedroom at 1.30, had been very numerously attended.

Dr. Palacios was again in his study, and promised not to let Castañon out of sight. On the previous night his wife had been brought to bed of a little girl, and was doing well.

Friday, $14^{\text {th }}$ of January 1876 . Once more a meeting of the Directory of the Banco de Lima at 2 O'clock convened by the Gerente, and at the same time by Cucalon. The former made known that the Esperanza had abandoned their claim for the $\mathrm{S} / 100,000$ spoken of on the previous day, but wished that it might be made quite clear that if, owing to some unexpected fall in the exchange, the $\mathrm{S} / 900,000$ at 44 pence to be received from the Government, did not come up to $S / 1,000,000$ the bank had no further claim on them than the $S / 900,000$. This was agreed to. Cucalon was of opinion, like Bernales, that it would be safer that the bank should present itself to the Government, and not the "Esperanza". Dr Aranivar however convinced him of the contrary, and he gave in. Bernales persisted. At 7 p.m. Sagastabeytia came to my house, and said he required a new meeting at eight. At 8.30 we sat down. Gallagher and Castillo were wanting, Aliaga was present. The Gerente said that it had come to his knowledge that the "Esperanza" had already presented a petition to the Government in which they had requested the reconsideration of the valuation of S/900,00o to which the Government had given a decidedly negative answer, and fears were now entertained that a new petition of the "Esperanza" would not be admitted by the Government. Bernales was of opinion that it would be well to call in José Vicente Oyague, because he was one of the largest shareholders, and intimate with the President and Finance Minister. I offered to go for him, which proposal was readily accepted. Sagastabeytia accompanied me. We drove to his house where we were told that he had just gone with two of his young daughters [_] a juvenile party given by Frederic Marriott, to celebrate 
the birth- [...] his daughter Maria. Maria and [_] Garland had [...] [872] been invited. Whilst one of his sons went for Oyague, Sagastabeytia and I conversed with his agreeable lady Isabel Soyer. After ten minutes or a quarter of an hour had elapsed the son came back with the message that Oyague wished us to see him at Marriott's. Sagastabeytia would not go, and I drove thither by myself. Oyague said he could not possibly leave his daughters, not even for ten minutes, they having been especially recommended to his care by Mrs. Oyague. I then explained to him why we wished his presence in the bank, when he told me in the clearest terms that if the bank presented a new escrito to the Government accepting in straightforward terms - llana y lisamente - the S/90o,ooo at 44d without making the slightest reference to the previous petition, he had the firm conviction that the proposal would be accepted - no seria rechazado. This he repeated to me twice. I drove back to the bank, and communicated to those assembled the very words which Oyague had told me. Hereupon it was resolved that the Esperanza should present the petition, and the bank another, confirming that of the Salitrera. Cucalon at the very last moment moved that a general meeting of the shareholders should be convoked for Wednesday next, and this was resolved, for Aliaga and I voted with, Barrios and Armero against him. Cisneros and Sagastabeytia would not say either yes or no.

This day in the forenoon Palacios commenced in the Supreme Court his pleading in Schutte \& Co.'s case against Garcia Calderon.

Saturday, $15^{\text {th }}$ of January 1876 . When I went to the Banco de Lima to enquire how things were going on, Sagastabeytia told me, and Oyague confirmed it to me at a later hour, that the previous evening at Marriott's, when I had gone, the President Pardo had come in, that Oyague had consulted with him about the Esperanza, and been told that if the "Esperanza" did not withdraw the former escrito, in which they had asked for the reconsideration of the valuation, their present proposal, in which they declared themselves satisfied with the S/90o,ooo could not be admitt[_]. [873] Accordingly, an addition was made to the Esperanza's petition and both this and that of the bank were handed in to the Government before 5 O'clock in the afternoon, the last hour allowed by the Government. At the usual time, about four, Oyague, Jimenez, and I met in the Banco Hipotecario, when we were mainly occupied with listening to the extensive and detailed memoria to the shareholders, in the drawing out of which Garland had spent many an hour. Oyague, with his customary importance, introduced some trifling, almost ridiculous, alterations. The expression which I disapproved of, and which was altered, was "el exacto conocimiento" which the new Directory had of the defraudation of Soyer, which was changed into "el pleno convencimiento". In the Supreme Court, 
Dr. Fernandez Palacios for Garland, and Dr. Francisco Garcia Calderon for himself, concluded the pleading.

This day my wife engaged as her companion, particularly to be with her in the evening, when I was absent, a very respectable elderly lady, Angela Villena, aunt of Nicolas Pierola. Her servant girl came with her and to my great joy we got rid of a servant woman whom we had had for some time, Isabel, and her three children. She washed fairly, the only thing to be said in her favor; she was beyond measure, dirty, forgetful, talkative and noisy. In the Comercio appeared a representation made by a certain Almonte, in which he stated that he was the owner of a tract of Nitrate-producing land in the province of Tarapacá, known as "Las Lagunas", that he had let this land to a joint-stock company called "La Esperanza", for ten years; that of these ten years, one or two had elapsed, and that he as the real owner opposed himself to the sale which he knew the "Esperanza" was about making to the Government of the time the lease had still to run, of the railway, the machinery, various buildings etc., which the "Esperanza" had constructed upon his property.

A telegraphic dispatch was received from Puno, advising the death of Manuel Ferreyros, late gerente of the Insurance Coy. Lima.

Sunday, $16^{\text {th }}$ of January 1876 . Dolores Harmsen of Arequipa wrote Enriqueta that the Bank of Puno had been sacked, probably by the Indians. Rafael Velarde, on whom I called in the forenoon [...] to me a letter received from Ugarteche of Arequipa, $\operatorname{Pr}[. .$.$] [874] brother-in-law, who merely said that there had been$ a trifling rising in Puno, which had been easily quelled. I called on a few of our acquaintances, to tell them that on the following day my wife intended to remove to Chorrillos for a short time.

In the evening we had with us Rafael Velarde and wife, also Guillermo, with Eliza.

Monday, $17^{\text {th }}$ of January. We rose early. I had a good deal to do with our preparations, packing up etc. At ten I sent off our luggage to the Chorrillos terminus, under the care of Serapio, apparently an honest man, husband of Isabel, whom we had just turned off. At noon my wife, Enriqueta, Doña Angela Villena and I, with the servant Serapio, the Chinese Ayao, and Doña Angela's girl Isabel, followed for the same destination. When we arrived at our rancho there was no water. I with Serapio went in search of a member of the Municipality who had to attend to the water, but had to return without having found him. I then ordered Serapio to open the water-key in the street without waiting for any further permission. I also went to the Gas Coy., where I ordered coal, and obtained one of their employés to look after our metre. When the luggage had come, Enriqueta busied herself in arranging everything, 
in which Doña Angela rendered some assistance. My wife was very unwell, and so weak that she could hardly move. Antonio came, and with him his mother returned at 4 O'clock to Lima. At the same hour I went to bathe. To me it seemed that the sea had retired since last year perhaps eight yards. Others told me that it was not the sea which had retired, but that the sand had accumulated, and thus raised the bottom. Our cook Achipe had also come down, and he gave us the usual dinner, near seven O'clock. At a later hour I had my tea. Baltazar Aranivar - el cándido - with his wife Adela, came in, so did Alejandro and Enrique. I had to look round that all doors were properly shut, and at about half past ten we retired to rest.

Tuesday, $18^{\text {th }}$ of January. I awoke by daylight at half [...]. [875] We all rose early. My wife had slept well, which for a long time past she had not done in Lima. By seven I was again in the water, which was very cold; the sun was not out. I walked as far as the extremity of the mole without the water coming up to my breast. By the nine train I returned to Lima, and took my breakfast with the Garlands. From Andrés Rey I received a note informing me that I had been re-elected one of the Directors of the Water Company. Instead of Meliton Porras, who had gone out, José Basagoytia had been chosen.

At 2.30 the Insurance Company Lima had its usual annual meeting of shareholders in the Exchange Rooms. Moscoso Melgar presided. Elizalde as Gerente sat next to him. Of Directors, Carrol, Peña, and I attended, and five other shareholders were present. All went on quietly and smoothly. J. M. Cardenas voted thanks to the Directory. In lieu of four Directors who had gone out, viz.: James Henry, absent, Carlos Elizalde, who had been named Gerente, and Carrol and Gil, drawn by lot, four were unanimously named: Michael Carrol, Valentin Gil, M. G. Chavez, and A. Robertson of Sawers Woodgate \& Co. I dined with the Garlands. Mr. Bryson read to me Margaret of Anjou in Miss Strickland's Queens of England, Enriqueta sent me a bowl of tea and I was in bed before nine.

Wednesday, $19^{\text {th }}$ of January 1876. I was up by 6. At 7.30 I was in the Chorrillos terminus where Josefa Velarde, cousin of my wife, she being the daughter of Manuel, one of the brothers of my wife's mother, was waiting for me with one of her daughters, a grown up girl, Felicita, who was to stay some time with my wife in Chorrillos. She and I arrived there at about 8.30. The day before my wife had been very unwell, so much so that Doña Trinidad, General Cisneros' wife, had called in Dr. Ulloa, who, though he had given over practice, had, at Trinidad's earnest request, prescribed some medicine which had had a beneficial effect. Nevertheless, Doña Angela had been up the whole night to attend to my wife's wants. I bathed, breakfasted with Doña Angela and 
Felicita, and when I was on the point of returning to Lima by the 11 O'clock train, Enriqueta and the two [...] girls arrived to remain till four. At 1 I [_] to [_] [876] notary Escobar, when his clerk Orbegoso told me that the autos had been returned by the architect Castañon, together with his written opinion, which, Dr. Palacios told me, he had seen, and considered satisfactory. The forenoon I was at home.

In the Eclectic Magazine we found an amusing article on the Duc de St. Simon, and his writings, which gave a true account of the wonderful state of despotism on the one, and the equally surprising servility on the other hand, which Louis XIV had established at his Court. Much of it was already known to me; nevertheless, I listened with great interest.

Enriqueta and children came by the train which arrived at half past six. I was waiting for her at the station, and she told me that she had left Mariquita sound asleep. Bryson read as usual, and we finished the life of Margaret of Anjou. Enriqueta and the children rather tired had gone to bed. Garland and all the young men were out. I took my tea and retired to rest at 9.30.

Thursday, $20^{\text {th }}$ of January. I was up early. The negro woman Aurelia was sent to Chorrillos with clean linen of which my wife stood in great need. Enrique, who came in from Chorrillos had seen her this morning, and found her pretty well. I went to the notary Escobar and asked him whether the autos would now be sent up to the Superior Court. He enquired at Dr. Quiroga's what was to be done, and brought the reply that, as Leyva and I had been notified the previous day, three days must again elapse before this step could be taken. Dr. Palacios considered this out of order, but counselled me to keep quiet in order, as he said, not to stir up a wasp's nest. At the usual hour I was at the Banco de Lima but no more than six Directors, not sufficient to form the quorum, having made their appearance, I went at four to the Banco Hipotecario, where Jimenez and I had, as alw[_] to wait for O[_]. Perhaps as many as ten [...] [877] proposals made by debtors to the bank, Gallagher laid before us, and we unanimously resolved what was to be done. Some we admitted, others we rejected. On one point, however, Jimenez and I decidedly opposed Oyague, and though strictly speaking we had the majority we preferred calling in another Director before taking a resolution. In a former meeting we had agreed that $5 \%$ dividend for last year should be paid to the shareholders in Cedulas at $75 \%$. Both gerentes called our attention to the following, firstly, that the bank would give its own paper at a discount, which it ought not to do; and secondly, that by giving the Cedulas at $75 \%$ the bank would suffer a heavy loss, for they had actually cost $100 \%$. These reasons were to me convincing, and consequently I gave it as my opinion that we should pay them to the shareholders at par, not at a 
discount, nor did I allow myself to be moved, by Oyague's talking, reasoning I could hardly call it. We broke up at six. I took the half-past six train and reached Chorrillos by seven, where I found my wife so unwell that without loss of time I went in search of Dr. Middendorf whom I expected to find at Macandrew's, but he not being there, I hurried to the shop of the apothecary who gave me the names of several medical men residing in the place of whom I gave the preference to Dr. Aranda, $\mathrm{N}^{\circ} 14$ Calle de Tarapacá. Though suffering from a cold he accompanied me to the rancho and prescribed an injection and some powders which I fetched from the apothecary's and whilst they were administered I sat down to my nine O'clock dinner, and excellent beefsteak from the hotel, two soft-boiled eggs, and two cups of tea. My wife told me she was well pleased with Doña Anjela, Felicita, and the two servants Serapio and Ayao. Achipe had been again obstreperous.

$[878]$ 
Index

1868

Mar. $\quad 20$ to 31 Our residence in Chorrillos (2) - Yellow fever $(2,5,7,9$, 14-16) - Municipality beleagured for certificates of citizenship (2) - Resignation of Earl Derby (2) Differences between President Johnson of U.S. and his Ministers (3-4, 12, 15) $1-16$

April 2/3 Elections in Lima (3-5) - D'Israeli Prime Minister (4) 3-5 April 8 Arrival of Leon Dreyfus

Departure of the family Schutte and of M. Porterie for Europe - Departure of Stgo. Tavara for Payta -

Garland and Juan in charge of Schutte \& Cos. establt. $\quad$ 5-6

April 24 Death of Fermin Miota and others

May 3

Death of Richard Eggert (7) - and a son of Manuel

Pardo (8)

$\begin{array}{ll}\text { May } & 7 \\ \text { May } & 8\end{array}$

Proceedings of English army in Abyssinia

Contract with Henry Meiggs for railway from Coast to Arequipa

May 11

Departure of Juan for Chile

May $\quad 13 / 16$

Death of Toribio Pacheco - Result of Lima elections

Day spent in J.

. G. Paz-Soldan's chacra San Isidro

10-11

May 18

Death of Edmond Lesseps French Charge

11-12

May 19

Attempt to murder Prince Alfred in Sydney

Duel of two Russian Ambassadors

June 3

Death of Lord Brougham

Cause of Abyssinian Expedition (14-15) - Result of

Abyssinian Expedition (17-19)

Life in Chorrillos

July 4

Voyage and arrival of the Schuttes in Europe

Return of my family to Lima, and life there

Qualification of Senators and Deputies - Rafael

Velarde qualified

July $\quad 21 / 3 \quad[\ldots]$ late Ramon Castilla

July 25/7 Dinner given by Beneficencia to Manuel Pardo 
July 29 to Horse races - Cordes' illness - Death of Felipe Barriga

Augt. $\quad 2$

Augt. 2/5 Death and funeral of Juan Aliaga y Calatayud

Augt. 4

José Balta, President - and his cabinet

$24-25$

Augt. 4

My opinion of Goethe's Wilhelm Meister

Augt. 12

Juan's return from Chile

26

Augt. 13

Marriage of José Maria Sancho-Davila - Earthquake

26

Augt. 14

Meeting of the Diplomatic and Consular Bodies

27

Augt. $\quad 16 / 18$

Marriage of Juan Aliaga y Puente

Augt. 20

Consequences of the earthquake of the $13^{\text {th }}$ in

Arequipa, and all along the Coast

Augt. 20

Attempt to assassinate Carmen Vidaurre

Augt. 29

Augt. 29

Ill success of my law-suit in the Superior Court

Septr. 3

Meeting at Telegraph Coy. - Death of Thos. Podmore

I engage George Graham in lieu of Barker

Septr. 3

Earthquake in Ecuador

36

Septr. 3

Reappearance of Encke's Comet

36

Septr. $12 / 21$

Death of F. Cordes on the $11^{\text {th }}$ Augt.

Septr. $12 / 21$

Death and biography of Stanhope Prevost

37,39

Septr. $12 / 21$

Death of wife of Andres Alvarez Calderon

38

Octr. 9

Election of Francisco Diez de Canseco, $2^{\text {nd }}$ Vice President

Octr. 16

Swindling transactions of Mo. Osma and a certain CeliI take shares in the Huach, and in the Pasco Railways

I lose my suit in Superior Court - Successful revolution in Spain

Octr. $\quad 26$

Death of Josefa Palacios

Novr. 6

Losses of the Paraguayos

Novr. 17

Death of Juan Lavalle

Novr. 19

Evening party at Manuel Mendoza's - Garland's

Thursdays tertulia

$\begin{array}{lll}\text { Novr. } & 21 & \text { My wife's birthday } \\ \text { Novr. } & 30 & \text { Insurance of my house and furniture Calle del Correo }\end{array}$ (45) - Dr. Teodoro de la Rosa, Minister of Justice (45)

- Difference between the Govt. and Bishop (46) [...] 45-[_]

[880]

1868

Dec. 12 Appearance of an Indian from the Montaña Eruption of Vesuvius - Death of Rossini - of the Archbishop of Canterbury - of Baron Lionel

Rothschild - and of Cheatham former clerk of Cordes 
Dec. $12 \quad$ Election of Grant, President of the United States 47

Dec. 13 Dinner party given at J. G. Paz-Soldan's

Dec. 14

My wife's sudden illness

Dec. 17

Financial difficulties

$48,50-51$

Dec. 18

Death of General Wright

$5^{0}, 5^{2}$

50

Dec. 24

Lawsuit agst. Sotomayor - Resignation of Finance

Minister Garcia Calderon

$51-5^{2}$

$5^{2}$

Dec. 25 Death and funeral of Felipe Pardo

Dec. $28 \quad$ Funeral ceremonies in honor of Genl. B. O'Higgins

1869

Jany. 1/4 My law-suit agst. the Sotomayors

63,66 , $70,76-77$,

$84-85$, $87-88,91$, 94, 105, 108-109, 113-115, 118-119, 126,128

Jany. $\quad 1 / 4 \quad$ Tories out, Whigs in

Death of Mrs. Sealy and Doña Francisca Rocafuerte

Mariquita's relapse

Nicolas Pierola Minister of Finance

Scene between President Balta and Amunategui

Meetings of shareholders of Pasco R'way Coy.

60,63

Removal to Chorrillos

Meeting of the Shareholders of the S.A. Insurance

Coy.

62

Jany. $\quad 29$

Instalment of the Comision Permanente

Jany. 30

Meeting of shareholders of the Huacho R'way Coy.Assault of Mariano Osma upon Gaspar Puente

Feb. 3

Charles Duval engaged by me - Dr. Pedro Carbajal and family 
Feb. 3 Revolution in Ecuador in fav. of Gabriel Garcia Moreno

Feb. $\quad 7$ to 28 Stay with the Garlands in Lima (66) - Monk Zapata (67) - Ascent of San Cristoval (67) - Banco Hipotecario (67) - Wreck of Str. Santiago (68) Accident on Lake Titicaca (68) - Arrival of Chinese Actors in Lima (68) - Opening of Suez Canal (68) - Death of Ed. Sieveking of London (69)

March 1 to 11 Return to our house Calle del Correo (69) Mariquita's and my testaments (70) - Rafael Velarde, visitador of Cm. Houses (70) - New Guano Loading Coy. (70) - Loan by Guano consignees to Government (71) - Fire in Valparaiso (71) - Rising in Cuba (71-72) - Establishment of Banco de Lima (71, 74) - Juan takes shares in Banco del Perú (71) Dinner in Palace (71) - Tomas Mosquera (72)

12 to 31 Callao Cm. House Employes discharged (73) Foundation stone laid of Puente Balta (73) - My visit to Chiarini's circus (74) - Yellow fever (74) - William Harmsen and successor (74-75) - Municipality in Lima (76) - Convention for cutting Darien Canal (76) $73-76$

April 6

Family of Schutte in Paris

Grant, President of the United States

May 14 Osterling chief of Alsop \& Co. (83) - Cuban insurgents recognized as belligerents by Peruvian Government (83) 
May 19 J. A. Garcia y Garcia's purchase of two Monitores in the U. States

May 19 Enrique Garland enters the house of Schutte \& Co.

May $29 \quad$ Suit agst. Sotomayor gained $85-86$

June 7

Conclusion of interoceanic Railway

June 14

Rising of Indians in Cañete

June 23

House Calle de Zarate delivered to me

Departure of Andres Alvarez Calderon [...]

Death and funeral of Theordore Müller, Consul

General of North German Confederation

July $\quad 15 / 16$

Death and funeral of Estanislao Bergmann

89-90

July $\quad 15 / 16$

Prophecy of astronomer Falb

90

July $\quad 15 / 16$

Peruvian financial operations

July $\quad 15 / 16$

Difficulties of Templeman \& Bergmann

91-92

July 17

Inauguration of Pisco/Ica Railway

92

July 19

Meetings of shareholders of Gas Company

July 20

Callao Muelle Darsena

July $\quad 26$

Rafael Velarde, Minister of the Interior

July $\quad 28$

Exhibition of Peruvian Produce and works of art

July $29 / 3$

Celebration of anniversary of Peruvian Independence

Augt. $\quad 1 / 8$

Arrival of Augustus Dreyfus and others

Augt. 9

Particulars about Dreyfus - Amputation of Josefa

Bazo's arm

Augt. 9

Death of Miguel Carpio

Augt. $\quad 15$

Guano consignees propose making a loan to Govt.

Dreyfus contract with Government accepted

Petition of Peruvian Capitalists against this contract

Augt. 20

New transatlantic submarine cable

100

101

Augt. 22

Sentence of Supreme Court in favor of Peruvian

Capitalists

101

Augt. $\quad 28$

Disputes between Dreyfus and Peruvian Capitalists

103-104,

110

Septr. 2

Death of wife of Dr. J. M. Perez

106

Septr. 3

Banco de Lima decides not to lend money to Dreyfus

107

Septr. 9

Earthquakes and apprehensions 108-109, 
Septr. 9 Death of Teresa, daughter of Henry Sieveking and his wife

Septr. 19 Favourable sentence obtained by Juan Aliaga y Puente - not against me 110

Septr. 23 Marriage of Adela Velarde with Baltazar Aranivar 112 Septr. 25 Sentences of Supreme Court in Dreyfus' case 113,115 , 120

Septr. 30

Repairs in house Calle de Zarate 114,116 , 120

Octr. 3

Maria Gaenslie engaged to George Semper 115

Octr. 8 Treasury Bonds 116

Octr. $\quad 22$

Resignation given in by La Rosa, Barrenechea and Raf. Velarde 118 [_] Resignation of Pierola

Party at Rafael Velardes on his saints day 119

Oct. 29

Nomination of four new ministers

Nov. 6

Death of Adela Luzarraga, widow of Tomasa

121

Nov. 6

Père Jacinte's opposition to the Pope's infallibility

Nov. 6

Advices from Frances Cresswell in Winchmore Hill 122

Nov. 13

Party at Diego Masias' on his Saints day

Nov. 16

Removal of Garland's family to Chorrillos

Nov. 17

Nov. 21

Death of Earl Derby

Party in Chorrillos on my wife's birthday

Nov. 23

Incidents of Dreyfus contract

Nov. 30

Disagreement between the Govt. and Bishop Huertas of Puno

Dec. 8

Schutte \& Co. deprived of Guano consignment and consequences

Dec. 15

First mention of Ferrinafe - Eten Railway Coy.

Dec. 20

First mention of Aerial Railway

Dec. $\quad 26$

Death of Thomas Buckley

Dec. $\quad 27$

Dec. $\quad 28$ Arrest of Emilio Althaus (132-134) - Concession to

Meiggs of Railways to Puno and to La Oroya (132)

1870

Jany. 1

Congratulatory visit to President 
Ascents of San Cristoval, 135, 137, 140, 143, 154, 185, 201

Meetings of Directors and Shareholders of:

Banco de Lima, 136, 146-147, 154, 168, 179, 217

Banco Hipotecario, 137

S.A. Insurance Coy., 141

Eten Railway Coy., 196

Lima and Huacho Coy., 192

Pasco Coy., 141-142, 192, 196, 210

\section{Deaths}

Samuel Bright, 148

Tho. Valle, 155

Ybarra, 155

Lopez, Prest. of Paraguay, 157

Burlingham, Chinese Diplomat, 157

Enrique de Bourbon, 157

Ma. Flores, 157

Lino de la Barrera, 157

Eloiza Gomez-Sanchez, 158

Enrique Berckemeyer, 158

My aunt Frances Willink, 160

Urquiza, 160

Buenaventura Seoane, 161

Barrenechea, 165

Charles Dickens, 172

Hen $[. .]$.

[884]

1870

Jerome Bonaparte Jr., 172

Earl Clarendon, 179

John Dartnell, 187

Lacroix, 193

B. Browne, 205

J. M. Goyeneche, 208

Josefa Arauzo, 212

Wife of Dr. Morales, 213

Jany. 6 Dinner at Manuel Velarde's 
Jany. 14

Final settlement with the Sotomayors

Jany. 15

Jany. 15

Jany. $\quad 16$

Jany. 22

Jany. 22

Jany. 29

Feb. $\quad 12$

Feb. 13

Feb. 13

Feb. $\quad 26$

Feb. $\quad 26$

Mar. 5

Mar. 5

Mar. 14

Mar. 20

Mar. 28

Mar. 28

Ap. $\quad 2$

Ap. 9

Ap. 10

Ap. $\quad 16$

May 11

May 13

May 13

May 18

May 19

May 25

[885]

1870

May 30

June 1

June 1

June 1

June 19

Possession given of the same

Dreyfus' affairs

My way of living

Railway Coy. (144)

Victor Noir shot by Pierre Napoleon

Henri Rochefort

Repairs of house

Nicolas Pierola, Finance Minister

Uncommon rise of the Rimac

Lima-Chancay Railway

Ball in honor of the President Balta

Unfavourable state of my finances

office

I much indisposed

Mr. Ochsenius

Lawsuit against [_] M. Varela

Accident on the Ancon Railway

Accident in Richmond, United States
Purchase of four shops Calle de Zarate

Resignation of Vocal Franco. Javier Mariategui

Loans to Cotes and Althaus (143), and Pasco

Dinner at Arthur Heeren's in Chorrillos

Signing of convention for cutting Darien Canal

Excursion per rail to river Chillon and back

$\$ 60,000$ borrowed from Oyague (153) - Daring

robbery on the other side of the bridge (153)

$\$ 60,000$ borrowed from South Am. Ins. Coy.

Enrique Garland left Schutte's entered Meiggs'

Constitutional Govt. introduced into France

Marriage of Rufino Torrico and Maria Araoz

Drunken bout of Melgarejo (160) - Cauquenes (161)

Juan's and my share in Dreyfus Contract

Murder of English travellers by Greek banditti

Aerial Railway and accident in New York

Garland's difficulties with the fiscal commission
162,166

163

164

164

165

139-140,

150

$139-140$

207

140

142

143-144

144, 159

145

144, 146

147,184 ,

195

147

148

148

149, 155

150

$150-153$

153

154

154-155

155

156,167

159

160 162,16 [_]

[-]

165-166 


\begin{tabular}{|c|c|c|c|}
\hline \multirow[t]{2}{*}{ June } & \multirow[t]{2}{*}{27} & $\begin{array}{l}\text { Col. Santa Maria, Minister of the Interior instead } \\
\text { of Col. Secada }\end{array}$ & 168 \\
\hline & & Railway to La Oroya (165) - Railway to Arequipa (168) & 165,168 \\
\hline June & 30 & $\begin{array}{l}\text { Sentence of the Supreme Court in favor of } \\
\text { Schutte \& Co. against the Government }\end{array}$ & 170 \\
\hline July & 3 & First sale in Paris, of the lately issued Peruvian Bonds & 170 \\
\hline July & 10 & Dinner in Palace to Benavente, Bolivian Minister & 171 \\
\hline July & 12 & Particulars regarding Pope Pius IX & 173 \\
\hline July & 12 & Particulars regarding Peruvian Loan & 173 \\
\hline July & 12 & $\begin{array}{l}\text { Arrival of German Chargé, Mr. Von Bundsen, and } \\
\text { dinner given to him }\end{array}$ & $173-174$ \\
\hline July & 15 & Walk to Callao on the Oroya line & 174 \\
\hline July & 15 & Murder of Bartolo Marique & 175 \\
\hline July & 18 & Arrival of Alejandro and Geraldo Garland & 176 \\
\hline July & 20 & My lector Charles Duval's clandestine departure & 176 \\
\hline July & 23 & Enriqueta's danger at Corina's birth & 176 \\
\hline July & 27 & Election of Presidents in the two chambers & 177 \\
\hline July & 28 & Opening of Congress & 177 \\
\hline July & 29 & $\begin{array}{l}\text { Distribution of prizes to teachers and pupils in } \\
\text { Municipal schools }\end{array}$ & 178 \\
\hline Augt. & 1 & Rees, my new lector & 179 \\
\hline Augt. & 6 & Outrages committed in Pekin & 179 \\
\hline Augt. & 12 & Franco-German war & $\begin{array}{r}180-181, \\
184-185 \\
190-191, \\
193-194, \\
197-199, \\
201-202, \\
206-208, \\
211,213\end{array}$ \\
\hline Augt. & 12 & Infallibility of the Pope made a dogma & 181 \\
\hline Augt. & $18 / 20$ & First discovery of Charles Duval's robbery & 182,186 \\
\hline Augt. & 21 & Engagement of Edward Knaur to Miss Fritsch & 183 \\
\hline Augt. & 22 & Departure of Limpricht for Europe & 184 \\
\hline Sept. & 3 & Receipt of $\$ 29,995$ from C. W. Schutte & 186 \\
\hline Sept. & 3 & Celebration of Garland's birthday & 187 \\
\hline & [-] & Trip to Ancon & $187,1[-]$ \\
\hline
\end{tabular}


Septr. 11

Septr. 17

Septr. 22

Octr. 3

Octr. 20

Octr. 24

Octr. 30 to

Nov. 1

Nov. 3

Nov. 21

Nov. $\quad 25$

Dec. 3

Dec. 8

Dec. 8

Dec. $\quad 16$

Dec. $\quad 17$

Dec. 17

Dec. 19/31
Attempt to assassinate one of the sons of Perez

Velasco

190

193

Dreyfus' contract discussed in Chamber of

Deputies

194

Dreyfus' contract approved by Senators, Deputies and Executive

201, 205

198

198

Occupation of Rome by Italians

202-203

204

Dinner at Rafael Verlardes

Accusation and defence of M. F. Benavides in the

Senate

204-205

Limpricht's want of success in catching C. Duval

206

My wife's birthday - State of my finances

209

210

212

212

213

214

214

215

216,220

Meetings of the Directors and of the shareholders of:

Banco de Lima, 219, 244-245, 300

La Constructora, 235, 237, 240-241, 246, 249, 251, 265, 278, 297-298

Insurance Coy. Lima, 236-237, 241, 244, 247, 265, 284, 297, 300, 302

Pasco Railway Coy., 237, 241, 244, 257, 266, 277

Lima \& Huacho Coy., 301

Lima Water Coy., 301

Banco Hipotecario, 301

Telegraph Coy., 246 
Ascents of San Cristoval, 242, 253-254, 268, 289, 297, 304-305

Repairs of House 96 Zarate, 250, 259, 267, 274, 276

[887]

1871

Deaths:

General Prim, 226

Mrs. Rodrigo, 253

Enrique Armero, 256

Juan Centeno, 256

Pedro Dinegri, 263

Mrs. Isaac Hesse, 267

Genl. Iturregui, 270

M. M. Cotes, 271

Lucas Willink, 283

Archibald Gallagher, 284

Monk Zapata, 289

Carmen Rey de Castro, 289

Mrs. Dreyfus, 291

Th. Gortsch, 297

Pedro Salmon, 299

Jany. 1

Summary of 1870

218-219

Jany. 6

Changes in the environs of Lima

221, 231

Jany. 6

Muelle Darsena

220

Jany. 6

Amnesty to Bishop Huertas

220, 233

Jany. 8

Accidents on Chancay Railway

221

Jany. 8

War between Germany and France

221, 225,

234,

237-240

Jany. $\quad 10$

Railway from Mollendo to Arequipa

Geraldo, clerk at Chavez' - S.A. Insurance

Company in London

Jany. $\quad 15$

Description of railway from Lima to Chorrillos

Authorization given by Congress for loan of

$£ 15,000,000$

226, 228

Jany. $\quad 22$

Excursion to Manzanilla

227

Marriage of Miss Whiting to Henry Backus

227

Marriage of Mathias Gildemeister

231

Marriage of Jesus Rabago to Salinas

258

Marriage of R. Canevaro to Inéz Laos

258

Marriage of Emilio Althaus to Maria Dartnell

276 
Jany. $\quad 25 \quad$ Results of Lima joint stock companies 228

Jany. 25

German Subscribers in Lima for sufferers in the war 228-229

Jany. $\quad 26$

Overthrow of President Melgarejo in Bolivia

230

Jany. 27

Completion of Mont Cenis tunnel

231

Feb. 2

Dispute between Schutte \& Co. and the Peruvian Govt.

232, 238 ,

Advices from friends in Altona and Hamburg

262

Feb. 2

Removal of President Balta to Ancon

233-234

Feb. 8

Arrival of Coleman

235

Feb. 8

King William of Prussia, Emperor of Germany

236

Feb. 14

Our removal from Calle del Correo to Calle de

Mar. 11

Zarate

237

[888]

Lawsuit against Leyva about Ac [...]

240, 249

240, 2[_]

1871

Mar. $\quad 16$

Excessive rains

242

Mar. $\quad 16$

Arrest of Palacios

242

Mar. $\quad 16$

Peace between Germany and France

243, 247,

262

Mar. 19

Congratulation to President Balta on his birthday

243

Mar. 26

Celebration of peace in German Club

245

April 2

Lucio Barrios gains in the Supreme Court

246

April 6

Two days occupation of Paris by German army

247

April 15

Revolt in Paris of the Red Republicans

249 ,

251-253,

258, 260

April $20 \quad$ Repairs of house

250, 259,

267, 274,

276,278

April $\quad 27$

Accident on Callao Railway

250, 210

April 29

Electioneering proceedings

249, 251,

264, 271,

273,278 ,

283,287 ,

290-292

Celebration of my birthday in Chorrillos

252

Ridiculous conduct of three Peruvian Ministers

253

My way of living

254

May 23

Drs. Aranivar - Paz Soldan - and Muñoz

255

May 29

Exportation of Peruvian gold and silver coins and bars prohibited 


\begin{tabular}{|c|c|c|c|}
\hline May & 29 & Proposals of King of Italy to Pope Pius IX & 256,262 \\
\hline June & 1 & Manuel Pardo & 257 \\
\hline June & 4 & Sale of Chorrillos and Callao Railway to Peruv. & \\
\hline & & Govt. & $257^{-2} 5^{8}$ \\
\hline June & 4 & Exportation of Chinese coolies prohibited & $25^{8}$ \\
\hline June & 14 & $\begin{array}{l}\text { Flogging of Col. Garrido by order of Tomas } \\
\text { Gutierrez }\end{array}$ & $\begin{array}{r}260-261, \\
273\end{array}$ \\
\hline June & 18 & Establishment of South American Coy. in London & 262 \\
\hline June & 27 & $\begin{array}{l}\text { Disputes between President Balta, Dr. Mo. Alvarez } \\
\text { and Minister Santa Maria }\end{array}$ & 264 \\
\hline July & 14 & Federico Errazuriz, President of Chile & 266 \\
\hline July & 19 & Inauguration of Pisco-Ica Railway & 267 \\
\hline July & 19 & $\begin{array}{l}\text { Nicolas Pierola, finance Minister, superceded by } \\
\text { Camilo Carrillo }\end{array}$ & 267 \\
\hline July & $28 / 30$ & $\begin{array}{l}\text { Festivities in celebration of Peruvian } \\
\text { Independence }\end{array}$ & $268-270$ \\
\hline Augt. & 2 & Dinner party in Palace & 270 \\
\hline Augt. & 3 & $\begin{array}{l}\text { J. F. Balta, War Minister, superceded by Gen. } \\
\text { Buendia }\end{array}$ & 271 \\
\hline Augt. & 6 & French Finances & 273 \\
\hline Augt. & 14 & Departure of Bartolomé Araoz & $\begin{array}{r}273, \\
27[-]\end{array}$ \\
\hline
\end{tabular}

$[\ldots]$ Paz Soldan's [...]

1871

Septr. 10

Septr. 13

Septr. 17

Septr. 20

Septr. 27

Octr. 7

Octr. 8

Octr. 25

Nov. $\quad 1 / 2$

Nov. 19

Nov. 20

Nov. 21
Celebration of Garland's birthday

Details referring to National Guano Company

Public demonstration in Lima of the Ultra

montanes

Demonstration of friends of Italian Unity

Assassination of Dr. John Gallagher

Camilo Carrillo, finance-minister superceded by

Felipe Masias

Details relative to A. Gibbs \& Sons London

Robbery committed in Banco del Peru

Party at Rafael Velardes

Walk to pantheon and botanic garden

Chicago destroyed by fire

Scandalous transactions relative to Chimbote railway

Commercial annoyances - Party in celebration of

my wife's Saint's day
277

278-279

280

281

281-283

273

284

285

288-289

290

292

293

294-295 
Nov. $24 \quad$ Murder of General Melgarejo

296

Nov. $\quad 25 \quad$ President Baltas injustice towards Carlos Lopez

Aldana

Dec. $7 \quad$ Sale of Juan's shares in National Guano Coy.

Dec. 8 Minister of War, Allende, superceded by Tomás Gutierrez

Dec. 8 Minister of Justice Aranivar superceded by Melchor Garcia

Dec. 8

Concession of Arequipa/Puno Railway to Meiggs

Dec. $\quad 24 / 6$

Christmas days

Dec. 29

Death of dog Tippo

Dec. 31

Predios Urbanos

Meetings of the Directors and of the Shareholders of:

Banco del Peru, 337, 362, 386

Banco de Lima, 306, 308, 312, 324, 332, 339, 346-347,

$357,367,371,380$

Lima \& Huacho Railway Co., 324, 327

Pasco Railway Co., 309, 338-339, 367, 369-370, 373-374,

379, 381, 386, 388-389

Eten \& Ferrinafe Co., 343, 346, 359-362

Insurance Coy. Lima, 307-308, 310, 316, 324, 346, 357,

373, 386

Gas Coy., 327

Water Coy., 314, 317 [...]

[890]

1872

\section{Deaths:}

Laurie, 310

Mrs. Barton, 310

Mr. and Mrs. Codecido, 310

E. Robinson, 312

Archbishop Goyeneche, 314-315

William Brauns, 328-329

John Renner, 332-333

Maria Josefa Moreira, 334

Flor, 336

General Frisancho, 336

Genl. Rivas, 346

Adelina Barrera, 347

Son of J. M. Pena, 355

Juarez, Prest. of Mexico, 360 
Castilla's mother-in-law, 371

Juan José Pinillos, 371

Manl. Ferreyros Sr., 371

Rosa Quiroz de Pelegrin, 374

Charles XV of Sweden, 376

Marriages:

Julius Pflucker with Rosalia Puente, 308

George Shattuck with Amalia Schutte, 348

Mariana Prevost with Godoy, 364

Julius Pflücker with his cousin Hortencia, 364

Rufino P. Echenique with Ellen Bryce, 371

Josefa, widow of Prada, with Andrés Zavala, 374

Ascents of San Cristoval, 319, 322, 324, 327, 337,

372, 379, 381, 388

Jany. 1 Congratulatory visit of Diplomatic and Consular

Corps to the President of the Republic

Jany. 1 Repairs of the house

307,311 ,

317,333 ,

336-337,

341

307

Jany. 6

Drive to village Magdalena

308

Lawsuit against Leyva, about Acequia

308,326 ,

336,365 ,

368,381

Jany. 13

Predios Urbanos - Cancelment of Censon on my house

Jany. $\quad 31$

Difficulties with Danish vessel "Margrethe"

Feb. 1

Victor Dupont my new lector and secretary

Feb. 1

Projected fusion of Dreyfus firm and Banco del

Perú

Feb. 4

Breakfast in Chorrillos at Juan Bazo's

Feb. 11

French Budget 1872

Feb. $14 \quad$ Meetings relative to German clergyman in Lima

Feb. 25 Establishment of Banco Nacional

Mar. $\quad 10$

Dinner at Juan Bazo's in Chorrillos 
Mar. $20 \quad$ Squabbles in French Legislative assembly 321 $[\ldots]$

[891]

1872

Mar. $25 \quad$ Visit to El Barranco and Chorrillos

Mar. 27

Settlement of dispute between Peruvian

Government and Schutte \& Co., and

consequences

Fire close to my house Calle del Correo

Fraud committed by a certain Ramos

Dinner given to officers of German man-of-war

Accusation of Balta's Ministers moved in Chamber

Augt. $\quad 15$

Augt. 17

Augt. 17 of Deputies

Ball given by Diego Masias

Attempt to assassinate King and Queen of Spain Advices from France about Garland and family 360,385 360 361 361 , 382-383, 
Ground-floor of my house let to F. Dibos

Augt. $\quad 25$

Election of $1^{\text {st }}$ and $2^{\text {nd }}$ Vice-Presidents, Costas and

Garmendia

[...] Evening party in palace

[892]

Septr. $\quad 16$

Financial difficulties in Perú

368,370

Septr. 19

Dinner in palace

Septr. 23

Award given on the subject of the "Alabama" 369-370

Septr. 26

Establishment of El Banco Garantizador

371

Septr. 30

Guillermo thrown from his horse

372

Oct. 15

Establishment of Banco Anglo-Peruano, in which

372

I was to take a share

$375-378$,

Earthquake

380

Oct. 17

Livingstone found by Stanley in Africa

376

Oct. $\quad 26$

Halls Artic exploration

378

Oct. $\quad 26$

378-379, 383-384,

453

380

Oct. $\quad 30 \quad$ Lunch given by Feliz Dibos

Nov. 10

Dispute between Japan and Peru, arising from vessel Maria Luz

382

Nov. $\quad 21$

My wife's birthday

383

John Donner's account of my Altona friends $\quad 384$

Nov. 27

Comision Permanente

385

National Debts of various states

385

Dec. 7

Sale effected by Gibbs of Lima Callao and

Chorrillos Railway

Dec. 7

Increase of steam navigation on West Coast

Dec. 14

Meliton Porras

Dec. 14

Conflagration in Boston

Dec. 22

Departure of Geraldo, attaché to the Peruvian

Embassy to Japan and China

Dec. 14

Disorders in Arequipa

Dec. $\quad 25 / 6$

Christmas visits

Dec. 31

Attempt to assassinate M. Pardo

Meetings of the Directors and of the Shareholders of: La Constructora, 419, 433-434, 437, 439, 445, 447, 455, $461-462,465,472-474,478,491$ 
Banco de Lima, 397, 403-404, 409-410, 444, 451-452, $454,459,465475,490,497-499$

[...]

[893]

1873

\section{Meetings continued}

Cerro de Pasco Railway, 398, 401, 405-406, 421, 423, 427-428, 434-436, 440, 451, 455, 484, 488, 493,

495

Eten \& Ferriñafe Railway, 402, 404, 432, 436,

438-439, 465

Insurance Coy. Lima, 401, 404, 406, 417, 427, 452,

459, 496

South American Ins. Coy., 401

Gas Company, 470

Water Company, 406, 415-416, 418, 428, 432, 444, 454,

471,489

Deaths:

Napoleon, 405

Ed. Bulwer Lytton, 409

Cristoval Conroy, 409

Mrs. McCall, 409

Mother of Carmen Lopez Aldana, 410

Mrs. Gallagher, 413

Mrs. Böhl, 413

Wm. Müller, 414

Francisco Garmendia, 420

Generals Morote and Vigil, 441-442

Rosa Rabago, 420

Ciriaca Sierra, 421

Ml. Velarde, 441-442

Fco. Calderon, 443

M. Espantoso, 443

Admiral Forcelledo, 443

Gen. Guarda, 445

Ernest Wagner, 448

Genl. Allende, 449

Paula Cortes, 449

Mrs. Bergmann, 449-450 
F. Von Raumer, 459

P. J. Bustamante, 460

J. S. Tejeda, 463

B. de la Torre, 463

Antonio Ugarte, 466

Manuela Puente, 470

General Vivanco, 476

Micaela Cañete, 476

G. N. Knauer, 483, 513

Bamberger's wife, 490

Juan Figari, 490

J. Santos Castañeda, 491

Capt. Maclure, 492

\section{Marriages:}

Augustus Dreyfus with Luisa Gonzales, 401

Serapio Orbegoso with Zoila Elespuru, 435

daughter of Evo. Gomez Sanchez with a certain

Aparicio, 497

Prince Alfred with daughter of Alexander of Russia, 497,523

Ascents of San Cristoval, 401, 410, 416, 420, 424, 426, 433, 440, 470, 483, 485, 490, 493-494

Jany. 1

Jany. 1

Jany. 1

Jany. 8

[894]

1873

Jany. $\quad 9$

Jany. 9

Jany. 20

Jany. $\quad 25$

Feby. 9

Feby. 15

Feby. 15

Feby. $\quad 15$
Laying of foundation stone of Pardo's college

Congratulatory visits to Manuel Pardo

New Years visits

Return of Garland and family

[...] Description of Monitor "Manco Capac"

Account given by Enriqueta of her life in Paris and London $399-400$

Liquidation of the firm of Templeman \&

Bergmann

400

Difficulty as to election of Archbishop overcome

402

Estanco of Nitrate of Soda

404, 444,

455,463

Visits in Chorrillos

405-406

Law to raise loan of $£_{3} 6,000,000$

406

Differences between Manl. Pardo and Dreyfus

$407-408$

Death of Herencio Zevallos and Dr. Gamio 
Feby. $\quad 15$

Feby. 21

Feby. 25

Feby. 25

Feby. $\quad 26$

Difference between Fiscal Delegates in London

408

Loan of six million Soles by Bank to Government

410

Details relative to Muelle Darsena

411

Visit to the Masias in Ancon

412

Negotiations between Peruvian Govt. and firm of

Dreyfus

413,415 ,

435 ,

484 ,

486-488

Disturbances in Arequipa

414

Spain a Republic

414, 419

Dinner at Juan Bazo's

March 9

Extraordinary scarcity of money

416

418

Ingenious burglary

420

Final decision as to the gutter in my garden

421

Purchase of a set of furniture

422

Speculations of Guillermo, Enrique and Alejandro

Garland

422-423

Failure of Anto. Salinas' firm in Liverpool

426

Young Lord Cochrane

426

Huth's house attacked by thieves

Review - Evening party in the palace

429-431

May 2

May 2

May 3

May 3

May 7

Foundation stone laid of Monument 2 de Mayo

429-430

430

Inauguration of School 2 de Mayo

430

Details relative to $\mathrm{S} / 50,000$ lent to Pasco

Railway Coy.

431-433,

436,443 ,

$485-487$

May 18

Mount Cenis tunnel (435)

May 22

Fire at Manuel Mendoza's, Calle de Zarate

438

Nervous attack of which my wife suffered

443

Mac Mahon succeeds Thiers as President of the

French Republic

446 ,

June 23

Removal to Chorr.

$4[-]$

[...] Chorrillos and in Lima

[-]

[895]

1873

July 5

Murder and suicide

$45^{2}$

July 26

Adolfo Balivian, President of Bolivia

456

July $\quad 31$

Crasy Dane in Chorrillos

$45^{8}$

July $\quad 31$

Details of Gibbs firm in London 
Augt. 8

Augt. 11

Augt. 17

Augt. 19

Augt. 30

Augt. 31

Septr. 4

Septr. 10

Septr. 11

Septr. 14

Septr. 14

Septr. 21 to

Octr. 1

Octr. 1

Octr. $\quad 16$

Octr. $\quad 17$

Octr. 21

Octr. 24

Octr. 24

Octr. 27

Nov. 8

Nov. $\quad 21$

Decr. 4

Decr. 20
Revolutionary movement in Ayacucho

Cesar Canevaro, Gerente del Banco del Perú

Establishment of Banco Anglo Peruano

Titeres in celebration of Maria Garland's birthday

Details relative to Anglo Peruvian Bonds

Differences between Augustus Dreyfus and his brother-in-law

Evening party in celebration of Mr. Garland's birthday

Fancy ball and murder of Mesquita

General Medina superceded by Freyre as Minister of War

Assassination of Juan Anto. Olmus

Failure of Bianchi

Deeble my lector, in lieu of Dupont

Dinner at General Pezet's in Chorrillos

Mr. and Mrs. Garland resume their Thursday evening parties

Purchase of the Ayres of Leyva's house

Loan to Manuel Rosa O'Phelan

Lawsuit agst. J. S. Leyva about ayres

Manner in which I spent my time

Dinner party at Henrys

La Jara superceded by C. Carrillo as

finance-minister

My wife's birthday

Serious indisposition of my wife

Pardo's decree about loan to be made by banks
460,463

460

461

462

$463-464$

465

467

467-469

468

469

471-472,

484

472

474

477

477

478

479 ,

484 ,

$494-496$

479, 481

$482-483$

484

487

491, 493

496 ,

499

1874

Meetings of the Directors and of the Shareholders of:

Banco de Lima, 502-503, 527, 539, 548, 564, 570, 572,

$574,585,596-597,601,612-613,619-620,623,629$

La Constructora, 512, 528, 556

Banco del Perú, 511

Banco Nacional, 51[_] 
Meetings continued

La Providencia, 517

Eten \& Ferriñafe Railway, 604-605

Insurance Coy. Lima, 501, 516, 522, 526, 530, 538,

$541,586,590,607$

S.A. Insurance Coy., 508

Gas Coy., 568, 610, 619

Pasco Railway Coy., 504, 507-509, 512, 519, 521,

$523,540,567$

Deaths:

Isabel R. O'Phelan, 501

Ed. McCall, 505

Mother of Bandini, 507

Mother of Gaspar Puente, 507

Stgo. Tavara, 511

Livingstone, 523

Siamese Twins, 523

Adolfo Alvarez, 528

Adolfo Balivian, 529

Carlos Aliaga y Puente, 532

Dr. A. Garcia, 532

Sagastabeytia's mother, 534

Genl. Echenique's mother, 559

Candelaria G. Gomez, 560

Juana Velarde, $561-562$

Mariana Garland, 565

Petronila S. de Puente, 567

Paul Bobertag, 584

Edward Knauer's wife, 584

Daughter of Dr. Muñoz, 613

Hannchen Willink, 616

Antonio Salinas, 616

Calista Thwaites, 616

Dr. Luhrsen's child, 618

Rafael Saco, 626

Marriages:

Dr. Adan Melgar with Wm. Brauns widow, 500 
Gaspar Puente with daughter of M. Panizo, 520

Ureta with Angelica Palacios, 549

Larrabure with Srta. Correa, 617

Ascents of San Cristoval, 502, 508, 513, 517, 521, 526, $538,541,554,557,561,587,602,604,611,617$

Lawsuit agst. Leyva about Ayres of his house, 505, 512, $518,571,573,575-577,587,589,607,609,613,616$, $620,624,649,631,633$

Details relative to Loan of S/50,0oo to Pasco Railway Co., 501, 506-508, 533, 535, 537, 546, 56o, 563, 585, 6o6, $608,611,615$

[...]

[897]

1874

Jany. $\quad 1$

Marshal Bazaine sentenced to be shot

Jany. 1

Extinction of the firm of Alsop \& Co., Lima, and establishment of Prevost \& Co.

Jany. $\quad 25$

Prohibition of exportation of Chinese from Macao

Jany. $\quad 25$

Frustrated attempt at revolution

509-510

Jany. 28

Accidental death of a child of J. N. Vargas

Feby. 1

New Imperial German coin

Feby. 2

Failure of Pedro Marcone

Feby. 9

Difficulties of Zaracondegui $(518,522)$ and failure (555)

Feby. $\quad 15$

Dinner at Henry's in Chorrillos

Feby. 22

Murder of a Chilian called Vargas

$5^{22}$

Feby. 22

Failure of Mazzini

Feby. 24

Details relative to a promissory note of $£ 10,000$

524-525

Three fires in Lima

525

Gladstone and his party out, D'Israeli in

March 14

Illness of Dane Bernstein (531) - Death (532) -

Consequences (533)

March 18

Failure of Lopez Hurtado \& Co.

March 24

Failure of Navarro y Mesa 
April $\quad 18$

April 21

April 21

April 22

April 22

April 27

April 30

May 10

May 11

May 12

May $\quad 15$

May 23

May 23

[898]

1874

May 15

May 15

June 8

June 8

June 27

July 5

July $\quad 28$

July 29

July 30

Augt. 10

Augt. 20

Augt. 20

Augt. 22

Augt. 25

Augt. $\quad 26$
Agreement between the Government and Dreyfus

542,571

573

Failure of Castillo Kast \& Co.

543,545

Barrenechea - Salitrera Barrenechea

543-544

Conflagration in Church La Encarnacion

544,563

Failure of Thiessen \& Co.

545

Regatta in Chorrillos

$545-546$

Farmer on spiritualism

546

Duke of Genoa's reception of Diplomatic and

Consular Corps

549

Dinner in celebration of my birthday

$55^{\circ}$

My new tenants - Compañia de Obras Publicas y

Fomento del Perú

551,565

Horrible murder committed in Hamburg by Rusau in 1803

$55^{2}$

Agustin Escudero gerente of the Banco

Hipotecario

556

Failure of Juan de Ugarte

556-557,

559, 561,

565

$[\ldots]$

How the French war indemnity was paid

$55^{8}$

Population of the British Empire

$55^{8}$

Failure of Maron \& Co.

561

561

Failure of José Maria Velis of Tacna

568

Failure of Agustin Gonzales, y P.

572

578

580

580

586

589

Dinner and evening party at Garlands

589,617

Difficulties of the firm of Valdeavellano \& Co.

Attempt to assassinate Manuel Pardo

591-593

Luciano B. Cisneros, insulted by Minister Rosas in

Chamber of Deputies

595

Congratulatory visit of the Diplomatic and

Consular Corps to the President 
Augt. $\quad 26 \quad$ Testament of Mrs. Ramirez, declared legal by Supreme Court $\quad 596$

Septr. $1 \quad$ Comision Permanente abolished by Congress 598

$\begin{array}{lll}\text { Septr. } 2 & \text { State of my fortune } & 600\end{array}$

$\begin{array}{lll}\text { Septr. } 3 & \text { Celebration of Garland's birthday } & 601\end{array}$

$\begin{array}{lll}\text { Septr. } 4 & \text { Origen and growth of British funded debt } 603\end{array}$

$\begin{array}{lll}\text { Septr. } 29 & \text { Serious indisposition of my wife }\end{array}$

$\begin{array}{llll}\text { Oct. } & 1 & \text { Return of Geraldo from China }\end{array}$

$\begin{array}{llll}\text { Oct. } & 3 & \text { Von Meding's political novels } & 611\end{array}$

Oct. 3 J. Blas Alzamora Vocal of Supreme Court 612

Oct. 17 Details about Guano and nitrate 614, 616

$\begin{array}{lll}\text { Oct. } & 17 & \text { Austrian Artic expedition }\end{array}$

Oct. 24 Nicolas Pierolas expedition in the "Talisman" 617,619 ,

Oct. $\quad 26 \quad$ Jas. Bryson takes the place of Deeble as my lector $\quad 618$

Novr. 5 Lawsuit between Garcia Calderon and Schutte \& Co. 621-622

$\begin{array}{llll}\text { Novr. } 10 \quad \text { Alejandro Garland begins business } & 624\end{array}$

$\begin{array}{lll}\text { Novr. } 21 & 625\end{array}$

$[\ldots]$

[899]

1874

Nov. $26 \quad$ My family present at the Ristori's performance $\quad 628$

Nov. $28 \quad$ Geraldo Garland second secretary to Peruvian

Embassy in Prussia and Russia $\quad 628$

$\begin{array}{llll}\text { Dec. } & 17 & \text { Arrival of Juan Diez } & 631\end{array}$

Dec. $25 \quad$ Christmas eve at Scheel's 634

Dec. 25/7 My various visits $\quad 635^{-643}$

$1875 \quad$ Meetings of the Directors and Shareholders of

Banco de Lima, 651, 659, 668, 671, 675-679, 681,

684-685, 688, 690, 700-701, 712, 714, 721, 732, 736-737,

638-639, 742, 747-748, 756-757, 759, 761, 763, 769,

771, 773, 777-778, 780, 788, 791, 797, 804, 810, 815,

$817,819,823,825,830,834,839-840,845,847$

La Constructora, 830

Banco del Perú, 674

La Providencia, 745 
Banco Hipotecario, 68o, 684-685, 687, 693, 695, 701-702, 706-707, 711, 713, 715, 718, 724-725, 727, 732, 734, 739, 743, 746, 748-749, 751-752, 754-758, 761, 764, 767-770, 775, 779-780, 784-787, 791, 796-797, 799, 801-802, 805-806, 810-811, 816, 820, 828, 831, $834-835,839,843,848-849,854-855$

Insurance Coy. "Lima”, 651, 658, 672, 690, 762, 80o, 834,844

S. American Coy., 667, 839

Banco Nacional, 668, 822

Gas Company, 739, 796-797, 810, 830

Water Company, 651, 653, 694, 707, 726, 792

Pasco Railway Coy., 676, 686, 689, 693, 819, 826, 830

Eten Railway Coy., 679-680

Chilete Mining Coy., 730-731, 739

The four associated Banks, 775-778, 781-783, 787,

$836-837$

Marriages:

Flores, with Micaela Araoz, 666

Dr. Fernando Palacios with Josefina Palacios, 672 $[\ldots]$

[900]

1875

\section{Deaths:}

Widow of Manuel Ferreyros, 653

Widow of Juan Ugarte, 653

Mariano Blas de la Fuente, 654

Federico Malagrida, 654

Mercedes Castañeda, 655

Juana Carbajal, 676

Godoy's child, 679

E. Perez Velasco and wife, 686

F. Bergmann Jr., 702

Gustavus Duval, 702

Mrs. Lavalle, 712

Wm. Gibbs, 717

G. T. Davy, 717

F. de P. Vigil, 726-729 
Octavia Vigil, 761

Stgo. Lanfranco, 761

Toribio Ureta, 762

Admiral Collins, 762

Ramon Aspillaga, 763

J. M. Varela, 805

Irene Vazquez, 809

J. J. Rowe, 814

Benito Dorca, 814

Bartolomé Araoz, 815, 838

Lady Franklin, 832

Telesforo Llerena, 835

Manuel Sagastabeytia, 838

J. G. Paz Soldan, 845,848

Herman Woldt, $85^{\circ}$

Clemente Althaus, 850

Lawsuit with Leyva, about Ayres of his house, 668,

672, 716-720, 724, 733, 757, 761, 765, 787, 799, 826,

$835,841-842,844,847,849-850,853-854$

Jany. $\quad 1 / 6 \quad$ My Christmas visits continued

$644-650$

Jany. 7

End of Pierola's expedition per "Talisman"

$651-654$

Jany. 7

Death of young Vargas Machuca and Felipe

Cucalon

$653-654$

Jany. $\quad 15 \quad$ Illegal arrest of two Deputies

655,658 ,

664

Jany. $17 \quad$ My Christmas visits concluded

$656-657$

Manuel Pardo resumes the Presidency

Jany. $\quad 22 / 3$

Guillermo Garland's marriage with Eliza Higginson 661-663

Jany. $\quad 24$

Description of Miraflores - Capt. Oldenburg

664-665

Jany. $\quad 24$

Measures taken to secure Genl. Prado's election

665,708

Alfonso, King of Spain

666

Jany. $\quad 31$

Feby. 2

Visits to El Barranco

$669-670$

Change in Ministry - Riva Agüero again Gerente of the Banco Hipotecario

Feby. $\quad$ 7/9 Carnival days - John Bryce just arrived - Francis

Bryce in difficulties

$672-673$

$\begin{array}{lll}\text { Feby. } & 13 & \text { Conflagration in Callao } \\ \text { Mar. } & 2 & \text { Description of Hospital "2 de Mayo" }\end{array}$

675

682 
Mar. 3 Soyer, Cashkeeper of Banco Hipotecario

685 $[\ldots]$

[901]

1875

March 7

Tarapacá Salitreras bought by Government

686,720

March 14

Anibal V. de la Torre, Minister for Foreign Affairs

689

March 19

Dreyfus' refusal to pay patente

693,695

March 20

Details relative to loan of S/50,00o to Pasco Coy.

693,711 ,

739

March $20 \quad$ José Canevaro, President of Concejo

Departamental

694

April 3

Failure of Marcone - Departure of him and family

698

April 3

Failure of South American Company in London

699, 712

April 3

State of trade in Lima

700 ,

702-703

April 4

Repairs of Chorrillos Rancho

700 ,

706, 714,

719

702

April 9

Failure of J.

C. im Thurn \& Co.

704-705

April 25

Departure of Juan - Description of Callao

April 25

Arrival of M. Y. Prado, candidate for the Presidency

708

Patentes for 1875

708-709

April 28

May 6

English expedition against Abyssinia

709-710

Ascents of San Cristoval

714,720 ,

740,753 ,

813,820 ,

847,851

May 10

Lawsuit of F. G. Calderon against Schutte \& Co.

715,803

Arrangements between Peruvian Government and

Telegraph Coy., and United States Guano Coy.

$715-716$

Purchase of diamond necklace

716

Failure of Kochen under the firm of Lorent \& Co. in

Hamburg

718

Ages of notable persons

719

May 22

Arrival of Geraldo and Juan Garland

720-721

Tribunal de Responsabilidad

722-723,

733

June 2

Railways contracted for by Peruvian Government

$723-724$

June 5

Failure of Salitrera Barrenechea

725 


\begin{tabular}{|c|c|c|}
\hline June & 6 & Evening party at Anibal de la Torre's \\
\hline June & 8 & F. Huth \& Co. liquidate \\
\hline June & 13 & Public demonstrations in favor of Genl. Prado \\
\hline June & 15 & Enriquetas serious indisposition \\
\hline June & 16 & How I spent my time \\
\hline June & 18 & Congress Extraordinary \\
\hline June & 22 & $\begin{array}{l}\text { Theft committed by Barrios, clerk in Banco } \\
\text { Hipotecario }\end{array}$ \\
\hline June & 24 & A Cuzco lady admitted as student at law \\
\hline [_] & 1 & $\begin{array}{l}\text { Laying of submarine cable from Chorrillos to } \\
\text { Caldera }\end{array}$ \\
\hline $\begin{array}{l}{[902]} \\
18[75]\end{array}$ & & {$[\ldots]$} \\
\hline July & 6 & Santa Sofia \\
\hline July & 7 & Failure of Anibal Gonzalez in London \\
\hline July & 14 & Alejandro's marriage with Eloida Roel \\
\hline July & 15 & $\begin{array}{l}\text { I present in the Banco Territorial at the drawing of } \\
\text { Cedulas }\end{array}$ \\
\hline July & 19 & Stoppage of Escudero and Roca \\
\hline July & 20 & Riva Agüero culpable of great mismanagement \\
\hline
\end{tabular}

Disturbances in Arequipa put down

Augt. $24 \quad$ My quarrel with Lembcke in Banco de Lima Failure of Dinegri Bros. London 
Augt. $\quad 27$

Septr. 4

Loan asked by Government from the bank

Counter project presented by Derteano, approved of

779,783

797

Septr. 7 to 17 Election of John Gallagher and G. Garland, Gerentes of the Banco Hipotecario

Septr. 10

Septr. 19

Septr. 25

Septr. 27

Septr. 27

Septr. 30

Oct. 2

Oct. 7

Oct. 10

Oct. 11

Oct. 14

[903]

1875

Octr. 30

Nov. 1

Nov. 2

Nov. 10

Nov. 15

Nov. 17

Nov. 17

Nov. 20

Nov. 21

Nov. 28

Dec. $\quad 17$

Dinner at Guillermo Garland's

How I spent a Sunday

Fair in the Exhibition Palace - Dinner at Oyague's

Failure of Californian Bank in San Francisco

Difficulties of U. States Guano Coy. in Lima

Delegation of 4 associated Banks

I chosen Director of Gas Company

Transfer to Paris of Cedulas del Bco. Hipotecario

Conflagration in Iquique

Severe illness of Mr. James Henry

Suicide of Errequeta in Paris

Assassination of Dr. Santos Chavez

$[\ldots]$

Children's fancy ball at R. Zevallos

Heterodox Sects amongst the Roman Catholics

Telephon in its infancy

Serious accident which befel Mrs. J. Basagoytia

In Tacna the Lima bank notes are not current

Guano contract concluded by P[_] commissioners

not ratified by Pardo

781,788

$785-786$

789-790

792

794

793-795

795

795

798, 801,

831

801-802

803,813

803

804,806

812

813

814

814

819

821

826

taken by the four banks

825

827 ,

838-839

829

833

844 
Dec. 17 Closure of Hamburg Bank - Establishment of Imperial German Bank

Dec. $17 \quad$ Losses sustained on Peruvian Bonds

Dec. 18 Decree relative to expropriation of Tarapacá

Salitreras

Dec. $26 \quad$ New proposal for guano consignment

Dec. 30 Lembcke resigns his post as Gerente of Banco de Lima

Dec. 25/6 Christmas days - My calls

1876

Loss sustained by the Barredas of Paris on

Jany. $\quad 1$

Peruvian Bonds

Jany. 1

My wife's illness

859 ,

Meetings of Directors and Shareholders of:

Banco de Lima, 860-863, 865, 867-868

Water Coy., 862, 867-868

Banco Hipotecario, 868, 873, 877

Insurance Coy. Lima, 875

[...]

[904]

1876

Jany. $\quad 1 / 9 \quad$ My calls

858,860 ,

Deaths:

Rosa Garcia, widow of Robinet, 865

M. Ferreyros Jr., 873

Jany. $\quad 15$

My wife engages Doña Angela Villena

873

Almonte's opposition to the sale of "La Esperanza" $\quad 873$

Jany. $\quad 15$

Our removal to Chorrillos

874

Jany. 18

I re-elected one of the Directors of the Water Coy.

875 


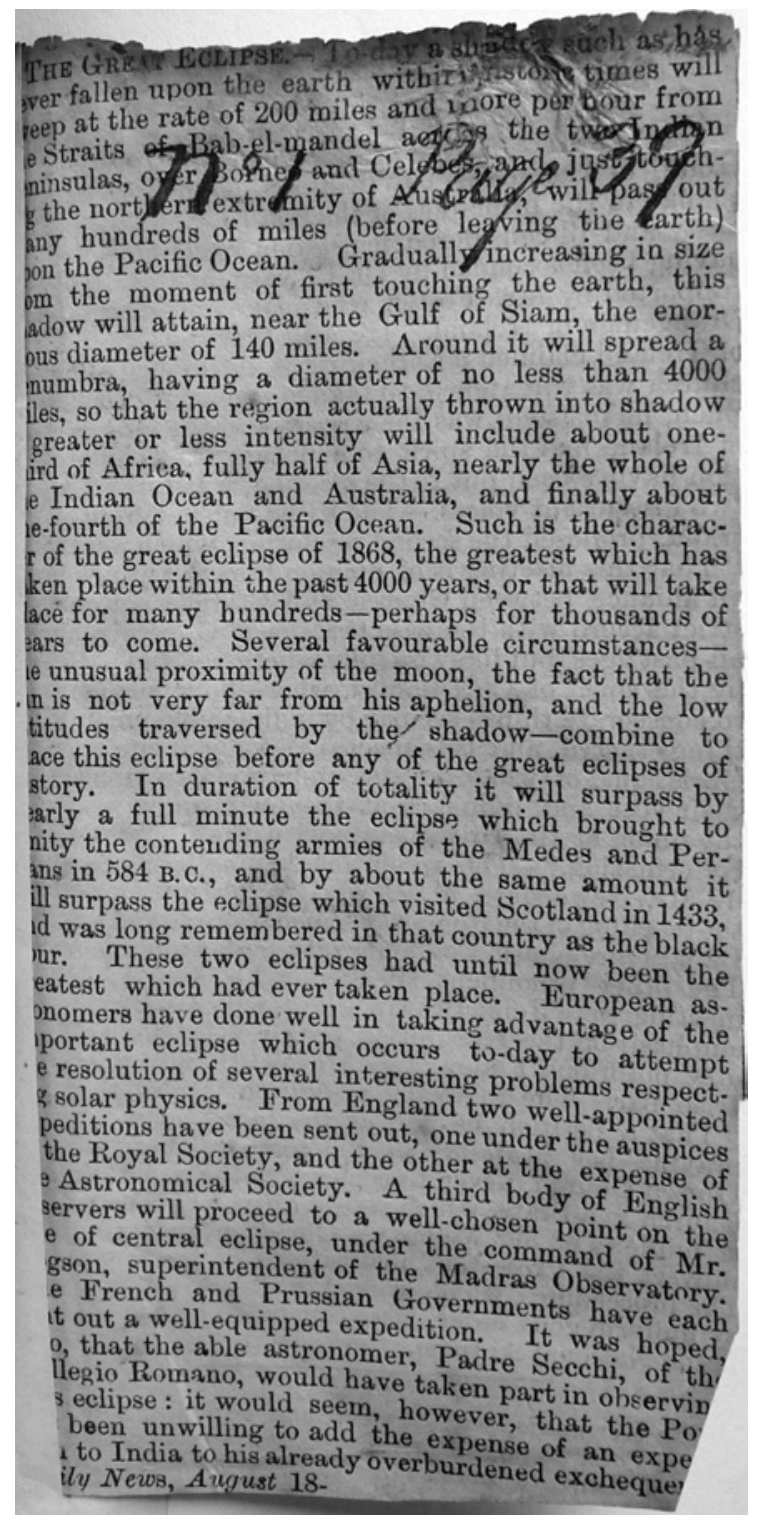

A-7-1. OA-7-1-1 


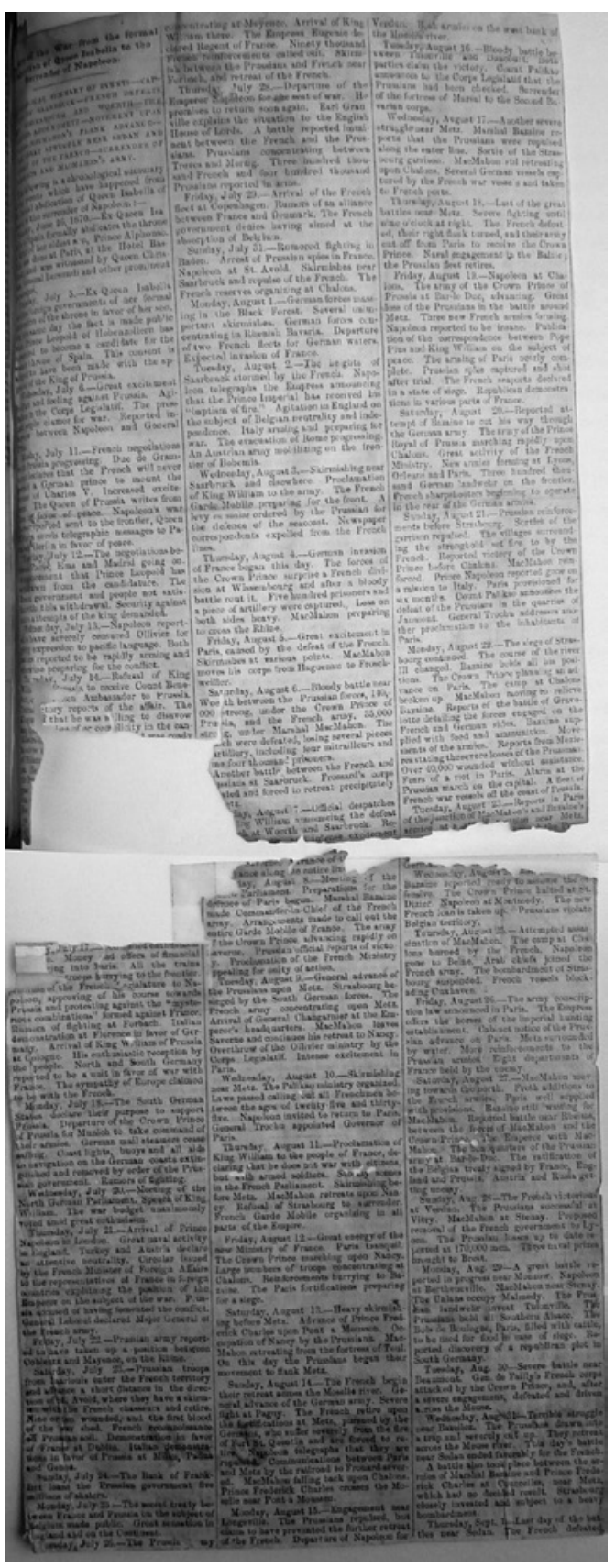

A-7-2. OA-7-2-1 


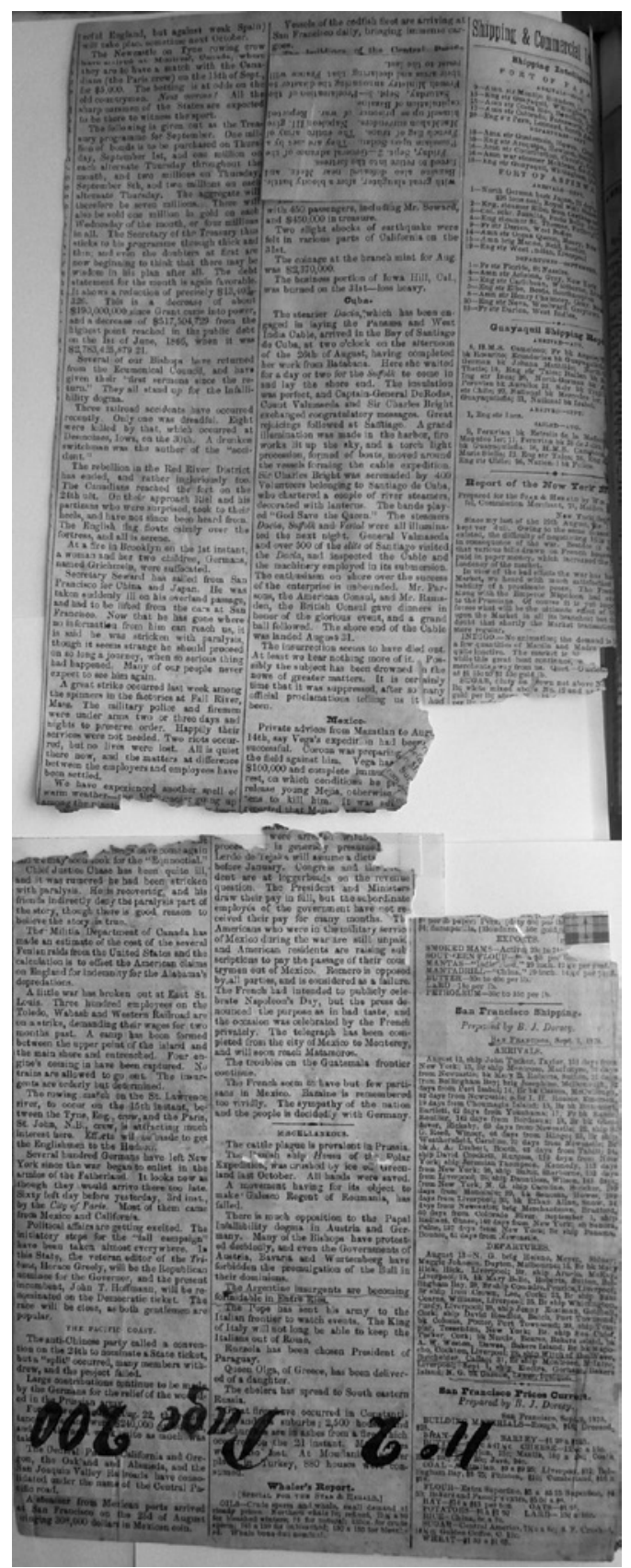

A-7-3. OA-7-2-2 


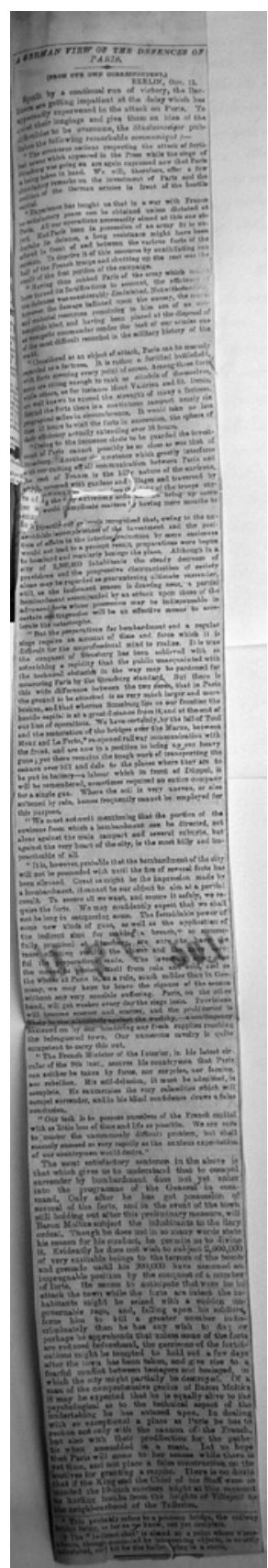

A-7-4. OA-7-3-1 


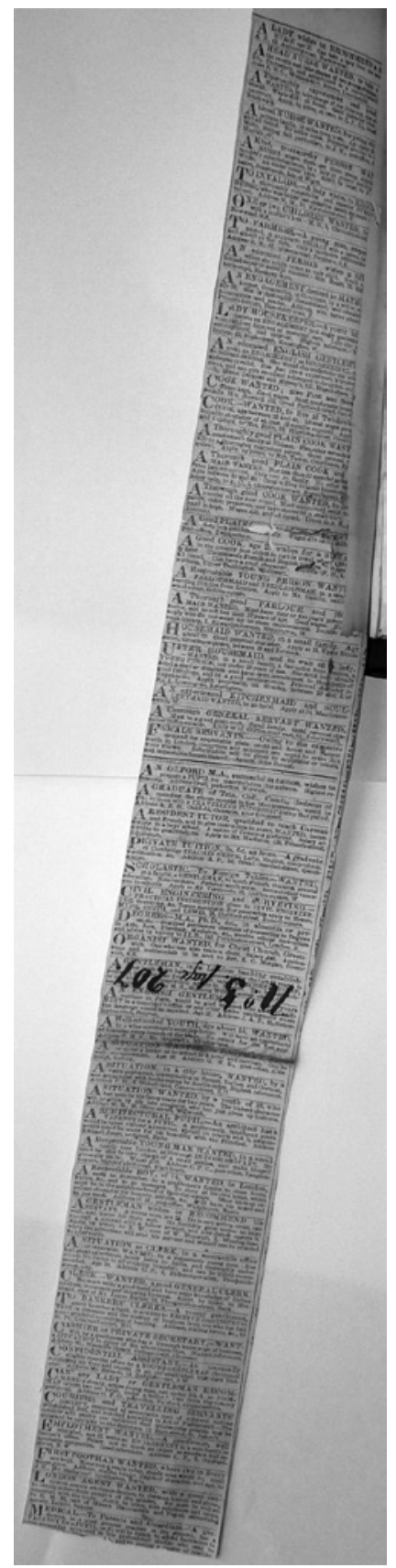

A-7-5. OA-7-3-2 


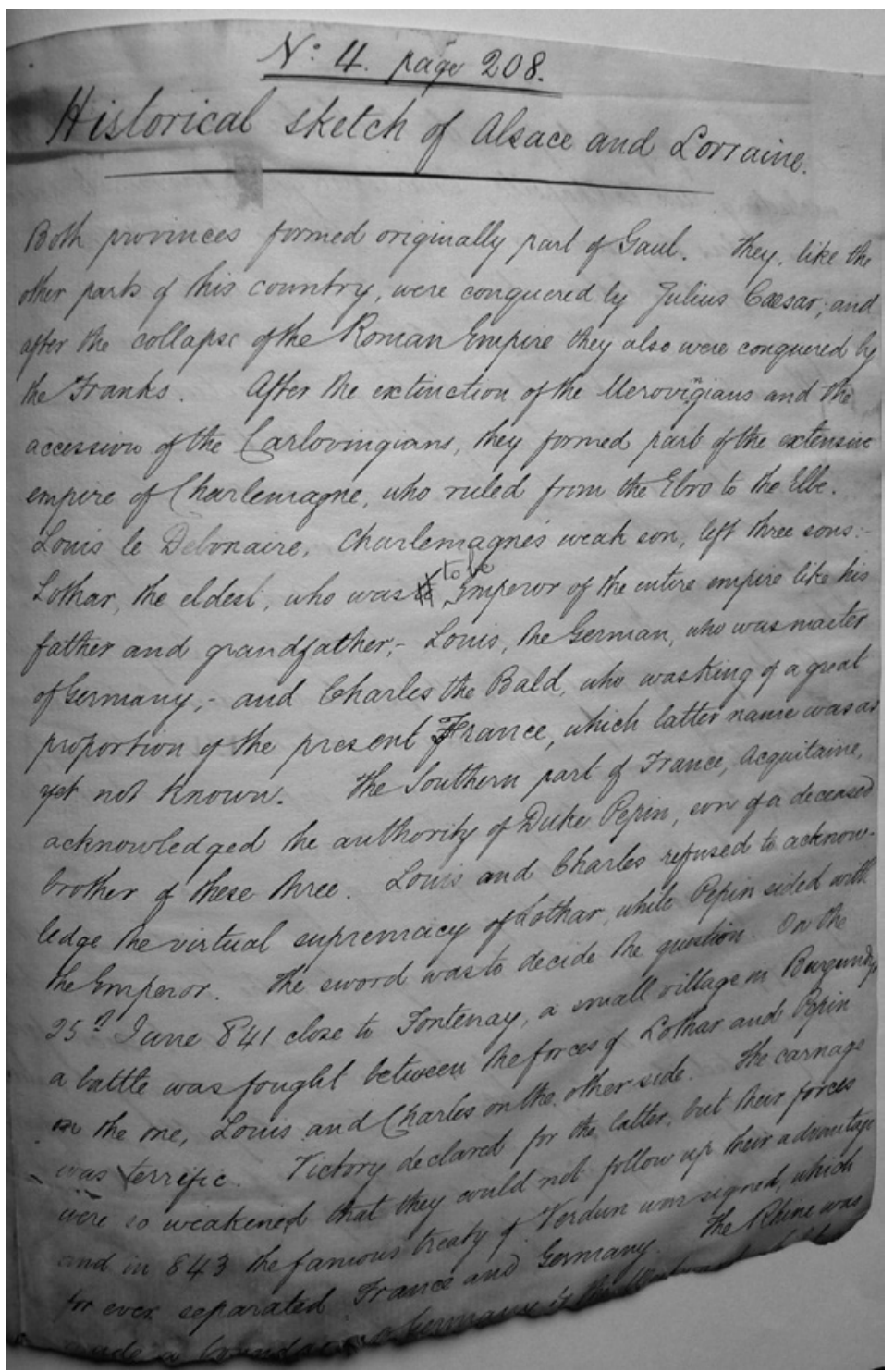

A-7-6. OA-7-4-1 
namove etrip oland from the Woth dea down to the llediterianean including Aus-la-Chafell, Chartemagnes farmite residence, more of lew the present Lorracie. Aleace, doun to tho Hediternamen was alltted to Lothar, which new impire toote the name of athar. ingen - uhenee the Kerman Lotringen, and the Trench Lorraine. Thenee to the Wretward, ineluding Acquitacire, arf ar ae the Pysonees fell to the shave obharles the rald. Lotharingen did not laet long, it fell asunder, and in the II" century as tint that brh Alsace and Lorracine achnowledged the eupinugy, of the Lerman inferor. In Aleace, Austried poreceed conce

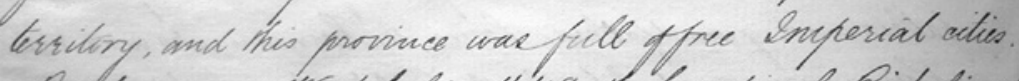
By the peace of Meet thalia, 1648, Me bardinal Pichelieno dimed

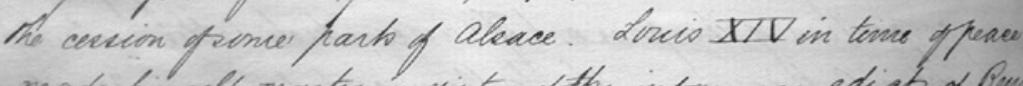
made himself mastes in virtue of the infomons edi cts of Puminn, oftrasherg, and ther places in Alsace, and thece acquiritime were secured to hive hy he peace of Pysurich in 169\%. Itell Lemany contenued to preces eone troceb ofland in this

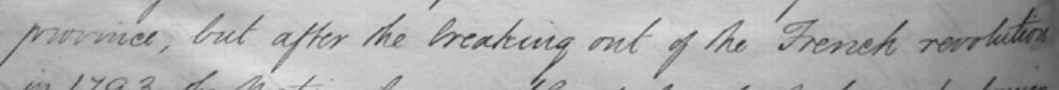
in 1793 the hational arsenelly declared hat ench frrign

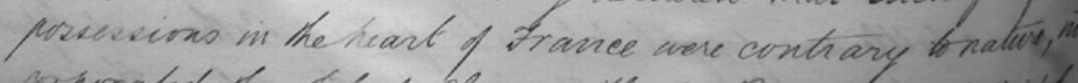
in purated the whiste of Alsace with the Pequlled, and tivitut it int departments. The second reace of 1815 atf off ow: emall piece, apecially he fortress of Dandaiv, and hanth

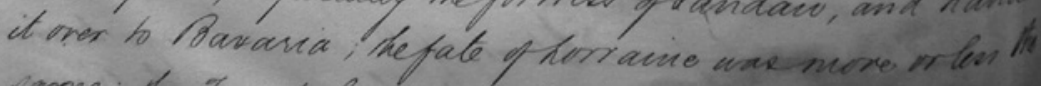

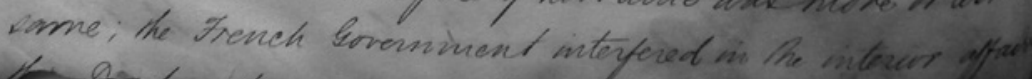

A-7-7. OA-7-4-2 


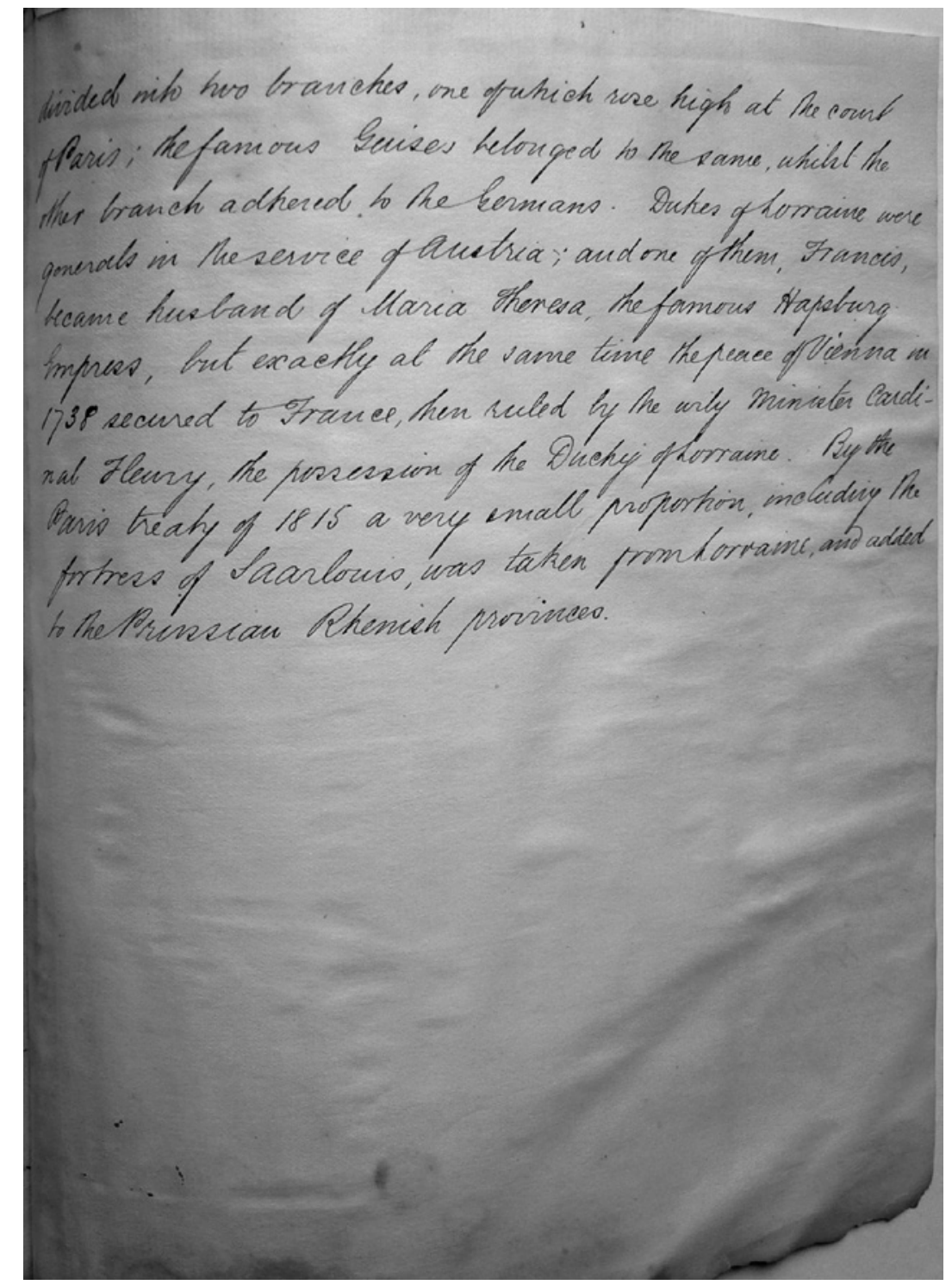

A-7-8. OA-7-4-3 


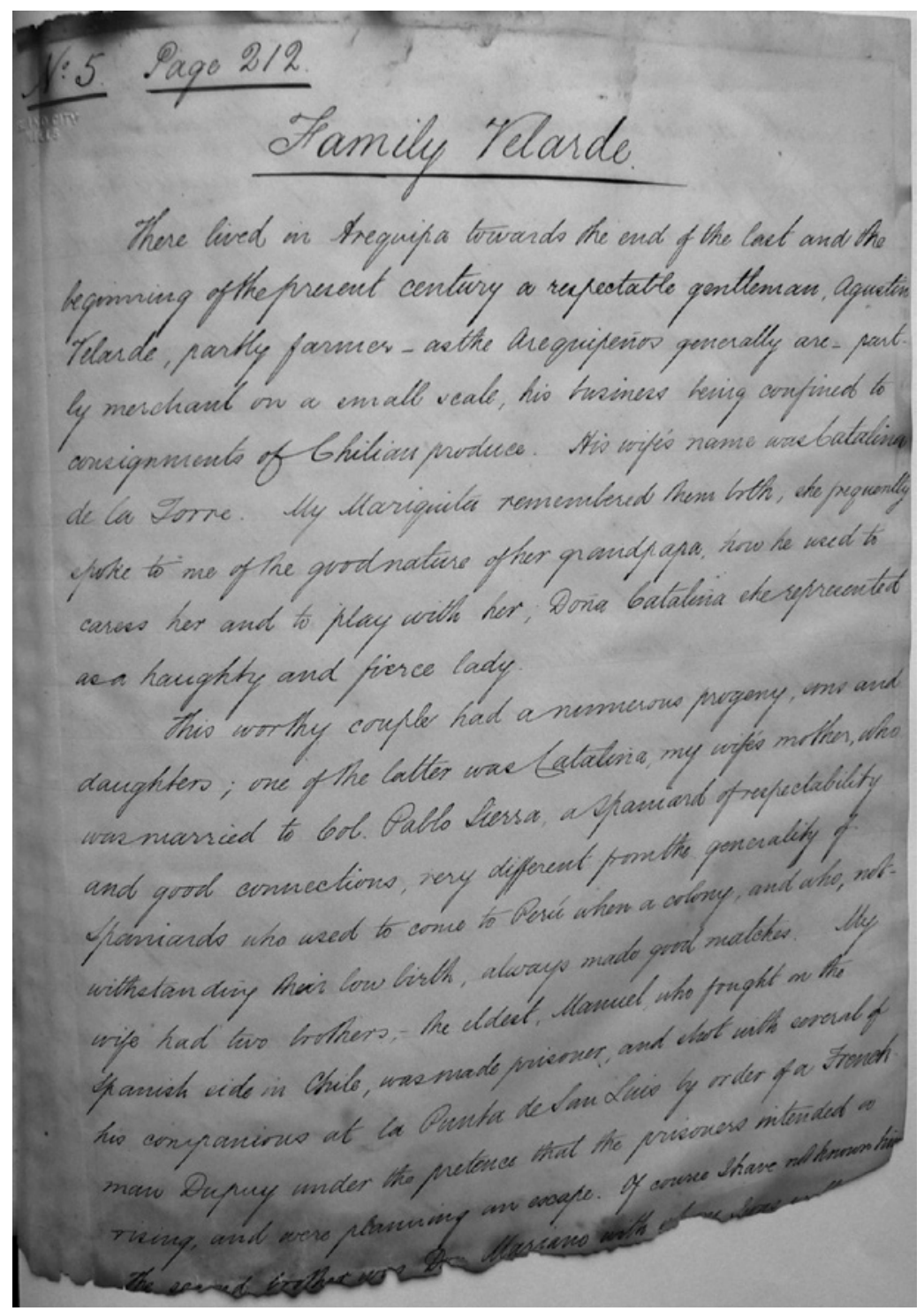

A-7-9. OA-7-5-1 


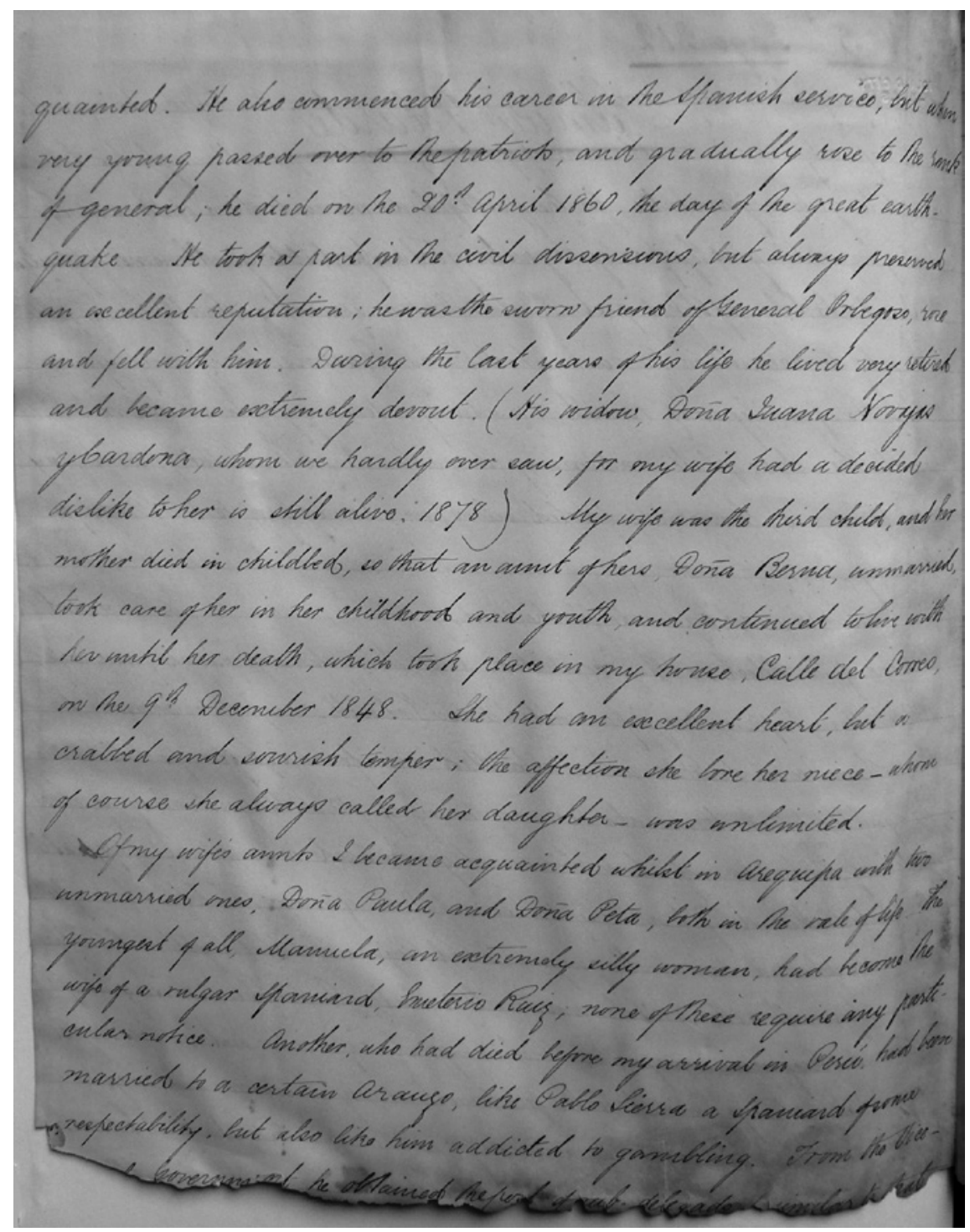

A-7-10. OA-7-5-2 


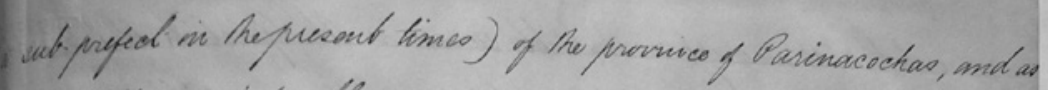

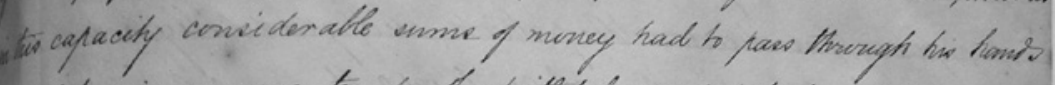
lad to que a quarantee in the paithful admenceliation of the vame,

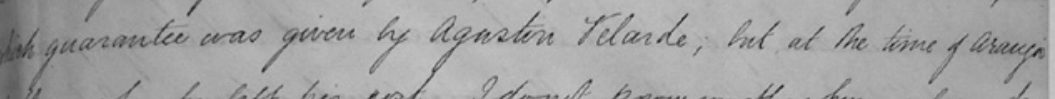

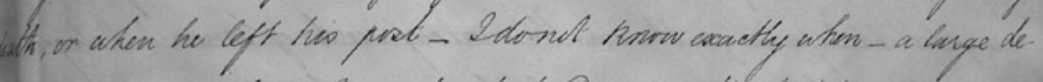

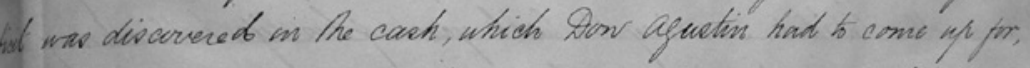
1- the forniles was ruined. Many a tome my urfo vdaled to ne

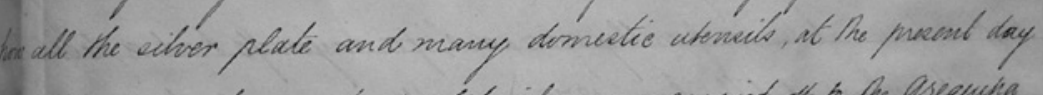

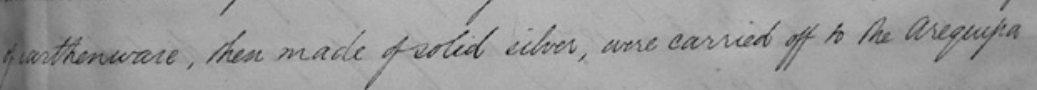
kearecry.

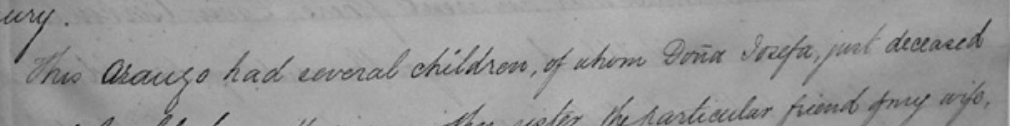

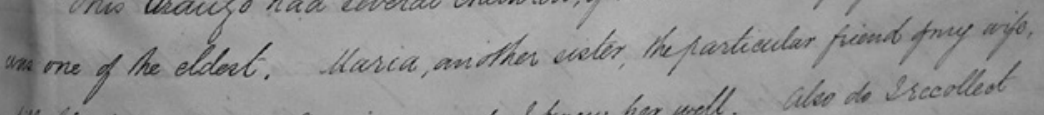

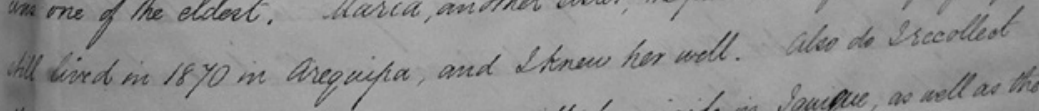

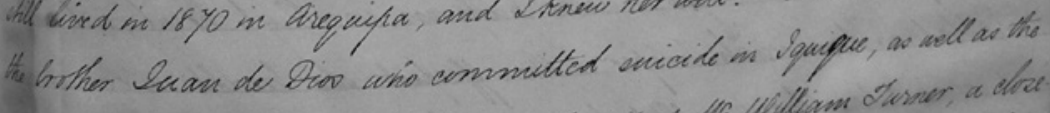

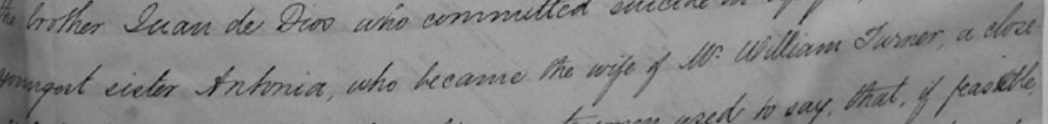

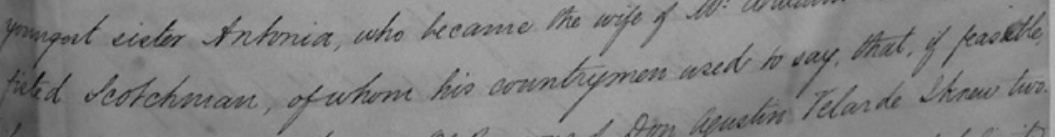

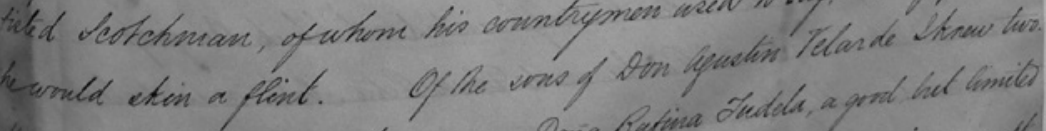

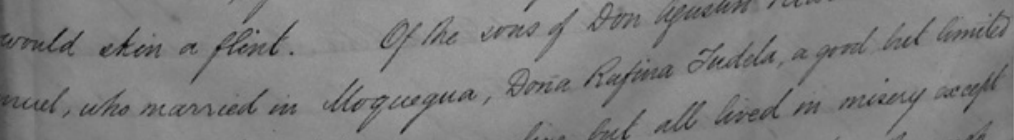

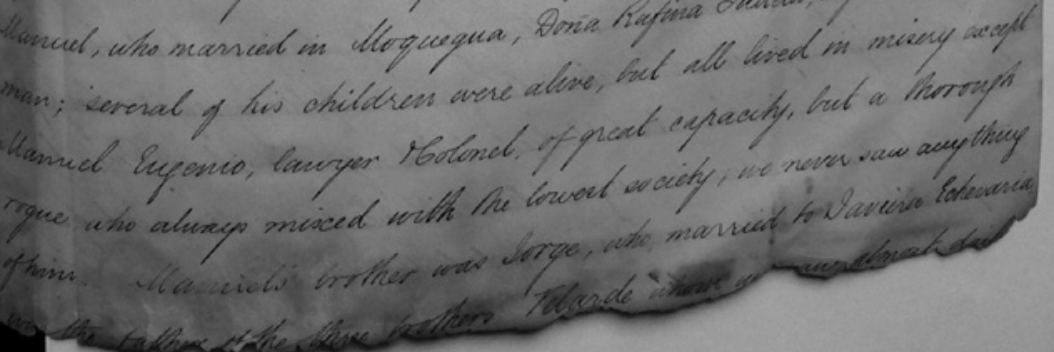

A-7-11. OA-7-5-3 


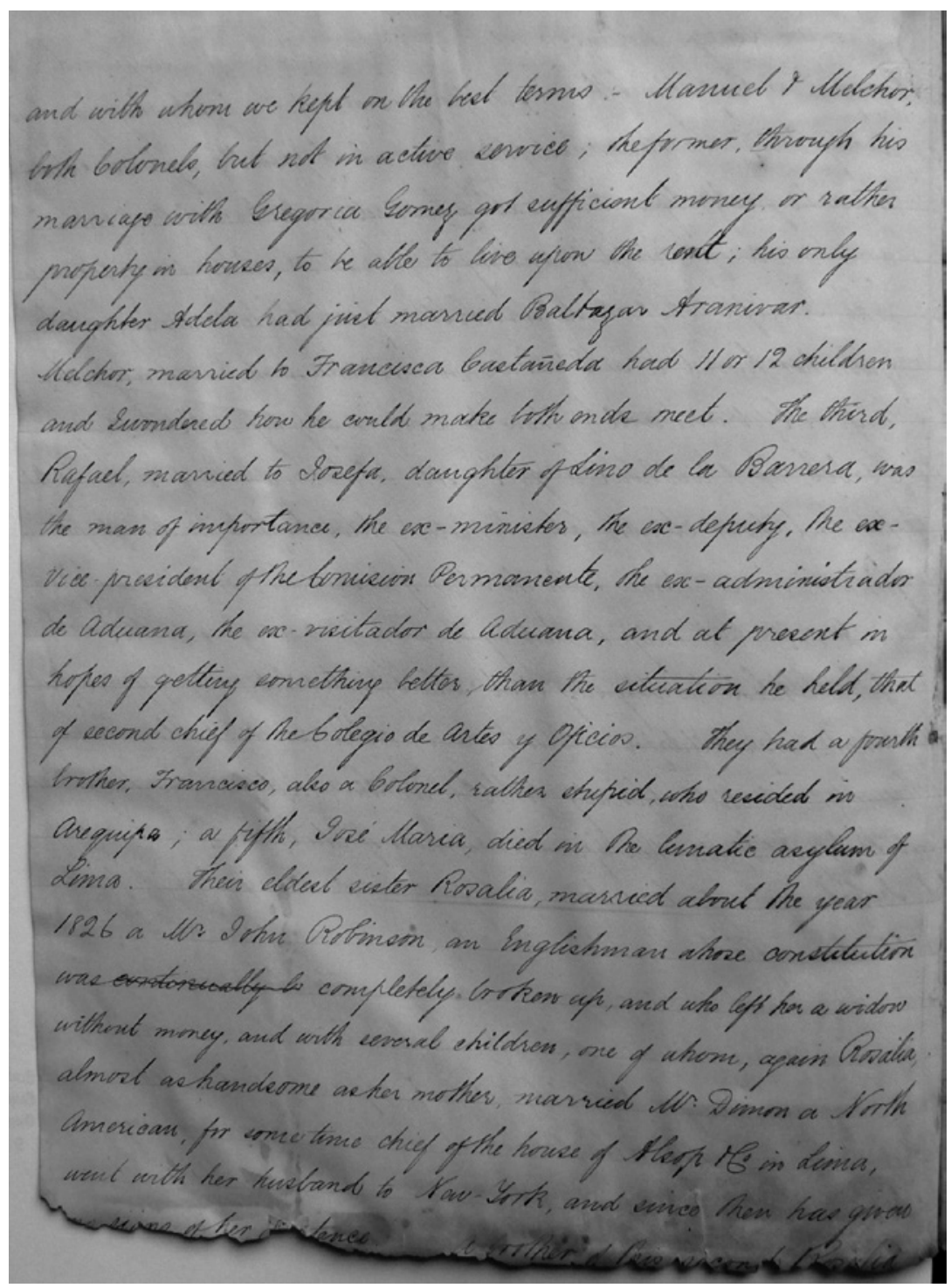

A-7-12. OA-7-5-4 


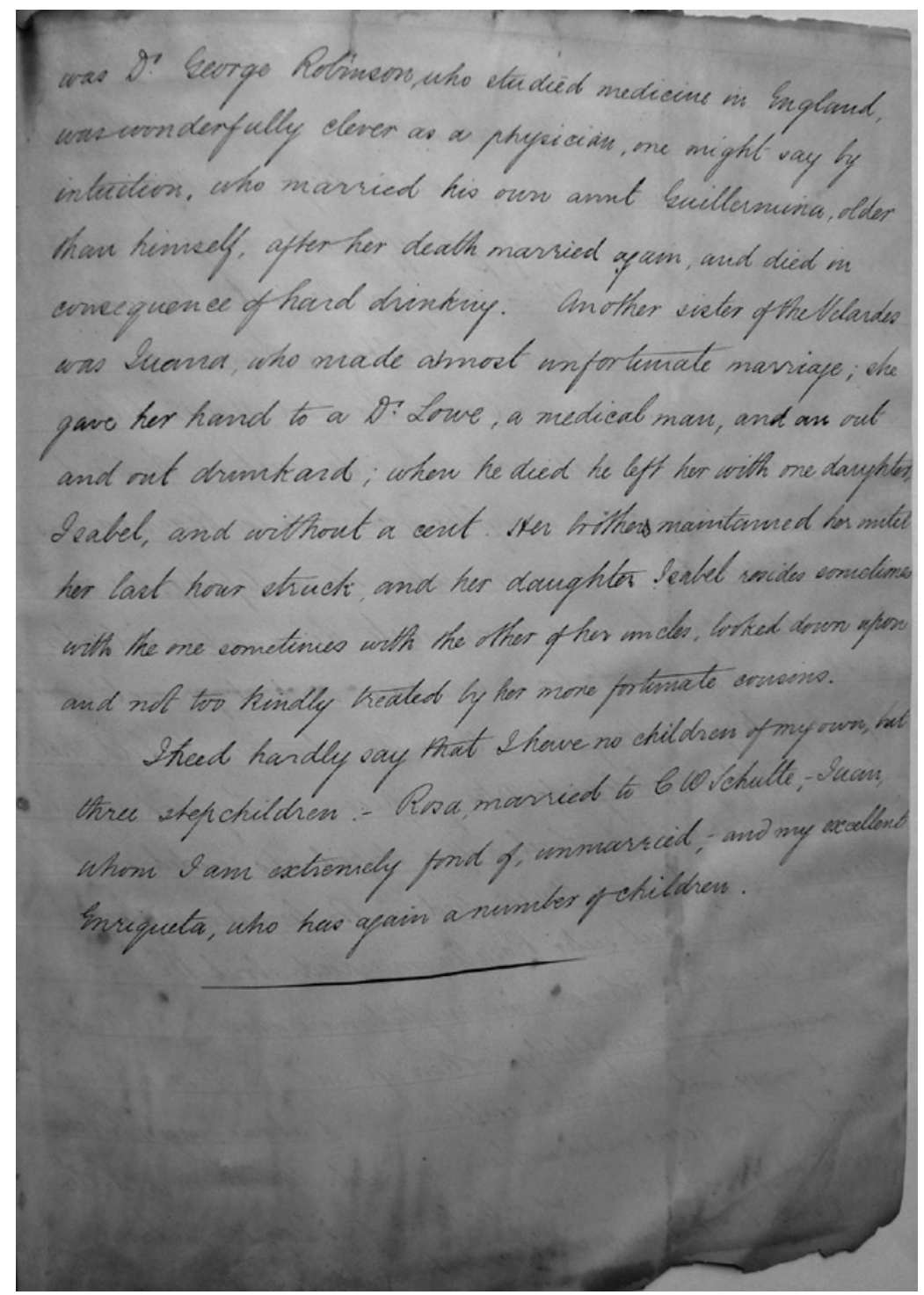

A-7-13. OA-7-5-5 


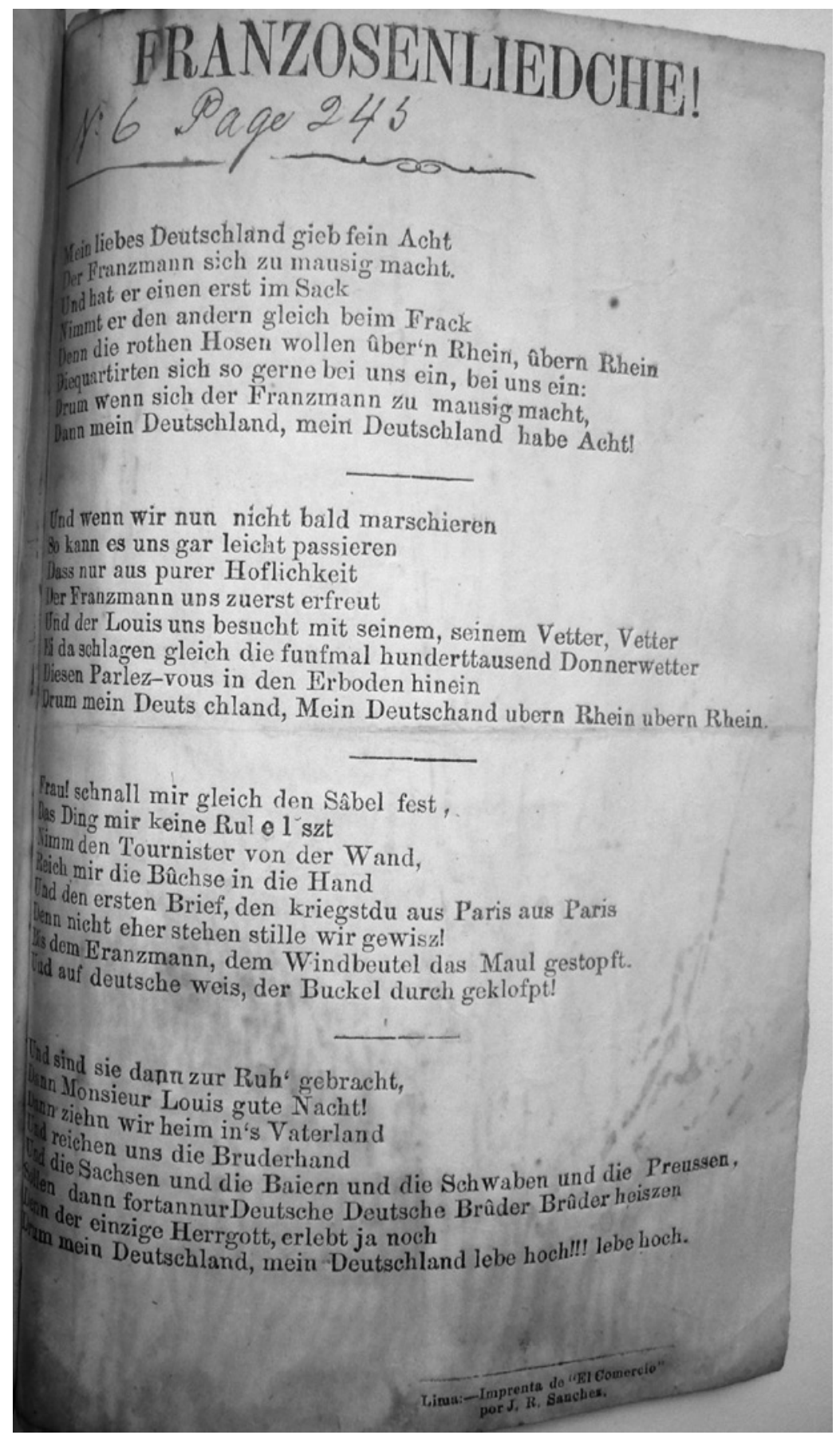

A-7-14. OA-7-6-1 


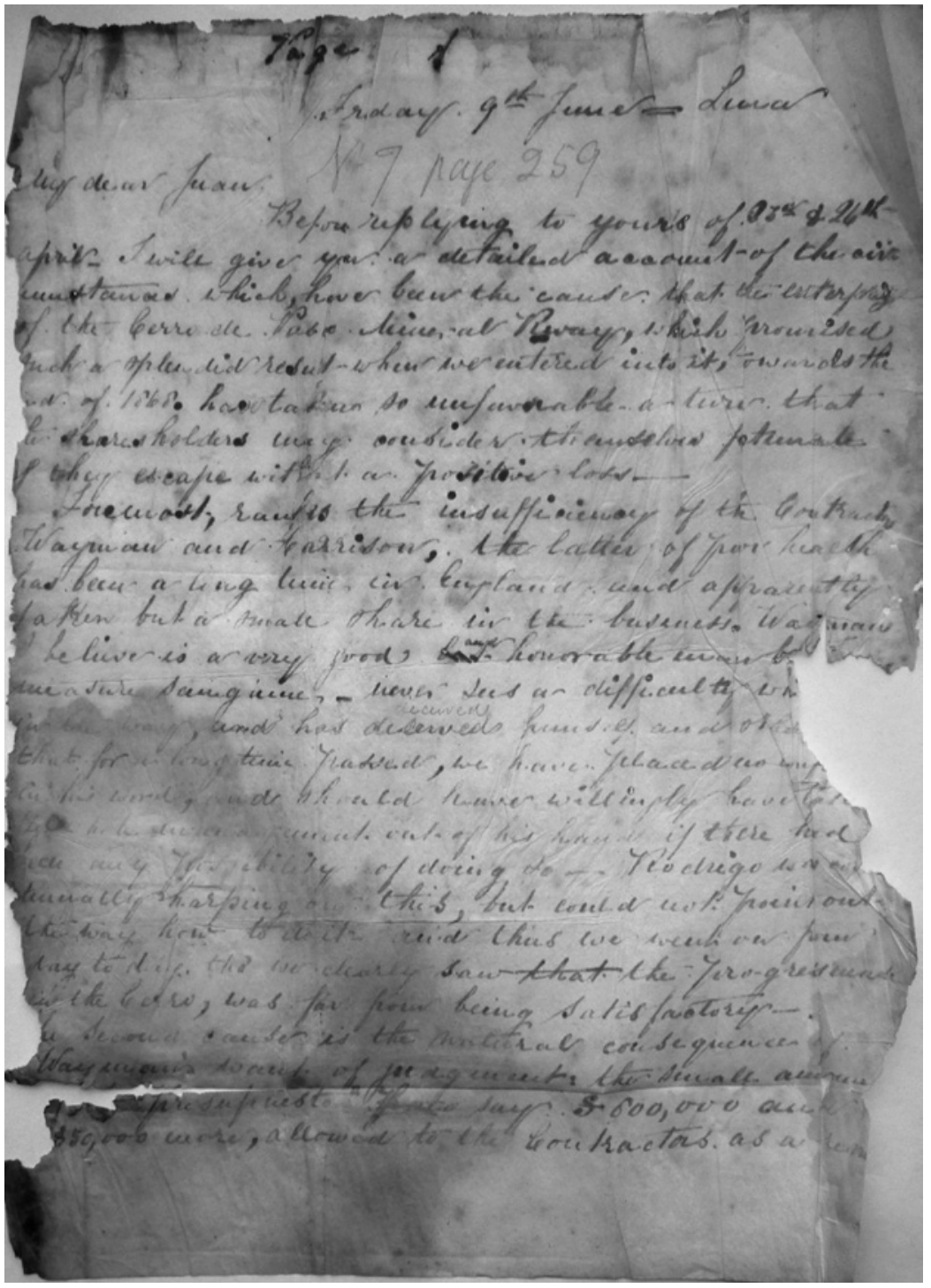

A-7-15. OA-7-9-1 


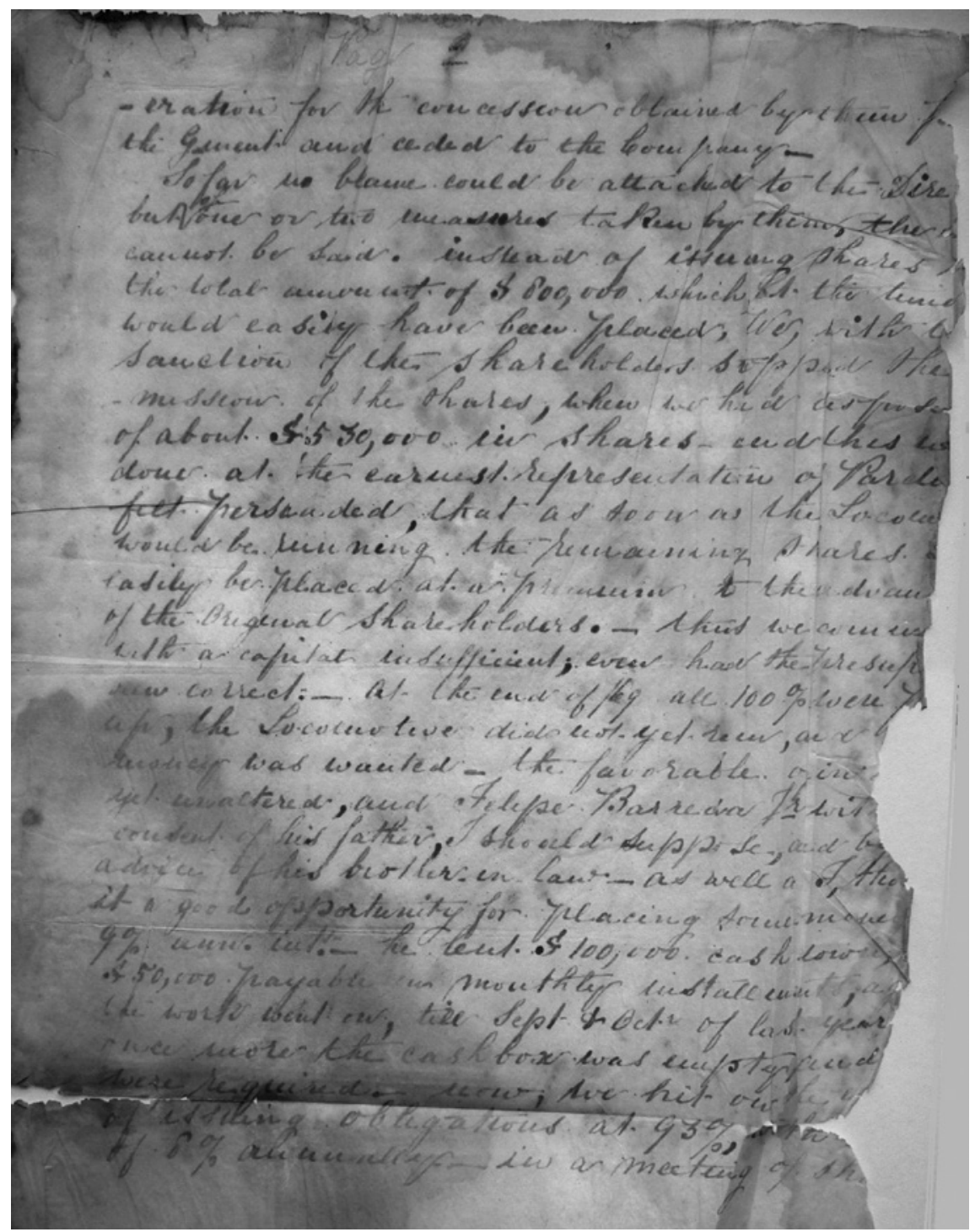

A-7-16. OA-7-9-2 


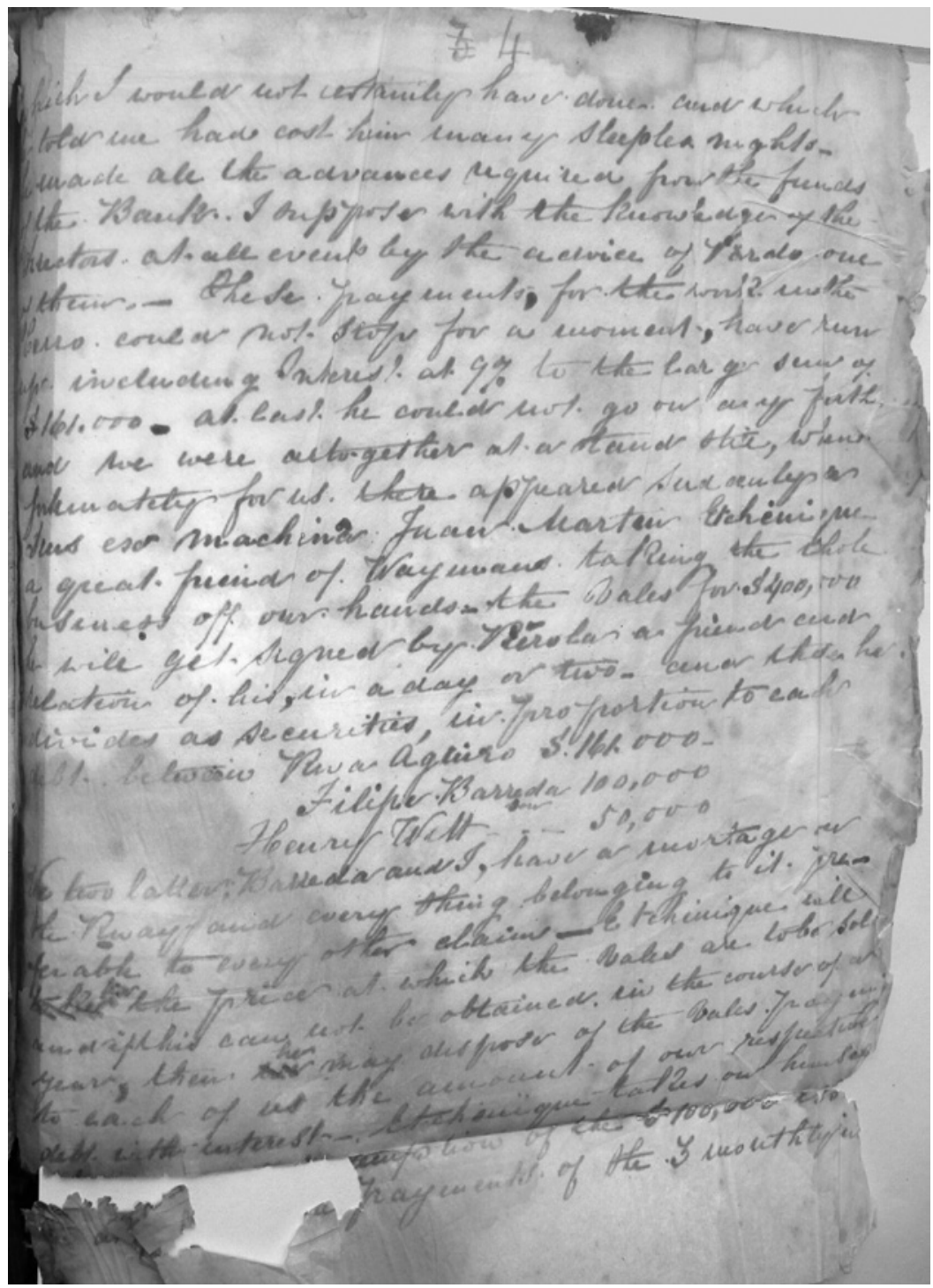

A-7-17. OA-7-9-3 


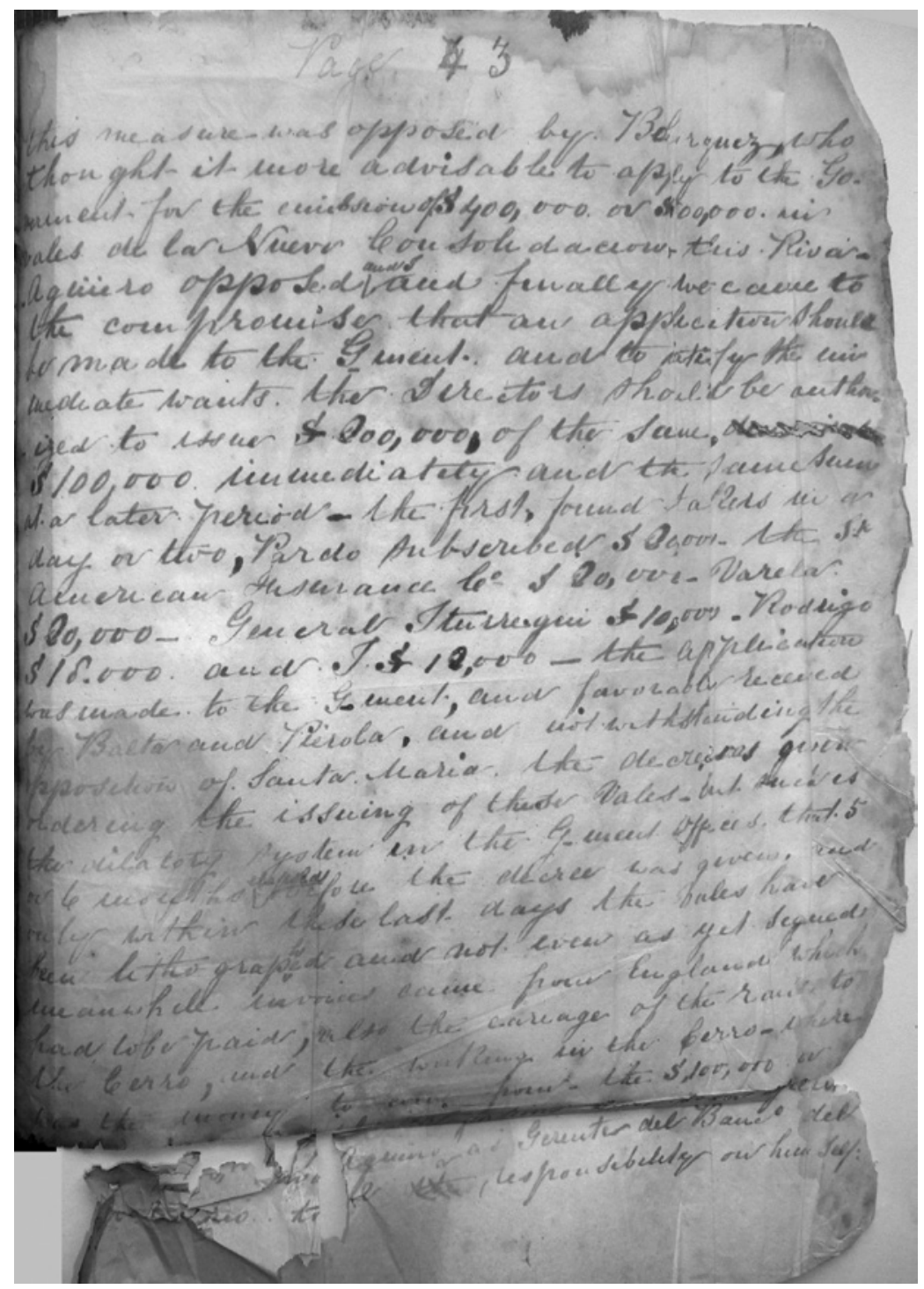

A-7-18. OA-7-9-4 


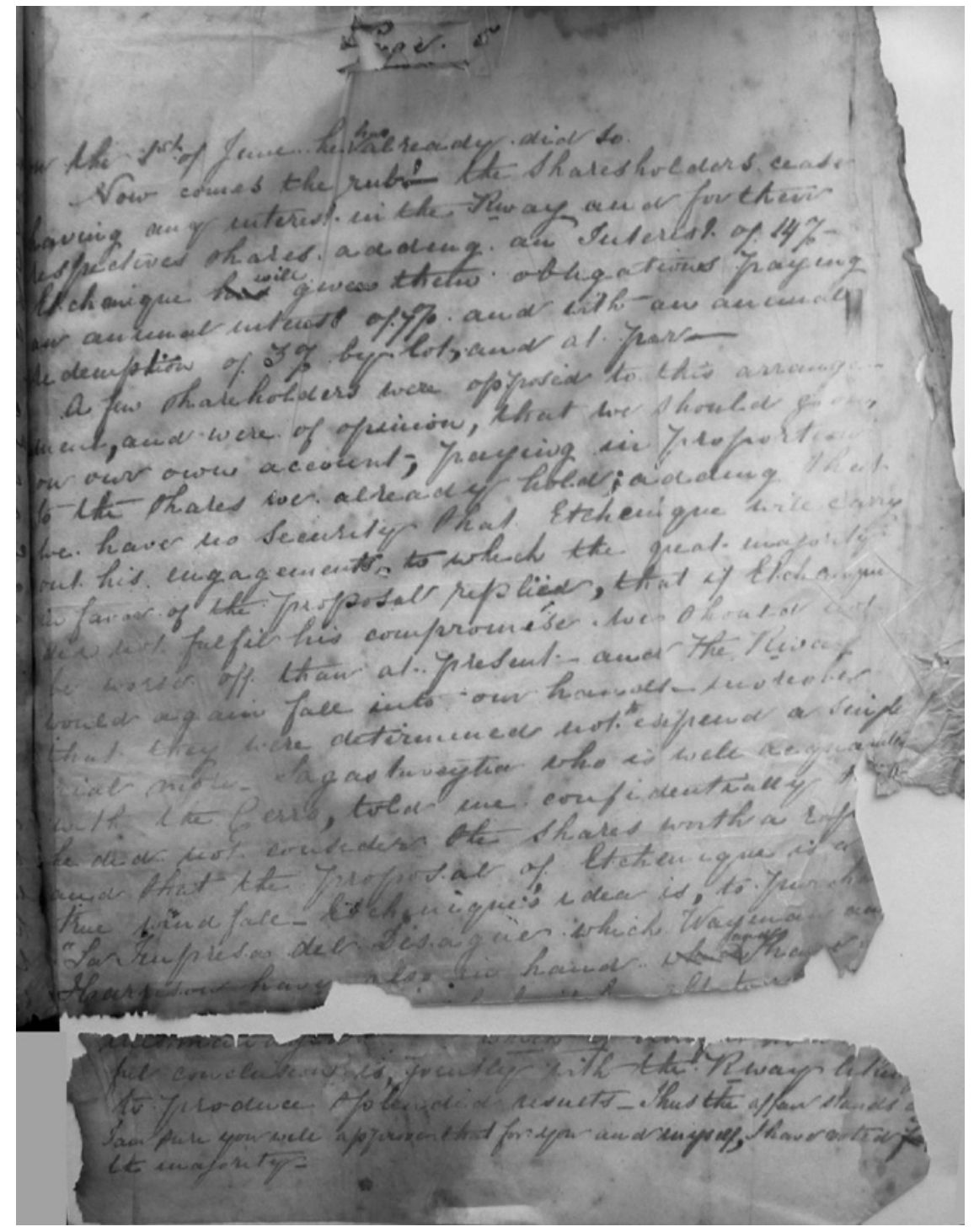

A-7-19. OA-7-9-5 


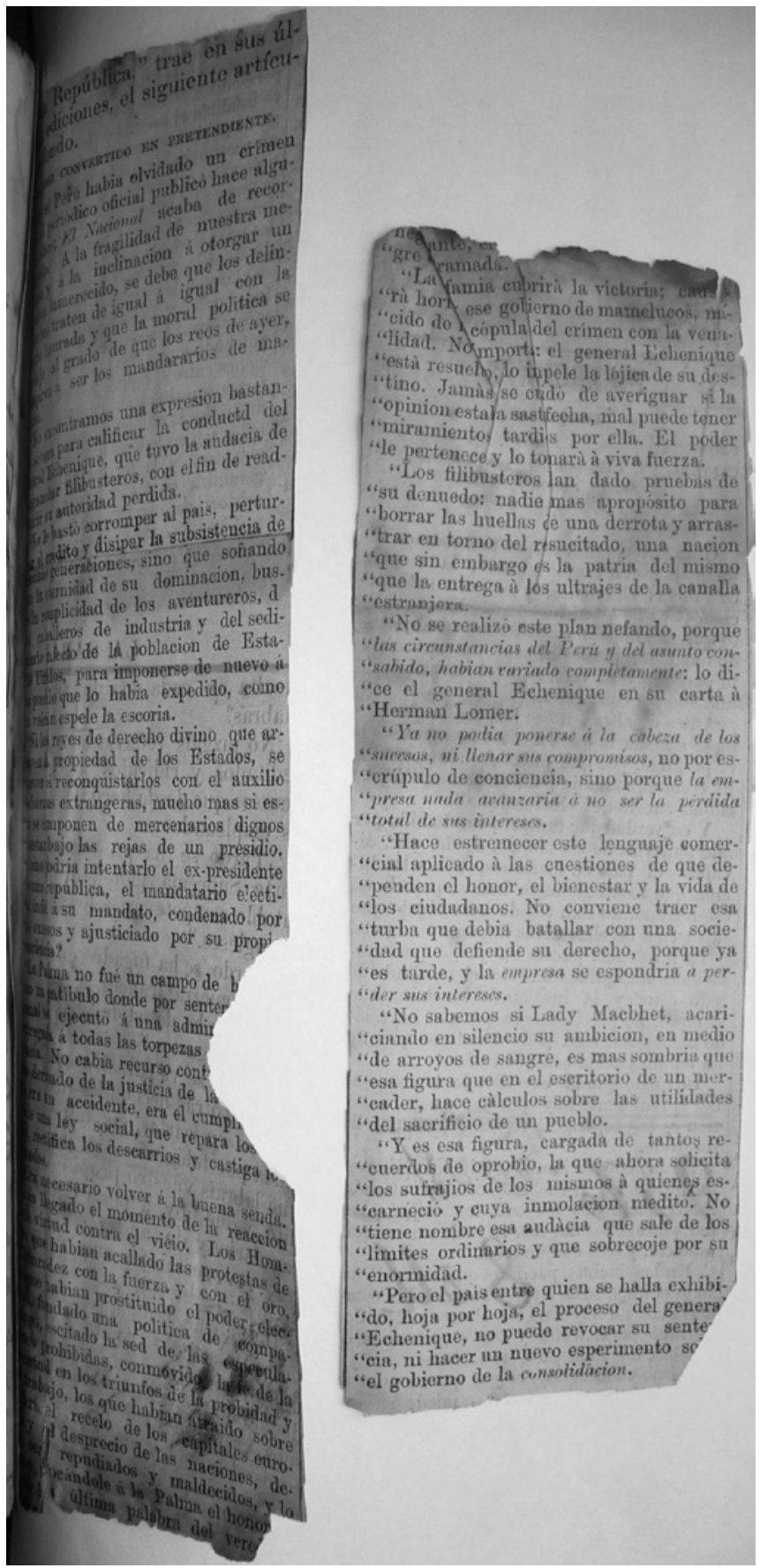

A-7-20. OA-7-8-1 


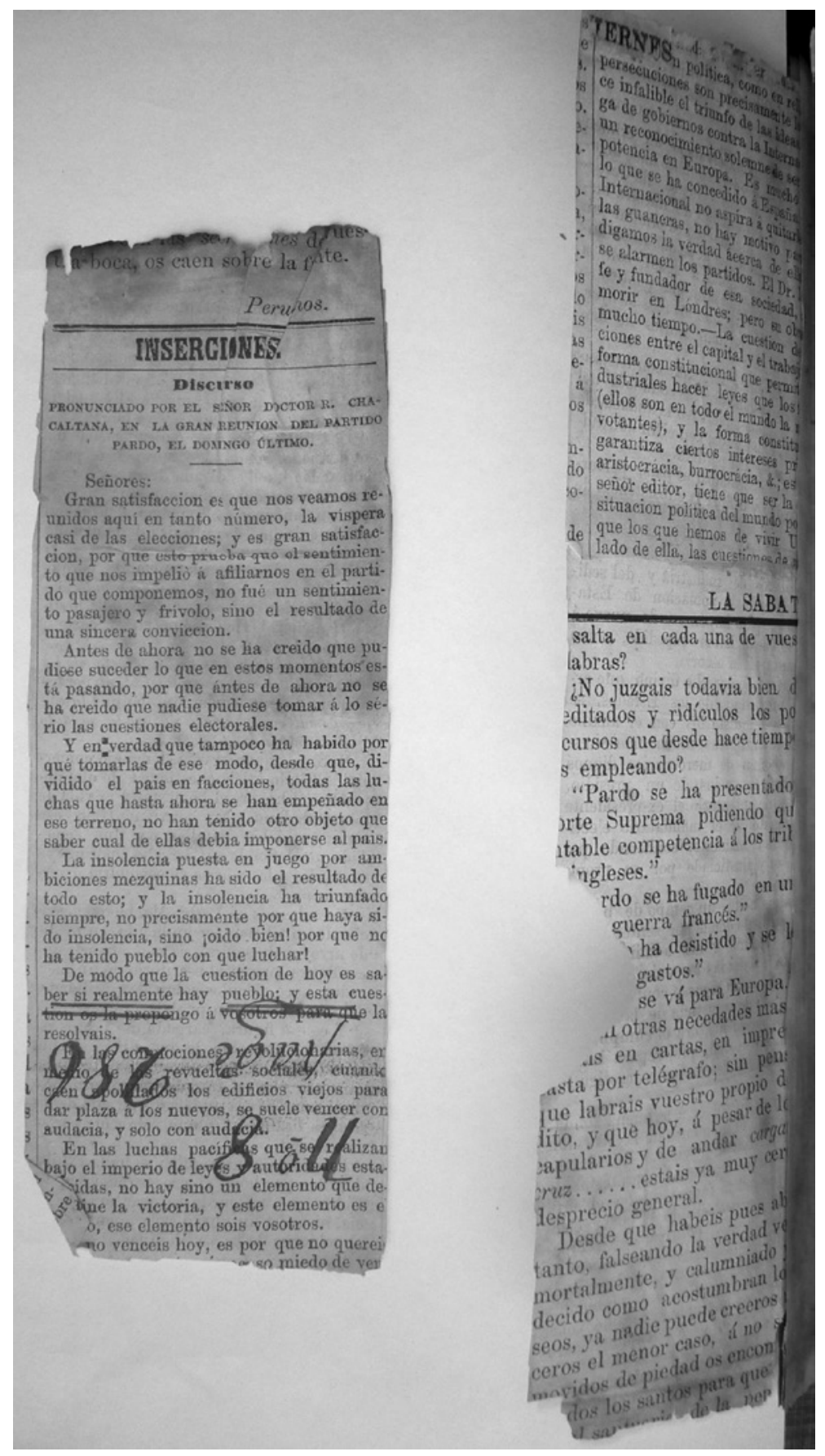

A-7-21. OA-7-8-2 


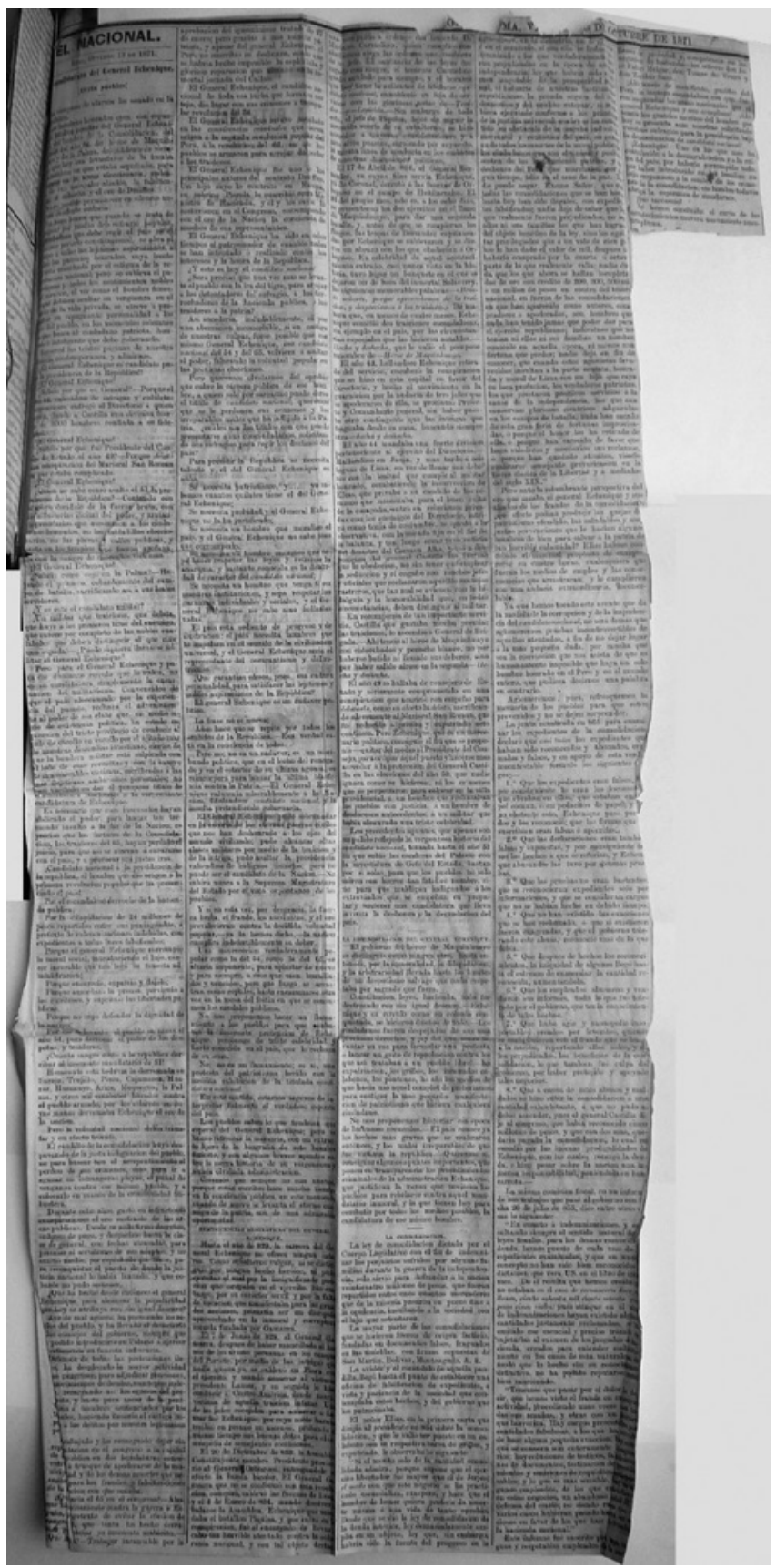

A-7-22. OA-7-9a-1

Ulrich Muecke - 9789004307247 


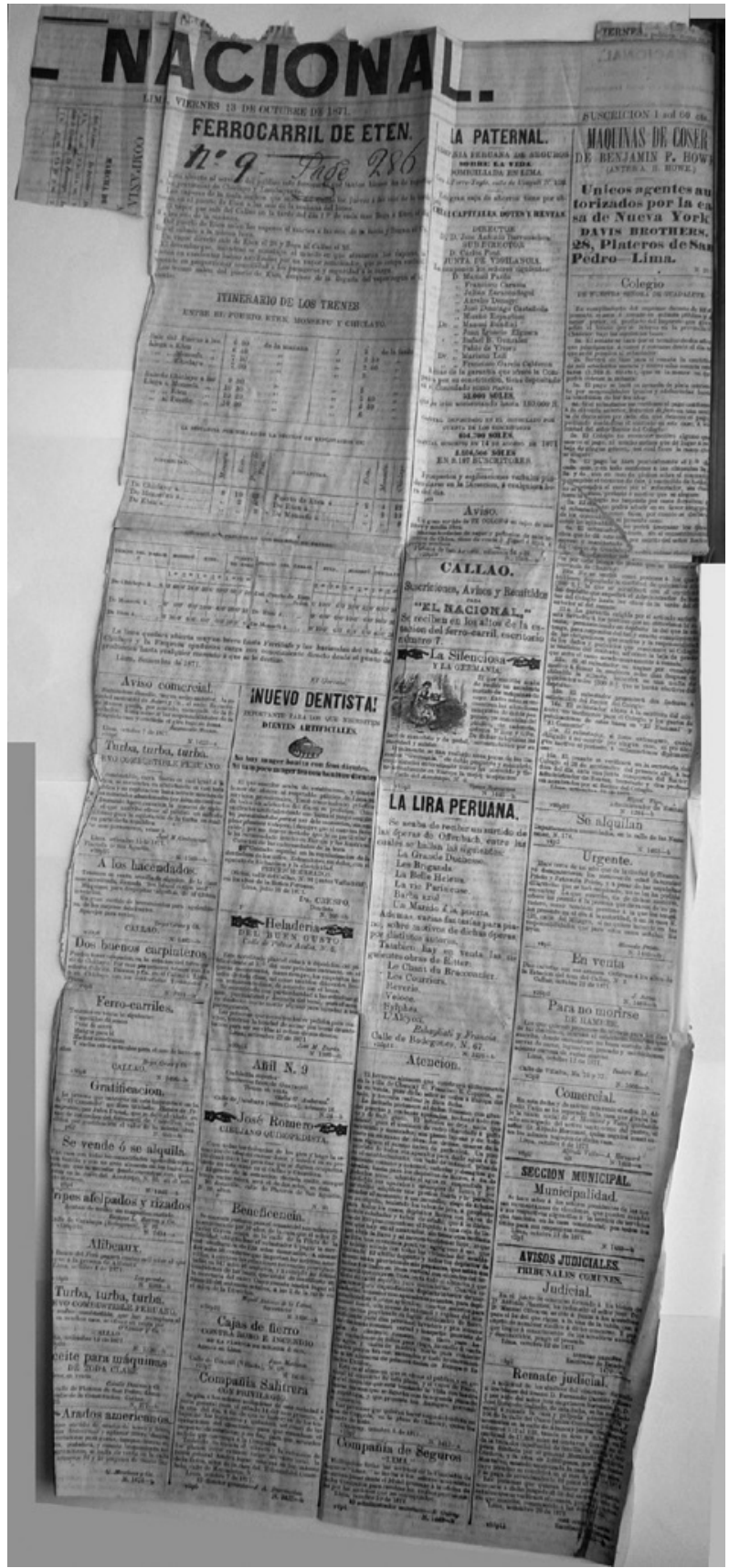

A-7-23. OA-7-9a-2 
786

THE DIARY OF HEINRICH WITT

Paso 350

Goria

Consulado Seneral de Dinamarea enel Peris. Lima 24 de julio 1879

In contestacion à la nota-arcular deT. fecha de ayer, que me fue entregada troy á luo 4\%2 de la larde, me limito á mdicar a' YS. que ningun arilado se halla en we fonsulado Seneral

the suserito de W.S.

re

Ginor Seerctaris Seneral de S. S. el Tefe Supremo dela Repultiea.

$$
\text { A-7-24. OA-7-10-1 }
$$

Ulrich Muecke - 9789004307247

Downloaded from Brill.comఠ4/26/2023 02:18:48PM

via free access 


\section{11 9ago 340 \\ Extract from Precident Pardes Alessage to the

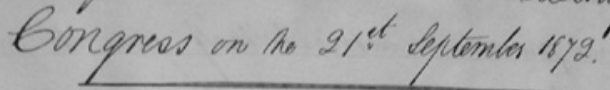

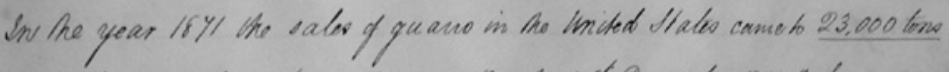

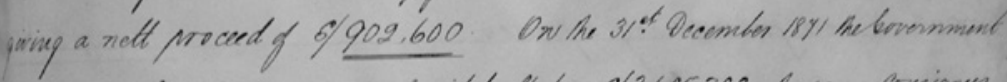

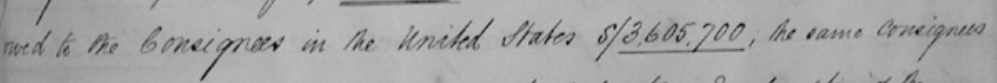

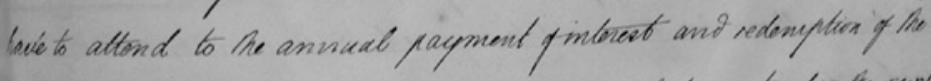
besurian-Chile Bonds, and accordengly from that quarter for the neot from years, induding that of 18Y2, no pecuniary asivatanes can be nopeled.

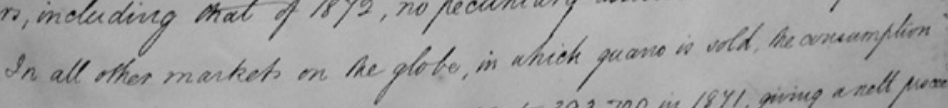

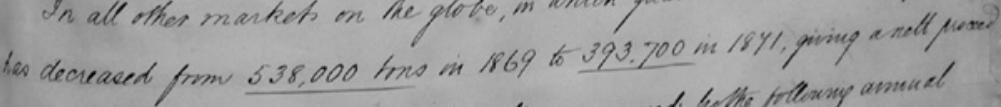

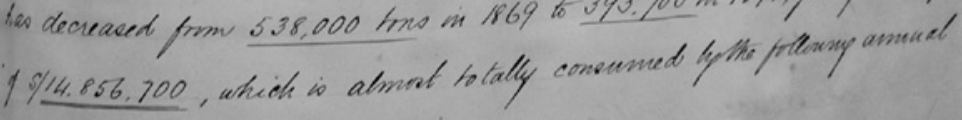
cauments:-

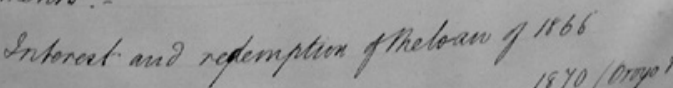

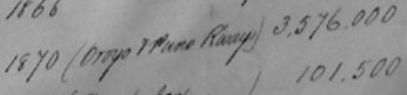

$-1$ ,

$+$ Plivented.

$7 \%$ on $5 \% 75,000,000$ loan $4187^{2}$

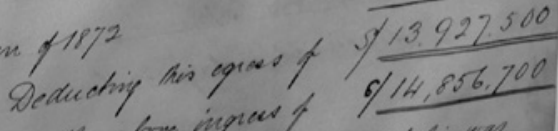
from the abro ingies y het his was

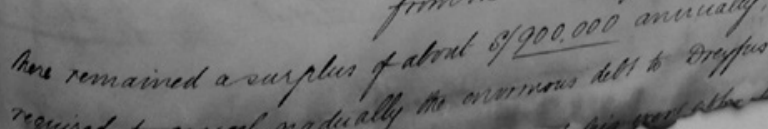

A-7-25. OA-7-11-1 


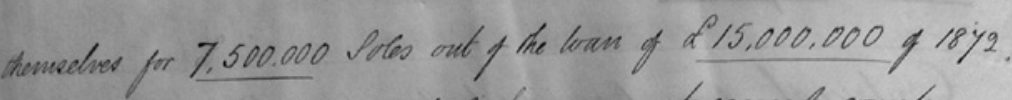
$7 \mathrm{~m}$ his of is to be cow that the Evomment cament conent upow mo ein rial of he quano proeceds to evetricato itelf from its present financial

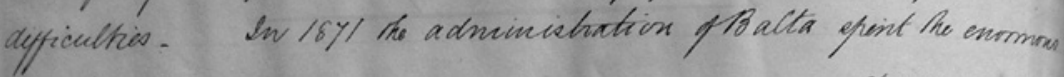

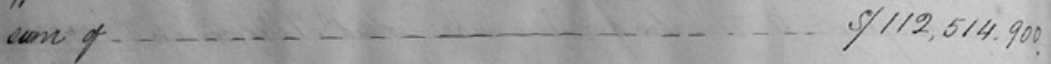
fwhich were for ordinary axpemses _... . . . $95,385.000$ leavmy for ordinacy oxtenses $\quad S / 17,130.000$

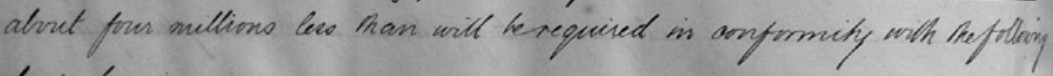
ludget ry:-

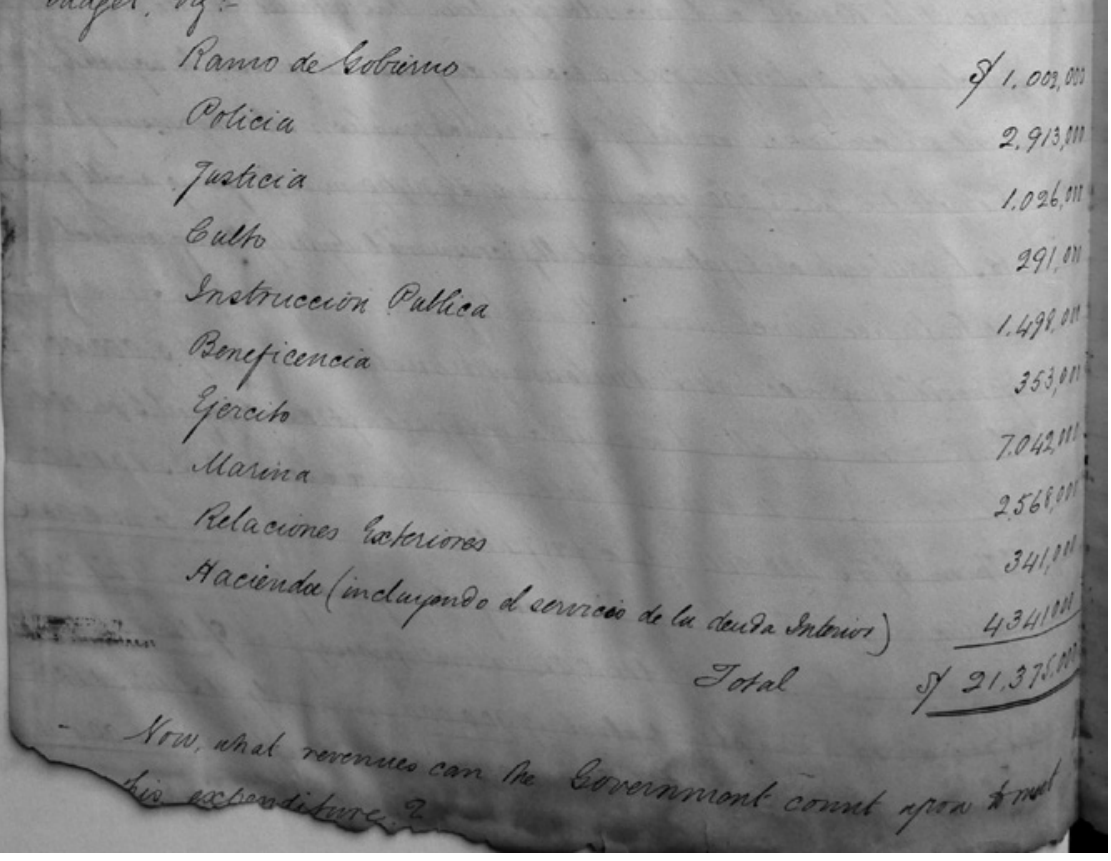

A-7-26. OA-7-11-2 


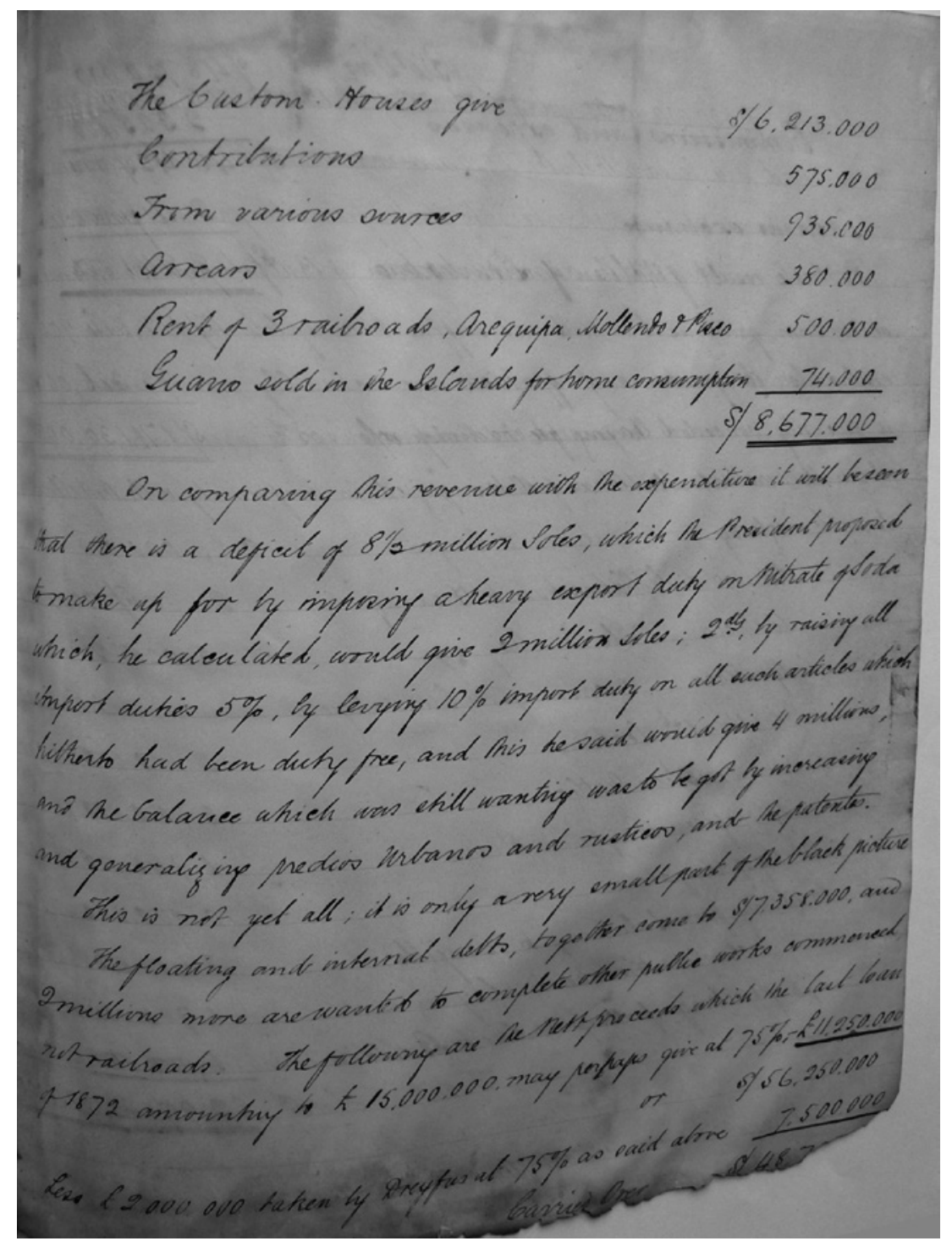

A-7-27. OA-7-11-3 


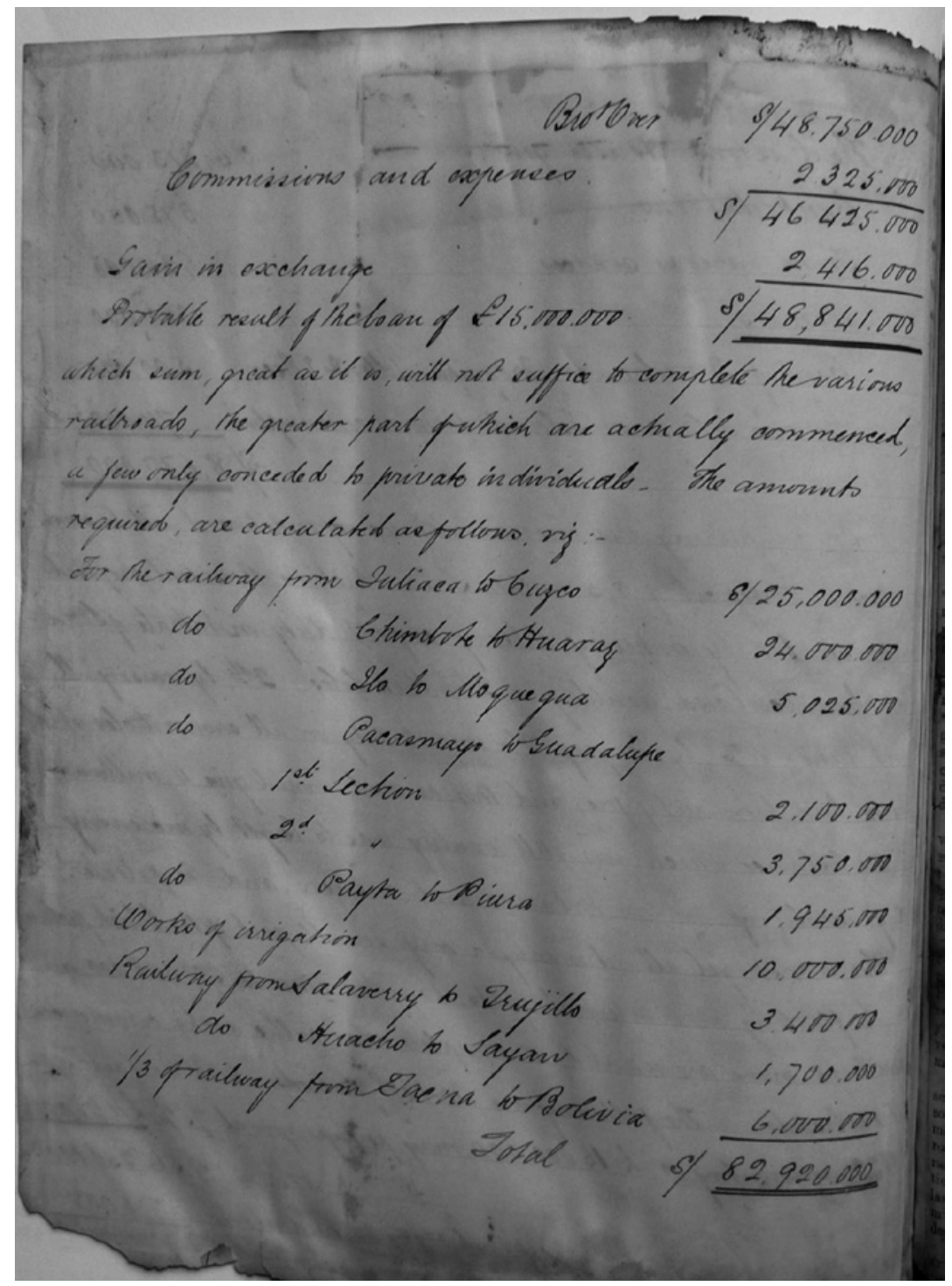

A-7-28. OA-7-11-4 


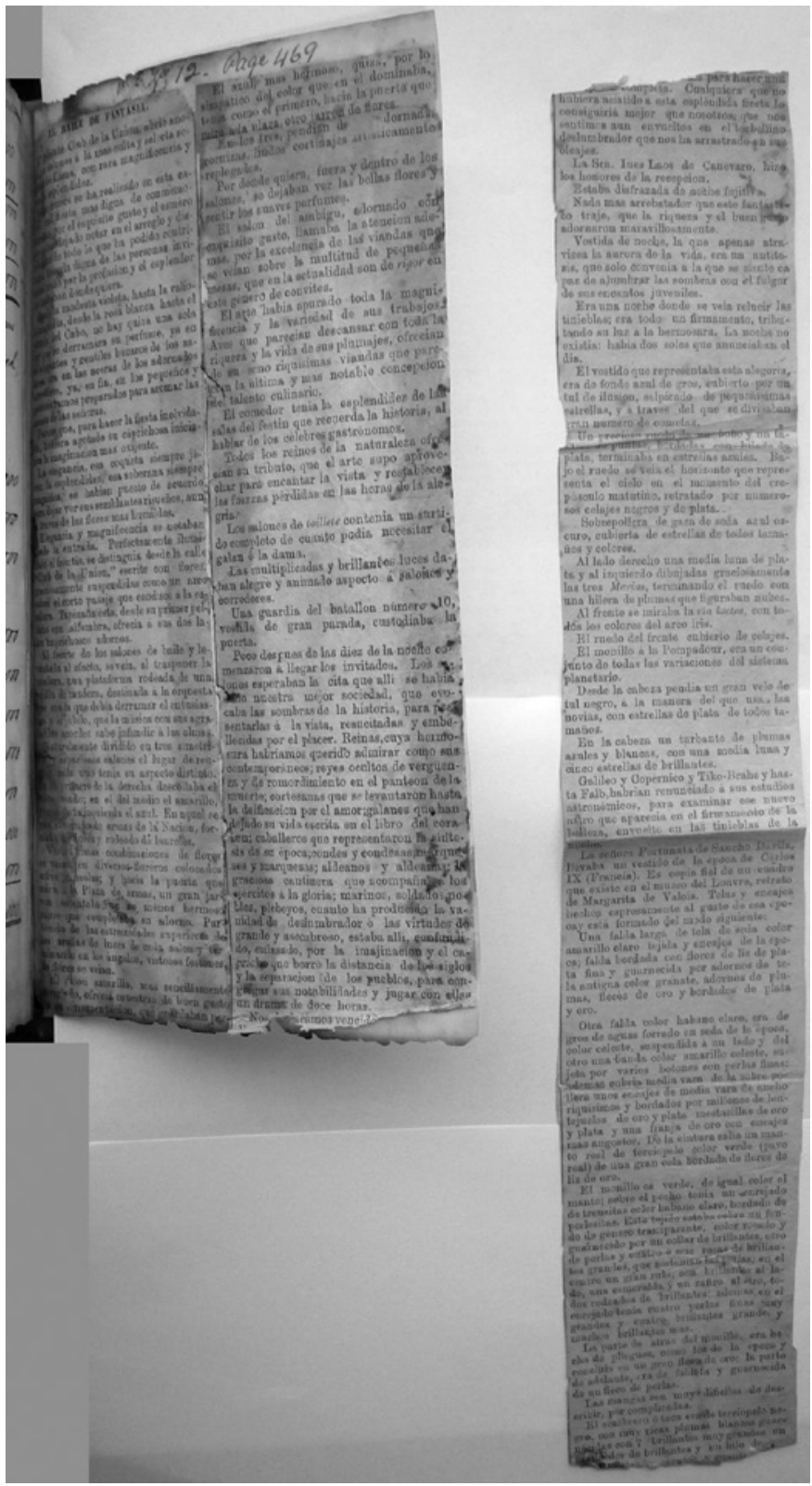

A-7-29. OA-7-12-1 


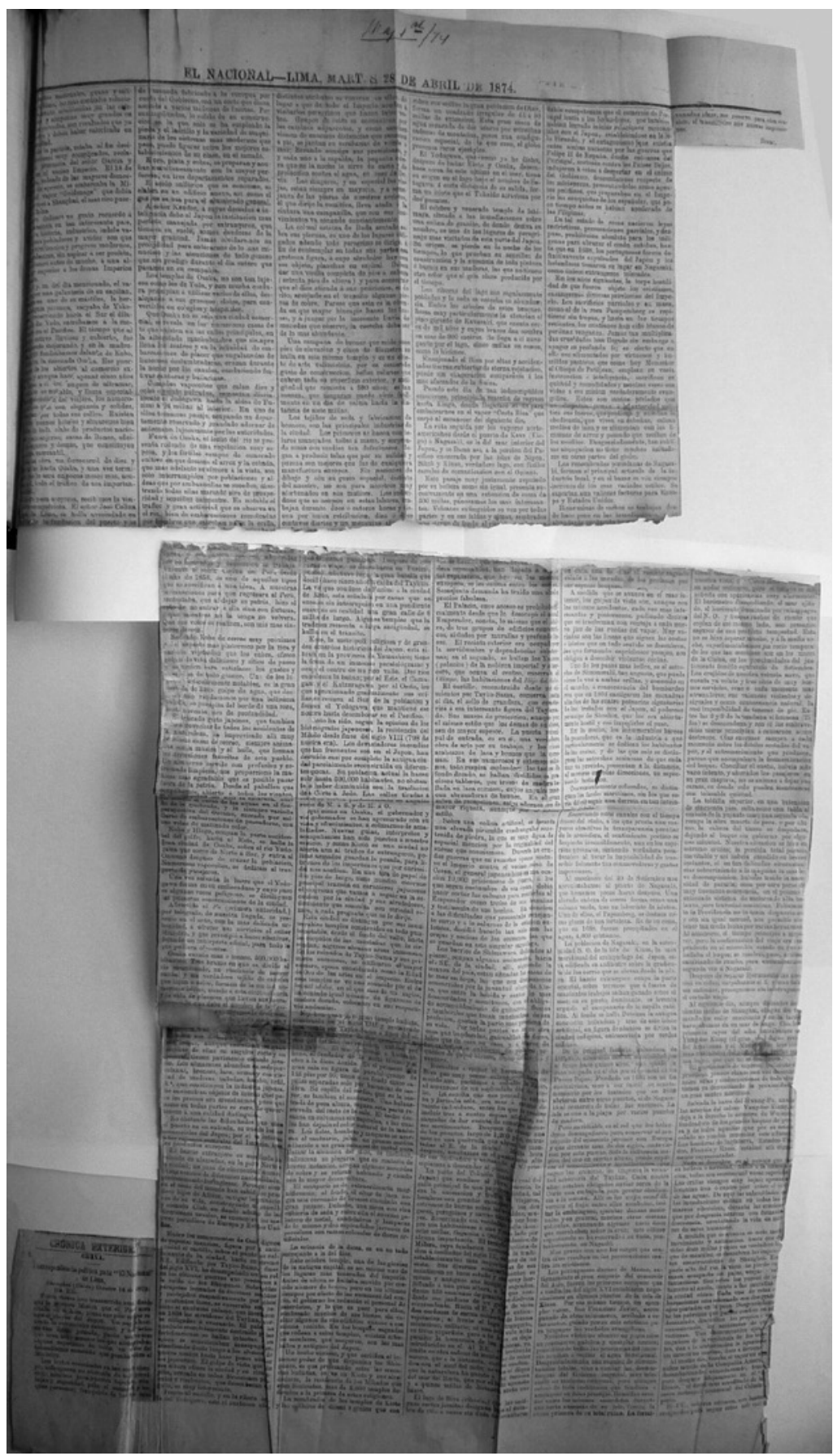

A-7-30. OA-7-13-1 


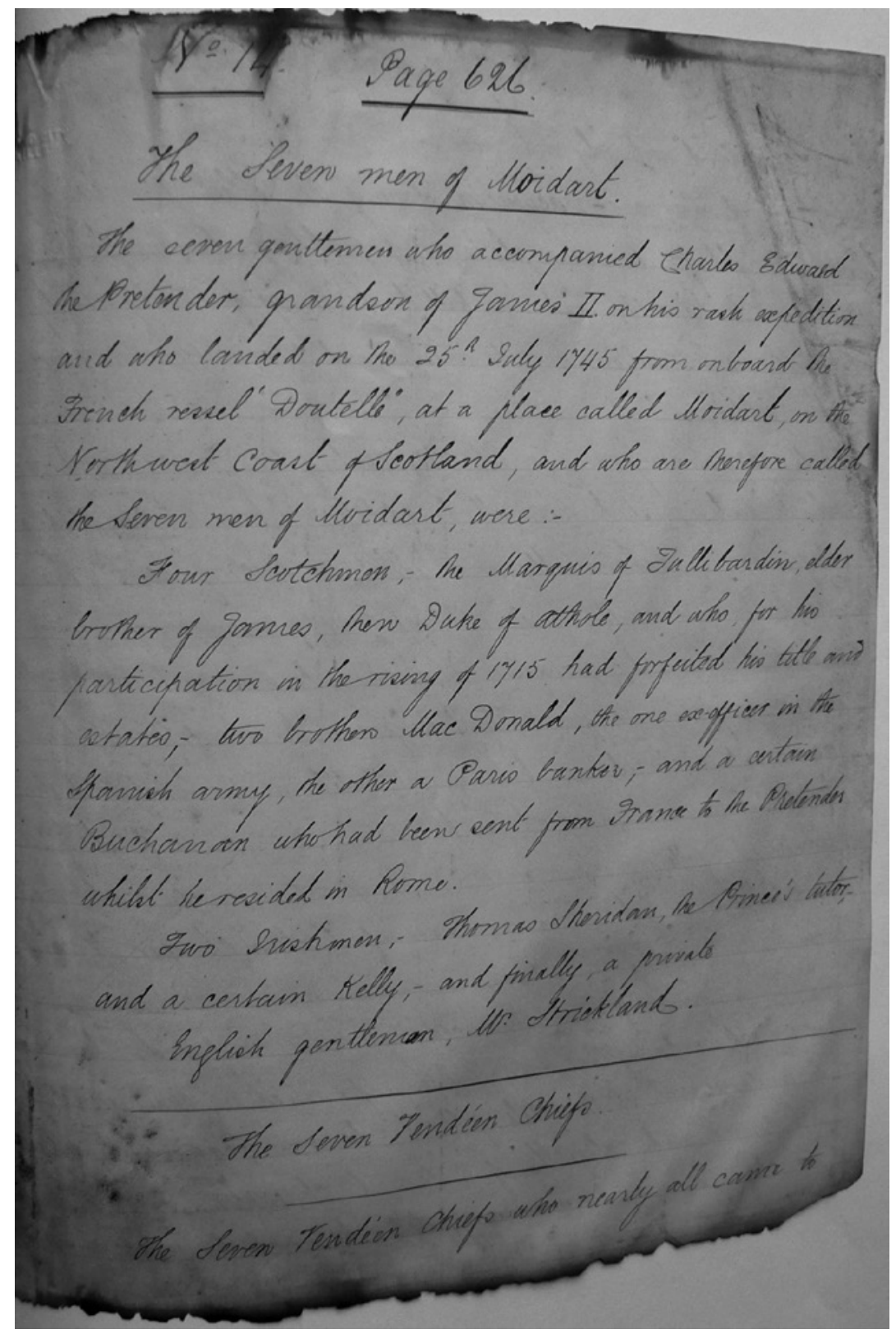

A-7-31. OA-7-14-1 


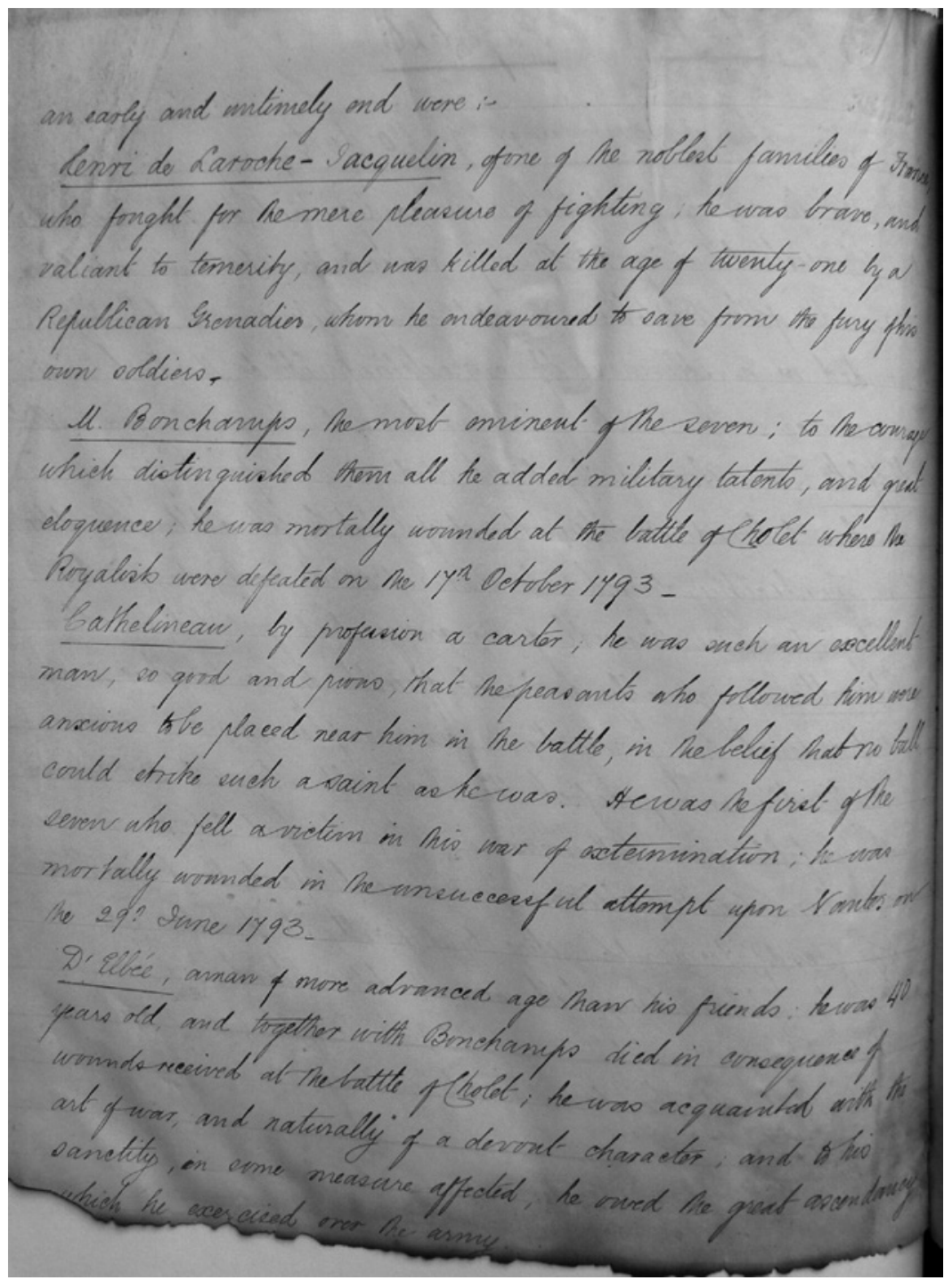

A-7-32. OA-7-14-2 


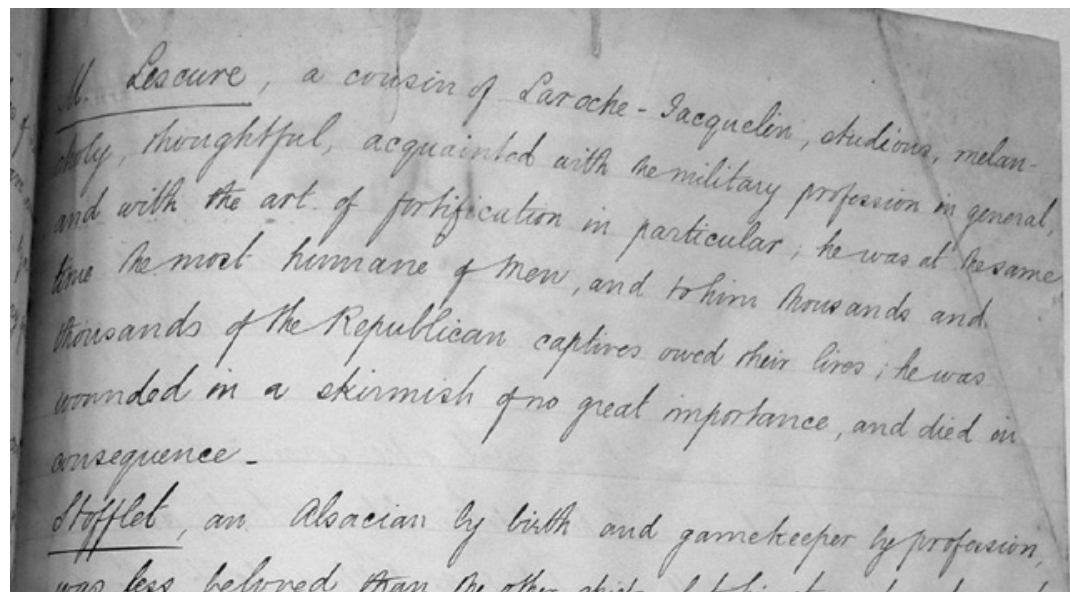
was less heloned than the other chiefs, hut his etern chasacter made tim implicitly obeyed; he was rather a leader of queisilla sarhis hav ne Eeneral of an army.

bharette, originally a naval fficen, and of a dolicate contutiction had hardoned his frome by the oxencirs of the chave. When the

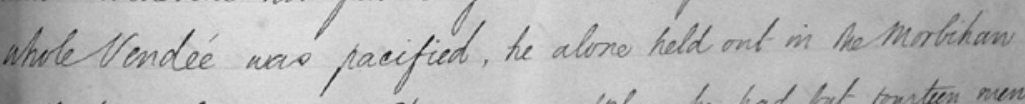
with his followers - Ohonans. Cohen he had hot prostuen men with him the Repullicam Sorrament fored him a smillion ofranes of he would retire hingland, which heropreed at lact he abo euccumbed, was nuade prinoner, and was ohit at Nankes on the 26" manch 1496 , Shyflet haming nit the came fate at ampers in the 24 " Bebruary f the imme year.

-7-33. OA-7-14-3 


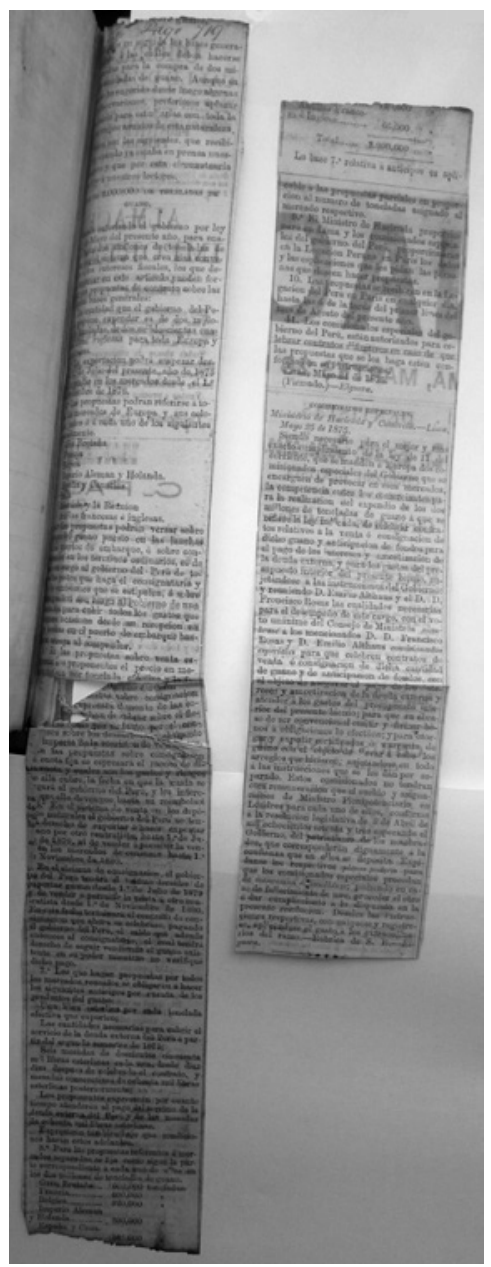

A-7-34. OA-7-15-1 


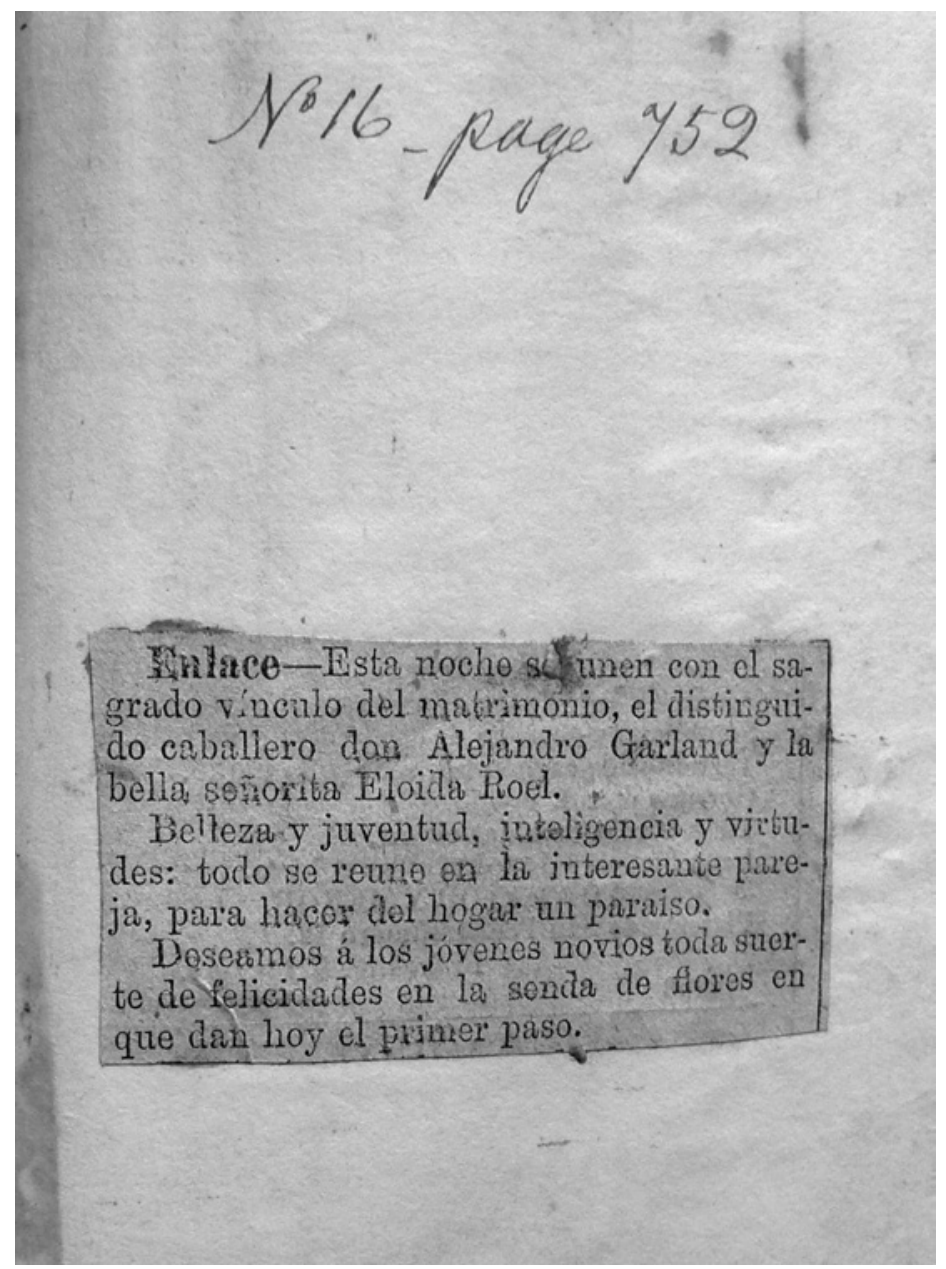

A-7-35. OA-7-16-1 


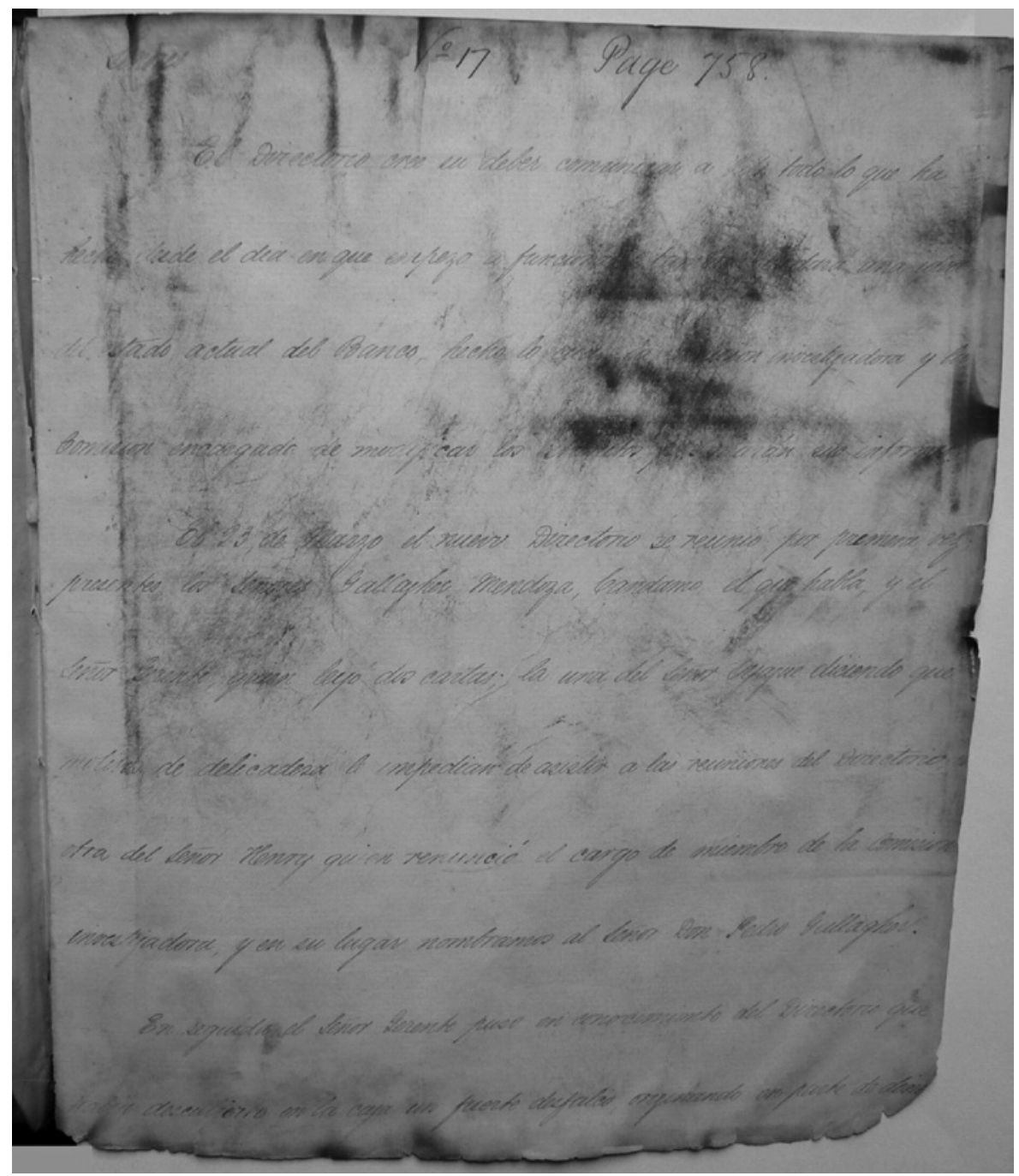

A-7-36. OA-7-17-1 


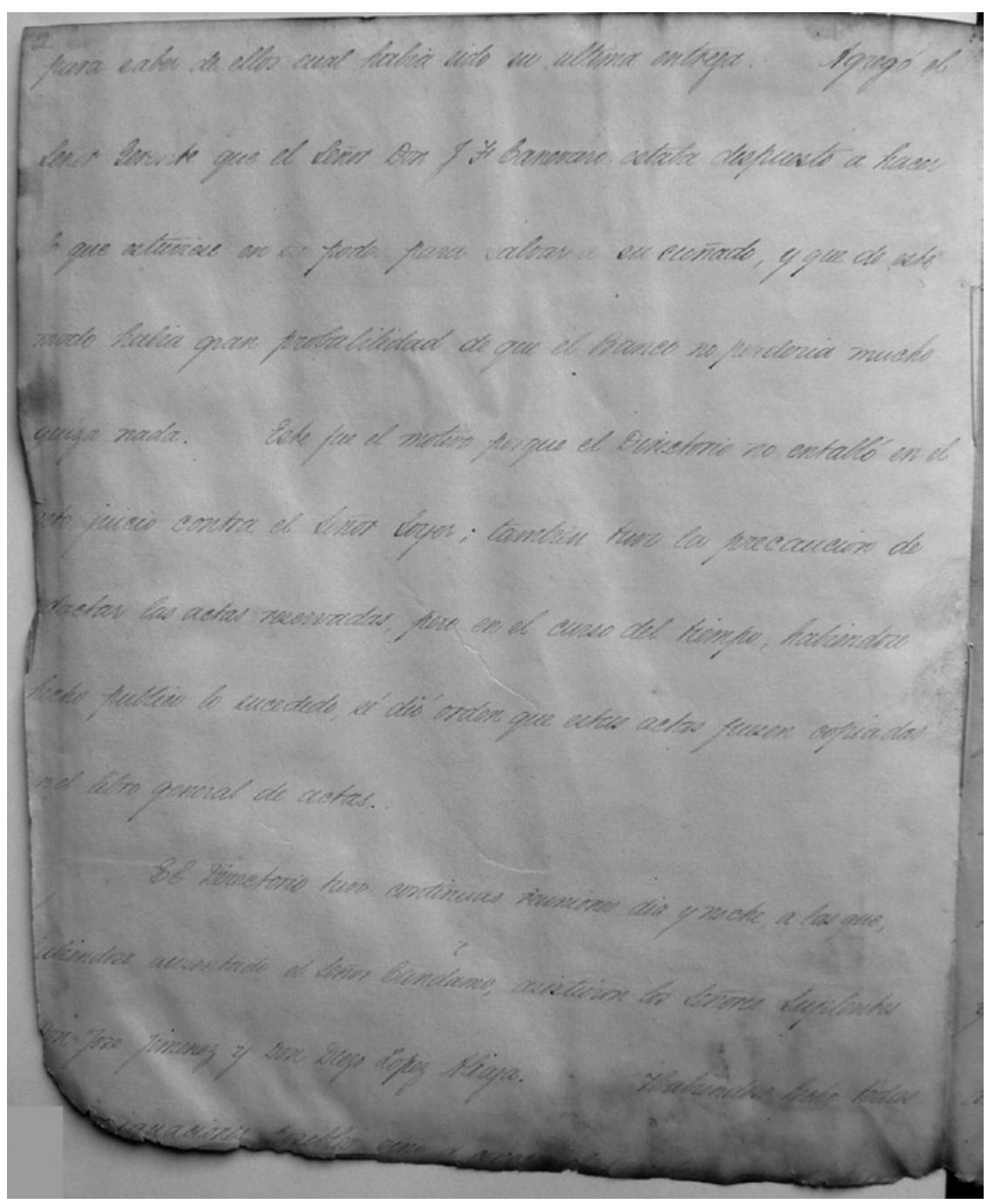

A-7-37. OA-7-17-2 


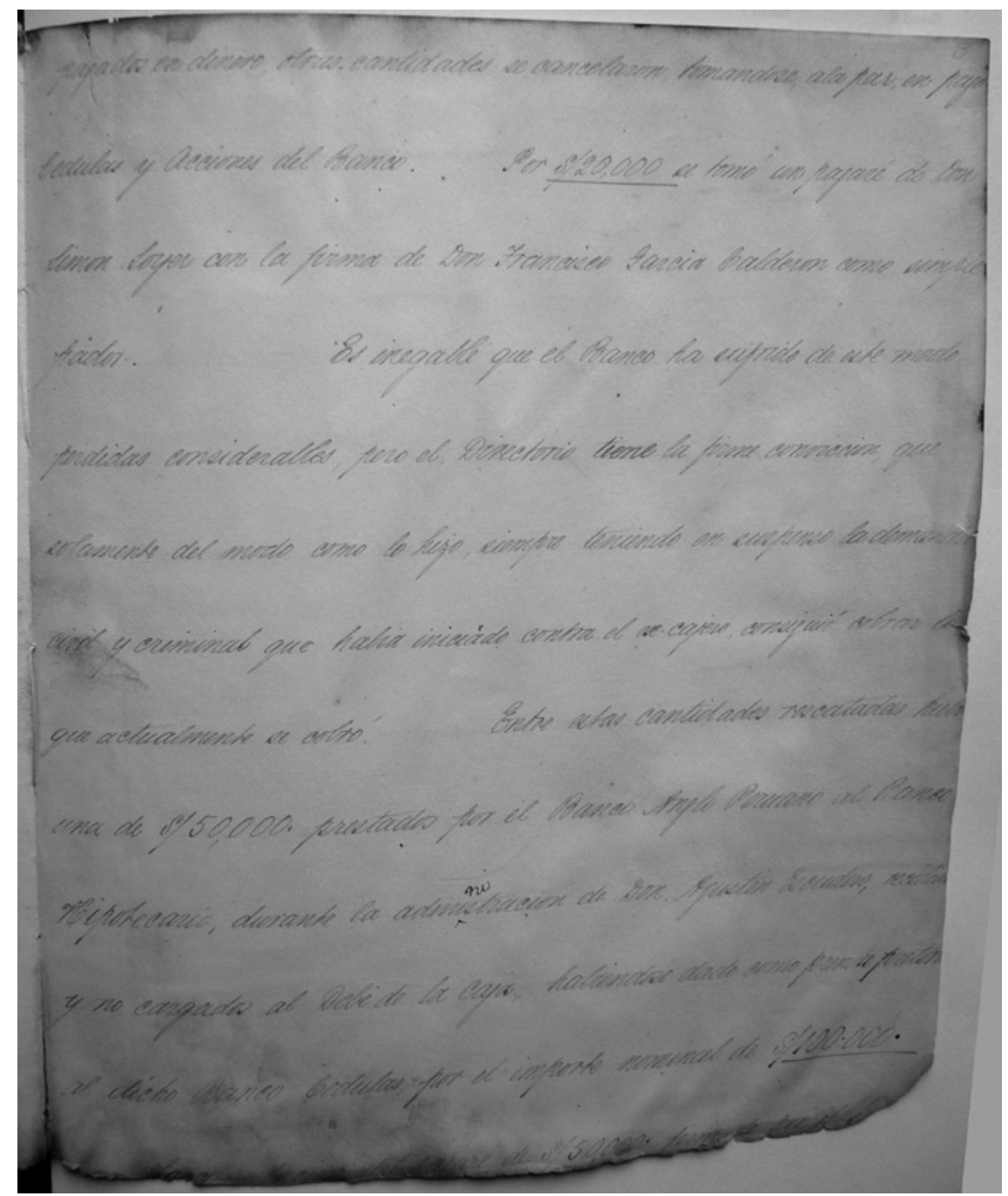

A-7-38. OA-7-17-3 


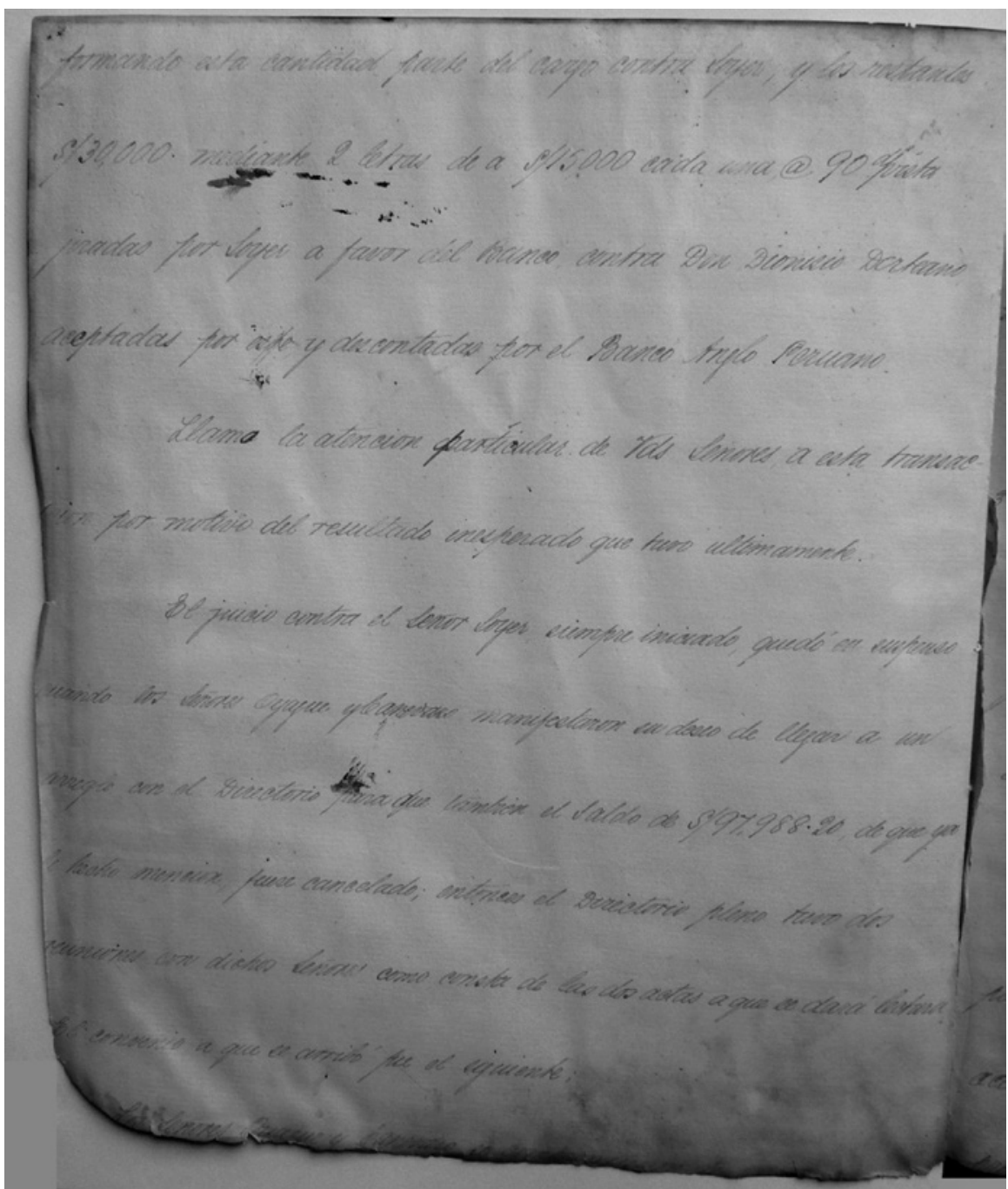

A-7-39. OA-7-17-4 


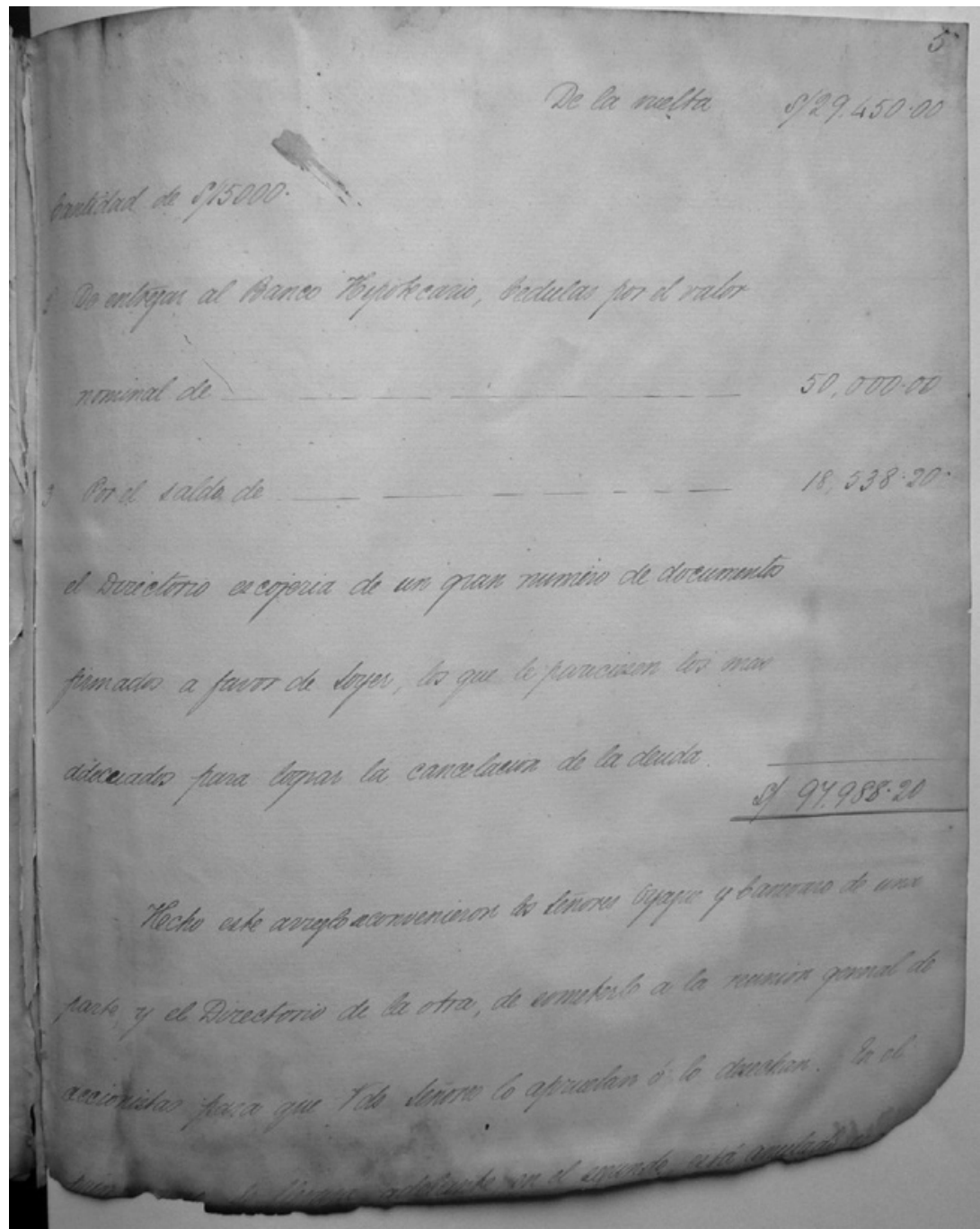

A-7-40. OA-7-17-5 


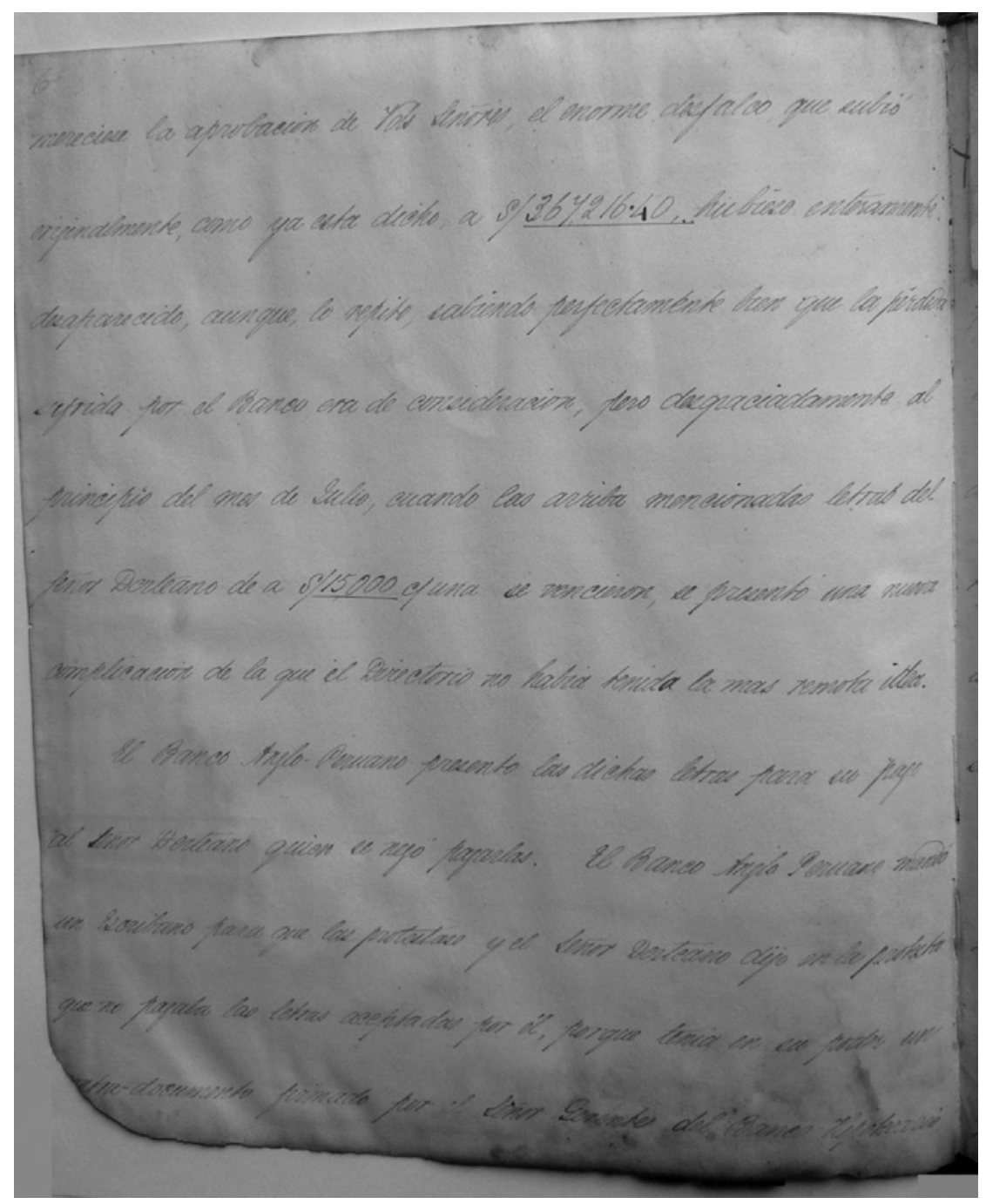

A-7-41. OA-7-17-6 


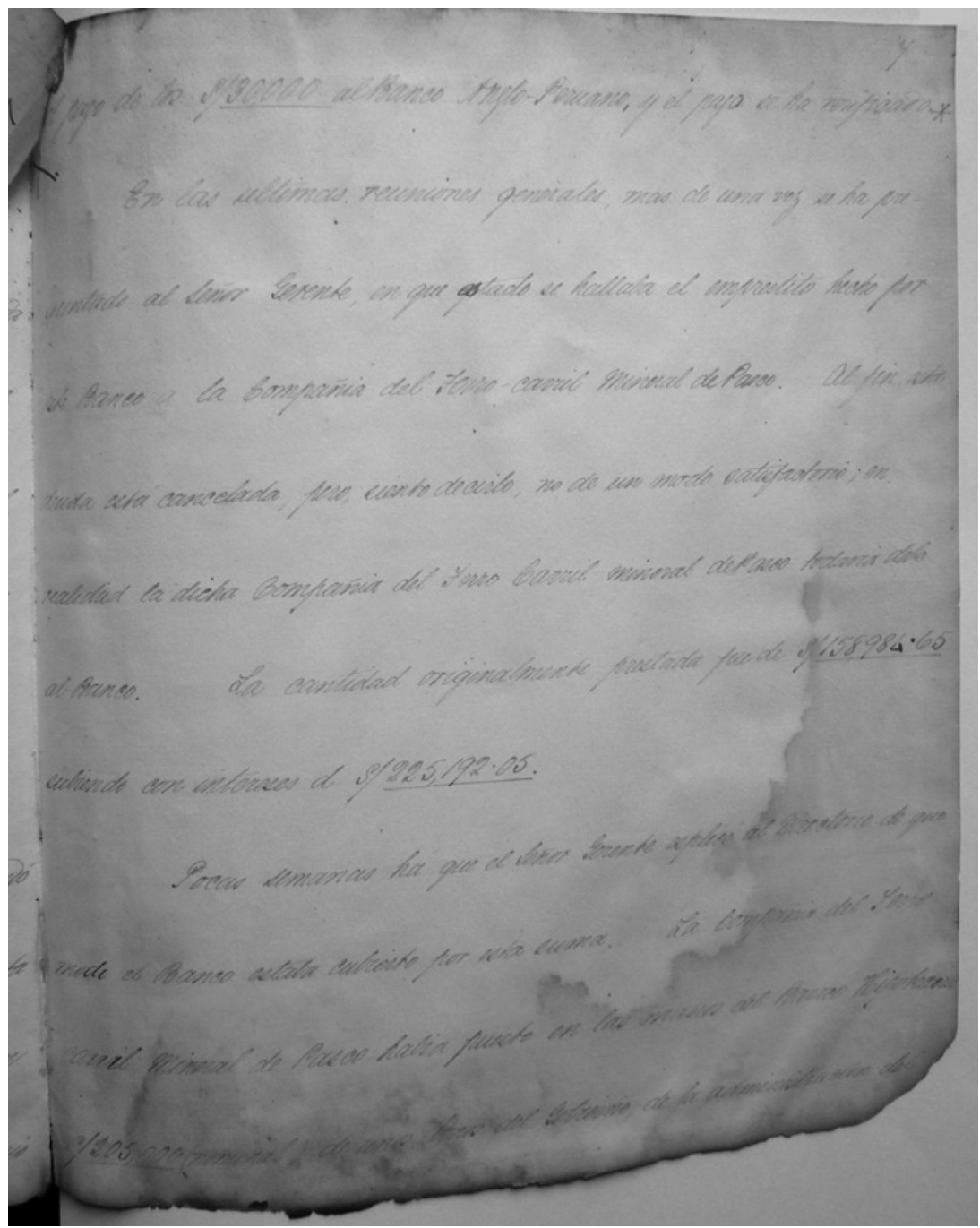

A-7-42. OA-7-17-7 


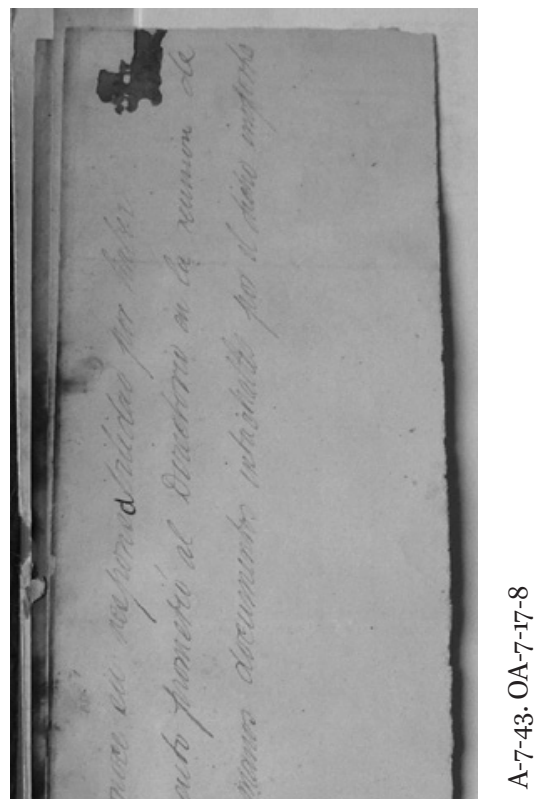




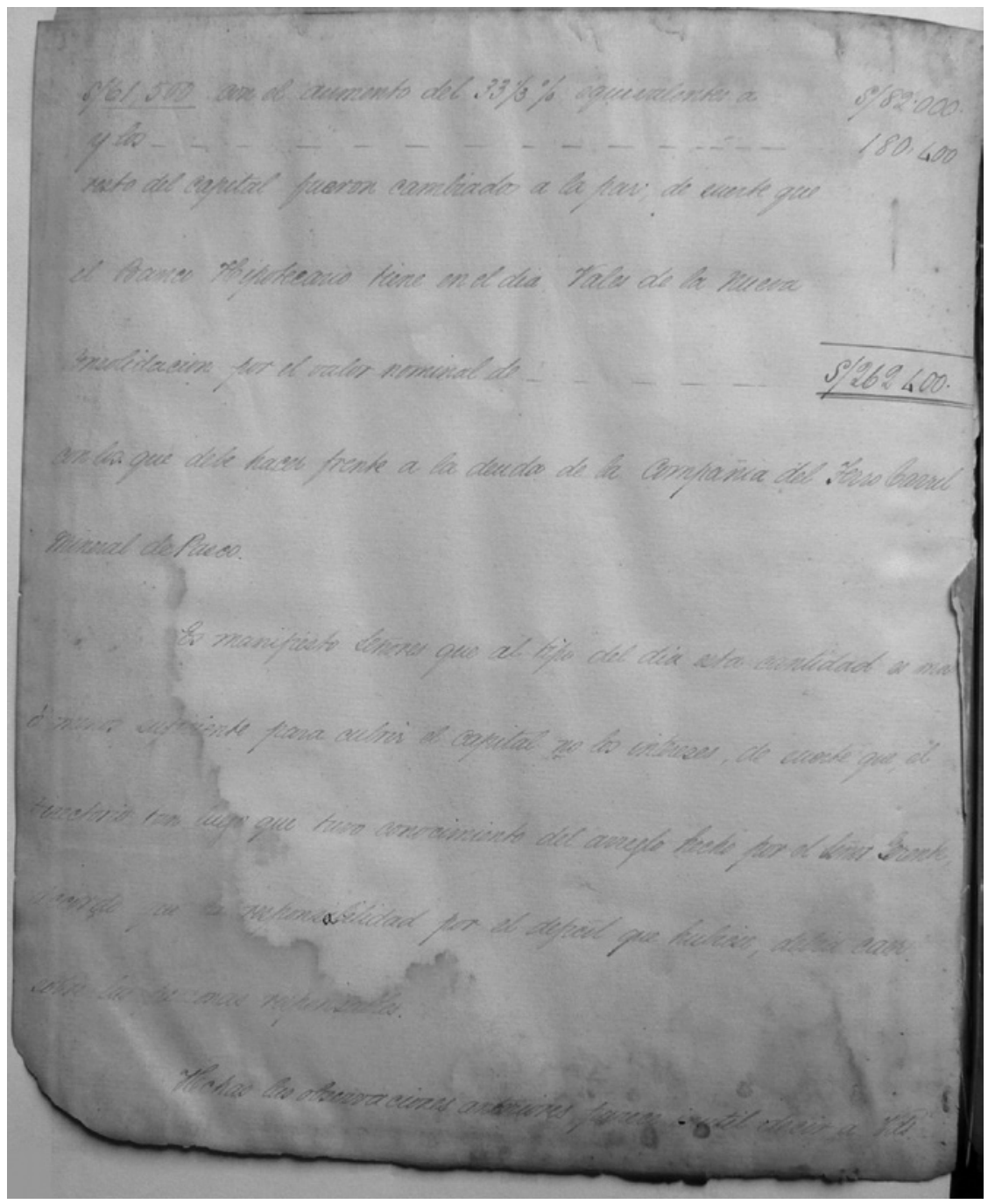

A-7-44. OA-7-17-9 


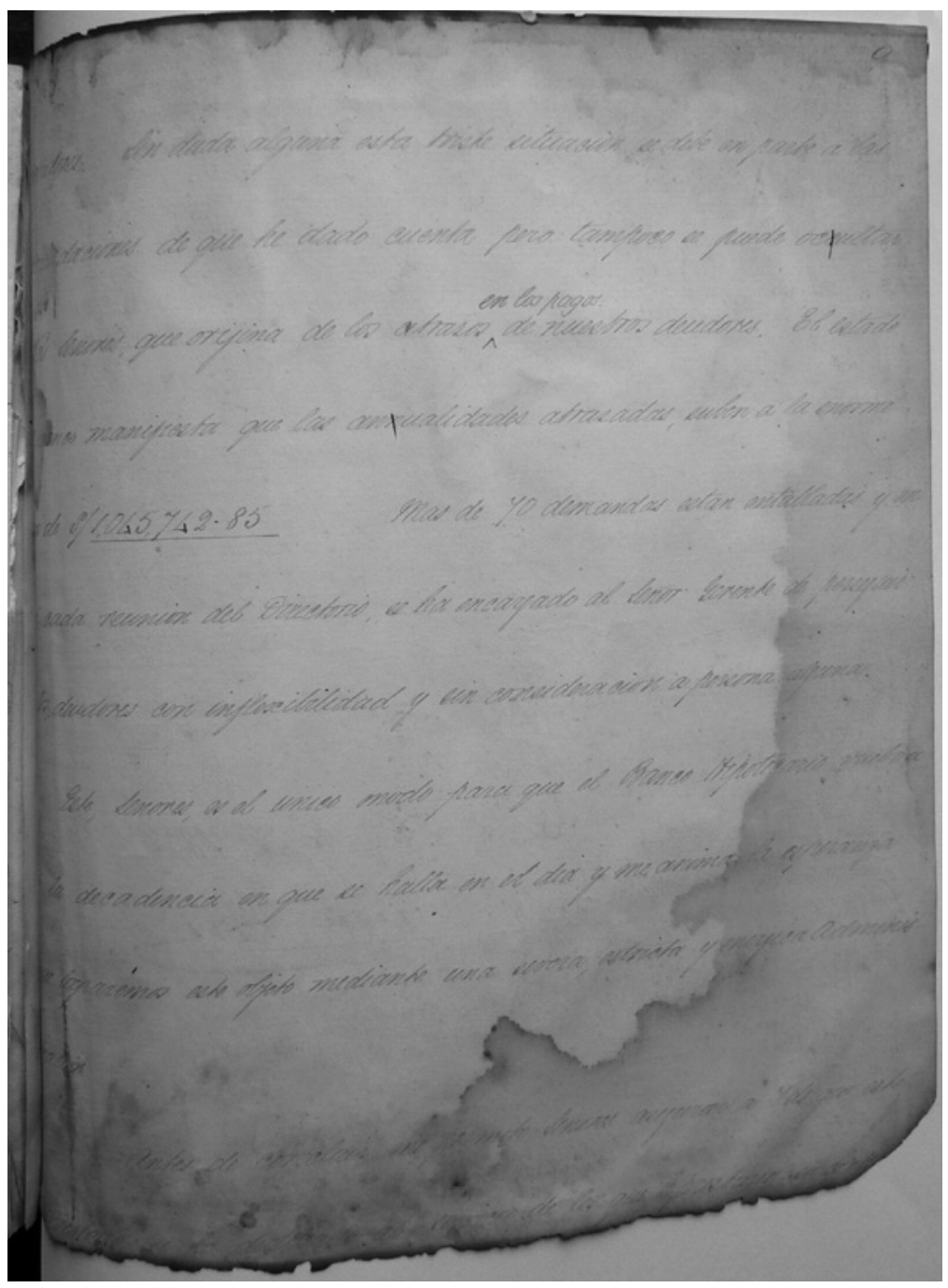

A-7-45. OA-7-17-10 


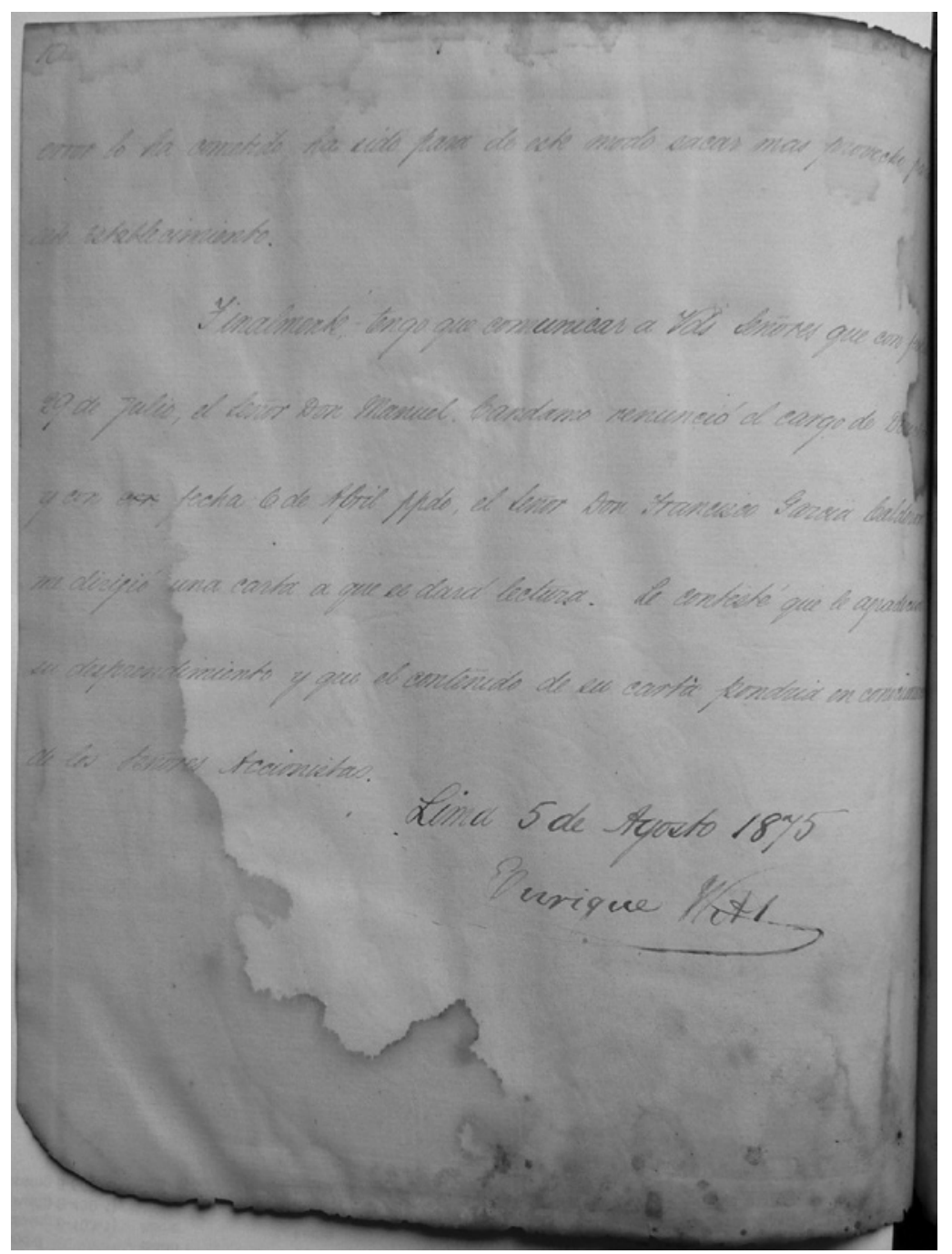

A-7-46. OA-7-17-11 


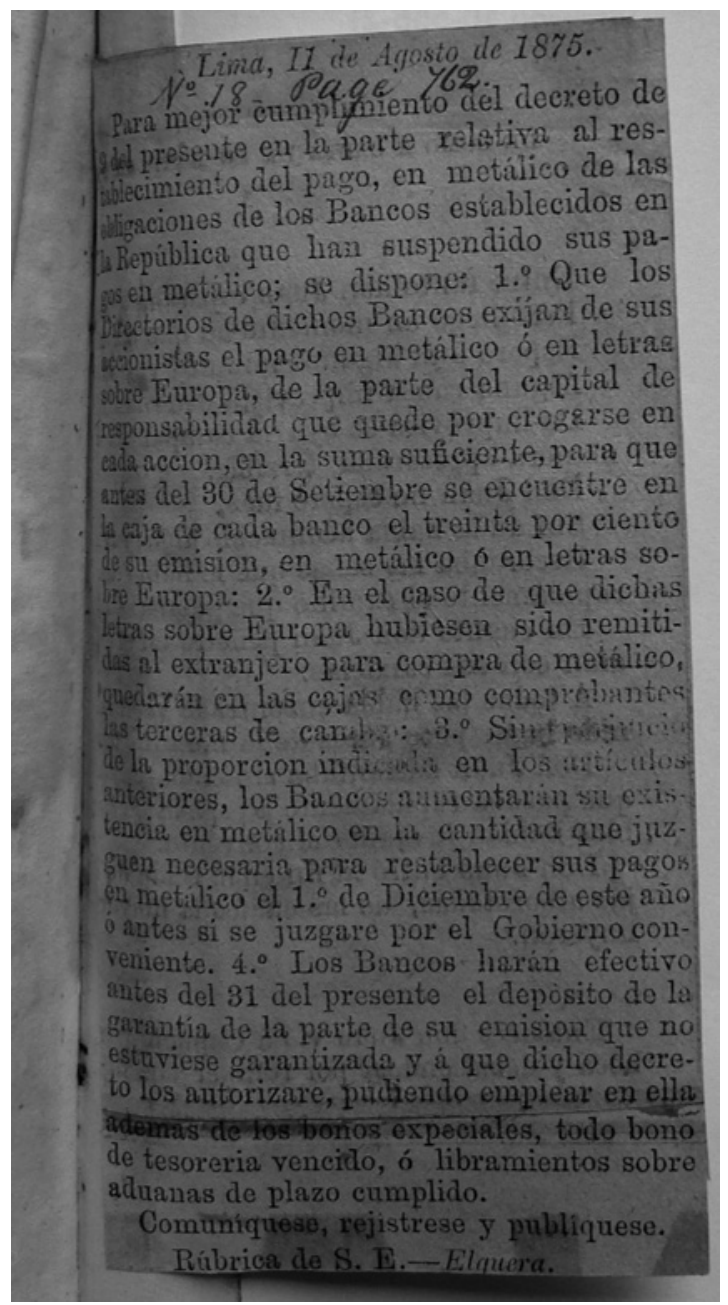

A-7-47. OA-7-18-1 


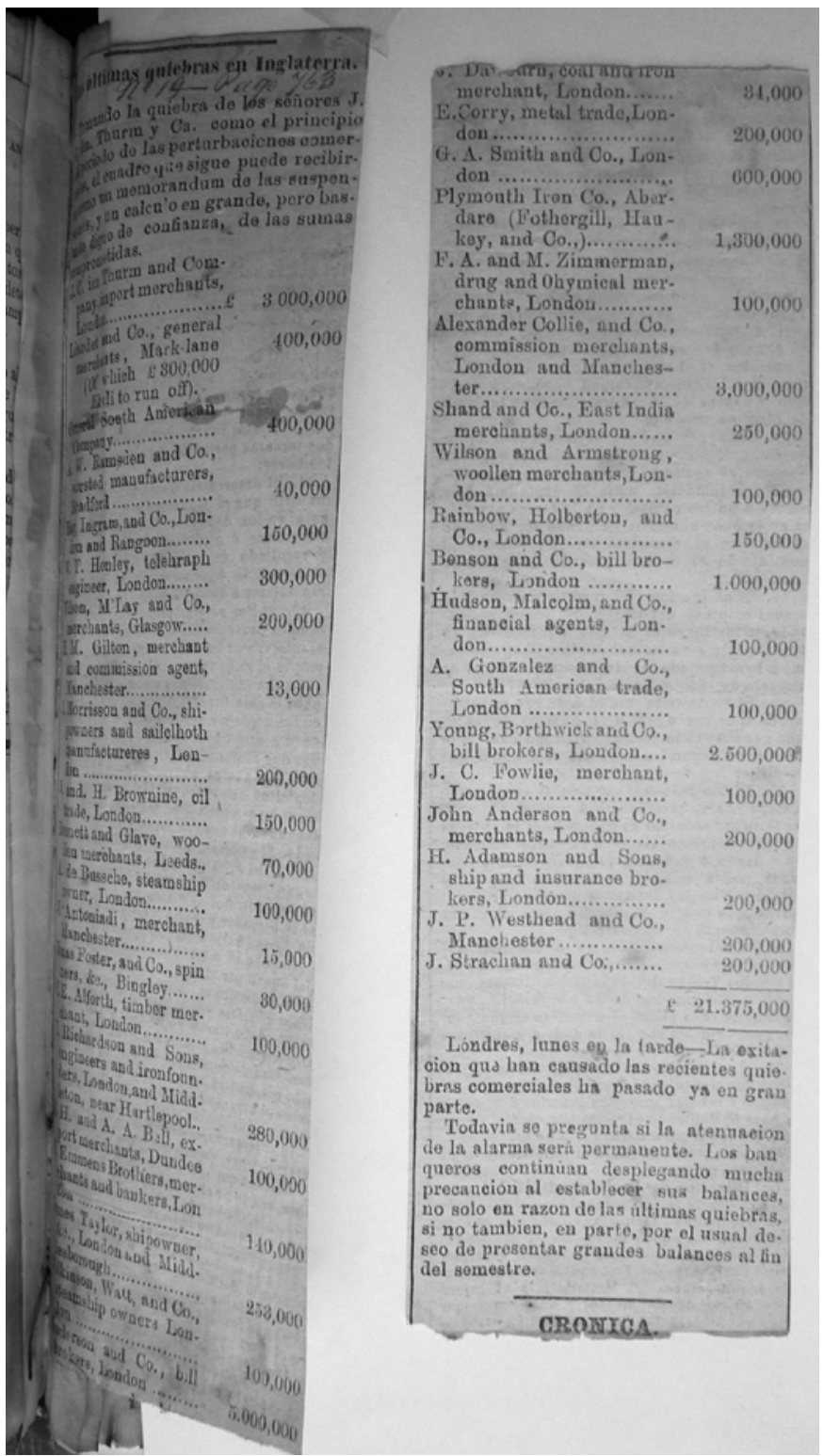

A-7-48. OA-7-19-1 


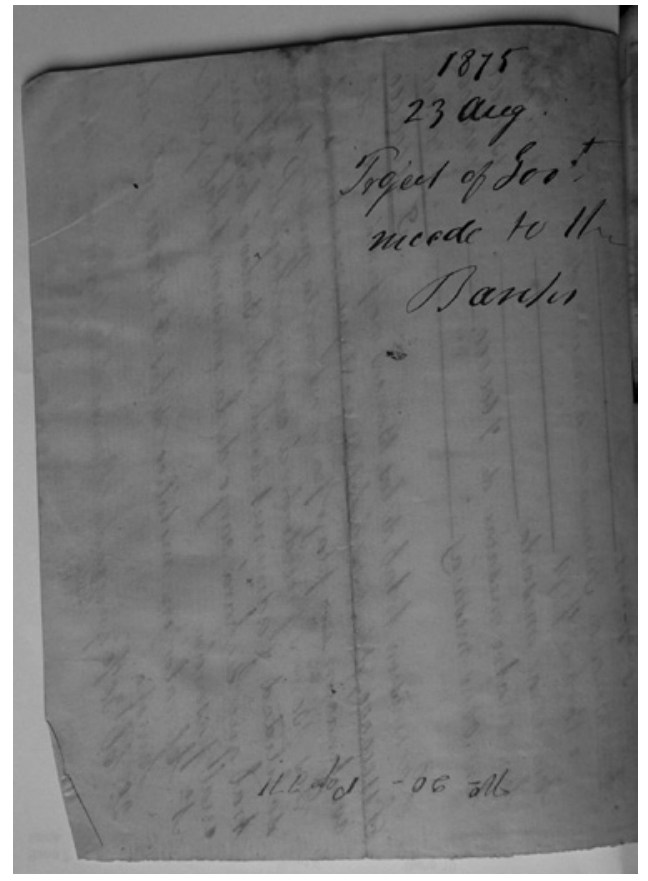

A-7-49. OA-7-20-1 


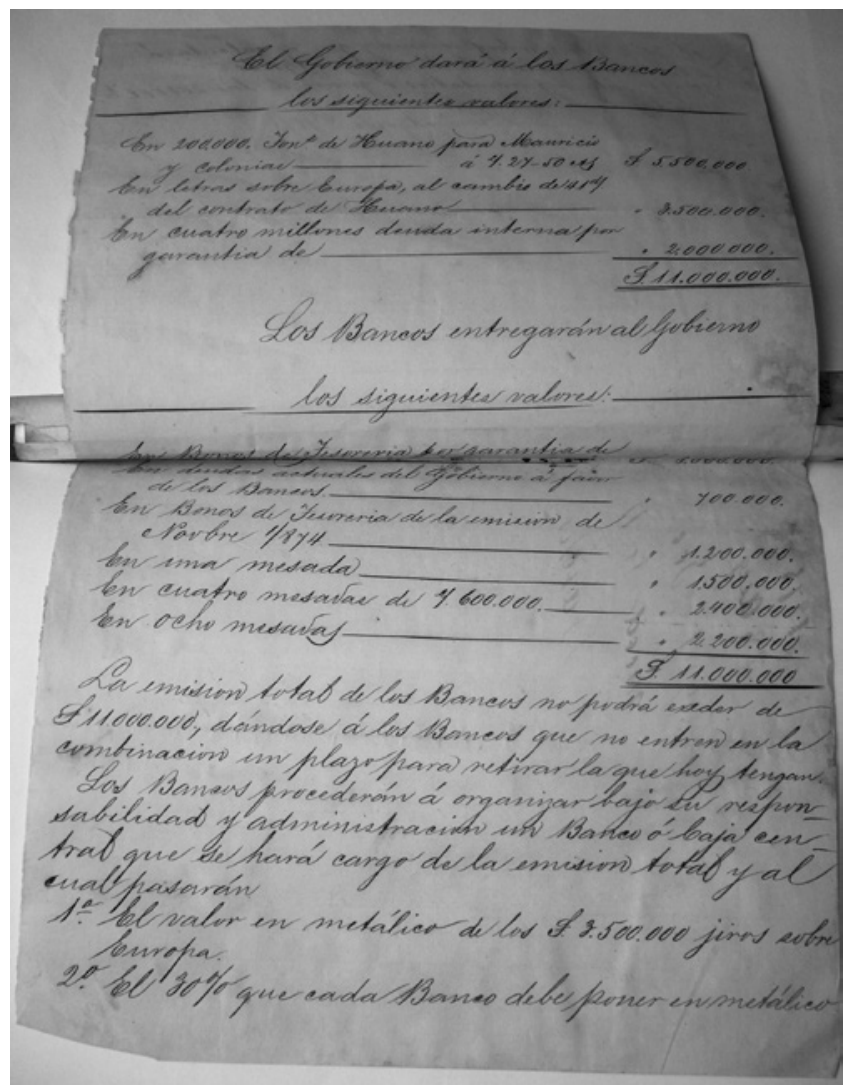

A-7-50. OA-7-20-2 


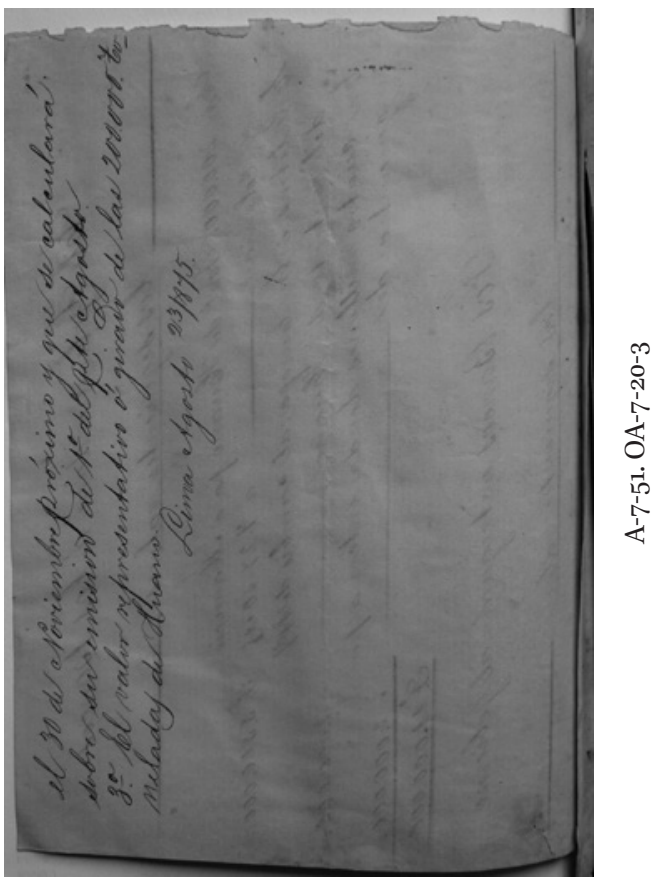




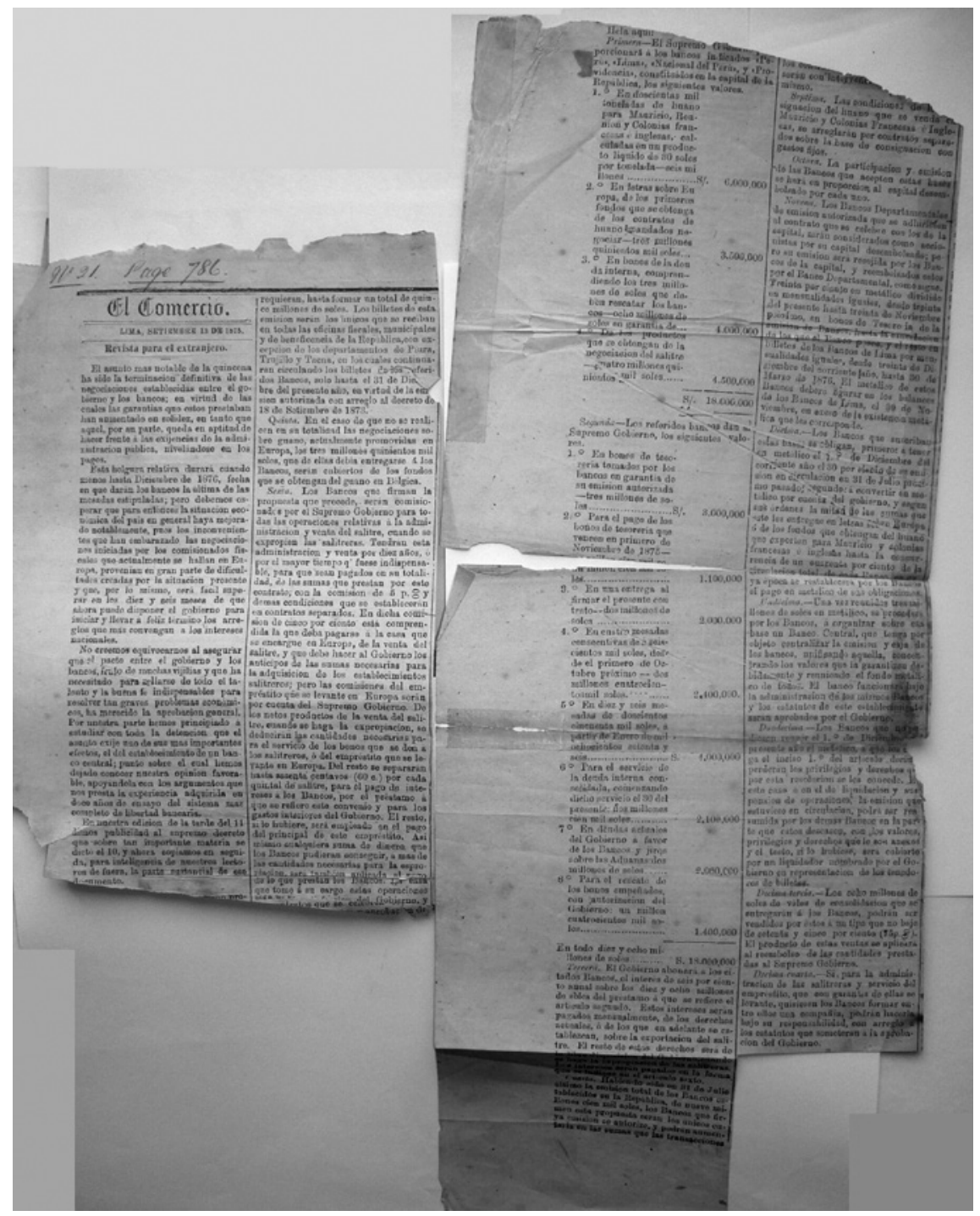

A-7-52. OA-7-21-1 


\section{1-22. Oage 811}

Ballows, Aeronauts, and Carrier-pigeons.

In 1783 . Touph and Btienne Ulonity olfier inmonted the fird ballom, which hey mifated with heated air, and a muntar called Pilatre des Rojiers made ne piret wont. Sorn after, a IVS. Gharles suletidused nydrogen for heated air, and inice 1814 when the common yas canne into we, his, owing to its che afmess, has lation ho place of the hy droyen, he afecific wreight owhich latler is mesicth of that of yas.

Dhe olmme of ain contained niaballoon whidh meneares mide 70.600 culic feet, weighs 5000 lls, the gas contannet in the same ballown weighs 2000 ds conregienthy here umains a raising force of woos lls, and as the ballow ikelf waighs rovo do, here unains a weight of sosolds for he cas, ballast, anchos, provicions, parempers, and any ming mone requiced. If he ballown wore filled with hydrogon, hies hydrogen wonld weigh no more han 350 , and emvequently the raving prover ionto he 4650 Cle, including lons allowed for nee weight of the bellosn iteelf. Ith

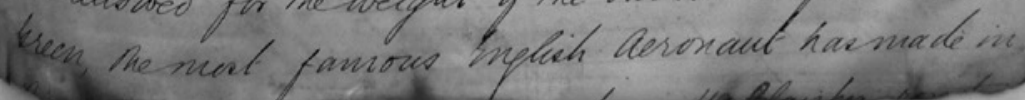

A-7-53. OA-7-22-1 


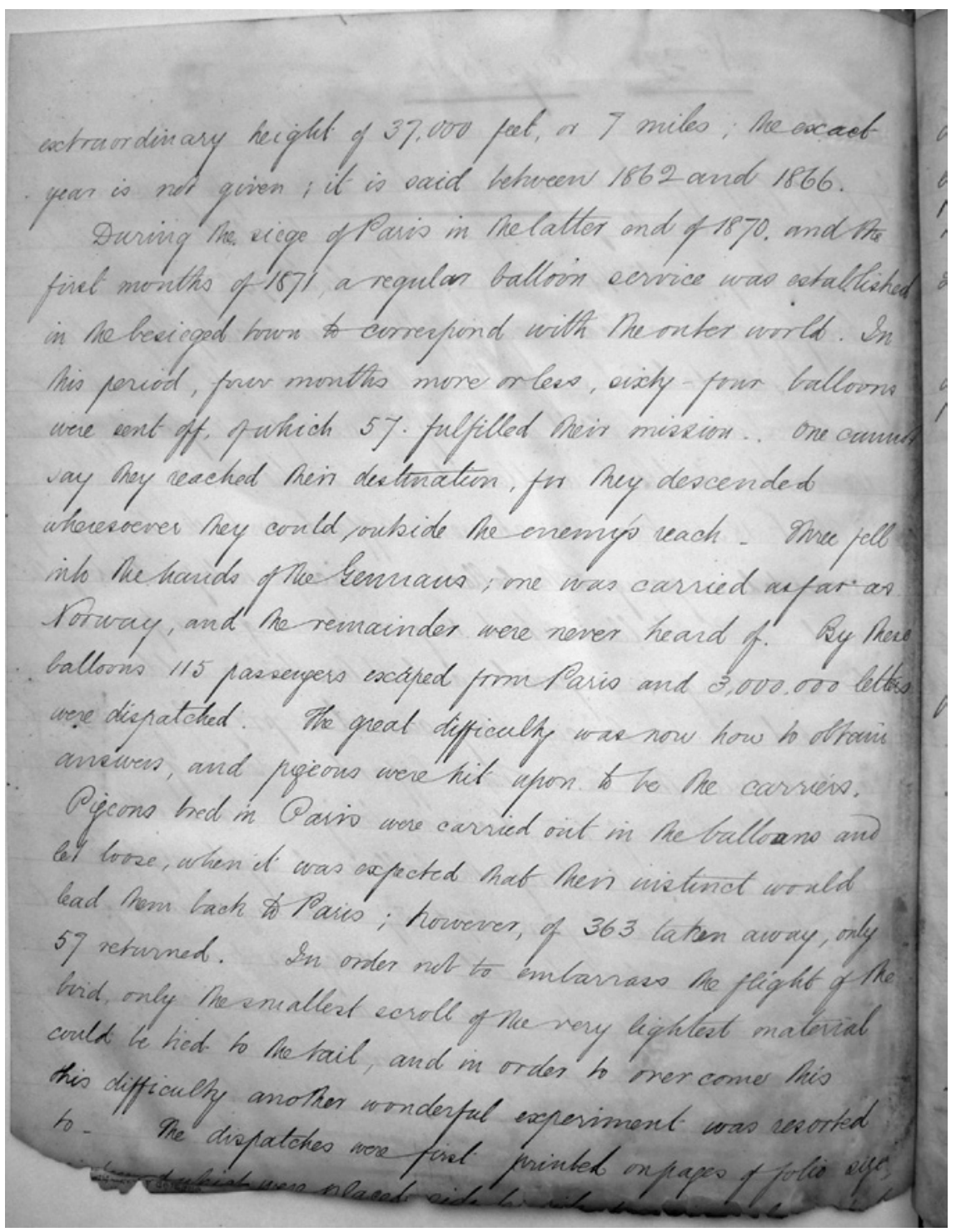

A-7-54. OA-7-22-2 


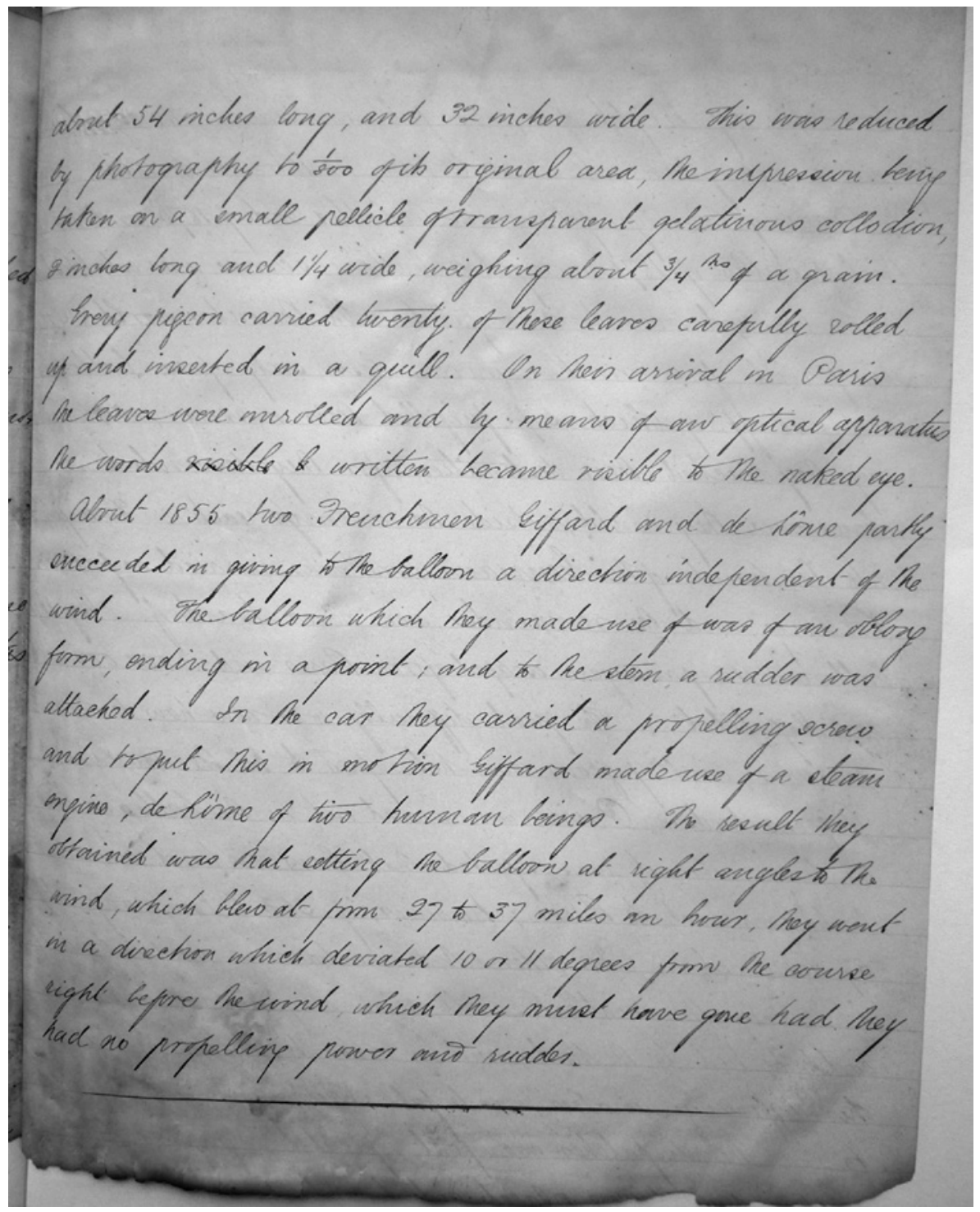

A-7-55. OA-7-22-3 


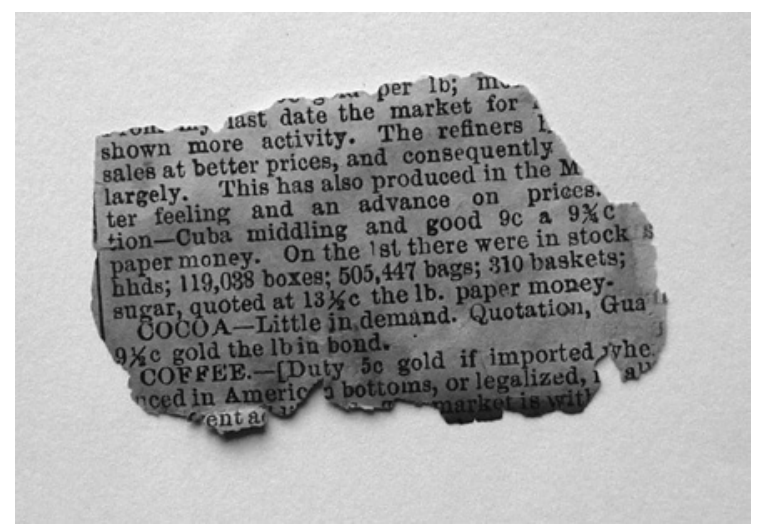

A-7-56. OA-unknown 


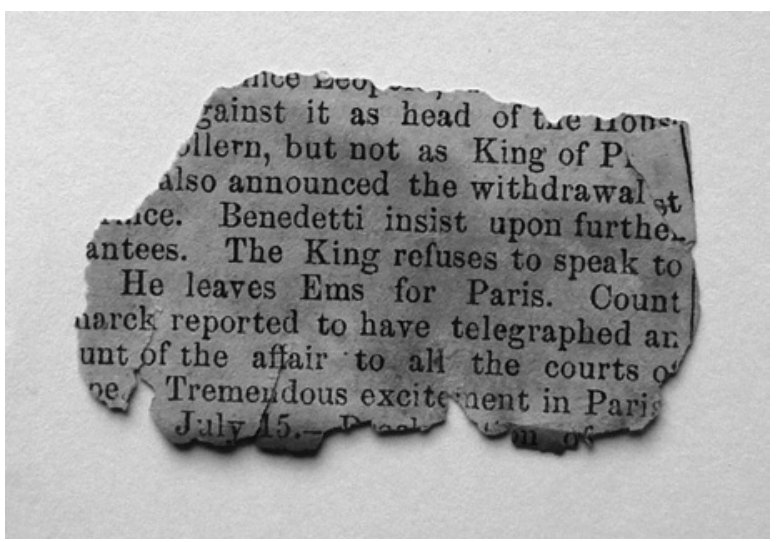

A-7-57. OA-unknown 